\title{
AlPHABETIC LIST OF DISEASES \\ AND CONDITIONS, WITH RECOMMENDATIONS FOR CASE-SPECIFIC AUTOPSY PROCEDURES
}




\section{Organization of Part II}

Some general remarks about objectives for the preparation of Part II can be found in the preface of this third edition. The following paragraphs explain the format in which diseases and conditions are listed in Part II.

Diseases and Conditions. All main entries are arranged in alphabetic order of the noun. Thus, "Viral hepatitis" will be found under "Hepatitis, viral" and "Lung abscess" under "Abscess, lung." In general, the organization of the entries corresponds to that used in Dorland's Illustrated Medical Dictionary, 28th ed., W. B. Saunders, Philadelphia, PA, 1994. Findings related to operative procedures are listed under the alphabetized entry of "Surgery,..." or "Transplantation,...." Diseases or conditions that are not included in the alphabetic list may still be found in the index.

"See..." Such a reference to another disease or condition indicates that the autopsy procedures are the same for both but not necessarily that the two diseases or conditions are the same.

Diseases and Conditions, followed by a Table. If diseases or conditions (in bold print) are listed in both the right and left column of text preceding a table, the table always belongs to the bold entry in the right column.
Synonyms and Related Terms. This subtitle has been modified to either "Synonym(s)" or "Related Term(s)" whenever the entries seemed to fit definitely into one of these categories. An asterisk indicates a disease or condition that is included in the alphabetic list in Part II.

Note. Suggestions pertaining to the entire autopsy procedure are made under this heading. For instance, a warning will be given here whenever special precautions are indicated in the presence of certain infectious diseases or whenever a disease or condition must be reported to the authorities.

Possible Associated Conditions. Diseases or conditions listed under this heading are generally assumed to be linked to the main entry by a common pathogenetic mechanism. An example is the association of malformations, such as coarctation of the aorta and congenital mitral stenosis.

Organs and Tissues. These are listed in the order in which they are generally handled during an autopsy.

Procedures. Ample reference is made to the appropriate page numbers in Part I. We have assumed that routine hematoxylin and eosin sections will be prepared in all instances. Most special stains that are listed below represent but one of several available methods; many pathologist undoubtedly will have other preferences. 


\section{Special Histological Stains ${ }^{a}$}

Name of Stain (as used in text)

Alcian blue stain

Alcian blue and phloxine-tartrazine stain of Lendrum

Aldehyde-Fuchsin stain

Aldehyde-thionin stain

Auramine-rhodamine

Azure-eosin stain

Best's carmine stain

Bielschowsky stain

Bodian stain

Congo red stain

Cresyl echt violet stain

Crystal violet stain

Cyanuric chloride stain

Ferric ferricyanide reduction test

Fluorochrome stain for acid fast bacteria

Fontana-Masson silver stain

Giemsa stain

Gomori's chromium hematoxylin phloxine stain

Gomori's iron stain

Gram stain

\section{Grimelius silver stain \\ (Grimelius' argyrophil stain) \\ Grocott's methenamine silver stain (GMS stain)}

Hale's colloidal iron stain

Jones' silver stain

Kinyoun's stain

Lendrum's stain

Levaditi's stain

Luxol fast blue stain (LFB stain)

\section{Complete Designation and/or Purpose of Stain}

For demonstration of sulfated mucosubstances (at $\mathrm{pH} 1.0$ ) or acid mucopoly-saccharides (at $\mathrm{pH} 2.5$ ).

For demonstration of mucus and squamous epithelial cells in one section.

For staining of beta cells of pancreatic islets, of elastic fibers, and of cells of adenohypophysis.

For staining of cells of adenohypophysis.

Truant's fluorescent method for tubercle and Leprae bacilli.

Routine stain (can be substituted for the hematoxylin and eosin methods).

Best's carmine method for glycogen.

Bielschowsky's method for axis cylinders and dendrites. Bodian's method for nerve fibers and nerve endings. Bennhold's method for amyloid.

Lieb's method for amyloid (crystal violet). Cyanuric chloride method of Yoshiki for osteoid. Schmorl's ferric ferricyanide reduction test for the demonstration of melanin and other reducing substances. Truant's fluorescent method for acid fast organisms

Fontana-Masson silver method for demonstration of argentaffin granules and melanin.

May-Grünwald Giemsa method for hematologic and nuclear elements.

Gomori's method for pancreatic islet cells.

Gomori's method for iron.

Brown and Benn, Brown-Hopps, MaccallumGoodpasture, or Taylor's method for demonstration of Gram positive and Gram negative bacteria.

For demonstration of argyrophil neurosecretory granules (e.g., in pancreatic islets).

Grocott's method for fungi.

The Hale colloidal ferric oxide procedure for acid mucopolysaccharides.

Jones' method for reticulum and basement membranes.

Kinyoun's method for acid-fast bacteria.

Lendrum's method for inclusion bodies.

Levaditi-Manovelian method for spirochetes. Klüver-Barrera method for myelin and nerve cells.

\section{Source and Comments}

Ref. (1)

Also used with periodic acid Schiff stain (Alcian blue/PAS).

Ref. (2)

See also below under Lendrum's stain.

Ref. (3)

Aldehyde fuchsin also stains sulfated mucosubstances and hepatitis B surface antigen.

Ref. (3)

Can be combined with periodic acid Schiff stain (PAS) and with Luxol fast blue (LFB).

Ref. (2)

Ref. (3)

The Giemsa stain and the Wright stain for blood cells also are azure-eosin stains.

Ref. (2)

Ref. (2)

Ref. (2)

Ref. (2)

See Luxol fast blue stain.

Ref. (2)

Ref. (4)

Ref. (3)

See also Fontana-Masson silver stain.

Ref. (2)

Ref. (2)

See also Ferric ferricyanide reduction test and Grimelius silver stain.

Ref. (2)

Several modifications of this methods are in use.

Ref. (2)

Ref. (2)

Ref. (2)

As shown in the middle column, several modifications of this method are in use. The Gram-Weigert stain (ref. [3]) also stains fungi and Pneumocystis carinii.

Ref. (1)

The Fontana-Masson stain for melanin and argentaffin granules can also be used.

Ref. (2)

Also stains Pneumocystis carinii.

Ref. (5)

The alcian blue stain at pH. 2.5 (see above) also can be used.

Ref. (3)

See also methenamine silver stain.

Ref. (2)

Ref. (2)

For use with alcian blue, see above.

Ref. (2)

Ref. (2)

Also used with periodic acid Schiff stain (LFB/PAS) or with cresyl echt violet stain (ref. [1]). 


\begin{tabular}{l} 
Name of Stain (as used in \\
\hline Masson's trichrome stain \\
Methenamine silver stain \\
Methyl violet stain \\
Mucicarmine stain \\
Periodic acid-Schiff stain \\
(PAS stain)
\end{tabular}

PAS-alcian blue stain

(PAS/alcian blue)

Perl's stain for iron

Peroxidase reaction

Phosphotungstic acid hematoxylin stain (PTAH stain)

Reticulum stain

Rhodanine stain

Shikata's orcein stain

Sirius red stain

Sudan stain

\author{
Sulfated alcian blue \\ Thioflavine S \\ Thioflavine $\mathrm{T}$ stain \\ Toluidine blue $\mathrm{O}$ stain
}

Trichrome stain

Van Gieson's stain

Verhoeff-van Gieson stain
Complete Designation and/or Purpose of Stain

Masson's trichrome method.

Chromotrope silver methenamine stain of glomerular lesions.

Highman's method for amyloid (methyl violet).

Mayer's mucicarmine method for mucin and

Cryptococcus.

The periodic acid, Schiff Reagent (PAS) for

demonstration of polysaccharides, neutral

mucosubstances, and basement membranes.

PAS-alcian blue method for mucosubstances.

Perl's method for iron.

Immunoenzymic staining methods for the detection of antigens or antibodies.

Mallory's phosphotungstic acid hematoxylin method.

Gomori's method for reticulum.

Rhodanine method for copper.

Orcein method for demonstration of hepatitis B surface antigen in paraffin sections of liver biopsy specimens.

Sweat-Puchtler method for amyloid (Sirius red).

Sudan black B method for fat (in frozen sections).

For other Sudan stains, see right-hand column.

Sodium sulfate alcian blue (SAB) method for amyloid.

Fluorochrome technics for acid fast bacteria and protozoa.

Vassar-Culling method for amyloid (thioflavine T).

Toluidine blue $\mathrm{O}$ nuclear stain.

Van Gieson's method for collagen fibers.

Verhoeff-van Gieson technic.

Von Braunmühl's stain for senile plaques.

Von Kossa's silver test for calcium.

Warthin-Starry method for spirochetes and Donovan bodies.

Wright stain for blood smears.

Ziehl-Neelsen method for acid-fast bacteria.
Source and Comments

Ref. (2) Used to distinguish between collagen (blue) and smooth muscle fibers (red).

Ref. (6)

See also Jones' silver stain.

Ref. (2)

Ref. (1)

Ref. (1)

Also used with diastase digestion (diastase digests glycogen, e.g., in liver tissue). For use with alcian blue, see under that heading. See above under "Alcian blue stain."

Ref. (2)

Ref. (3)

Direct and indirect staining methods can be applied, usually with horseradish peroxidase (HPR).

Ref. (2)

Stains skeletal muscle with cross striations (blue), collagen (red), nuclei, and fibrin (both blue).

Ref. (2)

Ref. (3)

Rhodanine should not be confused with rhodamine, which is a fluorochrome, e.g., for the detection of mycobacteria.

Ref. (3)

Orcein also is an excellent stain for elastic fibers.

Ref. (2)

Ref. (2)

Oil red $\mathrm{O}$ solution also can be used; it gives better results than either Sudan III or Sudan IV (ref. [5]).

Ref. (8)

Ref. (7)

Ref. (2)

Ref. (3)

Toloidin blue can be used for mast cells, mucin, nerve cells and glia.

See Masson's trichrome stain.

Ref. (2)

See also Verhoeff-van Gieson stain.

Ref. (3)

Stains elastic fibers black, collagen red, nuclei blue to black, and other tissue elements yellow. See also Shikata's orcein stain.

Ref. (9)

Ref. (3)

Ref. (2)

Also stains $H$. pylori.

Ref. (3) Also used with Giemsa stain.

Ref. (2)

\section{Ziehl-Neelsen stain}

${ }^{a}$ Most of these stains are recommended with appropriate entries in Part II. Some of them can be used for more purposes than stated in the middle column. For alternative stains and recommended fixatives, see current staining manuals. 
Possible or Expected Findings. Listed under this heading are manifestations of the disease or condition in the alphabetic title. Also included in this column are many causes and complications, provided they can be identified at autopsy. Occasionally, some overlap will be found with "Possible Associated Conditions" (see above).

\section{Removal of Formalin Pigment}

from Histological Sections (2)

1. Deparaffinize sections through two changes each of xylene, absolute alcohol, and 95\% alcohol.

2. Rinse well in distilled water.

3. Place slides for 5-10 min in freshly made up bleaching solution, consisting of $25 \mathrm{~mL}$ hydrogen peroxide $3 \%$, $25 \mathrm{~mL}$ acetone, and 1 drop ammonium hydroxide.

4. Wash well in running tap water and distilled water.

5. Stain as desired.

\section{References}

1. Carson FL. Histotechnology. A Self-Instructional Text. ASCP Press, American Society of Clinical Pathology, Chicago, IL, 1990.

2. Luna LG. Histopathologic Methods and Color Atlas of Special Stains and Tissue Artifacts. Johnson Printers, Downer's Grove, IL, 1992.

3. Sheehan DC, Hrapchak BB. Theory and Practice of Histotechnology, 2nd ed. CV Mosby Company, St. Louis, MO, 1980.

4. Clark WE. Osteomalacia, histopathologic diagnosis made simple (letter to the editor). Am J Clin Pathol 1976;66:1025-1026.

5. Lillie RD. Histopathologic Technic and Practical Histochemistry, 3rd ed. McGraw-Hill, New York, 1965.

6. Ehrenreich T, Espinosa T. Chromotrope silver methenamine stain of glomerular lesions. Am J Clin Pathol 1971;56:448-451.

7. Bancroft JD, Stevens A. Theory and practice of histological techniques. Churchill Livingstone, New York, 1982.

8. Thompson SW, Hunt RD. Selected Histochemical and Histopathological Methods. Charles C. Thomas, Springfield, IL, 1966.

9. Putt FA. Manual of Histopathological Staining Methods. John Wiley \& Sons, New York, 1972. 


\section{A}

\section{Abetalipoproteinemia}

Synonyms and Related Terms: Acanthocytosis; Bassen-Kornzweig syndrome.

NOTE: Autopsies on patients with this rare genetic disease $(1,2)$ should be considered research procedures.

Possible Associated Conditions: Hemolytic anemia;* malabsorption syndrome.*

\begin{tabular}{ll}
\hline Organs and Tissues & Procedures \\
\hline External examination & Record body weight and length. \\
& $\begin{array}{l}\text { Prepare chest roentgenogram } \\
\text { (frontal and lateral view). }\end{array}$ \\
Blood & Submit for serum lipid analysis
\end{tabular}

Possible or Expected Findings

Blood

Submit for serum lipid analysis.

Below-normal weight in infants.

Kyphoskoliosis.

Very low concentrations of cholesterol and triglycerides; serum $\beta$-lipoprotein decreased or absent; $\alpha$-lipoproteins present.

Acanthocytosis (spiny red cells).

Small bowel For preservation of small intestinal

Abnormal shape of villi; vacuolation of epithelial cells. mucosa and for preparation for study under dissecting microscope, see

Part I, Chapter 5. Submit sample for histologic study.

Large bowel Submit stool for chemical analysis.

Liver Record weight and submit sample for histologic study.

Other organs

Record appearance of spine

Spine (see also chest roentgenogram).

Brain, spinal cord, peripheral nerves For removal and specimen preparation, see pp. 65,67 , and 79 , respectively. Request Luxol fast blue stain (p. 172).

Fatty stools

Fatty changes.

Systemic manifestations of malabsorption syndrome* and of vitamin A deficiency.* Kyphoscoliosis.

Axonal degeneration of the spinocerebellar tracts; demyelination of the fasciculus cuneatus and gracilis (2). Possible involvement of posterior columns, pyramidal tracts, and peripheral nerves.

Eyes For removal and specimen preparation, Atypical retinitis pigmentosa (2) with see p. 85 . involvement of macula. Angioid streaks (3).

\section{References}

1. Case records of the Massachussetts General Hospital. Case 35-1992. N Engl J Med 1992;327:628-635.

2. Rader DJ, Brewer HB Jr. Abetalipoproteinemia. New insights into lipoprotein assembly and vitamin $\mathrm{E}$ metabolism from a rare genetic disease [clinical conference]. JAMA 1993;270:865-869.

3. Gorin MB, Paul TO, Rader DJ. Angioid streaks associated with abetalipoproteinemia. Ophthalmic Genet 1994;15:151-159.

\section{Abortion}

NOTE: If a fetus is present, follow procedures described under "Stillbirth." If no recognizable fetal tissue is found, an indication might exist to submit material for chromosome study as decribed in Chapter 10. If attempts to induce abortion appear to have caused the death of the mother, see "Death, abortionassociated." 


\section{Abscess, Brain}

Synonym: Cerebral abscess.

NOTE: For microbiologic study of tissues and abscesses, see Part I, Chapter 9. Include samples for anaerobic culture. It is best to study the brain after fixation but if specimen is examined fresh, aspirate and prepare smears of abscess content. Photograph surface and coronal slices of brain. Request Giemsa stain, Gram stain, PAS stain, and Grocott's methenamine silver stain for fungi (p. 172, 173).

\begin{tabular}{ll}
\hline Organs and Tissues & Procedures \\
\hline External examination & $\begin{array}{l}\text { Record presence or absence of features } \\
\text { listed in right-hand column. }\end{array}$
\end{tabular}
listed in right-hand column.

Cerebrospinal fluid Brain and spinal cord

Base of skull with sinuses and middle ears

Eyes

Other organs
If there is evidence of trauma, see also under "Injury, head." Prepare roentgenograms of chest and skull.

Submit for microbiologic study (p. 104). For removal and specimen preparation, see pp. 65 and 67, respectively. For microbiologic study, photography, and special stains, see under "Note."

For exposure of venous sinuses, see p. 71. Sample walls of sinuses for histologic study. For exposure of paranasal sinuses, mastoid cells, and middle ears, see p. 71-73.

For removal and specimen preparation, see p. 85 .

Procedures depend on suspected lesions as listed in right-hand column.

\section{Possible or Expected Findings}

Skin infections in upper half of face. Edema of forehead, eyelids, and base of nose, proptosis, and chemosis indicate cerebral venous sinus thrombosis.* Trauma; craniotomy wounds.

Skull fracture and other traumatic lesions. For possible intrathoracic lesions, see below under "Other organs."

Traumatic lesions of brain. Foreign body.

Cerebral venous sinus thrombosis* or thrombophlebitis.

Paranasal sinusitis and mastoiditis. Subacute and chronic otitis media.* Osteomyelitis* and fractures of base of skull may be present. Thrombosis of angular and superior ophthalmic veins, associated with cavernous sinus thrombosis.*

Congenital heart disease with right-to-left shunt; infective endocarditis.* Bronchiectasis;* lung abscess; * pleural empyema.* Entamoeba histolytica abscesses in liver and lung.

\section{Abscess, Epidural \\ Synonym: Epidural Empyema. \\ NOTE: Procedures are the same as those suggested under "Empyema, epidural." \\ Abscess, Lung \\ Synonym: Pulmonary abscess. \\ NOTE: For microbiologic procedures and related suggestions, see also under "Pneumonia."}

\begin{tabular}{lll}
\hline Organs and Tissues & Procedures & Possible or Expected Findings \\
\hline External examination & Prepare chest roentgenogram. & $\begin{array}{l}\text { Pulmonary cavities and infiltrates; foreign } \\
\text { body. }\end{array}$ \\
& $\begin{array}{l}\text { Record appearance of oral cavity. } \\
\text { If peripheral veins contain potentially infected } \\
\text { catheters, see below under "Central veins." } \\
\text { Before chest is opened, puncture pleural cavity } \\
\text { and submit exudate for microbiologic study }\end{array}$ & $\begin{array}{l}\text { Periodontal infection. } \\
\text { Infected intravenous catheter. }\end{array}$ \\
\hline Chest cavity & Empyema;* pleural effusion or exudate.*
\end{tabular}
and submit exudate for microbiologic study (p. 102).

Prepare smears of exudate and request Gram,

Bacteria or fungi in exudate.

Kinyoun, and Grocott methenamine silver stains (p. 172). 


\begin{tabular}{|c|c|c|}
\hline Organs and Tissues & Procedures & Possible or Expected Findings \\
\hline Central veins & $\begin{array}{l}\text { If a metastatic abscess from an infected intra- } \\
\text { venous catheter is suspected, ligate appropriate } \\
\text { vein proximal and distal to catheter tip and } \\
\text { submit for microbiologic study. }\end{array}$ & Infected intravenous catheter. \\
\hline Heart & See "Endocarditis, infective." & $\begin{array}{l}\text { Infective endocarditis* of tricuspid or } \\
\text { pulmonary valve. }\end{array}$ \\
\hline Lungs & $\begin{array}{l}\text { For bronchography and pulmonary arterio- } \\
\text { graphy, see Part I, Chapter 5. If abscess contents } \\
\text { are aspirated or microbiologic studies are } \\
\text { not crucial, perfuse intact lung with formalin } \\
\text { (p. 47). }\end{array}$ & $\begin{array}{l}\text { Tumor of lung, }{ }^{*} \text { foreign body, or other } \\
\text { obstructive bronchial lesion. }\end{array}$ \\
\hline Other organs & $\begin{array}{l}\text { Procedures depend on expected sources of } \\
\text { infection. }\end{array}$ & $\begin{array}{l}\text { Manifestations of possible underlying } \\
\text { conditions such as acquired } \\
\text { immunodeficiency syndrome.* }\end{array}$ \\
\hline
\end{tabular}

\section{Abscess, Subdural (See “Empyema, epidural.”)}

\section{Abscess, Subphrenic (See “Empyema, subphrenic.”)}

Abuse, Child (See "Infanticide.")

Abuse, Drugs or Other Chemicals

(See "Abuse, hallucinogen(s)," "Abuse, marihuana," "Dependence,..." "Poisoning,..." See also "Alcoholism and alcohol intoxication.")

\section{Abuse, Hallucinogen(s) \\ Related Terms: Diethyltryptamine (DET); dimethyltrypt- amine (DMT); lysergic acid diethylamide (see "Poisoning, LSD"); marihuana;* mescaline; psilocin; psilocybin ("magic mushrooms"); psychedelics; psychotomimetics; and others (1). \\ NOTE: See also under "Dependence, drug(s), all types or type unspecified." For routine toxicologic sampling, see p. 16. There are no specific morphologic findings related to hallucino- gen intake.}

\section{Reference}

1. Baselt RC, Cravey RH. Disposition of Toxic Drugs and Chemicals in Man, 4th ed. Chemical Toxicology Institute, Foster City, CA, 1995.

\footnotetext{
Abuse, Marihuana

Synonyms: Cannabis; hashish.

NOTE: The tissues at autopsy show no specific changes. Tetrahydrocannabinol is routinely detected by the EMIT screening procedure (see Part I, Chapter 2) in urine, and is confirmed and quantitated by specific assays on a variety of body fluids, including blood. However, these latter procedures are rarely needed. If abuse of other drugs is suspected, see under "Dependence, $\operatorname{drug}(\mathrm{s})$, all types or type unspecified."
}

\section{Accident, Aircraft}

In the event of a major catastrophic air carrier accident, the local police should be called and then The Federal Aviation Administration (FAA) in Washington, DC. ${ }^{*}$ The FAA will notify the National Transportation Safety Board (NTSB). Most fatal air crashes are investigated by the NTSB. ${ }^{* *}$ The FAA investigates crashes in which the gross weight of the craft is less than 12,500 pounds ( 1 ). The investigations are conducted by a team of federal and other specialists. Local police, firemen, or other officials will seal off the area of the crash, and no one should be allowed to approach the bodies or any objects until the identification teams and the medical examiner or coroner have taken charge.

Several medical examiner and coroner offices have published accounts detailing their approaches to managing mass fatality disasters (2-6). The sudden influx of bodies after a commercial air carrier accident and the request for speedy identification of the victims and for detailed autopsy reports of the crew members would overburden almost any institution. Managing such a disaster requires an efficient organization, and it seems advisable to devise a plan before the necessity arises. Temporary morgue facilities may have to be established near the scene of the crash. Refrigerated trucks may serve as storage space. A practical approach is to deal first with those bodies that seem to be the easiest to identify, in order to narrow the field for the more difficult cases.

If bodies are scattered, the exact locations should be identified by stakes in the ground or spray paint on pavement; only then should these bodies (or remaining parts) and all objects that might belong to them be collected. For this, plastic bags with paired tags are generally used. One tag is used as a marker for the stake; the other stays with the bag. Or, if the stakes are numbered, one tag can be used and the stake number is put on the tag, in addition to the bag number. Proper records and diagrams 
of the relative positions of victims are prepared during this phase. If the victims are still within the airplane, their exact positions within the wreckage must also be recorded, and appropriate photographs should be taken.

For the identification of the victims, the airline will provide a list of the passengers and the Federal Bureau of Investigation (FBI) disaster team will take fingerprints and aid in the acquisition of other identifying data such as age, race, weight, height, and hair color and style. If dental records can be obtained, this provides one of the most certain methods of identification. A medical history indicating amputations, internal prostheses, or other characteristic surgical interventions or the presence of nephrolithiasis, gallstones, and the like will be helpful. Fingerprints (and footprints of babies) should be taken in all instances. Wallets with identification cards, jewelry, name tags in clothing, or other personal belongings may provide the fastest tentative identification.

The medical examiner may elect to autopsy only the flight crew but not the passengers of an aircraft crash. However, the grossly identifiable fatal injuries should be described, photographed, and x-rayed. This may reveal identifying body changes. If comparison of somatic radiographs, dental records, fingerprints, or photographs do not identify the victim, DNA comparison must be considered. Burned or fragmented bodies of passengers and the bodies of crew members, and particularly the pilots, must have a complete autopsy, including roentgenographic and toxicologic examinations, which must always include alcohol and carbon monoxide determinations. Internal examination might reveal a coronary occlusion, or roentgenograms may disclose a bullet as evidence that violence preceded the crash. In some airplane crashes, particularly in light airplane accidents, suicide must be considered and a suicide note should be sought. Some authors recommend performing autopsies on all deceased occupants of aircraft crashes, including passengers, and cite the need to distinguish among blunt impact trauma, smoke inhalation, and flash fires as causes of death, in order to answer future questions concerning pain and suffering, intoxication, and sequence of survivorship.

After a crash victim has been identified, the coroner or medical examiner will issue a death certificate. If remains of a decedent cannot be found, a judge can, upon petition, declare a passenger dead and sign a death certificate prepared by a medical examiner.

*Phone \# of FAA Command Center: 202-267-3333

**Phone \# of NTSB Command Center: 202-314-6290.

\section{References}

1. Wagner GN, Froede $\mathrm{CH}$. Medicolegal investigation of mass disaster. In: Medicolegal Investigation of Death, 3rd ed. Spitz WU, ed. Charles C. Thomas, 1993.

2. Clark MA, Hawley DA, McClain JL, Pless JE, Marlin DC, Standish SM. Investigation of the 1987 Indianapolis Airport Ramada Inn incident. J Forens Sci 1994;39:644-649.

3. Clark MA, Clark SR, Perkins DG. Mass fatality aircraft disaster processing. Aviation Space Environm Med 1989;60:A64-A73.

4. McCarty VO, Sohn AP, Ritzlin RS, Gauthier JH. Scene investigation and victim examination following the accident of Galaxy 203: disaster preplanning does work. J Forens Sci 1987;32:983-987.
5. Randall B. Body retrieval and morgue operations at the crash of United Flight 232. J Forens Sci 1001;36:403-409.

6. Wagner GN. Aerospace pathology. In: Handbook of Forensic Pathology. Froede RC, ed. College of American Pathologists, Northfield, IL, 1990.

\section{Accident, Automobile (See “Accident, vehicular.”)}

\section{Accident, Diving (Skin or Scuba)}

NOTE: Skin diving fatalities are usually caused by drowning, ${ }^{*}$ and autopsy procedures described under that entry should be followed. Usually, the circumstances that led to drowning are not apparent from the autopsy findings but can be reconstructed from reports of witnesses and the police. Because the reflex drive to seek air is triggered by hypercarbia, not hypoxia, loss of consciousness and drowning can ensue after hyperventilation and breath-holding by experienced swimmers who then drown without a struggle. There are no specific autopsy findings. A search for trauma, including a posterior neck dissection (see p. 67), should be made in all instances. Head and cervical injuries may be responsible for loss of consciousness and drowning, usually in individuals diving into shallow water with the head striking the bottom. Toxicologic examination as described below for scuba diving accidents is always indicated.

With scuba diving fatalities, investigation of the equipment and circumstances is far more important than the autopsy. Scuba fatalities should be studied by or with the aid of diving experts-for instance, members of the nearest diving club or the U.S. Navy. Careful investigation of the scene and study of reports of witnesses and the police are essential. Records should state the site of diving (currents and other underwater hazards), the estimated depth, the water temperature (exposure to cold), and a description of water clarity. Water of the area should be sampled, particularly if it seems heavily polluted. Records should also state whether there were electric underwater cables (if electrocution might have occurred, see "Injury, electric") and whether explosives had been used in the vicinity (blast injury). The method of recovery of the body (injuries by grappling hooks) and the type of resuscitation efforts should be noted. The medical history of the diving victim should be reviewed (for example, evidence of seizure disorders or drug use).

The most frequent cause of death ascribed to scuba diving accidents is drowning. Although drowning may be the terminal event in many scuba deaths, the investigation should be focused on the adverse environmental and equipment factors that place a capable swimmer at risk of drowning (see "Embolism, air" and "Sickness, decompression"). If exhaustion, panic, or cardioinhibitory reflexes were responsible for loss of consciousness, autopsy findings will only be those of drowning. Gas bubbles should be documented at autopsy, but their interpretation is problematic. Bodies recovered immediately are subjected to resuscitation efforts, which can by themselves produce extraalveolar air artifacts. Bodies not recovered immediately tend to be found in a putrified condition, full of postmortem gas. In the remaining cases, the pathologist must consider the potential of introducing artifactual gas bubbles by the forcible retraction of the chest plate and by sawing the calvarium. The following procedures apply primarily to scuba diving accidents $(1-4)$. 
Organs and Tissues

External examination

Eyes and ears

Head (skull and brain)

Middle ears

Chest

Blood (from heart and peripheral vessels)
Procedures

Photograph victim as recovered and after removal of wet suit and other diving gear. Record condition of clothing and gear. Impound all diving equipment for study by experts, particularly scuba tank, breathing hoses, and regulators. Residual air in tank should be analyzed.

Record color of skin (including face, back, soles, palms, and scalp).

Palpate skin and record presence or absence of crepitation.

Record extent and character of wounds. Prepare histologic specimens.

Record appearance of face (including oral and nasal cavities) and of ears.

Prepare roentgenograms. If air embolism must be expected, as in the presence of pneumomediastinum, follow procedures described under "Embolism, air."

For evaluation of findings, see also above under "Note."

Otoscopic examination.

Funduscopic examination.

Save vitreous (p. 85) for possible toxicologic and other studies.

For removal of brain, see pp. 65 and 71. Record contents of arteries of the circle of Willis and its major branches and basilar artery.

Strip dura from base of skull and from calvarium.

For removal and specimen preparation, see p. 72 .

For demonstration of pneumothorax, see p. 430.

If gas is visible in coronary arteries, photograph. Photograph and aspirate gas in heart chambers. (For procedures, see p. 290.)
Possible or Expected Findings

Mask, fins, weight belt, life vest, scuba tank and regulator, watch, depth gauge, or other gear may be missing. Clothing may be torn. Quick-release mechanisms of scuba tank or of weight belt may have been improperly adjusted and may not work. Mask, mouthpiece, regulator, or exhalation hose may contain vomitus. Air supply may be contaminated.

Cyanosis after hypoxia,* cherry-red color after $\mathrm{CO}$ poisoning, ${ }^{*}$ or marbling after air embolism.*

Crepitation from subcutaneous emphysema.

Antemortem and postmortem abrasions, lacerations, contusions, bites, or puncture wounds (marine life-for instance, coelenterate stings). Electrocution marks, blast injuries.

Froth on mouth and nares. Facial edema and edema of pinnae. ("Facial squeeze" and "external ear squeeze" occur during descent.) Vomitus in mouth and nose.

Fractures-for example, of cervical spine in skin diving accidents (see above); bone necroses (see below); foreign bodies. Pneumothorax,* pneumoperitoneum, pneumopericardium, and mediastinal and subcutaneous emphysema (all indicating rapid ascent).

Otitis externa. Rupture of tympanic membrane.

Gas in retinal vessels after air embolism. For interpretation of other studies, see p. 115.

Gas bubbles in cerebral arteries after air embolism* (after rapid ascent). Nitrogen bubbles in cerebral vessels are found in victims who had "staggers."

Subdural and subarachnoid hemorrhages. Cerebral edema, with ischemic necroses and focal hemorrhages, after air embolism. Skull fracture.

Edema and hemorrhage. ("Middle ear squeeze" occurs during descent; hemorrhage occurs in drowning.) Ruptured tympanic membranes.

Pneumothorax; pneumomediastinum. Petechial hemorrhages of serosal surfaces. Air embolism.* 


\begin{tabular}{|c|c|c|}
\hline Organs and Tissues & Procedures & Possible or Expected Findings \\
\hline $\begin{array}{l}\text { Blood (from heart and } \\
\text { peripheral vessels) } \\
\text { (continued) }\end{array}$ & $\begin{array}{l}\text { Submit samples of heart blood and peripheral } \\
\text { blood for toxicologic study and drug screen } \\
\text { (p. 16). }\end{array}$ & $\begin{array}{l}\text { Alcohol intoxication (see "Alcoholism and } \\
\text { alcohol intoxication"); carbon monoxide } \\
\text { poisoning.* }\end{array}$ \\
\hline Heart & & $\begin{array}{l}\text { Ischemic heart disease;* patent oval } \\
\text { foramen. }\end{array}$ \\
\hline $\begin{array}{l}\text { Tracheobronchial tree } \\
\text { and lungs }\end{array}$ & $\begin{array}{l}\text { Examine lungs in situ. Save bronchial } \\
\text { washings for analysis of debris. } \\
\text { Fresh dissection is recommended. }\end{array}$ & $\begin{array}{l}\text { Foam, aspirated vomitus, or other } \\
\text { aspirated material in tracheobronchial } \\
\text { tree. Pulmonary lacerations, bullae, } \\
\text { and atelectases. Pulmonary edema and } \\
\text { hemorrhage. "Pulmonary squeeze" develops } \\
\text { during descent; nitrogen bubbles in pre- } \\
\text { capillary pulmonary arteries develop } \\
\text { during rapid ascent ("chokes"). }\end{array}$ \\
\hline Other organs & $\begin{array}{l}\text { Complete toxicologic sampling should be } \\
\text { carried out (p. 16). Record nature of gastric } \\
\text { contents. }\end{array}$ & \\
\hline Neck organs and tongue & $\begin{array}{l}\text { Remove neck organs toward end of autopsy. } \\
\text { For posterior neck dissection, see p. } 67 \text {. } \\
\text { Incise tongue. }\end{array}$ & $\begin{array}{l}\text { Interstitial emphysema. Aspiration (see above). } \\
\text { Trauma to cervical spine. } \\
\text { Mottled pallor of tongue after air embolism. } \\
\text { Contusion of tongue after convulsive } \\
\text { chewing. }\end{array}$ \\
\hline Spinal cord & $\begin{array}{l}\text { For removal and specimen preparation, } \\
\text { see p. } 67 .\end{array}$ & $\begin{array}{l}\text { Nitrogen bubbles in spinal cord arteries may } \\
\text { occur after rapid ascent. }\end{array}$ \\
\hline Bones and joints & $\begin{array}{l}\text { For removal, prosthetic repair, and specimen } \\
\text { preparation, see p. } 95 \text {. } \\
\text { Consult roentgenograms. }\end{array}$ & $\begin{array}{l}\text { Aseptic necroses (infarcts, "dysbaric } \\
\text { osteonecrosis"), most often in head of femur, } \\
\text { distal femur, and proximal tibia. Infarcts } \\
\text { indicate repeated hyperbaric exposures. } \\
\text { Nitrogen bubbles in and about joints and in } \\
\text { periosteal vessels ("bends") occur during } \\
\text { rapid ascent. }\end{array}$ \\
\hline
\end{tabular}

\section{References}

1. Gallagher TJ. Scuba diving accidents: decompression sickness, air embolism. J Florida Med Assoc 1997;84:446-451.

2. Blanksby BA, Wearne FK, Elliott BC, Blitvich JD. Aetiology and occurrence of diving injuries. A review of diving safety. Sports Med 1997;23:228-246.

3. Arness MK. Scuba decompression illness and diving fatalities in an overseas military community. Aviation Space Environm Med 1997; 68:325-333.

4. Hardy KR. Diving-related emergencies. Emerg Med Clin North Am 1997; 15:223-240.

\section{Accident, Vehicular}

Related Terms: Automobile accident; motorcycle accident.

NOTE: A visit to the scene can make the interpretation of the autopsy findings easier. The vehicle can also be inspected in a more leisurely fashion at the impound lot. This is particularly useful for correlating patterned injuries with objects in the vehicle. Most vehicular crashes occur as intersection crashes or because a vehicle with excessive speed left a curved road.

The medical examiner or coroner should gain a basic understanding of the crash mechanism so that informed descriptions can be rendered, e.g., "Impact to the B pillar of the decedent's automobile by the front of a pickup truck which failed to stop for a stop sign at an intersection, resulting in a 2-feet intrusion into the cabin; restraint belts not employed; air bag deployed; extrication required which took 15 minutes."

Police are responsible for determining mechanical and environmental risk factors for the crash and for determining some human risk factors such as suicidal or homicidal intent. The pathologist determines other risk factors for crashes such as heart disease, a history of epilepsy, and intoxication by carbon monoxide, drugs, and alcohol.

Suicide as a manner of death should be considered when a single-occupant vehicle strikes a bridge abutment or a large tree head-on, with no evidence of evasive action or braking. In such a situation, the standard police traffic investigation should be supplemented of interviews of the victim's family and friends.

The ambulance run sheet is an invaluable source of observations that often are not available from the police. This document should be acquired in all instances, even if the paramedics determined that death occurred and did not transport. 
The basic autopsy procedures are listed below. Most traffic victims who die at the scene or who are dead on arrival at the hospital died from neurogenic shock caused by wounds of the head or vertebral column, or from exsanguination from a torn vessel or heart. As such, they have little lividity, and little blood is found in the vehicles. Presence of intense lividity may indicate suffocation or heart disease as a cause of death.

If postural asphyxia is suspected, the first responders to the scene should be interviewed to determine the position of the decedent in the vehicle, and the vital signs, if any, of the decedent from the time of the crash to the time of extrication. Posterior neck dissection (p. 67) is indicated in these instances.

If manifestations of heart disease, intense lividity, and absence of lethal wounds suggest that a crash occurred because the driver was dead, other drivers on the road may have observed that the victim was slumped at the wheel before the crash. The determination of heart attack at the wheel is usually simple, because most such victims realize that something is wrong, and bring the vehicle to a stop at the side of the road, or coast gently into a fixed object. In such instances, damage to the vehicle is minor, and wounds to the decedent are usually trivial.

While patterned wounds can often be matched to objects (see below), patternless wounds usually cannot be visually matched to specific objects, although an opinion can sometimes be given as to what object was struck, based on the direction of motion and position of the body with respect to the vehicle. Impacts with the A-pillar produce narrow vertical zones of facial laceration and fractures extending from forehead to jaw. Tempered glass shatters into small cubes on impact, and leaves so-called "dicing" wounds, which are abraded cuts arranged in a somewhat rectilinear pattern. Windshield glass leaves shallow, abraded, vertically oriented cuts on the face or scalp.

With pedestrians, the lower extremities are of particular forensic interest, to determine the height and direction of impact from vehicles that left the scene. Scalp hair and blood should be collected from such "hit and run" victims and from occupants of a suspect car if police have a question as to which occupant was the driver; these exemplars can be compared to fibers and tissue recovered from the vehicle in question. Likewise, foreign material in wounds can sometimes be matched to suspect vehicles, and should be sought and retained as evidence. For pedestrians, the distance between the impact point on the lower extremities and the soles of the feet should be recorded. The legs should be opened to inspect tibial fractures; cortical fractures initiate propagation opposite to the side of impact, where they usually have a pulled-apart appearance, and then splinter the cortex at the side of impact. Abrasions are better impact markers than contusions, because subcutaneous blood extravasation can be caused not only by impact to the skin, but also from blood extravasating from underlying fractures. If no cutaneous abrasions or fractures of the leg bones are found, the skin of the legs should be incised to expose contusions.

Fracture descriptions should include location in the bone (e.g., proximal metaphysis or shaft), whether the fracture is complete or incomplete, and whether the fracture is displaced or distracted. Lacerations of intervertebral disks, facet joint capsules, and ligamenta flava should not be loosely termed "frac- tures." The presence or absence of blood extravasation in soft tissue adjacent to the fractures should be recorded, and its volume estimated if it appears severe enough.

Venous air embolism from torn dural sinuses cannot be diagnosed without a pre-autopsy chest radiograph or an in situ bubble test. If an X-ray machine is readily available, an anterior-posterior chest radiograph should be obtained in every traffic victim who dies at the scene or after a failed resuscitation attempt.

If a hemothorax is shown by the pleural window technique (p. 13), the rib cuts should be placed further lateral and the chest plate reflected so that the internal mammary vessels can be inspected before the chest plate is removed. After measuring and removing the bloody effusion, the underlying serosal surfaces should be inspected for defects. Lacerations of the heart and aorta will be obvious. Tamponaded lacerations of the aorta, around which the adventitia still holds, must be noted as such. If no lacerations are found at the usual sites, lacerations of the azygous veins must be considered, especially in association with fracture dislocations of the thoracic vertebral column; other sites are the internal mammary arteries, especially with fractures of ribs 1 and 2 or of the sternum, and intercostal arteries with displaced rib fractures. Only after the serosal defect is identified should the organs be removed, because that procedure creates many more holes in the serosa. For that reason, as much information as possible should be gained by in situ observation.

The only evidence of concussion of the heart may be a cardiac contusion or a sternal fracture. The usual clinical history suggests cardiovascular instability that is not associated with craniocerebral trauma and which does not respond to the infusion of intravenous volume agents.

The autopsy assistant may saw but should not retract the skull cap and remove the brain. The pathologist should observe in situ whether shallow lacerations of the pontomedullary junction with stretching of the midbrain are present; these lesions cannot be distinguished from artifact by examining the brain later. Thus, only after appropriate in situ inspection should the pathologist remove the brain.

A posterior neck dissection is required if no lethal craniocerebral or cardiovascular trauma can be found, or if suffocation is suspected; neck trauma must be ruled out to diagnose suffocation in a traffic fatality. Sudden death in a patient with seemingly trivial wounds may be caused by undiagnosed trauma of the craniocervical articulation. A posterior neck dissection (p. 67) is required in these instances.

The diagnosis of diffuse axonal injury of the brain in victims with no appreciable survival interval requires that suffocation was ruled out and that no resuscitaion from a cardiac arrest had been attempted. Clinicians are quick to apply the label "closed head injury" when a victim of a traffic crash has cerebral edema on a computerized axial tomogram of the head, even if no cerebral contusions, scalp contusions, or skull fractures are evident. This may be a misinterpretation, because cerebral edema can be caused by hypoxic encephalopathy made evident after resuscitation from a cardiac arrest, or by hypoxia caused by suffocation. 


\begin{tabular}{lll}
\hline Organs and Tissues & Procedures & Possible or Expected Findings
\end{tabular}

External examination $\quad$ Record presence of lividity.

Blood, urine, and vitreous

Chest cavities

Heart and great vessels

Abdomen

Skull and brain

Neck

Soft tissue compartments at any location
Photograph all external wounds; measure all lacerations.

Photograph and measure all patterned abrasions and patterned contusions.

Record cuts from windshield glass.

Determine impact injuries in pedestrians.

Collect scalp hair and blood (see below)

from victims of hit and run accidents.

Collect foreign material in wounds.

Prepare roentgenograms if venous air embolism is supected.

Collect sample for toxicologic study (p. 16)

from all victims, including passengers.

Create pleural window to detect pneumothorax.

If blood is seen, examine internal mammary

vessels (see under "Note"). Measure volume

of blood.

Record evidence of cardiac contusion.

Laceration of heart or great vessels

(measure volume of blood).

Follow routine procedures for dissection of heart and great vessels (see Chapter 3).

In situ bubble test may reveal venous air embolism.

Record evidence of trauma and volume of blood in peritoneal cavity; estimated volume of blood in retroperitoneal soft tissues.

Autopsy assistant may saw the skull but pathologist should inspect brain in situ and remove it personally. For removal and specimen preparation of brain, see p. 65 . Record brain weight.

Posterior neck dissection is indicated (p. 67) if there is no craniocerebral or cardio-vascular trauma, or if suffocation is suspected.
Intense lividity and absence of lethal wounds may indicate that the crash occurred because the driver was dead from heart disease.

Small, medium, or large patternless abrasions and contusions.

Patterned injuries often can be matched to objects in or about the vehicle.

Tempered glass injuries (see above under "Note").

Impact injuries in pedestrians may help to reconstruct the accident. Hair and blood of the victim may identify the vehicle involved in a hit and run accident.

Venous air embolism.*

Evidence of alcohol or drug intoxication.

Pneumothorax, hemothorax, e.g., after laceration of internal mammary vessels.

Cardiac contusion after concussion of the heart.

Evidence of exsanguination.

Evidence of coronary occlusion or other major cardiovascular disease that may have been the cause of the accident. Air embolism.*

Laceration of solid organs; rupture of hollow viscera or vessels, other evidence of trauma and hemorrhage into the abdominal cavity or soft tissues.

Cerebral lacerations at the pontomedullary junction. Cerebral edema.

Trauma to the craniocervical articulation.

\section{Achalasia, Esophageal}

Synonyms and Related Terms: Cardiospasm; diffuse esophageal spasm; primary symptomatic achalasia; secondary achalasia. Possible Associated Conditions: Chagas disease;* gastric malignancies; irradiation; lymphoma.*

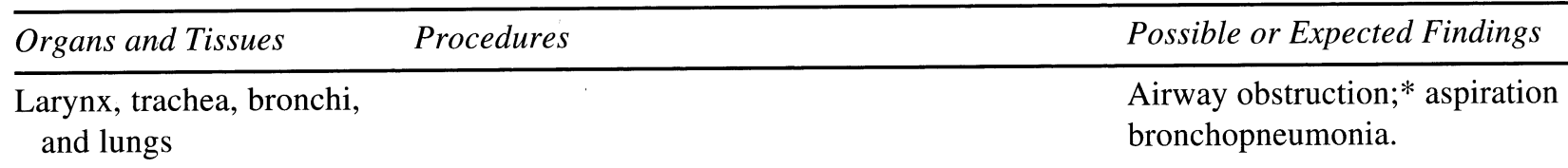




\begin{tabular}{lll}
\hline Organs and Tissues & Procedures & Possible or Expected Findings \\
\hline Esophagus & $\begin{array}{l}\text { Remove esophagus together with stomach. } \\
\text { Photograph esophagus and record diameter of } \\
\text { lumen at various levels. }\end{array}$ & $\begin{array}{l}\text { Segmental dilatation and hypertrophy of } \\
\text { esophagus. Accumulation of ingested food } \\
\text { and esophagitis. Squamous cell carcinoma is }\end{array}$ \\
& $\begin{array}{l}\text { Prepare histologic sections (cut on edge) of } \\
\text { narrow and dilated segments. }\end{array}$ & $\begin{array}{l}\text { Barrett's esophagus* with or without } \\
\text { adenocarcinoma may be found (2). }\end{array}$ \\
& $\begin{array}{l}\text { Request Bodian stains and Verhoeff-van Gieson } \\
\text { (p. 172). }\end{array}$ & $\begin{array}{l}\text { Loss of myenteric ganglion cells; partial } \\
\text { replacement of myenteric nerves. }\end{array}$ \\
\hline
\end{tabular}

\section{References}

1. Streitz JM Jr, Ellis FH Jr, Gibb SP, Heatley GM. Achalasia and squamous cell carcinoma of the esophagus: analysis of 241 patients. Ann Thorac Surg 1995;59:1604-1609.

2. Ellis FH Jr, Gibb SP, Balogh K, Schwaber JR. Esophageal achalasia and adenocarcinoma in Barrett's esophagus: a report of two cases and a review of the literature. Dis Esophagus 1997;10:55-60.

\section{Achondroplasia}

Synonyms: Chondrodystrophia fetalis; Parrot syndrome.

NOTE: The appropriate resource is the International Skeletal Dysplasia Registry

(Cedars-Sinai Medical Center, 444 S. San Vincente Blvd, Ste. 1001, Los Angeles, CA 90048. Phone \#310-855-7488).

\begin{tabular}{ll}
\hline Organs and Tissues & Procedures \\
\hline External examination & Record body length, head circumference, \\
& length of extremities, and abnormal features. \\
& Prepare skeletal roentgenograms. Photograph \\
& head, thorax, hands, and all abnormalities. \\
& Radiographs should be reviewed by a pediatric \\
& radiologist.
\end{tabular}

Base of skull and spinal canal; brain and spinal cord; pituitary gland

Bones
For removal and specimen preparation of brain and spinal cord, see pp. 65 and 67, respectively. For removal of pituitary gland, see p. 71.

Record appearance and photograph base of skull; record diameter of foramen magnum (1). Submit sections of spinal cord at sites of compression.

For removal, prosthetic repair, and specimen preparation, see p. 95.

Submit samples (especially of epiphyses) for histologic study. Snap-freeze tissue for molecular analysis.

\section{Possible or Expected Findings}

Dwarfism;* micromelia with pudgy fingers; frontal bossing; depressed nasal bridge.

Bowing of legs; kyphosis; short pelvis; broad iliac wings; horizontal acetabular roofs; narrowed vertebral interpedicular distance; shortened tubular bones of hands and feet; precocious ossification centers of epiphyses. Growth retardation of base of skull with compression of foramen magnum. Internal hydrocephalus.* Narrow spinal canal with compression of spinal cord (and clinical symptoms of paraplegia). Atrophy of pituitary gland.

Dorsolumbar kyphosis and lumbosacral lordosis; short iliac wings; short and thick tubular bones; excessive size of epiphysis in long bones; elongated costal cartilage.

Decreased cartilage cell proliferation at costochondral junction and at epiphyses of long bones.

\section{Reference}

1. Knisely AS, Singer DB. A technique for necropsy evaluation of stenosis of the foramen magnum and rostral spinal canal in osteochondrodysplasia. Hum Pathol 1988;19:1372-1375.

\section{Acidosis}

NOTE: Acidosis cannot be diagnosed from postmortem blood $\mathrm{pH}$ values. Ketone values remain fairly constant in blood and vitreous and may thus support the diagnosis-for instance, of diabetic acidosis. See also under "Disorder, electrolyte(s)" and p. 115.

\section{Acromegaly}

Synonyms and Related Terms: Familial acromegaly; hyperpituitary gigantism.

Possible Associated Condition: Multiple endocrine neoplasia 1 (MEN 1)* (1). See also below under "Other organs." 


\begin{tabular}{lll}
\hline Organs and Tissues & Procedures & Possible or Expected Findings
\end{tabular}

External examination, Record body length and weight, length of skin and subcutaneous extremities, and abnormal features. tissue

Breast

Blood

Other organs

Pituitary gland

Skeletal muscles

Bones and joints
Prepare sections of skin and subcutaneous tissue.

Prepare skeletal roentgenograms, including skull.

Incise and prepare sections.

Submit sample for calcium analysis and radioimmunoassay of plasma growth hormone. Record organ sizes and weights.

Sample all endocrine glands for histologic study. See also below under "Pituitary gland."

Other procedures depend on expected findings or grossly identified abnormalities as listed in right-hand column.

For in situ cerebral arteriography, see p. 80. For removal of pituitary gland, see p. 71. Weigh and photograph gland (include scale). Snap-freeze tumor tissue for histochemical study and hormone assay. For preparation for electron microscopic study, see p. 132.

For sampling and specimen preparation, see p. 80.

For removal, prosthetic repair, and specimen preparation, see p. 95 .
Gigantism in younger persons; coarse facial features with prominent eyebrows and prognathism; maloccluded, wide-spaced teeth. Large, furrowed tongue with tooth marks. Parotid enlargement. Narrow ear canal.

Increased subcutaneous tissue; thickened skin; hypertrichosis; acanthosis nigricans. Osteoporosis;* kyphosis. See also below under "Bones and joints." Lactating breast tissue.

Hypercalcemia in MEN 1 syndrome. Growth hormone excess.

Splanchnomegaly, involving heart ("acromegalic heart disease"), liver, spleen, intestine, kidneys, and prostate.

Endocrine organs may be enlarged (diffuse or nodular goiter; adrenal cortical hyperplasia; enlarged gonads; and parathyroid hyperplasia or adenoma). Pulmonary infections. Nephrolithiasis.* Manifestations of congestive heart failure, ${ }^{*}$ diabetes mellitus, ${ }^{*}$ hyperparathyroidism, ${ }^{*}$ hypertension, ${ }^{*}$ and pituitary insufficiency.* Tumors of breast, colon, thyroid gland, and other organs $(1-4)$. Usually, pituitary adenoma with predominantly eosinophilic or with mixed eosinophilic-chromophobe cells. Enlargement or destruction of pituitary fossa. Tumor growth (see also "Tumor, pituitary") or hemorrhage may be the cause of death. Tumors may be ectopic (sphenoid sinus or parapharyngeal).

Proximal myopathy.

Overgrowth of facial bones and enlarged sinuses (best seen in roentgenogram); thickening of long bones and of clavicles. Periosteal growth of metacarpal and metatarsal bones. Osteoporosis* (primarily of spine). Hypertrophy of costal cartilages. Acromegalic arthritis.

\section{References}

1. The BT, Kytola S, Farnebo F, Bergman L, Wong FK, Weber G, et al. Mutation analysis of the MEN 1 gene in multiple endocrine neoplasia type 1 , familial acromegaly and familial isolated hyperparathyroidism. J Clin Endocrinol Metabol 1998;83:2621-2626.

2. Melmed S. Acromegaly. N Engl J Med 1990;322:966-971.

3. Cheung NW, Boyages SC. Increased incidence of neoplasia in females with acromegaly. Clin Endocrinol 1997;47:323-327.

4. Barzilay J, Heatley GJ, Cushing GW. Benign and malignant tumors in patients with acromegaly. Arch Intern Med 1991;151:1629-1632.

\section{Actinomycosis}

Synonym: Actinomyces infection.

NOTE: (1) Collect all tissues that appear to be infected. (2) Request anaerobic cultures for Actinomyces. (3) Request Gram stain (p. 172). (4) No special precautions are indicated. (5) Serologic studies are not reliable at present. (6) This is not a reportable disease. 


\begin{tabular}{|c|c|c|}
\hline Organs and Tissues & Procedures & Possible or Expected Findings \\
\hline \multirow[t]{2}{*}{ External examination } & $\begin{array}{l}\text { Prepare roentgenograms (p. 117) and } \\
\text { photographs of fistulas. }\end{array}$ & $\begin{array}{l}\text { Fistulas to skin of face, neck, and other sites. } \\
\text { Periostitis or osteomyelitis of mandible. } \\
\text { Extension of fistulas into orbits or paranasal } \\
\text { sinuses. Mixed infections (microaerophilic } \\
\text { streptococci, Bacteroides spp.). }\end{array}$ \\
\hline & $\begin{array}{l}\text { Submit samples of infected tissue for histologic } \\
\text { study. For culturing fistules, see p. } 104 \text {. }\end{array}$ & $\begin{array}{l}\text { Suppurative fibrosing reaction with "sulfur } \\
\text { granules" or gram-positive filaments of } \\
\text { bacteria. }\end{array}$ \\
\hline Chest organs & $\begin{array}{l}\text { Submit samples of infected tissue for } \\
\text { histologic study. }\end{array}$ & $\begin{array}{l}\text { Chronic cavitary pneumonia; empyema; } \\
\text { fistulas through chest wall, pericardium, or } \\
\text { diaphragm or into thoracic vertebrae. }\end{array}$ \\
\hline Gastrointestinal tract & $\begin{array}{l}\text { Submit samples of infected tissue for histologic } \\
\text { study. For proper tracing of fistulas, in situ } \\
\text { dissection is recommended. }\end{array}$ & $\begin{array}{l}\text { Inflammatory masses. Fistulas through } \\
\text { abdominal wall, to kidneys or pelvic organs } \\
\text { (rare), or ileocecal and anorectal fistulas. }\end{array}$ \\
\hline Other organs & $\begin{array}{l}\text { Procedures depend on expected findings or } \\
\text { grossly identified abnormalities as listed in } \\
\text { right-hand column. }\end{array}$ & $\begin{array}{l}\text { Rare manifestations include cerebral, renal, } \\
\text { or hepatic abscess, abscesses in other organs } \\
\text { or tissues, endocarditis,* or periostitis and } \\
\text { osteomyelitis* with fistulas to skin. }\end{array}$ \\
\hline
\end{tabular}

Addiction (See "Abuse, hallucinogen(s)," "Abuse, marihuana," "Dependence,..." and "Poisoning,..."

See also "Alcoholism and alcohol intoxication.")

Adenoma (See "Neoplasia, multiple endocrine" and "Tumor...")

Adenomatosis, Multiple Endocrine (See "Neoplasia, multiple endocrine.")

Afibrinogenemia (See "Dysfibrinogenemia.")

Agammaglobulinemia (See "Syndrome, primary immunodeficiency.")

Agenesis, Renal

Synonym: Renal aplasia.

\begin{tabular}{lll}
\hline Organs and Tissues & Procedures & Possible and Expected Findings
\end{tabular}

External examination Photograph infant. Record anomalies.

Lungs

Weigh lungs; calculate ratio of lung weight to body weight. (For expected weights, see Part III.)

Abdominal cavity

Placenta

Agranulocytosis (See "Pancytopenia")

AIDS (See "Syndrome, acquired immunodeficiency.")

Alcohol, Ethyl (Ethanol) (See "Alcoholism and alcohol intoxication.")

Alcohol, Isopropyl (See "Poisoning, isopropyl alcohol.")

Alcohol, Methyl (See "Poisoning, methanol (methyl alcohol).")

Alcohol, Rubbing or Wood (See "Poisoning, isopropyl alcohol.”)
Evidence of oligohydramnios: flattened nose; prominent palpebral folds; flattened low set ears; flattened hands; recessed chin; joint contractures.

Pulmonary hypoplasia. Normal LW/BW ratio is greater than 0.015 , less than $28 \mathrm{wk}$ gestation and 0.012 , older than $28 \mathrm{wk}$ gestation.

Absence of kidneys and associated malformations (see middle column).

Amnion nodosum. 


\section{Alcoholism and Alcohol Intoxication}

Synonyms and Related Terms: Alcoholic cirrhosis; alcoholic liver disease; ${ }^{*}$ ethanol intoxication; ethyl alcohol intoxication; fetal alcoholic syndrome;* Wernicke-Korsakoff syndrome.*

NOTE: Interpretation of alcohol concentrations can be problematic if body has been embalmed or is putrefied.

\begin{tabular}{|c|c|c|}
\hline Organs and Tissues & Procedures & Possible or Expected Findings \\
\hline External examination & & $\begin{array}{l}\text { Malnutrition; signs of exposure, injuries, } \\
\text { needle marks. }\end{array}$ \\
\hline $\begin{array}{l}\text { Blood from femoral, } \\
\text { subclavian, or brachial } \\
\text { veins }\end{array}$ & $\begin{array}{l}\text { Use heart blood only if peripheral blood is } \\
\text { unavailable. In this instance, massage heart gently } \\
\text { for good mixing. If the blood is not analyzed } \\
\text { immediately, add sodium fluoride ( } 10 \mathrm{mg} / \mathrm{mL} \text { of } \\
\text { blood). Fill container to just under the lid so that } \\
\text { evaporation remains minimal. Shake thoroughly. } \\
\text { Record time of sampling and refrigerate. Request } \\
\text { determination of alcohol concentration and drug } \\
\text { screen and carbon monoxide determination. }\end{array}$ & $\begin{array}{l}\text { See below under "Can Postmortem Changes } \\
\text { and Specimen Storage Affect Blood Alcohol } \\
\text { (Ethanol) Concentrations?" }\end{array}$ \\
\hline Hematoma & $\begin{array}{l}\text { If there are subdural or other hematomas, submit } \\
\text { blood for alcohol determination. }\end{array}$ & $\begin{array}{l}\text { Hematoma may show alcohol concentration } \\
\text { at time of injury (1). }\end{array}$ \\
\hline Vitreous & $\begin{array}{l}\text { Submit (pp. } 16 \text { and } 85 \text { ) for alcohol determination, } \\
\text { particularly if blood is not available. Process } \\
\text { like blood. Request determination of potassium, } \\
\text { sodium, and chloride concentrations. }\end{array}$ & $\begin{array}{l}\text { See below under "Interpretation of } \\
\text { Laboratory Reports" and p. } 113 .\end{array}$ \\
\hline Cerebrospinal fluid & $\begin{array}{l}\text { Submit with or instead of vitreous (p. 104). } \\
\text { (Vitreous is probably preferable.) }\end{array}$ & \\
\hline Urine & $\begin{array}{l}\text { Submit for alcohol determination (p. 16). } \\
\text { Process like blood. Record volume. }\end{array}$ & $\begin{array}{l}\text { See below, "How Can One Estimate Blood } \\
\text { Alcohol (Ethanol) Concentrations From } \\
\text { Vitreous, Urine, or Tissue Alcohol Levels and } \\
\text { From Alcohol in Stomach Contents? }\end{array}$ \\
\hline Stomach & $\begin{array}{l}\text { Record character and volume of contents. } \\
\text { Submit samples for histologic study. }\end{array}$ & Gastritis. See also note above under "Urine." \\
\hline Bile & Store for possible drug screen. & \\
\hline Heart & Record weight. Submit samples for histologic study. & Alcoholic cardiomyopathy.* \\
\hline Lungs & Submit for microbiologic study (p. 103). & $\begin{array}{l}\text { Aspiration of vomitus. Lobar pneumonia. } \\
\text { Tuberculosis.* }\end{array}$ \\
\hline Liver & $\begin{array}{l}\text { Record weight and submit samples for histo- } \\
\text { logic study. }\end{array}$ & Alcoholic liver disease.* \\
\hline Pancreas & & Acute or chronic pancreatitis.* \\
\hline Brain & $\begin{array}{l}\text { For removal, see p. } 65 . \text { Submit for determina- } \\
\text { tion of alcohol concentration (p. 16). } \\
\text { Submit samples for histologic study (p. 79). }\end{array}$ & $\begin{array}{l}\text { See below under "Interpretation of } \\
\text { Laboratory Reports." } \\
\text { Cerebellar cortical degeneration;* } \\
\text { Marchiafava-Bignami disease;* Wernicke- } \\
\text { Korsakoff syndrome.* }\end{array}$ \\
\hline $\begin{array}{l}\text { Peripheral nerves and } \\
\text { skeletal muscles }\end{array}$ & $\begin{array}{l}\text { For sampling and specimen preparation, } \\
\text { see p. } 79 .\end{array}$ & $\begin{array}{l}\text { Alcoholic neuropathy or alcoholic myopathy } \\
\text { (or both). }\end{array}$ \\
\hline Bones & & Osteonecrosis* ("aseptic necrosis of bone"). \\
\hline
\end{tabular}

\section{INTERPRETATION OF LABORATORY REPORTS IN ALCOHOL INTOXICATION}

\section{How Are Alcohol (Ethanol) \\ Concentrations in Body Fluids Expressed?}

In European countries, the concentration is expressed in promille (grams per liter). In the United States, it has become customary to refer to concentration by percentage (grams per deciliter), and values in these units have been written into legislation and included in the uniform vehicle codes. Unless qualified, the use of promille or percentage does not indicate whether the result of the analysis is weight/weight, weight/ volume, or volume/volume. Another common way of expressing concentration, milligrams per deciliter, has also been used to indicate alcohol concentrations. The method of expressing concentration must be clearly specified whenever the alcohol level is mentioned. The desired expression can be derived from the toxicologic report by using the following equation:

$1,000 \mu \mathrm{g} / \mathrm{mL}=100 \mathrm{mg} / \mathrm{dL}=21.74 \mathrm{mmol} / \mathrm{L}=1.0$ promille $=0.10 \%$ 


\section{What Are the Effects of Alcohol (Ethanol) Intoxication? Physiologic Effects:*}

\author{
Blood-Alcohol \\ Concentration $\mathrm{g} / 100 \mathrm{~mL}$
}

$0.01-0.05$

$0.03-0.12$

Euphoria

$0.09-0.25$

Excitement

$0.18-0.30$

Confusion

$0.25-0.40$

Stupor

$0.35-0.50$

Coma

$0.45+$

Death
Clinical Signs/Symptoms

No apparent influence. Behavior nearly normal by ordinary observation.

Slight changes detectable by special tests.

Decreased inhibitions. Increased self-confidence.

Diminution of attention, judgment, and control.

Beginning of sensory-motor impairment.

Slowed information processing. Loss of efficiency in

finer performance tests.

Emotional instability; loss of critical judgement.

Impairment of perception, memory, and comprehension.

Decreased sensory response; increased reaction time.

Reduced visual acuity, peripheral vision, and glare

recovery. Sensory-motor incoordination; impaired balance.

Drowsiness.

Disorientation, mental confusion; dizziness. Exaggerated emotional states (e.g., fear, rage, sorrow). Disturbances of vision (e.g., diplopia) and of perception of color, form, motions, dimensions. Increased pain threshold. Increased muscular incoordination; staggering gait; slurred speech. Apathy; lethargy.

General inertia; approaching loss of motor function.

Markedly decreased response to stimuli. Marked muscular incoordination; inability to stand or walk. Vomiting;

incontinence of urine and feces. Impaired consciousness; sleep or stupor.

Complete unconsciousness; coma; anesthesia. Depressed or abolished reflexes. Subnormal temperature.

Incontinence of urine and feces. Impairment of circulation and respiration. Possible death.

Death from respiratory arrest.

*Reprinted by permission from KM Dubowsky. Copyright 1987, (2).

\section{Biochemical effects:}

Hyponatremia and hypochloremia are common in the chronic alcoholic (3). Hyperlipidemia also may be found.

\section{What is the Legal Interpretation of Alcohol (Ethanol) Intoxication?}

Objective impairment of driving ability is observed at threshold blood alcohol concentrations of $35-40 \mathrm{mg} / \mathrm{dL}$. However, values less than $50 \mathrm{mg} / \mathrm{dL}$ are considered evidence of "not under the influence" by courts in most states. Values greater than $150 \mathrm{mg} / \mathrm{dL}$ are prima facie evidence of "under the influence"; most persons are obviously intoxicated in this range. In 1971 the National Safety Council Committee of Alcohol and Drugs released the following statement: "The National Safety Council Committee on Alcohol and Drugs takes the position that a concentration of 80 milligrams of ethanol per 100 milliliters of whole blood $(0.08 \% \mathrm{w} / \mathrm{v})$ in any driver of a motor vehicle is indicative of impairment in his driving performance."

\section{Can Postmortem Changes and Specimen}

Storage Affect Blood Alcohol (Ethanol) Concentrations?

Blood alcohol concentrations obtained at autopsy are valid until putrefaction begins. This may vary from several hours to a few days, depending on the environment. Sodium fluoride in a concentration of $10 \mathrm{mg} / \mathrm{mL}$ of blood should be added to the sample, and the specimen should be stored in the refrigerator. If the blood is analyzed soon after withdrawal or if the blood is kept in the refrigerator, results are usually reliable even if no sodium fluoride has been added. If the air space above the blood samples in the container is large, alcohol can evaporate and a falsely low blood alcohol level can result. Putrefactive changes before autopsy or during storage may cause a falsely high blood alcohol concentration. Ethanol can be produced in the specimen container; this is more like in the absence of a preservative. Because fluoride inhibits bacteria far more than fungi, higher fluoride concentrations are required for the inhibition of fungal growth (4). 
Can the Sites Where Blood Was Withdrawn

Affect Alcohol (Ethanol) Concentrations?

Although there is no major difference in the alcohol concentrations of blood samples from the intact heart chambers and the femoral vessels (5), autopsy samples from pooled blood in the pericardial sac or pleural cavity are unsatisfactory. We therefore recommend that blood be withdrawn from peripheral vessels.

\section{Is There Normal "Endogenous" \\ Blood Alcohol (Ethanol) in a Living Person?}

Blood alcohol concentrations are generally believed to be negligible in the absence of ingested alcohol. "Endogenous" ethanol in human blood exists at a concentration of about $0.0002 \mathrm{~g} / \mathrm{dL}$, which is below the limit of detection for most methods (6).

\section{Which Conditions or Factors May Lower the Tolerance to Alcohol (Ethanol) So That Death May Occur at Levels That Are Not Usually Fatal?}

First in such a list would be postural asphyxia, for example, in drunks who fall asleep face down. Also, depressant drugs in the tricyclic, analgesic, barbiturate, and benzodiazepine classes all potentiate the effect of alcohol (7). Also included in such a list would be infancy and childhood; ischemic heart disease;* chronic bronchitis and emphysema;* other chronic debilitating diseases; poisoning with carbon tetrachloride* or carbon monoxide;* and other causes of hypoxia.*

\section{How Can One Estimate Blood Alcohol (Ethanol)} Concentrations From Vitreous, Urine, or Tissue Alcohol Levels and From Alcohol in Stomach Contents?

The ratio of serum, plasma, urine, vitreous, and various tissues has been compiled by Garriot (8). The values may vary considerably. For vitreous, the ratios varied from 0.46-1.40. These variations may depend on whether blood alcohol concentrations were increasing or decreasing at the time of death. Most other body fluids and tissues showed ranges closer to 1 . Most urine values were above the blood alcohol concentrations. In another study (9), the blood/vitreous (B/V) ratio in the early absorption phase was 1.29 (range, 0.71-3.71; SD 0.57) and in the late absorption and elimination phase, the $\mathrm{B} / \mathrm{V}$ ratio was 0.89 (range, 0.32-1.28; SD 0.19). Blood ethanol concentrations probably can be estimated using $\mathrm{B}=1.29 \mathrm{~V}$ for early absorption and $\mathrm{B}=0.89 \mathrm{~V}$ for later phases. A urine/blood ethanol ratio of 1.20 or less indicates that the diceased was in the early absorption phase.

\section{How Can One Use Alcohol (Ethanol) Concentrations in Postmortem Specimens To Estimate the Blood Alcohol Concentration at Various Times Before Death?}

With certain limitations, one can base calculations of this kind on the assumption that the blood alcohol level decreases from its peak at a fairly constant rate of $0.015-0.018 / \mathrm{h}$ until death (10). If blood is not available, conversion factors (see above) must be used. Alcoholics have been reported to metabolize at a rate of up to $0.043 \% / \mathrm{h}(6)$.

Example: The driver of an automobile had been drinking at a party until midnight. He had left his host at about 1:30 a.m. and was involved in a head-on collision at 2:15 a.m. He died in the emergency room of the hospital at 6:35 a.m. There were multiple injuries and the patient had exsanguinated. The autopsy was done at 1:30 p.m. Although this appears quite unlikely, let us assume that no satisfactory blood sample was obtained and that no blood or plasma expanders were given. If under such circumstances the alcohol concentration in the vitreous was found to be $157 \mathrm{mg} / \mathrm{dL}$, what was the alcohol concentration in the blood at the time of the accident?

Vitreous and blood alcohol concentrations may be assumed to have remained unchanged after death. Therefore, the blood alcohol level at the time of death must have been approx 157 (vitreous humor alcohol) $\times 0.89$ (conversion factor, see above) $=140 \mathrm{mg} / \mathrm{dl}$. The time interval between the accident (2:15 a.m.) and death (6:35 a.m.) was $4 \mathrm{~h}$ and $20 \mathrm{~min}$ or $41 / 3 \mathrm{~h}$. If we assume that the decedent was not an alcoholic and that the blood alcohol concentration was decreasing from its peak at a constant rate of $15 \mathrm{mg} / \mathrm{dL} / \mathrm{h}$, then the concentration at the time of the accident is estimated to have been 140 (concentration at time of death) $+(41 / 3 \times 15)=140+65=205 \mathrm{mg} / \mathrm{dL}$ or $0.2 \%$.

The blood alcohol concentration at the time of the accident could have been lower if the victim stopped drinking later than $1 \mathrm{~h}$ or $11 / 2 \mathrm{~h}$ before the accident. In the latter case, the peak alcohol level would have occurred after the accident, reflecting the time to absorb the latest drink.

The blood alcohol concentration at the time of the accident could have been lower or higher if the time when the patient stopped drinking, the time of the accident, or the time of the death is uncertain.

The blood alcohol concentration at the time of the accident could have been higher if the victim was a chronic alcoholic (based on the history or the presence of alcoholic hepatitis or alcoholic cirrhosis). The elimination rate in such persons may be as high as $40 \mathrm{mg} / \mathrm{dL}$, which would change the figures in our example above to $140+(41 / 3 \times 40)=140+173=313 \mathrm{mg} / \mathrm{dl}$ or $0.3 \%$.

\section{How Can One Use Alcohol (Ethanol) Concentrations in Postmortem Specimens To Estimate How Much the Victim Had Been Drinking?}

Only rough estimates are possible. First, the peak blood alcohol level must be determined or calculated, as described in the previous paragraphs. Tables (see below) are available that relate blood alcohol level to the minimal amounts of whiskey, wine, or beer that must have been consumed (10). However, tables of this type are often based on the minimum amount of alcohol circulating in the body after specific numbers of drinks; such tables do not yield reliable results if used conversely. Furthermore, inasmuch as drinking and elimination of alcohol may take place concomitantly, over a longer period the total amount of alcohol consumed may have been much greater than the tables would indicate. It cannot be lower. According to these tables, 6 pints of ordinary beer or $8 \mathrm{fl} \mathrm{oz}$ of whiskey would be the minimal amounts needed to produce a blood alcohol level of about $200 \mathrm{mg} / \mathrm{dL}$ in a person weighing $140-180$ pounds. The total body alcohol can be calculated from the blood alcohol level by using Widmark's formula:

Average concentration of alcohol in entire body $=.68$

Concentration of alcohol in the blood 
In a person weighing $70 \mathrm{~kg}$, the blood alcohol concentration would be increased $50 \mathrm{mg} / \mathrm{dL}(0.05 \%)$ by the absorption of 1 oz of ethanol ( $2 \mathrm{oz}$ of 100-proof whiskey).

\section{What Is the Alcohol}

\section{(Ethanol) Content of Various Beverages?}

Strength of alcohol is measured in "proof"; absolute alcohol is 200 proof. Therefore, in the United States, alcohol content as volume percent is half the proof (for example, 100-proof whiskey contains $50 \%$ alcohol by volume). The alcohol content of various beverages is shown in the following table.

\begin{tabular}{lc} 
Approximate Alcohol Content in Various Beverages & ${ }^{\dagger}$ \\
\hline Beverage & Ethanol Content in $\%$ \\
\hline Whiskey and gin & 40 \\
Brandy & $45.5-48.5$ \\
Sherry and port wines & $16-20$ \\
Liqueurs & $34-59$ \\
Rum & $50-69.5$ \\
Beers (Lager) & $2-6$ \\
Light wines & $10-15$ \\
\hline
\end{tabular}

${ }^{\dagger}$ Data from Glaister, Rentoul E. Medical Jurisprudence and Toxicology, 12th ed. E \& S Livingstone, Edinburgh, 1966 with permission.

What Blood Alcohol (Ethanol) Concentrations Can Be Predicted From a Known Amount and Type of Alcoholic Beverage?

\section{Number of Drinks}

\section{and Predicted Blood Alcohol Concentrations ${ }^{\dagger}$}

\begin{tabular}{lc}
\hline Drinks $(\text { no. })^{\ddagger}$ & $\begin{array}{c}\text { Predicted } \\
\text { Blood Alcohol Level } \\
(\mathrm{mg} / \mathrm{dL})\end{array}$ \\
\hline 1 & $10-30$ \\
2 & $30-50$ \\
3 & $50-80$ \\
4 & $80-100$ \\
5 & $100-130$ \\
6 & $130-160$ \\
8 & $160-200$ \\
10 & $190-230$ \\
12 & $250-320$ \\
\hline
\end{tabular}

†Within $1 \mathrm{~h}$ after consumption of diluted alcohol (approx 15\%) on an empty stomach, assuming body weight of $140-180$ pounds $(63.6-81.7 \mathrm{~kg})$ reproduced from (11) with permission.

$\ddagger$ One ounce (about $30 \mathrm{~mL}$ ) of whiskey or $12 \mathrm{oz}$ (about $355 \mathrm{~mL}$ ) of beer.

\section{What Is the Toxicity of Alcohol Other Than Ethanol?}

In general, the toxicity increases as the number of carbon atoms in the alcohol increases. Thus, butyl alcohol is two times as toxic as ethyl alcohol,* but isopropyl alcohol is only twothirds as toxic as isobutyl alcohol and one-half as toxic as amyl alcohol. Primary alcohols are more toxic than the corresponding secondary isomers $(10)$.

\section{References}

1. Hirsch CS, Adelson L. Ethanol in sequestered hematomas. Am J Clin Pathol 1973;59:429-433.

2. Dubowsky KM. Stages of acute alcoholic influence/intoxication. In: Medicolegal Aspects of Alcohol. Garriott JC, ed. Lawyers \& Judges Publishing Co., Phoenix AZ, 1997, p. 40.

3. Sturner WQ, Coe JI. Electrolyte imbalance in alcoholic liver disease. J Forensic Sci 1973;18:344-350.

4. Harper DR, Corry JEL. Collection and storage of specimens for alcohol analysis. In: Medicolegal Aspects of Alcohol. Garriott JC, ed. Lawyers \& Judges Publishing Co., Phoenix, AZ, 1997, pp. 145169.

5. Garriott JC. Analysis for alcohol in postmortem specimens. In: Medicolegal Aspects of Alcohol. Garriott JC, ed. Lawyers \& Judges Publishing Co., Phoenix, AZ, 1997, pp. 87-100.

6. Baselt RC, Danhof IE. Disposition of alcohol in man. In: Medicolegal Aspects of Alcohol. Garriott JC, ed. Lawyers \& Judges Publishing Co., Tuscon, AZ, 1993, pp. 55-74.

7. Garriott JC. Pharmacology of ethyl alcohol. In: Medicolegal Aspects of Alcohol. Garriott JC, ed. Lawyers \& Judges Publishing Co., Phoenix, AZ, 1997, pp. 36-54.

8. Caplan YH. Blood, urine and other tissue specimens for alcohol analysis. In: Medicolegal Aspects of Alcohol. Garriott JC, ed. Lawyers \& Judges Publishing Co., Phoenix, AZ, 1997, pp. 74-86.

9. Chao TC, Lo DS. Relationship between postmortem blood and vitreous humor ethanol levels. Am J Forens Med Pathol 1993;14:303308.

10. Larson CP. Alcohol: fact and fallacy. In: Legal Medicine Annual 1969. Wecht CH, ed. Appleton-Century-Crofts, New York, 1969, pp. 241-268.

11. Camps FE. Gradwohl's Legal Medicine, 2nd ed. Williams \& Wilkins Company, Baltimore, MD, 1968, p. 554.

\section{Aldosteronism}

Synonyms and Related Terms: Bartter's syndrome; Conn's syndrome; hyperaldosteronism; idiopathic aldosteronism; primary aldosteronism; secondary aldosteronism.

\begin{tabular}{lll}
\hline Organs and Tissues & Procedures & Possible or Expected Findings
\end{tabular}

External examination $\quad$ Record presence or absence of edema.

Vitreous

Heart Adrenals (pp. 16 and 33).
Submit for sodium and potassium determination

Weigh heart and measure thickness of ventricles. Dissect, weigh, and photograph both adrenal glands.

Place portion (including tumor, if present) of gland in deep freeze for hormone assay.

Submit samples for light and electron microscopic (p. 132) study.
Edema of lower extremities (absent in most uncomplicated cases).

Changes reflecting high sodium and low potassium concentrations in the blood. Prominent left ventricular hypertrophy (1). Aldosterone-secreting adrenal cortical adenoma (Conn's syndrome), adrenal cortical nodular hyperplasia, or, rarely, adrenal carcinoma. Primary aldosteronism may be present in all these instances. Idiopathic aldosteronism is characterized by normal adrenal glands. 


\begin{tabular}{lll}
\hline Organs and Tissues & Procedures & Possible or Expected Findings \\
\hline Kidneys & $\begin{array}{l}\text { Weigh, measure, photograph. Submit samples } \\
\text { for histologic and electron microscopic (p. 132) } \\
\text { study. If there is a renal tumor, place portion in } \\
\text { a deep freeze for hormone assay. }\end{array}$ & $\begin{array}{l}\text { Vacuolar (osmotic) nephropathy due to } \\
\text { hypokalemia. Various renal diseases may be } \\
\text { associated with secondary hyperaldosteronism; } \\
\text { features of juxtaglomerular cell hyperplasia } \\
\text { may be present. }\end{array}$ \\
Other organs & $\begin{array}{l}\text { Procedures in secondary aldosteronism depend } \\
\text { on expected cause. }\end{array}$ & $\begin{array}{l}\text { Manifestations of hypertension.* Cirrhosis,* } \\
\text { nephrotic syndrome, toxemia of } \\
\text { pregnancy, }{ }^{*} \text { and many other conditions that } \\
\text { may be associated with secondary } \\
\text { aldosteronism. }\end{array}$ \\
Brain & $\begin{array}{l}\text { Ruptured intracranial aneurysm* and } \\
\text { hemorrhagic stroke (2). }\end{array}$ \\
\hline
\end{tabular}

\section{References}

1. Tanabe A, Naruse M, Naruse K, Hase M, Yoshimoto T, Tanaka M, et al. Left ventricular hypertrophy is more prominent in patients with primary aldosteronism than in patients with other types of secondary hypertension. Hypertension Res 1997;20:85-90.

2. Litchfield WR, Anderson BF, Weiss RJ, Lifton RP, Dluhy RG. Intracranial aneurysm and hemorrhagic stroke in glucocorticoid-remediable aldosteronism. Hypertension 1998;31:445-450.
Alkalosis

NOTE: There are no diagnostic findings. Postmortem chemical analysis is of limited value in these instances. See also under "Disorder, electrolyte(s)" and p. 115.

\section{Alkaptonuria \\ Synonyms and Related Terms: Alkaptonuric ochronosis (1); familial (hereditary) ochronosis (2).}

Organs and Tissues Procedures Possible or Expected Findings

External examination and skin

Urine

Heart and large arteries

Larynx and trachea

Kidneys and prostate

Other organs and tissues

Middle ears

Eyes

Bones and joints
Record extent of discoloration of skin and eyes. Photograph these features. Prepare histologic sections of pigmented areas.

Record appearance of joint deformities. Prepare skeletal roentgenograms.

Submit sample for biochemical study. Prepare histologic sections of pigmented areas. If electron microscopic study is intended, see p. 132.

Prepare histologic sections of pigmented cartilage.

Submit samples for histologic study.

Submit samples for histologic study.

For removal and specimen preparation, see p. 72.

For removal and specimen preparation, see p. 85 .

For removal, prosthetic repair, and specimen preparation, see p. 95. Submit samples of cartilage of diarthrodial joints and from adjacent tendons for histologic study. Prepare frontal section through spine.
Brown-black pigment in skin, eyes (conjunctivas, corneas, scleras), and external ears. Pigment in dermal sweat glands.

Deformities of knees and other joints.

Ochronotic arthropathy, particularly of knee joints; spondylosis and disk calcification with fusion of vertebrae.

Hemogentisic aciduria.

Pigmentation of heart valves (e.g., with stenosis [2]), endocardium, and intima of large arteries.

Pigmentation of laryngotracheal cartilage.

Nephrolithiasis;* prostatitis; ochronotic pigmentation.

Pigmentation in islets of Langerhans, pituitary gland, and other endocrine organs; pigment in reticuloendothelial system.

Pigmentation of tympanic membranes and ossicles of middle ears.

See under "External examination and skin."

Ochronotic arthropathy (see above under "External examination and skin"). Fragments of pigmented cartilage may be found in the synovia. 


\section{References}

1. Gaines JJ Jr. The pathology of alkaptonuric ochronosis. Hum Pathol 1989;20:40-46.

2. Cortina R, Moris C, Astudillo A, Gosalbez F, Cortina A. Familial ochronosis. Eur Heart J 1995;16:285-286.

\section{Aluminosis (See "Pneumoconiosis.")}

Alveolitis, Extrinsic Allergic (See "Pneumoconiosis" and "Pneumonia, interstitial.")

Amaurosis Fugax

\begin{tabular}{lll}
\hline Organs and Tissues & Procedures & Possible or Expected Findings \\
\hline Eyes & For removal and specimen preparation, see p. 85. & Papilledema. \\
Brain & For removal and specimen preparation, see p. 65. & Tumor of the brain or other cause of \\
& Other procedures depend on expected findings or & intracranial hypertension, including benign \\
& grossly identified abnormalities as listed in right- & intracranial hypertension (pseudotumor \\
& hand column. & cerebri*). \\
\hline
\end{tabular}

\section{Amblyopia, Nutritional}

Related Terms: Alcohol amblyopia; retrobulbar neuropathy; tobacco amblyopia.

NOTE: If chronic malnutrition is associated with corneal degeneration, glossitis, stomatitis, and genital dermatitis, the condition is referred to as Strachan's syndrome.

\begin{tabular}{lll}
\hline Organs and Tissues & Procedures & Possible or Expected Findings \\
\hline Brain & $\begin{array}{l}\text { For removal and specimen preparation, } \\
\text { see p. 65. Leave optic nerve attached } \\
\text { (see below). }\end{array}$ & See below under "Eyes with optic nerves." \\
Eyes with optic nerves & $\begin{array}{l}\text { For removal and specimen preparation, } \\
\text { see p. 85. Request Luxol fast blue stain of } \\
\text { optic nerves (p. 172). }\end{array}$ & $\begin{array}{l}\text { Bilateral symmetric loss of myelinated fibers } \\
\text { in central parts of optic nerves. Ganglion cells } \\
\text { in macula may be lost. }\end{array}$ \\
Other organs & $\begin{array}{l}\text { Manifestations of alcoholism,* diabetes } \\
\text { grossly identified abnormalities as listed in } \\
\text { right-hand column. }\end{array}$ & $\begin{array}{l}\text { mellitus, }{ }^{*} \text { malnutrition, }{ }^{*} \text { megaloblastic } \\
\text { anemia, }{ }^{*} \text { tobacco dependence, and } \\
\text { tuberculosis* (isoniazid treatment may } \\
\text { cause the optic nerve damage). }\end{array}$ \\
\hline
\end{tabular}

\section{Amebiasis}

Synonym: Entamoeba histolytica infection.

NOTE: (1) Collect all tissues that appear to be infected. (2) Request parasitologic examination as well as aerobic and anaerobic cultures. Bacterial infections may be associated with amebiasis. (3) Request Gram and Giemsa stains (p. 172). (4) No special precautions are indicated. (5) Serologic studies are available in many local and state health department laboratories (p. 135).

(6) This is a reportable disease.

Possible Associated Conditions: Acquired immunodeficiency syndrome (AIDS)* (1).

\begin{tabular}{ll}
\hline Organs and Tissues & Procedures \\
\hline $\begin{array}{l}\text { External examination } \\
\text { and skin }\end{array}$ & $\begin{array}{l}\text { Photograph and prepare sections of cutaneous } \\
\text { mucosal lesions. }\end{array}$ \\
& \\
$\begin{array}{l}\text { Chest organs, } \\
\text { abdominal cavity, } \\
\text { retroperitoneal space, } \\
\text { and pelvic organs }\end{array}$ & $\begin{array}{l}\text { Record presence and course of fistulas before } \\
\text { removal of organs. Material for parasitologic } \\
\text { study and bacterial cultures is best removed } \\
\text { at this time. }\end{array}$
\end{tabular}

Possible or Expected Findings

Perianal and perineal ulcers after extension of amebic colitis; rarely, destruction of external genitalia. Cutaneous amebiasis from fistulas after hepatic abscess, laparotomy, or, rarely, distant spread.

Amebic pneumonia, often associated with hepatic abscess (see below).

Pleuropulmonary amebiasis, with or without empyema. Amebic pericarditis or amebic peritonitis is rare. Intestinal perforation into peritoneal cavity, retroperitoneal space, or other hollow viscera. 


\begin{tabular}{|c|c|c|}
\hline Organs and Tissues & Procedures & Possible or Expected Findings \\
\hline \multirow[t]{2}{*}{ Intestine } & $\begin{array}{l}\text { Examine as soon as possible so as to reduce the } \\
\text { effects of autolysis. }\end{array}$ & \\
\hline & $\begin{array}{l}\text { Photograph ulcers and collect samples for smears } \\
\text { and histologic study. Specimens should include } \\
\text { cecum; ascending, sigmoid, transverse, and } \\
\text { descending colon; appendix; and ileum. }\end{array}$ & $\begin{array}{l}\text { Buttonhole or flask-shaped mucosal ulcers } \\
\text { are always present, in an order of involvement } \\
\text { as listed in the middle column. }\end{array}$ \\
\hline \multirow[t]{2}{*}{ Liver } & $\begin{array}{l}\text { If there is a hepatic abscess with fistulas, record } \\
\text { their course before removal of liver. Use Letulle } \\
\text { technique (p. 3) for organ removal, and open } \\
\text { inferior vena cava along posterior midline. }\end{array}$ & $\begin{array}{l}\text { Hepatic abscess(es) with or without } \\
\text { perforation and fistula(s). Hepatic fibrosis } \\
\text { and necroses. Portal vein thrombosis can } \\
\text { occur. Abscess may communicate with } \\
\text { inferior vena cava, gallbladder, bile ducts, } \\
\text { and other structures. }\end{array}$ \\
\hline & $\begin{array}{l}\text { Aspirate abscess contents and submit for micro- } \\
\text { biologic study. Prepare smears and sections } \\
\text { from periphery of abscess. }\end{array}$ & $\begin{array}{l}\text { Amebae are difficult to demonstrate in } \\
\text { amebic hepatic abscesses. }\end{array}$ \\
\hline Urinary tract & $\begin{array}{l}\text { If urinary tract system appears involved, incise } \\
\text { kidneys in situ, in frontal plane from periphery } \\
\text { toward pelvis (leave vessels attached); open } \\
\text { renal pelves, ureters, and urinary bladder in situ. }\end{array}$ & $\begin{array}{l}\text { Rarely, ascending amebic infection } \\
\text { associated with amebic colitis and perianal } \\
\text { spread. }\end{array}$ \\
\hline Other organs & $\begin{array}{l}\text { Procedures depend on expected findings or } \\
\text { grossly identified abnormalities as listed in } \\
\text { right-hand column. }\end{array}$ & $\begin{array}{l}\text { Rarely, spread to spleen, aorta, or larynx. } \\
\text { Other sites may be affected by systemic } \\
\text { hematogenous dissemination. }\end{array}$ \\
\hline Brain & $\begin{array}{l}\text { For removal and specimen preparation, } \\
\text { see p. } 65 \text {. }\end{array}$ & $\begin{array}{l}\text { Cerebral abscess* almost always associated } \\
\text { with hepatic abscess and pulmonary } \\
\text { amebiasis. }\end{array}$ \\
\hline
\end{tabular}

\section{Reference}

1. Fatkenheuer G, Arnold G, Steffen HM, Franzen C, Schrappe M, Diehl $\mathrm{V}$, Salzberger B. Invasive amebiasis in two patients with AIDS and cytomegalovirus colitis. J Clin Microbiol 1997;35:2168-2169.

\section{Aminoaciduria}

Related Terms: Proprionic acidemia; methyl malonic acidemia; isovaleric acidemia; cystinuria; homocystinuria;* maple syrup urine disease; ${ }^{*}$ urea cycle disorders; tyrosinemia; phenylketonuria.*

NOTE: Aminoaciduria is a collective name for all the conditions mentioned under "Related Terms." Because few autopsy studies of aminoaciduria have been done, each case should be considered a potential source of new, unpublished information. Multiple abnormalities of virtually all organ systems are possible.

\begin{tabular}{|c|c|c|}
\hline Organs and Tissues & Procedures & Possible or Expected Findings \\
\hline $\begin{array}{l}\text { Blood, cerebrospinal } \\
\text { fluid, and urine }\end{array}$ & $\begin{array}{l}\text { For removal of cerebrospinal fluid, see p. } 104 \text {. } \\
\text { Freeze samples for biochemical study. }\end{array}$ & $\begin{array}{l}\text { Many abnormalities may be present. } \\
\text { For specific enzyme defects, see ref. (1). }\end{array}$ \\
\hline $\begin{array}{l}\text { Fascia lata, liver, spleen, } \\
\text { or blood }\end{array}$ & $\begin{array}{l}\text { These specimens should be collected using } \\
\text { aseptic technique for tissue culture for } \\
\text { chromosome analysis and biochemical studies } \\
\text { (see Chapter 10). }\end{array}$ & Rare translocations are described (2). \\
\hline Other organs & See above under "Note." & $\begin{array}{l}\text { Multiple organs and tissues may be involved. } \\
\text { Frequently affected is the central nervous } \\
\text { system, eyes, liver, kidneys, and skeletal } \\
\text { system (rickets). }\end{array}$ \\
\hline
\end{tabular}

\section{References}

1. Chalmers RA, Lawson AM. Organic Acids in Man: The Analytical Chemistry, Biochemistry and Diagnosis of the Organic Acidurias. Chapman and Hall, London, 1982.
2. Hodgson SV, Heckmatt JZ, Hughes E, Crolla JA, Dubowitz V, Bobrow M. A balanced de novo X/autosome translocation in a girl with manifestations of Lowe syndrome. Am J Med Gen 1986;23:837-847. 


\section{Ammonia (See "Poisoning, gas" and "Bronchitis, acute chemical."')}

\section{Amphetamine(s) (See “Dependence, amphetamine(s).")}

\begin{abstract}
Amyloidosis
Related Terms: Familial amyloidosis (multiple forms, including familial Mediterranean fever and familial amyloid nephropathy with urticaria and deafness; hereditary cerebral angiopathies); idiopathic or primary amyloidosis (AL protein) (1); localized or isolated amyloidosis (amyloid in islets of Langerhans and insulinoma; congophil cerebral angiopathy;* isolated atrial amyloid; medullary carcinoma of thyroid); reactive or secondary amyloidosis (AA protein); systemic senile amyloidosis.
\end{abstract}

Possible Associated Conditions: Alzheimer's disease;* Behçet's disease; ${ }^{*}$ bronchiectasis; ${ }^{*}$ chronic dialysis; ${ }^{*}$ Creutz-
feldt-Jakob disease;* Crohn's disease;* diabetes mellitus type II; Down's syndrome;* leprosy;* malignant lymphoma, Hodgkin's type; macroglobulinemia; multiple myeloma;* osteomyelitis;* paraplegia; Reiter's syndrome;* rheumatoid arthritis* and other immune connective tissue diseases (all types); syphilis;* tuberculosis;* Whipple's disease.*

NOTE: Stain 15-micron tissue sections with Congo red and examine under polarized light for green birefringence. In AAtype amyloid but not in AL amyloid, pretreatment of tissue with permanganate, followed by routine staining with Congo red, will abolish the green birefringence. An immunohistochemistry panel is available to differentiate the subtypes of amyloidosis. Crystal violet, methyl violet, Sirius red, sodium sulfate alcian blue, and thioflavin $\mathrm{T}$ also stain amyloid in many instances. Electron microscopic studies (2) are particularly useful if routine stains are negative or controversial. For macroscopic staining of amyloid, e.g., in the heart, see p. 133.

\begin{tabular}{|c|c|c|}
\hline Organs and Tissues & Procedures & Possible or Expected Findings \\
\hline $\begin{array}{l}\text { External examination } \\
\text { and skin }\end{array}$ & $\begin{array}{l}\text { Submit grossly involved and uninvolved skin } \\
\text { for histologic study (look for amyloid in } \\
\text { subcutaneous fat). For special stains, see above } \\
\text { under "Note." }\end{array}$ & $\begin{array}{l}\text { Papules or plaques, particularly around eyes, } \\
\text { ears, axillae, inguinal regions, and anus. } \\
\text { Papules may be tumorous or pigmented. } \\
\text { Periorbital ecchymoses may be present. }\end{array}$ \\
\hline Mouth & $\begin{array}{l}\text { Submit gingiva, palate, and tongue for histologic } \\
\text { study. }\end{array}$ & Amyloid infiltrates; macroglossia. \\
\hline Blood and urine & $\begin{array}{l}\text { In unsuspected cases, submit samples for } \\
\text { immunoelectrophoresis and immunofixation. }\end{array}$ & Presence of monoclonal light chain. \\
\hline Heart & $\begin{array}{l}\text { Submit tissue from atria and myocardium of } \\
\text { ventricles. Photograph endocardial lesions. } \\
\text { For gross and microscopic staining, see above } \\
\text { under "Note." }\end{array}$ & $\begin{array}{l}\text { Amyloid deposits may be identifiable under } \\
\text { endocardium of left atrium. Nonischemic } \\
\text { congestive heart failure (1). }\end{array}$ \\
\hline Liver & $\begin{array}{l}\text { Record size and weight. For gross and } \\
\text { microscopic staining, see above under "Note." }\end{array}$ & Hepatomegaly with amyloid infiltrates. \\
\hline Gastrointestinal tract & $\begin{array}{l}\text { Take sections of all segments of the gastro- } \\
\text { intestinal tract. }\end{array}$ & $\begin{array}{l}\text { Amyloid infiltrates with ulcerations and } \\
\text { hemorrhages. }\end{array}$ \\
\hline Other organs & $\begin{array}{l}\text { Microscopic samples should include respiratory } \\
\text { system with larynx, gallbladder, pancreas, } \\
\text { spleen, all portions of urogenital system, } \\
\text { including prostate, seminal vesicles, and vasa } \\
\text { deferentia, and all endrocrine glands, blood } \\
\text { vessels, lymph nodes, and other tissues, } \\
\text { such as omentum. For gross and microscopic } \\
\text { staining methods, see above under "Note." }\end{array}$ & $\begin{array}{l}\text { Almost all organs and tissues may be } \\
\text { involved. Diffuse, nodular, or primary } \\
\text { vascular deposits may predominate. } \\
\text { Evidence of portal hypertension* may be } \\
\text { found but splenomegaly also may be caused } \\
\text { by amyloid infiltrates. Nephrotic syndrome;* } \\
\text { renal involvement also may be associated } \\
\text { with renal vein thrombosis.* See also above } \\
\text { under "Possible Associated Conditions." }\end{array}$ \\
\hline Eyes & $\begin{array}{l}\text { For removal and specimen preparation, } \\
\text { see p. } 85 \text {. }\end{array}$ & Ocular amyloidosis (3). \\
\hline $\begin{array}{l}\text { Brain, spinal cord, } \\
\text { and peripheral nerves }\end{array}$ & $\begin{array}{l}\text { For removal and specimen preparation, } \\
\text { see pp. } 65,67 \text {, and } 79, \text { respectively. }\end{array}$ & $\begin{array}{l}\text { Amyloid associated with senile plaques or } \\
\text { neurofibrillary tangles; congophilic } \\
\text { angiopathy (4). Spinal cord compression (5). } \\
\text { Peripheral amyloid neuropathy. }\end{array}$ \\
\hline $\begin{array}{l}\text { Bones and bone marrow, } \\
\text { joints, tendons }\end{array}$ & $\begin{array}{l}\text { For removal, prosthetic repair of bones and } \\
\text { joints, and specimen preparation, see p. } 95 \text {. }\end{array}$ & $\begin{array}{l}\text { Amyloid in bone marrow, synovium, and } \\
\text { carpal tunnel. Bone may contain osteolytic } \\
\text { tumor (multiple myeloma*). }\end{array}$ \\
\hline
\end{tabular}




\section{References}

1. Gertz MA, Lacy MQ, Dispenzieri A. Amyloidosis: recognition, confirmation, prognosis, and therapy. Mayo Clin Proc 1999;74:490494.

2. Lin CS, Wong CK. Electron microscopy of primary and secondary cutaneous amyloidosis and systemic amyloidosis. Clin Dermatol 1990; $8: 36-45$.

3. Gorevic PD, Rodrigues NM. Ocular amyloidosis. Am J Ophthalmol 1994;117:529-532.

4. Duchen LW. Current status review: cerebral amyloid. Intern J Exp Pathol 1992;73:535-550.

5. Villarejo F, Perez Diaz C, Perla C, Sanz J, Escalona J, Goyenechea F. Spinal cord compression by amyloid deposits. Spine 1994;19:11781181.

\section{Amyotonia Congenita}

NOTE: Amyotonia congenita encompasses several different neuromuscular disorders. See under "Disease, motor neuron." Anaphylaxis (See "Death, anaphylactic.")

\section{Ancylostomiasis}

Synonyms: Hookworm disease; miners' anemia; uncinariasis.

NOTE: (1) Collect all tissues that appear to be infected. (2) Cultures are usually not necessary, only parasitologic examination. (3) Request azure-eosin stains (p. 172). (4) No special precautions are indicated. (5) Serologic studies are available at the state health department laboratories (p. 135). (6) This is not a reportable disease.

\begin{tabular}{lll}
\hline Organs and Tissues & Procedures & Possible or Expected Findings
\end{tabular}

Small intestine

For in situ fixation and preparation for study by dissecting microscopy, see p. 54. Request PAS with diastase treatment, azure-eosin, Perl's (or Gomori's) stain for iron, and Verhoeffvan Gieson stains (p. 172).

Mesentery

Liver and spleen

Other organs
Submit lymph nodes for histologic study. Submit tissue samples for histologic study. Procedures depend on expected findings or grossly identified abnormalities as listed in right-hand column.
Erosions; hemorrhages (1); mucus in lumen; thickening of wall. Sprue-like mucosal changes (atrophy of villi) with deposition of hemosiderin, necrosis of mucosa, eosinophils in wall, and fibrosis of submucosa. Worms in second and third portions of jejunum.

Mesenteric lymphadenitis.

Myeloid metaplasia.

Manifestations of iron deficiency anemia,* hypoproteinemia, and congestive heart failure.*

\section{Reference}

1. Kuo YC, Chen PC, Wu CS. Massive intestinal bleeding in an adult with hookworm infection. J Clin Gastroenterol 1995;20:348-350.

Anemia (See under specific designations.)

Anemia, Aplastic (See “Anemia, Fanconi's” or "pancytopenia.")

Anemia Associated With Chronic Systemic Diseases
Related Term: Normochromic normocytic anemia.

NOTE: This type of anemia occurs with chronic inflammatory conditions such as endocarditis, ${ }^{*}$ osteomyelitis, * or tuberculosis* but may also be associated with connective tissue disorders such as lupus erythematosus* or rheumatoid arthritis.* Malignancies, uremia, chronic liver disease, endocrine disorders (e.g., Adrenal insufficiency,* hypothyroidism,* or pituitary insufficiency*), or poisoning with chemicals or drugs and radiation injury may also be involved.* The anemia in some of these conditions may be slightly microcytic or macrocytic.

\begin{tabular}{lll}
\hline Organs and Tissues & Procedures & Possible or Expected Findings \\
\hline All organs & Request iron stain. & $\begin{array}{l}\text { See above under "Note." Extramedullary } \\
\text { hematopoiesis and hemosiderosis, } \\
\text { particularly of liver and spleen. }\end{array}$ \\
Bone marrow & For preparation of sections and smears, & $\begin{array}{l}\text { Frequently hyperplastic. Hypoplastic in bone } \\
\text { marrow failure (pancytopenia*). }\end{array}$ \\
\hline
\end{tabular}

\section{Anemia, Fanconi's}

Synonyms: Congenital aplastic anemia; congenital pancytopenia; constitutional infantile panmyelopathy; familial panmyelophthisis; Fanconi's pancytopenia; Fanconi's syndrome (see also under "NOTE"); pancytopenia-dysmelia syndrome.

NOTE: Another disease group, also named "Fanconi's syndrome," is marked by proximal renal tubular transport defect; this latter syndrome is unrelated to Fanconi's anemia. 


\begin{tabular}{|c|c|c|}
\hline Organs and Tissues & Procedures & Possible or Expected Findings \\
\hline External examination & $\begin{array}{l}\text { Record and photograph abnormalities. } \\
\text { Request radiographs of skeleton. }\end{array}$ & $\begin{array}{l}\text { Short stature; microcephaly; café au lait } \\
\text { spots; dyskeratosis congenita; absent/ } \\
\text { hypoplastic thumbs; hyperpigmentation; nail } \\
\text { dystrophy; hypogonadism; microphthalmia. }\end{array}$ \\
\hline $\begin{array}{l}\text { Blood, fascia lata, } \\
\text { or liver (liver obtained } \\
\text { by percutaneous biopsy) }\end{array}$ & $\begin{array}{l}\text { These specimens should be collected using } \\
\text { aseptic technique for tissue culture for } \\
\text { chromosome analysis (see Chapter 10). }\end{array}$ & Chromosomal breaks. \\
\hline Other organs & $\begin{array}{l}\text { Culture any sites suggestive of infection. } \\
\text { Record and photograph sites of bleeding. } \\
\text { Record weight of spleen. } \\
\text { Request iron stains. }\end{array}$ & $\begin{array}{l}\text { Hemosiderosis. Small spleen. Small pituitary } \\
\text { gland. Evidence of infection or hemorrhage } \\
\text { at various sites. Solid tumors (1) (liver and } \\
\text { other organs or tissues, including eyes and } \\
\text { bones). }\end{array}$ \\
\hline Bone marrow & $\begin{array}{l}\text { For preparations of sections and smears, } \\
\text { see p. } 96 \text {. If the patient underwent bone marrow } \\
\text { transplantation, follow procedures under that } \\
\text { heading also. }\end{array}$ & $\begin{array}{l}\text { Pancytopenia;* myelodysplastic syndromes } \\
\text { and leukemia* }(1) .\end{array}$ \\
\hline Eyes & $\begin{array}{l}\text { For removal and specimen preparation, } \\
\text { see p. } 85 \text {. }\end{array}$ & Epiphoria, blepharitis, cataracts. \\
\hline
\end{tabular}

\section{Reference}

1. Alter BP. Fanconi's anemia and malignancies. Am J Hematol 1996; 53:99-110.

\section{Anemia, Hemolytic}

Synonyms and Related Terms: Acquired hemolytic anemia; extracorpuscular hemolytic anemia; hereditary hemolytic anemia (hereditary elliptocytosis, pyropoikilocytosis, stomatocytosis. spherocytosis); immunohemolytic anemia; intracorpuscular hemolytic anemia; microangiopathic hemolytic anemia; spur cell anemia.
Possible Associated Conditions: Disseminated intravascular coagulation;* eclampsia;* glucose-6-phosphatase deficiency (G6PD); hemolytic uremic syndrome;* malignant hypertension; lymphoma* and other malignancies; paroxysmal nocturnal hemoglobinuria; sickle cell disease; * thalassemia;* thrombotic thrombocytopenic purpura.* (See also below under "NOTE.")

NOTE: Hemolysis also may be caused by conditions such as poisoning with chemicals or drugs, heat injury, snake bite,* or infections or may develop as a transfusion reaction* or be secondary to adenocarcinoma, heart valve prostheses (see below), liver disease (see below), renal disease, or congenital erythropoietic porphyria.*

\begin{tabular}{ll}
\hline Organs and Tissues & Procedures \\
\hline External examination & Prepare skeletal roentgenograms.
\end{tabular}

Blood
In the absence of in vivo studies, submit samples for bacterial and viral cultures, or toxicologic, immunologic, or other laboratory studies, depending on the expected cause.

For hemoglobin electrophoresis, autolyzed blood can be used; one can also use blood that was drained from tissues.

\section{Possible or Expected Findings}

Jaundice; skin ulcers over malleoli. In young patients: thickening of frontal and parietal bones with loss of outer table ("hairon-end" appearance); paravertebral masses caused by extramedullary hematopoiesis; deformities of metacarpals, metatarsals, and phalanges. Osteonecrosis* of femoral heads. Osteoporosis.*

Bacteremia or septicemia. Viremia (e.g., parvovirus infection in hereditary spherocytosis). Chemical poisons or drugs. Beta-lipoprotein deficiency (abetalipoproteinemia*). Abnormal antibodies. Hyperbilirubinemia. Abnormal hemoglobins. 


\begin{tabular}{|c|c|c|}
\hline Organs and Tissues & Procedures & Possible or Expected Findings \\
\hline Urine & See above under "Blood." & Hemoglobinuria. \\
\hline Heart & Record weight. Request iron stain (p. 172). & $\begin{array}{l}\text { Hemosiderosis and cardiomegaly. Valvular } \\
\text { heart disease with or without inserted } \\
\text { prosthesis may be cause of hemolytic anemia. }\end{array}$ \\
\hline Lungs & Perfuse one lung with formalin (p. 47). & Infarcts in sickle cell disease. ${ }^{*}$ \\
\hline Liver & Record weight. Request iron stain (p. 172). & $\begin{array}{l}\text { Hemosiderosis and hepatomegaly. } \\
\text { Extramedullary hematopoiesis. Liver } \\
\text { diseases such as viral hepatitis* and acute } \\
\text { fatty change may cause hemolytic anemia. }\end{array}$ \\
\hline $\begin{array}{l}\text { Gallbladder and common } \\
\text { bile duct }\end{array}$ & $\begin{array}{l}\text { Describe appearance of stones or request } \\
\text { chemical analysis. }\end{array}$ & $\begin{array}{l}\text { Cholelithiasis, }{ }^{*} \text { cholecystitis, }{ }^{*} \text { or } \\
\text { choledocholithiasis associated with pigment } \\
\text { stones (particularly in hereditary hemolytic } \\
\text { anemia such as spherocytosis). }\end{array}$ \\
\hline Spleen & $\begin{array}{l}\text { See above under "Liver" and below under } \\
\text { "Kidneys." Request iron stain. }\end{array}$ & $\begin{array}{l}\text { Hemosiderosis and splenomegaly. } \\
\text { Extramedullary hematopoiesis. Infarctions in } \\
\text { sickle cell disease.* }\end{array}$ \\
\hline Kidneys & $\begin{array}{l}\text { If abnormalities are present, photograph cut } \\
\text { sections. }\end{array}$ & $\begin{array}{l}\text { Infarcts and papillary necrosis in sickle cell } \\
\text { disease.* Renal diseases may also be cause of } \\
\text { hemolytic anemia. }\end{array}$ \\
\hline Other organs and tissues & $\begin{array}{l}\text { Extensive histologic sampling is indicated, } \\
\text { particularly if the cause of the hemolysis is not } \\
\text { known. }\end{array}$ & $\begin{array}{l}\text { See above under "Possible Associated } \\
\text { Conditions" and under "Note." Search for } \\
\text { fibrin deposits in microvasculature as seen in } \\
\text { thrombotic thrombocytopenic purpura.* }\end{array}$ \\
\hline Bones and bone marrow & $\begin{array}{l}\text { For preparation of sections and smears, } \\
\text { see p. } 96 \text {. Request Giemsa stains and } \\
\text { Gomori's or Perl's iron stains (p. 172). } \\
\text { Consult roentgenograms for proper sampling. }\end{array}$ & $\begin{array}{l}\text { Erythroid hyperplasia or, rarely, hypoplasia } \\
\text { or normal marrow; hemosiderosis of bone } \\
\text { marrow. Osteonecrosis* in sickle cell } \\
\text { disease.* }\end{array}$ \\
\hline
\end{tabular}

\section{Anemia, Hypochromic (See “Anemia, iron deficiency.")}

\section{Anemia, Iron Deficiency}

Possible Associated Conditions: Conditions associated with blood loss (e.g., Crohn's disease; ${ }^{*}$ diaphragmatic hernia, ${ }^{*}$ diverticula, ${ }^{*}$ malabsorption syndrome, ${ }^{*}$ tumor, ${ }^{*}$ ulcer of stomach or duodenum,* or ulcerative colitis); lead poisoning* in children.

\begin{tabular}{lll}
\hline Organs and Tissues & Procedures & Possible or Expected Findings \\
\hline External examination & $\begin{array}{l}\text { Record body weight and height. } \\
\text { Photograph finger nails. } \\
\text { Plood }\end{array}$ & $\begin{array}{l}\text { Manifestations of malnutrition.* Angular } \\
\text { stomatitis; spoon nails (koilonychia). }\end{array}$ \\
$\begin{array}{l}\text { Heart } \\
\text { Esophagus and neck } \\
\text { organs with tongue }\end{array}$ & $\begin{array}{l}\text { Remove as one specimen. Photograph web or } \\
\text { stricture from above. Submit tissue samples of } \\
\text { all segments for histologic study. }\end{array}$ & $\begin{array}{l}\text { Dilatation of chambers. } \\
\text { Glossitis; postcricoid esophageal web or } \\
\text { stricture (Plummer-Vinson syndrome*). }\end{array}$ \\
$\begin{array}{l}\text { Gastrointestinal tract } \\
\text { with anus }\end{array}$ & $\begin{array}{l}\text { Search for possible source of chronic } \\
\text { hemorrhage. }\end{array}$ & $\begin{array}{l}\text { See above under "Possible Associated } \\
\text { Conditions." Hemorrhoids. }\end{array}$ \\
$\begin{array}{l}\text { Spleen } \\
\text { Genitourinary system }\end{array}$ & $\begin{array}{l}\text { Record weight. } \\
\text { Search for possible source of chronic } \\
\text { hemorrhage. }\end{array}$ & $\begin{array}{l}\text { Splenomegaly. } \\
\text { Tumors or inflammatory conditions. }\end{array}$ \\
$\begin{array}{l}\text { Other organs } \\
\text { Bone marrow }\end{array}$ & $\begin{array}{l}\text { For preparation of sections and smears, } \\
\text { see p. 96. Request iron stain. }\end{array}$ & $\begin{array}{l}\text { Manifestations of congestive heart failure** } \\
\text { Hyperplasia. Reduced or absent iron in } \\
\text { macrophages. }\end{array}$ \\
\hline
\end{tabular}




\section{Anemia, Megaloblastic}

Related Terms: Pernicious anemia; vitamin $\mathrm{B}_{12}$ deficiency.

NOTE: The condition can be caused by many disorders associated with cobalamin or folic acid deficiency (e.g., malabsorption-related); other causes include adverse drug effects, alcoholism, and rare metabolic disorders. The condition may occur in infancy or during pregnancy. Hemolytic anemia, ${ }^{*}$ hypoparathyroidism, ${ }^{*}$ adrenal cortical insufficiency* (Addison's disease), or scurvy may be present.

\begin{tabular}{ll}
\hline Organs and Tissues & Procedures \\
\hline $\begin{array}{l}\text { External examination } \\
\text { and oral cavity }\end{array}$ & $\begin{array}{l}\text { Record body weight, color of skin and sclerae, } \\
\text { and presence or absence of conditions listed in } \\
\text { right-hand colum. }\end{array}$
\end{tabular}

Blood

Prepare smears.

\section{Esophagus and neck organs with tongue Stomach}

Intestinal tract

Liver and spleen

Vagina

Thyroid gland

Brain, spinal cord, and peripheral nerves

Eyes with optic nerves

Bone marrow
Submit tissue samples of tongue.

Remove and place in fixative as early as possible in order to minimize autolysis (alternatively, formalin can be injected in situ; see below). Samples should include oxyntic corpus and fundus mucosa.

For in situ fixation and preparation for study by dissecting microscopy, see p. 54. For preservation of jejunal diverticula by air drying, see p. 55.

Record weights.

Submit tissue samples for histologic study.

Record weight of thyroid gland.

For removal and specimen preparation, see pp. 65 , and 67 , respectively. Request Luxol fast blue stain (p. 172).

For removal and specimen preparation, see p. 85. If there is a clinical diagnosis of anemia-related amblyopia, follow procedures described under "Amblyopia, nutritional." For preparation of sections and smears, see p. 96.
Possible or Expected Findings

Jaundice. Manifestations of malnutrition.*

Stomatitis with cheilosis and perianal ulcerations due to folic acid deficiency. Chronic exfoliative skin disorders. Vitiligo. Macrocytosis; poikilocytosis; macroovalocytes; hypersegmentation of leukocytes; abnormal platelets.

Atrophic glossitis with ulcers.

Pharyngoesophagitis (folic acid deficiency).

Previous total or subtotal gastrectomy.

Carcinoma of stomach.

Autoimmune gastritis (diffuse corporal atrophic gastritis) with intestinal metaplasia. Crohn's disease;* sprue;* other chronic inflammatory disorders; jejunal diverticula; intestinal malignancies; fish tapeworm infestation; previous intestinal resection or blind intestinal loop; enteric fistulas.

Hepatosplenomegaly. Alcoholic liver disease.* Giant epithelial cells.

Hyperthyroid goiter; thyroiditis.

Demyelination of cerebral white matter (in advanced cases). Demyelination in posterior and lateral columns of spinal cord, most frequently in thoracic and cervical segments. Demyelination of peripheral nerves.

Retinal hemorrhages; demyelination of optic nerves.

Hypercellular; megaloblastic.

Myeloproliferative disorder.

Anemia, Pernicious (See “Anemia, megaloblastic.”)

Anemia, Sickle Cell (See “Anemia, hemolytic" and "Disease, sickle cell.”)

Anencephaly

\begin{tabular}{lll}
\hline Organs and Tissues & Procedures & Possible or Expected Findings \\
\hline External examination & Photograph all abnormalities. & $\begin{array}{l}\text { Absence of calvarial bones; protrusion of } \\
\text { orbits; area cerebrovasculosa (disorganized } \\
\text { hypervascular neuroglial tissue at the base of } \\
\text { the skull). }\end{array}$ \\
& Prepare full-body skeletal roentgenograms. & Delay in development of ossification centers.
\end{tabular}




\begin{tabular}{lll}
\hline Organs and Tissues & Procedures & Possible or Expected Findings \\
\hline Eyes & For removal and specimen preparation, & $\begin{array}{l}\text { Absence of ganglion cells in retina; absence } \\
\text { or hypoplasia of optic nerves. }\end{array}$ \\
Thymus, adrenals, & see 85. & Thymic and thyroid enlargement. Small \\
gonads, and thyroid & hecord weights. Submit tissue samples for & adrenal glands with rudimentary fetal cortex \\
histologic study. & after 20 wk gestation; small gonads. \\
Base of skull & Identify and record structures at base of skull. & $\begin{array}{l}\text { Shallow sella turcica; small pituitary gland; } \\
\text { hypoplastic medulla oblongata. }\end{array}$ \\
Lungs & Prepare histologic sections. & Aspiration of brain tissue. \\
\hline
\end{tabular}

\section{Anesthesia (See "Death, anesthesia-associated.")}

\section{Aneurysm, Aortic Sinus}

NOTE: For general dissection techniques, see Part I, Chapter 3. Prepare sections of aorta and request Verhoeff-van Gieson stain (p. 173). Rupture of aneurysm usually causes a fistula to the right ventricle or right atrium.

Possible Associated Conditions: Cystic medial degeneration of aorta; infective endocarditis; * ventricular septal defect.*

\section{Aneurysm, Ascending Aorta}

Possible Associated Conditions: History of polymyalgia rheumatica;* see also below under "Possible or Expected Findings."

\begin{tabular}{lll}
\hline Organs and Tissues & Procedures & Possible or Expected Findings \\
\hline Aorta & Collect 5-6 specimens for microscopic study. & $\begin{array}{l}\text { Cystic medial degeneration; active arteritis } \\
\text { (often giant cell type), or healed arteritis. }\end{array}$ \\
Muscular arteries & Request Verhoeff-van Gieson stain (p. 173). & Temporal arteritis; systemic giant cell \\
& Collect specimens for microscopic study. & arteritis.* \\
\hline
\end{tabular}

\section{Aneurysm, Atherosclerotic Aortic}

\begin{tabular}{lll}
\hline Organs and Tissues & Procedures & Possible or Expected Findings \\
\hline Aorta & $\begin{array}{l}\text { If aneurysm was perforated, identify location of } \\
\text { rupture in situ. Record location and volume of } \\
\text { blood in peritoneum and retroperitoneum. } \\
\text { Transverse or longitudinal sections of aneurysms } \\
\text { are instructive. }\end{array}$ & $\begin{array}{l}\text { Saccular aneurysm, often inferior to origin of } \\
\text { renal arteries. Mural thrombosis in aneurysm. } \\
\text { Request Verhoeff-van Gieson stain (p. 173). } \\
\text { Decalcification may be required (p. 97). } \\
\text { retroperitoneum, or hollow viscus. } \\
\text { Major arteries and kidneys may be left attached } \\
\text { to aorta. }\end{array}$ \\
Kidneys & $\begin{array}{l}\text { Arterial and arteriolar nephrosclerosis. } \\
\text { Atheromatous emboli and microinfarcts } \\
\text { of kidneys. }\end{array}$ \\
\hline
\end{tabular}

\section{Aneurysm, Atrial Septum of Heart}

Synonyms: Aneurysm of valve of fossa ovalis; fossa ovalis aneurysm.

NOTE: For general dissection techniques, see Part I, Chapter 3.

Possible Associated Conditions: Patent oval foramen (patent foramen ovale).

\section{Aneurysm, Berry (See “Aneurysm, cerebral artery.”)}




\begin{tabular}{|c|c|c|}
\hline Organs and Tissues & Procedures & Possible or Expected Findings \\
\hline \multirow[t]{2}{*}{ Brain } & $\begin{array}{l}\text { If mycotic aneurysms are expected and micro- } \\
\text { biologic studies are intended, follow procedures } \\
\text { described below under "Aneurysm, mycotic } \\
\text { aortic." Request Verhoeff-van Gieson, Gram, } \\
\text { and Grocott's methenamine silver stains (p. 172). } \\
\text { For cerebral arteriography, see p. } 80 .\end{array}$ & $\begin{array}{l}\text { Mycotic aneurysms are often multiple and } \\
\text { deep in brain substance. }\end{array}$ \\
\hline & $\begin{array}{l}\text { If arteriography cannot be carried out, rinse fresh } \\
\text { blood gently from base of brain until aneurysm } \\
\text { can be identified. Record site of rupture and } \\
\text { estimated amount of extravascular blood. For } \\
\text { paraffin embedding of aneurysms, careful } \\
\text { positioning is required. }\end{array}$ & $\begin{array}{l}\text { Berry aneurysms are the most frequent types } \\
\text { and often are multiple. Most frequent sites } \\
\text { are the bifurcations and trifurcations of the } \\
\text { circle of Willis. Saccular atherosclerotic } \\
\text { aneurysms are more common than dissecting } \\
\text { aneurysms, which are very rare. }\end{array}$ \\
\hline Other organs & Expected findings depend on type of aneurysm. & $\begin{array}{l}\text { With congenital cerebral artery aneurysm: } \\
\text { coarctation of aorta;* manifestations of } \\
\text { hypertension;* and polycystic renal disease. } \\
\text { With mycotic aneurysm: infective } \\
\text { endocarditis;* pulmonary suppurative } \\
\text { processes; and pyemia. }\end{array}$ \\
\hline
\end{tabular}

\section{Aneurysm, Dissecting Aortic (See “Dissection, aortic.”)}

\section{Aneurysm, Membranous Septum of Heart}

NOTE: For general dissection techniques, see Part I, Chapter 3. Most aneurysms of the membranous septum probably represent spontaneous closure of a membranous ventricular septal defect by the septal leaflet of the tricuspid valve.

\section{Aneurysm, Mycotic Aortic}

NOTE: (1) Collect all tissues that appear to be infected. (2) Request aerobic, anaerobic, and fungal cultures. (3) Request Gram and Grocott methenamine silver stains (p. 172). (4) No special precautions are indicated. (5) No serologic studies are available. (6) This is not a reportable disease.

\begin{tabular}{lll}
\hline Organs and Tissues & Procedures & Possible or Expected Findings \\
\hline $\begin{array}{l}\text { Chest and abdominal } \\
\text { organs }\end{array}$ & $\begin{array}{l}\text { Submit blood samples for bacterial culture } \\
\text { (p. 102). En masse removal of adjacent organs } \\
\text { is recommended (p. 3). }\end{array}$ & $\begin{array}{l}\text { Septicemia and infective endocarditis.* } \\
\text { Aorta }\end{array}$ \\
$\begin{array}{l}\text { Photograph all grossly identifiable lesions. } \\
\text { Aspirate material from aneurysm or para-aortic } \\
\text { abscess and submit for culture. Prepare sections } \\
\text { and smears of wall of aneurysm and of aorta } \\
\text { distant from aneurysm. Request Verhoeff- } \\
\text { van Gieson and Gram stains (p. 172). }\end{array}$ & $\begin{array}{l}\text { Streptococcus, staphylococcus, spirochetes, } \\
\text { and salmonella can be found in mycotic } \\
\text { aneurysm. Para-aortic abscess. }\end{array}$ \\
\hline Other organs & & $\begin{array}{l}\text { Septic emboli with infarction or abscess } \\
\text { formation. }\end{array}$ \\
\hline
\end{tabular}

\section{Aneurysm, Syphilitic Aortic}

\begin{tabular}{lll}
\hline Organs and Tissues & Procedures & Possible or Expected Findings \\
\hline Heart and aorta & $\begin{array}{l}\text { En masse removal of organs is recommended } \\
\text { (p. 3). For coronary arteriography, see p. 118. }\end{array}$ & $\begin{array}{l}\text { Aneurysm usually in ascending aorta. May } \\
\text { erode adjacent bone (sternum). Syphilitic } \\
\text { aortitis may cause intimal wrinkling, } \\
\text { narrowing of coronary ostia, and shortening } \\
\end{array}$ \\
& $\begin{array}{l}\text { of aortic cusps. } \\
\text { Request Verhoeff-van Gieson stain from sections }\end{array}$ \\
& Disruption of medial elastic fibrils.
\end{tabular}




\begin{tabular}{lll}
\hline Organs and Tissues & Procedures & Possible or Expected Findings \\
\hline Other organs & See also under "Syphilis." & $\begin{array}{l}\text { Aortic valvulitis and insufficiency;* } \\
\text { syphilitic coronary arteritis; syphilitic } \\
\text { myocarditis. }\end{array}$ \\
\hline
\end{tabular}

\section{Aneurysm, Traumatic Aortic}

\begin{tabular}{|c|c|c|}
\hline Organs and Tissues & Procedures & Possible or Expected Findings \\
\hline External examination & $\begin{array}{l}\text { Penetrating or blunt trauma with wounds, abra- } \\
\text { sions, hematomas, and other traumatic lesions. } \\
\text { Prepare chest and abdominal roentgenograms. }\end{array}$ & Fractures of ribs. \\
\hline \multirow[t]{2}{*}{ Aorta } & $\begin{array}{l}\text { Open aorta along line of blood flow, or bisect } \\
\text { into anterior and posterior halves. Photograph } \\
\text { tear(s). Measure or estimate amount of blood } \\
\text { in mediastinum. }\end{array}$ & Hemorrhage into mediastinum. \\
\hline & $\begin{array}{l}\text { Request Verhoeff-van Gieson stain } \\
\text { (p. 173). }\end{array}$ & $\begin{array}{l}\text { Microscopy may show transmural rupture, } \\
\text { false aneurysm, or localized dissection. }\end{array}$ \\
\hline
\end{tabular}

\section{Angiitis (See “Arteritis, all types or type unspecified.”)}

\section{Angina Pectoris}

NOTE: See under "Disease, ischemic heart" and Table 3-2 (p. 32) in Part I, Chapter 3.

\section{Angiokeratoma Corporis Diffusum (See "Disease, Fabry's.")}

\section{Angiomatosis, Encephalotrigeminal (See “Disease, Sturge-Weber-Dimitri.”)}

\section{Angiopathy, Congophilic Cerebral}

Synonyms and Related Terms: Beta amyloid angiopathy due to $\beta$-amyloid peptide deposition ( $\beta$ A4) (associated with Alzheimer's disease; hereditary cerebral hemorrhage with amyloid angiopathy of Dutch type; or sporadic beta amyloid angiopathy); hereditary cerebral amyloid angiopathy, due to deposition of other amyloidogenic proteins such as cystatin C (Icelandic type) and others (e.g., transthyretin, gelsolin) (1).

\begin{tabular}{lll}
\hline Organs and Tissues & Procedures & Possible or Expected Findings
\end{tabular}

Brain For removal and specimen preparation, see p. 65.

Request stains for amyloid, particularly Congo red (p. 172), and thioflavine S (examine with polarized and ultraviolet light, respectively). Request immunostain for $\beta \mathrm{A} 4$. Some tissue should be kept frozen for biochemical studies. Prepare material for electron microscopy (p. 132).

Other organs Multiple recent cerebral cortical infarctions or small cortical hemorrhages, or both, or massive hemispheric hemorrhages, both recent and old.

Amyloid deposition in leptomeninges and cortical blood vessels. Senile plaques are usually present. In some cases, angiopathy is part of Alzheimer's disease.*

Electron microscopic study permits definite confirmation of diagnosis.

Organs and tissues may be minimally affected by amyloidosis.

\section{Reference}

1. Kalimo H, Kaste M, Haltia M. Vascular diseases. In: Greenfield's Neuropathology, vol. 1. Graham BI, Lantos PL, eds. Arnold, London, 1997, pp. 315-396.

\section{Anomaly, Coronary Artery}

Possible Associated Conditions: With double outlet right ventricle; persistent truncal artery; tetralogy of Fallot; ${ }^{*}$ and transposition of the great arteries.*
NOTE: Coronary artery between aorta and pulmonary artery, often with flap-valve angulated coronary ostium. Coronary artery may communicate with cardiac chamber, coronary sinus, or other cardiac veins, or with mediastinal vessel through pericardial vessel. Saccular aneurysm of coronary artery with abnormal flow, infective endarteritis of arteriovenous fistula, and myocardial infarction may be present. If one or both coronary arteries originate from pulmonary trunk, myocardial infarction may be present. 


\begin{tabular}{lll}
\hline Organs and Tissues & Procedures & Possible or Expected Findings \\
\hline Heart & For coronary angiography, see p. 118. & $\begin{array}{l}\text { Ectopic origin of coronary arteries or single } \\
\text { coronary artery. }\end{array}$ \\
& $\begin{array}{l}\text { If infective endarteritis is suspected, submit } \\
\text { blood sample for microbiologic study (p. 102). }\end{array}$ & $\begin{array}{l}\text { Sudden death. For a detailed description of } \\
\text { possible additional findings, see above under } \\
\text { "Note." }\end{array}$ \\
\hline
\end{tabular}

\section{Anomaly, Ebstein's (See “Malformation, Ebstein's”)}

\section{Anorexia Nervosa}

NOTE: Sudden death from tachyarrhythmias may occur in advanced cases and thus, autopsy findings may not reveal the immediate cause of death.

\begin{tabular}{lll}
\hline Organs and Tissues & Procedures & Possible or Expected Findings \\
\hline External examination & $\begin{array}{l}\text { Record height and weight, and prepare } \\
\text { photographs to show cachectic features. }\end{array}$ & $\begin{array}{l}\text { Cachexia, often with preserved breast tissue; } \\
\text { hirsutism; dry, scaly, and yellow skin }\end{array}$ \\
& $\begin{array}{l}\text { Record abnormalities as listed in right- } \\
\text { hand column. }\end{array}$ & $\begin{array}{l}\text { Parotenemia). Mild edema may be present. } \\
\text { All organs }\end{array}$ \\
& $\begin{array}{l}\text { Follow procedures described under be enlarged. } \\
\text { "Starvation." Record weight of endocrine }\end{array}$ & $\begin{array}{l}\text { Manifestations of starvation.* Ovaries tend } \\
\text { to be atrophic; other endocrine organs should }\end{array}$ \\
& organs and submit samples for histologic study. & not show abnormalities. \\
\hline
\end{tabular}

\section{Anthrax}

Synonyms: Cutaneous anthrax; gastrointestinal anthrax; pulmonary (inhalational) anthrax.

NOTE: (1) Collect all tissues that appear to be infected. (2) Request aerobic cultures. (3) Request Gram stain (p. 172). For the study of archival tissue samples, polymerase chain reaction (PCR) analysis can be attempted (1). (4) Special precautions are indicated because the infection can be transmitted by aerosolization (see Part I, Chapter 16). (5) Serologic studies are available at the Center for Disease Control and Prevention, Atlanta, GA. (6) This is a reportable disease. Bioterrorism must be considered in current cases.

\begin{tabular}{|c|c|c|}
\hline Organs and Tissues & Procedures & Possible or Expected Findings \\
\hline $\begin{array}{l}\text { External examination } \\
\text { and skin }\end{array}$ & $\begin{array}{l}\text { Photograph cutaneous papules, vesicles, and } \\
\text { pustules. Prepare smears and histologic sections. } \\
\text { Submit samples for bacteriologic study. }\end{array}$ & $\begin{array}{l}\text { Disseminated anthrax infection may occur } \\
\text { without skin lesions. } \\
\text { Edema of neck and anterior chest in } \\
\text { nasopharyngeal anthrax. }\end{array}$ \\
\hline Blood & Submit sample for serologic study. & Anthrax septicemia. See above under "Note." \\
\hline Lungs & $\begin{array}{l}\text { Record character and volume of effusions. } \\
\text { After sampling for bacteriologic study (see } \\
\text { above under "Note") perfuse one or both lungs } \\
\text { with formalin (p. } 47 \text { ). Extensive sampling for } \\
\text { histologic study is indicated. }\end{array}$ & $\begin{array}{l}\text { Pleural effusions; * hemorrhagic } \\
\text { mediastinitis; anthrax pneumonia } \\
\text { (inhalational anthrax; Woolsorter's disease). } \\
\text { Histologic sections reveal hemorrhagic } \\
\text { necrosis, often with minimal inflammation } \\
\text { and gram-positive, spore-forming, } \\
\text { encapsulated bacilli. }\end{array}$ \\
\hline $\begin{array}{l}\text { Gastrointestinal tracts } \\
\text { and mesentery }\end{array}$ & $\begin{array}{l}\text { For in situ fixation of intestines, see p. } 54 . \\
\text { Extensive sampling for histologic study is } \\
\text { indicated. }\end{array}$ & $\begin{array}{l}\text { Gastrointestinal anthrax with mucosal edema } \\
\text { and ulcerations. Hemorrhagic mesenteric } \\
\text { lymphadenitis. }\end{array}$ \\
\hline Neck organs & & $\begin{array}{l}\text { Tongue, nasopharynx, and tonsils may be } \\
\text { involved. }\end{array}$ \\
\hline Brain & $\begin{array}{l}\text { For removal and specimen preparation, see } \\
\text { p. } 65 \text {. Photograph meningeal hemorrhage in situ. }\end{array}$ & $\begin{array}{l}\text { Hemorrhagic meningitis (hemorrhage tends } \\
\text { to predominate). }\end{array}$ \\
\hline
\end{tabular}

1. Jackson PJ, Hugh-Jones ME, Adair DM, Green G, Hill KK, Kuske CR, et al. PCR analysis of tissue samples from the 1979 Sverdlovsk anthrax victims: the presence of multiple Bacillus anthracis strains in different victims. Proc Natl Acad Sci USA 1998;95:1224-1229. 


\section{Antifreeze (See "Poisoning, ethylene glycol.”)}

\section{Antimony (See "Poisoning, antimony.")}

\section{Anus, Imperforate}

Related Terms: Anorectal malformation; ectopic anus.

Possible Associated Conditions: Abnormalities of sacrococcygeal vertebrae; cardiovascular malformations; esophageal and intestinal atresias, ${ }^{*}$ including rectal stenosis or atresia; malformations of the urinary tract.

\begin{tabular}{lll}
\hline Organs and Tissues & Procedures & Possible or Expected Findings
\end{tabular}

External examination

Distal colon and rectum
Photograph perineum. Measure depth of anal pit, if any.

Dissect distal colon, rectum, and perirectal pelvic organs in situ (as much as possible). Search for opening of fistulous tracts from lumen; inject tract with stained contrast medium (see Part I, Chapter 12). Use roentgenologic study or dissection, or both, to determine course of tract.
Absence of normally located anus; anal dimple.

Abnormal termination of the bowel into the trigone of the urinary bladder, the urethra distal to the verumontanum, the posterior wall of the vagina, the vulva, or the perineum.

\section{Aortitis}

NOTE: See also under "Arteritis" and "Aneurysm, ascending aortic."

\begin{tabular}{lll}
\hline Organs and Tissues & Procedures & Possible or Expected Findings \\
\hline Heart and aorta & $\begin{array}{l}\text { Remove heart with whole length of aorta and } \\
\text { adjacent major arteries. Record width and } \\
\text { circumference of aorta at different levels. } \\
\text { Describe and photograph appearance of intima } \\
\text { and of orifices of coronary arteries and other } \\
\text { aortic branches. }\end{array}$ & $\begin{array}{l}\text { Secondary aortic atherosclerosis or intimal } \\
\text { fibroplasia. Widening of aorta; syphilitic } \\
\text { aneurysm.* }\end{array}$ \\
& $\begin{array}{l}\text { Submit multiple samples for histologic study } \\
\text { and request Verhoeff-van Gieson stain (p. 173). } \\
\text { Procedures depend on expected findings or } \\
\text { grossly identified abnormalities as listed in } \\
\text { right-hand column. }\end{array}$ & $\begin{array}{l}\text { Giant cell aortitis; rheumatoid aortitis; } \\
\text { syphilitic aortitis; Takayasu's arteritis.* } \\
\text { Manifestations of rheumatoid arthritis, }\end{array}$ \\
& $\begin{array}{l}\text { syphilis, } \text { systemic sclerosis, }^{*} \text { Hodgkin's } \\
\text { lymphoma, and many other diseases } \\
\text { associated with vasculitis. }\end{array}$ \\
\hline
\end{tabular}

Aplasia, Thymic (See “Syndrome, primary immunodeficiency.")

Arachnoiditis, Spinal

Synonym: Chronic spinal arachnoiditis.

\begin{tabular}{lll}
\hline Organs and Tissues & Procedures & Possible or Expected Findings \\
\hline External examination & Prepare roentgenogram of spine. & $\begin{array}{l}\text { Signs of previous spinal surgery or lumbar } \\
\text { puncture (myelography). } \\
\end{array}$ \\
& & $\begin{array}{l}\text { Evidence of previous trauma or previous } \\
\text { myelography. }\end{array}$ \\
Brain & For removal and specimen preparation, & Cerebral arachnoiditis.
\end{tabular}

Spine and spinal cord see p. 65.

For removal of spinal cord and specimen preparation, see p. 67. Expose nerve roots. Record appearance and photograph spinal cord in situ.

Submit samples of spinal cord and inflamed tissue for histologic study. Request Gram, Gomori's iron, and Grocott's methenamine silver stains (p. 172).
Fibrous arachnoidal adhesions and loculated cysts.

Tuberculosis;* syphilis; * fungal or parasitic infection. 


\begin{tabular}{lll}
\hline Organs and Tissues & Procedures & Possible or Expected Findings \\
\hline Other organs & $\begin{array}{l}\text { Procedures depend on expected findings or } \\
\text { grossly identified abnormalities as listed in } \\
\text { right-hand column. }\end{array}$ & $\begin{array}{l}\text { Systemic infection (see above). Ascending } \\
\text { urinary infection or other manifestations of } \\
\text { paraplegia. }\end{array}$ \\
\hline
\end{tabular}

\section{Arch, Aortic, Interrupted}

Synonym: Severe coarctation.

NOTE: The basic anomaly is a discrete imperforate region in the aortic arch, with a patent ductal artery joining the descending thoracic aorta. Type A interruption is between the left subclavian and ductal arteries; type B between the left subclavian and left common carotid arteries; and type $\mathrm{C}$ (rare) between the left common carotid and brachiocephalic (innominate) arteries. For general dissection techniques, see Part I, Chapter 3.

Possible Associated Conditions: Bicuspid aortic valve (with type A); di George syndrome* with thymic and parathyroid aplasia (with type B); hypoplasia of ascending aorta (with all types); persistent truncal artery (truncus arteriosus); ventricular septal defect.

\section{Arrhythmia, Cardiac}

NOTE: See also under "Death, sudden cardiac." Toxicologic studies may be indicated, for instance, if digitalis toxicity (see "Poisoning, digitalis") is suspected. If a cardiac pacemaker had been implanted, the instrument should be tested for malfunction.

\begin{tabular}{lll}
\hline Organs and Tissues & Procedures & Possible or Expected Findings \\
\hline Heart & For coronary arteriography, see p. 118. & Coronary atherosclerosis. \\
& Dissection techniques depend on nature of & Congenital heart disease. \\
& expected underlying disease. & Valvular heart disease. \\
& Submit samples for histologic study (p. 30). & Myocardial infarction. Myocarditis.* \\
& For study of conduction system, see p. 26. & Cardiomyopathy.* \\
\hline
\end{tabular}

\section{Arsenic (See "Poisoning, arsenic.")}

\section{Arteriosclerosis (See “Atherosclerosis.”)}

\section{Arteritis, All Types or Type Unspecified}

Synonyms and Related Terms: Allergic angiitis and granulomatosis (Churg-Strauss);* allergic vasculitis; anaphylactoid purpura* and its synonyms; angiitis; Buerger's disease;* cranial arteritis; giant cell arteritis; ${ }^{*}$ granulomatous arteritis (angiitis); hypersensitivity angiitis; infectious angiitis; necrotizing arteritis; polyarteritis nodosa; $*$ rheumatic arteritis; rheumatoid arteritis, syphilitic arteritis; Takayasu's arteritis;* temporal arteritis; thromboangiitis obliterans; and others (see also below under "Note").

NOTE: Autopsy procedures depend on (1) the expected type of arteritis, such as giant cell arteritis, ${ }^{*}$ polyarteritis nodosa,* or thromboangiitis obliterans (Buerger's disease*); and (2) the nature of suspected associated or underlying disease, such as aortic arch syndrome, * Behçet's syndrome, * Cogan's syndrome, Degos' disease, ${ }^{*}$ dermatomyositis, ${ }^{*}$ erythema nodosum and multiforme, ${ }^{*}$ Goodpasture's syndrome, ${ }^{*}$ polymyositis, rheumatic fever, ${ }^{*}$ rheumatoid arthritis, ${ }^{*}$ syphilis, ${ }^{*}$ and other nonspecific infectious diseases, systemic lupus erythematosus,* systemic sclerosis (scleroderma), ${ }^{*}$ or Takayasu's disease. For histologic study of blood vessels, Verhoeff-van Gieson stain or a similar stain is recommended (p. 172).

\section{Arteritis, Giant Cell}

Synonyms and Related Terms: Cranial arteritis; giant cell aortitis; juvenile temporal arteritis; systemic giant cell arteritis; temporal arteritis.

Possible Associated Conditions: Polymyalgia rheumatica.

\begin{tabular}{lll}
\hline Organs and Tissues & Procedures & Possible or Expected Findings \\
\hline $\begin{array}{l}\text { External examination } \\
\text { and skin }\end{array}$ & $\begin{array}{l}\text { Prepare sections of skin lesions. } \\
\text { Record appearance of oral cavity; submit tissue } \\
\text { samples of tongue. }\end{array}$ & $\begin{array}{l}\text { Skin nodules; scalp necroses. } \\
\text { Gangrene of tongue. }\end{array}$ \\
& $\begin{array}{l}\text { Probe nasal cavity and record appearance of } \\
\text { septum. }\end{array}$ & Perforation of nasal septum. \\
Heart & For coronary arteriography, see p. 118. & $\begin{array}{l}\text { Coronary arteritis; myocardial infarction. } \\
\text { Pericardial infiltrates. }\end{array}$
\end{tabular}




\begin{tabular}{lll}
\hline Organs and Tissues & Procedures & Possible or Expected Findings \\
\hline $\begin{array}{l}\text { Aorta and other elastic } \\
\text { arteries }\end{array}$ & $\begin{array}{l}\text { For angiographic procedures, see p. 118 } \\
\text { and below, under “Arteritis, Takayasu's." } \\
\text { Request Verhoeff-van Gieson stain (p. 172). }\end{array}$ & $\begin{array}{l}\text { Aortic dissection;* spontaneous rupture of } \\
\text { aorta. Arteritis of aorta, aortic arch branches } \\
\text { (carotid arteries, subclavian arteries, } \\
\text { vertebral arteries, brachiocephalic artery) and } \\
\text { celiac, mesenteric, renal, iliac, and femoral } \\
\text { arteries. Arteries may show aneurysms. }\end{array}$ \\
$\begin{array}{l}\text { Lungs } \\
\text { Other organs }\end{array}$ & $\begin{array}{l}\text { Pulmonary arteritis. } \\
\text { Giant cell arteritis may occur in many organs } \\
\text { and tissues. }\end{array}$ \\
$\begin{array}{l}\text { Brain and spinal cord } \\
\text { Temporal and } \\
\text { ophthalmic arteries }\end{array}$ & $\begin{array}{l}\text { For removal and specimen preparation, } \\
\text { see pp. 65 and 67, respectively. }\end{array}$ & $\begin{array}{l}\text { Cxpose temporal and ophthalmic arteries; } \\
\text { prepare histologic sections. }\end{array}$ \\
$\begin{array}{l}\text { Eyes } \\
\text { Skeletal muscles } \\
\text { Bone marrow }\end{array}$ & $\begin{array}{l}\text { For removal and specimen preparation, see p. 85. } \\
\text { For sampling and specimen preparation, see p. 80. }\end{array}$ & $\begin{array}{l}\text { Trteritis of ciliary and retinal vessels. } \\
\text { Clinically, polymyalgia. } \\
\text { For preparation of sections and smears, see p. 96. }\end{array}$ \\
\hline
\end{tabular}

Arteritis, Takayasu's

Synonyms: Aortic arch syndrome; pulseless disease.

\begin{tabular}{|c|c|c|}
\hline Organs and Tissues & Procedures & Possible or Expected Findings \\
\hline External examination & & Facial muscular atrophy and pigmentation. \\
\hline \multirow[t]{5}{*}{$\begin{array}{l}\text { Heart, aorta, and adjacent } \\
\text { great vessels }\end{array}$} & $\begin{array}{l}\text { For in situ aortography, clamp distal descending } \\
\text { thoracic aorta and neck vessels as distal as } \\
\text { possible from takeoff at aortic arch. }\end{array}$ & $\begin{array}{l}\text { Narrowing at origin of brachiocephalic } \\
\text { arteries. }\end{array}$ \\
\hline & $\begin{array}{l}\text { Remove heart together with aorta and long } \\
\text { sleeves of neck vessels. For coronary arterio- } \\
\text { graphy, see p. } 118 \text { (method designed to show } \\
\text { coronary ostia). }\end{array}$ & $\begin{array}{l}\text { Dilated ascending aorta. Narrowing of } \\
\text { coronary arteries at origins. Myocardial } \\
\text { infarction. }\end{array}$ \\
\hline & Test competence of aortic valve. & Aortic insufficiency.* \\
\hline & $\begin{array}{l}\text { Open aortic arch anteriorly and measure (with } \\
\text { calipers) lumen at origin of great neck vessels. }\end{array}$ & \\
\hline & $\begin{array}{l}\text { Photograph aorta and neck vessels and submit } \\
\text { samples for histologic study. Request Verhoeff- } \\
\text { van Gieson stain (p. 173). }\end{array}$ & $\begin{array}{l}\text { Aortic atherosclerosis. Thromboses of } \\
\text { brachiocephalic arteries. Giant cell arteritis.* }\end{array}$ \\
\hline Eyes and optic nerve & $\begin{array}{l}\text { For removal and specimen preparation, } \\
\text { see p. } 85 \text {. }\end{array}$ & $\begin{array}{l}\text { Atrophy of optic nerve, retina, and iris; } \\
\text { cataracts; retinal pigmentation. }\end{array}$ \\
\hline Brain & $\begin{array}{l}\text { For removal and specimen preparation, } \\
\text { see p. } 65 \text {. }\end{array}$ & Ischemic lesions. \\
\hline
\end{tabular}

\section{Artery, Patent Ductal}

Synonym: Patent ductus arteriosus.

NOTE: The basic anomaly is persistent postnatal patency of the ductal artery, usually as an isolated finding (in 75\% of cases in infants, and in $95 \%$ in adults). It is more common in premature than full-term infants and at high altitudes than at sea level. Possible complications in unoperated cases include congestive heart failure, * plexogenic pulmonary hypertension,* ductal artery aneurysm or rupture, fatal pulmonary embolism,* or sudden death. In some conditions, such as aortic atresia* or transposition with an intact ventricular septum,* ductal patency may be necessary for survival. For general dissection techniques, see p. 33.
Possible Associated Conditions: Atrial or ventricular septal defect;* coarctation of the aorta;* conotruncal anomalies; necrotizing enterocolitis in premature infants; postrubella syndrome; and valvular or vascular obstructions.

\section{Artery, Persistent Truncal}

Synonym and Related Terms: Type 1, pulmonary arteries arise from single pulmonary trunk (in 55\%); type 2, pulmonary arteries arise separately but close-by (in $35 \%$ ); type 3, pulmonary arteries arise separately but distal from one another (in 10\%).

NOTE: The basic anomaly is a common truncal artery, with truncal valve, giving rise to aorta, pulmonary arteries, and coronary arteries, usually with a ventricular septal defect. Interven- 
tions include complete Rastelli-type repair, with closure of ventricular septal defect, and insertion of valved extracardiac conduit between right ventricle and detached pulmonary arteries. For general dissection techniques, see p. 33.

Possible Associated Conditions: Absent pulmonary artery (in 15\%); atrial septal defect (in 15\%); absent ductal artery (in
$50 \%$ ); coronary ostial anomalies (in 40\%); Di George syndrome; $*$ double aortic arch; extracardiac anomalies (in 25\%); interrupted aortic arch* (in 15\%); right aortic arch (in 30\%); truncal valve insufficiency (uncommon) or stenosis (rare); truncal valve with three (in 70\%), four (in 20\%), or two (in 10\%) cusps.

\begin{tabular}{lll}
\hline Organs and Tissues & Procedures & Possible or Expected Findings \\
\hline Heart and great vessels & $\begin{array}{l}\text { If infective endocarditis is suspected, follow } \\
\text { procedures described on p. 103. }\end{array}$ & $\begin{array}{l}\text { Infective endocarditis, }{ }^{*} \text { usually of truncal } \\
\text { valve. Late postoperative conduit } \\
\text { obstruction. Postoperative late progressive } \\
\text { truncal artery dilation with truncal valve } \\
\text { insufficiency. }\end{array}$ \\
& & $\begin{array}{l}\text { Hypertensive pulmonary vascular disease. } \\
\text { Cerebral abscess, }{ }^{*} \text { if right-to-left-shunt was } \\
\text { present. }\end{array}$ \\
Brain & Request Verhoeff-van Gieson stain (p. 173). & \\
\hline
\end{tabular}

\section{Arthritis, All Types or Type Unspecified}

NOTE: For extra-articular changes, see under the name of the suspected underlying conditions. Infectious diseases that may be associated with arthritis include bacillary dysentery, ${ }^{*}$ brucellosis, ${ }^{*}$ gonorrhea, rubella, ${ }^{*}$ syphilis, ${ }^{*}$ tuberculosis, ${ }^{*}$ typhoid fever, ${ }^{*}$ and varicella.* Noninfectious diseases in this category include acromegaly, ${ }^{*}$ Behçet's syndrome, ${ }^{*}$ Felty's syndrome, ${ }^{*}$ gout, ${ }^{*}$ rheumatoid arthritis, ${ }^{*}$ and many others, too numerous to mention.

\begin{tabular}{lll}
\hline Organs and Tissues & Procedures & Possible or Expected Findings \\
\hline Joints & Remove synovial fluid and prepare smears. & In suppurative arthritis, organisms most \\
& Submit synovial fluid for microbiologic and & frequently involved are Streptococcus \\
& chemical (p. 96) study. For removal of joints, & hemolyticus, Staphylococcus aureus, \\
& prosthetic repair, and specimen preparation, & Pneumococcus, and Meningococcus. \\
& see p. 96. & \\
\hline
\end{tabular}

\section{Arthritis, Juvenile Rheumatoid}

Synonym: Juvenile chronic arthritis; Still's disease.

NOTE: Involvement of more than five joints defines the polyarticular variant of the disease.

Possible Associated Condition: Amyloidosis.*

\begin{tabular}{ll}
\hline Organs and Tissues & Procedures \\
\hline External examination & Submit samples of skin or subcutaneous lesions. \\
and skin & Prepare skeletal roentgenograms.
\end{tabular}

Possible or Expected Findings

Rheumatoid nodules.

Monarthritis or polyarthritis; abnormalities of bone, cartilage, and periosteal growth adjacent to inflamed joint(s). Osteoporosis.* In the polyarticular variant, facial asymmetry may be noted.

Blood Submit samples for serologic study and for microbiologic study (p. 102).

Heart

Lungs

Lymph nodes

Spleen

Bones and joints
Perfuse one lung with formalin (p. 47); submit one lobe for microbiologic study. Submit samples for histologic study; record average size.

Record size and weight; submit samples for histologic study.

For removal, prosthetic repair, and specimen preparation, see p. 95. Include joints of cervical spine and sacroiliac joints.
Rheumatoid factor positive in some cases.

Pericarditis.*

Interstitial pneumonitis; pleuritis. (See also under "Arthritis, rheumatoid.")

Lymphadenopathy.

Splenomegaly.

Monarthritis or severe, erosive polyarthritis; see also under "Arthritis, rheumatoid" and above under "External examination and skin." Ankylosing spondylitis* may be present. 


\begin{tabular}{lll}
\hline Organs and Tissues & Procedures & Possible or Expected Findings \\
\hline Eyes & For removal and specimen preparation, see p. 85. & Chronic iridocyclitis. \\
Other organs and tissues & & See “Arthritis, rheumatoid." \\
\hline
\end{tabular}

\section{Arthritis, Rheumatoid}

Synonyms and Related Terms: Ankylosing spondylitis;* Felty's syndrome;* juvenile rheumatoid arthritis* (Still's disease); rheumatoid disease; and others.

Possible Associated Conditions: Amyloidosis;* polymyositis (dermatomyositis*); psoriasis;* Sjögren's syndrome;* systemic lupus erythematosus; $*$ systemic vasculitis, and others.

\begin{tabular}{lll}
\hline Organs and Tissues & Procedures & Possible or Expected Findings \\
\hline $\begin{array}{l}\text { External examination } \\
\text { and skin }\end{array}$ & $\begin{array}{l}\text { Record character and extent of skin and nail } \\
\text { changes. Prepare sections of normal and } \\
\text { abnormal skin and of subcutaneous nodules. }\end{array}$ & $\begin{array}{l}\text { Subcutaneous rheumatoid nodules on } \\
\text { elbows, back, areas overlying ischial and } \\
\text { femoral tuberosities, heads of phalangeal and } \\
\text { metacarpal bones, and occiput. }\end{array}$ \\
& Prepare skeletal roentgenograms. & $\begin{array}{l}\text { Deformities and subluxation of peripheral } \\
\text { joints (see also below under "Joints"). }\end{array}$ \\
& & $\begin{array}{l}\text { Subaxial dislocation of cervical spine may be } \\
\text { cause of sudden death. }\end{array}$ \\
& & Pneumothorax; pleural empyema.* \\
Theural cavities & Prepare chest roentgenogram. &
\end{tabular}

Blood study.

Submit samples for microbiologic study (p. 102).

Keep frozen sample for serologic or

Bacteremia. immunologic study.

Heart and blood vessels For coronary arteriography, see p. 118. Open heart in direction of blood flow. For histologic sampling, see p. 30. Submit specimens with blood vessels from all organs and tissues.

Lungs Record weights. Submit one lobe for microbiologic study (p. 103). For pulmonary arteriography and bronchography, see p. 50. For perfusionfixation, see p. 47.

Esophagus

Stomach

Mesentery and intestine

Spleen

Adrenals

Lymph nodes

Neck organs
Record width of lumen.

Submit samples for histologic study.

For mesenteric angiography, see p. 55.

Submit samples from mesenteric vessels for histologic study.

Record weight.

Submit samples of axillary, cervical, mediastinal, and retroperitoneal lymph nodes for histologic study.

In patients with suspected Sjögren's syndrome,* snap-freeze sample of salivary (submaxillary) gland for immunofluorescent study.

Search for evidence of upper airway obstruction. Submit samples of base of tongue, thyroid gland, cricoarytenoid joints (see p. 96), and paralaryngeal soft tissues for histologic study.
Positive rheumatoid factor.

Rheumatoid granulomas in myocardium (septum), pericardium, and at base of aortic and mitral valves; constrictive pericarditis;* aortic stenosis; ${ }^{*}$ coronary arteritis. Systemic vasculitis (arteritis*).

Rheumatoid granulomas in pleura and lung (with pneumoconiosis*); bronchopleural fistula; rheumatoid pneumonia with interstitial pulmonary fibrosis and honeycombing; bronchiectasis;* bronchiolitis with cystic changes; pulmonary arteritis.

Pneumoconiosis* in Caplan's syndrome.* Dilatation.

Mucosal atrophy in Sjögren's syndrome.* Mesenteric vasculitis (acute necrotizing arteritis; subacute arteritis; arterial thrombosis; venulitis) and intestinal infarctions.

Splenomegaly; rupture of spleen (2).

Cortical atrophy.

Lymphadenopathy.

Atrophic sialadenitis with salivary gland atrophy and atrophy of taste buds in Sjögren's syndrome.*

Hashimoto's struma; cricoarytenoid arthritis. Rheumatoid granulomas in paralaryngeal soft tissues. 


\begin{tabular}{|c|c|c|}
\hline Organs and Tissues & Procedures & Possible or Expected Findings \\
\hline $\begin{array}{l}\text { Brain, spinal cord, } \\
\text { and pituitary gland }\end{array}$ & $\begin{array}{l}\text { For removal and specimen preparation, } \\
\text { see pp. } 65,67 \text {, and } 71 \text {, respectively. } \\
\text { For cerebral arteriography, see p. } 80 .\end{array}$ & $\begin{array}{l}\text { Rheumatoid granulomas in dura mater and in } \\
\text { leptomeninges of brain and spinal canal. } \\
\text { Cerebral vasculitis and microinfarcts. Spinal } \\
\text { cord compression after cervical subluxation } \\
\text { (see above under "External examination and } \\
\text { skin"). }\end{array}$ \\
\hline Eyes and lacrimal glands & $\begin{array}{l}\text { For removal and specimen preparation, } \\
\text { see pp. } 85 \text { and } 87 \text {, respectively. }\end{array}$ & Uveitis and scleritis. Dacryosial adenitis. \\
\hline Middle ears & $\begin{array}{l}\text { For removal and specimen preparation, } \\
\text { see p. } 72 \text {. If patient had a hearing problem, } \\
\text { prepare sections of incudomalleal joints. }\end{array}$ & $\begin{array}{l}\text { Rheumatoid arthritis of joints of middle ear } \\
\text { ossicles. }\end{array}$ \\
\hline \multirow[t]{2}{*}{ Joints } & $\begin{array}{l}\text { Remove synovial fluid from affected joints } \\
\text { for microbiologic study (p. 96). }\end{array}$ & Bacterial arthritis. \\
\hline & $\begin{array}{l}\text { For removal, prosthetic repair, and specimen } \\
\text { preparation, see p. } 96 \text {. Remove peripheral } \\
\text { diarthroidial joints together with synovia, } \\
\text { adjacent tendons, adjacent bones, and bursae. } \\
\text { Snap-freeze synovial tissue for fluorescent } \\
\text { microscopic and histochemical study. }\end{array}$ & $\begin{array}{l}\text { Destructive rheumatoid arthritis; rheumatoid } \\
\text { tenosynovitis (particularly tendon of flexor } \\
\text { digitorum profundus muscle); synovial } \\
\text { outpouchings; subluxations; osteoporosis* } \\
\text { with pseudocysts; bursitis with "rice bodies." }\end{array}$ \\
\hline Skeletal muscles & $\begin{array}{l}\text { For sampling and specimen preparation, } \\
\text { see p. } 80 .\end{array}$ & $\begin{array}{l}\text { Lymphorrhagias; perivascular nodular } \\
\text { myositis; vasculitis. }\end{array}$ \\
\hline Bone marrow & $\begin{array}{l}\text { For preparation of sections and smears, } \\
\text { see p. } 96 .\end{array}$ & $\begin{array}{l}\text { Megaloblastic changes; normoblastic } \\
\text { hypoplasia; relative plasmacytosis; } \\
\text { hemosiderosis. }\end{array}$ \\
\hline
\end{tabular}

\section{References}

1. Weyand CM, Goronzy JJ. Pathogenesis of rheumatoid arthritis. Med Clin North Am 1997;81:29-55.

2. Fishman D, Isenberg DA. Splenic involvement in rheumatic diseases. Semin Arthr Rheum 1997;27:141-155.

\section{Arthrogryposis Multiplex Congenita}

Synonyms and Related Terms: Congenital contractures; amyoplasia (1); congenital muscular dystrophy; fetal akinesia/ hypokinesia sequence.

\section{NOTE:}

Arthrogryposis (2) may be a primary muscle disease, or it may involve abnormalities of the brain, spinal cord, and/or peripheral nerves. Etiologies are numerous, as are the modes of inheritance. Critical to making the appropriate diagnosis is the collection of muscles from various sites for routine histology, muscle histochemistry, and electron microscopy. Portions of peripheral motor nerves must also be prepared for histology and electron microscopy.

\begin{tabular}{|c|c|c|}
\hline Organs and Tissues & Procedures & Possible and Expected Findings \\
\hline External examination & $\begin{array}{l}\text { Record and photograph all contractures. } \\
\text { Obtain routine external measurements and } \\
\text { body weight. Prepare full body radiographs. }\end{array}$ & $\begin{array}{l}\text { Contractures. Facial anomalies, such as } \\
\text { hypertelorism, telecanthus, epicanthal folds, } \\
\text { malformed ears, small mouth, micrognathia. }\end{array}$ \\
\hline Lungs & $\begin{array}{l}\text { Record weights; perfuse one or both lungs with } \\
\text { formalin (see p. 47) and submit samples for }\end{array}$ & Pulmonary hypoplasia. \\
\hline
\end{tabular}

Muscles histologic study.

(e.g., quadriceps, biceps, psoas, diaphragm) for histochemical study. Submit sections in glutaraldehyde and formalin for electron microscopy and histologic study, respectively. For specimen preparation see also p. 80.

Nerves Submit segments of peripheral motor nerves for electron microscopy and histologic study (see pp. 79 and 132). Request Luxol fast blue stain for myelin.

Fiber type disproportion; myofiber hypoplasia; fatty replacement; fibrosis.

Hypomyelination of nerves. 


\begin{tabular}{lll}
\hline Organs and Tissues & Procedures & Possible and Expected Findings \\
\hline Brain and spinal cord & For removal and specimen preparation, & Polymicrogyria, cortical white matter \\
& see pp. 65 and 67, respectively. Prepare for & dysplasia, variable decrease of anterior horn \\
& histologic study. & cells; increased numbers of abnormally small \\
& & anterior horn cells. \\
Placenta & Short umbilical cord. \\
\hline
\end{tabular}

\section{References}

1. Sawark JF, MacEwen GD, Scott CI. Amyoplasia (A common form of arthrogryposis). J Bone Joint S 1990;72:465-469.

2. Banker BQ. Arthrogryposis multiplex congenita: spectrum of pathologic changes. Hum Path 1986;17:656-672.

\section{Asbestosis (See "Pneumoconiosis.")}

\section{Ascites, Chylous}

\begin{tabular}{lll}
\hline Organs and Tissue & Procedures & Possible or Expected Findings \\
\hline Abdominal cavity & $\begin{array}{l}\text { Puncture abdominal cavity and submit fluid for } \\
\text { microbiologic study (p. 102). }\end{array}$ & \\
& $\begin{array}{l}\text { Record volume of exudate or transudate and } \\
\text { submit sample for determination of fat and } \\
\text { cholesterol content. }\end{array}$ & $\begin{array}{l}\text { For interpretation of chemical analysis, see } \\
\text { "Chylothorax." }\end{array}$ \\
& $\begin{array}{l}\text { Prior to routine dissection, lymphangiography } \\
\text { (see below) may be indicated. }\end{array}$ & $\begin{array}{l}\text { Lymphoma and other retroperitoneal } \\
\text { neoplasms; surgical trauma; intestinal } \\
\text { obstruction. }\end{array}$ \\
$\begin{array}{ll}\text { Intra-abdominal } \\
\text { lymphatic system }\end{array}$ & $\begin{array}{l}\text { For lymphangiography, see p. 34. Cannulate chylous cyst; intestinal } \\
\text { lymphatics as distally as possible. }\end{array}$ & $\begin{array}{l}\text { lymphangiectasia and other malformations of } \\
\text { lymph vessels. See also above under } \\
\text { "Abdominal cavity." }\end{array}$ \\
\hline
\end{tabular}

\section{Aspergillosis}

Related Term: Allergic bronchopulmonary aspergillosis.

NOTE: (1) Collect all tissues that appear to be infected. (2) Request fungal cultures. (3) Request Grocott's methenamine silver stain (p. 172). (4) No special precautions are indicated. (5) Serologic studies are available in local and state health department laboratories (p. 135). (6) This is not a reportable disease.

Possible Associated Conditions: With pulmonary aspergillosis—bronchiectasis;* bronchocentric granulomatosis; ${ }^{*}$ sarcoidosis; * tuberculosis.* With systemic aspergillosis_leukemia;* lymphoma;* and other conditions complicated by immunosuppression $(1,2)$.

\begin{tabular}{lll}
\hline Organs and Tissues & Procedures & Possible or Expected Findings \\
\hline Lungs & $\begin{array}{l}\text { Carefully make multiple parasagittal sections } \\
\text { through the unperfused lungs. Culture areas of } \\
\text { consolidation. If diagnosis was confirmed, } \\
\text { perfuse lungs with formalin (p. 47). }\end{array}$ & $\begin{array}{l}\text { Bronchiectasis;* tumor cavities; cysts. } \\
\text { Fungus ball may be present in any of these. }\end{array}$ \\
& $\begin{array}{l}\text { Prepare histologic sections from walls of cavities, } \\
\text { cavity contents, and pneumonic infiltrates. } \\
\text { Procedures depend on expected findings or } \\
\text { grossly identified abnormalities as listed in } \\
\text { right-hand column. }\end{array}$ & $\begin{array}{l}\text { Suppuration and necrotic lesions from } \\
\text { disseminated aspergillosis in heart (3), brain } \\
\text { (1), bones (1,2), and other organs (3). }\end{array}$ \\
\hline
\end{tabular}

\section{References}

1. The W, Matti BS, Marisiddaiah H, Minamoto GY. Aspergillus sinusitis in patients with AIDS: report of three cases and review. Clin Infect Dis 1995;21:529-535.

2. Gonzales-Crespo MR, Gomes-Reino JJ. Invasive aspergillosis in systemic lupus erythematosus. Semin Arthritis Rheum 1995;24:304-314.

3. Sergi C, Weitz J, Hofmann WJ, Sinn P, Eckart A, Otto G, et al. Aspergillus endocarditis, myocarditis and pericarditis complicating necrotizing fasciitis. Case report and subject review. Virchows Arch 1996;429:177-180. 


\section{Asphyxia (See "Hypoxia.")}

\section{Aspiration (See "Obstruction, acute airway.")}

\section{Assault}

NOTE: All procedures described under "Homicide" must be followed.

\section{Asthma}

NOTE: Spray death* may occur in asthma sufferers from pressurized aerosol bronchodilators.

\begin{tabular}{lll}
\hline Organs and Tissues & Procedures & Possible or Expected Findings \\
\hline $\begin{array}{l}\text { External examination } \\
\text { and skin }\end{array}$ & $\begin{array}{l}\text { Record appearance of skin and conjunctivae. } \\
\text { Palpate subcutaneous tissue to detect evidence } \\
\text { of crepitation. }\end{array}$ & $\begin{array}{l}\text { Eczema. Conjunctival hemorrhages and } \\
\text { subcutaneous emphysema may be present } \\
\text { after fatal attack. }\end{array}$ \\
Chest & $\begin{array}{l}\text { Prepare chest roentgenogram. For tests for } \\
\text { pneumothorax, see under that heading. }\end{array}$ & $\begin{array}{l}\text { Pneumothorax; mediastinal emphysema. } \\
\text { Low diaphragm (see below). }\end{array}$ \\
Blood & Submit sample for biochemical study. & $\begin{array}{l}\text { Increased IgE concentrations in fatal asthma; } \\
\text { postmortem tryptase determination is of } \\
\text { doubtful value in this regard (1). }\end{array}$ \\
Diaphragm & Record thickness and position. & Hypertrophy. Low position of diaphragm. \\
Lungs & Perfuse one lung with formalin (p. 47). & Hyperinflated lungs.
\end{tabular}

Because mucous plugs may block bronchial tree, attach perfusion apparatus to pulmonary artery or to bronchus and pulmonary artery. Monitor perfusion to ensure proper inflation.

Prepare photograph of fixed cut section.

Submit samples of pulmonary parenchyma and bronchi for histologic study. Request azure-eosin and Verhoeff-van Gieson stains (p. 172).

Heart
Esophagus
Stomach and duodenum
Intestine
Liver
Kidneys

Neck organs

Brain and spinal cord
Record weight and thickness of walls.

Leave attached to stomach.

Photograph and submit samples for histologic study.

Record weights. Submit samples of both kidneys for histologic study.

Submit samples of larynx and trachea for histologic study. Request azure-eosin stains (p. 172).

For removal and specimen preparation, see pp. 65 and 67 , respectively.
Nasal cavities

Bone marrow
For exposure, see p. 71. Submit samples of mucosa and polyps for histologic study. Request azure-eosin stains (p. 172). For preparation of sections and smears, see p. 96.
Thick-walled bronchi with prominent viscid mucous plugs.

Typical microscopic inflammatory changes (2). Asthmatic bronchitis with eosinophilic infiltrates. Bronchocentric granulomatosis.* Pulmonary atherosclerosis with breakup of elastic fibers.

Cor pulmonale.

Reflux esophagitis (3).

Peptic ulcer.*

Pneumatosis of small intestine; emphysema of colon.

Centrilobular congestion and necrosis.

Kidneys and glomeruli may be enlarged.

Laryngitis and tracheitis.

Petechial hemorrhages in hypothalamus; necrosis of cerebellar folia; anoxic changes in cortex, globus pallidus, thalamus, Sommer's sector of hippocampus, and Purkinje cells of cerebellum. Suspected changes in anterior horn cells of spinal cord in patients with asthma-associated poliomyelitis-like illness (Hopkins syndrome) (4).

Allergic polyps and other allergic inflammatory changes (5).

Increased erythropoiesis. 


\section{References}

1. Salkie ML, Mitchell I, Revers CW, Karkhanis A, Butt J, Tough S, Green FH. Postmortem serum levels of tryptase and total and specific IgE in fatal asthma. Allergy Asthma Proc 1998;19:131-133.

2. Hogg JC. The pathology of asthma. APMIS 1997;105:735-745.

3. Sontag SJ. Gastroesophageal reflux and asthma. Am J Med 1997;103: $84 \mathrm{~S}-90 \mathrm{~S}$.
4. Mizuno Y, Komori S, Shigetomo R, Kurihara E, Tamagawa K, Komiya K. Polyomyelitis-like illness after acute asthma (Hopkins syndrome): a histological study of biopsied muscle in a case. Brain Dev 1995; 17:126-129.

5. Glovsky MM. Upper airway involvement in bronchial asthma. Curr Opin Pulm Med 1998;4:54-58.

\section{Ataxia, Friedreich's (See "Degeneration, spinocerebellar.")}

\section{Atherosclerosis}

Synonyms and Related Terms: Arteriosclerosis obliterans.

\begin{tabular}{lll}
\hline Organs and Tissues & Procedures & Possible or Expected Findings \\
\hline Arteries & $\begin{array}{l}\text { For grading of atherosclerotic lesions, } \\
\text { see p. 34. For angiographic techniques, } \\
\text { see under affected organ or p. 118. }\end{array}$ & Atherosclerotic aneurysm.* \\
Other organs & & $\begin{array}{l}\text { Manifestations of vascular occlusions, such } \\
\text { as infarctions and gangrene. Manifestations } \\
\text { of diabetes mellitus.* }\end{array}$ \\
\hline
\end{tabular}

\section{Atresia, Anal and Rectal (See “Anus, imperforate.”)}

\section{Atresia, Aortic Valvular}

Synonym: Aortic atresia; aortic atresia with intact ventricular septum; hypoplastic left heart syndrome.

NOTE: The basic anomaly is an imperforate aortic valve, with secondary hypoplasia of left-sided chambers and ascending aorta. For possible surgical interventions, see two-stage Norwood and modified Fontan procedures in Chapter 3 Appendices 3 and 4, p. 41. For general dissection techniques, see p. 33.

Possible Associated Conditions: Atrial septal defect* (or patent foramen ovale, usually restrictive); dilatation of myocardial sinusoids that communicate with coronary vessels; dilatation of right atrium, right ventricle, and pulmonary trunk; fibroelastosis of left atrial and left ventricular endocardium; hypertrophy of ventricular and atrial walls; hypoplastic left atrium, mitral valve, left ventricle, and ascending aorta; mitral atresia* with minute left ventricle; patent ductal artery (ductus arteriosus); small left ventricle with hypertrophic wall; tubular hypoplasia of aortic arch, with or without discrete coarctation.

\section{Atresia, Biliary}

Synonyms and Related Terms: Congenital biliary atresia; extrahepatic biliary atresia; infantile obstructive cholangiopathy; syndromic (Alagille's syndrome) or nonsyndromic paucity of intrahepatic bile ducts ("intrahepatic" biliary atresia).

Possible Associated Conditions: Alpha ${ }_{1}$-antitrypsin deficiency;* choledochal cyst;* congenital rubella syndrome;* polysplenia syndrome* (1); small bowel atresia; trisomy 17-18; trisomy 21; Turner's syndrome;* viral infections (cytomegalovirus infection;* rubella*).

\begin{tabular}{lll}
\hline Organs and Tissues & Procedures & Possible or Expected Findings \\
\hline External examination & & Jaundice. \\
Blood & Submit samples for serologic or microbiologic & Congenital rubella and other viral infections.
\end{tabular}

\section{Blood}

Extrahepatic bile ducts and liver study (p. 102).

Submit sample of serum for determination of alpha $_{1}$-antitrypsin concentrations. Submit sample for chromosomal analysis (p. 108). After removal of small and large bowel, open duodenum anteriorly. Squeeze gallbladder and record whether bile appeared at papilla.

For cholangiography, see p. 56.

Dissect extrahepatic bile ducts in situ or leave hepatoduodenal ligament intact for later fixation and sectioning (see below). Record appearance and contents of gallbladder and course of cystic duct.

In postoperative cases, submit sample of anastomosed hepatic hilar tissue for demonstration of microscopic bile ducts.
Alpha ${ }_{1}$-Antitrypsin deficiency;* defects in bile acid synthesis.

Chromosomal abnormalities.

In atresia of the hepatic duct, the gallbladder will be empty. In isolated atresia of the common bile duct, the gallbladder contains bile but it cannot be squeezed into the duodenum.

Atresia or hypoplasia of bile duct(s); choledochal cyst(s).

Biliary drainage created by Kasai operation. 


\begin{tabular}{lll}
\hline Organs and Tissues & Procedures & Possible or Expected Findings \\
\hline $\begin{array}{l}\text { Extrahepatic bile ducts } \\
\text { and liver } \\
\text { (continued) }\end{array}$ & $\begin{array}{l}\text { Remove liver with hepatoduodenal ligament. } \\
\text { Prepare horizontal sections through ligament } \\
\text { and submit for histologic identification of ducts } \\
\text { or duct remnants. } \\
\text { Prepare frontal slices of liver and sample for } \\
\text { histologic study. Request PAS stain with diastase } \\
\text { digestion (p. 173). }\end{array}$ & $\begin{array}{l}\text { Obliterative cholangiopathy (2). } \\
\text { Intrahepatic cholelithiasis; postoperative } \\
\text { ascending cholangitis; secondary biliary } \\
\text { cirrhosis; giant cell transformation; paucity } \\
\text { of intrahepatic bile ducts. PAS-positive } \\
\text { inclusions in alpha } \text {-antitrypsin deficiency.* }^{*}\end{array}$ \\
& $\begin{array}{l}\text { Polysplenia syndrome* (1) with malrotation, } \\
\text { situs inversus, preduodenal portal vein, } \\
\text { absent inferior vena cava, anomalous hepatic } \\
\text { grossly identified abnormalities as listed in } \\
\text { right-hand column. }\end{array}$ & $\begin{array}{l}\text { abrery supply, and cardiac defects. For other } \\
\text { abnormalities outside the biliary tree, see } \\
\text { under "Possible Associated Conditions"). } \\
\text { Nephromegaly (3). }\end{array}$ \\
\hline
\end{tabular}

\section{References}

1. Vazquez J, Lopex Gutierrez JC, Gamez M, Lopez-Santamaria M, Murcia J, Larrauri J, et al. Biliary atresia and the polysplenia syndrome: its impact on final outcome. J Pediatr Surg 1995;30:485-487.

2. Lefkowitch JH. Biliary atresia. Mayo Clin Proc 1998;73:90-95.

3. Tsau YK, Chen CH, Chang MH, Teng RJ, Lu MY, Lee PI. Nephromegaly and elevated hepatocyte growth factor in children with biliary atresia. Am J Kidney Dis 1997;29:188-192.

Atresia, Cardiac Valves (See "Atresia, aortic valvular," "Atresia, mitral valvular," "Atresia pulmonary valvular, with intact ventricular septum," "Atresia, pulmonary valvular, with ventricular septal defect," and "Atresia, tricuspid valvular.")

\section{Atresia, Duodenal}

Possible Associated Conditions: With membranous obstruction of the duodenum - annular pancreas; atresia of esophagus* with tracheoesophageal fistula; congenital heart disease; cystic fibrosis;* Down's syndrome;* Hirschsprung's disease; imperforate anus* or other congenital obstructions of the intestinal tract (1); intestinal malrotation; lumbosacral, rib-, and digit/ limb anomalies; single umbilical artery; spinal defects; undescended testis (1).

\section{NOTE:}

See also under "Atresia, small intestinal."

\begin{tabular}{lll}
\hline Organs and Tissues & Procedures & Possible or Expected Findings \\
\hline $\begin{array}{l}\text { Fascia lata, blood, } \\
\text { or liver }\end{array}$ & $\begin{array}{l}\text { Obtain cells for tissue culture for karyotype } \\
\text { analysis (see p. 108). }\end{array}$ & Trisomy 21 and other aneuploidies. \\
& $\begin{array}{l}\text { Photograph and dissect organ in situ. Inflate } \\
\text { duodenum with formalin; open only after } \\
\text { fixation. For air-drying techniques and } \\
\text { for mesenteric angiography, see p. 55, } \\
\text { respectively. }\end{array}$ & $\begin{array}{l}\text { Fibrous membrane across lumen of intact } \\
\text { duodenum. Septum may have orifice so that } \\
\text { duodenal stenosis results. Rarely, fusiform } \\
\text { narrowing. }\end{array}$ \\
Other organs & & $\begin{array}{l}\text { See above under "Possible Associated } \\
\text { Findings." }\end{array}$ \\
\hline
\end{tabular}

\section{Reference}

1. Kimble RM, Harding J, Kolbe A. Additional congenital anomalies in babies with gut atresia or stenosis: when to investigate, and which investigation. Pediatr Surg Intl 1997;12:565-570.

\section{Atresia, Esophageal}

Possible Associated Condition: Congenital rubella syndrome;*VACTERL syndrome (Vertebral anomalies, $\underline{\text { Anal atre- }}$

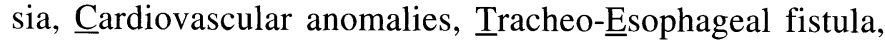
Rib anomalies, Limb anomalies) (1).

\begin{tabular}{lll}
\hline Organs and Tissues & Procedures & Possible or Expected Findings \\
\hline $\begin{array}{l}\text { External examination } \\
\text { Chest organs }\end{array}$ & $\begin{array}{l}\text { Photograph the atresia prior to opening the } \\
\text { esophagus. Open the esophagus posteriorly or } \\
\text { the trachea anteriorly for best visualization }\end{array}$ & $\begin{array}{l}\text { Limb anomalies. } \\
\text { Tracheoesophageal fistula or } \\
\text { tracheoesophageal atresia; cardiac, rib, and } \\
\text { (see Chapter 4, Fig. 4-1 in Part I). }\end{array}$
\end{tabular}




\begin{tabular}{lll}
\hline Organs and Tissues & Procedures & Possible or Expected Findings \\
\hline Abdominal organs & $\begin{array}{l}\text { Photograph all anomalies. Procedures depend on } \\
\text { expected findings or grossly identified } \\
\text { abnormalities as listed in right-hand column. }\end{array}$ & $\begin{array}{l}\text { Renal agenesis or dysplasia; anal atresia; } \\
\text { duodenal or other small intestinal atresia;* }\end{array}$ \\
& \begin{tabular}{l} 
lumbosacral anomalies; undescended testis(2). \\
\hline
\end{tabular}
\end{tabular}

\section{References}

1. Perel Y, Butenandt O, Carrere A, Saura R, Fayon M, Lamireau T, Vergnes P. Oesophageal atresia, VACTERL association: Fanconi's anemia related spectrum of anomalies. Arch Dis Child 1998;78:375376.

2. Kimble RM, Harding J, Kolbe A. Additional congenital anomalies in babies with gut atresia or stenosis: when to investigate, and which investigation. Pediatr Surg Intl 1997;12:565-570.

\section{Atresia, Mitral Valvular}

Synonym: Congenital mitral atresia.

NOTE: For general dissection techniques, see p. 33.

Possible Associated Conditions: Aortic valvular hypoplasia or atresia;* closed foramen ovale with anomalous venous channel (levoatriocardinal vein) connecting left atrium with left innominate vein; patent foramen ovale; transposition of great arteries associated with single functional ventricle; * ventricular septal defect(s).*

\section{Atresia, Pulmonary Valvular, With Intact Ventricular Septum}

NOTE: The basic anomaly is an imperforate pulmonary valve, with a hypoplastic right ventricle. In unoperated cases, ductal closure is the most common cause of death. For possible surgical interventions, see modified Blalock-Taussig shunt, modified Fontan procedure, and pulmonary valvulotomy in Chapter 3 Appendix 3-4, p. 41. For general dissection techniques, see p. 33.

Possible Associated Conditions: Dilated myocardial sinusoids that may communicate with epicardial coronary arteries or veins; patent ductal artery (ductus arteriosus); patent oval foramen (foramen orale); tricuspid atresia with minute right ventricle; tricuspid stenosis with hypoplastic right ventricle (in 95\%); tricuspid insufficiency with dilated right ventricle (in 5\%).

\section{Atresia, Pulmonary Valvular, With Ventricular Septal Defect}

Synonym: Tetralogy of Fallot with pulmonary atresia.

NOTE: The basic anomaly is atresia of the pulmonary valve and of variable length of pulmonary artery, and ventricular septal defect (membranous or outlet type), with overriding aorta, and with pulmonary blood supply from ductal or systemic collateral arteries. For possible surgical interventions, see Rastelli-type repair and unifocalization of multiple collateral arteries in Chapter 3 Appendix 3-4, p. 41. For general dissection techniques, see p. 33.

Possible Associated Conditions: Right ventricular outflow tract a short blind-ended pouch (70\%) or absent (30\%); atresia of pulmonary artery bifurcation, with nonconfluent pulmonary arteries; right aortic arch (40\%); atrial septal defect (50\%); persistent left superior vena cava; anomalous pulmonary venous connection; tricuspid stenosis or atresia; complete atrioventricular septal defect; transposed great arteries; double inlet left ventricle; asplenia, polysplenia, or velocardiofacial syndromes; dilated ascending aorta, with aortic insufficiency.

\section{Atresia, Small Intestinal}

Related Term: Jejuno-ileal atresia.

Possible Associated Findings: Esophageal atresia* with tracheoesophageal fistula; lumbosacral, rib-, or digit/limb anomalies; undescended testes (1).

NOTE: See also under "Atresia, duodenal."

\begin{tabular}{lll}
\hline Organs and Tissues & Procedures & Possible or Expected Findings \\
\hline Fascia lata, blood, or liver & $\begin{array}{l}\text { These specimens should be collected using } \\
\text { aseptic technique for tissue culture for } \\
\text { chromosome analysis (see Chapter 10). }\end{array}$ & Trisomy 21. \\
Intestinal tract & $\begin{array}{l}\text { For mesenteric angiography, see p. 55. } \\
\text { Leave mesentery attached to small bowel, } \\
\text { particularly to the atretic portion. }\end{array}$ & $\begin{array}{l}\text { Multiple atresias; proximal dilatation; } \\
\text { volvulus; malrotation; meconium impaction; } \\
\text { other evidence of cystic fibrosis. Anorectal } \\
\text { malformation }(1) .\end{array}$ \\
Pancreas & Annular pancreas (1). \\
\hline
\end{tabular}

\section{Reference}

1. Kimble RM, Harding J, Kolbe A. Additional congenital anomalies in babies with gut atresia or stenosis: when to investigate, and which investigation. Pediatr Surg Intl 1997;12:565-570.

\section{Atresia, Tricuspid Valvular}

NOTE: The basic anomaly is an absent right atrioventricular connection $(85 \%)$ or imperforate tricuspid valve $(15 \%)$, with a hypoplastic right ventricle (100\%), muscular ventricular septal defect $(90 \%)$ that is restrictive $(85 \%)$, and a patent oval for- amen $(80 \%)$ or secundum atrial septal defect $(20 \%)$. For possible surgical interventions, see modified Fontan or Glenn procedures in Chapter 3 Appendix 3-4, p. 41. For general dissection techniques, see p. 33.

Possible Associated Conditions: Juxtaposed atrial appendages; large left ventricular valvular orifice; large left ventricular chamber; persistent left superior vena cava; pulmonary atresia; transposition of the great arteries $(25 \%)$, with aortic co-arctation ( $35 \%$ of those); anomalies of musculoskeletal or digestive systems (20\%); Down's, ${ }^{*}$ asplenia, or other syndromes. 


\section{Atresia, Urethral}

\begin{tabular}{lll}
\hline Organs and Tissues & Procedures & Possible or Expected Findings \\
\hline Pelvic organs & Prepare urogram (see pp. 59 and 62). & $\begin{array}{l}\text { Posterior urethral valves; strictures; absence } \\
\text { For canalization of penile urethra; dilated }\end{array}$ \\
& $\begin{array}{l}\text { Fee p. 59. Leave ureters and kidneys attached to } \\
\text { bladder. Open penile urethra (see Figs. 5-12; }\end{array}$ & $\begin{array}{l}\text { bladder; hypoplastic prostate; hydroureters } \\
\text { and hydronephrosis; } * \text { renal cystic dysplasia; }\end{array}$ \\
& $\begin{array}{l}\text { p. 63). Search for fistulas. If there is evidence } \\
\text { of drainage via the urachus, demonstrate this }\end{array}$ & $\begin{array}{l}\text { Ascites with attenuation of anterior } \\
\text { before removal of pelvic organs. }\end{array}$ \\
\end{tabular}

\section{Atrial Septal Defect (See “Defect, atrial septal.”)}

\section{Atrium, Common (See "Defect, atrial septal.")}

\section{Atrophy, Multiple System}

Synonyms and Related Terms: Olivopontocerebellar atrophy, Shy-Drager syndrome, striatonigral degeneration.

\begin{tabular}{lll}
\hline Organs and Tissues & Procedures & Possible or Expected Findings \\
\hline $\begin{array}{c}\text { Brain, spinal cord, and } \\
\text { paraspinal sympathetic } \\
\text { chain }\end{array}$ & $\begin{array}{l}\text { For removal and specimen preparation of brain } \\
\text { and spinal cord, see pp. 65 and 67, respectively. }\end{array}$ & $\begin{array}{l}\text { Cell loss and gliosis with characteristic } \\
\text { cytoplasmic and nuclear glial and neuronal }\end{array}$ \\
& $\begin{array}{l}\text { Modified Bielschowsky, Bodian or Gallyas silver } \\
\text { stains are necessary to highlight the characteristic }\end{array}$ & $\begin{array}{l}\text { inclusions and neuropil threads in affected } \\
\text { areas. Clinical subtype and duration of illness }\end{array}$ \\
& glial cytoplasmic inclusions (see p. 172). & influence distribution of lesions. Involved \\
Record pallor of white matter tracts related to & areas include: putamen, especially dorso- \\
& neuronal loss in affected areas. This can be seen & lateral, substantia nigra, locus coeruleus, \\
especially in external capsule, striatopallidal & cerebellar cortex (Purkinje's cells), basis \\
fibers, cerebellar white matter, cerebellar & pontis, inferior olive, dorsal motor nucleus of \\
& peduncles and transverse pontine fibers. & vagus, intermediolateral column of spinal \\
& Immunostain for synuclein is positive in & \\
& cord. & \\
\hline
\end{tabular}

\section{Atrophy, Pick's Lobar (See “Disease, Pick's.”)}

\section{Atrophy, Progressive Spinal Muscular (See "Disease, motor neuron.")}

\section{Atropine (See "Poisoning, atropine.")}

\section{Attack, Transient Cerebral Ischemic}

Synonyms and Related Terms: Cerebrovascular disease; transient cerebral ischemia; transient stroke.

\begin{tabular}{lll}
\hline Organs and Tissues & Procedures & Possible or Expected Findings \\
\hline Heart & $\begin{array}{l}\text { If infective endocarditis* is suspected, follow } \\
\text { procedures described on p. 102. }\end{array}$ & $\begin{array}{l}\text { Vegetative endocarditis; mural cardiac } \\
\text { thromboses. }\end{array}$ \\
$\begin{array}{l}\text { Aorta and cervical } \\
\text { arteries }\end{array}$ & $\begin{array}{l}\text { For dissection of carotid and vertebral arteries, } \\
\text { Aortic, carotid, and vertebral atherosclerosis } \\
\text { (see also under "Infarction, cerebral"). }\end{array}$ \\
& see p. 82. & $\begin{array}{l}\text { Atherosclerotic or other type of stenosis of } \\
\text { subclavian artery proximal to takeoff of }\end{array}$ \\
Brain & Fortebral artery (subclavian steal syndrome). \\
& see p. 65. For cerebral arteriography, see p. 80. & Basilar atherosclerosis. \\
\hline
\end{tabular}


Bagassosis (See "Pneumoconiosis.")

\section{Barbiturate(s) (See “Poisoning, barbiturate(s).") \\ Baritosis (See "Pneumoconiosis.")}

\section{Bartonellosis}

Synonyms and Related Terms: Bacillary angiomatosis (1); Bartonella bacilliformis, henselae, or quintana infection; Carrión's disease; cat scratch disease (1);* Oroya fever; Peruvian anemia; verruga peruana.
NOTE: (1) Collect all tissues that appear to be infected. (2) Organisms are usually demonstrated by direct stains rather than by culture. Detection by polymerase chain reaction (PCR) is possible (2). (3) Request Giemsa stains (p. 172). (4) No special precautions are indicated. (5) Serologic studies are available from the Center for Disease Control and Prevention, Atlanta GA (p. 135). (6) This is a reportable disease.

Possible Associated Conditions: Acquired immunodeficiency syndrome (AIDS)* and other immunodeficiency states (3); hemolytic anemia;* Salmonella infection.

\begin{tabular}{|c|c|c|}
\hline Organs and Tissues & Procedures & Possible or Expected Findings \\
\hline $\begin{array}{l}\text { External examination } \\
\text { and skin }\end{array}$ & $\begin{array}{l}\text { Prepare sections of skin lesions. Request Giemsa } \\
\text { stain (p. 172). }\end{array}$ & $\begin{array}{l}\text { Jaundice. Miliary and nodular skin lesions } \\
\text { with or without ulceration. Histologically, } \\
\text { pigmented (hemosiderin) vascular } \\
\text { granulomas. Bacillary angiomatosis (1). }\end{array}$ \\
\hline Blood & Prepare smears. Request Giemsa stain (p. 172). & Bartonella in erythrocytes. \\
\hline $\begin{array}{l}\text { Blood and lymphatic } \\
\text { vessels (all organs } \\
\text { and lesions) }\end{array}$ & Request Giemsa stain (p. 172). & $\begin{array}{l}\text { Bartonella bacilliformis in swollen } \\
\text { reticuloendothelial cells lining blood and } \\
\text { lymphatic vessels. Thromboses. } \\
\text { Erythrophagocytosis. }\end{array}$ \\
\hline Heart & $\begin{array}{l}\text { For demonstration of fat, prepare frozen section } \\
\text { of myocardium with Sudan IV stain. }\end{array}$ & $\begin{array}{l}\text { Fatty changes of myocardium in anemic } \\
\text { patients. }\end{array}$ \\
\hline Liver and spleen & $\begin{array}{l}\text { Record weights. Submit samples for histologic } \\
\text { study and request Giemsa and Gomori iron stains } \\
\text { (p. 172). }\end{array}$ & $\begin{array}{l}\text { Centrilobular hepatic necrosis; bacillary } \\
\text { peliosis hepatis and bacillary splenitis; } \\
\text { granulomatous hepatitis (3); hemosiderosis } \\
\text { of liver and spleen. Erythrophagocytosis; } \\
\text { thromboses; necrosis (3); and infarcts of } \\
\text { spleen. }\end{array}$ \\
\hline Lymph nodes & See above under "Liver and Spleen." & $\begin{array}{l}\text { Lymphadenopathy (see above under } \\
\text { "Blood and lymphatic vessels"). }\end{array}$ \\
\hline Bone marrow & See above under "Liver and Spleen." & Erythroid hyperplasia. \\
\hline
\end{tabular}

\section{References}

1. Wong R, Tappero J, Cockerell CJ. Bacillary angiomatosis and other Bartonella species infections. Semin Cutan Med Surg 1997;16:188-199.

2. Goldenberger D, Zbinden R, Perschil I, Altwegg M. Nachweis von Bartonella (Rochalimaea) henselae/B. quintana mittels PolymeraseKettenreaktion (PCR). Schweiz Med Wschr 1996;126:207-213.
3. Liston TE, Koehler JE. Granulomatous hepatitis and necrotizing splenitis due to Bartonella henselae in a patient with cancer: case report and review of hepatosplenic manifestations of bartonella infections. Clin Infect Dis 1996;22:951-957. 


\section{Beriberi}

Synonyms and Related Terms: Thiamine deficiency; Wernicke encephalopathy (cerebral beriberi).

Possible Associated Conditions: Chronic alcoholism; chronic peritoneal dialysis; hemodialysis; Wernicke disease; WernickeKorsakoff syndrome.*

\begin{tabular}{lll}
\hline Organs and Tissues & Procedures & Possible or Expected Findings \\
\hline $\begin{array}{l}\text { External examination } \\
\text { and oral cavity }\end{array}$ & & Evidence of malnutrition;* edema. Glossitis. \\
Heart & $\begin{array}{l}\text { Record weight and submit samples for } \\
\text { histologic study (p. 30). }\end{array}$ & $\begin{array}{l}\text { Alcoholic cardiomyopathy;* cardiac } \\
\text { hypertrophy.* }\end{array}$ \\
$\begin{array}{l}\text { Brain and spinal cord } \\
\text { with dorsal-root } \\
\text { ganglia }\end{array}$ & $\begin{array}{l}\text { For removal and specimen preparation, see } \\
\text { pp. 65, 67, and 69, respectively. Request } \\
\text { Luxol fast blue and Bielschowsky stains } \\
\text { (p. 172) }\end{array}$ & $\begin{array}{l}\text { For cerebral changes, see "Syndrome, } \\
\text { Wernicke-Korsakoff." }\end{array}$ \\
$\begin{array}{l}\text { Ferebral, spinal, and } \\
\text { peripheral nerves }\end{array}$ & peripheral nerves, see p. 79. & \\
& & $\begin{array}{l}\text { Axonal degeneration with relative sparing of } \\
\text { small myelinated and unmyelinated fibers. } \\
\text { Proximal segmental demyelination is }\end{array}$ \\
& & $\begin{array}{l}\text { considered a secondary phenomenon }(1) . \\
\text { Degeneration may also occur in terminal } \\
\text { branches of vagus and phrenic nerves. }\end{array}$ \\
\hline
\end{tabular}

Reference

1. Windebank AJ. Polyneuropathy due to nutritional deficiency and alcoholism. In: Peripheral Neuropathy, vol. 2. Dyck PJ, Thomas PK, eds., W.B. Saunders, Philadelphia, PA, 1993, pp. 1310-1321.

\section{Berylliosis}

NOTE: Close similarities exist between berylliosis and sarcoidosis $(1)^{*}$.

\begin{tabular}{|c|c|c|}
\hline Organs and Tissues & Procedures & Possible or Expected Findings \\
\hline Skin & Prepare sections from various sites. & Granulomas. \\
\hline Vitreous & $\begin{array}{l}\text { For removal and specimen preparation, } \\
\text { see p. } 85 \text {. }\end{array}$ & $\begin{array}{l}\text { Increased calcium concentration (associated } \\
\text { with hypercalcemia }[1] \text { ). }\end{array}$ \\
\hline Lungs & $\begin{array}{l}\text { Perfuse one lung with formalin (p. 47). Freeze } \\
\text { one lobe for possible chemical study. See also } \\
\text { under "Pneumoconiosis." }\end{array}$ & $\begin{array}{l}\text { Chronic interstitial and granulomatous } \\
\text { pneumonia. }\end{array}$ \\
\hline Other organs & $\begin{array}{l}\text { Procedures depend on expected findings or } \\
\text { grossly identified abnormalities as listed in } \\
\text { right-hand column. }\end{array}$ & $\begin{array}{l}\text { Noncaseating tuberculoid granulomas with } \\
\text { giant cells and calcific inclusions in liver, } \\
\text { spleen, lymph nodes, and other organs. } \\
\text { Nephrolithiasis (1). }\end{array}$ \\
\hline
\end{tabular}

\section{Reference}

1. Rossman MD. Chronic beryllium disease: diagnosis and management. Environm Health Perspect 1996;104:945-947.

\section{Bilharziasis (See "Schistosomiasis.")}

Bismuth (See "Poisoning, bismuth.")

Blastomycosis, European (See “Cryptococcosis.”)

\section{Blastomycosis, North American}

Synonym: Blastomyces dermatitidis infection.

NOTE: (1) Collect all tissues that appear to be infected. (2) Request fungal cultures. (3) Request Grocott's methenamine silver stain (p. 172). (4) No special precautions are indicated. (5) Serologic studies are available from the state health department laboratories (p. 135). (6) This is not a reportable disease. 


\begin{tabular}{|c|c|c|}
\hline Organs and Tissues & Procedures & Possible or Expected Findings \\
\hline \multirow[t]{3}{*}{$\begin{array}{l}\text { External examination } \\
\text { and skin }\end{array}$} & $\begin{array}{l}\text { Prepare sections of skin and of subcutaneous } \\
\text { lesions. Submit scrapings of skin lesion for } \\
\text { fungal cultures. }\end{array}$ & $\begin{array}{l}\text { Weeping and crusted elevated skin lesions, } \\
\text { predominantly of face and hands. Abscesses, } \\
\text { fistulas, and ulcers with central healing and } \\
\text { scarring may be present. }\end{array}$ \\
\hline & Request mucicarmine stain (p. 173). & $\begin{array}{l}\text { Organisms should not be stainable with } \\
\text { mucicarmine. }\end{array}$ \\
\hline & $\begin{array}{l}\text { Prepare chest roentgenogram and roentgeno- } \\
\text { graphic survey of bones. }\end{array}$ & $\begin{array}{l}\text { Pulmonary infiltrates; osteomyelitis* and } \\
\text { periostitis of thoracic, lumbar, and sacral } \\
\text { spine, long bones of lower extremities, pelvic } \\
\text { bones, and ribs (in this order of frequency). }\end{array}$ \\
\hline Lungs & $\begin{array}{l}\text { Perfuse one lung with formalin (p. } 47 \text { ). } \\
\text { Photograph cut surface. For histologic staining, } \\
\text { see above under "External examination and skin." }\end{array}$ & $\begin{array}{l}\text { Chronic pneumonia; possibly, suppurative } \\
\text { and granulomatous lesions; rarely, cavitation } \\
\text { and calcification. }\end{array}$ \\
\hline Other organs and tissues & $\begin{array}{l}\text { Prepare cultures of grossly affected organs and } \\
\text { tissues. Other procedures depend on expected } \\
\text { findings or grossly identified abnormalities as } \\
\text { listed in right-hand column. }\end{array}$ & $\begin{array}{l}\text { Involvement probably secondary to } \\
\text { hematogenous dissemination; cerebral } \\
\text { abscess;* meningitis;* adrenalitis; } \\
\text { endocarditis;* pericarditis;* thyroiditis.* } \\
\text { Other organs, such as eyes and larynx may } \\
\text { also be affected. }\end{array}$ \\
\hline Genital organs & For dissection techniques, see Part I, Chapter 5. & $\begin{array}{l}\text { Inflammatory infiltrates-rarely with } \\
\text { fistulas-of prostate, epididymis, and } \\
\text { seminal vesicles. }\end{array}$ \\
\hline Bones & $\begin{array}{l}\text { For removal, prosthetic repair, and specimen } \\
\text { preparation, see p. } 95 \text {. }\end{array}$ & $\begin{array}{l}\text { Osteomyelitis* or periostitis (see above under } \\
\text { "External examination and skin"). Psoas } \\
\text { abscess may be present. }\end{array}$ \\
\hline
\end{tabular}

\section{Blastomycosis, South American \\ (See "Paracoccidioidomycosis.")}

\section{Block (Heart) (See “Arrhythmia, cardiac.”)}

\section{Bodies, Foreign}

If a foreign body is discovered during a medicolegal autopsy or if the discovery of a foreign body may have medicolegal implications (e.g., presence of a surgical instrument in the abdominal cavity), the rules of the chain of custody apply (p. 17). For the handling of bullets or bullet fragments, see "Injury, firearm." For museum display of foreign bodies, see p. 137. Metallic foreign objects are particularly suitable for embedding in plastic for display (p. 138). If analysis of foreign material is required, commercial laboratories may be helpful.

\section{Bolus (See "Obstruction, acute airway.")}

\section{Botulism}

Synonym: Clostridium botulinum infection.

NOTE: (1) Submit sample of feces (1). Best confirmation of diagnosis is demonstration of toxin in the same food that the victim ingested. (2) Cultures are usually not indicated. (3) Special stains are usually not indicated. (4) No special precautions are indicated. (5) Serologic studies and toxin assays are available from the state health department laboratories (p. 135). (6) This is a reportable disease.

\begin{tabular}{|c|c|c|}
\hline Organs and Tissues & Procedures & Possible or Expected Findings \\
\hline Blood & $\begin{array}{l}\text { Refrigerate a specimen until toxicologic study } \\
\text { of serum can be done. }\end{array}$ & $\begin{array}{l}\text { Toxin lethal to mice. Can be neutralized } \\
\text { by specific antitoxin. }\end{array}$ \\
\hline Other organs and tissues & & $\begin{array}{l}\text { No diagnostic morphologic findings. } \\
\text { Aspiration;* bronchopneumonia; } \\
\text { manifestations of hypoxia.* }\end{array}$ \\
\hline $\begin{array}{l}\text { Serum, gastric, } \\
\text { or intestinal contents; } \\
\text { stool return form sterile } \\
\text { water enema; exudate } \\
\text { from wound }\end{array}$ & Submit for toxicologic study. & $\begin{array}{l}\text { Clostridium botulinum and its toxins may } \\
\text { be found in feces. }\end{array}$ \\
\hline
\end{tabular}

1. Dezfulian M, Hatheway CL, Yolken RH, Bartlett JG. Enzyme-linked immunosorbent assay for detection of Clostridium botulinum type A and type B toxins in stool samples of infants with botulism. J Clin Microbiol 1984;20(3):379-383. 


\section{Bromide (See “Poisoning, bromide.”)}

\section{Bronchiectasis}

Possible Associated Conditions: Abnormalities of airway cartilage (Williams-Campbell syndrome; Mounier-Kahn syndrome); allergic bronchopulmonary fungal disease; alpha ${ }_{1}$-antitrypsin deficiency;* amyloidosis;* cystic fibrosis;* $\operatorname{IgA}$ deficiency with or without deficiency of IgG subclasses; Kartagener's syndrome (situs inversus, chronic sinusitis, and bronchiectasis) and other primary ciliary dyskinesias; obstructive azoospermia (Young syndrome); panhypogammaglobulinemia; ulcerative colitis; rheumatoid arthritis;* yellow nail syndrome (hypoplastic lymphatics).

\begin{tabular}{|c|c|c|}
\hline Organs and Tissues & Procedures & Possible or Expected Findings \\
\hline \multirow[t]{2}{*}{ External examination } & & Clubbing of fingers and toes. \\
\hline & Prepare chest roentgenogram. & $\begin{array}{l}\text { Pneumothorax;* pulmonary infiltrates; } \\
\text { pleural effusion or exudate.* }\end{array}$ \\
\hline Chest cavity & $\begin{array}{l}\text { For tests for pneumothorax, see under that } \\
\text { heading. }\end{array}$ & $\begin{array}{l}\text { Pneumothorax;* pleural empyema.* Situs } \\
\text { inversus in Kartagener's syndrome. }\end{array}$ \\
\hline Blood & Submit sample for microbiologic study (p. 102). & Septicemia. \\
\hline Heart & $\begin{array}{l}\text { Record weight and thickness of right and left } \\
\text { ventricles. }\end{array}$ & Cor pulmonale. \\
\hline \multirow[t]{7}{*}{ Lungs } & $\begin{array}{l}\text { Submit one lobe for bacterial and fungal cultures. } \\
\text { If only one lobe contains bronchiectases, aspirate } \\
\text { contents for microbiologic study. }\end{array}$ & $\begin{array}{l}\text { Bronchiectasis, usually in lower lobes. In } \\
\text { cystic fibrosis,* upper lobes are more } \\
\text { severely affected. Purulent bronchitis.* } \\
\text { Peribronchiectatic pneumonia or abscess. } \\
\text { Allergic bronchopulmonary aspergillosis; } \\
\text { tuberculosis.* }\end{array}$ \\
\hline & For bronchography, see p. 50. & Fungus ball in cavity (aspergillosis*). \\
\hline & For bronchial arteriography, see p. 50. & $\begin{array}{l}\text { Dilatation of bronchial arteries. } \\
\text { Bronchopulmomary anastomoses. }\end{array}$ \\
\hline & $\begin{array}{l}\text { Slice perfused lung along probes introduced } \\
\text { into bronchiectases for guidance. }\end{array}$ & $\begin{array}{l}\text { Saccular, tubular, or varicose bronchiectases. } \\
\text { (See Fig. 4-6, p. 49.) }\end{array}$ \\
\hline & $\begin{array}{l}\text { Request Gram, Grocott's methenamine silver, and } \\
\text {-if indicated because of suspected tuberculosis }\end{array}$ & $\begin{array}{l}\text { Evidence of bacterial (P. aeruginosa; } \\
\text { Staphylococcus aureus; } H . \text { influenzae; }\end{array}$ \\
\hline & —Kinyoun's stains (p. 172). & $\begin{array}{l}\text { Escherichia coli), mycobacterial, or fungal } \\
\text { (aspergillus sp.) infection. }\end{array}$ \\
\hline & $\begin{array}{l}\text { Prepare sections of tracheobronchial } \\
\text { cartilage. }\end{array}$ & $\begin{array}{l}\text { Abnormal cartilage; see above under } \\
\text { "Possible Associated Conditions." }\end{array}$ \\
\hline Kidneys & & Amyloidosis;* glomerular enlargement. \\
\hline \multirow[t]{2}{*}{ Other organs } & $\begin{array}{l}\text { If amyloidosis is suspected, request Congo red, } \\
\text { crystal violet, methyl violet, Sirius red, and } \\
\text { thioflavine T stains (p. 172). }\end{array}$ & Amyloidosis.* \\
\hline & $\begin{array}{l}\text { If cystic fibrosis is present, follow procedures } \\
\text { described under that heading. }\end{array}$ & Cystic fibrosis.* \\
\hline $\begin{array}{l}\text { Brain and spinal cord; } \\
\text { nasal cavity and sinuses }\end{array}$ & $\begin{array}{l}\text { For removal and specimen preparation, } \\
\text { see pp. } 65,67 \text {, and } 71 \text {, respectively. }\end{array}$ & Cerebral abscess.* Nasal polyps; sinusitis. \\
\hline
\end{tabular}

\section{Bronchitis, Acute Chemical}

NOTE: This occurs after inhalation of toxic gases, such as sulfurous acid $\left(\mathrm{H}_{2} \mathrm{SO}_{3}\right)$, sulfur dioxide $\left(\mathrm{SO}_{2}\right)$, chlorine $\left(\mathrm{Cl}_{2}\right)$, and ammonia $\left(\mathrm{NH}_{3}\right)$. See also under "Poisoning, gas" and under "Edema, chemical pulmonary."

\begin{tabular}{lll}
\hline Organs and Tissues & Procedures & Possible or Expected Findings \\
\hline Upper airways and lungs & $\begin{array}{l}\text { Remove lungs together with pharynx, larynx, } \\
\text { and trachea. Open airways in posterior midline. }\end{array}$ & Acute chemical laryngotracheitis. \\
& $\begin{array}{l}\text { Perfuse one lung with formalin under low } \\
\text { pressure (tissue may be viable) (p. 47). }\end{array}$ & $\begin{array}{l}\text { Necrotizing bronchitis; aspiration of acid } \\
\text { vomitus; chemical pulmonary edema.* }\end{array}$ \\
\hline
\end{tabular}




\section{Bronchitis, Chronic}

Synonyms and Related Terms: Chronic asthmatic bronchitis; chronic bronchitis with obstruction; chronic chemical bronchitis; chronic mucopurulent bronchitis; infectious bronchitis.

\begin{tabular}{|c|c|c|}
\hline Organs and Tissues & Procedures & Possible or Expected Findings \\
\hline Heart & $\begin{array}{l}\text { Record weight and thickness of right and left } \\
\text { ventricles. }\end{array}$ & $\begin{array}{l}\text { Cor pulmonale. See also under "Failure, } \\
\text { congestive heart." }\end{array}$ \\
\hline \multirow[t]{4}{*}{ Lungs } & $\begin{array}{l}\text { Submit one lobe for microbiologic study (p. 103). } \\
\text { Slice fresh lung in sagittal plane. After submitting } \\
\text { samples of cross-sections of bronchi for histologic } \\
\text { study, open remainder of bronchi longitudinally. } \\
\text { For bronchography, see p. } 50 \text {. }\end{array}$ & $\begin{array}{l}\text { Bronchopneumonia. Bronchiectasis.* } \\
\text { Emphysema.* }\end{array}$ \\
\hline & For bronchial arteriography, see p. 50. & $\begin{array}{l}\text { Dilatation of bronchial arteries; } \\
\text { bronchopulmonary anastomoses. }\end{array}$ \\
\hline & $\begin{array}{l}\text { Perfuse one lung with formalin (p. } 47 \text { ). For } \\
\text { semiquantitative determination of severity of } \\
\text { bronchitis, use the Reid index or related } \\
\text { morphologic methods (1). }\end{array}$ & $\begin{array}{l}\text { Most methods of wet inflation tend to distend } \\
\text { bronchi and to overinflate lungs. Hyperplasia } \\
\text { of submucosal bronchial glands and smooth } \\
\text { muscle tends to parallel severity of chronic } \\
\text { bronchitis. }\end{array}$ \\
\hline & $\begin{array}{l}\text { Request Gram and Grocott's methenamine } \\
\text { silver stains (p. 172). }\end{array}$ & Bacterial or fungal infection. \\
\hline Diaphragm & $\begin{array}{l}\text { Record size and thickness of muscular } \\
\text { diaphragm. }\end{array}$ & $\begin{array}{l}\text { Decrease in surface area and thickness in } \\
\text { chronic bronchitis. }\end{array}$ \\
\hline Stomach and duodenum & & Peptic ulcers.* \\
\hline Kidneys & & Glomerular enlargement. \\
\hline Brain and spinal cord & $\begin{array}{l}\text { For removal and specimen preparation, } \\
\text { see pp. } 65 \text { and } 67 \text {, respectively. }\end{array}$ & Hypoxic changes. \\
\hline
\end{tabular}

\section{Reference}

1. Thurlbeck WM. Pathology of chronic airflow obstruction. In: Chronic Obstructive Pulmonary Disease, Chernack NS, ed. W.B. Saunders, Philadelphia, PA, 1991.

\section{Bronchopneumonia (See "Pneumonia, all types or type unspecified.")}

\section{Brucellosis}

Synonyms: Brucella spp. infection; undulant fever; Mediterranean fever; Malta fever.

NOTE: (1) Collect all tissues that appear to be infected. (2) Request aerobic cultures for Brucella. (3) Request Gram stains (p. 172). (4) Special precautions are indicated (p. 146). (5) Serologic studies are available from local or state health department laboratories (p. 135). (6) This is a reportable disease.

\begin{tabular}{|c|c|c|}
\hline Organs and Tissues & Procedures & Possible or Expected Findings \\
\hline External examination & $\begin{array}{l}\text { For exposure of joints and microbiologic } \\
\text { specimen preparation, see p. } 96 \text {. }\end{array}$ & $\begin{array}{l}\text { Subcutaneous abscesses. Purulent arthritis } \\
\text { (sacroiliac and hip joints) and periarticular } \\
\text { bursitis. }\end{array}$ \\
\hline
\end{tabular}

Blood

Lymph nodes

Heart

Arteries and veins
Submit samples for culture and serum agglutination tests. See also above under "Note."

If endocarditis is suspected, follow procedures described on p. 103.

For angiography, see under specific site or organ. Submit samples for histologic study. Request Verhoeff-van Gieson stain (p. 173).
Generalized lymphadenopathy.

Infective endocarditis* (particularly with pre-existing aortic stenosis); myocarditis;* pericardial effusions.

Arterial aneurysms; arteriovenous fistulas. Granulomatous endophlebitis. 


\begin{tabular}{lll}
\hline Organs and Tissues & Procedures & Possible or Expected Findings \\
\hline Lungs & $\begin{array}{l}\text { Submit sample for culture (see above under } \\
\text { "Note" and p. 103). }\end{array}$ & $\begin{array}{l}\text { Pleural effusions;* granulomas that may be } \\
\text { associated with abscesses and calcification. } \\
\text { Embolism secondary to granulomatous } \\
\text { endophlebitis. }\end{array}$ \\
Liver & $\begin{array}{l}\text { Record weight. Submit sample for culture } \\
\text { (see above under "Note" and p. 102). }\end{array}$ & $\begin{array}{l}\text { Hepatomegaly; granulomatous hepatitis; } \\
\text { nonspecific reactive changes. } \\
\text { Acute cholecystitis.* }\end{array}$ \\
$\begin{array}{ll}\text { Gallbladder } \\
\text { Spleen }\end{array}$ Kidneys and ureters & $\begin{array}{l}\text { Record weight. Submit sample for culture (p. 102). } \\
\text { Submit samples of renal tissue for histologic } \\
\text { study. Record appearance of renal pelvic and }\end{array}$ & $\begin{array}{l}\text { Splenomegaly with granulomas. } \\
\text { Granulomas; ulceration of mucosa of renal } \\
\text { pelvis. See also above under "Lungs." }\end{array}$ \\
Urinary bladder & $\begin{array}{l}\text { Photeral mucosa. } \\
\text { Submit samples for culture (see also above under } \\
\text { Ovaries, prostate, } \\
\text { epididymides, and testes }\end{array}$ & $\begin{array}{l}\text { Ulceration of mucosa. } \\
\text { Abscesses. }\end{array}$ \\
Bones and joints & $\begin{array}{l}\text { For removal, prosthetic repair, and specimen } \\
\text { preparation, see p. 95. }\end{array}$ & $\begin{array}{l}\text { Osteomyelitis* of long bones and of spine; } \\
\text { arthritis (1). }\end{array}$ \\
Brain & $\begin{array}{l}\text { For removal and specimen preparation, } \\
\text { see p. 65. Submit for culture (see p. 102). } \\
\text { See also above under "Note." For cerebral } \\
\text { arteriography, see p. 80. }\end{array}$ & $\begin{array}{l}\text { Meningoencephalitis; mycotic intracerebral } \\
\text { aneurysm* with rupture and hemorrhage. }\end{array}$ \\
& For removal and specimen preparation, see p. 85. & Iritis; choroiditis; keratitis. \\
\hline Eyes & &
\end{tabular}

\section{Reference}

1. Colmenero JD, Reguera JM, Martos F, Sanchez-De-Mora D, Delgado M, Causse M, et al. Complications associated with Brucella melitensis infection: a study of 530 cases. Medicine 1996;75:195-211.

\section{Burns}

NOTE: Fatal burns should be reported to the medical examiner's or coroner's office. The questions to be answered by the pathologist depend on whether the incident was accidental, suicidal, or homicidal, and whether the victim survivied to be treated in the hospital. A pending death certificate should be issued if the fire and police investigators are not sure of the circumstances at the time of the autopsy. For electrical burns, see under "Injury, electrical."

For victims who were treated at the hospital, autopsy procedures should be directed toward the discovery or confirmation of the mechanism of death, such as sepsis or pulmonary embolism.* Death can be caused primarily by heart disease, with otherwise minor burns and smoke inhalation serving as the trigger that leads to lethal ventricular arrhythmia. Because carbon monoxide concentrations are halved approx every $30 \mathrm{~min}$ with $100 \%$ oxygen therapy, the pathologist must obtain the first clinical laboratory test results for CO-hemoglobin. Soot can be detected with the naked eye 2 or $3 \mathrm{~d}$ after inhalation of smoke. Ambulance records should be examined to determine whether a persistent coma might have been caused by hypoxic encephalopathy following resuscitation from cardiac arrest at the scene.

Admission blood samples should be acquired to test for COhemoglobin and alcohol. This may not have been done in the emergency room. Persons suffering from chronic alcoholism succumb to fire deaths more often than persons who do not drink. A very high initial serum alcohol concentration suggests a risk factor for the fire and presence of chronic alcoholism. Patients with chronic alcoholism typically are deprived of alcohol when they are in the burn unit and this can cause sudden, presumably cardiac, death, just as it occurs under similar circumstances, not complicated by burns. Under these circumstances, the heart fails to show major abnormalities. This mode of dying seems to have no relationship to the presence or absence of liver disease.

\begin{tabular}{lll}
\hline Organs and Tissues & Procedures & Possible or Expected Findings \\
\hline $\begin{array}{l}\text { External examination } \\
\text { and skin }\end{array}$ & $\begin{array}{l}\text { If the body is found dead and charred at the scene, } \\
\text { prepare whole body roentgenograms, before and }\end{array}$ & $\begin{array}{l}\text { Roentgenograms may detect bullets in cases } \\
\text { where arson was used to mask murder. Bullets }\end{array}$ \\
& $\begin{array}{l}\text { after removal of remnants of clothing. See also } \\
\text { under "Identification of the body" (p. 11) and }\end{array}$ & $\begin{array}{l}\text { or knife blades must be secured as evidence. } \\
\text { Onder such as hairpins, keys, jewelry, }\end{array}$ \\
& $\begin{array}{l}\text { two fingerpads may yield sufficient ridge detail } \\
\text { for identification. If this is not possible, ante- and }\end{array}$ & $\begin{array}{l}\text { of old fractures may help provisionally } \\
\text { identify the victim. Fractures of bones and }\end{array}$ \\
& postmortem somatic and dental radiographs & lacerations of soft tissue can all occur as heat \\
must be compared for identification, or DNA & artifacts and must be identified as such. \\
& comparison must be used. & See also above under "Note."
\end{tabular}




\begin{tabular}{|c|c|c|}
\hline Organs and Tissues & Procedures & Possible or Expected Findings \\
\hline $\begin{array}{l}\text { External examination } \\
\text { and skin }\end{array}$ & $\begin{array}{l}\text { Photograph burnt body and make diagrams of } \\
\text { wounds. }\end{array}$ & \\
\hline (continued) & $\begin{array}{l}\text { Prepare histologic sections of blisters and of } \\
\text { surrounding skin. }\end{array}$ & $\begin{array}{l}\text { Inflammatory changes in the skin indicate a } \\
\text { vital reaction. }\end{array}$ \\
\hline \multirow[t]{2}{*}{ Blood } & $\begin{array}{l}\text { If victim was found burnt, submit samples } \\
\text { for carbon monoxide determination and toxico- } \\
\text { logic study, primarily for alcohol and illicit drugs. }\end{array}$ & $\begin{array}{l}\text { Increased carbon monoxide concentration } \\
\text { (saturation of }>15-20 \% \text { ) is strong evidence } \\
\text { that the victim was alive and breathing for } \\
\text { some time during burning. CO-concentra- } \\
\text { trations may not be elevated in flash-fire } \\
\text { victims. }\end{array}$ \\
\hline & $\begin{array}{l}\text { If victim survived for some time, submit samples } \\
\text { for bacterial and fungal culture (p. 102). }\end{array}$ & Septicemia and bacteremia. \\
\hline Vitreous & $\begin{array}{l}\text { Submit sample for alcohol and other toxicologic } \\
\text { studies (p. } 85 \text { ), particularly if no blood is } \\
\text { available, and also for electrolyte determination. }\end{array}$ & $\begin{array}{l}\text { Water and electrolyte loss in patients who had } \\
\text { survived burns for some time. }\end{array}$ \\
\hline Serosal surfaces & $\begin{array}{l}\text { Record volume and character of exudate or } \\
\text { transudate. }\end{array}$ & $\begin{array}{l}\text { Exudate indicates vital reaction. Watery } \\
\text { transudate may develop with rigorous } \\
\text { infusions of crystalloid during fruitless } \\
\text { resuscitation efforts. }\end{array}$ \\
\hline \multirow[t]{4}{*}{$\begin{array}{l}\text { Neck organs and } \\
\text { tracheobronchial tree }\end{array}$} & $\begin{array}{l}\text { Remove carefully. Inspect hyoid bone; search } \\
\text { for hemorrhages in soft tissues of neck. }\end{array}$ & Strangulation effect (fractured hyoid bone). \\
\hline & $\begin{array}{l}\text { Record appearance and photograph mucosal } \\
\text { surfaces of larynx and trachea. If patient had } \\
\text { survived for some time and had been intubated, } \\
\text { search for intubation trauma. }\end{array}$ & $\begin{array}{l}\text { Soot particles and other heat injuries indicate } \\
\text { that the patient was breathing in fire. Absence } \\
\text { of soot particles does not prove that the patient } \\
\text { was already dead when fire started unless } \\
\text { there is reasonable evidence that the fire was } \\
\text { not a flash fire. }\end{array}$ \\
\hline & Inspect supraglottic area. & $\begin{array}{l}\text { Supraglottic edema may cause sudden } \\
\text { death in patients who had survived burns- } \\
\text { particularly of face-for some time. }\end{array}$ \\
\hline & $\begin{array}{l}\text { Submit samples of tracheobronchial mucosa } \\
\text { for histologic study. }\end{array}$ & $\begin{array}{l}\text { Herpes virus inclusions in tracheobronchial } \\
\text { ulcerations of victims who had survived } \\
\text { burns for some time. }\end{array}$ \\
\hline Other organs & Follow routine autopsy procedures. & $\begin{array}{l}\text { Bronchopneumonia; pulmonary emboli; } \\
\text { heart disease in victims who survive for } \\
\text { some time. See also above under "Note." }\end{array}$ \\
\hline Pelvic organs & $\begin{array}{l}\text { Examination of pelvic organs may permit sex } \\
\text { determination in severely burnt bodies. } \\
\text { In female victims whose burns are less severe, } \\
\text { a search should be made for evidence of rape. }\end{array}$ & Sex determination. \\
\hline Durae and brain & & $\begin{array}{l}\text { Epidural hematomas may occur as heat } \\
\text { artifacts. }\end{array}$ \\
\hline
\end{tabular}

Bypass, aortocoronary (See “Surgery, aortocoronary bypass.”)

Byssinosis (See “Pneumoconiosis.”) 
Cadmium (See "Poisoning, cadmium.")

\section{Calcinosis, Mönckeberg's Medial}

Synonyms: Medial sclerosis of arteries; Mönckeberg's arteriosclerosis.

NOTE: This is generally considered an age-related phenomenon that is usually of little clinical consequence, with calcification of the internal elastic membrane and subjacent media. It commonly involves femoral and thyroid arteries.

Calcium (See "Disorder, electrolyte(s).")

Calculi, Renal (See "Nephrolithiasis.")

Canal, Complete Atrioventricular (See "Defect, complete atrioventricular septal.")

\section{Candidiasis}

Synonyms and Related Terms: Candidosis, moniliasis, thrush.

NOTE: Candidiasis may follow or complicate antibacterial or corticosteroid therapy, cardiac surgery, ${ }^{*}$ dehydration, ${ }^{*}$ diabetes mellitus, ${ }^{*}$ drug (heroin) dependence, ${ }^{*}$ leukemia* or other systemic malignant diseases, tuberculosis, ${ }^{*}$ and other debilitating diseases.

(1) Collect all tissues that appear to be infected. (2) Request fungal cultures. (3) Request Grocott's methenamine silver or PAS stain, or both (p. 172). (4) No special precautions are indicated. (5) Serologic studies are available from many reference laboratories (p. 135). (6) This is not a reportable disease.

\begin{tabular}{|c|c|c|}
\hline Organs and Tissues & Procedures & Possible or Expected Findings \\
\hline $\begin{array}{l}\text { External examination } \\
\text { and skin }\end{array}$ & $\begin{array}{l}\text { Prepare sections of skin. For special stains, } \\
\text { see above under "Note." }\end{array}$ & $\begin{array}{l}\text { Intertrigo. Nail destruction may occur } \\
\text { without skin involvement. }\end{array}$ \\
\hline Oral cavity & & Creamy patches. \\
\hline Blood & Submit sample for fungal culture (p. 102). & Candida septicemia. \\
\hline Heart & $\begin{array}{l}\text { If endocarditis is suspected, for instance, } \\
\text { in drug addicts or after cardiac surgery, } \\
\text { follow procedures described on p. } 103 \text {. }\end{array}$ & Candida endocarditis. \\
\hline Lungs & $\begin{array}{l}\text { Submit one lobe for bacterial and fungal culture. } \\
\text { For special stains, see above under "Note." }\end{array}$ & $\begin{array}{l}\text { Candida bronchopneumonia, often in } \\
\text { association with other processes. }\end{array}$ \\
\hline $\begin{array}{l}\text { Pharynx, esophagus, } \\
\text { and gastrointestinal } \\
\text { tract with rectum; } \\
\text { vagina, and cervix }\end{array}$ & $\begin{array}{l}\text { Photograph all lesions. Submit samples for } \\
\text { histologic study. For special stains, see above } \\
\text { under "Note." }\end{array}$ & $\begin{array}{l}\text { Candida infection with membranes, erosions, } \\
\text { and ulcers. }\end{array}$ \\
\hline Other organs & $\begin{array}{l}\text { Submit samples of liver, pancreas, kidneys, } \\
\text { adrenal glands, thyroid, and joints for histologic } \\
\text { study. If available, sample umbilical cord. }\end{array}$ & $\begin{array}{l}\text { Systemic candidiasis; multiple abscesses due } \\
\text { to septic embolization. } \\
\text { In the umbilical cord, necrotizing } \\
\text { inflammation (funisitis) may be found. }\end{array}$ \\
\hline Cerebrospinal fluid & Submit sample for fungal culture (p. 104). & Meningitis. \\
\hline Brain & $\begin{array}{l}\text { For removal and specimen preparation, } \\
\text { see p. } 65 \text {. For special stains, see above } \\
\text { under "Note." }\end{array}$ & Meningitis. \\
\hline
\end{tabular}

Carbon Monoxide (See “Poisoning, carbon monoxide.")

Carbon Tetrachloride (See "Poisoning, carbon tetrachloride.") 


\section{Carcinoma (See "Tumor...")}

Cardiomegaly (See “Cardiomyopathy,... and "Hypertrophy, cardiac.”)

Cardiomyopathy, Alcoholic

NOTE: For general dissection techniques, see p. 22.

\begin{tabular}{lll}
\hline Organs and Tissues & Procedures & Possible or Expected Findings \\
\hline $\begin{array}{l}\text { External examination, } \\
\text { heart and lungs }\end{array}$ & See below under "Cardiomyopathy, dilated." & See below under "Cardiomyopathy, dilated." \\
$\begin{array}{l}\text { Abdominal cavity } \\
\text { and liver }\end{array}$ & $\begin{array}{l}\text { Record volume of ascites. Record actual and } \\
\text { expected weight of liver. Request iron stain } \\
\text { (p. 172). }\end{array}$ & $\begin{array}{l}\text { Alcoholic cirrhosis and alcoholic } \\
\text { cardiomyopathy rarely coexist. However, } \\
\text { in genetic hemochromatosis, }{ }^{*} \text { cirrhosis } \\
\text { and heart failure are common findings. }\end{array}$ \\
\hline
\end{tabular}

Cardiomyopathy, Dilated (Idiopathic, Familial, and Secondary Types)

NOTE: For general dissection techniques, see p. 22.

\begin{tabular}{|c|c|c|}
\hline Organs and Tissues & Procedures & Possible or Expected Findings \\
\hline External examination & Prepare chest roentgenogram. & $\begin{array}{l}\text { Cardiomegaly; pleural or pericardial } \\
\text { effusions;* pacemaker. }\end{array}$ \\
\hline Chest cavity & Record volume of pleural and pericardial effusions. & Hydrothorax; hydropericardium. \\
\hline Heart & $\begin{array}{l}\text { Record actual and expected heart weights. } \\
\text { Measure and record maximum internal short- } \\
\text { axis diameter of left ventricular chamber. } \\
\text { Record ventricular thicknesses and valvular } \\
\text { circumferences. Note location and size of } \\
\text { mural thrombus. Request iron stain (p. 172). }\end{array}$ & $\begin{array}{l}\text { Cardiomegaly; biventricular hypertrophy; } \\
\text { four-chamber dilatation; focal left ventricular } \\
\text { fibrosis; dilated valve annuli; relatively mild } \\
\text { coronary atherosclerosis; possible iron in } \\
\text { cardiac myocytes; microfocal interstitial } \\
\text { fibrosis, particularly subendocardial; } \\
\text { myocarditis (idiopathic or drug-related). }\end{array}$ \\
\hline Lungs & $\begin{array}{l}\text { Record actual and expected weights. } \\
\text { Request Verhoeff-van Gieson and iron stains } \\
\text { from one lower lobe (p. 172). }\end{array}$ & $\begin{array}{l}\text { Pulmonary congestion; pulmonary edema; } \\
\text { changes of chronic pulmonary venous } \\
\text { hypertension; pulmonary emboli; pulmonary } \\
\text { infarcts; bronchopneumonia. }\end{array}$ \\
\hline Abdominal cavity & Record volume of ascites. & Ascites. \\
\hline Liver & Record actual and expected weights. & $\begin{array}{l}\text { Chronic congestive hepatomegaly; } \\
\text { centrilobular (zone 3) steatosis, fibrosis, } \\
\text { or necrosis (not true cirrhosis). }\end{array}$ \\
\hline
\end{tabular}

Cardiomyopathy, Hypertrophic (Idiopathic, Familial, and Secondary Types)

Synonyms: Idiopathic hypertrophic subaortic stenosis (IHSS); hypertrophic obstructive cardiomyopathy (HOCM); and many others.

NOTE: For general dissection techniques, see p. 22.

Possible Associated Conditions: See below under "Possible or Expected Findings."

\begin{tabular}{lll}
\hline Organs and Tissues & Procedures & Possible or Expected Findings \\
\hline External examination & Sample skin lesions for histologic study. & Lentiginosis (part of LEOPARD syndrome). \\
& Prepare chest roentgenogram. & Mild cardiomegaly. \\
Heart & Record actual and expected weights. & Biventricular hypertrophy; disproportionate \\
& Record ventricular thicknesses and valvular & septal hypertrophy (>1.3 in 90\%); gross and \\
& circumferences. Determine ratio between left & microscopic fibrosis; thickened anterior \\
& ventricular septal and free wall thicknesses & mitral leaflet; subaortic septal endocardial \\
& (normal, <1.3) at basal, midventricular, and & fibrotic patch (contact lesion from mitral \\
& apical levels. Request amyloid stain (Congo & valve); left atrial dilatation; focal septal \\
& red or sulfated alcian blue) (p. 172). & myofiber disarray microscopically. \\
Brain and spinal cord & For removal and specimen preparation, & Friedreich's ataxia.* \\
& see pp. 65 and 67, respectively. & \\
\hline
\end{tabular}




\section{Cardiomyopathy, Restrictive (Non-eosinophilic and Secondary Types)}

NOTE: For general dissection techniques, see p. 22.

\begin{tabular}{lll}
\hline Organs and Tissues & Procedures & Possible or Expected Findings \\
\hline Heart & Record actual and expected weights. & Prominent biatrial dilatation. Relatively \\
& Record ventricular thicknesses and valvular & normal ventricular size. Prominent \\
& circumferences. Evaluate atrial size, compared & biventricular interstitial fibrosis or \\
& to ventricular chamber size. Request amyloid & amyloidosis, microscopically. \\
& stain (Congo red or sulfated alcian blue) (p. 172). & \\
\hline
\end{tabular}

\section{Cardiomyopathy, Restrictive (With Eosinophilia)}

Synonyms: Eosinophilic endomyocardial disease; hypereosinophilic syndromes; Löffler's eosinophilic endomyocarditis; Davies' endomyocardial fibrosis.

NOTE: For general dissection techniques, see p. 22.

\begin{tabular}{lll}
\hline Organs and Tissues & Procedures & Possible or Expected Findings \\
\hline Heart & $\begin{array}{l}\text { Record actual and expected weights. } \\
\text { Record ventricular thicknesses and valvular } \\
\text { circumferences. Evaluate relative atrial and } \\
\text { ventricular chamber sizes. }\end{array}$ & $\begin{array}{l}\text { Mural thrombus along apex and inflow tract } \\
\text { of one or both ventricles, with extensive intact } \\
\text { or degranulated eosinophils microscopically. }\end{array}$ \\
& $\begin{array}{l}\text { Ventricular dilatation only if mitral or } \\
\text { tricuspid valve or both are regurgitant. }\end{array}$ \\
Other organs and tissues & $\begin{array}{l}\text { Conditions associated with eosinophilia, such } \\
\text { grossly identified abnormalities as listed in }\end{array}$ & $\begin{array}{l}\text { as asthmatic bronchiolitis or Churg-Strauss } \\
\text { syndrome (see also under "Syndrome, } \\
\text { hypht-hand column. }\end{array}$ \\
& & $\begin{array}{l}\text { hypeosinophilic"); malignancies; parasitic } \\
\text { disease; vasculitis. }\end{array}$ \\
\hline
\end{tabular}

\section{Cardiomyopathy, Arrhythmogenic Right Ventricular}

Synonyms: Arrhythmogenic right ventricular dysplasia; right ventricular cardiomyopathy.

NOTE: For general dissection techniques, see p. 22.

\begin{tabular}{lll}
\hline Organs and Tissues & Procedures & Possible or Expected Findings \\
\hline Heart & Record actual and expected weights. & Prominent right ventricular dilatation, \\
& Record ventricular thicknesses and valvular & grossly; right ventricular hypertrophy, \\
& circumferences. Evaluate pattern and extent of & fibrosis, and adiposity, by microscopy \\
& epicardial fat, especially over right ventricle. & (excessive for patient's age and body size). \\
& Take multiple samples from right ventricle for & Occasional left ventricular involvement. \\
& microscopic study. & Microfocal myocarditis or epicarditis. \\
\hline
\end{tabular}

\section{Carditis (See "Myocarditis.")}

\section{Chickenpox (See "Varicella.")}

Chloride (See "Disorder, electrolyte(s)" and p. 114.)

\section{Chloroma}

NOTE: Follow procedures described under "Leukemia, all types or type unspecified." For gross staining of chloroma, see p. 134.

\section{Cholangiopathy, Infantile Obstructive (See "Atresia, biliary" and "Hepatitis, neonatal.")}

\section{Cholangitis, Chronic Nonsuppurative Destructive}

Synonym: Primary bilary cirrhosis.

NOTE: Follow procedures described under "Cirrhosis, liver."

\section{Cholangitis, Sclerosing}

Synonyms: Idiopathic sclerosing cholangitis; primary sclerosing cholangitis; secondary sclerosing cholangitis.

Possible Associated Conditions: Acquired immunodeficiency syndrome;* acute or chronic pancreatitis;* ankylosing spondylitis;* autoimmune hemolytic anemia;* autoimmune hepatitis; bronchiectasis; ${ }^{*}$ chronic ulcerative colitis; ${ }^{*}$ celiac disease; Crohn's disease;* eosinophilia; glomerulonephritis;* immune thrombocytopenic purpura; Peyronie's disease; pseudotumor of the orbit; retroperitoneal fibrosis;* rheumatoid arthritis;* Riedel's struma; sclerosing mediastinitis; ${ }^{*}$ Sjogren's syndrome;* systemic lupus erythematosus; $*$ systemic sclerosis; ${ }^{*}$ vasculitis; and many others (the associations are not equally well documented) (1). 


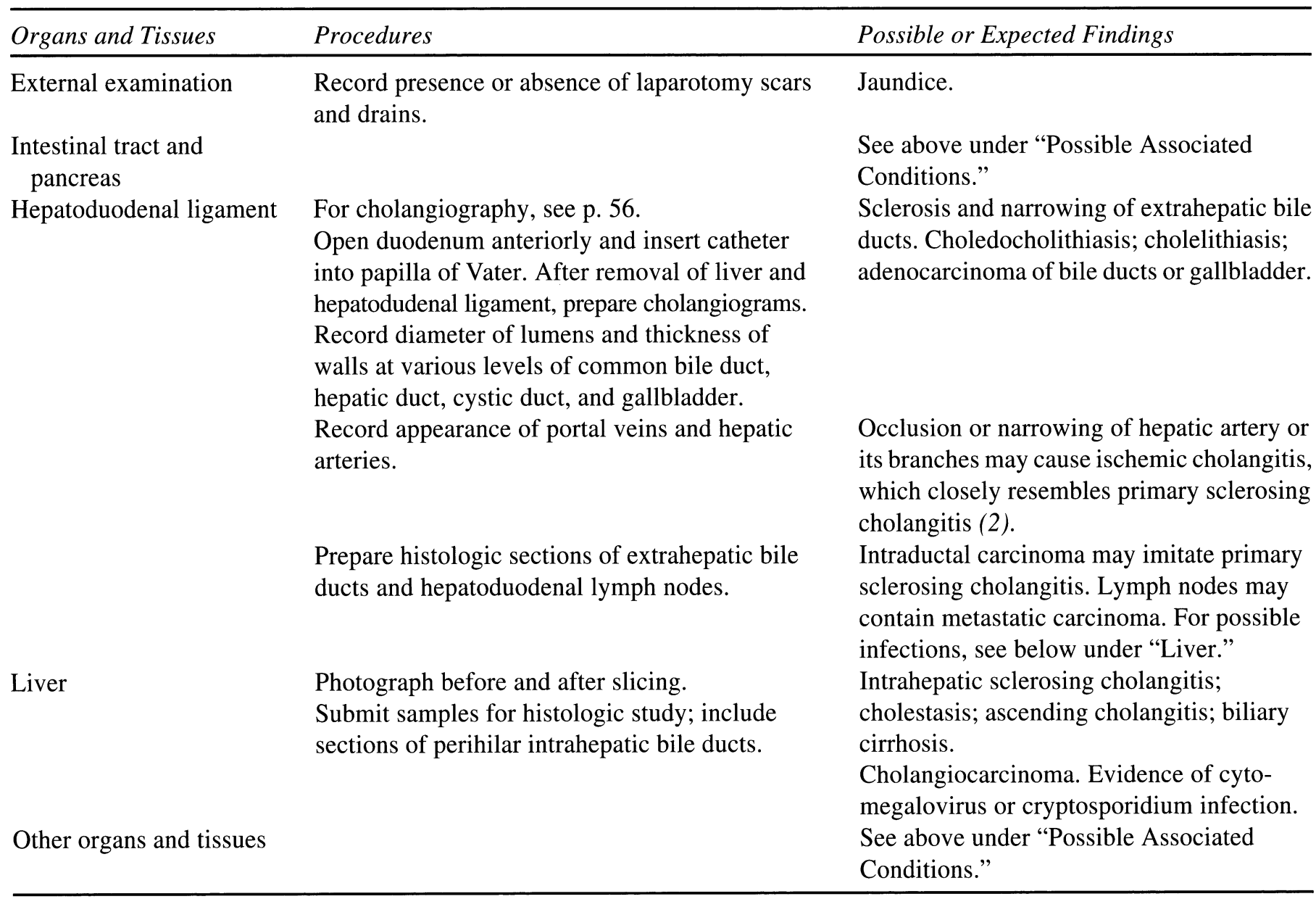

\section{References}

1. Lazarides KN, Wiesner RH, Porayko MK, Ludwig J, LaRusso NF. Primary sclerosing cholangitis. In: Diseases of the Liver, 8th ed. Schiff ER, Sorrell MF, Maddray WC, eds. Lippincott-Raven, Philadelphia, PA, 1999.

2. Batts KP. Ischemic cholangitis. Mayo Clin Proc 1998;73:380-385.

\section{Cholangitis, Suppurative}

Related Terms: Ascending cholangitis; obstructive suppurative cholangitis; (oriental) recurrent pyogenic cholangitis.

\begin{tabular}{lll}
\hline Organs and Tissues & Procedures & Possible or Expected Findings \\
\hline $\begin{array}{l}\text { External examination } \\
\text { Blood }\end{array}$ & $\begin{array}{l}\text { Submit sample for microbiologic study (p. 102). } \\
\text { If infective endocarditis is suspected, follow } \\
\text { procedures described on p. 103. }\end{array}$ & $\begin{array}{l}\text { Jaundice. } \\
\text { Septicemia. } \\
\text { Infective endocarditis.* }\end{array}$ \\
$\begin{array}{l}\text { Fepatoduodenal ligament cholangiography, see p. 56. Dissect common } \\
\text { bile duct, hepatic duct, and portal vein in situ. } \\
\text { Liver and gallbladder }\end{array}$ & $\begin{array}{l}\text { Secord weight of liver and photograph it. } \\
\text { Submit portion of liver for aerobic and anaerobic stones. Portal vein } \\
\text { thrombosis; pylephlebitis. }\end{array}$ \\
& $\begin{array}{l}\text { Cholangitic abscesses; cholecystitis,* } \\
\text { cholelithiasis.* Carcinoma or other } \\
\text { study and request Gram stain (p. 172). }\end{array}$ & $\begin{array}{l}\text { conditions causing obstruction or } \\
\text { compression of bile ducts. }\end{array}$ \\
\hline
\end{tabular}

\section{Cholecystitis}

Related Terms: Acute acalculous cholecystitis; chronic cholecystitis; gallstone cholecystitis.

Possible Associated Conditions: Brucellosis;* major trauma or operation unrelated to biliary system; polyarteritis nodosa;* Salmonella typhosa infection (typhoid fever*). 


\begin{tabular}{|c|c|c|}
\hline Organs and Tissues & Procedures & Possible or Expected Findings \\
\hline External examination & Prepare roentgenogram of upper abdomen. & $\begin{array}{l}\text { Jaundice. } \\
\text { Air in biliary tract indicates biliary fistula. } \\
\text { Gallstones }\end{array}$ \\
\hline Abdominal cavity & $\begin{array}{l}\text { Submit peritoneal exudate and aspirated contents } \\
\text { of gallbladder for aerobic and anaerobic culture. } \\
\text { Also submit exudate from subphrenic empyema* } \\
\text { or other intraperitoneal empyemas (abscesses). }\end{array}$ & $\begin{array}{l}\text { Peritonitis;* intraperitoneal empyemas } \\
\text { (abscesses). }\end{array}$ \\
\hline Blood & Submit sample for bacterial culture (p. 102). & Septicemia. \\
\hline Heart & $\begin{array}{l}\text { If endocarditis is suspected, follow procedures } \\
\text { described on p. } 103 \text {. }\end{array}$ & Infective endocarditis. $*$ \\
\hline Intestine & $\begin{array}{l}\text { If biliary fistula is suspected, open stomach, } \\
\text { duodenum, and hepatic flexure of colon in situ. } \\
\text { Record location and size of fistula. }\end{array}$ & Biliary fistula, with or without gallstone ileus. \\
\hline $\begin{array}{l}\text { Gallbladder; } \\
\text { hepatoduodenal ligament } \\
\text { with extrahepatic bile } \\
\text { ducts }\end{array}$ & $\begin{array}{l}\text { For cholangiography, see p. } 56 . \text { Open all } \\
\text { extrahepatic bile ducts, portal vein, and hepatic } \\
\text { artery in situ. Remove liver and gallbladder. } \\
\text { For specimen preparation, see p. } 57 \text {. } \\
\text { Describe appearance, position, and contents of } \\
\text { gallbladder. Record number and character of } \\
\text { stones. For preservation of gallbladder and } \\
\text { stones, see pp. } 134 \text { and } 137 .\end{array}$ & $\begin{array}{l}\text { Acute or chronic cholecystitis; } \\
\text { cholelithiasis;* cholangitis;* } \\
\text { choledocholithiasis. Ulcers, abscesses, } \\
\text { empyema, gangrene, or perforation of } \\
\text { gallbladder; emphysematous cholecystitis; } \\
\text { fistula. Hydrops or porcelain gallbladder; } \\
\text { limey bile. Torsion of gallbladder. Portal vein } \\
\text { thrombosis; pylephlebitis. Polyarteritis } \\
\text { nodosa* of gallbladder. Hepatoduodenal } \\
\text { lymphadenitis. }\end{array}$ \\
\hline Liver & $\begin{array}{l}\text { Record size and weight. Submit samples for } \\
\text { histologic study. }\end{array}$ & $\begin{array}{l}\text { Suppurative cholangitis; }{ }^{*} \text { cholangitic } \\
\text { abscesses; pylephlebitis; pylephlebitic } \\
\text { abscesses; venous thromboses. }\end{array}$ \\
\hline Pancreas & $\begin{array}{l}\text { If pancreatitis is present, record whether } \\
\text { common bile duct and pancreatic duct have a } \\
\text { common entry. }\end{array}$ & Pancreatitis.* \\
\hline
\end{tabular}

\section{Choledocholithiasis}

NOTE: Follow procedures described under "Cholecystitis."

\section{Cholelithiasis}

NOTE: Follow procedures described under "Cholecystitis." Cholelithiasis may be associated with all types of cholecystitis, with cholesterosis of the gallbladder, and with polyps of the gallbladder. The presence of "white bile" (limey bile) indicates obstruction of the cystic duct. Record number and character of stones. To prevent the green discoloration of gallbladder mucosa, see Chapter 14, p. 134.

\section{Cholera}

Synonym: Vibrio cholerae infection; asiatic cholera.

NOTE: The disease may complicate anemia, ${ }^{*}$ chronic atrophic gastritis, vagotomy, gastrectomy, chronic intestinal disease, and malnutrition.

(1) Collect all tissues that appear to be infected. (2) Request cultures of intestinal contents for cholera. (3) Request Gram stain (p. 172). (4) Special precautions are indicated (p. 146). (5) For serologic studies, see below under "Blood." (6) This is a reportable disease.

\begin{tabular}{ll}
\hline Organs and Tissues & Procedures \\
\hline External examination & $\begin{array}{l}\text { Record body weight and length and extent } \\
\text { of rigor. }\end{array}$
\end{tabular}

\section{Vitreous}

Blood
Submit sample for sodium, chloride, and urea nitrogen determination (p. 85).

Prepare serum for tube agglutination or enzyme-linked immunosorbent assay (ELISA) test for retrospective diagnosis or epidemiologic purposes.

\section{Possible or Expected Findings}

Early onset and prolongation of rigor mortis. Shriveled fingers ("washer-woman's hands") and toes.

Dehydration.* (See also p. 115). 


\begin{tabular}{|c|c|c|}
\hline Organs and Tissues & Procedures & Possible or Expected Findings \\
\hline \multirow[t]{2}{*}{ Intestinal tract } & $\begin{array}{l}\text { Record volume and appearance of intestinal } \\
\text { contents. Submit samples of feces and other } \\
\text { intestinal contents for culture and for } \\
\text { determination of sodium, potassium, and } \\
\text { chloride content. }\end{array}$ & $\begin{array}{l}\text { Blood-stained or "rice-water type" intestinal } \\
\text { contents. The organism may be present in } \\
\text { pure culture. }\end{array}$ \\
\hline & $\begin{array}{l}\text { Submit samples of all portions of the intestinal } \\
\text { tract for histologic study. }\end{array}$ & $\begin{array}{l}\text { Intact mucosa with edema of lamina propria; } \\
\text { dilatation of capillaries and lymphatics; } \\
\text { mononuclear infiltrates and goblet cell } \\
\text { hyperplasia. All changes confined to small } \\
\text { bowel. Bacteria situated on or between } \\
\text { epithelial cells. }\end{array}$ \\
\hline Kidneys & Submit samples for histologic study. & Tubular necrosis;* focal cortical necrosis. \\
\hline Adrenal glands & & Lipid depletion. \\
\hline Urine & Record volume and specific gravity. & $\begin{array}{l}\text { Absence or minimal amount of urine suggests } \\
\text { dehydration.* }\end{array}$ \\
\hline Other organs and tissues & & $\begin{array}{l}\text { All tissues appear abnormally dry. Lungs are } \\
\text { usually pale and shrunken, less frequently } \\
\text { congested. }\end{array}$ \\
\hline
\end{tabular}

\section{Chondrocalcinosis (See "Pseudogout.")}

\section{Chondrodysplasia}

Synonyms and Related Terms: Achondroplasia; chondrodystrophia fetalis; Ellis-van Creveld syndrome.*

\begin{tabular}{|c|c|c|}
\hline Organs and Tissues & Procedures & Possible or Expected Findings \\
\hline \multirow[t]{2}{*}{ External examination } & $\begin{array}{l}\text { Record body length, length of extremities, } \\
\text { and abnormal features. Measure head, chest, } \\
\text { and abdominal circumferences. }\end{array}$ & $\begin{array}{l}\text { Dwarfism;* micromelia with pudgy fingers; } \\
\text { bulging head with saddle nose. }\end{array}$ \\
\hline & $\begin{array}{l}\text { Prepare skeletal roentgenograms. All } \\
\text { radiographs should be reviewed by a } \\
\text { radiologist. }\end{array}$ & $\begin{array}{l}\text { Chest deformities; separation of spinal } \\
\text { ossification centers; abnormal pelvis and, in } \\
\text { infants, ossification centers in metaphyseal } \\
\text { ends of long bones. }\end{array}$ \\
\hline Thyroid gland & $\begin{array}{l}\text { Record weight and submit sample for histologic } \\
\text { study. }\end{array}$ & Atrophy. \\
\hline Other organs & Perfuse at least one lung with formalin (p. 47). & Restrictive and obstructive lung disease (1). \\
\hline $\begin{array}{l}\text { Base of skull, pituitary } \\
\text { gland, brain, and spinal } \\
\text { canal with cord }\end{array}$ & $\begin{array}{l}\text { For removal and specimen preparation of brain } \\
\text { and spinal cord, see pp. } 65 \text { and } 67 \text {, respectively. } \\
\text { For removal of pituitary gland, see p. } 71 . \\
\text { Record appearance and photograph base of } \\
\text { skull; record size of foramen magnum. } \\
\text { Remove middle ears (see p. } 72 \text { ). }\end{array}$ & $\begin{array}{l}\text { Growth retardation of base of skull with } \\
\text { compression of foramen magnum. Internal } \\
\text { hydrocephalus.* Narrow spinal canal with } \\
\text { compression of spinal cord. (Clinically: } \\
\text { paraplegia.) Atrophy of pituitary gland. } \\
\text { Otitis media* (2). }\end{array}$ \\
\hline \multirow[t]{2}{*}{ Bones } & $\begin{array}{l}\text { For removal, prosthetic repair, and specimen } \\
\text { preparation, see p. } 95 \text {. }\end{array}$ & $\begin{array}{l}\text { Dorsolumbar kyphosis and lumbosacral } \\
\text { lordosis; short iliac wings; short and thick } \\
\text { tubular bones; excessive size of epiphysis in } \\
\text { long bones; elongated costal cartilage; tibial } \\
\text { bowing. }\end{array}$ \\
\hline & $\begin{array}{l}\text { Submit samples (especially epiphyses, if present) } \\
\text { for histologic study. }\end{array}$ & $\begin{array}{l}\text { Decreased cartilage cell proliferation at } \\
\text { costochondral junction and at epiphysis- } \\
\text { diaphysis junction of long bones. }\end{array}$ \\
\hline
\end{tabular}

\section{References}

1. Hunter AG, Bankier A, Rogers JC, Sillence D, Scott CL Jr. Medical complications of achondroplasia: a multicenter patient review. J Med Genet 1998;35:705-712.
2. Erdincler P, Dashti R, Kaynar MY, Canbaz B, Ciplak N, Kuday C. Hydrocephalus and chronically increased intracranial pressure in achondroplasia. Childs Nerv System 1997;13:345-348. 


\section{Chondrosarcoma (See “Tumor of bone or cartilage.")}

\section{Chordoma (See "Tumor of bone or cartilage.")}

\section{Chorea, Acute}

Related Terms: Infectious chorea (poststreptococcal; often part of rheumatic fever); St. Vitus' dance; Sydenham's chorea.

\begin{tabular}{lll}
\hline Organs and Tissues & Procedures & Possible or Expected Findings \\
\hline Brain and spinal cord & $\begin{array}{l}\text { For removal and specimen preparation, } \\
\text { see pp. 65 and 67, respectively. } \\
\text { Submit sample of cerebral tissue for micro- } \\
\text { biologic study (p. 102). }\end{array}$ & $\begin{array}{l}\text { Morphologic changes largely unknown. } \\
\text { Degenerative processes of basal ganglia. }\end{array}$ \\
Other organs & $\begin{array}{l}\text { Procedures depend on expected findings or } \\
\text { grossly identified abnormalities as listed in } \\
\text { right-hand column. }\end{array}$ & $\begin{array}{l}\text { Manifestations of carbon monoxide } \\
\text { poisoning;* diphtheria;* hyperthyroidism;* } \\
\text { idiopathic hypocalcemia; pertussis;* } \\
\text { pregnancy; rheumatic fever;* systemic lupus } \\
\text { erythematosus.* }\end{array}$ \\
\hline
\end{tabular}

\section{Chorea, Hereditary}

Synonyms: Chronic progressive chorea; Huntington's chorea; Huntington's disease.

NOTE: Huntington's disease maps to the short arm of chromosome 4. The gene is widely expressed but of unknown function; it contains a CAG repeat sequence, which is expanded (range, 37 to 86) in patients with Huntington's disease. A sensitive diagnostic test is based on the determination of this CAG sequence, which can be done on fresh-frozen tissue or blood (1). In the absence of genetic confirmation, sampling of organs and tissues cannot be excessive because a complex differential diagnosis must be resolved.

\begin{tabular}{lll}
\hline Organs and Tissues & Procedures & Possible or Expected Findings \\
\hline Brain and spinal cord & $\begin{array}{l}\text { For removal and specimen preparation, } \\
\text { see pp. 65 and 67, respectively. } \\
\text { Place fresh cerebral tissue in deep freeze for } \\
\text { further study. }\end{array}$ & $\begin{array}{l}\text { Mild to severe cerebral atrophy. Atrophy of } \\
\text { head of caudate nucleus, putamen, and globus } \\
\text { pallidus (due to neuronal loss and gliosis). }\end{array}$ \\
& $\begin{array}{l}\text { Samples should include peripheral nerves } \\
\text { Other organs }\end{array}$ & Respiratory and other intercurrent infections. \\
& $\begin{array}{l}\text { and bone marrow (p. 96). (See also above } \\
\text { under "Note"). }\end{array}$ & \\
\hline
\end{tabular}

\section{Reference}

1. Lowe J, Lennox G, Leigh PN. Disorders of movement and system degenerations. In: Greenfield's Neuropathology, vol. 2. Graham BI, Lantos PL, eds. Arnold, London, 1997, pp. 281-366.

\section{Choriomeningitis, Lymphocytic (See “Meningitis.”)}

\section{Chylothorax}

Related Terms: Congenital chylothorax.

\begin{tabular}{ll}
\hline Organs and Tissues & Procedures \\
\hline External examination & $\begin{array}{l}\text { Prepare chest roentgenogram. } \\
\text { Puncture pleural cavity and submit fluid for } \\
\text { microbiologic study (p. 102). }\end{array}$ \\
Record volume of exudate or transudate and \\
submit sample for determination of fat and \\
cholesterol content. If infection is suspected \\
(extremely rare in true chylothorax), submit \\
sample for microbiologic study.
\end{tabular}

Possible or Expected Findings

Pleural effusion.*

Chylous pleural effusions have high fat content. Nonchylous milky effusions-for instance, in tuberculosis* and rheumatoid arthritis*- have high cholesterol and low fat content. Tumor of pleura, lung, or chest wall; lymphangiomatosis (1). 


\begin{tabular}{lll}
\hline Organs and Tissues & Procedures & Possible or Expected Findings \\
\hline Thoracic duct & $\begin{array}{l}\text { For lymphangiography and for dissection of } \\
\text { the thoracic duct, see p. 34. }\end{array}$ & $\begin{array}{l}\text { Surgical or other traumatic lesions of thoracic } \\
\text { duct. Tumor in posterior mediastinum. }\end{array}$ \\
Skeletal system & $\begin{array}{l}\text { Prepare skeletal roentgenogram and, if } \\
\text { abnormalities are present, sample bone for } \\
\text { histologic study. }\end{array}$ & $\begin{array}{l}\text { Massive osteolysis in Gorham's syndrome } \\
\text { (2). }\end{array}$ \\
\hline
\end{tabular}

\section{References}

1. Moerman P, van Geet C, Devlieger H. Lymphangiomatosis of the body wall: a report of two cases associated with chylothorax and fatal outcome. Pediatr Pathol Lab Med 1997;17:617-624.

2. Riantawan P, Tansupasawasdikul S, Subhannachart P. Bilateral chylothorax complicating massive osteolysis (Gorham's syndrome). Thorax 1996;51:1277-1278.

\section{Cirrhosis, Liver}

NOTE: All types of cirrhosis are included here (alcoholic, autoimmune, biliary, cryptogenic, pigment [hemochromatosis], cirrhosis with viral hepatitis, and other types).

If the cause or underlying condition is known, see also under the appropriate heading, such as alcoholic liver disease, $\mathrm{a}_{1}$-antitrypsin deficiency, sclerosing cholangitis, or viral hepatitis. If the patient had undergone liver transplantation, see also under that heading.

\begin{tabular}{ll}
\hline Organs and Tissues & Procedures \\
\hline External examination & $\begin{array}{l}\text { Record body weight and length, nutritional state, } \\
\text { distribution of hair, type of skin pigmentation, } \\
\text { appearance of breasts and hands, and abdominal } \\
\text { circumference. Prepare sections of skin and } \\
\text { breast tissue. }\end{array}$
\end{tabular}

Blood

Abdominal
and chest cavity

Lungs

Diaphragm

Gastrointestinal tract
Prepare skeletal roentgenograms

Submit samples for bacterial culture (p. 102) and for biochemical or immunologic study, depending on expected underlying disease (see above under "Note").

Record volume and character of ascites.

Culture exudate.

Record volume and character of pleural effusions.

For lymphangiography, see p. 34.

For arteriography and for cholangiography, see p. 56. Record appearance and contents of extrahepatic bile ducts.

If liver transplantation had taken place, see also under that heading.

Remove esophagus together with stomach. Clamp midportion of stomach and remove together with esophagus for demonstration of varices (p. 53). Record appearance of varices and preserve specimen, particularly in cases where attempts had been made to sclerose the varices. Perfuse one lung with formalin (p. 47).

Record defects and presence of dilated lymphatics.

Record estimated volume of blood in gastrointestinal tract.

Submit samples of abnormal lesions for histologic study
Possible or Expected Findings

Jaundice; spider nevi; pectoral alopecia and loss or abnormal distribution of pubic hair; gynecomastia; white nail beds; clubbing of fingers. Diffuse or nodular (e.g., cervical) lipomatosis (Madelung collar) in alcoholism. Xanthelasmas and vitiligo in primary biliary cirrhosis. Skin pigmentation of hemochromatosis.* Bruises and hemorrhages. Hypertrophic osteoarthropathy* of tibia and fibula; osteomalacia;* osteoporosis.* Septicemia; hyperbilirubinemia. Viral antigens and/or antibodies.

Ascites; spontaneous bacterial peritonitis.

\section{Hydrothorax.}

Dilatation of abdominal lymphatics and thoracic duct. Strictures, stones, or tumors in secondary biliary cirrhosis; portal or splenic vein thrombosis; thrombosis of surgical anastomosis. A peritoneovenous shunt may be in place.

Esophageal* or gastric varices, or both, with or without evidence of rupture and hemorrhage. Gastroesophageal mucosal tears in Mallory-Weiss syndrome. (See also below under "Gastrointestinal tract.")

Manifestations of portopulmonary hypertension.

Gastrointestinal hemorrhage.*

Gastric varices.

Peptic ulcers.* Crohn's disease* or chronic ulcerative colitis in primary sclerosing cholangitis.* Portal hypertensive gastropathy. 


\begin{tabular}{|c|c|c|}
\hline Organs and Tissues & Procedures & Possible or Expected Findings \\
\hline \multirow[t]{2}{*}{ Liver and gallbladder } & $\begin{array}{l}\text { Record size and weight of liver and average } \\
\text { size of regenerative nodules of liver. } \\
\text { Describe appearance and contents of gallbladder. } \\
\text { Prepare frontal or horizontal slices of liver } \\
\text { (p. 56). If there is evidence of tumor(s), see } \\
\text { under "Tumor of the liver." For macroscopic } \\
\text { iron stain, see p. } 133 \text {. }\end{array}$ & $\begin{array}{l}\text { Cirrhosis. Cholelithiasis.* Hepatocellular } \\
\text { carcinoma. Hemosiderosis. An intrahepatic } \\
\text { portal-caval shunt may be in place. }\end{array}$ \\
\hline & $\begin{array}{l}\text { Freeze hepatic tissue for possible biochemical or } \\
\text { histochemical study. Request van Gieson's stain, } \\
\text { PAS stain with diastase digestion, and Gomori's } \\
\text { iron stain (p. 172). If hepatitis B virus infection is } \\
\text { suspected, request immunostains for B antigens. } \\
\text { For preparation for electron microscopic study, } \\
\text { see p. } 132 \text {. }\end{array}$ & Hepatitis B or other viral antigens. \\
\hline Spleen & Record size and weight. & Congestive splenomegaly. \\
\hline Pancreas & $\begin{array}{l}\text { Prepare pancreatogram (p. 57) and dissect } \\
\text { pancreatic ducts. }\end{array}$ & $\begin{array}{l}\text { Chronic pancreatitis, particularly with } \\
\text { alcoholic cirrhosis. }\end{array}$ \\
\hline Urine & Chemical study is feasible. & Urobilinuria; aminoaciduria. \\
\hline Testes and prostate & $\begin{array}{l}\text { Record weights of testes. Submit samples of } \\
\text { testes and prostate for histologic study. }\end{array}$ & Atrophy of testes and prostate. \\
\hline Brain & For removal and specimen preparation, see p. 65 . & $\begin{array}{l}\text { Hepatic encephalopathy. Histologic changes, } \\
\text { primarily in cerebral cortex, putamen, globus } \\
\text { pallidus, and cerebellum. }\end{array}$ \\
\hline Eyes & For removal and specimen preparation, see p. 85 . & Yellow sclerae. Cataracts in galactosemia.* \\
\hline
\end{tabular}

\section{Clonorchiasis}

Synonyms: Clonorchis sinensis infection; Chinese or oriental liver fluke infection; Opisthorchis sinensis infection (1).

NOTE: (1) Collect all tissues that appear to be infected. (2) Culture methods are not generally available. However, aerobic and anaerobic cultures may be indicated in patients who die of superimposed sepsis. (3) Request Gram stain (p. 172); parasites can be identified with hematoxylin and eosin stain. (4) No special precautions are indicated. (5) Serologic studies are not available. (6) This is not a reportable disease.

\begin{tabular}{lll}
\hline Organs and Tissues & Procedures & Possible or Expected Findings \\
\hline Blood & $\begin{array}{l}\text { Submit sample for anaerobic and aerobic culture } \\
\text { (p. 102). }\end{array}$ & Septicemia. \\
$\begin{array}{l}\text { Stool } \\
\text { Liver and extrahepatic } \\
\text { biliary system }\end{array}$ & $\begin{array}{l}\text { For postmortem cholangiography, see p. 56. } \\
\text { Leave extrahepatic bile ducts and gallbladder } \\
\text { attached to liver. Dissect and fix as shown in } \\
\text { Chapter 5, Figs. 5-5 and 5-6, pp. 57 and 58. } \\
\text { Submit samples of liver, gallbladder, and } \\
\text { extrahepatic bile ducts for histologic study. }\end{array}$ & $\begin{array}{l}\text { Hyperplasia of bile duct epithelium; } \\
\text { periductal chronic inflammation; severe } \\
\text { portal fibrosis; cirrhosis. Acute or recurrent } \\
\text { suppurative cholangitis;* } \\
\text { Request Verhoeff-van Gieson stain (p. 173). }\end{array}$ \\
& $\begin{array}{l}\text { Weigh liver, spleen. Examine veins around } \\
\text { esophagus and rectum carefully. }\end{array}$ & Evidence of portal hypertension. \\
Abdominal organs & $\begin{array}{l}\text { Submit samples for histologic study. } \\
\text { If roentgenographic study is intended, see p. 57. }\end{array}$ & $\begin{array}{l}\text { Acute pancreatitis.* Parasitic invasion of } \\
\text { pancreatic duct with fibrosis and dilatation. }\end{array}$ \\
\hline Pancreas & &
\end{tabular}

\section{Reference}

1. Case Records of Massachusetts. General Hospital. Clonorchis sinensis [Opisthorchis sinensis] infection of biliary tract. N Engl J Med 1990;323: 467-475. 


\section{Coagulation, Disseminated Intravascular}

Synonyms and Related Terms: Consumption coagulopathy; hypofibrinogenemia; intravascular coagulation and fibrinolysis syndrome (ICF).

NOTE: Disseminated intravascular coagulation (DIC) often is a complication of obstetrical mishaps such as abruptio placentae or amniotic fluid embolism, ${ }^{*}$ or it complicates malignancies (such as adenocarcinomas or leukemia*) or bacterial, viral, and other infections. Other conditions such as aortic aneurysm* or hemolytic uremic syndrome* are known causes also. If the nature of the underlying disease is known, follow the procedures under the appropriate heading also.

\begin{tabular}{|c|c|c|}
\hline Organs and Tissues & Procedures & Possible or Expected Findings \\
\hline $\begin{array}{l}\text { External examination } \\
\text { and skin }\end{array}$ & $\begin{array}{l}\text { Prepare sections of skin of grossly involved } \\
\text { and of uninvolved areas. }\end{array}$ & $\begin{array}{l}\text { Petechiae, purpura, hemorrhagic bullae, } \\
\text { gangrene, and other skin lesions. }\end{array}$ \\
\hline Heart & & Nonbacterial thrombotic endocarditis.* \\
\hline Large blood vessels & & $\begin{array}{l}\text { Thromboses, predominantly around } \\
\text { indwelling catheters. }\end{array}$ \\
\hline \multirow[t]{2}{*}{ Other organs } & $\begin{array}{l}\text { Submit tissue samples from grossly involved } \\
\text { and uninvolved areas. Organs involved include } \\
\text { brain, heart, kidneys, lungs, adrenal glands, } \\
\text { spleen, gastrointestinal tract, pancreas, and liver, } \\
\text { approximately in this order. Skin, testes, and } \\
\text { choroid plexus also are frequently involved. }\end{array}$ & $\begin{array}{l}\text { Fibrin or hyaline thrombi in capillaries, } \\
\text { venules, or arterioles, and occasionally in } \\
\text { larger vessels. Hemorrhages and ischemic } \\
\text { infarcts may occur. }\end{array}$ \\
\hline & $\begin{array}{l}\text { Special stains such as phosphotungstic acid } \\
\text { hematoxylin (p. 173) are not particularly helpful. } \\
\text { Postmortem determination of fibrin split products } \\
\text { is not helpful either. }\end{array}$ & $\begin{array}{l}\text { For common underlying diseases or } \\
\text { conditions, see above under "Note." }\end{array}$ \\
\hline
\end{tabular}

\section{Coarctation, Aortic}

Related Term: Aortic isthmus stenosis.

Possible Associated Conditions: Anomalous origin of right subclavian artery; atresia or stenosis of left subclavian artery; biscuspid aortic valve;* congenital mitral stenosis;* double aortic arch with stenosis of the right arch and coarctation of the left; stenosis of right subclavian artery; Turner's syndrome;* ventricular septal defect;* Shone's syndrome.

\begin{tabular}{ll}
\hline Organs and Tissues & Procedures \\
\hline External examination & Prepare chest roentgenogram.
\end{tabular}

Blood

Heart

Aorta and adjacent arteries techniques, see p. 33.
Submit sample for microbiologic study (p. 102).

If endocarditis is suspected, follow procedures described on p. 103. For general dissection

For coronary angiography, see p. 118. Record size and location of coarctation (relation to ductal artery and great vessels).

If bacterial aortitis is suspected, obtain sample for microbiologic study through sterilized window in wall of aorta.

For arteriography, clamp proximal and distal thoracic aorta before injecting contrast medium.

\section{Possible or Expected Findings}

Pressure atrophy of ribs with enlargement of costal grooves or focal erosions at inferior and ventral aspects of main body of ribs (rib notching).

Septicemia associated with endocarditis* or endarteritis (see below).

Infective endocarditis* (of bicuspid aortic valve); endocardial fibroelastosis.

For associated malformations, see above under "Possible Associated Conditions." Premature coronary atherosclerosis.

Preductal coarctation (isthmus stenosis) is often classified as "infantile type of coarctation." "Adult type" is at insertion of duct or distal to it. Rarely, coarctation occurs proximal to left subclavian artery, in lower thoracic aorta, or at multiple sites.

Bacterial aortitis. For ductal artery, see below.

Dilatation of subclavian, internal mammary, intercostal, scapular, and anterior spinal arteries. Among the intercostal arteries, the fourth through seventh pairs are predominantly affected. 


\begin{tabular}{|c|c|c|}
\hline Organs and Tissues & Procedures & Possible or Expected Findings \\
\hline $\begin{array}{l}\text { Aorta and adjacent } \\
\text { arteries } \\
\text { (continued) }\end{array}$ & $\begin{array}{l}\text { Record width of left subclavian artery and } \\
\text { compare with contralateral vessel; record width } \\
\text { of aorta and of vessels proximal and distal } \\
\text { to coarctation. Request Verhoeff-van Gieson } \\
\text { stain (p. 173). }\end{array}$ & $\begin{array}{l}\text { Subclavian artery is considerably dilated if } \\
\text { proximal to coarctation. Other complications } \\
\text { include poststenotic dilatation of aorta, } \\
\text { mycotic or noninfectious saccular aneurysm } \\
\text { distal to coarctation (with or without rupture), } \\
\text { and dissecting hematoma of aorta* (with or } \\
\text { without rupture). }\end{array}$ \\
\hline \multirow[t]{2}{*}{$\begin{array}{l}\text { Ductal artery } \\
\text { Abdominal arteries }\end{array}$} & Probe duct and record width of lumen. & $\begin{array}{l}\text { Ductal artery may be patent or closed. } \\
\text { Dilatation of epigastric and lumbar arteries. } \\
\text { Rarely, coarctation of abdominal aorta. }\end{array}$ \\
\hline & $\begin{array}{l}\text { After surgical correction of coarctation, search } \\
\text { for infarcts and sample arteries for histologic } \\
\text { study. }\end{array}$ & $\begin{array}{l}\text { Abdominal hypertensive arteritis and visceral } \\
\text { infarctions after correction of coarctation. }\end{array}$ \\
\hline Other organs & & Manifestation of congestive heart failure.* \\
\hline Brain & $\begin{array}{l}\text { For removal and specimen preparation, see } \\
\text { p. } 65 \text {. For cerebral arteriography, see p. } 80 \text {. }\end{array}$ & Rupture of aneurysm, circle of Willis. \\
\hline
\end{tabular}

\section{Cocaine (See "Dependence, cocaine.")}

\section{Coccidioidomycosis}

Synonyms and Related Terms: Coccidioides immitis infection; San Joaquin fever; valley fever.

NOTE: (1) Collect all tissues that appear to be infected. (2) Request fungal cultures. (3) Request Grocott methenamine silver stain (p. 172). (4) Special precautions are indicated (p. 146). (5) Serologic studies are available from many reference and state health department laboratories (p. 135). (6) This is a reportable disease in some states.

\begin{tabular}{lll}
\hline Organs and Tissues & Procedures & Possible or Expected Findings \\
\hline $\begin{array}{l}\text { External examination } \\
\text { and skin }\end{array}$ & Prepare chest roentgenogram. & $\begin{array}{l}\text { Pulmonary infiltrates; pulmonary } \\
\text { cavitations; hilar lymphadenopathy. } \\
\text { Erythema nodosum or multiforme,* } \\
\text { various types of skin rashes; skin ulcers. }\end{array}$ \\
Lungs & $\begin{array}{l}\text { Prepare histologic sections of skin lesions. } \\
\text { For a special stain, see above under "Note." }\end{array}$ & $\begin{array}{l}\text { Chronic pulmonary cavitation; pulmonary } \\
\text { fubmit sample for serologic study. }\end{array}$ \\
& $\begin{array}{l}\text { Prior to sectioning lungs, culture for fungi } \\
\text { and bacteria any areas of consolidation (p. 103). }\end{array}$ & fibrosis. \\
& $\begin{array}{l}\text { Prepare smears from fresh, grossly infected } \\
\text { pulmonary tissue. For special stain, see above }\end{array}$ & \\
& under "Note." & \\
& $\begin{array}{l}\text { Perfuse one lung with formalin (p. 47). } \\
\text { Submit samples of hilar lymph nodes for } \\
\text { histologic study. }\end{array}$ & Bronchiectasis.* \\
& $\begin{array}{l}\text { Submit samples of material for culture and } \\
\text { histologic study wherever extrapulmonary } \\
\text { lesions are suspected. }\end{array}$ & $\begin{array}{l}\text { Lymphogenous and hematogenous } \\
\text { dissemination to almost all organs may occur, } \\
\text { causing abscesses and sinuses of skin, } \\
\text { subcutaneous tissue, bones, and joints. } \\
\text { Other organs }\end{array}$ \\
& $\begin{array}{l}\text { If involvement of central nervous system is } \\
\text { suspected, submit sample of cerebrospinal fluid } \\
\text { for culture and serologic study (p. 104). }\end{array}$ & \\
\hline
\end{tabular}

Codeine (See "Dependence, $\operatorname{drug}[\mathrm{s}]$, all types or type unspecified.”)

Cold (See "Exposure, cold.")

Colitis, All Types or Type Unspecified (See “Enterocolitis, Other Types or Type Undetermined.”)

Colitis, Chronic Ulcerative (See "Disease, inflammatory bowel.") 


\section{Colitis, Collagenous}

Related Terms: Lymphocytic colitis; microscopic colitis.

NOTE: This is a cause of diarrhea. The colon is grossly normal but microscopically, increased lymphocytes in the lamina propria and a subepithelial band of collagen is found. If only the lymphocytic infiltrate is found, the term "lymphocytic colitis" or "microscopic colitis" should be applied. A trichrome stain should be ordered in all instances, because the collagen band may be difficult to see without the special stain.

\section{Coma, Hepatic}

NOTE: See under name of suspected underlying hepatic disease, such as "Cirrhosis, liver" or "Hepatitis, viral."

Complex, Eisenmenger's (See “Defect, ventricular septal.”)

Complex, Taussig-Bing (See "Ventricle, double outlet, right.")

Craniopharyngioma (See "Tumor of the pituitary gland.")

\section{Cretinism (See “Hypothyroidism.”)}

Crisis, Sickle Cell (See "Disease, sickle cell.”)

\section{Croup (See "Laryngitis.")}

\section{Cryptococcosis}

Synonyms: European Blastomycosis; torulosis.

NOTE: Cryptococcosis may follow or complicate AIDS (1) and other immunodeficient states, bronchiectasis, ${ }^{*}$ bronchitis, ${ }^{*}$ diabetes mellitus, ${ }^{*}$ leukemia, ${ }^{*}$ lymphoma, ${ }^{*}$ sarcoidosis, ${ }^{*}$ and tuberculosis.* (1) Collect all tissues that appear to be infected. (2) Request fungal cultures. (3) Request Grocott's methenamine silver, periodic acid Schiff, and mucicarmine stains (p. 172). (4) No special precautions are indicated. (5) Serologic studies are available from many reference laboratories and from state health department laboratories (p. 135). (6) This is not a reportable disease.

\begin{tabular}{|c|c|c|}
\hline Organs and Tissues & Procedures & Possible or Expected Findings \\
\hline Cerebrospinal fluid & $\begin{array}{l}\text { Submit sample for fungal culture (p. 104). } \\
\text { Use India ink or a nigrosin preparation for } \\
\text { direct examination. }\end{array}$ & \\
\hline Brain and spinal cord & $\begin{array}{l}\text { For removal and specimen preparation, see } \\
\text { pp. } 65 \text { and } 67 \text {, respectively. Submit material } \\
\text { for Gram stain and fungal culture. For special } \\
\text { stains, see above under "Note." }\end{array}$ & $\begin{array}{l}\text { Meningitis; } * \text { meningoencephalitis; } \\
\text { hydrocephalus; } * \text { cysts in cortical gray matter } \\
\text { and basal ganglia. Note that inflammation } \\
\text { may be minimal. }\end{array}$ \\
\hline Eyes & For removal and specimen preparation, see p. 85. & Endophthalmitis; optic neuritis. \\
\hline Other organs & $\begin{array}{l}\text { See above under "Note." Procedures depend on } \\
\text { expected findings or grossly identified abnor- } \\
\text { malities as listed in right-hand column. }\end{array}$ & $\begin{array}{l}\text { Infiltrates and abscesses in skin, } \\
\text { endocardium, pericardium, liver, kidneys, } \\
\text { adrenal glands, prostate, bones, and joints. } \\
\text { Other infections may coexist ( } 2 \text { ). } \\
\text { Hypereosinophilia may be noted (3). }\end{array}$ \\
\hline
\end{tabular}

\section{References}

1. Kanjanavirojkul N, Sripa C, Puapairoj A. Cytologic diagnosis of Cryptococcus neoformans in HIV-positive patients. Acta Cytol 1997;41: 493-496.

2. Benard G, Gryschek RC, Duarte AJ, Shikanai-Yasuda MA. Cryptococcosis as an opportunistic infection in immunodeficiency secondary to paracoccidioidomycosis. Mycopathologia 1996;133:65-69.

3. Marwaha RK, Trehan A, Jayashree K, Vasishta RK. Hypereosinophilia in disseminated cryptococcal disease. Pediatr Inf Dis J 1995;14: 1102-1103.

\section{Cryptosporidiosis}

Synonym: Cryptosporidium parvum infection.

Possible Associated Conditions: AIDS ( 1 ) and other immunodeficient states.

NOTE: (1) Collect feces, intestinal wall tissue, bile ducts, and pancreas. (2) Cultures are not available. (3) Request Kinyoun stain (p. 172). (4) No special precautions are indicated. (5) Serologic studies are unreliable. (6) This is not a reportable disease.

\begin{tabular}{lll}
\hline Organs and Tissues & Procedures & Possible or Expected Findings \\
\hline External examination & $\begin{array}{l}\text { Record body weight and length and extent } \\
\text { of rigor. } \\
\text { Submit sample for sodium, chloride, and urea } \\
\text { Vitreous }\end{array}$ & $\begin{array}{l}\text { Evidence of dehydration following chronic } \\
\text { diarrhea in immunosuppressed hosts. } \\
\text { Dehydration.* (See p. 247). }\end{array}$ \\
Lungs & $\begin{array}{l}\text { Perfuse one lung with formalin (p. 47) } \\
\text { and submit samples of bronchi and lung for }\end{array}$ & $\begin{array}{l}\text { Bronchopulmonary cryptosporidiosis in } \\
\text { HIV (2). }\end{array}$
\end{tabular}

histologic study. 


\begin{tabular}{lll}
\hline Organs and Tissues & Procedures & Possible or Expected Findings \\
\hline Intestinal tract & $\begin{array}{l}\text { Record volume and appearance of intestinal } \\
\text { contents. Submit samples of feces prepared } \\
\text { with saline or iodine solution. Submit samples } \\
\text { for determination of sodium, potassium, and } \\
\text { chloride content. } \\
\text { Submit samples of small bowel for histologic } \\
\text { and electron microscopic study. }\end{array}$ & $\begin{array}{l}\text { Cryptosporidiosis may complicate } \\
\text { inflammatory bowel disease (3).* }\end{array}$ \\
$\begin{array}{l}\text { For cholangiography, see p. 56. } \\
\text { Bile ducts, gallbladder, } \\
\text { and pancreas }\end{array}$ & Parasites attached to mucosa. \\
& $\begin{array}{l}\text { Submit samples for histologic study and } \\
\text { electron microscopic study. }\end{array}$ & $\begin{array}{l}\text { Changes resembling sclerosing cholangitis } \\
\text { in patients with AIDS or other } \\
\text { immunodeficiency states complicated by } \\
\text { cryptosporidiosis (4). } \\
\text { Cryptosporidium parvum may be found on } \\
\text { mucosal surfaces. }\end{array}$ \\
\hline
\end{tabular}

\section{References}

1. Ramratnam B, Flanigan TP. Cryptosporidiosis in persons with HIV infection. Postgrad Med J 1997;73:713-716.

2. Poirot JL, Deluol AM, Antoine M, Heyer F, Cadranel J, Meynard JL, et al. Broncho-pulmonary cryptosporidiosis in four HIV-infected patients. J Eukaryotic Microbiol 1996;43:78S-78S.

3. Manthey MW, Ross AB, Soergel KH. Cryptosporidiosis and inflammatory bowel disease. Dig Dis Sci 1997;42:1580-1586.

4. Davis JJ, Heyman MB, Ferrell L, Kerner J, Kerlan R Jr, Thaler MM. Sclerosing cholangitis associated with chronic cryptosporidiosis in a child with a congenital immunodeficiency disorder. Am J Gastroenterol 1987;82:1196-1202.

\section{Cyanide (See "Poisoning, cyanide.")}

\section{Cyst(s), Choledochal}

Synonyms and Related Terms: Choledochocyst; congenital cystic dilatation of the common bile duct; idiopathic dilatation of the common bile duct.

Possible Associated Conditions: Biliary atresia;* Caroli's disease;* congenital hepatic fibrosis.*

\begin{tabular}{lll}
\hline Organs and Tissues & Procedures & Possible or Expected Findings \\
\hline $\begin{array}{l}\text { External examination } \\
\text { and skin }\end{array}$ & Prepare sections of skin lesions. & Jaundice; xanthomas. \\
$\begin{array}{l}\text { Abdominal cavity } \\
\begin{array}{l}\text { Gallbladder and } \\
\text { extrahepatic bile ducts }\end{array}\end{array}$ & $\begin{array}{l}\text { Submit peritoneal exudate for culture. } \\
\text { Follow procedures described under } \\
\text { "Cholecystitis." Record size and location } \\
\text { of cyst(s) and relationship to surrounding } \\
\text { organs, particularly to the portal vein. } \\
\text { Puncture cyst(s) and submit contents } \\
\text { for aerobic and anaerobic bacterial cultures. } \\
\text { Dissect and photograph in situ. }\end{array}$ & $\begin{array}{l}\text { Bile peritonitis. } \\
\text { Cyst may displace stomach, duodenum, and } \\
\text { colon. Portal vein may be compressed, which } \\
\text { may cause portal hypertension.* Cyst may } \\
\text { perforate or contain stones or a carcinoma. }\end{array}$ \\
& $\begin{array}{l}\text { Congenital anomalies such as double } \\
\text { gallbladder, double common bile ducts, } \\
\text { absence of gallbladder, biliary atresia, or } \\
\text { annular pancreas may co-exist. }\end{array}$ \\
& Record size and weight. Submit samples for \\
histologic study. & $\begin{array}{l}\text { Abscesses. Fibropolycystic disease of the } \\
\text { liver.* See also above under "Possible } \\
\text { Liver }\end{array}$ & Associated Conditions." \\
\hline
\end{tabular}

\section{Reference}

1. Crittenden SI, McKinley MJ. Choledochal cyst-clinical features and classification. Am J Gastroenterol 1985;80:643-647.

\section{Cyst(s), Liver (See “Disease, fibropolycystic, of the liver and biliary tract.”)}

\section{Cyst(s), Pulmonary}

Related Terms: Congenital cystic adenomatoid malformation; congenital pulmonary lymphangiectasis; intralobular bronchopulmonary sequestration.

Possible Associated Conditions: Polycystic kidney disease;* renal cysts* or cysts of other organs. 


\begin{tabular}{lll}
\hline Organs and Tissues & Procedures & Possible or Expected Findings \\
\hline $\begin{array}{l}\text { External examination } \\
\text { Chest organs }\end{array}$ & $\begin{array}{l}\text { Prepare chest roentgenogram. } \\
\text { Search-in situ or after en bloc removal of } \\
\text { chest organs-for anomalous arterial supply } \\
\text { from aorta. Prepare pulmonary (see below) } \\
\text { and thoracic aortic arteriograms. If infection } \\
\text { of cyst is suspected, submit cyst contents or } \\
\text { portions of the lung for bacterial culture (p. 103). } \\
\text { For bronchial and pulmonary arteriography, } \\
\text { see p. 50. Perfuse lung with formalin (p. 47). }\end{array}$ & $\begin{array}{l}\text { Cyst(s) with air, fluid, or both. } \\
\text { Congenital cysts in lower lobes may have } \\
\text { anomalous arterial supply ("intralobular } \\
\text { bronchopulmonary sequestration"). } \\
\text { Perifocal bronchopneumonia; hemorrhage. } \\
\text { (see above under "Related Terms"). }\end{array}$ \\
& & $\begin{array}{l}\text { In rare instances, cysts may co-exist in other } \\
\text { organs, e.g. the kidneys. }\end{array}$ \\
\hline
\end{tabular}

\section{Cyst(s), Renal}

Related Terms: Acquired cystic renal disease; autosomal dominant (adult) polycystic renal disease (1); autosomal recessive (infantile and childhood form) polycystic renal disease (1); cystic renal lymphangiectasis; familial juvenile nephronophthisis; glomerulocystic disease; medullary cystic disease; multicystic dysplasia.

NOTE: Bilateral cystic disease of the kidneys may be acquired after long-term hemodialysis.

Possible Associated Conditions: Alagille's syndrome; Caroli's disease;* cerebral artery aneurysm* (with adult polycystic disease) (2); congenital hepatic fibrosis; ${ }^{*}$ congenital pyloric stenosis; cysts of liver, pancreas, spleen, lungs, ${ }^{*}$ and testes; EhlersDanlos syndrome; $*$ hemihypertrophy.

\begin{tabular}{|c|c|c|}
\hline Organs and Tissues & Procedures & Possible or Expected Findings \\
\hline Kidneys & $\begin{array}{l}\text { For renal arteriography, venography, or urography, } \\
\text { see p. } 59 \text {. If infection of cysts is suspected, } \\
\text { submit cyst contents or portions of the kidney for } \\
\text { bacteriologic study (p. 102). For demonstration } \\
\text { of cysts by injection of plastics, see p. } 139 \text {. } \\
\text { Formalin-gelatin mixtures are usually preferred. }\end{array}$ & $\begin{array}{l}\text { Infection or calcification of cysts; } \\
\text { pyelonephritis;* perinephric abscess. } \\
\text { Obstructive uropathy;* nephrolithiasis;* } \\
\text { carcinoma (3) (see "Tumor of the kidneys"); } \\
\text { hemorrhages, and related complications (4). }\end{array}$ \\
\hline Liver & $\begin{array}{l}\text { Prepare photographs and sample for histologic } \\
\text { study. }\end{array}$ & $\begin{array}{l}\text { In recessive polycystic renal disease, diffuse } \\
\text { biliary dysgenesis may be present but the bile } \\
\text { ducts are normal in dominant cases. }\end{array}$ \\
\hline Other organs & $\begin{array}{l}\text { See above under "Possible Associated } \\
\text { Conditions." Other procedures depend on } \\
\text { expected findings or grossly identified } \\
\text { abnormalities as listed in right-hand column. }\end{array}$ & $\begin{array}{l}\text { See above under "Possible Associated } \\
\text { Conditions." Manifestations of portal or } \\
\text { systemic hypertension* and kidney failure;* } \\
\text { polycythemia.* }\end{array}$ \\
\hline
\end{tabular}

\section{References}

1. Rapola J, Kaariainen H. Polycystic kidney disease. Morphological diagnosis of recessive and dominant polycystic kidney disease in infancy and childhood. APMIS 1988;96:68-76.

2. Chapman AB, Rubinstein D, Hughes R, Stears JC, Earnest MP, Johnson AM, et al. Intracranial aneurysm in autosomal dominant polycystic kidney disease. N Engl J Med 1992;327:916-920.
3. Banyai-Falger S, Susani M, Maier U. Renal cell carcinoma in acquired renal cystic disease 3 years after successful kidney transplantation. Two case reports and review of the literature. Eur Urol 1995;28:7780.

4. Wilson PD, Falkenstein D. The pathology of human renal cystic disease. Curr Topics Pathol 1995;88:1-50.

\section{Cystinosis}

Synonyms and Related Terms: Cystine storage disease; de Toni-Debré-Fanconi syndrome;* infantile Fanconi syndrome.

\begin{tabular}{lll}
\hline Organs and Tissues & Procedures & Possible or Expected Findings \\
\hline External examination & Record body weight and length. & Growth retardation. \\
Kidneys & Freeze tissue samples or fix them in absolute & Cystine crystals in tubular epithelial \\
& alcohol or Carnoy's fixative (p. 130) for & cells (1) and foam cells in the \\
& preservation of cystine crystals. See also & interstitium. "Swan's neck" deformity \\
& under "Glomerulonephritis." For preparation & of nephrons (not specific). Atrophy \\
& for electron microscopy, see p. 132. & with interstitial scarring and tubular \\
& (See also under "Other organs.) & degeneration.
\end{tabular}


Organs and Tissues

Urine

Other organs

Bone and bone marrow

\section{Procedures}

Submit sample for chemical analysis.

Submit samples of lymph nodes for histologic study (see above under "Kidneys"). For removal and specimen preparation of eyes, see p. 85 . Excellent views of crystals can be provided in scanning electron microscopic preparations.

For removal, prosthetic repair, and specimen preparation of bones, see p. 95 .

For preparation of sections and smears of bone marrow, see p. 96. See also above under "Kidneys."
Possible or Expected Findings

Glycosuria; generalized aminoaciduria. Cystine crystals occur throughout the reticuloendothelial system and in many other tissues, such as liver (2) or corneae and conjunctivae. Diagnostic doubly refractive brick- or needle-shaped cystine crystals in frozen sections or in smears from spleen, liver, lymph nodes, and bone marrow. Cystine crystals in bone marrow.

Hypophosphatemic rickets.

\section{References}

1. Thoene JG. Cystinosis. J Inherited Metabolic Dis 1995;18(4):380-386.

2. Klenn PJ, Rubin R. Hepatic fibrosis associated with hereditary cystinosis: a novel form of noncirrhotic portal hypertension. Modern Pathol 1994; $7: 879-882$.

\section{Cytomegalovirus (See "Infection, cytomegalovirus.")}




\section{D}

\section{Damage, Diffuse Alveolar (See "Syndrome, Adult Respiratory Distress [ARDS].”)}

\section{Death, Abortion-Associated}

Related Terms: Criminal abortion; stillbirth.*

NOTE: Anesthesia-associated death* must be considered in some of these cases. If criminal abortion is suspected, notify coroner or medical examiner.

\begin{tabular}{|c|c|c|}
\hline Organs and Tissues & Procedures & Possible or Expected Findings \\
\hline \multirow{3}{*}{$\begin{array}{l}\text { External examination } \\
\text { and breasts }\end{array}$} & Prepare roentgenograms of chest and abdomen. & Pulmonary air embolism.* \\
\hline & $\begin{array}{l}\text { Describe appearance of breasts and sample } \\
\text { glandular tissue for histologic study. }\end{array}$ & Pregnancy changes. \\
\hline & Record appearance of external genitalia. & Instrument marks on vulva. \\
\hline Peritoneal cavity & Submit exudate for bacteriologic study (p. 102). & Peritonitis.* \\
\hline Blood vessels and heart & $\begin{array}{l}\text { Inspect and puncture right atrium and right } \\
\text { ventricle of heart under water, also retro- } \\
\text { peritoneal and pelvic veins. }\end{array}$ & $\begin{array}{l}\text { Pulmonary air embolism.* Abdominal and } \\
\text { pelvic veins may also contain air. }\end{array}$ \\
\hline Blood & $\begin{array}{l}\text { Submit for bacteriologic (p. 102) and toxicologic } \\
\text { study (p. 16). }\end{array}$ & $\begin{array}{l}\text { Septicemia. Absorption of intrauterine } \\
\text { corrosives or other chemicals. }\end{array}$ \\
\hline \multirow[t]{2}{*}{ Lungs } & Submit portion for bacteriologic study (p. 103). & Abscesses; bacterial pneumonia. \\
\hline & Prepare sample for electron microscopy (p. 132). & $\begin{array}{l}\text { Thromboembolism; embolism of soap and } \\
\text { other chemicals. }\end{array}$ \\
\hline \multirow[t]{3}{*}{ Pelvic organs } & If there are vascular lacerations, identify vessel. & Lacerated blood vessels; pelvic hemorrhages. \\
\hline & $\begin{array}{l}\text { Submit samples of placenta and fetal parts for } \\
\text { histologic study. Submit liquid intrauterine }\end{array}$ & $\begin{array}{l}\text { Instrument marks; foreign bodies; } \\
\text { perforation(s). Placenta, fetus, and fetal parts. }\end{array}$ \\
\hline & $\begin{array}{l}\text { contents for toxicologic study. Sample ovaries } \\
\text { for histologic study. }\end{array}$ & $\begin{array}{l}\text { Soap or other toxic foreign intrauterine } \\
\text { materials. Corpus luteum of pregnancy. }\end{array}$ \\
\hline Fetus & $\begin{array}{l}\text { Determine weight and length, and estimate age } \\
\text { (pp. } 557 \text { and 560). }\end{array}$ & Malformations. See also under "Stillbirth." \\
\hline
\end{tabular}

\section{Death, Anaphylactic}

Synonym: Generalized anaphylaxis.

NOTE: Autopsy should be done as soon as possible after death. Neck organs should be removed before embalming. If death is believed to be caused by drug anaphylaxis, inquire about type of drug(s), drug dose, and route of administration (intravenous, intramuscular, and oral or other). This will determine proper sampling procedures-for instance, after penicillin anaphylaxis. Allergy to bee stings, wasp stings, fire ants, and certain plants may also be responsible for anaphylaxis. However, envenomation also can be fatal in the absence of anaphylaxis.

\begin{tabular}{lll}
\hline Organs and Tissues & Procedures & Possible or Expected Findings \\
\hline External examination & $\begin{array}{l}\text { Search for injection sites or sting marks. If such } \\
\text { lesions are present, photograph and excise with }\end{array}$ & $\begin{array}{l}\text { Foam in front of mouth and nostrils. Swelling } \\
\text { of involved tissue. }\end{array}$ \\
& $\begin{array}{l}\text { 5-cm margin. } \\
\text { Freeze excised tissue at }-70^{\circ} \mathrm{C} \text { for possible } \\
\text { analysis. Prepare chest roentgenogram. }\end{array}$ & $\begin{array}{l}\text { Antigen-antibody reaction in involved } \\
\text { tissues. }\end{array}$
\end{tabular}

From: Handbook of Autopsy Practice, 3rd Ed. Edited by: J. Ludwig @ Humana

Press Inc., Totowa, NJ 


\begin{tabular}{|c|c|c|}
\hline Organs and Tissues & Procedures & Possible or Expected Findings \\
\hline Blood & $\begin{array}{l}\text { Submit sample for immunologic study and study } \\
\text { of drug levels. For serum IgE testing (Mayo } \\
\text { Medical Laboratories), sample must be kept } \\
\text { refrigerated (frozen or refrigerated coolant). }\end{array}$ & Antibodies against suspected antigen. \\
\hline Neck organs & $\begin{array}{l}\text { Remove as soon as possible after death. } \\
\text { Photograph rima of glottis from above, together } \\
\text { with epiglottis. For histologic study, fix larynx } \\
\text { and epiglottis in Zenker's (p. 131) or Bouin's } \\
\text { (p. 129) solution. }\end{array}$ & $\begin{array}{l}\text { Laryngeal edema may recede soon after } \\
\text { death. }\end{array}$ \\
\hline $\begin{array}{l}\text { Tracheobronchial tree } \\
\text { and lungs }\end{array}$ & $\begin{array}{l}\text { Record character of contents of tracheobronchial } \\
\text { tree. Photograph lungs and record weights. } \\
\text { In order to avoid artificial distention, do not } \\
\text { perfuse with fixative. For proper fixation, see } \\
\text { above under "Neck organs." Request Giemsa } \\
\text { stain (p. 172). }\end{array}$ & $\begin{array}{l}\text { Foamy edema in trachea and bronchi; diffuse } \\
\text { or focal pulmonary distention ("acute } \\
\text { emphysema") alternating with collapse; } \\
\text { pulmonary edema and congestion; } \\
\text { accumulation of eosinophilic leukocytes. }\end{array}$ \\
\hline Spleen & & Eosinophilic leukocytes in red pulp. \\
\hline
\end{tabular}

\section{Death, Anesthesia-Associated}

NOTE: There are many possible causes of anesthesia-associated death that are not drug-related, such as acute airway obstruction* by external compression, aspiration, tumor, or an inflammatory process. Some of the complications are characteristically linked to a specific phase of the anesthesia, and many cannot be proved morphologically.

The most important step in these autopsies is to obtain the anesthesia-associated records and to secure the consulting services of an independent anesthesiologist. When information is gathered about drugs and chemical agents that had been administered or to which the victim may have had access, pathologists must keep in mind that some nonmedical chemicals and many drugs are known to affect anesthesia. Drugs and their metabolic products, additives, stabilizers, impurities, and deterioration products may be present and can be identified in portmortem tissues. Therefore, all appropriate body fluids, particularly bile, and organs (see p. 16) should be submitted for toxicologic examination. If the anesthetic agent had been injected into or near the spinal canal, spinal fluid should be withdrawn from above the injected site, preferably from the suboccipital cisterna; $250 \mathrm{mg}$ of sodium fluoride should be added per $30 \mathrm{~mL}$ of fluid. If the anesthetic agent was injected locally, tissue should be excised around needle puncture marks, at a radius of $2-4 \mathrm{~cm}$. Serial postmortem analysis of specimens may permit extrapolation to tissue concentration at the time of death. The time interval between drug administration and death sometimes can be calculated from the distribution and ratio of administered drugs and their metabolic products. For a review of anesthetic death investigation, see ref. (1).

Halothane anesthesia and some other anesthetic agents may cause fulminant hepatitis and hepatic failure. The autopsy procedures suggested under "Hepatitis, viral" should be followed.

\section{Reference}

1. Ward RJ, Reay DT. Anesthetic death investigation. Legal Med 1989; 39-58.
Death, Bolus (See “Obstruction, acute airway.”)

\section{Death, Crib (See "Death, sudden unexpected, of infant.")}

\section{Death due to Child Abuse or Neglect (See "Infanticide.")}

\section{Death, Intrauterine (See "Stillbirth.")}

\section{Death, Postoperative}

NOTE: For special autopsy procedures, see p. 4. In some instances, procedures described under "Death, anesthesia-associated" may be indicated. For a thorough review of investigational procedures and autopsy techniques in operating-roomassociated deaths, see ref. (1). In patients who developed a cerebral infarct after open heart surgery, arterial air embolism should be considered as a possible cause. The diagnosis often must be based on excluding other causes because the air has been absorbed prior to death. If a patient bled to death despite attempted repair, e.g., of hepatic lacerations, hospital records may not suffice to reach competent opinions but personal accounts from the surgeon and anesthesiologist may be needed.

\section{Reference}

1. Start RD, Cross SS. Pathological investigations of deaths following surgery, anaesthesia and medical procedures. J Clin Pathol 1999;52: 640-652.

\section{Death, Restaurant \\ (See "Obstruction, acute airway.")}

\section{Death, Sniffing and Spray}

Related Terms: Glue sniffing; sudden sniffing death syndrome.

NOTE: No anatomic abnormalities will be noted at autopsy. Sudden death may occur after cardiac dysrhythmia or respiratory arrest. 


\begin{tabular}{|c|c|c|}
\hline Organs and Tissues & Procedures & Possible or Expected Findings \\
\hline \multirow[t]{2}{*}{ Lungs } & $\begin{array}{l}\text { If poison had been inhaled at the time when } \\
\text { death occurred, tie main bronchi. Submit lungs } \\
\text { in glass container for gas analysis. }\end{array}$ & $\begin{array}{l}\text { Trichloroethane, fluorinated refrigerants, and } \\
\text { other volatile hydrocarbons are most often } \\
\text { involved in the "sudden sniffing death } \\
\text { syndrome." }\end{array}$ \\
\hline & $\begin{array}{l}\text { Submit samples of small bronchi for histologic } \\
\text { study. }\end{array}$ & $\begin{array}{l}\text { Spray death may occur in asthma sufferers } \\
\text { using pressurized aerosol bronchodilators. } \\
\text { Freons and related propellants may also be } \\
\text { responsible for sudden death. }\end{array}$ \\
\hline Brain & $\begin{array}{l}\text { For removal and specimen preparation, } \\
\text { see p. } 65 \text {. Submit samples of fresh or frozen } \\
\text { brain for toxicologic study. }\end{array}$ & $\begin{array}{l}\text { Toxic components of glue-such as } \\
\text { toluene-accumulate in the brain of glue } \\
\text { sniffers. Also present in various glues are } \\
\text { acetone, aliphatic acetates, cyclohexane, } \\
\text { hexane, isopropanol, methylethyl ketone, and } \\
\text { methylisobutyl ketone. }\end{array}$ \\
\hline Other organs & $\begin{array}{l}\text { Submit samples in glass containers (not plastic) } \\
\text { for toxicologic study. }\end{array}$ & $\begin{array}{l}\text { Aerosols may occlude the airway by freezing } \\
\text { the larynx. Carbon tetrachloride sniffing may } \\
\text { cause hepatorenal syndrome (see also under } \\
\text { "Poisoning, carbon tetrachloride"). }\end{array}$ \\
\hline
\end{tabular}

\section{Death, Sudden Unexpected, of Adult}

NOTE: Medicolegal autopsies are usually indicated, and appropriate procedures should be followed (p. 8). If anaphylactic death is suspected, see also under that heading. A history of recent drinking (e.g., among college students) or of chronic alcoholism may be an important clue. The list of "Possible or Expected Findings" below is not complete. For general toxicologic sampling, see p. 16.

\begin{tabular}{ll}
\hline Organs and Tissues & Procedures \\
\hline $\begin{array}{l}\text { Abdomen } \\
\text { Chest cavity }\end{array}$ & $\begin{array}{l}\text { Submit sample of blood or exudate. } \\
\text { Record volume and character of contents of } \\
\text { pleural and pericardial cavities. }\end{array}$ \\
Blood & $\begin{array}{l}\text { Submit samples for microbiologic (p. 102) and } \\
\text { toxicologic (p. 16) study. } \\
\text { Submit samples of myocardium (p. 30) with } \\
\text { the conduction system (p. 26) for histologic } \\
\text { study. For coronary arteriography, see p. 118. }\end{array}$
\end{tabular}

Possible or Expected Findings

Hemoperitoneum; peritonitis.*

Hemothorax may occur-for instance, after rupture of aortic aneurysm.

Hemopericardium usually occurs after rupture of myocardial infarction or of aortic dissection.*

Meningococcal disease* or streptococcal septicemia may cause sudden death. Coronary atherosclerosis, thrombosis, or arteritis; myocardial infarction, with or without perforation; myocarditis; * valvular heart disease, such as aortic stenosis or ballooning posterior leaflet syndrome.* Anatomic conduction system defects may indicate presence of arrhythmia (p. 34). Pulmonary thromboembolism; tumor embolism. Pulmonary intravascular (arterial and arteriolar) platelet aggregates may be cause of sudden death.

Ruptured aneurysm;* aortic dissection.*

Islet cell tumor.

Hemorrhage may indicate presence of meningococcal disease.*

Occlusion of larynx by bolus (see "Obstruction, acute airway"). Laryngeal edema may be cause of anaphylactic death.* 


\begin{tabular}{lll}
\hline Organs and Tissues & Procedures & Possible or Expected Findings \\
\hline Brain and spinal cord & $\begin{array}{l}\text { For removal and specimen preparation, } \\
\text { see pp. 65 and 67, respectively. For cerebral } \\
\text { arteriography, see p. 80. }\end{array}$ & $\begin{array}{l}\text { Intracranial hemorrhage after trauma or } \\
\text { rupture of aneurysm or-occasionally-with } \\
\text { no apparent reason. Changes suggestive of } \\
\text { epilepsy* may be present. } \\
\text { Vitreous }\end{array}$ \\
& $\begin{array}{l}\text { Submit samples for possible chemical and } \\
\text { toxicologic study (pp. 85 and 113). }\end{array}$ & $\begin{array}{l}\text { indicate the presence of hyperglycemia } \\
\text { in undetected diabetes mellitus.* }\end{array}$ \\
\hline
\end{tabular}

\section{Death, Sudden Unexpected, of Infant}

Synonyms and Related Terms: Sudden infant death syndrome; SIDS; cot death; crib death.

NOTE: The autopsy alone does not suffice as an adequate investigation of sudden death of an infant. A thorough medical history, as well as complete information regarding the scene and circumstances of death must also be conducted. It should be recorded whether the infant was found in a prone position.
Photographs of the scene should be taken. The environmental and the infant's body temperature should be recorded as close to the time of death as possible. Cases of infanticide have been disguised as SIDS; a high level of suspicion should be maintained, particularly if more than one SIDS case reportedly occurred in the same family. Thus, while some of the "Possible or Expected Findings" in the table refer to typical cases of SIDS (1), other refer to possible infanticide (2).

\begin{tabular}{lll}
\hline Organs and Tissues & Procedures & Possible or Expected Findings \\
\hline External examination & Record weight of infant; measure crown-rump & Growth retardation. Signs of dehydration. \\
& and crown-heel length and head, chest and & Crusts or frothy fluid around nose and mouth. \\
& abdominal circumference. For expected & Emaciation indicates organic disease or \\
& values, see p. 554. Test skin turgor and look & neglect. Bruises or burns indicative of \\
& for "sunken eyes" (signs of deydration). & child abuse. Jaundice; edema. \\
& Prepare skeletal roentgenograms. & Old or recent fractures due to child abuse. \\
& Ophthalmic examination. & $\begin{array}{l}\text { Retinal hemorrhages indicative of } \\
\text { Eyes }\end{array}$ \\
& & "shaken baby syndrome." Conjunctival \\
& & petechiae may be a sign of strangulation (2).
\end{tabular}

Cerebrospinal fluid

Vitreous

Chest cavity

Thymus

Blood

Heart and great vessels; ductus arteriosus
If there is clinical or pathologic evidence of infection, submit sample for bacterial and viral cultures (p. 104). Prepare smear.

Submit sample for possible electrolyte studies and urea nitrogen and glucose determination (pp. 85 and 113). In suspected child abuse, photograph fundus (see p. 85) before considering an aspiration.

Record weight and submit samples for histologic study.

Submit for culture (p. 102). Submit blood drops dried on filter paper for tests for inborn errors of metabolism. Refrigerate blood samples for toxicologic study (p. 16). Check venous return and origin and course of coronary arteries and great vessels. Submit samples for histologic study (p. 30).

Lungs
Record weights; culture and Gram-stain areas of consolidation. Submit samples for histologic study.
Increased glucose concentrations may indicate undiagnosed diabetes mellitus.* Manifestations of dehydration.*

Petechial serosal hemorrhages.

Accelerated involution indicates stress and/or disease, of prolonged duration. Thymic petechiae.

In SIDS, blood in heart chambers tends to remain fluid.

In rare instances, congenital heart disease, myocarditis, coronary artery aneurysm, or coronary artery arising from the pulmonary artery may explain the sudden death. Congestion; hemorrhage; edema; pleural petechiae; atelectasis. Acute pulmonary emphysema may indicate strangulation (2). 


\begin{tabular}{|c|c|c|}
\hline Organs and Tissues & Procedures & Possible or Expected Findings \\
\hline \multirow[t]{2}{*}{ Neck organs and trachea } & $\begin{array}{l}\text { Photograph and culture sites of infection. } \\
\text { Samples submitted for histologic study should } \\
\text { include trachea, larynx, epiglottis, pharyngeal } \\
\text { wall, tonsils, submaxillary glands, parathyroid } \\
\text { glands, and cervical lymph nodes. }\end{array}$ & $\begin{array}{l}\text { Laryngitis;* tracheitis. } \\
\text { Epiglottitis. Infection affecting other neck } \\
\text { organs and tissues. }\end{array}$ \\
\hline & Dissect, weigh, and section carotid bodies. & $\begin{array}{l}\text { Hypoplasia of carotid bodies (few are } \\
\text { hyperplastic). }\end{array}$ \\
\hline Stomach & Record character and amount of contents. & $\begin{array}{l}\text { This may be pertinent to allegations of } \\
\text { starvation. }\end{array}$ \\
\hline Intestinal tract & $\begin{array}{l}\text { Record appearance of serosal surface (exudate? } \\
\text { discoloration?). Assess attachment of the } \\
\text { mesenteric root, which normally runs obliquely } \\
\text { from the left upper quadrant (ligament of Treitz) } \\
\text { to the right lower quadrant near the inferior pole } \\
\text { of the right kidney. }\end{array}$ & $\begin{array}{l}\text { Contusions; malrotation; volvulus; } \\
\text { infarction. }\end{array}$ \\
\hline Pancreas & Submit samples for histologic study. & $\begin{array}{l}\text { Degeneration of islets may indicate presence } \\
\text { of undetected diabetes mellitus.* }\end{array}$ \\
\hline Urine & $\begin{array}{l}\text { Obtain two samples; one saved in preservative } \\
\text { and the other frozen or refrigerated for toxico- } \\
\text { logic assays (p. 16). }\end{array}$ & $\begin{array}{l}\text { Drug intoxication, increased organic acids } \\
\text { with medium chain acyl-coenzyme A } \\
\text { dehyrogenase deficiency (3). }\end{array}$ \\
\hline Other organs & $\begin{array}{l}\text { Submit portions of spleen, for culture as a } \\
\text { double check for the blood culture. Carefully } \\
\text { examine, weigh, and submit samples of organs, } \\
\text { including endocrine organs, for histologic study. }\end{array}$ & $\begin{array}{l}\text { Extramedullary hematopoiesis in the liver. } \\
\text { Congenital adrenal hypoplasia. }\end{array}$ \\
\hline Brain and spinal cord & $\begin{array}{l}\text { For removal and specimen preparation, } \\
\text { see pp. } 66 \text { and } 70 \text {, respectively. Submit portion } \\
\text { of brain for microbiologic study if indicated by } \\
\text { clinical history or pathologic findings. }\end{array}$ & $\begin{array}{l}\text { Head trauma in abused child. Birth injuries; } \\
\text { encephalitis. Astroglial proliferations in brain } \\
\text { stem. Retarded myelination of brain stem. }\end{array}$ \\
\hline Middle ears & $\begin{array}{l}\text { Open middle ears and mastoid cells } \\
\text { (pp. 71-73). } \\
\text { Submit exudate for microbiologic study. } \\
\text { Prepare Gram-stained smears of exudate and } \\
\text { histologic sections of middle ears. }\end{array}$ & Otitis media.* \\
\hline Bones and bone marrow & $\begin{array}{l}\text { Submit samples from costochondral junctions. } \\
\text { For removal and specimen preparation of bone, } \\
\text { see p. } 95 \text {. For preparation of sections and } \\
\text { smears of bone marrow, see p. } 96 \text {. }\end{array}$ & $\begin{array}{l}\text { Bone changes of vitamin D deficiency* } \\
\text { (rickets). Normoblastic hyperplasia of bone } \\
\text { marrow. Retardation of the rate of enchondral } \\
\text { ossification such that hematopoiesis abuts the } \\
\text { transition zone. }\end{array}$ \\
\hline
\end{tabular}

\section{References}

1. Valdez-Dapena M, McFeeley PA, Hoffman HJ, et al., eds. Histopathology Atlas for the Sudden Infant Death Syndrome. Armed Forces Institute of Pathology Washington, DC, 1993. (Order from American Registry of Pathology Sales Office, AFIP, Room 1077, Washington, DC 20,306-26,000.)

2. Becroft DM, Lockett BK. Intra-alveolar pulmonary siderophages in sudden infant death: a marker for previous imposed suffocation. Pathology 1997;29:60-63.

3. Betz P, Hausmann R, Eisenmenger W. A contribution to a possible differentiation between SIDS and asphyxiation. For Sci Intl 1998;91: 147-152.

\section{Decompression (See "Sickness, decompression.")}

\section{Defect, Aortopulmonary Septal}

Synonyms: Aortopulmony window; aorticopulmonary window or septal defect.

NOTE: The basic anomaly is a defect between ascending aorta and main pulmonary artery. For general dissection techniques, see p. 33.

Possible Associated Conditions: Atrial septal defect; * bicuspid aortic valve;* coarctation,* hypoplasia, or interruption (type A) of aortic arch; coronary artery from main pulmonary artery; right atrial arch; patent ductal artery; ${ }^{*}$ right pulmonary artery from ascending aorta; subaortic stenosis; * tetralogy of Fallot;* ventricular septal defect.* (In approx 50\% of the cases, one or more of these associated conditions are found.) 


\section{Defect, Atrial Septal}

NOTE: The basic anomaly is a defect of the atrial septum, usually at the oval fossa (in 85\%). Possible complications in unoperated cases include atrial arrhythmias, congestive heart failure; paradoxic embolism; plexogenic pulmonary hypertension $(<10 \%)$, and pulmonary artery aneurysm. Possible surgical interventions include surgical and transcatheter closure of defect. For general dissection techniques, see p. 33.

Possible Associated Conditions: With secundum type: Often isolated; may occur with conotruncal anomalies, patent ductal artery, * valvular atresia,* and ventricular septal defect.* With primum type: Cleft in anterior mitral leaflet. With sinus venosus type: Anomalous connection of right pulmonary veins. With coronary sinus type (unroofed coronary sinus): Left atrial connection of a persistent left superior vena cava. With absent atrial septum or multiple large defects (common atrium): Complete atrioventricular defect;* asplenia syndrome.*

\section{Defect, Complete Atrioventricular Septal}

Synonyms and Related Terms: Complete atrioventricular canal; complete AV canal; endocardial cushion defect.

NOTE: The basic anomaly is a large combined atrioventricular septal defect and a common atrioventricular valve, with displacement of the atrioventricular conduction tissues. For possible surgical interventions, see complete repair, "mitral" valve replacement in Chapter 3 Appendix 3-4, p. 41. For general dissection techniques, see p. 33.

Possible Associated Conditions: Aortic coarctation; (35\%); asplenia or polysplenia syndrome;* atrial septal defect;* common atrium; discrete subaortic stenosis; ${ }^{*}$ double outlet right ventricle;* Down's syndrome;* patent ductal artery;* persistent left superior vena cava; pulmonary stenosis; $*$ tetralogy of Fallot.*

\section{Defect, Partial Atrioventricular Septal}

Synonyms and Related Terms: Endocardial cushion defect; primum atrial septal defect with cleft mitral valve.

NOTE: The basic anomaly is a primum atrial septal defect and a cleft in the anterior mitral leaflet. Possible surgical interventions consist of surgical repair of both malformations. For general dissection techniques, see p. 33.

Possible Associated Conditions: Mitral regurgitation.

\section{Defect, Ventricular Septal}

Synonyms: Inlet (subtricuspid, AV canal type); membranous (paramembranous, perimembranous, infracristal); muscular (persistent bulboventricular foramen); and outlet (subarterial, supracristal, conal, doubly committed juxta-arterial).

NOTE: The basic anomaly is a defect of the ventricular septum, usually at the membranous septum (in 75\%). Possible surgical intervention consists of surgical closure of the defect. Late postoperative death may be sudden and related to residual pulmonary hypertension or ventricular arrhythmias. For general dissection techniques, see p. 33. If hypertensive pulmonary artery disease is suspected, perfuse one lung with formalin (p. 47) and request Verhoeff-van Gieson stain (p. 173).

Possible Associated Conditions: With membranous type: Often isolated; may occur with atrial septal defect,* conotruncal anomalies, or patent ductal artery.* With outlet type: Conotruncal anomalies such as double outlet right ventricle, ${ }^{*}$ persistent truncal artery, ${ }^{*}$ or tetralogy of Fallot.* With inlet type: Atrioventricular septal defect* or atrioventricular discordance. With muscular type: Isolated or with tricuspid atresia* or double inlet left ventricle.

\section{Deficiency, alpha ${ }_{1}$-Antitrypsin}

Possible Associated Conditions: See below under "Possible or Expected Findings."

\begin{tabular}{|c|c|c|}
\hline Organs and Tissues & Procedures & Possible or Expected Findings \\
\hline $\begin{array}{l}\text { Skin and subcutaneous } \\
\text { tissue }\end{array}$ & $\begin{array}{l}\text { Sample normal and abnormal appearing areas } \\
\text { for histologic study. }\end{array}$ & Panniculitis ( 1 ). \\
\hline Blood (serum) & 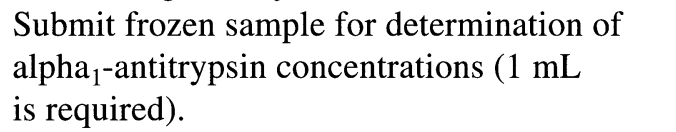 & $\begin{array}{l}\text { Decreased } a_{1} \text {-antitrypsin values. Many } \\
\text { genetic alleles can be determined by starch- } \\
\text { gel electrophoresis. }\end{array}$ \\
\hline Lungs & $\begin{array}{l}\text { Perfuse lungs with formalin (p. 47). } \\
\text { See also under "Emphysema." }\end{array}$ & $\begin{array}{l}\text { Panlobular pulmonary emphysema,* } \\
\text { primarily of lower lobes; chronic } \\
\text { bronchitis and, rarely, brochiectases; } \\
\text { interstitial pulmonary fibrosis. }\end{array}$ \\
\hline \multirow[t]{2}{*}{ Liver } & $\begin{array}{l}\text { If cirrhosis or tumor is present, follow } \\
\text { procedures described under those headings. } \\
\text { Request PAS stain, with diastase digestion } \\
\text { (p. 56). }\end{array}$ & $\begin{array}{l}\text { Cirrhosis in infants and adults; } \\
\text { cholangiocellular or hepatocellular } \\
\text { carcinoma; paucity of intrahepatic bile ducts; } \\
\text { neonatal (giant cell) hepatitis; periportal } \\
\text { hepatitis or cirrhosis and hepatocellular } \\
\text { carcinoma in adults }(2,3) \text {. }\end{array}$ \\
\hline & $\begin{array}{l}\text { Characteristic accumulations of alpha }{ }_{1} \text {-anti- } \\
\text { trypsin can be shown in routine paraffin } \\
\text { sections with PAS-D or immunostains. }\end{array}$ & $\begin{array}{l}\text { PAS-positive, diastase-resistant globular } \\
\text { inclusions, primarily in periportal } \\
\text { hepatocytes or in the periphery of } \\
\text { regenerative nodules. }\end{array}$ \\
\hline
\end{tabular}




\begin{tabular}{|c|c|c|}
\hline Organs and Tissues & Procedures & Possible or Expected Findings \\
\hline Small and large intestine & & Inflammatory bowel disease (rare) (3). \\
\hline Extrahepatic bile ducts & $\begin{array}{l}\text { For cholangiography, see p. } 56 \text {. Dissect bile } \\
\text { ducts in situ. }\end{array}$ & $\begin{array}{l}\text { Biliary atresia.* Generally no abnormalities } \\
\text { in adults. }\end{array}$ \\
\hline Pancreas & & Chronic pancreatitis; fibrosis of pancreas. \\
\hline Kidneys & See under "Glomerulonephritis." & $\begin{array}{l}\text { Membranoproliferative glomerulonephritis* } \\
\text { in childhood (4). }\end{array}$ \\
\hline
\end{tabular}

\section{References}

1. O'Riordan K, Blei A, Rao MS, Abecassis M. Alpha 1-antitrypsin deficiency-associated panniculitis: resolution with intravenous alpha 1-antitrypsin administration and liver transplantation. Transplantation 1997;63:480-482.

2. Perlmutter DH. Clinical manifestations of alpha 1-antitrypsin deficiency. Gastroenterol Clin North Am 1995;24:27-43.

3. Elzouki AN, Eriksson S. Risk of hepatobiliary disease in adults with severe alpha 1-antitrypsin deficiency (PiZZ): is chronic viral hepatitis $\mathrm{B}$ or $\mathrm{C}$ an additional risk factor for cirrhosis and hepatocellular carcinoma? Eur J Gastroenterol 1996;8:989-994.

4. Yang P, Tremaine WJ, Meyer RL, Prakash UB. Alpha 1-antitrypsin deficiency and inflammatory bowel disease. Mayo Clin Proc 2000;75: 450-455.

5. Elzouki AN, Lindgren S, Nilsson S, Veress B, Erisksson S. Severe alpha1-antitrypsin deficiency (PiZ homozygosity) with membranoproliferative glomerulonephritis and nephrotic syndrome, reversible after orthotopic liver transplantation. J Hepatol 1997;26:14031407.
Deficiency, alpha-Lipoprotein (See “Disease, Tangier's.”)

Deficiency, beta-Lipoprotein (See “Abetalipoproteinemia.”)

Deficiency, Congenital Transferrin (See “Hemochromatosis.”)

Deficiency, Folic Acid (See "Anemia, megaloblastic.")

Deficiency, Myeloperoxidase (See "Disorder, inherited, of phagocyte function.")

Deficiency, Vitamin A

Synonyms and Related Terms: Hypovitaminosis A; keratomalacia; xerophthalmia.

\begin{tabular}{lll}
\hline Organs and Tissues & Procedures & Possible or Expected Findings \\
\hline External examination & $\begin{array}{l}\text { Record extend and character of skin lesions } \\
\text { and appearance of eyes; prepare sections of skin. }\end{array}$ & $\begin{array}{l}\text { Sebaceous glands covered with keratin; } \\
\text { keratomalacia; enlarged meibomian glands } \\
\text { of eyelids. } \\
\text { Other organs }\end{array}$ \\
& & $\begin{array}{l}\text { For conditions that may produce vitamin A } \\
\text { deficiency, see under "Syndrome, } \\
\text { malabsorption." }\end{array}$ \\
Eyes & For removal and specimen preparation, & $\begin{array}{l}\text { Bitot's spots (keratinized epithelium and air } \\
\text { bubbles at corneal rim); keratomalacia. }\end{array}$ \\
\hline
\end{tabular}

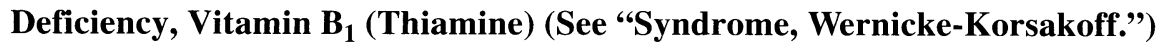

Deficiency, Vitamin $B_{6}$ (See "Beriberi.")

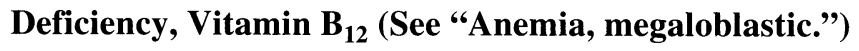

Deficiency, Vitamin C

Synonyms: Hypovitaminosis C; scurvy.
}

\begin{tabular}{ll}
\hline Organs and Tissues & Procedures \\
\hline $\begin{array}{l}\text { External examination } \\
\text { and skin }\end{array}$ & $\begin{array}{l}\text { Record extent and character of skin lesions; } \\
\text { prepare sections of skin. }\end{array}$
\end{tabular}

Possible or Expected Findings

Hyperkeratotic hair follicles with perifollicular hemorrhages (posterior thighs, anterior forearms, abdomen); petechiae and ecchymoses (inner and posterior thighs); subcutaneous hemorrhages.

Describe appearance of gums, and prepare Gingivitis. sections. 


\begin{tabular}{lll}
\hline Organs and Tissues & Procedures & Possible or Expected Findings \\
\hline Other organs & Record evidence of bleeding. & $\begin{array}{l}\text { In rare instances, gastrointestinal or } \\
\text { genitourinary hemorrhages. }\end{array}$ \\
$\begin{array}{l}\text { Bones, joints, } \\
\text { and soft tissues }\end{array}$ & $\begin{array}{l}\text { For removal, prosthetic repair, and specimen } \\
\text { preparation of bones and joints, see p. 95. }\end{array}$ & $\begin{array}{l}\text { Hemorrhages into muscles and joints. } \\
\text { Subperiosteal hemorrhages occur primarily } \\
\text { in distal femora, proximal humeri, tibiae, and } \\
\text { costochondral junctions (scorbutic rosary). }\end{array}$ \\
\hline
\end{tabular}

\section{Deficiency, Vitamin D}

Synonyms: Hypovitaminosis D; rickets.

NOTE: Features or rickets may be found in familial hypophosphatemia (vitamin D-resistent rickets; Fanconi syndrome).

\begin{tabular}{lll}
\hline Organs and Tissues & Procedures & Possible or Expected Findings
\end{tabular}

External examination Prepare skeletal roentgenograms.

Vitreous or blood (serum) Submit samples for calcium, magnesium, and

Other organs

Bones phosphate determination (p. 85).

In infants with suspected rickets, record size of anterior fontanelle and shape of head; state of dentition; and shape of costochondral junctions, wrists, long bones, and spine.

Procedures depend on expected findings or grossly identified abnormalities as listed in right-hand column.

Weigh parathyroid glands and submit samples for histologic study.

Submit samples of intestine for histologic study. For removal, prosthetic repair, and specimen preparation, see p. 95 .

In infantile rickets, diagnostic sites for histologic sampling are costochondral junctions, distal ends of radius and ulna, and proximal ends of tibia and humerus. For adults, see under "Osteomalacia."
In infants, rachitic changes at costochondral junctions; in adults, osteoporosis* and osteomalacia*_-with or without pseudofractures (Milkman's syndrome). Craniotabes; delayed dentition and enamel defects; protrusion of sternum; rachitic rosary; swelling of costochondral junctions and of wrists.

Hypocalcemia, hypomagnesemia, hypophosphatemia.

Possible causes of vitamin D deficiency include diseases associated with malabsorption syndrome, * biliary atresia,* and primary biliary cirrhosis.

Parathyroid hyperplasia (hyperparathyroidism*) secondary to hypocalcemia and impaired absorption of vitamin D.

Conditions causing malabsorption.

Osteomalacia.*

Characteristic abnormalities of osteochondral growth plates in infants.

Abundant osteoid in osteomalacia.*

\section{Deformity, Klippel-Feil}

Synonym: Congenital fusion of cervical vertebrae.

\begin{tabular}{|c|c|c|}
\hline Organs and Tissues & Procedures & Possible or Expected Findings \\
\hline \multirow[t]{2}{*}{ External examination } & & $\begin{array}{l}\text { Short neck; low posterior hairline. Disorders } \\
\text { with dysraphia (see below). }\end{array}$ \\
\hline & $\begin{array}{l}\text { Prepare roentgenograms of chest, neck } \\
\text { (lateral view), and head. }\end{array}$ & $\begin{array}{l}\text { Fusion of cervical vertebrae. Congenital ele- } \\
\text { vation of the scapula (Sprengel's deformity) }\end{array}$ \\
\hline Neck organs & & Malformed larynx (1). \\
\hline Skull, spine, brain, & $\begin{array}{l}\text { For removal and specimen preparation of } \\
\text { brain and spinal cord, see pp. } 65 \text { and } 67 \text {, } \\
\text { respectively. }\end{array}$ & $\begin{array}{l}\text { Arnold-Chiari malformation;* basilar } \\
\text { impression; meningomyelocele; platybasia; } \\
\text { spinal cord compression; syringomyelia.* } \\
\text { Intracranial or spinal cord tumors }(2) \text {. }\end{array}$ \\
\hline
\end{tabular}

\section{References}

1. Clarke RA, Davis PJ, Tonkin J. Klippel-Feil syndrome associated with malformed larynx. Case report. Ann Otol Rhinol Laryngol 1994; 103:201-207.
2. Diekmann-Guiroy B, Huang PS. Klippel-Feil syndrome in association with a craniocervical dermoid cyst presenting as aseptic meningitis in an adult: case report. Neurosurgery 1989;25:652-655. 


\section{Degeneration, Cerebellar Cortical}

Synonyms and Related Terms: Alcoholic cerebellar degeneration; parenchymatous cerebellar degeneration.

\begin{tabular}{lll}
\hline Organs and Tissues & Procedures & Possible or Expected Findings \\
\hline Brain and spinal cord & $\begin{array}{l}\text { For removal and specimen preparation, } \\
\text { see pp. 65 and 67, respectively. }\end{array}$ & $\begin{array}{l}\text { Cortical atrophy (predominantly loss of } \\
\text { Purkinje cells) of dorsal vermis of cerebellum } \\
\text { and adjacent anterior lobe. }\end{array}$ \\
Other organs & $\begin{array}{l}\text { Procedures depend on expected findings or } \\
\text { grossly identified abnormalities as listed in } \\
\text { right-hand column. }\end{array}$ & $\begin{array}{l}\text { Manifestations of chronic alcoholism,* } \\
\text { amebiasis,* cirrhosis,* malnutrition, or } \\
\text { pellagra.* }\end{array}$ \\
\hline
\end{tabular}

Degeneration, Cerebello-Olivary

(See "Degeneration, spinocerebellar.")

\section{Degeneration, Hepatolenticular}

(See "Disease, Wilson's.")

\section{Degeneration, Spinocerebellar}

Related Terms: Familial cortical cerebellar atrophy; Friedreich's ataxia; hereditary ataxia; Machado-Joseph disease; olivopontocerebellar atrophy.

NOTE: The term spinocerebellar degeneration encompasses a variety of lesions whose classification is controversial.
A new approach has come from linkage analysis and molecular biology. For instance, Friedreich's ataxia, the classic form of hereditary ataxia, is due to an intronic expansion of a GAA trinucleotide repeat. Other forms are also identified by their specific gene loci. Neuropathologic examination still is important and ample sampling is suggested, which should include cerebral cortex, basal ganglia (caudate nucleus, putamen, and globus pallidus), thalamus, subthalamic nucleus, midbrain (red nucleus and substantia nigra), pons (pontine nuclei), spinal cord (at cervical, thoracic, and lumbar levels), optic tract, optic nerves with lateral geniculate nucleus, and sensory and motor peripheral nerves.

\begin{tabular}{lll}
\hline Organs and Tissues & Procedures & Possible or Expected Findings \\
\hline Brain and spinal cord & $\begin{array}{l}\text { For removal and specimen preparation, } \\
\text { see pp. 65 and 67, respectively. }\end{array}$ & $\begin{array}{l}\text { Symmetric neuronal loss with reactive } \\
\text { astrocytosis in the affected areas. } \\
\text { See also above under "Note." }\end{array}$ \\
Peripheral nerves & $\begin{array}{l}\text { For removal and specimen preparation, } \\
\text { see p. 79. }\end{array}$ & \\
\hline
\end{tabular}

\section{Reference}

1. Koeppen AH. The hereditary ataxias. J Neuropathol Exp Neurol 1998;57:531-543.

\section{Degeneration, Spongy, of White Matter}

Synonyms and Related Terms: Bertrand-van Bogaert disease; Canavan's disease; familial leukodystrophy.

NOTE: The disease is caused by defective asparto acylase activity. The gene has been cloned and mutations found.

\begin{tabular}{lll}
\hline Organs and Tissues & Procedures & Possible or Expected Findings \\
\hline External examination & $\begin{array}{l}\text { Record head circumference. } \\
\text { Prepare roentgenograms of skull. }\end{array}$ & Enlargement of head. \\
Brain and spinal cord & $\begin{array}{l}\text { For removal and specimen preparation, } \\
\text { see pp. 66 and 70, respectively. Request } \\
\text { Luxol fast blue stain (p. 72). }\end{array}$ & $\begin{array}{l}\text { Poor demarcation between cortex and } \\
\text { gelatinous white matter. Extensive } \\
\text { demyelination and vacuolation of white } \\
\text { matter, particularly subcortically. }\end{array}$ \\
& For removal and specimen preparation, \\
Eyes and optic nerves & Optic atrophy. \\
\hline
\end{tabular}

\section{Degeneration, Striatonigral (See “Atrophy, multiple system.”)}

\section{Dehydration}

Related Term: Thirst.

NOTE: Possible underlying conditions not related to inaccessibility of water include burns, exposure to heat, gastrointestinal diseases, recent paracentesis, renal diseases, and use of diuretic drugs. See also under "Disorder, electrolyte(s)." 


\begin{tabular}{|c|c|c|}
\hline Organs and Tissues & Procedures & Possible or Expected Findings \\
\hline \multirow[t]{2}{*}{ External examination } & & $\begin{array}{l}\text { Skin turgor may be decreased and eyes may } \\
\text { be sunken. }\end{array}$ \\
\hline & $\begin{array}{l}\text { Prepare histologic sections of blisters, ulcers, } \\
\text { or skin abrasions. }\end{array}$ & $\begin{array}{l}\text { Microscopic changes help to } \\
\text { decide whether skin lesions are antemortem } \\
\text { or postmortem. }\end{array}$ \\
\hline Vitreous & $\begin{array}{l}\text { Submit sample for sodium, chloride, and urea } \\
\text { nitrogen determination (p. 85). }\end{array}$ & $\begin{array}{l}\text { Sodium concentrations more than } 155 \mathrm{meq} / \mathrm{L} \text {, } \\
\text { chloride concentrations more than } 130 \mathrm{meq} / \\
\text { and urea nitrogen concentrations between } 40 \\
\text { and } 100 \mathrm{meq} / \mathrm{dL} \text { indicate dehydration. }\end{array}$ \\
\hline Urine & Record volume and specific gravity & Absence or minimal amount of urine (p. 115). \\
\hline
\end{tabular}

\section{Dementia (See “Disease, Alzheimer's.")}

\section{Dependence, Amphetamine(s)}

NOTE: There are no diagnostic autopsy findings. Follow procedures described under "Dependence, $\operatorname{drug}(\mathrm{s}) . "$

\section{Dependence, Cocaine}

NOTE: Cocaine is spontaneously hydrolyzed by blood esterases, even after death. However, its major metabolite, benzoylecgonine, is routinely identifiable by EMIT and ELISA screening tests (see p. 17). When cocaine is abused concurrently with heroin or other drugs, it may be difficult to ascribe death to a single agent.

\begin{tabular}{lll}
\hline Organs and Tissues & Procedures & Possible or Expected Findings \\
\hline External examination & Record condition of nasal septum. & $\begin{array}{l}\text { Chronic inflammation and perforation of } \\
\text { nasal septum after prolonged sniffing of } \\
\text { cocaine. }\end{array}$ \\
& $\begin{array}{l}\text { Submit nasal swab for toxicologic study. } \\
\text { Blomnant of cocaine. } \\
\text { Submit sample with NaF added for toxicologic } \\
\text { study (see Chapter 2); request drug screen }\end{array}$ & $\begin{array}{l}\text { See above under "Note." } \\
\end{array}$
\end{tabular}

Heart Record heart weight and thickness of ventricles. For dissection of the heart and coronary arteries, and for histologic sampling, see also Chapter 3.

Left ventricular hypertrophy caused by hypertension complicating or aggravated by cocainism. Cardiotoxicity with focal myocarditis and myocyte necrosis (2), contraction bands (3), and coronary occlusion.

Stomach and colon Save gastric contents for toxicologic study. Sample stomach and colon for histologic study.

Ischemia of gastric mucosa after ingestion of cocaine. Ischemic colitis (4).

Liver and gallbladder Save liver tissue and bile for toxicologic study. Sample liver for histologic study.

Other body fluids Save vitreous (p. 16), urine, kidneys, and brain and organs for toxicologic study.

Zonal hepatic necrosis (5).

See above under "Note."

\section{References}

1. Brody SL, Slovis CM, Wrenn KD. Cocain-related medical problems. Consecutive series of 233 cases. Am J Med 1990;88:325-331.

2. Peng SK, French WJ, Pelikan PCD. Direct cocaine cardiotoxicity demonstrated by endomyocardial biopsy. Arch Pathol Lab Med 1989; 113:842-845.

3. Karch SB, Billingham ME. The pathology and etiology of cocaineinduced heart disease. Arch Pathol Lab Med 1988;112:225-230.

4. Brown DN, Rosenholtz MJ, Marshall JB. Ischemic colitis related to cocaine abuse. Gastroenterology 1994;89:1558-1561.

5. Silva MO, Roth D, Reddy KR, Fernandez JA, Albores-Saavedra J, Schiff ER. Hepatic dysfunction accompanying acute cocaine intoxication. J Hepatol 1991;12:312-315.

\section{Dependence, $\operatorname{Drug}(\mathbf{s})$, all Types or Type Unspecified}

Related Terms: Cocaine dependence;* crack dependence; heroin dependence; intravenous narcotism; morphinism.

NOTE: If narcotic paraphernalia and samples of the drug itself are found at the scene of the death, they should be submitted for analysis. Helpful information about the nature of a drug may be obtained from witnesses. State crime laboratories may provide much assistance. If name of drug is known, see also under "Poisoning,..." The slang name of a drug may be insufficient for identification because these names often are used for different compounds at different times of places. 
Opoid narcotics can be injected intravenously, or subcutaneously, or snorted. Death may occur with such speed that the bodies may be found with needles and syringes in the veins or clenched in the hands. Drug dependence may be associated with a multitude of local (see below) or systemic complications, including malaria* and tetanus.*

For general toxicologic study, see p. 14. As stated in Chapter 2 , for a growing number of analytes, most notably tricyclic antidepressants, peripheral blood is preferred over central blood.
Peripheral blood is aspirated by percutaneous puncture before autopsy, from the femoral vein or the subclavian vein. The authors prefer the femoral approach in order to avoid any question of artifact in the diagnosis of venous air embolism. It may be prudent to add $\mathrm{NaF}$ to some of the samples.

Possible Associated Conditions: Acquired immunodeficiency syndrome (AIDS) and many other acute and chronic infections; malnutrition.*

\begin{tabular}{lll}
\hline Organs and Tissues & Procedures & Possible or Expected Findings
\end{tabular}

External examination and skin

Blood

Heart

Lungs

Gallbladder

Liver

Perihilar lymph nodes

Spleen

Urine

Brain and spinal cord

Bones and joints
In suspected homicides or other unusual circumstances, excise fresh needle marks with surrounding skin and underlying tissues and submit for toxicologic analysis. (In routine accidental drug-related deaths, this is not necessary.) Submit samples with needle marks for histologic study under polarized light. If victim has not been identified, follow procedures described on p. 11. Photograph changes that indicate addiction.

For toxicologic sampling, see above under "Note." Submit samples for bacterial, fungal, and viral cultures, study of viral antibodies (hepatitis B and $\mathrm{C}$ ), and blood alcohol determination. If endocarditis is suspected, follow procedures described under that heading (p. 103).

Submit portions for toxicologic and microbiologic study (p. 103). Submit multiple samples for histologic study. Request Verhoeff-van Gieson stain (p. 173). Study sections under polarized light.

Submit sample of bile for toxicologic study (p. 16).

Submit samples for toxicologic and histologic study.

Record weight.

Submit sample for toxicologic study.

For removal and specimen preparation, see pp. 65 and 67 , respectively.

Submit samples of grossly abnormal areas for histologic study.
Foam may exude from nostrils. Erosions of the nasal septum occur in heroin sniffers. Needle marks may be found at any accessible site. Scars, "track hyperpigmentation," ulcers, skin abscesses, and subcutaneous hemorrhages may be abundant. Other complications are ischemic crush injuries with acute rhabdomyolysis, myositis ossificans (brachial muscle), and thrombophlebitis.

Septicemia; evidence of acute or chronic viral infection; alcohol intoxication.

Infective endocarditis* that is often on the right side. Expected organisms include Acinebacter spp., Staphylococcus aureus, Staphylococcus albus, Salmonella spp., enterococci, and Staphylococcus epidermidis.

Pulmonary edema; aspiration; diffuse lobular pneumonia. Septic pulmonary abscesses. Perivascular pulmonary talc granulomas; foreign body emboli; pulmonary necrotizing angiitis; atelectases and fibrosis.

Heroin is metabolized to morphine. Morphine accumulates in bile, where it is sometimes easier to detect than in blood. Nonspecific portal hepatitis; acute or chronic viral hepatitis;* alcoholic liver disease.* Foreign body granulomas may be present in the liver.

Chronic lymphadenitis.

Splenomegaly with follicular hyperplasia.

Detects monoacetylmorphine to distinguish heroin from morphine poisoning.

Bilateral symmetric necrosis of globus pallidus; cerebral abscess;* meningitis;* transverse myelitis; mycotic aneurysms; subdural or epidural empyema.* Acute cerebral falciparum malaria.* Infectious spondylitis and sacroiliitis. 


\section{Depressant(s) (See “Dependence, $\operatorname{drug}(s), . . . ”)$}

\section{Dermatomyositis}

Related Term: Childhood dermatomyositis (or polymyositis) associated with vasculitis; dermatomyositis (or polymyositis) associated with neoplasia or collagen vascular disease; primary idiopathic dermatomyositis; primary idiopathic polymyositis.

Possible Associated Conditions: Carcinoma (lung, stomach, intestine, and prostate in males; breast, ovary, and uterus in females; miscellaneous sites in both sexes); lymphoma* (rare) and other malignancies (1); lupus erythematosus; ${ }^{*}$ mixed connective tissue disease; progressive systemic sclerosis;* rheumatoid arthritis;* Sjögren's syndrome;* and others. Vasculitis of childhood polymyositis (dermatomyositis).

\begin{tabular}{ll}
\hline Organs and Tissues & Procedures \\
\hline $\begin{array}{l}\text { External examination } \\
\text { and skin }\end{array}$ & Photograph grossly involved skin. \\
& \\
& $\begin{array}{l}\text { Prepare sections of involved (anterior chest, } \\
\text { knuckles, knees) and grossly uninvolved skin } \\
\\
\end{array}$ \\
& and subcutaneous tissue.
\end{tabular}

Prepare roentgenograms.

$\begin{array}{ll}\text { Heart } & \begin{array}{l}\text { Submit samples from myocardium for } \\ \text { histologic study (p. 30). }\end{array} \\ \text { Lungs } & \text { Perfuse one lung with formalin (p. 47). }\end{array}$

$\begin{array}{ll}\text { Esophagus and } & \text { Submit samples from all segments for } \\ \text { gastrointestinal tract } & \text { histologic study. }\end{array}$

Kidneys

Other organs

Skeletal muscles

Peripheral nerves

Joints
Submit samples of liver for histologic study. For sampling in diabetes mellitus, see under that heading.

Submit samples from deltoid, biceps, cervical, gluteal, and femoral muscles, and also from other muscles that may have been involved clinically (pharynx, tongue), for histologic study. Photograph abnormal gross specimens. For specimen preparation, see p. 80.

For removal and specimen preparation, see p. 79.

For removal, prosthetic repair, and specimen preparation, see p. 95 .

\section{Possible or Expected Findings}

Erythema; maculopapular eruption; eczematoid or exfoliative dermatitis; ulcerations; calcification.

Microscopically, dermatitis and panniculitis with edema and fibrinoid necroses are found. Vasculitis in childhood cases.

Lipodystrophy (2).

Pneumomediastinum and subcutaneous emphysema (3).

Mycarditis* (rare).

Microscopic changes similar to those in skeletal muscles (see below).

Lymphocytic pneumonitis; obliterating bronchiolitis; edema; interstitial pulmonary fibrosis (see "Pneumonia, interstitial").

Vasculitis; myositis, rarely with rupture (4). Features of inflammatory bowel disease may be present.

Arteritis* and phlebitis* with thrombosis, fibrosis, and infarctions.

Steatohepatitis and manifestations of diabetes mellitus* may be found (2).

Myositis with muscular atrophy and fibrosis; vasculitis in childhood cases.

Polyneuropathy (rare) (5).

Arthritis.

\section{References}

1. Maoz CR, Langevitz P, Livneh A, Blumstein Z, Sadeh M, Bank I, et al. High incidence of malignancies in patients with dermatomyositis and polymyositis: an 11-year analysis. Semin Arthritis Rheum 1998; 27:319-324.

2. Quecedo E, Febrer I, Serrano G, Martinez-Aparicio A, Aliaga A. Partial lipodystrophy associated with juvenile dermatomyositis: report of two cases. Pediatr Dermatol 1996;13:477-482.
3. de Toro-Santos FJ, Verea-Hernando H, Montero C, Blanco-Aparicio M, Torres Lanzas J, Pombo Felipe F. Chronic pneumomediastinum and subcutaneous emphysema: association with dermatomyositis. Respiration 1995;62:53-56.

4. Dougenis D, Papathanasopoulos PG, Paschalis C, Papapetropoulos T. Spontaneous esophageal rupture in adult dermatomyositis. Eur $\mathbf{J}$ Cardio-Thor Surg 1996;10:1021-1023.

5. Vogelsang AS, Gutierrez J, Klipple GL, Katona IM. Polyneuropathy in juvenile dermatomyositis. J Rheumatol 1995;22:1369-1372. 


\section{Diabetes Insipidus}

\begin{tabular}{|c|c|c|}
\hline Organs and Tissues & Procedures & Possible or Expected Findings \\
\hline Brain and pituitary gland & $\begin{array}{l}\text { For cerebral arteriography, see p. } 80 \text {. For } \\
\text { removal and specimen preparation of brain and } \\
\text { pituitary gland, see pp. } 65 \text { and } 71 \text {, respectively. } \\
\text { If infection is suspected, follow procedures } \\
\text { described on p. } 102 \text {. Submit samples from brain } \\
\text { and pituitary gland for histologic study. }\end{array}$ & $\begin{array}{l}\text { Head injury* (including birth trauma); } \\
\text { Langerhans cell (eosinophilic) } \\
\text { granulomatosis; } * \text { local infection; metastatic } \\
\text { tumor (frequently from carcinoma of breast); } \\
\text { neurosurgical procedures; primary neoplasm } \\
\text { involving neurohypophyseal system; } \\
\text { sarcoidosis.* }\end{array}$ \\
\hline Vitreous & $\begin{array}{l}\text { Submit sample for sodium, chloride, and urea } \\
\text { nitrogen determination (p. 85). }\end{array}$ & Changes associated with dehydration.* \\
\hline Other organs & $\begin{array}{l}\text { Procedures depend on expected findings or } \\
\text { grossly identified abnormalities as listed in } \\
\text { right-hand column. }\end{array}$ & $\begin{array}{l}\text { No diagnostic findings. } \\
\text { Nephrogenic diabetes insipidus is caused by } \\
\text { renal tubular defect. } \\
\text { Manifestations of histiocytosis, }{ }^{*} \\
\text { sarcoidosis, }{ }^{*} \text { and other possible underlying } \\
\text { conditions. }\end{array}$ \\
\hline
\end{tabular}

\section{Diabetes Mellitus}

Synonyms: Type I (insulin-dependent or juvenile-onset) diabetes mellitus; type II (insulin-independent or adult onset) diabetes mellitus; secondary diabetes mellitus (e.g., due to drugs or pancreatic disease).

NOTE: In infants of diabetic mothers, megasoma and congenital malformations of the cardiovascular and central nervous systems must be expected. Record size and weight of placenta and total weight and length, crown to rump length, and crown to heel length of infant. Compare with expected measurements (pp. 555 and 561). Expected histologic finding include hyperplasia with relative increase of $B$ cells of the islands of Langerhans with interstitial and peri-insular eosinophilic infiltrates, decidual changes of the endometrium, enhanced follicle growth in the ovaries, and Leydig cell hyperplasia.

Possible Associated Conditions: Acanthosis nigricans; acromegaly;* amyotrophic lateral sclerosis;* ataxia telangiectasia;* Fanconi's anemia;* Friedreich's ataxia;* gout;* hemochromatosis;*hyperlipoproteinemia;* hyperthroidism;* obesity;* Turner's syndrome;* and many others, too numerous to mention.

\begin{tabular}{ll}
\hline Organs and Tissues & Procedures \\
\hline $\begin{array}{l}\text { External examination } \\
\text { and skin }\end{array}$ & \\
& $\begin{array}{l}\text { Prepare sections of skin lesions, of grossly } \\
\text { unaffected skin, and of subcutaneous tissue. }\end{array}$
\end{tabular}

Blood

Heart
If there is evidence of mastopathy, sample tissue for histologic study.

Prepare sections and smears of intertriginous and other skin infections. Request Gram and Grocott's methenamine silver stains (p. 172). Prepare whole-body roentgenograms.

Submit samples of skin tissue for electron microscopic study (p. 132).

Submit sample for bacterial and fungal cultures (p. 102). If diabetic coma must be ruled out or if disease is only suspected, submit samples of blood and vitreous (see below) for biochemical study. For interpretation, see p. 114.

Record weight and thickness of walls. For coronary arteriography, see p. 118. For histologic sampling, see p. 30.
Possible or Expected Findings

Gangrene of lower extremities and other ischemic changes.

Xanthelasmas of eyelids. Diabetic xanthomas on forearms. Diabetic lipoatrophy. Subcutaneous atrophy at former sites of insulin injection.

Diabetic mastopathy.

Fungal vulvitis.

Subcutaneous and vascular calcifications. Joint deformities (see below under "Joints"). Diabetic microangiopathy.

Septicemia. Increased concentrations of blood glucose (unreliable for diagnosis) and serum ketones and lipids. Postmortem insulin determination may permit the diagnosis of insulin poisoning.

Cardiac hypertrophy;* coronary atherosclerosis; $*$ myocardial infarction. 


\begin{tabular}{|c|c|c|}
\hline Organs and Tissues & Procedures & Possible or Expected Findings \\
\hline $\begin{array}{l}\text { Heart } \\
\quad \text { (continued) }\end{array}$ & $\begin{array}{l}\text { If glycogen content is to be evaluated, place } \\
\text { specimens in alcohol (p. 129) or Carnoy's } \\
\text { fixative (p. 130) or-preferably-prepare for } \\
\text { electron microscopic study (p. 132). }\end{array}$ & \\
\hline Lungs & $\begin{array}{l}\text { Submit one lobe for bacterial and fungal cultures } \\
\text { (p. 103). Request Gram and Grocott's methen- } \\
\text { amine silver stain (p. 172). }\end{array}$ & $\begin{array}{l}\text { Bacterial or fungal (aspergillosis, }{ }^{*} \\
\text { candidiasis, }{ }^{*} \text { cryptococcosis*) pneumonia. }\end{array}$ \\
\hline Esophagus & $\begin{array}{l}\text { Sample for histologic study. For special stains, } \\
\text { see "Lungs." }\end{array}$ & $\begin{array}{l}\text { Intramural pseudodiverticulosis (dilatation } \\
\text { of submucosal gland ducts). Fungal } \\
\text { esophagitis. }\end{array}$ \\
\hline Liver & Record weight and sample for histologic study. & $\begin{array}{l}\text { Hepatomegaly; fatty changes; diabetic } \\
\text { steatohepatitis or steatohepatitic cirrhosis. } \\
\text { Other types of cirrhosis may be a cause of } \\
\text { secondary diabetes (Naunyn's diabetes). }\end{array}$ \\
\hline Gallbladder & Record appearance of concrements. & Cholelithiasis.* \\
\hline Spleen & Submit sample for histologic study. & Lipoid histiocytosis. \\
\hline Stomach & $\begin{array}{l}\text { Record size and shape of stomach and } \\
\text { appearance of mucosa. }\end{array}$ & Gastric dilatation; mucosal hemorrhages. \\
\hline Pancreas & $\begin{array}{l}\text { Prepare soft tissue roentgenogram. Dissect } \\
\text { pancreas and record weight. Slice organ in 2-mm } \\
\text { sagittal sections. Place one slice in alcohol or } \\
\text { Carnoy's fixative (p. 130). Request Best's } \\
\text { carmine, Masson's trichrome, Congo red, and } \\
\text { Gomori's chromium hematoxylin phloxine stains } \\
\text { (p. 172). For the last stain, formalin- } \\
\text { fixed organs should be refixed for 12-24 h in } \\
\text { Bouin's solution (p. 129). Whenever granules } \\
\text { are to be demonstrated in beta cells, a slice of } \\
\text { fresh tissue should be placed in Bouin's or } \\
\text { Helly's fixative (p. 131). }\end{array}$ & $\begin{array}{l}\text { Glycogenosis of beta cells in prolonged } \\
\text { hyperglycemia (in type II diabetes); } \\
\text { degranulation of islets of Langerhans; } \\
\text { lymphocytic or eosinophilic infiltration } \\
\text { around islets (in type I diabetes); amyloid- } \\
\text { osis or fibrosis of islets. Lesions that may } \\
\text { have caused secondary diabetes include } \\
\text { pancreatitis, tumors of the pancreas,* cystic } \\
\text { fibrosis, }{ }^{*} \text { and hemochromatosis.* Focal or } \\
\text { diffuse nesidioblastosis in infants of diabetic } \\
\text { mothers (may be a cause of hyperinsulinemic } \\
\text { hypoglycemia). }\end{array}$ \\
\hline Adrenal glands & $\begin{array}{l}\text { Record weights. If abnormalities are noted, } \\
\text { sample for histologic study. }\end{array}$ & $\begin{array}{l}\text { Adrenocortical nodules or tumor or } \\
\text { pheochromocytoma (see also under } \\
\text { "Syndrome, Cushing's" and "Tumor of the } \\
\text { adrenal glands"). }\end{array}$ \\
\hline Kidneys & $\begin{array}{l}\text { Record weights of both organs. For renal } \\
\text { arteriography, see p. } 59 \text {. Submit samples for } \\
\text { histologic and electron microscopic study } \\
\text { (p. 132). Request PAS-alcian blue and Grocott's } \\
\text { methenamine silver stains (p. 172). } \\
\text { All sections should include papillae. }\end{array}$ & $\begin{array}{l}\text { Diabetic nephropathy and microangiopathy. } \\
\text { Arteriolonephrosclerosis; diabetic } \\
\text { intercapillary glomerulosclerosis; tubular } \\
\text { atrophy and interstitial fibrosis; } \\
\text { pyelonephritis* and necrotizing papillitis. }\end{array}$ \\
\hline & $\begin{array}{l}\text { Submit fresh material for immunofluorescence } \\
\text { study. }\end{array}$ & $\begin{array}{l}\text { Glomerular capillary and tubular basement } \\
\text { membranes stain for IgG and albumin. }\end{array}$ \\
\hline Urine & $\begin{array}{l}\text { Prepare sediment and submit sample for protein, } \\
\text { glucose, and acetone determination. }\end{array}$ & $\begin{array}{l}\text { Abnormal sediment. Proteinuria, glycosuria, } \\
\text { and acetonuria. }\end{array}$ \\
\hline Urinary bladder & & Urocystitis. \\
\hline $\begin{array}{l}\text { Seminal vesicles, } \\
\text { spermatic cords, } \\
\text { and testes }\end{array}$ & Submit samples for histologic study. & $\begin{array}{l}\text { Submucosal granular deposits in seminal } \\
\text { vesicles; calcification of vas deferens; tubular } \\
\text { atrophy of testes. }\end{array}$ \\
\hline Ovaries & Submit samples for histologic study. & Stromal hyperthecosis. \\
\hline \multirow[t]{2}{*}{ Lower extremities } & $\begin{array}{l}\text { For arteriography, see p. } 120 \text {. Submit samples } \\
\text { from smaller arteries for histologic study. } \\
\text { For decalcification procedures, see p. } 97 \text {. }\end{array}$ & $\begin{array}{l}\text { Gangrene. Obliterating arteriosclerosis } \\
\text { of anterior and posterior tibial arteries, } \\
\text { peroneal arteries, and dorsal artery of } \\
\text { the foot. }\end{array}$ \\
\hline & $\begin{array}{l}\text { Request von Kossa's and Verhoeff-van Gieson } \\
\text { stains (p. 172). }\end{array}$ & $\begin{array}{l}\text { Mönckeberg's sclerosis* of muscular } \\
\text { arteries. }\end{array}$ \\
\hline
\end{tabular}




\begin{tabular}{|c|c|c|}
\hline Organs and Tissues & Procedures & Possible or Expected Findings \\
\hline Calvarium & Record color of bone. & $\begin{array}{l}\text { Calvarium often strikingly yellow (carotene } \\
\text { deposition). }\end{array}$ \\
\hline \multirow[t]{3}{*}{ Brain and spinal cord } & $\begin{array}{l}\text { For removal and specimen preparation, } \\
\text { see pp. } 65 \text { and } 67 \text {, respectively. }\end{array}$ & $\begin{array}{l}\text { Degeneration of spinal tracts and micro- } \\
\text { infarctions. }\end{array}$ \\
\hline & $\begin{array}{l}\text { If cerebral infection is suspected, submit sample } \\
\text { for bacterial and fungal cultures (p. 102). }\end{array}$ & Cerebral mucormycosis.* \\
\hline & For cerebral arteriography, see p. 80 . & Cerebral infarctions.* \\
\hline Pituitary gland & For removal and specimen preparation, see p. 71 . & Infarctions. \\
\hline Eyes & For removal and specimen preparation, see p. 85. & $\begin{array}{l}\text { Diabetic retinopathy with capillary micro- } \\
\text { aneurysms; cataracts; microaneurysms of } \\
\text { conjunctival vessels. Nutritional amblyopia.* }\end{array}$ \\
\hline Vitreous & $\begin{array}{l}\text { If diabetic coma or ketoacidosis must be ruled } \\
\text { out, submit sample of vitreous ( } \mathrm{p} .85 \text { ) from } \\
\text { one eye for determination of glucose and ketone } \\
\text { concentrations (see p. 115). }\end{array}$ & $\begin{array}{l}\text { Glucose values less than } 2 \mathrm{~h} \text { after death or } \\
\text { combined glucose and lactate values several } \\
\text { days after death can be used for the diagnosis } \\
\text { of hyperglycemia (1). }\end{array}$ \\
\hline Peripheral nerves & $\begin{array}{l}\text { For sampling and specimen preparation, see } \\
\text { p. } 79 \text {. Include anterior tibial and sciatic nerves. } \\
\text { Request Luxol fast blue stain for myelin (p. 172). }\end{array}$ & $\begin{array}{l}\text { Diabetic neuropathy. Patchy } \\
\text { demyelinization. }\end{array}$ \\
\hline Skeletal muscles & For sampling and specimen preparation, see p. 80. & Diabetic myopathy. \\
\hline Breast tissue & Submit sample for histologic study. & Hyalinization around mammary ducts. \\
\hline Joints & $\begin{array}{l}\text { For removal, prosthetic repair, and specimen } \\
\text { preparation, see p. } 96 \text {. }\end{array}$ & $\begin{array}{l}\text { Deformation (Charcot joints) of tarsal and } \\
\text { metatarsal joints or-less commonly-of } \\
\text { ankle and knee joints. Such deformations } \\
\text { occur after diabetic neuropathy. }\end{array}$ \\
\hline
\end{tabular}

\section{Reference}

1. Sippel H, Möttönen M. Combined glucose and lactate values in vitreous humor for postmortem diagnosis of diabetes mellitus. Forens Sci Internat 1982;19:217-222.

\section{Dialysis (for Chronic Renal Failure)}

NOTE: Body fluids and tissues may be infectious (e.g., hepatitis C).

\begin{tabular}{|c|c|c|}
\hline Organs and Tissues & Procedures & Possible or Expected Findings \\
\hline External examination & $\begin{array}{l}\text { Expose intraperitoneal catheters or arteriovenous } \\
\text { shunts with as little contamination as possible. } \\
\text { Submit material for aerobic and anaerobic } \\
\text { bacterial and fungal cultures. Remove vessel } \\
\text { from shunt site for histologic study. }\end{array}$ & $\begin{array}{l}\text { Infection of catheters and shunts. } \\
\text { Infectious vasculitis. }\end{array}$ \\
\hline Blood & $\begin{array}{l}\text { Submit sample for aerobic and anaerobic } \\
\text { bacterial and for fungal cultures (p. 102). }\end{array}$ & Septicemia. \\
\hline Heart & $\begin{array}{l}\text { If endocarditis is suspected, follow procedures } \\
\text { described under that heading (p. 103). }\end{array}$ & Infective endocarditis.* \\
\hline Peritoneal cavity & $\begin{array}{l}\text { If peritoneal dialysis had been used, culture } \\
\text { contents of peritoneal cavity (see above under } \\
\text { "Blood"). Submit samples of peritoneum for } \\
\text { histologic study. }\end{array}$ & Peritonitis.* \\
\hline Liver & Submit samples for histologic study. & $\begin{array}{l}\text { Chronic hepatitis B or C.* } \\
\text { Hepatic granulomas }(1) .\end{array}$ \\
\hline Kidneys and other organs & $\begin{array}{l}\text { Procedures depend on expected findings or } \\
\text { grossly identified abnormalities as listed in } \\
\text { right-hand column. }\end{array}$ & $\begin{array}{l}\text { Chronic renal disease (e.g., glomerulo- } \\
\text { nephritis) and systemic manifestations of } \\
\text { kidney failure.* }\end{array}$ \\
\hline
\end{tabular}

\section{Reference}

1. Kurumaya H, Kono N, Nakanuma Y, Tomoda F, Takazahura E. Hepatic granulomata in long-term hemodialysis patients with hyperalbuminemia. Arch Pathol Lab Med 1989;113:1132-1134. 


\section{Diathesis, Bleeding (See "Coagulation, disseminated intravascular," "Disease, Christmas," "Disease, von Willebrand's," and "Hemophilia."}

\section{Digitalis (See "Poisoning, digitalis.")}

\section{Diphtheria}

Synonyms: Corynebacterium diphtheriae infection; diphtheric fever.
NOTE: The disease has been nearly eliminated in the USA but not in many other countries.

(1) Collect all tissues that appear to be infected. (2) Request aerobic bacterial cultures. (3) Request Gram stain (p. 172). (4) Special precautions are indicated (p. 146). (5) Serologic studies are not helpful, but the organism may be typed for epidemiologic purposes. Toxin assays are also available. (6) This is a reportable disease.

\begin{tabular}{|c|c|c|}
\hline Organs and Tissues & Procedures & Possible or Expected Findings \\
\hline \multirow[t]{2}{*}{ Head and neck } & $\begin{array}{l}\text { Remove neck organs with oropharynx, tongue, } \\
\text { tonsils, soft palate, and uvula. Record degree } \\
\text { of laryngeal obstruction. Photograph larynx and } \\
\text { pharynx before and after opening. }\end{array}$ & Diphtheric pharyngitis. \\
\hline & $\begin{array}{l}\text { Submit sample of pharyngeal pseudomembranes } \\
\text { for culture; prepare smears of membranes. }\end{array}$ & Gram-positive pleomorphic bacilli. \\
\hline Heart & $\begin{array}{l}\text { Photograph. Record weight and submit samples } \\
\text { for histologic study (see p. } 30 \text { ). }\end{array}$ & Diphtheric myocarditis. \\
\hline Kidneys & Submit samples for histologic study. & $\begin{array}{l}\text { Nonsuppurative interstitial nephritis. } \\
\text { Renal tubular necrosis.* }\end{array}$ \\
\hline $\begin{array}{l}\text { Brain and peripheral } \\
\text { nerves }\end{array}$ & $\begin{array}{l}\text { For removal and specimen preparation, see } \\
\text { pp. } 66 \text { and } 70 \text {, respectively. Request Luxol } \\
\text { fast blue stain (p. 172). }\end{array}$ & $\begin{array}{l}\text { Myelin degeneration and destruction of } \\
\text { myelin sheaths. }\end{array}$ \\
\hline $\begin{array}{l}\text { Nasal cavities, sinuses, } \\
\text { and middle ears }\end{array}$ & $\begin{array}{l}\text { For exposure of epipharynx, nasal cavities, } \\
\text { sinuses, and middle ears, see pp. } 71-73 . \\
\text { Prepare smears and swab cultures of these spaces. } \\
\text { Photograph, prepare histologic sections, and } \\
\text { request Gram stain (p. 172). }\end{array}$ & Diphtheritic pseudomembranes. \\
\hline
\end{tabular}

\section{Disease,... (See subsequent entries and under "Sickness,..." and "Syndrome,...")}

Disease, Addison's (See “Insufficiency, adrenal.”)

\section{Disease, Albers-Schönberg (See “Osteopetrosis.”)}

\section{Disease, Alcoholic Liver}

Related Terms: Alcoholic cirrhosis; alcoholic fatty liver; alcoholic hepatitis.

NOTE: Several conditions such as obesity-related steatohepatitis may be histologically indistinguishable from alcoholic liver disease (1). Thus, the diagnosis should not be based on liver histology alone.

\begin{tabular}{ll}
\hline Organs and Tissues & Procedures \\
\hline External examination & $\begin{array}{l}\text { Record presence or absence of features listed in } \\
\text { right-hand column. }\end{array}$
\end{tabular}

Serosal cavities

Blood and urine

Heart

Lungs

Esophagus

Liver
Record volume of effusions.

Submit samples for alcohol determination and other toxicologic studies.

Prepare frozen sections for fat stains.

For demonstration of varices, see p. 53.

Record weight and sample for histologic study.
Possible or Expected Findings

Jaundice; clubbing of fingers; Dupuytren's contractures; decreased body hair and gynecomastia in men.

Ascites; pleural effusions.*

Alcoholic cardiomyopathy* (2).

Record weight. Alcoholic cardiomyopathy* (2). Fat embolism* (if severe, systemic circulation may be involved-for instance, kidneys and brain).

Esophageal varices.

Micro- or macronodular alcoholic cirrhosis; alcoholic hepatitis (steatohepatitis); alcoholic fatty liver. Hepatocellular carcinoma. Typical groundglass changes in some patients who were treated with disulfiram or cyanamide (3). 


\begin{tabular}{|c|c|c|}
\hline Organs and Tissues & Procedures & Possible or Expected Findings \\
\hline Portal vein system & & See "Hypertension, portal." \\
\hline Spleen & Record weight. & Congestive splenomegaly. \\
\hline Pancreas & & Alcoholic pancreatitis. ${ }^{*}$ \\
\hline \multirow[t]{2}{*}{$\begin{array}{l}\text { Brain, peripheral nerves, } \\
\text { skeletal muscles, and } \\
\text { other organs }\end{array}$} & $\begin{array}{l}\text { For removal of muscles, peripheral nerves, and } \\
\text { brain, see pp. } 65,67 \text {, and } 85 \text {, respectively. }\end{array}$ & $\begin{array}{l}\text { Myopathy; neuropathy;* see also under } \\
\text { "Alcoholism and alcohol intoxication" and } \\
\text { "Syndrome, Wernicke-Korsakoff." }\end{array}$ \\
\hline & $\begin{array}{l}\text { For removal of lacrimal glands, see p. } 87 \text {. } \\
\text { Remove parotid tissue from scalp incision } \\
\text { (p. 65) with biopsy needle. }\end{array}$ & $\begin{array}{l}\text { Parotid and lacrimal gland enlargement with } \\
\text { increased glandular secretions. }\end{array}$ \\
\hline Testes & Record weights. & Testicular atrophy. \\
\hline
\end{tabular}

\section{References}

1. Kanel GC. Hepatic lesions resembling alcoholic liver disease. Pathology 1994;3:77-104.

2. Estruch R, Fernandez-Sola J, Sacanella E, Pare C, Rubin E, UrbanoMarquez A. Relationship between cardiomyopathy and liver disease in chronic alcoholism. Hepatology 1995;22:532-538.

Disease, alpha-Chain (See "Disease, heavy-chain.")

\section{Disease, Alzheimer's}

Synonyms and Related Terms: Alzheimer's dementia; presbyophrenic dementia; presenile dementia syndrome.

NOTE: For pathogenesis and criteria for staging, see refs. (1-3).

\begin{tabular}{lll}
\hline Organs and Tissues & Procedures & Possible or Expected Findings
\end{tabular}

Brain and spinal cord $\quad$ For removal and specimen preparation, see pp. 65 and 67, respectively. Record brain weight. Histologic sections should include frontal, temporal, occipital, cingulate, enthorinal, and amygdala, hippocampus, deep nuclei and thalamus, substantia nigra, and occipital cortex and hippocampus. For silver impregnation of paraffin sections, request Bielchowsky silver stain (p. 172). Immunostain for $\beta A 4$ and tau protein are available for plaques and tangles. Some tissue samples should be kept frozen for biochemical studies.
Cortical atrophy, particularly of frontal and temporal lobes, with dilatation of ventricles. Neuronal loss and reactive astrocytosis; characteristic senile plaques (argentophilic neuritic plaques) and Alzheimer's neurofibrillary tangles. In some cases, cerebral meningeal and cortical blood vessels show amyloid angiopathy.

\section{References}

1. Esiri MM, Hyman BT, Beyreuther K, Masters CL. Aging and dementia in Greenfield's Neuropathology, vol. 2. Graham BI, Lantos PL, eds. Arnold, London, 1997, pp. 153-233.

2. The National Institute on Aging, and Reagan Institute Working Group on Diagnostic Criteria for the Neuropathological Assessment of Alzheimer's Disease. Consensus recommendations for the postmortem diagnosis of Alzheimer's disease. Neurobiol Aging 1997;Jul-Aug;18(4 Suppl): S1-2.

\section{Disease, Atherosclerotic Heart (See "Disease, ischemic heart.")}

\section{Disease, Bornholm (See “Pleurodynia, epidemic.”)}

\section{Disease, Bourneville's (See “Sclerosis, tuberous.”)}

Disease, Buerger's

Synonyms: Thromboangitis obliterans; Winiwater-Buerger syndrome.
3. The Ronald and Nancy Reagan Research Institute of the Alzheimer's Association and the National Institute on Aging Working Group. Consensus report of the Working Group on: Molecular and Biochemical Markers of Alzheimer's Disease. Neurobiol Aging 1998;Mar-Apr;19 (2):109-116. (Published erratum appears in Neurobiol Aging 1998; May-Jun;19(3):285.) 


\begin{tabular}{ll}
\hline Organs and Tissues & Procedures \\
\hline External examination & $\begin{array}{l}\text { Record presence or absence of abnormalities } \\
\text { listed in right-hand column. }\end{array}$
\end{tabular}

Extremities
If permitted, submit samples from dorsal artery of the foot, and tibial, anterior fibular, popliteal, and femoral arteries. Include specimens of accompanying veins (p. 34).

Section arteries and veins crosswise at different levels. Request Verhoeff-van Gieson stain (p. 173). Section veins that have gross evidence of thrombosis* or thrombophlebitis.*

Dissect abdominal aorta with iliac, mesenteric, and renal arteries. Dissect coronary arteries. Submit samples for histologic study, including Verhoeff-van Gieson stain (p. 173).

Brain
For removal and specimen preparation, see p. 65. For cerebral arteriography, see p. 80 .

\section{Possible or Expected Findings}

Ischemic ulcers of digits; gangrene; amputations; elevated skin lesions accompanying thrombophlebitis.* Arterial lesions are often segmental. Digital arteries are involved more often than are ulnar and radial arteries. Thrombophlebitis* is part of the disease.

Thrombi in small and medium-sized vessels contain mixed inflammatory cells, giant cells, and sterile microabscesses. Later stages of the process are characterized by hypercellular intraluminal granulation tissues without medial scarring.

Thromboses in mesenteric, renal, and coronary arteries are rare. Aortoiliac disease is also rare. Manifestations of the BuddChiari syndrome* may be present.

Cerebral artery involvement may be present and may be associated with cortical ischemic lesions.

\section{Disease, Caisson (See “Sickness, decompression.”) \\ Disease, Canavan's (See “Degeneration, spongy, of white matter.")}

\section{Disease, Caroli's}

Synonyms and Related Terms: Caroli's syndrome; fibropolycystic liver disease; idiopathic dilatation of intrahepatic bile ducts.

NOTE: The term "Caroli's syndrome" often is used for cases that also show histologic features of congenital hepatic fibrosis or other manifestations of fibropolycystic liver disease,* whereas the name "Caroli's disease" refers to idiopathic dilatation of intrahepatic bile ducts, without associated abnormalities.

Possible Associated Conditions: Choledochal cyst* and related extrahepatic biliary abnormalities (1); congenital hepatic fibrosis;* cysts of kidneys (renal tubular ectasia or medullary sponge kidney; autosomal-recessive polycystic kidney disease, and rarely, autosomal-dominant polycystic kidney disease $[2])^{*}$ and of pancreas.

\begin{tabular}{|c|c|c|}
\hline Organs and Tissues & Procedures & Possible or Expected Findings \\
\hline Blood & $\begin{array}{l}\text { Submit samples for aerobic and anaerobic } \\
\text { bacterial cultures (p. 102). }\end{array}$ & Septicemia. \\
\hline $\begin{array}{l}\text { Liver and extrahepatic } \\
\text { bile ducts }\end{array}$ & $\begin{array}{l}\text { If there are superficial abscesses or easily } \\
\text { accessible cysts, sterilize capsule of liver and } \\
\text { aspirate contents for aerobic and anaerobic } \\
\text { cultures. Remove small and large bowel, and } \\
\text { open duodenum in situ. Aspirate bile from } \\
\text { gallbladder or dilated ducts for bacterial culture. } \\
\text { For cholangiography, see p. 56. Open extra- } \\
\text { hepatic bile ducts in situ and record width. } \\
\text { Slice liver in frontal or horizontal plane and } \\
\text { submit samples for histologic study. }\end{array}$ & $\begin{array}{l}\text { Dilatation of the hepatic and common bile } \\
\text { ducts (may not involve entire liver [1]); } \\
\text { choledochal-type cyst;* hepatolithiasis; } \\
\text { cholelithiasis; * choledocholithiasis; rupture } \\
\text { of bile duct ( } 3 \text { ); suppurative cholangitis;* } \\
\text { hepatic abscesses. } \\
\text { Adenocarcinoma of bile ducts. }\end{array}$ \\
\hline Kidneys & $\begin{array}{l}\text { If abnormalities are present, prepare photographs } \\
\text { prior to histologic sampling. }\end{array}$ & $\begin{array}{l}\text { See above under "Possible Associated } \\
\text { Conditions." }\end{array}$ \\
\hline Other organs & & Manifestations of portal hypertension.* \\
\hline
\end{tabular}

\section{References}

1. Dagli U, Atalay F, Sasmaz N, Bostanoglu S, Temucin G, Sahin B. Caroli’s disease: 1977-1995 experiences. Eur J Gastroenterol Hepatol 1998;10: 109-112.

2. Mousson C, Rabec M, Cercueil JP, Virot JS, Hillon P, Rifle G. Caroli's disease and autosomal dominant polycystic kidney disease: a rare association? Nephrol Dialysis Transplant 1997;12:1481-1483.

3. Chalasani N, Nguyen CC, Gitlin N. Spontaneous rupture of a bile duct and its endoscopic management in a patient with Caroli's syndrome. Am J Gastroenterol 1997;92:1062-1063. 


\section{Disease, Cat Scratch}

Possible Associated Conditions: AIDS and other immunodeficient conditions.

\begin{tabular}{|c|c|c|}
\hline Organs and Tissues & Procedures & Possible or Expected Findings \\
\hline $\begin{array}{l}\text { External examination } \\
\text { and skin }\end{array}$ & & Cat-scratch mark and lymphadenopathy. \\
\hline Heart & $\begin{array}{l}\text { If endocarditis is suspected, follow procedures } \\
\text { described under that heading (p. 103). }\end{array}$ & Endocarditis $(1)$ \\
\hline Liver & Sample for histologic study. & $\begin{array}{l}\text { Granulomatous hepatitis; bacillary peliosis } \\
\text { hepatis }(2) \text { (see also below under "Other } \\
\text { organs"). }\end{array}$ \\
\hline Other organs & $\begin{array}{l}\text { Photograph lesions that might have been caused } \\
\text { by the infection. } \\
\text { Sample material for microbiologic and histologic } \\
\text { study; prepare Gram stains (p. 172). }\end{array}$ & $\begin{array}{l}\text { Infection caused by Bartonella hensleae or } \\
\text { Afipia felis. In patients with AIDS, bacillary } \\
\text { (epithelioid) angiomatosis and bacillary } \\
\text { peliosis hepatis are associated with } B \text {. } \\
\text { hensleae (1) infection. }\end{array}$ \\
\hline Skeletal system & $\begin{array}{l}\text { If osteomyelitis is suspected, follow procedures } \\
\text { described under that heading. }\end{array}$ & Osteomyelitis.* \\
\hline Brain and spinal cord & $\begin{array}{l}\text { For removal and specimen preparation, } \\
\text { see pp. } 65 \text { and } 67 \text {, respectively. }\end{array}$ & Encephalitis; meningitis; transverse myelitis. \\
\hline
\end{tabular}

\section{References}

1. Holmes AH, Greenough TC, Balady GJ, Regnery RL, Anderson BE, O'Keane JC, et al. Bartonella henselae endocarditis in an immunocompetent adult. Clin Inf Dis 1995;21:1004-1007.

2. Chomel BB. Cat-scratch disease and bacillary angiomatosis. Rev Scientifique Technique 1996;15:1061-1073.

\section{Disease, Celiac (See "Sprue, celiac.”)}

Disease, Cerebrovascular (See "Attack, transient cerebral ischemic" and "Infarction, cerebral.")

\section{Disease, Chagas'}

Synonyms and Related Terms: American trypanosomiasis; Chagas' syndrome; Trypanosoma cruzi infection.

NOTE: (1) Collect all tissues that appear to be infected. (2) Request cultures for trypanosomiasis. (3) Request Giemsa stain (p. 172). (4) Special precautions are indicated (p. 146). (5) Serologic studies are available from the Centers for Disease Control and Prevention, Atlanta, GA (p. 135). (6) Usually, this is not a reportable disease.

Possible Associated Conditions: AIDS (1) and other conditions associated with immunosuppression.

\begin{tabular}{ll}
\hline Organs and Tissues & Procedures \\
\hline $\begin{array}{l}\text { External examination } \\
\text { and skin }\end{array}$ & $\begin{array}{l}\text { Record and photograph the findings listed in } \\
\text { right-hand column. Prepare sections of skin }\end{array}$
\end{tabular}
lesions.

Body cavities

Blood

Heart
Record volume of effusions.

Prepare smears of fresh blood or of buffy coat, or make thick-drop preparation.

Submit sample for xenodiagnosis or animal inoculation and for serologic study (p. 102).

Record weight. In chronic Chagas' disease, perfuse intact heart with formalin (p. 28) and slice fixed heart in a frontal plane so as to create anterior and posterior halves. Prepare photographs. Histologic samples should include conduction system (p. 26).

\section{Possible or Expected Findings}

In acute disease, unilateral bipalpebral edema, chemosis, and swelling of preauricular lymph nodes (Romaña's sign); skin nodules showing histiocytic and granulomatous inflammation; regional lymphadenitis, primarily in uncovered regions (chagoma), and subcutaneous edema. Hypopigmentation.

Effusions in congestive cardiac failure.* In acute Chagas' disease, trypanosomes in blood.

In acute cases, positive hemagglutination and precipitin tests; in chronic cases, positive complement-fixation tests.

In chronic Chagas' disease, cardiac hypertrophy and dilatation; fibrous epicarditis, myocardial cell hypertrophy; apical aneurysm; endomyocardial fibrosis, and atrial and apical ventricular mural thrombi. Valves and coronary arteries are normal. 


\begin{tabular}{ll}
\hline Organs and Tissues & Procedures \\
\hline Heart & Include several sections of atrial (auricular) \\
(continued) & walls for histologic study of autonomous ganglia.
\end{tabular}

Lungs

Esophagus and gastrointestinal tract

Liver and biliary system

Spleen

Kidneys, ureters, and urinary bladder

Placenta

Brain and spinal cord

Skeletal muscles, peripheral nerves, and other tissues
Leave affected hollow viscera intact and fill with formalin. Cut fixed organs in half, photograph, and cut histologic sections on edge.

Record liver weight and submit samples for histologic study.

Record weight.

Prepare photographs of abnormalities.

Weigh and examine. Prepare histologic sections.

For removal and specimen preparation, see pp. 65 and 67 , respectively.

For sampling of skeletal muscles, see p. 80 .

For sampling of peripheral nerves, see p. 79 .
Possible or Expected Findings

There may be parasitic pseudocysts or granulomas, fibrosis, myocytolysis, and degeneration and fibrous replacement of ganglion cells. In acute Chagas' disease, heart shows acute or subacute myocarditis* with dilatation. Intracellular parasites (i.e., pseudocysts with amastigote forms); necrosis of ganglion cells in atrial walls.

In chronic Chagas' disease, emboli with infarctions, bronchiectasis, * fibrosis, hemosiderosis, and, rarely, acute hemorrhage. Megaesophagus is frequent, with or without carcinoma. Stomach, duodenum, colon (2), and appendix (rarely) may be enlarged; diminution in number of ganglion cells in Auerbach plexus.

In acute Chagas' disease, hepatomegaly may be present. Rarely, in chronic cases, the gallbladder and bile ducts may be enlarged. Infarctions. In acute Chagas' disease, splenomegaly.

Renal infarctions. Rarely, in chronic Chagas' disease, the ureters and urinary bladder may be enlarged.

Pale, enlarged placenta; chronic villitis; increased perivillous fibrin; amastigotes in Hofbauer cells, amniotic epithelium and syncytiotrophoblasts.*

Cerebral infarctions.* Meningoencephalitis (particularly in reactivated forms in immunodeficient patients [3]) with or without involvement of spinal cord; cerebral atrophy with pressure atrophy of frontal gyri. Histologically, ruptured pseudocysts with spread of amastigote forms.

There is a predilection for muscle and nerve tissue, but all organs and tissues can be involved.

\section{References}

1. Sartori AM, Shikanai-Yasuda MA, Amato Neto V, Lopes MH. Follow-up of 18 patients with human immunodeficiency virus infection and chronic Chagas' disease, with reactivation of Chagas' disease causing cardiac disease in three patients. Clin Inf Dis 1998;26: 177-179.
2. Oliveira EC, Lette MS, Ostermayer AL, Almeida AC, Moreira H. Chagasic megacolon associated with colon cancer. Am J Trop Med Hyg 1997;56:596-598.

3. Chimelli L, Scaravilli F. Trypanosomiasis. Brain Pathol 1997;7:599611.

\section{Disease, Cholesteryl Ester Storage}

Related Terms: Lysosomal acid lipase deficiency; Wolman's disease.*

\begin{tabular}{ll}
\hline Organs and Tissues & Procedures \\
\hline Fascia lata & Specimens should be collected using aseptic \\
& $\begin{array}{l}\text { technique for tissue culture for biochemical } \\
\text { studies (see Chapter 10). }\end{array}$
\end{tabular}

Blood

Possible or Expected Findings

The lysosomal acid lipase deficiency can be demonstrated in cultured fibroblasts.

Hyperbetalipoproteinemia; hypercholesterolemia. 


\begin{tabular}{lll}
\hline Organs and Tissues & Procedures & Possible or Expected Findings \\
\hline Liver and spleen & $\begin{array}{l}\text { Accumulation of cholesteryl esters may be } \\
\text { demonstrated by thin-layer chromatography of } \\
\text { lipid extracts of liver tissue. Lipid is PAS and } \\
\text { aldehyde-fuchsin positive. }\end{array}$ & $\begin{array}{l}\text { Hepatosplenomegaly. Hepatic fibrosis or } \\
\text { cirrhosis with fatty changes in hepatocytes, } \\
\text { cholangiocytes, portal macrophages, and } \\
\text { Kupffer cells; deposition of cholesteryl } \\
\text { crystals and triglycerides in Kupffer cells }(1) .\end{array}$ \\
Other organs and tissues & & $\begin{array}{l}\text { Atherosclerosis and its manifestations may } \\
\text { be more severe than expected for the age of } \\
\text { the patient }(2) .\end{array}$ \\
\hline
\end{tabular}

\section{References}

1. Di Bisceglie AM, Ishak KG, Rabin L, Hoeg JM. Cholesteryl ester storage disease: Hepatopathology and effects of therapy with lovestatin. Hepatology 1990;11:764-772.
2. Tylki-Szymanska A, Rujner J, Lugowska A, Sawnor-Korsznska D, Wozniewicz B, Czarnowska E. Clinical, biochemical and histological analysis of seven patients with cholesterol ester storage disease. Acta Paediatr Japan 1997;39:643-646.

\section{Disease, Christmas}

Synonyms: Christmas factor deficiency; Factor IX deficiency.

NOTE: Follow procedures described under "Hemophilia." The expected findings are the same as for hemophilia.

\section{Disease, Chronic Granulomatous}

Synonyms and Related Terms: Autosomal recessive chronic granulomatous disease; chronic granulomatous disease of childhood; X-linked chronic granulomatous disease.

NOTE: The condition occurs not only in children but also in adults. Infections with catalase-positive microorganisms such as S. aureus, Pseudomonas sp. or Aspergillus sp., predominate. The disease is part of a family of inherited disorders of phagocyte function (neutrophil dysfunction syndrome); other disorders in this family include the Chediak-Higashi syndrome, ${ }^{*}$ myeloperoxidase deficiency, and other rare disorders.

\begin{tabular}{cl}
\hline Organs and Tissues & Procedures \\
\hline External examination, & Record extend and character of skin lesions, \\
skin, and oral cavity & $\begin{array}{l}\text { particularly those around body orifices. } \\
\text { Photograph skin lesions and prepare sections. }\end{array}$
\end{tabular}

Prepare chest and skeletal roentgenograms.

\begin{abstract}
Abdominal cavity
Chest cavity

Blood

Submit sample of exudate for microbiologic study (see below under "Lymph nodes"). Submit sample of exudate for microbiologic study (see below under "Lymph nodes"). Record volume of contents.

Submit sample for bacterial and fungal cultures (p. 102).
\end{abstract}

Lymph nodes

Submit samples of inguinal, axillary, mediastinal, mesenteric, and other grossly involved lymph nodes for microbiologic (p. 102) and histologic study. Request Gram and Grocott methenamine silver stains for fungi and Sudan black-stained frozen sections for lipid (p. 172).

Heart
If pericarditis or endocarditis are suspected, follow procedures described under these headings (p. 103).
Possible or Expected Findings

Seborrheic dermatitis, mainly around eyes (with conjunctivitis), around mouth (with stomatitis), and around nose and anus. Aphthous ulcers; gingivitis.

Bacterial or fungal perianal and perineal abscesses and fistulas; wound infections. Skin granulomas with pigmented macrophages (1).

Pulmonary infiltrates. Osteomyelitis, * particularly of hands and feet.

Subphrenic empyema.*

Pleural effusions;* empyema.

Septicemia (staphylococci, gram-negative organisms, or fungi, such as Aspergillus and Candida).

Lymphadenitis with abscesses and lipidfilled macrophages; granulomas with central necrosis. For suspected organisms, see above under "Blood."

Pericarditis and, rarely, endocarditis* (2). 


\begin{tabular}{ll}
\hline Organs and Tissues & Procedures \\
\hline Lungs & $\begin{array}{l}\text { Submit one lobe for microbiologic study } \\
\text { (p. 103); perfuse one lung with formalin (p. 47). }\end{array}$ \\
$\begin{array}{l}\text { Esophagus and } \\
\text { gastrointestinal tract }\end{array}$ & $\begin{array}{l}\text { Prepare photographs of abnormal lesions. } \\
\text { appearing areas for histologic study. }\end{array}$ \\
Liver and spleen & $\begin{array}{l}\text { Record weights; photograph. Submit samples } \\
\text { for microbiologic and histologic study }\end{array}$ \\
& (see above under "Lymph nodes"). \\
Other organs & Submit samples of abnormal appearing areas \\
for histologic study. & For removal and specimen preparation, \\
Brain, spinal cord, & see pp. 65, 67, and 85. \\
and eyes & For removal, prosthetic repair, and specimen \\
Bones and bone marrow & preparation of bones, see p. 95. For micro- \\
& biologic sampling, see p. 102. For preparation \\
& of sections and smears of bone marrow, \\
& see p. 96.
\end{tabular}

Possible or Expected Findings

Bacterial and fungal bronchopneumonia and abscesses; hilar lymphadenitis.

Involvement by granulomatous disease may occur from mouth to anus. Colon lesions may resemble chronic ulcerative colitis (3).

Hepatosplenomegaly with bacterial and fungal abscesses and granulomas.

Abscesses and granulomas may occur in all organs and tissues.

Granulomatous lesions in central nervous system (4) and eyes (5).

Fungal osteomyelitis* that may be multifocal, including sites such as metacarpals and metatarsals.

\section{References}

1. Dohil M, Prendiville JS, Crawford RI, Speert DP. Cutaneous manifestations of chronic granulomatous disease. A report of four cases and review of the literature. J Am Acad Dermatol 1997;36:899-907.

2. Casson DH, Riordan FA, Ladusens EJ. Aspergillus endocarditis in chronic granulomatous disease. Acta Pediatr 1996;85:758-759.

3. Sloan JM, Cameron CH, Maxwell RJ, McCluskey DR, Collins JS. Colitis complicating chronic granulomatous disease. A clinicopathological case report. Gut 1996;38:619-622.

4. Adachi M, Hayashi A, Ohkoshi N, Nagata H, Mizusawa H, Shoji S, et al. Hypertrophic cranial pachymeningitis with spinal epidural granulomatous lesion. Intern Med 1995;34:806-810.

5. Valluri S, Chu FC, Smith ME. Ocular pathologic findings of chronic granulomatous disease of childhood. Am J Ophthalmol 1995;120: $120-123$.

\section{Disease, Chronic Obstructive Pulmonary (See "Bronchitis, chronic" and "Emphysema.")}

\section{Disease, Collagen}

Synonym: Connective tissue disease.

NOTE: See under specific name, such as "Arthritis, rheumatoid," "Dermatomyositis," "Lupus erythematosus, systemic," "Polyarteritis nodosa," "Sclerosis, systemic," and "Syndrome, Sjögren's."

\section{Disease, Congenital Heart (See under specific name of malformation.)}

\section{Disease, Creutzfeldt-Jakob}

Synonyms and Related Terms: Creutzfeldt-Jakob disease (CJD), "new variant"; iatrogenic Creutzfeldt-Jakob disease; familial Creutzfeldt-Jakob disease; fatal familial insomnia; Gerstmann-Straussler-Scheinker syndrome; Kuru; Prion disease; sporadic spongiforme encephalopathy; subacute spongiforme encephalopathy; transmissible spongiforme encephalopathy; variant Creutzfeldt-Jakob disease.

\section{NOTE:}

Autopsy is desirable in suspected cases because the diagnosis can only be firmly established after neuropathologic examination. Serologic studies are not available. Unfortunately, all tissues (not just the brain and spinal cord) may remain infectious even after prolonged fixation and histologic processing. Thus, the autopsy recommendations for most other infectious diseases do not apply here. This is a reportable disease in some states. Special precautions are indicated and therefore, the procedures described here should be followed strictly $(1-4)$ :

All persons in the autopsy room must wear disposable longsleeved gowns, gloves, and masks. Contamination of the autopsy table should be prevented by covering it with a disposable, nonpermeable plastic sheet. Autopsy generally should be restricted to the brain. If organs in the chest or abdomen need to be examined, this is best done in situ. To prevent aerosolization of potentially infectious bone dust, a hood or other protective device (see p. 67) should be used while opening the skull with a Stryker saw. After completing the autopsy, instruments and other potentially contaminated objects should be autoclaved in a steam autoclave $\left(1 \mathrm{~h}\right.$ at $\left.134^{\circ} \mathrm{C}\right)$. Porous load is considered more effective than gravity displacement autoclaves. Immerse autopsy instruments in distilled water before and during autoclaving, in order to protect them from corrosion. If no autoclave is available, chemical disinfection (see below) is a satisfactory alternative. Disposable items should be put in a container for infectious hospital waste and ultimately incinerated. Contaminated objects not suitable for autoclaving (such as the Stryker saw) should be soaked with a $2 \mathrm{~N} \mathrm{NaOH}$ solution for $1 \mathrm{~h}$ (alternatively, $1 \mathrm{~N} \mathrm{NaOH}$ may be used for $2 \mathrm{~h}$ ). Contaminated surfaces should be thoroughly washed with the same solution. Aluminum should be treated for $2 \mathrm{~h}$ with a fresh $5 \% \mathrm{NaOCl}$ (sodium hypochlorite) solution with at least $20,000 \mathrm{ppm}$ free chloride. Wash waters should be collected; if no autoclave is available, $2 \mathrm{~N} \mathrm{NaOH}$ or $>4$ volumes of $5 \%$ sodium hypochlorite bleach should be added to the water and left for a minimum of $2 \mathrm{~h}$ before being discarded. Before removing the body from the 
autopsy room, it should be sponged with 5\% sodium hypochlorite.

To deactivate CJD infectivity, tissue blocks, $5 \mathrm{~mm}$ or less in thickness, should be fixed in formalin in a formalin-to-tissue ratio of at least 20:1 for at least $48 \mathrm{~h}$ and then soaked in concentrated formic acid (95-100\%) for $1 \mathrm{~h}$, followed by another 48 $\mathrm{h}$ of formalin fixation. The fixation fluid should be collected and decontaminated, as described earlier for wash water. Glassware and tissue carriers should also be decontaminated as previously described. After this deactivation, the tissue blocks can be processed in a routine fashion. At any stage of these procedures, special care must be taken to avoid cuts with potentially contaminated glassware, blades, or other objects. Parenteral exposure to potentially contaminated material also should be avoided.

Remains of patients who have died of the disease should not be accepted for anatomy teaching for students. If specimens are prepared for pathology collections, they should be handled with great caution. Morticians and mortuary workers should be warned of possible hazards posed by tissues of patients with transmissible spongiforme encephalopathies; they should be advised about proper use of disinfectants. Clinical laboratories that receive autopsy tissues or fluids must be warned about the infectious nature of the material. If possible, decontamination should be done at the site where the autopsy was done. For the shipping of potentially infected material, see p. 135.

\begin{tabular}{lll}
\hline Organs and Tissues & Procedures & Organs and Tissues
\end{tabular}

Cerebrospinal fluid Submit sample (p. 104) for neuron-specific enolase (NSE).

Brain

For removal and specimen preparation, see p. 65 and above under "Note." Submit fresh-frozen material for confirmation of diagnosis by histoblot technique on protease $\mathrm{K}$-digested frozen tissue or Western blot preparations on brain homogenates. Immunohistochemical localization of PrPres protein on paraffin-embedded tissue is possible.
Increased concentrations of NSE (5).

Spongiforme changes, astrocytosis, neuronal loss, and amyloid plaque formation are the typical findings.

\section{References}

1. Ironside JW. Review: Creutzfeldt-Jakob disease. Brain Pathol 1996;6: 379-388.

2. Gajdusek DC, Gibbs CJ Jr. Survival of Creutzfeldt-Jakob disease virus in formol-fixed brain tissue. N Engl J Med 1976;294:553.

3. Brown P. Guidelines for high risk autopsy cases: special precautions for Creutzfeldt-Jakob disease. In: (Hutchins GM, ed.) Autopsy Performance and Reporting. College of American Pathologists, Northfield, IL, 1990, pp. 68-74.
4. Budka H, Aguzzi A, Brown P, Brucher JM, Bugiani O, Collinge J, et al. Tissue handling in suspected Creutzfeldt-Jakob disease and other human spongiforme encephalopathies (prion diseases). Brain Pathol 1995;5:319-322.

5. Zerr I, Bodemer M, Racker S, Grosche S, Poser S, Kretzschmar HA, Weber T. Cerebrospinal fluid concentration of neuron-specific enolase in diagnosis of Creutzfeldt-Jakob disease. Lancet 1995;345: $1609-1610$.

\section{Disease, Crohn's}

Synonyms and Related Terms: Inflammatory bowel disease;* regional enteritis.

NOTE: If the distinction between Crohn's disease and chronic ulcerative colitis cannot be made clearly, see under "Disease, inflammatory bowel."

Possible Associated Conditions: Amyloidosis;* ankylosing spondylitis;* polyarthritis; Sjögren's syndrome.*

\begin{tabular}{ll}
\hline Organs and Tissues & Procedures \\
\hline External examination & Record character and extent of skin lesions. \\
and skin & Submit samples for histologic study.
\end{tabular}

Vitreous
Prepare skeletal roentgenograms.

If dehydration or other electrolyte disturbances are expected, request determination of sodium, chloride, potassium, and urea nitrogen concentrations (pp. 85 and 115).

\section{Possible or Expected Findings}

Orbital edema and lid edema; ulcerative oral lesions; cutaneous fistulas after laparotomies; clubbing of fingers; perianal fistulas; vulval abscesses; cutaneous polyarteritis nodosa; erythema multiforme; erythema nodosum; pyoderma gangrenosum. Granulomatous inflammatory changes in mucosal/skin lesions (1).

See below under "Bones and joints." Dehydration;* electrolyte disorders.* 


\begin{tabular}{|c|c|c|}
\hline Organs and Tissues & Procedures & Possible or Expected Findings \\
\hline$\overline{\text { Blood }}$ & $\begin{array}{l}\text { Submit sample for culture and for determination } \\
\text { of immunoglobulin concentrations (p. 102). }\end{array}$ & Septicemia; selective IgA deficiency. \\
\hline Heart & See "Stenosis, acquired valvular aortic." & Aortic stenosis.* \\
\hline Lung & $\begin{array}{l}\text { Submit at least one sample from each lobe for } \\
\text { histologic study. }\end{array}$ & Noncaseating granulomas in rare instances (2). \\
\hline Esophagus & $\begin{array}{l}\text { Leave specimen attached to stomach; submit } \\
\text { tissue samples for histologic study. }\end{array}$ & Esophagus may be affected by the disease. \\
\hline \multirow[t]{2}{*}{ Gastrointestinal tract } & $\begin{array}{l}\text { For in situ fixation and preparation for study } \\
\text { under the dissecting microscope, see p. } 54 \text {. } \\
\text { In some instances, adhesions may be so severe } \\
\text { that the intestines must be removed and sliced } \\
\text { en bloc. Dissect fistulas in situ, or inject for } \\
\text { roentgenographic study. }\end{array}$ & $\begin{array}{l}\text { All segments of the gastrointestinal tract } \\
\text { (appendix included) may be affected. } \\
\text { Complications include adenocarcinoma, } \\
\text { lymphoma,* or other tumors (rare), } \\
\text { pneumatosis coli, fistulas (enterovaginal, } \\
\text { perirectal, and others), and perirectal abscess. } \\
\text { Acute toxic dilatation of the colon may be } \\
\text { present. }\end{array}$ \\
\hline & $\begin{array}{l}\text { Submit samples of stomach and of all portions } \\
\text { of intestinal tract for histologic study. }\end{array}$ & $\begin{array}{l}\text { Mucosal abnormalities also may be present } \\
\text { in grossly normal portions of colon and } \\
\text { rectum. }\end{array}$ \\
\hline Mesentery & Submit lymph nodes for histologic study. & $\begin{array}{l}\text { Granulomatous lymphadenitis. Mesenteric } \\
\text { fibromatosis (3). }\end{array}$ \\
\hline Liver & $\begin{array}{l}\text { Record weight. For postmortem cholangiography, } \\
\text { see p. } 56 \text {. Submit multiple samples for histologic } \\
\text { study. }\end{array}$ & $\begin{array}{l}\text { Primary sclerosing cholangitis, } * \text { with or } \\
\text { without cholangiocarcinoma* }(4) \text {; biliary } \\
\text { cirrhosis;* fatty changes; granulomas. }\end{array}$ \\
\hline Gallbladder & Record nature of concrements. & Cholelithiasis.* \\
\hline $\begin{array}{l}\text { Retroperitoneal tissues } \\
\text { with pancreas }\end{array}$ & $\begin{array}{l}\text { Submit abscess contents for microbiologic study } \\
\text { (p. 102). }\end{array}$ & $\begin{array}{l}\text { Psoas abscess; para-aortic lymphadenopathy. } \\
\text { Granulomatous pancreatitis (5). }\end{array}$ \\
\hline Kidneys with ureters & $\begin{array}{l}\text { Submit stones for chemical analysis. Photo- } \\
\text { graph kidneys with renal pelves and ureters. } \\
\text { Sample for histologic study. }\end{array}$ & $\begin{array}{l}\text { Nephrolithiasis* (uric acid and calcium } \\
\text { stones); hydronephrosis.* Hydroureters; } \\
\text { periureteral fibrosis and ureteral obstruction. }\end{array}$ \\
\hline Internal genital organs & Submit purulent material for microbiologic study. & Pyosalpinx. \\
\hline Eyes & $\begin{array}{l}\text { For removal and specimen preparation, } \\
\text { see p. } 85 \text {. }\end{array}$ & $\begin{array}{l}\text { Conjunctivitis; marginal corneal ulcers; } \\
\text { keratitis; scleritis; episcleritis; retinitis; } \\
\text { neuroretinitis; optic neuritis. }\end{array}$ \\
\hline Skeletal muscles & $\begin{array}{l}\text { For sampling and specimen preparation, } \\
\text { see p. } 80 .\end{array}$ & $\begin{array}{l}\text { Myositis; in rare instances, dermatomyo- } \\
\text { sitis*(6). }\end{array}$ \\
\hline Bones and joints & $\begin{array}{l}\text { For removal, prosthetic repair, and specimen } \\
\text { preparation, see p. } 95 .\end{array}$ & $\begin{array}{l}\text { Aseptic necrosis of bone; ossifying } \\
\text { periostitis; granulomatous bone disease; } \\
\text { ankylosing spondylitis;* polyarthritis; } \\
\text { nonspecific or granulomatous synovitis. }\end{array}$ \\
\hline Brain and spinal cord & $\begin{array}{l}\text { For removal and specimen preparation, } \\
\text { see pp. } 65 \text { and } 67 \text {, respectively. }\end{array}$ & $\begin{array}{l}\text { Manifestations of disseminated intravascular } \\
\text { coagulation.* }\end{array}$ \\
\hline
\end{tabular}

\section{References}

1. Kafity A, Pellegrini A, Fromkes J. Metastatic Crohn's disease: a rare cutaneous manifestation. J Clin Gastroenterol 1993;17:300-303.

2. Calder CJ, Lacy D, Raafat F, Weller PH, Booth IW. Crohn's disease with pulmonary involvement in a 3 year old boy. Gut 1993;34:16361638.

3. DiGiacomo JC, Lasenby AJ, Salloum LJ. Mesenteric fibromatosis associated with Crohn's disease. Am J Gastroenterol 1994;89:1103-1105.
4. Choi PM, Nugent FW, Zelig MP, Munson JL, Schoetz DJ Jr. Cholangiocarcinoma and Crohn's disease. Dig Dis Sci 1994;39:667-670.

5. Gschwantler M, Kogelbauer G, Klose W, Bibus B, Tscholakoff D, Weiss W. The pancreas as a site of granulomatous inflammation in Crohn's disease. Gastroenterology 1995;108:1246-1249.

6. Leibowitz G, Eliakim R, Amir G, Rachmilewitz D. Dermatomyositis associated with Crohn's disease 1994;18:48-52.

\section{Disease, Cushing's (See “Syndrome, Cushing's.”)}




\section{Disease, Demyelinating}

(See "Degeneration, spongy, of white matter," "Encephalomyelitis, all types or type unspecified," "Leukodystrophy, globoid cell," "Leukodystrophy, sudanophilic," "Sclerosis, multiple," and "Sclerosis, Schilder's cerebral.")

\section{Disease, Diffuse Alveolar}

Synonym: Diffuse pulmonary disease.

NOTE: Autopsy procedures are listed under the more specific diagnoses, such as "Hemosiderosis, idiopathic pulmo- nary," "Lipoproteinosis, pulmonary alveolar," "Microlithiasis, pulmonary alveolar," "Pneumonia, lipoid," and "Syndrome, Goodpasture's."

\section{Disease, Eosinophilic Endomyocardial (See "Cardiomyopathy, restrictive [eosinophilic type].")}

\section{Disease, Fabry's}

Synonyms: Alpha-galactosidase deficiency; Anderson-Fabry disease; angiokeratoma corporis diffusum; glycosphingolipid lipidosis.

\begin{tabular}{ll}
\hline Organs and Tissues & Procedures \\
\hline External examination & Prepare skin sections from multiple sites. \\
and skin & Request Sudan black, PAS, and toluidine blue \\
& O stains (p. 173).
\end{tabular}

Blood

Heart

Lungs

Urine

Kidneys

Other organs

Brain and spinal cord

Eyes
For recommended special stains, see above under "External examination and skin."

For recommended special stains, see above under "External examination and skin."

Examine sediment.

For recommended special stains, see above under "External examination and skin."

Procedures depend on expected findings or grossly identified abnormalities as listed in right-hand column.

For removal and specimen preparation, see pp. 65 and 67. For cerebral angiography and dissection of vertebral arteries, see pp. 80 and 82. For recommended special stains, see above under "External examination and skin." For removal and specimen preparation, see p. 85. For recommended special stains, see above under "External examination and skin."

\section{Possible or Expected Findings}

Telangiectatic lesions. Glycolipid storage (PAS-positive, Sudan black-positive, metachromatic, and double refractile with toluidine blue) in arrectores pilorum muscles, vascular endothelium, and sweat glands. Leukocyte alpha-galactosidase deficiency. Glycolipid storage with nonobstructive hypertrophic cardiomyopathy* (this may be the only manifestation $[1,2])$. Myocardial infarction.

Narrowing of airways by glycosphingolipid in patients with clinical features of obstructive lung disease (3). "Mulberry cells" in sediment. Glycosphingolipids in glomeruli and distal convoluted tubules. If applicable, see also under "Failure, kidney."

Glycosphingolipid storage in liver, spleen, small and large bowel, lymph nodes, and bone marrow.

Elongated tortuous and ectatic vertebral and basilar arteries (4), sometimes with thrombosis (5). Glycosphingolipid storage. Cerebral infarction(s)* or hemorrhages.

Glycosphingolipid storage in cornea; lens opacities; dilated vessels in conjunctiva and lens; thrombi in blood vessels (5).

\section{References}

1. Elleder M, Bradová V, Smid F, Budesinsky M, Harzer K, Kustermann-Kuhn B, et al. Cardiocyte storage and hypertrophy as a sole manifestation of Fabry's disease. Report on a case simulating hypertrophic non-obstructive cardiomyopathy. Virchows Arch [Pathol Anat] 1990;417:449-455.

2. Von Scheidt W, Eng CM, Fitzmaurice TF, Erdmann E, Hubner G, Olsen EG, et al. An atypical variant of Fabry's disease with manifestations confined to the myocardium. N Engl J Med 1991;324:395-399.
3. Brown LK, Miller A, Bhuptani A, Sloane MF, Zimmerman MI, Schilero G, et al. Pulmonary involvement in Fabry disease. Am J Respir Crit Care Med 1997;155:1004-1110.

4. Mitsias P, Levine SR. Cerebrovascular complications of Fabry's disease. Ann Neurol 1996;40:8-17.

5. Utsumi K, Yamamoto N, Kase R, Takata T, Okumiya T, Saito H, et al. High incidence of thrombosis in Fabry's disease. Intern Med 1997;36:327-329.

\section{Disease, Fibropolycystic, of the Liver and Biliary Tract}

NOTE: "Fibropolycystic disease of the liver and biliary tract" comprises a group of well defined conditions, which, however, may overlap or occur together and hence need a collective designation. The conditions include autosomal-recessive (infantile) and autosomal dominant (adult) polycystic disease of the liver; Caroli's disease or syndrome;* choledochal cyst, * congenital hepatic fibrosis, ${ }^{*}$ multiple biliary microhamartomas, and related disorders. For autopsy procedures, see also under more specific designations. 


\begin{tabular}{|c|c|c|}
\hline Organs and Tissues & Procedures & Possible or Expected Findings \\
\hline External examination & Record and photograph abnormalities. & Polydactyly; spina bifida. \\
\hline Lungs & $\begin{array}{l}\text { If cysts can be identified, prepare arteriograms } \\
\text { (p. 50) and perfuse with formalin (p. 47). } \\
\text { See also below under "Liver and hepatoduodenal } \\
\text { ligament." }\end{array}$ & Cysts of lungs.* \\
\hline Esophagus & $\begin{array}{l}\text { For demonstration of esophageal varices, } \\
\text { see p. } 53 \text {. }\end{array}$ & Esophageal varices.* \\
\hline Gastrointestinal tract & Estimate and record volume of blood in lumen. & $\begin{array}{l}\text { Gastrointestinal hemorrhage* after rupture } \\
\text { of varices. }\end{array}$ \\
\hline Spleen & Record weight. & $\begin{array}{l}\text { Splenomegaly in presence of portal } \\
\text { hypertension.* }\end{array}$ \\
\hline $\begin{array}{l}\text { Liver and hepatoduodenal } \\
\text { ligament }\end{array}$ & $\begin{array}{l}\text { Dissect common bile duct in situ (see also under } \\
\text { "Cyst(s), choledochal"). Record weight of liver; } \\
\text { photograph surface of liver. For cholangiography, } \\
\text { venography, or arteriography, see p. } 56 \text {. Aspirate } \\
\text { contents of infected cysts or abscesses and } \\
\text { submit samples for microbiologic study (p. 102). } \\
\text { Prepare smears of exudate. Inject large cysts } \\
\text { with warm, freshly prepared, 5\% gelatin solution } \\
\text { dissolved in } 10 \% \text { formalin. Slice with large knife } \\
\text { (p. 57) after solution has hardened. Photograph } \\
\text { cut surface; record size and distribution of cysts; } \\
\text { submit tissue samples for histologic study. }\end{array}$ & $\begin{array}{l}\text { Microcysts associated with ductal plate } \\
\text { malformations as in autosomal-recessive } \\
\text { polycystic liver disease, may not be } \\
\text { noticeable macroscopically. Large intra- } \\
\text { hepatic cysts may be calcified (1). } \\
\text { Choledochal cyst.* Hepatomegaly. } \\
\text { Abscesses. }\end{array}$ \\
\hline Other organs & $\begin{array}{l}\text { Procedures depend on expected findings or } \\
\text { grossly identified abnormalities as listed in } \\
\text { right-hand column. }\end{array}$ & $\begin{array}{l}\text { Cysts of kidneys, }{ }^{*} \text { pancreas, and ovaries. } \\
\text { Polycystic kidney disease (autosomal- } \\
\text { recessive or autosomal-dominant) may be the } \\
\text { main finding at autopsy. }\end{array}$ \\
\hline
\end{tabular}

Reference

1. Coffin B, Hadengue A, Degos F, Benhamou JP. Calcified hepatic and renal cysts in adult dominant polycystic kidney disease. Dig Dis Sci 1990; $35: 1172-1175$.

\section{Disease, Gaucher's}

Synonyms and Related Terms: Adult, infantile, or juvenile Gaucher's disease; glucosylceramide lipidosis; acute neuronopathic (infantile) Gaucher's disease; chronic non-neuronopathic (adult) Gaucher's disease.

Possible Associated Conditions: Leukemia,* lymphoma,* and other malignant neoplasms.

\begin{tabular}{lll}
\hline Organs and Tissues & Procedures & Possible or Expected Findings \\
\hline $\begin{array}{l}\text { External examination } \\
\text { and skin }\end{array}$ & $\begin{array}{l}\text { Record and photograph skin changes. } \\
\text { Prepare histologic sections of skin. } \\
\text { Request Gomori's iron stain (p. 172). } \\
\text { Prepare skeletal roentgenograms. }\end{array}$ & $\begin{array}{l}\text { Yellowish brown skin pigmentation; } \\
\text { pingueculae near cornea. Sinus tracts. }\end{array}$ \\
& & $\begin{array}{l}\text { Lytic defects and osteonecrosis may occur in } \\
\text { long bones, phalanges, ribs, spine, pelvis, and } \\
\text { skull. Aseptic necrosis of femoral head. }\end{array}$ \\
& Submit sample for biochemical study. & $\begin{array}{l}\text { Fractures of long bones may be present. } \\
\text { Increased plasma glucosylceramide } \\
\text { Blood }\end{array}$ \\
Heart & & $\begin{array}{l}\text { concentrations. } \\
\text { Cor pulmonale. }\end{array}$ \\
& $\begin{array}{l}\text { Perfuse one lung with formalin (p. 47). } \\
\text { Submit one fresh lobe for bacterial culture } \\
\text { (p. 103). }\end{array}$ & $\begin{array}{l}\text { Gaucher's disease (1); manifestations of } \\
\text { pulmonary hypertension* in adults. }\end{array}$ \\
& & Pulmonary infections in children.
\end{tabular}




\begin{tabular}{|c|c|c|}
\hline Organs and Tissues & Procedures & Possible or Expected Findings \\
\hline Spleen & $\begin{array}{l}\text { Record weight. Photograph cut surface. } \\
\text { Submit samples of fresh material for } \\
\text { biochemical study, and snap-freeze specimens } \\
\text { for histochemical analysis. Prepare unstained } \\
\text { smears for phase-contrast microscopy. Request } \\
\text { PAS and Masson's trichrome stains (p. 173). } \\
\text { Prepare material for electron microscopy (p. 132). }\end{array}$ & $\begin{array}{l}\text { Splenomegaly caused by accumulation of } \\
\text { glucocerebroside-containing Gaucher cells. } \\
\text { Increased acid phosphatase in Gaucher cells. }\end{array}$ \\
\hline Other organs & $\begin{array}{l}\text { Submit tissue samples of liver, pancreas, kidneys, } \\
\text { gastrointestinal tract, intrathoracic and intra- } \\
\text { abdominal lymph nodes, thymus, tonsils, } \\
\text { thyroid, and adrenal glands. For processing, } \\
\text { see above under "Spleen." }\end{array}$ & $\begin{array}{l}\text { Hepatomegaly; manifestations of portal } \\
\text { hypertension; lymphadenopathy. Infiltration } \\
\text { of organs (listed in middle column) by } \\
\text { Gaucher cells; hemosiderosis. }\end{array}$ \\
\hline Brain and spinal cord & $\begin{array}{l}\text { For removal and specimen preparation, } \\
\text { see pp. } 65 \text { and } 67 \text {, respectively. See also } \\
\text { above under "Spleen." }\end{array}$ & $\begin{array}{l}\text { Acute nerve cell degeneration. Accumulation } \\
\text { of glucocerebrosides and-in children with } \\
\text { acute neuronopathic disease-gangliosides. }\end{array}$ \\
\hline Bones and bone marrow & $\begin{array}{l}\text { Submit specimens of involved bones, as } \\
\text { indicated on skeletal roentgenograms; include } \\
\text { femur in all instances. Photograph saw section of } \\
\text { femur. For prosthetic repair and for decalcification, } \\
\text { see p. } 97 \text {; for specimen preparation, see p. } 95 \text {. } \\
\text { For preparation of bone marrow sections and } \\
\text { smears, see p. } 96 \text {. }\end{array}$ & $\begin{array}{l}\text { See above under "External examination } \\
\text { and skin." }\end{array}$ \\
\hline
\end{tabular}

\section{Reference}

1. Cox TM, Schofield JP. Gaucher's disease: clinical features and natural history. Baillieres Clin Haematol 1997;10:657-689.

\section{Disease, Glycogen Storage}

Synonyms: Andersen's disease or brancher deficiency (glycogenosis, type IV); Cori's or Forbes' disease (glycogenosis, type III); cyclic AMP dependent kinase (type X); glycogen synthetase deficiency (type $\mathrm{O}$ ); Hers' disease (glycogenosis, type VI); McArdle's disease (glycogenosis type V); phosphorylase B kinase deficiency (types IXa, b, and c); Pompe's disease (glycogenosis, type II); Tarui disease (glycogenosis type VII); von Gierke's disease (glycogenosis, type Ia); X-linked glycogenosis (type VIII).

NOTE: If the diagnosis had not been confirmed prior to death, samples of liver, skeletal muscle, blood, and fascia (for fibroblast culture, see below) should be snap-frozen for enzyme assay, which will determine the specific deficiency. Types Ia and b,
III, VI, and hepatic phosphorylase B kinase deficiency (types IXa, b and c) are hepatic-hypoglycemic disorders, whereas types $\mathrm{V}$ and VII affect muscle energy processes. Type II also affects the musculature, whereas type IV may cause cirrhosis and death in infancy from extreme hypotonia.

Determination of type of glycogenosis usually can be based on (1) pattern of glycogen storage in liver, (2) presence or absence of nuclear hyperglycogenation in liver, (3) cytoplasmic lipid in liver, (4) presence or absence of liver cirrhosis, and (5) presence or absence of glycogen and basophilic deposits in skeletal muscles.

Possible Associated Conditions: Fanconi syndrome* or gout* with type Ia glycogenosis; neutropenia, recurrent infections, and Crohn's disease with types Ib or Ic.

\begin{tabular}{lll}
\hline Organs and Tissues & Procedures & Possible or Expected Findings \\
\hline External examination & Record body weight and length. & Growth retardation. \\
and skin & Submit tissue samples of skin lesions. Record & Xanthomas in von Gierke's disease. \\
& size of tongue and submit specimens for & Macroglossia. \\
& histologic study (may be easier to do after &
\end{tabular}

histologic study (may be easier to do after removal with neck organs). For specimen preparation, see below under "Heart...."

Blood Submit sample for uric acid and ketone determination. If blood is to be used for tissue culture, follow procedures described in Chapter 10 (see also "Fascia lata" below).

Hyperuricemia in gout.* Ketoacidosis may be associated with sudden death. Hypoglycemia* and hyperlipidemia occur in von Gierke's disease. 


\begin{tabular}{|c|c|c|}
\hline Organs and Tissues & Procedures & Possible or Expected Findings \\
\hline Fascia lata & $\begin{array}{l}\text { Specimens should be collected using aseptic } \\
\text { technique for tissue culture for biochemical } \\
\text { studies (see Chapter 10). }\end{array}$ & $\begin{array}{l}\text { For enzyme deficiencies, see above under } \\
\text { "Note." }\end{array}$ \\
\hline \multirow[t]{2}{*}{ Liver } & $\begin{array}{l}\text { For recommended fixatives and special stains, } \\
\text { see below. Frozen sections protected with } \\
\text { celloidin and then stained with PAS allows an } \\
\text { accurate determination of the glycogen content. }\end{array}$ & $\begin{array}{l}\text { Enlarged hepatocytes with glycogen storage } \\
\text { in types I, III, and IV. Fatty changes most } \\
\text { common in types } 0 \text {, I and III. Periportal } \\
\text { fibrosis in types III and IV and, rarely, } \\
\text { cirrhosis in type IV. }\end{array}$ \\
\hline & $\begin{array}{l}\text { Prepare samples for electron microscopic study } \\
\text { (p. 132), particularly in glycogenosis types II } \\
\text { and IV. }\end{array}$ & $\begin{array}{l}\text { Adenomas and, rarely, hepatocellular } \\
\text { carcinomas may be found in type Ia. No } \\
\text { abnormalities in types V and VII. See also } \\
\text { above under "Note." }\end{array}$ \\
\hline $\begin{array}{l}\text { Heart, blood vessels, } \\
\text { lungs, skeletal muscles, } \\
\text { esophagus, intestine, } \\
\text { pancreas, spleen, } \\
\text { kidneys, adrenal glands, } \\
\text { urinary bladder, } \\
\text { lymph nodes, } \\
\text { bone marrow. }\end{array}$ & $\begin{array}{l}\text { Photograph enlarged or discolored organs and } \\
\text { obtain samples for histologic study. } \\
\text { Recommended fixatives for glycogen include } \\
\text { alcohol, Bouin's (p. 129) or Carnoy's fixative } \\
\text { and formalin alcohol (p. 130). Glycogen may } \\
\text { still be dissolved during exposure to watery } \\
\text { staining solutions. Request van Gieson's stain, } \\
\text { PAS stain with and without diastase digestion, } \\
\text { and Best's stain for glycogen (p. 172). } \\
\text { Request Sudan-stained frozen sections }\end{array}$ & $\begin{array}{l}\text { Uric acid nephropathy and glomerulo- } \\
\text { sclerosis in type Ia. Distribution of glycogen } \\
\text { storage and other abnormalities varies with } \\
\text { subtype of disease. Glycogen depositis may } \\
\text { be found in myocardium (cardiomegaly), } \\
\text { small and large arteries, skeletal muscle (for } \\
\text { instance, of diaphragm, neck, trunk, and } \\
\text { extremities), bronchial mucosa, and all other } \\
\text { organs listed in left-hand column. See also } \\
\text { above under "Note." }\end{array}$ \\
\hline
\end{tabular}

of myocardium, liver, and skeletal muscles.

For use of frozen sections for study of glycogen, see above under "Liver." Embed tissue samples

for electron microscopic study.

Eyes $\quad$ For removal and specimen preparation, see p. 85. Use Zenker's solution for fixation (p. 131). Other fixatives and procedures are listed above.

Brain and spinal cord For removal and specimen preparation, see pp. 65 and 67, respectively. Submit specimens of sympathetic nerve ganglia for histologic study.

Joints For removal, prosthetic repair, and specimen preparation, see p. 95 .

Glycogen primarily in retinal ganglion cells and ciliary muscle.

Glycogen in sympathetic nerve ganglia and neurons of cranial nerves in type VII.

Gouty arthritis.

\section{Disease, Graft-Versus-Host}

NOTE: This disease occurs most commonly after bone marrow transplantation. The disease has also occurred after transfusion of viable lymphocytes, for example, to patients with cancer or leukemia.*

In patients with graft-versus-host disease (GVHD), autopsy also may reveal recurrence of the underlying disease such as leukemia.

\begin{tabular}{cl}
\hline Organs and Tissues & Procedures \\
\hline External examination & Record and photograph skin lesions and prepare \\
and skin; oral cavity & histologic sections of normal and abnormal skin.
\end{tabular}

Small biopsies of labial salivary glands and buccal mucosa may be useful to evaluate chronic GVHD (1).

\section{Possible or Expected Findings}

Generalized erythroderma and jaundice. Microscopic examination shows irregular epidermal-dermal junctions with basal cell vacuolation, spongiosis, and eosinophilic bodies associated with infiltrates of aggressor lymphocytes.

Buccal mucositis; lichenoid lesions in chronic GVHD (1). 


\begin{tabular}{|c|c|c|}
\hline Organs and Tissues & Procedures & Possible or Expected Findings \\
\hline Heart & Record volume of pericardial fluid. & $\begin{array}{l}\text { Pericardial effusion (in rare cases with fea- } \\
\text { tures of polyserositis in chronic GVHD) (2). }\end{array}$ \\
\hline Lungs & $\begin{array}{l}\text { Perfuse one lung with formalin (p. } 47 \text { ). Submit } \\
\text { samples from other lung for microbiologic study } \\
\text { (p. 103). }\end{array}$ & $\begin{array}{l}\text { Diffuse alveolar damage; lymphocytic } \\
\text { bronchitis/bronchiolitis obliterans; } \\
\text { organizing pneumonia (3). Bronchiectases in } \\
\text { rare instances (4). }\end{array}$ \\
\hline Liver & $\begin{array}{l}\text { Record weight. Submit samples for histologic } \\
\text { study. }\end{array}$ & $\begin{array}{l}\text { Hepatomegaly. Portal and periportal hepatitis } \\
\text { with destruction of interlobular ducts; } \\
\text { oncocytic metaplasia of bile duct epithelium } \\
\text { (5); endotheliitis; cholestasis. }\end{array}$ \\
\hline Esophagus & $\begin{array}{l}\text { Prepare photographs of mucosa and sample for } \\
\text { histologic study. }\end{array}$ & $\begin{array}{l}\text { Infectious esophagitis or chronic GVHD with } \\
\text { vesicobullous lesions or, in late stages, } \\
\text { strictures. }\end{array}$ \\
\hline Small and large intestine & $\begin{array}{l}\text { For in situ fixation of small intestinal mucosa, } \\
\text { see p. 54. Submit samples for histologic study. }\end{array}$ & $\begin{array}{l}\text { Enteritis with cellular debris in crypts, } \\
\text { atypical epithelial lining of crypts, and } \\
\text { inflammatory infiltrates. }\end{array}$ \\
\hline Other organs & $\begin{array}{l}\text { Procedures depend on expected findings or } \\
\text { grossly identified abnormalities as listed in } \\
\text { right-hand column. }\end{array}$ & $\begin{array}{l}\text { Inflammatory infiltrates. Hemorrhagic } \\
\text { necroses in lymph nodes and spleen. } \\
\text { Immune-mediated myelopathy }(6) .\end{array}$ \\
\hline Eyes & $\begin{array}{l}\text { For removal and specimen preparation, } \\
\text { see p. } 85 \text {. }\end{array}$ & Keratoconjunctivitis. Optic neuropathy (6). \\
\hline Bone marrow & $\begin{array}{l}\text { For preparation of sections and smears, } \\
\text { see p. } 96 .\end{array}$ & Evidence of proliferating graft cells. \\
\hline
\end{tabular}

References

1. Nakamura S, Hiroki A, Shinohara M, Gondo H, Ohyama Y, Mouri T, et al. Oral involvement in chronic graft versus host disease after allogenic bone marrow transplantation. Oral Surg Oral Med Oral Pathol 1996;82:556-563.

2. Toren A, Nagler A. Massive pericardial effusion complicating the course of chronic graft-versus-host disease (cGVHD) in a child with acute lymphoblastic leukemia following allogeneic bone marrow transplantation. Bone Marrow Transplant 1997;20:805-807.

3. Yousem AS. The histological spectrum of pulmonary graft-versushost disease in bone marrow transplant recipients. Hum Pathol 1995; 26:668-675.

4. Morehead RS. Bronchiectasis in bone marow transplantation. Tho$\operatorname{rax}$ 1997;52:392-393.

5. Bligh J, Morton J, Durrant S, Walker N. Oncocytic metaplasia of bile duct epithelium in hepatic GVHD. Bone Marrow Transplant 1995; 16:317-319.

6. Openshaw H, Slatkin NE, Parker PM, Forman SJ. Immune-mediated myelopathy after allogeneic marrow transplantation. Bone Marrow Transplant 1995;15:633-636.

\section{Disease, Graves' (See “Hyperthyroidism.”)}

\section{Disease, Günther's (See “Porphyria, congenital erythropoietic.")}

\section{Disease, Heavy-Chain}

Synonyms and Related Terms: Gamma heavy-chain disease(Franklin's disease); alpha heavy-chain disease (Seligmann's disease); $\mu$ heavy-chain disease.

NOTE: Alpha heavy-chain disease is related to Mediterranean lymphoma and $\mu$ heavy-chain disease occurs in rare patients with chronic lymphocytic leukemia.* Infections generally are the cause of death in gamma heavy-chain disease. Evidence of malabsorption* may be observed in alpha heavy-chain disease.

\begin{tabular}{|c|c|c|}
\hline Organs and Tissues & Procedures & Possible or Expected Findings \\
\hline $\begin{array}{l}\text { External examination } \\
\text { and oral cavity }\end{array}$ & Record body weight and length. & $\begin{array}{l}\text { Profound wasting in alpha-chain disease. For } \\
\text { oral changes, see under "Neck organs." }\end{array}$ \\
\hline Blood & $\begin{array}{l}\text { Submit samples for microbiologic study } \\
\text { and for protein electrophoresis (p. 102). }\end{array}$ & $\begin{array}{l}\text { Septicemia. See also above under "Note." } \\
\text { Anomalous serum M component in gamma } \\
\text { heavy-chain disease. }\end{array}$ \\
\hline Lungs & $\begin{array}{l}\text { Submit one lobe for microbiologic study. } \\
\text { (p. 103). }\end{array}$ & $\begin{array}{l}\text { Pneumonia in gamma heavy-chain disease. } \\
\text { Rarely lymphoplasmacytoid infiltrates in } \\
\text { alpha heavy-chain disease. }\end{array}$ \\
\hline Urine & Submit sample for protein electrophoresis. & $\begin{array}{l}\text { Anomalous serum } \mathrm{M} \text { component in gamma } \\
\text { heavy-chain disease. }\end{array}$ \\
\hline
\end{tabular}




\begin{tabular}{|c|c|c|}
\hline Organs and Tissues & Procedures & Possible or Expected Findings \\
\hline Lymph nodes & $\begin{array}{l}\text { Prepare Wright stains of touch preparations } \\
\text { (p. 173). Fix tissue in Zenker's or Helly's } \\
\text { solution (p. 131). }\end{array}$ & $\begin{array}{l}\text { Mesenteric and para-aortic lympha- } \\
\text { denopathy with infiltrates of lymphocytes } \\
\text { and plasma cells. }\end{array}$ \\
\hline $\begin{array}{l}\text { Small bowel } \\
\text { and mesentery }\end{array}$ & $\begin{array}{l}\text { For in situ fixation and preparation for study } \\
\text { under dissecting microscope, see p. } 54 \text {. } \\
\text { For microscopic study, submit samples of all } \\
\text { segments of gastrointestinal tract and portions } \\
\text { of mesentery with lymph nodes. }\end{array}$ & $\begin{array}{l}\text { Infiltrates of lymphocytes and plasma cells in } \\
\text { lamina propria of small bowel in alpha heavy- } \\
\text { chain disease. See also under "Syndrome, } \\
\text { malabsorption." }\end{array}$ \\
\hline Neck organs & Remove together with pharynx. & $\begin{array}{l}\text { Palatal edema (Waldeyer ring lympha- } \\
\text { denopathy) in gamma heavy-chain } \\
\text { disease. }\end{array}$ \\
\hline Bone marrow & $\begin{array}{l}\text { For preparation of sections and smears, } \\
\text { see p. } 96 .\end{array}$ & $\begin{array}{l}\text { Infiltrates of lymphocytes and plasma cells; } \\
\text { eosinophilia. }\end{array}$ \\
\hline Bones & $\begin{array}{l}\text { For removal, prosthetic repair, and specimen } \\
\text { preparations, see p. } 95 \text {. }\end{array}$ & Osteoporosis* in alpha heavy-chain disease. \\
\hline
\end{tabular}

\section{Disease, Hippel-Lindau (See "Disease, von Hippel-Lindau.")}

\section{Disease, Hirschsprung's (See “Megacolon, congenital.”)}

Disease, Hodgkin's (See “Lymphoma.”)

\section{Disease, Hookworm (See “Ancylostomiasis.”)}

Disease, Huntington's (See “Chorea, hereditary.”)

Disease, Hydatid (See "Echinococcosis.")

\section{Disease, Inflammatory Bowel}

Synonyms and Related Terms: Chronic ulcerative colitis; Crohn's disease; * idiopathic proctocolitis.

Possible Associated Conditions: Alpha ${ }_{1}$-antitrypsin deficiency;* amyloidosis;* ankylosing spondylitis;* primary sclerosing cholangitis; ${ }^{*}$ Sjögren's syndrome.* See also below under "Possible or Expected Findings."

NOTE: In many instances, either chronic ulcerative colitis or Crohn's disease* had been diagnosed clinically, but sometimes, the distinction is difficult to make, even at autopsy. Many features described below occur in chronic ulcerative colitis but some manifestations of Crohn's disease or conditions that may occur in all types of inflammatory bowel disease also are listed so that both positive and negative findings can be recorded properly.

\begin{tabular}{lll}
\hline Organs and Tissues & Procedures & Possible or Expected Findings \\
\hline $\begin{array}{c}\text { External examination, } \\
\text { skin, and oral cavity }\end{array}$ & $\begin{array}{l}\text { Record nature and extent of skin lesions, } \\
\text { photograph, and submit specimens of accessible } \\
\text { lesions for histologic study. }\end{array}$ & $\begin{array}{l}\text { Aphthous stomatitis; pyoderma } \\
\text { gangrenosum; erythema nodosum and } \\
\text { multiforme; papular or pustular dermatitis; } \\
\text { ulcerating erythematous plaques; neuro- }\end{array}$ \\
& $\begin{array}{l}\text { Record appearance of hands and feet. } \\
\text { dermatitis; herpes zoster; anal fissures. }\end{array}$ \\
& $\begin{array}{l}\text { Prepare roentgenograms of fistulas after } \\
\text { injection of contrast medium (p. 138). }\end{array}$ & $\begin{array}{l}\text { Clubbing of fingers and toes. Emaciation. } \\
\text { Prepare skeletal roentgenograms. }\end{array}$ \\
& $\begin{array}{l}\text { Pee below under "Bones and joints." } \\
\text { If arthritis is suspected, submit sample of }\end{array}$ & Arthritis.*
\end{tabular}
synovial fluid for microbiologic study, cell counts, and smears (p. 96).

Blood Submit sample for microbiologic study (p. 102).

Heart If pericarditis or endocarditis are expected, follow procedures described under these headings (p. 103).

Lungs Dissect pulmonary arteries; sample all lobes for histologic study. Request Verhoeffvan Gieson stain (p. 173).

Septicemia.

Endocarditis;* pericarditis.*

Thromboemboli; pulmonary vasculitis. 


\begin{tabular}{ll}
\hline Organs and Tissues & Procedures \\
\hline $\begin{array}{l}\text { Abdominal cavity with } \\
\text { retroperitoneum and } \\
\text { pelvic organs }\end{array}$ & $\begin{array}{l}\text { If peritonitis is present, submit exudate for } \\
\text { aerobic and anaerobic bacteriologic study } \\
\text { (p. 102). Aspirate contents of abscesses and } \\
\text { record their size and location. Record volume } \\
\text { of exudate and prepare smears. }\end{array}$ \\
Small and large intestine & $\begin{array}{l}\text { For in situ fixation, see p. 54. If fistulas are } \\
\text { present, dissect affected areas in situ. Opened } \\
\text { colon and affected portions of small bowel } \\
\text { should be pinned on corkboard and fixed with } \\
\text { formalin. Submit samples of all types of lesions } \\
\text { for histologic study. }\end{array}$
\end{tabular}

Bile ducts

Liver

Stomach and duodenum

Pancreas

Kidneys, ureters, and urinary bladder

Veins and arteries

Eyes

Brain and cerebral venous sinuses Bones and joints
For cholangiography, see p. 56. Dissect extrahepatic bile ducts in situ (see also under "Tumor of the bile ducts").

Record weight; submit samples for histologic study.

Submit samples for histologic study. Submit samples for histologic and bacteriologic study. If glomerulitis is suspected, follow procedures described under "Glomerulonephritis."

Describe size and contents of urinary bladder, ureters, and renal pelves.

For removal of femoral vessels, see p. 34 .

For removal and specimen preparation, see p. 85. If there is evidence of Sjögren's syndrome, ${ }^{*}$ remove lacrimal glands (p. 87). For removal and specimen preparation, see pp. 65 and 67 , respectively.

For removal, prosthetic repair, and specimen preparation, see p. 95 .
Possible or Expected Findings

Peritonitis.* Perianal, presacral, and ischiorectal abscesses; fistulas and anal fissures. Dilatation of colon ("toxic megacolon"). Fournier's gangrene (necrotizing fasciitis of the genitalia) in Crohn's disease.

Segmental (skip areas), transmural and granulomatous inflammation in Crohn's disease. Toxic megacolon more common in chronic ulcerative colitis. Retroperitoneal and rectovaginal fistulas; mucosal ulcers and pseudopolyps; multicentric lymphoma; dysplasia; carcinoma(s); hemorrhage. Rectal stricture. "Backwash ileitis." Colonic cytomegalovirus inclusions, associated with toxic dilatations. See also ref. (1).

Sclerosing cholangitis; ${ }^{*}$ adenocarcinoma of bile ducts.

Biliary cirrhosis.* Cholangiocarcinoma.

Ulcerative gastritis and duodenitis in Crohn's disease.

Pancreatitis.

Glomerulonephritis;* pyelonephritis;* tubular degeneration; nephrocalcinosis.

Renovascular disease (2).

Cystopyelitis; urolithiasis; nephrolithiasis (oxalate stones).

Thrombophlebitis; arteritis (2) and arterial thromboses.

Blepharitis; conjunctivitis; corneal ulcers; iritis; keratitis; neuroretinitis; retrobulbar neuritis; uveitis.

Cerebral venous sinus thrombosis* (3).

Osteoporosis;* ankylosing spondylitis;* arthritis of peripheral joints; periarthritis; hypertrophic osteoarthropathy;* tendinitis (particularly of ankle and Achilles tendons).

\section{References}

1. Podolsky D. Inflammatory bowel disease (first of two parts). N Engl J Med 1991;325:928-937 (part 1) and 1008-1016 (part 2).

2. Sakhuja V, Gupta KL, Bhasin DK, Malik N, Chugh KS. Takayasu's arteritis associated with idiopathic ulcerative colitis. Gut 1990;31:831-833.

3. Johns D. Cerebrovascular complications of inflammatory bowel disease. Am J Gastroenterol 1991;86:367-370.

\section{Disease, Iron Storage (See "Hemochromatosis.")}

\section{Disease, Ischemic Heart}

Related Terms: Atherosclerotic heart disease.

NOTE: The most common anatomic finding at autopsy in subjects older than $30 \mathrm{yr}$ is coronary atherosclerosis. Unusual underlying or associated conditions include chronic aortic stenosis or regurgitation; coronary artery anomalies; coronary artery dissection; coronary embolism; coronary ostial stenosis (due to calcification of aortic sinotubular junction or, rarely, to syphilitic aortitis); 


\section{Disease, Ischemic Heart (continued)}

coronary vasculitis (for instance, in polyarteritis nodosa* or acute hypersensitivity arteritis); hyperthyroidism,* gastrointestinal hemorrhage;* hypothyroidism, * idiopathic arterial calcification of infancy; intramural coronary amyloidosis; pheochromocytoma, polycythemia vera;* pseudoxanthoma elasticum, ${ }^{*}$ radiation-induced coronary stenosis; severe pulmonary hypertension (with right ventricular ischemia); sickle cell disease;* and others. If bypass surgery had been performed, see "Surgery, coronary bypass."

\begin{tabular}{lll}
\hline Organs and Tissues & Procedures & Possible or Expected Findings
\end{tabular}

External examination

Blood

Heart

Aorta

Other organs
Prepare chest roentgenogram.

If underlying metabolic disease is suspected, submit sample for biochemical study.

For coronary arteriography, see p. 118.

For specimen preparation and grading of coronary arteries, see p. 21.

Request Verhoeff-van Gieson stain (p. 172).

For dissection technique of the heart and for histologic sampling, see pp. 22 and 30.

For detection of early myocardial infarction, see p. 32.

For study of valvular cardiac lesions, see p. 32. Record actual and expected heart weight, ventricular wall thicknesses, and valvular annular circumferences. Record appearance, extent, and location of infarcts, mural thrombus, and aneurysms.
Cyanosis; edema of legs; venous congestion. Gangrene of toes. Diabetic ulcers. Cardiomegaly; pleural effusions.* See above under "Note."

Coronary atherosclerosis; coronary thrombosis or embolism; congenital malformation(s) of coronary arteries; accidental operative coronary ligation; coronary arteritis (see above under "Note.") Myocardial infarction, old or acute. Mural thrombus. Ventricular aneurysm, true or false. Ventricular rupture (free wall, septum, or papillary muscles).

Aortic insufficiency;* aortic stenosis.*
Acute aortic dissection.*

Manifestations of congestive heart failure* and of possible underlying conditions (see above under "Note"), such as diabetes mellitus.*

\section{Disease, Jakob-Creutzfeldt (See "Disease, Creutzfeldt-Jakob.")}

Disease, Kawasaki (See "Syndrome, mucocutaneous lymph node.")

Disease, Krabbe's (See "Leukodystrophy, globoid cell.")

\section{Disease, Legionnaires'}

Synonyms and Related Terms: Legionella pneumophila infection; Pontiac fever.

NOTE: (1) Collect lung specimens, serum, and other tissues that appear to be infected. These should be inoculated on a nonselective medium, such as BCYE agar supplemented with $\alpha$-ketoglutaric acid. A good selective agar is BCYE supplemented with antibiotics. (2) Request aerobic and anaerobic cultures for exclusion of other bacterial diseases. (3) Request Gram, Kinyoun, and Grocott's methenamine silver stains for exclusion of other bacterial or fungal diseases (p. 172). The Dieterle silver impregnation procedure is recommended for demonstration of the organism in paraffin-embedded sections (1-3). (4) No special precautions are indicated. (5) Serologic immunofluorescent studies are available from the Centers for Disease Control and Prevention, Atlanta, GA (p. 135). (6) This is a reportable disease.

\begin{tabular}{lll}
\hline Organs and Tissues & Procedures & Possible or Expected Findings \\
\hline Blood, pleural fluid & Submit sample for culture (p. 102). & \\
Lungs & $\begin{array}{l}\text { Culture any areas of consolidation (p. 102). } \\
\text { Perfuse one lung with formalin (see p. 47). }\end{array}$ & $\begin{array}{l}\text { Multifocal fibrinopurulent pneumonia with } \\
\text { sparing of the bronchi and bronchioles. }\end{array}$ \\
& $\begin{array}{l}\text { Slice in the parasagittal plane. Submit affected } \\
\text { areas for histological study. }\end{array}$ & $\begin{array}{l}\text { Exudate is rich in phagocytes, fibrin, and } \\
\text { karyorrhectic debris. }\end{array}$
\end{tabular}




\section{References}

1. Edelstein PH. Legionnaires' disease. Clin Infect Dis 1993;16(6):741-747.

2. Stout JE, Yu VL. Legionellosis. NEJM 1997;337(10):682-687.

3. Bhopal R. Source of infection for sporadic Legionnaires' disease: a review. J Infect 1995;30:9-12.

\section{Disease, Lyme}

Synonym: Lyme arthritis

NOTE: This infection is caused by the spirochete, Borrelia burgdorferi, which is transmitted from rodents to human by the hard deer ticks, Ixodes dammini, I. ricinus, and others.

\begin{tabular}{|c|c|c|}
\hline Organs and Tissues & Procedures & Possible and Expected Findings \\
\hline $\begin{array}{l}\text { External examination } \\
\text { and skin }\end{array}$ & $\begin{array}{l}\text { Photograph skin lesions. Record presence of } \\
\text { enlarged lymph nodes. Submit sections of } \\
\text { affected skin for histologic study. }\end{array}$ & $\begin{array}{l}\text { Erythema chronicum migrans; skin vesicles; } \\
\text { annular skin lesions; lymphadenopathy; } \\
\text { conjunctivitis. }\end{array}$ \\
\hline Cerebrospinal fluid & $\begin{array}{l}\text { For removal, see p. 104. Submit for IgG study } \\
\text { and prepare smear. }\end{array}$ & $\begin{array}{l}\text { Antispirochete IgG; lymphocytes and plasma } \\
\text { cells (1). }\end{array}$ \\
\hline Blood & Obtain blood for chemical and serologic analysis. & $\begin{array}{l}\text { Elevated liver enzymes; elevated IgM early } \\
\text { in illness; normal or elevated C } 3 \text { and C4; } \\
\text { rheumatoid factor usually absent. }\end{array}$ \\
\hline Joints & $\begin{array}{l}\text { Aspirate fluid from joint effusions. Submit } \\
\text { synovium of affected joints for histologic study. }\end{array}$ & $\begin{array}{l}\text { Neutrophils in synovial fluid; synovitis } \\
\text { resembling early rheumatoid arthritis with a } \\
\text { distinctive arteritis with onionskin-like } \\
\text { lesions; later in the disease, cartilage } \\
\text { destruction. }\end{array}$ \\
\hline Heart & Submit sections for histologic study (p. 30). & $\begin{array}{l}\text { Myocarditis; spirochetes may be } \\
\text { demonstrable. }\end{array}$ \\
\hline Liver & Submit sections for histologic study. & Dense portal infiltrates. \\
\hline Brain and spinal cord & $\begin{array}{l}\text { For removal and specimen preparation, } \\
\text { see pp. } 65 \text { and } 67 \text {, respectively. Include } \\
\text { meninges in histologic sections. }\end{array}$ & $\begin{array}{l}\text { Mononuclear meningitis and } \\
\text { meningoradiculitis. }\end{array}$ \\
\hline
\end{tabular}

\section{Reference}

1. Sindern E, Malin JP. Phenotypic analysis of cerebrospinal fluid cells over the course of Lyme meningoradiculitis. Acta Cytol 1995;39:73-75.

\section{Disease, Lymphatic}

NOTE: In all diseases of the thoracic duct and its major tributaries and also in cases of lymphedema or other peripheral lymphovascular diseases, postmortem lymphangiography (p. 34) may be an effective method of study.

\section{Disease, Maple Syrup Urine}

Synonyms and Related Terms: Branched-chain hyperaminoacidemia (various types); classic maple syrup urine disease; hyperleucinemia; hypervalinemia. See also aminoaciduria.*

NOTE: Collect all obtainable urine and freeze at $-20^{\circ} \mathrm{C}$; this should be done as soon as possible.

\begin{tabular}{|c|c|c|}
\hline$\underline{\text { Organs and Tissues }}$ & Procedures & Possible or Expected Findings \\
\hline Blood and urine & Submit samples for biochemical study. & $\begin{array}{l}\text { Increased amino acids and urinary organic } \\
\text { acids. The urine may have a "maple syrup" } \\
\text { odor. }\end{array}$ \\
\hline Fascia lata (or skin) & $\begin{array}{l}\text { Submit sample for karyotype and biochemical } \\
\text { analysis (p. 109). }\end{array}$ & $\begin{array}{l}\text { Enzyme deficiency can be demonstrated in } \\
\text { cultured fibroblasts, leukocytes, or } \\
\text { amniocytes. }\end{array}$ \\
\hline Other organs & & $\begin{array}{l}\text { Bronchopneumonia. Steatosis or increased } \\
\text { glycogen deposition in liver. }\end{array}$ \\
\hline Brain and spinal cord & $\begin{array}{l}\text { For removal and specimen preparation, } \\
\text { see p. } 65 \text { and } 67 \text {, respectively. }\end{array}$ & $\begin{array}{l}\text { Spongiosis; gliosis; edema; defective } \\
\text { myelinization. }\end{array}$ \\
\hline
\end{tabular}




\section{Disease, Marble Bone (See “Osteopetrosis.”)}

\section{Disease, Marchiafava-Bignami}

NOTE: Patients with this disease suffer from chronic alcoholism. Malnutrition, nutritional amblyopia,* and WernickeKorsakoff syndrome* may be present.

\begin{tabular}{lll}
\hline Organs and Tissues & Procedures & Possible or Expected Findings \\
\hline Brain and spinal cord & For removal and specimen preparation, & $\begin{array}{l}\text { Symmetric and zonal demyelination in } \\
\text { corpus callosum, anterior commissure, optic } \\
\text { chiasm, optic tracts, and white matter of } \\
\end{array}$ \\
Luxol fast blue stain for myelin (p. 172). & frontal lobes. \\
\hline
\end{tabular}

Disease, Mast Cell (See “Mastocytosis, systemic.”)

\section{Disease, Medullary Cystic Renal (See “Cyst(s), renal.”)}

\section{Disease, Meningococcal}

Synonyms: Meningococcemia; Neisseria meningitidis infection; Waterhouse-Friderichsen syndrome (fulminant meningococcemia).
NOTE: (1) Submit all tissues that appear to be infected (2). Request aerobic bacterial cultures. (3) Request Gram stain (p. 172). (4) Special precautions are indicated (p. 146). (5) Usually, serologic studies are not available. However, isolates should be segregated by seroagglutination into serogroups, i.e., A,B,C,D,X,Y,Z. (6) This is a reportable disease.

Possible Associated Conditions: Disseminated intravascular coagulation* is a common component of the disease.

\begin{tabular}{ll}
\hline Organs and Tissues & Procedures \\
\hline External examination & Record extent of skin lesions and prepare \\
and skin & $\begin{array}{l}\text { photographs; submit tissue samples of skin } \\
\text { for histologic study. }\end{array}$
\end{tabular}

Prepare skeletal roentgenograms if bone lesions are expected.

\section{Cerebrospinal fluid}

Blood

Heart and pericardial fluid

Lungs
Spleen

Adrenal glands

Genital organs

Brain and spinal cord

Submit sample for aerobic bacterial culture (p. 104).

\section{Submit sample for microbiologic study} (p. 102) and determination of serum cortisol concentration.

Submit samples of pericardium, pericardial fluid, and myocardium for aerobic bacterial cultures and Gram stain (p. 172). For procedures in infective endocarditis, see p. 103.

Submit consolidated areas for culture (p. 103). Record weight and submit tissue specimens for histologic study.

Photograph; record weights; request Gram stain for histologic sections (p. 172).

Submit tissue samples for histologic study.

Infectious material should be obtained as described on p. 104. For removal and specimen preparation of brain and spinal cord, see pp. 65 and 67, respectively. Request Bodian stain (p. 74).

Middle and inner ears
For removal and specimen preparation, see p. 72 .

\section{Possible or Expected Findings}

Cutaneous or subcutaneous hemorrhages (purpura fulminans, with or without skin loss and deep muscle damage (1)); herpes labialis; rarely, jaundice.

Osteomyelitis and osteonecrosis (see below) (2).

Meningococcal septicemia. Low serum cortisol level.

Pericarditis.* Infective endocarditis.*

Primary or secondary pneumonia; pleuritis. Splenitis.

Acute hemorrhage and necrosis.

Urethritis; orchitis; epididymitis; endometritis.

Scant exudate with numerous bacteria in the hyperacute form; In the acute form, abundant pus surrounds the entire brain, vertex, and base and may extend to the ventricular system. In the chronic form, communicating hydrocephalus and cortical infarction are common complications.

Otitis media.* 


\begin{tabular}{|c|c|c|}
\hline Organs and Tissues & Procedures & Possible or Expected Findings \\
\hline Nasopharynx & $\begin{array}{l}\text { For exposure, see p. } 71 \text {. Prepare smears and } \\
\text { submit tissue samples for histologic study. }\end{array}$ & $\begin{array}{l}\text { Posterior nasopharyngeal meningococcal } \\
\text { infection. }\end{array}$ \\
\hline Eyes & $\begin{array}{l}\text { For removal and specimen preparation, } \\
\text { see p. } 85 \text {. }\end{array}$ & Conjunctivitis; panophthalmitis. \\
\hline $\begin{array}{l}\text { Bones, joints, } \\
\text { and soft tissues }\end{array}$ & $\begin{array}{l}\text { Remove synovial fluid and submit sample for } \\
\text { bacteriologic study (p. 96). For removal of } \\
\text { bones and joints, prosthetic repair, and specimen } \\
\text { preparation, see pp. 95-97, respectively. } \\
\text { Prepare histologic sections of synovia and skeletal } \\
\text { muscle. }\end{array}$ & $\begin{array}{l}\text { Purulent arthritis; necrosis and hemorrhage } \\
\text { of synovia. Osteonecrosis (rare in adults [2]) } \\
\text { and osteomyelitis; rhabdomyolysis (3). }\end{array}$ \\
\hline
\end{tabular}

\section{References}

1. Huang S, Clarke JA. Severe skin loss after meningococcal septicemia: complications in treatment. Acta Paediatr 1997;86:1263-1266.

2. Campbell WN, Joshi M, Sileo D. Osteonecrosis following meningococcemia and disseminated intravascular coagulation in an adult: case report and review. Clin Infect Dis 1997;24:452-455.
3. Van Deuren M, Neeleman C, Assmann KJ, Wetzels JF, van der Meer JW. Rhabdomyolysis during the subacute stage of meningococcal sepsis. Clin Infect Dis 1998;26:214-215.

\section{Disease, Motor Neuron}

Synonyms and Related Terms: Infantile spinal muscular atrophy; progressive spinal muscular atrophy, Werdnig-Hoffman disease.

\begin{tabular}{|c|c|c|}
\hline Organs and Tissues & Procedures & Possible or Expected Findings \\
\hline External examination & & $\begin{array}{l}\text { Congenital fixation of multiple joints of } \\
\text { extremities. }\end{array}$ \\
\hline $\begin{array}{l}\text { Brain and } \\
\text { spinal cord }\end{array}$ & $\begin{array}{l}\text { For removal and specimen preparation, } \\
\text { see pp. } 65 \text { and } 67 \text {, respectively. }\end{array}$ & $\begin{array}{l}\text { Degeneration and loss of motor neurons from } \\
\text { anterior horn and brainstem motor nuclei } \\
\text { (particularly hypoglossal and facial) and } \\
\text { thalamus (posteroventral nucleus). }\end{array}$ \\
\hline Skeletal muscles & $\begin{array}{l}\text { For sampling and specimen preparation, } \\
\text { see p. } 80 \text {. }\end{array}$ & Neurogenic atrophy. \\
\hline
\end{tabular}

\section{Disease, Multicystic Renal (See “Cyst(s), renal.”)}

\section{Disease, Niemann-Pick}

Synonyms and Related Terms: Sphingomyelinase deficiency; sphingomyelin lipidosis; Niemann-Pick disease, types A, B, C, or D.

NOTE: For further details on specimen preparation, see ref. (1).

\begin{tabular}{|c|c|c|}
\hline Organs and Tissues & Procedures & Possible or Expected Findings \\
\hline $\begin{array}{l}\text { External examination } \\
\text { and fascia lata }\end{array}$ & $\begin{array}{l}\text { If diagnosis must be confirmed, prepare fibro- } \\
\text { blast culture for assay of sphingomyelinase } \\
\text { (p. 109). }\end{array}$ & Growth retardation. \\
\hline Skin and conjunctiva & $\begin{array}{l}\text { Prepare samples for electron microscopic study } \\
\text { (see p. 132). }\end{array}$ & $\begin{array}{l}\text { Membrane-bound lamellar cytoplasmic } \\
\text { inclusions. }\end{array}$ \\
\hline Heart & & Endocardial fibroelastosis. \\
\hline Lungs & $\begin{array}{l}\text { In infants, snap-freeze portion of fresh lung } \\
\text { and perfuse one lung with formalin (p. } 47) \text {. } \\
\text { Submit consolidated areas for microbiologic } \\
\text { study (p. 103). }\end{array}$ & $\begin{array}{l}\text { Vacuolated histiocytes (foam cells) } \\
\text { containing sphingomyelin, cholesterol, and } \\
\text { ganglioside within alveoli and interstitium. } \\
\text { Acute or organizing bronchopneumonia. }\end{array}$ \\
\hline Liver and spleen & $\begin{array}{l}\text { Record sizes and weights; snap-freeze tissue } \\
\text { for biochemical sphingomyelin determination. } \\
\text { Special stains of frozen sections for phospho- } \\
\text { lipids and cholesterol are positive but not } \\
\text { diagnostic. }\end{array}$ & $\begin{array}{l}\text { Hepatosplenomegaly; foam cell transforma- } \\
\text { mation of Kupffer cells and hepatocytes; } \\
\text { cholestasis; intra-acinar fibrosis and, rarely, } \\
\text { cirrhosis. Hepatocellular giant cells may be } \\
\text { present. Abundant foam cells in spleen. }\end{array}$ \\
\hline
\end{tabular}




\begin{tabular}{|c|c|c|}
\hline Organs and Tissues & Procedures & Possible or Expected Findings \\
\hline $\begin{array}{l}\text { Liver and spleen } \\
\text { (continued) }\end{array}$ & $\begin{array}{l}\text { Submit sample for electron microscopic study } \\
\text { (p. 132). }\end{array}$ & $\begin{array}{l}\text { Laminated inclusions in the cytoplasm of } \\
\text { affected cells. }\end{array}$ \\
\hline Other organs & & $\begin{array}{l}\text { Transformation of reticuloendothelial cells to } \\
\text { autofluorescent foam cells. }\end{array}$ \\
\hline Bone marrow & $\begin{array}{l}\text { For preparation of sections and smears, } \\
\text { see p. } 96 . \\
\text { Prepare sample for electron microscopic study } \\
\text { (p. 132). } \\
\text { Prepare unstained smears for phase-contrast } \\
\text { microscopy. }\end{array}$ & $\begin{array}{l}\text { "Sea-blue" histiocytes may be present in } \\
\text { variant forms of the disease. } \\
\text { Lipid-laden cells have membrane-bound } \\
\text { lamellar cytoplasmic inclusions. }\end{array}$ \\
\hline Brain and spinal cord & $\begin{array}{l}\text { For removal and specimen preparation, see } \\
\text { pp. } 65 \text { and } 67, \text { respectively. See also under } \\
\text { "Liver and spleen." }\end{array}$ & $\begin{array}{l}\text { In the infantile form but not in the childhood } \\
\text { form of the disease, neurons are distended } \\
\text { with lipid. Eventually, neuronal loss, gliosis, } \\
\text { and demyelination occur. Cerebral atrophy; } \\
\text { neurons with inclusion; neuronal loss; gliosis } \\
\text { and demyelination. }\end{array}$ \\
\hline Eyes & $\begin{array}{l}\text { For removal and specimen preparation, } \\
\text { see p. } 85 \text {. }\end{array}$ & $\begin{array}{l}\text { In the infantile form of the disease, retinal } \\
\text { degeneration. }\end{array}$ \\
\hline
\end{tabular}

\section{Reference}

1. Jevon GP, Dimmick JE. Histopathologic approach to metabolic liver disease. Persp Pediatr Pathol 1998;1:179-199.

\section{Disease, Ollier's (See “Dyschondroplasia, Ollier's.”)}

\section{Disease, Osler-Rendu-Weber}

Synonyms: Hereditary familial angiomatosis; hereditary hemorrhagic telangiectasia.

\begin{tabular}{cll}
\hline Organs and Tissues & Procedures & Possible or Expected Findings \\
\hline External examination & Record distribution of skin lesions and submit & Telangiectatic (often papular) lesions most \\
and skin; oral cavity & tissue samples for histologic study. & commonly found in cheeks, scalp, nasal \\
& & orifices, oral cavity, ears, neck, shoulders, \\
& & fingers, toes, and nail beds. Cyanosis and \\
& & clubbing may be prominent.
\end{tabular}

Lungs

Aorta

Mesenteric vasculature

Gastrointestinal tract

Liver

Urinary bladder and internal sex organs
For preparation of angiograms or corrosion casts of the pulmonary arterial and venous vasculature, see pp. 50 and 51, respectively. If aneurysm or dissection is present, follow procedures described under those headings. Prepare mesenteric angiograms (p. 55).

For demonstration of esophageal varices, see p. 53 .

If cirrhosis is present, prepare angiograms of hepatic arteries and veins (p. 56). For preparation of corrosion casts of hepatic arteries, portal veins, and hepatic veins, see p. 57. Photograph and prepare sections of angiomatous lesions.
Arteriovenous malformations/fistulas.

Aneurysm;* aortic dissection.*

Mesenteric arteriovenous fistulas; aneurysms of the splenic and hepatic arteries; arteriovenous malformations of the colon. Telangiectasias in stomach and intestinal tract; see also above under "Mesenteric vasculature." Gastrointestinal hemorrhage.* Hepatohepatic or hepatoportal arteriovenous malformations/fistulas with cirrhosis-like changes. Cavernous hemangiomas.

Telangiectatic lesions. 


\begin{tabular}{lll}
\hline Organs and Tissues & Procedures & Possible or Expected Findings \\
\hline Brain and spinal cord & $\begin{array}{l}\text { For removal and specimen preparation, see } \\
\text { pp. 65 and 67, respectively. For preparation } \\
\text { of cerebral arteriograms, see p. 80. }\end{array}$ & $\begin{array}{l}\text { Arteriovenous malformations; aneurysms of } \\
\text { cerebral arteries.* Brain abscess.* }\end{array}$ \\
$\begin{array}{l}\text { For removal and specimen preparation, see p. 85. } \\
\text { Nasal cavities }\end{array}$ & $\begin{array}{l}\text { For exposure, see p. 71. } \\
\text { Bone marrow }\end{array}$ & $\begin{array}{l}\text { Retinal arteriovenous malformations. } \\
\text { Telangiectatic lesions. }\end{array}$ \\
\hline
\end{tabular}

\section{Disease, Paget's, of Bone}

Synonym: Osteitis deformans.

\begin{tabular}{|c|c|}
\hline Organs and Tissues & Procedures \\
\hline External examination & Prepare skeletal roentgenograms. \\
\hline Bones & $\begin{array}{l}\text { For removal, prosthetic repair, and specimen } \\
\text { preparation, see p. } 95 \text {. If there was a history } \\
\text { of cranial nerve palsies, measure diameter of } \\
\text { corresponding bony apertures. If there were } \\
\text { symptoms of paraplegia, expose and measure } \\
\text { diameter of vertebral foramina. For maceration } \\
\text { of bone, see p. } 97 \text {. }\end{array}$ \\
\hline
\end{tabular}

Heart

Other organs

Parathyroid glands

Record weights and submit samples for histologic study.

Possible or Expected Findings

Most commonly involved are sacrum, pelvic bones, tibia, and femur. Skull and other parts of the skeleton may also be affected.

Kyphosis; deformities of long bones; osteosarcomas and other malignant tumors $(1,2)$. See also under "Tumor of bone or cartilage." Thickening of calvarium (Fig. 8-1, p. 98). Accelerated osteoarthritis of joints in the vicinity of Paget's disease of bone (3).

Cardiac hypertrophy.*

Manifestations of congestive heart failure.*

Normal size and histologic appearance.

\section{References}

1. Brandolini F, Bacchini P, Moscato M, Bertoni F. Chondrosarcoma as a complicating factor in Paget's disease of bone. Skeletal Radiol 1997;26:497-500.

2. Yu T, Squires F, Mammone J, DiMarcangelo M. Lymphoma arising in Paget's disease. Skeletal Radiol 1997;26:729-731.

3. Helliwell PS. Osteoarthritis and Paget's disease. Br J Rheumatol 1995; 34:1061-1063.

\section{Disease, Parainfluenza Viral} (See "Laryngitis.")

\begin{abstract}
Disease, Parkinson's
Synonyms and Related Terms: Idiopathic Parkinson's disease; paralysis agitans.

NOTE: Parkinson's syndrome is caused by conditions that may simulate Parkinson's disease; these include carbon monoxide* and manganese poisoning, corticobasal degeneration, druginduced parkinsonism, Huntington's disease, multiple system atrophy, ${ }^{*}$ progressive supranuclear palsy* (Steele-RichardsonOlszewski syndrome), space-occupying lesions (rare), trauma (dementia pugilistica), and causes related to tumors and vascular diseases.
\end{abstract}

\begin{tabular}{lll}
\hline Organs and Tissues & Procedures & Possible or Expected Findings \\
\hline Brain & For removal and specimen preparation, see & Depigmentation of substantia nigra and locus \\
& p. 65. Histologic sections should include & coeruleus; neuronal loss and reactive gliosis; \\
& midbrain (substantia nigra), upper pons & eosinophilic intracytoplasmic inclusion bodies \\
& (locus ceruleus), medulla, nucleus basalis & (Lewy bodies) in some of the surviving \\
& (substantia innominata), and basal ganglia. & neurons; no significant changes in basal \\
& If Parkinsonian syndrome was diagnosed, & ganglia. \\
& follow procedures described under the name & \\
& of the suspected underlying condition & \\
& (see above under "Note"). & \\
\hline
\end{tabular}

\section{Disease, Pelizaeus-Merzbacher}

Synonyms: Sudanophilic (orthochromatic) leukodystrophy. 


\begin{tabular}{lll}
\hline Organs and Tissues & Procedures & Possible or Expected Findings \\
\hline Brain and spinal cord & For removal and specimen preparation, see & Brain generally atrophic. Myelin loss in \\
& pp. 66 and 70, respectively. Request Luxol fast & centrum ovale, cerebellum, and part of brain \\
& blue/PAS stain for myelin and Bielschowsky's & stem, with a tigroid pattern of residual myelin \\
& stain for axons (p. 172). Prepare frozen sections & near vessels. Axons are preserved. Diffuse \\
& for Sudan stain. & gliosis with relatively few lipoid-containing \\
& & macrophages, compared to the myelin loss. \\
& Lipoid material stains with Sudan. \\
\hline
\end{tabular}

\author{
Disease, Periodic (See “Fever, familial Mediterranean.”) \\ Disease, Perthes' (See “Osteonecrosis.”) \\ Disease, Pick's \\ Synonym: Pick's lobar atrophy.
}

\begin{tabular}{lll}
\hline Organs and Tissues & Procedures & Possible or Expected Findings \\
\hline Brain and spinal cord & $\begin{array}{l}\text { For removal and specimen preparation, see } \\
\text { pp. 65 and 67, respectively. Request silver } \\
\text { stains (Bielchowsky or Bodian stain), (p. 172). }\end{array}$ & $\begin{array}{l}\text { Severe cerebral atrophy, involving primarily } \\
\text { frontal and anterior temporal lobes (knife- } \\
\text { blade atrophy; walnut brain). Micro- }\end{array}$ \\
& $\begin{array}{l}\text { Histochemical stains in Pick's cells and bodies } \\
\text { reveal phosphorylated neurofilaments, ubiquitin, }\end{array}$ & $\begin{array}{l}\text { scopilly, severe neuronal loss accompanied } \\
\text { by astrocytosis. Characteristic argyrophilic, }\end{array}$ \\
& $\begin{array}{l}\text { and tubulin. Some tissue should be kept frozen } \\
\text { for biochemical studies. }\end{array}$ & $\begin{array}{l}\text { intracytoplasmic inclusions (Pick's bodies), } \\
\text { particularly in hippocampus and swollen, } \\
\text { distended "ballooned"neurons (Pick's cells). }\end{array}$ \\
& & These changes are not always present. \\
\hline
\end{tabular}

Disease, Polycystic Kidney (See “Cyst(s), renal.”)

Disease, Polycystic Liver (See "Disease, fibropolycystic, of the liver and biliary tract.")

Disease, Prion (See “Disease, Creutzfeldt-Jakob.”)

Disease, Pulmonary Veno-Occlusive (See “Obstruction, pulmonary venous.”)

Disease, Pulseless (See “Arteritis, Takayasu's.”)

Disease, Raynaud's

Related Term: Raynaud's phenomenon.

\begin{tabular}{lll}
\hline Organs and Tissues & Procedures & Possible or Expected Findings
\end{tabular}

External examination Record extent of ischemic lesions.

Chest cavity and upper extremity

Abdominal cavity and lower extremity
Dissect upper mediastinal, supraclavicular, and axillary soft tissues. Subclavian or axillar arteriograms can be prepared at this time. Tissue samples of brachial, ulnar, radial, and digital arteries can be submitted after embalming (consult with funeral director first).

Submit tissue samples for histologic study of aorta and other elastic arteries, muscular arteries, and veins. For angiography of lower extremities, see p. 120. For removal of femoral vessels, see p. 34.
Sclerodactyly; necrosis of fingertips; rarely, ischemic necroses on toes, ears, nose, cheeks, and chin.

Thoracic outlet compression by tumor or other lesions; thromboangiitis obliterans (Buerger's disease*); arteriosclerosis obliterans; arterial emboli; mural thrombosis of heart.

Thromboangiitis and arteriosclerosis obliterans. 


\begin{tabular}{lll}
\hline Organs and Tissues & Procedures & Possible or Expected Findings \\
\hline Other organs & & $\begin{array}{l}\text { Systemic sclerosis* or other immune } \\
\text { connective tissue diseases may be present. } \\
\text { Brain and spinal cord }\end{array}$ \\
& $\begin{array}{l}\text { For removal and specimen preparation, } \\
\text { see pp. 65 and 67, respectively. }\end{array}$ & \\
\hline
\end{tabular}

\section{Disease, Recklinghausen's (See "Hyperparathyroidism" and "Neurofibromatosis.")}

\section{Disease, Refsum}

Synonym: Phytanoyl-coenzyme A hydroxylase deficiency.

NOTE: This peroxisomal disorder may occur in adults but also in an infantile form where it may be a cause of neonatal cholestatic jaundice. For a current review, see ref. (1).

\begin{tabular}{|c|c|c|}
\hline Organs and Tissues & Procedures & Possible or Expected Findings \\
\hline $\begin{array}{l}\text { External examination, } \\
\text { skin, and adipose tissue }\end{array}$ & & $\begin{array}{l}\text { Ichthyosis. Phytanic acid accumulation in } \\
\text { adipose tissues. }\end{array}$ \\
\hline Blood & $\begin{array}{l}\text { Submit sample for determinaion of phytanic } \\
\text { acid concentration. }\end{array}$ & Phytanic acidemia. \\
\hline $\begin{array}{l}\text { Cerebrospinal fluid } \\
\text { Heart }\end{array}$ & For obtaining a sample, see p. 104. & $\begin{array}{l}\text { Increased protein concentrations. } \\
\text { Cardiomyopathy.* }\end{array}$ \\
\hline Liver and kidneys & Sample for histologic study. & Phytanic acid accumulation. \\
\hline $\begin{array}{l}\text { Brain, spinal cord, } \\
\text { and peripheral nerves }\end{array}$ & $\begin{array}{l}\text { For removal and specimen preparation, } \\
\text { see pp. } 65,67 \text {, and } 79 \text {, respectively. }\end{array}$ & Axonal neuropathy. \\
\hline Eyes & For removal and specimen preparation, see p. 85 . & Retinitis pigmentosa. \\
\hline
\end{tabular}

\section{Reference}

1. Hochner I, Blickle JF, Brogard JM. La maladie de Refsum. Revue Med Interne 1996; 17:391-398.

Disease, Schilder's (See "Sclerosis, Schilder's cerebral.")

Disease, Schüller-Christian (See "Histiocytosis, Langerhans cell.")

Disease, Sheehan's (See “Insufficiency, pituitary.”)

\section{Disease, Sickle Cell}

Synonyms and Related Terms: Hemolytic anemia;* sickle cell anemia; sickle cell crisis.

NOTE: See also under "Anemia, hemolytic" and-if applicable-under "Exposure, cold," "Hypoxia," or the name of the infection that may have precipitated a fatal sickle cell crisis. Sickling of erythrocytes may be produced by formalin fixation, in the absence of sickle cell disease. If complications of transfusions or bone marrow transplantation (1) are expected, see under those headings.

\begin{tabular}{ll}
\hline Organs and Tissues & Procedures \\
\hline External examination & Record body weight, length, and habitus.
\end{tabular}

Prepare skeletal roentgenograms.

Blood

Heart

Lungs

Liver

Gallbladder and common bile duct
Submit sample for culture, toxicologic study, hemoglobin electrophoresis, and determination of bilirubin level. Prepare smears.

Submit one lobe for microbiologic study (p. 103).

Record weight. Request Gomori's iron stain (p. 172).

Describe appearance of stones or request chemical analysis.
Possible or Expected Findings

Asthenic habitus; jaundice; skin ulcers over malleoli.

Abnormal trabeculations and infarctions of bone; osteonecrosis* of heads of femora or humeri; deformities of metacarpals, metatarsals, and phalanges; elevation of periosteum; widening of marrow cavities. Bacteremia; septicemia; presence of hemoglobin S; hyperbilirubinemia.

Cardiomegaly; cor pulmonale.

Pneumonia (various types); embolism;* infarctions.

Hepatocellular ischemic necrosis caused by accumulation of erythrocytes in sinusoids; sinusoidal dilatation (2).

Cholelithiasis;* cholecystitis;* choledocholithiasis. 


\begin{tabular}{|c|c|c|}
\hline Organs and Tissues & Procedures & Possible or Expected Findings \\
\hline Spleen & Record weight. & $\begin{array}{l}\text { In infants, splenomegaly; in adults, } \\
\text { infarctions and fibrosis. }\end{array}$ \\
\hline $\begin{array}{l}\text { Kidneys, renal veins, } \\
\text { ureters, and } \\
\text { urinary bladder }\end{array}$ & $\begin{array}{l}\text { Open renal veins in situ; section kidneys in } \\
\text { frontal plane and prepare photographs. }\end{array}$ & $\begin{array}{l}\text { Infarctions; papillary necroses; renal vein } \\
\text { thrombosis;* renal failure;* urinary tract } \\
\text { infection. }\end{array}$ \\
\hline Penis & $\begin{array}{l}\text { Submit tissue samples for histologic study } \\
\text { of corpora cavernosa (p. } 60 \text { ). }\end{array}$ & Priapism. \\
\hline Other organs & & $\begin{array}{l}\text { Manifestations of congestive heart failure* } \\
\text { and of hemolytic anemia.* }\end{array}$ \\
\hline \multirow[t]{2}{*}{ Bones and bone marrow } & $\begin{array}{l}\text { For removal, prosthetic repair, and specimen } \\
\text { preparation of bone, see p. } 95 \text {. For preparation } \\
\text { of sections and smears of bone marrow, } \\
\text { see p. } 96 \text {. }\end{array}$ & $\begin{array}{l}\text { Hyperplastic bone marrow; megaloblastic } \\
\text { changes. }\end{array}$ \\
\hline & $\begin{array}{l}\text { For microbiologic study of osteomyelitis, } \\
\text { see p. } 102 \text {. Consult roentgenograms for proper } \\
\text { sampling. }\end{array}$ & Salmonella osteomyelitis.* \\
\hline Eyes & $\begin{array}{l}\text { For removal and specimen preparation, } \\
\text { see p. } 85 \text {. }\end{array}$ & $\begin{array}{l}\text { Angioid streaks; anterior segment necrosis; } \\
\text { inferior conjunctival capillary abnormalities; } \\
\text { retinopathy; central vitreous hemorrhage. }\end{array}$ \\
\hline
\end{tabular}

\section{References}

1. Lane PA. Sickle cell disease. Pediatr Clin North Am 1996;43:639-664.

2. Charlotte F, Bachir D, Nenert M, et al. Vascular lesions of the liver in sickle cell disease. A clinicopathologic study in 26 living patients. Arch Pathol Lab Med 1995;119:46-52.

\section{Disease, Silo-Filler's (See “Edema, chemical pulmonary.”)}

\section{Disease, Still's (See “Arthritis, juvenile rheumatoid.”)}

\section{Disease, Sturge-Weber-Dimitri}

Synonym: Encephalotrigeminal angiomatosis; encephalofacial angiomatosis.

\begin{tabular}{|c|c|c|}
\hline Organs and Tissues & Procedures & Possible or Expected Findings \\
\hline External examination & $\begin{array}{l}\text { Descibe extent of facial angioma, and } \\
\text { photograph. Prepare roentgenogram of skull. } \\
\text { Record appearance of limbs. }\end{array}$ & $\begin{array}{l}\text { Facial angioma; unilateral exophthalmos; } \\
\text { hemiatrophy of skull; linear cortical cerebral } \\
\text { calcifications. Hypoplasia of limb. }\end{array}$ \\
\hline Brain and spinal cord & $\begin{array}{l}\text { For removal and specimen preparation, see } \\
\text { pp. } 65 \text { and } 67 \text {, respectively. Photograph } \\
\text { surface and coronal slices of brain. } \\
\text { Prepare roentgenograms of whole brain and } \\
\text { of slices to demonstrate calcifications. } \\
\text { Submit tissue samples for histologic study } \\
\text { of vascular lesions. }\end{array}$ & $\begin{array}{l}\text { Excessive unilateral capillary and venous- } \\
\text { type vessels in leptomeninges; calcification } \\
\text { within underlying cortex of one hemisphere } \\
\text { that may be atrophic (ipsilateral to facial } \\
\text { angioma) (1). }\end{array}$ \\
\hline Eyes & $\begin{array}{l}\text { For removal and specimen preparation, } \\
\text { see p. } 85 \text {. }\end{array}$ & $\begin{array}{l}\text { Choroidal hemangioma; manifestations of } \\
\text { congenital glaucoma. }\end{array}$ \\
\hline
\end{tabular}

\section{Reference}

1. Harding B, Copp AJ. Pathology of Malformations. In: Greenfield's Neuropathology, vol. I. Graham BI, Lantos BL, eds. Arnold, London, 1997, pp. 397-507.

\section{Disease, Takayasu's (See “Arteritis, Takayasu's.”)}

\section{Disease, Tangier}

Synonyms: Alpha-lipoprotein deficiency; familial high-density lipoprotein deficiency. 


\begin{tabular}{|c|c|c|}
\hline Organs and Tissues & Procedures & Possible or Expected Findings \\
\hline Blood & $\begin{array}{l}\text { Submit sample for electrophoretic and immuno- } \\
\text { chemical analysis. }\end{array}$ & Hypoalphalipoproteinemia. \\
\hline Lymph nodes & $\begin{array}{l}\text { Submit samples for histologic study; } \\
\text { snap-freeze samples for histochemical study } \\
\text { and prepare specimens for electron microscopy } \\
\text { (p. 132). }\end{array}$ & $\begin{array}{l}\text { Lymphadenopathy with diffuse deposition of } \\
\text { cholesterol esters. }\end{array}$ \\
\hline $\begin{array}{l}\text { Heart; elastic and } \\
\text { muscular arteries }\end{array}$ & & $\begin{array}{l}\text { Premature atherosclerotic cardiovascular } \\
\text { disease (1). }\end{array}$ \\
\hline Liver and spleen & $\begin{array}{l}\text { Record weights. For preparation of specimens, } \\
\text { see above under "Lymph nodes." }\end{array}$ & Hepatosplenomegaly with foam cells. \\
\hline Neck organs and pharynx & $\begin{array}{l}\text { If pharyngeal tonsils cannot be removed with } \\
\text { neck organs, attempts should be made to take } \\
\text { samples perorally. For preparation of specimens, } \\
\text { see above under "Lymph nodes." }\end{array}$ & $\begin{array}{l}\text { Enlarged tonsils with characteristic orange } \\
\text { discoloration. }\end{array}$ \\
\hline Peripheral nerves & $\begin{array}{l}\text { For removal and specimen preparation, } \\
\text { see p. } 79 .\end{array}$ & Polyneuropathy (2). \\
\hline Eyes & $\begin{array}{l}\text { For removal and specimen preparation, } \\
\text { see p. } 85 \text {. }\end{array}$ & In adults, corneal infiltrates. \\
\hline Bone marrow & $\begin{array}{l}\text { For preparation of sections and smears, } \\
\text { see p. } 95 \text { and above under "Lymph nodes." }\end{array}$ & Foam cells. \\
\hline
\end{tabular}

\section{References}

1. Vega GL, Grundy SM. Hypoalphalipoproteinemia (low density lipoprotein) as a risk factor for coronary heart disease. Curr Opin Lipidol 1996;7:209-216.

2. Case Rec Mass Gen Hosp. Case 16-1996. A 36-year-old woman with bilateral facial and hand weakness and impaired truncal sensation [clinical conference]. N Engl J Med 1996;334:1389-1394.

\section{Disease, Tay-Sachs (See “Gangliosidosis.”)}

\section{Disease, Thomsen's (See “Myotonia congenita [Thomsen's disease].")}

\author{
Disease, Valvular Heart (See "Insufficiency,..." \\ and "Stenosis,..." For congenital valvular diseases, \\ see also under "Valve, congenitally...and name of specific \\ malformation.)
}

\section{Disease, Veno-Occlusive, of Liver}

NOTE: Follow procedures described under "Syndrome, Budd-Chiari." Most cases of fatal veno-occlusive disease in the USA are drug-induced (1).

\section{Reference}

1. Culic S, de Kraker J, Kuljis D, Kuzmic I, Saraga M, Culic V, et al. Fatal hepatic veno-occlusive disease with fibrinolysis as the cause of death during preoperative chemotherapy for nephroblastoma. Med Pediatr Oncol 1998;31:175-176.

\section{Disease, Veno-occlusive, of Lung}

(See "Hypertension, pulmonary.")

Disease, von Gierke's (See “Disease, glycogen storage.”)

\section{Disease, von Hippel-Lindau}

NOTE: The gene for the disease has been identified. Type I VHL-disease without pheochromocytoma and type II VHL-disease with pheochromocytoma result from different mutations.

\begin{tabular}{lll}
\hline Organs and Tissues & Procedures & Possible or Expected Findings \\
\hline $\begin{array}{l}\text { Pancreas and kidneys; } \\
\text { other organs }\end{array}$ & & $\begin{array}{l}\text { Cysts; } * \text { renal cell carcinoma; papillary } \\
\text { cystadenoma of the epidydimis. }\end{array}$ \\
$\begin{array}{l}\text { Adrenal glands } \\
\text { Brain and spinal cord }\end{array}$ & $\begin{array}{l}\text { See "Tumor of the adrenal glands." } \\
\text { For removal and specimen preparation, } \\
\text { see p. 65 and p. 67, respectively. For }\end{array}$ & $\begin{array}{l}\text { Pheochromocytoma. } \\
\text { Eyes }\end{array}$ \\
$\begin{array}{l}\text { cerebral arteriography, see p. 80. } \\
\text { For removal and specimen preparation, }\end{array}$ & $\begin{array}{l}\text { and spinal cord, very rarely involving } \\
\text { supratentorial area or peripheral nerve. }\end{array}$ \\
& see p. 85. & Retinal angiomatosis.
\end{tabular}




\section{Disease, von Recklinghausen's (See "Hyperparathyroidism" and "Neurofibromatosis.")}

\section{Disease, von Willebrand's}

Synonyms: Factor VIII deficiency; vascular hemophilia.

NOTE: Follow procedures described under "Hemophilia." The expected findings are essentially the same as in classic hemophilia. However, hemarthrosis is rare in von Willebrand's disease.

\section{Disease, Vrolik's (See “Osteogenesis imperfecta.”)}

\section{Disease, Waldenström's (See “Macroglobulinemia, Waldenström's.”)}

\section{Disease, Weber-Christian}

NOTE: This probably is not a specific entity but represents panniculitis, which may be an incidental finding or part of a systemic disease. For further details, see under "Panniculitis."

\section{Disease, Werdnig-Hoffmann (See "Disease, motor neuron.")}

\section{Disease, Whipple's}

\begin{tabular}{lll}
\hline Organs and Tissues & Procedures & Possible or Expected Findings \\
\hline $\begin{array}{l}\text { External examination } \\
\text { and skin }\end{array}$ & $\begin{array}{l}\text { Record body weight and length and extent } \\
\text { and character of pigmentation and edema. }\end{array}$ & $\begin{array}{l}\text { Emaciation. Hyperpigmentation, particularly } \\
\text { of exposed skin and in scars. }\end{array}$ \\
& $\begin{array}{l}\text { Submit skin samples for histologic study. } \\
\text { If joints are swollen, remove synovial fluid for }\end{array}$ & $\begin{array}{l}\text { Hyperkeratosis. } \\
\text { Arthritis involving ankles, knees, shoulders, } \\
\text { and wrists. }\end{array}$ \\
& $\begin{array}{l}\text { cell counts and smears. See also below under } \\
\text { "Other organs and tissues." }\end{array}$ & $\begin{array}{l}\text { Ascites; fibrinous peritonitis.* Nodules in } \\
\text { Record character and volume of fluid, submit }\end{array}$ \\
Abdominal cavity containing sickle-form particle- \\
& $\begin{array}{l}\text { sample for microbiologic study, and prepare } \\
\text { smears of sediment. Prepare sections of small } \\
\text { intestinal serosa and of parietal peritoneum. }\end{array}$ & $\begin{array}{l}\text { containing cells (SPC cells). For a } \\
\text { classification of the bacillus, see ref. (1) }\end{array}$ \\
& $\begin{array}{l}\text { Request PAS stain (p. 172). In granulomas, } \\
\text { Tropheryma whippelii. }\end{array}$
\end{tabular}

Heart

Lungs

Intestine and mesentery

Other organs and tissues bacilli are not always PAS positive (2).

For collection of histologic samples, see p. 30. Include all grossly involved tissues. For preparation for electron microscopy, see p. 132. Request PAS stain of paraffin sections (p. 173).

Perfuse one lung with formalin (p. 47).

For in situ fixation and preparation for study in dissecting microscope, see p. 54. Submit tissue samples of various segments of intestinal wall; request PAS stain (p. 173). Submit portions of mucosa and of mesenteric lymph nodes for electron microscopy (p. 132). If immunofluorescent studies are intended, snap-freeze tissue samples.

Submit tissue samples for histologic study of all gross lesions and-even in the absence of macroscopic changes - of esophagus, stomach, colon, spleen, pancreas, retroperitoneal soft tissues, kidneys, adrenal glands, urinary bladder, peripheral and other extramesenteric lymph nodes, brain, spinal cord, synovium with joint capsules, bone marrow, and skeletal muscles. For histologic techniques, see above under "Intestine and mesentery."
Pancarditis; SPC cells in cardiac valves, interstitium of ventricles and atria, and pericardium. Fibrous-adhesive pericarditis; myocardial fibrosis; endocarditis with valvular fibrosis.

SPC cells in parenchymal stroma and visceral pleura.

SPC cells, primarily in lamina propria of villi; villous atrophy; thickening of intestinal wall. Rod-shaped bacillary bodies and serpiginous membranes in cytoplasm of SPC cells or extracellularly. Mesenteric lymphadenitis with SPC cells, granulomas, and giant cells.

Characteristic SPC cells can occur in practically all organs and tissues, particularly in capsule and portal areas of spleen, interstitium of pancreas, stomach, retroperitoneal organs and tissues, lymph nodes, and central nervous system. Myopathy may occur. 


\section{References}

1. Dutly F, Altwegg M. Whipple's disease and "Tropheryma whippelii." Clin Microbiol Rev 2001;14:561-583.

2. Wilcox GM, Tronic BS, Schecter DJ, Arron MJ, Righi DF, Weiner NJ. Periodic acid-Schiff-negative granulomatous lymphadenopathy in patient with Whipple's disease. Localization of the Whipple bacillus to noncaseating granulomas by electron microscopy. Am J Med 1987;83:165-170.

\section{Disease, Willebrand's (See “Disease, von Willebrand's.")}

\section{Disease, Wilson's}

Synonym: Hepatolenticular degeneration.

NOTE: For the gene defect, see ref. (1).

\begin{tabular}{ll}
\hline Organs and Tissues & Procedures \\
\hline $\begin{array}{l}\text { External examination } \\
\text { and skin }\end{array}$ & $\begin{array}{l}\text { Record character and extent of pigmentation; } \\
\text { submit skin samples for histologic study. }\end{array}$ \\
& $\begin{array}{l}\text { Prepare skeletal roentgenograms. } \\
\text { Submit sample for biochemical study and for } \\
\text { Blood }\end{array}$ \\
\end{tabular}

Urine

Lung

Liver

Record weight and photograph. Tissue copper concentrations can be determined from sample in paraffin block (2). Request rhodanine stain for copper (p. 173).

Kidneys See above under "Liver."

Other organs and tissues Brain and spinal cord

For removal and specimen preparation, see pp. 65 and 67, respectively. If biochemical copper determination is intended, see above under "Liver."

For removal and specimen preparation, see p. 85. For copper staining, use rhodanine method (p. 173).

For removal, prosthetic repair, and specimen preparation, see p. 95.
Possible or Expected Findings

Jaundice; hyperpigmentation of anterior aspects of lower legs; blue lunulae of nails; increased fingerprint "whorl" pattern. See below under "Bones and joints." Low ceruloplasmin concentration $(<20 \mathrm{mg}$ / $\mathrm{dL}$ ); normal or decreased serum copper concentrations. Hemolytic anemia and increase in hemoglobin $\mathrm{A}_{2}$. Increased copper ( $>100 \mu \mathrm{g} \mathrm{Cu}$ in $24 \mathrm{~h}$ ) excretion, but single specimen of little use. See below under "Kidneys."

Fatty changes, periportal hepatitis or cirrhosis, ${ }^{*}$ depending on stage of disease.

Rarely massive hepatic necrosis. Stainable copper in many but not all specimens. Tissue copper concentrations $>250 \mu \mathrm{g} / \mathrm{g}$ dry wt.

Copper in proximal tubules; tubular fatty changes.

Increased copper in skeletal muscles.

Symmetrical dilatation of lateral ventricles; discoloration of striatum, often with cavitation of putamen. Thalamic and cortical involvement is common. Microscopically, neuronal loss and gliosis, among other possible abnormalities (3). Alzheimer's type 2 cells increased. Copper deposition primarily perivascular.

Copper of Kayser-Fleischer ring lies in Descemet's membrane. Copper-containing foreign bodies are found in posterior layer of lens capsule.

Osteoarthritis; * bone fragmentation; osteochrondritis of the vertebral column; osteochondritis dissecans of knees and ankles.

\section{References}

1. Bull PC, Thomas GR, Rommens JM, Forbes JR, Cox DW. The Wilson's disease gene is a putative copper transporting P-type ATPase similar to Menke's gene. Nature Genet 1993;5:327-337.

2. Ludwig J, Moyer TP, Rakela J. The liver biopsy diagnosis of Wilson's disease. Methods in pathology. Am J Clin Pathol 1994;102:443-446.

3. Harper C, Butterworth R. Hepatolenticular degeneration (Wilson's disease). In: Greenfield's Neuropathology, vol. 1. Graham BI, Lantos PL, eds. Arnold, London, 1997, pp. 632-633. 


\section{Disorder, Electrolyte(s)}

\begin{tabular}{|c|c|c|}
\hline Organs and Tissues & Procedures & Possible or Expected Findings \\
\hline Vitreous & $\begin{array}{l}\text { Submit sample for determination of sodium, } \\
\text { potassium, chloride, glucose, urea nitrogen, } \\
\text { and creatinine concentrations (p. 85). } \\
\text { Calcium and phosphate concentrations can } \\
\text { also be tested. } \\
\text { If sample is small, indicate priority for testing. }\end{array}$ & $\begin{array}{l}\text { Considerably increased or decreased values } \\
\text { for sodium (more than } 155 \mathrm{meq} / \mathrm{L} \text { or less } \\
\text { than } 130 \mathrm{meq} / \mathrm{L} \text { ) and chloride }(\mathrm{more} \text { than } \\
135 \mathrm{meq} / \mathrm{L} \text { or less than } 105 \mathrm{meq} / \mathrm{L}) \text { indicate } \\
\text { that changes were present before death. For } \\
\text { further interpretation, see } \mathrm{p} .113 \text {. }\end{array}$ \\
\hline Blood & & $\begin{array}{l}\text { Postmortem electrolyte concentrations are } \\
\text { quite unreliable (see p. 113). }\end{array}$ \\
\hline Urine & If indicated, submit sample for chemical study. & May be useful for calcium determination. \\
\hline Kidneys & Submit tissue samples for histologic study. & $\begin{array}{l}\text { Vacuolar nephropathy (vacuolar changes in } \\
\text { proximal convoluted tubules) in potassium } \\
\text { deficiency (may also occur after infusion of } \\
\text { hypertonic solutions). }\end{array}$ \\
\hline
\end{tabular}

\section{Disorder, Hemorrhagic}

(See "Coagulation, disseminated intravascular," "Disease, Christmas," "Disease, von Willebrand's," "Hemophilia," and "Purpura,...")

\section{Disorder, Inherited, of Phagocyte Function}

NOTE: Several conditions represent phagocyte function disorders. Autopsy procedures for one of these disorders can be found under "Disease, chronic granulomatous." Consult this entry for other phagocyte function disorders.

\section{Disorder, Lysosomal Storage}

Synonyms and Related Terms: Fabry's disease* (angiokeratoma corporis diffusum); gangliosidosis;* Gaucher's disease;* glycogenosis,* type II; leukodystrophies (Krabbe's or globoid cell,* metachromatic leukoencephalopathy*); mucopolysaccharidoses* (Hunter, Hurler, Morquio, and Sanfilippo disease); mucolipidosis; Niemann Pick disease* (type A, B, C, or sphingomyelinase deficiency); neuraminidase deficiency; neuronal ceroid lipofuscinosis (Batten's disease or Kufs' disease).

\begin{tabular}{|c|c|}
\hline Organs and Tissues & Procedures \\
\hline External examination & $\begin{array}{l}\text { Obtain routine body measurements and } \\
\text { weights. Photograph all abnormalities } \\
\text { Prepare skeletal roentgenograms. }\end{array}$ \\
\hline Fascia lata & $\begin{array}{l}\text { Prepare specimen for fibroblast culture } \\
\text { (see p. 109), for enzyme assay, and for } \\
\text { electron microscopy. }\end{array}$ \\
\hline $\begin{array}{l}\text { Other organs and tissues } \\
\text { (including bone marrow) }\end{array}$ & $\begin{array}{l}\text { Record weights. See also below under } \\
\text { "Brain and spinal cord." }\end{array}$ \\
\hline
\end{tabular}

Brain and spinal cord
For removal and specimen preparation, see pp. 66 and 70, respectively. Request LFB/PAS stain (p. 172). Submit samples for electron microscopy (p. 132). Store fresh/frozen tissue for enzyme assay or molecular genetic studies.
Possible or Expected Findings

Coarse facial features are frequently present. Corneal clouding. Skeletal abnormalities may be present.

See entries listed under "Synonyms and Related Terms."

Storage deposits in histiocytes ("sea-blue histiocytes" in Niemann-Pick disease); heart, liver, spleen (with hepatosplenomegaly), and kidneys may be involved.

Atrophy. Cellular storage in neurons, histiocytes, and other cells. For possible storage sites, see under name of specific disorder.

\section{Reference}

1. Lake B. Lysosomal and peroxisomal disorders. In: Greenfield's Neuropathology, vol. 1. Graham BI, Lantos PL, eds. Arnold, London, 1997, pp. $658-753$.

Disorder, Myeloproliferative (See "Leukemia, all types or type unspecified," "Myelofibrosis with myeloid metaplasia," and "Polycythemia.")

Disorder, Plasma Cell (See "Amyloidosis," "Disease, heavy chain," "Macroglobulinemia, Waldenström's," and "Myeloma, multiple.") 


\section{Dissection, Aortic}

Synonym: Dissecting aortic aneurysm; dissecting aortic hematoma.

\begin{tabular}{|c|c|c|}
\hline Organs and Tissues & Procedures & Possible or Expected Findings \\
\hline External examination & $\begin{array}{l}\text { Record and photograph abnormal features } \\
\text { (see right-hand column). Prepare chest } \\
\text { roentgenogram. }\end{array}$ & $\begin{array}{l}\text { Features of Marfan's syndrome* or Turner's } \\
\text { syndrome.* Widened aorta or mediastinum. }\end{array}$ \\
\hline Pericardium & Record appearance and volume of contents. & Hemopericardium. \\
\hline Aorta & $\begin{array}{l}\text { Remove heart and major arteries attached to } \\
\text { intact aorta. Open aorta along posterior midline. } \\
\text { Photograph intimal tears and record their location } \\
\text { and size. Record external rupture site, if possible, } \\
\text { and extent of mediastinal or retroperitoneal } \\
\text { hemorrhage. Record location and volume of } \\
\text { blood in "false" lumen and presence or absence } \\
\text { of intramural hematoma, not connected to lumen. } \\
\text { Record location and size of re-entry tear, if } \\
\text { present. } \\
\text { Request Verhoeff-van Gieson and PAS-alcian } \\
\text { blue stains (p. 173). } \\
\text { Sections should include grossly involved and } \\
\text { uninvolved portions of aortic wall and of } \\
\text { adjacent elastic arteries. }\end{array}$ & $\begin{array}{l}\text { Coarctation of the aorta.* Dissection may } \\
\text { involve major branches of aorta. Blood may } \\
\text { be present in periaortic tissues and } \\
\text { pericardium (see above). Intimal tear is most } \\
\text { commonly located in ascending thoracic } \\
\text { aorta. False lumen occurs with or without tear } \\
\text { of reentry. The aorta may be atherosclerotic. } \\
\text { In the descending thoracic or abdominal } \\
\text { aorta, an intimal tear may involve an } \\
\text { ulcerated plaque (penetrating ulcer). } \\
\text { Cystic medial degeneration of aorta. Rarely, } \\
\text { giant cell aortitis. }\end{array}$ \\
\hline Heart & $\begin{array}{l}\text { Procedures depend on expected findings or } \\
\text { grossly identified abnormalities as listed in } \\
\text { right-hand column. }\end{array}$ & $\begin{array}{l}\text { Congenitally bicuspid aortic valve.* } \\
\text { Concentric left ventricular hypertrophy. } \\
\text { Myxomatous mitral valve. }\end{array}$ \\
\hline Other organs & & $\begin{array}{l}\text { Manifestations of hypertension* or of third- } \\
\text { trimester pregnancy. }\end{array}$ \\
\hline Brain and spinal cord & $\begin{array}{l}\text { For removal and specimen preparation of brain } \\
\text { and spinal cord, see pp. } 65 \text { and } 67 \text {, respectively. }\end{array}$ & $\begin{array}{l}\text { Ischemic lesions in brain and spinal cord and } \\
\text { in other organs. }\end{array}$ \\
\hline
\end{tabular}

\section{Diverticula}

Related Terms: Diverticular disease; diverticulitis; diverticulosis; Meckel's diverticulum; pulsion diverticulum; traction diverticulum; Zenker's diverticulum.

\begin{tabular}{|c|c|c|}
\hline Organs and Tissues & Procedures & Possible or Expected Findings \\
\hline Esophagus & $\begin{array}{l}\text { Dissect diverticulum in situ and photograph. } \\
\text { Fix specimen in formalin before opening. }\end{array}$ & $\begin{array}{l}\text { Hypopharyngeal pulsion diverticulum } \\
\text { (Zenker's diverticulum) at lower margin of } \\
\text { inferior constrictor muscle of pharynx. } \\
\text { Traction diverticulum at midesophagus after } \\
\text { an inflammatory process-for instance, } \\
\text { tuberculous lymphadenitis. Epiphrenic } \\
\text { diverticulum may also occur. }\end{array}$ \\
\hline Stomach & & Juxtacardiac or juxtapyloric diverticulum. \\
\hline Small bowel & $\begin{array}{l}\text { For preservation of jejunal diverticula by air } \\
\text { drying, see p. } 55 \text {. Prepare histologic sections } \\
\text { of Meckel's diverticulum. }\end{array}$ & $\begin{array}{l}\text { Heterotopic tissue in Meckel's diverticulum, } \\
\text { with or without peptic ulceration. }\end{array}$ \\
\hline Colon & $\begin{array}{l}\text { Rinse carefully; openings of diverticula may } \\
\text { be difficult to identify. Record thickness of } \\
\text { colonic wall and extent, approximate number, } \\
\text { and location of diverticula. }\end{array}$ & $\begin{array}{l}\text { Colonic muscular hypertrophy and stenosis, } \\
\text { usually in sigmoid colon. Diverticulitis with } \\
\text { perforation, fistulas, or peritonitis.* }\end{array}$ \\
\hline
\end{tabular}

\section{Diverticulitis (See "Diverticula.")}

\section{Diving (See “Accident, diving (skin or scuba).”)}




\section{Drowning}

Related Terms: Dry drowning; fresh-water drowning; near-drowning; salt (sea)-water drowning (see the following table).

Table II-1

Deaths from Drowning

\section{Primary Drowning \\ ("Immediate Drowning")}

Deaths occurring within minutes after immersion, before or without resuscitative measures
Secondary Drowning

("Near-Drowning")

Deaths occurring from within 30 min to several weeks after resuscitation, because of metabolic acidosis, pulmonary edema, or infective or chemical pneumonitis

\begin{tabular}{ll}
\hline \multicolumn{1}{c}{$\begin{array}{c}\text { Type I } \\
\text { ("Dry Drowning") }\end{array}$} & \multicolumn{1}{c}{$\begin{array}{c}\text { Type II } \\
\text { ("Wet Drowning") }\end{array}$} \\
\hline $\begin{array}{l}\text { Deaths from hypoxia and acidosis caused by glottal spasm } \\
\text { on breath holding. There may be no evidence of water }\end{array}$ & $\begin{array}{l}\text { Deaths from hypoxia and acidosis caused by obstruction } \\
\text { of airway by water related to: }\end{array}$ \\
entering stomach or lungs and no appreciable morphologic & Hypervolemia \\
changes at autopsy. & Hemolysis \\
& Hyponatremia \\
& Hypochloremia \\
\hline
\end{tabular}

NOTE: The diagnosis is one of exclusion. The pathologist should help the police to determine: 1) How did the person (or dead body) get in the water, and 2) why could that person not get out of the water? It is not enough to ask if a person could swim but investigators should find out how well (what strokes did the victim know?) and how far he or she could swim. The inquiry must include the depth of the water and must address hazards such as undertow or underwater debris, and the behavior of the victim immediately before submerging. Deaths of adults in bathtubs and swimming pools are usually from natural, cardiac causes, or they are suicides, unless the victim was drunk.
Diatom tests (1) have not proven useful in the United States but there is enthusiasm for such tests among European pathologists. The distinction between hyponatremic deaths in fresh water and hypernatremic deaths in salt water derives from experimental studies; in practice, one cannot reliably predict the salinity of the immersion medium from autopsy studies. Because many bodies of drowning victims are recovered only after the body floats to the surface, decomposition will often obscure even the nondiagnostic findings such as pleural effusions, which are often associated with drowning.

\begin{tabular}{lll}
\hline Organs and Tissues & Procedures & Possible or Expected Findings
\end{tabular}

External examination and skin (wounds)
If identity of drowning victim is not known, record identifying features as described on p. 11.

Prepare dental and whole-body roentgenograms. Submit tissue samples for histologic study of wounds.

Inspect inside of hands.

Collect fingernail scrapings.

Record appearance and contents of body orifices.
There may be wounds that were inflicted before drowning occurred-for instance, in shipwrecks or vehicular and diving accidents.

Other wounds may be inflicted after deathfor instance, from ship propellers or marine animals. Sometimes, premortem and postmortem wounds can be distinguished histologically.

Object (hair?) held by hands in cadaveric spasm. Cutis anserina and "washerwoman" changes of hands and feet are of no diagnostic help.

Foreign bodies; semen (see also under "Rape"). 


\begin{tabular}{|c|c|}
\hline Organs and Tissues & Procedures \\
\hline \multirow[t]{3}{*}{$\begin{array}{l}\text { External examination } \\
\text { and skin (wounds) } \\
\text { (continued) }\end{array}$} & Record features indicative of drowning. \\
\hline & $\begin{array}{l}\text { Photograph face from front and in profile. } \\
\text { Take pictures of all injuries, with and without } \\
\text { scale and autopsy number. } \\
\text { Remove vitreous (p. 85). }\end{array}$ \\
\hline & $\begin{array}{l}\text { If diatom search is intended, clean body } \\
\text { thoroughly before dissection to avoid con- } \\
\text { tamination of organs and body fluids with } \\
\text { algae and diatoms (see below). }\end{array}$ \\
\hline Blood & Submit sample for toxicologic study. \\
\hline $\begin{array}{l}\text { Organ samples } \\
\text { for diatom search }\end{array}$ & $\begin{array}{l}\text { Sample early during autopsy, before carrying } \\
\text { out other dissections. Use fresh instruments } \\
\text { for removal of specimens to avoid contamination. } \\
\text { Submit subpleural portion of lung: subcapsular } \\
\text { portions of liver, spleen, and kidneys; bone } \\
\text { marrow; and brain. Store samples in clean glass } \\
\text { jars. For technique of diatom detection, see below. }\end{array}$ \\
\hline $\begin{array}{l}\text { Serosal surfaces } \\
\text { and cavities }\end{array}$ & $\begin{array}{l}\text { Record volume of fluid in pleural spaces. } \\
\text { Photograph petechial hemorrhages. }\end{array}$ \\
\hline
\end{tabular}

Neck organ and lungs

\section{Heart}

Intestinal tract and stomach

Other organs

Genital organs

Brain

Middle ears, paranasal sinuses, and mastoid spaces
Photograph layerwise neck dissection if strangulation* is suspected.

Open airways posteriorly, and photograph, remove and save mud, algae, and any other material in tracheobronchial tree. Record size and weight of lungs.

Request frozen sections for Sudan fat stain (p. 173).

For coronary arteriography, see p. 118.

Save stomach contents (p. 16) and record volume. Record character of intestinal contents and submit for toxicologic study.

Record appearance of serosal and mesenteric lymphatics.

Search for evidence of rape, ${ }^{*}$ pregnancy, ${ }^{*}$ or both.

For removal and specimen preparation, see p. 65. absence of hemorrhages; photograph hemorrhages; inspect eardrums for presence of perforation (p. 72). If perforated, prepare histologic sections.
Expose with chisel, and record presence or
Possible or Expected Findings

Foam cap over mouth and nose.

In the autopsy room, water running from nose and mouth is usually pulmonary edema or water from the stomach.

Identification (p. 11).

High concentrations of alcohol indicate intoxication (see under "Alcoholism and alcohol intoxication").

Evidence of alcohol intoxication may be found.

Diatoms may occur in the liver and in other organs of persons who have died from causes other than drowning. Comparison with diatoms in water sample from area of drowning may be helpful.

Penny-sized or smaller hemorrhages may indicate violent respiratory efforts or merely intense lividity.

Presence of pleural fluid suggests drowning.

Presence of "aqueous emphysema" indicates violent respiratory efforts.

Fat emboli and bone marrow emboli indicate fractures during life.

Coronary atherosclerosis and coronary thrombosis.*

Gastric and intestinal contents indicate type and occasionally time of last meal. Intestinal lymphatics ("lacteals") dilated and quite conspicuous during resorptive state. Tablet residues may be present.

Evidence of disseminated intravascular coagulation* may be found after fresh-water submersion.

\section{Anoxic changes.}

Hemorrhages in middle ears or mastoid air spaces are strong evidence of drowning. Middle ear or mastoid hemorrhages can be documented histologically. Watery liquid in sphenoid sinuses. 


\section{Technique of Diatom Detection}

For diatom detection (1), boil 2-5 g of tissue for 10-15 min in $10 \mathrm{~mL}$ of concentrated nitric acid and $0.5 \mathrm{~mL}$ of concentrated sulfuric acid. Then, add sodium nitrate in small quantities until the black color of the charred organic matter has been dispelled. It may be necessary to warm the acid-digested material with weak sodium hydroxide, but the material must soon be washed free from alkali to avoid dissolving the diatoms. The diatoms should be washed, concentrated, and stored in distilled water. For examination, allow a drop of the concentrate to evaporate on a slide, and then mount it in a resin of high refractive index. All equipment must be well-cleaned, and distilled water must be used for all solutions. There are several variations and adaptations of this method.

\section{Reference}

1. Camps FE. Immersion in fluids. In: Recent Advances in Forensic Pathology. J \& A Churchill, London, 1969, pp. 70-79.

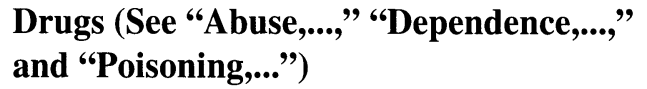

\section{Ductus Arteriosus, Patent (See “Artery, patent ductal.”)}

\section{Dwarfism}

Synonyms and Related Terms. Achondroplastic dwarf; asexual dwarf; ateliotic dwarf; micromelic dwarf; normal dwarf; pituitary dwarf; true dwarf; and many other terms, too numerous to mention.

\begin{tabular}{|c|c|c|}
\hline Organs and Tissues & Procedures & Possible or Expected Findings \\
\hline External examination & $\begin{array}{l}\text { Record lengths of extremities and length of } \\
\text { rump (calculate ratio), head circumference, } \\
\text { and other suspected abnormal dimensions. } \\
\text { Prepare skeletal roentgenograms. }\end{array}$ & $\begin{array}{l}\text { Short or deformed extremities, deformed } \\
\text { head, and other deformities. Abnormalities } \\
\text { of primary and secondary sex characteristics. } \\
\text { Osseous and cartilaginous deformities; } \\
\text { skeletal tumor (adamantinoma). }\end{array}$ \\
\hline Endocrine organs & $\begin{array}{l}\text { Record weights and prepare histologic } \\
\text { sections of all endocrine organs. For removal } \\
\text { and specimen preparation of pituitary gland, } \\
\text { see p. } 71 .\end{array}$ & $\begin{array}{l}\text { Tumor; infection; posttraumatic lesions; } \\
\text { infiltrates of Langerhans cell histiocytosis.* }\end{array}$ \\
\hline Other organs & $\begin{array}{l}\text { Follow procedures described under suspected } \\
\text { underlying disease (see right-hand column). } \\
\text { In true or primordial dwarfism, no associated } \\
\text { abnormalities can be suspected. }\end{array}$ & $\begin{array}{l}\text { Achondroplasia;* congenital heart disease;* } \\
\text { Hurler's syndrome (see "Mucopolysaccha- } \\
\text { ridosis"); hypothyroidism;* malabsorption } \\
\text { syndrome;* pituitary insufficiency;* renal } \\
\text { failure* (chronic); sexual precocity with } \\
\text { premature fusion of epiphyses; other } \\
\text { systemic diseases. }\end{array}$ \\
\hline
\end{tabular}

\section{Dysbetalipoproteinemia, Familial (See "Hyperlipoproteinemia.")}

\section{Dyschondroplasia, Ollier's}

Synonyms and Related Terms: Multiple enchondromatosis; Ollier's disease; osteochondrodysplasia.

\begin{tabular}{ll}
\hline Organs and Tissues & Procedures \\
\hline External examination & $\begin{array}{l}\text { Record height and weight. Prepare skeletal } \\
\text { roentgenograms. }\end{array}$
\end{tabular}

Skin and soft tissues

Bones and joints

For removal, prosthetic repair, and specimen preparation, see p. 95.

\section{Possible or Expected Findings}

Growth retardation. Abnormal growth of epiphyseal cartilage with enlargement of metaphysis. Long bones and pelvis most commonly affected.

Cavernous hemangiomas (Maffucci's syndrome).

See above under "External examination." Chondrosarcoma.

\section{Dyscrasia, Plasma Cell}

NOTE: These conditions are characterized by abnormally proliferated B-immunocytes that produce a monoclonal immunoglobulin. Multiple myeloma, ${ }^{*}$ plasma cell leukemia, plasmacytoma, and Waldenström's macroglobulinemia* as well as heavy-chain diseases and monoclonal gammopathies of unknown type belong to this disease family. Amyloidosis* is closely related to these conditions. For autopsy procedures, see under "amyloidosis," "macroglobulinemia," or "multiple myeloma" and under name of condition that may have caused the plasma cell dyscrasia. Such conditions include carcinoma (colon, breast, or biliary tract), Gaucher's disease, ${ }^{*}$ hyperlipoproteinemia,* infectious or noninfectious chronic inflammatory diseases, and previous cardiac surgery. 


\section{Dysentery, Bacillary}

Synonym: Shigella dysentery.

NOTE: (1) Collect all tissues that appear to be infected. (2) Request aerobic bacterial cultures. (3) Request Gram stain (p. 172). (4) Special precautions are indicated (p. 146). (5) Serologic studies are available from local and state health department laboratories (p. 135). (6) This is a reportable disease.

\begin{tabular}{|c|c|c|}
\hline Organs and Tissues & Procedures & Possible or Expected Findings \\
\hline Blood & $\begin{array}{l}\text { Submit sample for culture and for serologic } \\
\text { study (p. 102). }\end{array}$ & Escherichia coli septicemia. \\
\hline Bowel & $\begin{array}{l}\text { Submit sample of feces or preferably blood- } \\
\text { tinged mucus for culture. If bacteriologic } \\
\text { diagnosis has already been confirmed, pin colon } \\
\text { on corkboard, photograph, and fix in formalin for } \\
\text { histologic study. }\end{array}$ & $\begin{array}{l}\text { Colitis with microabscesses; transverse } \\
\text { shallow ulcers and hemorrhages, most often } \\
\text { in terminal ileum and colon. }\end{array}$ \\
\hline \multirow[t]{2}{*}{ Eyes } & $\begin{array}{l}\text { Submit sample of vitreous for study of sodium, } \\
\text { potassium, chloride, and urea nitrogen concen- } \\
\text { trations (p. 85). }\end{array}$ & $\begin{array}{l}\text { Dehydration* pattern of electrolytes and urea } \\
\text { nitrogen (p. 115). }\end{array}$ \\
\hline & $\begin{array}{l}\text { For removal and specimen preparation of eyes, } \\
\text { see p. } 85 \text {. }\end{array}$ & Conjunctivitis, iritis. \\
\hline Joints & $\begin{array}{l}\text { For removal, prosthetic repair, and specimen } \\
\text { preparation, see p. } 96 .\end{array}$ & $\begin{array}{l}\text { Serous arthritis* of knee joints is a late } \\
\text { complication. }\end{array}$ \\
\hline
\end{tabular}

\section{Dysfibrinogenemia}

NOTE: Bleeding and thromboembolism* may be noted at autopsy. Clotting studies with postmortem blood are not indicated. AIDS, * liver disease, and lymphoproliferative disorders are possible underlying conditions.

\section{Dysgenesis, Gonadal (Ovarian) (See “Syndrome, Turner’s.”)}

\section{Dysgenesis, Seminiferous Tubule (See “Syndrome, Klinefelter’s.”)}

\section{Dyskinesia, Ciliary}

Synonyms and Related Terms: Immotile cilia syndrome; Kartagener's triad.

NOTE: Multiple conditions belong into this disease category, all characterized by a hereditary defect of the axoneme (the "motor" of the cilia).

\begin{tabular}{lll}
\hline Organs and Tissues & Procedures & Possible or Expected Findings \\
\hline Chest cavity & $\begin{array}{l}\text { If situs inversus is present, photograph chest } \\
\text { organs in situ. } \\
\text { Lungs }\end{array}$ & $\begin{array}{l}\text { Situs inversus in Kartagener's triad (with } \\
\text { sinusitis and bronchiectases-see below). } \\
\text { logic study (p. 103). Perfuse on lung with } \\
\text { formalin (p. 47). }\end{array}$ \\
$\begin{array}{l}\text { Nonchiectases and bronchopneumonia. } \\
\text { Nasal cavities, sinuses, } \\
\text { and middle ears }\end{array}$ & $\begin{array}{l}\text { For exposure and specimen preparation, } \\
\text { see pp. 71 and 72. }\end{array}$ & Nasal polyps; sinusitis, and otitis media.* \\
& $\begin{array}{l}\text { Prepare samples of mucosa for electron micro- } \\
\text { scopic study of cilia (p. 132). }\end{array}$ & Missing dynein arms. \\
\hline
\end{tabular}

\section{Dysphagia, Sideropenic (See “Syndrome, Plummer-Vinson.”)}

\section{Dysplasia, Chrondroectodermal (See "Syndrome, Ellis-van Creveld.")}

\section{Dysplasia, Fibrous, of Bone}

Related Term: McCune-Albright syndrome.

Possible Associated Conditions: Acromegaly;* Cushing's syndrome;* hyperthyroidism.* 


\begin{tabular}{lll}
\hline Organs and Tissues & Procedures & Possible or Expected Findings \\
\hline External examination & $\begin{array}{l}\text { Record extent of pigmentation, facial features, } \\
\text { and primary and secondary sex characteristics. }\end{array}$ & $\begin{array}{l}\text { Unilateral skin pigmentation and precocious } \\
\text { puberty in females (Albright's syndrome), } \\
\text { less commonly in males. Abnormal facial } \\
\text { features caused by distortion of facial bones. } \\
\text { Cystlike lesions in metaphyses and shafts of } \\
\text { bone; fractures; deformities. } \\
\text { Myxomas. } \\
\text { Soft tissues }\end{array}$ \\
$\begin{array}{lll}\text { Bones } & \text { Prepare skeletal roentgenograms. }\end{array}$ & $\begin{array}{l}\text { For remove under "External examination." } \\
\text { preparation, see p. 95. } \\
\text { Record size of apertures of cranial nerves in } \\
\text { base of skull. }\end{array}$ & Encroachment of cranial nerves. \\
\hline
\end{tabular}

\section{Dysplasia, Renal (See “Cyst(s), renal.”)}

\section{Dysplasia, Thymic (See “Syndrome, primary immunodeficiency.”)}

\section{Dystonia, Torsion (See “Syndrome, Dystonia.")}

\section{Dystrophy, Duchenne's Progressive muscular (See "Dystrophy, muscular.")}

\section{Dystrophy, Muscular}

Synonyms and Related Terms: Becker's muscular dystrophy; congenital muscular dystrophy; Duchenne's progressive muscular dystrophy; dystrophinopathy; Emery-Dreifuss mucular dystrophy; facioscapulohumeral dystrophy; limb girdle dystrophy; myotonic muscular dystrophy.

\begin{tabular}{|c|c|c|}
\hline Organs and Tissues & Procedures & Possible or Expected Findings \\
\hline \multirow[t]{2}{*}{ External examination } & Record pattern of scalp hair. & $\begin{array}{l}\text { Frontal baldness (in myotonic muscular } \\
\text { dystrophy). }\end{array}$ \\
\hline & Record status of skeletal musculature. & $\begin{array}{l}\text { Atrophy and wasting of muscles (generalized } \\
\text { or local: predominantly distal in myotonic } \\
\text { muscular dystrophy). } \\
\text { Pseudohypertrophy of calf muscles in } \\
\text { Duchenne's muscular dystrophy. }\end{array}$ \\
\hline Skeletal muscle & $\begin{array}{l}\text { For sampling and specimen preparation, see } \\
\text { p. } 80 \text {. Dystrophin staining of the sarcolemma } \\
\text { is absent in Duchenne's muscular dystrophy } \\
\text { and patchy in Becker's dystrophy. }\end{array}$ & $\begin{array}{l}\text { Dystrophic changes include variations in } \\
\text { fiber size, fiber degeneration and } \\
\text { regeneration, peri- and endomysial fibrosis, } \\
\text { and fatty replacement of muscle. }\end{array}$ \\
\hline
\end{tabular}

\section{Reference}

1. Engel AG, Yamamoto M, Fischbeck KH. Dystrophinopathies. In: Myology, 2nd ed., vol. 2. Engel AG, Franzini-Armstrong C, eds. MacGrawHill, New York, 1994, pp. 1130-1187.

Dystrophy, Myotonic Muscular (See “Dystrophy, muscular.”) 


\section{$\mathbf{E}$}

\section{Echinococcosis}

Synonym: Hydatid disease.

NOTE: (1) Collect all tissues that appear to be infected. (2) Usually, cultures are not required, only direct examination for parasites. (3) Request Giemsa stain for parasites (p. 172). (4) Special precautions should be exercised in removing the cysts, as the contents are highly infectious (p. 146). (5) Serologic studies are available from the Center for Disease Control and Prevention, Atlanta, GA (p. 135). (6) This is not a reportable disease.

\begin{tabular}{lll}
\hline Organs and Tissues & Procedures & Possible or Expected Findings \\
\hline Liver & $\begin{array}{l}\text { If the liver is the site of involvement, prepare } \\
\text { roentgenogram. Prepare cholangiogram if } \\
\text { Echinococcus multilocularis organisms are } \\
\text { present (p. 56). Photograph intact cysts and } \\
\text { cut sections. Cysts should be placed in formalin } \\
\text { before processing. }\end{array}$ & $\begin{array}{l}\text { The liver, especially the right lobe, is the most } \\
\text { common site of involvement. Secondary } \\
\text { infection or calcification may be present. }\end{array}$ \\
If the lung is the site of involvement, \\
prepare roentgenogram. Photograph cysts. \\
Lungs
\end{tabular}

\section{Eclampsia (See "Toxemia of pregnancy.")}

\section{Edema, Angioneurotic}

Synonym: Angioedema.

NOTE: Possible causes and suggested autopsy procedures are described under "Death, anaphylactic."

\section{Edema, Chemical Pulmonary}

Related Term: Silo-filler's disease.

NOTE: This condition is caused by inhalation of toxic gases, such as oxides of nitrogen (silo-filler's disease) and phosgene $\left(\mathrm{COCl}_{2}\right)$. See also "Bronchitis, acute chemical" and "Poisoning, gas."

\begin{tabular}{lll}
\hline Organs and Tissues & Procedures & Possible or Expected Findings \\
\hline Upper airways and lungs & Remove lungs together with pharynx, larynx, & Acute chemical laryngotracheitis; acute \\
& and trachea. Open airways posteriorly. & pulmonary edema. Obliterating fibrous \\
& Record lung weights. Submit one lobe for & bronchiolitis and diffuse, progressive \\
& microbiologic study (p. 103). Perfuse one lung & pulmonary fibrosis may be present after \\
& with formalin (p. 47). & prolonged survival. \\
\hline
\end{tabular}


Effusion(s) and Exudate(s), Pleural

\begin{tabular}{|c|c|c|}
\hline Organs and Tissues & Procedures & Possible or Expected Findings \\
\hline External examination & Prepare chest roentgenogram. & $\begin{array}{l}300-500 \mathrm{~mL} \text { of fluid must be present before } \\
\text { it becomes visible. }\end{array}$ \\
\hline $\begin{array}{l}\text { Chest cavities and } \\
\text { chest organs }\end{array}$ & $\begin{array}{l}\text { Submit samples of pleural fluid for microbiologic } \\
\text { study (p. 102). These samples should be obtained } \\
\text { before the chest is opened because laceration of } \\
\text { the subclavian veins renders clear exudates or } \\
\text { transudates hemorrhagic. In true hemorrhagic } \\
\text { exudates, determination of the hematocrit value } \\
\text { may be useful. For cytologic study, spin down } \\
\text { pleural fluid and prepare smears and histologic } \\
\text { sections of pellet. Record volume of pleural fluid; } \\
\text { remove fluid with vacuum suction apparatus. } \\
\text { If the fluid is milky-white, dissect and record } \\
\text { appearance of thoracic duct system (p. 34). }\end{array}$ & $\begin{array}{l}\text { Myocardial infarction or other cardiac } \\
\text { abnormalities that may have caused } \\
\text { congestive heart failure;* pneumonia; } \\
\text { pulmonary infarction; tumor(s); bacterial, } \\
\text { fungal, or viral infection; immune connective } \\
\text { tissue disease; amebiasis; } * \text { trauma to thoracic } \\
\text { duct system; other causes. }\end{array}$ \\
\hline Other organs & & $\begin{array}{l}\text { Pancreatitis;* subphrenic empyema;* other } \\
\text { intra-abdominal disease, with or without } \\
\text { ascites. }\end{array}$ \\
\hline
\end{tabular}

Electricity (See "Injury, electrical.")

\section{Electrocution (See "Injury, electrical.”)}

\section{Electrolyte(s) (See "Disorder, electrolyte(s).”)}

\section{Elliptocytosis, Hereditary (See "Anemia, hemolytic.")}

\section{Embolism, Air}

NOTE: Possible causes include: (1) blood transfusion when the bottle had emptied unnoticed (particularly when the pressure in the bottle had been artificially increased or when a pump had been used); (2) injury to large veins, particularly cranial sinuses (during neurosurgical procedures) and veins of the neck (knife wounds, surgery) or uterus (criminal abortion); (3) insufflation of fallopian tubes (particularly in pregnancy or during menstrual period); (4) malfunctioning of dialysis machine; (5) positive-pressure ventilation in newborn infants; (6) subclavian vein catheterization in the semi-Fowler position; and (7) fracture in the hub of a central venous catheter used for parenternal nutrition.

\section{Autopsy Procedure and Diagnosis}

If air embolism is suspected, the autopsy should be performed as soon after death as possible. Decomposition gases may be produced within a few hours. Roentgenography of the whole body may detect large quantities of air, and the roentgenograms may serve as a guide to the most advantageous way of dissection.

Air embolism can be diagnosed if one succeeds in demonstrating, with an ophthalmoscope, air bubbles in the retinal arteries. This should be done as a first step of the autopsy in all cases in which this diagnosis is entertained. The cornea must be moistened with isotonic saline so that the opaqueness of it does not interfere with this method of diagnosing air embolism (1).
After the ophthalmoscopic examination, the prosector opens the thoracic cavity, lifts the bony chest plate, and clamps the internal mammary vessels below the sternoclavicular joints. (Particular care must be taken to clamp but not lacerate the upper thoracic or neck veins.) The prosector then cuts across the sternum distal to these clamped vessels so that the sternoclavicular joint area remains intact. The pericardial sac is carefully opened. Large fatal pulmonary air embolism is readily apparent. The right atrium and ventricle are distended with fine, frothy, brightred blood, which also may distend the pulmonary arteries and large systemic veins. The blood is fluid throughout the body, the viscera are congested, and petechiae are present in the serous surfaces and in the white matter of the brain. Microbiologic examination of blood and pericardial sac contents (p. 102) will help to rule out the presence of gas-forming bacteria that may simulate air embolism (Fig. II-1). However, the differentiation between air and decomposition gases should be done at the autopsy table with the pyrogallol test.

A $2 \%$ pyrogallol solution is prepared (it should be waterclear). Two $10-\mathrm{mL}$ syringes (syringe $A$ and syringe $B$ ) are loaded with $4 \mathrm{~mL}$ of the pyrogallol solution in each, without permitting any air to enter the system. Immediately before the solution is used, 4 drops of $0.5 \mathrm{~N} \mathrm{NaOH}$ is aspirated through the needle of syringe A to adjust the $\mathrm{pH}$ to about 8 ( 1 drop per $1 \mathrm{~mL}$ of solution); the mixture will turn faint yellow. Six $\mathrm{mL}$ of gas is then aspirated from the heart or blood vessels. The needle is immediately sealed with a cork or replaced by a cap, and the syringe is vigorously shaken for about $1 \mathrm{~min}$. In the presence of air, the pyrogallol solution will turn brown. If the solution remains clear, decomposition gases were present. In the latter instance, 4 drops of $0.5 \mathrm{~N} \mathrm{NaOH}$ and $6 \mathrm{~mL}$ of room air should be aspirated into syringe $\mathrm{B}$, which is then also sealed and shaken for $1 \mathrm{~min}$. The mixture should turn brown, thus serving as a control that the pyrogallol solution had been properly prepared. Syringe $B$ may also serve as a reserve. If only one syringe is used, the 


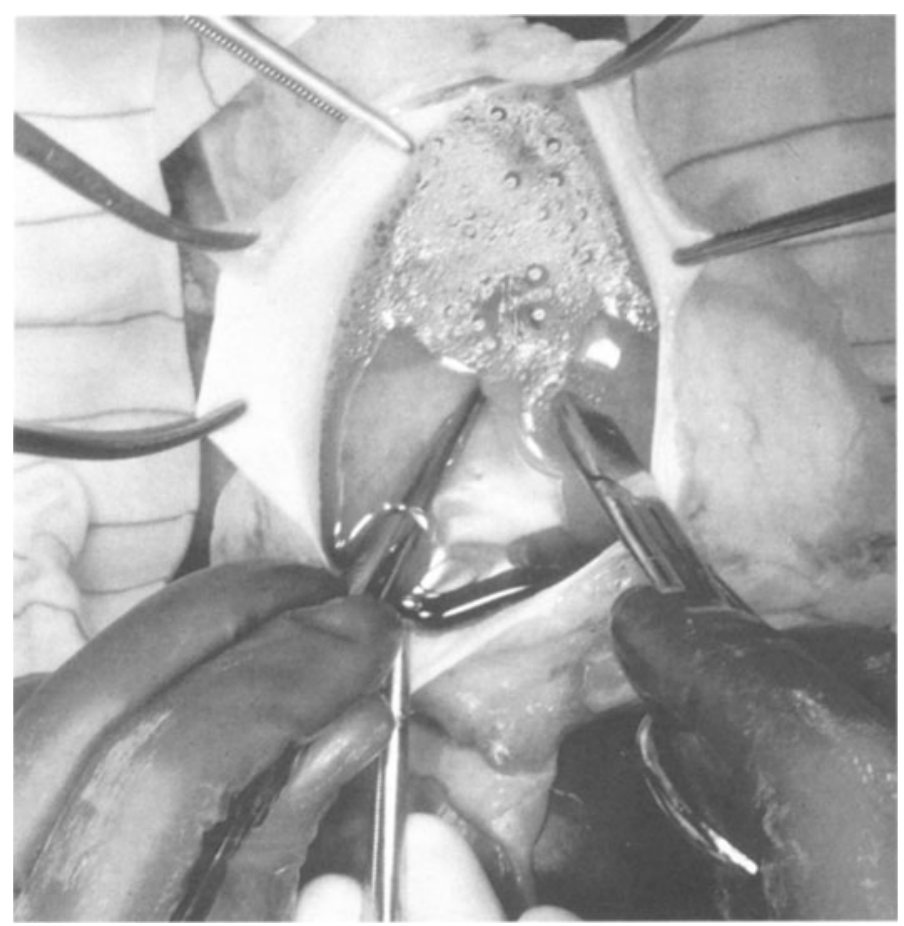

Fig. II-1. Gas-forming bacteria simulating air embolism. The pericardial sac is opened and filled with water. The heart is kept submerged with a pair of scissors. The coronary arteries have been incised with a scalpel. Note gas bubbles and foam on the water surface. No discoloration of $2 \%$ pyrogallol was noted. Blood cultures were positive for Enterococcus organisms. Microscopically, gram-negative rods were found in most tissues.

decomposition gas can be expelled and room air can be aspirated for the control test.

If only small amounts of gas can be aspirated, the volume of the pyrogallol solution should be decreased so that the gasfluid volume ratio is at least $3: 2$.

If no bacterial gas formation is present, the edges of the pericardial incision are elevated and the pericardial sac is filled with water. Clamping of the ascending aorta and venae cavae prevents the escape of gas into these vessels. The heart is held under water while the coronary arteries are incised, and the escape of bubbles is recorded. When the right coronary artery is opened, care must be taken that the right atrium is not incised. Air in the coronary arteries indicates systemic embolism. The heart chambers are then incised.

When there is gas in any of the arteries or heart chambers, gas bubbles rise to the surface of the water in the pericardial sac ("bubble test"). Sometimes the vessels have to be somewhat compressed in order to cause the gas to escape. Because large amounts of air or other gases cause the heart to float, it must be kept submerged before the vessels and chambers are incised. Basically the same procedure is used for demonstrating the presence of gas in the superior or inferior vena cava and the pelvic veins (for example, in cases of criminal abortion). In this situation, the abdominal cavity is filled with water and the inferior vena cava and its tributaries are incised.
For the diagnosis of systemic air embolism, the skull vault should be removed without puncturing the meninges, so that the meningeal vessels can be inspected for gas bubbles. The demonstration of gas bubbles in the meningeal vessels and in the circle of Willis is meaningful only when the neck vessels are still intact and the internal carotid artery and basilar artery have been clamped before the brain is removed. In acute cases, gas bubbles will be visible within the cerebral vessels. They are released under water when the clamps are removed and the vessels are slightly compressed.

For the collection of gas from blood vessels or cavities, a system of little quantitative reliability is an air-tight, waterfilled glass syringe with a needle. The needle is inserted into the vessel or cavity in question and gas is carefully aspirated.

A combined qualitative and quantitative method has been described by Kulka (2) (see Fig. II-2). He devised an apparatus for gas collection and described it as shown in Fig. II-2 and caption.

The entire system is filled with mineral oil so that, when the funnel is level with the upright bottle, the oil fills only about half of the funnel. In operation, the funnel is first raised to a position $30-40 \mathrm{~cm}$ above the level of the upright bottle. All the cocks are opened and the position is held until every trace of gas has been driven from the system through the needle, which is thereby coated on the inside by a film of oil. After all air has been expelled, the cocks are closed and the funnel is lowered to its original position.

As a precautionary measure and control, the air-tightness of the whole system should be tested before operation. This is done by inserting the needle into musculature or skin and attempting aspiration in the manner described in the next paragraph.

To make the test, the bottle is inverted and the needle is inserted into the cavity in question. When the needle is in position, all cocks are opened. The funnel is lowered about 70-90 $\mathrm{cm}$, or until adequate suction is created. This aspirates the contents of the cavity, which may consist of air or other gases, either pure or mixed with blood or other liquid. Any gas or liquid entering this system may be observed through the wall of the short bent glass tubing. In a positive test, gas bubbles will collect in the bottle above the level of the oil. If desired, this gas can be saved for further examination by closing all the cocks and returning the bottle to its upright position (4).

\section{Interpretation of Findings}

The volume of intravenous air needed to cause death in adults is probably in the range of $100 \mathrm{~mL}$. Very small amounts entering the systemic circulation may cause death within minutes. Delayed air embolism with fatal outcome may also occur.

\section{References}

1. Kevorkian J. The fundus oculi and the determination of death. Am J Pathol 1956;32:1253-1269.

2. Kulka W. A practical device for demonstrating air embolism. J Forens Med 1965; 12:3-7.

3. Kulka W. Laboratory methods and technical notes: a practical device for demonstrating air embolism. Arch Pathol 1949; 48:366-369.

4. Bajanowski T, West A, Brinkmann B. Proof of fatal air embolism. Int J legal Med 1998;111:208-211. 

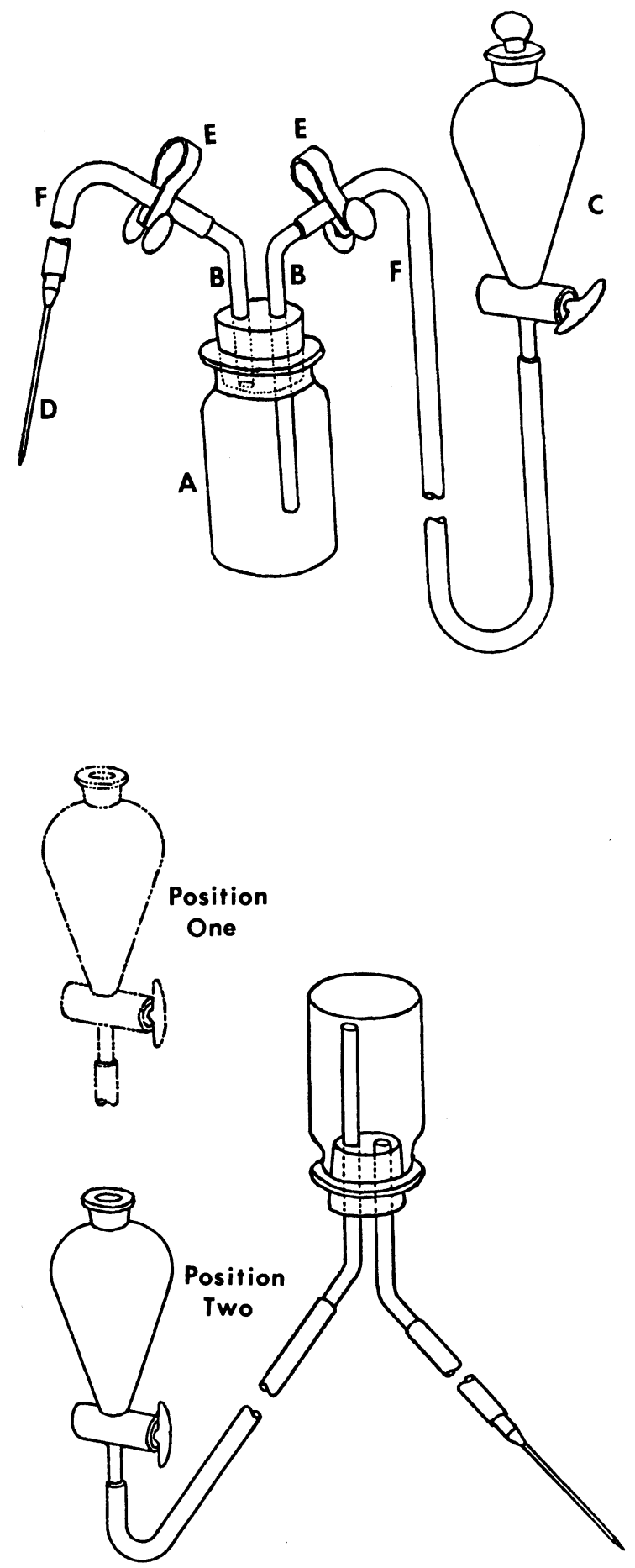

Fig. II-2. Apparatus for demonstration of air embolism. Top, Apparatus. Bottom, Position of separatory funnel during test. (A) One wide-mouth glass bottle (2-3 ounces; $60-90 \mathrm{~mL}$ ) fitted tightly with a two-hole rubber stopper. (B) Two sections of glass tubing, approx $3 \mathrm{~mm}$ inside diameter, each bent at an angle of $120^{\circ}$. One of these sections should be longer than the other. The shorter one should reach just through and be even with the inner surface of the stopper. The longer one should reach to within 1 or $1.5 \mathrm{~cm}$ of the bottom of the bottle. Both tubes should fit tightly into the holes of the stopper. (C) One separatory funnel (60$100 \mathrm{~mL}$, pear-shaped) connected to the longer section of bent glass tubing by rubber tubing $100 \mathrm{~cm}$ in length (F). An amber, pure gum rubber tubing, such as is used on blood-diluting pipets, has proved satisfactory. (D) One transfusion needle, 14- or 15-gauge and 4-5 cm long, connected to the shorter glass tube by a short $(<5 \mathrm{~cm})$ section of rubber tubing $(\mathrm{F})$. (E) Two pinchcocks, one for each length of tubing. They may be of the spring type or of the household syringe type. The latter will prove advantageous if the gas collected is to be transported for analysis. Adapted with permission from ref. (3). 


\section{Embolism, Amniotic Fluid}

\begin{tabular}{|c|c|c|}
\hline Organs and Tissues & Procedures & Possible or Expected Findings \\
\hline External examination & $\begin{array}{l}\text { If purpura is present, prepare photographs } \\
\text { and record extent. }\end{array}$ & Skin purpura. \\
\hline \multirow[t]{2}{*}{ Blood } & $\begin{array}{l}\text { Submit sample (from right atrium) for micro- } \\
\text { biologic study (p. 102). } \\
\text { Collect blood from right atrium and right } \\
\text { ventricle. After the heart has been removed, } \\
\text { allow blood in pulmonary vessels to pool in } \\
\text { the pericardial sac. }\end{array}$ & \\
\hline & $\begin{array}{l}\text { Centrifuge this blood and submit sample of } \\
\text { flocculent layer above buffy coat for micro- } \\
\text { scopic study (1). }\end{array}$ & $\begin{array}{l}\text { Vernix, lanugo hairs, and meconium can be } \\
\text { found in pericardial blood pool. }\end{array}$ \\
\hline Lungs & $\begin{array}{l}\text { Submit one lobe for bacteriologic study (p. 103). } \\
\text { Dissect pulmonary arteries (p. 45); prepare } \\
\text { histologic sections of all lobes; request muci- } \\
\text { carmine stain and the alcian blue and phloxine- } \\
\text { tartrazine stain of Lendrum (p. 172). } \\
\text { Also request Sudan stain on frozen sections } \\
\text { (p. 172). }\end{array}$ & $\begin{array}{l}\text { Meconium-type material in blood vessels. } \\
\text { In histologic sections, squamous epithelium, } \\
\text { meconium, and fat from vernix caseosa. }\end{array}$ \\
\hline Uterus and placenta & For dissection techniques, see p. 60. & $\begin{array}{l}\text { Complete or incomplete lower uterine tear; } \\
\text { chorioamnionitis. }\end{array}$ \\
\hline Other organs & & $\begin{array}{l}\text { Manifestations of disseminated intravascular } \\
\text { coagulation* and fibrinolysis. }\end{array}$ \\
\hline Lungs of stillborn & & Intrauterine pneumonia. \\
\hline
\end{tabular}

\section{Interpretation of Findings}

Large amounts of debris in the blood vessels of all sections of the lungs may be considered to be lethal if there is no other cause of death. Small amounts in one or more blocks of pulmonary tissue are more likely incidental (1). A small uterine tear is more likely followed by a fatal amniotic fluid embolization than is a large tear, which may result in fatal hemorrhage or fibrinogen depletion. Chorioamnionitis, intrauterine pneumonia, and positive lung cultures of the mother indicate infection of the amniotic fluid.

\section{Reference}

1. Attwood HD. Amniotic fluid embolism. In: Pathology Annual 1972. Sommers SC, Rosen PP, eds. Appleton-Century-Crofts, New York, 1972, pp. 145-172.

\section{Embolism, Arterial}

Synonyms and Related Terms: Arterial thromboembolism; atheroembolism; bone marrow embolism; embolic syndrome; foreign body embolism; paradoxic embolism; tumor embolism.

NOTE: A history of urinary eosinophilia may have been obtained in patients with renal atheroembolism.

\begin{tabular}{lll}
\hline Organs and Tissues & Procedures & Possible or Expected Findings
\end{tabular}

External examination Heart

Aorta and elastic artery branches
Record patency and size of oval foramen, or presence of septal defect(s).*

If infective endocarditis is suspected, follow procedures described on p. 103. For general dissection techniques, see p. 22.

For celiac or mesenteric arteriography, see p. 55.
Gangrene of extremities.

In presence of intracardiac right-to-left communication, paradoxic embolism may occur.

Infective endocarditis.*

Myocardial infarction; mural or valvular thrombi in left atrium or in left ventricle; atrial dilatation in patients who had atrial fibrillation; mitral or aortic valve prostheses. Thrombi on atheromatous ulcers; thrombi in aneurysms.

Embolism to celiac or mesenteric artery system. 


\begin{tabular}{lll}
\hline Organs and Tissues & Procedures & Possible or Expected Findings \\
\hline Other organs & & $\begin{array}{l}\text { Multiple infarctions may be present. See also } \\
\text { above under "Note." }\end{array}$ \\
Peripheral arteries & $\begin{array}{l}\text { Focalized arterial disease may simulate } \\
\text { embolism. This includes infectious arteritis, } \\
\text { see p. 21. For removal of femoral vessels } \\
\text { after embalming, see p. 34. Submit samples } \\
\text { of arteries and veins for histologic study. } \\
\text { Request Verhoeff-van Gieson stain (p. 173). }\end{array}$ & $\begin{array}{l}\text { such acterial arteritis after infective } \\
\text { endocarditis* or syphilitic or tuberculous } \\
\text { arteritis. }\end{array}$ \\
\hline
\end{tabular}

\section{Embolism, Cerebral (See “Infarction, cerebral.”)}

\section{Embolism, Fat}

NOTE: Formalin-fixed tissues can be postfixed with osmium tetroxide, embedded in epoxy or paraffin, and stained with toluidine blue, hematoxylin, or Oil red O. Fat emboli are more easily recognized than in frozen tissue after Oil Red O staining (l).

\begin{tabular}{|c|c|c|}
\hline Organs and Tissues & Procedures & Possible or Expected Findings \\
\hline \multirow[t]{3}{*}{ External extermination } & & $\begin{array}{l}\text { Petechial hemorrhages of skin (chest, neck, } \\
\text { and face). }\end{array}$ \\
\hline & Record evidence of trauma. & Wounds; other traumatic lesions. \\
\hline & Prepare skeletal roentgenograms. & Bone fractures. \\
\hline Eyes & For ophthalmoscopic examination, see p. 290. & Petechiae of conjunctivas and retinas. \\
\hline Blood & Pool blood from pulmonary arteries. & $\begin{array}{l}\text { Fat may accumulate on surface of blood pool. } \\
\text { No useful technique is available for } \\
\text { estimating the amount of fat globules in } \\
\text { the blood. }\end{array}$ \\
\hline Urine & Record presence of fat droplets. & \\
\hline $\begin{array}{l}\text { Lungs, myocardium, } \\
\text { spleen, adrenal glands, } \\
\text { kidneys }\end{array}$ & $\begin{array}{l}\text { Record weights. Prepare frozen sections of fresh } \\
\text { or formalin-fixed material. Request Sudan IV } \\
\text { or oil red O stain (p. 173). }\end{array}$ & $\begin{array}{l}\text { Fat emboli in lumen of small vessels and in } \\
\text { pulmonary air spaces. }\end{array}$ \\
\hline Liver & Record weight and sample for histologic study. & $\begin{array}{l}\text { Severe fatty changes may be the cause of fat } \\
\text { embolism. }\end{array}$ \\
\hline Bones & & $\begin{array}{l}\text { Fractures are the most common cause of fat } \\
\text { embolism. }\end{array}$ \\
\hline \multirow[t]{2}{*}{ Brain and spinal cord } & $\begin{array}{l}\text { For removal and specimen preparation, } \\
\text { see p. } 65 \text { and } 67 \text {, respectively. Photograph } \\
\text { horizontal sections through brain, brain stem, } \\
\text { and spinal cord. }\end{array}$ & Petechial hemorrhages. \\
\hline & $\begin{array}{l}\text { Prepare frozen sections and request Sudan stain } \\
\text { (p. 173). }\end{array}$ & Fat emboli. \\
\hline Pituitary gland & $\begin{array}{l}\text { For removal and specimen preparation, see p. } 71 . \\
\text { Prepare frozen sections of one-half of gland and } \\
\text { paraffin sections of the other half. }\end{array}$ & $\begin{array}{l}\text { Fat emboli and hemorrhages are common in } \\
\text { posterior lobe. }\end{array}$ \\
\hline
\end{tabular}

\section{Reference}

1. Davison PR, Cohle SD. Histologic detection of fat emboli. J Forensic Sci 1987;32:1426-1430.

\section{Embolism, Pulmonary}

Synonyms and Related Terms: Bone marrow embolism; foreign body embolism; pulmonary thromboembolism; tumor embolism.

NOTE: If air embolism, amniotic fluid embolism, or fat embolism is suspected, see under those headings. See also under "Phlebitis" and "Thrombosis, venous." 


\begin{tabular}{|c|c|c|}
\hline Organs and Tissues & Procedures & Possible or Expected Findings \\
\hline External examination & $\begin{array}{l}\text { Record circumference of legs, } 20 \mathrm{~cm} \text { above and } \\
\text { below patella. } \\
\text { For postmortem phlebography, see p. } 121 . \\
\text { Prepare chest roentgenogram. }\end{array}$ & $\begin{array}{l}\text { Leg edema accompanying venous } \\
\text { thrombosis. } \\
\text { Thrombosis most common in deep leg veins. } \\
\text { Infarction; pneumothorax* complicating } \\
\text { perforated pulmonary infarction. }\end{array}$ \\
\hline Pleural cavities & $\begin{array}{l}\text { Record volume and character of pleural } \\
\text { contents. }\end{array}$ & $\begin{array}{l}\text { Effusion }(\mathrm{s}) ; * \text { serofibrinous pleuritis; } \\
\text { empyema.* }\end{array}$ \\
\hline Heart & $\begin{array}{l}\text { In the presence of systemic embolism, record } \\
\text { patency of oval foramen or presence of septal } \\
\text { defect(s).* Open pulmonary arteries in situ. }\end{array}$ & $\begin{array}{l}\text { Paradoxic embolism. Mural thrombi in right } \\
\text { atrium or right ventricle. Thrombi on pacing } \\
\text { leads or indwelling central catheters. }\end{array}$ \\
\hline Lungs & $\begin{array}{l}\text { Inspect lumens of hilar pulmonary arteries to } \\
\text { detect emboli. Perfuse lungs for a brief period } \\
\text { during autopsy and then inspect slices to detect } \\
\text { peripheral emboli. }\end{array}$ & $\begin{array}{l}\text { Bland infarcts are more common in lower } \\
\text { lobes; infarct abscesses are more common in } \\
\text { upper lobes. }\end{array}$ \\
\hline Veins & $\begin{array}{l}\text { Remove and dissect femoral veins (after } \\
\text { embalming) and pelvic veins (p. } 34 \text { ). }\end{array}$ & $\begin{array}{l}\text { Phlebothrombosis or thrombophlebitis. } \\
\text { See also above under "Note." }\end{array}$ \\
\hline
\end{tabular}

\section{Emphysema}

Synonyms and Related Terms: Chronic obstructive lung disease; pulmonary emphysema; vanishing lung disease.

Possible Associated Conditions: Alpha ${ }_{1}$-antitrypsin deficiency; chronic bronchitis.*

\begin{tabular}{lll}
\hline Organs and Tissues & Procedures & Possible or Expected Findings \\
\hline External examination & $\begin{array}{l}\text { Prepare chest roentgenogram (roentgenograms } \\
\text { are of limited value for detecting or assessing } \\
\text { severity of emphysema). }\end{array}$ & $\begin{array}{l}\text { Cyanosis; clubbing of fingers. } \\
\text { Low diaphragm; pneumothorax.* Unilateral } \\
\text { emphysema (congenital lobar emphysema) } \\
\text { in infants. Incidental unilateral emphysema } \\
\text { in adults (Macleod's syndrome) }\end{array}$ \\
& Record weight of heart and thickness of & $\begin{array}{l}\text { Cor pulmonale. } \\
\text { Heart }\end{array}$
\end{tabular}

Pulmonary artery

Lungs

Diaphragm

Stomach and duodenum Liver

\section{Kidneys}

Bone marrow ventricles. For separate weighing of right and

left ventricles, see p. 26.

Record width of artery and appearance of intima. For histologic sections, request Verhoeff-van Gieson stain (p. 173).

For pulmonary arteriography and bronchography, see p. 50. For gaseous or perfusion fixation, slicing, barium impregnation, preparation of paper-mounted sections, see pp. 46 to 49 .

Submit one lobe for microbiologic study (p. 103).

Record thickness; submit specimens for histologic study.

For histologic sections, request PAS stain with diastase digestion (p. 173).

For preparation of sections and smears, see p. 96.
Pulmonary atherosclerosis; broken-up elastic membranes.

Rarefaction of pulmonary artery tree. Chronic bronchitis;* bronchial obstruction; pneumoconiosis.* Emphysema may be centriacinar (centrilobular), focal, giant bullous, irregular, panacinar (panlobular), or paraseptal (distal acinar), or it may be related to scars (para-cicratical airspace enlargement).

Haemophilus influenzae and Streptococcus pneumoniae or other infections.

Muscular hypertrophy.

Peptic ulcer(s).*

Centrilobular congestion. In alpha ${ }_{1}$-antitrypsin deficiency, ${ }^{*}$ PAS-positive, diastaseresistant hepatocellular intracytoplasmic globules.

Glomerular enlargement.

Increased erythropoiesis. 


\begin{tabular}{lll}
\hline Organs and Tissues & Procedures & Possible or Expected Findings \\
\hline Brain & $\begin{array}{l}\text { For removal and specimen preparation, } \\
\text { see p. 65. }\end{array}$ & $\begin{array}{l}\text { Anoxic changes in cortex, corpus striatum, } \\
\text { globus pallidus, thalamus, Sommer's sector } \\
\text { of hippocampus, and Purkinje cells of } \\
\text { cerebellum. Petechial hemorrhages of } \\
\text { hypothalamus and necrosis of cerebellar } \\
\end{array}$ \\
& folia may be present. \\
\hline
\end{tabular}

\section{Empyema, Epidural}

Synonym: Epidural abscess.

\begin{tabular}{lll}
\hline Organs and Tissues & Procedures & Possible or Expected Findings \\
\hline External examination & $\begin{array}{l}\text { Prepare roentgenogram of skull. } \\
\text { Cerebrospinal fluid }\end{array}$ & $\begin{array}{l}\text { Infected surgical wound(s). } \\
\text { Skull fracture(s). }\end{array}$ \\
$\begin{array}{l}\text { In order to avoid contamination, aspirate } \\
\text { infectious material for microbiologic study } \\
\text { as soon as calvarium can be lifted (p. 65)- } \\
\text { before complete removal of the calvarium. For } \\
\text { exposure of sinuses, middle ears, and adjacent } \\
\text { structures, see p. 71. }\end{array}$ & $\begin{array}{l}\text { Mastoiditis; osteomyelitis* of parietal, } \\
\text { mastoid, and other cranial bones; purulent } \\
\text { sinusitis; skull fracture(s); postoperative } \\
\text { state. }\end{array}$ \\
\hline
\end{tabular}

\section{Empyema, Pleural}

Synonym: Pyothorax.

\begin{tabular}{|c|c|c|}
\hline Organs and Tissues & Procedures & Possible or Expected Findings \\
\hline External examination & Prepare chest roentgenogram. & Pneumothorax.* \\
\hline Pleural cavities & $\begin{array}{l}\text { Record volume and appearance of empyema } \\
\text { fluid. Submit sample of empyema fluid for } \\
\text { microbiologic study (p. 102). } \\
\text { Prepare smears and request Gram, Kinyoun's, } \\
\text { and Grocott's methenamine silver stains (p. 172). } \\
\text { Submit tissue samples of visceral and parietal } \\
\text { pleura for histologic study. }\end{array}$ & $\begin{array}{l}\text { Seropurulent or purulent empyema fluid with } \\
\text { evidence of bacteria or fungi. Rarely other } \\
\text { infectious agents. }\end{array}$ \\
\hline Lungs & $\begin{array}{l}\text { Submit any consolidated areas for microbiologic } \\
\text { study (p. 103). }\end{array}$ & $\begin{array}{l}\text { Emboli; infarcts; abscesses; pneumonia } \\
\text { (various types); tuberculosis;* lung } \\
\text { abscess;* tumor;* surgical or other trauma. }\end{array}$ \\
\hline Other organs and tissues & & $\begin{array}{l}\text { Subphrenic empyema* and other intra- } \\
\text { abdominal inflammatory diseases. }\end{array}$ \\
\hline
\end{tabular}

\section{Empyema, Subdural}

Synonym: Subdural abscess.

NOTE: Autopsy procedures and possible or expected findings are essentially the same as those described under "Empyema, epidural."

\section{Empyema, Subphrenic}

Synonyms: Subdiaphragmatic abscess; subphrenic abscess.

\begin{tabular}{lll}
\hline Organs and Tissues & Procedures & Possible or Expected Findings \\
\hline Abdominal cavity & Submit sample of subphrenic exudate for & Possible causes of subphrenic empyema \\
& aerobic and anaerobic cultures (p. 102). & include appendicitis, cholecystitis,* \\
& Record location and volume of subphrenic & diverticulitis, intrahepatic abscess, \\
exudate. & pancreatitis, ${ }^{*}$ ruptured viscus; penetrating \\
& abdominal wound(s), perforated ulcer of \\
& stomach or duodenum, ${ }^{*}$ and other conditions.
\end{tabular}




\begin{tabular}{lll}
\hline Organs and Tissues & Procedures & Possible or Expected Findings \\
\hline Pleural cavities and lungs & $\begin{array}{l}\text { Record volume of effusion or exudate in } \\
\text { pleural space. }\end{array}$ & $\begin{array}{l}\text { Basal pleuritis and pneumonia, adjacent } \\
\text { to empyema. }\end{array}$ \\
\hline
\end{tabular}

\section{Encephalitis, All Types or Type Unspecified}

Synonyms and Related Terms: Acute disseminated encephalomyelitis;* acute hemorrhagic encephalitis; acute infective encephalitis or encephalomyelitis; acute poliovirus encephalitis or encephalomyelitis; amoebic encephalitis; Arbovirus encephalitis (Japanese encephalitis; eastern encephalitis, western encephalitis, venezuelan equine encephalitis, St. Louis encephalitis); bulbar encephalitis;* brain stem encephalitis;* herpes encephalitis (cytomegalovirus encephalits, Epstein-Barr virus encephalitis, varicella-zoster encephalitis); herpes simplex encephalitis; HIV encephalitis; measles encephalitis; measles inclusion body encephalitis; postinfectious encephalitis; postvac- cinal encephalitis; progressive multifocal leukoencephalitis or leukoencephalopathy; rabies* encephalitis; subacute encephalitis; subacute sclerosing panencephalitis; viral encephalitis, and many other terms (1), too numerous to mention. See also under "Note" and under "Possible or expected findings."

NOTE: If the condition that caused the encephalitis is known, see also under that heading. If the cause of the encephalitis is unknown, submit samples of tissue for microbiologic and toxicologic study, particularly if there is a suspicion of lead poisoning.* See also under "Encephalitis, brain stem," "Encephalomyelitis,...," "Encephalopathy" and "Myelopathy, Myelitis."

\begin{tabular}{ll}
\hline Organs and Tissues & Procedures \\
\hline Cerebrospinal fluid & Submit sample for microbiologic study. \\
& $\begin{array}{l}\text { Prepare cytospin. } \\
\text { Blood }\end{array}$ \\
& $\begin{array}{l}\text { Submit sample for microbiologic or } \\
\text { toxicologic study, or both. Freeze serum } \\
\text { sample for possible serologic study. }\end{array}$
\end{tabular}

Brain and spinal cord; $\quad$ For removal and specimen preparation, anterior and posterior see pp. 65, 67, and 71, respectively. spinal roots; sensory ganglia

Other organs For microbiologic study, submit sample of fresh cerebral tissue. If infectious agent is known and need not be confirmed, fix intact brain in formalin. For toxicologic sampling, see Chapter 6.

Microbiologic, toxicologic, and histologic studies may be indicated, depending on the expected underlying disease.

\section{References}

1. Esiri MM, Kennedy PGE. Viral diseases. In: Greenfield's Neuropathology, vol. 2. Graham BI, Lantos PL, eds. Arnold, London, 1997 , pp. 3-64.

2. Scaravilli F, Cook GC. Parasitic and fungal infections. In: Greenfield's Neuropathology, vol. 2. Graham BI, Lantos PL, eds. Arnold, London, 1997, pp. 65-112.

3. Gray F, Nordmann P. Bacterial infections. In: Greenfield's Neuropathology, vol. 2. Graham BI, Lantos PL, eds. Arnold, London, 1997, pp. 113152.

\section{Encephalitis, Brain Stem}

Synonyms and Related Terms: Brain stem abscess; infectious brain stem encephalitis; Listeria monocytogenes brain stem encephalitis; viral brain stem encephalitis.

NOTE: See also under "Encephalitis, limbic."

\begin{tabular}{lll}
\hline Organs and Tissues & Procedures & Possible or Expected Findings \\
\hline Brain & For removal and specimen preparation, & $\begin{array}{l}\text { Necrotizing encephalitis, with or without } \\
\text { abscess formation (1). }\end{array}$ \\
\hline
\end{tabular}

\section{Reference}

1. Hall WA. Infectious lesions of the brain stem. Neurosurg Clin North Am 1993;4:543-551. 


\section{Encephalitis, Herpes Simplex (See “Infection, herpes simplex.”)}

\section{Encephalitis, Limbic}

Synonyms and Related Terms: Brain stem encephalitis; limbic encephalopathy; paraneoplastic encephalomyelitis; paraneoplastic sensory neuropathy.

\begin{tabular}{|c|c|c|}
\hline Organs and Tissues & Procedures & Possible or Expected Findings \\
\hline $\begin{array}{l}\text { Blood and } \\
\text { cerebrospinal fluid }\end{array}$ & & $\begin{array}{l}\text { Commonly high titers of antibodies anti-Hu } \\
\text { (anti neuronal nuclear antibodies, type } 1 \text { or } \\
\text { ANNA 1) (1). }\end{array}$ \\
\hline $\begin{array}{l}\text { Brain, spinal cord, } \\
\text { and dorsal root ganglia }\end{array}$ & $\begin{array}{l}\text { For removal and specimen preparation, } \\
\text { see pp. } 65,67 \text {, and } 69 \text {, respectively. }\end{array}$ & $\begin{array}{l}\text { Neuronal degeneration; neuronophagia; } \\
\text { microglial nodules; gliosis in hippocampus, } \\
\text { brain stem, and dorsal root ganglia; } \\
\text { perivascular lymphoid infiltrates, especially } \\
\text { in nerve roots. }\end{array}$ \\
\hline Other organs & $\begin{array}{l}\text { See also under "Tumor...," depending on } \\
\text { expected primary site. }\end{array}$ & $\begin{array}{l}\text { Carcinoma (bronchogenic small cell } \\
\text { carcinoma in most instances; other primary } \\
\text { tumors include non-small cell lung cancer or } \\
\text { cancers of breast, ovary, uterus, and } \\
\text { stomach). }\end{array}$ \\
\hline
\end{tabular}

\section{Reference}

1. Moll JWB, Vecht CH. Immune diagnosis of paraneoplastic neurological disease. Clin Neurol Neurosurg 1995;97:71-81.

\section{Encephalomyelitis, Acute Disseminated}

Synonyms and Related Terms: Acute hemorrhagic necrotizing encephalomyelitis; acute perivascular myelinoclasis; allergic encephalomyelitis; perivenous encephalomyelitis; postinfectious or parainfectious encephalomyelitis; postrabies vaccinal encephalomyelitis; postvaccinal encephalomyelitis.

\begin{tabular}{lll}
\hline Organs and Tissues & Procedures & Possible or Expected Findings \\
\hline $\begin{array}{l}\text { Brain and spinal cord; } \\
\text { anterior and posterior } \\
\text { spinal roots; sensory } \\
\text { ganglia }\end{array}$ & $\begin{array}{l}\text { For removal and specimen preparation, } \\
\text { see pp. 65, 67, and 69, respectively. } \\
\text { Microscopic findings vary and depend } \\
\text { on the phase of the disease. }\end{array}$ & $\begin{array}{l}\text { In acute phase, swelling and congestion of } \\
\text { brain. Scattered perivenous demyelination } \\
\text { with histiocytic and lymphocytic infiltrates, } \\
\text { predominantly in white matter. Small } \\
\text { perivascular hemorrhages may be present. In } \\
\text { the hyperacute form of the condition (acute } \\
\text { hemorrhagic necrotizing encephalopathy), } \\
\text { swelling and congestion of the brain with }\end{array}$ \\
& $\begin{array}{l}\text { signs of herniation. Petechial hemorrhages in } \\
\text { the centrum semiovale white matter. }\end{array}$ \\
& $\begin{array}{l}\text { Neutrophilic perivascular infiltrates with } \\
\text { venule necrosis and fibrinous exudate. }\end{array}$ \\
\hline
\end{tabular}

\section{Encephalomyelitis, All Types or Type Unspecified}

Synonyms and Related Terms: Acute disseminated encephalomyelitis;* allergic encephalomyelitis; carcinomatous encephalomyelitis; hemorrhagic necrotizing encephalomyelitis; postinfectious or parainfectious encephalomyelitis; postrabies vaccinal encephalomyelitis; postvaccinal encephalomyelitis.

NOTE: For other related terms and for suggested procedures, see under "Encephalitis, ...," "Encephalomyelitis, acute disseminated," and "Myelopathy, Myelitis."

\section{Encephalomyopathy (See “Myopathy.")}

\section{Encephalopathy, Hepatic}

Synonyms and Related Terms: Acute hepatic encephalopathy; portal-systemic encephalopathy; Reye's syndrome.* 


\begin{tabular}{|c|c|c|}
\hline Organs and Tissues & Procedures & Possible or Expected Findings \\
\hline Brain and spinal cord & $\begin{array}{l}\text { For removal and specimen preparation, } \\
\text { see pp. } 65 \text { and } 67 \text {, respectively. }\end{array}$ & $\begin{array}{l}\text { In fulminant hepatic failure, cytotoxic } \\
\text { brain swelling with herniation and } \\
\text { Duret's hemorrhages. In portal systemic } \\
\text { encephalopathy, brain may be grossly } \\
\text { normal. Alzheimer type } 2 \text { astrocytes, with } \\
\text { pale watery nuclei (common in globus } \\
\text { pallidus, thalamus, and deep layers of cortex). }\end{array}$ \\
\hline Liver & $\begin{array}{l}\text { Procedures depend on suspected underlying } \\
\text { conditions as listed in right-hand column. }\end{array}$ & $\begin{array}{l}\text { Alcoholic liver disease; } * \text { cirrhosis; } * \text { massive } \\
\text { or submassive hepatic necrosis; } \\
\text { microvesicular fatty changes in Reye's } \\
\text { syndrome,* fatty liver of pregnancy, and } \\
\text { other conditions; poisoning with hepatotoxic } \\
\text { substances (e.g., mushroom poisoning with } \\
\text { Amanita phalloides). }\end{array}$ \\
\hline
\end{tabular}

\section{Encephalopathy, Hypertensive}

Synonyms and Related Terms: Acute hypertensive encephalopathy; Binswanger's disease; progressive subcortical encephalopathy; subcortical dementia.

NOTE: See also under "Hypertension (systemic arterial), all types or type unspecified."

\begin{tabular}{|c|c|c|}
\hline Organs and Tissues & Procedures & Possible or Expected Findings \\
\hline Brain & $\begin{array}{l}\text { For removal and specimen preparation, } \\
\text { see p. } 65 . \text { Request Luxol fast blue-PAS } \\
\text { stains (p. 172). }\end{array}$ & $\begin{array}{l}\text { Edema in sudden malignant hypertension. } \\
\text { Focal ischemic changes; intracerebral } \\
\text { hemorrhages. In Binswanger's disease, } \\
\text { multiple small old infarctions or patchy or } \\
\text { diffuse demyelination of the cerebral white } \\
\text { matter is present, associated with sclerosis of } \\
\text { small arteries. Demyelination and infarctions } \\
\text { may occur together. Infarctions may be } \\
\text { present in other portions of the brain. }\end{array}$ \\
\hline $\begin{array}{l}\text { Heart, kidneys, vascular } \\
\text { system, and other organs }\end{array}$ & & $\begin{array}{l}\text { Causes (e.g., chronic renal disease) and } \\
\text { manifestations of acute or chronic } \\
\text { hypertension. }\end{array}$ \\
\hline
\end{tabular}

\section{Encephalopathy, Type Unspecified}

Related Term: Toxic encephalopathy.

NOTE: If a specific toxic exposure is expected—for example, lead poisoning, see under that heading.

\section{Enchondromatosis, Multiple (See "Dyschondroplasia, Ollier's.")}

\section{Endocarditis, Infective}

Synonyms and Related Terms: Acute endocarditis; bacterial endocarditis; prosthetic valve endocarditis; subacute endocarditis.

Possible Associated Conditions: See below under "Possible or Expected Findings."

\begin{tabular}{lll}
\hline Organs and Tissues & Procedures & Possible or Expected Findings \\
\hline $\begin{array}{l}\text { External examination } \\
\text { and skin; peripheral }\end{array}$ & $\begin{array}{l}\text { If jaundice is present, search for evidence } \\
\text { of gonococcal infection. }\end{array}$ & $\begin{array}{l}\text { Manifestations of malnutrition; jaundice; } \\
\text { clubbing of fingers and toes; petechial } \\
\text { veins }\end{array}$ \\
& Record skin changes and prepare photographs. & $\begin{array}{l}\text { hemorrhages of skin and mucous membranes; } \\
\text { splinter hemorrhages of nail beds. }\end{array}$ \\
& $\begin{array}{l}\text { Needle marks, furuncles, and other skin } \\
\text { infections or scars may indicate dependence } \\
\text { on intravenous drug(s).* }\end{array}$
\end{tabular}




\begin{tabular}{|c|c|c|}
\hline Organs and Tissues & Procedures & Possible or Expected Findings \\
\hline $\begin{array}{l}\text { External examination } \\
\text { and skin; peripheral } \\
\text { veins (continued) }\end{array}$ & $\begin{array}{l}\text { If intravenous catheter is present, leave in } \\
\text { place, tie vessel proximally and distally from } \\
\text { tip, and submit for microbiologic study. If this } \\
\text { is not possible, prepare smears and sections of } \\
\text { thrombus at tip of catheter. Request Gram and } \\
\text { Grocott's methenamine silver stains (p. 172). } \\
\text { Submit tip for culture, even if it is contaminated. } \\
\text { Record appearance of oral cavity. } \\
\text { Prepare chest roentgenogram. }\end{array}$ & $\begin{array}{l}\text { Infected surgical arteriovenous shunts; } \\
\text { infected intravenous catheters, including } \\
\text { devices in surgically treated patients with } \\
\text { hydrocephalus.* }\end{array}$ \\
\hline Eyes & For removal and specimen preparation, see p. 85. & $\begin{array}{l}\text { Petechial hemorrhages of conjunctivas; } \\
\text { Roth's spots. }\end{array}$ \\
\hline Blood & $\begin{array}{l}\text { If cultures had not been prepared antemortem, } \\
\text { submit samples for bacterial and fungal cultures } \\
\text { (p. 102). Request aerobic and anaerobic bacterial } \\
\text { cultures. Freeze serum sample for serologic study. }\end{array}$ & Septicemia. \\
\hline Heart & $\begin{array}{l}\text { For sterile removal of infectious material, see } \\
\text { p. } 103 \text {. Photograph valvular lesions; prepare } \\
\text { sections of vegetations; request Gram and } \\
\text { Grocott's methenamine silver stains (p. 172). } \\
\text { For coronary arteriography, see p. } 118 \text {. } \\
\text { For collection of nonvalvular tissue for histo- } \\
\text { logic study, see p. } 30 \text {. }\end{array}$ & $\begin{array}{l}\text { Rheumatic valvulitis; congenital cardiac } \\
\text { malformations; prosthetic valve(s) with } \\
\text { valvular ring abscesses; mycotic aneurysms } \\
\text { of ascending aorta; valvular perforations. } \\
\text { Coronary arterial emboli. } \\
\text { Myocardial infarction; myocardial abscesses. }\end{array}$ \\
\hline Arteries and veins & $\begin{array}{l}\text { For histologic sections, request Verhoeff- } \\
\text { van Gieson stain (p. 173). }\end{array}$ & Mycotic aneurysms; septic thrombophlebitis. \\
\hline Lungs & & $\begin{array}{l}\text { Metastatic abscesses-for instance, after } \\
\text { right-sided endocarditis in heroin addicts. }\end{array}$ \\
\hline $\begin{array}{l}\text { Intestinal tract } \\
\text { and mesentery }\end{array}$ & $\begin{array}{l}\text { Dissect mesenteric arteries. Other procedures } \\
\text { depend on expected findings or grossly identified } \\
\text { abnormalities as listed in right-hand column. }\end{array}$ & $\begin{array}{l}\text { Mesenteric emboli; intestinal infarction. } \\
\text { Adenocarcinoma of colon may be associated } \\
\text { with Strep. bovis endocarditis. }\end{array}$ \\
\hline Spleen & Record size and weight. & Infarctions or abscesses, or both. \\
\hline Liver & & Alcoholic liver disease. \\
\hline Kidneys & $\begin{array}{l}\text { For histologic sections, request } 4-\mu \mathrm{m} \text { sections, } \\
\text { stained with PAS and with methenamine silver } \\
\text { for glomerular lesions (p. 173). }\end{array}$ & $\begin{array}{l}\text { Glomerulitis. Macroscopically, minute } \\
\text { hemorrhages, infarctions, and abscesses may } \\
\text { be present. }\end{array}$ \\
\hline Internal genital organs & & $\begin{array}{l}\text { Complications of abortion;* gonococcal } \\
\text { infection. }\end{array}$ \\
\hline Bones & $\begin{array}{l}\text { For removal; prosthetic repair, and specimen } \\
\text { preparation, see p. } 95 \text {. }\end{array}$ & Osteomyelitis.* \\
\hline Brain & $\begin{array}{l}\text { For removal and specimen preparation, } \\
\text { see p. } 65 \text {. If cerebral involvement is suspected, } \\
\text { submit sample for microbiologic study (p. 102). }\end{array}$ & $\begin{array}{l}\text { Infarctions, abscesses, or hemorrhages; } \\
\text { mycotic aneurysms. }\end{array}$ \\
\hline
\end{tabular}

Endocarditis, Löffler's (See “Cardiomyopathy, restrictive [with eosinophilia].”)

\section{Endocarditis, Nonbacterial Thrombotic (NBTE)}

Synonyms and Related Terms: Libman-Sacks verrucous nonbacterial endocarditis; marantic endocarditis; verrucous endocarditis.

NOTE: A history of multiple miscarriages may have been obtained.

Possible Associated Conditions: Disseminated intravascular coagulation;* antiphospholipid antibody syndrome; lupus anticoagulant.

\begin{tabular}{lll}
\hline Organs and Tissues & Procedures & Possible or Expected Findings \\
\hline Heart & $\begin{array}{l}\text { If the diagnosis is suspected, photograph } \\
\text { and remove vegetations, as described for }\end{array}$ & $\begin{array}{l}\text { The mitral valve is usually affected, without } \\
\text { other valvular abnormalities. }\end{array}$
\end{tabular}

infective endocarditis, and submit portions for

microbiologic (p. 103) and histologic study. 


\begin{tabular}{lll}
\hline Organs and Tissues & Procedures & Possible or Expected Findings \\
\hline $\begin{array}{l}\text { Heart } \\
\text { (continued) }\end{array}$ & $\begin{array}{l}\text { Prepare histologic sections of vegetations and } \\
\text { of affected valve(s). If microorganisms appear } \\
\text { to be present, request Gram stain (p. 172). } \\
\text { Procedures depend on expected findings or } \\
\text { grossly identified abnormalities as listed in } \\
\text { right-hand column. }\end{array}$ & $\begin{array}{l}\text { Emboli and infarctions. Possible underlying } \\
\text { conditions include carcinoma of the lung, } \\
\text { pancreas, stomach, and other, primarily } \\
\text { mucus-producing adenocarcinomas, systemic } \\
\text { systemic lupus erythematosus, }{ }^{*} \text { antiphospho- } \\
\text { lipid syndrome, and chronic debilitating } \\
\text { diseases. }\end{array}$ \\
\hline
\end{tabular}

Enteritis, All Types or Type Unspecified

(See "Enterocolitis,...," "Enteropathy,...," "Gastroenteritis, eosinophilic," and names of specific infectious diseases, such as "Fever, typhoid," or possible noninfectious underlying conditions, such as "Shock.")

\section{Enteritis, Eosinophilic}

(See "Gastroenteritis, eosinophilic.")

\section{Enteritis, Granulomatous (See “Disease, Crohn's.”)}

\section{Enteritis, Necrotizing}

Synonyms and Related Terms: Clostridial gastroenteritis; Darmbrand; enteritis necroticans.

NOTE: Follow procedures described under "Enterocolitis, pseudomembranous." Clostridial enterotoxemia (C. perfringens) seems to be the cause of necrotizing enteritis. Hemorrhagic necrosis of the small bowel mucosa with pseudomembranes, ulcers, and peritonitis is the main finding at autopsy.
Enteritis, Other Types or Type Undetermined (See "Enterocolitis, Other types or Type Undetermined.)

\section{Enteritis, Regional (See “Disease, Crohn's.”)}

\section{Enterocolitis, Ischemic}

Synonyms and Related Terms: Hemorrhagic enteropathy; hemorrhagic necrosis (gangrene; infarction) of intestine; intestinal ischemia; ischemic enteritis; ischemic colitis; pseudomembranous enterocolitis.*

NOTE: It is assumed here that the intestinal changes are clearly ischemic. If primary infection may be the cause of the condition, see below under "Enterocolitis, neutropenic," Enterocolitis, pseudomembranous," and "Enterocolitis, staphylococcal." In ischemic enterocolitis, superinfection should be ruled out and therefore, appropriate studies may be needed also: (1) Collect all tissues that appear to be infected. (2) Request aerobic and anaerobic bacterial cultures. (3) Request Gram stain (p. 172). (4) No special precautions are indicated. (5) Serologic studies are not available. (6) This is not a reportable disease.

\begin{tabular}{lll}
\hline Organs and Tissues & Procedures & Possible or Expected Findings \\
\hline $\begin{array}{l}\text { Intestinal tract and } \\
\text { mesentery }\end{array}$ & $\begin{array}{l}\text { For mesenteric arteriography, see p. 55. Dissect } \\
\text { mesenteric vessels. If infection is expected as a } \\
\text { cause, submit portions of intestine for aerobic } \\
\text { and anaerobic cultures (p. 102). For } \text { in situ } \\
\text { perfusion fixation of intestine, see p. 54. }\end{array}$ & $\begin{array}{l}\text { Emboli, atherosclerosis, or other conditions } \\
\text { that may cause obstruction of mesenteric } \\
\text { arteries. Primary or secondary thrombosis } \\
\text { of mesenteric veins. Fibrinous ischemic } \\
\text { membranes or pseudomembranes and }\end{array}$ \\
& & $\begin{array}{l}\text { ulcers may be present in small and large } \\
\text { intestine. }\end{array}$ \\
Other organs & Manifestations of hypotension and shock.* \\
\hline
\end{tabular}

Enterocolitis, Neutropenic

Synonyms and Related Terms: C. septicum enterocolitis; necrotizing cecitis or typhlitis.

NOTE: (1) Collect all tissues that appear to be infected. (2) Request aerobic and anaerobic bacterial cultures. (3) Request Gram stain (p. 172). (4) No special precautions are indicated. (5) Serologic studies are not available. (6) This is not a reportable disease.

\begin{tabular}{ll}
\hline Organs and Tissues & Procedures \\
\hline Intestinal tract & Collect material from lesions in cecum for \\
& aerobic and anaerobic culture. Sample for \\
& histologic study (p. 54).
\end{tabular}

Other organs

and tissues

\section{Possible or Expected Findings}

C. septicum infection (or infection with other Clostridiae) with ulcers, hemorrhages, and pseudomembranes, primarily in cecum and ascending colon.

Malignancies that required chemotherapy or other conditions associated with neutropenia and treatment with antibiotics. 


\section{Enterocolitis, Other Types or Type Undetermined}

NOTE: A multitude of infectious and noninfectious agents may cause inflammation of the small bowel, large bowel, or both. If the condition is not listed under "Colitis," "Enteritis," or "Enterocolitis" or under another specific heading such as "Dysentery, bacillary," obtain sufficient material for microbiologic and histologic study to identify organisms such as Clostridium, Chlamydia, Shigella, Salmonella, Yersinia, Helicobacter, verotoxic E. coli, and others. If lymphogranuloma venereum,* or tuberculosis* are suspected, see also under these headings. See also under "Disease, inflammatory bowel" and "Disease, Crohn's."

\section{Enterocolitis, Pseudomembranous}

Synonyms and Related Terms: $C$. difficile colitis; Darmbrand; hemorrhagic necrosis (gangrene; infarction) of intes- tine; ischemic enteritis or enterocolitis; ${ }^{*}$ neutropenic enterocolitis;* pseudomembranous colitis.

NOTE: The name "Pseudomembranous enterocolitis" is descriptive; the condition may be infectious, ischemic, or both. If the intestinal changes are clearly ischemic, see above under "Enterocolitis, ischemic." If the cause is in doubt and if pseudomembranes can be identified, follow the procedures described here.

(1) Collect all tissues that appear to be infected. (2) Request aerobic and anaerobic bacterial cultures. (3) Request Gram stain (p. 172). (4) No special precautions are indicated. (5) Serologic studies are not available. (6) This is not a reportable disease.

For other infectious intestinal diseases, see under specific names, such as "Enterocolitis, neutropenic" or "Enterocolitis, staphylococcal."

\begin{tabular}{lll}
\hline Organs and Tissues & Procedures & Possible or Expected Findings \\
\hline $\begin{array}{l}\text { Intestinal tract } \\
\text { and mesentery }\end{array}$ & $\begin{array}{l}\text { Collect material from pseudomembranes for } \\
\text { aerobic and anaerobic culture (p. 102) and for } \\
\text { C. difficile toxin assay. }\end{array}$ & $\begin{array}{l}\text { Bacterial growth (C. difficile or verocyto- } \\
\text { toxin producing E. coli or other organisms } \\
\text { such as Shigelladysenteriae). Generally, the } \\
\text { condition is confined to the colon. }\end{array}$ \\
& $\begin{array}{l}\text { Sample intestinal wall with pseudomembranes } \\
\text { for histologic study. }\end{array}$ & $\begin{array}{l}\text { Lamellated pseudomembranes with much } \\
\text { mucin and layers of neutrophils and necrotic } \\
\text { epithelial cells. Mucous glands distended }\end{array}$ \\
& with mucin. Gram-positive bacilli in exudate.
\end{tabular}

Enterocolitis, Staphylococcal

Related Term: Staphylococcal diarrhea.

NOTE: (1) Collect all tissues that appear to be infected. (2) Request aerobic bacterial cultures. (3) Request Gram stain (p. 172). (4) No special precautions are indicated. (5) Usually, serologic studies are not helpful. (6) This is not a reportable disease.

\begin{tabular}{lll}
\hline Organs and Tissues & Procedures & Possible or Expected Findings \\
\hline $\begin{array}{l}\text { External examination } \\
\text { Gastrointestinal tract }\end{array}$ & $\begin{array}{l}\text { Culture contents of stomach, small intestine, } \\
\text { and large intestine (p. 102). Prepare sections and } \\
\text { Gram-stained smears of mucus on intestinal wall. } \\
\text { Procedures depend on expected findings as listed } \\
\text { in right-hand column. }\end{array}$ & $\begin{array}{l}\text { Dehydration. } \\
\text { Sther ondoccus aureus. }\end{array}$ \\
& $\begin{array}{l}\text { Conditions that may have required } \\
\text { administration of antibiotics. Previous } \\
\text { surgery. }\end{array}$ \\
\hline
\end{tabular}

\section{Enteropathy, Gluten-Sensitive (See “Sprue, celiac.")}

\section{Enteropathy, Hemorrhagic (See "Enterocolitis, pseudomembranous.")}

\section{Enteropathy, Protein-Losing}

NOTE: This a collective name for a diverse group of diseases and conditions that cause gastrointestinal protein loss. Carcinoma of the esophagus, heart diseases, ${ }^{*}$ nephrosis, and primary immunodeficiency syndrome also may be causes of this condition. 


\begin{tabular}{|c|c|c|}
\hline Organs and Tissues & Procedures & Possible or Expected Findings \\
\hline Heart & $\begin{array}{l}\text { Dissection procedures depend on the specific } \\
\text { type of heart disease. }\end{array}$ & $\begin{array}{l}\text { Atrial septal defect; }{ }^{*} \text { primary } \\
\text { cardiomyopathy; }{ }^{*} \text { constrictive pericarditis.* } \\
\text { Other conditions associated with congestive } \\
\text { heart failure. }{ }^{*}\end{array}$ \\
\hline Esophagus & $\begin{array}{l}\text { If a carcinoma is present, see also under } \\
\text { "Tumor of the esophagus." }\end{array}$ & Carcinoma.* \\
\hline Stomach & $\begin{array}{l}\text { For fixation and specimen preparation, } \\
\text { see p. } 53 . \text { If a carcinoma is present, see also } \\
\text { under "Tumor of the stomach." }\end{array}$ & $\begin{array}{l}\text { Allergic gastroenteropathy; carcinoma; giant } \\
\text { hypertrophy of mucosa (Ménétrier's } \\
\text { disease); atrophic gastritis. Status post } \\
\text { gastrectomy. }\end{array}$ \\
\hline \multirow[t]{2}{*}{ Small intestine } & $\begin{array}{l}\text { For postmortem lymphangiography, see } \\
\text { p. } 34 \text {. For in situ fixation and for preparation of } \\
\text { intestinal mucosa for study under the dissecting } \\
\text { microscope, see p. } 54 \text {. For histologic sections, } \\
\text { request PAS and azure-eosin stains (p. 172). }\end{array}$ & $\begin{array}{l}\text { Allergic gastroenteropathy; celiac* or } \\
\text { tropical sprue;* Crohn's disease; intestinal } \\
\text { lymphangiectasia; jejunal diverticulosis; } \\
\text { lymphenteric fistula; lymphoma* and other } \\
\text { malignancies; primary tuberculosis;* other } \\
\text { infectious intestinal diseases (see also under }\end{array}$ \\
\hline & $\begin{array}{l}\text { If infectious intestinal disease is suspected, } \\
\text { submit portions of intestine for microbiologic } \\
\text { study (p. 102). }\end{array}$ & “Enterocolitis,...”); Whipple’s disease.* \\
\hline Colon & $\begin{array}{l}\text { Procedures depend on expected findings or } \\
\text { grossly identified abnormalities as listed in } \\
\text { right-hand column. }\end{array}$ & $\begin{array}{l}\text { Carcinoma and other malignancies; chronic } \\
\text { ulcerative colitis or Crohn's disease;* } \\
\text { megacolon. }\end{array}$ \\
\hline Other organs & $\begin{array}{l}\text { Procedures depend on expected findings or } \\
\text { grossly identified abnormalities as listed in } \\
\text { right-hand column. }\end{array}$ & $\begin{array}{l}\text { Manifestations of malabsorption syndrome* } \\
\text { with osteomalacia;* manifestations of } \\
\text { congestive heart failure.* Conditions } \\
\text { associated with nephrotic syndrome; } \\
\text { systemic sclerosis* (sclerodema) in cases } \\
\text { with involvement of small intestine. }\end{array}$ \\
\hline
\end{tabular}

Eosinophilia, Tropical Pulmonary (See "Syndrome, eosinophilic pulmonary.")

\section{Epiglottiditis (See "Laryngitis.")}

Epilepsy, Idiopathic (Cryptogenic)

Related Term: Status epilepticus.

\begin{tabular}{|c|c|c|}
\hline Organs and Tissues & Procedures & Possible or Expected Findings \\
\hline Brain & $\begin{array}{l}\text { For removal and specimen preparation, } \\
\text { see p. } 65 . \text { Histologic sections should include } \\
\text { (as a minimum) both hippocampi, cerebellar } \\
\text { cortex, cerebral cortex, and thalami. }\end{array}$ & $\begin{array}{l}\text { By definition, no gross changes or histologic } \\
\text { lesions are demonstrable that could be } \\
\text { responsible for seizures. In chronic epilepsy, } \\
\text { secondary tissue changes, attributable to } \\
\text { repeated anoxic episodes, are found. These } \\
\text { include hippocampal sclerosis and Purkinje } \\
\text { cell loss in cerebellum and changes } \\
\text { attributable to closed head injury, }{ }^{*} \text { such as } \\
\text { superficial contusions in frontal or temporal } \\
\text { lobes. }\end{array}$ \\
\hline Other organs & & $\begin{array}{l}\text { For possible side effects of therapy, see } \\
\text { "Epilepsy, symptomatic." }\end{array}$ \\
\hline
\end{tabular}

\section{Epilepsy, Myoclonus}

Synonyms and Related Terms: Baltic myoclonus; Lafora's disease; Lafora body disease; progressive myoclonus epilepsy with Lafora bodies; progressive myoclonus epilepsy without Lafora bodies; Unverricht-Lundborg disease.

NOTE: Myoclonic seizures also have been described in a number of progressive encephalopathies with complex neurological symptoms, such as GM1 and GM2 gangliosidosis, * and Niemann-Pick* and Krabbe's disease but also acquired disorders, including 


\section{Epilepsy, Myoclonus (continued)}

Alzheimer's disease, ${ }^{*}$ Creutzfeldt-Jakob disease, ${ }^{*}$ posthypoxic encephalopathy, and subacute sclerosing panencephalitis. Mitochondrial encephalomyopathy also can present with myoclonus epilepsy and a mitochondrial myopathy with ragged red fibers (MERRF syndrome) in skeletal muscles.

\begin{tabular}{ll}
\hline Organs and Tissues & Procedures \\
\hline Brain & For removal and specimen preparation, see \\
& p. 65. For histologic sections, request methyl \\
& violet or toluidine blue, Alcian blue, and PAS \\
& stains, with and without diastase digestion \\
& (p. 172).
\end{tabular}

Other organs and tissues, including eyes and peripheral nerves

Skeletal muscles
For removal and specimen preparation of eyes, see p. 85. For sampling and specimen preparation of peripheral nerves, see p. 79. For histologic sections, request methyl violet or toluidine blue stain and PAS stain with and without diastase digestion (p. 173). For removal and specimen preparation, see p. 80. Request modified Gomori's trichrome stain.
Possible or Expected Findings

Mild cortical atrophy. Diffuse neuronal loss with mild astrocytosis. In Lafora's disease, basophilic, metachromatic, PAS-positive, diastase-resistant, single or multiple (1-30 $\mu \mathrm{m}$ diameter) intracytoplasmic neuronal inclusion bodies (Lafora bodies), primarily in cerebral cortex (central region and prefrontal motor cortex), thalamus, globus pallidus, substantia nigra, cerebellar cortex, and dentate nuclei. Cerebellar atrophy (Dilantin).

Lafora-body-type material in the heart, liver, retinas, peripheral nerves, skeletal muscles, and sweat gland ducts (especially axillary).

\section{Ragged red fibers in mitochondrial} myopathies.

\section{Epilepsy, Symptomatic}

NOTE: Possible causes or underlying conditions include cerebrovascular diseases, congenital malformations of the brain, degenerative and demyelinating diseases of the brain, head injury,* intracranial and cerebral infections, toxic or metabolic disorders (alcoholism, ${ }^{*}$ barbiturate, ${ }^{*}$ carbon monoxide, ${ }^{*}$ and lead poisoning, ${ }^{*}$ hemodilution, hypocalcemia, or hypoglycemia), ${ }^{*}$ and tumors of the brain.*

\begin{tabular}{|c|c|}
\hline Organs and Tissues & Procedures \\
\hline External examination & $\begin{array}{l}\text { If gum hypertrophy or hirsutism are present, } \\
\text { record and prepare photographs. Record skin } \\
\text { changes and presence or absence of lymph- } \\
\text { adenopathy. }\end{array}$ \\
\hline
\end{tabular}

Brain

For removal and specimen preparation, see p. 65. For histologic sampling, see also under "Epilepsy, idiopathic (cryptogenic)., For cerebral arteriography, see p. 80. If intracranial infection is suspected, follow procedures described on p. 102.

Other organs
If a toxic or metabolic disorder is suspected, submit samples of body fluids and tissues for toxicologic study (p. 16).

\section{Possible or Expected Findings}

Gum hypertrophy, hirsutism (in young women), and lymphadenopathy may be found in patients who received phenytoin (Dilantin); drug-related dermatitis may be found also.

See above under "Note."

Cerebrovascular abnormalities. Intracranial and cerebral infections.

Complications of anticonvulsive therapy: agranulocytosis (carbamazepine), megaloblastic anemia* (barbiturates) or liver damage (dilantin, valproic acid).

\section{Erythema Multiforme}

Synonyms and Related Terms: Erythema exudativum multiforme major; Stevens-Johnson syndrome; toxic epidermal necrolysis.

NOTE: The histologic changes of erythema multiforme, Stevens-Johnson syndrome, and toxic epidermal necrolysis may be quite similar (1). 


\begin{tabular}{|c|c|c|}
\hline Organs and Tissues & Procedures & Possible or Expected Findings \\
\hline $\begin{array}{l}\text { External examination } \\
\text { and skin }\end{array}$ & $\begin{array}{l}\text { Record extent and character of skin lesions. } \\
\text { Submit samples of affected and of unaffected } \\
\text { skin for histologic study. Record extent and } \\
\text { character of lesions in oral cavity. }\end{array}$ & $\begin{array}{l}\text { Macules; papules; vesicles; bullae; } \\
\text { hemorrhages. Vulvitis may be present. } \\
\text { Ulcers, fissures, and hemorrhagic lesions } \\
\text { of oral cavity. }\end{array}$ \\
\hline Pleural cavities & & Effusion(s).* \\
\hline Lungs & $\begin{array}{l}\text { Submit one lobe for microbiologic study } \\
\text { (p. 103). Perfuse one lung with formalin (p. 47). }\end{array}$ & Bronchitis;* bronchopneumonia. \\
\hline Heart & & Pericarditis.* \\
\hline Other organs & $\begin{array}{l}\text { Record appearance of all mucosal surfaces. } \\
\text { Submit samples for histologic study. } \\
\text { Other procedures depend on expected findings } \\
\text { or grossly identified abnormalities as listed in } \\
\text { right-hand column. }\end{array}$ & $\begin{array}{l}\text { Laryngitis;* pharyngitis; esophagitis; } \\
\text { colitis; vaginitis; urethritis. Possible } \\
\text { underlying diseases include nephritis, } \\
\text { infectious disease, collagen disease, and } \\
\text { malignant tumor. Radiation treatment may } \\
\text { have been given also. }\end{array}$ \\
\hline Eyes & $\begin{array}{l}\text { For removal and specimen preparation, } \\
\text { see p. } 85 \text {. }\end{array}$ & $\begin{array}{l}\text { Conjunctivitis; iritis, iridocyclitis; } \\
\text { panophthalmitis. }\end{array}$ \\
\hline Other organs and tissues & & $\begin{array}{l}\text { Lymphoma* (with erythema multiforme as } \\
\text { paraneoplastic syndrome) (2). }\end{array}$ \\
\hline
\end{tabular}

\section{References}

1. Rzany B, Hering O, Mockenhaupt M, Schroder W, Goerttler E, Ring J, Schopf E. Histopathological and epidemiological characteristics of patients with erythema exudativum multiforme major, Stevens Johnson syndrome and toxic epidermal necrolysis. Br J Dermatol 1996;135:6-11.

2. Kreutzer B, Stubiger N, Thiel HJ, Zierhut M. Oculomucocutaneous changes as paraneoplastic syndrome. Ger J Ophthalmol 1996;5:176-181.

\section{Erythroblastosis Fetalis}

Related Terms: Bilirubin encephalopathy; fetal hydrops; hemolytic anemia of the newborn; kernicterus.

NOTE: Cytomegalovirus, Parvovirus, syphilis, and Toxoplasma infections can cause erythroblastosis fetalis. These may be sought with routine histological as well as immunohistochemical methods on tissue sections. Immune-mediated destruction of fetal red cells or platelets, causing fetal hemorrhages and erythroblastosis. Serologic tests are also available.

\begin{tabular}{lll}
\hline Organs and Tissues & Procedures & Possible or Expected Findings \\
\hline $\begin{array}{c}\text { Blood } \\
\text { (maternal and fetal) }\end{array}$ & $\begin{array}{l}\text { Perform a direct Coomb's test on fetal cells and } \\
\text { antibody screen on fetal or maternal cells. }\end{array}$ & Alloantibody-mediated hemolysis; anemia.
\end{tabular}

Determine the hematocrit on the fetal blood.

External examination Record body weight and length.

and oral cavity

Thymus

Heart and lungs

Liver

Spleen

Pancreas

Retroperitoneal tissues with adrenal glands and kidneys

Lymph nodes

Bone marrow
Record weight.

Submit samples for histologic study.

Record weight. Submit samples for histologic study. Request Gomori's stain for iron (p. 172). Use immunohistochemical stains to confirm the presence of Parvovirus.

Record weight. See also above under "Liver."

Submit sample for histologic study.

Submit samples for histologic study.

For preparation of sections and smears, see p. 96.
Generalized, severe edema (fetal hydrops); jaundice; purpuric rash. In long-term survivors, discolored deciduous teeth with hypoplastic enamel.

Accelerated maturation.

Erythroblasts in vessels of myocardium and of lungs. Look for intranuclear inclusions typical of Parvovirus.

Hepatomegaly with increased extramedullary hematopoiesis and hemosiderosis.

Splenomegaly with increased extramedullary hematopoiesis; hemosiderosis; small or absent Malpighian corpuscles.

Increased extramedullary hematopoiesis. Extramedullary hematopoiesis in adrenal glands and in retroperitoneal (peripelvic and renal) soft tissues.

Hypoplasia with hemosiderosis.

Erythroblastic hyperplasia. 


\begin{tabular}{lll}
\hline Organs and Tissues & Procedures & Possible or Expected Findings \\
\hline Brain and spinal cord & $\begin{array}{l}\text { For removal and specimen preparation, } \\
\text { see pp. 65 and 67, respectively. Prepare } \\
\text { photographs of stained areas of brain. }\end{array}$ & $\begin{array}{l}\text { Diffuse cerebral icterus or selective staining } \\
\text { of subthalamic nuclei, globus pallidus, } \\
\text { hippocampus, pontine nuclei, medullary } \\
\text { nuclei in the floor of the fourth ventricle, } \\
\text { thalamus, and cerebellar nuclei. Cortical and }\end{array}$ \\
& Wpinal gray matter is rarely involved. \\
Placenta & Villous edema; erythroblasts in vessels; \\
& & $\begin{array}{l}\text { inclusions consistent with Cytomegalovirus } \\
\text { or Parvovirus infection; chronic plasma cell } \\
\text { villitis. }\end{array}$ \\
\hline
\end{tabular}

Esophagus, Barrett's

\begin{tabular}{lll}
\hline Organs and Tissues & Procedures & Possible or Expected Findings \\
\hline Lungs & Perfuse one lung with formalin (p. 47). & Aspiration (reflux) pneumonitis with fibrosis. \\
Diaphragm & Record size of diaphragmatic hernia. & Diaphragmatic hernia.* \\
Esophagus and stomach & Remove whole length of esophagus, together & The esophagus (most commonly the \\
& with stomach and portion of diaphragm with & distal portions) is lined by columnar \\
hiatus. Record diameter of esophageal stricture & epithelium that causes a brownish red \\
(a glass cone or wooden cone can be used) & discoloration of the mucosa. Chronic reflux \\
& before opening narrowed portion of esophagus. & esophagitis is present, and an ulcer and a \\
After opening, pin esophagus and stomach on & stricture often are found at the squamoco- \\
& corkboard, photograph, and fix in formalin & $\begin{array}{l}\text { lumnar junction. Dysplasia and adenocar- } \\
\text { cinoma are common complications and }\end{array}$ \\
& (in this position). & $\begin{array}{l}\text { arise in the areas of intestinal metaplasia. } \\
\text { Laryngitis and pharyngitis in cases of severe } \\
\text { chronic reflux. }\end{array}$ \\
\hline
\end{tabular}

Ethanol (Ethyl Alcohol) (See "Alcoholism and alcohol intoxication," "Cardiomyopathy, alcoholic," "Disease, alcoholic liver," "Syndrome, fetal alcoholic," and "Syndrome, Wernicke-Korsakoff.")

\section{Exposure, Cold}

NOTE: In all instances, the blood alcohol level should be determined and a drug screen should be done. The tissues tend to be well preserved.

Possible Associated Conditions: Age-related increased susceptibility to cold (in infancy and senility); alcohol intoxication;* myxedema; pituitary insufficiency;* poisoning by depressants, narcotics, or other drugs; stroke.

\begin{tabular}{|c|c|c|}
\hline Organs and Tissues & Procedures & Possible or Expected Findings \\
\hline \multirow[t]{2}{*}{$\begin{array}{l}\text { External examination, } \\
\text { skin, and subcutaneous } \\
\text { tissues }\end{array}$} & $\begin{array}{l}\text { Prepare photographs of abnormalities, as listed } \\
\text { in right-hand column. }\end{array}$ & $\begin{array}{l}\text { Red discoloration of the face and extremities; } \\
\text { generalized edema; erythematous patches } \\
\text { on trunk and limbs. }\end{array}$ \\
\hline & $\begin{array}{l}\text { Submit samples of skin and of subcutaneous } \\
\text { tissue for histologic study. }\end{array}$ & $\begin{array}{l}\text { Frostbite; bullae; gangrene. Subcutaneous } \\
\text { tissue usually contains little blood. }\end{array}$ \\
\hline Blood and vitreous & $\begin{array}{l}\text { Submit samples for toxicologic study. } \\
\text { (See above under "Note" and p. 16). }\end{array}$ & Blood is fluid and bright red. \\
\hline Lungs & Record weights and sample for histologic study. & Pulmonary hemorrhages. \\
\hline Gastrointestinal tract & $\begin{array}{l}\text { Record sites of lesions and submit samples for } \\
\text { histologic study. }\end{array}$ & $\begin{array}{l}\text { Small mucosal hemorrhages or-if patient } \\
\text { had survived exposure for some time-- } \\
\text { ulcers. Rarely, perforation of ulcers. }\end{array}$ \\
\hline Pancreas & $\begin{array}{l}\text { Prepare photographs and sample for histologic } \\
\text { study. }\end{array}$ & $\begin{array}{l}\text { Peripancreatic fat tissue necroses, with or } \\
\text { without pancreatitis.* }\end{array}$ \\
\hline Other organs & & $\begin{array}{l}\text { Fatty changes of myocardium, liver, and } \\
\text { kidneys; congestion of viscera; sludging of } \\
\text { blood in small vessels. }\end{array}$ \\
\hline Brain & $\begin{array}{l}\text { For removal and specimen preparation, } \\
\text { see p. } 65 \text {. }\end{array}$ & $\begin{array}{l}\text { Perivascular hemorrhages around third } \\
\text { ventricle. }\end{array}$ \\
\hline
\end{tabular}




\section{Failure, Congestive Heart}

NOTE: Coronary atherosclerosis and manifestations of ischemic heart disease, ${ }^{*}$ valvular heart disease, congenital cardiovascular diseases, and manifestations of systemic or pulmonary hypertension are the most frequent findings in patients dying of or with congestive cardiac failure. Other causes include cardiomyopathies* and secondary myocardial disease (such as amyloid or pericardial constriction). If the cause of the congestive cardiac failure is unknown or not immediately evident after dissection of the heart and of the great vessels, myocardium and other appropriate tissues may be submitted for microbiologic study—including viral cultures (p. 102) - and for electron microscopy (p. 132). Specimens can also be snap-frozen for possible immunofluorescent, biochemical, or histochemical studies, particularly of the myocardium.

\begin{tabular}{|c|c|c|}
\hline Organs and Tissues & Procedures & Possible or Expected Findings \\
\hline External examination & $\begin{array}{l}\text { Record body weight and length. } \\
\text { Prepare roentgenogram of chest. }\end{array}$ & $\begin{array}{l}\text { Cyanosis; edema of legs; dilatation of veins. } \\
\text { Cardiomegaly; pleural effusion(s).* }\end{array}$ \\
\hline $\begin{array}{l}\text { Chest and abdominal } \\
\text { cavities }\end{array}$ & Record volume and character of effusion(s). & Hydrothorax; ascites. \\
\hline Heart and great vessels & $\begin{array}{l}\text { See above under "Note." Record weight } \\
\text { of heart, valve circumferences, and ventricular } \\
\text { wall thickness. Estimate extent of dilatation } \\
\text { of each cardiac chamber. Note consistency of } \\
\text { myocardium. }\end{array}$ & $\begin{array}{l}\text { Possible causes of congestive cardiac failure } \\
\text { are too numerous to mention. Dilatation of } \\
\text { heart, with or without mural thrombosis. } \\
\text { Myocardium may be soft, normal, or firm. }\end{array}$ \\
\hline Other organs & $\begin{array}{l}\text { Organs mentioned in right-hand column should } \\
\text { be described and, if appropriate, weighed and } \\
\text { measured. Submit samples for histologic study. }\end{array}$ & $\begin{array}{l}\text { Pulmonary congestion, with or without } \\
\text { hemosiderosis; congestion of viscera with } \\
\text { organomegaly. Other organ manifestations } \\
\text { include bowel edema or hemorrhagic } \\
\text { enteropathy (without mechanical vascular } \\
\text { occlusion) and zonal hepatic steatosis, } \\
\text { fibrosis, or necrosis, with or without evidence } \\
\text { of liver failure. Acute renal tubular } \\
\text { necrosis may be present also. }\end{array}$ \\
\hline
\end{tabular}

\section{Failure, Kidney}

Synonyms and Related Terms: Acute kidney failure; chronic kidney failure; renal failure; uremia.

NOTE: If acute kidney failure had been diagnosed, the autopsy procedures will depend on the expected causes, such as poisoning with ethylene glycol, ${ }^{*}$ lead, ${ }^{*}$ mercury, ${ }^{*}$ or methyl alcohol;* disseminated intravascular coagulation* and its various under- lying conditions; glomerulonephritis* and its various underlying conditions; diabetes mellitus; ${ }^{*}$ or multiple myeloma.* The procedures described below deal primarily with chronic renal failure. If the patient had had dialysis, see also under "Dialysis (for chronic renal failure)." If transplantation had been carried out, see also under "Transplantation, kidney."

\begin{tabular}{lll}
\hline Organs and Tissues & Procedures & Possible or Expected Findings \\
\hline External examination & Submit samples of skin for histologic study. & "Uremic frost." Uremic skin discoloration. \\
and skin & Record position of shunts. & Teflon-Silastic shunts. \\
& Prepare skeletal roentgenograms and roentgeno- & Bone deformities and fractures. (See also \\
& grams of soft tissues. & below under "Bones and joints.") Metastatic \\
& & calcifications in soft tissues and bursae.
\end{tabular}




\begin{tabular}{|c|c|c|}
\hline Organs and Tissues & Procedures & Possible or Expected Findings \\
\hline Vitreous & $\begin{array}{l}\text { Submit sample for determination of urea } \\
\text { nitrogen, creatinine, sodium, and chloride } \\
\text { concentrations (p. 85). }\end{array}$ & $\begin{array}{l}\text { For interpretation of findings (biochemical } \\
\text { diagnosis of uremia), see p. } 115 .\end{array}$ \\
\hline Blood & $\begin{array}{l}\text { Submit sample for microbiologic study (p. 102). } \\
\text { Retain frozen serum for serologic or immuno- } \\
\text { logic study. Submit sample for determination of } \\
\text { urea nitrogen and creatinine concentrations. }\end{array}$ & For interpretation of findings, see p. 114. \\
\hline Heart & & Myocarditis;* pericarditis.* \\
\hline Blood vessels & $\begin{array}{l}\text { If infection or clotting of shunt is suspected, } \\
\text { remove shunt together with ligated vessels and } \\
\text { submit for culture. }\end{array}$ & $\begin{array}{l}\text { Infected shunts; manifestations of } \\
\text { hypertension;* metastatic calcification. }\end{array}$ \\
\hline Lungs & $\begin{array}{l}\text { Submit one lobe for bacterial, fungal, and viral } \\
\text { cultures (p. 103); prepare smear of fresh cut } \\
\text { section for the demonstration of Pneumocystis } \\
\text { carinii.* } \\
\text { Collect fresh lung samples and freeze for } \\
\text { possible immunofluorescent study. Perfuse } \\
\text { one lung with formalin (p. } 47 \text { ). }\end{array}$ & $\begin{array}{l}\text { Bacterial, fungal, viral, and/or uremic } \\
\text { pneumonitis; pulmonary edema. }\end{array}$ \\
\hline Esophagus & & Candida esophagitis. \\
\hline Gastrointestinal tract & $\begin{array}{l}\text { Record character of contents; submit tissue } \\
\text { samples for histologic study. }\end{array}$ & Hemorrhages; gastroenteritis. \\
\hline Liver & For gross iron staining, see p. 133. & $\begin{array}{l}\text { Transfusion hemosiderosis. } \\
\text { Chronic hepatitis C. }\end{array}$ \\
\hline Pancreas & Submit samples for histologic study. & Inspissation of pancreatic ducts. \\
\hline Kidneys & $\begin{array}{l}\text { For renal arteriography, renal venography, } \\
\text { and retrograde urography, see p. } 59 \text {. For other } \\
\text { procedures, see under name of specific renal } \\
\text { disease. }\end{array}$ & $\begin{array}{l}\text { See under name of specific renal disease, such } \\
\text { as "Glomerulonephritis." Acquired cystic } \\
\text { disease may occur after long-term } \\
\text { intermittent maintenance hemodialysis. }\end{array}$ \\
\hline Urine & Collect and submit sample for urinalysis. & \\
\hline Testes & Submit samples for histologic study or rete testis. & Cystic transformation of rete testis (1). \\
\hline Parathyroid glands & $\begin{array}{l}\text { Record weights; submit samples for histologic } \\
\text { study. }\end{array}$ & Hyperplasia, with or without adenoma(s). \\
\hline Brain and spinal cord & $\begin{array}{l}\text { For removal and specimen preparation, see } \\
\text { pp. } 65 \text { and } 67 \text {, respectively. If the choroid } \\
\text { plexus is to be used for immunologic study, } \\
\text { dissect fresh brain and snap-freeze plexus. }\end{array}$ & $\begin{array}{l}\text { Edema and petechiae. } \\
\text { Neuronal damage. }\end{array}$ \\
\hline Eyes & For removal and specimen preparation, see p. 85 . & Hypertensive retinopathy; steroid cataracts. \\
\hline Skeletal muscles & For sampling and specimen preparation, see p. 80. & Myopathy. \\
\hline Bones and joints & $\begin{array}{l}\text { For removal, prosthetic repair, and specimen } \\
\text { preparation, see p. } 95 \text {. }\end{array}$ & $\begin{array}{l}\text { Renal osteodystrophy (osteoporosis;* } \\
\text { osteomalacia*). Gout.* }\end{array}$ \\
\hline
\end{tabular}

\section{Reference}

1. Nistal M, Santamaria L, Paniagua R. Acquired cystic transformation of the rete testis secondary to renal failure. Hum Pathol 1989;20:1065-1070.

\section{Failure, Liver}

NOTE: See under name of suspected underlying disease, such as "Cirrhosis, liver" or "Hepatitis, viral."

\section{Failure, Lung}

NOTE: See under name of suspected underlying conditions such as "Pneumonia,...," "Syndrome, adult respiratory distress (ARDS)," or "Syndrome, respiratory distress, of infant."

\section{Fascioliasis (See “Clonorchiasis.”)}

\section{Feminization, Testicular}

Related Term: Hereditary male pseudohermaphroditism. NOTE: This $x$-linked recessive condition is characterized by impairment of male phenotypic differentiation or virilization; it occurs in a complete and an incomplete (see below) form. Together with Reifenstein's syndrome* and the infertile male syndrome, these conditions represent androgen receptor disorders. 


\begin{tabular}{|c|c|c|}
\hline Organs and Tissues & Procedures & Possible or Expected Findings \\
\hline $\begin{array}{l}\text { External examination } \\
\text { and breasts }\end{array}$ & $\begin{array}{l}\text { Record body weight and length. Record } \\
\text { appearance of breasts and submit samples of } \\
\text { breast tissue for histologic study. }\end{array}$ & $\begin{array}{l}\text { Female appearance with female external } \\
\text { genitalia; sparse axillary and pubic hair. }\end{array}$ \\
\hline Blood or fascia lata & $\begin{array}{l}\text { Specimens should be collected using aseptic } \\
\text { technique for tissue culture for chromosome } \\
\text { analysis (see Chapter 10). Record presence of } \\
\text { sex chromatin. }\end{array}$ & Karyotype is $46, \mathrm{XY}$. \\
\hline Gonads and vagina & $\begin{array}{l}\text { Record weights of testes and prepare histologic } \\
\text { sections of both. Prepare histologic sections of } \\
\text { vaginal mucosa. }\end{array}$ & $\begin{array}{l}\text { Blind-ending vagina; absent internal } \\
\text { genitalia except for testes, which may } \\
\text { have descended to inguinae or labia. No } \\
\text { spermatogenesis (but Leydig cells and } \\
\text { seminiferous tubules are present). In } \\
\text { incomplete testicular feminization, partial } \\
\text { fusion of labioscrotal folds, clitoromegaly, } \\
\text { and normal pubic hair are found. }\end{array}$ \\
\hline
\end{tabular}

\section{Fever, Colorado Tick}

Related Term: Orbivirus infection.

NOTE: (1) Collect all tissues that appear to be infected. (2) Request cultures for orbiviruses (Reoviridae family). This requires animal inoculation, and not all laboratories have the capability of isolating orbiviruses. (3) Special stains are not indicated.
(4) Special precautions are indicated (p. 146). (5) Serologic studies are available from local or state health department laboratories (p. 135). The virus also can be detected by reverse transcription PCR of whole blood specimens (1). (6) This is not a reportable disease.

\begin{tabular}{ll}
\hline Organs and Tissues & Procedures \\
\hline $\begin{array}{l}\text { External examination } \\
\text { Cerebrospinal fluid }\end{array}$ & $\begin{array}{l}\text { If meningitis or encephalitis is suspected, } \\
\text { submit samples for viral culture and for } \\
\text { cytologic study (p. 104). }\end{array}$ \\
& $\begin{array}{l}\text { Submit samples for viral culture and for } \\
\text { Blood }\end{array}$ \\
& serologic study (p. 102) or study by PCR \\
& (see above under "Note.").
\end{tabular}

Other organs and tissues

Brain and spinal cord
For removal and specimen preparation, see pp. 65 and 67, respectively. Submit fresh cerebral tissue for viral culture (p. 102).
Possible or Expected Findings

Skin rash; thrombocytopenic hemorrhages. Increased leukocyte counts and positive viral culture.

Thrombocytopenic hemorrhages; focal necrosis in multiple organs.

Meningitis* and encephalitis.*

\section{Reference}

1. Johnson AJ, Karabatsos N, Lanciotti RS. Detection of Colorado tick fever virus by using reverse transcription PCR and application of the technique in laboratory diagnosis. J Clin Microbiol 1997;35:1203-1208.

\section{Fever, Familial Mediterranean}

Synonyms: Familial paroxysmal polyserositis; periodic fever; periodic polyserositis; recurrent polyserositis.

\begin{tabular}{lll}
\hline Organs and Tissues & Procedures & Possible or Expected Findings
\end{tabular}

Chest and abdomen Record volume of pericardial, pleural, and peritoneal exudates. Submit samples for microbiologic study (p. 102). Prepare smears or sections of spun-down sediment. Submit samples of serosal surfaces for histologic study.
Exudate should be sterile, with many neutrophils. Acute serositis. 


\begin{tabular}{lll}
\hline Organs and Tissues & Procedures & Possible or Expected Findings \\
\hline Other organs & Request Congo red or other amyloid stains. & Amyloidosis* (common cause of death) \\
& For further details on staining procedures, & involving arterioles, venules, glomeruli, and \\
& see under "Amyloidosis." Other procedures & spleen. Heart and liver show only small- \\
& depend on expected findings or grossly & vessel amyloidosis. Acalculous \\
& identified abnormalities as listed in right- & cholecystitis* is a common complication. \\
& hand column. & Acute orchitis (1). \\
& For removal, prosthetic repair, and specimen \\
Joints & Arthritis, ${ }^{*}$ mostly of large joints. \\
& synovium for histologic study. & \\
& & \\
\hline
\end{tabular}

\section{Reference}

1. Moskovitz B, Bolkier M, Nativ O. Acute orchitis in recurrent polyserositis. J Pediatr Surg 1995;30:1517-1518.

\section{Fever, Hemorrhagic, with Renal Syndrome}

Related Terms: Balkan hemorrhagic fever with renal syndrome; Bunyaviridae infection; endemic or epidemic nephrosonephritis; Far Eastern hemorrhagic fever; Hantaan virus infection (1); Korean hemorrhagic fever; Manchurian epidemic hemorrhagic fever; nephropathia epidemica.
NOTE: (1) Collect all tissues that appear to be infected. (2) Viral cultures are not available. (3) Special stains are not indicated. (4) Special precautions are indicated (p. 146). (5) Serologic studies are available from the Centers for Disease Control and Prevention, Atlanta, GA (p. 135). (6) This is a reportable disease. Bioterrorism must be considered in current cases.

\begin{tabular}{|c|c|c|}
\hline Organs and Tissues & Procedures & Possible or Expected Findings \\
\hline External examination & Record presence and location of petechiae. & $\begin{array}{l}\text { Conjunctival petechiae; subconjunctival } \\
\text { hemorrhages. Widespread petechiae. }\end{array}$ \\
\hline Vitreous & For removal technique, see p. 85 . & $\begin{array}{l}\text { Increased potassium and phosphate } \\
\text { concentrations, calcium concentrations } \\
\text { decreased. }\end{array}$ \\
\hline Blood & $\begin{array}{l}\text { Submit sample for demonstration of specific } \\
\text { IgM antibodies by ELISA and for determination } \\
\text { of immune adherence hemagglutination titers. }\end{array}$ & See also above under "Note." \\
\hline Gastrointestinal tract & $\begin{array}{l}\text { Open bowel and fix samples of mucosa as early } \\
\text { in the autopsy procedure as possible. Measure } \\
\text { volume of blood in lumens. (If contents are fluid, } \\
\text { one can attempt to obtain a hematocrit value.) }\end{array}$ & Intraluminal hemorrhages. \\
\hline Liver & Submit samples for histologic study. & Midzonal necrosis (2). \\
\hline $\begin{array}{l}\text { Kidneys, ureters } \\
\text { and urinary bladder }\end{array}$ & $\begin{array}{l}\text { Remove kidneys, ureters, and urinary bladder } \\
\text { en block. Photograph cut surfaces of kidneys } \\
\text { with renal pelves and ureters; submit samples } \\
\text { for histologic study. }\end{array}$ & $\begin{array}{l}\text { Parenchymal hemorrhages; tubular necrosis. } \\
\text { Blood in renal pelves, ureters, and urinary } \\
\text { bladder. }\end{array}$ \\
\hline Other organs and tissues & Submit samples for histologic study. & $\begin{array}{l}\text { Manifestations of hemorrhagic shock and } \\
\text { hypotension;* retroperitoneal edema. }\end{array}$ \\
\hline Brain and spinal cord & $\begin{array}{l}\text { For removal and specimen preparation, } \\
\text { see p. } 65 \text { and } 67 \text {, respectively. }\end{array}$ & Hemorrhages. \\
\hline
\end{tabular}

\section{References}

1. Duchin JS, Koster FT, Peters CJ, Simpson GL, Tempest B, Zaki SR, et al. Hantavirus pulmonary syndrome: a clinical description of 17 patients with a newly recognized disease. N Engl J Med 1994;330: 949-955.

2. Elisaf M, Stefanaki S, Repanti M, Korakis H, Tsianos E, Siamopoulos $\mathrm{KC}$. Liver involvement in hemorrhagic fever with renal syndrome. J Clin Gastroenterol 1993;17:33-37.

\section{Fever, Lassa}

Related Terms: Arenavirus infection; Argentine or Bolivian hemorrhagic fever.

\section{NOTE:}

Lassa fever is a highly communicable disease and autopsy studies are not recommended in the usually available surround-ings. If Lassa fever is suspected, contact the state health department and the Centers for Disease Control and Prevention, Atlanta, GA, for disposition and further studies (1). If an autopsy is done, disinfection can be accomplished by washing instruments with $0.5 \%$ phenol in detergent (i.e., Lysol), $0.5 \%$ hypochlorite solution, formalin, or paracetic acid. (See also p. 143.) For shipping procedures, see p. 135. This is not a reportable disease. 


\section{Organs and Tissues}

All organs

Blood

Other body fluids (e.g., urine, cerebrospinal fluid, breast milk, or joint fluid)

Possible or Expected Findings

Gastrointestinal and cerebral hemorrhages; intercurrent infection; foci of necrosis.

Experience is quite limited with cases of should be regarded as a research procedure. Prepare photographs. Submit samples of many organs and tissues for viral and other microbiologic studies and for histologic study. Prepare material for electron microscopic study (p. 132). Collect serum for serologic testing and for culture of the virus. An early diagnosis can be made from serum samples by reverse transcription PCR (3).

Freeze fluids at $-70^{\circ} \mathrm{C}$ for arenavirus isolation.
Fourfold rise in antibody titer; high IgG titer or virus-specific IgM. Detection of Lassa virus RNA.

\section{References}

1. Holmes GP, McCormick JB, Trock SC, Chase RA, Lewis SM, Mason $\mathrm{CA}$, et al. Lassa fever in the United States. Investigation of a case and new guidelines for management. N Engl J Med 1990;323:1120-1123.

2. Nzerue MC. Lassa fever: review of virology, immunopathogenesis, and algorithms for control and therapy. Centr Afr J Med 1992;38:247252.

3. Demby AH, Chamberlain J, Brown DW, Clegg CS. Early diagnosis of Lassa fever by reverse transcription-PCR. J Clin Microbiol 1994; 32:2898-2903.

\section{Fever, Periodic}

(See "Fever, familial Mediterranian.")

\section{Fever, Q}

Synonyms: Acute Q fever; chronic Q fever; Coxiella burnetii infection.

NOTE: (1) Collect blood, urine, and all tissues that appear to be infected. (2) For the definite diagnosis of this rickettsial disease, inoculation into animals or embryonated eggs is required, which cannot be done safely in the usual clinical laboratory. (3) Special stains are not indicated. (4) This is a highly communicable disease, and special precautions are indicated (p. 146). (5) Serologic studies are available from local and state health department laboratories (p. 135). (6) This is a reportable disease.

\begin{tabular}{ll}
\hline Organs and Tissues & Procedures \\
\hline Blood & Submit blood sample for microbiologic study \\
& (p. 102) and serum for complement-fixation or \\
& agglutination tests.
\end{tabular}

Heart If endocarditis is suspected, follow procedures described on p. 103.

Lungs

Liver

Spleen and bone marrow

Kidneys

Veins

Brain

Eyes

Bones, joints, and skeletal muscles
Submit consolidated areas for microbiologic study (p. 103). Perfuse at least one lung with formalin (p. 47).

Record weight and submit samples for histologic study.

Record weight and submit samples for histologic study.

For removal of femoral veins, see p. 34.

For removal and specimen preparation, see p. 65 . For removal and specimen preparation, see p. 85 . For removal and specimen preparation, see p. 95 and 80 , respectively
Possible or Expected Findings

Bacterial suppurative vegetative endocarditis* may be present, and this is a likely cause of death. Pericarditis* and pericardial effusion. Patchy hemorrhagic, necrotizing pneumonia; necrotizing bronchitis (1) and bronchiolitis.

Hepatomegaly; granulomas with fibrin ring and central lipid vacuole (not specific for the disease).

Splenomegaly; splenitis with large granulomas.

Glomerulonephritis (2).

Thrombophlebitis.

Meningitis.*

Uveitis; optic neuritis.

Osteoarticular infection (3); rhabdomyolysis (4).

\section{References}

1. Kayser K, Wiebel M, Schulz V, Gabius HJ. Necrotizing bronchitis, angiitis, and amyloidosis associated with chronic Q fever. Respir 1995; 62:114-116.
2. Korman TM, Spelman DW, Perry GJ, Dowling JP. Acute glomerulonephritis associated with acute $Q$ fever: case report and review of the renal complications of Coxiella burnetii infection. Clin Inf Dis 1998; 26:359-364. 
3. Cottalorda J, Jouve JL, Bollini G, Touzet P, Poujol A, Kelberine F, Raoult D. Osteoarticular infection due to Coxiella burnetii in children. J Pediatr Orthopaed 1995;4:219-221.

4. Carrascosa M, Pascual F, Borobio MV, Gonzales Z, Napal J. Rhabdomyolysis associated with acute Q fever. Clin Inf Dis 1997;25:12431244.

\section{Fever, Relapsing}

Synonyms: Borreliosis; louseborne (epidemic) relapsing fever; tickborne (endemic) relapsing fever.
NOTE: (1) Collect all tissues that appear to be infected. (2) Rat/mouse inoculation with infected blood is the most sensitive method for the detection of the organism. Consult the state health department. (3) Before the autopsy, consultation with the microbiology laboratory is advised. (4) Request direct darkfield examination and Giemsa or Wright stain (p. 172). (4) No special precautions are indicated. (5) Serologic studies are of questionable value due to the antigenic variability of the organism. (6) This is not a reportable disease.

\begin{tabular}{lll}
\hline Organs and Tissues & Procedures & Possible or Expected Findings \\
\hline Blood & $\begin{array}{l}\text { Prepare smears and request Giemsa or Wright } \\
\text { stain (p. 172). }\end{array}$ & Species of spirochetes of the genus Borrelia. \\
Spleen & $\begin{array}{l}\text { Record weight. Stain touch preparations and } \\
\text { paraffin sections with Giemsa or Wright stain } \\
\text { (p. 172) }\end{array}$ & $\begin{array}{l}\text { Organisms abundant in reticulum cells of } \\
\text { white pulp. }\end{array}$ \\
Other organs & $\begin{array}{l}\text { See above under "Note" and under "Spleen." } \\
\text { Sample for histologic study as suggested in } \\
\text { right-hand column. }\end{array}$ & $\begin{array}{l}\text { Organisms in biliary epithelium, } \\
\text { gastrointestinal tract, convoluted tubules of } \\
\text { kidneys, brain, and meninges. }\end{array}$ \\
\hline
\end{tabular}

\section{Fever, Rheumatic}

NOTE: In young children, arthritis may be less conspicuous. Cardiac and other visceral manifestations may predominate in this age group.

\begin{tabular}{lll}
\hline Organs and Tissues & Procedures & Possible or Expected Findings \\
\hline $\begin{array}{l}\text { External examination, } \\
\text { skin, and throat }\end{array}$ & $\begin{array}{l}\text { Prepare histologic sections of subcutaneous } \\
\text { nodules and other skin lesions and of grossly } \\
\text { unaffected skin. }\end{array}$ & $\begin{array}{l}\text { Rheumatic nodules (over bony prominences, } \\
\text { such as elbow or occiput); erythema } \\
\text { marginatum(annulare); cutaneous rheumatic } \\
\text { arteritis. }\end{array}$ \\
& $\begin{array}{l}\text { Submit swabs for throat culture. } \\
\text { Suboup A streptococci. }\end{array}$ \\
Pericardium & $\begin{array}{l}\text { Submit fluid from pericardial sac for culture } \\
\text { (p. 102). Record volume of pericardial contents. }\end{array}$ & Pericardial effusion or pericarditis.*
\end{tabular}

Blood

Heart and ascending aorta

Lungs (p. 102). Record volume of pericardial contents.

Submit samples for microbiologic and serologic studies (C-reactive protein, immunoglobulin, serum haptoglobin). For proper removal of microbiologic sample, see p. 102.

If infective endocarditis is suspected, follow procedures described on p. 102.

Record weight of heart; use inflow-outflow method for dissection (p. 21) and submit samples for histologic study (p. 30). Histologic samples should include posterior wall of the left atrium and chordae tendineae with papillary muscles. For histochemical and immunologic studies, freeze samples of epicardium and myocardium and of valves. Submit samples of coronary arteries and of ascending aorta for histologic study. Request Verhoeff-van Gieson stain (p. 173).

Submit one lobe for microbiologic study (p. 103). Perfuse one lung with formalin (p. 47). For pulmonary arteriography, see p. 50. Request Verhoeff-van Gieson stain (p. 173).
In chronic cases, infective endocarditis.*

Rheumatic myocarditis; Aschoff bodies, predominantly beneath endocardium of leftsided heart chambers and within valves. Rheumatic valvular aseptic vegetative endocarditis. Coronary arteritis; intimal hyperplasia of ascending aorta, just above aortic valve.

Rheumatic pneumonitis (1); pulmonary vasculitis (arteritis). Chronic rheumatic mitral valvulitis may be complicated by hypertensive pulmonary vascular disease and-in rare instances-intra-alveolar ossification. 


\begin{tabular}{|c|c|c|}
\hline Organs and Tissues & Procedures & Possible or Expected Findings \\
\hline Kidneys & $\begin{array}{l}\text { Prepare thin }(4-\mu \mathrm{m}) \text { paraffin sections; submit } \\
\text { tissue samples for immunofluorescent study } \\
\text { and for electron microscopy (p. 132). }\end{array}$ & Glomerulonephritis (2); rheumatic arteritis. \\
\hline Other organs & $\begin{array}{l}\text { Prepare histologic sections of all organs and } \\
\text { tissues, including skeletal muscles and cerebro- } \\
\text { spinal tissue. For immunofluorescent and } \\
\text { electron microscopic study, see p.132. } \\
\text { Request Verhoeff-van Gieson stain (p. 173). }\end{array}$ & $\begin{array}{l}\text { Rheumatic arteritis with lesions distributed } \\
\text { as in polyarteritis nodosa.* Thrombotic } \\
\text { microangiopathy. }\end{array}$ \\
\hline Eyes & For removal and specimen preparation, see p. 85 . & Scleritis; uveitis (3). \\
\hline Brain & & Sydenham's chorea. ${ }^{*}$ \\
\hline Joints & $\begin{array}{l}\text { Submit samples of synovial fluid from swollen } \\
\text { joints for microbiologic study and prepare smears } \\
\text { for cytologic study (p. 96). For joint removal, } \\
\text { prosthetic repair, and specimen preparation, } \\
\text { see p. } 95 \text {. Histologic samples should include } \\
\text { synovia and periarticular tissue. }\end{array}$ & $\begin{array}{l}\text { Rheumatic arthritis. Knees, ankles, hands, } \\
\text { and wrists are primarily involved. In adults, } \\
\text { large joints of lower extremities are usually } \\
\text { affected. }\end{array}$ \\
\hline
\end{tabular}

\section{References}

1. Burgert SJ, Classen DC, Burke JP, Veasy LG. Rheumatic pneumonia: reappearance of a previously recognized complication of rheumatic fever. Clin Inf Dis 1995;21:1020-1022.

2. Imanaka H, Eto S, Takei S, Yoshinaga M, Hokonohara M, Miyata K. Acute rheumatic fever and poststreptococcal acute glomerulonephritis caused by T serotype 12 Streptococcus. Acta Paediatr Jap 1995;37: 381-383.

3. Ortiz JM, Kamerling JM, Fischer D, Baxter J. Scleritis, uveitis, and glaucoma in a patient with rheumatic fever. Am J Ophthalmol 1995; 120:538-539.

\section{Fever, Rocky Mountain Spotted}

Related Terms: Rickettsia rickettsii infection; tick typhus.
NOTE: (1) Collect all tissues that appear to be infected. (2) Request cultures for Rickettsia. This requires a special laboratory, and previous consultation with such a laboratory is recommended. Specimens for culture must be processed immediately or frozen at $-60^{\circ} \mathrm{C}$ to ensure viability. (3) Request Giemsa stain for rickettsiae (p. 172). (4) Special precautions are indicated (p. 146). Laboratory infections have occurred (1). Gloves should be worn when handling blood specimens. 5) Serologic studies are available from local and state health department laboratories (p.135). Direct fluorescent antibody tests are available for formalin-fixed paraffin-embedded tissue (2). (6) This is a reportable disease.

\begin{tabular}{lll}
\hline Organs and Tissues & Procedures & Possible or Expected Findings \\
\hline $\begin{array}{l}\text { External examination } \\
\text { and skin }\end{array}$ & Submit samples of skin lesions. & Maculopapular and petechial skin lesions. \\
Blood & Collect serum for serologic diagnosis. & $\begin{array}{l}\text { Indirect immunofluorescence positivity; } \\
\text { ELISA positivity. }\end{array}$ \\
Lungs & $\begin{array}{l}\text { Submit consolidated areas for microbiologic } \\
\text { study (see p. 103 and above under "Note"). }\end{array}$ & Bronchopneumonia.
\end{tabular}

Liver and spleen

Other organs and tissues Submit samples for microbiologic and histologic study (p. 102).

Submit tissue samples with hemorrhages and other gross lesions for microbiologic and histologic study.

Brain and middle ears Skeletal muscles
For removal and specimen preparation, see pp. 65 and 72 , respectively.

For sampling and specimen preparation, see p. 80 .
Hepatitis and splenitis.

Manifestations of disseminated intravascular coagulation* and of kidney failure.* (These conditions are the most frequent causes of death.) Arteriolar thromboses and necrosis with hemorrhage.

Otitis media.*

Necrosis.

\section{References}

1. Oster CN, Burke DS, Kenyon RH, Ascher MS, Harber P, Pedersen CE Jr. Laboratory-acquired Rocky Mountain spotted fever: the hazard of aerosol transmission. N Engl J Med 1977;297:859-863.
2. Walker DH, Cain BG. A method for specific diagnosis of Rocky Mountain Spotted Fever on fixed paraffin-embedded tissue by immunofluorescence. J Inf Dis 1978;137:206-209. 


\section{Fever, Scarlet}

NOTE: Usually, this disease is a nonfatal group A streptococcal tonsillitis and pharyngitis with skin rash. Potentially fatal complications include suppurative otitis media, ${ }^{*}$ mastoiditis, and pharyngeal abscess (1), with or without septicemia.

(1) Collect all tissues that appear to be infected. (2) Request aerobic bacterial cultures. (3) Request Gram stain (p. 172). (4) Usually, no special precautions are indicated. (5) Serologic studies are available from local and state health department laboratories (p. 135). (6) This is not a reportable disease.

\section{Reference}

1. Chan TC, Hayden S. Early retropharyngeal abscess formation after treatment of scarlet fever. J Emerg Med 1996;14:377.
Fever, Tick

(See "Fever, relapsing"

and "Fever, Rocky Mountain spotted.")

Fever, Typhoid

Synonym: Salmonella typhi infection.

NOTE: (1) Collect all tissues that appear to be infected. (2) Request aerobic bacterial cultures especially of blood. (3) Request Gram stain (p. 172). (4) Special precautions are indicated (p. 146). (5) Serologic studies are available from local and state health department laboratories (p. 135). (6) This is a reportable disease.

\begin{tabular}{lll}
\hline Organs and Tissues & Procedures & Possible or Expected Findings \\
\hline $\begin{array}{l}\text { External examination } \\
\text { and skin }\end{array}$ & Prepare sections of skin lesions. & Maculopapular lesions; rose spots.
\end{tabular}

Cerebrospinal fluid

Abdominal cavity

Intestine

Mesentery

Blood

Heart

Lungs

Liver and extrahepatic biliary system

Spleen

Urine

Veins

Brain and spinal cord

Bone, joints, and bone marrow
If meningitis or other intracranial abnormalities are suspected, submit sample of cerebrospinal fluid for culture and cell count (p. 104).

If peritonitis is present, record volume of exudate and submit sample for aerobic bacterial culture (p. 102); prepare sections of peritoneum.

Inspect intestine in situ and record site(s) of perforation. For in situ fixation of small bowel, see p. 54. If intestinal hemorrhage is suspected, collect bowel contents and record volume of blood. Submit feces for aerobic bacterial culture (p. 102).

Submit lymph nodes for histologic study. Submit samples for aerobic bacterial culture and for serologic study (p. 102).

If endocarditis is suspected, follow procedures described on p. 103. Submit sample of myocardium for aerobic bacterial culture (p. 102). Submit areas of consolidation for aerobic bacterial culture (p. 103).

Submit bile for aerobic bacterial culture. Submit samples of extrahepatic bile ducts, gallbladder, and liver for histologic study.

Record weight. Submit sample for histologic study.

Submit sample for aerobic bacterial culture (p. 102).

For removal of femoral veins, see p. 34. For removal and specimen preparation, see pp. 65 and 67, respectively. Submit samples of bone marrow for aerobic bacterial culture (p. 102). For removal, prosthetic repair, and specimen preparation of bones, see p. 95. For preparation of sections and smears of bone marrow, see p. 96. If osteomyelitis is present, submit sample for aerobic bacterial culture. Aspirate joint fluid at sites of joint effusion.
Peritonitis* (1).

Perforation of ileum (1); inflammation and ulceration of Peyer's plaques. Intestinal hemorrhage. Between third and fifth weeks of the disease, feces most often positive for Salmonella typhi.

Mesenteric lymphadenitis.

See above under "Note."

Endocarditis;* myocarditis.*

Bronchitis and bronchopneumonia; diffuse alveolar damage (1).

Cultures of bile may be positive for

Salmonella typhi, particularly in chronic carriers. Acute acalculous cholecystitis;* cholelithiasis;* hepatitis (2) with focal necroses.

Splenitis; abscess.

During third and fourth weeks of the disease, urine cultures most often positive for Salmonella typhi.

Thrombophlebitis.

Meningitis;* thrombosis of intracranial vessels; hydrocephalus.*

Bone marrow may still harbor Salmonella typhi when blood cultures have become negative. Megakaryocytosis may be present (1). Osteomyelitis;* arthritis. 


\section{References}

1. Azad AK, Islam R, Salam MA, Alam AN, Islam M, Butler T. Comparison of clinical features and pathologic findings in fatal cases of typhoid fever during the initial and later stages of the disease. Am $\mathrm{J}$ Trop Med Hyg 1997;56:490-493.

2. Khan M, Coovadia Y, Sturm AW. Typhoid fever complicated by acute renal failure and hepatitis: case reports and review. Am J Gastroenterol 1998;93:1001-1003.

\section{Fever, Typhus}

Synonyms and Related Terms: Brill-Zinsser disease; classic typhus; endemic typhus; louse-borne typhus; murine typhus; primary epidemic typhus; recrudescent typhus; Rickettsia mooseri infection; Rickettsia prowazekii infection.

NOTE: (1) Collect all tissues that appear to be infected. (2) Request cultures for Rickettsia. This requires a special laboratory, and previous consultation with such a laboratory is recommended. (3) Request Giemsa stain for rickettsiae (p. 172). (4) Special precautions are indicated (p. 146). (5) Serologic studies are available from local and state health department laboratories (p. 135). Indirect fluorescent antibody tests are available for use with formalin fixed paraffin-embedded tissue. (6) This is not a reportable disease.

\begin{tabular}{|c|c|c|}
\hline Organs and Tissues & Procedures & Possible or Expected Findings \\
\hline \multirow[t]{2}{*}{$\begin{array}{l}\text { External examination } \\
\text { and skin }\end{array}$} & Submit skin lesions for histologic study. & $\begin{array}{l}\text { Macular and maculopapular rash; infectious } \\
\text { vasculitis of small vessels. Rarely } \\
\text { furunculosis. }\end{array}$ \\
\hline & $\begin{array}{l}\text { If gangrene of extremities is present, submit } \\
\text { samples of necrotic tissues for histologic study. }\end{array}$ & Gangrene due to small vessel thrombosis. \\
\hline Blood & $\begin{array}{l}\text { See above under "Note." Specimens with viable } \\
\text { organisms can be stored for a few days at } 5^{\circ} \mathrm{C} \text {. }\end{array}$ & $\begin{array}{l}\text { Indirect immunofluorescence positivity; } \\
\text { ELISA positivity. }\end{array}$ \\
\hline Heart & $\begin{array}{l}\text { Submit samples of myocardium for histologic } \\
\text { study (p. 30). }\end{array}$ & $\begin{array}{l}\text { Infectious vasculitis of small myocardial } \\
\text { vessels; myocarditis. }\end{array}$ \\
\hline Kidneys & Submit samples for histologic study. & $\begin{array}{l}\text { Infectious vasculitis. Renal failure* may be } \\
\text { the cause of death. }\end{array}$ \\
\hline Veins & For removal of femoral veins, see p. 34 . & Thrombophlebitis. \\
\hline Brain and spinal cord & $\begin{array}{l}\text { For removal and specimen preparation, } \\
\text { see pp. } 65 \text { and } 67 \text {, respectively. }\end{array}$ & $\begin{array}{l}\text { Infectious vasculitis and meningitis;* } \\
\text { inflammatory nodules within grey matter. }\end{array}$ \\
\hline Middle ears & $\begin{array}{l}\text { If otitis media is suspected, remove middle ears } \\
\text { for histologic study (p. 72). }\end{array}$ & Otitis media.* \\
\hline
\end{tabular}

\section{Fever, Yellow}

Synonyms and Related Terms: Flavivirus (Group B arbovirus) infection; hemorrhagic fever syndrome; yellow fever virus infection.

NOTE: (1) Collect all tissues that appear to be infected. (2) After consultation with microbiology laboratory, request viral culture. (3) Usually, special stains are not helpful. (4) Special precautions are indicated (p. 146). (5) Serologic studies are available from the Center for Disease Control and Prevention, Atlanta, GA (p. 135). (6) This is a reportable disease.

\begin{tabular}{lll}
\hline Organs and Tissues & Procedures & Possible or Expected Findings \\
\hline External examination & & $\begin{array}{l}\text { Jaundice; bleeding from nose and gums; rash; } \\
\text { "black vomit." }\end{array}$
\end{tabular}

Blood

Heart

Liver

Kidneys

Other organs
Submit sample for serologic and microbiologic study (p. 102). Store blood at $4^{\circ} \mathrm{C}$ to maintain viral viability.

Submit samples of myocardium for histologic study (p. 30). Request Sudan stain for frozen sections of myocardium (p. 173).

Record weight and submit tissue for virologic study (p. 102). Submit samples for histologic study. Request Sudan stain for frozen sections.

See above under "Heart."

Procedures depend on expected findings or grossly identified abnormalities as listed in right-hand column.

Brain
Myocardial degeneration.

Mild hepatitis with confluent focal and midzonal hepatic necrosis; Councilman bodies. Rarely, intranuclear Torres bodies. Fatty changes may be prominent.

Fatty changes of renal tubular epithelium. Disseminated intravascular coagulation* seems to be a frequent cause of death. Gastrointestinal hemorrhage* also may occur.

Focal hemorrhages. 


\section{Fibrillation and Flutter, Atrial (See “Arrhythmia, cardiac.”)}

\section{Fibroelastosis, Endocardial (EFE)}

NOTE: Most "primary" EFE is really secondary, associated with dilated cardiomyopathy* of infancy and childhood. EFE may also occur in hypoplastic ventricles due to congenital valvular atresia. EFE should not be confused with endomyocardial fibrosis (EMF), a condition associated with eosinophilic endomyocardial disease.

\begin{tabular}{|c|c|c|}
\hline Organs and Tissues & Procedures & Possible or Expected Findings \\
\hline Portal vein system & $\begin{array}{l}\text { For evaluation and display of portal vein, } \\
\text { see p. } 56 \text {. Record status of shunt if present. }\end{array}$ & Shunt for relief of portal hypertension.* \\
\hline Liver & $\begin{array}{l}\text { Record size and weight. For portal venous and } \\
\text { hepatic arterial angiography and cholangiography, } \\
\text { see p. } 56 \text {. Photograph cut surface of liver. }\end{array}$ & $\begin{array}{l}\text { Hepatomegaly; portal fibrosis; hypoplasia of } \\
\text { portal veins. Cysts may be the site of } \\
\text { hemorrhages. In rare instances, carcinoma of } \\
\text { bile duct may occur. }\end{array}$ \\
\hline Spleen & Record size and weight. & Congestive splenomegaly. \\
\hline $\begin{array}{l}\text { Esophagus and } \\
\text { gastrointestinal tract }\end{array}$ & $\begin{array}{l}\text { For demonstration of esophageal varices, } \\
\text { see p. } 53 \text {. Record volume of blood in lumen of } \\
\text { gastrointestinal tract. }\end{array}$ & $\begin{array}{l}\text { Esophageal varices.* } \\
\text { Gastrointestinal hemorrhage.* }\end{array}$ \\
\hline Kidneys & See under "Cyst(s), renal." & $\begin{array}{l}\text { Cysts (see above under "Possible Associated } \\
\text { Conditions"). }\end{array}$ \\
\hline
\end{tabular}

\section{Reference}

1. Desmet VJ. Congenital diseases of intrahepatic bile ducts: variations on a theme "ductal plate malformation." Hepatology 1992;16:1069-1083.

Fibrosis, Cystic

Synonym: Mucoviscidosis.

\begin{tabular}{ll}
\hline Organs and Tissues & Procedures \\
\hline External examination & Record body weight and length. \\
& $\begin{array}{l}\text { Prepare roentgenogram or do other tests for } \\
\text { pneumothorax.* }\end{array}$
\end{tabular}

Mediastinum

Blood

Heart

Lungs
Submit sample for microbiologic study (p. 102). Record weight and thickness of ventricles. Submit one lobe for microbiologic study (p. 103).
Esophagus and gastrointestinal tract
For postmortem bronchography and pulmonary angiography, see p. 50 .

If the bronchi are obstructed by tenacious secretions, formalin perfusion may be possible through pulmonary artery only. Photograph cut surface.

Submit samples of bronchi and parenchyma of all lobes for microscopic study. Request Gram stain (p. 172).

Submit samples of upper, middle, and lower esophagus; stomach, duodenum; jejunum; ileum; and colon for histologic study. If malabsorption was present, see under "Syndrome, malabsorption."

\section{Possible or Expected Findings}

Malnutrition (1) with growth retardation; clubbing of fingers.

Pneumothorax.

Hypertrophic osteoarthropathy.

Mediastinal emphysema.

Septicemia (see also under "Lungs").

Cor pulmonale.

Infections most frequently caused by Hemophilus influenzae, Pseudomonas aeruginosa, Staphylococcus aureus, and Streptococcus pyogenes.

Chronis bronchitis.* Bronchiectasis* and bronchiolectases; abscesses; bronchopneumonia; atelectases.

Esophageal varices (see below under "Liver"). Abnormal esophageal glands. Peptic esophagitis (2) and ulcers. * Meconium ileus* in small infants or meconium ileus equivalent in children and young adults. Fibrosing (submucosal) colonopathy (2). 


\begin{tabular}{|c|c|c|}
\hline Organs and Tissues & Procedures & Possible or Expected Findings \\
\hline Liver & $\begin{array}{l}\text { Record weight, measure, and photograph cut } \\
\text { section. Submit sample for histologic study. }\end{array}$ & $\begin{array}{l}\text { Cirrhosis* ("focal or multilobular biliary } \\
\text { cirrhosis"); fatty changes. }\end{array}$ \\
\hline Gallbladder & $\begin{array}{l}\text { Record volume and character of contents. Submit } \\
\text { sample for histologic study. For preservation, } \\
\text { see p. } 134 .\end{array}$ & $\begin{array}{l}\text { Cholecystitis; } * \text { cholelithiasis; } * \text { decreased } \\
\text { amount of bile. }\end{array}$ \\
\hline Pancreas & $\begin{array}{l}\text { Record weight of dissected organ and photo- } \\
\text { graph frontal section. Submit samples of head, } \\
\text { body, and tail for histologic study. }\end{array}$ & $\begin{array}{l}\text { Parenchymal atrophy with cystic fibrosis. } \\
\text { Islets of Langerhans often preserved } \\
\text { (manifestations of diabetes mellitus* } \\
\text { increasingly prevalent with age [3]). }\end{array}$ \\
\hline Male sex organs & $\begin{array}{l}\text { Submit samples of testes, prostate, seminal } \\
\text { vesicles, and spermatic ducts for histologic study. }\end{array}$ & $\begin{array}{l}\text { Occlusion of vasa deferentia and associated } \\
\text { changes, including absence or atrophy of } \\
\text { body of epididymis. }\end{array}$ \\
\hline Neck organs and skull & $\begin{array}{l}\text { Remove submaxillary (with floor of mouth, } \\
\text { p. } 4 \text { ) and lacrimal glands (p. 87). Expose } \\
\text { frontal and sphenoid sinuses (p. 71), and } \\
\text { prepare sections of mucosa. Inspect nasal } \\
\text { cavities, and prepare sections of mucosa. }\end{array}$ & Glandular fibrosis and atrophy. \\
\hline Bones and joints & $\begin{array}{l}\text { For removal, prosthetic repair, and specimen } \\
\text { preparation, see p. } 95 \text {. }\end{array}$ & $\begin{array}{l}\text { Hypertrophic osteoarthropathy in adults. } \\
\text { Joint abnormalities may be present also (4). }\end{array}$ \\
\hline
\end{tabular}

\section{References}

1. Reilly JJ, Edwards CA, Weaver LT. Malnutrition in children with cystic fibrosis: the energy-balance equation. J Pediatr Gastroenterol Nutr 1997; 25:127-136.

2. Eggermont E. Gastrointestinal manifestations in cystic fibrosis. Eur J Gastroenterol Hepatol 1996;8:731-738.

3. Lanng S. Diabetes mellitus in cystic fibrosis. Eur J Gastroenterol Hepatol 1996;8:744-747.

4. Turner MA, Baildam E, Patel L, David TJ. Joint disorders in cystic fibrosis. J Roy Soc Med 1997;31:13-20.

\section{Fibrosis, Endomyocardial (See "Cardiomyopathy restrictive [with eosinophilia].”)}

Fibrosis, Interstitial Pulmonary (See "Pneumonia, interstitial.")

Fibrosis, Mediastinal (See "Mediastinitis, chronic.”)

Fibrosis, Pulmonary (See “Pneumonia, interstitial.”)

\section{Fibrosis, Retroperitoneal}

Synonyms and Related Terms: Idiopathic retroperitoneal fibrosis; multifocal fibrosclerosis; ${ }^{*}$ periureteral fibrosis; systemic idiopathic fibrosis.

Possible Associated Conditions: Immune complex glomerulonephritis; Peyronie's disease; pseudotumor of the orbit (1); Riedel's fibrosing thyroiditis (Riedel's struma); sclerosing cholangitis;* sclerosing mediastinitis (mediastinal fibrosis).

\begin{tabular}{ll}
\hline Organs and Tissues & Procedures \\
\hline Retroperitoneal & For retrograde urography, see p. 59. \\
and pelvic tissues & $\begin{array}{l}\text { Remove retroperitoneal and pelvic organs } \\
\text { en bloc. Record character of dislocation and } \\
\text { of obstruction of ureter(s), of inferior vena cava, } \\
\text { and of other affected organs or tissues. This is } \\
\text { best demonstrated in horizontal slices through } \\
\text { the fibrosed areas. Submit samples for histologic } \\
\text { study. }\end{array}$
\end{tabular}

Abdominal wall

Other organs

Orbitae
See under "Failure, kidney" and above under "Possible Associated Conditions."

For exposure, see p. 73 (Figs. 6-10).

\section{Possible or Expected Findings}

Hydronephrosis;* pyelonephritis;* renal amyloidosis. Fibrosis adjacent to kidneys, duodenum, descending colon, and urinary bladder or surrounding ureter(s), inferior vena cava, or pelvic organs. Lymphoma,* scirrhous adenocarcinoma, severe atherosclerosis of aorta (2) with or without abdominal aortic aneurysm, ${ }^{*}$ or pelvic and retroperitoneal inflammatory diseases may imitate or be associated with retroperitoneal fibrosis.

Fibrosis of abdominal subcutaneous adipose tissue.

See above under "Possible Associated Conditions." Renal failure* is the most frequent cause of death.

Pseudotumor (1). 


\section{References}

1. Aylward GW, Sullivan TJ, Garner A, Moseley I, Wright JE. Orbital involvement in multifocal fibrosclerosis. Br J Ophthalmol 1995;79:246-249.

2. Gilkeson GS, Allen NB. Retroperitnoneal fibrosis. A true connective tissue disease. Rheum Dis Clin North Am 1996;22:23-38.

\section{Fire (See “Burns.”)}

\section{Fistula}

NOTE:

For study of wound fistulas and related conditions, see p. 104. For study of cerebral arteriovenous fistula, see "Malformation, arteriovenous, cerebral or spinal (or both)." For demonstration of congenital coronary artriovenous fistula, prepare coronary arteriogram (p. 118). Such a fistula is usually found between the right coronary artery and the coronary sinus. Dissection of tracheoesophageal fistulas is discussed in Chapters 4 (Fig. 4-1) and 5.

\section{Flukes, Hepatic (Biliary) (See “Clonorchiasis.”)}

\section{Fluorosis}

\begin{tabular}{|c|c|c|}
\hline Organs and Tissues & Procedures & Possible or Expected Findings \\
\hline \multirow[t]{2}{*}{ External examination } & & $\begin{array}{l}\text { Kyphosis; flexion contractures; enamel } \\
\text { changes. }\end{array}$ \\
\hline & Prepare skeletal roentgenograms. & $\begin{array}{l}\text { Osteosclerosis; formation of osteophytes; } \\
\text { ossification of tendons and ligaments. }\end{array}$ \\
\hline Bones and teeth & $\begin{array}{l}\text { For removal, prosthetic repair, and specimen } \\
\text { preparation of bones, see p. } 95 \text {. Snap-freeze } \\
\text { fresh bone tissue for possible chemical analysis. } \\
\text { Submit samples of tendons and ligaments for } \\
\text { histologic study. }\end{array}$ & $\begin{array}{l}\text { Osteomalacia* and osteosclerosis with } \\
\text { periosteal new bone formation. Abnormal } \\
\text { dental enamel. See also above under } \\
\text { "External examination." }\end{array}$ \\
\hline Spinal cord & $\begin{array}{l}\text { For removal and specimen preparation, } \\
\text { see p. } 67 .\end{array}$ & $\begin{array}{l}\text { Bone changes may have caused compression } \\
\text { of spinal cord. }\end{array}$ \\
\hline
\end{tabular}

Fructose (See “Intolerance, fructose.")

Fusion, Congenital, of Cervical Vertebrae (See "Impression, basilar.") 


\section{G}

\section{Galactosemia}

\begin{tabular}{|c|c|c|}
\hline Organs and Tissues & Procedures & Possible or Expected Findings \\
\hline External examination & $\begin{array}{l}\text { Record body weight and length and head } \\
\text { circumference. }\end{array}$ & $\begin{array}{l}\text { Manifestations of malnutrition; } \\
\text { dehydration;* jaundice; microcephaly. }\end{array}$ \\
\hline Vitreous & $\begin{array}{l}\text { Submit sample for determination of glucose; } \\
\text { galactose, lactic acid, and ketone concentrations } \\
\text { (p. 85). }\end{array}$ & \\
\hline Blood & $\begin{array}{l}\text { Submit sample for determination of } \\
\text { galactose-1-phosphate uridyl transferase activity } \\
\text { in erythrocytes. Compare with values in blood } \\
\text { of controls. }\end{array}$ & $\begin{array}{l}\text { Galactose-1-phosphate uridyl transferase } \\
\text { deficiency. }\end{array}$ \\
\hline Urine & Refrigerate immediately. & $\begin{array}{l}\text { Reducing substances; glucosuria; } \\
\text { aminoaciduria; phosphaturia. }\end{array}$ \\
\hline Abdomen & Record volume of fluid. & Ascites. \\
\hline Kidney & Submit sections for histologic study. & Tubular dilatation. \\
\hline Liver & $\begin{array}{l}\text { Record size and weight; photograph cut section; } \\
\text { submit samples for histologic and electron } \\
\text { microscopic study (p. 132). If histochemical } \\
\text { study (1) is intended, snap-freeze tissue. } \\
\text { Request frozen sections for Sudan stain (p. 173). }\end{array}$ & $\begin{array}{l}\text { Giant cell transformation; ductular } \\
\text { proliferation; acinar transformation of } \\
\text { hepatocytes; cholestasis; regenerative } \\
\text { nodules; macrovesicular steatosis; fibrosis; } \\
\text { cirrhosis* }(2) \text {. }\end{array}$ \\
\hline Pancreas & $\begin{array}{l}\text { Submit samples of head, body, and tail for } \\
\text { histologic study. }\end{array}$ & Hyperplasia of islets of Langerhans. \\
\hline Brain and spinal cord & $\begin{array}{l}\text { For removal and specimen preparation, see } \\
\text { pp. } 65 \text { and } 67 \text {, respectively. }\end{array}$ & $\begin{array}{l}\text { Fibrillary astrocytosis of white matter; } \\
\text { loss of Purkinje cells; lipofuscin overload } \\
\text { in large neurons. }\end{array}$ \\
\hline Eyes & For removal and specimen preparation, see p. 85 . & Cataracts. \\
\hline
\end{tabular}

\section{References}

1. Landing BH, Ang SM, Villarreal-Engelhardt G, Donnell GN. Galactosemia: clinical and pathologic features, tissue staining patterns with labeled galactose- and galactosamine-binding lectins, and possible loci of nonenzymatic galactosylation. Persp Pediatr Pathol 1993;17:99-124.

2. Jevon GP, Dimmick JE. Histopathologic approach to metabolic liver disease: Part 2. Pediatr Dev Pathol 1998;1:261-269.

\section{Ganglioneuroma (See "Tumor of the peripheral nerves.")}

\section{Gangliosidosis}

Synonyms and Related Terms: Activator protein deficiency (type AB); beta galactosidase deficiency; $\mathrm{GM}_{1}$ gangliosidosis, infantile, type 1 (with visceral involvement); late infantile, type 2; adult, type 3; GM2 gangliosidosis with infantile, late infantile, and adult forms; hexosaminidase A deficiency (type B); hexosamine A and B deficiency (type 0); lysosomal disorder (1); Tay Sachs disease; Sandhoff's disease. 


\begin{tabular}{ll}
\hline Organs and Tissues & Procedures \\
\hline External examination & $\begin{array}{l}\text { Obtain routine body measurements and weight. } \\
\text { Photograph all abnormalities. }\end{array}$
\end{tabular}

Fascia lata (see also

"Liver and spleen")

Liver and spleen

Other organs

Brain and spinal cord

Placenta
Fascia lata should be collected using aseptic technique for tissue culture for biochemical studies (see Chapter 10) and electron microscopic examination (p. 132).

Record weights. See also below under "Brain and spinal cord." Obtain tissue for tissue culture for assay of enzyme deficiency. Enzyme assay can be performed on fresh or frozen liver tissue. If evidence of other organ involvement (heart, kidney) is present, follow procedures described below under "Brain and spinal cord."

For removal and specimen preparation, see pp. 66 and 70, respectively. Request LFB/PAS and/or Sudan Black (on frozen tissue) stains (p. 172). Submit samples for electron microscopic study (p. 132). Enzyme assay can be performed on fresh or frozen brain tissue. If analysis of lipids is intended, place fresh tissue in liquid nitrogen and store at $-90^{\circ} \mathrm{C}$ until lipids can be extracted and analyzedfor instance, by thin-layer chromatography.
Possible or Expected Findings

Hydrops fetalis; coarse facies; macroglossia; depressed, broad nose; large ears; frontal bossing; gingival hypertrophy; squat hands and feet; flexor contractures; ascites; hernias. Cultured fibroblasts can be used for enzyme assay. "Empty" vacuoles in lymphocytes by EM.

Hepatosplenomegaly; accumulation of PAS and Sudan Black positive material (ganglioside) in histiocytes (1).

Cerebral atrophy; neurons distended by lipid (ganglioside); disintegration of neurons and reactive phagocytosis and astrocytosis; fibrillogranular inclusions in fibroblasts and endothelial cells $(2-4)$.

Vacuolated syncytiotrophoblast. for histologic study.

\section{References}

1. Jevon GP, Dimmick JE. Histopathologic approach to metabolic liver disease: Part 2. Pediatr Dev Pathol 1998;1:261-269.

2. Lake B. Lysosomal and peroxisomal disorders. In: Greenfield's Neuropathology, vol. 1. Graham BI, Lantos PL, eds. Arnold, New York, 1997, pp. 658-668.

\section{Gangrene, Gas}

Synonym: Clostridial infection.

NOTE: (1) Collect all tissues that appear to be infected. (2) Request aerobic and anaerobic bacterial cultures. (3) Request Gram stain (p. 172). Inflammation may be minimal or absent. (4) No special precautions are indicated. (5) Serologic studies are not indicated. (6) This is not a reportable disease.

\begin{tabular}{ll}
\hline Organs and Tissues & Procedures \\
\hline External examination & $\begin{array}{l}\text { Record appearance of wounds or of other } \\
\text { possibly infected lesions. If foreign bodies are } \\
\text { present, record their nature and location (roent- } \\
\text { genograms may be helpful). Prepare smears of } \\
\text { wounds and request Gram stain (p. 172). }\end{array}$
\end{tabular}

Skeletal muscles Prepare roentgenograms of suspected areas; palpate abnormal areas and record extent of crepitation; submit samples of grossly involved and of uninvolved skeletal muscle for bacteriologic and histologic study (see above under "Note").
Possible or Expected Findings

Edema surrounding wound; gas bubbles in a discharge; foul odor of the wound; loose blebs containing serosanguinous fluid.

Muscle necrosis (Clostridial myonecrosis) and accumulation of gas; little leukocytic infiltration. 


\begin{tabular}{lll}
\hline Organs and Tissues & Procedures & Possible or Expected Findings \\
\hline Other organs & $\begin{array}{l}\text { Procedures depend on expected findings or } \\
\text { grossly identified abnormalities as listed in } \\
\text { right-hand column. See also above under } \\
\text { "Note" and under "Skeletal muscles." }\end{array}$ & $\begin{array}{l}\text { Pneumonia;* empyema;* cholecystitis;* } \\
\text { uterine infection (postabortal or postpartum). }\end{array}$ \\
\hline
\end{tabular}

\section{Gastroenteritis, Eosinophilic}

\begin{tabular}{|c|c|c|}
\hline Organs and Tissues & Procedures & Possible or Expected Findings \\
\hline Abdomen & $\begin{array}{l}\text { Record volume of peritoneal exudate and } \\
\text { prepare smears of sediment. }\end{array}$ & $\begin{array}{l}\text { Chronic peritonitis and ascites in cases with } \\
\text { serosal involvement of the affected stomach } \\
\text { or gut segments. }\end{array}$ \\
\hline $\begin{array}{l}\text { Esophagus and } \\
\text { gastrointestinal tract }\end{array}$ & $\begin{array}{l}\text { Record location of and photograph involved } \\
\text { segments; state distance of these areas from } \\
\text { anatomic landmarks. Leave esophagus attached } \\
\text { to stomach. For in situ fixation of small bowel, } \\
\text { see p. } 54 \text {. Record thickness of wall, width of } \\
\text { lumen, and length of involved segments. } \\
\text { Submit samples of all grossly involved and of } \\
\text { grossly uninvolved segments for histologic study. } \\
\text { Request azure-eosin or Giemsa stain (p. 172). }\end{array}$ & $\begin{array}{l}\text { Eosinophilic esophagitis may occur }(1) \text {. } \\
\text { Presence of infiltrates most common in } \\
\text { antrum of stomach with thickening of the } \\
\text { pylorus. Ulcers may be found in antrum or } \\
\text { duodenum. Various portions of small bowel } \\
\text { also may be involved, with or without } \\
\text { intestinal obstruction. Colonic involvement } \\
\text { (2) is rare. Eosinophilic infiltrates may be } \\
\text { found in all layers of the affected hollow } \\
\text { viscera. There should be no evidence of } \\
\text { parasite infestation. }\end{array}$ \\
\hline Pancreas and bile ducts & $\begin{array}{l}\text { Submit samples for histologic study. } \\
\text { Request azure-eosin or Giemsa stain (p. 172). }\end{array}$ & $\begin{array}{l}\text { Pancreatitis ( } 3 \text { ) and cholangitis (2) in rare } \\
\text { instances. }\end{array}$ \\
\hline Other organs & $\begin{array}{l}\text { Procedures depend on expected findings or } \\
\text { grossly identified abnormalities as listed in } \\
\text { right-hand column. }\end{array}$ & $\begin{array}{l}\text { Manifestations of malabsorption syndrome* } \\
\text { and of protein-losing enteropathy.* } \\
\text { There should be no evidence systemic } \\
\text { eosinophilic disease. }\end{array}$ \\
\hline
\end{tabular}

\section{References}

1. Mahajan L, Wyllie R, Petras R, Steffen R, Kay M. Idiopathic eosinophilic esophagitis with stricture formation in a patient with longstanding eosinophilic gastroenteritis. Gastrointest Endosc 1997;46: $557-560$

2. Schoonbroodt D, Horsmans Y, Laka A, Geubel AP, Hoang P. Eosinophilic gastroenteritis presenting with colitis and cholangitis. Dig Dis Sci 1995; 40:308-314.

3. Maeshima A, Murakami H, Sadakata H, Saitoh T, Matsushima T, Tamura J, et al. Eosinophilic gastroenteritis presenting with acute pancreatitis. J Med 1997;28:265-272.

Gastroenteropathy, Hemorrhagic

(See "Enterocolitis, pseudomembranous" and "Shock.")

Gigantism, Hyperpituitary

(See "Acromegaly.")

\section{Glomerulonephritis}

Synonyms and Related Terms: Acute postinfectious glomerulonephritis (nonstreptococcal postinfectious glomerulonephritis;* minimal change disease; mesangial proliferative glomerulonephritis;* focal and segmental glomerulosclerosis with hyalinosis (focal sclerosis); poststreptococcal glomerulonephritis; idiopathic nephrotic syndrome; IgA nephropathy (Berger's disease); membranous glomerulonephritis; membranoproliferative glomerulonephritis; mesangial proliferative glomerulonephritis; rapidly progressive glomerulonephritis (associated with systemic infectious or immunologic multisystem diseases; drug idiosyncrasy; or as primary crescentic glomerulonephritis or superimposed on another primary glomerular disease).

Possible Associated Conditions: Acquired immunodeficiency syndrome (AIDS);* Alport's syndrome;* amyloidosis; anaphylactoid purpura; bee stings; chronic allograft rejection; dermatomyositis; * dermatitis herpetiformis; diabetes mellitus;* drug dependence;* Fabry's disease;* Goodpasture's syndrome;* Guillain-Barré syndrome;* Henoch-Schönlein purpura;* hemolytic uremic syndrome;* infective endocarditis; $*$ leprosy;* malignancies; mixed connective tissue disease; myxedema; polyarteritis nodosa;* rheumatoid arthritis; ${ }^{*}$ preeclamptic toxemia; renovascular hypertension; sarcoidosis; * serum sickness; ${ }^{*}$ Sjögren's syndrome;* syphilis;* systemic lupus erythematosus;* systemic sclerosis; * thrombotic thrombocytopenic purpura;* thyroiditis;* vasculitis; viral hepatitis; *Wegener's granulomatosis;* and many other conditions. 


\begin{tabular}{|c|c|c|}
\hline Organs and Tissues & Procedures & Possible or Expected Findings \\
\hline Blood & $\begin{array}{l}\text { Refrigerate sample for possible serologic study } \\
\text {-for instance, of basement membrane antibodies. }\end{array}$ & \\
\hline Urine & Submit sample for urinalysis. & Cylindruria; hematuria; proteinuria. \\
\hline Kidneys & $\begin{array}{l}\text { Record weights; photograph surfaces and cut } \\
\text { sections. Submit sample for immunofluorescent } \\
\text { study. For electron microscopic study, } \\
\text { see p. 132. Request 3- } \mu \text { m paraffin sections } \\
\text { stained with PAS, methenamine silver, and } \\
\text { Masson's trichrome stains (p. 173). }\end{array}$ & $\begin{array}{l}\text { For specific types of glomerulonephritis, } \\
\text { see above under "Synonyms and Related } \\
\text { Terms." For further information, appropriate } \\
\text { nephropathological texts should be } \\
\text { consulted. }\end{array}$ \\
\hline Other organs & $\begin{array}{l}\text { Procedures depend on expected underlying, } \\
\text { associated, or complicating conditions. If leg } \\
\text { ulcers, wounds, or other acute infections are } \\
\text { present, or if possibly nephritogenic chronic } \\
\text { infections are found, submit material for } \\
\text { appropriate bacterial cultures-for instance, } \\
\text { from pharynx or middle ears. }\end{array}$ & $\begin{array}{l}\text { See above under "Possible Associated } \\
\text { Conditions." See also under "Failure, } \\
\text { kidney" and, if applicable, under } \\
\text { "Dialysis (for chronic renal failure)." }\end{array}$ \\
\hline Eyes & $\begin{array}{l}\text { For removal and specimen preparation, } \\
\text { see p. } 85 \text {. }\end{array}$ & $\begin{array}{l}\text { Hypertensive retinopathy; in Alport's syn- } \\
\text { drome, }{ }^{*} \text { cataracts and other abnormalities. }\end{array}$ \\
\hline
\end{tabular}

\section{Glycogenosis (See "Disease, glycogen storage.")}

\section{Gout}

Related Term: Hyperuricemia.

Possible Associated Conditions: Alcoholism;* berylliosis; ${ }^{*}$ chronic renal failure with long-term renal dialysis; diabetes insipidus; ${ }^{*}$ Down's syndrome;* drug toxicity; glycogenosis
(III, V, and VII); hemolysis; hyperparathyroidism;* hypertension;* hypothyroidism;* lead poisoning;* obesity;* Paget's disease; polycystic renal disease; polycythemia vera;* previous chemotherapy or radiation therapy of myeloproliferative disease; psoriasis;* pyelonephritis; ${ }^{*}$ Reiter's syndrome;* rheumatoid arthritis; ${ }^{*}$ sarcoidosis;* status post renal transplantation; toxemia of pregnancy,* and others.

\begin{tabular}{|c|c|}
\hline Organs and Tissues & Procedures \\
\hline $\begin{array}{l}\text { External examination } \\
\text { and subcutaneous tissues }\end{array}$ & $\begin{array}{l}\text { Photograph and record location of tophi. For } \\
\text { fixation for histologic study, place tophi in } \\
\text { alcohol (p. 129), formalin-alcohol (p. 130), } \\
\text { or Carnoy's fixative (p. 130). For murexide } \\
\text { test for the macroscopic diagnosis of urates, } \\
\text { see p. 134. Prepare skeletal roentgenograms. }\end{array}$ \\
\hline
\end{tabular}

Blood

Heart and blood vessels

Trachea and major bronchi Kidneys

Other organs

Bones, joints, bursae, and tendons
Submit sample for determination of uric acid concentration.

Submit samples of myocardium and of elastic and muscular arteries for histologic study. For fixation procedures, see above under "External examination and subcutaneous tissues."

Submit samples for histologic study.

Prepare roentgenogram of soft tissues; photograph surfaces and cut sections. For fixation procedures, see above under "External examination and subcutaneous tissues."

In cases of secondary gout, procedures depend on suspected underlying disease, as listed above under "Possible Associated Conditions."

For removal of synovial fluid and for identification of crystals in gout and pseudogout, see p. 96. For removal, prosthetic repair, and specimen preparation of bones and joints, see p. 95 .

\section{Possible or Expected Findings}

In tophaceous gout, tophi at helices of ears and on elbows, knees, hands, and feet.

Acute or chronic gouty arthritis with punched-out bone lesions. Hyperuricemia. For interpretation of postmortem findings, see p. 114.

Sodium urate deposits (uncommon in heart but may be responsible for cardiac dysrhythmia*).

Nephrolithiasis; * urate nephropathy; uric acid nephropathy.

See above under "Possible Associated Conditions."

In rare instances, pseudogout* or pyarthrosis may occur. Monosodium urate in synovial neutrophils. 


\begin{tabular}{lll}
\hline Organs and Tissues & Procedures & Possible or Expected Findings \\
\hline $\begin{array}{l}\text { Bones, joints, bursae, } \\
\text { and tendons } \\
\text { (continued) }\end{array}$ & $\begin{array}{l}\text { Use brush to clean frontal saw section of spine, } \\
\text { and photograph. Photograph joint surfaces and } \\
\text { other synovial surfaces that show white deposits. } \\
\text { Submit samples of all involved tissues for histo- } \\
\text { logic study. For fixation procedures and murexide }\end{array}$ & $\begin{array}{l}\text { Urate deposits in intervertebral disks and on } \\
\text { synovial surfaces; gouty and tophaceous } \\
\text { arthritis. }\end{array}$ \\
& $\begin{array}{l}\text { test, see above under "External examination and } \\
\text { subcutaneous tissues." For proper sampling of } \\
\text { joints, consult roentgenograms. For preparation } \\
\text { of museum specimens, see p. 134. }\end{array}$ & \\
& $\begin{array}{l}\text { For removal and specimen preparation, } \\
\text { Eyes }\end{array}$ & Urate deposits in scleras and corneas. For fixation procedures, see above. \\
\hline
\end{tabular}

Granulocytopenia (See "Pancytopenia.")

Granuloma, All Types or Type Unspecified

(See "Disease, chronic granulomatous,"

"Granuloma,...," "Granulomatosis,...,"

and "Pneumoconiosis."

See also under name of specific granulomatous disease, such as "Sarcoidosis" and "Tuberculosis.")

Granuloma, Eosinophilic

(See "Histiocytosis, Langerhans cell.")

Granuloma, Midline
Synonyms: Idiopathic midline granuloma; lethal midline granuloma; granuloma gangrenescens. (The last two names are obsolete.)

NOTE: Midline granulomas may belong to the angiocentric immunoproliferative lesions, which are related to lymphomatoid granulomatosis* and malignant lymphoma. The name "idiopathic midline granuloma" should be reserved for the few cases without evidence of malignant lymphoma or Wegener's granulomatosis* (1). The diagnosis of idiopathic midline granuloma also can be ruled out if studies reveal fungal organisms or features of leishmaniasis; ${ }^{*}$ leprosy, ${ }^{*}$ rhinoscleroma, pseudotumor of the orbit or tuberculosis.* Complications of nasal cocaine abuse also may mimic midline granuloma (2).

\begin{tabular}{lll}
\hline Organs and Tissues & Procedures & Possible or Expected Findings \\
\hline External examination & $\begin{array}{l}\text { Record extent of necrosis, and photograph } \\
\text { facial lesions. }\end{array}$ & Necrosis of skin of nose and eyelids. \\
$\begin{array}{c}\text { Nasal cavities and } \\
\text { paranasal sinuses }\end{array}$ & $\begin{array}{l}\text { For exposure of nasal cavities and sinuses, } \\
\text { see p. 71. Submit material for bacterial and } \\
\text { fungal cultures. Prepare smears and histologic } \\
\text { sections of affected tissues. Request Verhoeff- } \\
\text { van Gieson, Gram, and Grocott's methenamine } \\
\text { silver stains (p. 172). }\end{array}$ & $\begin{array}{l}\text { Necrosis with perforation of nasal septum, } \\
\text { hard and soft palate, paranasal sinuses, and } \\
\text { orbital cavities. Noncaseating granulomas } \\
\text { with intense inflammatory reaction. Review } \\
\text { material to rule out conditions mentioned } \\
\text { under "Note." }\end{array}$ \\
& $\begin{array}{l}\text { Submit lymph nodes for microbiologic (p. 102) } \\
\text { and histologic study. }\end{array}$ & $\begin{array}{l}\text { See above under "Nasal cavities and } \\
\text { paranasal sinuses." }\end{array}$ \\
& & $\begin{array}{l}\text { For manifestations of diseases that may } \\
\text { produce features of midline granuloma, see } \\
\text { above under "Note." }\end{array}$ \\
\hline
\end{tabular}

References

1. Barker TH, Hosni AA. Idiopathic midline destructive disease: does it exist? J Laryngol Otol 1998;112:307-309.

2. Sevinsky LD, Woscoff A, Jaimovich L, Terzian A. Nasal cocain abuse mimicking midline granuloma. J Am Acad Dermatol 1995;32:286-287.

Granulomatosis, Allergic, and Angiitis (Churg-Strauss Syndrome)

Related Term: Pulmonary granulomatous vasculitis (1).

Possible Associated Condition: Asthma.*

\begin{tabular}{lll}
\hline Organs and Tissues & Procedures & Possible or Expected Findings \\
\hline External examination & $\begin{array}{l}\text { Record extent of skin lesions and prepare } \\
\text { photographs. }\end{array}$ & $\begin{array}{l}\text { Purpura; cutaneous and subcutaneous } \\
\text { nodules (see below under "Other organs"). }\end{array}$
\end{tabular}




\begin{tabular}{lll}
\hline Organs and Tissues & Procedures & Possible or Expected Findings \\
\hline Lungs & $\begin{array}{l}\text { Perfuse lungs with formalin (p. 47) and sample } \\
\text { for histologic study. }\end{array}$ & $\begin{array}{l}\text { Eosinophilic pneumonitis (degenerating } \\
\text { eosinophils with Charcot-Leyden crystals) } \\
\text { and granulomas. Angiitis (mostly arteritis), } \\
\text { typically with giant cells in tunica media (1). }\end{array}$ \\
$\begin{array}{l}\text { Other organs and } \\
\text { soft tissues }\end{array}$ & $\begin{array}{l}\text { Procedures depend on expected findings or } \\
\text { grossly identified abnormalities as listed in } \\
\text { right-hand column. Techniques are similar to } \\
\text { those described under "Polyarteritis nodosa." }\end{array}$ & $\begin{array}{l}\text { Findings resemble those in polyarteritis } \\
\text { nodosa.*Heart (2), grastrointestinal tract (3), } \\
\text { skin, muscles, and joints are commonly } \\
\text { involved. However, renal disease is often } \\
\text { (but not always) mild or absent. }\end{array}$ \\
& $\begin{array}{l}\text { Histologic sampling should include cutaneous } \\
\text { and subcutaneous nodules. }\end{array}$ & $\begin{array}{l}\text { Necrotizing vasculitis of small arteries and } \\
\text { veins is present, with extravascular } \\
\text { granulomas and eosinophilic infiltration of } \\
\text { vessels and perivascular tissues. }\end{array}$ \\
& & Optic neuritis may be found (4). \\
Eyes & For removal and specimen preparation, see p. 85. \\
Brain, spinal cord, & For removal and specimen preparation, \\
and peripheral nerves & see pp. 65, 67, and 79, respectively. & May be affected by the vasculitis (4).
\end{tabular}

\section{References}

1. Travis WD. Pathology of pulmonary granulomatous vasculitis. Sarcoid Vasculit Diff Lung Dis 1996;13:14-27.

2. Terasaki F, Hayashi T, Hirota Y, Okabe M, Suwa M, Deguchi H, et al. Evolution of dilated cardiomyopathy from acute eosinophilic pancarditis in Churg-Strauss syndrome. Heart Vessels 1997;12:43-48.

3. Matsuo K, Tomioka T, Tajima Y, Takayama K, Tamura H, Higami Y, et al. Allergic granulomatous angiitis (Churg-Strauss syndrome) with multiple intestinal fistulas. Am J Gastroenterol 1997;92:1937-1938.

4. Sehgal M, Swanson JW, DeRemmee RA, Colby TV. Neurologic manifestations of Churg-Straus syndrome. Mayo Clin Proc 1995;70:337-341.

\section{Granulomatosis, Bronchocentric}

Synonyms and Related Terms: Allergic bronchopulmonary aspergillosis (1); eosinophilic pneumonia (eosinophilic pulmonary syndrome*); extrinsic allergic alveolitis; idiopathic bronchocentric granulomatosis; microgranulomatous hypersensitivity reaction of lungs; mucoid impaction of bronchi.

Possible Associated Conditions: Asthma;* cystic fibrosis.*

\begin{tabular}{lll}
\hline Organs and Tissues & Procedures & Possible or Expected Findings \\
\hline Lungs & $\begin{array}{l}\text { Submit one lobe for bacterial and fungal cultures } \\
\text { (p. 103). Prepare smears of fresh cut sections. }\end{array}$ & $\begin{array}{l}\text { Aspergillus (usually Aspergillus fumigatus) } \\
\text { in dilated bronchi (2), with or without }\end{array}$ \\
& For pulmonary arteriography and bronchography, & inspissation of mucus or fungus ball; \\
& see p. 50. Perfuse one lung through bronchi & necrotizing granulomatous pneumonia or \\
& and also through pulmonary arteries (plugged & bronchitis (2) with bronchial chondritis; \\
& bronchi may prevent proper perfusion; & eosinophilic pneumonia; obstructive \\
(cholesterol-type) pneumonia; atelectases; & ee also p. 47). & emphysema.* Secondary arteritis may be \\
& & present. \\
\hline
\end{tabular}

\section{References}

1. Bosken C, Myers J, Greenberger P, Katzenstein A-L. Pathologic features of allergic bronchopulmonary aspergillosis. Am J Surg Pathol 1988;12: 216-222.

2. Yousem AS. The histological spectrum of chronic necrotizing forms of pulmonary aspergillosis. Hum Pathol 1997;28:650-656.

\section{Granulomatosis, Lymphomatoid}

Related Term: Angiocentric immunoproliferative lesion; angiocentric malignant lymphoma.

Possible Associated Conditions: AIDS* (1) and other immunodeficiency states such as Wiskott-Aldrich syndrome or posttransplant immunosuppression.

\begin{tabular}{lll}
\hline Organs and Tissues & Procedures & Possible or Expected Findings \\
\hline External examination & Record extent of skin lesions; photograph skin & Lymphoreticular infiltrates, primarily in \\
and skin & $\begin{array}{l}\text { lesions; prepare histologic sections of involved } \\
\text { skin and of grossly uninvolved skin. }\end{array}$ & $\begin{array}{l}\text { dermis but also in subcutis. See also under } \\
\text { "Lungs." }\end{array}$
\end{tabular}




\begin{tabular}{ll}
\hline Organs and Tissues $\quad$ Procedures & Possible or Expected Findings
\end{tabular}

External examination Prepare chest roentgenogram. and skin (continued) Blood

Lungs

Liver

Kidneys

Other organs and tissues

Brain and spinal cord
Submit sample for bacterial, fungal, and viral cultures (p. 102). Snap-freeze sample for possible biochemical and immunologic study.

Record weights; submit samples of fresh tissue for B- and T-cell gene derangement studies, frozensection immunostains, and other investigations (see refs. 3 and 4). Submit one lobe for microbiologic study (p. 103). Touch preparations of cut surfaces of lungs for cytologic study may be helpful.

For pulmonary arteriography, see p. 50.

Perfuse one lung with formalin (p. 47).

Photograph cut sections of lungs. Submit samples of all lobes and of hilar lymph nodes for histologic study. Request Verhoeff-van Gieson, Gram, and Gridley's fungal stains (p. 172). For preparation of specimens for electron microscopy, see p. 132.

Record weight and sample for histologic studies.

Follow procedures described under "Glomerulonephritis."

Samples for histologic study should include heart, pancreas, spleen, adrenal glands, urinary bladder, prostate, neck organs (with nasopharynx and tongue), salivary glands, lymph nodes, thymus, bone marrow, and all other tissues with grossly identifiable lesions.

For removal and specimen preparation, see pp. 65 and 67, respectively.
Multiple nodules, with or without cavitation; cavitation; rarely pneumothorax (2).

PCR studies on paraffin sections via RNA in situ hybridization may confirm presence of Epstein-Barr virus-positive B-cell proliferations combined with dense T-cell accumulations (3-5). The condition closely resembles angiocentric T-/NK cell lymphoma (3).

Infiltration of lymphocytoid cells, plasma cells, and macrophages with necroses and granulomatous features, which are found primarily in the vicinity of blood vessels. Special stains may reveal evidence of infection.

Lymphoreticular and granulomatous infiltrates (see "Lung").

Lymphoreticular and granulomatous infiltrates (see "Lung").

Characteristic infiltrates may be present in all organs and tissues. Involvement of spleen, lymph nodes, and bone marrow is uncommon. In rare instances, the disease is confined to the abdomen.

In most instances, characteristic infiltrates are present.

\section{References}

1. Haque AK, Myers JL, Hudnall SD, Gelman BB, Lloyd RV, Payne D, et al. Pulmonary lymphomatoid granulomatosis in acquired immunodeficiency syndrome: lesions with Epstein-Barr virus infection. Mod Pathol 1998;11:347-356.

2. Morris MJ, Peacock MD, Lloyd WC III, Johnson JE. Recurrent bilateral spontaneous pneumothoraces associated with pulmonary angiocentric immunoproliferative lesion. South Med J 1995;88:771-775.

3. Jaffe ES, Wilson WH. Lymphomatoid granulomatosis: pathogenesis, pathology and clinical implications. Canc Surv 1997;30:233-248.
4. McNiff JM, Cooper D, Howe G, Crotty PL, Tallini G, Crouch J, et al. Lymphomatoid granulomatosis of the skin and lung. An angiocentric T-cell-rich B-cell lymphoproliferative disorder. Arch Dermatol 1996; 132:1464-1470.

5. Myers J, Kurtin P, Katzenstein A-L, Tazelaar H, Colby T, Strickler J, et al. Lymphomatoid granulomatosis. Evidence of immunophenotypic diversity and relationship to Epstein-Barr virus infection. Am J Surg Pathol 1995;19:1300-1312.

\section{Granulomatosis, Wegener's}

Related Terms: Angiocentric granulomatosis; granulomatous angiitis; pulmonary angiitis and granulomatosis (1).

\begin{tabular}{ll}
\hline Organs and Tissues & Procedures \\
\hline $\begin{array}{c}\text { External examination } \\
\text { and skin; oral cavity; } \\
\text { breasts }\end{array}$ & $\begin{array}{l}\text { Prepare histologic sections of skin lesions and } \\
\text { of grossly uninvolved skin. }\end{array}$
\end{tabular}

Prepare histologic sections of accessible mucosal lesions in mouth.

Possible or Expected Findings

Skin papules, vesicles, ulcers. Subcutaneous nodules (vasculitis and granulomas). Granulomatous infiltrates of breast (2). Gangrene of digits $(2,3)$.

Necrotizing and ulcerative stomatitis. 


\begin{tabular}{|c|c|c|}
\hline Organs and Tissues & Procedures & Possible or Expected Findings \\
\hline Blood & $\begin{array}{l}\text { Submit samples for microbiologic (p. 102) } \\
\text { and for immunologic study. }\end{array}$ & $\begin{array}{l}\text { Septicemia; circulating immunoglobulin } \\
\text { complexes. }\end{array}$ \\
\hline Lungs & $\begin{array}{l}\text { Submit one lobe for microbiologic study } \\
\text { (p. 103). For pulmonary arteriography, see } \\
\text { p. 50. Perfuse one lung with formalin (p. 47). } \\
\text { Request Verhoeff-van Gieson stain (p. 172). }\end{array}$ & $\begin{array}{l}\text { Angiocentric granulomatosis (4); necrotizing } \\
\text { arteritis with infarctions; granulomatous } \\
\text { bronchitis; pleuritis. }\end{array}$ \\
\hline Spleen & $\begin{array}{l}\text { Record weight; submit samples for histologic } \\
\text { study. }\end{array}$ & Necrotizing arteritis. Infarctions (5). \\
\hline Kidneys & $\begin{array}{l}\text { Follow procedures described under "Glomerulo- } \\
\text { nephritis." }\end{array}$ & $\begin{array}{l}\text { Focal necrotizing glomerulitis; necrotizing } \\
\text { arteritis (1). }\end{array}$ \\
\hline $\begin{array}{l}\text { Neck organs with } \\
\text { larynx and trachea }\end{array}$ & $\begin{array}{l}\text { Remove neck organs together with oropharynx } \\
\text { and soft palate. Photograph lesions. For histo- } \\
\text { logic study, submit samples with gross lesions } \\
\text { and samples of grossly uninvolved tissue. }\end{array}$ & $\begin{array}{l}\text { Necrotizing granulomatous inflammation } \\
\text { and ulcers of soft palate, larynx, and trachea. } \\
\text { Subglottic stenosis. Acute obstruction may } \\
\text { be a cause of death (6). }\end{array}$ \\
\hline Other organs and tissues & $\begin{array}{l}\text { Procedures depend on expected findings or } \\
\text { grossly identified abnormalities as listed in } \\
\text { right-hand column. }\end{array}$ & $\begin{array}{l}\text { Necrotizing arteritis and granulomatous } \\
\text { inflammation-for example in heart, gastro- } \\
\text { intestinal tract, and urogenital organs (1). }\end{array}$ \\
\hline \multirow[t]{2}{*}{$\begin{array}{l}\text { Paranasal sinuses; } \\
\text { ear, nose }\end{array}$} & $\begin{array}{l}\text { For exposure of sinuses, see p. } 71 \text {. Specimens } \\
\text { should include surrounding bone; submit } \\
\text { samples for histologic study (for decalcification } \\
\text { procedures, see p. 97). }\end{array}$ & $\begin{array}{l}\text { Necrotizing and ulcerative sinusitis with } \\
\text { perifocal osteomyelitis. Necrotizing lesions } \\
\text { in nasal cavities. }\end{array}$ \\
\hline & For exposure of middle ear, see p. 72. & Otitis media. \\
\hline Brain and spinal cord & $\begin{array}{l}\text { For removal and specimen preparation, } \\
\text { see pp. } 65 \text { and } 67 \text {, respectively. }\end{array}$ & $\begin{array}{l}\text { Angiocentric granulomatous lesions may } \\
\text { be present (1). }\end{array}$ \\
\hline Eyes and orbitae & $\begin{array}{l}\text { For removal and specimen preparation, } \\
\text { see pp. } 85 \text { and } 73 \text {, respectively. }\end{array}$ & $\begin{array}{l}\text { Pseudotumor of the orbit; other ocular lesions } \\
\text { (1), such as conjunctivitis, dacryocystitis, } \\
\text { scleritis, and episcleritis, granulomatous } \\
\text { sclerouveitis; ciliary vasculitis. }\end{array}$ \\
\hline Bones and joints & & Arthritis.* \\
\hline
\end{tabular}

\section{References}

1. Lie JT. Wegener's granulomatosis: histological documentation of common and uncommon manifestations in 216 patients. VASA 1997; 26:261-270.

2. Trueb RM, Pericin M, Kohler E, Barandun J, Burg G. Necrotizing granulomatosis of the breast. Br J Dermatol 1997;137:799-803.

3. Handa R, Wali JP. Wegener's granulomatosis with gangrene of toes. Scand J Rheumatol 1996;25:103-104.
4. Travis WD. Pathology of pulmonary granulomatous vasculitis. Sarcoidosis, Vascul Diff Lung Dis 1996;13:14-27.

5. Fishman D, Isenberg DA. Splenic involvement in rheumatic diseases. Semin Arthritis Rheum 1997;27:141-155.

6. Matt BH. Wegener's granulomatosis, acute laryngotracheal airway obstruction and death in a 17-year-old female: case report and review of the literature. Int J Pediatr Otolaryngol 1996;37:163-172.

\section{Gunshot (See "Injury, firearm.")}




\section{Hallucinogen(s) (See “Abuse, hallucinogen(s).”)}

\section{Halothane (See "Death, anesthesia-associated.")}

\section{Hanging}

NOTE: Most hangings in the United States are suicides with short drops producing no cervical derangements, in contrast to the now uncommon judical hangings. A few hanging deaths are industrial accidents, and a few are consequences of asphyxia, selfinduced for the purpose of sexual pleasure. Clues to autoerotic asphyxia are nudity, cross dressing, bondage paraphernalia, pornography, remotely operated video cameras, escape mechanisms, and a history or evidence of prior such acts.

\begin{tabular}{|c|c|c|}
\hline Organs and Tissues & Procedures & Possible or Expected Findings \\
\hline \multirow[t]{4}{*}{$\begin{array}{l}\text { External examination } \\
\text { and skin }\end{array}$} & $\begin{array}{l}\text { Photograph the neck and head with and without } \\
\text { the ligature in place, from anterior, left, right, } \\
\text { and posterior aspects, and the ligature after } \\
\text { removal. }\end{array}$ & $\begin{array}{l}\text { Corresponding patterns of ligature and } \\
\text { furrow; presence or absence of cyanosis and } \\
\text { factial petecchiae; protrusion of tongue. }\end{array}$ \\
\hline & Record and photograph liver mortis. & $\begin{array}{l}\text { Shift from lower extremities to back; } \\
\text { Tardieau spots (petecchiae caused by } \\
\text { pooling). }\end{array}$ \\
\hline & $\begin{array}{l}\text { Measure diameter of the ligature and the depth } \\
\text { and width of the furrow. }\end{array}$ & $\begin{array}{l}\text { Size and pattern of ligature should match } \\
\text { size and pattern of furrow. }\end{array}$ \\
\hline & $\begin{array}{l}\text { Measure the circumference of both the ligature } \\
\text { and the neck. Measure the vertical distance of } \\
\text { the furrow from the ear lobe. }\end{array}$ & $\begin{array}{l}\text { Circumference of ligature will be less than } \\
\text { circumference of neck. }\end{array}$ \\
\hline Neck organs & Use layerwise anterior dissection (p. 14). & $\begin{array}{l}\text { Dessicated tan compressed subcutaneous } \\
\text { facia; fractures of superior laryngeal cornua } \\
\text { or hyoid in the elderly are consistent with } \\
\text { hanging and can occur after prolonged } \\
\text { suspension. }\end{array}$ \\
\hline
\end{tabular}

\section{Hashish (See “Abuse, marihuana.”)}

\section{Heart Disease, Congenital}

NOTE: See under individual malformations, such as "Defect, ventricular septal." For a listing of Latin terms and their Anglicized equivalents, see Chapter 3, Appendix 3-3, p. 39. Synonyms for various forms of congenital heart disease are compiled in Chapter 3, Appendix 3-2, p. 39. For eponyms of various operations for congenital heart disease, see Chapter 3, Appendix 3-4, p. 41. Finally, a template for recording information at autopsy on patients with congenital heart disease is presented in Chapter 3, Appendix 3-5, p. 42.

\section{Heat (See "Burns" and "Heatstroke.")}

\section{Heatstroke}

Synonyms and Related Terms: Heat exhaustion; heat syncope; hyperthermia.

NOTE: Possible complications include disseminated intravascular coagulation* and fibrinolysis syndrome and Gramnegative septicemia. 


\begin{tabular}{|c|c|c|}
\hline Organs and Tissues & Procedures & Possible or Expected Findings \\
\hline External examination & Inquire about ambient and body temperature. & Hyperthermia when body was discovered. \\
\hline Vitreous & $\begin{array}{l}\text { Submit sample for determination of chloride, } \\
\text { sodium, and urea nitrogen concentrations (p. 58). }\end{array}$ & $\begin{array}{l}\text { Frequently, evidence of hypertonic } \\
\text { dehydration.* See also p. } 115 .\end{array}$ \\
\hline Blood & $\begin{array}{l}\text { Submit sample for toxicologic study, particularly } \\
\text { for alcohol and drug screen ( } \mathrm{p} 16) \text {. }\end{array}$ & Alcohol intoxication. \\
\hline Urine & $\begin{array}{l}\text { Record volume; determine specific gravity; } \\
\text { record appearance of sediment. }\end{array}$ & High specific gravity; casts. \\
\hline Thyroid gland & $\begin{array}{l}\text { Sample for histologic study, particularly in } \\
\text { unusual cases of heatstroke. }\end{array}$ & $\begin{array}{l}\text { Thyroid disease such as Hashimoto's } \\
\text { thyroiditis may predispose to heatstroke (2). }\end{array}$ \\
\hline Other organs & $\begin{array}{l}\text { Submit samples for toxicologic (p. 16) and } \\
\text { histologic study. }\end{array}$ & $\begin{array}{l}\text { There may be no macroscopic changes ( } 2 \text { ). } \\
\text { Hemorrhages may be present, particularly in } \\
\text { central nervous system, kidneys, and liver. } \\
\text { Small parenchymal necroses with or without } \\
\text { microthrombi may be found. }\end{array}$ \\
\hline
\end{tabular}

\section{References}

1. Donoghue ER, Graham MA, Jentzen JM, Lifschultz BD, Luke JL, Mirchandani HG. Criteria for the diagnosis of heat-related deaths: National Association of Medical Examiners. Position paper. National Association of Medical Examiners Ad Hoc Committee on the Definition of HeatRelated Fatalities. Am J Forens Med Pathol 1997;18:11-14.

2. Siegler RW. Fatal heatstroke in a young woman with previously undiagnosed Hashimoto's thyroiditis. J Forens Sci 1998;43:1237-1240.

\section{Hematoma, Dissecting Aortic (See "Dissection, aortic.")}

\section{Hematoma, Spinal Epidural}

\begin{tabular}{lll}
\hline Organs and Tissues & Procedures & Possible or Expected Findings \\
\hline Spinal cord & $\begin{array}{l}\text { For removal and specimen preparation, } \\
\text { see p. } 67 .\end{array}$ & Traumatic lesions; vascular malformations. \\
Other organs & & Manifestations of hypertension.* \\
\hline
\end{tabular}

\section{Hematoma, Subdural}

Synonym: Subdural hemorrhage.

\begin{tabular}{|c|c|c|}
\hline Organs and Tissues & Procedures & Possible or Expected Findings \\
\hline \multirow[t]{2}{*}{ External examination } & Record evidence of trauma. & $\begin{array}{l}\text { Abrasions; lacerations; subcutaneous } \\
\text { hematomas. }\end{array}$ \\
\hline & Prepare roentgenogram of skull. & Fractures. \\
\hline \multirow[t]{3}{*}{$\begin{array}{l}\text { Skull, meninges, } \\
\text { and brain }\end{array}$} & $\begin{array}{l}\text { For opening of skull and removal of calvarium, } \\
\text { see p. } 65 \text {. }\end{array}$ & $\begin{array}{l}\text { Fractures may be identifiable only after } \\
\text { stripping of dura. }\end{array}$ \\
\hline & $\begin{array}{l}\text { Record site and volume of subdural hematoma } \\
\text { and relation of hematoma to burr holes } \\
\text { (if present). }\end{array}$ & $\begin{array}{l}\text { Compression of cerebral hemispheres, with } \\
\text { or without edema, and secondary } \\
\text { compression of rostral brain stem. }\end{array}$ \\
\hline & $\begin{array}{l}\text { Remove vitreous-particularly if subdural } \\
\text { hematoma appears to be nontraumatic-and } \\
\text { determine sodium, potassium, and chloride } \\
\text { concentrations (p. 85). }\end{array}$ & $\begin{array}{l}\text { Nontraumatic subdural hematoma rarely may } \\
\text { be caused by hypernatremia and other } \\
\text { hyperosmolar conditions. For interpretation } \\
\text { of electrolyte values, see p. } 113 \text {. }\end{array}$ \\
\hline
\end{tabular}

\section{Hemochromatosis}

Synonyms and Related Terms: Genetic hemochromatosis; pigment cirrhosis; primary hemochromatosis; secondary hemochromatosis.

NOTE: Secondary iron overload in other types of cirrhosis (e.g., alcoholic cirrhosis; alpha ${ }_{1}$-antitrypsin deficiency, chronic viral hepatitis) may be severe enough to suggest genetic hemochromatosis. In such cases, quantitative iron studies (see below under "Liver") and calculation of the iron index are indicated (1). 


\begin{tabular}{|c|c|}
\hline Organs and Tissues & Procedures \\
\hline $\begin{array}{l}\text { External examination } \\
\text { and skin and oral cavity }\end{array}$ & $\begin{array}{l}\text { Record character and extent of pigmentation. } \\
\text { Prepare histologic sections of pigmented areas } \\
\text { and request Gomori's iron and Fontana-Masson } \\
\text { silver stains (p. 172). }\end{array}$ \\
\hline
\end{tabular}

Prepare skeletal roentgenograms, which should include major joints, wrists, and hands, as listed in right-hand column.

Heart

Liver

Pancreas

Other organs and tissues

Testes

Bones and joints

Eyes
Record weight. For gross staining for iron, see p. 133. For dissection of the conduction system, see p. 26. Submit samples of myocardium for histologic study (p. 30) and request Gomori's iron stain (p. 172).

Record weight and photograph. For gross staining for iron, see Chapter 14, p. 133. For microscopic sections, request Gomori's iron stain (p. 172). For quantitative iron studies, submit sample (this can be dug out from a paraffin block) for atomic absorption spectrophotometry (1). Record color and weight. Submit samples for histologic study, particularly of tail. See also above under "Liver."

Histologic samples should include oral mucosa, tongue, stomach, intestinal tract, spleen, adrenal glands, kidneys, thyroid gland, parathyroid glands, lymph nodes, pituitary gland, and bone marrow. For gross and microscopic staining procedures, see above under "Liver."

Record weights and submit samples for histologic study.

For removal, prosthetic repair, and specimen preparation, see p. 95 .

For removal and specimen preparation, see p. 85. Request Gomori's iron stain (p. 172).
Possible or Expected Findings

Melanin hyperpigmentation of skin in face, neck, dorsal aspect of forearms and hands, genital area and scars; pigmentation of oral mucosa in some instances. A positive Fontana-Masson stain is not specific for the presence of melanin. Some hemosiderin may be present also.

Osteoporosis* and osteoarthritis* of hands and wrists, with chondrocalcinosis, subarticular cysts (second and third metacarpophalangeal joints), or osteophytes; osteoarthritis of hip, knee, and other major joints. Calcification of synovium.

Cardiomyopathy with hemosiderosis and fibrosis of cardiac musculature.

Pigment cirrhosis (see also above under "Note" and under "Cirrhosis, liver"). Hepatocellular carcinoma (see under "Tumor of the liver").

Hemosiderosis of exocrine and endocrine parenchyma; interstitial fibrosis.

Manifestations of diabetes mellitus; $*$ features of congestive heart failure, ${ }^{*}$ particularly in patients with hemochromatotic cardiomyopathy. Generalized hemosiderosis with fibrosis of adrenal glands and pituitary gland. Secondary hemochromatosis may be caused by various conditions, such as spherocytosis, thalassemia, * and other types of anemia (see "Anemia, hemolytic"), treated or untreated by transfusions. See also above under "Note." Tubular atrophy.

Osteoporosis* and osteoarthritis.* Hemosiderosis of joints and synovial membranes. Calcium pyrophosphate crystals in synovium. See also above under "External examination and skin and oral cavity." Hemosiderosis of margin of retinal disk, ciliary body, and corneal epithelium.

\section{Reference}

1. Ludwig J, Hashimoto E, Porayko MK, Moyer T, Baldus WP. Hemosiderosis in cirrhosis: a study of 447 native livers. Gastroenterology 1997 ; 112 : 882-888. 


\section{Hemophilia}

Synonyms: Hemophilia A (factor VIII coagulant protein deficiency); hemophilia B (Factor IX deficiency; Christmas disease).

NOTE: Rare hereditary deficiencies of other blood coagulation factors (II, V, VII, X, XI) may cause some symptoms of hemophilia. A reliable postmortem diagnosis is not possible; post-mortem blood coagulation studies do not yield useful results.

Possible Associated Conditions: Acquired immunodeficiency syndrome (AIDS)* (1), chronic viral hepatitis* with or without cirrhosis, and other infections from contaminated plasma products.

\begin{tabular}{ll}
\hline Organs and Tissues & Procedures \\
\hline External examination & Record character and extent of skin changes. \\
& Prepare skeletal roentgenograms. \\
& \\
Blood & $\begin{array}{l}\text { If infectious complications are expected, submit } \\
\text { samples for culture and serologic study (p. 102). } \\
\text { Liver }\end{array}$ \\
Record weight and sample for histologic study.
\end{tabular}

Other organs

Brain and spinal cord

Joints
Record sites and sizes of hematomas and hemorrhages, and photograph.

For removal and specimen preparation, see pp. 65 and 67 , respectively.

For removal, specimen preparation, and prosthetic repair, see p. 96. Photograph joint lesions.
Possible or Expected Findings

Cutaneous ecchymoses; soft tissue hematoma; blood in body orifices. Joint deformities (ankle, knee, elbow); erosions of bones by pseudotumors; soft tissue calcifications.

For common infections in hemophilic patients, see above under "Note."

Viral hepatitis $\mathrm{C}$ is very common but hepatitis B also may be encountered (2). (See also under "Hepatitis, chronic.") Hematomas and hemorrhages in soft tissues of floor of mouth, neck, subdural space, retroperitoneum, mesentery, renal pelves, gastrointestinal tract, and other sites.

Hemorrhage (1); microinfarctions, possibly related to treatment with large amounts of antihemophilic factor.

Arthropathy with severe degenerative changes (3); hemarthrosis.

\section{References}

1. Cahill MR, Colvin BT. Haemophilia. Postgrad Med J 1997;73:201-206.

2. Lee CA. Transfusion-transmitted disease. Baillieres Clin Haematol 1996;9:369-394.

3. Lan HH, Eustace SJ, Dorfman D. Hemophilic arthropathy. Radiol Clin North Am 1996;34:446-450.

Hemorrhage, Cerebral (See under name of suspected underlying condition, such as "Aneurysm, cerebral artery," "Infarction, cerebral," "Injury, head," and "Tumor of the brain." For removal of cerebrospinal fluid, see p. 104.)"

\section{Hemorrhage, Gastrointestinal}

\begin{tabular}{ll}
\hline Organs and Tissues & Procedures \\
\hline $\begin{array}{l}\text { Abdomen } \\
\text { Esophagus and stomach }\end{array}$ & $\begin{array}{l}\text { For demonstration of esophageal varices, } \\
\text { see p. 53. Record appearance of mucosa; } \\
\text { record volume of blood in lumen. }\end{array}$
\end{tabular}

\section{Duodenum}

Small bowel and large bowel

Other organs
If infectious enteritis is suspected, submit material for microbiologic study (p. 102). Submit samples of all segments for histologic study. If free blood is present, record volume. Procedures depend on expected findings or grossly identified abnormalities as listed in right-hand column.
Possible or Expected Findings

Diaphragmatic hernia.*

Reflux esophagitis; varices;* strictures with erosions; tumor;* mucosal erosions and peptic ulcer(s);* petechial mucosal hemorrhages.

Peptic ulcer(s).*

Infectious-for instance, in typhoid fever*and noninfectious enteritis; circulatory or neoplastic intestinal disease; other diseases, such as diverticulitis.

Cerebral space-occupying lesions; manifestations of coagulation disorder, including leukemia* or other neoplastic disease; pancreatitis; $*$ manifestations of portal hypertension* or of kidney failure.* 
Hemorrhage, Intracranial (See under "Hematoma, subdural" and under name of suspected underlying condition, such as "Aneurysm, cerebral artery," "Infarction, cerebral," "Injury, head," and "Tumor of the brain."

For removal of cerebrospinal fluid, see p. 104.)

Hemorrhage, Subarachnoid (See under name of suspected underlying condition, such as "Aneurysm, cerebral artery," "Infarction, cerebral," "Injury, head," and "Tumor of the brain." For removal of cerebrospinal fluid, see p. 104.)"

\section{Hemosiderosis, Idiopathic Pulmonary}

NOTE: This diagnosis is made by exclusion; involvement of organs other than the lungs (see below under "Kidneys") suggests another disease.

\begin{tabular}{|c|c|c|}
\hline Organs and Tissues & Procedures & Possible or Expected Findings \\
\hline Heart & & Cor pulmonale. \\
\hline \multirow[t]{2}{*}{ Lungs } & $\begin{array}{l}\text { Photograph fresh lungs (side by side with } \\
\text { normal lung). Perfuse lungs with formalin } \\
\text { (p. 47); for iron staining of gross specimens, } \\
\text { see p. 133; for microscopic sections, request } \\
\text { Gomori's iron stain (p. 172). For quantitation of } \\
\text { iron in paraffin blocks, see "Hemochromatosis." }\end{array}$ & $\begin{array}{l}\text { Hemorrhages into alveolar spaces. } \\
\text { Hemosiderin in pulmonary septa and } \\
\text { macrophages; interstitial pulmonary fibrosis; } \\
\text { degeneration, shedding, and hyperplasia } \\
\text { of alveolar epithelial cells. }\end{array}$ \\
\hline & $\begin{array}{l}\text { Immunofluorescent and electron microscopic } \\
\text { studies (see below) also may be of value. }\end{array}$ & $\begin{array}{l}\text { Goodpasture's syndrome and immune-com- } \\
\text { plex mediated vasculitis need to be ruled out. }\end{array}$ \\
\hline Kidneys & $\begin{array}{l}\text { Prepare tissue for immunofluorescent study. } \\
\text { Submit samples for electron microscopic study } \\
\text { p. 132). }\end{array}$ & $\begin{array}{l}\text { Kidneys should not be involved; if they } \\
\text { are, Goodpasture's syndrome* must be } \\
\text { considered as a cause. }\end{array}$ \\
\hline Bone marrow & For preparation of sections and smears, see p. 96. & Secondary hyperplasia caused by anemia. \\
\hline
\end{tabular}

\section{Hepatitis, Alcoholic (See "Disease, alcoholic liver.")}

\section{Hepatitis, Chronic}

Synonyms and Related Terms: Autoimmune hepatitis; chronic viral hepatitis B (with or without D) and C.

NOTE: The term "chronic hepatitis" is not a complete etiologic diagnosis and related names such as chronic active (aggressive) hepatitis, chronic active liver disease, and chronic persistent hepatitis are obsolete. Most cases in these categories represent autoimmune hepatitis or chronic viral hepatitis B or C. Many other liver diseases, including drug-induced hepatitis, inborn errors of metabolism (e.g., alpha ${ }_{1}$-antitrypsin deficiency* or Wilson's disease*), developmental disorders, and chronic biliary diseases such as primary biliary cirrhosis or primary sclerosing cholangitis also may present as chronic hepatitis.

If chronic hepatitis was the cause of death, submassive hepatic necrosis or cirrhosis* is usually present, often with manifestations of portal hypertension,* hepatic encephalopathy, hepatorenal syndrome, ${ }^{*}$ and with ascites or spontaneous bacterial peritonitis.

Possible Associated Conditions: See also below under "Possible or Expected Findings." Conditions that may be associated with hepatitis C include (1): autoimmune hepatitis; Behcet's disease; diabetes mellitus (type 2);* glomerulonephritis; ${ }^{*}$ GuillainBarré syndrome;* idiopathic pulmonary fibrosis; idiopathic thrombocytopenic purpura; IgA deficiency; lichen planus; mixed essential cryoglobulinemia; Mooren's corneal ulcers; polyarthritis; porphyria cutanea tarda;* thyroiditis.*

\begin{tabular}{ll}
\hline Organs and Tissues & Procedures \\
\hline $\begin{array}{l}\text { External examination } \\
\text { and skin }\end{array}$ & $\begin{array}{l}\text { Record body weight and length, habitus, and } \\
\text { extent and character of skin changes. Prepare } \\
\text { histologic sections of skin lesions. }\end{array}$
\end{tabular}

Blood

Heart

Arteries

Liver
Submit sample for serologic studies if type of viral hepatitis $(\mathrm{B}, \mathrm{D}$, or $\mathrm{C})$ or of autoimmune hepatitis is in question.

For histologic sampling, see p. 30.
Record weight and photograph surface and cut
Possible or Expected Findings

Hirsutism; cushingoid face; acne; maculopapular rash; erythema nodosum; lupus erythematosus-like changes in face; localized scleroderma; purpura; vitiligo; cutaneous small-vessel vasculitis and porphyria cutanea tarda in chronic hepatitis C (2).

Viral antigens or antibodies; autoantibodies (ANA, SMA, and others) in autoimmune hepatitis. Essential mixed cryoglobulinemia in chronic hepatitis $\mathrm{C}(2)$.

Pericarditis.

Polyarteritis nodosa*

Chronic viral or autoimmune hepatitis, with 


\begin{tabular}{|c|c|c|}
\hline Organs and Tissues & Procedures & Possible or Expected Findings \\
\hline Liver (continued) & $\begin{array}{l}\text { sections. If chronic hepatitis B is suspected, } \\
\text { order immunostains for B surface and core antigen. } \\
\text { Request PAS stain with diastase digestion, p. } 173 \text {. } \\
\text { If Wilson's disease must be ruled out, order } \\
\text { rhodanine stain and quantitative copper study. } \\
\text { Request Gomori's iron stain (p. 172). }\end{array}$ & $\begin{array}{l}\text { or without cirrhosis;* hepatocellular } \\
\text { carcinoma. } \\
\text { Alpha }_{1} \text {-antitrypsin deficiency.* } \\
\text { High hepatic tissue copper concentrations in } \\
\text { Wilson's disease.* } \\
\text { Hemosiderosis common in hepatitis C. }\end{array}$ \\
\hline Gallbladder & Describe concrements. & Cholelithiasis \\
\hline Pancreas & Submit samples for histologic study. & Changes associated with diabetes mellitus.* \\
\hline Intestinal tract & $\begin{array}{l}\text { Procedures depend on expected findings or } \\
\text { grossly identified abnormalities as in conditions } \\
\text { listed in right-hand column. }\end{array}$ & $\begin{array}{l}\text { Crohn's disease* or chronic ulcerative colitis } \\
\text { often associated with primary sclerosing } \\
\text { cholangitis.* (See above under "Note.") }\end{array}$ \\
\hline Kidneys & $\begin{array}{l}\text { Follow procedures described under "Glomerulo- } \\
\text { nephritis." }\end{array}$ & $\begin{array}{l}\text { Membranous and membranoproliferative } \\
\text { glomerulitis and nephrotic syndrome. }\end{array}$ \\
\hline Thyroid gland & $\begin{array}{l}\text { Record weight, photograph, and submit samples } \\
\text { for histologic study. }\end{array}$ & $\begin{array}{l}\text { Hashimoto's thyroiditis. } \\
\text { Thyroid dysfunction in interferon-treated } \\
\text { chronic hepatitis B and C (3). }\end{array}$ \\
\hline Brain and spinal cord & $\begin{array}{l}\text { For removal and specimen preparation, } \\
\text { see pp. } 65 \text { and } 67 \text {, respectively. }\end{array}$ & $\begin{array}{l}\text { Cerebritis and peripheral neuropathy in } \\
\text { chronic hepatitis } C(2) \text {. }\end{array}$ \\
\hline Eyes and lacrimal glands & $\begin{array}{l}\text { For removal and specimen preparation, } \\
\text { see pp. } 85 \text { and } 87 \text {, respectively. }\end{array}$ & $\begin{array}{l}\text { Keratoconjunctivitis; fibrosis and } \\
\text { inflammation of lacrimal glands; } \\
\text { manifestations of Sjögren's syndrome.* }\end{array}$ \\
\hline $\begin{array}{l}\text { Parotid and } \\
\text { submandibular glands }\end{array}$ & $\begin{array}{l}\text { Samples can be biopsied from scalp incision } \\
\text { (p. 65) and removed with floor of the mouth } \\
\text { (p. 41), respectively. }\end{array}$ & Fibrosis and inflammation. \\
\hline Nose, pharynx, and larynx & Submit samples of mucosa for histologic study. & Atrophy of mucosal glands. \\
\hline $\begin{array}{l}\text { Bone, bone marrow, } \\
\text { and joints }\end{array}$ & $\begin{array}{l}\text { For removal, specimen preparation, and } \\
\text { prosthetic repair of bones and joints, see p. } 95 \text {. } \\
\text { For preparation of sections and smears of bone } \\
\text { marrow, see p. } 96 \text {. }\end{array}$ & $\begin{array}{l}\text { Osteoporosis* (particularly after steroid } \\
\text { treatment); hypocellular bone marrow } \\
\text { (aplastic anemia). }\end{array}$ \\
\hline
\end{tabular}

\section{References}

1. Gordon SC. Extrahepatic manifestations of Hepatitis C. Dig Dis 1996; 14:157-168.

2. Gross JB Jr. Clinician's guide to hepatitis C. Mayo Clinic Proc 1998; 73:355-361.

3. Deutsch M, Dourakis S, Manesis EK, Gioustozi A, Hess G, Horsch A, Hadziyannis S. Thyroid abnormalities in chronic viral hepatitis and their relationship to interferon alpha therapy. Hepatology 1997;26: 206-210.

\section{Hepatitis, Fulminant (See "Hepatitis, viral.”)}

\section{Hepatitis, Neonatal}

Synonyms and Related Terms: Giant cell hepatitis; idiopathic neonatal hepatitis (familial or nonfamilial); infantile obstructive cholangiopathy; neonatal cholestasis.

NOTE: Neonatal hepatitis may have been a biopsy diagnosis in an earlier stage of paucity of intrahepatic bile ducts; at autopsy, biliary cirrhosis with ductopenia would be the main finding. For other conditions that may present clinically as neonatal hepatitis or jaundice, see below.

\begin{tabular}{ll}
\hline Organs and Tissues & Procedures \\
\hline External examination & \\
Blood & Submit samples for microbiologic (p. 102) \\
& and serologic study. \\
& $\begin{array}{l}\text { If chromosome abnormalities are suspected, } \\
\text { submit sample for chromosome } \\
\text { analysis (p. 108). }\end{array}$
\end{tabular}

Extrahepatic bile ducts
For postmortem cholangiography, see p. 56. If no roentgenologic studies can be carried out, open duodenum in situ, squeeze gallbladder, and record whether bile emerged from papilla.

\section{Possible or Expected Findings}

Jaundice. Lymphedema in one form of hereditary neonatal hepatitis (1). Hepatitis virus antigens or antibodies, including hepatitis B or C, cytomegalovirus, coxsackievirus, herpes simplex, rubeola, and varicella virus. Toxoplasmosis, ${ }^{*}$ congenital syphilis, ${ }^{*}$ and Listeria monocytogenes infection may also cause neonatal hepatitis. Biliary atresia;* paucity of intrahepatic bile ducts (syndromic [Alagille's syndrome] or nonsyndromic); choledochal cyst.* 


\begin{tabular}{|c|c|c|}
\hline Organs and Tissues & Procedures & Possible or Expected Findings \\
\hline Liver & $\begin{array}{l}\text { Record size and weight; photograph surface and } \\
\text { cut section; submit sample of fresh liver for viral } \\
\text { culture (p. 102); submit samples for histologic } \\
\text { study; request PAS stain with diastase digestion } \\
\text { (p. 173). }\end{array}$ & $\begin{array}{l}\text { Giant cell transformation of liver, with or } \\
\text { without biliary atresia or paucity of } \\
\text { intrahepatic bile ducts. Cholestasis and } \\
\text { cirrhosis may be present. Alpha }{ }_{1} \text {-antitrypsin } \\
\text { deficiency. Fatty livers also may be found (2). }\end{array}$ \\
\hline Other organs and tissues & $\begin{array}{l}\text { Procedures depend on expected findings or } \\
\text { grossly identified abnormalities as listed in } \\
\text { right-hand column. }\end{array}$ & $\begin{array}{l}\text { Manifestations of conditions that may present } \\
\text { clinically as neonatal hepatitis or jaundice, } \\
\text { e.g., cystic fibrosis }(3) ; * \text { erythroblastosis } \\
\text { fetalis;* congenital rubella syndrome;* } \\
\text { galactosemia;* Niemann-Pick disease;* } \\
\text { trisomy } 17-18 \text {; Turner's syndrome.* }\end{array}$ \\
\hline
\end{tabular}

\section{References}

1. Sharp HL, Krivit W. Hereditary lymphedema and obstructive jaundice. J Pediatr 1971;78:491-496.

2. Nishinomiya F, Abukawa D, Takada G, Tazawa Y. Relationships between clinical and histological profiles of non-familial idiopathic neonatal hepatitis. Acta Paediatr Japn 1996;38:242-247.

3. Lykavieris P, Bernard O, Hadchouel M. Neonatal cholestasis as the presenting feature in cystic fibrosis. Arch Dis Child 1996;75:67-70.

\section{Hepatitis, Viral}

Synonyms: Acute (or subacute) viral hepatitis; fulminant viral hepatitis; hepatitis virus hepatitis; viral hepatitis A, B, B with D, C, E, F, G, or type undetermined.

NOTE: Coinfection with other hepatitis viruses (e.g., $\mathrm{C}$ and G) and/or systemic viruses such as the immunodeficiency virus are common, particularly in drug addicts $(1,2)$. In many cases of fulminant hepatitis, tests for known hepatitis viruses are negative $(3,4)$. If the hepatitis was caused by a systemic virus, see under the specific disease name, for example, "Infection, cytomegalovirus." For chronic viral hepatitis, see under "Hepatitis, chronic." If the patients underwent liver transplantation
(3) or bone marrow transplantation for complicating aplastic anemia (4), see also under "Transplantation,..."

(1) Collect all tissues that appear to be infected. (2) Request viral cultures if systemic disease such as cytomegalovirus infection* is expected. (3) Stains for hepatitis B core and surface antigen may be helpful (p. 172). (4) Special precautions are indicated, particularly in suspected hepatitis B and D infection (p. 146). (5) Serologic studies are essential in undiagnosed cases and can be obtained from most clinical laboratories. (6) Hepatitis virus hepatitis is not a reportable disease.

Possible Associated Conditions: See "Hepatitis, chronic."

\begin{tabular}{ll}
\hline Organs and Tissues & Procedures \\
\hline External examination & $\begin{array}{l}\text { If patient was on dialysis for chronic renal } \\
\text { failure, see also under that heading. }\end{array}$
\end{tabular}

Blood

Heart

Lungs

Liver

Gallbladder

Pancreas

Spleen

Esophagus

Stomach
Submit sample for serologic studies for viral antigens or antibodies.

For histologic sampling, see p. 30.

Perfuse one lung with formalin (p. 47).

Sample for histologic study and request

Verhoeff-van Gieson stain (p. 173).

Record weight and photograph surface and cut sections. If hepatitis B is suspected, order immunostains for B surface and core antigen. Immunostains for hepatitis D are also available. Record appearance and volume of bile. Submit samples for histologic study. Record weight; request Gomori's stain for iron.

Leave attached to stomach; submit sample for histologic study.

Submit sample for histologic study.
Possible or Expected Findings

Jaundice; skin rash or hemorrhages and other abnormalities. Needle marks may indicate intravenous substance abuse.

Viral antigens or antibodies may or may not be positive.

Myocarditis; ${ }^{*}$ necrosis of fibers in bundle of His.

Manifestations of pulmonary hypertension.*

Lobular inflammation with bridging necrosis or multilobular collapse; massive necrosis with complete loss of parenchyma. Stains for viral antigens often are negative.

Bile may be absent.

Pancreatitis.*

Pulpal hyperplasia; hemosiderosis; congestive splenomegaly.

Ulcerations or erosions of distal esophagus; varices.

Gastritis. 


\begin{tabular}{|c|c|c|}
\hline Organs and Tissues & Procedures & Possible or Expected Findings \\
\hline Small intestine & $\begin{array}{l}\text { For in situ fixation, see p. } 54 \text {. Submit samples } \\
\text { for histologic study. }\end{array}$ & $\begin{array}{l}\text { Flattening, broadening, and possible fusion } \\
\text { of villi. Phlegmonous inflammation and } \\
\text { edema, mainly in ileocecal region. }\end{array}$ \\
\hline Kidneys & $\begin{array}{l}\text { Follow procedures described under "Glomerulo- } \\
\text { nephritis." }\end{array}$ & $\begin{array}{l}\text { Glomerular changes; bile casts in tubules; } \\
\text { interstitial edema. }\end{array}$ \\
\hline Lymph nodes & $\begin{array}{l}\text { Submit cervical and mediastinal lymph nodes } \\
\text { for histologic study. }\end{array}$ & Lymphadenitis. \\
\hline Thyroid & Sample for histologic study. & See "Hepatitis, chronic." \\
\hline Brain and spinal cord & $\begin{array}{l}\text { For removal and specimen preparation, } \\
\text { see pp. } 65 \text { and } 67 \text {, respectively. }\end{array}$ & Encephalitis.* \\
\hline Bone marrow & $\begin{array}{l}\text { For preparation of sections and smears, } \\
\text { see p. } 96 .\end{array}$ & $\begin{array}{l}\text { Leukopenia; thrombocytopenia; aplastic } \\
\text { anemia (4) (pancytopenia*). }\end{array}$ \\
\hline Joints & $\begin{array}{l}\text { For removal, prosthetic repair, and specimen } \\
\text { preparation, see p. } 96 \text {. Submit samples of } \\
\text { synovia for histologic study. }\end{array}$ & Synovitis (arthritis*). \\
\hline
\end{tabular}

\section{References}

1. Thiers V, Pol S, Persico T, Carnot F, Zylberberg H, Berthelot P, et al. Hepatitis $G$ virus infection in hepatitis $C$ virus-positive patients coinfected or not with hepatitis B virus and/or human immunodeficiency virus. J Viral Hep 1998;5:123-130.

2. Bortolotti F, Tagger A, Giacchino R, Zuccoti GV, Crivellaro C, Balli F, et al. Hepatitis $G$ and C coinfection in children. J Pediatr 1997;131: 639-640.

\section{Hepatoma (See "Tumor of the liver.")}

\section{Hernia, Diaphragmatic}

Related Terms: Congenital diaphragmatic hernia; hiatal hernia; sliding hiatus hernia.

NOTE: Congenital diaphragmatic hernia is right-sided or left-sided and may be associated with cardiac anomalies, such as the hypoplastic heart syndrome (with left-sided diaphragmatic hernia) (1) or anomalies of lungs or upper airways (2).

\begin{tabular}{lll}
\hline Organs and Tissues & Procedures & Possible or Expected Findings
\end{tabular}

Thoracic and abdominal cavity
Record extent of hernia by palpation from abdominal cavity, before organ removal. Remove esophagus and stomach as one specimen; photograph opened esophagus and stomach, and pin on corkboard for fixation and histologic study.

In infants, search for associated malformations in the chest cavity (see above under "Note").

In teenagers or adults with repaired congenital diaphragmatic hernias, prepare chest roentgenograms. Perfuse lungs with formalin (see p. 47).
Reflux esophagitis; esophageal ulcer(s) and stricture(s), Barrett's esophagus, * with or without adenocarcinoma.

In long-term survivors of repaired congenital diaphragmatic hernias, thoracic deformities, and restrictive or obstructive lung disease may be found (3).

\section{References}

1. Losty PD, Vanamo K, Rintala RJ, Donahoe PK, Schnitzer JJ, Lloyd DA. Congenital diaphragmatic hernia: does the side of the defect influence the incidence of associated malformations? J Pediatr Surg 1998;33:507-510.

2. Ryan CA, Finer NN, Etches PC, Tierney AJ, Peliowski A. Congenital diaphragmatic hernia: associated malformations: cystic adenomatoid malformation, extralobular sequestration, and laryngotracheoesophageal cleft: two case reports. J Pediatr Surg 1995;30:883-885.

3. Vanamo K, Rintala R, Sovijarvi A, Jaaskelainen J, Turpeinen M, Lindahl H, Louhimo I. Long-term pulmonary sequelae in survivors of congenital diaphragmatic defects. J Pediatr Surg 1996;31:1096-1099.

\section{Heroin}

(See "Dependence, $\operatorname{drug}(\mathrm{s})$, all types or type unspecified.")

\author{
Herpes Simplex \\ (See "Infection, herpes simplex.")
}

Herpes Zoster

(See "Infection, herpes zoster.") 


\section{Histiocytosis, Langerhans Cell}

Synonym and Related Terms: Abt-Letterer-Siwe disease; eosinophilic granuloma of bone; Hand-Schüller-Christian disease; histiocytosis $\mathrm{X}$ (use of these names is no longer recommended [1]).

NOTE: Langerhans cell histiocytosis is a monoclonal disorder and thus a true neoplasm (2). The disease most commonly is found in pediatric patients and is rare in adults (3).

Possible Associated Conditions: Diabetes insipidus; ${ }^{*}$ malignant lymphoma.*

\begin{tabular}{ll}
\hline Organs and Tissues & Procedures \\
\hline External examination, & $\begin{array}{l}\text { Prepare photograph of gross lesions as listed in } \\
\text { skin, and oral cavity }\end{array}$ \\
right-hand column.
\end{tabular}

Prepare skeletal roentgenograms.

Sample skin lesions for histologic study (see below under "Lymph nodes").

Blood

Lymph nodes

Heart

Lungs

Other organs and tissues

Brain and spinal cord

Eyes

Middle ears

Bones
Submit sample for microbiologic study

(see p. 102).

Sample grossly involved and uninvolved lymph nodes and set aside fresh material for the preparation of frozen sections (e.g., for CD1 stains). Prepare material for electron microscopy (see p. 132).

Record weight and thickness of walls.

Dissect one fresh lung and sample for histologic study (see above under "Lymph nodes). Submit sample for microbiologic study (see p. 103).

Perfuse one lung with formalin (see p. 47).

Sample grossly involved and uninvolved tissue for histologic study (see "Lymph nodes"), including liver, spleen, gastrointestinal tract, kidneys, and perirenal fat.

Submit tissue samples for biochemical study (total cholesterol) and for electron microscopic study.

For removal and specimen preparation, see p. 66 and 70, respectively. Histologic samples must include hypothalamus, pituitary gland, and cerebellum.

For removal and specimen preparation, see p. 85 . For removal and specimen preparation, see p. 72 .

Review roentgenograms. For removal and specimen preparation, see p. 95.
Possible or Expected Findings

Exophthalmos ("Hand-Schüller-Christian disease." see below under "Eyes").

Nodules in scalp. Vulvar lesions.

Hyperplasia and ulcerations of gums.

Monostotic or polyostotic destructive bone lesions (lesions most common is skull); pathological fractures.

Papular, eczema-like eruptions; xanthomas; erythematous, purpuric, and ecchymotic lesions. Histiocytic and eosinophilic infiltrates (see lymph nodes).

Septicemia.

Typical mononuclear cells and eosinophils in sinuses, with or without microabscess formation.

Mononuclear cells with Langerhans' or Birbeck granules.

Cor pulmonale.

Destructive granulomas centered around distal bronchioles (4). Pneumonia of various types.

Histiocytosis with hepatosplenomegaly ("Letterer-Siwe disease"). Many other organs and tissues may be involved.

Increased tissue concentrations of total cholesterol.

Langerhans cell infiltrates, most commonly in hypothalamic-pituitary area (5); infiltrates arise from bone lesions, meninges, or choroid plexus.

Orbital histiocytic infiltrates.

Otitis media* (in "Hand-Schüller-Christian disease").

Monostotic lesions may be found ("eosinophilic granuloma").

\section{References}

1. Nezelof C, Basset F. Langerhans cell histiocytosis research. Past, present, and future. Hematol Oncol Clin North Am 1998;12:385-406.

2. Willman CL, McClain KL. An update on clonality, cytokines, and viral etiology in Langerhans cell histiocytosis. Hematol Oncol Clin North Am 1998;12:407-416.

3. Malpas JS. Langerhans cell histiocytosis in adults. Hematol Oncol Clin North Am 1998; 12:259-268.

4. Soler P, Tazi A, Hance AJ. Pulmonary Langerhans cell granulomatosis. Curr Opin Pulm Med 1995;1:406-416.

5. Grois NG, Favara BE, Mostbeck GH, Prayer D. Central nervous system disease in Langerhans cell histiocytosis. Hematol Oncol Clin North Am 1998;12:287-305. 


\section{Histoplasmosis}

Synonyms: Darling's disease; Histoplasma capsulatum infection.

NOTE: (1) Collect all tissues that appear to be infected. (2) Request fungal cultures. (3) Request Grocott's stain for fungi (p. 172). (4) Usually, no special precautions are indicated. (5) Serologic studies are available from local and state health department laboratories (p. 135). (6) This is not a reportable disease.

Possible Associated Conditions: Histoplasmosis may be a complication of the acquired immunodeficiency syndrome*(1) and this possibility should be ruled out in all instances.

\begin{tabular}{|c|c|c|}
\hline Organs and Tissues & Procedures & Possible or Expected Findings \\
\hline Cerebrospinal fluid & $\begin{array}{l}\text { If there is suspicion of cerebral involvement, } \\
\text { submit for culture (p. 104). }\end{array}$ & \\
\hline Oral cavity & $\begin{array}{l}\text { Prepare histologic sections of ulcers. Submit } \\
\text { specimens for fungal culture. }\end{array}$ & Ulcerations of tongue and palate. \\
\hline Blood and urine & $\begin{array}{l}\text { Submit samples for fungal culture (p. 102). } \\
\text { Obtain sample for serologic study. }\end{array}$ & \\
\hline Heart & $\begin{array}{l}\text { If endocarditis is suspected, follow procedures } \\
\text { described on p. } 103 \text {. }\end{array}$ & Infective endocarditis; $*$ pericarditis. ${ }^{*}$ \\
\hline $\begin{array}{l}\text { Mediastinum and lungs } \\
\text { (see also below under } \\
\text { "Neck organs"). }\end{array}$ & $\begin{array}{l}\text { Perfuse one lung with formalin (p. 47). } \\
\text { Brief decalcification may be necessary in } \\
\text { chronic cases (p. 97). }\end{array}$ & $\begin{array}{l}\text { Miliary granulomas, with or without } \\
\text { calcification; cavitating pneumonia; } \\
\text { mediastinal fibrosis; obstruction of bronchi } \\
\text { by lymphadenopathy. }\end{array}$ \\
\hline Esophagus & Leave esophagus attached to fundus of stomach. & $\begin{array}{l}\text { Obstruction by enlarged mediastinal lymph } \\
\text { nodes; traction diverticula of esophagus. }\end{array}$ \\
\hline Liver & Record weight & Hepatomegaly; granulomatous hepatitis. \\
\hline Spleen & Record weight; decalcification may be necessary. & Splenomegaly; granulomatous splenitis. \\
\hline Adrenal glands & $\begin{array}{l}\text { Dissect glands, record weights, and photograph } \\
\text { (if there is evidence of involvement). }\end{array}$ & $\begin{array}{l}\text { Severe destruction in systemic } \\
\text { histoplasmosis; may be the cause of } \\
\text { Adrenal insufficiency.* }\end{array}$ \\
\hline Neck organs & After fixation, sample ulcers for histologic study. & Ulcers of epiglottis and larynx. \\
\hline Lymph nodes & & Granulomatous lymphadenopathy. \\
\hline Eyes & For removal and specimen preparation, see p. 85 . & Ocular histoplasmosis (3). \\
\hline Brain & $\begin{array}{l}\text { For removal and specimen preparation, see p. } 65 . \\
\text { See also above under "Note" }\end{array}$ & Histoplasma meningitis.* \\
\hline Bone marrow & For preparation of sections and smears, see p. 96. & $\begin{array}{l}\text { Histoplasma granulomas. Hemophagocytic } \\
\text { histiocytosis in patients with reactive } \\
\text { hemophagocytic syndrome }(2) \text {. }\end{array}$ \\
\hline
\end{tabular}

\section{References}

1. Raza J, Harris MT, Bauer JJ. Gastrointestinal histoplasmosis in a patient with acquired immune deficiency syndrome. Mt Sinai J Med 1996;63: $136-140$.

2. Koduri PR, Chundi V, DeMarais P, Mizock BA, Patel AR, Weinstein RA. Reactive hemophagocytic syndrome: a new presentation of disseminated histoplasmosis in patients with AIDS. Clin Inf Dis 1995;21:1463-1465.

3. Callanan D, Fish GE, Anand R. Reactivation of inflammatory lesions in ocular histoplasmosis. Arch Ophthalmol 1998;116:470-474.

\section{Homicide}

NOTE: The following procedures are listed in the order in which they are usually carried out. Of course, not all these procedures can be carried out or will be required in all cases, nor will this checklist be sufficient in all instances. Consult also the entries indicating the cause of death, such as "Injury, firearm" or "Injury, stabbing." If the victim is an infant, see also under "Infanticide."
Procedures Required Before the Body Arrives or Before Autopsy Is Begun:

1. Investigate the scene where the body was found and where the crime may have been committed (these may be two separate locations). If this is not possible, study the report and photographs submitted by the investigator or the police. Study all available information (p. 8). Request previous medical records and roentgenograms of the victim. 
2. Emphasize to funeral director and other personnel that the body of the victim should not be undressed, washed, or otherwise disturbed. Embalming is not permitted before completion of the autopsy. Advise funeral director to put plastic bags over the hands of the victim. This will protect possible evidence, such as hair from the assailant.

3. Appoint a technician who will be in charge of the record sheet (for sample, see pp. 339-342) and of the chain of custody (p. 17). On that sheet, record the name, age, sex, and other information about the victim, the name of the technician, and the name of the pathologist who will perform the autopsy.

4. Prepare roentgenographic and photographic equipment.

\section{Procedures Required After Body \\ Arrives but Before Autopsy Is Begun:}

1. The technician who is in charge of the record sheet should enter the time of arrival of the body. He/she should then stay with the body at all times. This technician will complete the record sheet that will also document the chain of custody. If the body must be left unguarded-for instance, overnight-a lock should be placed on the refrigerator or cool room where the deceased is kept, and the key should be retained by the technician.

2. Ask all persons other than the pathologist(s) and the technicians who are not immediately involved in the actual performance of the autopsy to leave the morgue. If detectives, police officers, police photographers, fingerprint experts, and other officials with legitimate assignments need access to the body of the victim, appropriate arrangements should be made. The technician in charge of the record sheet should ask these persons to identify themselves, and this should be entered on the record sheet, along with a statement about the arrival and departure times and what they were doing.

3. The body temperature of the victim can be recorded but this is rarely useful, particularly if the victim seems to have been dead for longer than a day or two or if the body had previously been stored in a refrigerator or cool room. Insert thermometer deep into the anus (about 7-8 cm). If this cannot be done, place thermometer in the axilla for about $3 \mathrm{~min}$. Press arm of the victim to his chest. This will ensure close contact of the thermometer with the skin. Record temperature and manner and time of procedure.

4. Aspirate vitreous from one or both eyes and place the specimen in a tube (p. 16). Close the tube tightly and invert 12 times to ensure proper mixing; record the time of removal from the eye(s); store the tube in a refrigerator.

5. Prepare roentgenograms. In each case, a decision must be made whether roentgenograms should be made of the entire body or only of parts of it—or not at all—and whether they should be made before the victim is undressed, after the victim is undressed, or at both times.

\section{Procedures During the Autopsy:}

1. While performing the autopsy, the pathologist should dictate the protocol (p. 12). Height, weight, extent of rigor, and color and distribution of livor should be recorded, along with the state of preservation, nutrition, and hydration. Record appearance of hands, particularly of the volar surfaces.

2. Photograph frontal aspect and profile of the victim for identification purposes. Photograph all injuries and other forensically significant findings. This should be done during the various steps of undressing the victim and during the actual autopsy. Two photographs should be taken of each finding. One should include the autopsy number, a running identification number (to permit easy reference in the protocol), and a scale (because of possible subsequent use in court, the scale should be in inches and in centimeters). A second photograph should be taken without any extraneous objects. After gross features have been recorded and photographed, and after evidence (such as gunpowder flakes) has been collected, wash the victim carefully, especially if the skin is dirty. After cleaning the skin, all photographs should be retaken. Prepare diagrams of wounds; identify their location anteriorly, laterally, or posteriorly by stating the distance from the top of the head and from the soles of the feet, the distance from and the side (right or left) of the midline, and the distance from fixed anatomic landmarks, such as the acromion or the tuber ischii.

3. On the record sheet, note when victim was fingerprinted and when fingernail scrapings or clippings were collected. Hair should also be collected (p. 17), and its source should be identified (hair pulled from scalp, axillae, and pubis is identified as that of the victim; hair in hands or under fingernails or on clothing of victim may be from the assailant).

4. If the body is decomposed or mutilated or for any other reason has not been identified, prepare dental roentgenograms, preferably with the help of a dentist. Whole-body roentgenograms, including films of the sella turcica, may help the pathologist to identify the victim. Other items useful for identification include laundry marks in clothing, keys, and jewelry. All such objects should be put in labeled plastic bags.

5. In cases in which sexual assault may have been involved, collect pieces of clothing that may contain seminal fluid stains. Follow procedures described under "Rape."

6. Blood stains that may have come from the assailant should be scraped off or excised and submitted to the appropriate laboratories. Excise wounds or portions of wounds and submit for histologic study. This will help to distinguish antemortem from postmortem injuries. Specimens should be labeled individually. If maggots or pupas are present, preserve some in formalin. This may aid in determining the time of death (p. 11). 
7. Preserve clothing or part of clothing as evidence. Wet clothing should be dried before it is stored in labeled and sealed plastic bags.

8. If air embolism is suspected, see p. 290. If pneumothorax is suspected, see p. 430. If there is evidence of strangulation or other neck injury, extend midline incision to tip of chin. This will ensure careful and complete removal of neck organs.

9. The record sheet should show when body fluids, tissues, and foreign bodies were collected, the volume and appearance of such specimens, and what was done with them. In all instances, the following items should be collected, as shown on p. 16: blood of victim for blood group determination and toxicologic study (determination of alcohol, carbon monoxide, and drug concentrations will be requested most frequently); vitreous; cerebrospinal fluid; urine; gastric contents; tissues for toxicologic study; and bullets or other foreign bodies (touch only with smooth anatomic forceps; see also p. 137 and under "Bodies, foreign").

For appropriate methods of sampling for toxicologic study, use of preservatives, methods of storage, type of containers, labeling, shipping, and chain of custody, see Chapters 2 and 14. Obtain receipts of specimens that were forwarded to the Forensic Physical Evidence Laboratory.

10. For general forensic autopsy protocols and procedures, see pp. 12 and 13, respectively. Retain appropriate gross organs that might be useful for further study or for demonstration in court. 
Address of Pathology Department

(morgue):

Head of Department:

Name of pathologist(s) in charge of autopsy

\section{Record Sheet for Suspected Homicide Cases}

Name of autopsy technician:

Body arrived at $\_\mathrm{m}$.

Date:

Body was brought to morgue by:

Persons not from this department who had access to the victim's body:

Name

Occupation

Date Time:

What did he/she do?

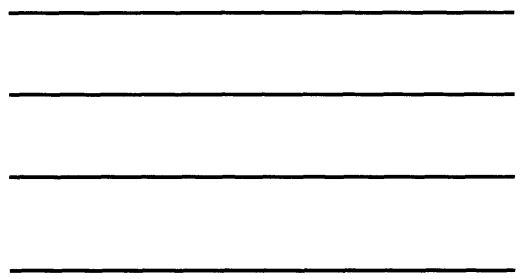

Body temperature (axillary/rectal) ${ }^{\dagger}$ was taken at m. Temperature was ${ }^{\circ} \mathrm{Cl}$ ${ }^{\circ} \mathrm{F}$.

Body of victim was/was not ${ }^{\dagger}$ stored in refrigerator/cool room before the temperature was recorded. Body was/was not ${ }^{\dagger}$ undressed during temperature measurements.

${ }^{\dagger}$ Circle correct word or group of words. 
Vitreous humor was aspirated at m.

$2 \mathrm{~mL}$ sent to chemistry laboratory:

$\mathrm{mL}$ labeled and stored in sterile tube in refrigerator:

$$
\begin{array}{cc}
\text { Yes }^{\dagger} & \mathrm{No}^{\dagger} \\
\text { Yes }^{\dagger} & \mathrm{No}^{\dagger}
\end{array}
$$

\section{Photographs}

Running

identification

Site

number

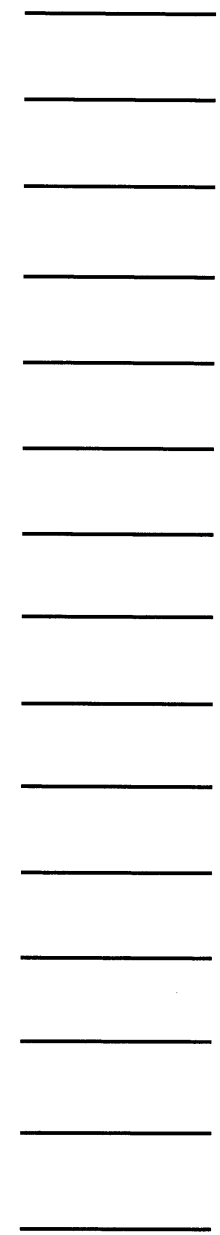

\section{$\underline{\text { Roentgenograms }}$}

4.

5.

6.

${ }^{\dagger}$ Circle correct word or group of words. 


\section{Fingernails}

Scrapings/clippings ${ }^{\dagger}$ taken by from

finger(s) of hand(s). Clippings (or scrapings) sealed, labeled,

and kept by /forwarded to

\section{$\underline{\text { Hair }}$}

From victim's head, axilla(e), and pubis taken by

labeled and kept by

/forwarded to

\section{$\underline{\text { Seminal Fluid }}$}

Scrapings of seminal fluid/clothing with seminal fluid stains ${ }^{\dagger}$ sealed, labeled, and kept by

/forwarded to . Other evidence (specify:

kept by /forwarded to

\section{Blood}

$\mathrm{mL}$ blood without preservation/with mg sodium fluoride ${ }^{\dagger}$

kept by /forwarded to

$\mathrm{mL}$ blood without preservation/with mg sodium fluoride ${ }^{\dagger}$

kept by /forwarded to

$\mathrm{mL}$ blood for blood grouping forwarded to

(Mix $40 \mathrm{mg}$ sodium fluoride with $5 \mathrm{~mL}$ of blood. If the volumes are larger, increase amount of sodium fluoride appropriately.)

${ }^{\dagger}$ Circle correct word or group of words. 


\section{Urine}

$\mathrm{mL}$ urine without preservation/with

mg sodium fluoride ${ }^{\dagger}$

kept by

/forwarded to

$\mathrm{mL}$ urine without preservation/with mg sodium fluoride ${ }^{\dagger}$

kept by /forwarded to

$\mathrm{mL}$ blood for blood grouping forwarded to

(Mix $40 \mathrm{mg}$ sodium fluoride with $5 \mathrm{~mL}$ of urine. If the volumes are larger, increase amount of sodium fluoride appropriately.)

\section{Other Body Fluids or Tissues}

$\mathrm{mL}$ cerebrospinal fluid, ${ }^{\dagger} \mathrm{ml}$ bile,$^{\dagger}$ other body fluids or tissues

(Specify type of fluid or tissue, weight, and volume; state whether preservative was added and how much, and what type of examination was requested.)

kept by /forwarded to

Clothing

Clothing put in plastic bag, labeled, and forwarded to

(Specify articles:

Body locked in refrigerator/cool room at m. Date: Body removed from refrigerator/cool room at

Date: Body transmitted to funeral director (name) at $-\mathrm{m}$.

Date:

${ }^{\dagger}$ Circle correct word or group of words. 


\section{Homocystinuria}

Related Terms: Aminoaciduria;* cystathionine $\beta$ synthase deficiency; cystathioninuria; sulfuraminoacidemia.

NOTE: For autopsy procedures and expected findings, see under "aminoaciduria*" and "Syndrome, Marfan's." Lax ligaments, lengthened extremities, and fine sparse hair may be present. Ocular abnormalities include dislocated lens, retracted zonular fibers, retinal degeneration with loss of pigmented epithelium and presence of pigment-laden macrophages, and cataracts. Ocular, vascular, and skeletal changes in older patients also may resemble those present in Marfan's syndrome.* Thromboembolism is a frequent cause of death. Submit sample of urine for determination of homocystine concentration (in homocystinuria, values should be increased).

\section{Hydrocephalus}

Synonyms and Related Terms: Active or progressive hydrocephalus; arrested hydrocephalus; communicating or malresorptive hydrocephalus; high pressure (or normal pressure or intermittent or occult) hydrocephalus; hydrocephalus ex vacuo; obstructive or noncommunicating hydrocephalus.

\begin{tabular}{ll}
\hline Organs and Tissues & Procedures \\
\hline External examination & $\begin{array}{l}\text { If size or shape of head is abnormal, record head } \\
\text { circumference. Prepare skull roentgenogram. }\end{array}$
\end{tabular}

Head

Brain

If an extracerebral congenital malformation is suspected, follow procedures described under "Malformation, Arnold-Chiari." If cerebrospinal fluid is aspirated with a syringe, record volume. For removal and specimen preparation, see p. 65. Record weight of brain; record size of brain in relation to inner dimensions of skull. Describe size of ventricles. For ventriculography or preparation of casts of the ventricular system, see p. 81 (rarely required).

Other procedures depend on expected findings or grossly identified abnormalities as listed in right-hand column. If a surgical shunt is present, its location should be recorded and both ends of the implanted specimen that was used for shunting may be submitted for microbiologic study. If the shunt is not patent, record site and nature of obstruction.

\section{Possible or Expected Findings}

Enlarged head in presence of hydrocephalus that was acquired early. Enlargement of skull with distended sutures.

Arnold-Chiari malformation* and related abnormalities; tentorial bleeding at time of birth; communicating or noncommunicating hydrocephalus.

In obstructive hydrocephalus, only one lateral ventricle may be enlarged or lateral and third ventricles may be involved (three-ventricular hydrocephalus); in communicating hydrocephalus, all ventricular cavities are enlarged.

Traumatic subarachnoid hemorrhage; rupture of congenital cerebral artery aneurysm;* adhesions after bacterial meningitis* or toxoplasmosis* in infancy or after tuberculosis, ${ }^{*}$ mycotic basal meningitis, sarcoidosis,* or cysticercosis in adulthood; intracranial tumor of third and fourth ventricles; meningeal carcinomatosis.

\section{Reference}

1. Squier MV. Pathological approach to the diagnosis of hydrocephalus. J Clin Pathol 1997;50:181-186.

\section{Hydronephrosis}

Related Term: Obstructive uropathy.

\begin{tabular}{lll}
\hline Organs and Tissues & Procedures & Possible or Expected Findings \\
\hline External examination & Prepare abdominal roentgenogram. & Stone; foreign bodies. \\
Blood & Submit sample for bacterial culture (p. 102). & Septicemia. \\
Retroperitoneal space & Record size of urinary bladder, width of & Tumor (lymphoma, carcinoma), cysts, \\
& ureters, and size of kidneys and renal pelves. & fibrous band, or aberrant renal artery. Other \\
& Dissect in situ: ureters, abdominal aorta, and & possible causes include retroperitoneal \\
& inferior vena cava and the major branches & fibrosis* and related extrinsic obstructive \\
& of these vessels. Prepare photographs of & processes-for instance, radiation fibrosis, \\
& dissected retroperitoneal structures, showing & trauma, or accidental surgical ligation \\
& the site of obstruction. & of ureter.
\end{tabular}




\begin{tabular}{|c|c|c|}
\hline Organs and Tissues & Procedures & Possible or Expected Findings \\
\hline $\begin{array}{l}\text { Kidneys, ureters, } \\
\text { and pelvic organs }\end{array}$ & $\begin{array}{l}\text { Record volume of urine in the three com- } \\
\text { partments. For postmortem angiography and } \\
\text { urography, see p. 59. Leave kidneys, } \\
\text { abdominal aorta, ureters, urinary bladder, } \\
\text { and-in male infants-entire urethra in one } \\
\text { specimen (p. 60). } \\
\text { Procedures depend on expected findings or } \\
\text { grossly identified abnormalities as listed in } \\
\text { right-hand column. }\end{array}$ & $\begin{array}{l}\text { Pyelonephritis; } * \text { ureteritis; intraluminal } \\
\text { tumor, clot, sloughed papillae, or foreign } \\
\text { body; congenital narrowing or obstruction of } \\
\text { ureterovesical junction, ureterocele, retro- } \\
\text { caval ureter, and anterior or posterior urethral } \\
\text { valves. } \\
\text { Meatal urethral stenosis or phimosis. } \\
\text { Acquired strictures, tumors, calculi. } \\
\text { Angulation or ptosis; diverticula; } \\
\text { Endometriosis; malakoplakia; benign } \\
\text { prostatic hyperplasia with median bar. }\end{array}$ \\
\hline $\begin{array}{l}\text { Spinal cord and } \\
\text { peripheral nerves }\end{array}$ & $\begin{array}{l}\text { For dissection and specimen preparation, } \\
\text { see pp. } 67 \text { and } 79 .\end{array}$ & $\begin{array}{l}\text { Spinal cord disease; diabetic neuropathy, } \\
\text { and other causes of neurogenic obstructive } \\
\text { uropathy. }\end{array}$ \\
\hline
\end{tabular}

\section{Hydrops Fetalis}

Related Terms: Antibody-mediated hydrops fetalis; erythroblastosis fetalis; * nonimmune hydrops fetalis.

NOTE: The classic example of antibody mediated $(\mathrm{Rh}$ incompatibility) hydrops fetalis is hemolytic disease of the newborn (erythroblastosis fetalis*). However, nonimmune hydrops fetalis also may be caused by hematologic disorders, e.g., alphathalassemia* (1) or it may have no known cause. Infections, e.g., with human parvovirus B19 (2), cytomegalovirus, or syphilis; * heart and vascular diseases (3) (cardiac tumors, cardiomyopathy, ${ }^{*}$ myocarditis, ${ }^{*}$ arterial calcification, and others); storage disease (4); tumors (including neonatal leukemia*); and many other fetal (e.g., congenital chylothorax* or lymphatic dysplasia; pulmonary sequestration and cystic adenomatoid malformation) or maternal conditions, e.g., maternal thyrotoxicosis, also may cause nonimmune hydrops fetalis.

\begin{tabular}{lll}
\hline Organs and Tissues & Procedures & Possible or Expected Findings
\end{tabular}

Placenta

Blood

External examination

Chest and abdominal cavities

Heart and great vessels

Lungs

Genitourinary system

Other organs and tissues
Record weight, size, and gross appearance.

Sample for histologic study.

Submit sample if there is no autolysis.

Record weight, size and gross appearance of neonate.

Photograph all external abnormalities.

Obtain fascia lata or percutaneous liver biopsy;

sample for karyotype analysis (see p. 109).

Obtain radiograph of fetus.

Record volume and color of effusions.

Ascertain venous and arterial connections before separating the heart from the organ block.

Note positioning of lungs in situ.

Ascertain patency of entire urinary system, from renal pelvis to urethra, including entire length of penis (p. 60).

Conduct complete autopsy with extensive histologic sampling; procedures depend on suspected underlying conditions (6).
Placental hydrops; chorangioma and other vascular abnormalities; erythroblastosis.* Anemia; alpha-thalassemia.*

Fetal hydrops; sacrococcygeal teratoma; cystic hygroma.

Monosomy X (Turner's syndrome*); Trisomy 21 (Down's syndrome*); Trisomy 18

(Edward's syndrome).

Chondrodysplasia* (many types).

Pleural effusions that may be chylous; ascites. (Effusions become serosanguinous with intrauterine retention following fetal death.)

Left or right ventricular hypoplasia;* atrioventricular septal defect;* rhabdomyoma.

Right-sided diaphragmatic hernia with impingement on the inferior vena cava.

Urethral obstruction due to urethral valves or lack of canalization of distal penile urethra; cloacal malformations. Cystic renal disease (5).

See above under "Note" and also under the heading "Erythroblastosis fetalis." 


\section{References}

1. Barron SD, Pass RF. Infectious causes of hydrops fetalis. Semin Perinatol 1995;19:493-501.

2. Cameron AD, Swain S, Patrick WJ. Human parvovirus B19 infection associated with hydrops fetalis. Aust NZ J Obstet Gynaecol 1997;37 :316-319.

3. Knilans TK. Cardiac abnormalities associated with hydrops fetalis. Semin Perinatol 1995;19:483-492.

4. Tasso MJ, Martinez-Gutierrez A, Carrascosa C, Vazquez S, Tebar R. GM1-gangliosidosis presenting as nonimmune hydrops fetalis: a case report. J Perinat Med 1996;24:445-449.

5. Kim CK, Kim SK, Yang YH, Lee MS, Yoon JH, Park CI. A case of recurrent infantile polycystic kidney associated with hydrops fetalis. Yonsei Med J 1989;30:95-103.

6. Knisely AS. The pathologist and the hydropic placenta, fetus, or infant. Semin Perinatol 1995;19:525-531.

Hyoscyamine (See "Poisoning, alkaloid" and "Poisoning, atropine.")

Hyperaminoaciduria (See “Aminoaciduria.")

Hyperbetalipoproteinemia (See “Hyperlipoproteinemia.")
Hypercalcemia (See "Disorder, electrolyte(s).”)

Hypercholesterolemia (See "Hyperlipoproteinemia.")

Hypercorticism (See "Hyperplasia, congenital adrenal" and "Syndrome, Cushing's.")

Hyperglycemia (See "Diabetes mellitus" and p. 114.)

Hyperkalemia (See "Disorder, electrolyte(s)" and p. 114.)

Hyperlipemia (See "Hyperlipoproteinemia.")

\section{Hyperlipoproteinemia}

Synonyms and Related Terms: Primary hyperlipoproteinemia (familial forms of apoprotein CII deficiency, hyperalphalipoproteinemia; hypercholesterolemia, hypertriglyceridemia, lipoprotein lipase deficiency, multiple lipoprotein-type hyperlipidemia, and type 3 hyperlipoproteinemia; polygenic hypercholesterolemia).

\begin{tabular}{ll}
\hline Organs and Tissues & Procedures \\
\hline External examination & Record body weight and length. \\
and skin & Record extent and nature of skin changes, \\
& including evidence of gangrene. Prepare \\
& photographs and histologic sections of skin \\
& tumors and other cutaneous lesions.
\end{tabular}

Blood

Heart

Arteries

Pancreas

Other organs
Submit sample of serum for biochemical study. Photograph valvular lesions; freeze involved tissue for biochemical and histochemical study. Submit samples of involved tissue for electron microscopic study (p. 132). If valvular leaflets contain calcific deposits, decalcification may be required (p. 97). Request Verhoeff-van Gieson stain and frozen sections for Sudan stain (p. 173). If coronary insufficiency or myocardial infarction is suspected, follow procedures described under "Disease, ischemic heart." For coronary arteriography, see p. 118. Record distribution of atherosclerotic lesions in aorta. Samples for histologic study should include aorta, coronary arteries, and peripheral arteries. See also above under "Heart."

Submit samples of head, corpus, and tail for histologic study. If applicable, see also under "Diabetes mellitus."

For special procedures and stains, see above under "Heart." Other procedures depend on expected findings or grossly identified abnormalities as listed in right-hand column.
Possible or Expected Findings

Obesity* is a common finding. Eruptive xanthomas (palms, elbows, knees) in some but not all types of hyperlipoproteinemia. Most prominent in apoprotein CII deficiency. Xanthomas of tendons (knees, elbows, dorsum of hands), xanthelasmas, and arcus corneae in familial hypercholesterolemia. Gangrene of lower extremities (see below under "Arteries").

Severe coronary atherosclerosis and myocardial infarcts in type 3 hyperlipoproteinemia and multiple lipoprotein-type hyperlipidemia.

Atherosclerosis of abdominal aorta and its branches and of carotid arteries. Coronary atherosclerosis (see above).

Pancreatitis* in familial apoprotein CII deficiency.

Foam cells with triglycerides in liver, spleen, and bone marrow in familial lipoprotein lipase deficiency. Manifestations of diabetes mellitus* and hypothyroidism* in some cases of type 3 hyperlipoproteinemia. 


\begin{tabular}{lll}
\hline Organs and Tissues & Procedures & Possible or Expected Findings \\
\hline Brain & For removal and specimen preparation, & $\begin{array}{l}\text { Cerebral infarct (stroke*) in type 3 } \\
\text { hyperlipoproteinemia. }\end{array}$ \\
\hline
\end{tabular}

\section{Hypernatremia (See "Disorder, electrolyte(s)" and p. 114.)}

\section{Hyperoxaluria}

Synonyms and Related Terms: Oxalosis; primary hyperoxaluria type I (alanineglyoxylate aminotransferase deficiency); primary hyperoxaluria type II (D-glyceric acid dehydrogenase deficiency); secondary hyperoxaluria (see under "Note").

NOTE: In ethylene glycol poisoning,* oxalate crystals in media of small arteries, with associated ischemic lesions. Similar deposits may occur after long-term hemodialysis (1). These conditions must be distinguished from the genetic disease. Also, oxalate nephropathy may be a complication of short bowel syndrome.

If patient with congenital hyperoxaluria underwent liver or combined liver/kidney transplantation (2), see also under these headings.

\begin{tabular}{|c|c|c|}
\hline Organs and Tissues & Procedures & Possible or Expected Findings \\
\hline $\begin{array}{l}\text { External examination } \\
\text { and skin }\end{array}$ & $\begin{array}{l}\text { Submit samples of skin for histologic study. } \\
\text { Prepare skeletal roentgenograms. }\end{array}$ & $\begin{array}{l}\text { Oxalates in skin. } \\
\text { Osteosclerosis, periosteal changes; } \\
\text { calcifications of vessels and soft tissues. }\end{array}$ \\
\hline Liver & $\begin{array}{l}\text { Record weight and submit samples for } \\
\text { histologic study. }\end{array}$ & $\begin{array}{l}\text { Grossly normal but site of peroxisomal } \\
\text { enzyme deficiency in type I hyperoxaluria } \\
\text { (see "Synonyms and Related Terms"). }\end{array}$ \\
\hline Kidneys & $\begin{array}{l}\text { Record weights, photograph surfaces and cut } \\
\text { surfaces with renal pelves. Submit samples for } \\
\text { histologic study. }\end{array}$ & $\begin{array}{l}\text { Calcium oxalate nephrolithiasis; }{ }^{*} \\
\text { nephrocalcinosis. }\end{array}$ \\
\hline Other organs and tissues & $\begin{array}{l}\text { Procedures depend on expected findings or } \\
\text { grossly identified abnormalities as listed in } \\
\text { right-hand column. }\end{array}$ & $\begin{array}{l}\text { Oxalosis. } \\
\text { Manifestations of kidney failure (uremia).* } \\
\text { For oxalate deposits unrelated to congenital } \\
\text { hyperoxaluria, see above under "Note." }\end{array}$ \\
\hline Urine & $\begin{array}{l}\text { Submit sample for biochemical study } \\
\text { (see right-hand column). }\end{array}$ & $\begin{array}{l}\text { Excess oxalate and glycolate in type I } \\
\text { hyperoxaluria. In type II disease, L-glyceric } \\
\text { acid and oxalate are found in excess. }\end{array}$ \\
\hline Peripheral nerves & For removal and specimen preparation, see p. 79. & Oxaluria-associated polyneuropathy (3). \\
\hline Bones & For removal and specimen preparation, see p. 95. & Osteosclerosis, periosteal changes. \\
\hline
\end{tabular}

\section{References}

1. Elmstahl B, Rausing A. A case of hyperoxaluria. Radiological aspects. Acta Radiol 1997;38:1031-1034.

2. Watts RWE, Morgan SH, Danpure CJ, Purkiss P, Calne RY, Rolles K, et al. Combined hepatic and renal transplantation in primary hyperoxaluria type I: clinical report of nine cases. Am J Med 1991;90:179-188.

3. Galloway G, Giuliani MJ, Burns DK, Lacomis D. Neuropathy associated with hyperoxaluria: improvement after combined renal and liver transplantation. Brain Pathol 1998;8:247-251.

\section{Hyperparathyroidism}

Synonyms and Related Terms: Primary hyperparathyroidism; secondary hyperparathyroidism (see below under "Kidneys").

Possible Associated Conditions: Multiple endocrine neoplasia, type 1 (Wermer's syndrome): Hyperparathyroidism, tumors of the pituitary gland* and tumors of pancreatic islet cells, often with peptic ulcers; Multiple endocrine neoplasia, type 2a (Sipple's syndrome): Hyperparathyroidism, pheochromocytoma, and medullary carcinoma of the thyroid.

\begin{tabular}{lll}
\hline Organs and Tissues & Procedures & Possible or Expected Findings \\
\hline $\begin{array}{l}\text { External examination } \\
\text { and skin }\end{array}$ & $\begin{array}{l}\text { Record location of scars of previous operations } \\
\text { in neck area. }\end{array}$ & \\
& $\begin{array}{l}\text { If skin gangrene is present, prepare photographs } \\
\text { and sample for histologic study. }\end{array}$ & $\begin{array}{l}\text { Cutaneous skin gangrene in hyperparathy- } \\
\text { roidism due to chronic renal failure (1). }\end{array}$ \\
& $\begin{array}{l}\text { Prepare skeletal roentgenograms (include } \\
\text { calvarium, distal clavicles, phalanges, and }\end{array}$ & $\begin{array}{l}\text { In severe cases, generalized osteitis fibrosa } \\
\text { cystica (osteoclastic osteoporosis) may be } \\
\text { present. }\end{array}$ \\
& lamina dura of tooth sockets). & a
\end{tabular}




\begin{tabular}{lll}
\hline Organs and Tissues & Procedures & Possible or Expected Findings \\
\hline Vitreous & $\begin{array}{l}\text { Submit specimen for calcium and phosphate } \\
\text { determination (see p. 85). } \\
\text { Blood }\end{array}$ & $\begin{array}{l}\text { Increased calcium concentrations. } \\
\text { calcium concentration. }\end{array}$ \\
& & $\begin{array}{l}\text { Hypercalcemia occurs in primary hyperpara- } \\
\text { thyroidism. Phosphate and phosphatase } \\
\text { determinations are not reliable in postmortem } \\
\text { blood. Calcium values may also increase } \\
\text { after death. }\end{array}$ \\
Urine & $\begin{array}{l}\text { Photograph neck organs with parathyroid glands } \\
\text { Neck organs }\end{array}$ & $\begin{array}{l}\text { Solitary adenoma; double or multiple } \\
\text { adenomas; chief cell hyperplasia; }\end{array}$ \\
& $\begin{array}{l}\text { or tumor(s) in situ. Dissect all 4 (or more) } \\
\text { glands, trim carefully, and record weight of } \\
\text { each gland. Snap-freeze adenomatous, }\end{array}$ & $\begin{array}{l}\text { carcinoma(s). Adenomas usually in the } \\
\text { inferior glands. }\end{array}$
\end{tabular}

Aberrant glands in thymus, thyroid gland, pericardium, or behind esophagus.

tissue for biochemical study. Prepare tissue sample for electron microscopic study (p. 132). Embed all glands in paraffin for histologic study. If metastases are suspected or identified, dissect all cervical lymph nodes and embed for histologic study. Dissect and record weight of thyroid gland. Prepare thin slices of gland and record presence and location of tumor(s) or intrathyroid parathyroid tissue.

Lungs Submit samples for histologic study and request von Kossa's stain (p. 173).

Stomach and duodenum Submit samples of stomach for histologic study.

Gallbladder

Pancreas

Submit samples of head, body, and tail for histologic study.

Kidneys Photograph cut surfaces with renal pelves. For histologic specimens, decalcification may be required (p. 97). Request von Kossa's stain (p. 173).

Other endocrine glands

Dissect all endocrine glands. If endocrine tumors or other abnormalities are present, follow procedures described above under "Neck organs."

Bones For removal, prosthetic repair, and specimen preparation, see p. 95; consult also roentgenograms.

Joints

For study of synovial fluid, see under "Gout." For removal, prosthetic repair, and

Cervical lymph node metastases from thyroid (medullary carcinoma of the thyroid gland) or parathyroid carcinoma.

\section{Metastatic calcification.}

Metastatic carcinoma.

Peptic ulcer(s);* metastatic calcification. Cholelithiasis.*

Pancreatitis* (2), with or without calcifications.

Nephrocalcinosis; nephrolithiasis* with calcium oxalate or calcium phosphate stones; pyelonephritis;* chronic glomerulonephritis* or other chronic renal disease causing secondary hyperparathyroidism. See above under "Possible Associated Conditions."

Osteitis fibrosa generalisata (osteoclastic osteoporosis); osteoclastomas.

Chondrocalcinosis; pseudogout.* specimen preparation, see p. 96.

Eyes For removal and specimen preparation, see p. 85 .

Band keratopathy; cataracts.

\section{References}

1. Torok L, Kozepessy L. Cutaneous gangrene due to hyperparathyroidism secondary to chronic renal failure (uremic gangrene syndrome). Clin Exp Dermatol 1996;21:75-77.

2. Inabnet WB, Baldwin D, Daniel RO, Staren ED. Hyperparathyroidism and pancreatitis during pregnancy. Surgery 1996;119:710-713.

\section{Hyperpituitarism (See "Acromegaly.")}

\section{Hyperplasia, Congenital Adrenal}

Synonyms and Related Terms: Adrenocortical hyperplasia; deficiency of $17 \alpha$-hydroxylase, $20 \alpha$-hydroxylase, or $11 \beta$-hydroxylase (1); deficiency of 21-hydroxylase (1,2); deficiency of 3 $\beta$-hydroxysteroid dehydrogenase (1); deficiency of 18-hydroxylase/ hydroxysteroid dehydrogenase; deficiency of 20,22 desmolase; female pseudohermaphroditism. 


\begin{tabular}{lll}
\hline Organs and Tissues & Procedures & Possible or Expected Findings \\
\hline External examination & $\begin{array}{l}\text { Record body weight and length. Describe and } \\
\text { photograph primary and secondary sex } \\
\text { characteristics. }\end{array}$ & $\begin{array}{l}\text { Ambiguous, incompletely differentiated } \\
\text { external genitalia; virilism in female infants } \\
\text { and teenagers; precocious puberty in male } \\
\text { patients; premature pubic hair (3). }\end{array}$ \\
$\begin{array}{ll}\text { Adrenal glands } \\
\text { Record sizes and weights. Snap-freeze material } \\
\text { for biochemical, DNA or histochemical study. }\end{array}$ & $\begin{array}{l}\text { Cortical hyperplasia (for expected weights, } \\
\text { see pp. 560, 561, and 571). }\end{array}$ \\
$\begin{array}{ll}\text { Other organs and body } \\
\text { fluids, including urine }\end{array}$ & $\begin{array}{l}\text { Submit samples for histologic study. } \\
\text { Submit urine sample for biochemical study. }\end{array}$ & $\begin{array}{l}\text { Manifestations of hypertension.* } \\
\text { Increased concentration of urinary } \\
\text { pregnanetriol and 17-ketosteroids. }\end{array}$ \\
& For removal of vitreous, see p. 85. & $\begin{array}{l}\text { Electrolyte abnormalities in vitreous, } \\
\text { related to dehydration,* hyperkalemia, } \\
\text { and hyponatremia. Hypoglycemia* may } \\
\text { have been present but usually cannot be } \\
\text { demonstrated after death. }\end{array}$ \\
& & \\
& Submit tissue (i.e., fascia lata) for karyotype \\
analysis (p. 109). &
\end{tabular}

\section{References}

1. Pang S. Congenital adrenal hyperplasia. Baillieres Clin Obstet Gynaecol 1997;11:281-306.

2. Cutler GB Jr, Lave L. Congenital adrenal hyperplasia due to 21-hydroxylase deficiency. N Engl J Med 1990;323:1806-1813.

3. Rosenfield RL. Hyperandrogenism in peripubertal girls. Ped Clin North Am 1990;37:1333-1358.

\section{Hypertension (Systemic Arterial), All Types or Type Unspecified}

Synonyms and Related Terms: Arterial hypertension; benign hypertension; essential hypertension; idiopathic hypertension; malignant hypertension; paroxysmal hypertension.

NOTE: If underlying disease is known —-for instance, coarctation of the aorta, pheochromocytoma, or toxemia of pregnancysee also under that entry.

\begin{tabular}{ll}
\hline Organs and Tissues & Procedures \\
\hline External examination & $\begin{array}{l}\text { Record body weight and length. Prepare chest } \\
\text { roentgenogram. } \\
\text { Submit samples for biochemical and toxicologic } \\
\text { study. }\end{array}$ \\
Record actual and expected weights \\
Heart & (pp. 562 and 568). For coronary arteriography, \\
& see p. 118. For histologic sampling of myo- \\
& cardium, see p. 30. \\
& For carotid and cerebral arteriography, see \\
p. 82. For arteriography of lower extremities, & see p. 120. For renal arteriography, see p. 59. \\
& Request Verhoeff-van Gieson stain for histologic \\
& sections of elastic and muscular arteries (p. 173). \\
& Submit samples for histologic study.
\end{tabular}

Kidneys

Record appearance of renal ostia and arteries. If parenchymal renal disease is suspected, follow procedures described under "Glomerulonephritis."

Freeze tissue for possible biochemical study (indicated only if a tumor is present or evidence is obtained of adrenocortical hyperfunction). "See also under "Tumor, of the adrenal glands."
Possible or Expected Findings

Obesity;* cushingoid features.

Lead poisoning;* porphyria.*

Hypertrophy of the heart, primarily of the left ventricle; coronary atherosclerosis; ischemic myocardial changes; catecholamine cardiomyopathy (see below under "Adrenal glands").

Atherosclerosis and arteriolosclerosis. Renal artery stenosis* or fibromuscular dysplasia. Coarctation of the aorta.* Polyarteritis nodosa.*

Arteriolar necrosis with hemorrhages and infarctions (in malignant hypertension).

Renal artery stenosis* or dysplasia.

Diabetic nephropathy. Renal involvement in immune connective tissue disease; chronic or acute glomerulonephritis;* pyelonephritis.*

Pheochromocytoma; congenital adrenal hyperplasia.* (See also under

"Aldosteronism.") 


\begin{tabular}{lll}
\hline Organs and Tissues & Procedures & Possible or Expected Findings \\
\hline Ovaries & $\begin{array}{l}\text { If a tumor is present, snap-freeze tissue for } \\
\text { possible biochemical study. }\end{array}$ & Hypertension-producing ovarian tumor. \\
Parathyroid glands & See under "Hyperparathyroidism." & $\begin{array}{l}\text { Hyperplasia or adenoma with hyperpara- } \\
\text { thyroidism.* }\end{array}$ \\
Brain & For removal and specimen preparation, see p. 65. & $\begin{array}{l}\text { Subarachnoid or intraparenchymal } \\
\text { hemorrhage; infarction* or other condition } \\
\text { causing increased intracranial pressure. }\end{array}$ \\
Eyes & For removal and specimen preparation, see p. 85. & Hypertensive retinopathy. \\
\hline
\end{tabular}

\section{Hypertension, Intracranial (See "Pseudotumor cerebri.")}

\section{Hypertension, Portal}

Related Terms: Idiopathic portal hypertension; postsinusoidal portal hypertension; presinusoidal portal hypertension.

\begin{tabular}{lll}
\hline Organs and Tissues & Procedures & Possible or Expected Findings \\
\hline External examination & Record circumference of abdomen. & $\begin{array}{l}\text { Periumbilical veins that were distended dur- } \\
\text { ing life (caput medusae; Cruveilhier-Baum- }\end{array}$ \\
& garten syndrome) usually collapse after death. \\
Abdominal cavity & Submit fluid for bacterial culture (p. 102); & $\begin{array}{l}\text { Ascites; peritonitis;* carcinomatosis. }\end{array}$
\end{tabular}

Abdominal cavity

Heart, inferior vena cava, and hepatic veins

Lungs

Abdominal wall

Portal vein system

Thoracic duct

Esophagus, stomach, and intestinal tract (with anus)

Liver record volume; submit samples of peritoneum for histologic study.

If portal hypertension is suspected to have been caused by cardiac or other postsinusoidal venous disease, follow procedures described under "Syndrome, Budd-Chiari."

Submit samples for histologic evaluation of pulmonary vasculature. Request Verhoeff-van Gieson stain.

If presence of portal vein thrombosis is suspected in a neonate, submit samples of umbilicus and umbilical vein for histologic study.

In adults with caput medusae, submit samples of ductus venosus and of umbilical vein for determination of luminal width.

For portal venography, see p. 56. For hepatoduodenal lymphangiography, see p. 56. Open portal, splenic, and mesenteric veins in situ or after en bloc removal of abdominal organs (p. 56). If site of obstruction is unknown, prepare portal angiogram from splenic or mesenteric vein.

If cavernous transformation of portal vein is suspected, prepare horizontal sections through hepatoduodenal ligament.

For dissection of the thoracic duct, see p. 34.

For demonstration of varices, see p. 53.

Record volume of blood in lumen.

Record weight and photograph. Slice liver in frontal planes and leave hepatoduodenal ligament attached to slice in hilar plane.

Submit samples for histologic study. Other procedures depend on expected findings or grossly identified abnormalities as listed in right-hand column.
Manifestations of Budd-Chiari syndrome.*

Coexistent pulmonary hypertension; hepatopulmonary syndrome.

Umbilical sepsis in neonate.

Caput medusae.

Portal vein thrombosis; pylephlebitis. Developmental obliteration or valve formation of portal vein is rare. Splenic arteriovenous fistula, tumor, or abscess may be present.

Cavernous transformation of portal vein.

Dilatation of thoracic duct.

Esophageal varices; ${ }^{*}$ gastric varices; gastrointestinal hemorrhage;* hemorrhoids.

Cirrhosis;* tumor of the liver;* congenital hepatic fibrosis; ${ }^{*}$ chronic alcoholic or nonalcoholic steatohepatitis; nodular regenerative hyperplasia, associated with conditions such as Felty's syndrome* or rheumatoid arthritis.* Schistosomiasis, * vascular malformation, and other hepatic conditions also may cause portal hypertension. 


\begin{tabular}{lll}
\hline Organs and Tissues & Procedures & Possible or Expected Findings \\
\hline Spleen & $\begin{array}{l}\text { Record weight and size. Submit samples for } \\
\text { histologic study. }\end{array}$ & $\begin{array}{l}\text { Congestive splenomegaly; extramedullary } \\
\text { hematopoiesis (see above under "Liver"). } \\
\text { Pancreas }\end{array}$ \\
$\begin{array}{ll}\text { Pancreatitis.* } \\
\text { Other organs }\end{array}$ & $\begin{array}{l}\text { Appendicitis; other suppurative abdominal } \\
\text { character of suspected source of infection. }\end{array}$ & $\begin{array}{l}\text { infection; malignant tumor; manifestations of } \\
\text { polycythemia* or of other hematologic } \\
\text { disorder. See also above under "Liver." }\end{array}$ \\
& For removal and specimen preparation, see p. 65. & Hepatic encephalopathy.* \\
\hline Brain &
\end{tabular}

\section{Hypertension, Pulmonary}

Synonyms and Related Terms: Chronic pulmonary venous hypertension; coexistent portal and pulmonary hypertension; cor pulmonale; hypoxic pulmonary hypertension; neoplastic embolic pulmonary hypertension; primary pulmonary hypertension; plexogenic pulmonary hypertension; pulmonary heart disease; pulmonary veno-occlusive disease; thromboembolic pulmonary hypertension.

\begin{tabular}{|c|c|c|}
\hline Organs and Tissues & Procedures & Possible or Expected Findings \\
\hline External examination & Prepare chest roentgenogram. & Enlarged right atrium and pulmonary arteries. \\
\hline Heart & Record heart weight and dimensions. & $\begin{array}{l}\text { Hypertrophy and dilatation of right ventricle } \\
\text { and right atrium. Straightened septum with } \\
\text { D-shaped ventricles. Dilated tricuspid and } \\
\text { pulmonary valves. }\end{array}$ \\
\hline Lungs & $\begin{array}{l}\text { Record weights of lungs. For pulmonary } \\
\text { arteriography and venography, see p. } 50 . \\
\text { Perfuse lungs with formalin (p. } 47) \text {. Prepare } \\
\text { slides from each lobe, both centrally and } \\
\text { peripherally. Request Verhoeff-van Gieson } \\
\text { stain on all blocks (p. 173). }\end{array}$ & $\begin{array}{l}\text { Obstructive pulmonary arterial and/or } \\
\text { pulmonary venous lesions (most commonly } \\
\text { plexogenic or thrombotic type). Interstitial } \\
\text { pneumonia;* bronchiectases;* pulmonary } \\
\text { emphysema;* pulmonary artery aneurysm; } \\
\text { pulmonary artery rupture; pulmonary } \\
\text { capillary hemangiomatosis. See also above } \\
\text { under "Synonyms and Related Terms." }\end{array}$ \\
\hline Abdominal viscera & $\begin{array}{l}\text { Record actual and expected weights of liver } \\
\text { and spleen. }\end{array}$ & $\begin{array}{l}\text { Congestive hepatosplenomegaly. } \\
\text { Pre-existing cirrhosis with portal and } \\
\text { pulmonary hypertension. }\end{array}$ \\
\hline
\end{tabular}

\section{Hyperthermia (See “Heatstroke.")}

Hyperthyroidism

Synonyms and Related Terms: Basedow's disease; Graves' disease; thyrotoxicosis.

\begin{tabular}{lll}
\hline Organs and Tissues & Procedures & Possible or Expected Findings \\
\hline $\begin{array}{c}\text { External examination, } \\
\text { skin, and breasts }\end{array}$ & $\begin{array}{l}\text { Record body weight and length; photograph } \\
\text { face and neck; record neck circumference. } \\
\text { Prepare histologic sections of skin lesions and } \\
\text { of breast tissue. }\end{array}$ & $\begin{array}{l}\text { Emaciation; exophthalmos; hyperpigmenta- } \\
\text { tion and vitiligo, particularly of hands and } \\
\text { feet; fingernail (ring finger) abnormalities; } \\
\text { pretibial myxedema above level of lateral } \\
\text { malleolus; gynecomastia. }\end{array}$ \\
& $\begin{array}{l}\text { Prepare skeletal roentgenograms. } \\
\text { Osteoporosis.* }\end{array}$ \\
Blood and urine & $\begin{array}{l}\text { If hormone assay or preparation of a drug } \\
\text { screen is intended, store samples in deepfreeze. }\end{array}$ & $\begin{array}{l}\text { Postmortem concentrations of thyroxine } \\
\text { or thyroid-stimulating hormone appear to } \\
\text { reflect antemortem values. }\end{array}$ \\
& $\begin{array}{l}\text { Determination of serum calcium concentration } \\
\text { is unreliable (use vitreous). }\end{array}$ & $\begin{array}{l}\text { Hypercalcemia may be present. } \\
\text { Dissect and record weight. Submit samples for }\end{array}$ \\
Thymus & Hyperplasia of thymus.
\end{tabular}

Heart

histologic study.

Record weight of heart and size of heart chambers. For sampling for histologic study, see p. 30.
Atrial dilatation indicates previous episodes of atrial fibrillation (1). 


\begin{tabular}{|c|c|c|}
\hline Organs and Tissues & Procedures & Possible or Expected Findings \\
\hline Neck organs & $\begin{array}{l}\text { Remove neck organs together with goiter and } \\
\text { and tongue (p. 4); record weights of thyroid and } \\
\text { parathyroid glands. If thyroid tumor is present, } \\
\text { photograph together with scale. If carcinoma of } \\
\text { the thyroid gland is suspected, dissect regional } \\
\text { lymph nodes and submit for histologic study. }\end{array}$ & $\begin{array}{l}\text { Nodular (colloid) goiter; diffuse thyroid } \\
\text { hyperplasia; thyroid adenoma(s) or } \\
\text { carcinoma(s); subacute thyroiditis. }{ }^{*}\end{array}$ \\
\hline $\begin{array}{l}\text { Lymph nodes; other } \\
\text { endocrine glands }\end{array}$ & $\begin{array}{l}\text { Record average size of lymph nodes. In addition } \\
\text { to thyroid weight, record weights of all other } \\
\text { endocrine glands and submit samples for histo- } \\
\text { logic study. See also below under "Pituitary } \\
\text { gland." }\end{array}$ & Lymphadenopathy. \\
\hline $\begin{array}{l}\text { Tumor with possible } \\
\text { endocrine activity }\end{array}$ & $\begin{array}{l}\text { Submit samples for hormone assay, light } \\
\text { microscopic study, and electron microscopy } \\
\text { (p. 132). }\end{array}$ & $\begin{array}{l}\text { Choriocarcinoma of uterus or testis; } \\
\text { hydatidiform mole may cause } \\
\text { thyrotoxicosis without thyroid abnormalities. } \\
\text { See also below under "Pituitary gland". }\end{array}$ \\
\hline Other organs & & Manifestations of congestive heart failure.* \\
\hline Pituitary gland & $\begin{array}{l}\text { For removal and specimen preparation, } \\
\text { see p. } 71 \text {. If a pituitary tumor is present, it } \\
\text { should be weighed, measured, split in half, } \\
\text { photographed, and one-half placed in deep- } \\
\text { freeze for hormone assay. From the other half, } \\
\text { a small sample should be prepared for electron } \\
\text { microscopic study (p. 132) and the remainder } \\
\text { for light microscopy. }\end{array}$ & $\begin{array}{l}\text { Pituitary adenoma with secretion of thyroid- } \\
\text { stimulating hormone may cause } \\
\text { thyrotoxicosis without thyroid abnormalities. } \\
\text { Acromegaly* (see above) may be present. }\end{array}$ \\
\hline Vitreous & $\begin{array}{l}\text { If electrolyte abnormalities are suspected, } \\
\text { submit sample of vitreous (p. 85). }\end{array}$ & Manifestations of electrolyte disorder.* \\
\hline Eyes and their adnexae & $\begin{array}{l}\text { For removal and specimen preparation of eyes, } \\
\text { see p. } 85 \text {. Submit samples of retrobulbar tissue, } \\
\text { extraocular muscles, and lacrimal glands (p. } 87 \text { ). }\end{array}$ & $\begin{array}{l}\text { Exophthalmos with puffy lids, chemosis, } \\
\text { and eye infection. }\end{array}$ \\
\hline Skeletal muscles & $\begin{array}{l}\text { For sampling and specimen preparation, } \\
\text { see p. } 80 \text {. }\end{array}$ & \\
\hline Bones & $\begin{array}{l}\text { For removal, prosthetic repair, and specimen } \\
\text { preparation, see p. } 95 \text {. }\end{array}$ & Osteoporosis.* \\
\hline
\end{tabular}

\section{Reference}

1. Aronow WS. The heart and thyroid disease. Clin Geriatr Med 1995;11:219-229.

\section{Hypertrophy, Cardiac}

\begin{tabular}{|c|c|c|}
\hline Organs and Tissues & Procedures & Possible or Expected Findings \\
\hline Heart & $\begin{array}{l}\text { Record actual and expected weights. If } \\
\text { determination of myocardial mass is needed, } \\
\text { record specific gravity of heart (p. 569). } \\
\text { For coronary arteriography, see p. 118. } \\
\text { Record ventricular wall thicknesses and } \\
\text { appearance and annular circumferences of valves. } \\
\text { If cardiomyopathy is suspected, electron micro- } \\
\text { scopic study may be indicated (p. 132). }\end{array}$ & $\begin{array}{l}\text { Coronary atherosclerosis; myocardial } \\
\text { infarction; pericarditis;* congenital or } \\
\text { acquired valvular heart disease; other } \\
\text { congenital heart disease. Most abnormal } \\
\text { conditions of the heart are associated with } \\
\text { hypertrophy (or increased mass), with or } \\
\text { without chamber dilatation } \\
\text { Cardiomyopathy.* }\end{array}$ \\
\hline Other organs & $\begin{array}{l}\text { Procedures depend on expected findings or } \\
\text { grossly identified abnormalities as listed in } \\
\text { right-hand column. }\end{array}$ & $\begin{array}{l}\text { Manifestations of systemic hypertension;* } \\
\text { pulmonary vascular disease with hyper- } \\
\text { tension, including pulmonary embolism;* } \\
\text { amyloidosis, }{ }^{*} \text { hemochromatosis, }{ }^{*} \text { Fabry's } \\
\text { disease,* or glycogen storage disease.* }\end{array}$ \\
\hline
\end{tabular}




\section{Hypervitaminosis A}

Related Term: Vitamin A toxicity.

NOTE: The findings listed below refer to chronically increased vitamin A ingestion.

\begin{tabular}{ll}
\hline Organs and Tissues & Procedures \\
\hline External examination & $\begin{array}{l}\text { Record extent and character of skin lesions; } \\
\text { photograph skin lesions. Submit specimens } \\
\text { of affected and unaffected skin for histologic } \\
\text { study. Prepare skeletal roentgenograms. }\end{array}$
\end{tabular}

Liver

Other organs

Brain

Bones and joints
Record weight and size; photograph surface and cut section; submit fresh tissue for demonstration of vitamin A fluorescence in frozen sections or for chemical analysis. Request frozen sections for Sudan stain (p. 173).

For paraffin sections, request van Gieson's stain (p. 173).

Submit samples of spleen, kidneys, and parathyroid glands for histologic study.

For removal and specimen preparation, see p. 65.

For optimal sites for histologic study, see above under "External examination and skin."

For removal, prosthetic repair, and specimen preparation, see p. 95.
Possible or Expected Findings

Brittle hair; desquamation of skin, particularly of palms and soles; nail abnormalities. Clubbing of fingers (in children). Osteoporosis; ${ }^{*}$ fractures; periosteal proliferation, particularly of ulnae, clavicles, and metatarsal bones; tumefaction of midshafts of long bones. Osteoarthritis (1). Fatty changes in liver with characteristic quick-fading green fluorescence. Hepatic fibrosis or cirrhosis.*

Pseudotumor cerebri;* hydrocephalus, ${ }^{*}$ particularly in infants.

Calcification of cartilage, broadening of osseous trabeculae, and periosteal proliferations. Hyperostotic and destructive osteoarthritis (1). See also above under "External examination and skin."

\section{Reference}

1. Romero JB, Schreiber A, von Hochstetter AR, Wagenhauser FJ, Michel BA, Theiler R. Hyperostotic and destructive osteoarthritis in a patient with vitamin A intoxication syndrome: a case report. Bull Hosp Joint Dis 1996;54:169-174.

\section{Hypervitaminosis D}

Related Term: Vitamin D toxicity.

\begin{tabular}{ll}
\hline Organs and Tissues & Procedures \\
\hline $\begin{array}{l}\text { External examination } \\
\text { and skin }\end{array}$ & Prepare skeletal roentgenograms.
\end{tabular}

Possible or Expected Findings

Osteoporosis; ${ }^{*}$ para-articular calcifications; other metastatic calcifications. In infants, radiopacity may be found-primarily at epiphyseal ends of the shafts of long tubular bones.

Submit specimens of skin and of subcutaneous tissue for histologic study.

Vitreous

Submit sample for determination of calcium and phosphate concentrations (p. 85). If histologic study of eyes is intended, remove vitreous from only one eye.

Blood

Lungs
Postmortem calcium values are unreliable. Inflate one fresh lung with carbon dioxide and prepare roentgenogram for demonstration of calcium deposits. Then, perfuse lung with formalin (p. 47). For histologic sections, request von Kossa's stain for calcium (p. 173). Decalcification of tissue may be required (p. 97).
Metastatic calcification.

Increased calcium concentrations.

Hypercalcemia.

Metastatic calcification. 


\begin{tabular}{lll}
\hline Organs and Tissues & Procedures & Possible or Expected Findings \\
\hline Kidneys & $\begin{array}{l}\text { Prepare soft tissue roentgenograms. Request } \\
\text { von Kossa's stain (p. 173). Decalcification of } \\
\text { tissue may be required (p. 97). }\end{array}$ & Metastatic calcification. \\
Parathyroid glands & $\begin{array}{l}\text { Record weights of all parathyroid glands and } \\
\text { submit samples for histologic study. }\end{array}$ & Normal parathyroid glands. \\
Other organs & $\begin{array}{l}\text { Histologic samples should include heart, } \\
\text { pancreas, fundus and body of stomach, elastic } \\
\text { and muscular arteries, and lymph nodes. }\end{array}$ & $\begin{array}{l}\text { Metastatic calcification. If applicable, } \\
\text { see also under "Failure, kidney." }\end{array}$ \\
& $\begin{array}{l}\text { See also above under "Kidneys." } \\
\text { For removal and specimen preparation, see } \\
\text { pp. 65 and 67, respectively. Submit samples } \\
\text { of tentorium and falx cerebri for histologic study. }\end{array}$ & $\begin{array}{l}\text { Metastatic calcification of tentorium and } \\
\text { falx cerebri. }\end{array}$ \\
& $\begin{array}{l}\text { For removal and specimen preparation, see p. 85. } \\
\text { See also above under "Vitreous." }\end{array}$ & $\begin{array}{l}\text { Metastatic calcium deposits in corneas and } \\
\text { conjunctivas. } \\
\text { Eyes }\end{array}$ \\
$\begin{array}{l}\text { For removal, prosthetic repair, and specimen } \\
\text { preparation, see p. 95. For optimal sampling, } \\
\text { Bones and joints }\end{array}$ & $\begin{array}{l}\text { Metastatic calcification in synovial tissue and } \\
\text { in bone marrow. See also above under } \\
\end{array}$ & "External examination and skin." \\
\hline
\end{tabular}

Hypnotic(s) (See “Dependence, drug(s), all types or type unspecified" and "Poisoning, barbiturate(s).")

Hypocalcemia (See "Disorder, electrolyte(s).")

Hypofibrinogenemia (See “Coagulation, disseminated intravascular.”)

\section{Hypogammaglobulinemia}

Synonyms and Related Terms: Acquired hypogammaglobulinemia; agammaglobulinemia; congenital hypogammaglobulinemia; Good's syndrome (thymoma and hypogammaglobulinemia) (1).
Possible Associated Conditions: Campylobacter, meningogoccal, pneumococcal and other infections, including infections by $S$. pneumoniae and $H$. influenzae. Malabsorption syndrome;* multiple myeloma, ${ }^{*}$ and systemic amyloidosis* (2). (See also under "Syndrome, primary immunodeficiency.")

\begin{tabular}{|c|c|c|}
\hline Organs and Tissues & Procedures & Possible or Expected Findings \\
\hline Chest cavity & & Thymoma (1). \\
\hline Intestinal tract & $\begin{array}{l}\text { For fixation and specimen preparation, } \\
\text { see p. } 54 \text {. }\end{array}$ & $\begin{array}{l}\text { Sprue-type changes of intestinal mucosa with } \\
\text { malabsorption syndrome.* Giardia lamblia } \\
\text { infection. }\end{array}$ \\
\hline Liver & & Chronic hepatitis C (3). \\
\hline Brain and spinal cord & $\begin{array}{l}\text { For removal and specimen preparation, } \\
\text { see pp. } 65 \text { and } 67 \text {, respectively. }\end{array}$ & Encephalomyelitis (4). \\
\hline Bones and joints & $\begin{array}{l}\text { For removal, prosthetic repair, and specimen } \\
\text { preparation, see p. } 95 \text {. }\end{array}$ & $\begin{array}{l}\text { Arthritis (with features of rheumatoid } \\
\text { arthritis*) }\end{array}$ \\
\hline
\end{tabular}

\section{References}

1. Verne GN, Amann ST, Cosgrove C, Cerda JJ. Chronic diarrhea associated with thymoma and hypogammaglobulinemia (Good's syndrome). South Med J 1997;90:444-446.

2. Kotilainen P, Vuori K, Kainulainen L, Aho H, Saario R, Asola M, et al. Systemic amyloidosis in a patient with hypogammaglobulinemia. J Intern Med 1996;240:103-106.
3. Quinti I, Pandolfi F, Paganelli R, el Salman D, Giovannetti A, Rosso $\mathrm{R}$, et al. HCV infection in patients with primary defects of immunoglobulin production. Clin Exp Immunol 1995;102:11-16.

4. Rudge P, Webster AD, Revesz T, Warner T, Espanol T, CunninghamRundles $\mathrm{C}$, et al. Encepahomyelitis in primary hypogammaglobulinemia. Brain 1996;119:1-15.

\section{Hypoglycemia}

NOTE: Currently, no reliable diagnostic tests are available for the postmortem diagnosis of hypoglycemia. 


\begin{tabular}{lll}
\hline Organs and Tissues & Procedures & Possible or Expected Findings \\
\hline Vitreous & $\begin{array}{l}\text { Usually, aspiration of vitreous is not indicated. } \\
\text { If aspiration is desired, see p. 85. }\end{array}$ & $\begin{array}{l}\text { Postmortem glycolysis in vitreous may be } \\
\text { very rapid. Glucose may not be demonstrable } \\
\text { within 3 h after death (tested in individuals } \\
\text { who did not suffer from hypoglycemia). }\end{array}$ \\
$\begin{array}{ll}\text { Blood } \\
\text { Urine }\end{array}$ & $\begin{array}{l}\text { Glucose concentrations are totally unreliable. } \\
\text { In presence of hypoglycemia, urine contains } \\
\text { no glucose or ketone. }\end{array}$ \\
and ketone levels. & $\begin{array}{l}\text { For interpretation of findings, see p. 115. } \\
\text { Results may be unreliable. } \\
\text { Brain }\end{array}$ & $\begin{array}{l}\text { Petechial or larger hemorrhages; ganglion } \\
\text { cell degeneration, gliosis, and } \\
\text { demyelinization. }\end{array}$ \\
\hline
\end{tabular}

Hypokalemia (See "Disorder, electrolyte(s)" and p. 114.)

\author{
Hypolipoproteinemia (See "Abetalipoproteinemia" \\ and "Disease, Tangier's.") \\ Hyponatremia (See "Disorder, electrolyte(s)" \\ and p. 114.)
}

\section{Hypoparathyroidism}

Synonyms: Acquired hypoparathyroidism; hereditary hypoparathyroidism; idiopathic hypoparathyroidism.

Possible Associated Conditions: Autoimmune polyglandular deficiency (often with alopecia, megaloblastic anemia;* mucocutaneous candidiasis, and vitiligo); DiGeorge syndrome* (defective development of thymus, parathyroid glands, and other organs).

\begin{tabular}{|c|c|c|}
\hline Organs and Tissues & Procedures & Possible or Expected Findings \\
\hline $\begin{array}{l}\text { External examination } \\
\text { and skin; teeth }\end{array}$ & $\begin{array}{l}\text { Record location of scars of previous neck } \\
\text { surgery and abnormalities of skin, hair, nails, } \\
\text { and teeth. Submit samples of normal and } \\
\text { abnormal skin for histologic study. } \\
\text { Prepare skeletal roentgenograms. }\end{array}$ & $\begin{array}{l}\text { Scars of previous neck surgery; coarse skin, } \\
\text { with or without subcutaneous calcifications; } \\
\text { malformed nails; dysplasia of enamel; } \\
\text { alopecia. } \\
\text { Dense bones; thickening of calvarium. }\end{array}$ \\
\hline Urine and vitreous & $\begin{array}{l}\text { Submit samples (p. } 85 \text { ) for determination of } \\
\text { calcium concentrations. Postmortem calcium } \\
\text { values in blood are unreliable. }\end{array}$ & Hypocalcemia; hypocalciuria. \\
\hline Parathyroid glands & $\begin{array}{l}\text { Record weights of all parathyroid glands. } \\
\text { Submit samples for histologic study. }\end{array}$ & $\begin{array}{l}\text { Parathyroid glands may not be present (after } \\
\text { intentional or unintentional surgical } \\
\text { removal). }\end{array}$ \\
\hline Other organs & $\begin{array}{l}\text { Procedures depend on expected findings or } \\
\text { grossly identified abnormalities as listed in } \\
\text { right-hand column. If an infection is suspected, } \\
\text { submit material for microbiologic study. }\end{array}$ & $\begin{array}{l}\text { Cardiomyopathy* }(1) \text {; manifestations of } \\
\text { Addison's disease; candidiasis; } * \text { ovarian } \\
\text { failure, or megaloblastic anemia }(2)^{*} . \\
\text { Malabsorption with steatorrhea and } \\
\text { myopathy with muscular atrophy may occur. }\end{array}$ \\
\hline Brain and spinal cord & $\begin{array}{l}\text { For removal and specimen preparation, } \\
\text { see pp. } 65 \text { and } 67 \text {, respectively. }\end{array}$ & Calcification in basal ganglia. \\
\hline Eyes & For removal and specimen preparation, see p. 85 . & Cataracts. \\
\hline Bones & $\begin{array}{l}\text { For removal, prosthetic repair, and specimen } \\
\text { preparation, see p. } 95 \text {. Consult roentgenograms. }\end{array}$ & $\begin{array}{l}\text { See above under "External examination } \\
\text { and skin." }\end{array}$ \\
\hline
\end{tabular}

\section{References}

1. Suzuki T, Ikeda U, Fujikawa H, Saito K, Shimada K. Hypocalcemic heart failure: a reversible form of heart muscle disease. Clin Cardiol 1998;21: 227-228.

2. Abramowicz MJ, Cochaux P, Cohen LH, Vamos E. Pernicious anaemia and hypoparathyroidism in a patient with Kearns-Sayre syndrome with mitochondrial DNA duplication. J Inherit Metabol Dis 1996;19:109-111.

Hypophosphatasia (See "Deficiency, vitamin D" and “Osteomalacia.")

Hypophosphatemia, Familial (See “Syndrome, Fanconi.”) 


\section{Hypopituitarism (See "Insufficiency, pituitary.")}

\section{Hypoplasia, Left Ventricular}

NOTE: For general dissection techniques, see p. 33.

Possible Associated Conditions: Congenital aortic valvular stenosis* or atresia (hypoplastic left heart syndrome); coarctation of the aorta; * hypoplasia of ascending aorta; left ventricular endocardial fibroelastosis; * mitral atresia.*

\section{Hypoplasia, Right Ventricular}

NOTE: For general dissection techniques, see p. 33.

Possible Associated Conditions: Congenital pulmonary stenosis* or atresia with intact ventricular septum;* congenital tricuspid stenosis or atresia;* restrictive ventricular septal defect;* transposition of the great arteries.
Hypoplasia, Tubular, of Aortic Arch

NOTE: For general dissection techniques, see p. 33.

Possible Associated Conditions: Coarctation of the aorta;* malaligned ventricular septal defect; patent ductal artery;* subaortic stenosis.

\section{Hypothermia (See "Exposure, cold.")}

\section{Hypothyroidism}

Synonyms: Cretinism; goitrous hypothyroidism; myxedema; primary hypothyroidism; secondary hypothyroidism; suprathyroidal (trophoprivic) hypothyroidism; thyroprivic hypothyroidism.

\begin{tabular}{ll}
\hline Organs and Tissues & Procedures \\
\hline External examination, & Record body weight and length and facial \\
skin, and breasts & features; record location of scars of previous \\
& neck surgery.
\end{tabular}

Vitreous

Abdomen
Pleural and
pericardial cavities
Blood

Thymus

Heart

Arteries

Neck organs

Lymph nodes

Intestinal tract

Urine
Prepare histologic sections of skin and of breast tissue.

Prepare roentgenograms of chest and of joints.

Submit for determination of sodium concentration (p. 85).

Record volume of effusion.

Record volume of effusion(s).

Submit sample for microbiologic study (p. 102). If hormone assay is intended, snapfreeze sample.

Record weight and submit samples for histologic study.

Record weight; photograph; submit samples for histologic study (p. 30).

Record degree of atherosclerosis of aorta, coronary arteries, cerebral arteries, and other muscular arteries.

Remove neck organ together with tongue (p. 4). Prepare histologic sections of tongue with papillae. Record weight of thyroid gland; photograph and submit samples for histologic study. Record weights of parathyroid glands. If patient was recently treated with radionuclides, see Chapter 13.

Record average size and submit samples of histologic study.

For in situ fixation, see p. 54.

Submit sample for determination of glucose and ketone concentrations.

\section{Possible or Expected Findings}

In cretinism, body is small for age and head is large with coarse facial features and protruding tongue.

In adults, brittle hair, sparse eyebrows, and puffiness of face are present.

Surgical scars of neck.

Perifollicular keratosis of skin; thickened nails; galactorrhea.

Pleural* and pericardial effusions; joint effusions; degenerative joint disease involving knees, hips, hands, and other joints (1); thickening of joint capsules; bursitis. Low sodium concentration.

Ascites.

Hydrothorax and hydropericardium, with or without cardiac tamponade.

Septicemia; hypercholesterolemia.

Dilatation of the heart.* See also under "Failure, congestive heart." Increased atherosclerosis.

Macroglossia; Hashimoto's thyroiditis; Riedel's struma; subacute thyroiditis (see also under "Thyroiditis"); colloid goiter; tumor of the thyroid gland after treatment with radioactive iodine; surgically removed thyroid gland; thyroid aplasia (in cretinism).

Ileus; megacolon.

In presence of hypoglycemia, ${ }^{*}$ urine contains no glucose or ketone. 


\begin{tabular}{|c|c|c|}
\hline Organs and Tissues & Procedures & Possible or Expected Findings \\
\hline Other organs & $\begin{array}{l}\text { Submit samples of adrenal glands, gonads, } \\
\text { and tail of pancreas (for islets of Langerhans) } \\
\text { for histologic study. }\end{array}$ & \\
\hline $\begin{array}{l}\text { Brain, spinal cord, } \\
\text { and pituitary gland }\end{array}$ & $\begin{array}{l}\text { For removal and specimen preparation, } \\
\text { see pp. } 65,67 \text {, and } 71 \text {, respectively. }\end{array}$ & $\begin{array}{l}\text { Hypothalamic congenital defects, infections, } \\
\text { tumor, or sarcoidosis* may cause trophoprivic } \\
\text { hypothyroidsim. For other causes, see } \\
\text { "Insufficiency, pituitary." }\end{array}$ \\
\hline Skeletal muscles & $\begin{array}{l}\text { For sampling and specimen preparation, } \\
\text { see p. } 80 \text {. }\end{array}$ & \\
\hline Joints and bursae & $\begin{array}{l}\text { For removal, prosthetic repair, and specimen } \\
\text { preparation of joints, see p. } 96 \text {. }\end{array}$ & $\begin{array}{l}\text { See above under "External examination, skin, } \\
\text { and breasts." }\end{array}$ \\
\hline
\end{tabular}

\section{Reference}

1. McLean RM, Podell DN. Bone and joint manifestations of hypothyroidism. Semin Arthritis Rheum 1995;24:282-290.

\section{Hypovitaminosis A (See "Deficiency, vitamin A.")}

\section{Hypovitaminosis D (See “Deficiency, vitamin D.”)}

\section{Hypoxemia (See "Hypoxia.")}

\section{Hypoxia}

Related Terms: Asphyxia; hypoxemia; suffocation.

NOTE: There are no diagnostic autopsy findings for hypoxia. Possible causes of acute hypoxia include anesthesia-associated death,* diving accident, ${ }^{*}$ exposure to toxic gas(es) — for instance, carbon monoxide poisoning;* mechanical failure of an oxygen supply system, as in an airplane; and sudden mechanical airway obstruction, ${ }^{*}$ as in aspiration of a foreign body or strangulation. Causes of chronic asphyxia include prolonged exposure to high altitude and chronic pulmonary disease.

\begin{tabular}{|c|c|c|}
\hline Organs and Tissues & Procedures & Possible or Expected Findings \\
\hline External examination & $\begin{array}{l}\text { Record appearance of head, oral cavity, } \\
\text { and neck area. }\end{array}$ & $\begin{array}{l}\text { Cyanosis; foreign body in mouth or pharynx; } \\
\text { strangulation marks; scleral hemorrhages. }\end{array}$ \\
\hline Blood & $\begin{array}{l}\text { Submit sample for toxicologic study (p. 16), } \\
\text { for instance, for determination of carbon } \\
\text { monoxide concentration-and for determination } \\
\text { of hemoglobin saturation. }\end{array}$ & $\begin{array}{l}\text { Blood dark and liquid; oxygen saturation of } \\
\text { hemoglobin may be less than } 10 \% \text {. }\end{array}$ \\
\hline Pleura and pericardium & & Petechial hemorrhages; Tardieu's spots. \\
\hline Heart & Record weight. & Right ventricular hypertrophy. \\
\hline Lungs & $\begin{array}{l}\text { Record weights. Perfuse one lung with formalin } \\
\text { (p. 47). Request Verhoeff-van Gieson stain } \\
\text { (p. 173). }\end{array}$ & $\begin{array}{l}\text { Profound medial hypertrophy of small } \\
\text { pulmonary arteries and of pulmonary veins } \\
\text { in patients who chronically were exposed to } \\
\text { hypoxia. Acute pulmonary edema may also } \\
\text { occur in chronic hypoxia. }\end{array}$ \\
\hline Neck organs & $\begin{array}{l}\text { Remove carefully to avoid dislodging foreign } \\
\text { body. }\end{array}$ & \\
\hline Brain & For removal and specimen preparation, see p. 65. & Cerebral edema in acute mountain sickness. \\
\hline Middle ears & For removal and specimen preparation, see p. 72 . & Mucosal hemorrhages. \\
\hline
\end{tabular}




\section{Ileus, Meconium}

Possible Associated Conditions: Congenital megacolon;* cystic fibrosis;* syphilis.* (1).

\begin{tabular}{|c|c|c|}
\hline Organs and Tissues & Procedures & Possible or Expected Findings \\
\hline External examination & $\begin{array}{l}\text { Record height, weight, and abdominal } \\
\text { circumference. }\end{array}$ & Malnutrition. \\
\hline $\begin{array}{l}\text { Abdominal cavity } \\
\text { and intestinal tract }\end{array}$ & $\begin{array}{l}\text { Examine and sample the bowel early in the } \\
\text { procedure to minimize autolysis. Record } \\
\text { location and character of meconium and of } \\
\text { liquid contents, and determine thickness of } \\
\text { intestinal wall. Record location of stenosis, } \\
\text { atresia, or dilatation. Submit samples of all } \\
\text { portions of intestinal tract for histologic study. }\end{array}$ & $\begin{array}{l}\text { Empty and collapsed colon; small amounts } \\
\text { of gray and dry meconium in terminal } \\
\text { ileum; meconium masses in dilated and } \\
\text { hypertrophied mid-ileum; liquid contents } \\
\text { in proximal intestine (1); appendicitis; } \\
\text { bowel perforation. } \\
\text { Glandular inspissation and atrophy of } \\
\text { intestinal mucosa. } \\
\text { Volvulus, infarction, necrosis, perforation, } \\
\text { peritonitis, and acquired intestinal atresia } \\
\text { may be present. Absence of neural plexuses } \\
\text { in congential megacolon* (Hirschsprung's } \\
\text { disease). }\end{array}$ \\
\hline Other organs & $\begin{array}{l}\text { Procedures depend on expected findings or } \\
\text { grossly identified abnormalities as listed in } \\
\text { right-hand column. }\end{array}$ & $\begin{array}{l}\text { Manifestations of cystic fibrosis, with or } \\
\text { without cirrhosis;* biliary atresia* }(3) \text {. }\end{array}$ \\
\hline
\end{tabular}

\section{References}

1. Siplovich L, Davies MR, Kaschula RO, Cywes S. Intestinal obstruction in the newborn with congenital syphilis. J Pediatr Surg 1988;23:810-813.

2. Maurage C, Lenaerts C, Weber A, Brochu P, Yousef I, Roy CC. Meconium ileus and its equivalent as a risk factor for the development of cirrhosis: an autopsy study in cystic fibrosis. J Ped Gastroenterol Nutr 1989;9:17-20.

3. Adam G, Brereton RJ, Agrawal M, Lake BD. Biliary atresia and meconium ileus associated with Nieman-Pick disease. J Ped Gastroenterol Nutr 1988;7:128-131.

Immunodeficiency (See “Syndrome, acquired immunodeficiency” and “Syndrome, primary immunodeficiency.")

\section{Impression, Basilar}

NOTE: Basilar impression constitutes an upward bulging of the margins of the foramen magnum. When occipital condyles are displaced above the plane of the foramen magnum, basilar invagination is present.

Possible Associated Conditions: Klippel-Feil syndrome;* osteogenesis imperfecta;* osteomalacia;* Paget's disease of bone;* rheumatoid arthritis; rickets; syringobulbia; syringomylia.*

\begin{tabular}{lll}
\hline Organs and Tissues & Procedures & Possible or Expected Findings \\
\hline External examination & & $\begin{array}{l}\text { Shortness of neck. } \\
\text { Skull and spine }\end{array}$ \\
& $\begin{array}{l}\text { Prepare roentgenograms. For dissection of } \\
\text { cervical spine, see p. 71. }\end{array}$ & $\begin{array}{l}\text { Arnold-Chiari malformation; * fusion of atlas } \\
\text { to base of skull; malpositioning of odontoid } \\
\text { process; platybasia.* }\end{array}$
\end{tabular}




\begin{tabular}{lll}
\hline Organs and Tissues & Procedures & Possible or Expected Findings \\
\hline Brain and spinal cord & $\begin{array}{l}\text { For removal and specimen preparation, } \\
\text { see pp. 65 and 67, respectively. }\end{array}$ & $\begin{array}{l}\text { Compression and secondary ischemic injury } \\
\text { to lower brain stem and spinal cord. See also } \\
\text { above under "Skull and spine" and under } \\
\text { "Possible Associated Conditions." }\end{array}$ \\
\hline
\end{tabular}

\section{Incompetence,... (See "Insufficiency,...”)}

\section{Infanticide}

Related Terms: Battered-child syndrome; child-abuse or child-neglect death.

NOTE: As stated on p. 85, vitreous should not be aspirated because there is a risk of artifactual damage to the retina. The retina that bears the brunt of the injury in child abuse and the assessment and position of retinal hemorrhages is of prime impor- tance. Instead, prior to the removal of the eye, the fundus should be photographed.

Record appearance of clothing; undress body over plastic bag; dry clothing and then place in paper bags (each bag should be labeled separately). Record skin lesions after cleansing of body; record and photograph appearance of anus, genital, and oral frenula, if necessary. If sex-related crime is suspected, follow procedures described under "Rape." Collect hair from scalp and from wound sites (if hair present) for future comparison. Also follow other applicable procedures described under "Homicide." $a$

\begin{tabular}{|c|c|c|}
\hline Organs and Tissues & Procedures & Possible or Expected Findings \\
\hline External examination & $\begin{array}{l}\text { Record body weight and height. Photograph body } \\
\text { dressed and undressed; photograph and record } \\
\text { extent of injuries and of other skin lesions. } \\
\text { Collect any trace evidence. For additional } \\
\text { procedures, see above under "Note." } \\
\text { Prepare roentgenograms of entire body. } \\
\text { Postmortem MRI is a valuable addition to }\end{array}$ & $\begin{array}{l}\text { In the abused child, bruises, hematomas, burn } \\
\text { marks, or other patterned injuries. In any } \\
\text { child, diaper rash, Mongolian spots, self- } \\
\text { inflicted fingernail scratches, skin infections, } \\
\text { and emaciation. } \\
\text { In the previously battered child, fractures in } \\
\text { various states of healing. }\end{array}$ \\
\hline
\end{tabular}

Vitreous

Umbilical cord attachment

Blood

Lungs

Gastrointestinal tract autopsy findings in the investigation of child abuse (1).

For special considerations in suspected child abuse, see above under "Note."

In other situations, or after study of the fundus (see above) submit sample of vitreous for chemical and possible toxicologic study (p. 16).

Prepare histologic sections of umbilicus and end of umbilical cord.

Submit sample for toxicologic study (p. 16) and retain according to established schedule for possible additional testing (paternity testing may be required).

If there is a possibility that the cadaver represents a stillbirth, see p. 476 .

If infant is thought to have died shortly after birth, determine the location of air in the intestinal tract; roentgenograms may be helpful.

Save stomach contents and record amount.

Other organs
See also under "Homicide."
In hypertonic dehydration, ${ }^{*}$ sodium concentrations more than $150 \mathrm{meq} / \mathrm{L}$. This may be caused by organic disease, improper medical treatment, or physical neglect.

If infant was born alive, inflammatory changes may be found, depending on survival interval.

For the hydrostatic lung test, see "Stillbirth." The test is unreliable. Extraneous material in air passages indicates that child was alive. Air reaches the stomach after $15 \mathrm{~min}$, the small intestine after $1-2 \mathrm{~h}$, the colon after $5-6 \mathrm{~h}$, and the rectum after $12 \mathrm{~h}$. There is no difference in the speed of gas propulsion between full-term and premature infants. Bacterial gas production and previous resuscitation attempts are potential sources of errors.

In questionable stillbirth, presence of milk proves that infant was alive and had been nursed.

Traumatic lesions and signs of neglect may be present. 


\section{Reference}

1. Hart BL, Dudley MH, Zumwalt RE. Postmortem cranial MRI and autopsy correlation in suspected child abuse. Am J Forens Med Pathol 1996; 17: 217-224.

\section{Infarction, Cerebral \\ Related Term: Stroke}

\begin{tabular}{|c|c|c|}
\hline Organs and Tissues & Procedures & Possible or Expected Findings \\
\hline Heart & $\begin{array}{l}\text { If infective endocarditis is suspected, follow } \\
\text { procedures described on p. } 103 \text {. } \\
\text { Record presence or absence of patent oval } \\
\text { foramen or other septal defects. }\end{array}$ & $\begin{array}{l}\text { Myocardial infarction or other cardiac lesions } \\
\text { that may cause systemic circulatory failure. } \\
\text { Valvular vegetations and mural thrombi may } \\
\text { be source of cerebral emboli; paradoxic } \\
\text { embolism. }\end{array}$ \\
\hline Aorta & $\begin{array}{l}\text { Procedures depend on expected findings or } \\
\text { grossly identified abnormalities as listed in } \\
\text { right-hand column. }\end{array}$ & $\begin{array}{l}\text { Aortic dissection. } \\
\text { atherosclerosis with or without mural } \\
\text { thrombi; atheromas. }\end{array}$ \\
\hline Cervical arteries & $\begin{array}{l}\text { For dissection and roentgenologic demon- } \\
\text { stration of carotid and vertebral arteries, } \\
\text { see p. } 82 \text {. }\end{array}$ & $\begin{array}{l}\text { Dissecting hematoma of cervical arteries; } \\
\text { atherosclerosis with or without thrombosis; } \\
\text { atheromas of cervical arteries, particularly in } \\
\text { carotid bulb. }\end{array}$ \\
\hline $\begin{array}{l}\text { Femoral and other } \\
\text { systemic veins }\end{array}$ & For removal of femoral veins, see p. 34 . & $\begin{array}{l}\text { Thromboses as source of paradoxic cerebral } \\
\text { embolism. }\end{array}$ \\
\hline Brain & $\begin{array}{l}\text { For cerebral arteriography, see p. } 80 . \\
\text { For removal and specimen preparation, } \\
\text { see p. } 65 \text {. }\end{array}$ & $\begin{array}{l}\text { Atherosclerosis of intracranial arteries. } \\
\text { Cerebral infarcts (white or red) of different } \\
\text { size, age, and distribution. Watershed } \\
\text { (boundary) zones are most frequently } \\
\text { affected in global ischemia caused by } \\
\text { systemic circulatory failure. }\end{array}$ \\
\hline Cerebral venous sinuses & For exposure of venous sinuses, see p. 71 . & $\begin{array}{l}\text { Cerebral venous sinus thrombosis; } \\
\text { thrombosis of tributaries of venous sinuses. } \\
\text { Parasagittal, bilateral, and hemorrhagic } \\
\text { infarcts after sagittal sinus thrombosis. }\end{array}$ \\
\hline
\end{tabular}

Infarction, Myocardial (See "Disease, ischemic heart.")

Infarction, Pulmonary (See "Embolism, pulmonary.")

Infection, Cytomegalovirus

Synonyms: Cytomegalic inclusion disease; salivary gland virus disease.

NOTE: Cytomegalovirus infection may complicate any chronic debilitating disease, and may follow treatment with immunosuppressive and cytotoxic drugs.
(1) Collect all tissues that appear to be infected. (2) Request viral cultures. (3) Immunohistochemical stains on paraffinembedded sections are available in many laboratories. (4) No special precautions are indicated. (5) Serologic studies are available from many reference laboratories (p. 135), but these are not necessary to make the diagnosis. (6) This is not a reportable disease.

Possible Associated Conditions: Pneumocystis carinii infection.* Bacterial, fungal, protozoal, and other viral infections.

\begin{tabular}{lll}
\hline Organs and Tissues & Procedures & Possible or Expected Findings
\end{tabular}

Placenta

Record weight. For specimen preparation, see p. 60 .

External examination

Record changes as listed in right-hand column.

Urine

Submit sample for viral culture (p. 102).

Prepare smears of sediment.

Lungs
Culture consolidated areas of lung or random sites if the clinical suspicion is high.
In congenital cytomegalovirus infection, mononuclear plasma cell villitis with villous edema and intranuclear and cytoplasmic inclusions.

In congenital cytomegalovirus infection, microcephaly, jaundice, and a petechial rash may be found.

Focal interstitial pneumonia. See also above under "Possible Associated Conditions." 


\begin{tabular}{|c|c|c|}
\hline Organs and Tissues & Procedures & Possible or Expected Findings \\
\hline $\begin{array}{l}\text { Esophagus and } \\
\text { gastrointestinal tract }\end{array}$ & Submit samples for histologic study. & $\begin{array}{l}\text { Ulcers or grossly normal mucosa with } \\
\text { cytomegalic inclusions in epithelial and } \\
\text { endothelial cells. }\end{array}$ \\
\hline Liver & $\begin{array}{l}\text { Record weight and submit samples for } \\
\text { histologic study and viral culture. }\end{array}$ & Hepatitis with hepatomegaly. \\
\hline Other organs & $\begin{array}{l}\text { Submit samples of myocardium, pancreas, } \\
\text { spleen, kidneys, adrenal glands, and eyes } \\
\text { (p. 85) for histologic study and, if indicated, } \\
\text { viral culture. For special stains, see above } \\
\text { under "Note." If accessible, prepare sections } \\
\text { of salivary glands [e.g., submandibular gland } \\
\text { in floor of mouth (p. 4)]. }\end{array}$ & $\begin{array}{l}\text { Myocarditis; pancreatitis; splenitis; and } \\
\text { adrenalitis. In adult and in congenital } \\
\text { infections, focal necrotizing nephritis; } \\
\text { chorioretinitis. Virtually all organs may be } \\
\text { affected and have cytomegalic cells with viral } \\
\text { inclusions. }\end{array}$ \\
\hline Brain & $\begin{array}{l}\text { For removal and specimen preparation, } \\
\text { see p. } 65 \text {. }\end{array}$ & $\begin{array}{l}\text { Meningoencephalitis with subependymal } \\
\text { calcifications of lateral ventricles. }\end{array}$ \\
\hline Bone marrow & & Fibrin ring granulomas in rare instances $(1)$. \\
\hline
\end{tabular}

\section{Reference}

1. Young J, Goulian M. Bone marrow fibrin ring granulomas and cytomegalovirus infection. Am J Clin Pathol 1993;99:65-68.

Infection, Hantavirus (See "Fever, hemorrhagic, with renal syndrome.")

Infection, Herpes simplex

Synonyms and Related Terms: Herpes simplex, type I; herpes simplex, type II; sporadic acute herpes simplex type I (rarely type II) encephalitis. For other names and manifestations, see below under "Possible or Expected Findings."

\begin{tabular}{|c|c|c|}
\hline Organs and Tissues & Procedures & Possible or Expected Findings \\
\hline $\begin{array}{l}\text { Mouth, esophagus, } \\
\text { distal colon, liver, } \\
\text { adrenal glands, and } \\
\text { other organs and tissues }\end{array}$ & $\begin{array}{l}\text { Multiple organs and tissues may be involved, } \\
\text { including oral cavity, esophagus, colon, liver, } \\
\text { and adrenal glands. Sample tissue from these } \\
\text { sites. }\end{array}$ & $\begin{array}{l}\text { Herpetic gingivostomatitis, esophagitis, } \\
\text { distal colitis, and proctitis (mostly type II } \\
\text { infection); herpetic hepatitis with or without } \\
\text { extensive necrosis, and adrenalitis with } \\
\text { cortical necrosis. }\end{array}$ \\
\hline Brain & $\begin{array}{l}\text { For removal and specimen preparation, see } \\
\text { pp. } 65 \text { and } 67 \text {, respectively. Nuclear virus } \\
\text { antigens can be identified immunohisto- } \\
\text { chemically. Viral nucleic acid may persist } \\
\text { years after the acute phase and be identified } \\
\text { by in situ hybridization. } \\
\text { In the acute phase, submit tissue for culture. } \\
\text { For electron microscopic study, see p. } 132 .\end{array}$ & $\begin{array}{l}\text { In the acute phase, generalized swelling. } \\
\text { Bilateral, often asymmetrical necrosis, } \\
\text { involving particularly the temporal lobes. } \\
\text { Neocortex, white matter, hippocampus, amyg- } \\
\text { daloid nucleus, and putamen may be involved } \\
\text { and lesions may extend to the insular cortex. } \\
\text { Typically, diffuse necrotizing herpetic } \\
\text { meningoencephalitis; intranuclear inclusions } \\
\text { may be difficult to detect. In the chronic } \\
\text { phase, shrunken tissue with marked neuronal } \\
\text { loss, gliosis, and frequently cystic degeneration. }\end{array}$ \\
\hline Eyes & $\begin{array}{l}\text { For removal and specimen preparation, } \\
\text { see p. } 85 \text {. Electron microscopy (p. 132), } \\
\text { immunocytochemistry, in situ hybridization, } \\
\text { and the polymerase chain reaction may be } \\
\text { needed to confirm the diagnosis. }\end{array}$ & $\begin{array}{l}\text { Herpes simplex keratitis and retinal necrosis. } \\
\text { Corneal perforation. }\end{array}$ \\
\hline
\end{tabular}

\section{Infection, Herpes Zoster}

Synonyms and Related Terms: Herpes zoster oticus (Ramsay Hunt syndrome); postherpetic neuralgia; shingles; zona; zoster encephalomyelitis; zoster encephalopathy; zoster ophthalmicus.

NOTE: (1) Collect all tissues that appear to be infected. (2) Request viral cultures. (3) Stain for inclusion bodies (Lendrum's method; p. 172). Electron microscopy, labeled-antibody techniques, and in situ hybridization also can be useful in identifying viral particles. (4) Usually, no special precautions are indicated. (5) Serologic studies are available from the state health department laboratories (p. 135). (6) This is not a reportable disease. 
Possible Associated Conditions: Heavy metal poisoning; leukemia;* lymphoma;* multiple myeloma;* other malignant tumors (particularly when the spine is involved or when the patient had been treated with immunosuppressive agents or irradiation); trauma; tuberculosis;* other chronic debilitating diseases.

\begin{tabular}{lll}
\hline Organs and Tissues & Procedures & Possible or Expected Findings \\
\hline External examination & $\begin{array}{l}\text { Record distribution of lesions. Prepare } \\
\text { histologic sections of affected areas. For virus } \\
\text { culture, aspirate vesicles aseptically. }\end{array}$ & $\begin{array}{l}\text { Unilateral groups of skin vesicles, pustules, } \\
\text { and crusts in thoracic, cervical, facial, } \\
\text { lumbar, or sacral distribution. Eruptions may } \\
\text { be bullous or gangrenous. Vesicles may be } \\
\text { present on tip of nose. Generalized infections } \\
\text { may occur. Granuloma annulare-like lesions } \\
\text { following herpes zoster infection }(1) .\end{array}$ \\
& & Lymphadenitis.
\end{tabular}

\author{
Blood \\ Pleural and \\ peritoneal cavities \\ Gastrointestinal tract \\ Urinary bladder \\ Brain and spinal cord
}

Sensory ganglia

Peripheral nerves

Eyes

Ears

Other organs
For exposure of posterior root ganglia, see p. 69. If the face is involved, study trigeminal ganglia.

Submit samples from areas with gross lesions for histologic study.

Submit samples from areas with gross lesions for histologic study.

For removal and specimen preparation, see pp. 65 and 67, respectively. Submit fresh material for virologic study (p. 102).

For sampling and specimen preparation, see p. 79. Request Luxol fast blue stain (p. 172). For removal and specimen preparation; see p. 85. Indicated only if there is clinical evidence of zoster ophthalmitis. If eye is affected, study also trigeminal nerve and ganglia.

Record appearance of pinna. If there was clinical evidence of herpes zoster oticus, remove tympanic membrane, middle ear, and inner ear (p. 72).

Procedures depend on expected findings as listed in right-hand column and above under "Note."
Effusions in presence of visceral herpes zoster.

Inflammatory lesions in visceral zoster.

Unilateral ulcers in visceral zoster.

In rare instances, diffuse meningoencephalitis may occur. Limited necrotic and inflammatory lesions in the cord or brain stem at the level of the affected ganglion are common.

Ganglion cell necrosis; lymphocytic infiltration, hemorrhage, and, later, fibrosis. As a rule, only one ganglion is severely involved, but less severe lesions may occur in the ganglia that are immediately adjacent. Diffuse lymphocytic infiltration; demyelination; axonal destruction; fibrosis. Conjunctivitis; keratitis; iridocyclitis; retrobulbar neuritis; neuroretinitis; occlusion of retinal vessels.

Herpes zoster oticus.

Evidence of hematologic malignancies (2) or other conditions, as listed above under "Note."

\section{References}

1. Gibney MD, Nahass GT, Leonardi CL. Cutaneous reactions following herpes zoster infections: report of three cases and a review of the literature. Br J Dermatol 1996;134:504-509.

2. Smith JB, Fenske NA. Herpes zoster and internal malignancy. South Med J 1995;88:1089-1092.

\section{Infection, Middle Ear (See “Otitis media.”)}

\section{Infection, Pneumocystis carinii}

Synonym: Pneumocystosis.

NOTE: (1) Collect all tissues that appear to be infected. (2) This organism cannot be cultured at present but is frequently associated with viral, bacterial, or fungal infections that can be diagnosed by culture. (3) For rapid staining of aspirates, use GramWeigert stain, which will stain cysts of Pneumocystis carinii and also fungi and bacteria. Pneumocystis carinii is best demonstrated 


\section{Infection, Pneumocystis carinii (continued)}

with Grocott's methenamine silver stain (p. 172). (4) No special precautions are indicated. (5) Usually, no serologic studies are available. (6) This is not a reportable disease.

\begin{tabular}{|c|c|c|}
\hline Organs and Tissues & Procedures & Possible or Expected Findings \\
\hline Lungs & $\begin{array}{l}\text { Prepare smears of fresh cut sections. For } \\
\text { special stains for smears and paraffin sections, } \\
\text { see above under "Note." }\end{array}$ & $\begin{array}{l}\text { Pneumonia with foamy intra-alveolar } \\
\text { exudate containing cysts of Pneumocystis } \\
\text { carinii. }\end{array}$ \\
\hline Other organs & $\begin{array}{l}\text { Procedures depend on expected findings or } \\
\text { grossly identified abnormalities as listed in } \\
\text { right-hand column. }\end{array}$ & $\begin{array}{l}\text { Manifestations of conditions requiring high- } \\
\text { dose immunosuppressive therapy; AIDS;* } \\
\text { hypogammaglobulinemia, leukemia, }{ }^{*} \\
\text { lymphoma, }{ }^{*} \text { and prematurity. }\end{array}$ \\
\hline
\end{tabular}

Infection, Respiratory Syncytial Virus (See “Pneumonia, all types or type unspecified.”)

\section{Infection, Spinal Epidural}

\begin{tabular}{|c|c|c|}
\hline Organs and Tissues & Procedures & Possible or Expected Findings \\
\hline External examination & $\begin{array}{l}\text { If skin infections are presence, record } \\
\text { character and extent; prepare photographs. }\end{array}$ & $\begin{array}{l}\text { Pyogenic skin infections which may be trivial } \\
\text { (S. aureus). }\end{array}$ \\
\hline Cerebrospinal fluid & $\begin{array}{l}\text { Submit sample for microbiologic study } \\
\text { (p. 104); prepare smears. }\end{array}$ & $\begin{array}{l}\text { Protein concentrations increased; } \\
\text { WBC }<150 / \mathrm{mm}^{3} \text { (findings compatible } \\
\text { with parameningeal infection). }\end{array}$ \\
\hline $\begin{array}{l}\text { Spinal canal } \\
\text { and epidural space }\end{array}$ & $\begin{array}{l}\text { For exposure of epidural space, see p. } 65 \text {. } \\
\text { Local removal of uncontaminated infectious } \\
\text { material may not be possible. Prepare sections } \\
\text { and smears. Prepare saw sections through } \\
\text { adjacent bone. Submit samples of epidural } \\
\text { granulomas or from walls of abscesses for } \\
\text { histologic study. }\end{array}$ & $\begin{array}{l}\text { Trauma or osteomyelitis* (or both) of } \\
\text { vertebrae. Occasionally, pleural, sub- } \\
\text { diaphragmatic, or perirenal infections may } \\
\text { be present. Tuberculous abscesses may also } \\
\text { occur. }\end{array}$ \\
\hline Other organs & $\begin{array}{l}\text { Procedures depend on expected findings or } \\
\text { grossly identified abnormalities as listed in } \\
\text { right-hand column. }\end{array}$ & $\begin{array}{l}\text { Manifestations of cirrhosis; * diabetes } \\
\text { mellitus;* intravenous drug abuse; } \\
\text { malignancy; obstructive uropathy; or steroid- } \\
\text { treated degenerative joint disease. }\end{array}$ \\
\hline
\end{tabular}

\section{Influenza}

Related Terms: Influenza A and B.

NOTE: (1) Collect all tissues that appear to be infected. (2) Request viral and aerobic bacterial cultures. (3) Request Gram stain (p. 172). (4) Special precautions are indicated (p. 146). (5) Serologic studies are available from the state health department laboratories (p. 135). (6) This is not a reportable disease.

\begin{tabular}{|c|c|c|}
\hline Organs and Tissues & Procedures & Possible or Expected Findings \\
\hline \multirow[t]{3}{*}{ Larynx, trachea, and lungs } & $\begin{array}{l}\text { Remove en bloc; open extrapulmonary airways } \\
\text { posteriorly and photograph mucosa. }\end{array}$ & Necrosis of respiratory tract epithelium. \\
\hline & $\begin{array}{l}\text { Submit samples of trachea for histologic study. } \\
\text { Record weight of each lung. Submit consolidated } \\
\text { or hemorrhagic/edematous areas for viral and } \\
\text { bacterial culture (p. 103). }\end{array}$ & $\begin{array}{l}\text { Primary influenzal pneumonia; } \\
\text { super-infection with Pneumococcus, } \\
\text { Staphylococcus, Hemophilus influenzae, } \\
\text { and Streptoccocus. }\end{array}$ \\
\hline & Perfuse one lung with formalin (p. 47). & $\begin{array}{l}\text { Emphysema; interstitial pulmonary fibrosis; } \\
\text { chronic bronchitis. }\end{array}$ \\
\hline Nasal cavities and sinuses & For exposure, see p. 71. & Coryza. \\
\hline Other organs & $\begin{array}{l}\text { Procedures depend on expected findings or } \\
\text { grossly identified abnormalities as listed in } \\
\text { right-hand column. }\end{array}$ & $\begin{array}{l}\text { Myositis; myocarditis;* Reye's syndrome;* } \\
\text { transverse myelitis (rare). }\end{array}$ \\
\hline
\end{tabular}




\section{Injury, Electrical}

Synonyms and Related Terms: Electric burns; electric shock.

NOTE: Immediate scene investigation with an experienced electrical engineer may be crucial for reconstruction of the fatal events and for prevention of similar injuries to others (the expertise of electricians may not suffice; many erroneously believe that 110 volt alternating current cannot kill a human). Search for evidence of wetness that might have precipitated the fatal circuit through the victim. See also ref. (1).

\begin{tabular}{|c|c|c|}
\hline Organs and Tissues & Procedures & Possible or Expected Findings \\
\hline $\begin{array}{l}\text { External examination } \\
\text { and skin }\end{array}$ & $\begin{array}{l}\text { Record appearance of shoes and clothing, and } \\
\text { retain burned areas with surrounding clothing } \\
\text { for possible spectrographic and chemical tests. } \\
\text { Photograph (with scale) suspected electrical } \\
\text { burns. Record appearance and location of } \\
\text { electrical burns; record appearance of hair } \\
\text { around such lesions. Prepare histologic sections } \\
\text { of electrical injuries. }\end{array}$ & $\begin{array}{l}\text { Characteristic electric burns of shoes and } \\
\text { clothing. Metal particles may be found near } \\
\text { the burned areas. } \\
\text { Small, multiple, craterlike defects or massive } \\
\text { fourth-degree burns of hands or other areas } \\
\text { of contact; arborescent skin markings; } \\
\text { characteristic defects on surface of hair. } \\
\text { Degeneration of epithelium and collagen with } \\
\text { typical microblisters in epidermis. Gangrene } \\
\text { (after electrically induced vascular } \\
\text { thromboses) also may be present. }\end{array}$ \\
\hline Blood & $\begin{array}{l}\text { Record presence or absence of blood clots. } \\
\text { Submit sample for alcohol determination. } \\
\text { (Alcohol concentrations are important in } \\
\text { compensation cases.) }\end{array}$ & Fluid blood. \\
\hline Blood vessels & $\begin{array}{l}\text { Submit portions for histologic study. } \\
\text { Request Verhoeff-van Gieson stain (p. 173). }\end{array}$ & $\begin{array}{l}\text { Intimal degeneration and tearing of elastic } \\
\text { fibers, with or without thrombosis. }\end{array}$ \\
\hline Heart & $\begin{array}{l}\text { Record weight and sample for histologic study } \\
\text { (p. 30). }\end{array}$ & Myocardial hemorrhagic necroses (2). \\
\hline Lungs & Record lung weights. & Pulmonary edema. \\
\hline Kidneys & Prepare histologic sections. & $\begin{array}{l}\text { Congestion; lower nephron nephrosis in cases } \\
\text { with extensive muscle destruction. }\end{array}$ \\
\hline Other viscera & & Congestion. \\
\hline Urine & & Hemoglobinuria. \\
\hline Skeletal muscles & $\begin{array}{l}\text { Prepare histologic sections of traumatized } \\
\text { portions. }\end{array}$ & Tears after tetanic convulsions. \\
\hline
\end{tabular}

\section{References}

1. Wright RK. Death or injury caused by electrocution. In: Clinics of Laboratory Medicine, vol. 3, No. 2. Symposium on Forensic Pathology, DiMaio JM, ed. W.B. Saunders, Philadelphia, PA, 1983, pp. 343-353.

2. Colonna M, Caruso G, Nardulli F, Altamura B. Myocardial hemorrhagic necrosis in delayed death from electrocution. Acta Medicinae Legalis et Socialis 1989;39:145-147.

\section{Injury, Fire (See "Burns.”)}

\section{Injury, Firearm}

NOTE: Protect all drains of autopsy table, which will prevent accidental loss of bullets or bullet fragments. Recovery of bullet fragments and pellets can also be improved by passing tissue fragments, blood, and other appropriate materials through a fine nonmetallic sieve. Caution must be exercised because sharp edges and jagged projections of bullets and bullet fragments may cause injury (1). This applies particularly to the Black Talon bullet. Bullets and bullet fragments should not be touched with forceps or other metal instruments that may produce artifactual markings; they must be placed in properly labeled evidence containers, and the chain of custody must be preserved (p. 17). From a birdshot wound, at least 10 pellets should be recovered. The firearms examiner will divide the total pellet weight by 10 and derive median pellet weight. From a buckshot wound, all pellets should be recovered. In many of these cases, procedures described under "Homicide" must also be followed.

Do not excise wounds before completion of autopsy (see below). As an academic exercise, excised firearm wounds may be used later for analysis of metal traces by neutron activation or for tests for carboxyhemoglobin. In practice, however, $35 \mathrm{~mm}$ photography is adequate to establish the presence or absence of gunpowder stippling or soot deposition toward the end of establishing the range of fire. The dimensions of the stippled areas and soot deposits should be recorded.

After completion of external examination, dry the wet clothing and keep as evidence. Clothing may also be used for possible test firing or for stain, powder, or particle analysis. 


\begin{tabular}{|c|c|c|}
\hline Organs and Tissues & Procedures & Possible or Expected Findings \\
\hline \multirow[t]{4}{*}{ External examination } & $\begin{array}{l}\text { If identity of victim is unknown, follow } \\
\text { procedures described on p. } 11 .\end{array}$ & \\
\hline & $\begin{array}{l}\text { Prepare roentgenograms of entire body, before } \\
\text { and after disrobing of body, and then lateral } \\
\text { films of body regions with bullets. }\end{array}$ & $\begin{array}{l}\text { Systemic roentgenograms may reveal bullets } \\
\text { from obscure entrance wounds, particularly } \\
\text { in decomposed bodies, old bullets, or bullets } \\
\text { external to the body in clothing. }\end{array}$ \\
\hline & $\begin{array}{l}\text { Record location and number of bullet holes in } \\
\text { all layers of garments, indicating whether the } \\
\text { involved area is bloodstained or shows gun- } \\
\text { powder or soot. }\end{array}$ & $\begin{array}{l}\text { Bullet(s) may have been arrested in hollow } \\
\text { viscus or blood vessel and may have been } \\
\text { transported to distant sites by peristalsis or } \\
\text { bloodstream ("bullet embolus"). Bullets may } \\
\text { be deflected in unexpected directions from } \\
\text { bony surfaces (see Fig. 12-1, p. 118). }\end{array}$ \\
\hline & $\begin{array}{l}\text { Study clothing with hand lens or dissecting } \\
\text { microscope and record whether garment fibers } \\
\text { were turned inward or outward. If there are } \\
\text { several cutaneous perforations, number or letter } \\
\text { each consecutively and refer to these numbers }\end{array}$ & $\begin{array}{l}\text { Soot ("smudging") and gunpowder strippling } \\
\text { may occur around entrance wound, } \\
\text { depending on the muzzle-to-skin distance. } \\
\text { There may also be an impression from a } \\
\text { recoiling handgun or from a power piston. }\end{array}$ \\
\hline
\end{tabular}

in all records. Location of bullet holes should be described by recording distance from soles of feet or top of head, and from midline of body. Prepare diagrams and photograph holes, with and without labels.

Photographs should show surrounding garments and extent of blood stains. In hairy areas, shave around bullet wounds for better documentation. For evaluation of distance from where a shot had been fired, see Fig. II-3.

Inspect hands for powder marks. Skin samples can be used for neutron activation analysis for antimony and bismuth.

Internal examination Describe wound track(s) in anatomic order and in complete separate paragraphs, with summarizing description of course of bullet with respect to the standard anatomical position (e.g., front to back, left to right, somewhat down). Avoid using numerical angular measurements. For toxicologic sampling of body fluids and tissues, see p. 16.
Systemic roentgenograms may reveal bullets from obscure entrance wounds, particularly in decomposed bodies, old bullets, or bullets external to the body in clothing.

Bullet(s) may have been arrested in hollow viscus or blood vessel and may have been transported to distant sites by peristalsis or bloodstream ("bullet embolus"). Bullets may be deflected in unexpected directions from bony surfaces (see Fig. 12-1, p. 118).

Soot ("smudging") and gunpowder strippling may occur around entrance wound, depending on the muzzle-to-skin distance. recoiling handgun or from a power piston.

Wounds may be stellate, round, jagged, or slitlike, with or without wide margins of abrasion.

Primer residues on hand of suicide victim after use of a handgun.

Fatal secondary injuries, particularly hemorrhages.

Alcohol intoxication is a frequent finding.

\section{Reference}

1. Russell MA, Atkinson RD, Klatt EC, Noguchi TT. Safety in bullet recovery procedures: a study of the Black Talon bullet. Am J Forens Med 1995;16:120-123.

\section{Injury, Head}

Synonyms and Related Terms: Contact injury; diffuse axonal damage; diffuse white matter shearing injury; head motion injury; inner cerebral trauma; shearing injury.

NOTE: The brain may show coup and contrecoup lesions, swelling, hematoma, with microscopic evidence of axonal swelling ("retraction balls") in cerebral white matter, corpus callosum, and upper brainstem. Hemorrhages in frontal white matter and corpus callosum, dorsolateral midbrain, and rostral pons. If patient survived days or weeks, macrophages infiltrate, later followed by microglial clusters and gliosis at the sites of injury.

In cases of gunshot injury to the head, see under that heading. 


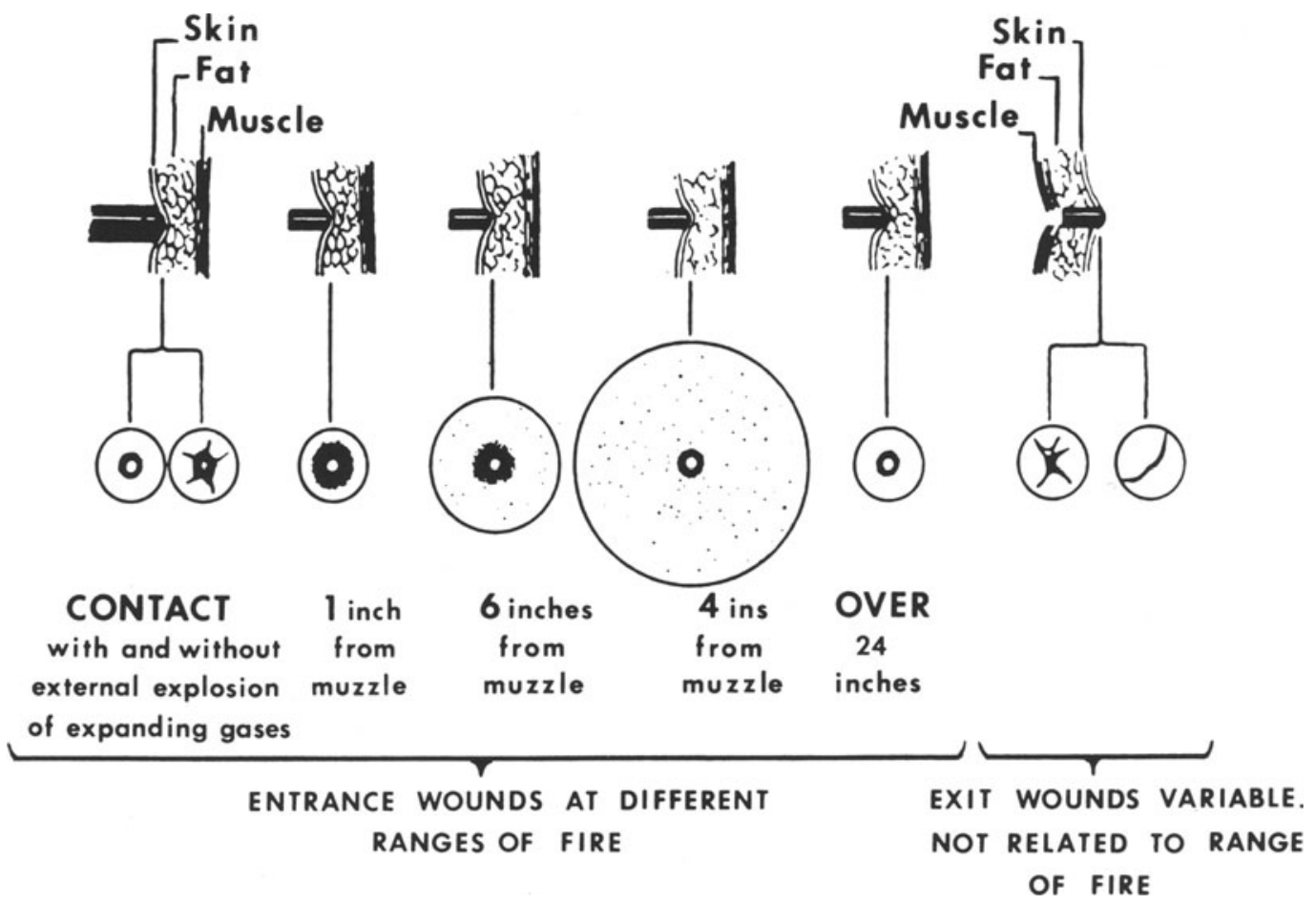

Fig. II-3. Bullet wounds. Differences in the appearance of cutaneous wounds of entrance and of exit and differences in wounds of entrance according to the distance between muzzle and skin at the moment of fire. Entrance wounds often differ from exit wounds in that the former are usually surrounded by a narrow zone of abrasion. If the muzzle of a gun is in close contact with the skin at the moment of fire, the combustion products will be blown into the wound and will not be visible on the surface. For close-range wounds, the stippling of the skin around the wound, produced by particles of burned and unburned powder, becomes progressively more dispersed as the range of fire increases and is ordinarily not perceptible if the range has been greater than 24 inches $(61 \mathrm{~cm})$ (with permission from Moritz AR, Morris CR. Handbook of Legal Medicine. Third edition, 1970. CV Mosby Company, St. Louis, MO.) Exit wounds usually have no marginal abrasion (1) and have no apparent tissue deficit.

\section{Reference}

1. DiMaio VJM. Gunshot Wounds: Practical Aspects of Firearms, Ballistics and Forensic Techniques. Elsevier Science Publishing Co., New York, 1985.

\section{Injury, Head (continued)}

\begin{tabular}{|c|c|c|}
\hline Organs and Tissues & Procedures & Possible or Expected Findings \\
\hline External examination & $\begin{array}{l}\text { Record extent and character of soft tissue and } \\
\text { scalp wounds. } \\
\text { Prepare roentgenogram of skull and, in case } \\
\text { of heart wound, roentgenogram of the chest. }\end{array}$ & $\begin{array}{l}\text { Face and scalp ecchymoses, hematomas, } \\
\text { lacerations. Firearm injury.* } \\
\text { Linear, radiating, depressed, bursting, } \\
\text { diastatic, and other skull fracture(s). } \\
\text { Cardiac air ambolism.* }\end{array}$ \\
\hline Neck organs & $\begin{array}{l}\text { Expose carotid arteries. For carotid arterio- } \\
\text { graphy, see p. } 82 \text {. }\end{array}$ & Carotid artery thrombosis. \\
\hline $\begin{array}{l}\text { Skull (see also } \\
\text { below under "Brain") }\end{array}$ & $\begin{array}{l}\text { Record sites, appearance, and length of } \\
\text { fractures. For detection of hairline fractures, } \\
\text { strip dura from the base of skull and vault. } \\
\text { Record separations or lacerations of dura. } \\
\text { Open dural sinuses. Locate air embolus ingress. } \\
\text { If osteomyelitis is suspected, submit material } \\
\text { for bacterial culture and smears (p. 102). }\end{array}$ & $\begin{array}{l}\text { Character of fractures may indicate site } \\
\text { impact. } \\
\text { Dural trauma indicates severe force. } \\
\text { Superior longitudinal sinus thrombosis. } \\
\text { Ingress of air embolus. } \\
\text { Osteomyelitis* of skull bones. }\end{array}$ \\
\hline Brain & $\begin{array}{l}\text { For removal and specimen preparation of } \\
\text { brain, see p. } 65 \text {. Record site and amount of } \\
\text { leptomeningeal hemorrhage. }\end{array}$ & $\begin{array}{l}\text { For gross and microscopic findings, see } \\
\text { above under "Note." Epidural or subdural } \\
\text { hematomas;* subarachnoid hemorrhage. } \\
\text { Cerebral abscess;* meningitis.* }\end{array}$ \\
\hline Lungs & Prepare frozen, Sudan-stained sections. & Fat embolism.* \\
\hline
\end{tabular}




\section{Injury, Intubation}

\begin{tabular}{|c|c|c|}
\hline Organs and Tissues & Procedures & Possible or Expected Findings \\
\hline $\begin{array}{l}\text { Extenal examination } \\
\text { and neck organs }\end{array}$ & $\begin{array}{l}\text { Intubation tube should be left in place until } \\
\text { position is verified. Prepare roentgenograms. } \\
\text { Remove neck organs with pharynx, and } \\
\text { base of tongue (p. 4). Open trachea posteriorly } \\
\text { or opposite perforation or fistula. Photograph } \\
\text { lesions and submit samples for histologic study. }\end{array}$ & $\begin{array}{l}\text { Intubation tube in wrong place; soft tissue } \\
\text { emphysema. } \\
\text { Ulcers; erosions; chondromalacia; } \\
\text { perforation; fistula; herpetic infection. }\end{array}$ \\
\hline
\end{tabular}

Injury, Lightning

\begin{tabular}{|c|c|c|}
\hline Organs and Tissues & Procedures & Possible or Expected Findings \\
\hline \multirow[t]{2}{*}{$\begin{array}{l}\text { External examination } \\
\text { and skin }\end{array}$} & & $\begin{array}{l}\text { Electrical burns (head and legs) (1) or } \\
\text { explosive tearing of clothing; mechanical } \\
\text { damage from blast effects. See also under } \\
\text { "Burns" and "Injury, electrical." }\end{array}$ \\
\hline & $\begin{array}{l}\text { Photograph erythema, electric burns, and } \\
\text { injuries. Prepare histologic sections. }\end{array}$ & $\begin{array}{l}\text { Fernlike distribution of electrically induced } \\
\text { erythema is characteristic for lightning injury. }\end{array}$ \\
\hline Other organs & $\begin{array}{l}\text { For procedures involving the heart, see } \\
\text { "Disease, ischemic heart." }\end{array}$ & $\begin{array}{l}\text { See under "Injury, electrical." The most } \\
\text { severe visceral manifestations of lightning } \\
\text { injury generally affect the cardiovascular and } \\
\text { central nervous system (see below) (2). } \\
\text { Sequelae of attempted resuscitation from } \\
\text { cardiac or respiratory arrest are commonly } \\
\text { noted. }\end{array}$ \\
\hline Brain and spinal cord & $\begin{array}{l}\text { For removal and specimen preparation, } \\
\text { see pp. } 65 \text { and } 67 \text {, respectively. }\end{array}$ & $\begin{array}{l}\text { Cerebral edema with brain stem herniation; } \\
\text { epidural hemorrhage. }\end{array}$ \\
\hline Middle ear & For exposure of the middle ear, see p. 72. & Rupture of eardrums. \\
\hline Eyes & $\begin{array}{l}\text { For removal and specimen preparation, } \\
\text { see p. } 85 \text {. }\end{array}$ & $\begin{array}{l}\text { Cataracts; interstitial keratitis; iridocyclitis; } \\
\text { chorioretinal atrophy; hemorrhages }(2) \text {. }\end{array}$ \\
\hline Skeletal muscle & $\begin{array}{l}\text { Sample for histologic study (p. } 80 \text { ), particularly } \\
\text { if myoglobinuria had been observed. }\end{array}$ & Muscle necroses. \\
\hline
\end{tabular}

\section{References}

1. Cooper MA. Lightning injuries: Prognostic signs of death. Ann Emerg Med 1980;9:134-138.

2. Tribble CG, Persing JA, Morgan RF, Kenney JG, Edlich RF. Lightning injuries. Comprehensive Ther 1985;11:32-40.

\section{Injury, Radiation}

Synonyms and Related Terms: Acute radiation syndrome; chronic (delayed) radiation injury; radiation enterocolitis; radiation nephritis; radiation pneumonitis.

NOTE: Procedures and expected findings depend on type of radiation damage, whether acute or chronic, localized or whole-body irradiation. If suspected radiation injury was associated with the administration of radionuclides such as ${ }^{32} \mathrm{P},{ }^{131} \mathrm{I}$, or ${ }^{198} \mathrm{Au}$, follow procedures suggested in Chapter 13 (p. 125). In fatal whole-body irradiation, findings are most likely related to bone marrow injury, and the suggested procedures and expected findings are those described under "Pancytopenia."
Record extent of oropharyngeal and intestinal ulcerations and hemorrhages. Late complications include malignant tumors (carcinoma, leukemia,* lymphoma*), manifestations of hypothyroidism, ${ }^{*}$ and cataracts. Organ changes in localized radiation injury depend on site of irradiation (lung, brain, kidney, intestine). The skin is involved in both acute (erythema) and chronic (atrophy, epilation) radiation injury.

\section{Injury, Stabbing}

Related Terms: Cutting injury; knife injury.

NOTE: In many of these cases, procedures described under "Homicide" must also be followed.

\begin{tabular}{cl}
\hline Organs and Tissues & Procedures \\
\hline External examination & Prepare diagrams and photographs of all \\
and skin (wounds) & wounds. Each wound can be labeled with \\
& $\begin{array}{l}\text { identifying number or letter that can also appear } \\
\text { on photographs and histologic sections. }\end{array}$
\end{tabular}

Possible or Expected Findings

Defense wounds occur on hands and arms. on photographs and histologic sections. 


\begin{tabular}{|c|c|c|}
\hline Organs and Tissues & Procedures & Possible or Expected Findings \\
\hline \multirow[t]{3}{*}{$\begin{array}{l}\text { External examination } \\
\text { and skin (wounds) } \\
\text { (continued) }\end{array}$} & $\begin{array}{l}\text { Examine edges of wounds on clothing and skin } \\
\text { with hand lens, if necessary; record appearance } \\
\text { of edges. Record location of wounds by stating } \\
\text { distance from top of head or from sole of foot, } \\
\text { distance from midline, location at front or back, } \\
\text { and relation to fixed anatomic landmarks. } \\
\text { Record the dimensions of the wounds and state } \\
\text { whether the measurement is taken with the } \\
\text { wound margins approximated (pushed together) } \\
\text { or unapproximated. Keep clothing as evidence. }\end{array}$ & $\begin{array}{l}\text { Serrations of skin tags along incised wound } \\
\text { margins are caused by dragging action of } \\
\text { knife. If contusions or abrasions are present, } \\
\text { wounds are more likely caused by laceration. } \\
\text { Undivided nerves, hair bulbs, and vessels in } \\
\text { depth of wounds indicate laceration. (Knives } \\
\text { or other sharp-edged instruments tend to cut } \\
\text { these structures.) }\end{array}$ \\
\hline & $\begin{array}{l}\text { Submit samples from edges of wounds for histo- } \\
\text { logic study, if necessary. }\end{array}$ & $\begin{array}{l}\text { Inflammatory changes indicate vital response } \\
\text { (absent in wounds received after death). }\end{array}$ \\
\hline & $\begin{array}{l}\text { Prepare roentgenograms of areas around wounds. } \\
\text { If wounds were not immediately fatal or if } \\
\text { tetanus* was present, cultures from wounds } \\
\text { may be indicated. }\end{array}$ & $\begin{array}{l}\text { Metallic parts may have broken off weapon. } \\
\text { Wound infection. }\end{array}$ \\
\hline Wound tracks & $\begin{array}{l}\text { Dissect layer by layer and follow tracks of } \\
\text { cutting or stabbing instrument. Do not probe. } \\
\text { Record lacerated vessels and organs penetrated. }\end{array}$ & \\
\hline Body cavities & Record volume of accumulated blood. & Hematomas; hemothorax; hemoperitoneum. \\
\hline Heart & $\begin{array}{l}\text { Submit blood samples for alcohol determination } \\
\text { and other toxicologic studies (p. 16). }\end{array}$ & \\
\hline Lungs & $\begin{array}{l}\text { Request Sudan stain of frozen sections } \\
\text { (p. 173). }\end{array}$ & Pulmonary fat embolism. \\
\hline Other organs & For toxicologic sampling, see p. 16. & \\
\hline
\end{tabular}

\section{Insecticides (See “Poisoning, organophosphate(s).")}

\section{Insuffiency, Adrenal}

Synonyms and Related Terms: Adrenocortical insufficiency; polyglandular autoimmune syndrome (type I, usually in childhood, with parathyroid insufficiency and chronic mucocutaneous moniliasis; type II, usually in adults, with two or more autoimmune endocrine disorders such as thyroiditis and diabetes mellitus*); primary adrenal insufficiency (Addison's disease); secondary adrenal insufficiency (in hypothalamic-pituitary disease or steroid induced); X-linked adrenal hypoplasia.
NOTE: Primary adrenal insufficiency (Addison's disease) is caused by anatomic changes (see below under "Adrenal glands"), drugs (enzyme inhibitors or cytotoxic drugs), or ACTH-blocking antibodies.

Possible Associated Conditions: AIDS with systemic infections (1); antiphospholipid antibody syndrome (2); autoimmune hepatitis; chronic lymphocytic thyroiditis; type I diabetes mellitus; * hypoparathyroidism;* hypothyroidism;* megaloblastic anemia;* surgical procedures, such as heart surgery or orthopedic procedures.

\begin{tabular}{ll}
\hline Organs and Tissues & Procedures \\
\hline $\begin{array}{l}\text { External examination } \\
\text { and skin }\end{array}$ & Prepare sections of pigmented areas of skin. \\
& Prepare photographs of pigmented abnormalities.
\end{tabular}

Vitreous

Blood

Adrenal glands
Submit sample for sodium, potassium, chloride, and urea nitrogen analysis (p. 85).

Submit sample for microbiologic (p. 102) and chemical study.

Record weights; photograph; prepare roentgenograms; submit portion for microbiologic study; submit samples for histologic study.

\section{Possible or Expected Findings}

Decreased axillary and pubic hair in women; diffuse brown hyperpigmentation; bluishblack spots on mucous surfaces of lips and cheeks.

Electrolyte changes associated with dehydration.* Decreased sodium and chloride in primary adrenal insufficiency. Septicemia, including systemic fungal infections. Low plasma cortisol concentration.

Idiopathic (autoimmune?) atrophy of adrenal cortex; tuberculosis* (also Mycobacterium avium intracellulare infection in AIDS); 


\begin{tabular}{|c|c|c|}
\hline Organs and Tissues & Procedures & Possible or Expected Findings \\
\hline $\begin{array}{l}\text { External examination } \\
\text { and skin } \\
\text { (continued) }\end{array}$ & $\begin{array}{l}\text { Decalcification may be necessary (p. 97). } \\
\text { Request acid fast, Gram, and Grocott's } \\
\text { methenamine silver stains (p. 172). }\end{array}$ & $\begin{array}{l}\text { coccidioidomycosis;* cryptococcosis* or } \\
\text { nocardiosis* (1) (in AIDS); cytomegalovirus } \\
\text { infection* (in AIDS); histoplasmosis;* rarely } \\
\text { amyloidosis;* hemorrhages (3); widespread } \\
\text { lymphoma* (4) or metastases of malignant } \\
\text { tumors. }\end{array}$ \\
\hline Other endocrine glands & $\begin{array}{l}\text { Describe and weigh all endocrine glands and } \\
\text { sample for histologic study. }\end{array}$ & $\begin{array}{l}\text { Abnormalities of pituitary gland (in } \\
\text { secondary adrenal insufficiency), thyroid, } \\
\text { parathroid glands, gonades, or islets of } \\
\text { Langerhans (see under "Possible Associated } \\
\text { Conditions.") }\end{array}$ \\
\hline Other organs & $\begin{array}{l}\text { Search for conditions that may have caused } \\
\text { adrenal insufficiency. }\end{array}$ & $\begin{array}{l}\text { See above under "Adrenal glands" and under } \\
\text { "Possible Associated Conditions." }\end{array}$ \\
\hline
\end{tabular}

\section{References}

1. Arabi Y, Fairfax MR, Szuba MJ, Crane L, Schuman P. Adrenal insufficiency, recurrent bacteremia, and disseminated abscesses caused by Nocardia asteroides in a patient with acquired immunodficiency syndrome. Diagn Microbiol Inf Dis 1996;24:47-51.

2. Argento A, DiBenedetto RJ. ARDS and adrenal insufficiency associated with the antiphospholipid antibody syndrome. Chest 1998;113: $1136-1138$

3. Cozzolino D, Peerzada J, Heaney JA. Adrenal insufficiency from bilateral adrenal hemorrhage after total knee replacement surgery. Urology 1997;50:125-127.

4. Nasu M, Aruga M, Itami J, Fujimoto H, Matsubara O. Non-Hodgkin's lymphoma presenting with adrenal insufficiency and hypothyroidism: an autopsy case report. Pathol Internat 1998;48:138-143.

\section{Insufficiency, Aortic}

Synonyms: Aortic incompetence; aortic regurgitation.

NOTE: For general dissection techniques in valvular heart disease, see p. 23. For procedures in infective endocarditis, see p. 103.

Possible Associated Conditions: Acute aortic dissection* with or without Marfan's syndrome;* ankylosing spondylitis;* aortitis; congenitally bicuspid aortic valve;* cystic medial degeneration of aorta; giant cell aortitis;* hypertension;* late postoperative conotruncal anomalies (e.g., tetralogy); rheumatic aortic valve disease; syphilitic aortitis; Takayasu's arteritis;* trauma; ventricular septal defect.*

\begin{tabular}{lll}
\hline Organs and Tissues $\quad$ Procedures & Possible or Expected Findings
\end{tabular}

External examination Prepare chest roentgenogram.

Blood

Heart and great vessels

Other organs
If infective endocarditis is suspected, submit sample for microbiologic study (p. 102).

For general dissection techniques in congenital heart disease, see p. 33.

If infective endocarditis is suspected, follow procedures described on p. 103.

Record weight and measurements of heart. For dissection, tests for valvular insufficiency, and measurement of valve size, see p. 29.
Cardiomegaly; dilated ascending aorta. Septicemia.

See above under "Possible Associated Conditions."

Infective endocarditis.*

Cardiomegaly; acute or old myocardial infarction.

See above under "Possible Associated Conditions."

\section{Insufficiency, Coronary (See "Disease, ischemic heart.")}

\section{Insufficiency, Mitral (Chronic or Acute)}

Synonyms and Related Terms: Acquired mitral insufficiency; mitral incompetence; mitral regurgitation; congenital mitral insufficiency; floppy valve syndrome; mitral annular calcification; mitral valve prolapse; mitral regurgitation; myxomatous mitral valve disease; rheumatic mitral valve disease.

Possible Associated Conditions: Autoimmune connective tissue disorders; bicuspid aortic valve; * cardiomyopathy* (dilated, hypertrophic, or restrictive); infective endocarditis;* Marfan's syndrome;* metabolic/storage diseases, such as mucopolysaccharidoses;* ischemic heart disease;* rheumatic heart disease.* 


\begin{tabular}{|c|c|c|}
\hline Organs and Tissues & Procedures & Possible or Expected Findings \\
\hline External examination & Prepare chest roentgenogram. & $\begin{array}{l}\text { Cardiomegaly; calcification in and around } \\
\text { mitral valve. }\end{array}$ \\
\hline Blood & $\begin{array}{l}\text { If infective endocarditis is suspected, submit } \\
\text { sample for microbiologic study (p. 102). }\end{array}$ & Septicemia. \\
\hline \multirow[t]{2}{*}{ Heart and great vessels } & $\begin{array}{l}\text { For general dissection techniques in valvular } \\
\text { and congenital heart disease, see p. } 33 \text {. } \\
\text { If infective endocarditis is suspected, follow } \\
\text { procedures described on p. } 103 \text {. }\end{array}$ & $\begin{array}{l}\text { See above under "Possible Associated } \\
\text { Conditions." } \\
\text { Infective endocarditis.* }\end{array}$ \\
\hline & $\begin{array}{l}\text { Record weight and measurements of heart. } \\
\text { For dissection, tests for valvular insufficiency, } \\
\text { and measurement of valve size, see p. } 29 .\end{array}$ & $\begin{array}{l}\text { Cardiomegaly; acute myocardial infarction, } \\
\text { with or without rupture of papillary muscles; } \\
\text { fibrosis of papillary muscles; myxomatous } \\
\text { (floppy) mitral valve; rheumatic valvulitis; } \\
\text { rupture of tendinous cords; other coexistent } \\
\text { valve disease. }\end{array}$ \\
\hline Other organs & & $\begin{array}{l}\text { See above under "Possible Associated } \\
\text { Conditions." }\end{array}$ \\
\hline
\end{tabular}

Insufficiency, Pituitary

Synonym: Hypopituitarism.

Possible Associated Conditions: Diabetes mellitus; * pregnancy;* and other conditions listed below under "Brain, spinal cord, and pituitary gland."

\begin{tabular}{|c|c|c|}
\hline Organs and Tissues & Procedures & Possible or Expected Findings \\
\hline External examination & $\begin{array}{l}\text { Record weight and length of body and } \\
\text { distribution and intensity of hair growth. }\end{array}$ & Dwarfism in childhood cases. \\
\hline & Prepare roentgenogram of skull. & Evidence of skull fractures or tumor. \\
\hline Blood & Freeze sample for possible biochemical study. & \\
\hline $\begin{array}{l}\text { Extrapituitary } \\
\text { endocrine organs }\end{array}$ & $\begin{array}{l}\text { Dissect and record weights of all endocrine } \\
\text { organs. Submit samples for histologic study. }\end{array}$ & Polyglandular atrophy. \\
\hline Other organs & $\begin{array}{l}\text { Procedures depend on expected findings or } \\
\text { grossly identified abnormalities as listed in } \\
\text { right-hand column. }\end{array}$ & $\begin{array}{l}\text { Fatty changes of liver }(1) \text {. Manifestations of } \\
\text { diabetes mellitus.* Systemic amyloidosis* } \\
\text { or genetic hemochromatosis* with secondary } \\
\text { infiltration of pituitary gland region. }\end{array}$ \\
\hline Urine & Freeze sample for possible biochemical study. & \\
\hline $\begin{array}{l}\text { Brain, spinal cord, } \\
\text { and pituitary gland }\end{array}$ & $\begin{array}{l}\text { For removal and specimen preparation, } \\
\text { see pp. } 65,67 \text {, and } 71, \text { respectively. } \\
\text { For cerebral arteriography, see p. } 80 \text {. } \\
\text { Record weight of pituitary gland. }\end{array}$ & $\begin{array}{l}\text { Developmental anomalies (pituitary aplasia } \\
\text { or basal encephalocele). Postpartum necrosis } \\
\text { of pituitary gland (Sheehan's syndrome*); } \\
\text { lymphocytic hypophysitis; granulomatous } \\
\text { inflammation (in sarcoidosis*); chromo- } \\
\text { phobe pituitary adenoma; craniopharyngioma } \\
\text { in childhood; other benign or malignant } \\
\text { pituitary tumors; extrasellar cysts; effects } \\
\text { of trauma or irradiation. }\end{array}$ \\
\hline Base of skull & $\begin{array}{l}\text { Expose venous sinuses (p. 71). Strip dura } \\
\text { for inspection of bone. }\end{array}$ & $\begin{array}{l}\text { Skull fractures; cavernous sinus thrombosis; } \\
\text { primary or metastatic tumors. }\end{array}$ \\
\hline Skeletal system & & Bone fractures (2). \\
\hline Vitreous & $\begin{array}{l}\text { Refrigerate sample for possible glucose } \\
\text { and electrolyte determination (p. } 85 \text { ). }\end{array}$ & \\
\hline
\end{tabular}

\section{References}

1. Takano S, Kanzaki S, Sato M, Kubo T, Seino Y. Effect of growth hormone on fatty liver in panhypopituitarism. Arch Dis Childhood 1997;76:537-538.

2. Rosen T, Wilhelmsen L, Landin-Wilhelmsen K, Lappas G, Bengtsson BA. Increased fracture frequency in adult patients with hypopituitarism and GH deficiency. Eur J Endocrinol 1997;137:240-245. 


\section{Insufficiency, Pulmonary}

Synonyms: Pulmonary incompetence; pulmonary regurgitation.

NOTE: Infective endocarditis due to Strept. bovis, especially when it involves the pulmonary valve, is often associated with an underlying adenocarcinoma of the colon.

Possible Associated Conditions: Carcinoid heart disease; congestive heart failure;* infective endocarditis;* pulmonary hypertension;* tetralogy of Fallot* with absent pulmonary valve (not the same as pulmonary atresia).

\section{Insufficiency, Tricuspid (Chronic or Acute)}

Synonyms: Tricuspid incompetence; tricuspid regurgitation.

Possible Associated Conditions: Cardiomyopathy* (dilated or restrictive); chronic congestive heart failure (any cause); chronic pulmonary hypertension (any cause)*. See also below under "Possible or Expected Findings."

\begin{tabular}{lll}
\hline Organs and Tissues & Procedures & Possible or Expected Findings \\
\hline $\begin{array}{l}\text { External examination } \\
\text { Heart }\end{array}$ & $\begin{array}{l}\text { If infective endocarditis is suspected, follow } \\
\text { procedures described on p. 103. For dissection } \\
\text { and histologic sampling, see pp. 23 and 30. }\end{array}$ & $\begin{array}{l}\text { Cyanosis; edema. } \\
\text { Infective endocarditis.* Carcinoid heart } \\
\text { disease; Epstein's anomaly; rheumatic valve } \\
\text { disease. }\end{array}$ \\
Lungs & $\begin{array}{l}\text { Perfuse both lungs with formalin (p. 47). } \\
\text { Request Verhoeff-van Gieson stain (p. 173). }\end{array}$ & $\begin{array}{l}\text { (see "Hypertension, pulmonary"). } \\
\text { See "Failure, congestive heart."* }\end{array}$ \\
Other organs & & Sunges \\
\hline
\end{tabular}

\section{Interruption of Aortic Arch (See "Coarctation, aortic.")}

\section{Intolerance, Fructose}

Synonyms: Hereditary fructose intolerance; hereditary fructosemia, deficiency of fructose-1-phosphate aldolase.

\begin{tabular}{|c|c|c|}
\hline Organs and Tissues & Procedures & Possible or Expected Findings \\
\hline External examination & Record body weight and length. & $\begin{array}{l}\text { Signs of extreme weight loss; evidence of } \\
\text { coagulopathy. }\end{array}$ \\
\hline Eyes & $\begin{array}{l}\text { Submit sample of vitreous for sodium, } \\
\text { potassium, chloride, urea nitrogen, and glucose } \\
\text { determination (p. 85). }\end{array}$ & $\begin{array}{l}\text { Evidence of dehydration.* } \\
\text { There is no reliable test for hypoglycemia.* }\end{array}$ \\
\hline Blood & $\begin{array}{l}\text { Submit plasma/serum for chemical study } \\
\text { (see right-hand column). }\end{array}$ & $\begin{array}{l}\text { Increased fructose and bilirubin } \\
\text { concentrations. }\end{array}$ \\
\hline Abdomen & Record volume of fluid. & Ascites. \\
\hline Urine & Submit sample for chemical study. & $\begin{array}{l}\text { Aminoaciduria;* fructosuria; proteinuria; } \\
\text { urobilinuria. }\end{array}$ \\
\hline Liver & $\begin{array}{l}\text { Record weight. Snap-freeze tissue for histo- } \\
\text { chemical or biochemical study. Submit samples } \\
\text { for light microscopic and electron microscopic } \\
\text { study (p. 132). }\end{array}$ & $\begin{array}{l}\text { Hepatomegaly; steatosis; cholestasis; } \\
\text { necrosis; fibrosis; cirrhosis; negative aldolase } \\
\text { activity; "fructose holes" by electron } \\
\text { microscopy (1). }\end{array}$ \\
\hline Spleen & & Splenomegaly. \\
\hline Other organs & $\begin{array}{l}\text { Submit samples for histologic and histochemical } \\
\text { study. }\end{array}$ & Evidence of coagulopathy. \\
\hline Brain and spinal cord & $\begin{array}{l}\text { For removal and specimen preparation, } \\
\text { see pp. } 65 \text { and } 67 \text {, respectively. }\end{array}$ & Cerebral edema. \\
\hline Bone & $\begin{array}{l}\text { Submit samples of epiphysis, if available, } \\
\text { for histologic study (p. 95). }\end{array}$ & Rickets. \\
\hline
\end{tabular}

\section{Reference}

1. Phillips MJ, Poucell S, Patterson J, Valencia P. The Liver: An Atlas and Text of Ultrastructural Pathology, Raven Press, New York, 1987.

Intubation (See “Injury, intubation.")

Iodine (See "Poisoning, iodine.")

Ischemia, Cerebral (See "Attack, transient cerebral ischemic" and "Infarction, cerebral.")
Ischemia, Heart (See "Disease, ischemic heart.")

Isomorism (See "Syndrome, polysplenia and asplenia.") 


\section{Kala-Azar}

Synonyms and Related Terms: Leishmania donovani infection; Dumdum fever; visceral leishmaniasis; infantile kala-azar.

NOTE: (1) Collect all tissues that appear to be infected. (2) Usually, cultures are not required, but direct examination for parasites is indicated. (3) Request Giemsa or Wright's stain (p. 172). (4) Usually, no special precautions are indicated. (5) Serologic studies are available from the Centers for Disease Control and Prevention, Atlanta, GA (p. 135). (6) This is not a reportable disease in the United States.

\begin{tabular}{lll}
\hline Organs and Tissues & Procedures & Possible or Expected Findings \\
\hline $\begin{array}{l}\text { External examination } \\
\text { and skin }\end{array}$ & $\begin{array}{l}\text { Photograph skin lesions; prepare histologic } \\
\text { sections of normal and abnormal skin; request } \\
\text { Giemsa or Wright's stain (p. 172). }\end{array}$ & $\begin{array}{l}\text { Emaciation; jaundice or skin pigmentation } \\
\text { from melanin accumulation; subcutaneous } \\
\text { edema; petechiae; macular or nodular dermal } \\
\text { leishmaniasis. Manifestations of vitamin C } \\
\text { deficiency.* }\end{array}$ \\
$\begin{array}{l}\text { Blood } \\
\begin{array}{l}\text { Oral cavity and other } \\
\text { mucosal surfaces }\end{array}\end{array}$ & Submit sample for bacterial culture (p. 102). & $\begin{array}{l}\text { Superimposed bacteremia. } \\
\text { Petechial hemorrhages and ulcers; noma. }\end{array}$
\end{tabular}

Abdominal and pleural cavities

Heart

Lungs

Liver

Spleen

Lymph nodes

Other organs

Bone marrow Brain and skeletal muscles
Record volume of effusions; centrifuge and prepare smears of sediment; request Giemsa or Wright's stain (p. 172).

For histologic sampling, see p. 30; request Giemsa or Wright's stain (p. 172).

Submit a section for bacterial culture. Prepare smears; request Giemsa and Gram stains (p. 172).

Record size and weight; photograph; submit samples for histologic study.

Record size and weight; photograph; prepare smears of cut section; submit samples for histologic study.

Submit samples for histologic study.

Procedures depend on expected findings or grossly identified abnormalities as listed in right-hand column.

For preparation of sections and smears, see p. 96.
Leishmanial infection or bacterial infection; pleural adhesions; intraperitoneal hemorrhages.

Infiltrates of lymphocytes and plasma cells with some eosinophils and mononuclear cells filled with Leishmania amastigotes.

Bacterial or leishmanial pneumonia, or both.

Hepatomegaly; diffuse leishmanial hepatitis, with or without cholestasis.

Splenomegaly, often extreme, with possible hemorrhage from diagnostic puncture; infarctions; leishmanial splenitis.

Lymphadenopathy; see also above under "Heart."

See above under "Heart."

Manifestations of anemia, agranulocytosis, or thrombocytopenia.

Osteomyelitis with amastigotes present. Not involved.

Ketoacidosis (See "Disorder, electrolyte(s)" and p. 115.)

\section{Knife Wounds (See “Injury, stabbing.”)}

\section{Kwashiorkor (See "Malnutrition...")}




\section{Laryngitis}

Synonyms and Related Terms: Acute infectious airway obstruction; croup; obstructive laryngitis with epiglottitis of infants.

NOTE: (1) Collect all tissues that appear to be infected. (2) Request aerobic bacterial and viral cultures. (3) Request Gram stain (p. 172). (4) Usually, no special precautions are indicated. (5) Serologic studies may be helpful in determining the etiologic agent. (6) This may be a reportable disease, depending on the etiologic agent.

\begin{tabular}{lll}
\hline Organs and Tissues & Procedures & Possible or Expected Findings \\
\hline Blood and lungs & $\begin{array}{l}\text { Submit for bacterial and viral cultures } \\
\text { (p. 102). If diphtheria is suspected, } \\
\text { see also under that heading. }\end{array}$ & $\begin{array}{l}\text { Hemophilus influenzae (cannot always be } \\
\text { isolated from larynx). Measles virus, } \\
\text { myxovirus, parainfluenza virus, and other } \\
\text { respiratory viruses that may affect infants } \\
\text { and children. }\end{array}$ \\
Larynx and pharynx & $\begin{array}{l}\text { Should be removed as soon as possible } \\
\text { (before embalming), either from cervical } \\
\text { midline incision or from chest (neck of } \\
\text { cadaver must be well-extended). Photograph } \\
\text { obstruction before laryn is opened, and } \\
\text { inside of larynx and epiglottis after larynx is } \\
\text { is opened in posterior midline. } \\
\text { Make Gram-stained touch preparations (p. 172). }\end{array}$ & $\begin{array}{l}\text { Hemophilus influenzae (small, pleomorphic, } \\
\text { Gram-negative bacilli) in smear. }\end{array}$ \\
& $\begin{array}{l}\text { Other pathogenic and nonpathogenic } \\
\text { Make histologic sections of larynx and } \\
\text { epiglottis. }\end{array}$ & $\begin{array}{l}\text { misms may be present. Acute } \\
\text { laryngitis, often with ulcerations. }\end{array}$ \\
\hline
\end{tabular}

\section{Lead (See “Poisoning, lead.”)}

\section{Leishmaniasis (See “Kala-azar.”)}

\section{Leprosy}

Synonyms: Hansen's disease; lepromatous leprosy; Mycobacterium leprae infection; tuberculoid leprosy.

NOTE: (1) Collect all tissues that appear to be infected and submit for direct examination. (2) Cultivation of leprosy bacilli is not yet available for routine use. (3) Request Gram, Ziehl-Neelsen, Kinyoun, or fluorochrome stains (p. 172). (4) Usually, no special precautions are indicated. (5) Serologic studies are now available in some laboratories (1). PCR assays are also available (2). (6) This is a reportable disease.

Possible Associated Conditions: Amyloidosis;* tuberculosis.*

\begin{tabular}{lll}
\hline Organs and Tissues & Procedures & Possible or Expected Findings \\
\hline $\begin{array}{l}\text { External examination } \\
\text { and skin }\end{array}$ & $\begin{array}{l}\text { Photograph lesions, and record extent of skin } \\
\text { involvement. }\end{array}$ & $\begin{array}{l}\text { Hyperpigmented macules; annular plaques; } \\
\text { nodules; erythematous lesions. In }\end{array}$ \\
& & $\begin{array}{l}\text { lepromatous leprosy, leonine face with } \\
\text { enlarged earlobes and loss of eyebrows. Other }\end{array}$ \\
& mutilations and plantar ulcerations.
\end{tabular}




\begin{tabular}{|c|c|c|}
\hline Organs and Tissues & Procedures & Possible or Expected Findings \\
\hline $\begin{array}{l}\text { External examination } \\
\text { and skin } \\
\text { (continued) }\end{array}$ & $\begin{array}{l}\text { Prepare sections of skin. For special stains, see } \\
\text { above under "Note." Make touch preparations } \\
\text { of skin specimens. }\end{array}$ & $\begin{array}{l}\text { Skin and dermal nerves may be involved } \\
\text { histologically. }\end{array}$ \\
\hline Other organs & $\begin{array}{l}\text { Submit samples of liver, spleen, kidneys, and } \\
\text { bone marrow for histologic study. }\end{array}$ & $\begin{array}{l}\text { Visceral involvement usually mild; } \\
\text { amyloidosis;* tuberculosis;* erythema } \\
\text { nodosum leprosum. }\end{array}$ \\
\hline Lymph nodes & $\begin{array}{l}\text { Submit samples for histologic study, } \\
\text { particularly from drainage area of skin lesions. }\end{array}$ & Lepromatous lymphadenitis. \\
\hline Peripheral nerves & $\begin{array}{l}\text { For sampling and specimen preparation, } \\
\text { see p. } 79 . \text { Include ulnar, radial, median, and } \\
\text { popliteal nerves. }\end{array}$ & $\begin{array}{l}\text { Dermal nerves may be involved (see } \\
\text { "External examination and skin"). Nerves } \\
\text { may be thickened and fibrotic and may } \\
\text { show obliteration of normal architecture. } \\
\text { Nerve abscesses. }\end{array}$ \\
\hline $\begin{array}{l}\text { Eyes and extraglobal } \\
\text { orbital tissues }\end{array}$ & $\begin{array}{l}\text { For removal and specimen preparation, } \\
\text { see pp. } 85 \text { and } 73 \text {, respectively. } \\
\text { Include ciliary nerves. }\end{array}$ & $\begin{array}{l}\text { Iritis and keratitis; granulomas of anterior } \\
\text { segment (in lepromatous leprosy) (3); } \\
\text { extraglobal granulomas, particularly in } \\
\text { ciliary nerves (in tuberculoid leprosy). }\end{array}$ \\
\hline Nasal cavity & $\begin{array}{l}\text { For exposure, see p. } 71 \text {. Submit tissue for } \\
\text { histologic study. }\end{array}$ & $\begin{array}{l}\text { Blockage of nasal cavity by lepromatous } \\
\text { rhinitis. }\end{array}$ \\
\hline
\end{tabular}

\section{References}

1. Parkash O, Chaturvedi V, Girdhar BK, Sengupta U. A study on performance of two serological assays for diagnosis of leprosy. Leprosy Rev 1995;66:26-30.

2. Wichitwechkarn J, Karnjan S, Shuntawuttisettee S, Sornprasit C. Detection of Mycobacterium leprae infection by PCR. J Clin Micro 1995;33:45-49.

3. Job CK, Ebenezer GJ, Thompson K, Daniel E. Pathology of eye in leprosy. Ind J Leprosy 1998;70:79-91.

\section{Leptospirosis}

Synonyms: Canicola fever; Weil's disease; Fort Bragg Fever.

\section{NOTE:}

(1) Collect all tissues that appear to be infected. (2) Special culture media are required to cultivate the organisms. We recommend consultation with the microbiology laboratory before the postmortem examination is begun. (3) Direct dark-field examination by an experienced technologist is recommended for demonstrating the Leptospira organisms. Silver impregnation techniques are also useful. (4) Special precautions may be indicated, as this is a communicable disease (p. 146). (5) Serologic studies can be obtained from the state health department laboratories (p. 135). (5) This is not a reportable disease.

\begin{tabular}{|c|c|c|}
\hline Organs and Tissues & Procedures & Possible or Expected Findings \\
\hline External examination & & Jaundice; skin hemorrhages. \\
\hline $\begin{array}{l}\text { Blood, urine, and } \\
\text { cerebrospinal fluid }\end{array}$ & $\begin{array}{l}\text { Submit samples for bacteriologic and serologic } \\
\text { study (p. 102). }\end{array}$ & Pleocytosis of CSF early in the course. \\
\hline Heart & Submit samples for histologic study (p. 30). & Myocarditis;* endocarditis;* hemorrhages. \\
\hline Lungs & Submit samples for histologic study. & Hemorrhages; pneumonia. \\
\hline Liver and spleen & $\begin{array}{l}\text { Record sizes and weights; submit samples for } \\
\text { histologic study. }\end{array}$ & $\begin{array}{l}\text { Cholestatic hepatitis; hemorrhages; } \\
\text { hepatomegaly and splenomegaly. }\end{array}$ \\
\hline Stomach & & Mucosal hemorrhages. \\
\hline Kidneys & $\begin{array}{l}\text { Submit samples for histologic and electron } \\
\text { microscopic study (p. 132). }\end{array}$ & $\begin{array}{l}\text { Hemorrhages; tubular degeneration and } \\
\text { necrosis; hyaline and bile casts; interstitial } \\
\text { nephritis; fusion of foot processes by electron } \\
\text { microscopy. }\end{array}$ \\
\hline Skeletal muscles & $\begin{array}{l}\text { For sampling and specimen preparation, } \\
\text { see p. } 80 \text {. }\end{array}$ & Hemorrhages; necrosis. \\
\hline Brain & $\begin{array}{l}\text { For removal and specimen preparation, } \\
\text { see p. } 65 .\end{array}$ & $\begin{array}{l}\text { Aseptic meningitis;* subarachnoid } \\
\text { hemorrhages.* }\end{array}$ \\
\hline Eyes & $\begin{array}{l}\text { For removal and specimen preparation, } \\
\text { see p. } 85 \text {. }\end{array}$ & $\begin{array}{l}\text { Optic neuritis; iridocyclitis; conjunctivitis; } \\
\text { uveitis. }\end{array}$ \\
\hline
\end{tabular}




\section{Leukemia, All Types or Type Unspecified}

Synonyms and Related Terms: Acute or chronic lymphocytic leukemia, acute or chronic myelogenous leukemia, and hairy cell leukemia. Multiple subtypes have been identified; they are characterized by cell surface markers, chromosomal abnormalities, staining reactions, and morphologic features.

NOTE: At the time of autopsy, most leukemias have been properly classified and often treated. In these cases, the goal of the autopsy is to document the extent of the disease and the presence of complications. If the leukemia had not been classified or if the features might have changed from the time of the last work-up (e.g., in suspected cases of superimposed diffuse large cell lymphoma [Richter's syndrome]), material should be snap-frozen and studied in more detail. If the patient was treated by bone marrow transplantation, ${ }^{*}$ see also under that heading.

The address of the appropriate registry is Hematologic and Lymphatic Pathology, Armed Forces Institute of Pathology (p. 148).

Possible Associated Conditions: Agnogenic myeloid metaplasia with myelofibrosis; Bloom's syndrome; ${ }^{*}$ cutaneous mastocytosis; Down's syndrome;* immunodeficiency syndromes* (Bruton's disease; Louis-Bar syndrome; Wiskott-Aldrich syndrome); infantile genetic agranulocytosis; Klinefelter's syndrome;* lymphoma;* multiple myeloma;* polycythemia;* and many others.

\begin{tabular}{|c|c|}
\hline Organs and Tissues & Procedures \\
\hline $\begin{array}{l}\text { External examination, } \\
\text { oral cavity, and skin }\end{array}$ & $\begin{array}{l}\text { Record extent and character of skin lesions; } \\
\text { photograph lesions and prepare histologic } \\
\text { sections. Record appearance of oral cavity } \\
\text { and eyes (see also below under "Eyes" and } \\
\text { "Lacrimal glands; parotid and other salivary } \\
\text { glands"). }\end{array}$ \\
\hline
\end{tabular}

Blood and fascia lata

If chromosome study is intended, see p. 109.

Submit sample of blood for bacterial, fungal, and viral studies (p. 102).

Thymus

Lungs

Gastrointestinal tract

Liver and spleen

Kidneys

Lymph nodes

Brain and spinal cord
Record weight. See also below under "Lymph nodes."

Submit one lobe for bacterial, fungal, and viral studies (p.103). Make touch preparation from cut sections and request Gram stain and Grocott's methenamine silver stain for demonstration of fungi and Pneumocystis carinii (p. 172). Perfuse one lung with formalin (p. 47).

Estimate volume of blood in lumen. If there are mucosal lesions, submit samples for histologic study.

Record weight and size.

Request Gomori's iron stain (p. 172).

Fix specimen in alcohol (p. 129) for preservation of urates.

Record average size. Fix specimens in B-5 fixative (p. 129). Make touch preparations. Request Giemsa or Wright stain (p. 172). For removal and specimen preparation, see pp. 65 and 67, respectively. Make touch preparations from meningeal lesions; request Gram and Grocott's methenamine silver stains for histologic sections (p. 172).
Possible or Expected Findings

Nonspecific skin reactions; petechial and other types of hemorrhages; leukemic infiltrates; perianal ulcerations and abscesses; exophthalmos and salivary gland enlargement (Mikulicz's syndrome); gingival hemorrhages; mucosal ulcerations of mouth and nose; alopecia.

Trisomy 21; Philadelphia chromosome; Christchurch chromosome; 47,XXY and less common variants of Klinefelter's syndrome. Septicemia. Blood most commonly positive for Escherichia coli, Pseudomonas aeruginosa, Klebsiella pneumoniae, Staphylococcus aureus, Candida spp., and Aspergillus.

Leukemic infiltrates.

Bacterial and fungal pneumonia; viral pneumonitis; hemorrhages and leukemic infiltrates.

Pneumocystis carinii pneumonitis.

Gastrointestinal hemorrhages; mucosal hemorrhagic necroses; leukemic infiltrates.

Hepatosplenomegaly.

Enlarged liver may be free of leukemic infiltrates.

Urate deposits.

Leukemic lymphadenopathy; lymphadenitis.

Meningeal leukemic infiltrates, particularly around brain stem; hydrocephalus; hemorrhages; meningitis* or meningoencephalitis. 


\begin{tabular}{|c|c|c|}
\hline Organs and Tissues & Procedures & Possible or Expected Findings \\
\hline Middle and inner ears & $\begin{array}{l}\text { For removal and specimen preparation, } \\
\text { see p. } 72 \text {. }\end{array}$ & $\begin{array}{l}\text { Otitis media;* hemorrhages; leukemic } \\
\text { infiltrates, particularly along eighth cranial } \\
\text { nerve. }\end{array}$ \\
\hline Eyes & $\begin{array}{l}\text { For removal and specimen preparation, see } \\
\text { p. } 85 . \text { Include extrabulbar orbital tissue (p. } 73 \text { ). }\end{array}$ & $\begin{array}{l}\text { Hemorrhages in conjunctiva and retina; } \\
\text { leukemic infiltrate in uvea. }\end{array}$ \\
\hline $\begin{array}{l}\text { Lacrimal glands; } \\
\text { parotid and other } \\
\text { salivary glands }\end{array}$ & $\begin{array}{l}\text { Remove for histologic study (p. 87). Parotid } \\
\text { gland can be biopsied from scalp incision (p. } 65 \text { ). } \\
\text { Submascillary gland can be removed with floor } \\
\text { of mouth (p. } 4 \text { ). }\end{array}$ & Leukemic infiltrates (Mikulicz's syndrome). \\
\hline Bone marrow & $\begin{array}{l}\text { For preparation of sections and smears } \\
\text { (imprints), see p. } 96 .\end{array}$ & $\begin{array}{l}\text { Leukemic infiltrates. Nonneoplastic } \\
\text { proliferation of hematopoietic cells after } \\
\text { bone marrow transplantation. }\end{array}$ \\
\hline Joints & $\begin{array}{l}\text { Remove synovial fluid for identification of } \\
\text { crystals in secondary gout (p. 96). For removal, } \\
\text { prosthetic repair, and specimen preparation of } \\
\text { joints, see p. } 96 . \\
\text { If gout is suspected, fix tissue specimen in alcohol. }\end{array}$ & Leukemic infiltrates; gout.* \\
\hline $\begin{array}{l}\text { Other organs } \\
\text { and tissues }\end{array}$ & $\begin{array}{l}\text { Use Helly's (p. 131) or Bouin's (p. 129) } \\
\text { fixative; request Wright stain (p. 173). For } \\
\text { color preservation of chloroma, see p. } 134 .\end{array}$ & $\begin{array}{l}\text { Leukemic infiltratès, thromboses, infections, } \\
\text { and hemorrhages may occur in all organs } \\
\text { or tissues. }\end{array}$ \\
\hline
\end{tabular}

\section{Leukemia, Eosinophilic ("Leukemia, all types or type unspecified.")}

\section{Leukemia, Mast Cell (See "Leukemia, all types or type unspecified" and "Mastocytosis, systemic.")}

\section{Leukodystrophy, All Types or Type Unspecified}

NOTE: This term describes a group of diseases characterized by widespread and often symmetric bilateral demyelination or failure of myelin formation, or both, in the central nervous system. These conditions are thought to be caused by inborn errors of metabolism and enzymatic defects, which have been identified in at least two instances-namely, metachromatic leukoencephalopathy* and globoid cell leukodystrophy.* See also under "Degeneration, spongy, of white matter" and "Leukodystrophy, sudanophilic."

\section{Leukodystrophy, Globoid Cell}

Synonyms: Galactocerebroside lipidosis; Krabbe's disease.

\begin{tabular}{|c|c|c|}
\hline Organs and Tissues & Procedures & Possible or Expected Findings \\
\hline Cerebrospinal fluid & $\begin{array}{l}\text { Submit sample for determination of protein } \\
\text { concentration (p. 104). }\end{array}$ & Increased protein concentration. \\
\hline $\begin{array}{l}\text { Brain, spinal cord, } \\
\text { and peripheral nerves }\end{array}$ & $\begin{array}{l}\text { For removal and specimen preparation, see } \\
\text { pp. } 65,67 \text {, and } 79 \text {, respectively. Place } \\
\text { samples of cerebral tissue into liquid nitrogen } \\
\text { and submit for biochemical and histochemical } \\
\text { studies. Submit tissue for electron microscopy } \\
\text { (p. 132). Request Luxol fast blue stain for } \\
\text { myelin (p. 172). }\end{array}$ & $\begin{array}{l}\text { Areas of myelin loss in the central nervous } \\
\text { system. Globoid cells containing } \\
\text { cerebrosides in areas of demyelination. } \\
\text { Segmental demyelination of peripheral } \\
\text { nerves. }\end{array}$ \\
\hline
\end{tabular}

\section{Leukodystrophy, Sudanophilic}

Synonym: Pelizaeus-Merzbacher disease.

\begin{tabular}{lll}
\hline Organs and Tissues & Procedures & Possible or Expected Findings \\
\hline Brain and spinal cord & For removal and specimen preparation, & Demyelination in centrum ovale, cerebellum, \\
& see pp. 65 and 66, respectively. Request & and part of brain stem. Diffuse gliosis and \\
& Luxol fast blue stain for myelin (p. 172). & perivascular sudanophilic lipid in white \\
& Prepare frozen sections for Sudan stain (p. 173). & matter. \\
\hline
\end{tabular}




\section{Leukoencephalopathy, Metachromatic}

Synonyms: Sulfatide lipidosis; sulfatidosis.

\begin{tabular}{lll}
\hline Organs and Tissues & Procedures & Possible or Expected Findings \\
\hline Cerebrospinal fluid & $\begin{array}{l}\text { Submit sample for determination of protein } \\
\text { concentration (p. 104). } \\
\text { Collect and stain sediment with toluidine blue } \\
\text { Urine }\end{array}$ & $\begin{array}{l}\text { Increased protein concentration. } \\
\text { Other organs }\end{array}$ \\
$\begin{array}{l}\text { Stain sections of liver, gallbladder, spleen, } \\
\text { kidneys, lymph nodes, adrenal glands, and } \\
\text { ovaries for metachromasia. }\end{array}$ & $\begin{array}{l}\text { Material in sediment stains red with toluidine } \\
\text { blue. } \\
\text { Metachromatic material. }\end{array}$ \\
Brain and spinal cord & $\begin{array}{l}\text { For removal and specimen preparation, see } \\
\text { fp. 65 and 67, respectively. Request Luxol } \\
\text { fast blue and cresyl echt violet stain (p. 172). }\end{array}$ & $\begin{array}{l}\text { Excessive loss of myelin with large amounts } \\
\text { of metachromatic material (see above under } \\
\text { "Urine") in white matter and also in some } \\
\text { neurons. } \\
\text { Demyelination with metachromatic material } \\
\text { (see above under "Urine"). }\end{array}$ \\
\hline
\end{tabular}

\section{Leukoencephalopathy, Progressive Multifocal}

Possible Associated Conditions: AIDS* and other immunosuppressed states; carcinoma; malignant myeloproliferative or lymphoproliferative disorder; sarcoidosis;* tuberculosis.*

\begin{tabular}{|c|c|c|}
\hline Organs and Tissues & Procedures & Possible or Expected Findings \\
\hline Brain and spinal cord & $\begin{array}{l}\text { For removal and specimen preparation, } \\
\text { see pp. } 65 \text { and } 67 \text {, respectively. Submit } \\
\text { portion of fresh brain for viral culture. Fix } \\
\text { remainder of brain and spinal cord in formalin } \\
\text { and submit samples for histologic study. } \\
\text { In situ hybridization for JC virus is available } \\
\text { on paraffin-embedded tissue. }\end{array}$ & $\begin{array}{l}\text { Small patches of demyelination with } \\
\text { tendency to form confluent areas in the } \\
\text { cerebral white matter. White matter necrosis } \\
\text { may be present. Eosinophilic intranuclear } \\
\text { inclusions occur in affected oligodendroglia } \\
\text { cells. Subsequently, large, bizarre astrocytes } \\
\text { develop. No inflammatory (lymphocyte) cell } \\
\text { reaction is present. }\end{array}$ \\
\hline
\end{tabular}

\section{Lightning (See “Injury, lightning.")}

\section{Lipoproteinemia (See "Hyperlipoproteinemia.")}

\section{Lipoproteinosis, Pulmonary Alveolar}

Synonym: Idiopathic alveolar lipoproteinosis.

NOTE: The condition has been described in allografts (1); in such cases, see also under "Transplantation, lung."

\begin{tabular}{lll}
\hline Organs and Tissues & Procedures & Possible or Expected Findings \\
\hline External examination & Prepare chest roentgenogram. & "Butterfly" shadow on chest roentgenogram. \\
Lungs & Submit one lobe for bacterial, fungal, and viral & Superinfection with fungi (nocardiosis;* \\
& cultures (p. 103). Prepare smears for identification & cryptococcosis*), viruses (cytomegalovirus \\
& of Pneumocystis carinii. & infection*), or Pneumocystis carinii.* \\
& Record weight of lungs; photograph. For & Increased lung weights.
\end{tabular}

perfusion fixation, see p. 47. Place some fresh tissue into Zenker's or Helly's fixative (p. 131).

Request PAS, toluidine blue, Gram, and Grocott's methenamine silver stains and fresh frozen sections for Sudan stain (p. 172).

Prepare samples for electron microscopic study (p. 132). Snap-freeze tissue for histochemical study.

Alveolar contents PAS-positive, metachromatic, and positive for lipids. Microorganisms may be present. Osmiophilic densities; myelin figures. 


\title{
Reference
}

1. Yousem AS. Alveolar lipoproteinosis in lung allograft recipients. Hum Pathol 1997;28:1383-1386.

\section{Listeriosis}

Synonyms: Listeria monocytogenes infection; listerosis.

NOTE: (1) Collect all tissues that appear to be infected. (2) Request aerobic bacterial cultures. Alert the laboratory that Listeria is suspected. (3) Request Gram stain (p. 172). (4) Usually, no special precautions are indicated. (5) Usually, serologic studies are not helpful. (6) This is not a reportable disease.

Possible Associated Conditions: Cirrhosis* of the liver; malignant neoplasms and other debilitating diseases, including human immunodeficiency virus infection (1); previous steroid therapy.

\begin{tabular}{|c|c|c|}
\hline Organs and Tissues & Procedures & Possible or Expected Findings \\
\hline Placenta & $\begin{array}{l}\text { Record weight and size; photograph. } \\
\text { Prepare histologic sections. }\end{array}$ & $\begin{array}{l}\text { Intervillous abscesses containing gram- } \\
\text { positive, non-acid-fast bacilli. }\end{array}$ \\
\hline $\begin{array}{l}\text { External examination } \\
\text { and skin }\end{array}$ & $\begin{array}{l}\text { Record extent of skin lesions; prepare histologic } \\
\text { sections of skin. }\end{array}$ & \\
\hline Heart & $\begin{array}{l}\text { If infective endocarditis is suspected, follow } \\
\text { procedures described on p. } 103 \text {. }\end{array}$ & $\begin{array}{l}\text { Infective endocarditis* and, rarely, } \\
\text { pericarditis (2). }\end{array}$ \\
\hline Lungs and trachea & $\begin{array}{l}\text { Culture consolidated areas. Then, perfuse both } \\
\text { lungs. }\end{array}$ & Tracheobronchitis and bronchopneumonia. \\
\hline Liver and spleen & $\begin{array}{l}\text { Record weights and submit samples for histo- } \\
\text { logic study. }\end{array}$ & $\begin{array}{l}\text { Hepatosplenomegaly; necrosis; granulomas; } \\
\text { abscesses (3). Bacteria are predominantly } \\
\text { intracellular. }\end{array}$ \\
\hline Intestine & Submit sample of meconium for culture. & $\begin{array}{l}\text { Enterocolitis. Listeria monocytogenes can be } \\
\text { cultured from meconium. }\end{array}$ \\
\hline Lymph nodes & Prepare samples for histologic study. & Generalized lymphadenitis. \\
\hline $\begin{array}{l}\text { Other organs and tissues, } \\
\text { including pharynx }\end{array}$ & $\begin{array}{l}\text { Procedures depend on expected findings or } \\
\text { grossly identified abnormalities as listed in } \\
\text { right-hand column. }\end{array}$ & $\begin{array}{l}\text { Disseminated abscesses and/or granulomas, } \\
\text { particularly after transplacental infection; } \\
\text { purulent conjunctivitis; uveitis; arthritis; } \\
\text { osteomyelitis; peritonitis; cholecystitis. }\end{array}$ \\
\hline Brain and spinal cord & $\begin{array}{l}\text { For removal and specimen preparation, } \\
\text { see pp. } 65 \text { and } 67 \text {, respectively. }\end{array}$ & $\begin{array}{l}\text { Meningitis; } * \text { brain abscess }(4) \text {; meningo } \\
\text { encephalitis. The organism may appear } \\
\text { coccoid in CSF. }\end{array}$ \\
\hline Middle ears & Remove for histologic study (p. 72). & Otitis media.* \\
\hline
\end{tabular}

\section{References}

1. Marron A, Roson B, Mascaro J, Carratala J. Listeria monocytogenes empyema in an HIV infected patient. Thorax 1997;52:745-746.

2. Manso C, Rivas I, Peraire J, Vidal F, Richart C. Fatal Listeria meningitis, endocarditis and pericarditis in a patient with haemochromatosis. Scand J Inf Dis 1997;29:308-309.
3. Marino P, Maggioni M, Preatoni A, Cantoni A, Invernizzi F. Liver abscesses due to Listeria monocytogenes. Liver 1996;16:67-69.

4. Turner D, Fried M, Hoffman M, Paleacu D, Reider I, Yust I. Brainstem abscess and meningitis due to Listeria monocytogenes in an adult with juvenile chronic arthritis. Neurology 1995;45:1020-1021.

\section{LSD (d-Lysergic Acid Diethylamide) (See “Abuse, hallucinogen(s).”)}

\author{
Lung, Farmer's (See "Pneumoconiosis.")
}

\section{Lung, Honeycomb (See “Pneumonia, interstitial.")}

\section{Lupus Erythematosus, Systemic}

Related Terms: Immune complex disease; immune connective tissue disease.

NOTE: The guide, Pathology of Systemic Lupus Erythematosus, 1995 can be ordered from the American Registry of Pathology Sales Office, AFIP, Room 1077, Washington, DC 20306-6000.

Possible Associated Conditions: Rheumatoid arthritis;* Sjögren's syndrome.* 


\begin{tabular}{|c|c|c|}
\hline Organs and Tissues & Procedures & Possible or Expected Findings \\
\hline \multirow[t]{4}{*}{$\begin{array}{l}\text { External examination } \\
\text { and skin; oral cavity }\end{array}$} & & $\begin{array}{l}\text { Malar, discoid, maculopapular, and other } \\
\text { rashes; oral ulcers; alopecia. }\end{array}$ \\
\hline & $\begin{array}{l}\text { Prepare histologic sections of grossly abnormal } \\
\text { and of unaffected skin. }\end{array}$ & $\begin{array}{l}\text { Hyperkeratotic dermatitis with liquefaction } \\
\text { necrosis. Vasculitis and panniculitis. }\end{array}$ \\
\hline & $\begin{array}{l}\text { Prepare histologic sections of subcutaneous } \\
\text { nodules. If joints appear swollen, withdraw } \\
\text { synovial fluid for cell count, and culture } \\
\text { (p. 96). }\end{array}$ & $\begin{array}{l}\text { Erosions and ulcers (including leg ulcers); } \\
\text { ischemic changes of fingers. Rheumatoid } \\
\text { granulomas (elbows, hands). }\end{array}$ \\
\hline & Prepare skeletal roentgenograms. & $\begin{array}{l}\text { Arthritis (see below under "Joints"); } \\
\text { osteoporosis* and osteonecrosis* in steroid- } \\
\text { treated patients. }\end{array}$ \\
\hline Serosal cavities & $\begin{array}{l}\text { Record volume of pericardial, pleural, or } \\
\text { peritoneal exudates or effusions, and submit }\end{array}$ & Pleuritis; pericarditis;* ascites. \\
\hline
\end{tabular}

Blood samples for culture (p. 102). Submit samples of serosal surfaces for histologic study.

Heart

Submit sample for microbiologic and serologic study (p. 102).

If infective endocarditis is suspected, remove vegetations for microbiologic study (p. 103).

Photograph valvular lesions and submit samples for histologic study. Include chordae tendineae, papillary muscles, and endocardium (where it borders on valves).

For coronary arteriography, see p. 118. Submit samples of all coronary arteries for histologic study.

Lymph nodes

Submit axillary, tracheobronchial, and inguinal lymph nodes for histologic study.

Lungs Submit one fresh lobe for microbiologic study (p. 103). Snap-freeze sample for possible special studies. Perfuse one lung with formalin (p. 47).

Gastrointestinal tract and mesentery

For mesenteric arteriography, see p. 55. Submit samples of all segments of gastrointestinal tract for histologic study. Dissect mesenteric vessels and submit sample, together with mesenteric lymph nodes, for histologic study.

Spleen, liver, and pancreas

\section{Kidneys}

Neck organs

Brain, spinal cord, and peripheral nerves Record weights; submit samples for histologic study.

Follow procedures described under "Glomerulonephritis."

Submit thyroid, parathyroid, and submandibular glands and cervical lymph nodes for histologic study.

For removal and specimen preparation, see pp. 65, 67, and 79, respectively.

Eyes and lacrimal glands For removal and specimen preparation, see pp. 85 and 87 , respectively.

Septicemia; circulating anticoagulant.

Infective endocarditis.*

Libman-Sacks endocarditis (lupus endocarditis), with small vegetations on all valves and adjacent structures; myocarditis;* pericarditis.*

Coronary occlusion; coronary arteritis. Myocardial infarction. Cor pulmonale in cases with pulmonary hypertension (1). Lymphadenitis.

Interstitial pneumonitis and fibrosis; bronchopneumonia. Adult respiratory distress syndrome and pulmonary hemorrhages. Arterial and arteriolar thrombi and plexiform lesions (1).

Hemorrhagic necroses; ulcers; gastro intestinal vasculitis; mesenteric vasculitis.

Splenitis; nonspecific hepatic changes; rarely arteritis, infarctions, or nodular regenerative hyperplasia (2). Chronic pancreatitis (3). Lupus glomerulonephritis. Kidney failure* is a common cause of death.

Manifestations of Sjögren's syndrome.*

Subarachnoid hemorrhage; aseptic meningitis; perivascular necroses (4); transverse myelitis; optic neuritis. Peripheral neuropathy.

Conjunctivitis; episcleritis; Retinal and choroidal hemorrhages. Dacryoadenitis in Sjögren's syndrome.* 


\begin{tabular}{|c|c|c|}
\hline Organs and Tissues & Procedures & Possible or Expected Findings \\
\hline Blood vessels & $\begin{array}{l}\text { For removal of femoral vessels, see p. } 34 \text {. } \\
\text { Submit samples of small blood vessels of } \\
\text { extremities for histologic study. }\end{array}$ & $\begin{array}{l}\text { Peripheral arteritis; arterial occlusions; } \\
\text { thrombophlebitis. }\end{array}$ \\
\hline Skeletal muscles & $\begin{array}{l}\text { For sampling and specimen preparation, } \\
\text { see p. } 80 \text {. Refer to neurologic findings for } \\
\text { proper sampling sites. }\end{array}$ & Myositis and vascultis (5). \\
\hline Joints & $\begin{array}{l}\text { Remove affected diarthrodial joints, together } \\
\text { with synovia, periarticular tissues, and tendon } \\
\text { sheaths. For removal, prosthetic repair, and } \\
\text { specimen preparation, see p. } 96 \text {. }\end{array}$ & $\begin{array}{l}\text { Arthritis, in decreasing order of frequency, } \\
\text { in knees, small joints of hands, wrists, } \\
\text { shoulders, ankles, elbows, and hips. }\end{array}$ \\
\hline \multirow[t]{2}{*}{ Bones and bone marrow } & $\begin{array}{l}\text { For removal, prosthetic repair, and specimen } \\
\text { preparation, see p. } 95 \text {. }\end{array}$ & $\begin{array}{l}\text { Osteoporosis* and osteonecrosis.* (Ischemic } \\
\text { necroses in hip joints }(6), \text { femoral condyles, } \\
\text { and small bones of hands.) These are } \\
\text { complications of steroid therapy. }\end{array}$ \\
\hline & $\begin{array}{l}\text { Sample bone marrow for histologic study } \\
\text { (p. 96). }\end{array}$ & Storage and hemophagocytic histiocytes (7). \\
\hline
\end{tabular}

\section{References}

1. Yokoi T, Tomita Y, Fukaya M, Ichihara S, Kakudo K, Takahashi Y. Pulmonary hypertension associated with systemic lupus erythematosus: predominantly thrombotic arteriopathy accompanied by plexiform lesions. Arch Pathol Lab Med 1998;122:467-470.

2. Matsumoto T, Yoshimine T, Shimouchi K, Shiotu H, Kuwabara N, Fukuda V, Hoshi T. The liver in systemic lupus erythematosus: pathologic analysis of 52 cases and review of Japanese autopsy registry data. Hum Pathol 1992;23:1151-1158.

3. Borum M, Steinberg W, Steer M, Freedman S, White P. Chronic pancreatitis: a complication of systemic lupus erythematosus. Gastroenterology 1993;104:613-615.

4. Shintaku M, Matsumoto R. Disseminated perivenous necrotizing encephalomyelitis in systemic lupus erythematosus: report of an autopsy case. Acta Neuropathol 1998;95:313-317.

5. Lim KL, Lowe J, Powell RJ. Skeletal muscle lymphocytic vasculitis in systemic lupus erythematosus: relation to disease activity. Lupus 1995;4:148-151.

6. Aranow C, Zelicof S, Leslie D, Solomon S, Barland P, Norman A, Klein R, et al. Clinically occult avascular necrosis of the hip in systemic lupus erythematosus. J Rheumatol 1997;24:2318-2322.
7. Morales-Polanco M, Jimenez-Balderas FJ, Yanez P. Storage histiocytes and hemophagocytosis: a common finding in the bone marrow of patients with active systemic lupus erythematosus. Arch Med Res 1996;27:57-62.

\section{Lye (See "Poisoning, lye.")}

\section{Lymphatics (See "Disease, lymphatic vascular.")}

\section{Lymphogranuloma Venereum}

Synonym: Lymphogranuloma venereum Chlamydia infection.

NOTE: (1) Collect all tissues that appear to be infected. (2) Culture of tissues can be performed but requires special laboratory tests. Request consultation with a microbiology laboratory before a specimen is submitted. (3) Usually, special stains are not helpful. (4) Usually, no special precautions are indicated. (5) Serologic tests are available from the state health department laboratories (p. 135). (6) This is a reportable disease.

\begin{tabular}{lll}
\hline Organs and Tissues & Procedures & Possible or Expected Findings \\
\hline $\begin{array}{l}\text { External examination } \\
\text { and skin }\end{array}$ & $\begin{array}{l}\text { Record skin changes and prepare sections of } \\
\text { affected skin. Record presence of perianal } \\
\text { fistulas (see also below under "Pelvic organs } \\
\text { and lymph nodes"). }\end{array}$ & $\begin{array}{l}\text { Elephantiasis of penis, scrotum, or vulva } \\
\text { (in chronic cases); skin rash (1) and } \\
\text { conjunctivitis (in acute cases); genital ulcers. }\end{array}$ \\
$\begin{array}{l}\text { Submit serum for complement-fixation test. } \\
\begin{array}{l}\text { Pelvic organs and } \\
\text { lymph nodes }\end{array}\end{array}$ & $\begin{array}{l}\text { If there are perirectal or lymphocutaneous } \\
\text { fistulas, injection of dyes or contrast media } \\
\text { (p. 138) may help for dissection. }\end{array}$ & $\begin{array}{l}\text { Suppurative or fibrosing inguinal, iliac, or } \\
\text { pelvic lymphadenitis, with or without sinus } \\
\text { tracts. Rectal strictures and fistulas in chronic } \\
\text { cases (2). }\end{array}$ \\
& $\begin{array}{l}\text { Prepare histologic sections of affected lymph } \\
\text { nodes. } \\
\text { Procedures depend on expected findings or } \\
\text { grossly identified abnormalities as listed in } \\
\text { right-hand column. }\end{array}$ & $\begin{array}{l}\text { Systemic involvement in the acute stage with } \\
\text { pericarditis,*and arthritis,*and meningitis.* }\end{array}$ \\
\hline
\end{tabular}

\section{References}

1. Rosen T, Brown TJ. Cutaneous manifestations of sexually transmitted diseases. Med Clin North Am 1998;82:1081-1104.

2. Papagrigoriadis S, Rennie JA. Lymphogranuloma venereum as a cause of rectal strictures. Postgrad Med J 1998;74:168-169. 


\section{Lymphoma}

Synonyms and Related Terms: AIDS-related lymphoma; adult T-cell leukemia/lymphoma; angioimmunoblastic lymphadenopathy; B-cell lymphoma; Burkitt's lymphoma; cutaneous T-cell lymphoma (includes mycosis fungoides and Sézary syndrome); Hodgkin's disease; non-Hodgkin's lymphoma (low grade, intermediate grade, high grade, all with multiple subtypes too numerous to list, which vary in natural history); natural killer cell neoplasms; post-transplant lymphoproliferative disorders (PTLD); T-cell lymphoma.

NOTE: At the time of autopsy, most lymphomas have been properly classified and often treated. In these cases, the goal of the autopsy is to document the extent of the disease and the presence of complications. If the lymphoma had not been classified or if the features might have changed from the time of the last work-up, material should be snap-frozen and studied in more detail. If the patient was treated by bone marrow transplantation,* see also under that heading.

The address of the appropriate registry is Hematologic and Lymphatic Pathology, Armed Forces Institute of Pathology (p. 148).

For current terminologies of Hodgkin's disease and nonHodgkin lymphomas as well as for staging criteria, appropriate hematologic textbooks should be consulted.

Possible Associated Conditions: Acquired immunodeficiency diseases (e.g., after organ transplantation; human immunodeficiency virus-1 infection); autoimmune disease (e.g., celiac sprue, ${ }^{*}$ rheumatoid arthritis, ${ }^{*}$ systemic lupus erythematosus, ${ }^{*}$ or Sjögren's syndrome*); chemotherapy with or without radiation treatment; Epstein-Barr virus infection; human T-cell leukemia virus infection; inherited diseases with immunodeficiency (e.g., Klinefelter syndrome;* common variable immunodeficiency disease, Wiskott-Aldrich syndrome); radiation.

\begin{tabular}{cl}
\hline Organs and Tissues & Procedures \\
\hline External examination, & Record distribution of hair; record facial features \\
skin, and oral cavity & $\begin{array}{l}\text { and character and extent of skin lesions and of } \\
\text { pigmentations. Record appearance of oral and } \\
\text { nasal mucosa. Prepare histologic sections of skin. }\end{array}$
\end{tabular}

Prepare skeletal and chest roentgenograms.

Blood and fascia lata

Thymus

Lungs

Lymph nodes

Liver and spleen
Submit sample of blood for bacterial, fungal, and viral cultures (p. 102).

If chromosomal abnormalities are suspected, submit sample of blood or fascia lata for chromosome analysis (pp. 108 and 109). Collect serum for study of antibodies and of immunoglobulins.

Record weight and submit samples for histologic study. See also below under "Lymph nodes." Submit one lobe for bacterial, fungal, and viral cultures (p. 103). Prepare smears of cut surface and request Grocott's methenamine silver stain for demonstration of fungi and Pneumocystis carinii (p. 172).

Perfuse one lung with formalin (p. 47).

Record average size. Fix specimens in B5 (p. 129) fixative or Zenker's or Helly's solution (p. 131). Make touch preparations and request Giemsa or Wright stain. Snap-freeze lymphomatous tissue if immunophenotype studies are intended or for identification of surface markers for B- and T-lymphocytes and other lymphoreticular cells.

Record size and weight. Submit samples for histologic study.
Possible or Expected Findings

Alopecia; disfigurement of face in Burkitt's lymphoma. Exophthalmos and salivary gland enlargement (Mikulicz's syndrome).

Lymphomatous infiltrates of skin with or without ulcerations; herpes zoster; ${ }^{*}$ jaundice. Lymphomatous bone changes-for instance, skull defects in Burkitt's lymphoma. Calcifying lymphomatous tumors. Pulmonary infiltrates.

Septicemia. Blood most commonly positive for Escherichia coli, Pseudomonas aeruginosa, Klebsiella pneumoniae, Staphyloccus aureus, Candida spp., and Aspergillus. Chromosomal abnormalities.

Antibodies against reovirus type 3 or EpsteinBarr virus in Burkitt's lymphoma.

Dysgammaglobulinemia.

Lymphomatous infiltrates.

Bacterial, fungal, and viral pneumonia. Pneumocystis carinii infection.*

Lymphomatous infiltrates. Lymphoma. Lymph nodes often unaffected in Burkitt's lymphoma.

Spleen often unaffected in Burkitt's lymphoma; hepatosplenomegaly in most lymphomas. 


\begin{tabular}{|c|c|c|}
\hline Organs and Tissues & Procedures & Possible or Expected Findings \\
\hline Other organs & $\begin{array}{l}\text { Submit samples of all grossly abnormal tissues } \\
\text { for histologic study. If systemic infection is } \\
\text { suspected, collect appropriate specimens for } \\
\text { microbiologic study. }\end{array}$ & $\begin{array}{l}\text { All organs and tissues can be involved by } \\
\text { lymphoma and by complicating infections. } \\
\text { Retroperitoneal lymphoma with renal and } \\
\text { ovarian involvement is common in Burkitt's } \\
\text { lymphoma. Complications of radiation or } \\
\text { cytostatic therapy also may be present. }\end{array}$ \\
\hline Cerebrospinal fluid & $\begin{array}{l}\text { Refrigerate sample for possible microbiologic } \\
\text { study (p. 104), depending on cerebral changes. } \\
\text { Prepare smear of sediment. }\end{array}$ & Lymphoma cells. \\
\hline Brain and spinal cord & $\begin{array}{l}\text { For removal and specimen preparation, } \\
\text { see pp. } 65 \text { and } 67 \text {, respectively. Make touch } \\
\text { preparations of meningeal lesions. Request } \\
\text { Giemsa, Gram, and Grocott's methenamine } \\
\text { silver stains (p. 172). }\end{array}$ & $\begin{array}{l}\text { Hydrocephalus.* Meningitis* or } \\
\text { meningoencephalitis. }\end{array}$ \\
\hline Eyes and lacrimal glands & $\begin{array}{l}\text { For removal and specimen preparation, } \\
\text { see pp. } 85 \text { and } 87 \text {, respectively. Include } \\
\text { lacrimal glands and orbital soft tissue. }\end{array}$ & $\begin{array}{l}\text { Burkitt's lymphoma may involve orbitae. } \\
\text { Lacrimal lymphoma is found in Mikulicz's } \\
\text { syndrome. }\end{array}$ \\
\hline Middle and inner ears & $\begin{array}{l}\text { For removal and specimen preparation, } \\
\text { see p. } 72 \text {. }\end{array}$ & \\
\hline $\begin{array}{l}\text { Salivary glands (parotid, } \\
\text { submandibular) }\end{array}$ & $\begin{array}{l}\text { Submit samples for histologic study. } \\
\text { Parotid gland can be biopsied from scalp } \\
\text { incision (p. 65). Submaxillary gland can be } \\
\text { removed with floor of mouth (p. } 4 \text { ). }\end{array}$ & $\begin{array}{l}\text { Lymphomatous infiltrates in Burkitt's } \\
\text { lymphoma and in Mikulicz's syndrome. }\end{array}$ \\
\hline Thyroid gland & & Often involved in Burkitt's lymphoma. \\
\hline Bones and bone marrow & $\begin{array}{l}\text { For sampling and specimen preparation of } \\
\text { bones, see p. } 95 . \text { For preparation of sections } \\
\text { and smears of bone marrow, see p. } 96 \text {. }\end{array}$ & $\begin{array}{l}\text { Lymphomatous infiltrates. Involvement of } \\
\text { maxilla and mandible in Burkitt's } \\
\text { lymphoma. }\end{array}$ \\
\hline
\end{tabular}




\section{Macroglobulinemia, Waldenström's}

Synonyms and Related Terms: Dysproteinemia; monoclonal gammopathy; paraproteinemia; plasma cell dyscrasia.*

\begin{tabular}{|c|c|c|}
\hline Organs and Tissues & Procedures & Possible or Expected Findings \\
\hline $\begin{array}{l}\text { External examination } \\
\text { and oral cavity }\end{array}$ & $\begin{array}{l}\text { Record extent of skin and oral mucosal lesions. } \\
\text { Prepare histologic sections of affected tissues. }\end{array}$ & $\begin{array}{l}\text { Vascular purpura. Gangrene after cold } \\
\text { exposure. }\end{array}$ \\
\hline Blood & $\begin{array}{l}\text { Submit samples for microbiologic study and } \\
\text { for protein electrophoresis (p. 102). }\end{array}$ & $\begin{array}{l}\text { Increased IgM concentration. } \\
\text { No evidence of hypercalcemia. }\end{array}$ \\
\hline Lymph nodes & $\begin{array}{l}\text { Record appearance and average size of lymph } \\
\text { nodes. Snap-freeze tissue for immunophenotype } \\
\text { study. Make touch preparations and request } \\
\text { Wright stain (p. 173). Tissue for paraffin } \\
\text { sections should be fixed in B-5 fixative } \\
\text { (p. 129). }\end{array}$ & $\begin{array}{l}\text { Lymphadenopathy. Follicular hyperplasia } \\
\text { with proliferation of lymphocytes and plasma } \\
\text { cells that exhibit IgM immunofluorescence. }\end{array}$ \\
\hline Liver and spleen & $\begin{array}{l}\text { Record size and weight; sample for histologic } \\
\text { study. }\end{array}$ & $\begin{array}{l}\text { Hepatosplenomegaly. Proliferation of } \\
\text { lymphocytes and plasma cells that exhibit } \\
\text { IgM immunofluorescence. }\end{array}$ \\
\hline Other organs and tissues & $\begin{array}{l}\text { Record size and weight of all parenchymatous } \\
\text { organs. For further procedures, see above under } \\
\text { "Lymph nodes." Request PAS and amyloid stains } \\
\text { (p. 172; see also under "Amyloidosis"). } \\
\text { Submit samples of all grossly abnormal tissues } \\
\text { for histologic study. }\end{array}$ & $\begin{array}{l}\text { Infiltrates of lymphocytes and plasma cells. } \\
\text { Evidence of recurrent infections is common. } \\
\text { Clinically, plasma hyperviscosity is a } \\
\text { common complication. If features of other } \\
\text { plasma cell disorders (amyloidosis,* heavy } \\
\text { chain disease,* multiple myeloma*) are } \\
\text { found, see under those headings. }\end{array}$ \\
\hline $\begin{array}{l}\text { Brain, spinal cord, } \\
\text { and peripheral nerves }\end{array}$ & $\begin{array}{l}\text { For removal and specimen preparation, } \\
\text { see pp. } 65,67 \text {, and } 79 \text {, respectively. }\end{array}$ & $\begin{array}{l}\text { Cerebral hemorrhages. Peripheral } \\
\text { neuropathy.* }\end{array}$ \\
\hline Eyes & $\begin{array}{l}\text { For removal and specimen preparation, } \\
\text { see p. } 85 \text {. }\end{array}$ & $\begin{array}{l}\text { Retinal hemorrhages and exudates. } \\
\text { Cyst of pars plana. }\end{array}$ \\
\hline Skeletal muscles & For sampling and specimen preparation, see p. 80. & Myopathy.* \\
\hline Bone marrow & $\begin{array}{l}\text { For preparation of sections and smears, } \\
\text { see p. } 96 .\end{array}$ & $\begin{array}{l}\text { Proliferation of lymphocytes and plasma cells } \\
\text { with clasmacytosis, eosinophilia, and mast } \\
\text { cell proliferation. No osteolytic lesions as in } \\
\text { multiple myeloma.* }\end{array}$ \\
\hline
\end{tabular}

\section{Malakoplakia}

NOTE: Malakoplakia is a chronic inflammatory lesion with foamy macrophages, intracellular bacteria, and laminated, calciumcontaing inclusions (Michaelis-Gutmann bodies). The lesions are found most commonly in the urinary bladder and other parts of the urinary tract, but may also occur at many other sites, including skin (1) and upper respiratory tract (2). 


\begin{tabular}{lll}
\hline Organs and Tissues & Procedures & Possible or Expected Findings \\
\hline $\begin{array}{l}\text { Urinary tract, colon, } \\
\text { or other tissues }\end{array}$ & Photograph gross lesions; record size and & Grayish nodular lesions with or without \\
& $\begin{array}{l}\text { location. Submit samples for histologic } \\
\text { and electron microscopic study (p. 132). }\end{array}$ & $\begin{array}{l}\text { ulceration. Microscopic Michaelis-Gutmann } \\
\text { bodies. Adenocarcinoma of the colon may be } \\
\text { Request PAS and von Kossa stains (p. 173). }\end{array}$ \\
\hline
\end{tabular}

\section{References}

1. Barnard M, Chalvardjian A. Cutaneous malakoplakia in a patient with acquired immunodeficiency syndrome (AIDS). Am J Dermatol 1998;20:185-188.

2. Salins PC, Trivedi P. Extensive malakoplakia of the nasopharynx: management of a rare disease. J Oral Maxillofac Surg 1998;56:483487.

3. Bates AW, Dev S, Baithun SI. Malakoplakia and colorectal adenocarcinoma. Postgrad Med J 1997;73:171-173.

\section{Malaria}

Synonyms and Related Terms: Plasmodium falciparum infection; Plasmodium malariae infection; Plasmodium ovale infection; Plasmodium vivax infection; malignant pernicious malaria; blackwater fever.
NOTE: (1) Collect all tissues that appear to be infected. (2) Usually, cultures are not indicated. (3) Request Giemsa or Wright stain (p. 172). Tissue blocks should be rinsed of blood and be as thin as possible before fixation in refrigerated buffered and neutral $10 \%$ formalin solution (p. 130). This is to avoid precipitation of formalin pigment that may be confused with malaria pigment. The formalin solution should be used in a ratio of 100 parts formalin to one part tissue and should be agitated every few hours. If one is dealing with tissues that contain formalin pigment, this pigment may be removed with a bleaching solution (p. 174). (4) Usually, no special precautions are indicated. (5) Serologic studies may be helpful and are available from the Centers for Disease Control and Prevention, Atlanta, GA (p. 135). (6) This is a reportable disease.

\begin{tabular}{ll}
\hline Organs and Tissues & Procedures \\
\hline Blood & Prepare "thick" and "thin" films. \\
Spleen & Record size and weight. Photograph cut section. \\
& For preparation of samples for histologic study, \\
& see above under "Note."
\end{tabular}

Liver

Kidneys

Other organs

Brain and spinal cord

Bone marrow
Record size and weight. Photograph cut section. For preparation of samples for histologic study, see above under "Note."

For preparation of samples for histologic study, see above under "Note."

Histologic sampling will depend on gross findings and clinical diagnosis of associated conditions. If placenta is present, prepare sections and smears. See also above under "Note."

For removal and specimen preparation, see pp. 65 and 67 , respectively.

For preparation of sections and smears, see p. 96.
Possible or Expected Findings

Parasites; malaria pigment in erythrocytes. Splenomegaly with brown to gray discoloration because of malaria pigment; diffuse cellular hyperplasia and congestion; black opaque globules in histiocytes and in erythrocytes; parasitized red cells in sinusoids. Hepatomegaly with congestion and centrilobular necrosis; malaria pigment in histiocytes; parasitized red cells in sinusoids. Ischemic cortex; congested medullary vessels; hemoglobin casts.

Manifestations of disseminated intravascular coagulation;* parasitized red cells in any organ. Placenta may appear black; parasitized maternal cells; fetal cells rarely infected.

Edema; "ring" hemorrhages; focal necrosis (acute cerebral malaria). Parasitized red cells in small vessels; reactive gliosis and malarial granulomas ("Dürck's" glial nodules). Erythroid and myeloid hyperplasia; parasitized red cells.
Malformation(s), Aortic Arch System (See "Artery, patent ductal," "Coarctation, aortic," and "Hypoplasia, tubular, of aortic arch.")

Malformation, Arnold-Chiari

Synonyms: Arnold-Chiari malformation, type I, adult form; Arnold-Chiari malformation, type II, infantile form; ArnoldChiari malformation, type III (see below under "Note").
NOTE: In type I, relative frequent craniocervical bony malformations (platybasia, ${ }^{*}$ basilar impression, ${ }^{*}$ suboccipital dysplasia, Klippel-Feil syndrome*). For type II cases, see below. In type III, occipitocervical bony defect with cerebellar herniation into the encephalocele.

Possible Associated Conditions: Syringomyelia* (in 50\% of type I cases); myelomeningocele, hydrocephalus, ${ }^{*}$ and often craniolacunia in type II cases. 


\begin{tabular}{|c|c|c|}
\hline Organs and Tissues & Procedures & Possible or Expected Findings \\
\hline External examination & Prepare roentgenograms of skull and cervix. & $\begin{array}{l}\text { For bony malformations, see above under } \\
\text { "Note." }\end{array}$ \\
\hline $\begin{array}{l}\text { Brain and spinal cord; } \\
\text { base of skull and } \\
\text { cervical spine }\end{array}$ & $\begin{array}{l}\text { For removal and specimen preparation of brain, } \\
\text { see p. } 65 \text {. For removal of spinal cord, use } \\
\text { combined approach (p. } 71 \text { ). If possible, prepare } \\
\text { photographs to show bony malformations. }\end{array}$ & $\begin{array}{l}\text { Downward displacement of cerebellar tonsils } \\
\text { and vermis through foramen magnum; } \\
\text { elongation and caudal displacement of brain } \\
\text { stem (medulla and } 4 \text { th ventricle). Herniated } \\
\text { cerebellar tissue shows neuronal loss and } \\
\text { gliosis. Beak-like deformity of quadrigem- } \\
\text { inal plate; upwards direction of the upper } \\
4 \text { to } 6 \text { cervical spinal roots. Aquaeduct } \\
\text { abnormalities may be present. Hydrocephalus* } \\
\text { may occur in all forms of the disease. }\end{array}$ \\
\hline
\end{tabular}

Malformation, Arteriovenous, Cerebral or Spinal (or Both)

Synonyms and Related Terms: Arteriovenous aneurysm; arteriovenous anomaly; Foix-Alajouanine syndrome; hemangioma of brain or spinal cord; vascular malformation of brain or spinal cord.

NOTE: A group of abnormal vessels is fed by one or more arteries without intermediate capillary channels and emptying directly into one or more large veins; this anomaly is associated with compressive atrophy of intervening and adjacent nervous tissue or with evidence of recent or old hemorrhage, or with both. In the Foix-Alajouanine syndrome, enlarged, tortuous subarachnoid veins cover the cord, especially posteriorly, and are associated with patchy necrosis of the spinal cord tissue and small blood vessels with thickened collagenous walls, not clearly distinguishable as arteries or veins.

\begin{tabular}{lll}
\hline Organs and Tissues & Procedures & Possible or Expected Findings \\
\hline Brain and spinal cord & $\begin{array}{l}\text { For cerebral arteriography, see p. 80. } \\
\text { For removal and specimen preparation, } \\
\text { see pp. 65 and 67, respectively. }\end{array}$ & $\begin{array}{l}\text { For expected findings, see above under } \\
\text { "Note." }\end{array}$ \\
Spine and spinal canal & & $\begin{array}{l}\text { Vertebral hemangioma. Calcification of } \\
\text { spinal canal. }\end{array}$ \\
\hline
\end{tabular}

Malformation(s), Biliary System (See "Atresia, biliary," "Cyst(s), choledochal," "Disease, Caroli's," "Disease, fibropolycystic, of the liver and biliary tract," and "Fibrosis, congenital hepatic.")

\section{Malformation(s), Congenital, Cardiac and Vascular NOTE: See under specific name of malformation.}

\section{Malformation(s), Coronary Artery (See "Anomaly, coronary artery.")}

\section{Malformation(s), Coronary Sinus}

NOTE: See also "Defect, atrial septal, coronary sinus type."

Possible Associated Conditions: Unroofed coronary sinus with atrial septal defect* at site normally occupied by coronary sinus and with left superior vena cava terminating in the left atrium. Absent coronary sinus associated with asplenia syndrome or right isomerism.

\section{Malformation, Ebstein's}

Synonym: Ebstein's anomaly of tricuspid valve.

NOTE: The basic anomaly is a downward placement of functional tricuspid annulus, with adherent septal and posterior leaflets, and with redundant deformed anterior leaflet. Sudden death may occur in this condition. It may become symptomatic at any age and is often associated with cardiomegaly due to marked right atrial and right ventricular dilatation.

Possible Associated Conditions: Congenitally corrected transposition of the great arteries; interatrial communication; pulmonary atresia; $*$ tricuspid insufficiency; ${ }^{*}$ Wolff-ParkinsonWhite ventricular preexcitation syndrome.*

\section{Malformation(s), Pulmonary Artery}

Related Terms: Absence of one pulmonary artery; aortic origin of one pulmonary artery; connection of pulmonary artery with left atrium; ductal origin of one or both pulmonary arteries; idiopathic dilatation of pulmonary trunk; discrete pulmonary artery stenosis; supravalvular pulmonary stenosis.*

Possible Associated Conditions: Post-rubella syndrome; pulmonary atresia with a ventricular septal defect; * tetralogy of Fallot;* supravalvular aortic stenosis; * Williams-Beuren syndrome.

\section{Malformation(s), Thoracic Vein}

Related Terms: Atresia of common pulmonary vein; azygos continuation of inferior vena cava; connection of a vena cava or hepatic vein with left atrium; continuity of inferior vena cava with left atrium; levoatriocardinal vein; partial anomalous pulmonary venous connection; persistent left superior vena cava; polysplenia syndrome;* pulmonary arteriovenous fistula; stenosis of common pulmonary vein (triatrial heart); scimitar syn- 
drome; stenosis of individual pulmonary vein; total anomalous pulmonary venous connection.

NOTE: Type of venous malformation usually must be determined before separartion of thoracoabdominal viscera, particularly the course and connections of the inferior vena cava, hepatic veins, and azygos and hemiazygos veins. En masse removal of organs is recommended (p. 3). Venography may be helpful.

Possible Associated Conditions: With anomalies of the pulmonary veins: asplenia syndrome (right isomerism), anomalous connections to the systemic veins, common atrium; complete atrioventricular septal defect;* polysplenia syndrome;* Scimitar syndrome. With connection of the inferior vena cava with the vena azygos: anomalous pulmonary venous return and polysplenia syndrome* (left isomerism). With intrapulmonary arteriovenous fistula: Osler-Weber-Rendu disease* or previ- ous Glenn cavopulmonary venous anastomosis (p. 41). With levoatriocardinal vein between left atrium or left pulmonary vein and left innominate vein; stenotic oval foramen, or mitral or aortic stenosis* or atresia* or both. With persistent left superior vena cava: isolated or with various malformations of the heart and great vessels.

\section{Malnutrition}

Synonyms and Related Terms: Hypoproteinemic malnutrition (kwashiorkor); marasmus; protein-energy malnutrition; starvation.*

Possible Associated Conditions: Anemia, iron deficiency, and vitamin deficiencies are common complications of malnutrition. Gastrointestinal, infectious, renal, and other diseases, including malignancies of all types, are found in many cases and represent the likely causes of the malnutrition.

\begin{tabular}{|c|c|c|}
\hline Organs and Tissues & Procedures & Possible or Expected Findings \\
\hline $\begin{array}{l}\text { External examination } \\
\text { and skin }\end{array}$ & $\begin{array}{l}\text { Record body weight and length (for body } \\
\text { mass index, see p. 567). } \\
\text { Photograph and record extent of skin lesions; } \\
\text { prepare histologic sections of skin. }\end{array}$ & $\begin{array}{l}\text { Weight loss (may be compensated by edema } \\
\text { and ascites). } \\
\text { Generalized pitting edema; pigmented, } \\
\text { pellagra-type skin lesions, particularly of } \\
\text { extremities and face; brittle hair. Atrophy } \\
\text { of epidermis with hyperkeratosis and } \\
\text { parakeratosis. }\end{array}$ \\
\hline Vitreous & $\begin{array}{l}\text { Submit sample for sodium, potassium, chloride, } \\
\text { and urea nitrogen determination (p. } 85 \text { ). }\end{array}$ & $\begin{array}{l}\text { Dehydration* and other electrolyte } \\
\text { disorders.* }\end{array}$ \\
\hline Abdomen & Record volume and character of fluid. & Ascites. \\
\hline Liver & $\begin{array}{l}\text { Record weight; request frozen sections for } \\
\text { Sudan stain (p. 173). }\end{array}$ & Fatty changes, predominantly periportal. \\
\hline Intestinal tract & $\begin{array}{l}\text { Prepare for study under dissecting microscope } \\
\text { (p. 54). Submit samples for histologic study. }\end{array}$ & Mucosal atrophy. \\
\hline Other organs & $\begin{array}{l}\text { Procedures depend on expected findings or } \\
\text { grossly identified abnormalities as listed in } \\
\text { right-hand column and above under "Note." }\end{array}$ & $\begin{array}{l}\text { Atrophy, particularly of pancreas and } \\
\text { endocrine glands. For possible underlying } \\
\text { conditions, see also above under "Note." }\end{array}$ \\
\hline
\end{tabular}

\section{Marasmus (See "Malnutrition" and "Starvation.")}

Marihuana (See “Abuse, marihuana.”)

Mast Cells (See "Mastocytosis, systemic.”)

Mastocytosis, Systemic Synonyms and Related Terms: Mast cell disease; mastocytic leukemia; urticaria pigmentosa of childhood. Possible Associated Conditions: Myelodysplastic or myeloproliferative disorders.

\begin{tabular}{lll}
\hline Organs and Tissues & Procedures & Possible or Expected Findings \\
\hline $\begin{array}{l}\text { External examination } \\
\text { and skin }\end{array}$ & $\begin{array}{l}\text { Record extent and character of skin lesions; } \\
\text { photograph skin lesions. Fix skin specimens in } \\
\text { formalin or alcohol (p. 129) and request Giemsa } \\
\text { or toluidine blue stains for mast cells (p. 172). } \\
\text { Prepare skeletal roentgenograms. }\end{array}$ & $\begin{array}{l}\text { Macules with telangiectasias, papules, and } \\
\text { nodules. Cachexia. Accumulation of mas } \\
\text { cells in dermis. }\end{array}$ \\
& $\begin{array}{l}\text { Multiple lytic bone lesions or new bone } \\
\text { formation. }\end{array}$
\end{tabular}




\begin{tabular}{lll}
\hline Organs and Tissues & Procedures & Possible or Expected Findings \\
\hline $\begin{array}{l}\text { Abdominal cavity } \\
\text { Gastrointestinal tract }\end{array}$ & $\begin{array}{l}\text { Submit samples from all segments for histologic } \\
\text { study. }\end{array}$ & $\begin{array}{l}\text { Ascites. } \\
\text { Peptic ulcer* with perforation; } \\
\text { gastroenteritis. See also under "Syndrome, } \\
\text { malabsorption." }\end{array}$ \\
$\begin{array}{l}\text { Liver, spleen, } \\
\text { and lymph nodes }\end{array}$ & $\begin{array}{l}\text { Record sizes and weights of liver and spleen } \\
\text { and average size of lymph nodes. Submit tissue } \\
\text { samples for histologic study (see above under } \\
\text { "External examination and skin"). }\end{array}$ & $\begin{array}{l}\text { Hepatosplenomegaly; hepatic fibrosis; } \\
\text { lymphadenopathy; mast cell infiltrates. } \\
\text { Manifestations of portal hypertension.* }\end{array}$ \\
$\begin{array}{l}\text { If infection is suspected, submit appropriate } \\
\text { material for microbiologic study. For staining } \\
\text { of histologic sections, see above under } \\
\text { "External examination and skin." }\end{array}$ & $\begin{array}{l}\text { Hemorrhages and infections may complicate } \\
\text { mast cell disease. Mast cell infiltrates may be } \\
\text { leukemic (see "Leukemia, all types or type } \\
\text { For removal, prosthetic repair, and specimen } \\
\text { preparation of bone, see p. 95. Consult } \\
\text { roentgenograms. For preparation of sections } \\
\text { and smears of bone marrow, see p. 96. }\end{array}$ & $\begin{array}{l}\text { Mast cell infiltrates with osteolysis and new } \\
\text { bone formation. Eosinophils, lymphocytes, } \\
\text { plasma cells and fibroblasts may be } \\
\text { prominent. Osteomalacia* in patients with } \\
\text { malabsorption syndrome.* }\end{array}$ \\
\hline
\end{tabular}

\section{Measles}

Synonyms: Morbilli; rubeola (the term rubeola is also used by some for "rubella").

NOTE: Various types of debilitating conditions may be complicated by measles-for instance, leukemia,* other neoplastic diseases and tuberculosis.*

(1) Collect all tissues that appear to be infected. (2) Request viral and aerobic bacterial cultures. (3) Request Gram stain (p. 172). Electron microscopy may demonstrate the virus (p. 132). (4) Special precautions are indicated (p. 146). (5) Serologic studies may be helpful. (6) This is a reportable disease.

Possible Associated Diseases: Adenovirus, parainfluenza virus, and other viral infections (1).

\begin{tabular}{ll}
\hline Organs and Tissues & Procedures \\
\hline $\begin{array}{l}\text { External examination } \\
\text { and skin }\end{array}$ & $\begin{array}{l}\text { If skin or oral lesions can be identified, submit } \\
\text { samples for histologic study. }\end{array}$
\end{tabular}

Thymus

Urine

Heart

Lungs

Intestinal tract

Kidneys, ureters, urinary bladder

Neck organs

Other organs and tissues

Brain and spinal cord
Record weight; submit sample for histologic study.

Submit sample for virologic culture.

Perfuse one lung with formalin (p. 47). Submit areas of consolidation for bacterial and viral cultures (p. 103). Obtain areas of infected tissue for electron microscopy and place in suitable fixative (p. 132).

Prepare histologic sections of Peyer's patches and appendix.

Submit samples for histologic study.

Remove together with palatine tonsils and pharyngeal lymphatic tissue (p. 4).

Prepare sections of lymphatic tissue and and larynx.

For removal and specimen preparation, see pp. 65 and 67 , respectively.
Possible or Expected Findings

Maculopapular rash, Koplik spots; congestion; edema; perivascular lymphocytic infiltrates; thrombosis; red cell extravasation; multinucleated giant cells. Hyperplasia (see below under "Intestinal tract").

Myocarditis* (very rare).

Bacterial pneumonia (1) (Pneumococcus, Streptococcus pyogenes, Staphylococcus aureus, Hemophilus influenzae); giant cells lining alveoli. Interstitial pneumonia* or giant cell pneumonia (2) and inclusion bodies in children with leukemia.*

Lymphoid hyperplasia with Warthin-

Finkeldey giant cells.

Mononuclear cells with cytoplasmic inclusions; giant cells.

See above under "Intestinal tract."

Thrombocytopenic hemorrhages at various sites.

Subacute sclerosing panencephalitis with inclusion bodies. 


\begin{tabular}{lll}
\hline Organs and Tissues & Procedures & Possible or Expected Findings \\
\hline Middle ears & $\begin{array}{l}\text { For removal and specimen preparation, } \\
\text { see p. 72. }\end{array}$ & Otitis media;* mastoiditis. \\
Eyes & $\begin{array}{l}\text { For removal and specimen preparation, } \\
\text { see p. 85. }\end{array}$ & $\begin{array}{l}\text { Optic neuritis; viral retinitis (3); } \\
\text { keratoconjunctivitis. }\end{array}$ \\
\hline
\end{tabular}

\section{References}

1. Quiambao BP, Gatchalian SR, Halonen P, Lucero M, Sombrero L, Paladin FJ, et al. Coinfection is common in measles associated pneumonia. Ped Inf Dis J 1998;17:89-93.

2. Rahman SM, Eto H, Morshed AS, Itakura H. Giant cell pneumonia: light microscopy, immunohistochemical, and ultrastructural study of an autopsy case. Ultrastr Pathol 1996;20:585-591.

3. Park DW, Boldt HC, Massicotte SJ, Akang EE, Roos KL, Bodnar A, et al. Subacute sclerosing panencephalitis manifesting as viral retinitis: clinical and histopathologic findings. Am J Ophthalmol 1997;123: 533-542.

\section{Measles, German (See "Rubella.")}

\section{Mediastinitis, Chronic}

Synonyms and Related Terms: Fibrosing mediastinitis; granulomatous mediastinitis; idiopathic sclerosing mediastinitis.

Possible Associated Conditions: Histoplasmosis* and other chronic fungal infections; immune connective tissue diseases such as rheumatoid arthritis* (1); malignancies (1); sarcoidosis; $*$ silicosis; $*$ tuberculosis* $(1)$.

NOTE: In rare instances, fibrosing mediastinitis appears to be associated with other chronic fibrosing conditions such as retroperitoneal fibrosis, * Riedel's thyroiditis (Riedel's struma), or sclerosing cholangitis.*

\begin{tabular}{lll}
\hline Organs and Tissues & Procedures & Possible or Expected Findings \\
\hline $\begin{array}{l}\text { Chest cavity and } \\
\text { mediastinum }\end{array}$ & $\begin{array}{l}\text { Dissect superior vena cava system, aorta, and } \\
\text { trachea, either } \text { in situ or after en bloc removal } \\
\text { of mediastinal organs. Horizontal slices may } \\
\text { be informative. }\end{array}$ & Superior vena cava obstruction. \\
& $\begin{array}{l}\text { Prepare histologic sections from sclerosing } \\
\text { process around great vessels, right atrium, } \\
\text { trachea, and pericardium and from mediastinal } \\
\text { lymph nodes. Submit tissue sample for fungal } \\
\text { culture, and request Grocott's methenamine } \\
\text { silver stain (p. 172). }\end{array}$ & $\begin{array}{l}\text { See above under "Possible Associated } \\
\text { Conditions." }\end{array}$ \\
\hline Other organs and tissues & & $\begin{array}{l}\text { See above under "Possible Associated } \\
\text { Conditions." }\end{array}$ \\
\hline
\end{tabular}

\section{Reference}

1. Mole TM, Glover J, Sheppard MN. Sclerosing mediastinitis: a report of 18 cases. Thorax 1995;50:280-283.

\section{Megacolon, Congenital}

Synonyms: Hirschsprung's disease; idiopathic megacolon; megacolon.

Possible Associated Conditions: Atrial septal defect;* Down's syndrome;* meconium ileus;* megalobladder; megaloureter; ventricular septal defect.*

\begin{tabular}{|c|c|c|}
\hline Organs and Tissues & Procedures & Possible or Expected Findings \\
\hline External examination & $\begin{array}{l}\text { Record weight, length, and abdominal } \\
\text { circumference of body. }\end{array}$ & $\begin{array}{l}\text { Manifestations of malnutrition;* abdominal } \\
\text { distention; growth retardation. }\end{array}$ \\
\hline \multirow[t]{2}{*}{ Intestinal tract } & $\begin{array}{l}\text { Photograph in situ. Remove colon with rectum } \\
\text { and anus; photograph colon before and after } \\
\text { opening. }\end{array}$ & $\begin{array}{l}\text { Necrotizing enterocolitis* and perforation } \\
\text { of the colon or appendix (in neonates and } \\
\text { infants). Narrow segment in distal colon. }\end{array}$ \\
\hline & $\begin{array}{l}\text { Submit samples for histologic study from all } \\
\text { portions of intestinal tract, particularly from } \\
\text { several portions of narrowed segment. Cut } \\
\text { sections on edge, and prepare frozen sections } \\
\text { (2). For paraffin sections, request van Gieson's } \\
\text { stain (p. 172). }\end{array}$ & $\begin{array}{l}\text { Aganglionosis of narrow distal segment; } \\
\text { intestinal neuronal dysplasia }(1) \text {. }\end{array}$ \\
\hline
\end{tabular}




\section{References}

1. Puri P, Wester T. Intestinal neuronal dysplasia. Sem Ped Surg 1998;7:181-186.

2. Kobayashi H, O’Brian DS, Hirakawa H, Wang Y, Puri P. A rapid technique of acetylcholinesterase staining. Arch Pathol Lab Med 1994;118:11271129.

\section{Melioidosis}

Synonyms and Related Terms: Glanders; Pseudomonas mallei infection; Pseudomonas pseudomallei infection.

NOTE: (1) Collect all tissues that appear to be infected. (2) Request aerobic bacterial cultures. (3) Request Gram stain (p. 172). Polyclonal antibodies can be used for the diagnosis. Formalin-fixed, paraffin embedded autopsy tissues can be stained with a modified immunoperoxidase technique (1). (4) Usually, no special precautions are indicated. (5) Serologic studies are available through state and local health departments (p. 135). (6) This is not a reportable disease.

\begin{tabular}{lll}
\hline Organs and Tissues & Procedures & Possible or Expected Findings \\
\hline Blood & $\begin{array}{l}\text { Submit sample for aerobic bacterial culture } \\
\text { (p. 102). }\end{array}$ & Septicemia. \\
Lungs & $\begin{array}{l}\text { Submit consolidated areas for microbiologic } \\
\text { study (p. 103). Perfuse at least one lung with } \\
\text { formalin (p. 47). }\end{array}$ & $\begin{array}{l}\text { Pneumonia, sometimes with cavitation and } \\
\text { calcification, resembling tuberculosis. }\end{array}$ \\
& $\begin{array}{l}\text { Procedures depend on expected findings or } \\
\text { grossly identified abnormalities as listed in } \\
\text { Other organs }\end{array}$ & $\begin{array}{l}\text { Abscesses may occur in skin, lymph nodes, } \\
\text { liver, lungs, heart, spleen, kidneys, and bones. }\end{array}$ \\
& & \\
\hline
\end{tabular}

\section{Reference}

1. Wong KT, Vadivelu J, Puthucheary SD, Tan KL. An immunohistochemical method for the diagnosis of melioidosis. Pathology 1996;28:188-191.

\section{Meningitis}

Related Terms: Meningoencephalitis; meningoencephalomyelitis.

NOTE: If the infectious agent is known, follow procedures described under the name of the corresponding infectious disease. Meningitis may complicate many noninfectious diseases, such as carcinoma, lymphoproliferative or myeloproliferative disorders, sarcoidosis, ${ }^{*}$ and other conditions, particularly if they require treatment with immunosuppressive agents.

\begin{tabular}{|c|c|c|}
\hline Organs and Tissues & Procedures & Possible or Expected Findings \\
\hline External examination & Prepare chest roentgenogram. & $\begin{array}{l}\text { Pulmonary infiltrates-for example, } \\
\text { in fungal pneumonia or tuberculosis.* }\end{array}$ \\
\hline Cerebrospinal fluid & $\begin{array}{l}\text { Submit sample for microbiologic study, cell } \\
\text { count, and chemical analysis (p. 104). }\end{array}$ & \\
\hline Brain and spinal cord & $\begin{array}{l}\text { Submit samples for viral, fungal, and bacterial } \\
\text { cultures (p. 102). For removal and specimen } \\
\text { preparation, see pp. } 65 \text { and } 67 \text {, respectively. } \\
\text { Record distribution of exudate; photograph, and } \\
\text { make smears, touch preparations, and sections. } \\
\text { Request Gram, acid fast (see "Tuberculosis"), } \\
\text { and Grocott's methenamine silver stains } \\
\text { (p. 172). Make India ink preparations. }\end{array}$ & $\begin{array}{l}\text { Bacterial (including tuberculous), fungal, and } \\
\text { viral meningitis. Aseptic nonsuppurative } \\
\text { inflammatory conditions. } \\
\text { Uncal and cerebellar herniation; subdural } \\
\text { effusion. }\end{array}$ \\
\hline $\begin{array}{l}\text { Blood } \\
\text { Other organs }\end{array}$ & $\begin{array}{l}\text { Submit sample for microbiologic study (p. 102). } \\
\text { Search for possible sites of primary infection. } \\
\text { Procedures depend on expected findings or } \\
\text { grossly identified abnormalities as listed in } \\
\text { right-hand column. }\end{array}$ & $\begin{array}{l}\text { Septicemia. } \\
\text { Infective endocarditis, }{ }^{*} \text { with or without } \\
\text { congenital heart disease; pulmonary infection } \\
\text { (origin of infection in tuberculous meningitis } \\
\text { in infancy); pulmonary fungal infection, with } \\
\text { or without bronchiectasis and cavitation; } \\
\text { purulent arthritis. Manifestations of } \\
\text { disseminated intravascular coagulation.* } \\
\text { Adrenal hemorrhages. }\end{array}$ \\
\hline
\end{tabular}




\section{Meningocele}

Related Terms: Complete rachischisis; meningomyelocele; spina bifida aperta; spina bifida occulta.

Possible Associated Conditions: Arnold-Chiari malformation;* diastematomyelia; diplomyelia; hydrocephalus; ${ }^{*}$ hydromyelia; syringomyelia;* tethered cord.

\begin{tabular}{lll}
\hline Organs and Tissues & Procedures & Possible or Expected Findings \\
\hline External examination & $\begin{array}{l}\text { Record location and extent of skin changes or skin } \\
\text { defects on back. Prepare skeletal roentgenograms. } \\
\text { If meningitis is suspected, submit sample of } \\
\text { cerebrospinal fluid for culture (p. 104). } \\
\text { For removal and specimen preparation, } \\
\text { see pp. 66 and 70, respectively. }\end{array}$ & $\begin{array}{l}\text { Atrophic skin over meningocele, lacking rete } \\
\text { pegs and skin appendages; skin defect in } \\
\text { complete rachischisis. Bony defects of spine. }\end{array}$ \\
& & $\begin{array}{l}\text { In meningocele and spina bifida occulta, } \\
\text { arachnoid and dura herniate through the } \\
\text { vertebral defect. Spinal cord and roots are } \\
\text { generally not involved. Lumbosacral mass in } \\
\text { meningomyelocele, with a highly vascular } \\
\text { mass (area medullovasculosa) in spina bifida } \\
\text { aperta. Neural defects in complete } \\
\text { rachischisis. } \\
\text { Pyelonephritis; } * \text { enlarged urinary bladder } \\
\text { (“neurogenic bladder"). }\end{array}$ \\
\hline
\end{tabular}

\section{Meningococcemia (See “Disease, meningococcal.”)}

Meningoencephalitis (See "Encephalitis, all types or type unspecified" and "Meningitis.")

Mercury (See "Poisoning, mercury.")

Metaplasia, Agnogenic Myeloid, With Myelofibrosis

Synonym: Idiopathic myelofibrosis.

\begin{tabular}{lll}
\hline Organs and Tissues & Procedures & Possible or Expected Findings
\end{tabular}

External examination Prepare skeletal roentgenograms.

Bones and bone marrow

Other organs
For removal, prosthetic repair, and specimen preparation of bone, see p. 95. For preparation of sections and smears of bone marrow, see p. 96. See above (under "External examination) for selection of bones.

Request Giemsa, Masson's trichrome, and reticulum stains for bone marrow sections (p. 172). See also under "Leukemia." Record weights of liver and spleen.

Other procedures depend on expected findings or grossly identified abnormalities as listed in right-hand column.
Osteosclerosis of vertebrae, ribs, clavicles, pelvic bones, scapulae, skull, and metaphyseal ends of femur and humerus. Osteomyelofibrosis or osteoreticulosis; rarely, panhyperplasia of bone marrow; increase of megakaryocytes.

Changes associated with chronic granulocytic leukemia* or with polycythemia vera* may imitate idiopathic myelofibrosis. Widespread extramedullary hematopoiesis (1) with splenomegaly. Infectious diseases, including tuberculosis; * gouty arthritis; ascites and other manifestations of portal hypertension;* or hepatic vein thrombosis (Budd-Chiari syndrome*). Cardiac tamponade (1).

\section{Reference}

1. Imam TH, Doll DC. Acute cardiac tamponade associated with pericardial extramedullary hematopoiesis in agnogenic myeloid metaplasia. Acta Haematol 1997;98:42-43.

Methanol (Methyl Alcohol) (See "Poisoning, methanol (methyl alcohol).") 


\section{Microangiopathy, Thrombotic Thrombocytopenic (See "Purpura, thrombotic thrombocytopenic.")}

\section{Microlithiasis, Pulmonary Alveolar}

\begin{tabular}{|c|c|c|}
\hline Organs and Tissues & Procedures & Possible or Expected Findings \\
\hline External examination & Prepare chest roentgenogram. & Miliary mottling in lower lung fields. \\
\hline Heart & $\begin{array}{l}\text { Procedures depend on expected findings or } \\
\text { grossly identified abnormalities as listed in } \\
\text { right-hand column. }\end{array}$ & $\begin{array}{l}\text { Mitral stenosis* may be a cause of } \\
\text { microlithiasis (mostly intra-alveolar } \\
\text { ossification).* Cor pulmonale and heart } \\
\text { failure (1) may complicate chronic } \\
\text { microlithiasis. }\end{array}$ \\
\hline \multirow[t]{3}{*}{ Lungs } & $\begin{array}{l}\text { Record weights. Prepare photographs and } \\
\text { roentgenograms of fresh and fixed lung } \\
\text { specimens. Specimens may have to be sawed } \\
\text { (p. 95). Perfuse one lung with formalin } \\
\text { (p. } 47 \text { ). For preparation of paper-mounted } \\
\text { sections, see p. } 49 \text {. }\end{array}$ & $\begin{array}{l}\text { Increased weights and hardness. } \\
\text { Miliary mottling, mainly in lower lobes. }\end{array}$ \\
\hline & $\begin{array}{l}\text { Submit one lobe for microbiologic and chemical } \\
\text { study. Decalcify tissue for histologic study } \\
\text { (p. 97). For preparation of undecalcified sections, } \\
\text { see p. } 97 \text {. }\end{array}$ & $\begin{array}{l}\text { Calcospherites containing calcium, } \\
\text { phosphate, iron, and magnesium. Reactive } \\
\text { pulmonary fibrosis. }\end{array}$ \\
\hline & $\begin{array}{l}\text { Request van Gieson's, Hale's colloidal iron, } \\
\text { PAS, and Sudan stains (pp. } 172 \text { and 173). }\end{array}$ & $\begin{array}{l}\text { Center of calcospherites strongly positive } \\
\text { with PAS and colloidal iron stains. } \\
\text { Sudanophilic and doubly refractile fatty } \\
\text { material in calcospherites. }\end{array}$ \\
\hline
\end{tabular}

\section{Reference}

1. Mariotta S, Guidi L, Mattia P, Torrelli L, Pallone G, Pedicelli G, Bisetti A. Pulmonary microlithiasis. Report of two cases. Respiration 1997;64: 165-169.

\section{Mongolism (See “Syndrome, Down's.")}

\section{Mononucleosis, Infectious}

Related Terms: Cytomegalovirus infection; Epstein-Barr virus (EBV) infection.

NOTE: If the EBV infection occurred after organ transplantation (1), see also under that heading.

(1) Collect all tissues that appear to be infected. (2) Viral isolation, especially with EBV, is not diagnostically useful, due to long incubation periods. (3) No special precautions are indicated. (4) Serologic studies are the method of choice and are available from local or state health department laboratories (p. 135). (6) This is not a reportable disease.

\begin{tabular}{|c|c|c|}
\hline Organs and Tissues & Procedures & Possible or Expected Findings \\
\hline External examination & & Jaundice; petechial rash. \\
\hline Blood & $\begin{array}{l}\text { Submit samples for bacterial and viral cultures } \\
\text { and for serologic study (p. 102). }\end{array}$ & $\begin{array}{l}\text { Septicemia. High Epstein-Barr virus } \\
\text { antibody and heterophil titers. }\end{array}$ \\
\hline & Prepare Giemsa-stained smear. & Atypical lymphocytes. \\
\hline Heart & $\begin{array}{l}\text { Record weight and submit samples for } \\
\text { histologic study (p. 30). }\end{array}$ & Myocarditis.* \\
\hline Lungs & $\begin{array}{l}\text { Submit consolidated areas for bacterial culture } \\
\text { (p. 103). }\end{array}$ & Edema and bacterial pneumonia. \\
\hline Gastrointestinal tract & & Hemorrhage.* \\
\hline Spleen & $\begin{array}{l}\text { Record size and weight. Submit sample for } \\
\text { histologic study and make touch preparations. } \\
\text { Request Giemsa stain (p. 172). }\end{array}$ & $\begin{array}{l}\text { Splenomegaly; hematomas and rupture. } \\
\text { Extensive hyperplasia of red pulp. See below, } \\
\text { under "Lymph Nodes." }\end{array}$ \\
\hline Liver & $\begin{array}{l}\text { Record size and weight. Submit sample for } \\
\text { histologic study. }\end{array}$ & $\begin{array}{l}\text { Massive EBV necrosis ( } 2) \text {; granulomatous } \\
\text { hepatitis; cytomegalovirus inclusions within } \\
\text { hepatocytes and endothelial cells. }\end{array}$ \\
\hline
\end{tabular}




\begin{tabular}{|c|c|c|}
\hline Organs and Tissues & Procedures & Possible or Expected Findings \\
\hline Lymph nodes & $\begin{array}{l}\text { Submit samples for histologic study and make } \\
\text { touch preparations. Request azure-eosin stain } \\
\text { (p. 172). }\end{array}$ & $\begin{array}{l}\text { Generalized lymphadenopathy; abundant } \\
\text { immunoblasts resembling Reed-Sternberg } \\
\text { cells. }\end{array}$ \\
\hline Neck organs & $\begin{array}{l}\text { Make touch preparations and request sections of } \\
\text { lingual, palatine, and pharyngeal lymphoid tissue } \\
\text { (p. 4). Request azure-eosin stain (p. 172). }\end{array}$ & $\begin{array}{l}\text { Nasopharyngeal hemorrhage. Glottis edema. } \\
\text { Lymphoid hyperplasia (see also above under } \\
\text { "Spleen" and "Lymph nodes"). }\end{array}$ \\
\hline Other organs & $\begin{array}{l}\text { Procedures depend on grossly identified } \\
\text { abnormalities as listed in right-hand column. }\end{array}$ & $\begin{array}{l}\text { Manifestations of bleeding due to } \\
\text { thrombocytopenia; lymphoid infiltrates in } \\
\text { any organ. }\end{array}$ \\
\hline $\begin{array}{l}\text { Brain, spinal cord, } \\
\text { and spinal ganglia }\end{array}$ & $\begin{array}{l}\text { For removal and specimen preparation, } \\
\text { see pp. } 65,67 \text {, and } 69 \text {, respectively. }\end{array}$ & $\begin{array}{l}\text { Meningoencephalitis; lymphocytic or serous } \\
\text { meningitis;* polyradiculitis (clinically, } \\
\text { Guillain-Barré syndrome*). }\end{array}$ \\
\hline Peripheral nerves & $\begin{array}{l}\text { For sampling and specimen preparation, } \\
\text { see p. } 79 .\end{array}$ & Peripheral neuritis. \\
\hline Bone marrow & $\begin{array}{l}\text { For preparation of sections and smears, } \\
\text { see p. } 96 .\end{array}$ & Agranulocytosis. \\
\hline
\end{tabular}

\section{References}

1. Hubscher SG, Williams A, Davison SM, Young LS, Niedobitek G. Epstein-Barr virus in inflammatory diseases of the liver and liver allografts: an in situ hybridization study. Hepatology 1994;20:899907.

2. Papatheodoridis GV, Delladetsima JK, Kavallierou L, Kapranos N, Tassopoulos NC. Fulminant hepatitis due to Epstein-Barr virus infection. J Hepatol 1995;23:348-350.

\section{Morphine (See "Dependence, $\operatorname{drug}(\mathrm{s})$, all types or type unspecified.")}

\section{Mucopolysaccharidosis}

Synonyms and Related Terms: Mucopolysaccharidosis I $\mathrm{H}$ (gargoylism, Hurler's disease or syndrome, $\alpha$-L-iduronidase deficiency, MPS I H); mucopolysaccharidosis I S (Scheie's syndrome, $\alpha$-L-iduronidase deficiency, MPS I S, MP V); mucopolysaccharidosis II (Hunter's disease or syndrome, MPS II); mucopolysaccharidosis III (heparitinuria, MPS III, polydystrophic oligophrenia, Sanfilippo's syndrome); mucopolysaccharidosis IV (Morquio's syndrome, keratosulfaturia, MPS IV); mucopolysaccharidosis VI (Maroteaux-Lamy syndrome, MPS VI, polydystrophic dwarfism); mucopolysaccharidosis VII ( $\beta$ glucuronidase deficiency, MPS VII).

NOTE: These diseases are characterized by a deficiency of a variety of hydrolases, resulting in accumulation of glycosami- noglycans (mucopolysaccharides) and glycolipids within lysosomes of fibroblasts, macrophages, white cells, and parenchymal cells of many organs $(1,2)$. Mucopolysaccharides are also excreted in the urine. The general approach is similar in all types. Formalin may dissolve all of the stored material and leave empty vacuoles in the involved cells. Therefore, frozen sections should be utilized or tissues should be fixed in absolute alcohol (p. 129). The accumulated material will show intense metachromasia if stained with toluidine blue. It will also stain with PAS, alcian blue, and colloidal iron. Oil red $\mathrm{O}$ will also stain the material from frozen sections (p. 172). For specimen preparation for electron microscopy, see p. 132.

Characteristic external features include dwarfism; thickened long bones; coarse facial features; coarse hair; macrocephaly; prognathism; hypertelorism; malformed teeth, and scaphocephalic skull with hyperostosis of sagittal suture; short neck; chest deformity; umbilical and inguinal hernias; lower thoracic and lumbar gibbus; genu valgum and coxa valga; pes planus and other joint deformities; wide hands (clawhands) and feet. Coarse thickened skin, covered with lanugo-like hair. Hyperlordosis; ovoid deformities of vertebrae; odontoid hypoplasia; large, shoe-shaped sella turcica; kyphosis; hypoplasia of femoral heads; osteoporosis.*

If patient underwent bone marrow transplantation (3), see also under that heading.

\begin{tabular}{cl}
\hline Organs and Tissues & Procedures \\
\hline $\begin{array}{r}\text { External examination } \\
\text { and extent and skin }\end{array}$ & $\begin{array}{l}\text { Record body weight and length and type } \\
\text { of deformities. Photograph head and } \\
\text { deformities. Prepare sections of skin. } \\
\text { Prepare skeletal roentgenograms. } \\
\text { Placenta }\end{array}$ \\
Submit sections for histologic study.
\end{tabular}

Fascia lata

Blood
Submit sample for fibroblast tissue culture for enzyme assay (p. 109).

Prepare smears (see below under "Bone marrow"). Submit sample for microbiologic study (p. 102).

\section{Possible or Expected Findings}

Characteristic external features and possible roentgenographic features are listed above under "Note."

Storage of material in Hofbauer cells and stromal cells.

Increased intracellular mucopolysaccharides. Cultures are well-suited for special studies. 


\begin{tabular}{lll}
\hline Organs and Tissues & Procedures & Possible or Expected Findings \\
\hline Urine & $\begin{array}{l}\text { Submit sample for biochemical study. } \\
\text { Recort weight. Prepare coronary arteriogram } \\
\text { (p. 118). }\end{array}$ & $\begin{array}{l}\text { Increased mucopolysaccharides. } \\
\text { Diffuse coronary narrowing because of the } \\
\text { presence of intimal gargoyle cells (smooth } \\
\text { muscle cells), elastic fiber proliferation, and } \\
\text { other deformities. (Heart disease is a frequent } \\
\text { cause of death.) }\end{array}$ \\
& Test competence of valves (p. 29). & $\begin{array}{l}\text { Nodular thickening of mitral (4), aortic (4), } \\
\text { tricuspid, and pulmonary valves (in this order } \\
\text { of involvement). }\end{array}$ \\
& & $\begin{array}{l}\text { Gargoyle cells in valves and chordae } \\
\text { tendineae. }\end{array}$ \\
& $\begin{array}{l}\text { Prepare histologic sections of all valves } \\
\text { and chordae tendineae. }\end{array}$ & $\begin{array}{l}\text { Hypertrophy of the heart. } \\
\text { Record thickness of ventricles and extent of } \\
\text { myocardial necroses or scarring. }\end{array}$ \\
Photograph valves and myocardium. & $\begin{array}{l}\text { Mndocardial fibroelastosis. } \\
\text { Submit samples of epicardium, myocardium, }\end{array}$ \\
coronary arteries, and conduction system for & $\begin{array}{l}\text { Mucopolysaccharide deposits in epicardium } \\
\text { and endocardium. }\end{array}$
\end{tabular}

Aorta, pulmonary arteries, histologic study (p. 26).

other great vessels, and peripheral muscular arteries

Tracheobronchial tree and lungs

Request Verhoeff-van Gieson stain (p. 173).

Extensive intimal deposits, as in coronary arteries.

For pulmonary arteriography, see p. 50 . Submit consolidated areas for microbiologic study (p. 103).

Perfuse one lung with formalin (p. 47).

Submit samples of tracheal and bronchial cartilage for histologic study.

Spleen

Record weight. Submit specimen for tissue culture (p. 108). Submit sample for histologic study.

Liver

Record weight and submit samples for histologic study.

Kidneys

Endocrine organs

Brain, spinal cord, and peripheral ganglia

Eyes

Middle and inner ears

Record weight and submit samples for histologic study.

Record weight of all endocrine organs and submit samples for histologic study. For removal and specimen preparation, see pp. 65, 67, and 69, respectively. Mucopolysaccharides may stain well with PAS reagent. For removal and specimen preparation, see p. 85 .

For removal and specimen preparation, see p. 72. (Study particularly indicated if patient was deaf.)

Sinuses and nasal cavities Expose from base of skull, and submit samples of mucosa for histologic study (p. 71).

Bone marrow For preparation of sections and smears, see p. 96. Prepare air-dried smears (without formalin fixation) for demonstration of metachromatic granules.

Bones and joints, periosteum, tendons, and fasciae For removal, prosthetic repair, and specimen preparation, see p. 95 .
Pulmonary vascular changes (see above). Purulent bronchitis and bronchopneumonia. (Respiratory infection is a frequent cause of death).

Gargoyle cells in cartilage.

Splenomegaly; gargoyle cells.

Hepatomegaly;* enlarged vacuolated hepatocytes with mucopolysaccharides; fibrosis. Vacuolated cells in Bowman's capsule.

Gargoyle cells.

Hydrocephalus; cerebral cortical atrophy; storage of mucopolysaccharides in ganglion cells.

Corneal clouding and retinal degeneration associated with storage of mucopolysaccharides in nuclear layer of retina. Chronic infections.

Chronic upper respiratory infections.

Large cytoplasmic granules in neutrophils.

Storage of mucopolysaccharides in osteocytes, chondrocytes, and fibroblasts of periosteum, tendons, fasciae, and other connective tissues; dysostosis multiplex. 


\begin{tabular}{lll}
\hline Organs and Tissues & Procedures & Possible or Expected Findings \\
\hline Other tissues & Histologic sampling cannot be excessive. & $\begin{array}{l}\text { Storage of mucopolysaccharides may occur } \\
\text { anywhere. }\end{array}$ \\
\hline
\end{tabular}

\section{References}

1. Wraith JE. The mucopolysaccharidoses: a clinical review and guide to management. Arch Dis Child 1995;72(3):263-267.

2. Di Natale P, Annella T, Daniele A, De Luca T, Morabito E, Pallini R, et al. Biochemical diagnosis of mucopolysaccharidoses: experience of 297 diagnoses in a 15-year period (1997-1991). J Inher Metabolic Dis 1993;16(2):473-483.
3. Gatzoulis MA, Vellodi A, Redington AN. Cardiac involvement in mucopolysaccharidosis: effects of allogeneic bone marrow transplantation. Arch Dis Childhood 1995;73:259-260.

4. Wippermann CF, Beck M, Schranz D, Huth R, Michel-Behnke I, Jungst BK. Mitral and aortic regurgitation in 84 patients with mucopolysaccharidosis. Eur J Pediatr 1995;154:98-101.

\section{Mucormycosis}

Synonym: Phycomycosis; zygomycosis.

NOTE: Diseases that may be complicated by mucormycosis include burns, ${ }^{*}$ diabetes mellitus, ${ }^{*}$ leukemia, ${ }^{*}$ lymphoma, ${ }^{*}$ and tuberculosis.*

(1) Collect all tissues that appear to be infected. (2) Request fungal culture. (3) Request Grocott's methenamine silver stain (p. 172). (4) No special precautions are indicated. (5) Serologic studies are not available. (6) This is not a reportable disease.

\begin{tabular}{lll}
\hline Organs and Tissues & Procedures & Possible or Expected Findings \\
\hline
\end{tabular}

External examination and skin

Lungs

Gastrointestinal tract

Other organs

Skull with brain
Photograph all lesions attributable to this infection.

Submit consolidated areas for fungal and bacterial culture (p. 103); make touch preparation of fresh lung. Perfuse both lungs with formalin (p. 47).

Culture all tissues with gross evidence of thrombosis or infarction. Other procedures depend on expected findings or grossly identified abnormalities as listed in right-hand column.

For removal of brain and exposure of orbitae and paranasal sinuses, see pp. 65, 73, and 71 , respectively. Prepare sections of abnormal tissues.
Skin ulcerations.

Necrotizing bronchopneumonia.

Mucosal ulcers.

Disseminated fungal arteritis with secondary thromboses and infarctions in heart, kidneys, and many other organs.

Primary infection in sinuses or orbitae; orbital cellulitis; fungal arteritis with cerebral infection; thrombosis of cavernous sinus and internal carotid artery.

\section{Mucoviscidosis (See “Fibrosis, cystic.")}

\section{Mumps}

NOTE: (1) Collect all tissues that appear to be infected. (2) Request viral cultures. (3) Usually, special stains are not helpful. (4) Special precautions are indicated (p. 146). (5) Serologic studies are available from state health department laboratories (p. 135). (6) This is not a reportable disease.

\begin{tabular}{|c|c|c|}
\hline Organs and Tissues & Procedures & Possible or Expected Findings \\
\hline $\begin{array}{l}\text { External examination } \\
\text { and skin }\end{array}$ & Prepare sections of skin. & Thrombocytopenic purpura. \\
\hline Breasts & Submit tissue sample for histologic study. & Mastitis. \\
\hline Blood & $\begin{array}{l}\text { Submit samples for biochemical (serum } \\
\text { amylase) and serologic study. }\end{array}$ & Complement-fixing antibodies. \\
\hline Urine & Submit sample for viral cultures (p. 102). & \\
\hline Heart & Submit samples for histologic study (p. 30). & $\begin{array}{l}\text { Myocarditis* may be cause of death. } \\
\text { Pericarditis* and endocardial fibroelastosis.* }\end{array}$ \\
\hline Liver and pancreas & $\begin{array}{l}\text { Record weights and submit samples for } \\
\text { histologic study. }\end{array}$ & Hepatitis* and pancreatitis.* \\
\hline Spleen & Record weight and size. & Splenomegaly. \\
\hline
\end{tabular}




\begin{tabular}{|c|c|c|}
\hline Organs and Tissues & Procedures & Possible or Expected Findings \\
\hline Kidneys & $\begin{array}{l}\text { Record weights and submit samples for } \\
\text { histologic study. }\end{array}$ & Nephritis.* \\
\hline Male sex organs & $\begin{array}{l}\text { Record weights of testes and epididymides; } \\
\text { prepare histologic sections of testes, epididymides, } \\
\text { seminal vesicles, and prostate, especially } \\
\text { in postpubertal males. }\end{array}$ & $\begin{array}{l}\text { Orchitis; epididymitis; seminal vesiculitis; } \\
\text { prostatitis. }\end{array}$ \\
\hline Female sex organs & $\begin{array}{l}\text { Submit samples of ovaries and Bartholin's } \\
\text { glands for histologic study. }\end{array}$ & Ovaritis (oophoritis); bartholinitis. \\
\hline Neck organs & $\begin{array}{l}\text { Prepare histologic sections of pharynx, submax- } \\
\text { illary and sublingual glands (p. 4), and thyroid. }\end{array}$ & Sialadenitis; thyroiditis. \\
\hline $\begin{array}{l}\text { Brain, spinal cord, } \\
\text { and spinal roots }\end{array}$ & $\begin{array}{l}\text { For removal and specimen preparation, see } \\
\text { pp. } 65 \text { and } 67 \text {, respectively. Prepare sections } \\
\text { of cranial nerves and spinal nerve roots (p. } 69 \text { ). }\end{array}$ & $\begin{array}{l}\text { Meningitis or postinfectious encephalitis; } \\
\text { perivenous demyelination and mononuclear } \\
\text { inflammation; neuritis of cranial nerves II, } \\
\text { III, VI, VII, and VIII. Polyneuritis; } \\
\text { meningoradiculitis. Myelitis. }\end{array}$ \\
\hline Eyes and lacrimal glands & $\begin{array}{l}\text { For removal and specimen preparation, } \\
\text { see pp. } 85 \text { and } 87 \text {, respectively. }\end{array}$ & $\begin{array}{l}\text { Conjunctivitis; keratitis; uveitis; retinitis; } \\
\text { dacryoadenitis. }\end{array}$ \\
\hline Middle and inner ears & For removal and specimen preparation, see p. 72 . & Labyrinthitis. \\
\hline Parotid glands & $\begin{array}{l}\text { Remove tissue from scalp incision (p. 65) } \\
\text { with biopsy needle. }\end{array}$ & Parotitis. \\
\hline Joints & $\begin{array}{l}\text { For removal, prosthetic repair, and specimen } \\
\text { preparation, see p. } 96 .\end{array}$ & Arthritis.* \\
\hline
\end{tabular}

\section{Murder (See “Homicide.”)}

\section{Mushroom (See "Poisoning, mushroom.")}

\section{Myasthenia Gravis}

Synonyms and Related Term: Acquired autoimmune myasthenic (due to anti-acetylcholine receptor antibodies, anti-AchR); myasthenic syndromes, acquired (Eaton-Lambert syndrome) or congenital.

NOTE: The acquired myasthenic syndrome is associated in $40-50 \%$ of cases with bronchogenic carcinoma.

\begin{tabular}{ll}
\hline Organs and Tissues & Procedures \\
\hline Thymus & $\begin{array}{l}\text { Record size and weight. Submit sample for } \\
\text { histologic studies. If a thymoma is present, } \\
\text { prepare sections of tumor and of uninvolved } \\
\text { thymus. }\end{array}$
\end{tabular}

Blood Submit sample for serologic study.

Other organs

Skeletal muscles
Search for tumors of any site (primarily lung small cell carcinoma) in acquired myasthenia syndrome (Eaton-Lambert); search for manifestations of "autoimmune" systemic diseases.

For sampling and specimen preparation, see p. 80. Respiratory musculature should always be included. Submit tissue samples for electron microscopic study (p. 132).

\section{Possible or Expected Findings}

In early onset myasthenia (55\% of cases), thymus shows hyperplasia with lymphoid follicles with germinal centers. In late onset myasthenia, thymus is atrophic. $10 \%$ of cases are associated with thymoma.

Serum concentrations of Anti Ach R (antiacetylcholine receptor) autoantibodies are high in myasthenia. $85 \%$ of patients with myasthenia and thymoma have high antistriated muscle autoantibodies.

Manifestations of diabetes mellitus,* hyperthyroidism, ${ }^{*}$ and rheumatoid arthritis* or other immune connective tissue diseases in myasthenia gravis. Thyroid abnormalities other than hyperplasia in myasthenia gravis. Tumors of lungs (small cell carcinoma), breast, and other sites in myasthenia syndrome (Eaton-Lambert).

Abnormalities of postsynaptic membrane in myasthenia gravis. 


\section{Reference}

1. Engel AG. Myasthenic syndromes. In: Myology, 2nd ed., vol. 2. Engel AG, Franzini-Armstrong C, eds. MacGraw-Hill, New York, 1994, pp. 17981835.

\section{Mycosis (See under specific disease designation, such as "Candidiasis.")}

\section{Mycosis Fungoides}

Related Terms: Lymphoma;* Sézary syndrome.

NOTE: If mycosis fungoides was the cause of death, the patient probably was in the tumor stage of the disease with lymph node and general organ involvement. Follow procedures described under "Lymphoma." Viscera most commonly involved in late mycosis fungoides are, in order of frequency, lungs, spleen, liver, kidneys, thyroid gland, pancreas, bone marrow, and heart. Almost all organs and tissues of the body may be involved.

\section{Myelinosis, Central Pontine}

\begin{tabular}{lll}
\hline Organs and Tissues & Procedures & Possible or Expected Findings \\
\hline External examination & & $\begin{array}{l}\text { Malnutrition* or severe burns* may be } \\
\text { causes of central pontine myelinosis. }\end{array}$ \\
$\begin{array}{l}\text { Cerebrospinal fluid } \\
\text { Brain and spinal cord }\end{array}$ & $\begin{array}{l}\text { Submit sample for microbiologic study (p. 104). } \\
\text { For removal and specimen preparation, see } \\
\text { pp. 65 and 67, respectively. Request Luxol } \\
\text { fast blue/PAS and Bielschowsky stains (p. 172). }\end{array}$ & $\begin{array}{l}\text { Demyld be sterile. } \\
\text { of the base of the pons, from just below the } \\
\text { midbrain through the upper two-thirds of the } \\
\text { pons. Myelin is lost and some axons may be } \\
\text { fragmented while neurons in the nuclei pontis } \\
\text { are preserved (unlike in centrale pontine }\end{array}$ \\
& & $\begin{array}{l}\text { infarct). Histiocytes may abound. } \\
\text { Manifestations of alcoholism;* electrolyte } \\
\text { disorders* (including too rapid correction of } \\
\text { hyponatremia); severe infections; liver } \\
\text { Other organs }\end{array}$ \\
& $\begin{array}{l}\text { Procedures depend on expected findings or } \\
\text { grossly identified abnormalities as listed in } \\
\text { right-hand column. }\end{array}$ & $\begin{array}{l}\text { transplantation*); neoplastic conditions; } \\
\text { renal diseases. }\end{array}$ \\
\hline
\end{tabular}

Myelofibrosis with Myeloid Metaplasia (See “Metaplasia, agnogenic myeloid, with myelofibrosis.”)

\section{Myeloma, Multiple}

Synonyms: Myeloma; osteosclerotic myeloma (1)(POEMS syndrome); plasma cell myeloma.

Possible Associated Condition: Acute myeloblastic or monocytic leukemia;* amyloidosis;* chronic myelogenous leukemia (2); hyperviscosity syndrome.

\begin{tabular}{cl}
\hline Organs and Tissues & Procedures \\
\hline $\begin{array}{c}\text { External examination, } \\
\text { skin, and tongue }\end{array}$ & $\begin{array}{l}\text { Record extent of skin lesions and size of tongue } \\
\text { (may be accessible only after removal of neck }\end{array}$ \\
& $\begin{array}{l}\text { organs). Take sections of skin lesions and tongue. } \\
\text { Request amyloid stains (see "Amyloidosis"). } \\
\text { Prepare skeletal roentgenograms. }\end{array}$
\end{tabular}

Possible or Expected Findings

Vascular purpura. Skin tumors. Macroglossia secondary to amyloid deposition.

Osteolytic skeletal tumors. Calvarium may be involved. Tumors are rarely osteoblastic (osteosclerotic [1]). Generally, no lymphadenopathy.

Vitreous

Blood
Submit sample for sodium, potassium, chloride, urea nitrogen, and calcium determination (p. 85). Submit samples for bacterial and fungal cultures (p. 102) for serum electrophoresis, and for determination of calcium (post-mortem values not reliable) and uric acid concentrations (p. 113).
Evidence of electrolyte and other disorders (see under "Blood").*

Septicemia. Anemia (may be megaloblastic*). Hyperglobulinemia with hypogammaglobulinemia Hypercalcemia; hyperuricemia. Hyperviscosity of serum. 


\begin{tabular}{|c|c|c|}
\hline Organs and Tissues & Procedures & Possible or Expected Findings \\
\hline Urine & $\begin{array}{l}\text { Submit sample for determination of Bence Jones } \\
\text { protein. }\end{array}$ & Bence Jones protein. Light-chain proteinuria. \\
\hline Heart & $\begin{array}{l}\text { Record weight. Request amyloid stains } \\
\text { (see "Amyloidosis"). }\end{array}$ & Cardiac amyloidosis. \\
\hline \multirow[t]{3}{*}{ Lungs } & $\begin{array}{l}\text { Submit one lobe for bacterial and fungal } \\
\text { cultures (p. 103). }\end{array}$ & Various types of pneumonia. \\
\hline & $\begin{array}{l}\text { Make touch preparations of cut surface and } \\
\text { request Grocott's methenamine silver stain } \\
\text { (p. 172). Perfuse one lung with formalin (p. 47). }\end{array}$ & Pneumocystis carinii pneumonia. \\
\hline & $\begin{array}{l}\text { Histologic sections may need decalcification } \\
\text { (p. 97). }\end{array}$ & Metastatic calcification. \\
\hline $\begin{array}{l}\text { Spleen and } \\
\text { gastrointestinal tract }\end{array}$ & Request amyloid stains (see "Amyloidosis"). & $\begin{array}{l}\text { Amyloidosis.* Metastatic calcification in } \\
\text { stomach. Tumor infiltrates generally are } \\
\text { inconspicuous. }\end{array}$ \\
\hline \multirow[t]{2}{*}{ Kidneys } & $\begin{array}{l}\text { Submit sample for histologic study. } \\
\text { Fix at least one specimen in alcohol (p. 129). } \\
\text { Decalcify (p. 97). }\end{array}$ & $\begin{array}{l}\text { Pyelonephritis.* Metastatic calcification; } \\
\text { calcium and urate casts. }\end{array}$ \\
\hline & Request amyloid stains (see "Amyloidosis"). & Amyloidosis.* \\
\hline Other organs & $\begin{array}{l}\text { Submit samples of liver, pancreas, adrenal } \\
\text { glands, thyroid, lymph nodes, and all grossly } \\
\text { involved tissues for histologic study. }\end{array}$ & $\begin{array}{l}\text { Amyloidosis;* myeloma infiltrates; evidence } \\
\text { of infection. Lymph nodes are rarely } \\
\text { involved. }\end{array}$ \\
\hline \multirow[t]{2}{*}{$\begin{array}{l}\text { Brain, spinal cord, } \\
\text { and peripheral nerves }\end{array}$} & $\begin{array}{l}\text { For removal and specimen preparation, } \\
\text { see pp. } 65,67 \text {, and } 79 \text {, respectively. }\end{array}$ & Cord compression after vertebral collapse. \\
\hline & $\begin{array}{l}\text { Request amyloid stains of peripheral nerves } \\
\text { (see "Amyloidosis"). }\end{array}$ & $\begin{array}{l}\text { Amyloidosis of peripheral nerves. } \\
\text { Demyelinating polyneuropathy in osteo- } \\
\text { sclerotic myeloma }(1) \text {. }\end{array}$ \\
\hline \multirow[t]{2}{*}{ Bones and bone marrow } & $\begin{array}{l}\text { For removal, prosthetic repair, and specimen } \\
\text { preparation of bone, see p. } 95 \text {. } \\
\text { For decalcification, see p. } 97 \text {; for maceration } \\
\text { of bone, see p. } 97 \text {. Also consult roentgenograms. }\end{array}$ & $\begin{array}{l}\text { Osteolytic tumors (Chapter 8, Fig. 8-2, } \\
\text { p. 98). }\end{array}$ \\
\hline & $\begin{array}{l}\text { For preparation of sections and smears of bone } \\
\text { marrow, see p. } 96 \text {. Snap-freeze bone marrow } \\
\text { if immuno-phenotype study of immunoglobulin- } \\
\text { producing cells is intended. }\end{array}$ & Plasmacellular bone marrow. \\
\hline
\end{tabular}

\section{References}

1. Lacy MQ, Gertz MA, Hanson CA, Inwards DJ, Kyle RA. Multiple myeloma associated with diffuse osteosclerotic bone lesions: a clinical entity distinct from osteosclerotic myeloma (POEMS syndrome). Am J Hematol 1997;56:288-293.

2. Tanaka M, Kimura R, Matsutani A, Zaitsu K, Oka Y, Oizumi K. Coexistence of chronic myelogenous leukemia and multiple myeloma. Case report and review of the literature. Acta Haematol 1998;99:221-223.

\section{Myelomeningocele (See “Meningocele.”)}

\section{Myelopathy/Myelitis}

Synonyms and Related Terms: Acute transverse myelitis; acute or subacute necrotizing myelopathy; angiodysgenetic necrotizing myelopathy; compression myelopathy; encephalomyelitis; * infectious myelitis; ischemic myelopathy; traumatic myelopathy; postvaccinal/postinfectious myelitis.

Possible Associated or Underlying Conditions: Angiodysgenetic (subacute) necrotizing myelopathy results from arteriovenous malformations* (Foix-Alajouanine syndrome); compression myelopathy may complicate degenerative vertebral disease, rheumatoid arthritis* or ankylosing spondylitis, ${ }^{*}$ bony abnormalities at the foramen magnum (basilar impression,* platybasia*), or infections (spinal epidural, tuberculous osteomyelitis), or neoplastic processes involving the vertebrae and meninges; subacute necrotizing myelopathy may be a manifestation of multiple sclerosis* or it may be a paraneoplastic condition, primarily associated with small cell carcinoma; traumatic myelopathy occurs with or without penetrating injury. Myelitis due to intramedullary infections may include bacterial or mycobacterial abscess, fungal or parasitic infections and viral infections, in particular, cytomegalovirus infection, ${ }^{*}$ Herpes zoster, * poliomyelitis, * and human immunodeficiency virus (HIV) infection (acquired immunodeficiency syndrome*). 


\begin{tabular}{lll}
\hline Organs and Tissues & Procedures & Possible or Expected Findings \\
\hline $\begin{array}{c}\text { Cerebrospinal fluid } \\
\begin{array}{c}\text { Chest and abdominal } \\
\text { organs; blood; spine }\end{array}\end{array}$ & $\begin{array}{l}\text { Submit sample for microbiologic study (p. 104). } \\
\text { If the myelitis is thought to be infectious, sub- } \\
\text { mit samples of blood and appropriate tissues } \\
\text { for microbiologic study. Procedures depend } \\
\text { on expected findings and grossly identified } \\
\text { abnormalities as listed in right-hand column. }\end{array}$ & $\begin{array}{l}\text { Bacterial, fungal, or viral infection. } \\
\text { Tuberculous osteomyelitis.* Cervical } \\
\text { spondylitis in acute transverse myelitis. }\end{array}$ \\
$\begin{array}{ll}\text { For removal and specimen preparation, } \\
\text { Manifestations of nutritional deficiencies } \\
\text { Brain, spinal cord, } \\
\text { spinal roots, and } \\
\text { sensory ganglia }\end{array}$ & $\begin{array}{l}\text { If there are abscesses or other acute infectious } \\
\text { lesions, submit material for culture, prepare }\end{array}$ & $\begin{array}{l}\text { Bacterial or fungal epidural or subdural } \\
\text { empyema or granuloma. }\end{array}$ \\
& $\begin{array}{l}\text { smears, and request Gram and Grocott's methen- } \\
\text { amine silver stains (p. 172). Request Luxol fast }\end{array}$ & \\
& blue stain for myelin and Bielschowsky's stain \\
& for axons (p. 172). & \\
\hline
\end{tabular}

\section{Myocardiopathy (See “Cardiomyopathy,...”)}

\section{Myocarditis}

Synonyms and Related Terms: Bacterial myocarditis; drug-induced myocarditis; fungal myocarditis; giant cell myocarditis; human immunodeficiency virus myocarditis; infectious myocarditis; interstitial myocarditis; Lyme carditis; protozoal myocarditis; rheumatic myocarditis; viral myocarditis.

Possible Associated Conditions: Bacterial, fungal, protozoal (toxoplasmosis) or viral infections (particularly coxsackievirus B); human immunodeficiency virus infection; hypersensitivity states (e.g., acute rheumatic fever); idiosyncratic or toxic reaction to drugs; irradiation; Lyme disease.

\begin{tabular}{|c|c|c|}
\hline Organs and Tissues & Procedures & Possible or Expected Findings \\
\hline Blood & $\begin{array}{l}\text { Submit sample for microbiologic (p. 102) and, } \\
\text { if, indicated, toxicologic and biochemical study } \\
\text { (p. 16). }\end{array}$ & Septicemia; viremia; toxemia. \\
\hline Pericardial sac & $\begin{array}{l}\text { Submit sample of pericardial exudate for micro- } \\
\text { biologic study (p. 102). Record volume of } \\
\text { exudate; centrifuge; prepare smear of pellet. } \\
\text { Request Gram and Grocott's methenamine } \\
\text { silver stains (p. 172). }\end{array}$ & Pericarditis.* \\
\hline \multirow[t]{3}{*}{ Heart } & Record heart weight. & \\
\hline & $\begin{array}{l}\text { Excise apical portion of myocardium and submit } \\
\text { for microbiologic study (p. 102). }\end{array}$ & $\begin{array}{l}\text { Infectious myocarditis (for possible } \\
\text { infectious agents, see above under } \\
\text { "Possible Associated Conditions). }\end{array}$ \\
\hline & $\begin{array}{l}\text { If infective endocarditis is suspected, follow } \\
\text { procedures described on p. 103. For histologic } \\
\text { sampling, see p. } 30 \text {. }\end{array}$ & Infective endocarditis.* \\
\hline $\begin{array}{l}\text { Other organs, tissues, } \\
\text { and body fluids }\end{array}$ & $\begin{array}{l}\text { Depending on clinical findings, submit samples } \\
\text { of cerebrospinal fluid (p. 104), serosal exudates } \\
\text { or transudates, intestinal contents, pulmonary } \\
\text { tissue, liver, spleen, kidneys, and cerebral tissue } \\
\text { for bacterial, fungal, and viral cultures. }\end{array}$ & $\begin{array}{l}\text { Bacterial, mycotic, protozoal, or viral } \\
\text { diseases. Postinfectious states. Manifesta- } \\
\text { tions of drug toxicity or hypersensitivity; } \\
\text { Pheochromocytoma. Burns.* Manifestations } \\
\text { of congestive heart failure:* }\end{array}$ \\
\hline
\end{tabular}

Myonecrosis, Clostridial (See “Gangrene, gas.”)

\section{Myopathy}

Synonyms and Related Terms: Congenital myopathy (central core disease, centronuclear myopathy, mitochondrial myopathy (see also "Epilepsy, myoclonus"); myotubular myopathy, nemaline or rod myopathy); familial myoglobinuria; familial periodic paralysis; myositis ossificans; myotonia congenita (Thomsen's disease).

NOTE: Muscular dystrophy and motor neuron disease are listed separately. 


\begin{tabular}{|c|c|c|}
\hline Organs and Tissues & Procedures & Possible or Expected Findings \\
\hline \multirow[t]{2}{*}{ External examination } & & $\begin{array}{l}\text { Kyphoscoliosis, pigeon breast, and pes cavus } \\
\text { in congenital myopathy. }\end{array}$ \\
\hline & Prepare soft tissue roentgenograms. & Myositis ossificans. \\
\hline Heart & $\begin{array}{l}\text { Submit samples for light microscopic (p. 30) } \\
\text { and electron microscopic (p. 132) study. } \\
\text { For study of the conduction system, } \\
\text { see p. } 26 .\end{array}$ & $\begin{array}{l}\text { Cardiomyopathy;* conduction system } \\
\text { abnormalities. }\end{array}$ \\
\hline Skeletal muscles & $\begin{array}{l}\text { For sampling and specimen preparation, } \\
\text { see p. } 80 \text {. Refer also to clinical findings. } \\
\text { Prepare specimens for electron microscopic } \\
\text { study (p. 132). }\end{array}$ & $\begin{array}{l}\text { Variable changes, depending on disease } \\
\text { entities. }\end{array}$ \\
\hline $\begin{array}{l}\text { Brain, spinal cord, } \\
\text { and spinal ganglia }\end{array}$ & $\begin{array}{l}\text { For removal and specimen preparation, } \\
\text { see pp. } 65,67 \text {, and } 69 \text {, respectively. }\end{array}$ & $\begin{array}{l}\text { Should be normal in primary myopathies } \\
\text { (important for differentiation from Werdnig- } \\
\text { Hoffmann and other primarily (central) } \\
\text { neurological disorders). }\end{array}$ \\
\hline Eyes and gonads & $\begin{array}{l}\text { If diagnosis is uncertain, prepare sections of } \\
\text { eyes (p. 85) and gonads. }\end{array}$ & $\begin{array}{l}\text { No cataracts and no gonadal atrophy } \\
\text { (important for differentiation from } \\
\text { muscular dystrophy). }\end{array}$ \\
\hline
\end{tabular}

Myotonia Congenita (Thomsen's Disease) (See “Myopathy.")

Myxedema (See “Hypothyroidism.”)

Myxoma, Heart (See “Tumor of the heart.") 


\section{Narcotic(s) (See "Dependence, drug(s), all types or type unspecified.")}

\section{Necrolysis, Toxic Epidermal}

Synonyms: Lyell's disease; scalded skin syndrome.

NOTE: Toxic epidermal necrolysis usually represent an adverse reaction to drugs or, rarely, other chemicals. If it appears linked to hyperacute graft-versus-host disease after allogeneic bone marrow transplantation (1), see also under that heading.

\begin{tabular}{cll}
\hline Organs and Tissues & Procedures & Possible or Expected Findings \\
\hline $\begin{array}{c}\text { External examination } \\
\text { and skin }\end{array}$ & $\begin{array}{l}\text { Record extent of skin lesions and prepare } \\
\text { photographs; prepare sections of affected } \\
\text { and unaffected skin. Request Gram stain } \\
\text { of sections and smears (p. 172). }\end{array}$ & $\begin{array}{l}\text { Extensive epidermal necrosis. } \\
\text { Shedding of granular and horny layers of } \\
\text { epidermis. }\end{array}$ \\
$\begin{array}{l}\text { Submit samples of blood (p. 102) and grossly } \\
\text { affected organs or tissues for microbiologic } \\
\text { and tissues }\end{array}$ & $\begin{array}{l}\text { Septicemia; staphylococcal infection of nose, } \\
\text { study. Other procedures depend on expected } \\
\text { findings or grossly identified abnormalities as and eyes, heart valves, urogenital } \\
\text { tract, and other sites. }\end{array}$ & $\begin{array}{l}\text { Bronchial epithelial detachment and bacterial } \\
\text { pneumonia (2). }\end{array}$ \\
\hline
\end{tabular}

\section{References}

1. Takeda H, Mitsuhashi Y, Kondo S, Kato Y, Tajima K. Toxic epidermal necrolysis possibly linked to hyperacute graft-versus-host disease after allogeneic bone marrow transplantation. J Dermatol 1997; 24:635-641.

2. Lebargy F, Wokenstein P, Gisselbrecht M, Lange F, Fleury-Feith J, Delclaux C, et al. Pulmonary complications in toxic epidermal necrolysis: a prospective clinical study. Intensive Care Med 1997;23:1237_ 1244.

\section{Necrosis, Aseptic, of Bone (See "Osteonecrosis.”)}

\section{Necrosis, Bilateral Renal Cortical (See "Coagulation, disseminated intravascular.")}

\section{Necrosis, Renal Tubular}

Synonyms and Related Terms: Acute kidney failure;* acute tubular necrosis; lower nephron nephrosis.

NOTE: The morphologic diagnosis of this condition may be difficult. The autopsy should be performed as soon as possible after death (see p. 5). Needle specimens of the kidneys obtained in the immediate postmortem period may yield acceptable material. If nephrotoxic drugs or chemicals are thought to be responsible for tubular necrosis, submit samples for toxicologic study (p. 16; see also under "Poisoning,..." and under name of suspected drug or poison). If tubular necrosis occurred after transfusion of incompatible blood, see under "Reaction to transfusion." Autopsy procedures depend on suspected underlying condition, such as trauma or infection.

\section{Neoplasia, Multiple Endocrine}

Synonyms and Related Terms: Multiple endocrine neoplasia (MEN), type 1 (parathyroid hyperplasia or adenoma; pancreatic islet cell hyperplasia, adenoma, or carcinoma; pituitary hyperplasia or adenoma); or type $\mathbf{2 A}$ (medullary thyroid carcinoma, parathyroid hyperplasia or adenoma; and pheochromocytoma); or type 2B (medullary thyroid carcinoma, pheochromocytoma, mucosal and gastrointestinal neuromas, and marfanoid features).

NOTE: In MEN, type 1, foregut carcinoids and subcutaneous and visceral lipomas also may be found. In type $2 \mathrm{~A}$, cutaneous lichen amyloidosis may be observed. Mixed syndromes include (1) familial pheochromocytoma and islet cell tumor, (2) von Hippel-Lindau syndrome, pheochromocytoma and islet cell tumor, (3) neurofibromatosis* with features of MEN1 or 2, and myxomas, spotty skin pigmentation, and generalized endocrine overactivity (Carney complex).

In all instances, the autopsy should be done as soon as possible after death so that tissues for biochemical study can be frozen without delay. 


\begin{tabular}{ll}
\hline Organs and Tissues & Procedures \\
\hline External examination & Record height, weight, habitus, and abnormal \\
& external features. \\
& Record appearance of skin and oral cavity.
\end{tabular}

Blood

Urine

Mediastinum

Neck organs

Small and large bowel

Stomach and duodenum

Pancreas

Adrenal glands

Ovaries

Testes

Other organs and tissues

Brain, spinal cord, and pituitary gland

Bones
Prepare skeletal roentgenograms. Studies should include long bones of extremities, bones of hands, feet, skull with calvarium, base of skull, and jaws. Snap-freeze specimen for hormone assay. Submit sample for determination of calcium concentration.

If chromosome studies are intended, see p. 102. Snap-freeze specimen for hormone assays. If pheochromocytoma is suspected, request catecholamine determination.

If a tumor is present, photograph in situ and after removal. See also under "Neck organs."

Dissect, photograph, and weigh thyroid and all parathyroid glands. Snap-freeze tumor tissue for histochemical and biochemical study. Prepare tumor tissue samples for electron microscopy (p. 132). Submit samples of normal and abnormal endocrine tissue and cervical lymph nodes for histologic study.

Also submit samples of cervical sympathetic chain and vagus nerves.

If tumors are present, prepare tissue for biochemical, histochemical, electron microscopic, and routine light microscopic study. See also above under "Neck organs." See above under "Small and large bowel."

Prepare 2-mm sagittal slices throughout entire pancreas. If tumor is present, follow procedures suggested above under "Neck organs." Submit samples of parapancreatic lymph nodes for histologic study.

Record weights and photograph. If tumors are present, follow procedures described under "Tumor of the adrenal glands" and above under "Neck organs."

Submit samples for histologic study. Record size and contents of cysts.

Record number and size of tumors. Submit samples for histologic study.

Procedures depend on expected findings or grossly identified abnormalities.

For removal and specimen preparation, see pp. 65,67 , and 71 , respectively. If tumor tissue is present, follow procedures suggested above under "Neck organs." For removal, prosthetic repair, and specimen preparation, see p. 95 .
Possible or Expected Findings

Marfanoid habitus; cushingoid features, features of acromegaly.*

Spotty skin pigmentation. Thickened lips; nodules in anterior third of tongue. Cleft palate.

Osteoporosis with osteoclastic cysts.

Acromegalic features.

Hypercalcemia.

Normal karyotype.

Increased catecholamine concentrations associated with pheochromocytoma. Thymoma and other mediastinal tumors or cysts. Cardiac myxoma.

Nodular (toxic) goiter; lymphocytic thyroiditis; multifocal hyperplasia of $\mathrm{C}$ cells of thyroid gland. Medullary carcinoma of thyroid with amyloid stroma. Chief cell hyperplasia of parathyroids. Parathyroid adenomas.

Ganglioneuromatosis.

Carcinoid tumors in small bowel. Diffuse ganglioneuromatosis of small and large bowel. Megacolon. Diffuse diverticulosis.

Carcinoid tumors. Ganglioneuromatosis. Diffuse gastric polyposis. Peptic ulcer of stomach or duodenum.*

Islet cell adenomas or carcinomas, usually of non-beta cell type.

Nodular hyperplasia of adrenal medulla; pheochromocytoms, frequently bilateral; primary pigmented nodular adrenal disease.

Ovarian cysts.

Large-cell calcifying Sertoli cell tumor.

See under "Synonyms and Related Terms" and under "Note."

Pinealoma.

Pituitary hyperplasia or adenoma, usually chromophobe type.

Osteoclastic osteoporosis secondary to hyperparathyroidism.* Benign cysts. 


\section{Nephritis}

NOTE: See under specific designation, such as "Glomerulonephritis" and "Pyelonephritis," or under name of suspected underlying condition, such as "Gout" or "Lupus erythematosus, systemic."

\section{Nephroblastoma (See "Tumor of the kidney(s).")}

\section{Nephrolithiasis}

Synonyms and Related Terms: Renal stones; urolithiasis.

Possible Associated Conditions: Carcinomatosis; Cushing's syndrome;* Cystinuria;* Fanconi syndrome;* hyperoxaluria;* hypervitaminosis D;* gout;* multiple myeloma;* osteoporosis;* polycystic renal disease;* primary hyperparathyroidism;* rheumatoid arthritis* (1); sarcoidosis* (2).

\begin{tabular}{|c|c|c|}
\hline Organs and Tissues & Procedures & Possible or Expected Findings \\
\hline Kidneys & $\begin{array}{l}\text { Remove kidneys, ureters, and urinary bladder } \\
\text { en bloc. Excise kidneys from convexity to } \\
\text { expose (but not cut) renal pelves and ureters. } \\
\text { Record size, number, and appearance of stones, } \\
\text { and save for chemical analysis. }\end{array}$ & $\begin{array}{l}\text { Pyelonephritis;* nephrocalcinosis; } \\
\text { granulomas; tumor infiltrates; manifestations } \\
\text { of the conditions listed below under "Other } \\
\text { organs." Calcium, cystine, struvite, and uric } \\
\text { acid stones may form staghorn calculi. }\end{array}$ \\
\hline $\begin{array}{l}\text { Ureters, urinary } \\
\text { bladder, and urethra }\end{array}$ & & $\begin{array}{l}\text { Obstructive uropathy with foreign bodies, } \\
\text { stones, strictures, valves, or other lesions. }\end{array}$ \\
\hline \multirow[t]{2}{*}{ Other organs } & Record heart weight. & Manifestations of hypertension (3). \\
\hline & $\begin{array}{l}\text { Dissect and record weights of all parathyroid } \\
\text { glands. Other procedures depend on suspected } \\
\text { underlying conditions, as listed above under } \\
\text { "Possible Associated Conditions." }\end{array}$ & Parathyroid hyperplasia. \\
\hline
\end{tabular}

\section{References}

1. Ito S, Nozawa S, Ishikawa H, Tohyama C, Nakazono K, Murasawa A, et al. Renal stones in patients with rheumatoid arthritis. J Rheumatol 1997;24:2123-2128.

2. Rizzato G, Colombo P. Nephrolithiasis as a presenting feature of chronic sarcoidosis: a prospective study. Sarcoidosis Vasculitis Diff Lung Dis 1996;13:167-172.

3. Madore F, Stampfer MJ, Rimm EB, Curhan GC. Nephrolithiasis and risk of hypertension. Am J Hypertension 1998;11:46-53.

\section{Nephropathy}

NOTE: See under name of suspected underlying condition, such as "Diabetes mellitus," "Disorder, electrolyte(s)" (hypercalcemia, potassium depletion), "Gout," "Hypertension (arterial), all types or type unspecified," or "Poisoning,..." (heavy metal). If kidney failure was present, procedures under that heading should also be followed. Renal tissue may need decalcification (p. 97) or fixation in water-free solution.

\section{Nephrosis, Lipoid (See “Glomerulonephritis.”)}

Neuroblastoma (See “Tumor of the peripheral nerves.”)

\section{Neurofibromatosis}

Synonyms and Related Terms: Neurofibromatosis type 1 (peripheral neurofibromatosis; von Recklinghausen's disease; von Recklinghausen's neurofibromatosis); neurofibromatosis, type 2 (bilateral acoustic neurofibromatosis).

NOTE: The term "von Recklinghausen's disease" should not be used for neurofibromatosis type 2. Because of the different manifestations, autopsy procedures for neurofibromatosis type 1 and type 2 are presented here separately.

Neurofibromatosis, type 1 (1)

\section{$\begin{array}{lll}\text { Organs and Tissues } \quad \text { Procedures } & \text { Possible or Expected Findings }\end{array}$}

External examination, skin, soft tissues, and skeletal system
Sample skin tumors, pigmented areas of skin, and soft tissue tumors for microscopic study. Prepare roentgenograms of skeletal abnormalities.
Arteries
Prepare longitudinal sections and request Verhoeff-van Gieson stains (p. 173).
Short stature; bone deformities (see below). Café au lait spots; axillary and/or inguinal freckling; dermal neurofibromas; rhabdomyosarcoma. Kyphoskoliosis; macrocephaly with asymmetry of facial and skull bones; sphenoid wing dysplasia; thinning, bending and pseudarthrosis of long bones (tibia). Fibromuscular dysplasia or renal and cervical arteries. 


\begin{tabular}{|c|c|c|}
\hline Organs and Tissues & Procedures & Possible or Expected Findings \\
\hline Gastrointestinal tract & Search for tumors. & Duodenal carcinoid. \\
\hline Adrenal glands & $\begin{array}{l}\text { Record weights. If a tumor is present, see also } \\
\text { under "Tumor of the adrenal gland(s)"). }\end{array}$ & $\begin{array}{l}\text { Pheochromocytoma (more common on } \\
\text { the left). }\end{array}$ \\
\hline $\begin{array}{l}\text { Brain, spinal cord, } \\
\text { and spinal roots; } \\
\text { base of skull }\end{array}$ & $\begin{array}{l}\text { For removal and specimen preparation, } \\
\text { see pp. } 65,67 \text {, and } 69 \text {, respectively. } \\
\text { Dissect cranial nerves (p. } 66 \text { ). }\end{array}$ & $\begin{array}{l}\text { Optic nerve gliomas; pilocytic astrocytomas; } \\
\text { glioblastomas; nerve sheath tumors. } \\
\text { Hydrocephalus* (due to aqueduct stenosis). }\end{array}$ \\
\hline Eyes and orbitae & $\begin{array}{l}\text { For removal and specimen preparation, } \\
\text { see p. } 85 \text {. }\end{array}$ & $\begin{array}{l}\text { Pigmented hamartomas, elevated on the } \\
\text { surface of the iris (Lisch nodules). } \\
\text { Neurofibromatosis of ciliary nerves; optic } \\
\text { nerve gliomas. }\end{array}$ \\
\hline $\begin{array}{l}\text { Peripheral nerves, } \\
\text { trunks, and plexuses }\end{array}$ & $\begin{array}{l}\text { For removal and specimen preparation, } \\
\text { see p. } 79 .\end{array}$ & $\begin{array}{l}\text { Benign neurofibromas and malignant } \\
\text { peripheral nerve sheath tumors, including } \\
\text { MPNST with divergent differentiation } \\
\text { (malignant triton tumor). Peripheral } \\
\text { neuropathy. }\end{array}$ \\
\hline $\begin{array}{l}\text { Other organs and } \\
\text { tissues; bones and }\end{array}$ & & $\begin{array}{l}\text { Neurofibromas rarely in other organs such } \\
\text { as the liver. }\end{array}$ \\
\hline bone marrow & $\begin{array}{l}\text { For removal of bones and prosthetic repair, } \\
\text { see p. } 95 \text {. For bone marrow preparations, } \\
\text { see p. } 96 \text {. If leukemia is expected, see also } \\
\text { under that heading. }\end{array}$ & $\begin{array}{l}\text { For skeletal abnormalitis, see above under } \\
\text { "External examination, skin, soft tissues, and } \\
\text { skeletal system." Bone marrow and other } \\
\text { tissues may show features of juvenile chronic } \\
\text { myeloid leukemia.* }\end{array}$ \\
\hline
\end{tabular}

Neurofibromatosis, type 2 (2)

NOTE: In this condition, lesions in the brain and cranial nerves, spinal cord, and spinal roots may be schwannomas (including bilateral vestibular schwannomas); multiple meningiomas; gliomas (generally of spinal cord), mostly ependymomas (75\%) and pilocytic astrocytomas; or schwannosis of spinal dorsal root entry zones. Intracortical meningioangiomatosis; glial hamartia (intracortical, basal ganglia, thalamus, cerebellum, and dorsal horns of spinal cord) and cerebral calcifications also may be found.

\begin{tabular}{lll}
\hline Organs and Tissues & Procedures & Possible or Expected Findings \\
\hline $\begin{array}{l}\text { External examination } \\
\text { and skin }\end{array}$ & Sample skin tumors for histologic study. & Schwannomas of skin. \\
$\begin{array}{c}\text { Brain with cranial } \\
\text { nerves, spinal cord, } \\
\text { and spinal roots }\end{array}$ & $\begin{array}{l}\text { For removal and specimen preparation, } \\
\text { see pp. 65, 67, and 69, respectively. }\end{array}$ & $\begin{array}{l}\text { A multitude of tumors or tumor-like lesions } \\
\text { may be found, as listed above under "Note." }\end{array}$ \\
$\begin{array}{l}\text { Eyes } \\
\text { Peripheral nerves }\end{array}$ & $\begin{array}{l}\text { For removal and specimen preparation, see p. 85. } \\
\text { For removal and specimen preparation, see p. 79. }\end{array}$ & $\begin{array}{l}\text { Posterior lens opacities; retinal hamartomas. } \\
\text { Peripheral neuropathy with focal } \\
\text { schwannomatous changes or onion-bulb-like } \\
\end{array}$ \\
& & Schwann cell or perineural cell proliferation. \\
\hline
\end{tabular}

\section{References}

1. Von Deimling A, Krone W. Neurofibromatosis type 1. In: Pathology and Genetics of Tumours of the Nervous System. Kleihues P, Cavenee WK, eds. IARC, Lyon, 1997, pp. 172-174.
2. Louis DN, Wiestler OD. Neurofibromatosis type 2. In: Pathology and Genetics of Tumours of the Nervous System. Kleihues P, Cavenee WK, eds. IARC, Lyon, 1997, pp. 175-178.

\section{Neuropathy}

Synonyms and Related Terms: Multiple neuropathy; peripheral neuropathy; polyneuropathy; polyradiculoneuropathy; retrobulbar neuropathy (nutritional amblyopia).

\begin{tabular}{lll}
\hline Organs and Tissues & Procedures & Possible or Expected Findings \\
\hline $\begin{array}{l}\text { Spinal cord, } \\
\text { dorsal root ganglia, } \\
\text { and peripheral nerves }\end{array}$ & For removal and specimen preparation, & Fiber loss; segmental demyelination or \\
wallerian degeneration, or both.
\end{tabular}




\begin{tabular}{lll}
\hline Organs and Tissues & Procedures & Possible or Expected Findings \\
\hline $\begin{array}{l}\text { Spinal cord, } \\
\text { dorsal root ganglia, } \\
\text { and peripheral nerves } \\
\text { (continued) }\end{array}$ & $\begin{array}{l}\text { Sural nerve is commonly used for peripheral } \\
\text { nerve study. Stains for paraffin sections may } \\
\text { include trichrome, LFB/PAS, methyl violet, } \\
\text { and Congo red (p. 172). Stain semithin sections } \\
\text { with toluidin blue. } \\
\text { Procedures depend on expected findings or } \\
\text { grossly identified abnormalities as listed in } \\
\text { right-hand column. }\end{array}$ & $\begin{array}{l}\text { Distribution of lesions depends on type of } \\
\text { neuropathy. Vasculitis; amyloid deposition } \\
\text { or other manifestations of the underlying } \\
\text { condition may be present. }\end{array}$ \\
& $\begin{array}{l}\text { Manifestations of underlying conditions, } \\
\text { such as alcoholism,* celiac sprue; }\end{array}$ \\
& $\begin{array}{l}\text { diabetes mellitus, hormonal disorder, } \\
\text { immune connective tissue disease, malignant } \\
\text { tumor, malnutrition, pellagra, peripheral }\end{array}$ \\
& $\begin{array}{l}\text { vascular disease, megaloblastic anemia,* } \\
\text { poisoning (with heavy metals, organo- } \\
\text { phosphates, or drugs), post-gastrectomy } \\
\text { syndrome, or uremia. }\end{array}$ \\
\hline
\end{tabular}

\section{Neurosyphilis, Adult (See “Syphilis, acquired.”)}

\section{Neurosyphilis, Congenital}

NOTE: See also "Syphilis, congenital."

\begin{tabular}{|c|c|c|}
\hline Organs and Tissues & Procedures & Possible or Expected Findings \\
\hline External examination & $\begin{array}{l}\text { Record presence or absence of abnormal } \\
\text { external features, as listed in right-hand column. } \\
\text { Prepare photographs. }\end{array}$ & $\begin{array}{l}\text { Hydrocephalus; * dental deformities } \\
\text { (Hutchinson's teeth); saddle nose; frontal } \\
\text { bossing of skull; saber shins; nasal septal } \\
\text { perforation; rhagades; ulnar deviation of } \\
\text { fingers. }\end{array}$ \\
\hline Cerebrospinal fluid & $\begin{array}{l}\text { Submit samples for biochemical, cytologic, } \\
\text { and microbiologic study (p. 104). }\end{array}$ & See below under "Brain and spinal cord." \\
\hline Blood & Submit sample for serologic study. & \\
\hline Brain and spinal cord & $\begin{array}{l}\text { For removal and specimen preparation, see } \\
\text { pp. } 65 \text { and } 67 \text {, respectively. For histologic } \\
\text { sections, request Warthin-Starry stain for } \\
\text { spirochetes (p. 173). }\end{array}$ & $\begin{array}{l}\text { Chronic syphilitic meningitis, encephalitis, } \\
\text { and myelitis. }\end{array}$ \\
\hline Eyes & $\begin{array}{l}\text { For removal and specimen preparations, } \\
\text { see p. } 85 \text {. }\end{array}$ & Interstitial keratitis; chorioretinitis. \\
\hline
\end{tabular}

\section{Nitrogen Oxide (See "Poisoning, gas.”)}

\section{Nocardiosis}

Synonym: Nocardia spp. infection.

NOTE: (1) Collect all tissues that appear to be infected. (2) Request culture for nocardiosis. (3) Request Gram and Ziehl-Neelsen stains (p. 172). (4) Usually, no special precautions are indicated. (5) Generally, serologic studies are not available. (6) This is not a reportable disease.

Possible Associated Conditions: Acquired immunodeficiency syndrome (AIDS);* alveolar lipoproteinosis of lungs; * anthracosilicosis; asthma;* chronic obstructive pulmonary disease; leukemia, ${ }^{*}$ post-transplantation, and other immunosuppressed or dysproteinemic states; systemic lupus erythematosus.*

\begin{tabular}{ll}
\hline Organs and Tissues & Procedures \\
\hline External examination & $\begin{array}{l}\text { Sample involved skin for culture and histo- } \\
\text { logic study. }\end{array}$ \\
Pleural cavities, & $\begin{array}{l}\text { Record presence (and sites) of pleural, pericardial, } \\
\text { and chest-wall fistulas. Prepare smears from } \\
\text { pericardium, and lungs } \\
\text { exudate or from caseating material. Culture } \\
\text { consolidated areas. If diagnosis has already been } \\
\text { confirmed, perfuse lungs with formalin (p. 47). }\end{array}$
\end{tabular}

Possible or Expected Findings

Cutaneous abscess (1).

Acute necrotizing nocardial pneumonia with abscesses or sinus formation into surrounding tissues; empyema. 


\begin{tabular}{lll}
\hline Organs and Tissues & Procedures & Possible or Expected Findings \\
\hline $\begin{array}{l}\text { Pulmonary and media- } \\
\text { stinal lymph nodes }\end{array}$ & $\begin{array}{l}\text { Submit samples for culture and histologic } \\
\text { study (p. 102). }\end{array}$ & Regional lymphadenitis. \\
Other organs & $\begin{array}{l}\text { Submit samples from all organs and tissues } \\
\text { with suspicious gross lesions for culture and } \\
\text { histologic study (p. 102). }\end{array}$ & $\begin{array}{l}\text { Poorly encapsulated abscesses of any organ; } \\
\text { endocarditis (2). }\end{array}$ \\
\hline
\end{tabular}

\section{References}

1. Merigou D, Beylot-Barry M, Ly S, Deutre MS, Texier-Maugein J, Billes P, Beylot C. Primary cutaneous Nocardia asteroides infection after heart transplantation. Dermatol 1998;196:246-247.

2. Dhawan VK, Gadgil VG, Paliwal YK, Chavroshiya PS, Trivedi RR. Native valve endocarditis due to Nocardia-like organisms. Clin Inf Dis 1998;27:902-904.

\section{Nutrition, Parenteral}

Related Term: Total parenteral nutrition.
NOTE: Air embolism* or blood loss may have occurred if line became detached from the catheter hub. Metabolic complications such as fluid overload or disturbances of acid-base and electrolyte balance often cannot be diagnosed reliably at autopsy.

The disease(s) that may have necessitated parenteral nutrition therapy are not considered here; they include the acquired immunodeficiency syndrome (AIDS); ${ }^{*}$ cancer cachexia; inflammatory bowel disease; liver or kidney failure;* severe pancreatitis; short bowel syndrome, and others.

\begin{tabular}{|c|c|c|}
\hline Organs and Tissues & Procedures & Possible or Expected Findings \\
\hline External examination & $\begin{array}{l}\text { Inspect skin site where catheter enters tunnel } \\
\text { to venous access (e.g., subclavian or jugular } \\
\text { vein; femoral vein). } \\
\text { Inspect gastrostomy or jejunostomy sites, } \\
\text { if present. } \\
\text { Prepare chest roentgenogram. }\end{array}$ & $\begin{array}{l}\text { Infection at any site along the catheter. } \\
\text { Displacement of intravenous catheter; } \\
\text { fractures or tears in catheter. } \\
\text { Enteral nutrition may have been combined } \\
\text { with parenteral nutrition. Infection and } \\
\text { displacement of tube may occur. } \\
\text { Pneumothorax.* }\end{array}$ \\
\hline Vitreous & For removal, see p. 85 & Electrolyte disorders.* \\
\hline Blood & Submit sample for culture (p. 102). & Septicemia (Staphylococcus or Candida). \\
\hline $\begin{array}{l}\text { Internal examination } \\
\text { of major veins }\end{array}$ & $\begin{array}{l}\text { Follow catheter from access site to its open end, } \\
\text { generally in the superior vena cava. If clots are } \\
\text { found, particulalry at the catheter tip, submit } \\
\text { material for culture and prepare sections and } \\
\text { smears (order Gram stain, p. 172). }\end{array}$ & $\begin{array}{l}\text { Infection at any site along the catheter. } \\
\text { Displacement of catheter with perforation } \\
\text { of wall of vein; hemothorax; pneumothorax.* }\end{array}$ \\
\hline Urine & & Hypercalciuria \\
\hline Trachea and lungs & $\begin{array}{l}\text { If an enteral feeding tube is in place, search for } \\
\text { feeding fluid in tracheobronchial tree and lungs. }\end{array}$ & $\begin{array}{l}\text { Aspiration* and aspiration } \\
\text { bronchopneumonia. }\end{array}$ \\
\hline Gallbladder & Record nature of contens. & Cholelithiasis* \\
\hline Liver & $\begin{array}{l}\text { Record weight. Submit samples for histologic } \\
\text { study. }\end{array}$ & $\begin{array}{l}\text { Chronic liver disease with cholestasis and } \\
\text { cirrhosis, particularly in children }(1,2) \text {. }\end{array}$ \\
\hline Gastrointestinal tract & If feeding tube is in place, determine location. & $\begin{array}{l}\text { Nasogastric, nasoduodenal, nasojejunal, and } \\
\text { other tubes (see also above under "External } \\
\text { examination"). }\end{array}$ \\
\hline Skeletal system & & Osteoporosis. \\
\hline
\end{tabular}

\section{References}

1. Fein B, Holt P. Hepatobiliary complications of total parenteral nutrition. J Clin Gastroenterol 1994;18:62-66.

2. Mullock FG, Ishak KG. Total parenteral nutrition: a histopathologic analysis of the liver changes in 20 children. Mod Pathol 1994;7:190-194. 


\section{$\mathbf{O}$}

\section{Obesity}

Related Term: Morbid obesity; primary obesity; secondary obesity.

\begin{tabular}{|c|c|c|}
\hline Organs and Tissues & Procedures & Possible or Expected Findings \\
\hline $\begin{array}{l}\text { External examination } \\
\text { and subcutaneous tissue }\end{array}$ & $\begin{array}{l}\text { Record body weight and length (for body } \\
\text { mass index, see p. 567), distribution of fat, } \\
\text { and thickness of subcutaneous fat layers. }\end{array}$ & Decubital ulcers; intertriginous infections. \\
\hline Breast & & Breast cancer $(1)$ \\
\hline Blood & & Hyperlipoproteinemia. \\
\hline Heart and arteries & $\begin{array}{l}\text { Record weight of heart and thickness of } \\
\text { ventricular walls. }\end{array}$ & $\begin{array}{l}\text { Cardiac hypertrophy* caused by pulmonary } \\
\text { or systemic hypertension. }{ }^{*} \text { Cor pulmonale in } \\
\text { Pickwickian syndrome. Atherosclerosis. }\end{array}$ \\
\hline Liver & $\begin{array}{l}\text { Record weight. Submit samples for histo- } \\
\text { logic study. Request trichrome stain (p. 172). }\end{array}$ & $\begin{array}{l}\text { Hepatomegaly and fatty changes; } \\
\text { steatohepatitis with or without cirrhosis (2). }\end{array}$ \\
\hline Stomach & Record features of surgical procedures. & $\begin{array}{l}\text { Weight-reducing surgery (gastroplasty or } \\
\text { gastric bypass). }\end{array}$ \\
\hline Pancreas & Cut in thin, sagittal slices. & Insulinoma (rare). \\
\hline Other organs & $\begin{array}{l}\text { Procedures depend on expected findings or } \\
\text { grossly identified abnormalities as listed in } \\
\text { right-hand column. }\end{array}$ & $\begin{array}{l}\text { Manifestations of Cushing's syndrome, }{ }^{*} \text { type } \\
\text { II diabetes mellitus, }{ }^{*} \text { hypothyroidism,* } \\
\text { hypothalamic disorders (Laurence-Moon- } \\
\text { Biedl syndrome* or Prader-Willi syndrome) } \\
\text { and systemic hypertension. }{ }^{*} \text { Nephrotic } \\
\text { syndrome* is a rare complication of obesity. }\end{array}$ \\
\hline
\end{tabular}

\section{References}

1. Pujol P, Galtier-Dereure F, Bringer J. Obesity and breast cancer risk. Hum Reprod 1997;12:116-125.

2. Ludwig J, McGill DB, Lindor KD. Nonalcoholic steatohepatitis. J Gastroenterol Hepatol 1997;12:398-403.

\section{Obstruction, Acute Airway}

Synonyms and Related Terms: Aspiration; bolus death; "café coronary"; croup; restaurant death.

NOTE: If permission has been obtained, remove neck organs through straight incision from chest to chin to avoid dislodging a foreign body. If dissection has to be accomplished from chest, neck of unembalmed cadaver should remain well extended during procedure. Inspect larynx and trachea from above and below, respectively, before opening them carefully along the posterior midline.

\begin{tabular}{lll}
\hline Organs and Tissues & Procedures & Possible or Expected Findings \\
\hline
\end{tabular}

Oral cavity

Blood
Submit sample for alcohol and other toxicologic studies (p. 16). If infectious airway obstruction is suspected, submit sample for microbiologic study (p. 102).
Edentulous mouth; malfitting dentures; food or other foreign body in oral cavity. Evidence of alcohol intoxication.* 


\begin{tabular}{lll}
\hline Organs and Tissues & Procedures & Possible or Expected Findings \\
\hline Larynx and pharynx & $\begin{array}{l}\text { For dissection procedures, see above under } \\
\text { "Note." }\end{array}$ & \\
& $\begin{array}{l}\text { Photograph larynx with foreign body } \\
\text { or tumor. }\end{array}$ & $\begin{array}{l}\text { Foreign body (food bolus; denture); } \\
\text { malignant tumor of pharynx or larynx. }\end{array}$ \\
& $\begin{array}{l}\text { If infectious obstructive laryngitis is expected, } \\
\text { follow procedures described under "Laryngitis." }\end{array}$ & $\begin{array}{l}\text { Obstructive laryngitis* with epiglottiditis } \\
\text { infants. }\end{array}$ \\
& Record weights. & $\begin{array}{l}\text { Acute pulmonary edema. } \\
\text { Chronic neurologic disorder. }\end{array}$ \\
Bungs & For removal and specimen preparation, & \\
& see pp. 65 and 67, respectively. & \\
\hline
\end{tabular}

\section{Obstruction, Arteriomesenteric}

\begin{tabular}{lll}
\hline Organs and Tissues & Procedures & Possible or Expected Findings \\
\hline $\begin{array}{l}\text { External examination } \\
\begin{array}{l}\text { Intestinal tract } \\
\text { and mesentery }\end{array}\end{array}$ & $\begin{array}{l}\text { For mesenteric arteriography, see p. 54. } \\
\text { Photograph obstruction in situ. }\end{array}$ & $\begin{array}{l}\text { Lax abdominal musculature. } \\
\text { Superior mesenteric artery or abnormal } \\
\text { arterial branch crosses and obstructs third } \\
\text { portion of duodenum; dilatation of duodenum } \\
\text { proximal to obstruction. }\end{array}$ \\
\hline
\end{tabular}

\section{Obstruction, Biliary (See "Atresia, biliary," "Cholelithiasis," and "Tumor of the bile ducts} (extrahepatic or hilar or of papilla of Vater.")

\section{Obstruction, Chronic Airway (See “Asthma," "Bronchitis, chronic," and “Emphysema.")}

\section{Obstruction, Hepatic Vein (See "Syndrome, Budd-Chiari.")}

\section{Obstruction, Inferior Vena Cava}

\begin{tabular}{|c|c|c|}
\hline Organs and Tissues & Procedures & Possible or Expected Findings \\
\hline $\begin{array}{l}\text { Chest organs and } \\
\text { abdominal organs }\end{array}$ & $\begin{array}{l}\text { Remove thoracoabdominal viscera en masse } \\
\text { (Letulle technique, p. } 3 \text { ) and dissect inferior } \\
\text { vena cava from posterior aspect. Phlebography } \\
\text { from lower extremities requires much contrast } \\
\text { medium and interferes with clean dissection. }\end{array}$ & $\begin{array}{l}\text { Adhesions; aortic aneurysm;* congenital } \\
\text { malformation; enlargement of pancreas; } \\
\text { annular pancreas; cirrhosis* and other } \\
\text { conditions that may cause hepatomegaly } \\
\text { (see also under "Syndrome, hepatorenal"); } \\
\text { IVC filter with entrapped thromboembolus; } \\
\text { surgical ligation; thrombosis; tumor } \\
\text { (especially renal cell or hepatocellular } \\
\text { carcinoma). }\end{array}$ \\
\hline
\end{tabular}

\section{Obstruction, Portal Vein (See "Hypertension, portal.")}

\section{Obstruction, Pulmonary Venous}

Synonyms and Related Terms: Congenital stenosis or atresia of pulmonary veins; pulmonary veno-occlusive disease; pulmonary venous hypertension.

\begin{tabular}{lll}
\hline Organs and Tissues & Procedures & Possible or Expected Findings \\
\hline External examination & Prepare chest roentgenogram. & Mediastinal fibrosis or tumor. \\
Chest cavity & Record appearance of mediastinum and hilum & Idiopathic mediastinal or pulmonary hilar \\
& of lungs. Remove chest organs en bloc. & fibrosis; mediastinal radiation fibrosis; \\
& If an infectious process is suspected, submit & sclerosing mediastinitis;* mediastinal \\
& samples for microbiologic study. & neoplasm; granulomas (histoplasma,
\end{tabular}




\begin{tabular}{lll}
\hline Organs and Tissues & Procedures & Possible or Expected Findings \\
\hline Lungs & $\begin{array}{l}\text { For pulmonary venography, see p. 50. } \\
\text { Perfuse lungs with formalin (p. 47). } \\
\text { Submit samples of tissues from periphery of } \\
\text { lungs and from perihilar areas. Record sites } \\
\text { from where tissues were sampled. Request } \\
\text { Verhoeff-van Gieson stain (p. 173). } \\
\text { Procedures depend on expected findings or } \\
\text { grossly identified abnormalities as listed in } \\
\text { Heart }\end{array}$ & $\begin{array}{l}\text { Congenital stenosis or atresia of pulmonary } \\
\text { veins. Pulmonary veno-occlusive disease } \\
\text { with old thrombi. Pulmonary venous } \\
\text { hypertensive changes, most prominent } \\
\text { in lower lobes. }\end{array}$ \\
& Thrombus or myxoma of left atrium; mitral \\
& or aortic stenosis;* chronic heart failure.*
\end{tabular}

\section{Obstruction, Superior Mesenteric Artery (or Vein)}

\begin{tabular}{|c|c|c|}
\hline Organs and Tissues & Procedures & Possible or Expected Findings \\
\hline $\begin{array}{l}\text { Superior mesenteric } \\
\text { artery system }\end{array}$ & $\begin{array}{l}\text { For mesenteric arteriography, see p. } 55 \text {. For } \\
\text { dissection, en masse removal is recommended } \\
\text { (p. 3). Open aorta posteriorly and record } \\
\text { appearance of celiac and mesenteric artery } \\
\text { orifices. }\end{array}$ & Atherosclerosis; emboli. \\
\hline $\begin{array}{l}\text { Superior mesenteric } \\
\text { vein system }\end{array}$ & $\begin{array}{l}\text { Dissect portal, splenic, and superior mesenteric } \\
\text { vein branches in situ. }\end{array}$ & Thrombosis; migratory thrombophlebitis. \\
\hline Intestine & Locate and photograph abnormalities in situ. & $\begin{array}{l}\text { Infarction; strangulation; volvulus; } \\
\text { intussusception. }\end{array}$ \\
\hline Other organs & $\begin{array}{l}\text { Procedures depend on expected findings or } \\
\text { grossly identified abnormalities as listed in } \\
\text { right-hand column. }\end{array}$ & $\begin{array}{l}\text { Thromboembolic disease; atherosclerosis or } \\
\text { vasculitis complicated by arterial occlusion; } \\
\text { peritonitis; * tumor; previous operations or } \\
\text { cirrhosis* complicated by venous } \\
\text { thromboses. }\end{array}$ \\
\hline
\end{tabular}

\section{Occlusion (See “Obstruction,...”)}

\section{Ochronosis (See “Alkaptonuria.”)}

\section{Onchocerciasis}

Synonyms and Related Terms: Disseminated microfilariasis; Onchocerca volvulus infection; river blindness.

NOTE: (1) Collect cerebrospinal fluid, blood, urine, and all tissues that appear to be infected. (2) Request parasitologic examination. (3) Request Giemsa and PAS stains (p. 172). (4) No special precautions are indicated. (5) No serologic studies are available. (6) This is not a reportable disease.

\begin{tabular}{|c|c|c|}
\hline Organs and Tissues & Procedures & Possible or Expected Findings \\
\hline $\begin{array}{l}\text { External examination, } \\
\text { skin, subcutaneous } \\
\text { tissue, and lymph nodes }\end{array}$ & Submit samples for histologic study. & $\begin{array}{l}\text { Granulomatous inflammation with fibrosis; } \\
\text { cutaneous lymphedema with leathery, } \\
\text { depigmented, thickened skin; pendulous sacs } \\
\text { of inguinal or femoral lymph nodes. }\end{array}$ \\
\hline Cerebrospinal fluid & $\begin{array}{l}\text { Submit sample for parasitologic study } \\
\text { (p. 104). See also above under "Note." }\end{array}$ & Microfilariae may be present. \\
\hline Abdomen & $\begin{array}{l}\text { If ascitic fluid is present, record volume } \\
\text { and submit sample for parasitologic study. }\end{array}$ & Microfilariae may be present. \\
\hline Blood and urine & $\begin{array}{l}\text { Prepare smears. Centrifuge urine prior to } \\
\text { smear preparation. }\end{array}$ & Microfilariae may be present. \\
\hline Other organs & $\begin{array}{l}\text { Procedures depend on expected findings or } \\
\text { grossly identified abnormalities as listed in } \\
\text { right-hand column. Submit samples for histo- } \\
\text { logic study. }\end{array}$ & $\begin{array}{l}\text { Microfilariae or, in rare instances, adult } \\
\text { Onchocerca volvulus may be found in } \\
\text { internal organs, such as lungs, liver, spleen, } \\
\text { pancreas, and kidneys. }\end{array}$ \\
\hline
\end{tabular}




\begin{tabular}{lll}
\hline Organs and Tissues & Procedures & Possible or Expected Findings \\
\hline Eyes & For removal and specimen preparation, & $\begin{array}{l}\text { Microfilariae, in anterior chamber and cornea } \\
\text { of eyes as seen with a slit lamp; punctate } \\
\text { kee p. 85. }\end{array}$ \\
& & keratitis; uveitis. \\
\hline
\end{tabular}

\section{Opiate(s) (See “Dependence, drug(s), all types or type unspecified.”)}

\section{Organophosphate(s) (See "Poisoning, organophosphate(s).")}

\section{Origin of Both Great Arteries from Right Ventricle (See "Ventricle, double outlet right.")}

\section{Ornithosis}

Synonyms and Related Terms: Chlamydia infection; psittacosis; parrot fever.

NOTE: (1) Collect all tissues that appear to be infected. (2) Request cultures for ornithosis. Consult with microbiology laboratory before obtaining postmortem specimens. (3) Stains are not helpful in demonstrating the organism. (4) Special precautions are indicated (p. 146). (5) Serologic studies are available from the state health department laboratories (p. 135). (6) This is a reportable disease.

\begin{tabular}{|c|c|c|}
\hline Organs and Tissues & Procedures & Possible or Expected Findings \\
\hline $\begin{array}{l}\text { External examination } \\
\text { and skin }\end{array}$ & Photograph lesion. & Pale macular rash (Horder's spots); jaundice. \\
\hline Chest & $\begin{array}{l}\text { Record volume of effusions; submit samples } \\
\text { for microbiologic and cytologic study. }\end{array}$ & Pleural effusions.* \\
\hline Blood & Submit sample for serologic study. & \\
\hline Heart & Submit samples for histologic study (p. 30). & Pericarditis* and myocarditis.* \\
\hline Lungs & $\begin{array}{l}\text { Perfuse one lung with formalin (p. } 47 \text { ). } \\
\text { Submit multiple samples for histologic study. }\end{array}$ & $\begin{array}{l}\text { Lymphocytic pneumonitis, which may be } \\
\text { focally hemorrhagic and necrotizing; } \\
\text { inclusion bodies. }\end{array}$ \\
\hline Liver and spleen & $\begin{array}{l}\text { Record weights and sample for histologic } \\
\text { study. }\end{array}$ & $\begin{array}{l}\text { Inclusion bodies in Kupffer cells; } \\
\text { hepatosplenomegaly. }\end{array}$ \\
\hline Other organs & Extensive histologic sampling is indicated. & $\begin{array}{l}\text { Inclusion bodies may occur in kidneys, } \\
\text { adrenal glands, brain and meninges, and other } \\
\text { organs. }\end{array}$ \\
\hline
\end{tabular}

\section{Osteitis Deformans (See “Disease, Paget's, of bone.”)}

\section{Osteoarthritis}

Related Term: Degenerative joint disease.

Possible Associated Conditions: Acromegaly;* acute and chronic trauma; alkaptonuria;* congenital or developmental bone diseases (e.g., congenital hip dislocation); diabetes mellitus;* Gaucher's disease;* hemochromatosis;* hyperparathyroidism;* hypothyroidism;* obesity;* Wilson's disease.*

\begin{tabular}{|c|c|c|}
\hline Organs and Tissues & Procedures & Possible or Expected Findings \\
\hline \multirow[t]{2}{*}{ External examination } & & $\begin{array}{l}\text { Heberden's nodes at interphalangeal joints of } \\
\text { fingers. }\end{array}$ \\
\hline & Prepare skeletal roentgenograms. & $\begin{array}{l}\text { Degenerative changes, primarily of spine, hip } \\
\text { joints, and knee joints. }\end{array}$ \\
\hline \multirow[t]{2}{*}{ Joints } & $\begin{array}{l}\text { For removal, prosthetic repair, and specimen } \\
\text { preparation, see p. } 96 \text {. Submit samples } \\
\text { of osteocartilaginous and synovial tissues } \\
\text { for histologic study; sagittal or frontal saw } \\
\text { section through spine provides for best routine } \\
\text { evaluation. }\end{array}$ & $\begin{array}{l}\text { Histologic and macroscopic degeneration of } \\
\text { cartilage; exposure of subchrondral bone; } \\
\text { formation of marginal osteophytes; bone } \\
\text { cysts; synovial fibrosis; hypertrophic } \\
\text { synovitis. }\end{array}$ \\
\hline & $\begin{array}{l}\text { If artificial joints (e.g., hip or knee) had been } \\
\text { implanted, record state of implant site. }\end{array}$ & Lose joint prostheses. \\
\hline
\end{tabular}




\section{Osteoarthropathy, Hypertrophic}

Synonyms: Hypertrophic pulmonary osteoarthropathy; pachydermoperiostosis (idiopathic hypertrophic osteoarthropathy [1]).

NOTE: In all instances, an underlying disease must be identified; they include cardiac disease (cyanotic congenital heart dis- ease with right-to-left shunt; infective endocarditis*); gastroesophageal reflux (3); neoplasms of lungs, esophagus, intestine, and liver; chronic liver disease; inflammatory bowel disease;* pulmonary disease (e.g., abscess; * bronchiectasis; ${ }^{*}$ cystic fibrosis; ${ }^{*}$ empyema;* emphysema;* lipoid pneumonia* (4); Pneumocystis pneumonia; sarcoidosis; * tuberculosis*); hyperthyroidism.*

\begin{tabular}{lll}
\hline Organs and Tissues & Procedures & Possible or Expected Findings \\
\hline
\end{tabular}

External examination

Prepare roentgenograms of extremities.

Bones

Elastic arteries

Other organs
For removal, prosthetic repair, and specimen preparation, see p. 95 .

Record presence of aneurysms (thoracic aorta, subclavian) or arteriovenous fistula of brachial vessels.

If abdominal aortic aneurysm had been surgically repaired, search for evidence of graft infection (2).

Procedures depend on expected findings or grossly identified abnormalities as listed above under "Note."
Clubbing of fingers or toes (see below under "Elastic arteries"); swelling of extremities. Periosteal new bone formation in distal shafts of bones of forearms and legs. All bones of extremities may be involved (see Chapter 8 , Fig. 8-3, p. 99).

See above under "External examination."

Unilateral clubbing.

Clubbing of toes but not of fingers.

See above under "Note."

\section{References}

1. Sinha GP, Curtis P, Haigh D, Lealman GT, Dodds W, Bennett CP. Pachydermoperiostitis in childhood. Br J Rheum 1997;36:1224-1247.

2. Stevens M, Helms C, El-Khoury G, Chow S. Unilateral hypertrophic osteoarthropathy associated with aortofemoral graft infection. Am J Roentgenol 1998;170:1584-1586.
3. Greenwald M, Couper R, Laxer R, Durie P, Silverman E. Gastroesophageal reflux and esophagitis-associated hypertrophic osteoarthropathy. J Pediatr Gastroenterol Nutr 1996;23:178-181.

4. Hugosson C, Bahabri S, Rifai A, al-Dalaan A. Hypertrophic osteoarthropathy caused by lipoid pneumonia. Pediatr Radiol 1995;25:482-483.

\section{Osteochondrodysplasia (See “Achondroplasia” and Dyschondroplasia, Ollier's.”)}

\section{Osteodystrophy, Renal (See "Failure, kidney.")}

\section{Osteogenesis Imperfecta}

Synonyms and Related Terms: Lobstein's syndrome; Osteogenesis imperfecta congenita; OI type I, II, and III; osteogenesis imperfecta cystica; osteogenesis imperfecta tarda; osteopsathyrosis; van der Hoeve's syndrome; Vrolik's disease (infantile form of $\mathrm{OI}$ ).

NOTE: Contact the Osteogenesis Imperfecta Foundation, 804 W. Diamond Avenue, Suite 210, Gaithersburg, MD 20878, phone: (301) 947-0083.

\begin{tabular}{|c|c|c|}
\hline Organs and Tissues & Procedures & Possible or Expected Findings \\
\hline $\begin{array}{l}\text { External examination } \\
\text { and skin }\end{array}$ & $\begin{array}{l}\text { Record body weight and length, shape of skull, } \\
\text { shape of extremities, and appearance of eyes } \\
\text { and teeth. } \\
\text { Prepare sections of skin for histologic study. } \\
\text { Prepare skeletal roentgenograms. Submit fascia } \\
\text { lata for tissue culture (p. 109) to reference } \\
\text { laboratory for classification of collagen } \\
\text { metabolism defect. }\end{array}$ & $\begin{array}{l}\text { Soft skull bones (caput membranaceum); } \\
\text { short and deformed long bones; blue sclerae } \\
\text { (Lobstein's syndrome); abnormal teeth. } \\
\text { Thin skin. } \\
\text { Narrow bones with multiple fractures in } \\
\text { various phases of healing; exuberant callus } \\
\text { formation; compression of vertebrae with } \\
\text { weight bearing. }\end{array}$ \\
\hline Blood & $\begin{array}{l}\text { Obtain serum to assay for alkaline phosphatase } \\
\text { activity. Postmortem and determination of }\end{array}$ & $\begin{array}{l}\text { Normal values rule out hypophosphatasia. } \\
\text { Hypercalcemia (1). }\end{array}$ \\
\hline
\end{tabular}

calcium concentration is unreliable. 


\begin{tabular}{|c|c|c|}
\hline Organs and Tissues & Procedures & Possible or Expected Findings \\
\hline Urine & $\begin{array}{l}\text { Submit urine for determination of phospho- } \\
\text { ethanolamine concentration. }\end{array}$ & \\
\hline Gastrointestinal tract & Photograph abnormalities in situ. & $\begin{array}{l}\text { Fecal impaction due to pelvic deformity in } \\
\text { OI, type III (2). }\end{array}$ \\
\hline Bones & $\begin{array}{l}\text { For removal, prosthetic repair, and specimen } \\
\text { preparation, see p. } 95 \text {. Samples for histologic } \\
\text { study should include areas of endochondral } \\
\text { and periosteal bone formation. }\end{array}$ & $\begin{array}{l}\text { Normal epiphysis; deficient ossification of } \\
\text { metaphysis, diaphysis and cortex; multiple } \\
\text { fractures with fibrosis and callus formation. }\end{array}$ \\
\hline Tendons and ligaments & Submit samples for histologic study. & $\begin{array}{l}\text { Thin, translucent structures that may have } \\
\text { ruptured. }\end{array}$ \\
\hline Eyes & $\begin{array}{l}\text { For removal and specimen preparation, } \\
\text { see p. } 85 \text {. }\end{array}$ & Thin sclerae (3). \\
\hline Parathyroid glands & $\begin{array}{l}\text { Record weights and submit samples for histo- } \\
\text { logic study. }\end{array}$ & Normal parathyroid glands. \\
\hline Middle ears & $\begin{array}{l}\text { For exposure of middle ears, see p. } 72 \text {. } \\
\text { This procedure is particularly indicated if } \\
\text { patient had been deaf. }\end{array}$ & Otosclerosis (van der Hoeve's syndrome). \\
\hline
\end{tabular}

\section{References}

1. Williams CJ, Smith RA, Ball RJ, Wilkinson H. Hypercalcemia in osteogenesis imperfecta treated with pamidronate. Arch Dis Child 1997;76: 169-170.

2. Lee JH, Gamble JG, Moore RE, Rinsky LA. Gastrointestinal problems in patients who have type-III osteogenesis imperfecta. J Bone Joint Surg 1995;77:1352-1356.

3. Mietz H, Kasner L, Green WR. Histopathologic and electron-microscopic features of corneal and scleral collagen fibers in osteogenesis imperfecta type III. Graefes Arch Clin Exp Ophthalmol 1997;235: 405-410.

\section{Osteomalacia}

Related Terms: Osteoporosis; ${ }^{*}$ renal osteodystrophy; rickets.

NOTE: Many possible causes of osteomalacia may not be apparent at autopsy, e.g., sodium fluoride or diphosphonate toxicity or use of anticonvulsant drugs.

Possible Associated Conditions: Neurofibromatosis; ${ }^{\text {hypo- }}$ phosphatasia (inborn error of metabolism) and hypophosphatemic states (1); parenteral nutrition;* vitamin D deficiency.* (See also below under "Other organs and tissues.")

\begin{tabular}{ll}
\hline Organs and Tissues & Procedures \\
\hline External examination & Prepare skeletal roentgenograms.
\end{tabular}

Bones

Other organs and tissues

Parathyroid glands
For removal, prosthetic repair, and specimen preparation, see p. 95. Consult roentgenograms. Request cyanuric chloride stain (p. 172). Procedures depend on expected findings or grossly identified abnormalities as listed in right-hand column.

Record weights and submit samples for histologic study.

\section{Possible or Expected Findings}

Pseudofractures (Looser's zones), most common at axillary borders of scapulae, ischial and pubic rami, femoral necks, and ribs.

Abundant osteoid. May be associated with fibro-osteoclastic osteoporosis (renal osteodystrophy).

Changes secondary to chronic kidney failure* with phosphate depletion, ${ }^{*}$ generalized renal tubular disorders (Fanconi syndrome*), vitamin D deficiency,* and chronic gastrointestinal, pancreatic or hepatobiliary diseases. Benign or malignant giant cell and other mesenchymal tumors or carcinoma of the prostate may cause (oncogenous) osteomalacia.

If chronic renal disease was present, secondary parathyroid hyperplasia can be expected.

\section{Reference}

1. Clarke BL, Wynne AG, Wilson DM, Fitzpatrick LA. Osteomalacia associated with adult Fanconi syndrome: clinical and diagnostic features. Clin Endocrinol 1995;43:479-490. 


\section{Osteomyelitis}

\begin{tabular}{|c|c|c|}
\hline Organs and Tissues & Procedures & Possible or Expected Findings \\
\hline \multirow[t]{2}{*}{ External examination } & & Swelling; fistulas. \\
\hline & Prepare skeletal roentgenograms. & Bone defect(s) and focal osteosclerosis. \\
\hline \multirow[t]{2}{*}{ Bones } & $\begin{array}{l}\text { For submission of material for microbiologic } \\
\text { study, see p. 102. Record presence of contiguous } \\
\text { infections. }\end{array}$ & $\begin{array}{l}\text { Bacterial or fungal infections, most common } \\
\text { in metaphyseal region of bones; paravertebral } \\
\text { or psoas abscess in osteomyelitis of spine. }\end{array}$ \\
\hline & $\begin{array}{l}\text { Submit samples for histologic study. Request } \\
\text { Gram stain and Grocott's methenamine silver } \\
\text { stain for fungi (p. 172). }\end{array}$ & $\begin{array}{l}\text { Bacterial or fungal osteomyelitis, with or } \\
\text { without cavitation and fistulas. }\end{array}$ \\
\hline Other organs & $\begin{array}{l}\text { Procedures depend on expected findings or } \\
\text { grossly identified abnormalities as listed in } \\
\text { right-hand column. }\end{array}$ & $\begin{array}{l}\text { Trauma, surgery, insertion of prosthesis, } \\
\text { generalized (1) or contiguous infection, } \\
\text { inflammatory bowel disease }(2) \text {, diabetes } \\
\text { mellitus, }{ }^{*} \text { and peripheral vascular diseases. }\end{array}$ \\
\hline
\end{tabular}

\section{References}

1. Copie-Bergmann C, Niedobitek G, Mangham DC, Selves J, Baloch K, Diss TC, et al. Epstein-Barr virus in B-cell lymphomas associated with chronic suppurative inflammation. J Pathol 1997;183:287-292.

2. Freeman HJ. Osteomyelitis and osteonecrosis in inflammatory bowel disease. Can J Gastroenterol 1997;11:601-606.

\section{Osteonecrosis}

Synonyms and Related Terms: Aseptic necrosis of bone; avascular necrosis of bone; idiopathic osteonecrosis; Perthes' disease; postfracture osteonecrosis; renal transplant associated osteonecrosis.

NOTE: Possible underlying conditions include chronic alcoholism, ${ }^{*}$ decompression sickness, ${ }^{*}$ diseases that have been treated with high doses of corticosteroids (1), Gaucher's disease, ${ }^{*}$ human immunodeficiency virus infection* (2), tuberculosis* (1), sickle cell disease, ${ }^{*}$ systemic lupus erythematosus, ${ }^{*}$ tuberculosis* $(2)$, and other conditions.

\begin{tabular}{lll}
\hline Organs and Tissues & Procedures & Possible or Expected Findings \\
\hline Blood & $\begin{array}{l}\text { Submit sample for biochemical study. } \\
\text { Bones and joints }\end{array}$ & $\begin{array}{l}\text { Fyperlipidemia; hyperuricemia. } \\
\text { preparation, see p. 95. If osteonecrosis is } \\
\text { suspected because one of the possible underlying } \\
\text { conditions (see above) is present, prepare saw } \\
\text { sections through femoral heads, medial femoral } \\
\text { condyles, and heads of humeri. }\end{array}$ \\
& $\begin{array}{l}\text { Procedures depend on suspected underlying } \\
\text { causing avascular necrosis of bone. }\end{array}$ & \\
conditions, as listed above under "Note." & See above under "Note." \\
\hline
\end{tabular}

\section{References}

1. Freeman HJ. Osteomyelitis and osteonecrosis in inflammatory bowel disease. Can J Gastroenterol 1997;11:601-606.

2. Rademaker J, Dobro JS, Solomon G. Osteonecrosis and human immunodeficiency virus infection. J Rheumatol 1997;24:601-604.

\section{Osteopetrosis}

Synonyms and Related Terms: Albers-Schönberg disease; autosomal-dominant osteopetrosis; carbonic anhydrase-II deficiency; malignant infantile osteopetrosis (1); marble bone disease.

NOTE: Manifestations of renal tubular acidosis may have been a clinical complication.

Possible Associated Conditions: Bone marrow transplantation* (for infantile osteopetrosis). Anemia, recurrent infections, bleeding, and bruises may have resulted from myelophthisis associated with osteopetrosis. Upper airway obstruction in malignant infantile osteopetrosis may have necessitated tracheostomy (1).

\begin{tabular}{lll}
\hline Organs and Tissues & Procedures & Possible or Expected Findings \\
\hline External examination & Record weight and height. & $\begin{array}{l}\text { Growth failure in infants; hypoplastic } \\
\text { dentition. }\end{array}$
\end{tabular}




\begin{tabular}{|c|c|c|}
\hline Organs and Tissues & Procedures & Possible or Expected Findings \\
\hline $\begin{array}{l}\text { External examination } \\
\text { (continued) }\end{array}$ & Prepare skeletal roentgenograms. & $\begin{array}{l}\text { Increased density of all bones; bone } \\
\text { deformities; narrowing of marrow spaces; } \\
\text { malformation of the mastoid and paranasal } \\
\text { sinuses; osteomyelitis* of jaws with facial } \\
\text { fistulas. Exophthalmos. }\end{array}$ \\
\hline Liver and spleen & $\begin{array}{l}\text { Record weights and sizes; submit samples for } \\
\text { histologic study. }\end{array}$ & $\begin{array}{l}\text { Hepatosplenomegaly; extramedullary } \\
\text { hematopoiesis. }\end{array}$ \\
\hline Kidneys & $\begin{array}{l}\text { Record weights and sizes; submit samples for } \\
\text { histologic study. }\end{array}$ & $\begin{array}{l}\text { Renal tubular acidosis in carbonic anhydrase } \\
\text { II deficiency (2). }\end{array}$ \\
\hline Parathyroid glands & $\begin{array}{l}\text { Record weights and submit samples for histo- } \\
\text { logic study. }\end{array}$ & Normal parathyroid glands. \\
\hline Brain & $\begin{array}{l}\text { For removal and specimen preparation, } \\
\text { see p. } 65 \text {. }\end{array}$ & $\begin{array}{l}\text { Hydrocephalus; * cerebral calcification. } \\
\text { See also under "Skeletal system and skull." }\end{array}$ \\
\hline Eyes & $\begin{array}{l}\text { Remove for study in patients with visual } \\
\text { disturbances (p. 85). }\end{array}$ & Retinal degeneration. \\
\hline Skeletal system with skull & $\begin{array}{l}\text { For removal, prosthetic repair, and specimen } \\
\text { preparation of bones, see p. } 95 \text {. Expose base } \\
\text { of skull (p. } 71 \text { ) and record size of nerve } \\
\text { foramina (optic, acoustic, and other cranial } \\
\text { nerves). If there is evidence of infection, } \\
\text { expose nasal cavities and prepare histologic } \\
\text { sections. } \\
\text { Histologic samples should include bone and } \\
\text { bone marrow. }\end{array}$ & $\begin{array}{l}\text { Spondylolysis in children (3). Rhinogenic } \\
\text { osteomyelitis; atrophy of cranial nerves } \\
\text { after compression at foramina. (This may } \\
\text { have caused optic atrophy or deafness, or } \\
\text { both. See also above under "External exam- } \\
\text { ination.") Otitis media* (1); osteomalacia* } \\
\text { or rickets may complicate osteopetrosis. } \\
\text { Myelophthisis secondary to osteopetrosis. }\end{array}$ \\
\hline
\end{tabular}

\section{References}

1. Stocks RM, Wang WC, Thompson JW, Stocks MC 2nd, Horwitz EM. Malignant infantile osteopetrosis: otolaryngological complications and management. Arch Otolaryngol Head Neck Surg 1998;124:689-694.

2. Nagai R, Kooh SW, Balfe JW, Fenton T, Halperin ML. Renal tubular acidosis and osteopetrosis with carbonic anhydrase II deficiency: pathogenesis of impaired acidification. Pediatr Nephrol 1997;11:633-636.

3. Martin RP, Deane RH, Collett V. Spondylolysis in children who have osteopetrosis. J Bone Joint Surg 1997;79:1685-1689.

\section{Osteoporosis}

Synonym and Related Terms: Drug-induced osteoporosis; idiopathic osteoporosis; juvenile osteoporosis; osteopenia; type I or type II osteoporosis; postmenopausal osteoporosis.

\section{NOTE:}

In heritable osteoporotic disorders of connective tissue (osteogenesis imperfecta, ${ }^{*}$ Marfan's syndrome, ${ }^{*}$ and others) are presented separately. For "osteomalacia," see above. For "osteodystrophy," see under "Failure, kidney."

Possible Associated Conditions: Acromegaly;* chronic alcoholism;* chronic obstructive pulmonary disease; chronic kidney failure* (1); Cushing's syndrome;* debilitating disease (various kinds, often with immobilization); diabetes mellitus* (2); epilepsy;* hyperthyroidism (2);* hypogonadism; malabsorption syndrome;* malnutrition;* primary biliary cirrhosis;* rheumatoid arthritis;* scurvy;* steroid therapy or anticonvulsant medication.

\begin{tabular}{ll}
\hline Organs and Tissues & Procedures \\
\hline External examination & Record body length and shape of spine. \\
& Prepare skeletal roentgenograms.
\end{tabular}

Other organs

Parathyroid glands
Procedures depend on expected underlying conditions, as listed in right-hand column and above under "Possible Associated Conditions."

Record weights and submit samples for histologic study.
Possible or Expected Findings

Kyphosis or kyphoscoliosis.

Gross deformities of bones; alveolar bone loss; fractures of vertebrae, wrist, hip, humerus, or tibia. Calvarium uninvolved in most uncomplicated cases. Malnutrition* and senility.

In acute cases, metastatic calcifications with nephrocalcinosis. For other findings, see above under "Possible Associated Conditions."

Normal parathyroid glands in uncomplicated cases. Hyperparathyroidism* (1) (without osteitis fibrosa) may be present, however. 


\begin{tabular}{|c|c|c|}
\hline$\overline{\text { Organs and Tissues }}$ & Procedures & Possible or Expected Findings \\
\hline Bones & $\begin{array}{l}\text { For removal, prosthetic repair, and specimen } \\
\text { preparation, see p. } 95 \text {. Record appearance } \\
\text { of saw sections of vertebral column, calvarium, } \\
\text { and femur. Submit samples for histologic study. }\end{array}$ & $\begin{array}{l}\text { Features of osteitis fibrosa (osteoclastic } \\
\text { osteoporosis; see "Hyperparathyroidism") } \\
\text { or osteomalacia* exclude the diagnosis of } \\
\text { uncomplicated osteoporosis. Osteoporosis, } \\
\text { which may be localized, occurs in various } \\
\text { neoplastic (e.g., mastocytosis) and } \\
\text { inflammatory diseases. }\end{array}$ \\
\hline
\end{tabular}

\section{References}

1. Nishizawa Y, Morii H. Osteoporosis and atherosclerosis in chronic renal failure. Osteoporos Int 1997;7 Suppl 3:S188-S192.

2. Rosen CJ. Endocrine disorders and osteoporosis. Curr Opin Rheumatol 1997;9:355-361.

\section{Otitis Media}

\begin{tabular}{lll}
\hline Organs and Tissues & Procedures & Possible or Expected Findings \\
\hline External examination & Examine external ear canal. & $\begin{array}{l}\text { Draining, foul-smelling greasy material } \\
\text { associated with acquired cholesteatoma. }\end{array}$ \\
$\begin{array}{l}\text { Brain and base of skull } \\
\text { with middle ears }\end{array}$ & $\begin{array}{l}\text { For removal and specimen preparation, } \\
\text { see pp. 65 and 72, respectively. For micro- }\end{array}$ & $\begin{array}{l}\text { Bacterial or viral infection, with or without } \\
\text { mastoid osteitis. }\end{array}$ \\
& biologic examination, see p. 102. & $\begin{array}{l}\text { Neck abscess, sinus thrombosis (1) and brain } \\
\text { abscess* and meningitis* may complicate } \\
\text { otitis media. }\end{array}$ \\
\hline
\end{tabular}

\section{Reference}

1. Garcia RD, Baker AS, Cunningham MJ, Weber AL. Lateral sinus thrombosis associated with otitis media and mastoiditis in children. Pediatr Inf Dis J 1995;14:617-623.

\section{Otosclerosis}

NOTE: Otosclerosis may be a measles-virus-associated disease $(l)$ and therefore, studies to rule out a past infection may be indicated.

\begin{tabular}{lll}
\hline Organs and Tissues & Procedures & Possible or Expected Findings \\
\hline Middle and inner ears & $\begin{array}{l}\text { For removal and specimen preparation, } \\
\text { see p. 72. For current methods of temporal } \\
\text { bone studies, see ref. (2). }\end{array}$ & $\begin{array}{l}\text { Spongy bone in the capsule of the labyrinth. } \\
\text { Trabeculae of woven bone show pagetoid } \\
\text { changes. If stapedectomy had been done, a } \\
\text { prosthesis may be in place. }\end{array}$ \\
\hline
\end{tabular}

\section{References}

1. Niedermeyer HP, Arnold W. Otosclerosis: a measles virus associated inflammatory disease. Acta Oto-Laryngol 1995;115:300-303.

2. Cherukupally SR, Merchant SM, Rosowski JJ. Correlations between pathologic changes in the stapes and conductive hearing loss in otosclerosis. Ann Otyol Rhinol Laryngol 1998;107:319-326.

\section{Oxaluria (see "Hyperoxaluria.")}


Palsy, Progressive Bulbar (See "Disease, motor neuron.")

\section{Palsy, Progressive Supranuclear}

Synonyms: Steele-Richardson-Olszewski syndrome.

\begin{tabular}{lll}
\hline Organs and Tissues & Procedures & Possible or Expected Findings \\
\hline Brain & For removal and specimen preparation, see & Brain is externally normal or mildly atrophic. \\
& p. 65. Histologic samples should include all & Characteristic is midbrain atrophy with \\
sites listed in right-hand column. Request & aqueduct dilatation and depigmentation of \\
Bielschowsky stain for paraffin sections & the substantia nigra. Neuronal loss with \\
(p. 172) and histochemical stains with ubiquitin & reactive gliosis, associated with neuro- \\
and tau proteins. & fibrillary tangles (globose tangles). Primarily \\
& affected are globus pallidus, subthalamic \\
& nucleus, red nucleus, substantia nigra, \\
& tectum, periaqueductal gray matter, and \\
& dentate nucleus (grumose degeneration). \\
\hline
\end{tabular}

\section{Palsy, Pseudobulbar (See “Disease, motor neuron.”)}

\section{Pancreatitis}

Related Terms: Acute pancreatitis; alcoholic pancreatitis; chronic (or chronic fibrosing) pancreatitis; interstitial pancreatitis.

NOTE: Some causes of pancreatitis such as adverse drug reactions (e.g., due to azathioprine, furosemide, or estrogens) cannot be diagnosed at autopsy.

Possible Associated Conditions: Acute fatty liver of pregnancy; apolipoprotein CII deficiency; cystic fibrosis; ${ }^{*}$ hyperparathyroidism;* kidney transplantation.* Status post endoscopic retrograde cholangiopancreatography.

\begin{tabular}{|c|c|c|}
\hline Organs and Tissues & Procedures & Possible or Expected Findings \\
\hline \multirow[t]{2}{*}{$\begin{array}{l}\text { External examination } \\
\text { and skin }\end{array}$} & $\begin{array}{l}\text { Record appearance of subcutaneous fat tissue } \\
\text { and prepare histologic sections. }\end{array}$ & Fat tissue necroses. \\
\hline & Prepare skeletal roentgenograms. & Intraosseous calcification (femur and tibia). \\
\hline Vitreous & $\begin{array}{l}\text { Submit sample for determination of calcium, } \\
\text { potassium, and sodium concentrations (p. } 85 \text { ). }\end{array}$ & Increased calcium concentration. \\
\hline Abdominal cavity & $\begin{array}{l}\text { If there are abscesses or other inflammatory } \\
\text { changes, aspirate pus or exudate and submit } \\
\text { sample for microbiologic study (p. 102). }\end{array}$ & $\begin{array}{l}\text { Exudate or abscesses in lesser sac or other } \\
\text { peritoneal pockets; ascites. }\end{array}$ \\
\hline Chest cavity & $\begin{array}{l}\text { Record volume of effusions. Submit sample } \\
\text { for lipase and amylase determination. }\end{array}$ & Pleural effusions.* \\
\hline Blood & $\begin{array}{l}\text { Submit sample for microbiologic study (p. 102). } \\
\text { Postmortem determination of calcium level is } \\
\text { unreliable. Study of viral antibodies may be } \\
\text { indicated. }\end{array}$ & $\begin{array}{l}\text { Hypercalcemia or hypertriglyceridemia. } \\
\text { Cultures or serologic studies may be positive } \\
\text { for cytomegalovirus infection,* infectious } \\
\text { mononucleosis,* mumps,* scarlet fever,* } \\
\text { typhoid fever,* or viral hepatitis. }\end{array}$ \\
\hline
\end{tabular}




\begin{tabular}{|c|c|c|}
\hline Organs and Tissues & Procedures & Possible or Expected Findings \\
\hline Heart and coronary arteries & & Coronary thrombosis. \\
\hline Lungs & & Pulmomary embolism.* \\
\hline $\begin{array}{l}\text { Liver, gallbladder, } \\
\text { extrahepatic bile ducts, } \\
\text { and pancreas; splenic } \\
\text { and portal veins }\end{array}$ & $\begin{array}{l}\text { After removal of pancreas, open pancreatic } \\
\text { ducts. Record type of entry of pancreatic ducts } \\
\text { in relationship to common bile duct. } \\
\text { Open common bile duct (including papilla of } \\
\text { Vater) and splenic and portal veins in situ. } \\
\text { For cholangiography and pancreatography, } \\
\text { see pp. } 56 \text { and 57, respectively. Remove liver } \\
\text { and gallbladder, and record contents of gall- } \\
\text { bladder. Sample pancreas, liver, and grossly } \\
\text { identifiable abnormalities for histologic study. }\end{array}$ & $\begin{array}{l}\text { Pancreatic and peripancreatic fat tissue } \\
\text { necroses; abscesses; hemorrhages; } \\
\text { pseudocysts; calcification. Pancreatolithiasis. } \\
\text { Carcinoma of pancreas (1). Stenosis of } \\
\text { intrapancreatic common bile duct in } \\
\text { chronic pancreatitis. Obstruction of ampulla } \\
\text { by ulcer in Crohn's disease* or duodenal } \\
\text { diverticulum. Ascariasis. Choledocholithiasis. } \\
\text { Splenic vein thrombosis; may also involve } \\
\text { portal vein. Cholecystitis* and cholelithiasis.* } \\
\text { Alcoholic liver disease. }\end{array}$ \\
\hline \multirow[t]{2}{*}{ Other organs and tissues } & $\begin{array}{l}\text { Procedures depend on expected findings or } \\
\text { grossly identified abnormalities as listed in } \\
\text { right-hand column. }\end{array}$ & $\begin{array}{l}\text { Extrahepatic manifestations of chronic } \\
\text { alcoholism,* chronic renal failure; hyper- } \\
\text { parathyroidism* }(2), \text { multiple myeloma, }{ }^{*} \\
\text { polyarteritis nodosa, }{ }^{*} \text { thrombotic thrombo- }\end{array}$ \\
\hline & $\begin{array}{l}\text { If polyarteritis nodosa is suspected, study } \\
\text { arteries of lower extremities. For possible } \\
\text { systemic infections, see above under "Blood." }\end{array}$ & $\begin{array}{l}\text { cytopenic purpura }(3) \text {; sarcoidosis, }{ }^{*} \text { surgical } \\
\text { and other types of trauma, systemic lupus } \\
\text { erythematosus,* and other conditions. }\end{array}$ \\
\hline Peripheral veins & $\begin{array}{l}\text { For venography, see p. } 120 \text {. For removal of } \\
\text { peripheral veins, see p. } 34 \text {. }\end{array}$ & Venous thromboses and thrombophlebitis. \\
\hline Bones and bone marrow & $\begin{array}{l}\text { For removal, prosthetic repair, and specimen } \\
\text { preparation of bones, see p. } 95 \text {. } \\
\text { For preparation of sections and smears of bone } \\
\text { marrow, see p. } 96 \text {. }\end{array}$ & Necroses. Multilacunar osteolysis. \\
\hline Eyes & For removal and specimen preparation, see p. 85 . & Retinopathy (rare) (4). \\
\hline
\end{tabular}

\section{References}

1. Andren-Sandberg A, Dervenis C, Lowenfels B. Etiologic links between chronic pancreatitis and pancreatic cancer. Scand J Gastroenterol 1997; 32:97-103.

2. Inabnet WB, Baldwin D, Daniel RO, Staren ED. Hyperparathyroidism and pancreatitis during pregnancy. Surgery 1996;119:710-713.
3. Silva VA. Thrombotic thrombocytopenic purpura/hemolytic uremic syndrome secondary to pancreatitis. Am J Hematol 1995;50:53-56.

4. Soledad Donoso Flores M, Narvaez Rodriguez I, Lopez Bernal I, del Mar Alcalde Rubio M, Galvan Ledesma A, et al. Retinopathy as a systemic complication of acute pancreatitis. Am J Gastroenterol 1995; 90:321-324.

\section{Pancytopenia}

Related Terms: Agranulocytosis;* aplastic anemia; Fanconi's anemia.*

NOTE: Some causes of pancytopenia such as adverse drug reactions (e.g., due to antimetabolites, sulfa drugs, or gold compounds) cannot be diagnosed at autopsy.

Possible Associated Conditions: Acquired immunodeficiency syndrome;* diffuse eosinophilic fasciitis; paroxysmal nocturnal hemoglobinuria; ;regnancy;* radiation injury;* systemic lupus erythematosus; * systemic viral infections and viral hepatitis; transfusion-related graft-versus-host disease.*

\begin{tabular}{|c|c|c|}
\hline Organs and Tissues & Procedures & Possible or Expected Findings \\
\hline External examination & $\begin{array}{l}\text { Record skin abnormalities and prepare } \\
\text { photographs. }\end{array}$ & $\begin{array}{l}\text { Jaundice; ulcers of skin. } \\
\text { Thrombocytopenic hemorrhages. }\end{array}$ \\
\hline Other organs and blood & $\begin{array}{l}\text { If toxicity of drugs or chemicals is } \\
\text { suspected, submit appropriate tissue } \\
\text { samples for toxicologic study. } \\
\text { If viral infection is suspected as a cause, } \\
\text { submit material for serologic or other } \\
\text { diagnostic studies. }\end{array}$ & $\begin{array}{l}\text { Manifestations of leukopenia or thrombo- } \\
\text { cytopenia (infections, including septicemia; } \\
\text { hemorrhages; various types of pneumonia*). } \\
\text { Systemic viral infection; viral hepatitis.* } \\
\text { Radiation injury.* }\end{array}$ \\
\hline
\end{tabular}




\begin{tabular}{|c|c|c|}
\hline Organs and Tissues & Procedures & Possible or Expected Findings \\
\hline $\begin{array}{l}\text { Neck organs with } \\
\text { oropharynx, tongue, } \\
\text { tonsils, and soft palate }\end{array}$ & $\begin{array}{l}\text { Request Gram and Grocott's methenamine silver } \\
\text { stains for bacteria and fungi, respectively (p. 172); } \\
\text { photograph lesions. }\end{array}$ & Ulcers in mouth and pharynx. \\
\hline Lymph nodes and spleen & Record weight of spleen. & Reactive lymphadenitis and splenitis. \\
\hline Rectum and vagina & See above under "Neck organs"). & Rectal and vaginal ulcers. \\
\hline Bone marrow & For specimen preparation, see p. 96. & $\begin{array}{l}\text { Bone marrow may be hypocellular, normal, } \\
\text { or hypercellular. Hematologic malignancies } \\
\text { (myelodysplastic syndromes) or metastases } \\
\text { may be present. Agnogenic myeloid } \\
\text { metaplasia,* osteopetrosis, }{ }^{*} \text { or storage } \\
\text { diseases are rare findings. }\end{array}$ \\
\hline
\end{tabular}

Panencephalitis, Subacute Sclerosing (See "Encephalitis, all types or type unspecified.")

\section{Panhypopituitarism (See "Insufficiency, pituitary.")}

\section{Panniculitis}

Synonyms and Related Terms: Calcifying panniculitis; histiocytic cytophagic panniculitis; mesenteric panniculitis (mesenteric lipodystrophy); "sclerema neonatorum."

NOTE: The term Weber-Christian disease described systemic panniculitis with fever, bleeding, pulmonary and pancre- atic lesions, and other abnormalities also involving lungs and pancreas, among others. However, this condition is not a specific entity and thus, the name has become obsolete. The term histiocytic cytophagic panniculitis is more descriptive and preferred.

Leukemia* and subcutaneous T-cell lymphoma* may closely simulate panniculitis.

Possible Associated Conditions: Alpha ${ }_{1}$-antitrypsin deficiency;* dermatomyositis;* rheumatoid arthritis;* scleroderma and morphea; Sjögren's syndrome;* systemic lupus erythematosus.*

\begin{tabular}{ll}
\hline Organs and Tissues & Procedures \\
\hline External examination, & Record extent and character of skin lesions. \\
skin, subcutaneous & Record size, location, and gross appearance of \\
tissue, and breasts & subcutaneous nodules. Submit tissue samples \\
& for histologic study of grossly unaffected skin, \\
& skin lesions, and subcutaneous nodules. \\
& Request Verhoeff-van Gieson, Gram, and \\
& Grocott's methenamine silver stains (p. 172).
\end{tabular}

Request S-100 protein stain. Ascertain that cell infiltrates are not leukemic or lymphomatous (1).

\section{Chest}

Heart

Lungs

Liver and spleen

Mesentery and intestine
Submit tissue samples for histologic study of pretracheal and pericardial fat tissue.

Record weight. For histologic sampling, see p. 30. Submit one lobe for microbiologic study (p. 103). Perfuse one lung with formalin (p. 47). Prepare frozen sections and request Sudan stain (p. 173). Record weights and submit samples for histologic study. Request PAS/diastase stain of liver (p. 173).

For mesenteric arteriography, see p. 55.

For in situ fixation of small bowel, see p. 54 . Submit tissue samples for histologic study of mucosal lesions and grossly uninvolved portions of intestine.

\section{Possible or Expected Findings}

Dimpling of skin; necroses; fistulas. Panniculitis with subcutaneous nodules in trunk, breasts, and thighs. Calcification may occur in breast tissue but also at other sites (e.g., in kidney failure*). Pancreatic enzymeinduced fat necroses associated with severe pancreatitis. Widespread hardening of fat tissue with rupture of fat cells and crystal formation in "sclerema neonatorum." Focal traumatic panniculitis also may occur in newborns.

S-100 stain negative in panniculitis but positive in Rosai-Dorfman disease (sinus histiocytosis with massive lymphadenopathy).

Mediastinal panniculitis.

Pericarditis;* interstitial myocarditis.* Pneumonia;* pleuritis. Fat embolism.*

Features of alpha ${ }_{1}$-antitrypsin deficiency* (2). Fatty changes of liver; splenitis.

Intestinal mucosal erosions and ulcers, with or without perforation. Massive gastrointestinal hemorrhage in histiocytic cytophagic panniculitis. Blind intestinal loop (3). 


\begin{tabular}{lll}
\hline Organs and Tissues & Procedures & Possible or Expected Findings \\
\hline $\begin{array}{l}\text { Mesentery and intestine } \\
\text { (continued) }\end{array}$ & $\begin{array}{l}\text { Prepare thin slices of mesentery. Record size } \\
\text { of nodules and appearance of vessels. } \\
\text { Submit tissue samples for histologic study } \\
\text { of nodules and vessels. }\end{array}$ & Mesenteric panniculitis. \\
$\begin{array}{l}\text { Retroperitoneum } \\
\text { with pancreas }\end{array}$ & $\begin{array}{l}\text { Sismit tissue samples for histologic study. } \\
\text { Kidneys and adrenal and adrenal vessels in situ. } \\
\text { glands }\end{array}$ & $\begin{array}{l}\text { Retroperitoneal panniculitis. Necrotizing } \\
\text { pancreatitis.* } \\
\text { Vasculitis with thrombi; adrenocortical } \\
\text { infarctions. }\end{array}$ \\
$\begin{array}{l}\text { Other organs and tissues } \\
\text { sample for histologic study. }\end{array}$ & $\begin{array}{l}\text { Submit tissue samples for histologic study } \\
\text { of large and small peripheral vessels. }\end{array}$ & $\begin{array}{l}\text { Vasculitis with thrombi and infarctions. } \\
\text { Relapsing polychondritis (4). } \\
\text { Request Verhoeff-van Gieson stain (p. 173). }\end{array}$ \\
& $\begin{array}{l}\text { Samples should include all organs and tissues } \\
\text { with gross lesions and also lymph nodes and } \\
\text { bone marrow. }\end{array}$ & Conditions." \\
\hline
\end{tabular}

\section{References}

1. Kumar S, Krenacs L, Medeiros J, Elenitoba-Johnson KS, Greiner TC, Sorbara L, et al. Subcutaneous panniculitic T-cell lymphoma is a tumor of cytotoxic T lymphocytes. Hum Pathol 1998;29:397-403.

2. O'Riordan K, Blei A, Rao MS, Abecassis M. Alpha 1-antitrypsin deficiency-associated panniculitis: resolution with intravenous alpha 1-antitrypsin administration and liver transplantation. Transplant 1997;63: 480-482.
3. Caux F, Halimi C, Kevorkian JP, Pinquier L, Dubertret L, Segrestaa JM. Blind loop syndrome: an unusual cause of panniculitis. J Am Acad Dermatol 1997;37:824-827.

4. Disdier P, Andrac L, Swiader L, Veit V, Fuzibet JG, Weiller-Merli C, et al. Cutaneous panniculitis and relapsing polychondritis: two cases. Dermatology 1996;193:266-268.

\section{Paracoccidioidomycosis}

Synonyms: Paracoccidioides brasiliensis infection; South American blastomycosis.

NOTE: (1) Collect all tissues that appear to be infected. (2) Request fungal cultures. (3) Request Grocott's methenamine silver stain for fungi (p. 172). A simple KOH mount of exudate or pus will demonstrate the organism in a majority of cases. (4) No special precautions are indicated. (5) Serologic studies are available from the Centers for Disease Control and Prevention, Atlanta, GA (p. 135). (6) This is not a reportable disease.

\begin{tabular}{lll}
\hline Organs and Tissues & Procedures & Possible or Expected Findings \\
\hline $\begin{array}{l}\text { External examination } \\
\text { with mouth and nose; } \\
\text { lymph nodes }\end{array}$ & $\begin{array}{l}\text { Record and photograph skin lesions. } \\
\text { Submit sample of exudate for fungal culture, } \\
\text { and prepare smears. } \\
\text { Record appearance of mouth, nose and } \\
\text { conjunctivas; record site of primary lesion. } \\
\text { Excise regional lymph nodes and submit for } \\
\text { histologic study. }\end{array}$ & $\begin{array}{l}\text { Mucosal ulcerations (mulberry-like) of } \\
\text { mouth and nose; cutaneous verrucous } \\
\text { or ulcerated lesions; regional lymph- } \\
\text { adenopathy. See below under "Other } \\
\text { organs..." } \\
\text { Consolidation; cavitation; fibrosis; bullae. }\end{array}$ \\
$\begin{array}{lll}\text { Lungs } & \begin{array}{l}\text { Submit samples of consolidated lung tissue } \\
\text { for culture (p. 103). }\end{array} & \begin{array}{l}\text { Stomach and intestines are common sites } \\
\text { of primary infection. Suppurative, ulcerative, } \\
\text { and granulomatous lesions may occur. }\end{array} \\
\text { study; include sample of anorectal mucosa. } \\
\text { Other organs and } \\
\text { tissues; nasal cavities }\end{array}$ & For exposure of nasal cavities, see p. 71. & $\begin{array}{l}\text { Nasal cavities may be the site of the primary } \\
\text { infection; hematogenous dissemination to } \\
\text { any organ, including the central nervous } \\
\text { system. }\end{array}$ \\
\hline
\end{tabular}




\section{Paralysis, Familial Periodic}

Synonyms and Related Terms: Hyperkalemic (hypokalemic, normokalemic) periodic paralysis; myotonia, paramyotonia congenita.

\begin{tabular}{lll}
\hline Organs and Tissues & Procedures & Possible or Expected Findings \\
\hline Skeletal muscles & For sampling and specimen preparation, see p. 80. & Vacuolar myopathy. \\
& Prepare samples for electron microscopy (p. 132). & \\
\hline
\end{tabular}

\section{Paralysis, Landry's Ascending (See “Syndrome, Guillain-Barré.”)}

Paralysis, Spinal (See name of suspected underlying condition, such as "Poliomyelitis" and "Sclerosis, multiple.")

Paresis, General (See “Syphilis, acquired.”)

Parkinsonism, All Types or Type Unspecified (See “Disease, Parkinson's.”)

Parotitis, Epidemic (See “Mumps.”)

Patent ductus arteriosus (See “Artery, patent ductal.")

\section{Pellagra}

Related Terms: Niacin deficiency; tryptophan deficiency.

Possible Associated Conditions: Chronic alcoholism;* chronic peritoneal dialysis;* hemodialysis; other vitamin deficiencies; refeeding after starvation.*

\begin{tabular}{|c|c|c|}
\hline Organs and Tissues & Procedures & Possible or Expected Findings \\
\hline $\begin{array}{l}\text { External examination, } \\
\text { skin, oral cavity, } \\
\text { and tongue }\end{array}$ & $\begin{array}{l}\text { Record extent of skin and mucosal lesions, } \\
\text { photograph, and prepare histologic sections } \\
\text { of skin and tongue. }\end{array}$ & $\begin{array}{l}\text { Dermatitis with dark pigmentation; cheilosis } \\
\text { (angular stomatitis); stomatitis; glossitis; } \\
\text { necrotizing ulcerative gingivitis with } \\
\text { Vincent's organisms. }\end{array}$ \\
\hline Esophagus & Photograph and sample for histologic study. & Esophagitis (1). \\
\hline Liver & $\begin{array}{l}\text { Record weight and submit samples for } \\
\text { histologic study. }\end{array}$ & Alcoholic cirrhosis.* \\
\hline Gastrointestinal tract & $\begin{array}{l}\text { Submit samples of all segments (with and } \\
\text { without ulcers) for histologic study. }\end{array}$ & $\begin{array}{l}\text { Proctocolitis with or without ulcers and } \\
\text { perianal excoriations (2). }\end{array}$ \\
\hline Urethra and vagina & Submit samples for histologic study. & Urethritis and vaginitis. \\
\hline Brain and spinal cord & $\begin{array}{l}\text { For removal and specimen preparation, } \\
\text { see pp. } 65 \text { and } 67 \text {, respectively. Request } \\
\text { Luxol fast blue stain for myelin (p. 172). }\end{array}$ & $\begin{array}{l}\text { Degeneration of large pyramidal cells (Betz's } \\
\text { cells) of motor cortex. Demyelination in } \\
\text { posterior and lateral columns of spinal cord. }\end{array}$ \\
\hline
\end{tabular}

\section{References}

1. Segal I, Hale M, Demetriou A, Mohamed AE. Pathological effects of pellagra on the esophagus. Nutr Canc 1990;14: 233-238.

2. Segal I, Ou Tim L, Demetriou A, Paterson A, Hale M, Lerios M. Rectal manifestations of pellagra. Int J Colorect Dis 1986;1:238-243.

\section{Pemphigus}

Synonyms: Paraneoplastic pemphigus; pemphigus erythematosus; pemphigus foliaceus; pemphigus neonatorum; pemphigus vegetans; pemphigus vulgaris.

Possible Associated Conditions: Leukemia,* lymphoma,* and other neoplastic disorders associated with paraneoplastic pemphigus (1).

\begin{tabular}{lll}
\hline Organs and Tissues & Procedures & Possible or Expected Findings \\
\hline $\begin{array}{l}\text { External examination, } \\
\text { skin, and mouth }\end{array}$ & $\begin{array}{l}\text { Record extent of skin lesions; photograph; } \\
\text { submit multiple samples for histologic study, } \\
\text { preferably of areas that are free of secondary }\end{array}$ & $\begin{array}{l}\text { Bullous and other lesions of scalp, eyelids, } \\
\text { nose, axillae, umbilicus, inframammary } \\
\text { infection. }\end{array}$ \\
& $\begin{array}{l}\text { areas, back, hands, groins, genitalia, anus, } \\
\text { knees, and feet. Similar lesions may occur in } \\
\text { the mouth. Acantholysis is suprabasal or near } \\
\text { granular layer. }\end{array}$ \\
& Prepare sections for immunofluorescent staining. & IgG deposits on the surfaces of keratinocytes.
\end{tabular}




\begin{tabular}{|c|c|c|}
\hline Organs and Tissues & Procedures & Possible or Expected Findings \\
\hline Blood & Submit sample for culture (p. 102). & Septicemia. \\
\hline Heart & For histologic sampling, see p. 30. & Focal myocarditis. \\
\hline Lungs & $\begin{array}{l}\text { Submit one lobe for microbiologic study } \\
\text { (p. 103). }\end{array}$ & $\begin{array}{l}\text { Bronchopneumonia; thromboemboli after } \\
\text { steroid therapy. }\end{array}$ \\
\hline Esophagus & Sample for histologic study. & May be involved in pemphigus vulgaris (2). \\
\hline Kidneys and urinary bladder & & Urinary tract infection. \\
\hline Adrenal glands & Record weights; record appearance of cortex. & Cortical lipid depletion. \\
\hline Neck organs & Sample for histologic study. & $\begin{array}{l}\text { Pemphigus lesions of mucosa of pharynx } \\
\text { and larynx. }\end{array}$ \\
\hline Bones & $\begin{array}{l}\text { For removal, prosthetic repair, and specimen } \\
\text { preparation, see p. } 95 \text {. }\end{array}$ & Osteoporosis* after steroid therapy. \\
\hline $\begin{array}{l}\text { Brain, spinal cord, } \\
\text { and spinal ganglia }\end{array}$ & $\begin{array}{l}\text { For removal and specimen preparation, } \\
\text { see pp. } 65,67 \text {, and } 69 \text {, respectively. }\end{array}$ & $\begin{array}{l}\text { Degenerative changes in brain, spinal cord, } \\
\text { and spinal ganglia. }\end{array}$ \\
\hline Eyes & $\begin{array}{l}\text { For removal and specimen preparation, } \\
\text { see p. } 85 \text {. }\end{array}$ & $\begin{array}{l}\text { Pemphigus lesions of conjunctivas. Invasion } \\
\text { of conjunctivas by connective tissue; possible } \\
\text { conjunctival shrinkage. }\end{array}$ \\
\hline
\end{tabular}

\section{References}

1. Anhalt GJ. Paraneoplastic pemphigus. Adv Dermatol 1997;12:77-96.

2. Amichai B, Grunwald MH, Gasper N, Finkelstein E, Halevy S. A case of pemphigus vulgaris with esophageal involvement. J Dermatol 1996;23: 214-215.

\section{Periarteritis Nodosa (See "Polyarteritis nodosa.")}

\section{Pericarditis}

\begin{tabular}{|c|c|c|}
\hline Organs and Tissues & Procedures & Possible or Expected Findings \\
\hline External examination & Prepare chest roentgenogram. & Pericardial calcification; effusion. \\
\hline Pleural cavities & $\begin{array}{l}\text { If there are pleural exudates, follow procedures } \\
\text { described below. }\end{array}$ & Pleuritis. \\
\hline \multirow[t]{2}{*}{ Pericardial sac } & $\begin{array}{l}\text { Aspirate exudate and submit for microbiologic } \\
\text { study (p. 102). Record volume of pericardial } \\
\text { fluid. Centrifuge fluid and prepare smear or } \\
\text { section of pellet. Request Gram, Grocott's } \\
\text { methenamine silver, and auramine-rhodamine } \\
\text { stains (p. 172). }\end{array}$ & $\begin{array}{l}\text { Infective pericarditis (pyogenic, tuberculous, } \\
\text { or other bacterial infection; fungal or viral } \\
\text { infection). (Gram-negative bacilli, } \\
\text { Staphylococcus aureus, Streptococcus, } \\
\text { and Pneumococcus.) }\end{array}$ \\
\hline & $\begin{array}{l}\text { If there is extensive calcification, see under } \\
\text { "Syndrome, Budd-Chiari." }\end{array}$ & $\begin{array}{l}\text { Constrictive pericarditis (idiopathic; } \\
\text { irradiation; tuberculous; postoperative). }\end{array}$ \\
\hline Blood & Submit sample for microbiologic study (p. 102). & Septicemia. \\
\hline Heart & $\begin{array}{l}\text { Histologic samples should include epicardium, } \\
\text { pericardium, and myocardium. }\end{array}$ & $\begin{array}{l}\text { Old or recent heart surgery; myocardial } \\
\text { infarction. }\end{array}$ \\
\hline & For coronary arteriography, see p. 118. & Coronary atherosclerosis with stenosis. \\
\hline Other organs & $\begin{array}{l}\text { Procedures depend on expected findings or } \\
\text { grossly identified abnormalities as listed in } \\
\text { right-hand column. }\end{array}$ & $\begin{array}{l}\text { Neoplasm; trauma; manifestations of kidney } \\
\text { failure* with uremia or of rheumatic fever;* } \\
\text { sternal osteomyelitis (postoperative wound } \\
\text { infection); rheumatoid arthritis* (1); lupus } \\
\text { erythematosus, }{ }^{*} \text { and other autoimmune } \\
\text { diseases. }\end{array}$ \\
\hline
\end{tabular}

\section{Reference}

1. McRorie ER, Wright RA, Errington ML, Lugmani RA. Rheumatoid constrictive pericarditis (clinical conference). Br J Rheumatol 1997;36:100-103. 


\section{Peritonitis, Infectious}

NOTE: (1) Collect all tissues that appear to be infected. (2) Request aerobic, anaerobic, acid-fast, and fungal cultures. (3) Request Gram, Grocott's methenamine silver, and Kinyoun's stains (p. 172). (4) No special precautions are indicated. (5) Serologic studies are not available. (6) This is not a reportable disease.

\begin{tabular}{|c|c|c|}
\hline Organs and Tissues & Procedures & Possible or Expected Findings \\
\hline External examination & Prepare chest and abdominal roentgenograms. & $\begin{array}{l}\text { Extraintestinal gas after perforation of hollow } \\
\text { viscus; foreign body. }\end{array}$ \\
\hline Vitreous & $\begin{array}{l}\text { Request determination of sodium, chloride, } \\
\text { and urea nitrogen concentrations (p. } 85 \text { ). }\end{array}$ & Manifestations of severe dehydration.* \\
\hline \multirow[t]{4}{*}{ Abdominal cavity } & $\begin{array}{l}\text { Aspirate fluid and submit for culture, } \\
\text { particularly if cloudy. }\end{array}$ & $\begin{array}{l}\text { Acute bacterial peritonitis (rarely, other } \\
\text { infective agents); bile or chemical peritonitis. }\end{array}$ \\
\hline & $\begin{array}{l}\text { If cause of acute peritonitis is unknown, } \\
\text { inspect in situ all intraperitoneal, pelvic, and } \\
\text { extraperitoneal organs. If abscess is present, } \\
\text { record location, size, and volume. Submit portion } \\
\text { for culture. }\end{array}$ & $\begin{array}{l}\text { Possible causes include appendicitis, colitis, } \\
\text { diverticulitis, enteritis, infarction, peptic } \\
\text { ulcer, trauma, tumor, surgical complication } \\
\text { and pelvic disease (for instance, after } \\
\text { attempted abortion). }\end{array}$ \\
\hline & Absence of causative lesions must be documented. & $\begin{array}{l}\text { Primary peritonitis, most commonly in } \\
\text { female children. }\end{array}$ \\
\hline & $\begin{array}{l}\text { If exudate is milky, lymphangiography may } \\
\text { be indicated (p. 34). }\end{array}$ & Chylous ascites. \\
\hline Blood & $\begin{array}{l}\text { Submit sample for aerobic, anaerobic, and } \\
\text { fungal cultures (p. 102). }\end{array}$ & Septicemia. \\
\hline
\end{tabular}

\section{Pertussis}

Synonyms: Bordatella pertussis infection; whooping cough.

NOTE: (1) Collect all tissues that appear to be infected. (2) Request culture for Bordatella, as well as aerobic and anaerobic cultures. Special medium is required (see below) (3) Request Gram stain (p. 172). (4) No special precautions are indicated. (5) Serologic studies are not available in most institutions. (6) This is a reportable disease.

\begin{tabular}{|c|c|c|}
\hline Organs and Tissues & Procedures & Possible or Expected Findings \\
\hline \multirow[t]{2}{*}{ External examination } & $\begin{array}{l}\text { Record body weight and length. If diagnosis had } \\
\text { not been confirmed, prepare nasopharyngeal } \\
\text { swabs, and culture immediately on Bordet- } \\
\text { Gengou medium. }\end{array}$ & $\begin{array}{l}\text { Manifestations of malnutrition;* petechiae, } \\
\text { especially on face; scleral hemorrhages. }\end{array}$ \\
\hline & Prepare chest roentgenogram. & Pneumothorax.* \\
\hline Cerebrospinal fluid & Culture on Bordet-Gengou medium (p. 104). & Infectious meningitis. ${ }^{*}$ \\
\hline Blood & $\begin{array}{l}\text { Submit sample for culture (p. } 102 \text { and above } \\
\text { under "Note"). }\end{array}$ & Septicemia. \\
\hline \multirow[t]{2}{*}{ Lungs } & $\begin{array}{l}\text { Submit one lobe for culture (see p. } 103 \text { and } \\
\text { above under "Note"). Prepare Gram-stained } \\
\text { smears from fresh cut section; perfuse one lung } \\
\text { with formalin (p. 47). }\end{array}$ & $\begin{array}{l}\text { Localized or interstitial pulmonary } \\
\text { emphysema; atelectasis. }\end{array}$ \\
\hline & $\begin{array}{l}\text { Prepare histologic sections of bronchi, bronchioli, } \\
\text { and pulmonary parenchyma. }\end{array}$ & $\begin{array}{l}\text { Bronchitis; bronchiolitis; } \\
\text { bronchopneumonia. }\end{array}$ \\
\hline Neck organs and trachea & $\begin{array}{l}\text { Prepare histologic sections of pharynx, larynx, } \\
\text { and trachea. }\end{array}$ & $\begin{array}{l}\text { Aspiration of vomitus; pharyngitis; } \\
\text { laryngitis; * tracheitis. }\end{array}$ \\
\hline Brain & $\begin{array}{l}\text { For removal and specimen preparation, } \\
\text { see p. } 65 .\end{array}$ & $\begin{array}{l}\text { Serous meningitis; * anoxic encephalopathy; } \\
\text { epidural hematoma; petechial hemorrhages. }\end{array}$ \\
\hline Middle ears & $\begin{array}{l}\text { For removal and specimen preparation, } \\
\text { see p. } 72 .\end{array}$ & Bacterial otitis media.* \\
\hline
\end{tabular}




\section{Phenylketonuria}

NOTE: See also under "Aminoaciduria."

\begin{tabular}{lll}
\hline Organs and Tissues & Procedures & Possible or Expected Findings \\
\hline Blood & $\begin{array}{l}\text { If diagnosis had not been confirmed, submit } \\
\text { plasma from a heparinized blood sample for } \\
\text { ion-exchange test. }\end{array}$ & Hyperphenylalaninemia. \\
See above under "Blood." & $\begin{array}{l}\text { Phenylketonuria. Urine may have a "mousy" } \\
\text { odor. }\end{array}$ \\
Urine & $\begin{array}{l}\text { Ficrocephaly; delayed neuronal and } \\
\text { Brain and spinal cord }\end{array}$ & $\begin{array}{l}\text { myelin maturation; demyelinization with } \\
\text { sudanophilic gitter cells; normal grey matter. } \\
\text { see pp. 65 and 67, respectively. Record } \\
\text { brain weight. Request Luxol fast blue stain } \\
\text { for myelin. Fresh material should be used } \\
\text { for Sudan stain for fat (p. 173). }\end{array}$ \\
\hline
\end{tabular}

\section{Pheochromocytoma (See "Tumor of the adrenal gland(s).")}

\section{Phlebitis}

Related Terms: Migratory phlebitis; phlebothrombosis; phlegmasia alba dolens; phlegmasia cerulea dolens; thrombophlebitis migrans, * Trousseau's syndrome; venous thrombosis.*

NOTE: A clear distinction between phlebothrombosis and thrombophlebitis generally cannot be made.

\begin{tabular}{|c|c|c|}
\hline Organs and Tissues & Procedures & Possible or Expected Findings \\
\hline External examination & $\begin{array}{l}\text { Describe discoloration of extremities, swelling } \\
\text { or palpable venous lesions. Compare leg } \\
\text { circumferences (measure above and below } \\
\text { knees). }\end{array}$ & $\begin{array}{l}\text { Stasis dermatitis of legs; varicous veins; } \\
\text { gangrene of toes. }\end{array}$ \\
\hline Lungs & & Pulmonary embolism.* \\
\hline Other organs & $\begin{array}{l}\text { If systemic emboli and infarctions are present, } \\
\text { record whether oval foramen was patent and } \\
\text { whether there were other lesions with possible } \\
\text { right-to-left shunt. }\end{array}$ & $\begin{array}{l}\text { Paradoxic embolism. Carcinoma of pancreas, } \\
\text { lung, stomach, colon, kidney, or other organs. } \\
\text { Arteritis. Nonbacterial thrombotic } \\
\text { endocarditis.* }\end{array}$ \\
\hline Veins and arteries & $\begin{array}{l}\text { For postmortem phlebography and aterio- } \\
\text { graphy, see p. } 120 \text {. For removal of femoral } \\
\text { vessels, see p. } 34 \text {. } \\
\text { If gangrene is present, demonstrate absence } \\
\text { of concomitant arterial occlusion. }\end{array}$ & $\begin{array}{l}\text { Thromboses are likely to be found (in } \\
\text { decreasing order of frequency) in small } \\
\text { saphenous veins, deep veins of calves, } \\
\text { iliofemoral veins, great saphenous veins, } \\
\text { superficial veins and varices of legs, and } \\
\text { veins of arms. Other sites are rarely involved. }\end{array}$ \\
\hline
\end{tabular}

Phlegmasia Alba (or Cerulea) Dolens (See “Phlebitis.")

Phosgene $\left(\mathrm{COCl}_{2}\right)$ (See "Poisoning, gas.")

Phosphate Ester (Insecticide)

(See "Poisoning, organophosphate(s).")

Phosphorus (See "Disorder, electrolyte(s)" or "Poisoning, phosphorus.")

Phycomycosis (See "Mucormycosis.")
Plague

Synonym: Yersinia (Pasteurella) pestis infection; Black Death; bubonic plague.

NOTE: (1) Collect all tissues that appear to be infected. (2) Request aerobic bacterial cultures. (3) Request Gram stain (p. 122). (4) Special precautions are indicated, as this is a highly communicable disease (p. 146). (5) Serologic studies are available from the Centers for Disease Control and Prevention, Atlanta, GA (p. 135). (6) This is a reportable disease.

\begin{tabular}{ll}
\hline Organs and Tissues & Procedures \\
\hline External examination & Photograph and record extent of hemorrhages. \\
and skin & Prepare histologic sections of skin. \\
Blood & Submit sample for microbiologic (see p. 102) \\
& and above under "Note") and serologic study. \\
& Prepare smear and stain with Wright-Giemsa \\
& (p. 173).
\end{tabular}

Possible or Expected Findings

Petechial and other types of hemorrhages in skin and subcutaneous tissues.

Septicemia; bipolar staining rods. 


\begin{tabular}{lll}
\hline Organs and Tissues & Procedures & Possible or Expected Findings \\
\hline Lymph nodes & $\begin{array}{l}\text { Collect inguinal, popliteal, axillary, and } \\
\text { supraclavicular lymph nodes for aerobic culture. }\end{array}$ & Hemorrhagic necrosis; variable suppuration. \\
& $\begin{array}{l}\text { Photograph enlarged lymph nodes, and prepare } \\
\text { smears of fresh cut surfaces. }\end{array}$ & \\
Lungs & $\begin{array}{l}\text { Submit consolidated areas for microbiologic } \\
\text { study (see p. 103 and above under "Note"). }\end{array}$ & $\begin{array}{l}\text { Severe hemorrhagic edema; pneumonia with } \\
\text { lobular to lobar features. }\end{array}$ \\
& $\begin{array}{l}\text { Perfuse both lungs with formalin (p. 47). } \\
\text { Submit samples of pulmonary tissue and } \\
\text { bronchial lymph nodes for histologic study. }\end{array}$ & \\
& Submit samples of grossly abnormal organs, \\
& exudates, or drainage fluids for culture and & $\begin{array}{l}\text { Large areas of necrosis teeming with } \\
\text { organisms and minimal to suppurative } \\
\text { inflammation. }\end{array}$ \\
\hline
\end{tabular}

\section{Plasmacytoma (See “Myeloma, multiple.”)}

\section{Platybasia}

NOTE: Possible causes or associated conditions include Arnold-Chiari malformation;* basilar impression* or invagination; fusion of atlas to the foramen magnum; Klippel-Feil syndrome;* malpositioning of odontoid process; osteitis deformans (Paget's disease of bone*); osteogenesis imperfecta;* osteomalacia;* rickets; syringobulbia, syringomyelia.*

\begin{tabular}{lll}
\hline Organs and Tissues & Procedures & Possible or Expected Findings \\
\hline Skull and spine & $\begin{array}{l}\text { Prepare roentgenograms of skull and cervical } \\
\text { spine. }\end{array}$ & $\begin{array}{l}\text { Flattening of the base of the skull (angle } \\
\text { formed by the plane of the clivus and the plane } \\
\left.\text { of the anterior fossa exceeds } 135^{\circ}\right) .\end{array}$ \\
\hline
\end{tabular}

\section{Pleuritis (See “Effusion(s) and exudate(s), pleural.”)}

\section{Pleurodynia, epidemic}

Synonyms: Bornholm disease; devil's grip; epidemic myalgia; epidemic myositis.

\begin{tabular}{lll}
\hline Organs and Tissues & Procedures & Possible or Expected Findings \\
\hline Blood & Submit samples for viral culture (p. 102). & Coxsackie B virus infection. \\
Heart and pericardium & Sample for histologic study (p. 30) and & Myocarditis* may be associated with \\
& for viral cultures (Coxsackievirus A and B; & Coxsackievirus B infection; may be rapidly \\
& echoviruses). If pericardial fluid can be & \\
& obtained, submit for viral culture also \\
& (p. 102). & \\
& Cultures may be negative and search for \\
& viral RNA by in situ hybridization may be & \\
& indicated. & \\
\hline
\end{tabular}

\section{Pneumatosis Cystoides Intestinalis}

NOTE: Some potential causes such as steroid, chemo- or immunosuppressive therapy may not be apparent at autopsy.

Possible Associated Conditions: Acquired immunodeficiency syndrome* (AIDS) (1); amyloidosis* (2); primary combined immunodeficiency (3); progressive systemic sclerosis;* organ or bone marrow (4) transplantation.* 


\begin{tabular}{lll}
\hline Organs and Tissues & Procedures & Possible or Expected Findings \\
\hline Abdomen & $\begin{array}{l}\text { Expose serosal surfaces. } \\
\text { Record location and size of cysts. }\end{array}$ & $\begin{array}{l}\text { Gas cysts in stomach, small bowel, colon, } \\
\text { mesentery, omentum, gastrohepatic } \\
\text { ligament, gallbladder, retroperitoneal tissues, } \\
\text { and renal capsule. } \\
\text { Gas in thoracic duct. Emphysema* of lungs. }\end{array}$ \\
Chest organs & $\begin{array}{l}\text { Dissect thoracic duct and its tributaries } \\
\text { (see p. 34). Perfuse one or both lungs with } \\
\text { formalin (p. 47). } \\
\text { Procedures depend on expected findings or } \\
\text { grossly identified abnormalities as listed in } \\
\text { right-hand column. }\end{array}$ & $\begin{array}{l}\text { Necrotizing enterocolitis in premature } \\
\text { infants.Pyloric stenosis, colitis(5), redundant } \\
\text { sigmoid colon, ischemic bowel disease. }\end{array}$ \\
& $\begin{array}{l}\text { Submit samples of cystic lesions for histologic } \\
\text { study. }\end{array}$ & $\begin{array}{l}\text { Mucosal pseudolipomatosis (6). } \\
\text { Usually, cysts are subserosal in adults and } \\
\text { located between muscularis mucosae and } \\
\text { muscularis propria in infants and children. }\end{array}$ \\
& & $\begin{array}{l}\text { Mucosa may be inflamed. } \\
\text { Extraintestinal cysts, as listed above under } \\
\text { "Abdomen." Cysts may also occur in vaginal } \\
\text { mucosa. }\end{array}$ \\
\hline
\end{tabular}

\section{References}

1. Cunnion KM. Pneumatosis intestinalis in pediatric acquired immunodeficiency syndrome. Pediatr Inf Dis J 1998;17:355-356.

2. Pearson DC, Price LM, Urbanski S. Pneumatosis cystoides intestinalis: an unusual complication of systemic amyloidosis. J Clin Gastroenterol 1996;22:74-76.

3. Tang ML, Williams LW. Pneumatosis intestinalis in children with primary combined immunodeficiency. J Pediatr 1998;132:546-549.

4. Takanashi M, Hibi S, Todo S, Sawada T, Tsunamoto K, Imashaku $\mathrm{S}$. Pneumatosis cystoides intestinalis with abdominal free air in a 2year-old girl after allogeneic bone marrow transplantation. Pediatr Hematol Oncol 1998;15:81-84.

5. Pear BL. Pneumatosis intestinalis: a review. Radiol 1998;207:13-19.

6. Gagliardi G, Thompson IW, Hershman MJ, Forbes A, Hawley PR, Talbot IC. Pneumatosis coli: a proposed pathogenesis based on study of 25 cases and review of the literature. Intl J Colorect Dis 1996;11: $111-118$.

\section{Pneumoconiosis}

Etiologic Types of Pneumoconiosis (With typical Examples): Collagenous inorganic dust pneumoconiosis, diffuse type: Aluminosis; asbestosis; chronic pulmonary berylliosis; talcosis; Collagenous inorganic dust pneumoconiosis, nodular type: Silicosis; Noncollagenous inorganic dust pneumoconiosis (includes mixed-dust fibrosis): Baritosis; China clay pneumoconiosis; chromite pneumoconiosis; coal worker's pneumoconiosis; fuller's earth pneumoconiosis; hematite or magnetite miner's lung; siderosis or welder's lung; stannosis; Organic dust pneumoconiosis: Byssinosis.

NOTE: In addition to the aforementioned classic forms of pneumoconiosis, many other airborne substances have been implicated in recent years, for example, cerium, manmade vitreous fibers, polyvinyl chloride, silicon carbide, and titanium (1).

Chemical analysis of large samples of digested tissue is best suited for quantitative studies, particularly of trace substances. If only small tissue samples are available and if individual particles are to be analyzed and correlated with histologic lesions,

in situ microanalysis must be done. Methods used include brightfield and polarized light microscopy, transmission electron microscopy, scanning or transmission electron microscopy with energy dispersive X-ray analysis (2) (p. 133), ion beam instrumentation, and secondary ion mass spectrometry. The last three methods are time-consuming, require much skill and expensive equipment, and do not lend themselves well to quantitation. Ideally, bulk analysis and in situ microanalysis should be used in combination. See also p. 52.

Analyses can be conducted in specialized laboratories at the following centers (for charges and other information, consult the appropriate laboratories):

Georgia Institute

of Technology

225 North Ave. N.W.

Atlanta, GA 30332

Medical University

of South Carolina

80 Barre St.

Charleston, SC 29401

Mount Sinai Hospital

5th Ave. E. 100th

New York, NY 10029

University of Utah

1400 East 2nd South

Salt Lake City, UT 84112

An appropriate National Registry, "Pulmonary and Mediastinal Pathology," is located in the Armed Forces Institute of Pathology, Washington, DC (see p. 148).
National Institute for Occupational Safety \& Health Robert A. Taft Laboratories 4676 Columbia Parkway Cincinnati, OH 45226

National Institute for Occupational Safety \& Health 1095 Willowdale Road Morgantown, WV 26505

University of Wisconsin 3203 N. Downer Milwaukee, WI 53201 


\begin{tabular}{|c|c|c|}
\hline Organs and Tissues & Procedures & Possible or Expected Findings \\
\hline \multirow[t]{2}{*}{ External examination } & & Clubbing of fingers. \\
\hline & Prepare chest roentgenogram. & Diffuse or nodular pulmonary infiltrates. \\
\hline \multirow[t]{2}{*}{ Blood } & Submit sample for microbiologic study (p. 102). & \\
\hline & $\begin{array}{l}\text { Refrigerate sample for possible immunologic } \\
\text { study. }\end{array}$ & $\begin{array}{l}\text { Rheumatoid factor in Caplan's syndrome.* } \\
\text { Positive in vitro lymphocyte transformation } \\
\text { test in berylliosis }(3) \text {. }\end{array}$ \\
\hline \multirow[t]{8}{*}{ Lungs } & $\begin{array}{l}\text { Submit one lobe or samples of all lobes for bulk } \\
\text { analysis and for in situ microanalysis (see above } \\
\text { under "Note"). Microincineration may permit } \\
\text { preliminary dust analysis. For demonstration } \\
\text { of asbestos fibers, see p. } 52 \text { and ref. (4). }\end{array}$ & $\begin{array}{l}\text { Large amounts of dust (up to } 20 \mathrm{~g} \text { ) in coal } \\
\text { worker's pneumoconiosis and other } \\
\text { noncollagenous inorganic dust pneumo- } \\
\text { conioses. Small amounts of dust in silicosis } \\
(5-6 \mathrm{~g}) \text {. }\end{array}$ \\
\hline & $\begin{array}{l}\text { Submit one lobe or segment for microbiologic } \\
\text { study. }\end{array}$ & $\begin{array}{l}\text { Tuberculosis* (including infection with } \\
\text { atypical mycobacteria }[5] \text { ). }\end{array}$ \\
\hline & $\begin{array}{l}\text { For pulmonary arteriography and bronchography, } \\
\text { see p. } 50 \text {. }\end{array}$ & \\
\hline & $\begin{array}{l}\text { Prepare roentgenograms of entire lungs and slices. } \\
\text { Perfuse one lung (or both, if only routine } \\
\text { studies are intended) with formalin (p. } 47 \text { ). }\end{array}$ & $\begin{array}{l}\text { Asbestosis may be associated with pleural } \\
\text { mesothelioma (see "Tumor of the pleural") } \\
\text { and carcinoma of lung (see "Tumor of the }\end{array}$ \\
\hline & $\begin{array}{l}\text { Submit samples for histologic study of nodular } \\
\text { dust lesions, diffuse fibrotic lesions, grossly } \\
\text { uninvolved areas, bronchi, and bronchopulmonary } \\
\text { lymph nodes. }\end{array}$ & $\begin{array}{l}\text { lung or bronchus"). In silicotic lungs, } \\
\text { squamous cell or small cell carcinomas are } \\
\text { rather common (6). }\end{array}$ \\
\hline & For preparation of paper-mounted sections, & Chronic bronchitis.* \\
\hline & see p. 49 & Coniosis of lymph nodes. \\
\hline & $\begin{array}{l}\text { Prepare samples for transmission and scanning } \\
\text { electron microscopic study (see p. 132) }\end{array}$ & Particle identification. \\
\hline Joints & $\begin{array}{l}\text { For removal, prosthetic repair, and specimen } \\
\text { preparation, see p. } 96 .\end{array}$ & Arthritis in Caplan's syndrome.* \\
\hline
\end{tabular}

\section{References}

1. Gong H Jr. Uncommon causes of occupational interstitial lung diseases. Curr Opin Pulm Med 1996;2:405-411.

2. McDonald JW, Ghio AJ, Sheehan CE, Bernhardt PF, Roggli VL. Rare earth (cerium oxide) pneumoconiosis: analytical scanning electron microscopy and literature review. Mod Pathol 1995;8:859-865.

3. Williams WJ. Diagnostic criteria for chronic beryllium disease (CBD) based on the UK registry 1945-1991. Sarcoidosis 1993;10:41-43.
4. King JA, Wong SW. Autopsy evaluation of asbestos exposure: retrospective study of 135 cases with quantitation of ferruginous bodies in digested lung tissue. South Med J 1996;89:380-385.

5. De Coster C, Verstraeten JM, Dumortier P, De Vuyst P. Atypical mycobacteriosis as a complication of talc pneumoconiosis. Eur Respir J 1996;9:1757-1759.

6. Honma K, Chiyotani K, Kimura K. Silicosis, mixed dust pneumoconiosis, and lung cancer. Am J Ind Med 1997;32:595-599.

\section{Pneumocystis Carinii (See "Infection, Pneumocystis carinii.")}

\section{Pneumomediastinum}

NOTE: This condition is diagnosed by inspection, palpation, and roentgenography. Tension pneumomediastinum may compromise venous return to the heart and may compress major bronchi. The condition is rapidly fatal and occurs after alveolar rupture with dissection of air into the mediastinum in neonates with respiratory distress (see "Syndrome, respiratory distress, of infant") and in adult patients ventilated on volume respirators.

\begin{tabular}{ll}
\hline Organs and Tissues & Procedures \\
\hline External examination & Prepare chest roentgenogram. \\
Chest cavity & $\begin{array}{l}\text { Photograph mediastinum. Explore major veins } \\
\text { and record compression in cases of tension } \\
\text { pneumomediatinum. }\end{array}$
\end{tabular}

Possible or Expected Findings

Roentgenograms provide the best permanent record of a pneumomediastinum.

Air bubbles in mediastinal soft tissues. 


\begin{tabular}{|c|c|c|}
\hline Organs and Tissues & Procedures & Possible or Expected Findings \\
\hline Lungs and mediastinum & $\begin{array}{l}\text { Perfuse one lung with formalin (p. 47). Other } \\
\text { procedures depend on expected findings or } \\
\text { grossly identified abnormalities as listed in } \\
\text { right-hand column. }\end{array}$ & $\begin{array}{l}\text { Intubation injury (1); perforation or rupture } \\
\text { of major bronchus, trachea, or esophagus. } \\
\text { Alveolar rupture, e.g., in asthma* (2), may } \\
\text { not be discernible. Bronchiolitis obliterans } \\
\text { (3), interstitial pneumonia* (4) and other } \\
\text { lung conditions also may lead to pneumo- } \\
\text { mediastinum. }\end{array}$ \\
\hline Abdomen and neck organs & $\begin{array}{l}\text { Search for evidence of trauma of other lesions } \\
\text { that may have allowed air to enter soft tissues. }\end{array}$ & $\begin{array}{l}\text { Dissection of air from lesions in abdomen } \\
\text { (e.g., retroperitoneal colonic perforation [5]) } \\
\text { or in neck area. }\end{array}$ \\
\hline
\end{tabular}

\section{References}

1. Vezina D, Lessard MR, Bussieres J, Topping C, Trepanier CA. Complications associated with the use of the Esophageal-Tracheal Combitube. Can J Anaesth 1998;45:76-80.

2. Van der Klooster JM, Grootendorst AF, Ophof PJ, Brouwers JW. Pneumomediastinum: an unusual complication of asthma in a young man. Netherl J Med 1998;52:150-154.

3. Galanis E, Litzow MR, Tefferi A, Scott JP. Spontaneous pneumomediastinum in a patient with bronchiolitis obliterans after bone marrow transplantation. Bone Marrow Transpl 1997;20:695-696.
4. Nagai Y, Ishikawa O, Miyachi Y. Pneumomediastinum and subcutaneous emphysema associated with fatal interstitial pneumonia in dermatomyositis. J Dermatol 1997;24:484-484.

5. Alvares JF, Dhawan PS, Tibrewala S, Shankaran K, Kulkarni SG, Rananavare R, et al. Retroperitoneal perforation in ulcerative colitis with mediastinal and subcutaneous emphysema. J Clin Gastroenterol $1997 ; 453-455$.

\section{Pneumonia, All Types or Type Unspecified}

NOTE: If the type of underlying infection is known, follow procedures suggested under the name of the infectious disease. If the etiologic agent of the pneumonia is unknown, proceed as follows: (1) Collect all tissues that appear to be infected. (2) Request aerobic, anaerobic, acid-fast, fungal, and viral cultures. (3) Request Gram, Kinyoun's acid-fast, and Grocott's methenamine silver stains (p. 172). (4) Special precautions may be required (p. 146). (5) Serologic studies may be helpful once a specific etiologic agent is suspected. Thus, collect serum at the time of autopsy or procure serum that was collected prior to death.

(6) This may be a reportable disease.

\begin{tabular}{lll}
\hline Organs and Tissues & Procedures & Possible or Expected Findings
\end{tabular}

External examination

Prepare chest roentgenogram.

Abdomen

Photograph abnormalities in situ.

Pleural cavities

Puncture; submit samples of fluid for culture (p. 102).

Blood

Heart

Lungs procedures described on p. 103.
Submit sample for culture (p. 102).

If infective endocarditis is suspected, follow

Record weights. Submit consolidated areas for culture (p. 103). Prepare touch preps of fresh cut sections. Perfuse lungs with formalin (p. 47). For special stains, see above under "Note."

For bronchography, see p. 50 .
Herpes labialis; pyoderma; jaundice.

Pneumothorax* or pneumatocele (in staphylococcal pneumonia of infancy); pleural effusions;* pulmonary infiltrates; abscesses.

Gastric dilatation and ileus; rarely, peritonitis.*

Fibrinous pleuritis; pleural effusions and exudates.*

Septicemia.

Infective endocarditis; ${ }^{*}$ pericarditis.*

Bacterial, fungal, viral, or protozoal pneumonia; abscesses (Staphylococcus aureus) or hemorrhages (influenza, infection with Pseudomonas spp., and others). See also under name of suspected underlying infectious disease or underlying noninfectious disorder, such as rheumatoid arthritis. ${ }^{*}$ Perifocal pneumonia around tumors. Bronchiectasis;* bronchial obstruction. 


\begin{tabular}{|c|c|c|}
\hline Organs and Tissues & Procedures & Possible or Expected Findings \\
\hline $\begin{array}{l}\text { Mediastinum and } \\
\text { neck organs }\end{array}$ & $\begin{array}{l}\text { Submit samples of larynx, trachea, and major } \\
\text { bronchi for histologic study. }\end{array}$ & Laryngotracheitis and tracheobronchitis. \\
\hline Arteries and veins & $\begin{array}{l}\text { For removal of femoral veins and arteries, } \\
\text { see p. } 34 \text {. }\end{array}$ & Infective vasculitis and thrombosis. \\
\hline Brain and spinal cord & For appropriate microbiologic study, see p. 102. & Meningitis.* \\
\hline Joints & $\begin{array}{l}\text { For removal, prosthetic repair, and specimen } \\
\text { preparation, see p. } 96 \text {. }\end{array}$ & Rarely, septic arthritis. \\
\hline
\end{tabular}

\section{Pneumonia, Eosinophilic (See "Syndrome, eosinophilic pulmonary.")}

\section{Pneumonia, Interstitial}

Related Terms: Acute interstitial pneumonia (HammanRich syndrome); desquamative interstitial pneumonia (DIP); idiopathic organizing pneumonia (or "bronchiolitis obliterans with patchy organizing pneumonia [BOOP]" or "cryptogenic organizing pneumonitis"); idiopathic pulmonary fibrosis; lymphoid interstitial pneumonitis (LIP); nonspecific interstitial pneumonia (NSIP) (or "cellular interstitial pneumonia" [CIP]); usual interstitial pneumonia (UIP); fibrosing alveolitis; pulmonary alveolitis; and many others.

NOTE: The conditions listed under "Related Terms" are histologic variants of idiopathic interstitial pneumonia. UIP is synonymous with idiopathic pulmonary fibrosis (IPF) (1). Diffuse alveolar damage is the histologic finding in patients with the adult respiratory distress syndrome* (ARDS) causing interstitial and intra-alveolar fibrosis. This is an acute condition, referred to as acute interstitial pneumonia when it occurs as an idiopathic form of rapidly progressive interstitial pneumonia.

Possible Associated Conditions: Acquired immunodeficiency syndrome* (AIDS) in patients with with LIP or nonspecific interstitial pneumonia (2,3); trauma and shock in ARDS. Secondary pulmonary fibrosis from inhalants (extrinsic allergic alveolitis or pneumonia; pneumoconiosis*), in drug-induced pneumonia, hypersensitivity pneumonitis (microgranulomatous hypersensitivity reaction of lung), rheumatoid arthritis, ${ }^{*}$ Sjögren's syndrome, ${ }^{*}$ and other collagen-vascular diseases; primary biliary cirrhosis in patients with nonspecific interstitial pneumonia (2).

\begin{tabular}{ll}
\hline Organs and Tissues & Procedures \\
\hline External examination & Prepare chest roentgenogram.
\end{tabular}

Blood

Lungs with hilar lymph nodes

Other organs
Submit sample for bacterial, fungal, and viral cultures (p. 102) and protein electrophoresis. Snap-freeze sample for possible serologic studies.

Record weights and photograph both lungs. Submit one lobe for viral, bacterial, and fungal cultures (p. 102). Make touch preparations from cut surfaces. Leave one lung intact and perfuse with formalin (p. 47). For barium sulfate impregnation, see p. 47. Request Gram and Grocott's methenamine silver for microorganisms, and Verhoeff-van Gieson or other special stains to identify collagen and smooth muscle fibers (p. 172).

Prepare samples of fresh lung for electron microscopy (see p. 132).

Prepare sections of hilar lymph nodes.

\section{Possible or Expected Findings}

Clubbing of fingers. Distribution of densities may be important for determining the specific type of the condition. Pleural effusions. Underlying or superimposed infections. Dysproteinemia in LIP (2).

Interstitial pulmonary fibrosis, often with interstitial inflammatory infiltrates, alveolar edema, Masson bodies, and bronchiolitis obliterans. Minute noncaseating granulomas in extrinsic allergic alveolitis (4) and large granulomas in sarcoidosis.* Diffuse aggregates of lightly pigmented macrophages in DIP. Hyaline membranes in diffuse alveolar damage. LIP may be difficult to separate from lymphoma, with or without evidence of Epstein-Barr virus DNA (2). Tubuloreticular structures and electrondense deposits in systemic lupus erythematosus; * identification of viruses, Pneumocystis, or particles in pneumoconiosis (5).

Granulomas in sarcoidosis.* Manifestations of conditions listed above under Possible Associated Conditions." 


\section{References}

1. Katzenstein A-L, Myers J. Idiopathic pulmonary fibrosis: clinical relevance of pathologic classification. Am J Respir Crit Care Med 1998; 157:1301-1315.

2. Fishback N, Koss M. Update on lymphoid interstitial pneumonitis. Curr Opin Pulm Med 1996;2:429-433.
3. Schneider RF. Lymphocytic interstitial pneumonitis and nonspecific interstitial pneumonitis. Clin Chest Med 1996;17:763-766.

4. Coleman A, Colby TV: Histologic diagnosis of extrinsic allergic alveolitis. Am J Surg Pathol 1988;12:514-518.

5. Panchal A, Koss MN. Role of electron microscopy in interstitial lung disease. Curr Opin Pulm Med 1997;3:341-347.

\section{Pneumonia, Lipoid}

Related Terms: Exogenous lipoid pneumonia; inhalation lipoid pneumonia; lipid pneumonia; mineral oil pneumonia.

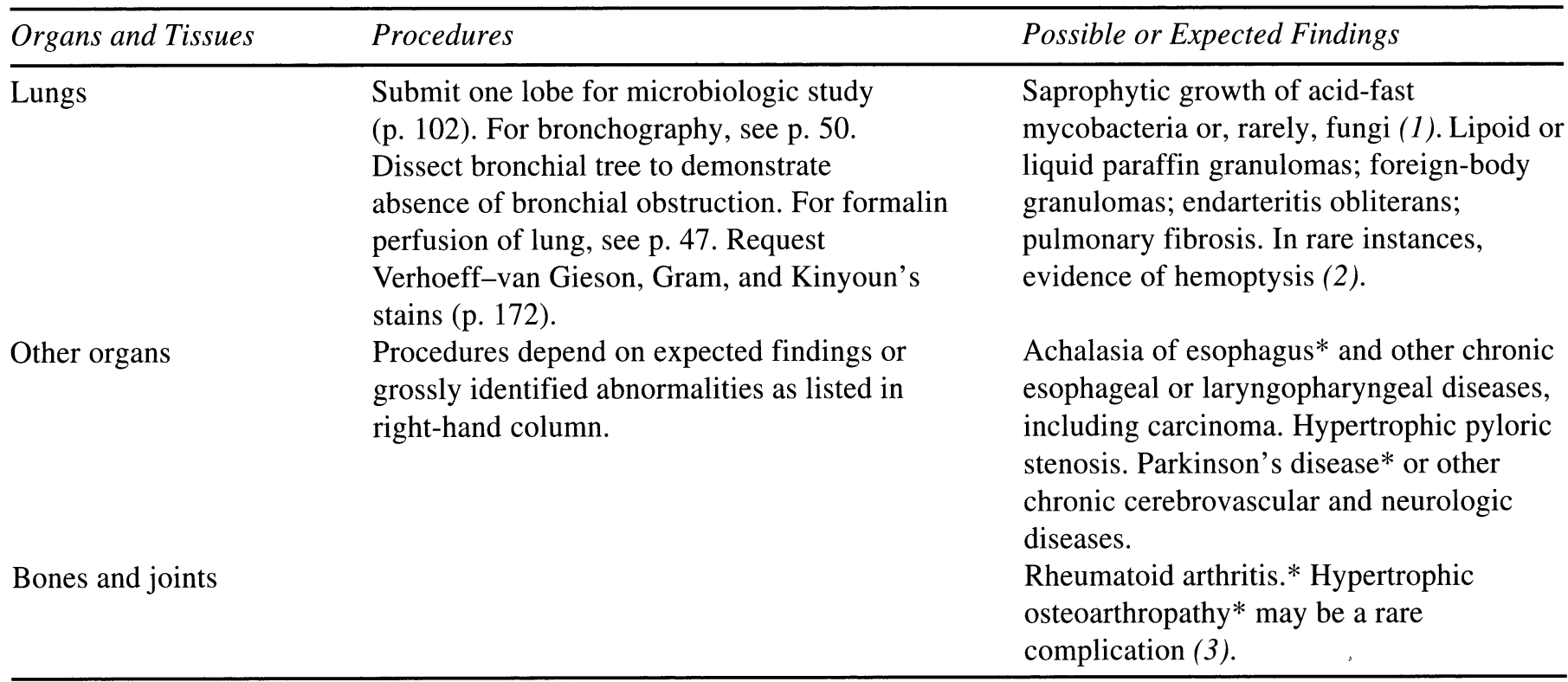

\section{References}

1. Jouannic I, Desrues B, Lena H, Quinquenel ML, Donnio PY, Delaval P. Exogenous lipoid pneumonia complicated by Mycobacterium fortuitum and Aspergillus fumigatus infection. Eur Respir J 1996;9:172-174.

2. Haro M, Murcia I, Nunez A, Julia E, Valer J. Massive haemoptysis complicating exogenous lipid pneumonia. Eur Respir J 1998;11:507-508.

3. Hugosson C, Bahabri S, Rifai A, al-Dalaan A. Hypertrophic osteoarthropathy caused by lipoid pneumonia. Pediatr Radiol 1995;25:482-483.

\section{Pneumothorax}

Postmortem chest roentgenograms provide the only reliable and permanent record of a pneumothorax and its main complication, mediastinal shift due to a tension pneumothorax (Fig. II-4). If roentgenograms cannot be prepared, a reasonably reliable diagnosis still can be made if the prosector inserts a needle through the lateral chest wall. The needle should be connected to a water-filled flask. If a pneumothorax is present, gas bubbles appear in the flask as shown in Fig. II-5. One can also expose the intact parietal pleura and observe if the lung tissue is separated from the parietal pleura by gas. Incising the thorax at the base of a water-filled skin pocket is the least reliable method.

Infants can be totally submerged under water before the chest cavity is incised. However, care must be taken not to make an accidental incision into the underlying lung tissue.

\section{Poisoning, All Types or Type Unspecified}

NOTE: If a specific substance is suspected-for instance, arsenic or ethylene glycol-follow procedures described under the appropriate entry. Similar entries can be found for poisons whose general character or source is known-for instance, gas or mushroom poisoning. For some substances, the appropriate entry can be found under "Abuse,...," "Death,...," or "Dependence,..." In all instances, routine sampling of toxicologic material should be done as described in pp. 14-17. If no specific substances can be incriminated, the toxicologist must be provided with all available clinical information, as shown in Chapter 2.

In most cases of fatal poisoning, the coroner or medical examiner must be notified.

\section{Poisoning, Alkaloid}

NOTE: See under specific name of alkaloid-for instance, "Dependence, cocaine," "Poisoning, atropine," "Poisoning, digitalis," or "Poisoning, strychnine." Only a fraction of this large group of plant poisons has been listed. Whether the specific name of the alkaloid is known or unknown, complete toxicologic sampling (p. 16) is recommended. 


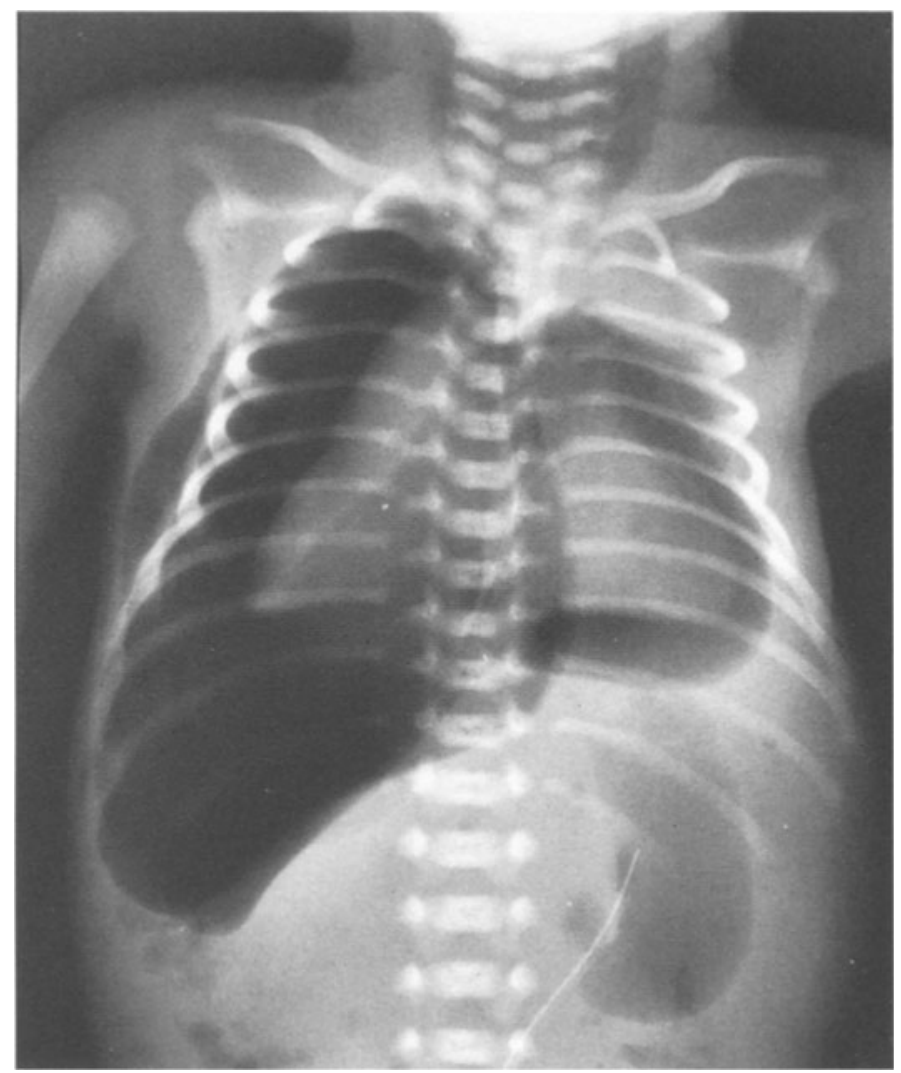

Fig. II-4. Tension pneumothorax. This premature newborn (26 wk gestation) had been intubated but died suddenly because of a pneumothorax on the left and a tension pneumothorax on the right. Pneumomediastinum was also present. These complications had not been recognized prior to death.

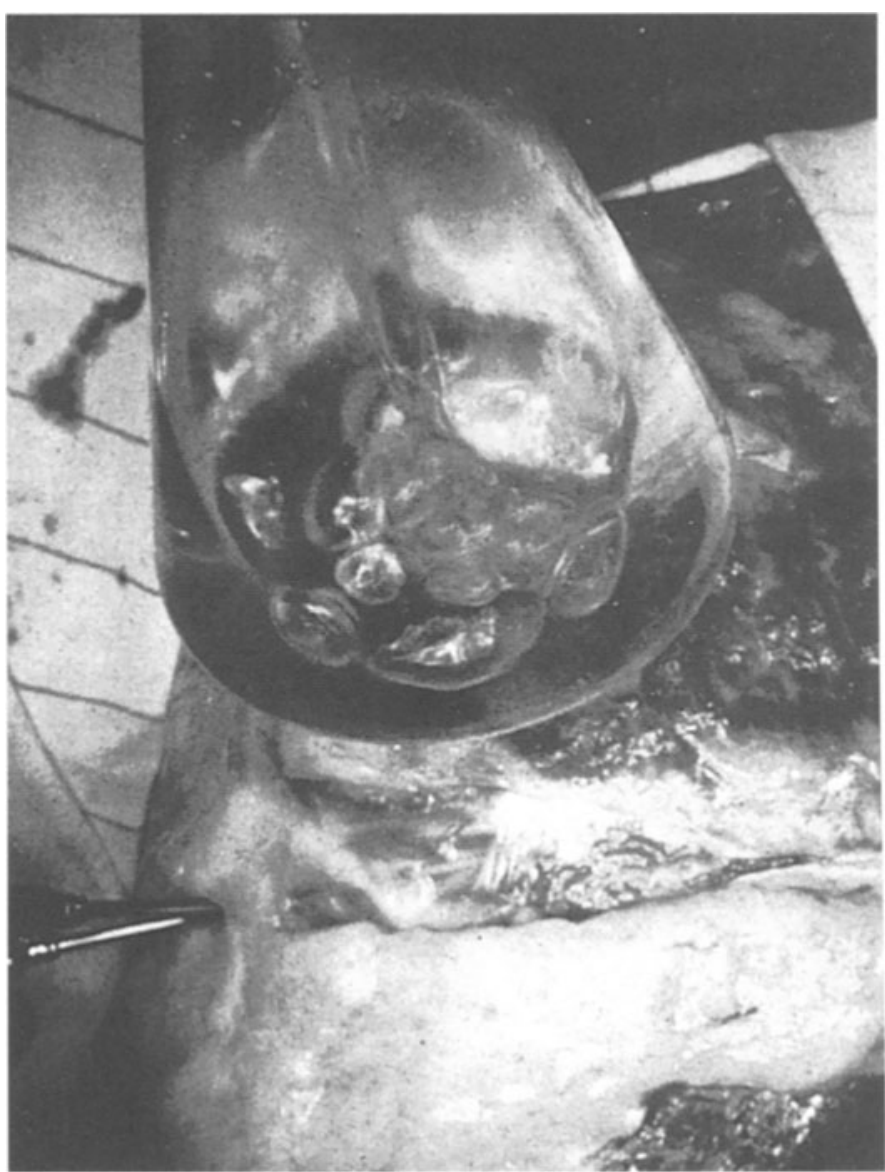

Fig. II-5. Tension pneumothorax. Skin has been dissected off right side of chest, and needle is inserted into chest wall. Rubber hose connects needle with glass tube. Note gas bubbles emerging from tip of glass tube at bottom of water-filled flask.

\section{Poisoning, Ammonia}

NOTE: The appropriate autopsy procedures are described under "Bronchitis, acute chemical" and under "Poisoning, gas." Blood ammonia concentrations are markedly increased. Formalin perfusion of lungs is not recommended; it may cause artifactual ballooning and internal ruptures of organ.

\section{Poisoning, Antifreeze (See "Poisoning, ethylene glycol.")}

\section{Poisoning, Antimony}

NOTE: Toxicologic material should be submitted for analysis, as suggested under "Poisoning, arsenic." Iatrogenic antimony toxicity may occur after treatment with antimony compounds for conditions such as filariasis, fungal infections, and schistosomiasis.*

\begin{tabular}{lll}
\hline Organs and Tissues & Procedures & Possible or Expected Findings \\
\hline $\begin{array}{l}\text { External examination } \\
\text { and eyes }\end{array}$ & Record skin changes and eye abnormalities. & $\begin{array}{l}\text { If exposure was from dust in smelting work, } \\
\text { dermatitis and conjunctivitis may be present. }\end{array}$ \\
$\begin{array}{c}\text { Pharynx and } \\
\text { gastrointestinal tract }\end{array}$ & $\begin{array}{l}\text { For toxicologic sampling of contents, see } \\
\text { p. 16. Submit tissue samples for histologic } \\
\text { study. }\end{array}$ & $\begin{array}{l}\text { Severe gastroenteritis in acute poisoning. } \\
\text { If victim drank antimony trichloride, } \\
\text { ulcerative pharyngitis and gastritis may } \\
\text { be present. }\end{array}$ \\
Heart, liver, and kidneys & Request frozen sections for Sudan stain (p. 173). & $\begin{array}{l}\text { Fatty changes of myocardium and hepatic and } \\
\text { renal parenchyma. }\end{array}$ \\
\hline
\end{tabular}




\section{Poisoning, Arsenic}

NOTE: Toxicologic material will be contaminated by bringing it in contact with fluids. Keratinized tissues take up arsenic from solutions. Put plastic bags over hands of victim.

If exhumed bodies are investigated for arsenic poisoning, include material from surrounding soil and coffin along with tissues submitted for chemical analysis.

Interpretation of toxicologic findings: After fatal poisoning, arsenic concentrations in the liver tend to exceed $0.5-1.0 \mathrm{mg} / 100$ $\mathrm{g}$ wet tissue. In acute poisoning, arsenic concentrations in hair may reach $3 \mu \mathrm{g} / \mathrm{g}(1)$ and in nails $8 \mu \mathrm{g} / \mathrm{g}$. Intervals between ingestion of a fatal dose of arsenic and death are given in Fig. 2-1, p. 15.

\begin{tabular}{|c|c|c|}
\hline Organs and Tissues & Procedures & Possible or Expected Findings \\
\hline $\begin{array}{l}\text { External examination } \\
\text { and skin }\end{array}$ & $\begin{array}{l}\text { Pull (do not cut) } 10 \mathrm{~g} \text { of hair from scalp and } \\
\text { tie in locks with cotton. The ends with the hair } \\
\text { roots should be identified. Collect some whole } \\
\text { fingernails and toenails. Collect skin for toxico- } \\
\text { logic study (p. 17). Record findings as listed in } \\
\text { right-hand column; prepare photographs. }\end{array}$ & $\begin{array}{l}\text { In chronic poisoning-manifestations of } \\
\text { malnutrition,* alopecia, hyperpigmentation, } \\
\text { eczematoid skin changes, hyperkeratosis of } \\
\text { plantar and palmar surfaces, and white streaks } \\
\text { (Mee's lines) on fingernails. }\end{array}$ \\
\hline Blood & $\begin{array}{l}\text { Submit sample for toxicologic study (p. 16). } \\
\text { Prepare smear. }\end{array}$ & Basophilic stippling; immature cells. \\
\hline Heart & $\begin{array}{l}\text { For histologic sampling, see p. } 30 \text {. Prepare } \\
\text { frozen section of myocardium and request } \\
\text { Sudan stain for fat. }\end{array}$ & $\begin{array}{l}\text { Subendocardial ventricular hemorrhages; } \\
\text { fatty changes and round cell infiltrates of } \\
\text { myocardium; myocardial infarction. }\end{array}$ \\
\hline Arteries & $\begin{array}{l}\text { Request Verhoeff-van Gieson stain (p. 173) } \\
\text { of samples from skin, heart, stomach, intestine, } \\
\text { mesentery, liver, pancreas, spleen, and kidney. }\end{array}$ & $\begin{array}{l}\text { Intimal thickening in chronic poisoning } \\
\text { of infants. }\end{array}$ \\
\hline Stomach & $\begin{array}{l}\text { Submit all contents for toxicologic analysis } \\
\text { (p. 16). Inspect wall with magnifying glass } \\
\text { for identification of crystals. }\end{array}$ & $\begin{array}{l}\text { Acute gastritis (in acute poisoning) with } \\
\text { arsenous sulfide crystals in mucus coating } \\
\text { wall of stomach. }\end{array}$ \\
\hline Intestinal tract & $\begin{array}{l}\text { Submit contents (feces) for toxicologic study } \\
\text { (p. 16). }\end{array}$ & $\begin{array}{l}\text { Congestion and inflammation of mucous } \\
\text { membranes. }\end{array}$ \\
\hline Liver & $\begin{array}{l}\text { Record weight. Submit (together with bile) } \\
\text { for toxicologic study (p. 16). Submit samples } \\
\text { for histolgic study. }\end{array}$ & Cirrhosis. Fatty changes. \\
\hline Kidneys & Submit samples for histologic study. & Fatty changes. Tubulo-interstitial nephritis (2). \\
\hline Urine & $\begin{array}{l}\text { Submit sample for toxicologic and chemical } \\
\text { study (p. 16). }\end{array}$ & Test for coproporphyrin positive. \\
\hline Pharynx and larynx & & Inflamed mucous membranes. \\
\hline Other organs and tissues & For general toxicologic sampling, see p. 16. & \\
\hline Bone & Submit sample for toxicologic study. & \\
\hline Bone marrow & For preparation of sections and smears, see p. 96. & Toxic changes. \\
\hline
\end{tabular}

\section{References}

1. Pazirandeh A, Brati AH, Marageh MG. Determination of arsenic in hair using neutron activation. Appl Radiat Isot 1998;49:753-759.

2. Prasad GV, Rossi NF. Arsenic intoxication associated with tubulointerstitial nephritis. Am J Kidney Dis 1995;26:373-376.

\section{Poisoning, Atropine}

Synonyms and Related Terms: Belladonna; hyoscine (scopolamine); hyoscyamine; hyoscyamus; stramonium.

\begin{tabular}{lll}
\hline Organs and Tissues & Procedures & Possible or Expected Findings \\
\hline $\begin{array}{l}\text { External examination } \\
\text { Eyes }\end{array}$ & $\begin{array}{l}\text { Record diameter of pupils. } \\
\text { Submit samples for toxicologic study } \\
\text { (p. 16). }\end{array}$ & $\begin{array}{l}\text { Body dry and warm after death. } \\
\text { Mydriasis. }\end{array}$ \\
$\begin{array}{l}\text { Heart } \\
\text { Gastrointestinal tract }\end{array}$ & $\begin{array}{l}\text { Collect all contents (p. 16), particularly in } \\
\text { accidental poisoning in children. }\end{array}$ & $\begin{array}{l}\text { Iatrogenic atrioventricular block (1). } \\
\text { Fruits of Atropa belladonna or seeds of } \\
\text { Oatura stramonium may be found. } \\
\text { No characteristic findings. }\end{array}$ \\
\hline
\end{tabular}




\section{Reference}

1. Brunner-La Rocca HP, Kiowski W, Bracht C, Weilenmann D, Follath F. Atrioventricular block after administration of atropine in patients following cardiac transplantation. Transplant 1997;63:1838-1839.

\section{Poisoning, Barbiturate(s)}

NOTE: This type of poisoning has become uncommon. Barbiturates may cause sudden death. In all instances, concomitant alcohol intoxication* must be ruled out. Standard toxicologic sampling is sufficient (p. 16).

\begin{tabular}{lll}
\hline Organs and Tissues & Procedures & Possible or Expected Findings \\
\hline Blood & $\begin{array}{l}\text { Submit samples of blood from portal vein and } \\
\text { peripheral veins or heart for toxicologic study. }\end{array}$ & $\begin{array}{l}\text { Evidence of alcohol intoxication.* } \\
\text { Poisoning by other addictive drugs. }\end{array}$ \\
$\begin{array}{l}\text { Bile } \\
\text { Urine }\end{array}$ & $\begin{array}{l}\text { Refrigerate for possible toxicologic study. } \\
\text { tests for protein, glucose, and ketones; } \\
\text { request drug screen. } \\
\text { Submit all contents and record their character. } \\
\text { Analyze for barbiturates and alcohol. }\end{array}$ & $\begin{array}{l}\text { Gritty residues of unabsorbed tablets, } \\
\text { powder, or capsules. Mucosal corrosion, } \\
\text { ulceration, and discoloration from capsules } \\
\text { may occur. } \\
\text { Concentration of barbiturate in parenchyma } \\
\text { important for interpretation. }\end{array}$ \\
\hline
\end{tabular}

\section{Poisoning, Bismuth}

NOTE: Accidental poisoning is common (industrial exposure or drugs with soluble bismuth compounds). Search also for other heavy metals. Acute kidney failure* may be the cause of death. For toxicologic sampling, see p. 16.

\begin{tabular}{|c|c|c|}
\hline Organs and Tissues & Procedures & Possible or Expected Findings \\
\hline $\begin{array}{l}\text { External examination } \\
\text { and oral cavity }\end{array}$ & $\begin{array}{l}\text { Record abnormalities as listed in right-hand } \\
\text { column. }\end{array}$ & $\begin{array}{l}\text { Stomatitis with bluish black discoloration of } \\
\text { gums; loose teeth; sticky white membranous } \\
\text { patches in mouth and throat. Jaundice. }\end{array}$ \\
\hline Blood & Submit sample for toxicologic study. & \\
\hline Urine & $\begin{array}{l}\text { Submit sample for toxicologic study. } \\
\text { Use one sample for preparation of sediment. }\end{array}$ & $\begin{array}{l}\text { Protein casts and tubular epithelial cells } \\
\text { in sediment. }\end{array}$ \\
\hline Gastrointestinal tract & $\begin{array}{l}\text { Submit contents for toxicologic study. } \\
\text { Record appearance of mucosa. Submit samples } \\
\text { for histologic study. }\end{array}$ & $\begin{array}{l}\text { Gray or black mucosal membranes; swelling } \\
\text { of mucosa; intestinal ulcers that may be } \\
\text { perforated. Hemosiderosis. }\end{array}$ \\
\hline Liver & $\begin{array}{l}\text { Submit samples for toxicologic and histologic } \\
\text { study. Request Gomori's iron stain (p. 172). }\end{array}$ & Fatty changes; hemosiderosis. \\
\hline Spleen & $\begin{array}{l}\text { Submit samples for toxicologic and histologic } \\
\text { study. }\end{array}$ & Hemosiderosis. \\
\hline Kidneys & $\begin{array}{l}\text { Submit samples for toxicologic and histologic } \\
\text { study. }\end{array}$ & $\begin{array}{l}\text { Fatty changes; renal tubular degeneration } \\
\text { with amorphic basophilic deposits in } \\
\text { epithelium of convoluted tubules. } \\
\text { Hemosiderosis. }\end{array}$ \\
\hline Neck organs & & See above under "External examination." \\
\hline Peripheral nerves & For removal and specimen preparation, see p. 79. & Peripheral neuritis. \\
\hline
\end{tabular}

\section{Poisoning, Bromide}

Synonyms: Bromine poisoning; bromism.

NOTE: The lethal dose is about $0.2 \mathrm{~g}$ in children and $1 \mathrm{~g}$ in adults (ingested). After fatal methyl bromide poisoning, headspace gas chromatography revealed a subclavian blood concentration of $3.0 \mathrm{microgram} / \mathrm{mL}$ whereas inorganic bromide concentrations were $530 \mathrm{micrograms} / \mathrm{mL}$ in the blood (1). Tissue concentrations were lower than those in the blood. For toxicologic sampling, see p. 16. 


\begin{tabular}{lll}
\hline Organs and Tissues & Procedures & Possible or Expected Findings \\
\hline $\begin{array}{l}\text { External examination, } \\
\text { skin, and eyes }\end{array}$ & $\begin{array}{l}\text { Prepare photographs and histologic sections } \\
\text { of skin lesions. }\end{array}$ & $\begin{array}{l}\text { Chemical burns on face and conjunctivitis } \\
\text { indicate direct exposure; skin pustules over } \\
\text { body and nodose bromoderma of the legs } \\
\text { indicate bromism. }\end{array}$ \\
Blood & Submit sample for toxicologic study. & $\begin{array}{l}\text { Blood is best suited for bromide } \\
\text { determination. }\end{array}$ \\
$\begin{array}{l}\text { Urine } \\
\text { Gastrointestinal tract }\end{array}$ & $\begin{array}{l}\text { Submit sample for toxicologic study. } \\
\text { Submit gastric contents for toxicologic } \\
\text { examination. Record appearance of gastro- } \\
\text { intestinal mucosa. } \\
\text { If possible, remove lungs together with neck } \\
\text { and lungs }\end{array}$ & $\begin{array}{l}\text { After ingestion of bromide, necrosis with } \\
\text { brown discoloration of mucosa of upper } \\
\text { gastrointestinal tract may be present. } \\
\text { After inhalation of bromide, swelling and } \\
\text { inflammation of mucous membranes in upper } \\
\text { and lower respiratory tracts may be present. }\end{array}$ \\
& & $\begin{array}{l}\text { There may be pulmonary edema. Pneumonia } \\
\text { occurs in bromism. }\end{array}$ \\
Other organs & Toxicologic samples should include liver \\
and kidneys. & \\
\hline
\end{tabular}

\section{Reference}

1. Michalodimitrakis MN, Tsatsakis AM, Christakis-Hampsas MG, Trikilis N, Christodoulou P. Death following intentional methyl bromide poisoning: toxicological data and literature review. Vet Hum Toxicol 1997;39:30-34.

\section{Poisoning, Cadmium}

Organs to be analyzed for $\mathrm{Cd}$ should have no contact with water or be contaminated with blood; they should be sealed in polyethylene bags. Cd leaks into fixation fluid. Postmortem blood concentrations are very high and no indicator of the antemortem values (1). For toxicologic sampling, see p. 16.

\begin{tabular}{|c|c|c|}
\hline Organs and Tissues & Procedures & Possible or Expected Findings \\
\hline $\begin{array}{l}\text { External examination } \\
\text { and oral cavity }\end{array}$ & & Yellow gingival line in chronic poisoning. \\
\hline Blood & Submit sample for toxicologic study. & \\
\hline Urine & $\begin{array}{l}\text { Submit sample for determination of cadmium } \\
\text { concentration. }\end{array}$ & Elevated urinary cadmium concentrations (2). \\
\hline Lungs & $\begin{array}{l}\text { Submit sample for toxicologic study. } \\
\text { and one lobe for microbiologic study (p. 103). } \\
\text { Perfuse one lung with formalin (p. } 47 \text { ). }\end{array}$ & $\begin{array}{l}\text { Pulmonary edema, alveolar wall damage, and } \\
\text { interstitial pneumonia after acute inhalation. } \\
\text { Severe pulmonary fibrosis may develop in } \\
\text { chronic cases. }\end{array}$ \\
\hline Gastrointestinal tract & For in situ fixation, see p. 54. & $\begin{array}{l}\text { Gastroenteritis after nonlethal food } \\
\text { poisoning. }\end{array}$ \\
\hline Kidneys & $\begin{array}{l}\text { Collect renal tissue for light microscopic and } \\
\text { electron microscopic study (p. 132). }\end{array}$ & $\begin{array}{l}\text { Degeneration of proximal tubules and } \\
\text { proteinuria in acute poisoning; interstitial } \\
\text { nephritis in chronic poisoning. } \\
\text { Nephrolithiasis (3). }\end{array}$ \\
\hline Other organs & $\begin{array}{l}\text { Sample for toxicologic study. } \\
\text { Submit samples for histologic study also. }\end{array}$ & $\begin{array}{l}\text { Degenerative changes of liver and } \\
\text { myocardium. }\end{array}$ \\
\hline
\end{tabular}

\section{References}

1. Koizumi N, Hatayama F, Sumino K. Problems in the analysis of cadmium in autopsied tissues. Environm Res 1994;64:192-198.

2. Ando Y, Shibata E, Tsuchiyama F, Sakai S. Elevated urinary cadmium concentrations in a patient with acute cadmium pneumonitis. Scand J Work Environ Health 1996;22:150-153.

3. Savolainen H. Cadmium-associated renal disease. Ren Fail 1995;17:483-487. 


\section{Poisoning, Carbon Monoxide}

NOTE: If the victim had been in a fire, see also under "Burns." Carbon monoxide poisoning may rarely be responsible for automobile accidents. Relatively low carboxyhemoglobin concentrations may contribute to death if there is concomitant poisoning_for instance, with alcohol or drugs, particularly sedatives. Anemia, atherosclerotic heart disease, and chronic pulmonary disease also increase sensitivity to carbon monoxide.

If blood had been withdrawn at time of hospital admissionfor instance, for crossmatching - submit this for carboxyhe- moglobin determination. If no blood can be obtained, see under "Heart, kidneys, and other organs." For quick-orienting qualitative tests, for quantitative methods of carbon monoxide determination, and for interpretation of toxicologic findings, see below. Request also determination of hemoglobin concentrations and of blood alcohol. Request drug screen. For shipping of blood and tissues for carbon monoxide determination, see p. 135. It should be noted that losses of up to $60 \%$ of the original saturation occurred when blood was kept in uncapped container at room temperature for $2 \frac{1 / 2}{\mathrm{wk}}$ or at $4^{\circ} \mathrm{C}$ for $3 \mathrm{wk}$.

\begin{tabular}{|c|c|c|}
\hline Organs and Tissues & Procedures & Possible or Expected Findings \\
\hline External examination & $\begin{array}{l}\text { Record color of fingernails, particularly in } \\
\text { heavily pigmented persons in whom lividity } \\
\text { is difficult to discern. }\end{array}$ & $\begin{array}{l}\text { Pink skin and fingernails; bullous edema } \\
\text { of skin; decubital ulcers. }\end{array}$ \\
\hline Blood & $\begin{array}{l}\text { Record appearance of blood and submit sample } \\
\text { of postmortem blood for toxicologic study } \\
\text { (p. 16). See also above under "Note." }\end{array}$ & $\begin{array}{l}\text { Blood tends to be cherry red. For } \\
\text { interpretation of toxicologic findings, } \\
\text { see below. }\end{array}$ \\
\hline $\begin{array}{l}\text { Heart, kidneys, } \\
\text { and other organs }\end{array}$ & $\begin{array}{l}\text { If no blood can be obtained, prepare water } \\
\text { extract of spleen, kidneys, or other organs. } \\
\text { Request determination of carbon monoxide } \\
\text { content and of carbon monoxide-binding } \\
\text { capacity of this mixture. Submit tissue } \\
\text { samples for histologic study. }\end{array}$ & $\begin{array}{l}\text { Necrosis of papillary muscles in the heart } \\
\text { or myocardial infarction may occur. Renal } \\
\text { tubular degeneration may also be found. } \\
\text { Acute kidney failure* has been observed } \\
\text { after rhabdomyolysis complicated by } \\
\text { compartment syndrome (2). }\end{array}$ \\
\hline Brain & $\begin{array}{l}\text { For removal and specimen preparation, } \\
\text { see p. } 65 .\end{array}$ & $\begin{array}{l}\text { Hemorrhagic necrosis of basal ganglia } \\
\text { (lenticular nucleus in globus pallidus); } \\
\text { diffuse petechial hemorrhages in white } \\
\text { matter; cerebral edema. Acute hydrocephalus } \\
\text { in infants (3). }\end{array}$ \\
\hline
\end{tabular}

\section{Methods of Carbon Monoxide Determination}

Many methods of carbon monoxide determination have been described. Currently, carboxyhemoglobin is detected in most medical examiner toxicology laboratories by visible spectrophotometry or gas chromatography. In hospitals, carboxyhemoglobin is frequently detected and reported in the course of routine arterial blood gas analysis.

Pink discoloration of skin and organs usually indicates the presence of more than $30 \%$ carboxyhemoglobin (but rule out cyanide poisoning* and exposure to cold*).

In a healthy, middle-aged person, a carboxyhemoglobin concentration greater than $50-60 \%$ is usually fatal. If the victim was anemic or suffered from chronic lung disease, particularly emphysema* or atherosclerotic heart disease, the concentration may be lower. In association with alcohol, sedatives, and other drugs, carboxyhemoglobin levels may also be much lower and yet fatal.

A heavy cigarette smoker may have a carboxyhemoglobin concentration of $8-10 \%$, and higher levels may occur in police officers and other persons exposed to automobile exhaust in dense traffic.

If the victim survived the carbon monoxide poisoning for several hours, postmortem blood samples usually will fail to show the presence of carboxyhemoglobin. In these instances, blood taken at the time of admission to the hospital may still be available and of particular value. If the victim had spent $1 \mathrm{~h}$ in fresh air before death, $40-50 \%$ of the carbon monoxide will have been removed, and $8-10 \%$ will have been removed during each subsequent hour. Even though clearance may be complete, death may still occur — primarily from brain damage and infectious complications in prolonged coma. 


\section{Physiologic Effects of Carbon Monoxide Poisoning ${ }^{\dagger}$}

\begin{tabular}{ll}
\hline \% of carboxy-hemoglobin & Clinical Signs/Symptoms \\
\hline 10 & No appreciable effect except shortness of breath on vigorous muscular exertion \\
20 & In most cases, no appreciable effect except dyspnea, even on moderate exertion; slight headache \\
& in some cases \\
30 & Decided headache; irritability; easy fatigability; disturbance of judgment \\
$40-50$ & Headache; confusion; fainting and collapse on exertion \\
$60-70$ & Unconsciousness, respiratory failure, and death if exposure is prolonged \\
80 & Rapidly fatal \\
$>80$ & Immediately fatal \\
\hline
\end{tabular}

${ }^{\dagger}$ Modified from Henderson Y, Haggard HW. Noxious Gases. The Chemical Catalog Co., New York, 1927.

\section{References}

1. Ocak A, Valentour JC, Blanke RV. The effects of storage conditions on the stability of carbon monoxide in postmortem blood. J Anal Toxicol 1985;9:202-206.

2. Abdul-Ghaffar NU, Farghaly MM, Swamy AS. Acute renal failure, compartment syndrome, and systemic capillary leak syndrome complicating carbon monoxide poisoning. J Toxicol 1996;34:713-719.

3. So GM, Kosofsky BE, Southern JF. Acute hydrocephalus following carbon monoxide poisoning. Pediatr Neurol 1997;17:270-273.

\section{Poisoning, Carbon Tetrachloride}

Synonym: Tetrachloromethane poisoning.

NOTE: Toxicologic sampling of body fluids and organs should be done routinely in all cases (p. 16). In many instances, however, death occurs $1 \mathrm{wk}$ to $10 \mathrm{~d}$ after exposure, and by this time no carbon tetrachloride is demonstrable. Death may be sudden or delayed by only a few hours, particularly after inhalation of carbon tetrachloride (see also Fig. 2-1, p. 15). Sudden death probably is caused by cardiac dysrrhythmia.

Alcohol concentrations should be determined in all cases or, if death was delayed, evidence of drinking at the time of exposure should be sought. Alcohol considerably increases the hazards of carbon tetrachloride.

\begin{tabular}{|c|c|c|}
\hline Organs and Tissues & Procedures & Possible or Expected Findings \\
\hline External examination & & Jaundice; pedal edema. \\
\hline Heart & $\begin{array}{l}\text { Submit samples for histologic study, and } \\
\text { request frozen sections for Sudan stain (p. 173). }\end{array}$ & Fatty changes of myocardium. \\
\hline Liver & $\begin{array}{l}\text { Record weight and photograph; submit samples } \\
\text { for histologic study. Request frozen sections for } \\
\text { Sudan stain. }\end{array}$ & $\begin{array}{l}\text { Centrilobular or diffuse hepatic necrosis and } \\
\text { fatty changes. Cirrhosis* after chronic } \\
\text { exposure. }\end{array}$ \\
\hline Kidneys & $\begin{array}{l}\text { Photograph and submit samples for histologic } \\
\text { study. Request frozen sections for Sudan stain. }\end{array}$ & $\begin{array}{l}\text { Acute tubular necrosis (lower nephron } \\
\text { nephrosis); fatty degeneration. }\end{array}$ \\
\hline Adrenal glands & Sample for histologic study. & Necrosis in zona fasciculata and reticularis. \\
\hline Brain & For removal and specimen preparation, see p. 65 . & $\begin{array}{l}\text { Perivenous necroses in cerebral white matter; } \\
\text { cerebellar degeneration (Purkinje cells). } \\
\text { Pontine necrosis. }\end{array}$ \\
\hline Eyes & For removal and specimen preparation, see p. 85 . & Optic neuritis in chronic cases. \\
\hline Peripheral nerves & $\begin{array}{l}\text { For sampling and specimen preparation, } \\
\text { see p. } 79 \text {. }\end{array}$ & Peripheral neuritis in chronic cases. \\
\hline
\end{tabular}

\section{Poisoning, Chlorine or Hydrochloric Acid}

Related Terms: $\mathrm{Cl}_{2}$ poisoning; $\mathrm{HCl}$ poisoning.

NOTE: See also under "Bronchitis, acute chemical" and under "Poisoning, gas." Hydrochloric acid is sold by plumbing supply houses and pool supply companies as muriatic acid. It is a liquid. Chlorine is a water-soluble gas. As supplied for pool sanitation, liquid chlorine is usually acidic. For convenience, chlorine and hydrochloric acid are discussed here together.

\begin{tabular}{lll}
\hline Organs and Tissues & Procedures & Possible or Expected Findings \\
\hline $\begin{array}{l}\text { External examination } \\
\text { and eyes }\end{array}$ & Prepare photographs of face. & $\begin{array}{l}\text { Conjunctivitis and cyanosis in chlorine gas } \\
\text { poisoning; burns of lips from hydrochloric } \\
\text { acid. }\end{array}$
\end{tabular}




\begin{tabular}{|c|c|c|}
\hline Organs and Tissues & Procedures & Possible or Expected Findings \\
\hline Lungs & $\begin{array}{l}\text { Submit one lung for toxicologic study (p. 16; } \\
\text { see also under "Poisoning, gas"). Record lung } \\
\text { weights. Formalin perfusion of lungs is not } \\
\text { recommended; it may cause artifactual } \\
\text { ballooning and internal ruptures of organ. }\end{array}$ & $\begin{array}{l}\text { Severe pulmonary edema, broncho- } \\
\text { pneumonia, and swelling of mucous } \\
\text { membranes in chlorine poisoning. Arterial } \\
\text { thrombosis may occur. Pulmonary fibrosis } \\
\text { may develop after prolonged survival. }\end{array}$ \\
\hline Larynx and trachea & $\begin{array}{l}\text { Leave esophagus and stomach attached to } \\
\text { neck organs. Open larynx anteriorly and check } \\
\text { whether a perforation has occurred. }\end{array}$ & $\begin{array}{l}\text { Swelling and ulceration of mucous } \\
\text { membranes in chlorine poisoning; acute } \\
\text { laryngotracheitis. Tracheoesophageal } \\
\text { perforation. }\end{array}$ \\
\hline \multirow[t]{2}{*}{ Esophagus and stomach } & $\begin{array}{l}\text { See also above under "Larynx and trachea." } \\
\text { Photograph opened esophagus and stomach. }\end{array}$ & $\begin{array}{l}\text { Corrosion of mucosa with thickening, } \\
\text { hemorrhage, and blackish discoloration after } \\
\text { ingestion of hydrochloric acid. }\end{array}$ \\
\hline & $\begin{array}{l}\text { Sample for histologic study, particularly if there } \\
\text { is doubt whether a perforation was antemortem } \\
\text { or postmortem. }\end{array}$ & $\begin{array}{l}\text { Antemortem and postmortem perforation } \\
\text { may occur. }\end{array}$ \\
\hline Kidneys & & Glomerular capillary thromboses. \\
\hline Brain & For removal and specimen preparation, see p. 65 . & Hemorrhages in white matter $(1)$. \\
\hline
\end{tabular}

\section{Reference}

1. Adelson L, Kaufman J. Fatal chlorine poisoning: report of two cases with clinicopathologic correlation. Am J Clin Pathol 1971;56:430-442.

\section{Poisoning, Cyanide}

Synonym: Hydrocyanic acid (hydrogen cyanide) poisoning.

NOTE: Hydrocyanic acid (hydrogen cyanide, $\mathrm{HCN}$ ) is a water-soluble gas. Its salts, sodium cyanide and potassium cyanide are sold as "eggs" to the jewelry industry. Hydrocyanic acid is formed when cyanide salts are dissolved in acidic solutions. Containers from which the poison might have been ingested or inhaled should also be submitted for toxicologic examination. For cyanide screening tests in the autopsy room and for interpretation of findings, see below. Caution: Stomach may still contain cyanide gas, formed by acidic reaction of cyanide salt. It may be best to open the stomach under a hood (1). The odor is quite characteristic for cyanide poisoning but most persons are unable to smell this odor. It is helpful to know in advance if any person in an office or laboratory can smell cyanide. Forensic pathologists who can smell the compound state that it has its own specific odor, which differs from the often quoted smell of bitter almonds (see Chapter 2). Autopsies also can be done in a negatively pressured isolation room (1). For toxicologic sampling, see p. 16.

\begin{tabular}{ll}
\hline Organs and Tissues & Procedures \\
\hline $\begin{array}{c}\text { External examination } \\
\text { and oral cavity }\end{array}$ & $\begin{array}{l}\text { Record color of skin and possible corrosion } \\
\text { marks, as listed in right-hand column. }\end{array}$
\end{tabular}

Blood

Stomach

Pharynx and esophagus Lungs

Liver

Brain
Submit sample for toxicologic study. For autopsy screening tests, see below.

See above under "Note." Submit contents for toxicologic study. Sample for histologic study.

See above under "Stomach."

Record lung weights and submit one lung for toxicologic study. Submit samples from other lung for histologic study. Submit portion for toxicologic study. For removal and specimen preparation, see p. 65. Submit portion for toxicologic study.
Possible or Expected Findings

For odor, see above under "Note." Bright red skin color is not always present. Corrosion around mouth and in oral cavity may be found after ingestion of potassium or sodium cyanide.

Blood is fluid and sometimes bright red.

If potassium or sodium cyanide was ingested, brown-red mucosal corrosion may be present in stomach or in upper digestive tract.

Pulmonary edema.

For odor, see above under "Note." If death was not instantaneous, there may be hyaline thrombi in small blood vessels, minute hemorrhages, and necroses of lenticular nuclei. 
Cyanide Screening Tests in the Autopsy Room

This test can be used for blood and gastric contents (2). Dip squares of filter paper in a small amount of saturated picric acid. Let these squares dry until barely moist. Place a drop of the material to be tested-e.g., blood or gastric contents-on a piece of paper. Let material dry for a moment, and then place one drop of $10 \%$ sodium carbonate in the center of the material to be tested. If cyanide is present, a reddish purple color will chromatograph out from the material. The higher the concentration of cyanide the more blue the color will be. It is possible to recognize whole blood because the blood turns a rather dark brown and the reddish to purple color is clearly visible. High concentrations of sulfide interfere by giving a false-positive test.

Another screening test is done as follows (3). Dip filter paper into normal blood. Then treat the paper with potassium chlorate, whereupon brown methemoglobin forms. Place this preparation into the fluid suspected of containing cyanide (e.g., blood, gastric contents, pulmonary edema fluid). If bright red cyanmethemoglobin forms, the reaction is positive.

\section{Interpretation of Findings}

If the concentration of cyanide in the stomach is high and the concentration in the lungs is low, cyanide was ingested. Alternatively, if the pulmonary cyanide concentration is high and the concentrtaion in the gastric contents is low, hydrogen cyanide most likely was inhaled. Occasionally, minimal cyanide levels will be present in decomposed bodies.

\section{References}

1. Nolte KB, Dasgupta A. Prevention of occupational cyanide exposure in autopsy prosectors. J Forens Sci 1996;41:146-147.

2. Camps FE. Gradwohl's Legal Medicine, 2nd ed. Williams \& Wilkins Company, Baltimore, 1968, pp. 615-617.

3. Glaister J, Rentoul E. Medical Jurisprudence and Toxicology, 12th ed. E \& S Livingstone, Edinburgh, 1966, p. 686.

\section{Poisoning, Digitalis}

Related Term: Digoxin toxicity.

NOTE: Certain drugs seem to interfere with correct digitalis determination.

\begin{tabular}{lll}
\hline Organs and Tissues & Procedures & Possible or Expected Findings \\
\hline Blood & $\begin{array}{l}\text { Submit sample of peripheral blood for digoxin } \\
\text { radioimmunoassay (p. 16). }\end{array}$ & $\begin{array}{l}\text { Digoxin values in digitalis toxicity are greater } \\
\text { than 2 ng/mL (1). }\end{array}$ \\
Heart & $\begin{array}{l}\text { Freeze fresh myocardium for digitalis extraction. } \\
\text { Submit sample for digoxin radioimmunoassay }\end{array}$ & $\begin{array}{l}\text { Increased digitalis concentrations (2). } \\
\text { Vitreous }\end{array}$ \\
(p. 16). & $\begin{array}{l}\text { lower than concentration may be higher or } \\
\text { on how long before death drug was taken }(1) .\end{array}$ \\
\hline
\end{tabular}

\section{References}

1. DiMaio VJM, Garriot JC, Putnam R. Digoxin concentrations in postmortem specimens after overdose and therapeutic use. J Forensic Sci 1975;20:340-347.
2. Jellifee RW, Stephenson RG. A fluorimetric determination of myocardial digoxin at autopsy, with identification of digitalis leaf, digitoxin and gitonin. Am J Clin Pathol 1969;51:347-357.

Poisoning, Drug(s) (See "Dependence, drug(s), all types or type unspecified" or under "Poisoning,..." followed by specific name of drug.)

Poisoning, Ethanol (Ethyl Alcohol) (See "Alcoholism and alcohol intoxication," "Cardiomyopathy, alcoholic," "Disease, alcoholic liver," “Syndrome, fetal alcoholic," and Syndrome, Wernicke-Korsakoff.")

\section{Poisoning, Ethylene Glycol}

Related Term: Antifreeze poisoning.

NOTE: Pulmonary and cerebral manifestations are the main findings in acute poisoning, and renal tubular necrosis is the primary finding in chronic poisoning. For general toxicologic sampling, see p. 16. Calcium oxalate crystals can be demonstrated in routine histologic sections but also in scanning electron micrographs of thick deparaffinized sections.

\begin{tabular}{ll}
\hline Organs and Tissues & Procedures \\
\hline Eyes & For removal and specimen preparation, see p. 85. \\
Blood & $\begin{array}{l}\text { In acute cases, submit sample for ethylene } \\
\text { glycol determination (p. 16); in chronic cases, }\end{array}$ \\
& $\begin{array}{l}\text { request determination of calcium concentrations. } \\
\text { Prepare sediment. }\end{array}$
\end{tabular}

\section{Possible or Expected Findings}

Papilledema; optic nerve atrophy.

Ethylene glycol in serum (1).

Protein casts; calcium oxalate crystals (2). Crystals are light yellow and birefringent, arranged as sheaves, rhomboids, or prisms. 


\begin{tabular}{lll}
\hline Organs and Tissues & Procedures & Possible or Expected Findings \\
\hline Heart & Sample for histologic study. & $\begin{array}{l}\text { Myocardial degeneration; petechial } \\
\text { hemorrhages. }\end{array}$ \\
Blood vessels & $\begin{array}{l}\text { Submit samples of small vessels from multiple } \\
\text { sites for histologic study. Request Verhoeff- } \\
\text { van Gieson stain (p. 173). }\end{array}$ & $\begin{array}{l}\text { Oxalate crystals in media of small arteries, } \\
\text { with associated ischemic lesions. }\end{array}$ \\
Lungs & Perfuse one lung with formalin (p. 47). & $\begin{array}{l}\text { Congestion; petechial hemorrhages; } \\
\text { bronchopneumonia; edema. }\end{array}$ \\
Gastrointestinal tract & $\begin{array}{l}\text { Submit contents for toxicologic study (p. 16). } \\
\text { Lecord weight; submit samples for histologic }\end{array}$ & $\begin{array}{l}\text { Petechial mucosal hemorrhages. } \\
\text { Hydropic hepatocellular degeneration; fatty } \\
\text { changes and focal necroses. }\end{array}$ \\
Kidneys & $\begin{array}{l}\text { study. } \\
\text { See above under "Note." }\end{array}$ & $\begin{array}{l}\text { Acute renal tubular necrosis; intratubular } \\
\text { crystals. }\end{array}$ \\
Brain & For removal and specimen preparation, see p. 65. & Petechial hemorrhages.
\end{tabular}

\section{References}

1. Eder AF, McGrath CM, Dowdy YG, Tomaszewski JE, Rosenberg FM, Wilson RB, et al. Ethylene glycol poisoning: toxicokinetic and analytical factors affecting laboratory diagnosis. Clin Chem 1998; 44:168-177.

2. Davis DP, Bramwell KJ, Hamilton RS, Williams SR. Ethylene glycol poisoning: case report of a record-high level and a review. J Emerg Med 1997; 15:653-667.

\section{Poisoning, Food}

Related Terms: Bacillary dysentery* (Shigella food poisoning); botulism;* Clostridium perfringens food poisoning; favism; mushroom poisoning;* Salmonella food poisoning; staphylococcal food poisoning.
NOTE: If cause of food poisoning is unknown, submit suspected food for aerobic and anaerobic cultures, Gram stain of smears, and routine toxicologic study. This should include tests for heavy metals (antimony, cadmium, and lead) that may have leaked from old cooking utensils. Test for the presence of staphylococcal enterotoxin are done only in specialized laboratories. If botulism is suspected, follow procedures described under that heading. Mushroom poisoning also is listed as a separate entity. If Salmonella food poisoning is suspected, see under "Fever, typhoid." See also under "Enteritis" or "Enterocolitis" or under another specific heading such as "Dysentery, bacillary." Obtain sufficient material for microbiologic and histologic study to identify organisms such as Chlamydia, Clostridium (type F strains), Salmonella, Shigella, verotoxic E. coli, Yersinia, and others.

\begin{tabular}{lll}
\hline Organs and Tissues & Procedures & Possible or Expected Findings \\
\hline $\begin{array}{l}\text { External examination } \\
\text { Gastrointestinal tract }\end{array}$ & $\begin{array}{l}\text { Submit contents for aerobic and anaerobic } \\
\text { cultures (p. 16 and above under "Note"); } \\
\text { prepare smears of contents for Gram stain } \\
\text { (p. 172). Submit samples for histologic study. }\end{array}$ & $\begin{array}{l}\text { Debilitated states; patients in extremes of life. } \\
\text { Enteritis or enterocolitis. }\end{array}$ \\
\hline
\end{tabular}

\section{Poisoning, Gas}

NOTE: Anesthesia-associated death,* carbon monoxide poisoning, ${ }^{*}$ and sniffing and spray death* are presented under the appropriate headings. Procedures discussed here deal with other volatile substances, including chemical irritants such as ammonia $\left(\mathrm{NH}_{3}\right)$, chlorine or hydrochloric acid poisoning (see also under that heading); methylene chloride, phosgene $\left(\mathrm{COCl}_{2}\right)$, sulfurous acid $\left(\mathrm{H}_{2} \mathrm{SO}_{3}\right)$, or sulfur dioxide $\left(\mathrm{SO}_{2}\right)$.
Gases from body cavities, heart chambers, or blood vessels can be removed as described under "Embolism, air." Gases can also be trapped with a rubber dam after cutting organs under water. Samples from various organs should be shipped in hermetically sealed nonplastic containers or in analyzing solutions.

\begin{tabular}{ll}
\hline Organs and Tissues & Procedures \\
\hline $\begin{array}{l}\text { External examination, } \\
\text { and oral cavity }\end{array}$ & Record extent of chemical burns. \\
Blood & $\begin{array}{l}\text { Submit sample for gas analysis (p. 16). } \\
\text { In many instances, inhaled gases can be } \\
\text { demonstrated chromatographically in gas } \\
\text { from head space above sealed blood specimen. }\end{array}$
\end{tabular}

Larynx and trachea Possible or Expected Findings

Chemical burns in and around mouth or conjunctivas.

Submit sample for gas analysis (p. 16). demonstrated chromatographically in gas Chemical burns. 


\begin{tabular}{lll}
\hline Organs and Tissues & Procedures & Possible or Expected Findings \\
\hline Lungs & If gas was inhaled and is to be analyzed, submit & Chemical pneumonia; pulmonary edema. \\
& intact lungs with bronchi ligated in airtight, & After longer survival, obliterating fibrous \\
& nonplastic container to laboratory that can & bronchiolitis, chronic bronchitis, and \\
& conduct gas analysis. If survival was short, \\
& formalin perfusion of lungs is not recommended; & \\
& it may cause artifactual ballooning and internal \\
& ruptures of organ. Submit samples of tissue for \\
& routine histologic study. \\
& See above under "Note." & \\
\hline
\end{tabular}

Poisoning, Glycol (See “Poisoning, ethylene glycol.”)

Poisoning, Halogen (See "Fluorosis," "Poisoning, bromide," “Poisoning, chlorine or hydrochloric acid," "Poisoning, gas," and "Poisoning, iodine.")

Poisoning, Heavy Metal (See "Poisoning, antimony," "Poisoning, arsenic," "Poisoning, cadmium," "Poisoning, lead," Poisoning, mercury," "Poisoning, thallium.")

\section{Poisoning, Insecticide (See "Poisoning, organophosphate(s)*)}

\section{Poisoning, Iodine}

Related Terms: Lugol's solution; tincture of iodine. For toxicologic sampling, see p. 16.

\begin{tabular}{|c|c|c|}
\hline Organs and Tissues & Procedures & Possible or Expected Findings \\
\hline $\begin{array}{l}\text { External examination } \\
\text { and eyes }\end{array}$ & $\begin{array}{l}\text { Record color of skin and extent of corrosive } \\
\text { lesions. }\end{array}$ & $\begin{array}{l}\text { Perioral corrosive lesions; yellow } \\
\text { discoloration of skin; conjunctivitis after } \\
\text { exposure to vapors. }\end{array}$ \\
\hline $\begin{array}{l}\text { Urine, blood, and } \\
\text { parenchymal organs }\end{array}$ & Submit samples for toxicologic study. & \\
\hline $\begin{array}{l}\text { Lungs and upper } \\
\text { respiratory tract }\end{array}$ & Submit samples for histologic study. & $\begin{array}{l}\text { Acute inflammation of respiratory tract after } \\
\text { inhalation of vapors. }\end{array}$ \\
\hline Stomach & $\begin{array}{l}\text { Submit contents for toxicologic study; } \\
\text { photograph mucosa; prepare histologic } \\
\text { sections. }\end{array}$ & $\begin{array}{l}\text { Corrosive gastritis; if starch was used as } \\
\text { antidote, gastric lining will be bluish. } \\
\text { Histologically, well-preserved mucosa is } \\
\text { present because of in vivo fixation. }\end{array}$ \\
\hline $\begin{array}{l}\text { Intestinal tract } \\
\text { Kidneys }\end{array}$ & See above under "Stomach." & $\begin{array}{l}\text { Mucosa may show same changes as stomach. } \\
\text { Swelling of tubular epithelium. }\end{array}$ \\
\hline
\end{tabular}

\section{Poisoning, Isopropyl Alcohol}

Synonyms: Propanol; rubbing alcohol.

\begin{tabular}{lll}
\hline Organs and Tissues & Procedures & Possible or Expected Findings \\
\hline All organs & $\begin{array}{l}\text { See under “Alcoholism and alcohol } \\
\text { intoxication." }\end{array}$ & $\begin{array}{l}\text { Nonspecific autopsy findings: visceral } \\
\text { congestion; pulmonary and cerebral edema. }\end{array}$ \\
\hline
\end{tabular}

\section{Poisoning, Lead}

NOTE: Lead-free syringes and lead-free polyethylene containers should be used. Blood lead concentrations can now be determined by inductively coupled plasma mass spectrometry (1). For screening methods, see ref. (2).

This is a reportable disease in some states.

\begin{tabular}{lll}
\hline Organs and Tissues & Procedures & Possible or Expected Findings \\
\hline $\begin{array}{c}\text { External examination, } \\
\text { oral cavity, and hair }\end{array}$ & $\begin{array}{l}\text { Bluish lead line at gingival margin in victims } \\
\text { with poor oral hygiene. }\end{array}$
\end{tabular}




\begin{tabular}{|c|c|c|}
\hline Organs and Tissues & Procedures & Possible or Expected Findings \\
\hline \multirow{2}{*}{$\begin{array}{l}\text { External examination, } \\
\text { oral cavity, and hair } \\
\text { (continued) }\end{array}$} & Prepare roentgenograms of long bones. & $\begin{array}{l}\text { Densities at the ends of the shafts of long } \\
\text { bones. }\end{array}$ \\
\hline & $\begin{array}{l}\text { For diagnosis of chronic plumbism, analysis of } \\
\text { scalp hair may be useful (p. 17). Analysis is } \\
\text { done by neutron activation (see also under } \\
\text { "Poisoning, arsenic"). }\end{array}$ & $\begin{array}{l}\text { Lead content of hair may be used to } \\
\text { estimate time and duration of exposure. } \\
\text { Evidence of old shotgun injury may explain } \\
\text { chronic lead poisoning (3). }\end{array}$ \\
\hline Blood & $\begin{array}{l}\text { Remove samples with lead-free syringe (see } \\
\text { above under "Note") or } 20-\mathrm{mL} \text { Vacutainer tubes } \\
\text { (Becton, Dickinson and Company). Do not add } \\
\text { anti-coagulant or preservative. }\end{array}$ & $\begin{array}{l}\text { Normal concentration in children is less than } \\
0.04 \mathrm{mg} / 100 \mathrm{~g} \text {; values for "safe" industrial } \\
\text { exposure in adults vary from } 0.01-0.07 \\
\mathrm{mg} / 100 \mathrm{~g} \text {. }\end{array}$ \\
\hline Urine & $\begin{array}{l}\text { For collection procedures, see above under } \\
\text { "Blood" and under "Note." Request also } \\
\text { determination of coproporphyrin concentrations. }\end{array}$ & $\begin{array}{l}\text { Values for "safe" industrial exposure in } \\
\text { adults vary from } 0.01-0.15 \mathrm{mg} / \mathrm{L} \text {. } \\
\text { Aminoaciduria and glycosuria after lead } \\
\text { poisoning in children (4). }\end{array}$ \\
\hline Liver & $\begin{array}{l}\text { Submit sample for histologic study; submit } \\
\text { remaining tissue for toxicologic analysis. }\end{array}$ & $\begin{array}{l}\text { Intranuclear inclusion bodies in acute } \\
\text { poisoning. }\end{array}$ \\
\hline Small and large bowel & $\begin{array}{l}\text { Submit with contents for toxicologic study, } \\
\text { particularly in acute poisoning (p. 16). }\end{array}$ & \\
\hline Kidneys & $\begin{array}{l}\text { Submit sample from each kidney for histologic } \\
\text { study; submit remaining tissue of both kidneys } \\
\text { separately for toxicologic study. }\end{array}$ & $\begin{array}{l}\text { Chronic nephritis; tubular degeneration } \\
\text { with intranuclear inclusion bodies. }\end{array}$ \\
\hline Bone & $\begin{array}{l}\text { Submit at least } 10 \mathrm{~g} \text { of fresh bone for toxicologic } \\
\text { study. }\end{array}$ & \\
\hline Brain & For removal and specimen preparation, see p. 65. & $\begin{array}{l}\text { Perivascular hemorrhages; cell necrosis; } \\
\text { edema. Possibly increased risk of gliomas in } \\
\text { chronic poisoning }(5) \text {. }\end{array}$ \\
\hline
\end{tabular}

\section{References}

1. Bergdahl IA, Schutz A, Gerhardsson L, Jensen A, Skerfving S. Lead concentrations in human plasma, urine and whole blood. Scand J Work Environ Health 1997;23:359-363.

2. Daher RT. Trace metals (lead and cadmium screening). Anal Chem 1995;67:405R-410R.

3. Wu PB, Kingery WS, Date ES. An EMG case report of lead neuropathy 19 years after a gunshot injury. Muscle Nerve 1995;18:326-329.
4. Loghman-Adham M. Aminoaciduria and glycosuria following severe childhood lead poisoning. Pediatr Nephrol 1998;12:218-221.

5. Anttila A, Heikkila P, Nykyri E, Kauppinen T, Pukkula E, Hernberg $\mathrm{S}$, et al. Risk of nervous system cancer among workers exposed to lead. J Occup Environ Med 1996;38:131-136.

\section{Poisoning, LSD (d-Lysergic Acid Diethylamide) (See “Abuse, hallucinogen(s).”)}

\section{Poisoning, Lye}

Related Terms: Ammonium hydroxide poisoning; calcium oxide or quicklime poisoning; poisoning by alkaline corrosives; potassium hydroxide poisoning; sodium hydroxide poisoning.

\begin{tabular}{cll}
\hline Organs and Tissues & Procedures & Possible or Expected Findings \\
\hline External examination & Record extent of oral, perioral, and other facial & Lye burns on face and chest in acute cases; \\
and oral cavity & $\begin{array}{l}\text { corrosive injuries. Photograph lesions. Prepare } \\
\text { histologic sections of tissue from inside of lips } \\
\text { or mouth. }\end{array}$ & $\begin{array}{l}\text { scars and manifestations of malnutrition* } \\
\text { in chronic cases. }\end{array}$
\end{tabular}

Blood

Neck organs, esophagus, trachea, and lungs
Submit sample for toxicologic study (p. 16).

After removal of heart, remove neck organs with hypopharynx, esophagus, larynx, and trachea. Leave stomach attached to esophagus. Open pharynx and esophagus along posterior midline. In acute cases, formalin perfusion of lungs is not recommended; it may cause artifactual ballooning and internal ruptures of organ.
Swelling, edema, and necrosis of mucous membranes in acute poisoning. Fibrosis and strictures in chronic cases. Bronchitis* and bronchopneumonia. 


\begin{tabular}{lll}
\hline Organs and Tissues & Procedures & Possible or Expected Findings \\
\hline Stomach & $\begin{array}{l}\text { Remove gastric contents carefully from in situ } \\
\text { incision. Caution - tissues are very friable. } \\
\text { Leave stomach attached to esophagus } \\
\text { (see above under "Neck organs,..."). }\end{array}$ & See below under "Intestinal tract." \\
Intestinal tract & $\begin{array}{l}\text { Describe color of duodenal mucosa and odor } \\
\text { of mucosa and contents. }\end{array}$ & $\begin{array}{l}\text { Mucosal corrosion, with or without } \\
\text { perforation. }\end{array}$ \\
\hline
\end{tabular}

\section{Poisoning, Mercury}

Related Term: Methylmercury poisoning (Minamata disease).

NOTE: For general toxicologic sampling, see p. 16. If kidney failure was present, see also under that heading. Analysis can be done by atomic absorption spectrophotometry (1).

\begin{tabular}{|c|c|c|}
\hline Organs and Tissues & Procedures & Possible or Expected Findings \\
\hline \multirow[t]{2}{*}{$\begin{array}{l}\text { External examination, } \\
\text { skin, and oral cavity }\end{array}$} & $\begin{array}{l}\text { Record extent of skin changes and prepare } \\
\text { histologic sections. }\end{array}$ & Exfoliative dermatitis. \\
\hline & Record appearance of oral cavity. & $\begin{array}{l}\text { Blue line at gingival margin; hypertrophy of } \\
\text { gum; acute and chronic gingivitis; exfoliation } \\
\text { and loss of teeth (2). }\end{array}$ \\
\hline Blood & Submit sample for toxicologic study. & \\
\hline Heart & $\begin{array}{l}\text { Submit tissue for toxicologic study. Prepare } \\
\text { histologic sections of myocardium (p. } 30) \text {. }\end{array}$ & Degeneration of myocardium. \\
\hline Lungs & $\begin{array}{l}\text { Submit samples for toxicologic and histologic } \\
\text { study. }\end{array}$ & Increased concentrations of mercury (1). \\
\hline Esophagus & Submit sample for histologic study. & Induration of mucosa. \\
\hline Liver and spleen & $\begin{array}{l}\text { Submit samples for toxicologic and histologic } \\
\text { study. }\end{array}$ & Congestion. \\
\hline Stomach and colon & $\begin{array}{l}\text { Submit samples for histologic study. Submit } \\
\text { sample of colon for toxicologic study. }\end{array}$ & Erosive gastritis and colitis. \\
\hline Kidneys & $\begin{array}{l}\text { Submit samples for toxicologic and histologic } \\
\text { study. }\end{array}$ & $\begin{array}{l}\text { Increased concentrations of mercury }(1) \text {. } \\
\text { Degeneration of proximal tubules; } \\
\text { calcifications. Chronic kidney failure* may } \\
\text { be the cause of death. }\end{array}$ \\
\hline Neck organs & $\begin{array}{l}\text { Submit specimen from pharynx for histologic } \\
\text { study. }\end{array}$ & Induration of mucosa. \\
\hline Brain and spinal cord & $\begin{array}{l}\text { For removal and specimen preparation, see } \\
\text { pp. } 65 \text { and } 67 \text {, respectively. Submit sample } \\
\text { of brain for toxicologic study. }\end{array}$ & $\begin{array}{l}\text { Increased concentrations of mercury }(1) \text {. } \\
\text { Cortical hemorrhages. }\end{array}$ \\
\hline
\end{tabular}

\section{References}

1. Opitz H, Schweinsberg F, Grossmann T, Wendt-Gallitelli MF, Meyerman R. Demonstration of mercury in the human brain and other organs 17 years after metallic mercury exposure. Clin Neuropathol 1996;15:139-144.

2. Martin MD, Williams BJ, Charleston JD, Oda D. Spontaneous exfoliation of teeth following severe elemental mercury poisoning: case report and histological investigation for mechanism. Oral Surg Oral Med Oral Pathol 1997;84:495-501.

Poisoning, Metal (See "Poisoning, antimony," "Poisoning, arsenic," "Poisoning, cadmium," "Poisoning, lead," "Poisoning, mercury," and "Poisoning, thallium.")

\section{Poisoning, Methanol (Methyl Alcohol)}

Synonym: Wood alcohol.
NOTE: Autopsy findings are not diagnostic. Pulmonary and cerebral edema and edema of other viscera may be present. See also under "Alcoholism and alcohol intoxication."

\section{Poisoning, Methylene Chloride (See "Poisoning, gas.")}

\section{Poisoning, Mushroom}

NOTE: Fatalities usually are caused by members of the genus Amanita. The results of the autopsy may be less diagnostic than examination of the leftovers of the incriminated meal. If patient underwent liver (1) or kidney (2) transplantation, see also under these headings. 


\begin{tabular}{lll}
\hline Organs and Tissues & Procedures & Possible or Expected Findings \\
\hline Gastrointestinal tract & $\begin{array}{l}\text { Submit gastric and intestinal contents for } \\
\text { toxicologic study (p. 16). }\end{array}$ & $\begin{array}{l}\text { Usually, study of gastrointestinal contents } \\
\text { gives no meaningful results because of the } \\
\text { long interval between consumption of the } \\
\text { poisoned meal and death. } \\
\text { Liver }\end{array}$ \\
& $\begin{array}{l}\text { Record size and weight. Submit samples } \\
\text { for histologic and toxicologic study. }\end{array}$ & $\begin{array}{l}\text { Massive or submassive hepatic necrosis, } \\
\text { involving primarily zones 2 and 3 (3). }\end{array}$ \\
Kidneys & Sample tissue for toxicologic study, light & Acute interstitial nephritis in Cortinarius \\
& microscopy, and electron microscopy & speciocissimus poisoning. Acute tubular \\
(see p. 132). & necrosis in Amanita phalloides poisoning (3) \\
& Fond in Cortinarius speciocissimus poisoning. & Hemorrhagic diathesis and cerebral edema in \\
& p. 16. Histologic sections should include brain. & Amanita phalloides poisoning (3). \\
\hline
\end{tabular}

\section{References}

1. Meunier B, Messner M, Bardaxoglou E, Spiliopoulos G, Terblanche J, Launois B. Liver transplantation for severe Lepiota helveola poisoning. Liver 1994;14:158-160.

2. Holmdahl J, Blohme I. Renal transplantation after Cortinarius speciocissimus poisoning. Nephrol Dialysis Transplant 1995;10:1920-1922.

3. Fineschi V, Di Paolo M, Centini F. Histological criteria for diagnosis of amanita phalloides poisoning. J Forens Sci 1996;41:429-432.

\section{Poisoning, Organophosphate(s)}

Synonyms and Related Terms: Compounds include diazinon, dichlorvos, malathion, and parathion. For updates, consult poison hotlines.

NOTE: Organophosphate insecticides may produce rapid and severe toxic affects leading to coma and pulmonary edema and respiratory insufficiency. Interpretation of toxicologic findings, see below. For toxicologic sampling, see p. 16.

\begin{tabular}{|c|c|c|}
\hline Organs and Tissues & Procedures & Possible or Expected Findings \\
\hline Blood and urine & $\begin{array}{l}\text { Submit samples for toxicologic study } \\
\text { and assay for cholinesterase activities. }\end{array}$ & Cholinesterase activity will be low. \\
\hline Lungs & $\begin{array}{l}\text { Record weights of lungs and contents of } \\
\text { airways. }\end{array}$ & $\begin{array}{l}\text { Pulmonary edema if poison was inhaled. } \\
\text { Airways may contain aspirated material. }\end{array}$ \\
\hline Gastrointestinal tract & Submit contents for toxicologic study. & \\
\hline Liver and kidneys & Submit samples for toxicologic study. & \\
\hline Skeletal muscles & $\begin{array}{l}\text { Submit unfixed material for histochemical } \\
\text { demonstration of reduced cholinesterase activity } \\
\text { at motor end-plates. }\end{array}$ & $\begin{array}{l}\text { Cholinesterase activity can be determined } \\
\text { reliably even after decomposition and } \\
\text { embalming. }\end{array}$ \\
\hline Brain and spinal cord & $\begin{array}{l}\text { For removal and specimen preparation, see } \\
\text { pp. } 65 \text { and } 67 \text {, respectively. }\end{array}$ & $\begin{array}{l}\text { Clinically, Guillain-Barré syndrome has been } \\
\text { observed after poisoning with organo- } \\
\text { phosphate. }\end{array}$ \\
\hline
\end{tabular}

\section{Interpretation of Toxicologic Findings (1)}

In acute poisoning, the cholinesterase levels may be $25 \%$ of the normal values (see below). The cholinesterase levels in the blood are not affected by the duration of the postmortem interval; measurement may be attempted even on decomposed or exhumed bodies.

Normal Cholinesterase Levels in Red Blood Cells (RBC) and in Whole Blood, Measured in Micromoles of Acetylcholine Hydrolyzed

\begin{tabular}{lccc}
\hline Substrate & Males & Females & Children \\
\hline RBC & $0.74-2.38$ & $0.90-2.33$ & $0.72-2.25$ \\
Whole blood & $0.78-3.88$ & $1.33-3.32$ & $1.52-2.88$ \\
\hline
\end{tabular}

\section{Reference}

1. Fatteh A. Organophosphates (parathion). In: Handbook of Forensic Pathology. J.B. Lippincott Company, Philadelphia, 1973, pp. 310-312. 


\section{Poisoning, Pesticide(s) (See “Poisoning, organophosphate(s).")}

\section{Poisoning, Phosphorus}

NOTE: Fatal dose is about 2-3 g. Phosphorus is used in some rat poisons. Phosphorus can be detected in exhumed bodies.

\begin{tabular}{ll}
\hline Organs and Tissues & Procedures \\
\hline $\begin{array}{l}\text { External examination, } \\
\text { skin, and hair }\end{array}$ & $\begin{array}{l}\text { Submit skin and hair for toxicologic study } \\
\text { (p. 16). }\end{array}$ \\
Gastrointestinal tract & $\begin{array}{l}\text { Tie stomach and various portions of intestinal } \\
\text { tract and submit unopened for toxicologic study. }\end{array}$ \\
& $\begin{array}{l}\text { If poisoning with yellow phosphorus is suspected, } \\
\text { these viscera must be opened under nitrogen, just } \\
\text { before analysis. Collect feces. }\end{array}$
\end{tabular}

Liver

Other organs
Record weight. Photograph. Submit portion for toxicologic study. Request Sudan stain of frozen sections (p. 173).

For general toxicologic sampling, see p. 16. Samples should include kidneys and pancreas. Submit samples for histologic study, and request Sudan-stained frozen sections (p. 173).
Possible or Expected Findings

Jaundice (indicates subacute poisoning with severe hepatic changes).

Gastric contents smell of garlic (1).

Severe fatty changes; periportal necroses.

Fatty changes in myocardium, skeletal muscles, and other organs.

\section{Reference}

1. Simon FA, Pickering LK. Acute yellow phosphorus poisoning: "smoking stool syndrome.” JAMA 1976;235:1343-1344.

Poisoning, Strychnine

\begin{tabular}{lll}
\hline Organs and Tissues & Procedures & Possible or Expected Findings \\
\hline External examination & $\begin{array}{l}\text { Record extent and severity of rigor mortis and } \\
\text { postmortem interval at time of recording. }\end{array}$ & $\begin{array}{l}\text { Rigor mortis after fatal strychnine poisoning } \\
\text { may occur very soon after death and may be } \\
\text { very severe (opisthotonos); it may persist } \\
\text { until decomposition sets in. }\end{array}$ \\
Organs and body fluids & & $\begin{array}{l}\text { Congestion of viscera; no characteristic } \\
\text { morphologic autopsy findings. Acute } \\
\end{array}$ \\
& For toxicologic sampling (gastric contents, & $\begin{array}{l}\text { pancreatitis has been observed (1). } \\
\text { High strychnine concentrations (also } \\
\text { demonstrable in exhumed bodies [2]). }\end{array}$ \\
& urine, blood, brain, and other organs), & \\
& see p. 16. &
\end{tabular}

\section{References}

1. Hernandez AF, Pomares J, Schiaffino S, Pla A, Villanueva E. Acute chemical pancreatitis associated with nonfatal strychnine poisoning. J Toxicol 1998;36:67-71.

2. Benomran FA, Henry JD. Homicide by strychnine poisoning. Med Sci Law 1996;36:271-273.

\section{Poisoning, Thallium}

NOTE: For toxicologic sampling, see below and p. 16.

\begin{tabular}{cll}
\hline Organs and Tissues & Procedures & Possible or Expected Findings \\
\hline $\begin{array}{c}\text { External examination } \\
\text { and oral cavity }\end{array}$ & $\begin{array}{l}\text { Record character and extent of skin and nail } \\
\text { changes; record distribution of hair. Submit } \\
\text { samples of skin for histologic study. }\end{array}$ & $\begin{array}{l}\text { Dermatitis and trophic changes of fingernails; } \\
\text { diffuse alopecia (1). Stomatitis in acute } \\
\text { poisoning. }\end{array}$ \\
$\begin{array}{l}\text { Examine hair under polarized light. } \\
\text { Gastrointestinal tract }\end{array}$ & $\begin{array}{l}\text { Submit samples of contents for toxicologic } \\
\text { study (p. 16). Prepare histologic sections of }\end{array}$ & Gastroenteritis in acute poisoning.
\end{tabular}

Liver all segments. 


\begin{tabular}{lll}
\hline Organs and Tissues & Procedures & Possible or Expected Findings \\
\hline Kidneys & $\begin{array}{l}\text { Submit samples for toxicologic and histologic } \\
\text { study. }\end{array}$ & Fatty changes. \\
Brain and spinal cord; & $\begin{array}{l}\text { For removal and specimen preparation, see } \\
\text { optic nerves }\end{array}$ & Retrobulbar neuritis. \\
& $\begin{array}{l}\text { for toxicologic study. Submit sections of } \\
\text { brain and optic nerves for histologic study. }\end{array}$ & \\
Skeletal muscles & $\begin{array}{l}\text { Submit specimens for toxicologic study } \\
\text { (take from lower extremity). }\end{array}$ & \\
Bones and bone marrow & $\begin{array}{l}\text { For removal, prosthetic repair, and specimen } \\
\text { preparation of bones, see p. 95. For preparation } \\
\text { of sections and smears of bone marrow, } \\
\text { see p. 96. Submit samples for toxicologic study. }\end{array}$ & \\
\hline
\end{tabular}

\section{Reference}

1. Tromme I, van Neste D, Dobbelaere F, Bouffioux B, Courin C, Dugernier T, et al. Skin signs in the diagnosis of thallium poisoning. Br J Dermatol 1998;138:321-325.

\section{Poliomyelitis}

Synonym: Acute anterior poliomyelitis.

NOTE: The disease has been nearly eliminated in the USA but not in many other countries.

(1) Collect all tissues that appear to be infected. (2) Request viral cultures. (3) Usually, special stains are not helpful. (4) Special precautions are indicated (p. 146). (5) Serologic studies may be helpful and are available from the Centers for Disease Control and Prevention, Atlanta, GA (p. 135). (6) This is a reportable disease.

\begin{tabular}{ll}
\hline Organs and Tissues & Procedures \\
\hline External examination & $\begin{array}{l}\text { If chronic paralysis had been present, record } \\
\text { circumference of extremities on right and left } \\
\text { sides. }\end{array}$ \\
Cerebrospinal fluid & $\begin{array}{l}\text { In acute cases, submit for viral culture (p. 104) } \\
\text { and cytologic study. }\end{array}$ \\
If water or electrolyte disturbances are expected, \\
vitreous & $\begin{array}{l}\text { Record weight; submit samples for histologic } \\
\text { study (p. 30). }\end{array}$ \\
Heart & $\begin{array}{l}\text { Submit one large sample for viral and bacterial } \\
\text { cultures (p. 103). Perfuse one lung with formalin } \\
\text { Lungs }\end{array}$ \\
& (p. 47).
\end{tabular}

\section{Esophagus}

Gastrointestinal tract

\section{Kidneys and urinary bladder \\ Veins}

Brain and spinal cord
If there is blood in the lumen, record measured or estimated total volume.

Open renal pelves and ureters in situ; prepare photographs.

For removal of femoral veins, see p. 34.

For removal and specimen preparation, see pp. 65 and 67, respectively. In acute cases, submit portions of brain and spinal cord for viral culture.
Possible or Expected Findings

Neurogenic atrophy of skeletal muscles in areas of paralysis.

Electrolyte disorder.*

Hypertensive heart disease; myocarditis.*

Aspiration or bronchopneumonia (or both); edema; atelectasis; embolism;* alveolar wall necrosis (acute or organizing diffuse alveolar damage) after oxygen toxicity.

Acute ulcers.

Acute gastric dilatation; acute gastroduodenal ulcers; gastrointestinal erosions and hemorrhages. Dilatation of colon; perforation of cecum.

Urolithiasis and nephrolithiasis, * pyonephrosis and pyelonephritis.* Phlebothrombosis of legs, most commonly on left side.

Necrosis of anterior horn cells of spinal cord, with neuronophagia and perivascular inflammatory reaction. Old lesions show neuronal loss and gliosis. Medulla ("bulbar polio") and other areas of brain stem, cerebellum, and cerebrum, particularly the motor cortex, may be affected in various degrees. 


\begin{tabular}{lll}
\hline Organs and Tissues & Procedures & Possible or Expected Findings \\
\hline Bones and joints & For removal, prosthetic repair, and specimen & Arthritis* in acute cases; disuse \\
& preparation, see p. 95. & osteoporosis* in chronic cases. \\
Skeletal muscles & For histologic sampling, see p. 80. & Neurogenic atrophy of affected muscles. \\
Eyes & For removal and specimen preparation, see p. 85. & Hypertensive retinopathy. \\
\hline
\end{tabular}

\section{Polyarteritis Nodosa}

Synonyms and Related Terms: Infantile polyarteritis nodosa; Kawasaki disease; mucocutaneous lymph node syndrome;* panarteritis nodosa; periarteritis nodosa. For other synonyms and related terms, see also under "Arteritis, all types or type unspecified."

Possible Associated Conditions: Acquired immunodeficiency syndrome* (1); familial Mediterranean fever* (2); polymyalgia rheumatica (3); systemic lupus erythematosus* (4); viral hepatitis B (5) or C (6).* See also under "Arteritis, all types or type unspecified."

\begin{tabular}{ll}
\hline Organs and Tissues & Procedures \\
\hline External examination & Record extent and character of skin lesions; \\
and skin & submit samples of skin for histologic study. \\
Heart & For coronary arteriography, see p. 118. \\
& Record heart weight.
\end{tabular}

Lungs

Kidneys

Other organs

Aorta and other

arteries

Skeletal muscles

Joints

Brain and spinal cord

Eyes
Perfuse with formalin (p. 47) and submit samples for histologic study.

Submit samples for light microscopic, electron microscopic (p. 132), and fluorescent microscopic study.

Submit samples of liver, gallbladder, spleen, pancreas, esophagus, gastrointestinal tract (all segments, including appendix), mesentery; adrenals; urinary bladder, epididymis, and endocrine glands, particularly testes. Submit samples of all other tissues with infarctions and related gross lesions. Request Verhoeff-van Gieson stain (p. 173). For special techniques, see above under "Kidneys."

Submit samples for histologic study.

For removal and specimen preparation, see p. 80.

For removal, prosthetic repair, and specimen preparation, see p. 96. Submit samples of synovium for histologic study.

For removal and specimen preparation, see pp. 65 and 67, respectively. For cerebral arteriography, see p. 80.

For removal and specimen preparation, see p. 85 .
Possible or Expected Findings

Subcutaneous nodules (rare), sometimes with ulceration (7).

Coronary arteritis, with or without aneurysms and infarctions, primarily in childhood.

Myocardial hypertrophy secondary to hypertension.*

Minimal or no involvement by polyarteritis nodosa; considerable involvement in other types of necrotizing vasculitis (see "Arteritis, all types or type unspecified").

Polyarteritis nodosa; glomerulitis; deposition of $\gamma$-globulin, fibrinogen, and albumin.

Polyarteritis, with or without formation of aneurysms and infarctions, may occur in all organs. The liver may show bile duct injury and rarely, nodular regenerative hyperplasia (8).

More frequently involved in giant cell elastic arteritis.*

Polyarteritis of small muscular arteries, including vasa nervorum.

Arthritis* may rarely be present with swollen joints.

Infarctions;* subarachnoid hemorrhage; arteritis of cerebral arteries.

Papillitis; retinal hemorrhages; hypertensive retinopathy.

\section{References}

1. Libman BS, Quismorio FP Jr, Stimmler MM. Polyarteritis nodosalike vasculitis in human immunodeficiency virus infection. J Rheumatol 1995;22:351-355.

2. Kocak H, Cakar N, Hekimoglu B, Atakan C, Akkok N, Unal S. The coexistence of familial Mediterranian fever and polyarteritis nodosa: report of a case. Pediatr Nephrol 1996;10:631-633.
3. Uematsu-Yanagita M, Cho M, Hakamata Y, Tanaka M, Ishii K, Kume $\mathrm{N}$, et al. Microscopic polyarteritis during polymyalgia rheumatica remission. Am J Kidney Dis 1996;28:289-291.

4. Vivancos J, Soler-Carrillo J, Ara-del Rey J, Font J. Development of polyarteritis nodosa in the course of inactive systemic lupus erythematosus. Lupus 1995; 4:494-495. 
5. Guillevin L, Lhote F, Cohen P, Sauvaget F, Jarrousse B, Lortholary $\mathrm{O}$, et al. Polyarteritis nodosa related to hepatitis B virus. A prospective study with long-term observation of 41 patients. Medicine 1995; 74:238-253.

6. Pateron D, Fain O, Sehonnou J, Trinchet JC, Beaugrand M. Severe necrotizing vasculitis in a patient with hepatitis $\mathrm{C}$ virus infection treated by interferon. Clin Exp Rheumatol 1996;14:79-81.
7. Daoud MS, Hutton KP, Gibson LE. Cutaneous periarteritis nodosa: a clinicopathological study of 79 cases. Br J Dermatol 1997;136:706713.

8. Goritsas CP, Repanti M, Papadaki E, Lazarou N, Andonopoulos AP. Intrahepatic bile duct injury and nodular regenerative hyperplasia of the liver in a patient with polyarteritis nodosa. J Hepatol 1997;26:727730 .

\section{Polychondritis, Relapsing}

Possible Associated Conditions: Dermatomyositis; myelodysplastic syndrome (1); rheumatoid arthritis;* Sjögren's syndrome* (2).

\begin{tabular}{|c|c|c|}
\hline Organs and Tissues & Procedures & Possible or Expected Findings \\
\hline \multirow[t]{3}{*}{$\begin{array}{l}\text { External examination } \\
\text { and skin }\end{array}$} & $\begin{array}{l}\text { Photograph and record appearance of head, } \\
\text { chest, hands, and feet. }\end{array}$ & $\begin{array}{l}\text { Chondritis involving nose (saddle nose) and } \\
\text { ears (floppy ears); flail chest. Arthritic } \\
\text { changes at any site. }\end{array}$ \\
\hline & $\begin{array}{l}\text { Submit sections of skin lesions for histologic } \\
\text { study. }\end{array}$ & $\begin{array}{l}\text { Erythemata nodosum; erythema multiforme; } \\
\text { panniculitis (3); vasculitis; venous } \\
\text { thromboses. }\end{array}$ \\
\hline & Prepare skeletal roentgenograms. & See below under "Bones and joints." \\
\hline Blood & Submit sample for antibody study. & Antibodies to type II collagen. \\
\hline \multirow[t]{2}{*}{ Heart } & $\begin{array}{l}\text { Record weight; test competence of valves } \\
\text { (p. 29), and submit samples for histologic } \\
\text { sudy (p. 30). }\end{array}$ & $\begin{array}{l}\text { Pericarditis.* Myocarditis.* Dilatation of } \\
\text { aortic ring and destruction of cusps with } \\
\text { aortic regurgitation.* Other valves may be } \\
\text { affected (4) (mitral regurgitation) }\end{array}$ \\
\hline & $\begin{array}{l}\text { For dissection of the conduction system, } \\
\text { see p. } 26 .\end{array}$ & $\begin{array}{l}\text { Conduction system abnormalities (4) with } \\
\text { atrioventricular block. }\end{array}$ \\
\hline Aorta & $\begin{array}{l}\text { If an aortic aneurysm appears to be present, } \\
\text { follow procedures described under that heading. }\end{array}$ & $\begin{array}{l}\text { Aneurysm* of proximal thoracic or } \\
\text { abdominal aorta. }\end{array}$ \\
\hline $\begin{array}{l}\text { Lungs, trachea, } \\
\text { and neck organs }\end{array}$ & $\begin{array}{l}\text { Larynx and trachea are best removed together } \\
\text { with other neck organs, mediastinum, and lungs. } \\
\text { Open airways in posterior midline, photograph } \\
\text { areas of collapse or obstruction, and record } \\
\text { mechanical state (pliability) of cartilage. }\end{array}$ & $\begin{array}{l}\text { Degeneration and inflammation of larynx and } \\
\text { tracheobronchial tree with tracheal stenosis } \\
\text { or collapse, which may be the cause of sudden } \\
\text { death and suffocation. Aspiration broncho- } \\
\text { pneumonia. }\end{array}$ \\
\hline
\end{tabular}

Kidneys

Lymph nodes

Other organs

Eyes

Base of skull with middle and inner ear

Bones and joints
Submit samples of all segments for histologic study.

Follow procedures described under "glomerulonephritis."

Submit samples for histologic study.

For removal and specimen preparation, see p. 85 .

For removal of middle and inner ear, see p. 72.

For removal, prosthetic repair, and specimen preparation, see p. 95 . For maceration techniques, see p. 97.

Prepare sections of bone marrow (see p. 96).
Segmental necrotizing glomerulonephritis* with crescent formation.

Castleman-like lymphadenopathy (5).

Vasculitis of small vessels; manifestations of Sjögren's syndrome.*

Conjunctivitis; episcleritis; iritis; keratitis; cataracts; optic neuritis; retinal vasculitis.

Swelling and occlusion of Eustachian tube; otitis media.* Cochleo-vestibular system may be affected by polychondritic changes. Eburnation of bones; periostitis; osteoarthritis;* degeneration of cartilage of costochondral junctions and peripheral joints, with joint deformities. Mylelodysplastic changes (1).

\section{References}

1. Diebold L, Rauh G, Jager K, Lohrs U. Bone marrow pathology in relapsing polychonditis: high frequency of myelodysplastic syndrome. Br J Haematol 1995;89:820-830.

2. Harada M, Yoshida H, Mimura Y, Ohishi M, Miyazima I, Ichikawa F, et al. Relapsing polychondritis associated with subclinical Sjö- gren's syndrome and phlegmon of the neck. Intern Med 1995;34:768771.

3. Disdier P, Andrac L, Swiader L, Veit V, Fuzibet JG, Weiller-Merli C, et al. Cutaneous panniculitis and relapsing polychonditis: two cases. Dermatology 1996:193:266-268. 
4. Del Rosso A, Petix NR, Pratesi M, Bini A. Cardiovascular involvement in relapsing polychondritis. Semin Arthr Rheum 1997;26:840844.
5. Manganelli P, Quaini F, Olivetti G, Savini M, Pileri S. Relapsing polychondritis with Castleman-like lymphadenopathy: a case report. Clin Rheumat 1997:16:480-484.

\section{Polycythemia}

Synonyms and Related Terms: Polycythemia vera; primary polycythemia; secondary polycythemia.

NOTE: If patient had recent radionuclide $\left({ }^{32} \mathrm{P}\right)$ treatment, special precautions are indicated (p. 125). Consult with radiation safety officer or other responsible person.

Possible Associated Conditions: For tumors producing erythropoietic substances and secondary polycythemia, see below under "Possible or Expected Findings." Certain drugs (androgens) or adrenal cortical hypersecretion also may cause polycythemia.

\begin{tabular}{ll}
\hline Organs and Tissues & Procedures \\
\hline Chest and abdomen & $\begin{array}{l}\text { If large vessel thrombosis is suspected, remove } \\
\text { chest and abdominal organs en masse (p. 3) } \\
\text { and open posterior aspect of inferior vena cava } \\
\text { and aorta. }\end{array}$ \\
& $\begin{array}{l}\text { For coronary arteriography, see p. 118. Other } \\
\text { procedures depend on expected findings or } \\
\text { grossly identified abnormalities as listed in } \\
\text { right-hand column. }\end{array}$ \\
& $\begin{array}{l}\text { Dissect one lung fresh and perfuse one lung } \\
\text { with formalin (p. 47). }\end{array}$ \\
\end{tabular}

Intestinal tract

Esophagus and stomach

Liver; portal, mesenteric, and splenic veins

Spleen

Lymph nodes

Peripheral arteries and veins

Kidneys

Brain and spinal cord

Bone marrow
Record volume of blood in lumen. Submit samples of all segments for histologic study. For demonstration of varices, see p. 53.

Dissect veins in situ.

Record appearance of hepatic veins. Record weight of liver and submit samples for histologic study.

Record weight and submit samples for histologic study.

Record average size and submit samples for histologic study.

For phlebography and removal of femoral vessels, see p. 34 .

Procedures depend on expected findings or grossly identified abnormalities as listed in right-hand column.

For cerebral arteriography, see p. 80. For removal and specimen preparation, see pp. 65 and 67 , respectively.

For preparation of sections and smears, see p. 96.
Possible or Expected Findings

Thrombosis of inferior vena cava or hepatic veins (or both); aortic thrombosis or thrombosis at other sites.

Coronary thrombosis; myocardial infarction. Chronic cardiac disease and right-to-left shunt may cause secondary polycythemia.

Emboli;* chronic pulmonary disease with alveolar hypoventilation may cause secondary polycythemia.

Ulcer of the duodenum.* Gastrointestinal hemorrhage. ${ }^{*}$ Venous infarction.

Esophageal varices; ${ }^{*}$ gastric varices.

Portal vein thrombosis (see also

"Hypertension, portal").

Budd-Chiari syndrome* (hepatic venous outflow obstruction); myeloid metaplasia or leukemic infiltrates (in primary polycythemia). Hepatocellular carcinoma may be a cause of secondary polycythemia. Congestive splenomegaly. Myeloid metaplasia or leukemic infiltrates (in primary polycythemia).

Infiltrative lymphadenopathy (see above under "Spleen").

Venous thrombosis;* thrombophlebitis. Leriche's syndrome.* Thromboses may occur in any vessel.

Chronic renal disease (hydronephrosis, parenchymal disease, nephrotic syndrome), kidney transplantation;* renal cell carcinoma and Wilms tumor (1) may be causes of secondary polycythemia.

Thrombotic or embolic vascular occlusions. Cerebral infarction.* Rarely, cerebellar hemangioblastoma may be a cause of secondary polycythemia. Hyperplasia. Leukemic infiltrates in some patients with primary polycythemia. Rarely, multiple myeloma* may be a cause of secondary polycythemia. Myeloid fibrosis, myeloid metaplasia, and acute myeloid leukemia* are complications of polycythemia vera. 


\begin{tabular}{lll}
\hline Organs and Tissues & Procedures & Possible or Expected Findings \\
\hline Other organs & $\begin{array}{ll}\text { Sample tumor tissue for histologic and electron } \\
\text { microscopic study. (Snap-freeze material for }\end{array}$ & $\begin{array}{l}\text { Tumors of the prostate, }{ }^{*} \text { rectum, ovary, }{ }^{*} \\
\text { uterus (leiomyoma) or breast, }{ }^{*} \text { as well as } \\
\text { determination of erythropoietic material). }\end{array}$ \\
& $\begin{array}{l}\text { pheochromocytoma or malignant melanoma, } \\
\text { rarely may be causes secondary polycythemia. }\end{array}$ \\
\hline
\end{tabular}

\section{Reference}

1. Lal A, Rice A, al Mahr M, Kern IB, Marshall GM. Wilms tumor associated with polycythemia: case report and review of the literature. J Pediatr Hematol/Oncol 1997;19:263-265.

\section{Polymyalgia Rheumatica}

Possible Associated Condition: Giant cell arteritis* (1).

\begin{tabular}{ll}
\hline Organs and Tissues & Procedures \\
\hline Blood & Submit sample for determination of rheumatoid \\
& factor, antinuclear factor, serum complement \\
& concentrations, immunoglobulins, and other \\
& serum proteins.
\end{tabular}

Other organs $\quad$ Follow procedures described under "Arteritis,

giant cell."

Possible or Expected Findings

Immunologic tests are important for distinguishing polymyalgia rheumatica from systemic lupus erythematosus, ${ }^{*}$ rheumatoid arthritis, ${ }^{*}$ multiple myeloma, ${ }^{*}$ and other diseases.

Giant cell arteritis* and polymyalgia rheumatica are commonly associated (1). Other associations such as scleritis (2) or ankylosing spondylitis* (3) need further confirmation.

Skeletal muscles $\quad$ For removal and specimen preparation, see p. 80 . Joints For removal, prosthetic repair, and specimen preparation, see p. 96.

No diagnostic changes.

Focal synovitis, mostly in neck, shoulder, and hip area.

\section{References}

1. Hunder GG. Giant cell arteritis and polymyalgia rheumatica. Med Clin North Am 1997;81:195-219.

2. Simmons IG, Kritzinger EE, Murray PI. Posterior scleritis and polymyalgia rheumatica. Eye 1997;11:727-728.

3. Elkayam O, Paran D, Yaron M, Caspi D. Polymyalgia rheumatica in patients with ankylosing spondylitis: a report of 5 cases. Clin Exp Rheumatol 1997;15:411-414.

Polymyositis (See “Dermatomyositis.")

Polyneuritis (See “Syndrome, Guillain-Barré.”)

\section{Polyneuropathy (See "Beriberi.")}

\section{Polyposis, Familial, and Related Syndromes}

Related Terms: Cowden's disease (multiple hamartoma syndrome); familial colonic polyposis; juvenile polyposis; Gardner's syndrome; non-polyposis syndrome (hereditary nonpolyposis colorectal cancer syndrome); Peutz-Jegher's syndrome; Turcot's syndrome.

NOTE: The conditions listed under "Related Terms" are hereditable (autosomal-dominant) polyp syndromes. The Cronkhite-Canada syndrome lacks a hereditary transmission.

\begin{tabular}{lll}
\hline Organs and Tissues & Procedures & Possible or Expected Findings \\
\hline $\begin{array}{l}\text { External examination } \\
\text { and oral cavity }\end{array}$ & Record and photograph skin lesions, cutaneous & Cachexia, edema, alopecia, hyperpigmen- \\
& tumors, and hair and nail abnormalities. & tations and vitiligo, and onychodystrophy in \\
& Sampling for histologic study depends on & Cronkhite-Canada syndrome; mucocutaneous \\
expected findings or grossly identified & pigmentations (buccal, perioral, priorbital, \\
abnormalities as listed in right-hand column. & distal extremities) in Peutz-Jeghers \\
& (See also below under "Soft tissues.") & syndrome; papules in face and oral mucosa \\
& & in Cowden's disease; tumors of skin and \\
& subcutis (see below under "Soft tissues...")in
\end{tabular}




\begin{tabular}{|c|c|c|}
\hline Organs and Tissues & Procedures & Possible or Expected Findings \\
\hline $\begin{array}{l}\text { Soft tissues (skin, } \\
\text { subcutis, mesentery, } \\
\text { retroperitoneum) }\end{array}$ & $\begin{array}{l}\text { Record size and distribution of tumors; } \\
\text { submit samples for histologic study. }\end{array}$ & $\begin{array}{l}\text { Epidermoid cysts, lipomas, desmoid tumors } \\
\text { (1), mesenteric fibromatosis, wound } \\
\text { fibromatosis, other fibromas or leiomyomas, } \\
\text { and fibrosarcomas in Gardner's syndrome. }\end{array}$ \\
\hline Stomach & $\begin{array}{l}\text { Prepare photographs of mucosa. Submit samples } \\
\text { for histologic study. }\end{array}$ & $\begin{array}{l}\text { Hamartomatous cystic-glandular polyps in } \\
\text { Cronkhite-Canada syndrome and in Peutz- } \\
\text { Jeghers syndrome. }\end{array}$ \\
\hline Small bowel & $\begin{array}{l}\text { For perfusion and specimen preparation, see } \\
\text { p. } 54 \text {. Photograph lesions. Submit samples } \\
\text { for histologic study. }\end{array}$ & $\begin{array}{l}\text { Hamartomatous cystic-glandular polyps in } \\
\text { Cronkhite-Canada syndrome, in Peutz- } \\
\text { Jeghers syndrome, and in juvenile polyposis. } \\
\text { Adenomatous polyps in Gardner's syndrome. }\end{array}$ \\
\hline Colon & $\begin{array}{l}\text { Prepare photographs. Submit samples of } \\
\text { several polyps for histologic study. Include } \\
\text { regional lymph nodes for identification of } \\
\text { metastases. }\end{array}$ & $\begin{array}{l}\text { Adenomatous polyps in familial colonic } \\
\text { polyposis, Gardner's syndrome, non- } \\
\text { polyposis syndrome, and Turcot's syndrome. } \\
\text { Colorectal carcinomas in familial polyposis, } \\
\text { in Gardner's syndrome and in rare cases of } \\
\text { juvenile polyposis (2). Hamartomatous } \\
\text { cystic-glandular polyps in Cronkhite-Canada } \\
\text { syndrome, in Peutz-Jeghers syndrome, and } \\
\text { in juvenile polyposis. }\end{array}$ \\
\hline Liver and bile ducts & $\begin{array}{l}\text { Open common bile duct in situ, prepare } \\
\text { photographs and sample for histologic study. }\end{array}$ & $\begin{array}{l}\text { Ampullary carcinoma (3) or adenoma of bile } \\
\text { duct (4) in Gardners syndrome. }\end{array}$ \\
\hline Other organs & $\begin{array}{l}\text { Procedures depend on expected findings or } \\
\text { grossly identified abnormalities as listed in } \\
\text { right-hand column. }\end{array}$ & $\begin{array}{l}\text { Tumors of the breast, pancreas, ovary, and } \\
\text { endometrium in Peutz-Jeghers syndrome; } \\
\text { breast and thyroid tumors in Cowden's } \\
\text { disease; endometrial adenocarcinoma in } \\
\text { nonpolyposis syndrome. Adrenocortical } \\
\text { adenomas or carcinomas or bilateral nodular } \\
\text { hyperplasia also may occur, rarely with } \\
\text { hypercortisolism. }\end{array}$ \\
\hline Brain & $\begin{array}{l}\text { For removal and specimen preparation, } \\
\text { see p. } 65 .\end{array}$ & $\begin{array}{l}\text { Brain tumor* (e.g., glioblastoma multiforme) } \\
\text { in Turcot syndrome. }\end{array}$ \\
\hline Eyes & $\begin{array}{l}\text { For removal and specimen preparation, } \\
\text { see p. } 85 \text {. }\end{array}$ & Orbital osteoma in Gardner's syndrome (5). \\
\hline
\end{tabular}

\section{References}

1. Clark SK, Philips RK. Desmoid in familial adenomatous polyposis. Br J Surg 1996;83:1494-1504.

2. Coburn MC, Pricolo VE, DeLuca FG, Bland KI. Malignant potential in intestinal juvenile polyposis syndromes. Ann Surg Oncol 1995;2: 386-391.

3. Tomia H, Fukunari H, Shibata M, Yoshinaga K, Iwama T, Mishima Y. Ampullary carcinoma in familial adenomatous polyposis. Surg Today 1996;26:522-526.

4. Futami H, Furuta T, Hanai H, Nakamura S, Baba S, Kaneko E. Adenoma of the common bile duct in Gardner's syndrome may cause relapsing acute pancreatitis. J Gastroenterol 1997;32:558-561.

5. McNab AA. Orbital osteoma in Gardner's syndrome. Austr NZ J Ophthalmol 1998;26:169-170.

Polyradiculoneuropathy (See "Encephalitis, all types or type unspecified," "Myelopathy/Myelitis," and "Syndrome, Guillain-Barré.")
Polyserositis, Familial Paroxysmal (See "Fever, familial Mediterranian.")

Porphyria, all Types or Type Unspecified (See "Porphyia,..." as listed in following entries, and "Protoporphria,...").

NOTE: A rare form of hepatic porphyria, delta-aminolevulinate dehydratase deficient porphyria, and the erythropoietic porphyria, X-linked sideroblastic anemia, have not been tabulated here.

\section{Porphyria, Acute Intermittent}

Related Terms: Hepatic porphyria; hydroxymethyl bilane synthase (HMB) deficiency; porphobilinogen deaminase deficiency (1).

NOTE: Multiple drugs such as barbiturates or sulfonamides may precipitate attacks of the disease, which generally is not a fatal condition. Infections or surgery also may precipitate attacks. 


\begin{tabular}{|c|c|c|}
\hline Organs and Tissues & Procedures & Possible or Expected Findings \\
\hline External examination & $\begin{array}{l}\text { Record body weight and length. Record extent } \\
\text { of pigmentation. }\end{array}$ & Pigmentation; emaciation. \\
\hline Urine & $\begin{array}{l}\text { Submit samples for determination of } \delta \text {-amino- } \\
\text { levulinic acid (ALA) and porphobilinogen } \\
(\mathrm{PBG}) \text {. }\end{array}$ & Increased concentrations of ALA and PBG. \\
\hline Heart and blood vessels & $\begin{array}{l}\text { If hypertension is suspected, see under that } \\
\text { heading. }\end{array}$ & Hypertensive cardiovascular disease. \\
\hline Liver & $\begin{array}{l}\text { Submit samples for histologic, electron } \\
\text { microscopic (p. 132), toxicologic (p. 16), } \\
\text { and porphyrin fluorescence study. }\end{array}$ & $\begin{array}{l}\text { Porphyrin fluorescence usually not } \\
\text { demonstrable. Hepatocellular carcinoma } \\
\text { may be present. }\end{array}$ \\
\hline $\begin{array}{l}\text { Brain, spinal cord, } \\
\text { and peripheral nerves }\end{array}$ & $\begin{array}{l}\text { For removal and specimen preparation, } \\
\text { see pp. } 65,67 \text {, and } 79 \text {, respectively. }\end{array}$ & $\begin{array}{l}\text { Peripheral motor neuropathy. Hypothalamic } \\
\text { involvement may be a cause of hyponatremia. }\end{array}$ \\
\hline Vitreous & $\begin{array}{l}\text { If dehydration is suspected, submit sample } \\
\text { for sodium, chloride, and urea nitrogen } \\
\text { determination (p. 85). }\end{array}$ & Manifestations of dehydration.* \\
\hline
\end{tabular}

\section{Reference}

1. Grandchamp B. Acute intermittent porphyria. Semin Liv Dis 1998;18:17-24.

\section{Porphyria, Congenital Erythropoietic}

Synonyms: Günther's disease; uroporphyrinogen III (URO) cosynthase deficiency.

NOTE: If bone marrow transplantation (1) was done, see also under that heading. Cord blood stem cell transplantation also has been done for this condition (2).

\begin{tabular}{|c|c|c|}
\hline Organs and Tissues & Procedures & Possible or Expected Findings \\
\hline $\begin{array}{l}\text { External examination } \\
\text { and skin }\end{array}$ & $\begin{array}{l}\text { Record extent and character of changes of hair, } \\
\text { skin, and teeth. Prepare histologic sections } \\
\text { of skin. }\end{array}$ & $\begin{array}{l}\text { Hypertrichosis; erythrodontia; scarring and } \\
\text { mutilation of hands and face. }\end{array}$ \\
\hline Blood and bone marrow & $\begin{array}{l}\text { For preparation of sections and smears, } \\
\text { see p. } 96 \text {. Submit fresh samples for porphyrin } \\
\text { studies. }\end{array}$ & $\begin{array}{l}\text { Hemolytic anemia. Erythrocytes contain } \\
\text { large amounts of uroporphyrin I; normoblasts } \\
\text { and reticulocytes exhibit intense red } \\
\text { fluorescence. }\end{array}$ \\
\hline Urine & $\begin{array}{l}\text { Submit sample for porphyrin study as listed in } \\
\text { right-hand column. }\end{array}$ & $\begin{array}{l}\text { Uroporphyrin I and coproporphyrin I in high } \\
\text { concentrations. }\end{array}$ \\
\hline Spleen & $\begin{array}{l}\text { Record size and weight. Photograph spleen } \\
\text { (with scale). }\end{array}$ & $\begin{array}{l}\text { Splenomegaly (may have been treated by } \\
\text { splenectomy). }\end{array}$ \\
\hline Kidneys & $\begin{array}{l}\text { Sample for histologic study; request Gomori's } \\
\text { stain for iron (p. 172). }\end{array}$ & Glomerulosclerosis and iron deposits (3). \\
\hline
\end{tabular}

\section{References}

1. Thomas C, Ged C, Nordmann Y, de Verneuil H, Pellier I, Fischer A, Blanche S. Correction of congenital erythropoietic porphyria by bone marrow transplantation. J Pediatr 1996;129:453-456.

2. Zix-Kieffer I, Langer B, Eyer D, Acar G, Racadot E, Schlaeder G, et al. Successful cord blood stem cell transplantation for congenital erythropoietic porphyria (Gunther's disease). Bone Marrow Transpl 1996;18:217-220.

3. Lange B, Hofweber K, Waldherr R, Scharer K. Congenital erythropoietic porphyria associated with nephrotic syndrome. Acta Pediatr 1995;84: 1325-1328.

\section{Porphyria Cutanea Tarda}

Synonyms and Related Terms: Hepatic porphyria; uroporphyrinogen decarboxylase deficiency.

Possible Associated Conditions: Adverse drug reaction; chronic alcoholism;* chronic hepatitis C ( 1 ); human immunodeficiency virus infection (AIDS)*(1). 


\begin{tabular}{|c|c|c|}
\hline Organs and Tissues & Procedures & Possible or Expected Findings \\
\hline $\begin{array}{l}\text { External examination } \\
\text { and skin }\end{array}$ & $\begin{array}{l}\text { Record extent and character of skin and hair } \\
\text { changes. Prepare histologic sections of skin. }\end{array}$ & $\begin{array}{l}\text { Vesicles and bullae in face and other sun- } \\
\text { exposed areas. Thickening and scarring } \\
\text { of skin, with or without calcifications; } \\
\text { hyperpigmentation. Hypertrichosis. }\end{array}$ \\
\hline Urine & $\begin{array}{l}\text { Submit sample for porphyrin study as listed } \\
\text { in right-hand column. }\end{array}$ & $\begin{array}{l}\text { Increased concentrations of uroporphyrin } \\
\text { and hepatocarboxylic porphyrin. }\end{array}$ \\
\hline Liver & $\begin{array}{l}\text { Submit fresh hepatic tissue for demonstration } \\
\text { of porphyrin fluorescence in Wood's light. } \\
\text { Record weight of liver and submit samples for } \\
\text { histologic study. Request Gomori's iron stain } \\
\text { (p. 172). Prepare sample for electron microscopy } \\
\text { (p. 132). Needle-shaped inclusions are best } \\
\text { seen by light microscopy in unstained } \\
\text { paraffin sections or after staining with the } \\
\text { ferric ferricyanide reduction test (p. 172). }\end{array}$ & $\begin{array}{l}\text { Ultraviolet light reveals red hepatic } \\
\text { porphyrin fluorescence. } \\
\text { Fatty changes, fibrosis, cirrhosis,* and } \\
\text { hepatocellular carcinoma. Hemosiderosis is } \\
\text { commonly found. Chronic hepatitis C may } \\
\text { be a cause of porphyria cutanea tarda (2). } \\
\text { Needle shaped cytoplasmic inclusions } \\
\text { (visible by light, fluorescence-, and electron } \\
\text { microscopy). }\end{array}$ \\
\hline
\end{tabular}

\section{References}

1. O'Connor WJ, Badley AD, Dicken CH, Murphy GM. Porphyria cutanea tarda and human immunodeficiency virus: two cases associated with hepatitis C. Mayo Clin Proc 1998;73:895-897.

2. Lacour JP, Bodokh I, Castanet J, Bekri S, Ortonne JP. Porphyria cutanea tarda and antibodies to hepatitis C virus. Br J Dermatol 1993; 128:121-123.

\section{Porphyria, Variegate}

Synonyms and Related Terms: Hepatic porphyria; protoporphyrinogen oxidase deficiency (1).

NOTE: The manifestations of the disease closely resemble those in porphyria cutanea tarda and hereditary coproporphyria. Measurements of porphyrins and porphyrin precursors are the only clearly distinguishing features. For autopsy procedures, see under "Porphyria cutanea tarda."

\section{Reference}

1. Kirsch RE, Meissner PN, Hift RJ. Variegate porphyria. Semin Liv Dis 1998;18:33-41.

\begin{tabular}{ll}
\hline Organs and Tissues & Procedures \\
\hline External examination & Record body weight and length; prepare \\
and skin & histologic sections of skin. \\
& Prepare skeletal roentgenograms.
\end{tabular}

Cardiovascular system

Other organs

Record weights of endocrine organs and submit samples for histologic study. Other procedures depend on expected findings or grossly identified abnormalities as listed in right-hand column.
Brain

Other organs

Brain
Potassium (See "Disorder, electrolyte(s) and p. 14.)

\section{Preexcitation, Ventricular}

Related Term: Aberrant atrioventricular conduction; WolffParkinson-White syndrome.

Possible Associated Conditions: Ebstein's malformation of tricuspid valve.

\section{Pregnancy}

NOTE: For general autopsy procedures, see p. 60 . In some instances, procedures described under "Death, abortion-associated," "Embolism, amniotic fluid," or "Toxemia of pregnancy" may be indicated.

\section{Progeria}

Synonym: Werner syndrome.
For cerebral arteriography, see p. 80. For removal and specimen preparation, see p. 65 .
Possible or Expected Findings

Growth retardation; short stature; alopecia; cutaneous atrophy; loss of subcutaneous fat. Premature fusion of epiphyses; large calvarium.

Myocardial infarction; coronary and peripheral atherosclerosis.

Manifestations of congestive heart failure;* normal endocrine system; osteoarthritis; * rare neoplasms, such as meningioma, soft tissue tumors, osteosarcoma, and myeloid tumors (1). Cerebral atherosclerosis and hemorrhage.

\section{Reference}

1. Goto M, Miller RW, Ishikawa Y, Sugano H. Excess of rare cancers in Werner syndrome (adult progeria). Cancer Epid Biomarkers Prev 1996;5: 239-246. 


\section{Propanol (See “Poisoning, isopropyl alcohol.”)}

\section{Proteinosis, Pulmonary alveolar (See "Lipoproteinosis, pulmonary alveolar.")}

\section{Protoporphyria, Erythropoietic}

Synonym: Ferrochelatase deficiency (1).

\begin{tabular}{|c|c|c|}
\hline Organs and Tissues & Procedures & Possible or Expected Findings \\
\hline $\begin{array}{l}\text { External examination } \\
\text { and skin }\end{array}$ & $\begin{array}{l}\text { Record character and extent of skin lesions and } \\
\text { prepare histologic sections of skin. Request } \\
\text { PAS stain, with diastase digestion (p. 173). }\end{array}$ & $\begin{array}{l}\text { Chronic eczematous skin lesions or } \\
\text { superficial scarring; nail changes. } \\
\text { Perivascular PAS-positive hyaline (2). }\end{array}$ \\
\hline Blood & Submit sample for protoporphyrin study (2). & $\begin{array}{l}\text { High concentration of protoporphyrin IX } \\
\text { in erythrocytes and plasma. }\end{array}$ \\
\hline Feces and urine & Submit samples for protoporphyrin study. & $\begin{array}{l}\text { High concentration of protoporphyrin IX } \\
\text { in feces; normal concentration in urine. }\end{array}$ \\
\hline Liver & $\begin{array}{l}\text { Record weight. Submit samples for routine } \\
\text { histologic study. } \\
\text { Submit fresh material for biochemical study, } \\
\text { and material for ultraviolet microscopy and } \\
\text { transmission electron microscopy (p. 132). }\end{array}$ & $\begin{array}{l}\text { Intrahepatic cholestasis. Cirrhosis* and } \\
\text { liver failure* is a rare complication }(3) \text {. } \\
\text { Brown protoporphyrin deposits with red to } \\
\text { yellow birefringence with a maltese cross } \\
\text { configuration in hepatocytes, Kupffer cells, } \\
\text { and bile canaliculi. }\end{array}$ \\
\hline Gallbladder and bile & Submit stones for protoporphyrin analysis. & $\begin{array}{l}\text { Cholelithiasis.* Increased protoporphyrin } \\
\text { in bile. }\end{array}$ \\
\hline
\end{tabular}

\section{References}

1. Cox TM. Erythropoietic protoporphyria. J Inherit Metab Dis 1997;20:258-269.

2. Schleiffenbaum BE, Minder EI, Mohr P, Decurtins M, Schaffner A. Cytofluorometry as a diagnosis of protoporphyria. Gastroenterology 1992; 102:1044-1048.

3. Sarkany RPE, Alexander GJMA, Cox TM. Recessive inheritance of erythropoietic protoporphyria with liver failure. Lancet 1994;343:1394-1396.

\section{Pseudogout}

Synonym: Calcium pyrophosphate dihydrate (CPPD) deposition disease.

\begin{tabular}{|c|c|c|}
\hline Organs and Tissues & Procedures & Possible or Expected Findings \\
\hline External examination & Prepare skeletal roentgenograms. & $\begin{array}{l}\text { Punctate calcium deposits in knee joints and, } \\
\text { less commonly, in joints of hips, ankles, } \\
\text { shoulders, or wrists or in symphysis ossium } \\
\text { pubis and intervertebral disks. }\end{array}$ \\
\hline Joints & $\begin{array}{l}\text { Puncture grossly affected joints and submit } \\
\text { sample of synovial fluid for crystal analysis } \\
\text { under compensated polarized light (2). See } \\
\text { also p. } 96 \text {. For removal of joints, prosthetic } \\
\text { repair, and specimen preparation, see p. } 96 \text {. } \\
\text { Consult roentgenograms (see above). }\end{array}$ & $\begin{array}{l}\text { Arthritis* with synovitis. Crystals of calcium } \\
\text { pyrophosphate dihydrate in periarticular } \\
\text { tissue (1) and synovial fluid. Cartilage } \\
\text { contains calcium salts of pyrophosphate, } \\
\text { hydroxyapatite, and orthophosphate. }\end{array}$ \\
\hline Other organs & $\begin{array}{l}\text { Procedures depend on expected underlying } \\
\text { disease, as listed in right-hand column. }\end{array}$ & $\begin{array}{l}\text { Alkaptonuria;* gout;* hemochromatosis;* } \\
\text { hyperparathyroidism.* }\end{array}$ \\
\hline
\end{tabular}

\section{References}

1. Luisiri P, Blair J, Ellman MH. Calcium pyrophosphate dihydrate deposition disease presenting as tumoral calcinosis (periarticular pseudogout). J Rheumatol 1996;23:1647-1650.

2. Joseph J, McGrath H. Gout or 'pseudogout': how to differentiate crystal-induced arthropathies. Geriatr 1995;50:33-39.

\section{Pseudohyperparathyroidism}

Synonyms: Ectopic hyperparathyroidism; hyperparathyroidism in malignancy.

NOTE: This condition is caused by pulmonary, renal, and other malignant tumors that secrete parathyroid hormone or a parathyroid hormone-like substance. If hormone assay is intended, snap-freeze tumor tissue. Other autopsy procedures are the same as in hyperparathyroidism. Parathyroid glands should be normal. 


\section{Pseudohypoparathyroidism}

Related Term: Pseudopseudohypoparathyroidism.

\begin{tabular}{|c|c|c|}
\hline Organs and Tissues & Procedures & Possible or Expected Findings \\
\hline $\begin{array}{l}\text { External examination } \\
\text { and oral cavity }\end{array}$ & $\begin{array}{l}\text { Record abnormalities of stature and appearance } \\
\text { of teeth. } \\
\text { Prepare roentgenograms of hands, feet, } \\
\text { and skull. }\end{array}$ & $\begin{array}{l}\text { Short stature, round face, brachydactyly with } \\
\text { shortening of carpal and metatarsal bones and } \\
\text { bowing of long bones, and heterotopic } \\
\text { calcification (Albright's hereditary osteo- } \\
\text { dystrophy). Coxa vara or coxa valga. } \\
\text { Exostoses and thickening of calvaria may } \\
\text { be found. }\end{array}$ \\
\hline & Inspect mouth. & Dental aplasia and enamel defects. \\
\hline Vitreous and urine & $\begin{array}{l}\text { Submit samples for calcium and phosphate } \\
\text { determination (pp. } 16 \text { and } 85 \text { ). }\end{array}$ & $\begin{array}{l}\text { Decreased calcium and increased phosphate } \\
\text { concentrations. }\end{array}$ \\
\hline Neck organs & $\begin{array}{l}\text { Dissect and record weights of parathyroid } \\
\text { glands; submit samples for histologic study. }\end{array}$ & $\begin{array}{l}\text { Parathyroid glands are normal or } \\
\text { hyperplastic. }\end{array}$ \\
\hline Other organs & $\begin{array}{l}\text { Soft tissue roentgenograms may reveal calcium } \\
\text { deposits. Sample for histologic study and } \\
\text { request van Kossa stain (p. 173). }\end{array}$ & $\begin{array}{l}\text { Metastatic calcification or ossification in } \\
\text { subcutaneous tissue, lungs, kidneys, basal } \\
\text { ganglia of brain, and other organs. }\end{array}$ \\
\hline Bones & $\begin{array}{l}\text { For removal, prosthetic repair, and specimen } \\
\text { preparation, see p. } 95 \text {. }\end{array}$ & $\begin{array}{l}\text { See above under "External examination and } \\
\text { oral cavity." }\end{array}$ \\
\hline Eyes & For removal and specimen preparation, see p. 85 . & Cataracts. \\
\hline
\end{tabular}

Pseudomyxoma Peritonei

Related Terms: Disseminated peritoneal adenomucinosis (1); peritoneal mucinous carcinomatosis (1).

\begin{tabular}{lll}
\hline Organs and Tissues & Procedures & Possible or Expected Findings \\
\hline Abdomen & Record volume of intraperitoneal fluid; prepare & Colloid carcinoma of stomach or colon. \\
& smears; submit samples of peritoneum for & Well-differentated adenocarcinoma of ovary \\
& histologic study. & or, rarely, of appendix; ruptured appendiceal \\
& mucinous adenoma is the most common \\
& cause of peritoneal adenomucinosis. \\
\hline
\end{tabular}

Reference

1. Ronnet BM, Shmookler BM, Sugarbaker PH, Kurman RJ. Pseudomyxoma peritonei: new concepts in diagnosis, origin, nomenclature, and relationship to mucinous borderline (low malignant potential) tumors of the ovary. Anat Pathol 1997;2:197-226.

\section{Pseudotumor Cerebri}

Synonym: Benign intracranial hypertension; meningeal hydrops.

NOTE: This condition, which generally affects young, obese females, is characterized by symptoms and signs of increased intracranial pressure without a demonstrable cause. Hence, intracranial mass lesions, infections, and related conditions should be excluded. Such conditions include adrenal insufficiency;* Guillain-Barré syndrome* (increased colloid-osmotic pressure); hyperadrenalism; hypervitaminosis A* (e.g., after treatment of acne); hypoparathyroidism;* hypothroidism;* infectious mononucleosis;* Lyme disease; pregnancy; Sydenham's chorea; thrombus of the lateral or superior sagittal sinus (otitic hydrocephalus); and Wiskott-Aldrich syndrome.

\begin{tabular}{lll}
\hline Organs and Tissues & Procedures & Possible or Expected Findings \\
\hline External examination & $\begin{array}{l}\text { Record body weight and external features. } \\
\text { Perfuse one lung with formalin (p. 47). }\end{array}$ & $\begin{array}{l}\text { Obesity* (pickwickian syndrome). } \\
\text { Emphysema.* }\end{array}$ \\
Genital organs & $\begin{array}{l}\text { Procedures depend on expected findings or } \\
\text { grossly identified abnormalities as listed in } \\
\text { right-hand column. }\end{array}$ & $\begin{array}{l}\text { Pregnancy* or postpartum changes. } \\
\text { Brain, spinal cord, } \\
\text { base of skull }\end{array}$ \\
$\begin{array}{l}\text { For removal and specimen preparation of brain } \\
\text { and spinal cord, see pp. 65 and 67, respectively. }\end{array}$ & $\begin{array}{l}\text { Mastoiditis; lateral sinus thrombosis; } \\
\text { marantic sinus thrombosis; head trauma. }\end{array}$ \\
Peripheral nerves & For removal and specimen preparation, see p. 79. & Polyneuritis. \\
\hline
\end{tabular}




\section{Pseudoxanthoma elasticum}

Synonym: Grönblad-Strandberg syndrome.

NOTE: This disease has not been studied thoroughly. Each autopsy should be regarded as a research procedure.

\begin{tabular}{ll}
\hline Organs and Tissues & Procedures \\
\hline External examination & Record extent and character of skin lesions, \\
and skin & photograph, and prepare histologic sections. \\
& Request von Kossa's and Verhoeff-van Gieson \\
& stains (p. 173). For decalcification procedures, \\
& see p. 97.
\end{tabular}

Prepare soft tissue roentgenograms.

\begin{abstract}
Abdomen
Heart
\end{abstract}

\section{Arteries}

Gastrointestinal tract

Kidneys

Urinary bladder and uterus

Other organs

Brain

Eyes

Joints
Record weight. Histologic samples should include pericardium, endocardium, and all valves. Photograph cardiac lesions. For special stains, see above under "External examination and skin."

Submit samples of large and medium-sized arteries from various sites; request von Kossa's and Verhoeff-van Gieson stains (p. 173).

Record estimated or measured amount of blood in lumen.

Dissect renal arteries. For renal arteriography, see p. 59.

Submit samples of all accessible organs and tissues, with or without gross lesions. Submit material for electron microscopy (p. 132). For removal and specimen preparation, see p. 65 .

For removal and specimen preparation, see p. 85 .

For removal, prosthetic repair, and specimen preparation, see p. 96.
Possible or Expected Findings

Skin papules and plaques, particularly in neck, axillae, groins, and popliteal fossae. Telangiectases at edge of lesions.

Hemorrhages (also in nose). Basophilic material and calcium deposits (1) in middle and lower dermis.

Calcifications in dermis; calcifications of blood vessels.

Diaphragmatic hernia.*

Hypertensive cardiomegaly. Characteristic plaques in pericardium and endocardium, with or without mitral valve involvement. Coronary atherosclerosis may have been a cause of angina (2). Coronary thrombosis and myocardial infarction may be present also.

Accelerated atherosclerosis; calcification of peripheral vessels.

Gastrointestinal hemorrhage;* peptic ulcer;* ulcerative colitis.*

Hemangiomas; abnormalities of renal arteries.

Hemorrhages.

See above under "Note."

Subarachnoid and intracerebral hemorrhage; hypertensive cerebrovascular disease.

Degeneration of Bruch's membrane with retinal hemorrhages; sclerosis of choroid vessels; angioid streaks; degenerative scleral changes, as in skin.

Hemarthrosis.

\section{References}

1. Truter S, Rosenbaum-Fiedler J, Sapadin A, Lebwohl M. Calcification of elastic fibers in pseudoxanthoma elasticum. Mt Sinai J Med 1996;63:210-215.

2. Kevorkian JP, Masquet C, Kural-Menasche S, Le Dref O, Beaufils P. New report of severe coronary artery disease in an eighteen-year-old girl with pseudoxanthoma elasticum. Case report and review of the literature. Angiology 1997;48:735-741.

\section{Psittacosis (See “Ornithosis.")}

\section{Psoriasis}

Possible Associated Conditions: Acquired immunodeficiency syndrome* (1); malabsorption syndrome.*

NOTE: The manifestations of psoriasis may be considerably aggravated if the patients have been infected with the human immunodeficiency virus.

\begin{tabular}{lll}
\hline Organs and Tissues & Procedures & Possible or Expected Findings \\
\hline External examination & $\begin{array}{l}\text { Record extent and character of skin lesions. } \\
\text { Prepare histologic sections of skin. } \\
\text { Prepare roentgenograms of joints. }\end{array}$ & Characteristic skin and nail changes. \\
& Arthritis. ${ }^{*}$
\end{tabular}




\begin{tabular}{lll}
\hline Organs and Tissues & Procedures & Possible or Expected Findings \\
\hline Heart & $\begin{array}{l}\text { Procedures depend on expected findings or } \\
\text { grossly identified abnormalities as listed in } \\
\text { right-hand column. }\end{array}$ & $\begin{array}{l}\text { Aortitis involving ascending aorta and aortic } \\
\text { valve with regurgitation; mitral valve and } \\
\text { adjacent myocardium and conduction system } \\
\text { also may be involved. }\end{array}$ \\
$\begin{array}{ll}\text { Small bowel } \\
\text { Liver }\end{array}$ & $\begin{array}{l}\text { For } \text { in situ fixation, see p. 54. } \\
\text { Record weight. Submit samples for histologic } \\
\text { study. }\end{array}$ & $\begin{array}{l}\text { Sprue-like changes with loss of villi. } \\
\text { Fibrosis or cirrhosis and other abnormalities, } \\
\text { particularly in patients who had been taking } \\
\text { methotrexate. }\end{array}$ \\
Bones and joints & $\begin{array}{l}\text { For removal, prosthetic repair, and specimen } \\
\text { preparation, see p. 95. }\end{array}$ & Psoriatic arthritis and spondylitis. \\
\hline
\end{tabular}

\section{Reference}

1. Weitzul S, Duvic M. HIV-related psoriasis and Reiter's syndrome. Semin Cut Med Surg 1997;16:213-218.

\section{Purpura, Anaphylactoid (See “Purpura, Schönlein-Henoch.”)}

\section{Purpura Fulminans}

NOTE: This nonthrombocytopenic purpura occurs mainly in children, following an infectious disease, e.g., a staphylococcal infection. Skin hemorrhages, intravascular thromboses, and gangrene are major manifestations. For additional autopsy procedures, see under the name of the underlying infection.

\section{Purpura, Schönlein-Henoch}

Synonyms and Related Terms: Allergic purpura; anaphylactoid purpura; hypersensitivity vasculitis.

\begin{tabular}{|c|c|c|}
\hline Organs and Tissues & Procedures & Possible or Expected Findings \\
\hline \multirow[t]{2}{*}{$\begin{array}{l}\text { External examination } \\
\text { and skin }\end{array}$} & $\begin{array}{l}\text { Record extent and character of skin lesions, } \\
\text { and photograph lesions. }\end{array}$ & $\begin{array}{l}\text { Macular, petechial, or vesicular purpura. } \\
\text { Ulcers of skin and dermal nodules. } \\
\text { Angioneurotic edema* of lips and neck. }\end{array}$ \\
\hline & $\begin{array}{l}\text { Prepare histologic sections of involved skin. } \\
\text { Request Gomori's iron stain (p. 172). }\end{array}$ & $\begin{array}{l}\text { Angiitis (necrotizing vasculitis) involving } \\
\text { capillaries, venules, and arterioles of dermis. }\end{array}$ \\
\hline Gastrointestinal tract & $\begin{array}{l}\text { Record estimated or measured volume of blood } \\
\text { in lumen. Submit samples of all segments for } \\
\text { histologic study. }\end{array}$ & $\begin{array}{l}\text { Gastrointestinal hemorrhage.* } \\
\text { Intussusception. Angiitis, as in skin. }\end{array}$ \\
\hline Kidneys & $\begin{array}{l}\text { Follow procedures described under } \\
\text { "Glomerulonephritis." }\end{array}$ & $\begin{array}{l}\text { Swollen cortex with subcapsular petechial } \\
\text { hemorrhages. Acute focal glomerulo- } \\
\text { nephritis with IgG, IgA, complement, and } \\
\text { fibrinogen in mesangium. Angiitis, as in skin. }\end{array}$ \\
\hline Neck organs & Open trachea and larynx in posterior midline. & Angioneurotic edema.* \\
\hline Other organs & & $\begin{array}{l}\text { Findings may be similar to those described } \\
\text { under "Polyarteritis nodosa" and "Failure, } \\
\text { kidney." }\end{array}$ \\
\hline Joints & $\begin{array}{l}\text { For removal, prosthetic repair, and specimen } \\
\text { preparation, see p. } 96 \text {. Submit samples of } \\
\text { synovium for histologic study. }\end{array}$ & $\begin{array}{l}\text { Swelling of joints. Synovial angiitis } \\
\text { (histologic manifestations as in skin). }\end{array}$ \\
\hline
\end{tabular}

\section{Purpura, Thrombotic Thrombocytopenic}

Synonyms and Related Term: Hemolytic uremic syndrome;* thrombotic microangiopathy.

Possible Associated Conditions: Acquired immunodeficiency syndrome* (1); angiotropic large cell lymphoma (2); glomerulonephritis;* polyarteritis nodosa;* rheumatoid arthritis;* Sjögren's syndrome;* systemic lupus erythematosus;* systemic sclerosis.*

\begin{tabular}{lll}
\hline Organs and Tissues & Procedures & Possible or Expected Findings \\
\hline
\end{tabular}

External examination and skin
Prepare histologic sections of skin with purpura; Purpura; jaundice.

for special stains, see below. 


\begin{tabular}{|c|c|c|}
\hline Organs and Tissues & Procedures & Possible or Expected Findings \\
\hline Blood & $\begin{array}{l}\text { Submit sample for microbiologic and serologic } \\
\text { study (p. 102). }\end{array}$ & \\
\hline Other organs and tissues & $\begin{array}{l}\text { Record extent of hemorrhages; submit samples } \\
\text { from all viscera and tissues listed in right-hand } \\
\text { column. Request phosphotungstic acid hema- } \\
\text { toxylin, PAS, and Verhoeff-van Gieson stain } \\
\text { (p. 173). Snap-freeze tissue samples for } \\
\text { immunofluorescent study. For preparation } \\
\text { for electron microscopy, see p. } 132 \text {. }\end{array}$ & $\begin{array}{l}\text { Fibrin and platelet thrombi, with or without } \\
\text { microaneurysms and purpura in kidneys, } \\
\text { adrenal glands, pancreas, heart, and brain; } \\
\text { lesions may also be present in liver; spleen } \\
\text { (3), lymph nodes, muscle, bone marrow, } \\
\text { and synovium. Fibrin thrombi can be } \\
\text { demonstrated with labeled antihuman fibrin } \\
\text { antibodies. Lesions in precapillary arterioles. }\end{array}$ \\
\hline
\end{tabular}

\section{References}

1. de Man AM, Smulders YM, Roozendaal KJ, Frissen PH. HIV-related thrombotic thrombocytopenic purpura: report of 2 cases and a review of the literature. Netherl J Med 1997;51:103-109.

2. Sill H, Hofler G, Kaufmann P, Horina J, Spuller E, Kleinert R, Beham-Schmid C. Angiotropic large cell lymphoma presenting as thrombotic microangiopathy (thrombotic thrombocytopenic purpura). Cancer 1995;75:1167-1170.

3. Saracco SM, Farhi DC. Splenic pathology in thrombotic thrombocytopenic purpura. Am J Surg Pathol 1990;14:223-229.

\section{Pyelonephritis}

Synonyms and Related Terms: Acute ascending pyelonephritis; calculous pyelonephritis; chronic interstitial nephritis; chronic pyelonephritis; emphysematous pyelonephritis; obstructive uropathy.

NOTE: If chronic renal insufficiency was diagnosed, see under "Failure, kidney."

Possible Associated Conditions: Diabetes mellitus* (1). See also below under "Possible or Expected Findings."

\begin{tabular}{lll}
\hline Organs and Tissues & Procedures & Possible or Expected Findings
\end{tabular}

Abdominal cavity Identify and record site of obstruction before removal of retroperitoneal and pelvic organs. For renal angiography and urography, see p. 59.

Urine

Urogenital system

Other organs

Neck organs

Brain and spinal cord

Bones
Submit sample for microbiologic study (p. 102). Prepare smear of sediment.

Remove kidneys, ureters, and pelvic organs in one block. Record weight of both kidneys. If microbiologic study is intended, submit one-half of a kidney (p. 102).

Record size of right and left renal pelves. Record character of contents. Cut kidneys in half and record number and size of abscesses and scars. Record appearance of papillae. Record width of ureters. Record size, contents, and degree of trabeculation of urinary bladder; record size and appearance of prostate. If urethral valves are suspected to be present, see p. 60 .

Procedures depend on suspected underlying conditions.

Dissect parathyroid glands, record weights, and submit samples for histologic study. For removal and specimen preparation, see pp. 65 and 67 , respectively. For sampling and specimen preparation, see p. 95.
Aberrant vessels; adhesions (postradiation lesions). Perirenal abscess in acute pyelonephritis. Retroperitoneal fibrosis.* Tumor.

Evidence of inflammation.

Fistulas between kidney and other sites may be observed $(2,3)$.

Hydronephrosis;* pyonephrosis; nephrolithiasis.*

Necrotizing papillitis.

Hydroureter; pyoureter. Urolithiasis; tumor of urinary bladder* or of adjacent organs; benign prostatic hyperplasia.

Urethral valves. A dilated bladder in a woman without obvious obstruction may indicate presence of descensus of uterus (which is difficult to demonstrate at autopsy).

Amyloidosis* (4). Manifestations of diabetes mellitus* or sickle cell disease.*

Hyperplasia or adenoma(s) of parathyroid glands.

Abnormal findings may explain obstructive uropathy ("neurogenic bladder").

Osteoclastic osteoporosis in primary or secondary hyperparathyroidism.* 


\section{References}

1. Pontin AR, Barnes RD, Joffe J, Kahn D. Emphysematous pyelonephritis in diabetic patients. Br J Urol 1995;75:71-74.

2. O'Brien JD, Ettinger NA. Nephrobronchial fistula and lung abscess resulting from nephrolithiasis and pyelonephritis. Chest 1995;108:11661168.

3. Nayir A, Kadioglu A, Sirin A, Emre S, Oney V. A case of an enterorenal fistula and pyelonephritis with air in renal pelvis. Pediatr Radiol 1995;25: 229-230.

4. Mazuecos A, Araque A, Sanchez R, Martinez MA, Guesmes A, Rivero M, et al. Systemic amyloidosis secondary to pyonephrosis. Resolution after nephrectomy. Nephrol Dial Transplant 1996;11:875-878.

\section{Pyothorax (See “Empyema, pleural.”)}




\section{$\mathbf{Q}, \mathbf{R}$}

\section{Q Fever (See "Fever, Q")}

\section{Rabies}

NOTE: (1) In most instances, an autopsy limited to the brain is sufficient to confirm the diagnosis. (2) Rabies virus is especially infectious and thus, universal precautions should be strictly followed (p. 146). Avoid the use of scalpels whenever possible. The generation of aerosols should be assiduously avoided. (3) Consult the state health department prior to commencing the autopsy. (4) Request viral cultures. (5) Request immunofluorescent stain for rabies. (6) Serologic studies are available from the state health department laboratories. (7) This is a reportable disease.

\begin{tabular}{lll}
\hline Organs and Tissues & Procedures & Possible or Expected Findings \\
\hline External examination & Photograph possible sites of animal bite. & \\
Chest and abdomen & $\begin{array}{l}\text { See above under "Note." If a complete autopsy } \\
\text { is done, sample heart, lungs, kidneys, pancreas, } \\
\text { submaxillary salivary glands, and adrenal } \\
\text { glands; freeze or refrigerate sampled tissues }\end{array}$ & $\begin{array}{l}\text { Myocarditis with necrosis of muscle fibers } \\
\text { and infiltrates of lymphocytes and } \\
\text { histiocytes. }\end{array}$
\end{tabular}

Blood

Brain and spinal cord

Lacrimal glands

Ganglia and submit for viral study (see below under

"Brain and spinal cord").

Obtain serum for serologic studies.

For removal and specimen preparation, see pp. 65 and 67, respectively. Freeze or refrigerate cerebral tissue immediately after removal and submit frozen to special laboratory for fluorescent antibody staining. Take these sections from hippocampus or brain stem. Place the refrigerated tissues in 50\% neutral glycerol saline solution for preservation. Fix remaining brain and spinal cord tissue in 15\% formalin and submit for histologic study. As an alternative to freezing of tissue, immunoperoxidase methods for detection of rabies viral antigens can now be applied to formalin-fixed tissue (1). Viral particles can be revealed by ultrastructural examination.

For technique of removal, see p. 87. Submit refrigerated sample for virologic study and fluorescent antibody testing.

Submit samples of cranial, spinal, and sympathetic ganglia for histologic study.
Neural degeneration with neuronophagia and lymphocytic infiltrates.

\section{Reference}

1. Mrack RE, Young L. Rabies encephalitis in humans: pathology, pathogenesis, and pathophysiology. J Neuropathol Exp Neurol 1994;53:1-10. 


\section{Rachischisis (See "Meningocele.")}

\section{Radiation (See "Injury, radiation.")}

\section{Rape}

Related Term: Sexual assault.

NOTE: In almost all instances, the procedures described under "Assault" and under "Homicide" must also be followed. See also refs. (1) and (2). For the evaluation of bite marks, photographs with and without scales and black and white film should be used. The help of a forensic dentist may be required for proper evaluation. For possible sperm or other stains, wet mount smears are made by smearing a specimen swab onto a slide and then adding a drop of sterile saline and covering with a coverslip, or one can drop saline first and then mix with a specimen swab. One can also swirl a specimen swab in a test tube with 1-2 $\mathrm{mL}$ of sterile saline, aspirate some of the specimen-enriched fluid, and place on the slide. The remainder can be used for other tests.

\begin{tabular}{lll}
\hline Organs and Tissues $\quad$ Procedures & Possible or Expected Findings
\end{tabular}

External examination

Blood

Other organs and tissues Genital organs
Comb pubic hair over a towel and then pull sample; also, pull samples of hair from head (p. 17). Collect fingernail clippings and place in containers marked "right" and "left." Collect blood, hair, fibers, and residues of urine or saliva and/or semen that may have stained the victim's clothing or that may be found on the skin of the victim. For study of stains and scrapings, see below.

Introduce sterile dry cotton swab into the posterior vault of the vagina or-preferablyinto the cervical canal. Prepare smear on glass slide and send to crime laboratory for identification of sperm (see also above under "Note"). Keep a second swab dry for acid phosphatase determination and other tests (fluorescence in situ hybridization, DNA fingerprinting, Southern blot analysis, and polymerase chain reaction). Repeat above tests with two other sets of swabs for study of lower rectum and anus (smears should be as thin as possible) and of oral cavity. A Woods lamp can be used to illuminate semen stains on the body or clothing.

Photograph face and oral cavity, if indicated. If a photocolposcope is available, vaginal vault and cervix can be photographed in situ.

Submit sample in EDTA tube for determination of blood groups. Retain specimens through end of office retention period. Further testing, e.g., for HIV or syphilis, may be requested during this period.

Submit samples for toxicologic study (p. 16). Photograph internal genitalia, anus, and vulva. Additional spermatic fluid may be retrieved from cervical canal during cervical dissection. Application of toluidine blue may enhance lacerations (3) (apply only after specimens for laboratory study have been obtained).

Record appearance of all segments of genital tract. Prepare histologic sections of lacerations and wounds and of endometrium. If there is enough spermatic fluid, submit sample for microbiologic study.
Blood, hair, and other material on the victim's body may be the assailant's and thus may become important legal evidence.

Saline swab may reveal saliva, particularly on breasts (areola, nipples). Photographs of the decedent's teets, with and without scales, may be useful if the victim may have bitten the assailant.

Material may be positive for acid phosphatase or p30 glycoprotein. Nonsperm male cells may be present, identified by $\mathrm{Y}$-chromosome specific DNA probes.

Spermatozoa and acid phosphatase-positive material may be found in rectum and oral cavity.

Due to the flavin residues, seminal fluid appears green-yellow.

Lips and buccal surfaces of cheeks may show evidence of trauma. Bite marks may be present (see above under "Note") and may help to identify the assailant.

The victim's blood groups are important for comparison with specimens from the alleged assailant. Evidence of acquired immunodeficiency syndrome, ${ }^{*}$ syphilis, ${ }^{*}$ or intoxication at time of rape may have legal implications.

There may be perineal, perianal or vaginal lacerations, evidence of trauma to the cervix, or foreign bodies.

Uterine contents and endometrium may reveal pregnancy.* 
How Does One Examine Stains

or Other Residues of Suspected Spermatic Fluid?

Using a sterile cotton swab moistened with sterile saline, lift suspected dried spermatic fluid from hair or skin of external genitalia, perineum, buttocks, or other sites. Stains on clothing will be extracted by forensic laboratory personnel. Let specimens air dry in absence of sunlight and then place in paper bags or envelopes and seal. Smears are made for the demonstration of spermatozoa, cytologic changes, bacteria, and other possible findings. Other samples are used for the determination of acid phosphatase, as described below.

How Is Acid Phosphatase Determined in Scrapings and Stains and What Does a Positive Test Mean?

Place frozen swab (see above) in $3 \mathrm{~mL}$ of isotonic saline and elute for one-half hour. Use $0.5 \mathrm{~mL}$ of this extract for acid phosphatase assay by the method of Shinowara, Jones, and Reinhart. For this, Harleco Dry-Pack Reagent is recommended. The presence of acid phosphatase indicates the presence of spermatic fluid. Determination of the acid phosphatase activity provides a guideline for a rough estimation of the time interval between intercourse and removal for freezing or testing of the specimen (see below).

\section{How Can One Estimate the Time Interval}

Between Intercourse and Removal for Freezing

or Testing of the Specimen?

Usually, the survival time of morphologically recognizable spermatozoa in the vagina is less than $24 \mathrm{~h}$, but on occasion this may be much longer. Thus, within the first $24 \mathrm{~h}$ after coitus, $64 \%$ of cervical smears have been found to be positive for spermatozoa. At day 10, spermatozoa have been found in $13 \%$ of the smears. Obviously, if the assailant had had a vasectomy, spermatozoa will not be found at any time.
Spermatozoa have been found in the vagina of some women several days or weeks after death. Dried stains (see above) may give positive results after longer intervals. Acid phosphatase activities greater than 5 Bodansky units (for method, see above) indicate that probably less than $12 \mathrm{~h}$ have elapsed since the time of intercourse (1). In another study, vaginal swab specimens showed acid phosphatase activities of more than 2,000 KingArmstrong units/dL during the first $12 \mathrm{~h}$ after intercourse. Vaginal acid phosphatase activities returned to normal $(<201$ King-Armstrong units/dL) within approx $48 \mathrm{~h}$. Regardless of the methods used, only very rough estimates can be made.

\section{References}

1. Spitz WU, Platt MS. Medicolegal Investigation of Death. Charles C. Thomas Publisher, Springfield, IL, 1993, pp. 716-722.

2. Collins KA. The laboratory's role in detecting sexual assault. Lab Med 1998;29:361-365.

3. Bays $\mathbf{J}$, Lewman LV. Toluidine blue in the detection at autopsy of perineal and anal lacerations in victimes of sexual abuse. Arch Pathol Lab Med 1992;116:620-621.

\section{Acknowledgement}

JuliaMartin, M.D., Associate MedicalExaminer, Hillsborough County Medical Examiner Department, has provided valuable advice on the procedures described in rape cases.

\section{Reaction, Microgranulomatous Hypersensitivity, of Lungs (See "Pneumoconiosis" and "Pneumonia, interstitial.")}

\section{Reaction to Transfusion}

NOTE: The autopsy should be done as soon as possible after death. Every attempt should be made to secure donor blood for typing and culture at $30^{\circ} \mathrm{C}$ and $37^{\circ} \mathrm{C}$ (see below).

\begin{tabular}{|c|c|c|}
\hline Organs and Tissues & Procedures & Possible or Expected Findings \\
\hline External examination & $\begin{array}{l}\text { Record color of skin. } \\
\text { If air embolism is suspected, follow procedures } \\
\text { described under that heading. }\end{array}$ & $\begin{array}{l}\text { Jaundice. } \\
\text { Air embolism.* }\end{array}$ \\
\hline Blood & $\begin{array}{l}\text { Submit samples for microbiologic (p. 102) } \\
\text { and serologic study and for typing. }\end{array}$ & $\begin{array}{l}\text { Gram-negative rods or other endotoxin- } \\
\text { producing bacteria may have been perfused } \\
\text { accidentally. More reliable is culture from } \\
\text { residual donor blood (see above) at } 30^{\circ} \mathrm{C} \text { and } \\
37^{\circ} \mathrm{C} \text {. Some contaminants do not grow at the } \\
\text { higher temperature. }\end{array}$ \\
\hline Lungs & $\begin{array}{l}\text { Record weights; submit samples for histologic } \\
\text { study. }\end{array}$ & $\begin{array}{l}\text { Shock lungs (see under "Syndrome, adult } \\
\text { respiratory distress"). }\end{array}$ \\
\hline Kidneys & $\begin{array}{l}\text { Photograph, record weights, and submit samples } \\
\text { for histologic study. }\end{array}$ & $\begin{array}{l}\text { Fibrin thrombi and platelet thrombi in small } \\
\text { vessels; hemoglobinuric nephrosis. }\end{array}$ \\
\hline Other organs & $\begin{array}{l}\text { Procedures depend on expected findings or } \\
\text { grossly identified abnormalities as listed in } \\
\text { right-hand column. }\end{array}$ & $\begin{array}{l}\text { Fibrin thrombi and platelet thrombi in small } \\
\text { vessels (see under "Coagulation, } \\
\text { disseminated intravascular"). }\end{array}$ \\
\hline Urine & Prepare sediment. & Hematuria. \\
\hline Neck organs and trachea & Open larynx and trachea along posterior midline. & Angioneurotic edema; aspiration of vomitus. \\
\hline
\end{tabular}

\section{Regurgitation, Aortic (See "Insufficiency, aortic [chronic or acute].")}

Regurgitation, Mitral (See "Insufficiency, mitral [chronic or acute].") 


\section{Regurgitation, Pulmonary (See “Insufficiency, pulmonary valvular.”)}

Regurgitation, Tricuspid (See "Insufficiency, tricuspid [chronic or acute].")

Reticulosis, Midline Malignant (See “Granuloma, midline.”)

Rhabdomyoma, Cardiac (See "Tumor of the heart.")

Rickets (See “Deficiency, vitamin D” and "Syndrome, Fanconi.")

Ring, Lower Esophageal

Synonym: Schatzki's ring.

\begin{tabular}{lll}
\hline Organs and Tissues & Procedures & Possible or Expected Findings \\
\hline External examination & $\begin{array}{l}\text { Prepare chest roentgenogram or follow other } \\
\text { procedures for diagnosis of pneumothorax } \\
\text { (p. 430). }\end{array}$ & Pneumothorax.* \\
Esophagus & $\begin{array}{l}\text { For postmortem demonstration of lower } \\
\text { esophageal ring, see p. 53. }\end{array}$ & Bolus in esophagus; reflux esophagitis. \\
\hline
\end{tabular}

\section{Rubella}

Synonyms and Related Terms: Congenital rubella syndrome;* German measles; three-day measles.

NOTE: Congenital rubella syndrome is presented under "Syndrome, congenital rubella."

(1) The virus may be isolated from blood, urine, feces, tears, and CSF. (2) Collect any tissues that appear to be infected. (3) Usually, special stains are not helpful. (4) Serologic studies are available from local and state health department laboratories (p. 135). (5) This is a reportable disease.

\begin{tabular}{|c|c|c|}
\hline Organs and Tissues & Procedures & Possible or Expected Findings \\
\hline $\begin{array}{l}\text { External examination, } \\
\text { skin, and eyes }\end{array}$ & Prepare histologic sections of skin lesions. & $\begin{array}{l}\text { Dermatitis and exanthema; subconjunctival } \\
\text { hemorrhages; lymphadenopathy. }\end{array}$ \\
\hline Blood & Obtain serum for serologic study. & \\
\hline Cerebrospinal fluid & $\begin{array}{l}\text { Submit sample for cell count and determination } \\
\text { of protein concentrations (p. 104). }\end{array}$ & $\begin{array}{l}\text { Increased cell count and elevated protein } \\
\text { concentrations in presence of encephalitis.* }\end{array}$ \\
\hline $\begin{array}{l}\text { Gastrointestinal tract; } \\
\text { kidneys }\end{array}$ & & Hemorrhages. \\
\hline Lymph nodes & $\begin{array}{l}\text { Submit postauricular, suboccipital, and } \\
\text { posterior cervical lymph nodes for histologic } \\
\text { study. }\end{array}$ & Lymphadenitis. \\
\hline Brain & $\begin{array}{l}\text { For removal and specimen preparation, } \\
\text { see p. } 65 \text {. Submit sample for microbiologic } \\
\text { study (see above under "Note" and p. 102). }\end{array}$ & $\begin{array}{l}\text { Acute rubella encephalitis with nonspecific } \\
\text { perivascular infiltrates, cerebral edema, } \\
\text { and neuronal degeneration. Rarely, severe } \\
\text { hemorrhages. }\end{array}$ \\
\hline Joints & $\begin{array}{l}\text { For removal, prosthetic repair, and specimen } \\
\text { preparation, see p. } 96 \text {. }\end{array}$ & $\begin{array}{l}\text { Arthritis (polyarthritis and tenosynovitis) } \\
\text { of fingers, wrists, and knees. }\end{array}$ \\
\hline
\end{tabular}

\section{Rubeola (See "Measles.")}




\section{St. Louis Encephalitis (See "Encephalitis, all types or type unspecified.”)}

\section{Sarcoidosis}

NOTE: The typical noncaseating granuloma of sarcoidosis is not pathognomonic. Fungal or mycobacterial infections, brucellosis, ${ }^{*}$ hypersensitivity pneumonitis, pneumoconiosis* (in rare instances, sarcoid granulomas may contain calcium oxalate crystals), and Wegener's granulomatosis* must be ruled out. Metastatic calcifications may occur (1).

\begin{tabular}{|c|c|c|}
\hline Organs and Tissues & Procedures & Possible or Expected Findings \\
\hline \multirow[t]{2}{*}{$\begin{array}{l}\text { External examination } \\
\text { and skin }\end{array}$} & Prepare histologic sections of skin lesions. & $\begin{array}{l}\text { Erythema nodosum; lupus pernio; } \\
\text { maculopapular eruptions; scars and keloids. }\end{array}$ \\
\hline & Prepare chest and skeletal roentgenograms. & $\begin{array}{l}\text { Pulmonary and hilar infiltrates; cystic bone } \\
\text { changes in phalanges of hands and feet. }\end{array}$ \\
\hline Blood & $\begin{array}{l}\text { Submit sample for determination of globulin } \\
\text { concentrations. }\end{array}$ & Hyperglobulinemia; hypercalcemia. \\
\hline Heart & $\begin{array}{l}\text { Record weight. If there was a history of heart } \\
\text { block, prepare histologic sections of conduction } \\
\text { system (p. 26). }\end{array}$ & $\begin{array}{l}\text { Cor pulmonale; myocardial sarcoidosis, } \\
\text { particularly of left ventricular wall } \\
\text { (cardiomyopathy*). The conduction system } \\
\text { may be involved also (1). }\end{array}$ \\
\hline Lungs & $\begin{array}{l}\text { Submit one lobe for microbiologic study } \\
\text { (p. 103). Perfuse one lung with formalin } \\
\text { (p. 47). If superinfection is expected, order } \\
\text { Grocott's methenamine silver, acid fast, and } \\
\text { Gram stain (p. 172). }\end{array}$ & $\begin{array}{l}\text { Noncaseating, noninfectious granulomas. } \\
\text { Pulmonary fibrosis with honeycombing; } \\
\text { aspergillomas or other mycetomas may be } \\
\text { found. Pleural sarcoidosis. See also above } \\
\text { under "Note." }\end{array}$ \\
\hline Lymph nodes & $\begin{array}{l}\text { Record size of hilar (mediastinal), abdominal, } \\
\text { and peripheral lymph nodes (cervical, axillary, } \\
\text { inguinal). Submit samples for histologic study. }\end{array}$ & $\begin{array}{l}\text { Granulomatous lymphadenitis with } \\
\text { epithelioid cells and giant cells (with or } \\
\text { without asteroid and conchoid or Schaumann } \\
\text { bodies). }\end{array}$ \\
\hline Liver & $\begin{array}{l}\text { Record weight; submit samples for histologic } \\
\text { study. }\end{array}$ & $\begin{array}{l}\text { Granulomatous hepatitis. Granulomatous } \\
\text { cholangitis (chronic cholestasis of } \\
\text { sarcoidosis) resembling primary biliary } \\
\text { cirrhosis. }\end{array}$ \\
\hline Spleen & $\begin{array}{l}\text { Record weight; submit samples for histologic } \\
\text { study. If there is splenomegaly or other } \\
\text { evidence of portal hypertension,* follow } \\
\text { procedures described under that heading. }\end{array}$ & $\begin{array}{l}\text { Granulomatous splenitis. For histologic } \\
\text { features, see under "Lymph nodes." }\end{array}$ \\
\hline Kidneys & $\begin{array}{l}\text { If there is evidence of kidney failure, } * \\
\text { see under that heading. }\end{array}$ & Nephrolithiasis;* nephrocalcinosis. \\
\hline Other tissues & $\begin{array}{l}\text { Procedures depend on expected findings or } \\
\text { grossly identified abnormalities as listed in } \\
\text { right-hand column. If metastatic calcifications } \\
\text { are found (1), order von Kossa stain (p. 173). }\end{array}$ & $\begin{array}{l}\text { Manifestations of portal hypertension* or of } \\
\text { kidney failure.* Granulomas and associated } \\
\text { lesions may occur in many organs and tissues, } \\
\text { such as nasal mucosa, tonsils, larynx with } \\
\text { epiglottis, stomach, or rectum. }\end{array}$ \\
\hline
\end{tabular}




\begin{tabular}{|c|c|c|}
\hline Organs and Tissues & Procedures & Possible or Expected Findings \\
\hline Brain and spinal cord & $\begin{array}{l}\text { For removal and specimen preparation, } \\
\text { see pp. } 65 \text { and } 67 \text {, respectively. }\end{array}$ & $\begin{array}{l}\text { Chronic meningitis; space-occupying lesions } \\
\text { (submeningeal nodular granulomas). }\end{array}$ \\
\hline Pituitary gland & $\begin{array}{l}\text { If there is evidence of diabetes insipidus* or } \\
\text { pituitary insufficiency, }{ }^{*} \text { see under those headings. }\end{array}$ & Granulomatosis. \\
\hline $\begin{array}{l}\text { Eyes, lacrimal glands, } \\
\text { and other orbital tissues }\end{array}$ & $\begin{array}{l}\text { For removal and specimen preparation, } \\
\text { see pp. } 85 \text { and } 87 .\end{array}$ & $\begin{array}{l}\text { Iridocyclitis; chorioretinitis; papilledema; } \\
\text { posterior uveitis; keratoconjunctivitis } \\
\text { sicca; conjunctival follicles; cataracts. } \\
\text { Involvement of lacrimal glands and other } \\
\text { orbital tissues (2). }\end{array}$ \\
\hline Parotid gland & $\begin{array}{l}\text { If there is evidence of parotid involvement, } \\
\text { other salivary glands should also be studied. } \\
\text { Parotid gland can be biopsied from scalp } \\
\text { incision (p. 65). Submaxillary gland can be } \\
\text { removed with floor of mouth (p. 4). }\end{array}$ & Sarcoidosis of parotid gland is common. \\
\hline $\begin{array}{l}\text { Skeletal muscles } \\
\text { and peripheral nerves }\end{array}$ & $\begin{array}{l}\text { For sampling and specimen preparation, } \\
\text { see pp. } 80 \text { and } 79 \text {, respectively. }\end{array}$ & Sarcoid neuropathy and sarcoid myopathy. \\
\hline Bones and joints & $\begin{array}{l}\text { For removal, prosthetic repair, and specimen } \\
\text { preparation, see p. } 95 \text {. }\end{array}$ & $\begin{array}{l}\text { Cystic changes, primarily of small bones of } \\
\text { hands and feet. Sarcoidosis of joints (3). }\end{array}$ \\
\hline
\end{tabular}

\section{References}

1. Nelson JE, Kirschner PA, Teirstein AS. Sarcoidosis presenting as heart disease. Sarcoidosis Vasculitis Diffuse Lung Dis 1996;13:178-182.

2. Smith JA, Foster CS. Sarcoidosis and its ocular manifestations. Int Ophthalmol Clin 1996;36:109-125.

3. Pettersson T. Rheumatic features of sarcoidosis. Curr Opin Rheumatol 1998;10:73-78.

\section{Schistosomiasis}

Synonyms and Related Terms: Bilharziasis; Schistosoma haematobium infection; Schistosoma japonicum infection; Schistosoma mansoni infection.

NOTE: Unless specifically stated, the changes listed below refer to chronic schistosomiasis mansoni and japonica.

(1) Collect all tissues that appear to be infected. (2) Request direct examination for Schistosoma. The following procedures have been described and recommended (1). For demonstration of Schistosoma eggs, compress 4-mm tissue fragments-for instance, mucosa of the urinary bladder-between glass slides. If this gives negative results, digest a 5 -g portion of tissue in potassium hydroxide.

For the recovery of adult worms of Schistosoma mansoni and Schistosoma haematobium, remove the viscera en bloc (p. 3) and rinse with water. Separate the intestines from the mesentery. Subsequently, perfuse the portal vein system, the liver, and one lung with saline (2). Then pass the perfusion fluid through a monofilament nylon cloth with an aperture size of $180 \mu \mathrm{m}$. Submerge the cloth in water and examine with a dissecting microscope. Fix worms in formalin solution. Examine the intestinal mucosa directly.

From the urinary bladder, ureters, and surrounding connective tissue, worms can be recovered as follows. Inject water into the tissue until the tissue increases 2 or 3 times in thickness. Then compress the tissue gently with a glass plate. Cut slices $0.1-0.2 \mathrm{~cm}$ in thickness. Compress these slices between the glass plate and the stage of a dissecting microscope and examine for the presence of adult worms. Many worms also will be present in the fluid expressed from the tissue as it is cut. For the counting of eggs in tissues, urine, and feces, see ref. (1). Immunodiagnostic methods (ELISA and immunoblot) also have been developed (3). (3) Request Giemsa stain (p. 172). (4) Usually, no special precautions are indicated. (5) Serologic studies are available from the Centers for Disease Control and Prevention, Atlanta, GA (p. 135). (6) This is not a reportable disease.

\begin{tabular}{|c|c|c|}
\hline Organs and Tissues & Procedures & Possible or Expected Findings \\
\hline $\begin{array}{l}\text { External examination } \\
\text { and skin }\end{array}$ & $\begin{array}{l}\text { Record extent and photograph skin lesions } \\
\text { and prepare histologic sections. }\end{array}$ & $\begin{array}{l}\text { Jaundice; edema and pyogenic infection of } \\
\text { penis, scrotum, and perineum in Schistosoma } \\
\text { haematobium. Clubbing of fingers and toes. }\end{array}$ \\
\hline Blood & Collect serum for serologic studies. & \\
\hline Heart & Record heart weight and thickness of ventricles. & Cor pulmonale. \\
\hline Lungs & $\begin{array}{l}\text { See above under "Note." For pulmonary } \\
\text { arteriography, see p. } 50 \text {. Perfuse one lung with } \\
\text { formalin (p. 47). Request Verhoeff-van Gieson } \\
\text { stain (p. 173). }\end{array}$ & $\begin{array}{l}\text { Embolized eggs with obstructive arteriolitis, } \\
\text { angiomatoid lesions, granulomas, and } \\
\text { arteriovenous fistulas. Arteriosclerosis; } \\
\text { hyaline emboli in small pulmonary arteries. }\end{array}$ \\
\hline Peritoneal cavity & $\begin{array}{l}\text { Submit samples with lesions for histologic } \\
\text { study. }\end{array}$ & $\begin{array}{l}\text { Subserosal granulomatous nodules; perito- } \\
\text { neal and retroperitoneal fibrosis;* ascites. }\end{array}$ \\
\hline
\end{tabular}




\begin{tabular}{|c|c|c|}
\hline Organs and Tissues & Procedures & Possible or Expected Findings \\
\hline $\begin{array}{l}\text { Intestinal tract } \\
\text { and mesentery }\end{array}$ & $\begin{array}{l}\text { See above under "Note." Submit samples } \\
\text { of all segments for histologic study. }\end{array}$ & $\begin{array}{l}\text { Submucosal granulomas and submucosal } \\
\text { fibrosis; mucosal ulcers; esophageal varices; } \\
\text { inflammatory polyps. }\end{array}$ \\
\hline Portal and splenic veins & $\begin{array}{l}\text { See above under "Note." Dissect in situ or } \\
\text { after en bloc removal of abdominal organs } \\
\text { (p. 3). If there is evidence of portal } \\
\text { hypertension,* follow procedures described } \\
\text { under that heading. }\end{array}$ & $\begin{array}{l}\text { Thrombosis or cavernous transformation of } \\
\text { portal vein system. }\end{array}$ \\
\hline Liver & $\begin{array}{l}\text { See above under "Note." For portal venography, } \\
\text { see p. } 56 \text {. Record weight, photograph, and } \\
\text { submit samples for histologic study. }\end{array}$ & $\begin{array}{l}\text { Hepatic fibrosis (4). Hepatic } \\
\text { thrombophlebitis. }\end{array}$ \\
\hline Spleen & Record weight. & Congestive splenomegaly. \\
\hline \multirow[t]{4}{*}{$\begin{array}{l}\text { Kidneys, ureters, } \\
\text { and pelvic organs }\end{array}$} & $\begin{array}{l}\text { See above under "Note." Remove kidneys } \\
\text { together with ureters and pelvic organs. }\end{array}$ & $\begin{array}{l}\text { Hydronephrosis, * pyonephrosis, } \\
\text { pyelonephritis,* granulomatous reaction } \\
\text { to eggs and urinary bladder papillomas } \\
\text { in Schistosoma haematobium infection. }\end{array}$ \\
\hline & $\begin{array}{l}\text { For in situ fixation of urinary bladder, } \\
\text { see p. } 59 .\end{array}$ & $\begin{array}{l}\text { Ureteritis with strictures and scars; } \\
\text { ureterolithiasis and urolithiasis; chronic } \\
\text { constricting bilharzial cystitis and tumor of } \\
\text { bladder in Schistosoma haematobium } \\
\text { infection. The uterus and Fallopian tubes also } \\
\text { may be involved (5). }\end{array}$ \\
\hline & $\begin{array}{l}\text { For dissection of penis and urethra, } \\
\text { see p. } 60 \text {. Submit samples of prostate and } \\
\text { seminal vesicles for histologic study. }\end{array}$ & $\begin{array}{l}\text { Hyperplastic and fibrotic seminal vesiculitis } \\
\text { and prostatitis; fibrotic granulomatous and } \\
\text { suppurative infection of urethra and penis in } \\
\text { Schistosoma haematobium infection. }\end{array}$ \\
\hline & $\begin{array}{l}\text { Submit samples of spermatic cord, } \\
\text { epididymis, and testicles for histologic study. }\end{array}$ & $\begin{array}{l}\text { Granulomatous infection by Schistosoma } \\
\text { haematobium. }\end{array}$ \\
\hline Other organs & $\begin{array}{l}\text { Submit sections from all sites with grossly } \\
\text { identifiable lesions. }\end{array}$ & $\begin{array}{l}\text { Schistosoma mansoni infection may occur in } \\
\text { every organ. Most frequent ectopic sites are } \\
\text { spinal cord, brain, and genital tract. }\end{array}$ \\
\hline
\end{tabular}

\section{References}

1. Kamel IA, Cheever AW, Elwi AM, Mosimann JE, Danner R: Schistosoma mansoni and S. haematobium infections in Egypt. I. Evaluation of techniques for recovery of worms and eggs at necropsy. Am J Trop Med Hyg 1977;26:696-701.

2. Cheever AW. A quantitative post-mortem study of schistosomiasis mansoni in man. Am J Trop Med Hyg 1968;17:38-64.

3. Tsang VC, Wilkins PP. Immunodiagnosis of schistosomiasis. Screen with FAST-ELISA and confirm with immunoblot. Clin Lab Med 1991; 11(4):1029-1039.

4. Andrade ZA, Peixoto E, Guerret S, Grimaud JA. Hepatic connective tissue changes in hepatosplenic schistosomiasis. Hum Pathol 1992; 23(5):566-573.

5. Helling-Giese G, Kjetland EF, Gundersen SG, Poggensee G, Richter J, Krantz I, et al. Schistosomiasis in women: manifestations in the upper reproductive tract. Acta Trop 1996;62(4):225-238.

\section{Scleroderma (See “Sclerosis, systemic.”)}

\section{Sclerosis, Amyotrophic Lateral} (See "Disease, motor neuron.")

\section{Sclerosis, Diffuse (See "Sclerosis, Schilder's cerebral.") \\ Sclerosis, Multiple}

Synonyms and Related Terms: Acute and subacute variants: Acute multiple sclerosis (Marburg type), acute necrotizing myelopathy; concentric sclerosis (Baló type); concentric lacunar leukoencephalopathy; encephalitis periaxialis diffusa (Schilder's type; see also next entry, "Sclerosis, Schilder's cerebral"*); neuromyelitis optica (Dèvic type).

Chronic Variants: Classic or Charcot type multiple sclerosis (relapsing and remitting, secondary progressive, arrested, benign, monosymptomatic and asymptomatic, primary progressive).

Possible Associated Conditions: Hypertrophic polyradiculoneuropathy.

\begin{tabular}{lll}
\hline Organs and Tissues & Procedures & Possible or Expected Findings
\end{tabular}

Brain and spinal cord

For removal and specimen preparation, see pp. 65 and 67, respectively. Record thickness of optic nerves. Request Luxol fast blue stain for myelin and Bielschowski's stain for axons (p. 172).
Changes most commonly in cerebral white matter (periventricular), spinal cord white matter, and optic nerves. Appearance of plaques varies, depending on whether they are active, chronic active, or inactive. 


\begin{tabular}{lll}
\hline Organs and Tissues & Procedures & Possible or Expected Findings \\
\hline $\begin{array}{l}\text { Brain and spinal cord } \\
\text { (continued) }\end{array}$ & & $\begin{array}{l}\text { Myelin loss, accompanied by a variable } \\
\text { histiocytic infiltrate and gliosis, are } \\
\text { characteristic findings. Perivascular } \\
\text { lymphocytic cuffs are present. }\end{array}$ \\
Other organs and tissues & $\begin{array}{l}\text { Procedures depend on expected findings or } \\
\text { grossly identified abnormalities as listed in } \\
\text { right-hand column. }\end{array}$ & $\begin{array}{l}\text { Aspiration bronchopneumonia; disuse } \\
\text { atrophy of skeletal muscles. }\end{array}$ \\
\hline
\end{tabular}

\section{Sclerosis, Schilder's Cerebral}

Synonyms: Encephalitis periaxialis diffusa; multiple sclerosis, Schilder's type.

NOTE: The pathologic changes in adrenoleukodystrophy may resemble those in Schilder's disease (see also under "Leukodystrophy,...").

\begin{tabular}{lll}
\hline Organs and Tissues & Procedures & Possible or Expected Findings \\
\hline Brain and spinal cord & $\begin{array}{l}\text { For removal and specimen preparation, see } \\
\text { pp. } 65 \text { and } 67, \text { respectively. See also above } \\
\text { under "Note." }\end{array}$ & $\begin{array}{l}\text { Diffuse or large patches of demyelination in } \\
\text { the cerebral white matter }(>2 \times 3 \mathrm{~cm}), \text { with } \\
\text { sudanophilic myelin breakdown products in } \\
\text { macrophages. }\end{array}$ \\
& $\begin{array}{l}\text { Submit wet tissue for determination of } \\
\text { phospholipids and cholesterol esters. }\end{array}$ & $\begin{array}{l}\text { Depletion of phospholipids and increase of } \\
\text { cholesterol esters (nonspecific manifestations } \\
\text { of myelin sheath breakdown). }\end{array}$ \\
\end{tabular}

Sclerosis, Systemic

Synonyms and Related Terms: Progressive systemic sclerosis; scleroderma.

Possible Associated Conditions: Sjögren's syndrome**

\begin{tabular}{ll}
\hline Organs and Tissues & Procedures \\
\hline External examination & $\begin{array}{l}\text { Record character and extent of skin lesions, } \\
\text { photograph, and submit samples for histologic } \\
\text { study, together with subcutaneous tissue. } \\
\text { Prepare roentgenograms of jaws. }\end{array}$
\end{tabular}

Breast

If breast implants are present, record type and state whether they are intact.

Diaphragm

Blood

Heart

Lungs with hilar lymph nodes

Aorta and other elastic arteries Esophagus
Freeze serum for possible serologic study. Measure volume of pericardial fluid. Record heart weight and measure thickness of ventricles. For histologic study of the conduction system, see p. 26.

Perfuse one lung with formalin (p. 47).

Submit samples of lungs and hilar lymph nodes for histologic study.

Leave esophagus attached to portion of stomach. Submit samples at various levels for histologic study.

\section{Possible or Expected Findings}

Dermal sclerosis, primarily of face and fingers. Cutaneous calcium deposits with ulcerations. Ischemic ulcers of fingers. Thickening of periodontal membrane with replacement of the lamina dura.

Ruptured implants have been considered (probably erroneously) a possible cause of systemic sclerosis (1).

Diaphragmatic hernia.*

Fibrinous pericarditis or hydropericardium. Cor pulmonale.

Interstitial fibrosis, which may involve the conduction system.

Diffuse alveolar damage (2). Interstitial pulmonary fibrosis with honey-combing. Vasculitis or intimal thickening of small pulmonary arteries and arterioles with pulmonary hypertension* (see "Heart"). Aspiration bronchopneumonia. Bronchioloalveolar carcinoma complicating advanced fibrosis.

Rarely involved by vasculitis.

Muscular fibrosis. Vasculitis. Dilatation and ulcers of lower esophagus; ulcers are secondary to systemic sclerosis or reflux. 


\begin{tabular}{|c|c|c|}
\hline Organs and Tissues & Procedures & Possible or Expected Findings \\
\hline Gastrointesinal tract & $\begin{array}{l}\text { For in situ fixation, see p. } 54 \text {. Other procedures } \\
\text { depend on expected findings or grossly identified } \\
\text { abnormalities as listed in right-hand column. }\end{array}$ & $\begin{array}{l}\text { Gastrointestinal fibrosis, most commonly of } \\
\text { duodenum, jejunum, and colon; colonic } \\
\text { muscular atrophy with large-mouth } \\
\text { diverticula. Rarely, pneumatosis* of small } \\
\text { intestine. }\end{array}$ \\
\hline Kidneys & $\begin{array}{l}\text { Follow procedures described under } \\
\text { "Glomerulonephritis." }\end{array}$ & $\begin{array}{l}\text { Intimal hyperplasia of interlobular arteries. } \\
\text { Fibrinoid changes of afferent arterioles and } \\
\text { glomeruli. Arteriolonecrosis. Cortical } \\
\text { infarctions or ischemic scars. Hypertensive } \\
\text { kidney failure* is a common cause of death. }\end{array}$ \\
\hline Other organs & $\begin{array}{l}\text { Procedures depend on expected findings or } \\
\text { grossly identified abnormalities as listed in } \\
\text { right-hand column. }\end{array}$ & $\begin{array}{l}\text { Vasculitis in many organs and tissues-for } \\
\text { instance, in pancreas, spleen, and central } \\
\text { nervous system. Fibrosis of thyroid gland } \\
\text { with hypothyroidism.* }\end{array}$ \\
\hline Brain and spinal cord & $\begin{array}{l}\text { For removal and specimen preparation, } \\
\text { see pp. } 65 \text { and } 67 \text {, respectively. }\end{array}$ & $\begin{array}{l}\text { Generally not affected. Rare cases of } \\
\text { cerebrovascular calcification have been } \\
\text { reported (3). }\end{array}$ \\
\hline Skeletal muscles & $\begin{array}{l}\text { For sampling and specimen preparation, } \\
\text { see p. } 80 \text {. }\end{array}$ & $\begin{array}{l}\text { Polymyositis (overlap syndrome). } \\
\text { Muscular fibrosis. Neurogenic changes also } \\
\text { may occur (4). }\end{array}$ \\
\hline Bones and joints & $\begin{array}{l}\text { For removal, prosthetic repair, and specimen } \\
\text { preparation, see p. } 95 \text {. }\end{array}$ & $\begin{array}{l}\text { Osteoporosis.* Symmetric polyarthritis* } \\
\text { with low-grade synovitis. }\end{array}$ \\
\hline
\end{tabular}

\section{References}

1. Anderson DR, Schwartz J, Cottrill CM, McClain AS, Ross JS, Magidson JG, et al. Silicone ganuloma in acral skin in a patient with silicone-gel implants and systemic sclerosis. Int J Dermatol 1996;35: 36-38.

2. Muir TE, Tazelaar HD, Colby TV, Myers JL. Organizing diffuse alveolar damage associated with progressive systemic sclerosis. Mayo Clin Proc 1997;72:639-642.

\section{Sclerosis, Tuberous}

Synonyms and Related Terms: Bourneville's disease; Bourneville-Pringle disease; neurocutaneous syndrome; phacomatosis. NOTE: There are probably more abnormalities than the ones listed below and some may have not yet been described (1).

\begin{tabular}{ll}
\hline Organs and Tissues & Procedures \\
\hline External examination & $\begin{array}{l}\text { Prepare photographs of face and pigment } \\
\text { abnormalities at other sites. If accessible, } \\
\text { and skin }\end{array}$ \\
& prepare sections of skin tumors.
\end{tabular}

Prepare skeletal roentgenograms.

Liver

Record weight; perfuse with formalin (p. 56); photograph cut sections and sample possible abnormalities for histologic study.

\section{Possible or Expected Findings}

Angiofibromas with characteristic facial distribution (so-called facial adenoma sebaceum). Peri- and subungual "fibromas." Rough yellow skin in lumbosacral region (shagreen patch). Hypopigmented spots (white spots; hypomelanotic macules) over trunk and limbs.

See below under "Bones."

Rhabdomyomas, often multiple.

Lymphangioleiomyomatosis characterized by multiple small cysts and honeycombing with proliferation of connective tissue and smooth muscle.

Focal fatty change.

Angioleiomyomas. 


\begin{tabular}{|c|c|c|}
\hline Organs and Tissues & Procedures & Possible or Expected Findings \\
\hline Intestine & $\begin{array}{l}\text { Fix intestinal wall samples on cork board } \\
\text { and submit polyps for histologic study. }\end{array}$ & Microhamartomatous rectal polyps. \\
\hline Kidneys & $\begin{array}{l}\text { Record weights. Photograph outer surface } \\
\text { and cut sections; submit tumor nodules for } \\
\text { histologic study. }\end{array}$ & $\begin{array}{l}\text { Angiomyolipomas; embryonal renal } \\
\text { blastomas; microscopic cysts; cystic } \\
\text { glomeruli; abnormal tubules. }\end{array}$ \\
\hline Uterus & Sample for histologic study. & Abnormal proliferation of smooth muscle. \\
\hline Neck organs & Open larynx in posterior midline. & Fibrous polyps of larynx. \\
\hline Other organs and tissues & $\begin{array}{l}\text { Procedures depend on expected findings or } \\
\text { grossly identified abnormalities as listed in } \\
\text { right-hand column. }\end{array}$ & $\begin{array}{l}\text { Record size and character of all tumorous or } \\
\text { other abnormal lesions. Angioleiomyomas in } \\
\text { pancreas and adrenal glands. }\end{array}$ \\
\hline Brain and spinal cord & $\begin{array}{l}\text { For removal and specimen preparation, } \\
\text { see pp. } 65 \text { and } 67 \text {, respectively. }\end{array}$ & $\begin{array}{l}\text { Cortical tuber; subependymal nodules; white } \\
\text { matter hamartomas; subependymal giant cell } \\
\text { astrocytoma. }\end{array}$ \\
\hline Eyes & $\begin{array}{l}\text { For removal and specimen preparation, } \\
\text { see p. } 85 \text {. }\end{array}$ & $\begin{array}{l}\text { Retinal hamartoma; retinal giant cell } \\
\text { astrocytoma; hypopigmented iris spot. }\end{array}$ \\
\hline Bones & $\begin{array}{l}\text { For removal, prosthetic repair, and specimen } \\
\text { preparation, see p. } 95 \text {. }\end{array}$ & $\begin{array}{l}\text { Rarefaction of phalanges; periosteal } \\
\text { thickening of metacarpals and metatarsals; } \\
\text { focal sclerosis of calvaria; melorheostosis- } \\
\text { type changes. }\end{array}$ \\
\hline
\end{tabular}

\section{Reference}

1. Wiestler OD, Lopex PS, Crino PB. Tuberous sclerosis complex and subependymal giant cell astrocytoma. In: Pathology and Genetics of the Nervous System. Kleihues P, Cavence WK, eds. IARC, Lyon, 1997, pp. 182-184.

Scopolamine (See "Poisoning, alkaloid.")

Scuba (See "Accident, diving [skin or scuba].")

Scurvy (See "Deficiency, vitamin C.")
Shigellosis (See "Dysentery, bacillary.")

\section{Shingles (See "Infection, Herpes zoster.”)}

\section{Shock}

Related Terms: Anaphylactic shock; bacteremic shock; cardiogenic shock; electric shock; hypovolemic shock; septic shock; and many others.

NOTE: See also under name of suspected underlying condition, such as "Burns," "Death, anaphylactic," "Injury, electrical," and "Stroke, heat."

\begin{tabular}{ll}
\hline Organs and Tissues & Procedures \\
\hline Blood & Submit sample for bacterial culture (p. 102). \\
Heart & $\begin{array}{l}\text { Dissection procedures depend on type of heart } \\
\text { disease. Sample myocardium for histologic } \\
\text { study (p. 30). }\end{array}$
\end{tabular}

Lungs

Gastrointestinal tract

Liver

Kidneys

Adrenal glands

Brain
Record weights. Perfuse one lung with formalin (p. 47). Submit one lobe for bacteriologic study (p. 103).

Record intestinal abnormalities and estimated amount of intraluminal blood.

Record weight and sample for histologic study.

Record weights. Submit samples of cortex and papillae for histologic study.

Record weights; record appearance of cortex.

For removal and specimen preparation, see p. 65 .
Possible or Expected Findings

Bacteremia or septicemia may be either the cause or the effect of shock.

Heart disease causing cardiogenic shock.

Other types of shock may cause

subendocardial and subepicardial interstitial hemorrhages, minute necroses, and patchy contraction band changes.

Shock lungs (wet lungs). See also under "Syndrome, respiratory distress, of adult." Pulmonary embolism* may be the cause of shock.

Mucosal hemorrhages and necroses; erosions and ulcers.

Centrilobular (zone 3) necroses, with or without fatty changes.

Acute tubular necrosis.

Cortical lipid depletion and atrophy.

Hypoxic encephalopathy with neuronal damage. 


\section{Sickness, Decompression}

Synonym: Caisson disease.

NOTE: See also "Accident, diving (skin or scuba)" and references below (1-4).

\begin{tabular}{lll}
\hline Organs and Tissues & Procedures & Possible or Expected Findings \\
\hline External examination & $\begin{array}{l}\text { Prepare roentgenograms of chest, elbows, hips, } \\
\text { and knees. }\end{array}$ & $\begin{array}{l}\text { Subcutaneous and mediastinal emphysema; } \\
\text { pneumothorax.* Osteonecrosis (aseptic } \\
\text { necrosis of bone). }\end{array}$ \\
Chest and lungs & $\begin{array}{l}\text { For tests for pneumothorax, see p. 430. Record } \\
\text { lung weights. Prepare fresh-frozen sections of } \\
\text { lung tissue and request Sudan stain (p. 173). } \\
\text { Liver and other organs }\end{array}$ & $\begin{array}{l}\text { Pleural effusions; Tardieu's spots; } \\
\text { pulmonary edema. Pulmonary fat embolism. } \\
\text { grocedures depend on expected findings or } \\
\text { right-hand column. }\end{array}$ \\
Brain & For removal and specimen preparation, see p. 65. & $\begin{array}{l}\text { Fatty changes of liver. Ischemic infarctions } \\
\text { in many organs. }\end{array}$ \\
\hline
\end{tabular}

\section{References}

1. Gallagher TJ. Scuba diving accidents: decompression sickness, air embolism. J Florida Med Assoc 1997;84:446-451.

2. Blanksby BA, Wearne FK, Elliott BC, Blitvich JD. Aetiology and occurrence of diving injuries. A review of diving safety. Sports Med 1997;23:228-246.
3. Arness MK. Scuba decompression illness and diving fatalities in an overseas military community. Aviation Space Environm Med 1997; 68:325-333.

4. Hardy KR. Diving related emergencies. Emerg Med Clin North Am 1997;15:223-240.

\section{Sickness, Serum}

Related Term: Immune complex disease.

NOTE: This is a nonfatal, self-limited disease, characterized by swelling of the face, rash, lymphadenopathy, and arthritis, mainly of large joints.* Globulin antibodies may be demonstrable. There may be proteinuria. Fatalities are caused by acute anaphylactic reactions, which may occur in the course of serum therapy. See under "Death, anaphylactic."

\section{Sickness, Sleeping (See “Trypanosomiasis, African.”)}

\section{Silicosis (See "Pneumoconiosis.")}

\section{Snakebite}

\begin{tabular}{lll}
\hline Organs and Tissues & Procedures & Possible or Expected Findings \\
\hline External examination & $\begin{array}{l}\text { Photograph and submit material from wound } \\
\text { and skin (wound) }\end{array}$ & $\begin{array}{l}\text { Necrosis, edema, and hemorrhage around } \\
\text { bite wound; bleeding from body orifices. }\end{array}$ \\
& $\begin{array}{l}\text { Use Gram stains if superinfection (e.g., with } \\
\text { clostridia) appears to be present (p. 172). }\end{array}$ & $\begin{array}{l}\text { Mild jaundice. Superinfection of wounds } \\
\text { with or without gangrene. }\end{array}$ \\
Kidneys & $\begin{array}{l}\text { Record weights, photograph, and sample for } \\
\text { histologic study. }\end{array}$ & $\begin{array}{l}\text { Renal cortical and tubular necrosis. } \\
\text { Myoglobin or hemoglobin in tubules. }\end{array}$ \\
Other organs & $\begin{array}{l}\text { Procedures depend on expected findings or } \\
\text { grossly identified abnormalities as listed in } \\
\text { right-hand column. }\end{array}$ & $\begin{array}{l}\text { Features of disseminated intravascular } \\
\text { coagulation.* Hemorrhages. }\end{array}$ \\
\hline
\end{tabular}

Sodium (See “Disorder, electrolyte(s)” and p. 114.)

Spherocytosis (See “Anemia, hemolytic.”)

Sphingolipidosis (See “Gangliosidosis.”)

Spina Bifida (See "Meningocele.")

Splenomegaly, Chronic Congestive (See "Hypertension, portal.") 


\section{Spondylitis, Ankylosing}

Synonyms and Related Terms: Bechterew's disease; Marie-Strümpell spondylitis; rheumatoid spondylitis; spondylarthropathy (1).

Possible Associated Conditions: Amyloidosis;* isolated heart block.

\begin{tabular}{l} 
Organs and Tissues \\
\hline External examination, \\
skin, and subcutaneous \\
tissue \\
Blood
\end{tabular}

Heart and aorta

Lungs

Intestine

Kidneys and prostate

Bones and joints

Bone marrow

Eyes
Procedures

Prepare skeletal roentgenograms.

There are no diagnostic laboratory tests but it still is advisable to save a blood sample.

Record heart weight. Test competence of valves (p. 29). Open heart in line of blood flow. Photograph and measure valvular lesions. Prepare sections of valves, myocardium, conduction system (if there was a history of heart block), and ascending aorta.

Perfuse one lung with formalin (p. 47). Submit abnormal lobe for microbiologic study (p. 103).

For in situ fixation, see p. 54. Other procedures depend on expected findings or grossly identified abnormalities as listed in right-hand column.

Sample for histologic study and request amyloid stains or renal parenchyma.

Prepare roentgenograms of spine, sacroiliac joints, symphysis ossium pubis, and manubriosternal, sternoclavicular, and humeroscapular joints. For removal of bones and joints, prosthetic repair, and specimen preparation, see p. 95 . If spine cannot be removed in its entirety, it can be split in midline and one half can be removed, with costovertebral and costotransversal joints. Hip joints should be exposed. Maceration (p. 97) yields excellent specimens.

Histologic sections should include synovia and periarticular tissue.

For preparation of sections and smears, see p. 96.

For removal and specimen preparation, see p. 85 .
Possible or Expected Findings

Deformities of rheumatoid arthritis.* Kyphosis.

See below under "Bones and joints." The HLA-B27 gene is present in most cases. Rheumatoid factor and antinuclear antibodies are absent.

Thickening of supravalvular aortic wall. Thickening of aortic cusps. Subaortic bump. Thickening of anterior mitral leaflet. Aortic and mitral insufficiency,* with signs of regurgitation. Aortitis.

Interstitial fibrosis and cysts in upper lobes. Pleuritis, pleural effusions, ${ }^{*}$ fibrobullous lesions, and cavitating lesions with fungal (Aspergillus) or bacterial infections. Chronic ulcerative colitis. Crohn's disease.* Microscopic inflammatory lesions may be the only manifestations (2).

Amyloid nephropathy. Prostatitis.

Fusion of sacroiliac and intervertebral joints and disks ("bamboo spine"). These changes often are associated with severe spinal osteoporosis.* The involvement of the sacroiliac joint is pathognomonic (3). Cervical spinal fracture may be a cause of quadriplegia.

Secondary and peripheral osteoarthritis* may be present.

Leukemia* developed in some patients who had had radiation treatment (1950 or earlier). Acute anterior uveitis.

\section{References}

1. Schumacher HR, Bardin T. The spondyloarthropathies: classification and diagnosis. Do we need new terminologies? Bailliers Clin Rheumatol 1998;12:551-565.

2. Porzio V, Biasi G, Corrado A, De Santi M, Vindigni C, Viti S, et al. Intestinal histological and ultrastructural inflammatory changes in spondyloarthropathy and rheumatoid arthritis. Scand J Rheumatol 1997;26:92-98.

3. Braun J, Sieper J. The sacroiliac joint in the spondyloarthropathies. Curr Opin Rheumatol 1996;8:275-287.

\section{Sporotrichosis}

Synonym: Sporothrix (Sporotrichum) schenckii infection. NOTE: (1) Collect all tissues that appear to be infected. (2) Request fungal culture. (3) Request Grocott's methenamine silver stain (p. 172). (4) No special precautions are indicated. (5) Serologic studies are available on a research basis from the Centers for Disease Control and Prevention, Atlanta, GA (p. 135). (6) This is not a reportable disease.

Possible Associated Conditions: Sarcoidosis; * tuberculosis.* 


\begin{tabular}{|c|c|c|}
\hline Organs and Tissues & Procedures & Possible or Expected Findings \\
\hline $\begin{array}{l}\text { External examination } \\
\text { and skin }\end{array}$ & $\begin{array}{l}\text { Prepare sections of cutaneous and subcutaneous } \\
\text { lesions. } \\
\text { Prepare skeletal roentgenograms. }\end{array}$ & $\begin{array}{l}\text { Acute or chronic skin infection, with or } \\
\text { without granulomas and suppuration. } \\
\text { Osteomyelitis* (metacarpals, phalanges, and } \\
\text { tibiae) and arthritis.* }\end{array}$ \\
\hline Lymph nodes & $\begin{array}{l}\text { Dissect lymph nodes that drain cutaneous } \\
\text { and subcutaneous infections. Submit samples } \\
\text { for microbiologic (p. 102) and histologic study. } \\
\text { See also above under "Note." }\end{array}$ & Lymphadenitis. \\
\hline Chest cavity & Record volume of pleural effusions. & $\begin{array}{l}\text { Pleural effusions* may be associated with } \\
\text { pulmonary sporotrichosis. }\end{array}$ \\
\hline Lungs & $\begin{array}{l}\text { Submit consolidated areas for culture } \\
\text { (see p. } 103 \text { and above under "Note"). Perfuse } \\
\text { both lungs with formalin (p. } 47 \text { ). }\end{array}$ & $\begin{array}{l}\text { Few sporadic cases with cavities and fungus } \\
\text { ball. Pulmonary fibrosis. }\end{array}$ \\
\hline Other organs & $\begin{array}{l}\text { See above under "Note." Other procedures } \\
\text { depend on expected findings or grossly } \\
\text { identified abnormalities as listed in right-hand } \\
\text { column. }\end{array}$ & $\begin{array}{l}\text { Gastrointestinal tract, central nervous } \\
\text { system, eyes, and skeletal system-among } \\
\text { others-may be involved by hematogenous } \\
\text { dissemination. }\end{array}$ \\
\hline
\end{tabular}

\section{Sprue, Celiac}

Synonyms and Related Terms: Adult celiac disease; collagenous sprue; gluten-sensitive enteropathy; idiopathic steatorrhea; nontropical sprue; protein-losing enteropathy; sprue syndrome.

Possible Associated Conditions: Chronic ulcerative colitis;* dermatitis herpetiformis; diabetes mellitus;* IgA deficiency; insufficiency, adrenal;* lipodystrophy (1); lymphoma* (2); primary biliary cirrhosis; ${ }^{*}$ primary sclerosing cholangitis* (See also below under "Possible or Expected Findings.")

\begin{tabular}{ll}
\hline Organs and Tissues & Procedures \\
\hline $\begin{array}{l}\text { External examination } \\
\text { and skin }\end{array}$ & $\begin{array}{l}\text { Submit samples of grossly normal and of } \\
\text { abnormal skin for histologic study. }\end{array}$
\end{tabular}

Prepare skeletal roentgenograms.

\section{Heart}

Lungs

Esophagus and stomach

Intestinal tract

Other organs
Perfuse one lung with formalin (p. 47).

Request Gomori's iron stain (p. 172).

See "Tumor of the esophagus" and

"Tumor of the stomach."

For in situ fixation and preparation for study under the dissecting microscope, see p. 54.

Record sites in small intestine from where histologic material was sampled (in centimeters from duodenojejunal junction or from ileocecal valve).

Submit samples of colonic mucosa for histologic study. Request PAS and azure-eosin stains (p. 172).

Procedures depend on expected findings or grossly identified abnormalities as listed in right-hand column.

\section{Possible or Expected Findings}

Baldness; perianal and perioral erosions; cutaneous vasculitis; dermatitis herpetiformis; eczema; psoriasis; ${ }^{*}$ other skin diseases.

Facial, upper extremity and truncal lipodystrophy (1).

Osteomalacia with compression fractures; kyphoskoliosis. Ischemic heart disease.*

Idiopathic pulmonary hemosiderosis; interstitial pneumonia.*

Carcinoma may be found in both organs.

Volvulus; mucosal diaphragms; villous atrophy. Sprue-like changes in patients with carcinoma or lymphoma, with or without intestinal ulceration and perforation.

Ulcerative colitis. Lymphocytic or microscopic colitis.

Manifestations of malabsorption syndrome* with osteomalacia.* 


\section{References}

1. O'Mahony D, O'Mahony S, Whelton MJ, McKiernan J. Partial lipodystrophy in coeliac disease. Gut 1990;31:717-718.

2. Mathus-Vliegen EM. Coeliac disease and lymphoma: current status. Netherlands J Med 1996;49:212-220.

\section{Sprue, Tropical}

NOTE: This term is not well-defined and has been applied to a variety of diseases.

\begin{tabular}{lll}
\hline Organs and Tissues & Procedures & Possible or Expected Findings \\
\hline Intestinal tract & $\begin{array}{l}\text { For } \text { in situ fixation of small bowel and for } \\
\text { preparation for study under dissecting micro- } \\
\text { scope, see p. 54. Submit samples for histologic } \\
\text { study. }\end{array}$ & $\begin{array}{l}\text { Partial mucosal atrophy of whole length of } \\
\text { the small bowel. Many geographic variations; } \\
\text { probably infectious etiology in many } \\
\text { instances. } \\
\text { Atrophic gastritis. } \\
\text { Stomach }\end{array}$ \\
$\begin{array}{ll}\text { Fone marrow } \\
\text { see p. } 96 .\end{array}$ & Macrocytic megaloblastic anemia.* \\
\hline
\end{tabular}

\section{Stabbing (See "Injury, stabbing.")}

\section{Stannosis (See "Pneumoconiosis.")}

\section{Starvation}

NOTE: In developed countries, psychiatric conditions such as anorexia nervosa* or organic diseases such as malignancies are the most common causes of starvation. See also under "Malnutrition."

\begin{tabular}{|c|c|c|}
\hline Organs and Tissues & Procedures & Possible or Expected Findings \\
\hline $\begin{array}{l}\text { External examination } \\
\text { and skin }\end{array}$ & $\begin{array}{l}\text { Record body weight and length and location } \\
\text { of edema. Prepare sections of skin lesions. }\end{array}$ & $\begin{array}{l}\text { Hunger edema; skin changes secondary to } \\
\text { vitamin deficiencies. }\end{array}$ \\
\hline Blood & Submit sample for biochemical studies. & Hypoproteinemia. \\
\hline Liver and spleen & Record weights. & Atrophy; hemosiderosis of spleen. \\
\hline Other organs and tissues & $\begin{array}{l}\text { Record weight of all organs (for expected } \\
\text { weights, see Appendix, p. 571). Submit samples } \\
\text { of all major organs, including endocrine glands, } \\
\text { lymphatic and fat tissue, bone, and bone marrow } \\
\text { for histologic study. }\end{array}$ & $\begin{array}{l}\text { Degree of atrophy varies from organ to organ; } \\
\text { atrophy of fat tissue, lymphoid tissue, and } \\
\text { gonads usually is most pronounced. Severe } \\
\text { infections, such as tuberculosis,* may be } \\
\text { present without having been apparent } \\
\text { clinically. }\end{array}$ \\
\hline
\end{tabular}

\section{Steatohepatitis, Nonalcoholic (NASH)}

NOTE: The morphologic findings in the liver are indistinguishable from those in alcoholic liver disease* (1). Follow autopsy procedures described under "Disease, alcoholic liver." If the patient had received a liver transplant, procedures described under "Transplantation, liver" should be followed also.

Possible Associated Conditions: Celiac sprue (rare); diabetes mellitus* (type 2); hyperlipidemia; malnutrition* from bulemia (rare); morbid obesity with liver failure particularly after episodes of rapid weight loss (e.g., after recent gastroplasty); lipodystrophy; mild obesity;* short bowel syndrome (rare); total parenteral nutrition.*

\begin{tabular}{lll}
\hline Organs and Tissues & Procedures & Possible or Expected Findings \\
\hline $\begin{array}{l}\text { External examination } \\
\text { and skin }\end{array}$ & Record body weight and length. & Obesity, ${ }^{*}$ which may be mild or severe. \\
Liver & Record weight and sample for histologic study. & $\begin{array}{l}\text { Chronic steatohepatitis with or without } \\
\text { cirrhosis. Submassive hepatic necrosis. }\end{array}$ \\
Other organs & $\begin{array}{l}\text { Procedures depend on expected findings or } \\
\text { grossly identified abnormalities as listed in } \\
\text { right-hand column. }\end{array}$ & $\begin{array}{l}\text { Manifestations of portal hypertension.* } \\
\text { See also above under "Possible Associated } \\
\text { Conditions." }\end{array}$ \\
Brain and spinal cord & $\begin{array}{l}\text { For removal and specimen preparation, } \\
\text { see pp. 65 and 67, respectively. }\end{array}$ & Wernicke's encephalopathy (2). \\
\hline
\end{tabular}




\section{References}

1. Ludwig J, McGill DB, Lindor KD. Review: nonalcoholic steatohepatitis. J Gastroenterol Hepatol 1997;12:398-403.

2. Yamamoto T. Alcoholic and non-alcoholic Wernicke's encephalopathy. Be alert to the preventable and treatable disease. Intern Med 1996;35:754-755.

\section{Steatorrhea, Idiopathic (See “Sprue, celiac.")}

\section{Stenosis, Acquired Valvular Aortic}

Related Terms: Acquired calcification of congenitally bicuspid aortic valve; degenerative (or senile) calcific aortic stenosis; rheumatic aortic stenosis.

NOTE: See also "Stenosis, congenital valvular aortic."

\begin{tabular}{lll}
\hline Organs and Tissues & Procedures & Possible or Expected Findings \\
\hline Heart & Follow procedures described under "Stenosis, & $\begin{array}{l}\text { Bicuspid aortic valve; calcific nodular aortic } \\
\text { stenosis. Chronic rheumatic mitral and } \\
\text { tricuspid valvulitis. }\end{array}$ \\
\hline
\end{tabular}

\section{Stenosis, Acquired Valvular Pulmonary}

NOTE: For general dissection techniques, see p. 33. Record weight of heart, thickness of ventricles, and valve circumferences.

Possible Associated Conditions: Carcinoid heart disease (both the pulmonary valve and the tricuspid valve may be involved).

\section{Stenosis, Congenital Supravalvular Aortic}

Synonyms: Supravalvular aortic stenosis, diffuse type; supravalvular aortic stenosis, discrete; Williams-Beuren syndrome.

NOTE: Sudden death may occur, as may acute aortic dissection. For acquired forms, see "Arteritis, Takayasu's."

Possible Associated Conditions: Adhesions of aortic valve cusps; obstruction of coronary ostia and brachiocephalic branches of the aortic arch; supravalvular pulmonary stenosis; Williams-Beuren syndrome.

\begin{tabular}{lll}
\hline Organs and Tissues & Procedures & Possible or Expected Findings \\
\hline External examination & Prepare photograph of face. & Unusual elfin-like facial features. \\
Blood & $\begin{array}{l}\text { Submit sample of serum for microbiologic } \\
\text { study (p. 102). Postmortem calcium values are }\end{array}$ & Hypercalcemia; septicemia.
\end{tabular}
study (p. 102). Postmortem calcium values are unreliable.

Heart If infective aortitis is suspected, expose stenosed Infective aortitis. area through sterilized aortic wall (similar to procedure suggested for valvular aortic endocarditis, p. 103). Culture vegetations, prepare smears and sections, and request Gram stain (p. 172).

Remove heart together with aortic arch and adjacent great neck vessels. Measure diameters of stenosed and nonstenosed portions of aorta (calipers work best); record extent and nature of stenosis. For coronary arteriography, see p. 118. Prepare histologic sections of multiple segments of coronary arteries. Request Verhoeff-van Gieson stain (p. 173).
Diffuse or discrete type of aortic stenosis. Increased heart weight. Substantial thickening and stenosis of involved arteries. Microscopic arterial dysplasia with merged intima and media, and with haphazard interlacing of elastic layers.

Manifestations of congestive heart failure.*

\section{Stenosis, Congenital Supravalvular Pulmonary}

Synonyms: Williams-Beuren syndrome.

NOTE: Follow procedures described under "Stenosis, congenital valvular pulmonary." For acquired forms, see "Arteritis, Takayasu's."

Possible Associated Conditions: Supravalvular aortic stenosis.* 


\section{Stenosis, Congenital Valvular Aortic}

Synonyms: Acommissural (dome-shaped) aortic valve; unicommissural aortic valve; unicuspid aortic valve (either acommissural or unicommissural).

NOTE: Congenital aortic stenosis may cause sudden death in infancy and childhood. Most valves are unicommissural, hypoplastic, and dysplastic (thickened and malformed). Occasionally, bicuspid aortic valves are stenotic at birth.

Possible Associated Conditions: Coarctation of aorta;* endocardial fibroelastosis* of left ventricle; hypoplasia of left ventricle;* interrupted aortic arch;* tubular hypoplasia of aortic arch.*

\begin{tabular}{|c|c|c|}
\hline Organs and Tissues & Procedures & Possible or Expected Findings \\
\hline \multirow[t]{3}{*}{ Heart } & $\begin{array}{l}\text { If infective endocarditis is suspected, follow } \\
\text { procedures described on p. } 103 \text {. }\end{array}$ & Infective endocarditis. $*$ \\
\hline & $\begin{array}{l}\text { Remove heart with ascending aorta; record } \\
\text { weight of heart and open in ventricular cross- } \\
\text { sections (p. 22). Test competence of valves } \\
\text { (p. 29). Leave aortic valve intact. Record } \\
\text { size of valve orifice and thickness of heart } \\
\text { chambers. }\end{array}$ & $\begin{array}{l}\text { Hypertrophy of left and right ventricles; } \\
\text { dilatation of left atrium. }\end{array}$ \\
\hline & $\begin{array}{l}\text { Histologic samples should include endocardium } \\
\text { and area(s) of fusion of aortic cusp(s). Request } \\
\text { Verhoeff-van Gieson stain (p. 173). }\end{array}$ & $\begin{array}{l}\text { Endocardial fibroelastosis* of left ventricle. } \\
\text { Infarction of mitral papillary muscles. } \\
\text { Subendocardial fibrosis, biventricular. }\end{array}$ \\
\hline Lungs & $\begin{array}{l}\text { Perfuse one lung with formalin (p. 47). } \\
\text { Request Verhoeff-van Gieson stain (p. 173). }\end{array}$ & Chronic pulmonary venous changes. \\
\hline
\end{tabular}

\section{Stenosis, Congenital Valvular Pulmonary}

Related Terms: Isolated (pure, simple, or dome-shaped) pulmonary stenosis.

NOTE: The pulmonary valve is usually acommissural in isolated congenital pulmonary stenosis. With other coexistant congenital heart disease (such as tetralogy), the pulmonary valve is usually bicuspid and hypoplastic, but may be unicommissural or dysplastic and tricuspid.

\begin{tabular}{|c|c|c|}
\hline Organs and Tissues & Procedures & Possible or Expected Findings \\
\hline $\begin{array}{l}\text { Heart and great vessels; } \\
\text { peripheral pulmonary } \\
\text { arteries }\end{array}$ & $\begin{array}{l}\text { If infective endocarditis is suspected, follow } \\
\text { procedures described on p. } 103 \text {. } \\
\text { For general dissection techniques, see p. } 33 \text {. } \\
\text { Record weight of heart, thickness of ventricles, } \\
\text { and annular circumferences. }\end{array}$ & $\begin{array}{l}\text { Infective endocarditis* of pulmonary valve } \\
\text { and tricuspid valve; infective endarteritis at } \\
\text { bifurcation of pulmonary trunk. } \\
\text { Thickened and incompetent tricuspid valve; } \\
\text { right ventricular hypertrophy; poststenotic } \\
\text { dilatation of pulmonary trunk; peripheral } \\
\text { pulmonary artery stenosis. }\end{array}$ \\
\hline Brain & $\begin{array}{l}\text { For removal and specimen preparation, } \\
\text { see p. } 65 .\end{array}$ & $\begin{array}{l}\text { Cerebral abscess* (would indicate presence } \\
\text { of right-to-left shunt). }\end{array}$ \\
\hline
\end{tabular}

\section{Stenosis, Mitral}

Synonyms and Related Terms: Acquired mitral stenosis; congenital mitral stenosis; rheumatic mitral stenosis.

Possible Associated Conditions: Acquired mitral stenosis generally is the result of rheumatic carditis (often decades earlier). Congenital mitral stenosis may be associated with bicuspid aortic valve;* coarctation of the aorta;* parachute mitral valve; Shone's syndrome; subaortic stenosis;* supravalvular stenosing ring of the left atrium; and ventricular septal defect.*

\begin{tabular}{|c|c|c|}
\hline Organs and Tissues & Procedures & Possible or Expected Findings \\
\hline External examination & $\begin{array}{l}\text { Record color of skin. } \\
\text { Prepare chest roentgenogram. }\end{array}$ & $\begin{array}{l}\text { Cyanosis. } \\
\text { Cardiomegaly; calcification in and aro } \\
\text { mitral valve. }\end{array}$ \\
\hline Blood & $\begin{array}{l}\text { If infective endocarditis* is suspected, submit } \\
\text { sample for microbiologic study (p. 102). }\end{array}$ & Septicemia. \\
\hline Heart and great vessels & $\begin{array}{l}\text { For general dissection techniques in congenital } \\
\text { mitral stenosis, see p. } 33 \text {. } \\
\text { If infective endocarditis is suspected, see p. } 103 .\end{array}$ & $\begin{array}{l}\text { See above under "Possible Associated } \\
\text { Conditions." } \\
\text { Infective endocarditis.* }\end{array}$ \\
\hline
\end{tabular}




\begin{tabular}{lll}
\hline Organs and Tissues & Procedures & Possible or Expected Findings \\
\hline $\begin{array}{l}\text { Heart and great vessels } \\
\text { (continued) }\end{array}$ & $\begin{array}{l}\text { Record weight and measurements of heart; } \\
\text { record size of left atrium; record appearance } \\
\text { and size of mitral orifice. For tests for } \\
\text { stenosis and measurement of valve size, } \\
\text { see p. 29. }\end{array}$ & $\begin{array}{l}\text { Cardiomegaly; dilatation of left atrium; } \\
\text { thrombi in atrial appendages. Rheumatic } \\
\text { valvulitis. }\end{array}$ \\
& $\begin{array}{l}\text { Perfuse lungs with formalin (p. 47); prepare } \\
\text { sections of bronchi, pulmonary arteries, and } \\
\text { pulmonary veins. Request Verhoeff-van Gieson }\end{array}$ & $\begin{array}{l}\text { Pulmonary congestion, emboli, and } \\
\text { infarctions; bronchopneumonia; } \\
\text { manifestations of pulmonary venous } \\
\text { stain (p. 173). }\end{array}$ \\
$\begin{array}{l}\text { Procedures depend on expected findings or } \\
\text { grossly identified abnormalities as listed in } \\
\text { right-hand column. }\end{array}$ & $\begin{array}{l}\text { Manifestations of congestive heart } \\
\text { failure; systemic emboli; cholelithiasis* } \\
\text { ather ohronic cholecystitis.* }\end{array}$ \\
\hline
\end{tabular}

Stenosis, Renal Artery

\begin{tabular}{|c|c|c|}
\hline Organs and Tissues & Procedures & Possible or Expected Findings \\
\hline \multirow[t]{2}{*}{ Retroperitoneal organs } & $\begin{array}{l}\text { For renal arteriography, see p. } 59 \text {. Open } \\
\text { aorta lengthwise in situ; record width of renal } \\
\text { artery orifices. } \\
\text { Probe renal arteries, record width of lumen, } \\
\text { and open lengthwise. }\end{array}$ & $\begin{array}{l}\text { Dissection, embolus, or thrombus of } \\
\text { renal artery. Fibromuscular renal artery } \\
\text { dysplasia. Atherosclerotic plaques. } \\
\text { Some lesions may have been induced by } \\
\text { previous percutaneous transluminal } \\
\text { angioplasty. }\end{array}$ \\
\hline & $\begin{array}{l}\text { Photograph; submit samples for histologic } \\
\text { study; request Verhoeff-van Gieson stain } \\
\text { (p. 173). }\end{array}$ & $\begin{array}{l}\text { Fibromuscular dysplasia with renal artery } \\
\text { stenosis must be shown in longitudinal } \\
\text { histologic sections of the artery. }\end{array}$ \\
\hline Kidneys & $\begin{array}{l}\text { Prepare histologic sections of both kidneys } \\
\text { (it is important to identify the side, right or } \\
\text { left, from which the sample was taken. }\end{array}$ & $\begin{array}{l}\text { Ischemic damage with scarring in affected } \\
\text { kidney. Hypertensive vascular changes in } \\
\text { unprotected kidney. Abnormalities of } \\
\text { juxtaglomerular apparatus. }\end{array}$ \\
\hline Other organs & & Manifestations of hypertension.* \\
\hline
\end{tabular}

\section{Stenosis, Subvalvular Aortic}

Synonyms and Related Terms: Discrete congenital subvalvular aortic stenosis; idiopathic hypertrophic subaortic stenosis (see "Cardiomyopathy, hypertrophic"); subaortic stenosis; subaortic stenosis of membranous type; subaortic stenosis of muscular type; tunnel subaortic stenosis.

Possible Associated Conditions: Accessory tissue (windsock deformity) of the mitral valve; age-related angled (sigmoid) ventricular septum; complete atrioventricular septal defect;* congenital rhabdomyoma; infundibular stenosis of right ventricle; mitral insufficiency;* supravalvular stenosis of left atrium, parachute mitral valve, and coarctation of aorta;* ventricular septal defect* (malalignment type); Shone's syndrome.

\begin{tabular}{|c|c|c|}
\hline Organs and Tissues & Procedures & Possible or Expected Findings \\
\hline Heart & $\begin{array}{l}\text { For general dissection techniques, see p. } 22 . \\
\text { Before opening outflow tract, measure diameter } \\
\text { of stenosis. Dissect by short axis (p. 22) or } \\
\text { long-axis method (see p. 23). Compare septal } \\
\text { thickness with thickness of lateral ventricular } \\
\text { wall. Histologic samples should include } \\
\text { ventricular septum. For fixation for electron } \\
\text { microscopy, see p. } 132 \text {. }\end{array}$ & $\begin{array}{l}\text { Membranous or muscular subaortic } \\
\text { (subvalvular) stenosis. Increased heart } \\
\text { weight. Ventricular septum may be thicker } \\
\text { than lateral wall of left ventricle (normal } \\
\text { ratio }<1.3 \text { ). }\end{array}$ \\
\hline
\end{tabular}

\section{Stenosis, Subvalvular Pulmonary}

Synonyms: Right ventricular infundibular stenosis; stenosis of ostium infundibuli; double-chambered right ventricle; dynamic right ventricular outflow tract obstruction.

NOTE: Infective endocarditis* may occur on the wall of the right infundibular chamber above the localized area of infundibular stenosis. If this is suspected, follow procedures described on p. 103. 


\section{Stenosis, Subvalvular Pulmonary (continued)}

Possible Associated Conditions: Congenital valvular pulmonary stenosis;* double outlet right ventricle;* tetralogy of Fallot;* ventricular septal defect.*

\section{Stenosis, Tricuspid}

NOTE: For general dissection techniques, see p. 22. Possible causes of tricuspid stenosis include carcinoid heart disease, chronic rheumatic valvulitis, and congenital anomaly.

\section{Stillbirth}

As stated in Chapter 1, it is preferable to have autopsies of fetuses, including stillbirth, performed by pathologists experienced in perinatal pathology. If such personnel are not immediately available, the attending pathologist may nevertheless collect important information. If attempts to induce abortion appear to have caused the death of the mother, see "Death, abortion-associated."

The placenta should be immediately procured from the delivery room should it not arrive in the laboratory with the fetus. This will avoid the possibility of the placenta being discarded by the delivery room staff. No fetal autopsy is complete without a careful examination of the placenta (for technical details, see Part I, Chapter 5, p. 60).

Fascia lata or other aseptically obtained tissue should be collected for tissue culture for karyotype analysis (p. 109). A portion of placenta and liver should be snap-frozen for possible molecular analysis.

The initial stage of the autopsy should include photography and radiography, taking anterior-posterior and lateral views. The photographs will record the degree of maceration, which can be roughly correlated with the duration of fetal demise before delivery (ref. [1], pp. 270-273). External measurements should include body weight, circumference of head, chest and abdomen, crown-rump length, crown-heel length, and foot length. These measurements are compared with Tables of standards for normal fetuses (see Part III of this book and perinatal pathology texts quoted in Chapter 1). Assessment of growth retardation may be based on these data. A careful external examination should search for abnormalities such as jaundice, bulging fontanel, cranial bone softening, hyper- or hypotelorism, choanal atresia, external ear anomalies, cleft lip, cleft palate, macroglossia, micrognathia, colobomata, cystic hygroma, shortened neck, contractures, omphalocele, gastroschisis, abnormal external genitalia, anal atresia, absent vagina, sacral pits, open neural tube defects, hemihypertrophy, syndactyly, clinodactyly, simian creases, or incomplete descent of testes.

The organ bloc may be removed in the manner similar to the adult, using the technique of Letulle (see p. 3). If the thyroid gland is noted to be in its usual location and if it appears normal, then the tongue may be left in the body. In macerated fetuses, it is suggested that the organ bloc be fixed overnight in formalin solution prior to dissection. To aid adequate fixation, the following simple steps may be done: 1) wash the organ bloc thoroughly prior to fixation; 2) place multiple transverse cuts through the liver; 3) dissect the posterior leaves of the diaphragm away from the adrenal glands and kidneys; 4) bivalve the adrenal glands and kidneys in the coronal plane; 5) instill formalin in the lumen of the intestine, using a syringe; and 6) gently instill formalin into both ventricles of the heart, being careful to avoid the ventricular septum.

The procedure for dissection of the organs is similar to that of the adult except: 1) The venous and arterial connections of the heart, including the patency of the ductus arteriosus must be determined before the heart is removed; 2) The esophageal hiatus should be examined in situ. The esophagus must be opened posteriorly prior to its complete removal so that esophageal atresia or tracheo-esophageal fistula may be recognized and photographed prior to further dissection; 3) The location of the appendix and of the testes should be recorded. Until the intestine has been examined for stenosis or atresia, the mesentery should be left attached.

The degree of autolysis as seen with histologic examination can be used to estimate the duration of time between fetal death and delivery (2). Trichrome stain is useful for better visualizing histologic features in severely autolyzed tissue.

To remove the brain, Benecke's technique of one of its modifications may be used (p. 66).

Stillbirth vs Livebirth. A decision has to be made whether the infant was born alive or was stillborn. The hydrostatic lung test, described in the previous edition, appears unreliable. The presence of gas in the lungs does not rule out stillbirth. After death, air can be introduced into the lungs, or putrefaction gases might be present. However, air artificially introduced after death will not distend the alveoli and can be squeezed out, whereas this does not seem to be the case after active ventilation. The distribution of fat in the fetal zone of the adrenal cortex may indicate whether intrauterine death was acute, more prolonged, or chronic (3). This is particularly helpful if the stillborn baby is macerated. If the mother died also, see under "Death, abortion-associated."

\section{References}

1. Valdéz-Dapena MA, Huff, DS. Perinatal Autopsy Manual. Armed Forces Institute of Pathology, Washington, DC, 1983.

2. Genest DR, Williams MA, Greene MF. Estimating the time of death in stillborn fetuses: I. Histologic examination of fetal organs: an autopsy study of 150 stillborns. Obstet Gynecol 1992;80:575-584.

3. Becker MJ, Becker AE. Fat distribution in the adrenal cortex as an indication of the mode of intrauterine death. Hum Pathol 1976;7:495504.

\section{Stimulant(s) (See "Dependence, $\operatorname{drug}(\mathrm{s})$, all types or type undetermined.")}

\section{Sting, Insect (See "Death, anaphylactic.")}

\section{Strangulation}

NOTE: In many instances, procedures described under "Homicide" must also be followed. If a rope or some other material had been used (see also under "Hanging"), leave ligature in place until autopsy can be done. See also under "Hypoxia." Toxicologic sampling, particularly for alcohol, should be done in all instances (p. 16). 


\begin{tabular}{lll}
\hline Organs and Tissues & Procedures & Possible or Expected Findings \\
\hline $\begin{array}{l}\text { External examination } \\
\text { and skin }\end{array}$ & $\begin{array}{l}\text { If identity of victim is unknown, follow } \\
\text { procedures described on p. 11. }\end{array}$ & \\
& $\begin{array}{l}\text { If a ligature and knot are present, record and } \\
\text { photograph their position. Do not disturb knot } \\
\text { but cut ligature at some distance and bind } \\
\text { ends together. }\end{array}$ & $\begin{array}{l}\text { Strangulation ligatures tend to run } \\
\text { horizontally. }\end{array}$ \\
& $\begin{array}{l}\text { Photograph skin and neck and prepare } \\
\text { histologic sections of strap muscles and fascia } \\
\text { for demonstration of vital reaction. Collect } \\
\text { fingernail scrapings. }\end{array}$ & $\begin{array}{l}\text { Abrasions; fingernail marks; laceration. } \\
\text { Defense marks. }\end{array}$ \\
& $\begin{array}{l}\text { Photograph sequentially during layer-wise } \\
\text { dissection (see p. 14). Handle neck organs } \\
\text { carefully. }\end{array}$ & \\
& $\begin{array}{l}\text { Prepare roentgenogram of hyoid bone and } \\
\text { submit tissues with evidence of trauma for } \\
\text { histologic study. }\end{array}$ & Contusions in soft tissues. Fracture of hyoid \\
& bone; laryngeal injury. \\
\hline
\end{tabular}

\section{Stroke, Cerebrovascular (See "Infarction, cerebral.")}

Stroke, Heat (See "Heatstroke.”)

Strychnine (See "Poisoning, strychnine.")

Sulfur (Dioxide or Sulfurous Acid) (See "Bronchitis, acute chemical" and "Poisoning, gas.")

Surgery (See following entries and under “Transplantation,..." See also under "Postoperative Autopsies," p. 4.)

\section{Surgery, Aortocoronary Bypass}

\begin{tabular}{|c|c|c|}
\hline Organs and Tissues & Procedures & Possible or Expected Findings \\
\hline \multirow[t]{10}{*}{ Heart and ascending aorta } & $\begin{array}{l}\text { Record in situ appearance of heart and } \\
\text { ascending aorta. Remove heart with ascending } \\
\text { aorta and graft(s) attached. } \\
\text { Record weight of heart. }\end{array}$ & Cardiomegaly. Injury to ascending aorta. \\
\hline & Prepare angiograms-first of saphenous & Focal or diffuse graft obstruction. \\
\hline & vein or internal mammary artery graft(s) & Aneurysm(s) of venous graft(s). \\
\hline & and then of coronary arteries (p. 118). & Twisting or kinking of graft(s). \\
\hline & $\begin{array}{l}\text { Record patency of distal and proximal } \\
\text { anastomoses of graft(s). Remove venous } \\
\text { graft(s) for histologic study, including } \\
\text { the distal anastomoses. }\end{array}$ & \\
\hline & Prepare cross-sections of coronary arteries & Obstructive coronary atherosclerosis. \\
\hline & and graft(s). Request Verhoeff-van Gieson & Thrombosis, intimal proliferation, \\
\hline & stain (p. 173). Decalcification (p. 97) of & calcification, and atherosclerosis of venous \\
\hline & coronary arteries and of graft(s) may be & $\operatorname{graft}(\mathrm{s})$. Scars, recent myocardial \\
\hline & $\begin{array}{l}\text { required. Prepare 1-cm-thick transverse } \\
\text { (coronal) slices of myocardium (p. } 22) \text {. }\end{array}$ & $\begin{array}{l}\text { infarctions, myocardial aneurysm, mural } \\
\text { thromboses. }\end{array}$ \\
\hline
\end{tabular}

\section{Surgery, Cardiac Valvular Replacement}

\begin{tabular}{ll}
\hline Organs and Tissues & Procedures \\
\hline External examination & Prepare chest roentgenogram. \\
Blood & Submit sample for microbiologic study (p. 102).
\end{tabular}

Possible or Expected Findings

Abnormal position of prosthesis or catheter. For identification of valve, see p. 33. Septicemia. 


\begin{tabular}{lll}
\hline Organs and Tissues & Procedures & Possible or Expected Findings
\end{tabular}

Heart If infective endocarditis is suspected, follow procedures described on p. 103.

Record weight of heart.

For coronary arteriography, see p. 118.

Open heart in cross sections (see p. 22). Leave valve prosthesis in place. For identification of valve type, see p. 33. Test function and record appearance of valves that had not been replaced.

Lungs $\quad$ Perfuse lungs with formalin (p. 47).

Request Verhoeff-van Gieson stain (p. 173).

Other organs

Procedures depend on expected findings or grossly identified abnormalities as listed in right-hand column.
Prosthetic infective endocarditis. * Staphylococcus aureus and Gram-negative bacilli are the most common microorganisms in earlyonset endocarditis, and viridans streptococci and Gram-negative bacilli are the most common in late-onset cases. Poppet variance or dislodgement; paravalvular leak; thrombosed valve; calcification of bioprosthetic valve. Cardiac hypertrophy.* Mural thrombi. Myocardial infarction.

Mechanical valve damage. Dislodged valve. Rheumatic and other diseases of valves that had not been replaced.

Emboli; diffuse alveolar damage. Chronic pulmonary venous hypertensive changes. Pneumonia.

Systemic emboli. Escaped poppet, usually at bifurcation of aorta. Hemorrhages secondary to coagulopathy or excessive anticoagulation.

\section{Surgery, Heart Transplantation (See “Transplantation, heart.")}

Surgery, Kidney Transplantation (See “Transplantation, kidney.”)

Surgery, Liver Transplantation (See "Transplantation, liver.”)

Surgery, Lung Transplantation (See "Transplantation, lung.")

Syndrome (See also under "Disease, ...." and "Sickness,...")

Syndrome, Acquired Immunodeficiency (AIDS)

Synonyms: Human immunodeficiency virus (HIV) infection; HIV infection.

NOTE: For a general review of findings, see ref. (1). Collect all tissues that appear to be infected. Tissue yields better culture results than body fluids. (2) Universal precautions should be strictly followed (p. 146). ${ }^{a}$ The generation of aerosols should be minimized. To sterilize tissue surfaces in preparation for culture, swab the surface with povidone iodine. Avoid searing the tissue surface since this will produce an aerosol. Keep no more than one scalpel in the dissecting area at any one time. Have an assistant available with clean, gloved hands to receive specimens in containers, so as to minimize the degree of contamination on the outside of the containers. For cleaning procedures and related information, see Chapter 16. (3) HIV-1 in tissue may be demonstrated using polymerase chain reaction (PCR), immunohistochemistry, in situ hybridization, or immunofluorescence. (4) For immunocytochemical and molecular studies, fix tissue in ethanol (p. 129) or Carnoy's solution (p. 130). The virus can be identified using PCR in most tissues, whether fresh, frozen, or fixed in ethanol. (5) Serologic tests as well as direct fluorescent antibody tests are available for many of the expected infections. (6) This is not a reportable disease.

In Adults:

\begin{tabular}{ll}
\hline Organs and Tissues & Procedures \\
\hline $\begin{array}{l}\text { External examination } \\
\text { and skin }\end{array}$ & $\begin{array}{l}\text { Record body weight and evidence of lipo- } \\
\text { dystrophy following AIDS medications. }\end{array}$
\end{tabular}

Record and photograph any skin lesions.

Examine oral cavity.

Blood and vitreous

Cardiovascular system
If the diagnosis is in doubt, samples can be submitted for enzyme immunoassay.

Procedures depend on expected findings or grossly identified abnormalities as listed in right-hand column.
Possible or Expected Findings

Cachexia. Severe loss of subcutaneous fat in face and extremities, associated with large fat deposits on upper back and upper abdomen ("protease paunch").

Cutaneous Kaposi's sarcoma (1).

Test may be positive for many weeks after death (2).

Increased lipochrome deposition; toxoplasmosis of myocardium; Cytomegalovirus and atypical mycobacterial infections (2). 


\begin{tabular}{ll}
\hline Organs and Tissues & Procedures \\
\hline Respiratory tract & $\begin{array}{l}\text { Culture any consolidated areas. If none can } \\
\text { be identified, take a random section for viral } \\
\text { culture. }\end{array}$
\end{tabular}

Gastrointestinal tract

Open and examine as soon as removed to minimize autolysis. Promptly fix any lesion. Submit sections for electron microscopy.

Liver

Pancreas

Adrenal glands

Lymph nodes and bone marrow

Record weight; sample for microbiologic and histologic study. If indicated, request acid fast stains, Grocott's methenamine silver stain, immunostains for hepatitis antigen, and Gomori's iron stain (p. 172). Sample for histologic study. Record weights. Sample for histologic study.

Sample enlarged lymph nodes for histologic study. For preparation of sections and smears of bone marrow, see pp. 96 and 97, respectively.

Spleen

Record weight and sample for histologic study.

For removal and specimen preparation, see p. 65. The saw should be used within a plastic bag (p. 67) or it should be fitted with a vacuum to collect aerosolized bone particles. Other procedures, including requests for special stains, depend on expected findings or grossly identified abnormalities as listed in right-hand column.
Possible or Expected Findings

Many routine and opportunistic infections; diffuse alveolar damage; diffuse interstitial fibrosis; malignant lymphoma; $*$ foreign body granulomas (in parenteral drug users). Villous atrophy and crypt hyperplasia of small bowel; cryptosporidiosis; microsporidiosis; Mycobacterium aviumintracellulare and other opportunistic infections; lymphoma.*

Hepatitis (3) due to hepatitis A,B,C,delta, Mycobacterium avium-intracellulare, Cytomegalovirus, Cryptococcus; Kaposi's sarcoma; lymphoma; erythrophagocytosis; increased hemosiderin.

Cytomegalovirus pancreatitis.

Medullary necrosis with Cytomegalovirus; lipid depletion.

Lymphadenopathy; follicular hyperplasia; absent germinal centers; sinus histiocytosis; hemophagocytosis. Bone marrow with plasmacytosis; variable cellularity; lymphoma;* lymphoproliferative disorder. Opportunistic infections; lymphoma;* depletion of white pulp with fibrosis; increased plasma cells; hemophagocytosis; increased hemosiderin in macrophages. Viral (HIV encephalitis (4); progressive herpes simplex, or varicella/zoster infection, multifocal leukoencephalopathy;* CMV), bacterial (Mycobacterium avium intracellulare infection; Whipple's disease; Nocardia), and fungal (Aspergillus fumigatus; Candida albicans; Coccidioidomycosis; Cryptococcosis; mucormycosis; histoplasmosis). Syphilis and infection with Toxoplasma gondii also may be found.

Lymphoma;* Kaposi's sarcoma; vacuolar myelopathy; lymphocytic meningitis; cerebral hemorrhage or infarction.

Demyelination of posterior columns and pyramidal tracts (vacuolar myelopathy) (5); lymphoma; opportunistic infections.

Spinal cord

For removal, see p. 67. The saw should be fitted with a vacuum or used under a plastic cover sheet to collect aerosolized bone particles.

${ }^{a}$ Vitreous tested up to $34 \mathrm{~h}$ postmortem and blood tested up to $58 \mathrm{~d}$ postmortem were consistently positive for HIV. No false-negatives ( 6 ).

\section{References}

1. Fisher BK, Warner LC. Cutaneous manifestations of the acquired immunodeficiency syndrome. Intl J Dermatol 1987;26(10):615-630.

2. Lewis W. AIDS: cardiac findings from 115 autopsies. Prog Cardiovasc Dis 1989;32(3):207-215.

3. Schaffner F. The liver in HIV infection. Prog Liver Dis 1990;9:505-522.

4. Kanzer MD. Neuropathology of AIDS. Crit Rev Neurobiol 1990:5(4):313-362.

5. Hénin D, Smith TW, De Girolami U, Sughayer M, Hauw J-J. Neuropathology of the spinal cord in the acquired immunodeficiency syndrome. Hum Pathol 1992;23:1106-1114.

6. Klatt EC, Shibata D, Strigle SM. Postmortem enzyme immunoassay for human immunodeficiency virus. Arch Pathol Lab Med 1989;113:485487. 
In Children (1,2):

\begin{tabular}{ll}
\hline Organs and Tissues & Procedures \\
\hline $\begin{array}{l}\text { External examination } \\
\text { and skin }\end{array}$ & $\begin{array}{l}\text { Obtain body weight and external measurements. } \\
\text { Photograph all abnormalities. Perform whole } \\
\text { body radiographs. }\end{array}$ \\
Oral cavity & $\begin{array}{l}\text { Obtain exudate of ulcers for smears and culture. } \\
\text { Scrape ulcers for Tzanck prep and viral culture. }\end{array}$
\end{tabular}

Salivary glands

Thymus

Cardiovascular system

Respiratory tract

Gastrointestinal tract

Liver

Pancreas

Lymph nodes, bone marrow

Spleen

Urinary system

Brain and spinal cord
Submit portion of parotid gland for histologic study. For sampling, see p. 382.

Weigh and submit for histologic study.

Procedures depend on expected findings or grossly identified abnormalities as listed in right-hand column.

Prepare sections for electron microscopy (p.132). Culture any consolidated areas for viruses, fungi, and bacteria. Submit sections for histologic study. Photograph any lesion suspicious for neoplasm.

Open and examine intestines as soon as they are removed, so as to limit autolysis. Promptly photograph and immerse lesions in fixative. Sample lesions for histologic study.

Photograph any grossly evident lesions. Submit lesions and grossly normal liver for histologic study.

Submit for histologic study.

For preparation of sections and smears, see p. 96.
Possible or Expected Findings

Developmental delay; cachexia.

Candidal, cytomegalovirus and herpetic ulcers; EBV-induced oral hairy leukoplakia; oral warts due to papillomavirus; bacteriainduced necrotizing ulcerative gingivitis. Lymphocytic infiltration; infectious sialoadenitis.

Precocious involution (3); dysinvolution (decrease or absence of Hassall's corpuscles); thymitis with giant cells.

Dilated cardiomyopathy;* myocarditis;* pericardial effusion; myocardial interstitial fibrosis; opportunistic infections; fibrocalcific vasculopathy; aneurysms. Myelin-like figures within myocytes.

Bacterial, fungal, viral, and mycobacterial pneumonias; diffuse alveolar damage; lymphoid hyperplasia; malignant lymphoma;* lymphoproliferative disorder; Kaposi's sarcoma. Infections due to parasites, viruses, fungi, bacteria, and mycobacteria; ulcers; necrotizzing inflammation; lymphoproliferative disorder; lymphoma (including MALT [mucosea associated lymphoid tissue] lymphoma); Kaposi's sarcoma; calcific arteriopathy. Chronic hepatitis;* opportunistic infections; cholestasis; steatosis; Kupffer cell hyperplasia; lymphoproliferative disorder; Kaposi's sarcoma.

Drug-related acute pancreatitis; chronic pancreatitis; opportunistic infections. Persistent generalized lymphadenopathy (hyperplasia, involution, or lymphoid depletion); lymphoproliferative disorder; Kaposi's sarcoma; opportunistic infections; hypercellular bone marrow with increased megakaryocytes, plasmacytosis,

hematophagocytosis; increased iron stores; lymphoma;* leukemia.*

Concentric vascular sclerosis; depletion of $\mathrm{red} /$ white pulp.

Focal segmental glomerulosclerosis; tubuloInterstitial nephritis; mesangial hypercellularrity; cytomegalovirus, candidal infection. Micrencephaly (4); enlarged ventricles; delayed myelination; interstitial mineralization of putamen, globus pallidus, frontal lobe white matter; mononuclear glial and microglial nodules with giant cells; leptomeningitis; lymphoma;* opportunistic infections. Spinal cord with pallor of corticospinal tracts; vacuolar myelopathy. 


\begin{tabular}{lll}
\hline Organs and Tissues & Procedures & Possible or Expected Findings \\
\hline Placenta & Record weight and photograph all gross lesions. & $\begin{array}{l}\text { Retroplacental hematoma; infarcts; acute } \\
\text { chorioamnionitis; funisitis; abnormal villous } \\
\text { maturation; villitis due to Cytomegalovirus, } \\
\end{array}$ \\
& Toxoplasma. \\
\hline
\end{tabular}

\section{References}

1. Systemic Pathology of HIV Infection and AIDS in Children. Moran C, Mullick FG, eds. Armed Forces Institute of Pathology. American Registry of Pathology, Washington, DC, 1997. (To order copies, call: 202-782-2100 or write to American Registry of Pathology Sales Office, AFIP, Room 1077, Washington, DC 20306-6000.)

2. Joshi W. Pathology of acquired immunodeficiency syndrome (AIDS) in children. Keio J Med 1996;45:306-312.

3. Grody WW, Fligiel S, Naeim F. Thymus involution in the acquired immunodeficiency syndrome. Am J Clin Pathol 1985;84:85-95.

4. Kozlowski PB, Brudkowska J, Kraszpulski M, Sersen EA, Wrzolek MA, Anzil AP, et al. Micrencephaly in children congenitally infected with human immunodeficiency virus-a gross-anatomical morphometric study. Acta Neuropathol 1997;93:136-145.
Syndrome, Adams-Stokes (See “Arrhythmia, cardiac.”)

\section{Syndrome, Adult Respiratory Distress [ARDS]}

Related Term: Diffuse alveolar damage; shock lung.

NOTE: For related changes in infancy, see "Syndrome, respiratory distress, of infant."

Possible Associated Conditions: Amniotic fluid embolism;* aspiration (e.g., in near-drowning accidents*); burns;* inhalation of toxic gases; major trauma (with or without fat embolism*); malignancies; pancreatitis; ${ }^{*}$ radiation injury;* severe infections, and many other potentially fatal conditions may cause ARDS, particularly if they are associated with shock.*

\begin{tabular}{lll}
\hline Organs and Tissues & Procedures & Possible or Expected Findings \\
\hline
\end{tabular}

External examination Prepare chest roentgenogram.

Blood

Heart

Trachea and lungs

Other organs
Submit sample for microbiologic study

(p. 102), particularly if septicemia is suspected.

Toxicologic studies (drug screen) are indicated in some instances (p. 16).

If the patient had cardiopulmonary surgery, see also under name of underlying condition. Determine position of endotracheal tube. Record lung weights. Submit samples for microbiologic study (p. 103), particularly if septicemia is suspected. Perfuse one lung with formalin (p. 47). For the demonstration of edema, some samples should be fixed in Bouin's solution (p. 129).

Procedures depend on expected associated conditions.
Pneumothorax* (including tension pneumothorax); pneumomediastinum. Septicemia.

Illicit drug use; paraquat or salicylate poisoning.

Surgical procedures that required cardiopulmonary bypass may cause ARDS. Endotracheal tube may become dislodged.

Diffuse alveolar damage, with or without evidence of underlying condition such as trauma, fat embolism, ${ }^{*}$ viral infection, damage from toxic inhalants (e.g., smoke, oxygen or nitrogen oxides), or aspiration (gastric acid or swimming pool water in near-drowning accidents).

Manifestations of conditions listed above under "Possible Associated Conditions"

\section{Syndrome, Afferent Loop}

Possible Associated Conditions: Malabsorption syndrome* in patients with stasis and bacterial overgrowth in afferent loop.

\begin{tabular}{lll}
\hline Organs and Tissues & Procedures & Possible or Expected Findings \\
\hline $\begin{array}{l}\text { Stomach, duodenum, } \\
\text { and jejunum }\end{array}$ & Dissect stomach and intestines in situ. & $\begin{array}{l}\text { Previous Billroth II operation. Distension, } \\
\text { lengthening, and kinking of afferent } \\
\text { duodenal loop. }\end{array}$ \\
\hline
\end{tabular}

\section{Syndrome, Albright's (See “Dysplasia, fibrous, of bone.")}

\section{Syndrome, Alport}

Synonyms and Related Terms: Classic (X-linked) Alport syndrome; hereditary congenital hemorrhagic nephritis; hereditary nephritis with nerve deafness; nonclassic (autosomal) Alport syndrome without deafness or eye changes. 


\begin{tabular}{lll}
\hline Organs and Tissues & Procedures & Possible or Expected Findings \\
\hline All organs & $\begin{array}{l}\text { Follow procedures described under "Glomerulo- } \\
\text { nephritis" and "Failure, kidney." }\end{array}$ & $\begin{array}{l}\text { Chronic glomerulonephritis* with foam cells. } \\
\text { Eyes }\end{array}$ \\
$\begin{array}{l}\text { For removal and specimen preparation, } \\
\text { see p. 85. }\end{array}$ & $\begin{array}{l}\text { Conical deformation of the anterior surface } \\
\text { of the lens (lenticonus) in classic Alport } \\
\text { syndrome. }\end{array}$ \\
\hline
\end{tabular}

\section{Syndrome, Aortic Arch (See “Arteritis, Takayasu's.”)}

\section{Syndrome, Asplenia (See "Syndrome, polysplenia and asplenia.")}

\section{Syndrome, Ataxia-Telangiectasia}

Synonym: Louis-Bar syndrome.

NOTE: See also under "Syndrome, immunodeficiency." Chronic pulmonary disease and malignancy (see below) are the most common causes of death.

Possible Associated Conditions: Malignant lymphomas* and, rarely, carcinomas.

\begin{tabular}{|c|c|c|}
\hline Organs and Tissues & Procedures & Possible or Expected Findings \\
\hline $\begin{array}{l}\text { External examination } \\
\text { and skin; oral cavity }\end{array}$ & $\begin{array}{l}\text { Record body weight and height. } \\
\text { Prepare photographs and histologic sections } \\
\text { of skin lesions. }\end{array}$ & $\begin{array}{l}\text { Growth retardation. } \\
\text { Telangiectases of conjunctivas, face, ears, } \\
\text { neck, and antecubital and popliteal fossae. } \\
\text { Telangiectases of palate. Café au lait spots. }\end{array}$ \\
\hline Thymus & $\begin{array}{l}\text { Record weight and submit samples for } \\
\text { histologic study. }\end{array}$ & $\begin{array}{l}\text { Atrophy of thymus (embryonic appearance } \\
\text { of thymus). }\end{array}$ \\
\hline Blood & Submit sample for immunoglobulin determination. & IgA deficiency. \\
\hline Lungs & $\begin{array}{l}\text { Perfuse one lung with formalin (p. 47). Submit } \\
\text { one lobe for microbiologic study (p. 103). } \\
\text { Submit samples of all lobes for histologic study. }\end{array}$ & $\begin{array}{l}\text { Bronchopulmonary infection, often with } \\
\text { bronchiectasis. Characteristic cells in ataxia- } \\
\text { telangiectasia (generalized nucleomegaly). }\end{array}$ \\
\hline Small bowel & $\begin{array}{l}\text { Record size of Peyer's plaques and prepare } \\
\text { histologic sections. }\end{array}$ & Atrophy of Peyer's plaques. \\
\hline Liver and kidneys & $\begin{array}{l}\text { Record weights and sample for histologic } \\
\text { study. }\end{array}$ & $\begin{array}{l}\text { Characteristic cells in ataxia-telangiectasia } \\
\text { (generalized nucleomegaly). }\end{array}$ \\
\hline Lymph nodes & Submit samples for histologic study. & Atrophy. \\
\hline Ovaries & Record presence or absence. & May be absent (agenesis). \\
\hline Neck organs & $\begin{array}{l}\text { Submit samples of tonsils and lymph nodes } \\
\text { for histologic study. Record sizes. }\end{array}$ & Atrophy of tonsils and cervical lymph nodes. \\
\hline Brain and spinal cord & $\begin{array}{l}\text { For removal and specimen preparation, } \\
\text { see pp. } 66 \text { and } 70 \text {, respectively. }\end{array}$ & $\begin{array}{l}\text { Atrophy of cerebellar cortex with loss of } \\
\text { Purkinje and granular cells; irregular } \\
\text { dendritic expansions and eosinophilic } \\
\text { cytoplasmic inclusions in some of the } \\
\text { remaining Purkinje cells. Degeneration of } \\
\text { posterior columns (fasciculus gracilis more } \\
\text { than fasciculus cuneatus) of spinal cord. }\end{array}$ \\
\hline Peripheral nerves & For removal and specimen preparation, see p. 79. & Abnormal and large cells with bizarre nuclei. \\
\hline
\end{tabular}

\section{Syndrome, Banti’s (See “Hypertension, portal.”)}

Syndrome, Barrett's (See “Esophagus, Barrett's.")

Syndrome, Bartter's (See “Aldosteronism.”)

\section{Syndrome, Bassen-Kornzweig (See “Abetalipoproteinemia.”)}

\section{Syndrome, Beckwith-Wiedemann}

NOTE: This cellular overgrowth syndrome may be sporadic or autosomal dominant. In some patients, a duplication of chromosome $11 \mathrm{p} 15.5$ is present. 


\begin{tabular}{|c|c|c|}
\hline Organs and Tissues & Procedures & Possible or Expected Findings \\
\hline $\begin{array}{l}\text { External examination } \\
\text { and skin }\end{array}$ & $\begin{array}{l}\text { Record body weight, as well as head, abdomen, } \\
\text { and chest circumference, crown-heel length, } \\
\text { crown-rump length. Record and photograph } \\
\text { all anomalies. }\end{array}$ & $\begin{array}{l}\text { Hemihypertrophy; macroglossia; infraorbital } \\
\text { hypoplasia; grooved ear lobules; capillary } \\
\text { nevus flammeus; large fontanels; prominent } \\
\text { occiput; malocclusion of teeth; cliteromegaly; } \\
\text { hypospadias. }\end{array}$ \\
\hline Abdominal organs & $\begin{array}{l}\text { Carefully examine organs and photograph } \\
\text { anomalies. Submit tissue for histologic study. } \\
\text { Submit fascia (p. 109), tissue, such as liver or } \\
\text { lung, or blood (p. 108) for karotype analysis. }\end{array}$ & $\begin{array}{l}\text { Portal-biliary dysgenesis; hepatoblastoma; } \\
\text { islet cell hyperplasia; cytomegaly of adrenal } \\
\text { cortical cells; dysplastic renal medulla; } \\
\text { Wilms tumor. Large ovaries, uterus, kidneys, } \\
\text { and bladder; bicornuate uterus. }\end{array}$ \\
\hline Brain & $\begin{array}{l}\text { For removal and specimen preparation, } \\
\text { see p. } 66 .\end{array}$ & Brain stem gliomas. \\
\hline $\begin{array}{l}\text { Placenta and } \\
\text { umbilical cord }\end{array}$ & $\begin{array}{l}\text { Record weight. Submit sections away from } \\
\text { periphery for histologic study. }\end{array}$ & Large placenta; edematous umbilical cord. \\
\hline
\end{tabular}

\section{Syndrome, Behçet's}

\begin{tabular}{ll}
\hline Organs and Tissues & Procedures \\
\hline $\begin{array}{l}\text { External examination } \\
\text { and skin }\end{array}$ & $\begin{array}{l}\text { Record extent and character of skin and mucosal } \\
\text { lesions. Prepare photographs; prepare sections } \\
\text { of skin. }\end{array}$ \\
& Prepare roentgenograms of joints. \\
$\begin{array}{l}\text { Central and peripheral } \\
\text { and veins }\end{array}$ & For removal of femoral vessels, see p. 34. \\
& \\
$\begin{array}{l}\text { Lungs } \\
\text { Esophagus } \\
\text { Colon, rectum, } \\
\text { and pelvic organs }\end{array}$ & $\begin{array}{l}\text { Remove together with stomach. } \\
\text { Pancreas }\end{array}$ \\
Neck organs & $\begin{array}{l}\text { Sample for histologic study. } \\
\text { Prepare sections of cricoarytenoid joint } \\
\text { (p. 96), particularly if peripheral joints cannot } \\
\text { be studied. }\end{array}$ \\
Brain & For removal and specimen preparation, see p. 65. \\
Base of skull & Expose venous sinuses (p. 71). \\
Eyes & For removal and specimen preparation, see p. 85.
\end{tabular}

Possible or Expected Findings

Ulcers (1) of oral mucosa; ulcers of perianal region and genitalia; erythema nodosum-

like skin lesions; skin ulcers; subungual infarctions.

Monarthritis or polyarthritis (without deformations).

Aortitis and other forms of arteritis;* arterial thromboses and peripheral arterial aneurysms; thrombophlebitis or thrombosis, ${ }^{*}$ primarily of thigh and calf veins.

Pulmonary embolism.*

Ulcers.

Colitis; rectovaginal fistula.

Pancreatitis.*

Ulcer of pharynx; scarring and stenosis of hypopharynx. Laryngeal arthritis.

Encephalitis; ${ }^{*}$ pseudotumor cerebri.* Thrombophlebitis of dural venous sinuses. Corneal ulceration; uveitis with hypopyon; iridocyclitis; thrombosis of central retinal vein. Eye changes may have caused blindness.

Peripheral nerves $\quad$ For sampling and specimen preparation, see p. 79.

Skeletal muscles For sampling and specimen preparation, see p. 80.

Joints For removal and specimen preparation, see p. 96.

For proper sampling, consult roentgenograms and clinical records.

Vasculitis; inflammatory lesions; fibrosis.

Monarthritis-for instance, of a sacroiliac joint—or polyarthritis.

\section{Reference}

1. Criteria for diagnosis of Behçet's Disease. International Study Group for Behçet's Disease. Lancet 1990;335:1078-1080. 
Syndrome, Bloom's

Possible Associated Condition: Acute leukemia* and other malignancies.

\begin{tabular}{|c|c|c|}
\hline Organs and Tissues & Procedures & Possible or Expected Findings \\
\hline $\begin{array}{l}\text { External examination, } \\
\text { oral cavity, and skin }\end{array}$ & $\begin{array}{l}\text { Record facial features and status of teeth; } \\
\text { appearance of hands; body weight and length. } \\
\text { Record and photograph skin abnormalities } \\
\text { and prepare sections. }\end{array}$ & $\begin{array}{l}\text { Small, narrow face with prominent nose and } \\
\text { ears; telangiectases on face, hands, forearms. } \\
\text { Defective dentition; polysyndactyly of } \\
\text { hands. Stunted growth or dwarfism;* } \\
\text { ichthyosis, café au lait spots. }\end{array}$ \\
\hline Blood or fascia lata & $\begin{array}{l}\text { Submit blood for immunoglobulin study. } \\
\text { For sampling for chromosome analysis, } \\
\text { see pp. } 108 \text { and } 109 \text {, respectively. Snap-freeze } \\
\text { tissue for identification of BLM gene (1). }\end{array}$ & $\begin{array}{l}\text { Reduced immunoglobulin concentrations } \\
\text { in blood. } \\
\text { Chromatid breaks and gaps. }\end{array}$ \\
\hline Other organs and tissues & $\begin{array}{l}\text { Procedures depend on expected findings or } \\
\text { grossly identified abnormalities as listed in } \\
\text { right-hand column. }\end{array}$ & Multiple malignancies. \\
\hline
\end{tabular}

\section{Reference}

1. Straughen JE, Johnson J, McLaren D, Proytcheva M, Ellis N, German J, Groden J. A rapid method for detecting the predominant Ashkenazi Jewish mutation in the Bloom's syndrome gene. Hum Mutation 1998;11:175-178.

\section{Syndrome, Bonnevie-Ullrich (See "Syndrome, Turner's.")}

\section{Syndrome, Budd-Chiari}

Synonyms and Related Terms: Acute veno-occlusive disease of the liver; hepatic vein thrombosis; hepatic venous outflow obstruction.

Possible Associated Conditions: Antithrombin III deficiency; oral contraceptive use; paroxysmal nocturnal hemoglobinuria;* polycythemia rubra vera;* pregnancy;* protein C deficiency.

\begin{tabular}{|c|c|c|}
\hline Organs and Tissues & Procedures & Possible or Expected Findings \\
\hline External examination & & $\begin{array}{l}\text { Dilatation of abdominal veins. } \\
\text { Edema of extremities. }\end{array}$ \\
\hline Chest organs & $\begin{array}{l}\text { In most cases, it seems best to remove chest } \\
\text { organs together with abdominal organs } \\
\text { (see below under "Portal and inferior vena } \\
\text { cava system; heart"). }\end{array}$ & $\begin{array}{l}\text { Constrictive pericarditis or right atrial } \\
\text { myxoma may be causes of hepatic venous } \\
\text { outflow obstruction. }\end{array}$ \\
\hline \multirow[t]{3}{*}{$\begin{array}{l}\text { Abdominal and } \\
\text { chest cavities }\end{array}$} & $\begin{array}{l}\text { Measure volume of effusions and submit for } \\
\text { culture (p. 102). }\end{array}$ & Ascites. \\
\hline & $\begin{array}{l}\text { For lymphangiography and dissection of } \\
\text { the thoracic duct, see p. } 34 \text {. }\end{array}$ & $\begin{array}{l}\text { Dilatation of retroperitoneal, hepatic } \\
\text { capsular, and anterior mediastinal lymphatics } \\
\text { and of the thoracic duct. }\end{array}$ \\
\hline & $\begin{array}{l}\text { For hepatic phlebography, see p. } 59 \\
\text { (under "Venography"). }\end{array}$ & $\begin{array}{l}\text { Dilatation (in suprahepatic obstruction) or } \\
\text { intrahepatic obstruction of hepatic veins. }\end{array}$ \\
\hline $\begin{array}{l}\text { Portal and inferior } \\
\text { vena cava system; } \\
\text { heart }\end{array}$ & $\begin{array}{l}\text { After removal of intestines, dissect mesenteric, } \\
\text { splenic, and portal veins in situ. Remove chest } \\
\text { and abdominal organs en masse (p. 3). }\end{array}$ & $\begin{array}{l}\text { Thromboses. Tumor of right atrium. } \\
\text { Compression of intrathoracic inferior vena } \\
\text { cava by constrictive (calcific) pericarditis. }\end{array}$ \\
\hline
\end{tabular}

Hepatic veins Open inferior vena cava and its branches along Identify right, middle, and left hepatic veins. Record type and location of obstruction.

Record appearance of venous ostia of caudate lobe.
Thrombosis, tumor, or webs on or near hepatic ostia. Webs usually obstruct left and middle hepatic veins and the inferior vena cava just cephalad to the patent right hepatic vein.

Veins of caudate lobe are not involved by disease process. 


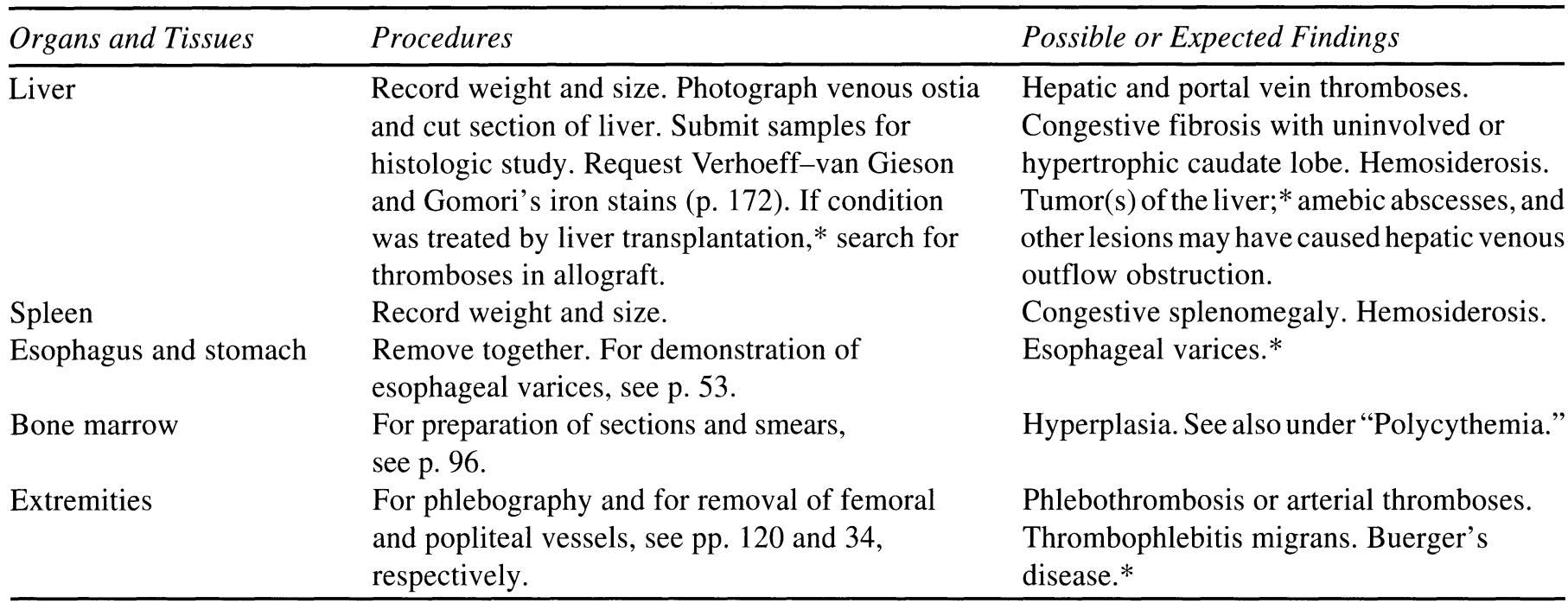

\section{Syndrome, Caplan's}

Synonyms and Related Terms: Complicated pneumoconiosis; ${ }^{*}$ conglomerate silicosis; progressive massive fibrosis of coal workers.

\begin{tabular}{|c|c|c|}
\hline Organs and Tissues & Procedures & Possible or Expected Findings \\
\hline External examination & $\begin{array}{l}\text { Prepare roentgenograms of the chest and } \\
\text { peripheral joints. }\end{array}$ & $\begin{array}{l}\text { Pulmonary nodules, often perihilar. Joint } \\
\text { changes of rheumatoid arthritis.* }\end{array}$ \\
\hline Lungs & $\begin{array}{l}\text { Submit one lobe for microbiologic study } \\
\text { (p. 103). Perfuse one lung with formalin (p. 47). } \\
\text { Photograph slices. Request Verhoeff-van Gieson } \\
\text { stain (p. 173). }\end{array}$ & $\begin{array}{l}\text { Rheumatoid-type pulmonary nodules } \\
(0.5-2.0 \mathrm{~cm}) \text { often with necrotic center. } \\
\text { Multiple small silicotic nodules. }\end{array}$ \\
\hline Joints & $\begin{array}{l}\text { For removal, prosthetic repair, and specimen } \\
\text { preparation, see p. } 96 \text {. }\end{array}$ & Rheumatoid arthritis.* \\
\hline Other organs & & $\begin{array}{l}\text { Systemic manifestations of rheumatoid } \\
\text { arthritis.* }\end{array}$ \\
\hline
\end{tabular}

\section{Syndrome, Carcinoid}

Synonyms and Related Terms: Argentaffinoma syndrome; carcinoid tumor; Cassidy-Scholte syndrome; malignant carcinoid syndrome.

NOTE: Autopsy should be performed as soon as possible, and tumor material should be removed first. Argentaffin cell reaction disappears within 3-6 h after death. If patient had undergone liver transplantation, see also under that heading.

Possible Associated Conditions: Cushing's syndrome;* multiple endocrine neoplasia.*

\begin{tabular}{|c|c|c|}
\hline Organs and Tissues & Procedures & Possible or Expected Findings \\
\hline External examination & $\begin{array}{l}\text { Record extend of skin changes and prepare } \\
\text { histologic sections of skin. }\end{array}$ & $\begin{array}{l}\text { Hyperpigmentation and keratosis of skin } \\
\text { (pellagra dermatosis). }\end{array}$ \\
\hline \multirow[t]{2}{*}{$\begin{array}{l}\text { Heart and inferior } \\
\text { vena cava system }\end{array}$} & $\begin{array}{l}\text { Remove chest and abdominal organs en masse } \\
\text { (p. 3). }\end{array}$ & \\
\hline & $\begin{array}{l}\text { Open inferior vena cava posteriorly and expose } \\
\text { hepatic vein orifices, right atrium of the heart, } \\
\text { and tricuspid valve. Photograph intimal lesions } \\
\text { and submit samples for histologic study. } \\
\text { Request Verhoeff-van Gieson stain (p. 173). } \\
\text { Test competence of tricuspid and pulmonary } \\
\text { valves (p. 29). Open heart in direction of } \\
\text { blood flow (p. 21). }\end{array}$ & $\begin{array}{l}\text { Intimal fibrosis may involve hepatic veins, } \\
\text { upper inferior vena cava, right atrium, } \\
\text { coronary sinus, superior vena cava, tricuspid } \\
\text { valve, right ventricle, pulmonary valve, and, } \\
\text { rarely, the left heart chambers. Appreciable } \\
\text { involvement of the left heart chambers } \\
\text { indicates active pulmonary tumor or right- } \\
\text { to-left shunt. Tricuspid stenosis* and } \\
\text { insufficiency, }{ }^{*} \text { pulmonary stenosis, }{ }^{*} \text { and } \\
\text { mild mitral and aortic fibrosis may occur. }\end{array}$ \\
\hline
\end{tabular}




\begin{tabular}{|c|c|}
\hline Organs and Tissues & Procedures \\
\hline$\overline{\text { Lungs }}$ & $\begin{array}{l}\text { If primary tumor is suspected in lungs, dissect } \\
\text { and snap-freeze fresh tumor tissue for chemical } \\
\text { analysis. For staining, see below under } \\
\text { "Gastrointestinal tract." } \\
\text { Perfuse tumor-free lung with formalin (p. 47). } \\
\text { Request Verhoeff-van Gieson stain (p. 173). }\end{array}$ \\
\hline Peritoneum & Submit samples for histologic study. \\
\hline Urine & Submit sample for chemical analysis. \\
\hline
\end{tabular}

Gastrointestinal tract

\section{Liver}

Bile ducts and gallbladder Pancreas

Lymph nodes

Ovaries

Testes

Bones and joints
Freeze fresh tumor for chemical analysis. For formalin-fixed tissue, request Bodian stain for argyrophil cell reaction and Fontana-Masson stain for argentaffin cell reaction (p. 172). Prepare tumor samples for electron microscopy (p. 132).

Record weight. Photograph cut section and submit samples for histologic study.

Dissect extrahepatic bile ducts in situ.

If tumor is present, submit samples as described above under "Gastrointestinal tract." Submit samples for histologic and chemical study.

If ovaries appear abnormal, record sizes and weights and sample for histologic study.
Possible or Expected Findings

Small cell (oat cell) carcinoma. Bronchial carcinoid.

Intimal fibrosis and fibroelastosis of small pulmonary arteries.

Fibrosis (rare).

Increased concentration of 5-hydroxyindoleacetic acid (5-HIAA). Results are not always reliable.

Endocrine-active carcinoid tumor may occur in all segments except in rectum. Most frequent in ileum; occurs also in Meckel's diverticulum.

High concentratios of 5-hydroxyindoles. Argyrophil cell reaction may persist for $24 \mathrm{~h}$ after death; argentaffin cell reaction disappears within 3-6h. Autofluorescence in ultraviolet light.

Peptic ulcer of stomach.* If malabsorption syndrome* was present, see under that heading.

Massive metastatic involvement in most instances.

May contain active tumor tissue.

Carcinoid tumor. Islet cell tumor.

Massive para-aortic metastases may produce carcinoid syndrome in absence of hepatic metastases.

Primary carcinoid tumors may occur in teratomas. Ovaries also may be site of metastases.

Rarely, primary carcinoid tumors may occur in teratomas.

Osteogenic metastases (rare). Rheumatoid arthritis.*

\section{Syndrome, Chédiak-Higashi}

Synonyms and Related Terms: Chédiak-Higashi anomaly; Béguez-César disease; hereditary neutrophil granule dysfunction syndrome.

Possible Associated Condition: Lymphoma*

\begin{tabular}{ll}
\hline Organs and Tissues & Procedures \\
\hline External examination & Record extent of hypopigmented areas and of \\
and skin & hemorrhagic and infected skin. Photograph and \\
& take sections of abnormal and of pigmented skin. \\
& Request Fontana-Masson silver stain (p. 172).
\end{tabular}

Blood
For removal, prosthetic repair, and specimen preparation, see pp. 65 and 67 , respectively.

\section{Possible or Expected Findings}

Decreased pigmentation of skin and hair (albinism). Pyoderma gangrenosum. Staphylococcal skin infection. Skin hemorrhages. Enlarged melanin granules in melanocytes of pigmented areas.

Bacteremia; septicemia. Hypogammaglobulinemia. Large azurophilic peroxidase-positive granules (giant lysosomes) in neutrophils. Granules in lymphocytes are peroxidasenegative and periodic acid-Schiff-positive. 


\begin{tabular}{|c|c|c|}
\hline Organs and Tissues & Procedures & Possible or Expected Findings \\
\hline Lungs & Submit one lobe for bacterial culture (p. 103). & Bacterial pneumonia. \\
\hline Liver and spleen & $\begin{array}{l}\text { Record sizes and weights. Submit samples for } \\
\text { histologic study. }\end{array}$ & $\begin{array}{l}\text { Hepatosplenomegaly. Lymphohistiocytic } \\
\text { infiltrates. }\end{array}$ \\
\hline Lymph nodes & $\begin{array}{l}\text { Request Wright stain for touch preparations. } \\
\text { Use Zenker's or Helly's fixative for paraffin } \\
\text { sections. }\end{array}$ & Lymphohistiocytic infiltrates. \\
\hline Kidneys & Snap-freeze tissue for histochemical study. & $\begin{array}{l}\text { Glycolipid inclusions in tubular epithelial } \\
\text { cells. }\end{array}$ \\
\hline Other organs & $\begin{array}{l}\text { Procedures depend on expected findings or } \\
\text { grossly identified abnormalities as listed in } \\
\text { right-hand column. }\end{array}$ & $\begin{array}{l}\text { Infections, particularly of upper respiratory } \\
\text { tract, and hemorrhages caused by thrombo- } \\
\text { cytopenia and coagulation factor deficiencies. }\end{array}$ \\
\hline Bone marrow & $\begin{array}{l}\text { For preparation of sections and smears, see } \\
\text { p. } 96 \text {. Snap-freeze material for histochemical } \\
\text { study. Prepare sample for electron microscopy. }\end{array}$ & $\begin{array}{l}\text { Large azurophilic granules in promyelocytes. } \\
\text { Granules positive for acid phosphatase and } \\
\text { myeloperoxidase. Lymphocytic infiltrates in } \\
\text { accelerated phase of disease. Megaloblastic } \\
\text { changes. }\end{array}$ \\
\hline Brain and spinal cord & $\begin{array}{l}\text { For removal and specimen preparation, see } \\
\text { pp. } 66 \text { and } 70 \text {, respectively. Snap-freeze } \\
\text { material for histochemical study. Prepare } \\
\text { sample for electron microscopy. }\end{array}$ & $\begin{array}{l}\text { Lymphohistiocytic infiltrates. Glycolipid } \\
\text { inclusions in neurons and histiocytes. } \\
\text { Giant lysosomes. }\end{array}$ \\
\hline Peripheral nerves & $\begin{array}{l}\text { For sampling and specimen preparation, see } \\
\text { p. } 79 . \text { Prepare sample for electron microscopic } \\
\text { study. }\end{array}$ & $\begin{array}{l}\text { Lymphohistiocytic infiltrates. Degeneration } \\
\text { of nerve tissue. Giant lysosomes. }\end{array}$ \\
\hline Eyes & $\begin{array}{l}\text { For removal and specimen preparation, } \\
\text { see p. } 85 \text {. }\end{array}$ & $\begin{array}{l}\text { Decreased pigmentation (oculocutaneous } \\
\text { albinism) of uvea and particularly of retina. }\end{array}$ \\
\hline
\end{tabular}

\section{Syndrome, Churg-Strauss (See “Granulomatosis, allergic, and angiitis (Churg-Strauss syndrome).”)}

\section{Syndrome, Congenital Rubella}

Synonym and Related Term: Congenital rubella; rubella.*

NOTE: See also "Rubella." (1) Collect all tissues that appear to be infected. (2) Request viral cultures. (3) Usually, special stains are not helpful. (4) No special precautions are indicated. (5) Serologic studies are available from local or state health department laboratories (p. 135). (6) This is a reportable disease.

\begin{tabular}{ll}
\hline Organs and Tissues & Procedures \\
\hline External examination & Record body weight and length. Record and \\
and umbilical cord; & photograph abnormalities as listed in right- \\
oral cavity & hand column.
\end{tabular}

\section{Cardiovascular system}

Lungs

Liver

\section{Spleen}

Blood
Record appearance of external genitalia. Procedures depend on expected findings or grossly identified abnormalities as listed in right-hand column.

Perfuse one lobe with formalin (p. 47). Record weight. Submit samples for histologic study. For cholangiography, see p. 56.

Record weight and sample for histologic study.

Submit sample for determination of IgM and IgG antibodies.

\section{Possible or Expected Findings}

Intrauterine growth retardation; failure to thrive; purpura; jaundice; hypoplastic mandible; microcephaly; enamel hypoplasia; caries; delayed eruption of deciduous teeth; skin dimples; abnormal dermatoglyphics; skin pigmentation.

Hypospadias; cryptorchidism. Congenital heart disease; myocarditis;* pulmonary artery branch stenosis; systemic arterial hypoplasia and stenosis due to intimal proliferation.

Interstitial pneumonia.*

Giant cell hepatitis; cholestasis; fibrosis; cirrhosis;* necrosis; extramedullary hematopoiesis; bile duct proliferation mimicking biliary atresia. Splenomegaly with extramedullary hematopoiesis. 


\begin{tabular}{|c|c|c|}
\hline Organs and Tissues & Procedures & Possible or Expected Findings \\
\hline Lymph nodes & Submit samples for histologic study. & $\begin{array}{l}\text { Lymphadenopathy with enlarged germinal } \\
\text { centers or lymphoid depletion. }\end{array}$ \\
\hline Kidneys & Submit samples for histologic study. & $\begin{array}{l}\text { Extramedullary hematopoiesis; } \\
\text { glomerulonephritis. }\end{array}$ \\
\hline Pancreas & Submit samples for histologic study. & Lymphocytic infiltration of islets. \\
\hline Brain and spinal cord & $\begin{array}{l}\text { For removal and specimen preparation, } \\
\text { see pp. } 66 \text { and } 70 \text {, respectively. }\end{array}$ & $\begin{array}{l}\text { Microcephaly; meningoencephalitis;* } \\
\text { ischemic necrosis; later in life, progressive } \\
\text { panencephalitis; perivascular mononuclear } \\
\text { infiltrates; glial nodules in white matter. }\end{array}$ \\
\hline Ears & $\begin{array}{l}\text { For removal and specimen preparation, } \\
\text { see p. } 72 .\end{array}$ & $\begin{array}{l}\text { Otitis media;* inflammation and scarring of } \\
\text { cochlea. }\end{array}$ \\
\hline Eyes & $\begin{array}{l}\text { For removal and specimen preparation, } \\
\text { see p. } 85 \text {. }\end{array}$ & $\begin{array}{l}\text { Microphthalmia; iridocyclitis; cataracts; } \\
\text { chorioretinitis. }\end{array}$ \\
\hline Skeletal muscles & For specimen preparation, see p. 80 . & Myositis. \\
\hline Bones & $\begin{array}{l}\text { For removal and specimen preparation, } \\
\text { see p. } 95 \text {. }\end{array}$ & $\begin{array}{l}\text { Metaphyseal osteoporosis;* retardation of } \\
\text { ossification. }\end{array}$ \\
\hline Placenta & Record weight and sample for histologic study. & $\begin{array}{l}\text { Villus vessel necrosis; villus edema; necrosis } \\
\text { of syncytiotrophoblast with fibrin accretion; } \\
\text { plasma cell deciduitis. With infection late in } \\
\text { gestation, villus sclerosis and small placenta. }\end{array}$ \\
\hline
\end{tabular}

\section{Syndrome, Conn's (See “Aldosteronism.”)}

\section{Syndrome, Cronkhite-Canada (See “Polyposis, familial, and related syndromes.")}

\section{Syndrome, Cushing's}

Related Terms: Cushing's disease (associated with ACTH-producing pituitary tumor); hypercorticism.

NOTE: Glucocorticoid therapy is the most common cause of Cushing's syndrome and thus, the autopsy also may show the features of the condition that had been treated-for example, an allograft with signs of rejection.

\begin{tabular}{ll}
\hline Organs and Tissues & Procedures \\
\hline External examination & Record body weight and length, abdominal \\
and skin & circumference, skeletal muscle development, \\
& and hair distribution. Prepare sections of skin \\
& and smears of infectious skin lesions. \\
& Request Gram and Grocott's methenamine \\
& silver stains (p. 172). \\
& Prepare skeletal roentgenograms. \\
& Submit sample for biochemical study.
\end{tabular}

Heart

Lungs

Pancreas

Adrenal glands
Record weight.

Snap-freeze tumor tissue for determination of ACTH-like substances.

See above under "Lungs."

Record weight, size, and thickness of cortex of both adrenal glands. Snap-freeze tumor tissue for biochemical study. See also under "Tumor of the adrenal glands." Submit samples of both glands for histologic study.
Possible or Expected Findings

"Moon face"; obesity of trunk; edema and striae of abdomen, hips, and shoulders. Muscle wasting. Virilism in women (acne and hirsutism) and children. Ecchymoses. Skin infections.

Osteoporosis.*

Increased concentrations of cortisol or adrenocorticotropic hormone (ACTH)-like substances. (This is not reliable because of diurnal variability.)

Hypertrophy secondary to hypertension.* Bronchogenic carcinoma (oat cell type) or malignant bronchial carcinoid, producing ACTH-like substances.

Malignant islet cell tumor, producing ACTHlike substances.

Adrenal nodular hyperplasia; adrenal cortical adenoma or carcinoma. Pheochromocytoma, producing ACTH-like substances.

Adrenocortical hypertrophy secondary to ACTH stimulation. Atrophy of adrenal cortex after steroid therapy or secondary to effects of adrenocortical tumor. 


\begin{tabular}{|c|c|c|}
\hline Organs and Tissues & Procedures & Possible or Expected Findings \\
\hline Kidneys & & Nephrolithiasis.* \\
\hline Ovaries & $\begin{array}{l}\text { Record sizes and weights. If tumor is present, } \\
\text { snap-freeze sample for determination of ACTH- } \\
\text { like substances. Submit samples for histologic } \\
\text { study. }\end{array}$ & $\begin{array}{l}\text { Ovarian tumor, producing ACTH-like } \\
\text { substances. }\end{array}$ \\
\hline Thyroid gland & See above under "Ovaries." & $\begin{array}{l}\text { Carcinoma of thyroid gland, producing } \\
\text { ACTH-like substances. }\end{array}$ \\
\hline Other organs & $\begin{array}{l}\text { See above under "Lungs," "Pancreas," } \\
\text { "Ovaries," and "Thyroid gland." }\end{array}$ & $\begin{array}{l}\text { ACTH-like substances may be produced by } \\
\text { tumors at various sites. }\end{array}$ \\
\hline Pituitary gland & $\begin{array}{l}\text { For removal and specimen preparation, } \\
\text { see p. } 71 \text {. Submit samples for histologic study. } \\
\text { Snap-freeze tumor tissue for biochemical study. } \\
\text { See also under "Tumor of the pituitary gland." }\end{array}$ & $\begin{array}{l}\text { A normal pituitary gland is compatible with } \\
\text { increased secretion of ACTH and with } \\
\text { Cushing's disease. Pituitary micro- or } \\
\text { macroadenoma (Cushing's disease), } \\
\text { basophilic or chromophobic type. Crooke's } \\
\text { hyaline degeneration in adenohypophysis } \\
\text { indicates that excessive amounts of } \\
\text { glucocorticoids had been present. }\end{array}$ \\
\hline Bones & $\begin{array}{l}\text { For removal and specimen preparation, } \\
\text { see p. } 95 \text {. }\end{array}$ & Osteoporosis.* \\
\hline Skeletal muscles & $\begin{array}{l}\text { For sampling and specimen preparation, } \\
\text { see p. } 80 \text {. }\end{array}$ & Steroid myopathy and atrophy. \\
\hline Vitreous & $\begin{array}{l}\text { Submit sample for glucose, sodium, and } \\
\text { chloride determination (p. 114). }\end{array}$ & $\begin{array}{l}\text { Hyperglycemia or electrolyte abnormalities } \\
\text { may be present. }\end{array}$ \\
\hline
\end{tabular}

\section{Syndrome, DiGeorge's}

Synonyms and Related Terms: Harrington syndrome; 3rd and 4th pharyngeal pouch syndrome; thymic agenesis.

NOTE: See also "Syndrome, primary immunodeficiency."

\begin{tabular}{lll}
\hline Organs and Tissues & Procedures & Possible or Expected Findings \\
\hline External examination & $\begin{array}{l}\text { Record body weight and length. Record and } \\
\text { photograph abnormalities as listed in right- } \\
\text { hand column. }\end{array}$ & $\begin{array}{l}\text { Growth retardation. Hypertelorism; anti- } \\
\text { mongoloid slant of eyes; short philtrum; } \\
\text { small and low set ears; notched pinnae; } \\
\text { micrognathia. Eczema (1). }\end{array}$ \\
Heart & $\begin{array}{l}\text { See under specific lesion as listed in right- } \\
\text { hand column. }\end{array}$ & $\begin{array}{l}\text { Conotruncal and aortic arch anomalies. } \\
\text { If any consolidated areas are identified, } \\
\text { submit for culture (p. 103). }\end{array}$ \\
Oungs & $\begin{array}{l}\text { Record and photograph abnormalities and sub- } \\
\text { mit possible infectious lesions for culture (p. 102). } \\
\text { Carefully search for thymus, parathyroid } \\
\text { glands, and isthmus of thyroid. }\end{array}$ & $\begin{array}{l}\text { Infections at various sites. } \\
\text { Neck organseng of thymus and parathyroid glands } \\
\text { (3rd and 4th pharyngeal pouch derivatives) } \\
\text { (2). Absence of thyroid gland (rare) or of } \\
\text { isthmus of thyroid. }\end{array}$ \\
\hline
\end{tabular}

\section{References}

1. Archer E, Chuang TY, Hong R. Severe eczema in a patient with DiGeorge's syndrome. Cutis 1990;45:455-459.

2. Robinson HB Jr. DiGeorge's syndrome or the III - IV pharyngeal pouch syndrome: pathology and a theory of pathogenesis. Perspect Pediatr Pathol $1975 ; 3: 773-206$

\section{Syndrome, Down's}

Synonyms and Related Terms: Mongolism; trisomy 21; trisomy G syndrome.

Possible Associated Conditions: Acute lymphocytic, myelocytic or megakaryocytic leukemia;* atresia of esophagus;* atresia or stenosis of duodenum;* congenital heart disease (especially ventricular septal defects and atrioventricular canal defects*). 


\begin{tabular}{ll}
\hline Organs and Tissues & Procedures \\
\hline $\begin{array}{c}\text { External examination } \\
\text { and oral cavity }\end{array}$ & $\begin{array}{l}\text { Record and photograph abnormalities as listed } \\
\text { in right-hand column. }\end{array}$
\end{tabular}

Heart

Gastrointestinal tract

Brain and spinal cord

Bone marrow
Prepare radiographs of pelvis.

Submit samples for chromosome study (p. 108).

Procedures depend on grossly identified abnormalities as listed in right-hand column. Open stomach and duodenum in situ; if indicated, probe anus.

For removal and specimen preparation, see p. 66 and 70, respectively.

\section{Possible or Expected Findings}

Epicanthal folds; cleft lip/palate; high arched palate; furrowed tongue; rhagades.

Depressed nasal bridge; dysplastic ears; small, broad or flat nose; slanted palpebral fissures; flat occiput; brachycephaly; palmar "simian crease"; short fifth middle finger; short limbs; abnormal dermatoglyphics;

Horizontal acetabular roof.

Complete trisomy 21 or trisomy $12 q$ due to a translocation.

Ventricular septal defect; $*$ complete atrioventricular septal defect* (1).

Duodenal stenosis and atresia; imperforate anus.

Microcephaly; poorly developed secondary gyri; open operculum; hypoplastic superior temporal gyrus (2); short corpus callosum; hypoplastic brain stem, medulla and cerebellum; polymicrogyria; neurofibrillary tangles; meningomyelocoele.

Acute lymphocytic leukemia; acute myelocytic leukemia; acute megakaryocytic leukemia.

see p. 96.

\section{References}

1. Spicer RL. Cardiovascular disease in Down syndrome. Pediatr Clin North Am 1984;31(6):1331-1344.

2. Jay V. Brain and eye pathology in an infant with Down syndrome and tuberous sclerosis. Pediatr Neurol 1996;15:57-59.

\section{Syndrome, Dystonia}

Synonyms or Related Terms: Dopa-responsive dystonia (Segawa's syndrome); inherited or sporadic primary (or idiopathic) dystonia; primary torsion dystonia (dystonia musculorum deformans); secondary (or symptomatic) dystonia.

NOTE: Primary dystonia includes primary torsion dystonia (autosomal-dominant), an X-linked form, and Dopa responsive dystonia. The condition may be focal, multifocal, segmental, generalized, or appear as hemidystonia.

\begin{tabular}{cll}
\hline Organs and Tissues & Procedures & Possible or Expected Findings \\
\hline Brain, spinal cord, & For removal and specimen preparation, & No diagnostic pathologic changes in primary \\
and spinal ganglia & see pp. 65, 67, and 69, respectively. & torsion dystonia. In hemidystonia, changes \\
& Autopsy in cases of primary torsion dystonia & in the basal ganglia may be found, such as \\
& should be considered a research procedure; & infarcts, tumors, or effects of trauma or toxic \\
& extensive collection of tissue is indicated, & damage. These last findings may have \\
& including frozen samples. & medicolegal implications. \\
\hline
\end{tabular}

\section{Syndrome, Eaton-Lambert (See “Myasthenia gravis.”)}

\section{Syndrome, Ehlers-Danlos}

NOTE: Nine subtypes have been distinguished, based primarily on the extent of the disease. However much overlap exists.

\begin{tabular}{ll}
\hline Organs and Tissues & Procedures \\
\hline $\begin{array}{c}\text { External examination, } \\
\text { skin, and oral cavity }\end{array}$ & $\begin{array}{l}\text { Record body weight, length, stature; record and } \\
\text { photograph all abnormal features, as listed in } \\
\text { right-hand column. }\end{array}$
\end{tabular}

Possible or Expected Findings

Widely spaced eyes; epicanthal folds; broad nasal bridge; lop ears. Flatfeet or clubfeet; genu recurvatum; arachnodactyly; pigeon breast; kyphoscoliosis. Umbilical and inguinal hernias. Subcutaneous emphysema (see below under "Chest cavity"). Poorly formed teeth. High arched palate. 


\begin{tabular}{ll}
\hline Organs and Tissues & Procedures \\
\hline External examination, & Prepare sections of skin and request \\
skin, and oral cavity & Verhoeff-van Gieson stain (p. 173). Submit \\
(continued) & samples of skin for electron microscopic study \\
& (p. 132).
\end{tabular}

Prepare skeletal roentgenograms.

\section{Chest cavity \\ Heart and great vessels}

Lungs

Other organs and tissues

Joints
Record appearance of pleural surfaces in situ.

Procedures depend on grossly identified abnormalities as listed in right-hand column.

Perfuse on lung with formalin (p. 47). Procedures depend on expected findings or grossly identified abnormalities as listed in right-hand column.

Record size and location of hematomas. Prepare tissue samples with small vessels for electron microscopic study (p. 132). For removal, prosthetic repair, and specimen preparation, see p. 96.
Possible or Expected Findings

Hyperelasticity of skin, bruises or scars, hemorrhages, and hyperpigmentation. Lipomatous pseudotumors that may be calcified or ossified. Normal or abnormal amounts and fragmentation of elastic tissue. Abnormalities of collagen.

Dislocation of hip, shoulder, patella, radius, or clavicle. Loose-end clavicles; spondylolisthesis; osteolytic changes in distal phalanges. Degenerative arthritis.

Rupture of lung with mediastinal and subcutaneous emphysema (see above). Congenital malformations of the heart. Mitral valve prolapse; aneurysm of aortic sinus.* Aortic insufficiency.* Dissecting hematoma of aorta. ${ }^{*}$ Spontaneous rupture of arteries.

Various congenital anomalies.

Congenital anomalies of gastrointestinal and genitourinary tracts.

Bleeding from various organ sites.

Arthritis; ${ }^{*}$ hemarthrosis. Effusions. Hyperextensibility of joints.

\section{Syndrome, Ellis-Van Creveld}

Synonyms and Related Terms: Chondrodysplasia;* chondroectodermal dysplasia; short-rib polydactyly chondrodysplasia.

NOTE: This syndrome belongs to a large family (with more than 30 subtypes) of chondrodysplasias. The suggested autopsy procedures are essentially the same in all chondrodysplasias.See also under "Chondrodysplasia."

\begin{tabular}{ll}
\hline Organs and Tissues & Procedures \\
\hline External examination & $\begin{array}{l}\text { Record and photograph abnormal features } \\
\text { as listed in right-hand column. }\end{array}$
\end{tabular}

Record appearance of external genitalia. Prepare skeletal roentgenograms.

Heart

Bones
For removal, prosthetic repair, and specimen preparation, see p. 95.

\section{Possible or Expected Findings}

Short-limb dwarfism* with narrowing of the rib cage; polydactyly; dysplasia of fingernails; thin and sparse hair; premature eruption of teeth; defective dentition; eye abnormalities; upper lip bound down by multiple frenula.

Cryptorchidism; epispadias; hypospadias. Chondrodysplasia with acromelic micromelia (shortening of the distal segment of the limb); fusion of capitate and hamate bones of wrist; defects of lateral aspect of proximal tibia.

Congenital heart disease (atrial septal defect*).

See lesions listed above under "External examination."

\section{Syndrome, Empty Sella}

Synonyms and Related Terms: Primary empty sella syndrome; secondary empty sella syndrome (e.g., after surgical removal or spontaneous infarction of pituitary adenoma). 


\begin{tabular}{lll}
\hline Organs and Tissues & Procedures & Possible or Expected Findings \\
\hline External examination & Record body weight and length. & $\begin{array}{l}\text { Empty sella syndrome relatively common in } \\
\text { obese females. } \\
\text { Enlargement of pituitary fossa visible on } \\
\text { lateral roentgenograms of the skull. }\end{array}$ \\
$\begin{array}{l}\text { Base of skull } \\
\text { and pituitary gland }\end{array}$ & $\begin{array}{l}\text { For exposure and specimen preparation, } \\
\text { see p. 71. Photograph sella. }\end{array}$ & $\begin{array}{l}\text { Flattening and postero-inferior displacement } \\
\text { of the gland. Necrosis of pituitary gland } \\
\text { (Sheehan's syndrome*) or of pituitary } \\
\text { adenoma. }\end{array}$ \\
Other organs & & $\begin{array}{l}\text { Manifestations of pituitary insufficiency* } \\
\text { (mostly in association with secondary empty } \\
\text { sella syndrome). }\end{array}$ \\
\hline
\end{tabular}

Syndrome, Eosinophilic (Unspecified) (See “Cardiomyopathy, restrictive [eosinophilic type]," “Gastroenteritis, eosinophilic," and "Syndrome, eosinophilic pulmonary.")

\section{Syndrome, Eosinophilic Pulmonary}

Synonyms and Related Terms: Acute eosinophilic pneumonia with respiratory failure (1); allergic bronchopulmonary aspergillosis; Carrington's chronic eosinophilic pneumonia; Churg-Strauss syndrome; eosinophilic pneumonia; hypereosinophilic syndrome; idiopathic acute eosinophilic pneumonia; Löffler's syndrome; pulmonary infiltration with eosinophilia (PIE syndrome); tropical pulmonary eosinophilia.

\begin{tabular}{|c|c|c|}
\hline Organs and Tissues & Procedures & Possible or Expected Findings \\
\hline External examination & Prepare chest roentgenogram. & Pulmonary infiltrates. \\
\hline Lungs & $\begin{array}{l}\text { Submit one lobe for culture (p. 103). Freeze } \\
\text { portion of same lung for special studies. } \\
\text { Prepare smears. Perfuse one lung with } \\
\text { formalin (p. 47). Request Giemsa or azure- } \\
\text { eosin stain for demonstration of eosinophilic } \\
\text { leukocytes (p. 172). }\end{array}$ & $\begin{array}{l}\text { Ascariasis and hookworm (pulmonary larval } \\
\text { migration) infestation ( } 2 \text { ); other parasitic } \\
\text { diseases or fungal infections. Bronchiolitis } \\
\text { obliterans; eosinophilic microabscesses ( } 3 \text { ). }\end{array}$ \\
\hline Other organs & $\begin{array}{l}\text { Procedures depend on expected findings or } \\
\text { grossly identified abnormalities as listed in } \\
\text { right-hand column. }\end{array}$ & $\begin{array}{l}\text { Systemic manifestations of eosinophilia; } \\
\text { parasitic or other infectious or allergic } \\
\text { disease. }\end{array}$ \\
\hline
\end{tabular}

\section{References}

1. Tazelaar H, Linz LJ, Colby TV, Myers JL, Limper AH. Acute eosinophilic pneumonia: Histopathologic features in nine cases. Am Rev Resp Crit Care Med 1997;155:296-302.

2. Sarinas PS, Chitkara RK. Ascariasis and hookworm. Semin Resp Inf 1997;12:130-137.

3. Jederlinic PJ, Sicilian L, Gaensler EA. Chronic eosinophilic pneumonia. A report of 19 cases and a review of the literature. Medicine 1988;67: $154-162$.

\section{Syndrome, Extrapyramidal (See “Chorea, acute," “Chorea, hereditary,” and "Disease, Parkinson's.”)}

\section{Syndrome, Fanconi}

Related Terms: Aminoaciduria;* cystinosis;* familial hypophosphatemic vitamin D-resistant rickets; galactosemia;* proximal tubular transport defect; tyrosinemia. * Excludes Fanconi's anemia (sometimes also called Fanconi's syndrome) due to a defect in DNA repair.

\begin{tabular}{lll}
\hline Organs and Tissues & Procedures & Possible or Expected Findings \\
\hline External examination & Record body weight and external measurements; & Red/blond hair, fair skin (diminished \\
& record and photograph abnormalities as & pigmentation); dehydration;* stigmata of \\
& listed in right-hand column. & hypothyroidism;*delay of sexual maturation. \\
& Prepare skeletal roentgenograms. & Rickets; osteomalacia.* \\
& Radiographs of long bones. &
\end{tabular}

Fascia lata Submit for tissue culture for possible enzyme analysis (p. 109). 


\begin{tabular}{|c|c|c|}
\hline Organs and Tissues & Procedures & Possible or Expected Findings \\
\hline Blood & $\begin{array}{l}\text { Obtain sample for possible assay of heavy } \\
\text { metals. Obtain sample for protein electro- } \\
\text { phoresis and parathyroid hormone assay. }\end{array}$ & $\begin{array}{l}\text { Lead,* mercury, }{ }^{*} \text { cadmium, }{ }^{*} \text { uranium } \\
\text { poisoning; myeloma;* parathyroid } \\
\text { hyperplasia (primary or secondary). }\end{array}$ \\
\hline Kidney & Photograph lesions. Submit for histologic study. & $\begin{array}{l}\text { Cysts; nephrocalcinosis; pyelonephritis;* } \\
\text { nephrolithiasis.* }\end{array}$ \\
\hline Urine & Obtain sample for biochemical analysis. & Glucosuria; phosphaturia; aminoaciduria. \\
\hline
\end{tabular}

\section{Syndrome, Felty's}

Related Terms: Pseudo-Felty syndrome (1); rheumatoid arthritis.*

\begin{tabular}{|c|c|c|}
\hline Organs and Tissues & Procedures & Possible or Expected Findings \\
\hline $\begin{array}{l}\text { External examination, } \\
\text { skin, and oral cavity }\end{array}$ & $\begin{array}{l}\text { Record body weight and length. } \\
\text { Record extent and character of skin infections } \\
\text { and ulcers, appearance of eyes and oral cavity, } \\
\text { and character of pigmentation. Sample skin } \\
\text { lesions for histologic study. }\end{array}$ & $\begin{array}{l}\text { Cachexia. } \\
\text { Infections involving skin, oral cavity, and } \\
\text { eyes (corneas). Chronic leg ulcers. Brown } \\
\text { pigmentation over exposed areas of } \\
\text { extremities. }\end{array}$ \\
\hline $\begin{array}{l}\text { Subcutaneous tissues } \\
\text { and lymph nodes }\end{array}$ & $\begin{array}{l}\text { Submit samples of axillary, cervical, and other } \\
\text { enlarged lymph nodes and all subcutaneous } \\
\text { nodules for histologic study. }\end{array}$ & Lymphadenopathy. Rheumatoid nodules. \\
\hline Blood & Submit sample for serologic study. & Positive rheumatoid factor. \\
\hline Lungs & $\begin{array}{l}\text { Submit one lobe for bacterial and fungal } \\
\text { cultures (p. 103). Perfuse one lung with } \\
\text { formalin (p. 47). }\end{array}$ & $\begin{array}{l}\text { Various types of pneumonia. } \\
\text { Bronchiectasis.* }\end{array}$ \\
\hline Liver & Record weight and sample for histologic study. & $\begin{array}{l}\text { Nodular regenerative hyperplasia (2); } \\
\text { sinusoidal lymphocytosis (3). }\end{array}$ \\
\hline Spleen & $\begin{array}{l}\text { Record size and weight. If splenectomy had } \\
\text { been done, record presence or absence of } \\
\text { accessory spleens. }\end{array}$ & $\begin{array}{l}\text { Splenomegaly (4). After splenectomy, } \\
\text { presence of accessory spleen may account } \\
\text { for treatment failure. }\end{array}$ \\
\hline Other organs & & Manifestations of portal hypertension.* \\
\hline $\begin{array}{l}\text { Mediastinal and } \\
\text { retroperitoneal } \\
\text { lymph nodes }\end{array}$ & Submit samples for histologic study. & $\begin{array}{l}\text { Lymphadenopathy of mediastinal and para- } \\
\text { aortic lymph nodes. }\end{array}$ \\
\hline \multirow[t]{2}{*}{$\begin{array}{l}\text { Bone marrow, bones, } \\
\text { and joints }\end{array}$} & $\begin{array}{l}\text { For preparation of bone marrow sections and } \\
\text { smears, see p. } 96 .\end{array}$ & Anemia;* neutropenia; thrombocytopenia. \\
\hline & $\begin{array}{l}\text { For removal, prosthetic repair, and specimen } \\
\text { preparation of bones and joints, see p. } 95 \text {. }\end{array}$ & Rheumatoid arthritis.* \\
\hline
\end{tabular}

\section{References}

1. Rosenstein ED, Kramer N. Felty's and pseudo-Felty's syndrome. Semin Arthritis Rheum 1991;21:129-142.

2. Perez-Ruiz F, Orte Martinez FJ, Zea Mendoza AC, Ruiz del Arbol L, Moreno Caparros A. Nodular regenerative hyperplasia of the liver in rheumatic diseases: report of seven cases and review of the literature. Semin Arthritis Rheum 1991;21:47-54.

3. Cohen ML, Manier JW, Bredfeldt JE. Sinusoidal lymphocytosis of the liver in Felty's syndrome with a review of the liver involvement in Felty's syndrome. J Clin Gastroenterol 1989;11:92-94.

4. Fishman D, Isenberg DA. Splenic involvement in rheumatic diseases. Semin Arthritis Rheum 1997;27:141-155.

\section{Syndrome, Fetal Alcoholic}

\begin{tabular}{lll}
\hline Organs and Tissues & Procedures & Possible or Expected Findings \\
\hline $\begin{array}{l}\text { External examination } \\
\text { and oral cavity }\end{array}$ & $\begin{array}{l}\text { Record body weight and length, and head } \\
\text { circumference. Record and photograph all } \\
\text { abnormalities as listed in right-hand column. }\end{array}$ & $\begin{array}{l}\text { Growth retardation; microcephaly; depressed } \\
\text { nasal bridge; thin upper lip; smooth philtrum; } \\
\text { epicanthal folds; small palpebral fissures; } \\
\end{array}$ \\
& $\begin{array}{l}\text { strabismus; midfacial hypoplasia; cleft } \\
\text { palate; pectus excavatum; small nails; } \\
\text { abnormal palmar creases; hirsutism; }\end{array}$ \\
& contractures; spina bifida; pigmented nevi.
\end{tabular}




\begin{tabular}{lll}
\hline Organs and Tissues & Procedures & Possible or Expected Findings \\
\hline $\begin{array}{l}\text { Diaphragm } \\
\text { Liver }\end{array}$ & Record location, character, and size of defects. & Anomalies of diaphragm. \\
Heart & Record weight and sample for histologic study. & Steatosis; fibrosis. \\
Brain & For removal, see p. 66. & Ventricular and atrial septal defects.* \\
& & $\begin{array}{l}\text { Hydrocephalus; micrencephaly; small frontal } \\
\text { lobes; irregular convolutions or microgyria; } \\
\text { small third ventricle; arhinencephaly; } \\
\end{array}$ \\
& & $\begin{array}{l}\text { abnormal lamination of cortical cells; } \\
\text { malorientaton of neurons; cerebellar } \\
\text { heterotopias (1). }\end{array}$ \\
& For removal and specimen preparation, & Hypoplasia of optic nerve head; increased \\
Eyes & toe p. 85. &
\end{tabular}

\section{Reference}

1. Johnson VP, Swayze VW II, Sato Y, Andreasen NC. Fetal alcohol syndrome: craniofacial and central nervous system manifestations. Am J Med Genet 1996;61(4):329-339.

\section{Syndrome, Fibrosing}

Synonyms and Related Terms: Dupuytren's contracture; mediastinal fibrosis; multifocal fibrosclerosis; periureteral fibrosis; Peyronie's disease; pseudotumor of the orbit; retroperitoneal fibrosis, ${ }^{*}$ Riedel's thyroiditis; sclerosing cholangitis; ${ }^{*}$ sclerosing mediastinitis.*

NOTE: In rare instances, the conditions listed under "Synonyms and Related Terms" appear to occur together or overlap. Autopsy procedures in the most important conditions are listed under the specific title (see names with *). In all cases, other possible sites of fibrosis should be carefully studied.

\begin{tabular}{lll}
\hline Organs and Tissues & Procedures & Possible or Expected Findings \\
\hline Mediastinum & $\begin{array}{l}\text { If there is evidence of fibrosis, submit tissues } \\
\text { for culture of Histoplasma capsulatum. Prepare } \\
\text { horizontal sections through fixed tissues. }\end{array}$ & $\begin{array}{l}\text { Superior vena cava obstruction. Sclerosing } \\
\text { mediastinitis.* Histoplasmosis.* }\end{array}$ \\
$\begin{array}{l}\text { Biliary system } \\
\text { Retroperitoneum }\end{array}$ & $\begin{array}{l}\text { Sclerosing cholangitis.* } \\
\text { Retroperitoneal fibrosis.* Periureteral } \\
\text { fibrosis. }\end{array}$ \\
Other organs and tissues & $\begin{array}{l}\text { Procedures depend on expected findings } \\
\text { or grossly identified abnormalities as listed } \\
\text { in right-hand column. Use cultures and } \\
\text { special stains to rule out underlying infection } \\
\text { or tumor. }\end{array}$ & $\begin{array}{l}\text { disease; and possibly other fibrosing } \\
\text { conditions. }\end{array}$ \\
\hline
\end{tabular}

Syndrome, Foix-Alajouanine (See "Malformation, arteriovenous, cerebral or spinal [or both].”)

Syndrome, Gardner's (See “Polyposis, familial, and related syndromes.")

Syndrome, Gasser's (See “Syndrome, hemolytic uremic.”)

Syndrome, Goodpasture's

Related Term: Goodpasture's disease.

NOTE: For a pertinent review, see ref. (1).

\begin{tabular}{lll}
\hline Organs and Tissues & Procedures & Possible or Expected Findings
\end{tabular}

Lungs Record weights. Photograph surface of lungs.

Influenza virus infection.

Submit one lobe for general bacterial and viral cultures (p. 103). 


\begin{tabular}{|c|c|c|}
\hline Organs and Tissues & Procedures & Possible or Expected Findings \\
\hline $\begin{array}{l}\text { Lungs } \\
\qquad \text { (continued) }\end{array}$ & $\begin{array}{l}\text { Photograph cut surface of fresh lung. Snap- } \\
\text { freeze tissue block for immunofluorescent } \\
\text { study. Perfuse one lung with formalin } \\
\text { (p. 47). Request Gomori's iron and } \\
\text { Verhoeff-van Gieson stains (p. 172). } \\
\text { Prepare samples for electron microscopic } \\
\text { study (p. 132). }\end{array}$ & $\begin{array}{l}\text { Pulmonary hemorrhages. Interstitial } \\
\text { pulmonary fibrosis. }\end{array}$ \\
\hline Kidneys & $\begin{array}{l}\text { Follow procedures described under } \\
\text { "Glomerulonephritis." }\end{array}$ & $\begin{array}{l}\text { Anti-basement membrane antibody } \\
\text { mediated nephritis (Goodpasture's disease). } \\
\text { Glomeruli may appear normal or show focal } \\
\text { proliferative or necrotizing changes. Linear } \\
\text { immunofluorescence of glomerular base- } \\
\text { ment membrane, indicating presence of IgG } \\
\text { (or rarely IgA). }\end{array}$ \\
\hline Urine & $\begin{array}{l}\text { Submit sample for protein determination } \\
\text { and study of sediment. }\end{array}$ & Proteinuria; hematuria; casts. \\
\hline Other organs & $\begin{array}{l}\text { Histologic samples should include heart, liver, } \\
\text { spleen, lymph nodes, intestine, testes, and } \\
\text { tissue from nasopharynx. }\end{array}$ & $\begin{array}{l}\text { Histologic study of multiple organs may be } \\
\text { needed to rule out other systemic diseases } \\
\text { such as Wegener's granulomatosis.* }\end{array}$ \\
\hline
\end{tabular}

Reference

1. Bolton WK. Goodpasture's syndrome. Kidney Intl 1996;50:1753-1766.

\section{Syndrome, Grönblad-Strandberg (See "Pseudoxanthoma elasticum.")}

\section{Syndrome, Guillain-Barré}

Synonyms: Acute inflammatory polyradiculoneuropathy; Guillain-Barré-Strohl syndrome; idiopathic polyneuritis; Landry's ascending paralysis.

\begin{tabular}{|c|c|c|}
\hline Organs and Tissues & Procedures & Possible or Expected Findings \\
\hline Cerebrospinal fluid & For removal, see p. 104. & Increased proteins; normocellular. \\
\hline $\begin{array}{l}\text { Brain, spinal cord, } \\
\text { dorsal and ventral } \\
\text { roots of spinal cord, } \\
\text { and spinal ganglia }\end{array}$ & $\begin{array}{l}\text { For removal and specimen preparation, } \\
\text { see pp. } 65,67 \text {, and } 69 \text {, respectively. } \\
\text { Request Luxol fast blue stain for demon- } \\
\text { stration of myelin and Bielschowky's stain } \\
\text { for axons (p. 172). Embed samples in plastic } \\
\text { for thick, toluidin-stained sections and for } \\
\text { electron microscopic study (p. 132). }\end{array}$ & $\begin{array}{l}\text { Segmental demyelination and mononuclear } \\
\text { infiltrates in cranial and spinal nerve roots. } \\
\text { If axons are involved, there is chromatolysis } \\
\text { of lower motor neurons (spinal cord and } \\
\text { brain stem). }\end{array}$ \\
\hline Peripheral nerves & $\begin{array}{l}\text { For sampling and specimen preparation, see } \\
\text { p. } 79 \text { and above under "Brain, spinal cord,..." }\end{array}$ & $\begin{array}{l}\text { Segmental demyelination and mononuclear } \\
\text { infiltrates. }\end{array}$ \\
\hline Eyes & $\begin{array}{l}\text { For removal and specimen preparation, } \\
\text { see p. } 85 \text {. }\end{array}$ & Papilledema. \\
\hline $\begin{array}{l}\text { Urinary bladder } \\
\text { and kidneys }\end{array}$ & $\begin{array}{l}\text { Procedures depend on grossly identified } \\
\text { abnormalities as listed in right-hand column. }\end{array}$ & $\begin{array}{l}\text { Urinary retention with urocystitis and } \\
\text { pyelonephritis.* }\end{array}$ \\
\hline
\end{tabular}

\section{Syndrome, Hamman-Rich (See "Pneumonia, interstitial.")}

\section{Syndrome, Hand-Schüller-Christian (See "Histiocytosis, Langerhans cell.”)}

\section{Syndrome, Hemolytic Uremic}

Related Term: Thrombotic thrombocytopenic purpura (1).

NOTE: If the patient underwent organ transplantation, see under "Transplantation,..."; use of cyclosporine may be a cause of hemolytic uremic syndrome (2). Antineoplastics may have a similar effect. 


\begin{tabular}{lll}
\hline Organs and Tissues & Procedures & Possible or Expected Findings \\
\hline Kidney & $\begin{array}{l}\text { Record weights, photograph, and sample for } \\
\text { histologic study. }\end{array}$ & $\begin{array}{l}\text { Renal cortical necrosis;* thromboses of } \\
\text { glomerular arterioles and capillaries. } \\
\text { Gastrointestinal tract }\end{array}$ \\
$\begin{array}{l}\text { If indicated, submit intestinal contents for } \\
\text { microbiologic study. }\end{array}$ & $\begin{array}{l}\text { Enterohemorrhagic E. coli 0157:H7 } \\
\text { infection (3). }\end{array}$ \\
Pancreas & Submit for histologic study. & $\begin{array}{l}\text { Pancreatitis may be a complication or, rarely, } \\
\text { a cause of the disease. }\end{array}$ \\
Other organs and tissues & $\begin{array}{l}\text { Procedures depend on expected findings or } \\
\text { grossly identified abnormalities as listed in } \\
\text { right-hand column. }\end{array}$ & $\begin{array}{l}\text { cular coagulation.* Toxemia of pregnancy.* } \\
\text { Premature separation of placenta. Manifes- } \\
\text { festations of HIV infection (4). Malignancies }\end{array}$ \\
& & such as carcinoma of prostate (5). \\
\hline
\end{tabular}

\section{References}

1. Neild GH. Hemolytic uremic syndrome/thrombotic thrombocytopenic purpura: pathophysiology and treatment. Kidney Intl 1998;64:S45-S49.

2. Katznelson S, Wilkinson A, Rosenthal TR, Cohen A, Nast C, Danovitch GM. Cyclosporin-induced hemolytic uremic syndrome: factors that obscure its diagnosis. Transpl Proc 1994;26:2608-2609.

3. Koutkia P, Mylonakis E, Flanigan T. Enterohemorrhagic Escherichia coli 0157:H7: an emerging pathogen. Am Family Physician 1997;56: 853-856.

4. Badesha PS, Saklayen MG. Hemolytic uremic syndrome as a presenting form of HIV infection. Nephron 1996;72:472-475.

5. Muller NJ, Pestalozzi BC. Hemolytic uremic syndrome in prostatic carcinoma. Oncol 1998;55:174-176.

\section{Syndrome, Hepatorenal}

NOTE: Decompensated cirrhosis* of the liver with ascites is almost always present. Most possible causes of hepatorenal failure, such as intrarenal shunting or reduced plasma volume, have no anatomic substrate. A possible and demonstrable mechanical cause is enlargement of the caudate lobe, which may compress the hepatic fossa of the inferior vena cava. For roentgenologic demonstration of this system, see p. 59 (renal venography). See also under "Obstruction, inferior vena cava." The kidneys are often autolytic - particularly if jaundice is severebut usually fail to show other morphologic abnormalities.
Syndrome, Heterotaxy (See "Syndrome, polysplenia and asplenia.")

Syndrome, Hunter-Hurler (See “Mucopolysaccharidosis.”)

Syndrome, Hypereosinophilic (See "Cardiomyopathy, restrictive [with eosinophilia]," "Gastroenteritis, eosinophilic," and "Syndrome, eosinophilic pulmonary.")

Syndrome, Hypoplastic Left Heart (See "Atresia, aortic valvular.")

Syndrome, Immunodeficiency (See "Syndrome, acquired immunodeficiency (AIDS)" and "Syndrome, primary immunodeficiency.")

Syndrome, Intravascular Coagulation and Fibrinolysis (See "Coagulation, disseminated intravascular.")

Syndrome, Kimmelstiel-Wilson (See "Diabetes mellitus.")

\section{Syndrome, Klinefelter's}

Synonym: Seminiferous tubule dysgenesis.

Possible Associated Conditions: Carcinoma; chronic pulmonary disease; congenital malformations; diabetes mellitus* (1); Down's syndrome;* leukemia;* malignant lymphoma;* Osler's disease;* progressive systemic sclerosis;* Sjögren's syndrome;* systemic lupus erythematosus.*

\begin{tabular}{ll}
\hline Organs and Tissues & Procedures \\
\hline $\begin{array}{c}\text { External examination } \\
\text { and breast tissue }\end{array}$ & $\begin{array}{l}\text { Record body weight and length and length } \\
\text { of lower extremities. } \\
\text { Record appearance of external genitalia. }\end{array}$ \\
& $\begin{array}{l}\text { Prepare histologic sections of breast tissue. } \\
\text { Prepare skeletal roentgenograms. }\end{array}$
\end{tabular}

Blood or fascia lata

Urine

Endocrine organs
Submit tissue or blood for chromosome analysis (p. 108). Refrigerate blood sample for possible hormone assay.

Refrigerate specimen for possible hormone assay.

Record weights and dimensions of both testes.

Record weights of all endocrine glands. Prepare histologic sections of adrenal glands and of pituitary gland (p. 71).

\section{Possible or Expected Findings}

Tall person with long lower extremities; eunuchoidism; varicose veins.

Hypoplastic external genitalia; cryptorchidism; hypospadias.

Gynecomastia.

Deformities-for instance, radioulnar synostosis.

47, XXY and less common variants, including sex chromosome mosaicism.

Germ cell deficiency or hyalinization of seminiferous tubules. Usually, longitudinal axis of testes is smaller than $2 \mathrm{~cm}$. 


\begin{tabular}{lll}
\hline Organs and Tissues & Procedures & Possible or Expected Findings \\
\hline Other organs and tissues & $\begin{array}{l}\text { Procedures depend on expected findings or } \\
\text { grossly identified abnormalities as listed in } \\
\text { right-hand column. }\end{array}$ & $\begin{array}{l}\text { Suprasellar tumors of maldevelopmental } \\
\text { origin (2). Tumors at other sites such } \\
\text { as prostate (3). }\end{array}$ \\
\hline
\end{tabular}

\section{References}

1. Robinson S, Kessling A. Diabetes secondary to genetic disorders. Baillieres Clin Endocrin Metabol 1992;6:867-898.

2. Hamed LM, Maria BL, Quisling R, Fanous MM, Mickle P. Suprasellar tumors of maldevelopmental origin in Klinefelter's syndrome. A report of two cases. J Clin Neuro-Ophthalmol 1992;12:192-197.

3. Tay HP, Bidair M, Shabaik A, Gilbaugh JH 3rd, Schmidt JD. Primary yolk sac tumor of the prostate in a patient with Klinefelter's syndrome. J Urol 1995;153:1066-1069.

\section{Syndrome, Klippel-Feil}

Synonym: Congenital fusion of cervical vertebrae.

\begin{tabular}{lll}
\hline Organs and Tissues & Procedures & Possible or Expected Findings \\
\hline External examination & & $\begin{array}{l}\text { Short neck. Disorders with dysraphia } \\
\text { (see below). }\end{array}$ \\
& $\begin{array}{l}\text { Prepare roentgenograms of chest, neck, } \\
\text { and head. }\end{array}$ & $\begin{array}{l}\text { Fusion of cervical vertebrae. Congenital } \\
\text { elevation of the scapula (Sprengel's } \\
\text { deformity). }\end{array}$ \\
$\begin{array}{l}\text { Skull, spine, brain, } \\
\text { and spinal cord }\end{array}$ & $\begin{array}{l}\text { For removal and specimen preparation of } \\
\text { brain and spinal cord, see pp. 65 and 67, } \\
\text { respectively. }\end{array}$ & $\begin{array}{l}\text { Arnold-Chiari malformation;* basilar } \\
\text { impression;* meningomyelocele; platybasia;* } \\
\text { spinal cord compression; syringomyelia.* }\end{array}$ \\
\hline
\end{tabular}

\section{Syndrome, Korsakoff (See "Syndrome, Wernicke-Korsakoff.”)}

\section{Syndrome, Lambert-Eaton (See "Myasthenia gravis.")}

\section{Syndrome, Laurence-Moon-Biedl}

Related Term: Bardet-Biedl syndrome (1).

\begin{tabular}{lll}
\hline Organs and Tissues & Procedures & Possible or Expected Findings \\
\hline External examination & $\begin{array}{l}\text { Record body weight and length; record and } \\
\text { photograph abnormalities as listed in } \\
\text { right-hand column. }\end{array}$ & $\begin{array}{l}\text { Obesity; } * \text { polydactyly; developmental delay } \\
\text { in infants. Dysmorphic extremities. }\end{array}$ \\
& $\begin{array}{l}\text { Record weight and sample for histologic study. } \\
\text { Liver }\end{array}$ & $\begin{array}{l}\text { Hypogonadism in males (1). } \\
\text { Congenital hepatic fibrosis* (2). }\end{array}$ \\
Kidneys & see also under that heading. Follow procedures & Multiple abnormalities, including renal, \\
& cysts, tubulointerstitial nephritis and focal \\
described under "glomerulonephritis." & sclerosing glomerulonephritis. \\
Gonads & Submit samples for histologic study. & Hypogonadism. \\
Eyes & For removal and specimen preparation, & Retinal dystrophy (1) and other retinal \\
& see p. 85. & changes. \\
\hline
\end{tabular}

\section{References}

1. Green JS, Parfrey PS, Harnett JD, Farid NR, Cramer BC, Johnson G, et al. The cardinal manifestations of Bardet-Biedl syndrome, a form of Laurence-Moon-Biedl syndrome. N Engl J Med 1989;321:1002-1009.

2. Nakamura F, Sasaki H, Kajihara H, Yamanoue M. Laurence-Moon-Biedl syndrome accompanied by congenital hepatic fibrosis. J Gastroenterol Hepatol 1990;5:206-210.

3. Collins CM, Mendoza SA, Griswold WR, Tanney D, Liebermann E, Reznik VM. Pediatric renal transplantation in Laurence-Moon-Biedl syndrome. Pediatr Nephrol 1994;8:221-222.

\section{Syndrome, Leriche's}

NOTE: The morphologic substrate is isolated aortoiliac atherosclerosis. Remove aorta together with common and external iliac arteries. For arteriography of lower extremities, see p. 120. 


\title{
Syndrome, Letterer-Siwe (See "Histiocytosis, Langerhans cell.”)
}

Syndrome, Löffler's (See “Cardiomyopathy, restrictive [eosinophilic type] and "Syndrome, eosinophilic pulmonary.”)

\author{
Syndrome, Louis-Bar (See "Syndrome, primary immunodeficiency.”)
}

\section{Syndrome, Malabsorption}

NOTE: If malabsorption is suspected to have been caused by a systemic disease, see also under that entry. Such systemic diseases include abetalipoproteinemia, ${ }^{*}$ amyloidosis, ${ }^{*}$ Degos' disease, diabetes mellitus, ${ }^{*}$ hyperthyroidism, ${ }^{*}$ hypoparathyroidism, ${ }^{*}$ hypothyroidism, ${ }^{*}$ mastocytosis, ${ }^{*}$ polyarteritis nodosa, ${ }^{*}$ and systemic lupus erythematosus.*

\begin{tabular}{ll}
\hline Organs and Tissues & Procedures \\
\hline $\begin{array}{l}\text { External examination } \\
\text { and oral cavity }\end{array}$ & $\begin{array}{l}\text { Record character and extent of skin and oral } \\
\text { changes. Prepare histologic sections of affected } \\
\text { skin. Prepare skeletal roentgenograms. }\end{array}$ \\
Intestinal tract & $\begin{array}{l}\text { If an infectious or parasitic intestinal disorder } \\
\text { is suspected, submit portions for microbiologic } \\
\text { study (p. 102). } \\
\text { For mesenteric angiography, see p. 55. }\end{array}$
\end{tabular}

\section{Possible or Expected Findings}

Brownish discoloration of skin; dermatitis; cheilosis; glossitis. Clubbing of fingers and toes. Osteomalacia;* rickets.

Bacterial, fungal, viral, or parasitic infection.

Mesenteric atherosclerosis,* vasculitis, thromboembolism, or other occlusive changes.

For in situ formalin perfusion of small intestine, see p. 54. If there were surgical resections, anastomoses, or blind loops, record length of remaining intestine, size and location of anastomoses, and length of blind loops. Submit samples of all segment for dissecting microscopic (p. 54) and histologic study. Identify exact location of samples in relation to ligament of Treitz or other anatomic landmarks.

Mesentery See also above under "Intestinal tract." Prepare histologic sections of arteries, veins, and lymph nodes.

Liver and extrahepatic bile ducts

Pancreas

Other organs and tissues

Bones, bone marrow, and joints

Vitreous
For postmortem cholangiography, see p. 56.

Dissect extrahepatic bile ducts in situ. For roentgenologic study of duct system, see p. 57. Prepare thin slices in order to detect minute lesions. If appropriate, see also under "Tumor of the pancreas."

Procedures depend on expected findings or grossly identified abnormalities as listed above under "Note."

For removal, prosthetic repair, and specimen preparation of bones and joints, see p. 95. For preparation of sections and smears of bone marrow, see p. 96 .

Submit sample (p. 85) for sodium, calcium, chloride, magnesium phosphate, and urea nitrogen determination.
Previous intestinal resection ("short bowel syndrome"), anastomoses, and blind loops. Diverticula;* strictures; fistulas; carcinoid tumors. Granulomatous or nongranulomatous enteritis; eosinophilic enteritis; radiation enteritis; sprue;* Whipple's disease.* Intestinal lymphangiectasia. Lymphoma,* carcinoma, and many other diseases and conditions (see also above under "Note").

Lymphoma.*

Granulomatous lymphadenitis. Vascular disease or other condition, as listed above under "Intestinal tract" and under "Note." Biliary obstruction.

Pancreatitis.* Non-beta islet cell tumor.

Manifestations of systemic diseases that may have caused malabsorption. See above under "Note."

Bone changes related to vitamin D deficiency.* Megaloblastic bone marrow.

Manifestations of dehydration.* Electrolyte changes associated with vitamin D deficiency.* 


\begin{tabular}{ll}
\hline Organs and Tissues & Procedures \\
\hline External examination & $\begin{array}{l}\text { Record body weight and length, arm span, } \\
\text { pubis-to-sole distance, and pubis-to-vertex } \\
\text { distance. }\end{array}$
\end{tabular}

Diaphragm

Heart and aorta
If infective endocarditis is suspected, follow procedures described on p. 103. Leave aorta attached to heart. Test competence of mitral and aortic valves (p. 29). Record circumference of aorta and pulmonary artery just above valves and further distally.

Request PAS, toluidine blue, and Verhoeffvan Gieson stains of sections of vascular walls (p. 173).

Lungs

Colon

Neck organs

Eyes
Perfuse one or both lungs with formalin (p. 47).

Record extent of diverticulosis.

Inspect carotid arteries.

For removal and specimen preparation,
Possible or Expected Findings

Typical skeletal proportions.

Arachnodactyly; pectus excavatum; pigeon breast; dolichocephaly; kyphoscoliosis; genu recurvatum; dislocation of joints; striae of skin.

Diaphragmatic hernia.*

Infective endocarditis.* Atrial septal defect.* Myxomatous transformation of mitral ring. Mitral valve prolapse. Aortic and pulmonary dilatation and valvular insufficiency.* Aortic dissection* with dissection of adjacent vessels. Ascending aortic aneurysm (rarely with aortopulmonary fistula [1]). Myocardial infarction (2).

Cystic change of media.

Multiple cysts (see "Cyst(s), pulmonary"). Diverticulosis.

Aneurysms (3).

Subluxation of lens. see p. 85 .

\section{References}

1. Massetti M, Babatasi G, Rossi A, Kapadia N, Neri E, Bhoyroo S, et al. Aortopulmonary fistula: an uncommon complication in dystrophic aortic aneurysm. Ann Thor Surg 1995;59:1563-1564.

2. Santucci JJ, Katz S, Pogo GJ, Boxer R. Peripartum acute myocardial infarction in Marfan's syndrome. Am Heart J 1994;127:1404-1407.

3. Ohyama T, Ohara S, Momma F. Aneurysm of the cervical internal carotid artery associated with Marfan's syndrome-case report. Neurologia Medico-Chirrugica 1992;32:965-968.

\section{Syndrome, Mucocutaneous Lymph Node}

Synonyms and Related Terms: Infantile polyarteritis nodosa;* Kawasaki disease.

NOTE: This syndrome is rarely fatal. The morphologic changes found at autopsy are identical to those seen in infantile polyarteritis nodosa.* The disease might be caused by an infectious agent (1). The disease is reportable in some states.

\begin{tabular}{ll}
\hline Organs and Tissues & Procedures \\
\hline $\begin{array}{l}\text { External examination } \\
\text { and skin }\end{array}$ & $\begin{array}{l}\text { Record and photograph abnormalities listed } \\
\text { in right-hand column. }\end{array}$
\end{tabular}

Heart

For coronary arteriography, see p. 118. Submit samples of all coronary arteries for histologic study, and request Verhoeff-van Gieson' stain (p. 173).

Other organs

Follow procedures described under "Polyarteritis nodosa."

Neck organs
Remove together with tongue. Submit samples of tongue and of cervical lymph nodes for histologic study.

\section{Possible or Expected Findings}

Congestion of conjunctivas. Fissuring of lips; protuberance of lingual papillae; edema of hands and feet; desquamation at junction of nails and skin of the fingers and toes; furrowing of the nails. Mild jaundice may be present.

Coronary thromboarteritis with coronary occlusion, indistinguishable from infantile polyarteritis nodosa.* Coronary artery aneurysms. Myocarditis and valvulitis in early phases of the disease (1).

Early in the disease, lymphocytic or mixed interstitial infiltrates in hilar area of liver, spleen, pancreas, and kidneys. Protuberance of lingual papillae. Cervical lymphadenopathy. 


\begin{tabular}{lll}
\hline Organs and Tissues & Procedures & Possible or Expected Findings \\
\hline Urine & $\begin{array}{l}\text { Submit sample for study of sediment. } \\
\text { Joints }\end{array}$ & $\begin{array}{l}\text { For removal, prosthetic repair, and specimen } \\
\text { preparation, see p. } 96 .\end{array}$ \\
Brain & $\begin{array}{l}\text { For removal and specimen preparation, } \\
\text { see p. } 66 .\end{array}$ & Aseptic meningitis.* \\
& & \\
\hline
\end{tabular}

\section{Reference}

1. Landing BH, Larson EJ. Pathological features of Kawasaki disease (mucocutaneous lymph node syndrome). Am J Cardiovasc Pathol 1987;1: 218-229.

\section{Syndrome, Myasthenia (See “Myasthenia gravis.")}

\section{Syndrome, Myelodysplastic}

Synonyms and Related Terms: Chronic myelomonocytic leukemia;* refractory anemia; refractory anemia with excess of blasts; refractory anemia with excess of blasts in transformation; refractory anemia with ringed sideroblasts; refractory dysmyelopoietic anemias.

NOTE: The myelodysplastic syndromes are represented by a heterogeneous group of normocytic anemias, often with neutropenia, thrombocytopenia, and monocytosis. For expected bone marrow changes, see above under "Synonyms and Related Terms." Autopsy procedures are similar to those recommended for most cases of leukemia, with particular attention paid to intercurrent infections and thrombocytopenic hemorrhages. In all instances, material should be collected using aseptic technique for tissue culture for chromosome analysis (see Chapter 10). Common findings in these conditions are deletion of the long arm of chromosome 5 , deletion of chromosome 5 or 7 , or trisomy 8 .

\section{Syndrome, Nephrotic}

NOTE: See under name of suspected underlying condition, such as amyloidosis, ${ }^{*}$ anaphylactoid purpura, ${ }^{*}$ diabetes melli- tus, * glomerulonephritis, * Goodpasture's syndrome, * heavy metal poisoning, hemolytic uremic syndrome, ${ }^{*}$ infective endocarditis, ${ }^{*}$ polyarteritis nodosa,* syphilis, ${ }^{*}$ or systemic lupus erythematosus.* If accelerated hypertension or constrictive pericarditis is the suspected underlying condition, see under "Hypertension (arterial), all types or type unspecified" or "Pericarditis," respectively.

In all instances, the renal veins and the inferior vena cava should be opened in situ. "En masse" removal of organs (p. 3) is recommended for this purpose. If thrombosis is found, record exact location and size of clot and submit sample of clot with wall of veins for histologic study. See also under "Thrombosis, venous." Coronary atherosclerosis and its complications seem to be increased in patients with the nephrotic syndrome.

\section{Syndrome, Neurocutaneous (See "Disease, Sturge-Weber-Dimitri," "Disease, von Hippel-Lindau," "Neurofibromatosis," and "Sclerosis, tuberous.")}

Syndrome, Neutrophil Dysfunction (See "Disease, chronic granulomatous," and "Syndrome, Chédiak-Higashi.")

\section{Syndrome, Noonan's}

Possible Associated Conditions: Acute leukemia (1).

\begin{tabular}{ll}
\hline Organs and Tissues & Procedures \\
\hline External examination & $\begin{array}{l}\text { Record body weight and length. Record and } \\
\text { prepare photographs of all abnormalities } \\
\text { listed in right-hand column. }\end{array}$
\end{tabular}

Prepare skeletal roentgenograms.

Blood or fascia lata

Heart

Lungs
For coronary arteriography, see p. 118.

These specimens should be collected using aseptic technique for tissue culture for chromosome analysis (see Chapter 10). Dissection techniques depend on expected abnormalities as shown in right-hand column.

Perfuse lungs with formalin (p. 47).
Possible or Expected Findings

Small stature; neck webbing; antimongoloid slant of palpebral fissures; micrognathia; hypertelorism; cubitus valgus; short curved fifth finger; broad, short fingernails; undescended testes. Hydrops fetalis* due to lymphatic dysplasia (2).

Pectus excavatum and other skeletal malformations;

Normal karyotype in most instances.

Congenital valvular pulmonary stenosis.* Congestive obstructive or nonobstructive hypertrophic cardiomyopathy.* Left ventricular hypoplasia;* aneurysms of the sinuses of valsalva (3). Congenital coronary anomalies. Pulmonary lymphangiectasis. 


\begin{tabular}{lll}
\hline Organs and Tissues & Procedures & Possible or Expected Findings \\
\hline $\begin{array}{l}\text { Kidneys } \\
\text { Brain }\end{array}$ & See “Cyst(s), renal." & Cystic renal disease. \\
& $\begin{array}{l}\text { For removal and specimen preparation, } \\
\text { see p. 66. For cerebral angiography, see p. 80. }\end{array}$ & Cerebral arteriovenous malformation (4). \\
\hline
\end{tabular}

\section{References}

1. Johannes JM, Garcia CR, De Vaan GA, Weening RS. Noonan's syndrome in association with acute leukemia. Pediatr Hematol Oncol 1995;12:571575.

2. Bloomfield FH, Hadden W, Gunn TR. Lymphatic dysplasia in a neonate with Noonan's syndrome. Pediatr Radiol 1997;27:321-323.
3. Noonan J, O'Connor W. Noonan syndrome: a clinical description emphasizing the cardiac findings. Acta Pediatr Japn 1996;38:76-83.

4. Schon F, Bowler J, Baraitser M. Cerebral arteriovenous malformation in Noonan's syndrome. Postgrad Med J 1992;68:37-40.

\section{Syndrome, Obesity-Hypoventilation (See "Obesity.")}

Syndrome, Parkinson's (See “Disease, Parkinson's.”)

\section{Syndrome, Peutz-Jeghers}

NOTE: For the gene location, see ref. (1).

\begin{tabular}{|c|c|c|}
\hline Organs and Tissues & Procedures & Possible or Expected Findings \\
\hline $\begin{array}{l}\text { External examination, } \\
\text { skin, and oral cavity }\end{array}$ & $\begin{array}{l}\text { Record extent of pigmentations; photograph } \\
\text { and prepare histologic sections of skin. }\end{array}$ & $\begin{array}{l}\text { Mucocutaneous pigmentations around lips } \\
\text { and of buccal mucosa, forearms, hands, feet, } \\
\text { and umbilical area. }\end{array}$ \\
\hline \multirow[t]{2}{*}{$\begin{array}{l}\text { Gastrointestinal tract and } \\
\text { regional lymph nodes }\end{array}$} & $\begin{array}{l}\text { Record location and size of polypoid lesions. } \\
\text { Leave polyps attached to wall of intestine until } \\
\text { after fixation is completed. Histologic section } \\
\text { should include polyps and wall of intestine. } \\
\text { Request van Gieson's and mucicarmine stains } \\
\text { (p. 173). }\end{array}$ & $\begin{array}{l}\text { Intussusception and hemorrhage. } \\
\text { Hamartomatous polyps in jejunum and ileum } \\
\text { and less commonly in stomach, duodenum, } \\
\text { appendix, and colon. Adenocarcinomas may } \\
\text { arise from the polyps. }\end{array}$ \\
\hline & $\begin{array}{l}\text { Submit samples of regional lymph nodes for } \\
\text { histologic study. }\end{array}$ & $\begin{array}{l}\text { Metastases in rare cases in which carcinoma } \\
\text { had developed. }\end{array}$ \\
\hline Other organs & $\begin{array}{l}\text { Procedures depend on expected findings or } \\
\text { grossly identified abnormalities as listed in } \\
\text { right-hand column. }\end{array}$ & $\begin{array}{l}\text { Rarely, hamartomatous polyps in pharynx, } \\
\text { urinary bladder, and other sites. Gonadal } \\
\text { tumors have been observed }(2,3) \text {. }\end{array}$ \\
\hline
\end{tabular}

\section{References}

1. Tomlinson IP, Houlston RS. Peutz-Jeghers syndrome. J Med Genet 1997;34:1007-1011.

2. Dreyer L, Jacyk WK, du Plessis DJ. Bilateral large-cell calcifying Sertoli cell tumor of the testes in Peutz-Jeghers syndrome: a case report. Pediatr Dermatol 1994;11:335-337.

3. Dozois RR, Kempers RD, Dahlin DC, Batholomew LG. Ovarian tumors associated with the Peutz-Jeghers syndrome. Ann Surg 1970;172:233-238.

\section{Syndrome, Pickwickian (Obesity-Hypoventilation syndrome) (See "Obesity.")}

\section{Syndrome, Pierre Robin}

Related Terms: Catel-Manzke syndrome (Pierre Robin complex with accessory metacarpal of index finger); Pierre-Robin sequence; Trisomy 18 .

NOTE: The Pierre-Robin phenotype (i.e., micrognathia with resulting retroglossia and cleft palate) may be present in numerous other malformation complexes. Other abnormalities comprising these malformation complexes are listed below.

\begin{tabular}{ll}
\hline Organs and Tissues & Procedures \\
\hline $\begin{array}{l}\text { External examination; } \\
\text { oral and nasal cavities; } \\
\text { soft tissues }\end{array}$ & $\begin{array}{l}\text { Record and prepare photographs of all } \\
\text { abnormalities as listed in right-hand column. }\end{array}$
\end{tabular}

Prepare skeletal roentgenograms, including hands.
Possible or Expected Findings

Micrognathia; cleft palate; bulging of upper rib cage; bifid uvula; choanal atresia; hypertelorism; hypertrophy of soft tissues of the neck.

Rib defects; syndactyly; hypoplastic digits; extra metacarpal of index finger; hypoplastic femora. 


\begin{tabular}{|c|c|c|}
\hline Organs and Tissues & Procedures & Possible or Expected Findings \\
\hline Chest & & Pneumothorax.* \\
\hline Blood or fascia lata & $\begin{array}{l}\text { These specimens should be collected using } \\
\text { aseptic technique for tissue culture for } \\
\text { chromosome analysis (see Chapter 10). } \\
\text { This is particularly important if condition } \\
\text { must be distinguished from trisomy } 18 \text { or } \\
\text { cri-du-chat syndrome. }\end{array}$ & $\begin{array}{l}\text { Usually normal karyotype but chromosomal } \\
\text { deletions may occur (1). }\end{array}$ \\
\hline Heart & For dissection techniques, see p. 33. & Congenital heart disease (2). Cor pulmonale. \\
\hline Liver & Record weight and sample for histologic study. & Congenital hepatic fibrosis. \\
\hline Neck organs and tongue & $\begin{array}{l}\text { Record size of tongue; record presence or } \\
\text { absence of signs of asphyxiation from } \\
\text { malformed organs and tissues. }\end{array}$ & $\begin{array}{l}\text { Tongue size normal or decreased. Rarely, } \\
\text { aglossia. Glossoptosis may lead to acute } \\
\text { airways obstruction ( } 3 \text { ). }\end{array}$ \\
\hline Brain & $\begin{array}{l}\text { For removal and specimen preparation, } \\
\text { see p. } 66 .\end{array}$ & Hypoxic encephalopathy. \\
\hline Eyes & $\begin{array}{l}\text { For removal and specimen preparation, } \\
\text { see p. } 85 \text {. }\end{array}$ & $\begin{array}{l}\text { Glaucomatous cupping of optic disk; myopic } \\
\text { disk changes; cataract; retinal detachment; } \\
\text { microphthalmia. }\end{array}$ \\
\hline
\end{tabular}

\section{References}

1. Menk FH, Madan K, Baart JA, Beukenhorst HL. Robin sequence and a deficiency of the left forearm in a girl with a deletion of chromosome 4g33gter. Am J Med Genet 1992;44:696-694.

2. Pearl W. Congenital heart disease in the Pierre Robin syndrome. Pediatr Cardiol 1982;2:307-309.

3. Cozzi F, Pierro A. Glossoptosis-apnea syndrome. Pediatr 1985;75:836-843.

\section{Syndrome, Plummer-Vinson}

Synonym: Sideropenic dysphagia.

\begin{tabular}{|c|c|c|}
\hline Organs and Tissues & Procedures & Possible or Expected Findings \\
\hline External examination & & Koilonychia. \\
\hline Esophagus and stomach & $\begin{array}{l}\text { Request PAS-alcian blue stain of histologic } \\
\text { samples (p. 173). }\end{array}$ & $\begin{array}{l}\text { Squamous cell carcinoma of esophagus (1). } \\
\text { Chronic gastritis. }\end{array}$ \\
\hline Neck organs & $\begin{array}{l}\text { Remove together with base of tongue and } \\
\text { oropharynx. Open esophagus in posterior } \\
\text { midline, photograph, and take sections of } \\
\text { grossly identifiable lesions and random } \\
\text { sections at various levels. }\end{array}$ & Web formation; postcricoid carcinoma. \\
\hline Other organs & $\begin{array}{l}\text { For preparation of sections and smears of } \\
\text { bone marrow, see p. } 96 .\end{array}$ & $\begin{array}{l}\text { Manifestations of hypochromic anemia.* } \\
\text { Blood smears reveal microsytosis. }\end{array}$ \\
\hline
\end{tabular}

\section{Reference}

1. Ribeiro U Jr, Posner MC, Safatle-Ribeiro AV, Reynolds JC. Risk factors for squamous cell carcinoma of the esophagus. Br J Surg 1996;83:11741185.

\section{Syndrome, Polysplenia and Asplenia}

Synonyms: Heterotaxy syndrome; Ivemark's syndrome; visceral isomerism.

Possible Associated Conditions: With asplenia: Right isomerism (bilateral mirror-image right-sided symmetry) of heart, lungs, and abdominal viscera; common atrium; total anomalous pulmonary venous connection; absent coronary sinus; complete atrioventricular septal defect;* subpulmonary steno- sis; ${ }^{*}$ pulmonary valve atresia;* midline symmetric liver; malrotation of bowel; absent spleen.

With polysplenia: Left isomerism (bilateral mirror-image left-sided symmetry) of heart and lungs, with variable sidedness of abdominal viscera; anomalous pulmonary venous connection; ventricular inversion; subpulmonary stenosis; ${ }^{*}$ transposition of the great arteries; * bilateral superior caval veins; azygos continuation of inferior vena cava; multiple spleens of variable size, all on same side as stomach and pancreas. 


\begin{tabular}{|c|c|c|}
\hline Organs and Tissues & Procedures & Possible or Expected Findings \\
\hline Blood & Prepare smears. & $\begin{array}{l}\text { Howell-Jolly bodies occur in asplenia } \\
\text { syndrome and, rarely, in polysplenia. }\end{array}$ \\
\hline $\begin{array}{l}\text { Chest and abdominal } \\
\text { cavity, cardiovascular } \\
\text { system, and lungs }\end{array}$ & $\begin{array}{l}\text { Procedures depend on expected findings or } \\
\text { grossly identified abnormalities as listed in } \\
\text { right-hand column and under "Possible } \\
\text { Associated Conditions." }\end{array}$ & $\begin{array}{l}\text { Two pulmonary lobes occur bilaterally in } \\
\text { polysplenia, and three lobes in asplenia } \\
\text { syndrome. If inferior vena cava is interrupted, } \\
\text { hepatic veins unite to form a vessel or vessels } \\
\text { that empty into either atrium. See also under } \\
\text { "Possible Associated Conditions." }\end{array}$ \\
\hline Spleen & $\begin{array}{l}\text { Dissect splenic artery and vein in situ. For } \\
\text { celiac arteriography, see p. } 55 \text {. }\end{array}$ & $\begin{array}{l}\text { In polysplenia, there are two or more splenic } \\
\text { masses but no normal-sized spleen. }\end{array}$ \\
\hline $\begin{array}{l}\text { Liver, gallbladder, } \\
\text { bile ducts }\end{array}$ & For postmortem cholangiography, see p. 56. & $\begin{array}{l}\text { Rarely, absence of gallbladder; biliary } \\
\text { atresia* in polysplenia. Large midline liver } \\
\text { in asplenia. }\end{array}$ \\
\hline
\end{tabular}

\section{Syndrome, Primary Immunodeficiency}

Synonyms and Related Terms (1): T-cell defects-Alymphocytosis (a severe combined immunodeficiency); ataxia telangiectasia; Bloom's syndrome;* deficit of T and NK cells (a severe combined immunodeficiency); DiGeorge's syndrome;* HLA-class I or II deficiency; hyper-IgM syndrome; WiskottAldrich syndrome; xeroderma pigmentosum; reticular dysgenesis (a severe combined immunodeficiency); and several others. B-cell defects-Bruton's agammaglobulinemia; common variable immunodeficiency; hyper IgE syndrome; IgA deficiency or IgG subclass deficiency, lymphoproliferative syndrome (X-linked or autoimmunity); and several others. Phagocytic defects-Chédiak-Higashi syndrome;* chronic granulomatous disease;* leukocyte adhesion deficiency; and several others. Complement deficiencies also belong here.

\section{NOTE:}

For the usual complications, such as skin diseases, hematologic diseases, and various types of infections, see above under "Synonyms and Related Terms" and below under "Possible or
Expected Findings." For the acquired immunodeficiency syndrome, see under "Syndrome, acquired immunodeficiency."

Possible Associated Conditions (syndromes associated with immunodeficiency): Chromosome abnormalities (Bloom's syndrome, * Down's syndrome, ${ }^{*}$ or Fanconi syndrome*); hereditary metabolic defects (acrodermatitis enteropathica [zinc deficiency], biotin dependent carboxylase deficiency, transcobalamin II deficiency, and type I orotic aciduria); hypercatabolism of Ig (familial hypercatabolism of Ig, intestinal lymphangiectasia, and myotonic dystrophy); multiple organ system abnormalities (agenesis of the corpus callosum, cartilage hair hypoplasia, partial albinism, or short-limbed dwarfism); and other deficiences (chronic mucocutaneous candidiasis, hyper IgE syndrome, immunodeficiency following hereditarily determined susceptibility to Epstein-Barr virus, and thymoma).

Conditions that are more common in immunodeficient patients: Infectious mononucleosis (with or without B cell lymphoma in $\mathrm{X}$-linked lymphoproliferative syndrome); rheumatoid arthritis;* systemic lupus erythematosus.*

\begin{tabular}{ll}
\hline Organs and Tissues $\quad$ Procedures & Possible or Expected Findings
\end{tabular}

External examination, skin, and oral cavity
Record body weight and length; record and photograph abnormalities as listed in righthand column. Prepare histologic sections of skin and oral mucosa, particularly of infected or eczematous areas.
Thymus
Record weight of intact organ. Record presence or absence of ectopic thymic tissue in neck organs. Submit samples for histologic study, and snap-freeze fresh material for immunofluorescent study.
Malformed ears, micrognathia, hypertelorism and short philtrum in Di George's syndrome.* Dermatomyositis* in immunoglobulin deficiency. Immunodeficiency may be associated with short-limbed dwarfism with absence of scalp hair, eyelashes, and eyebrows, ichthyosiform skin lesions, and erythroderma. Eczema in Wiskott-Aldrich syndrome; oculocutaneous telangiectasia (Louis-Bar syndrome); mucocutaneous infections, such as candidiasis* (chronic mucocutaneous candidiasis).

Thymus may be normal, hypoplastic (e.g., in ataxia telangiectasia), aplastic (for instance, in DiGeorge's syndrome*) or ectopic (see "Neck organs"). Spindle cell thymoma in hypogammaglobulinemia patients. 


\begin{tabular}{|c|c|}
\hline Organs and Tissues & Procedures \\
\hline$\overline{\text { Blood }}$ & $\begin{array}{l}\text { Submit samples for microbiologic study } \\
\text { (p. 102). Submit samples for determination } \\
\text { of immunoglobulins in serum and for B and } \\
\text { T lymphocyte counts. } \\
\text { Blood or fascia lata should be collected using } \\
\text { aseptic technique for tissue culture for } \\
\text { chromosome analysis (see Chapter 10). }\end{array}$ \\
\hline
\end{tabular}

Heart and great vessels

Lungs

Gastrointestinal tract

Lymph nodes and spleen

Neck organs

Other organs

Middle ears and sinuses

Eyes

Bone marrow

Joints
Submit one lobe for microbiologic study (p. 103). Stain touch preparations for Pneumocystis carinii.* Perfuse one lung with formalin (p. 47). Request Gram and Grocott's methenamine silver stain (p. 172).

For in situ fixation and preparation for study under the dissecting microscope, see p. 54. Submit contents for microbiologic study (p. 102). Submit samples of ileum, jejunum, appendix, and colon for histologic study.

Place specimens in omnifix fixative (p. 129). If lymphoma is suspected, follow procedures described under that heading.

Remove together with base of tongue, tonsils, soft palate, and pharyngeal wall (p. 4). Prepare histologic sections of lingual tonsils, palatine tonsils, and pharyngeal lymphatic tissue (see also above under "Thymus" and "Lymph nodes and spleen").

Dissect and record weights of thyroid gland and parathyroid glands. Submit samples for histologic study.

Procedures depend on expected findings or grossly identified abnormalities as listed in right-hand column.

For exposure and specimen preparation, see pp. 72 and 71 , respectively.

For removal and specimen preparation, see p. 85 .

For preparation of sections and smears, see p. 95. If bone marrow had been transplanted (e.g., in severe combined immunodeficiency), see also under "Transplantation, bone marrow."

If infectious arthritis is suspected, submit exudate for microbiologic study (p. 102).
Possible or Expected Findings

Bacterial or fungal septicemia; viremia. Hypogammaglobulinemia; dysgammaglobulinemia; hyperimmunoglobulinemia.

See above under "Possible Associated Conditions..."

Malformations of aortic arch and/or conotruncus in DiGeorge's syndrome. Bacterial, fungal, or viral pneumonia. Pneumocystis carinii infection.* Herpesvirus infection. Bronchiectasis, ${ }^{*}$ e.g., in transient hypogammaglobulinemia of infancy or common variable immunodeficiency.

Atrophy of intestinal villi and peripheral lymphoid tissue, most pronounced in Peyer's patches and appendix. Atrophic gastritis with megaloblastic anemia* or gastrointestinal infection, including giardiasis, may be present, e.g., in common variable immundeficiency.

$\mathrm{T}$ cells, primarily in paracortical zone of lymph nodes and in periarteriolar sheaths of the spleen. There may be generalized lymphadenopathy with or without lymphoma.*

Upper respiratory infections. Ectopic thymus may occur near the base of the tongue, or in or around thyroid and parathyroid glands.

Agenesis of parathyroid glands andrarely_of thyroid gland in DiGeorge's syndrome.

Manifestations of malabsorption syndrome.* Infections. Ovarian agenesis in ataxia telangiectasia.

Otitis media* and sinusitis.

Oculocutaneous telangiectasias in ataxia telangiectasia.

Hypoplasia (may be associated with agranulocytosis*). Leukemia* or related neoplastic disease. Megaloblastic anemia* in idiopathic late-onset immunoglobulin deficiency.

Mycoplasma infection in agammaglobulinemia.

\section{Reference}

1. Ten RM. Primary immunodeficiencies. Mayo Clin Proc 1998;73:865-872. 


\section{Syndrome, Reifenstein's}

Related Term: Hereditary familial hypogonadism; male pseudohermaphroditism.

\begin{tabular}{|c|c|c|}
\hline Organs and Tissues & Procedures & Possible or Expected Findings \\
\hline External examination & $\begin{array}{l}\text { Record and prepare photographs of all } \\
\text { abnormalities as listed in right-hand column. }\end{array}$ & $\begin{array}{l}\text { Microphallus; hypospadias; absent vas } \\
\text { deferens; incomplete fusion of labioscrotal } \\
\text { folds; gynecomastia. }\end{array}$ \\
\hline Blood and fascia lata & $\begin{array}{l}\text { These specimens should be collected using } \\
\text { aseptic technique for tissue culture for } \\
\text { chromosome analysis (see Chapter 10). }\end{array}$ & Normal karyotype. \\
\hline Gonads & Record weights and prepare histologic sections. & $\begin{array}{l}\text { Testicular atrophy; crytorchidism; germ } \\
\text { cell neoplasia. }\end{array}$ \\
\hline
\end{tabular}

\section{Syndrome, Reiter's}

Synonym: Urethritis-arthritis-conjunctivitis syndrome.

NOTE: AIDS-related psoriasiform dermatitis may show clinical features of Reiter's syndrome (1).

Possible Associated Condition: Ankylosing spondylitis.*

\begin{tabular}{|c|c|c|}
\hline Organs and Tissues & Procedures & Possible or Expected Findings \\
\hline \multirow[t]{2}{*}{$\begin{array}{l}\text { External examination, } \\
\text { skin, and oral cavity }\end{array}$} & $\begin{array}{l}\text { Record character and extent of lesions of } \\
\text { skin, external genitalia, and oral mucosa. } \\
\text { Prepare photographs of lesions. } \\
\text { Prepare histologic sections of skin and } \\
\text { mucosal lesions. }\end{array}$ & $\begin{array}{l}\text { Keratoderma (keratosis blennorrhagica) with } \\
\text { vasculitis ( } 2 \text { ) of sole of feet, of palms, and of } \\
\text { circumcised glans penis. }\end{array}$ \\
\hline & Prepare roentgenograms of joints. & $\begin{array}{l}\text { Arthritis* of knees, ankles, and metatarsal } \\
\text { and midtarsal joints, with or without } \\
\text { ankylosis. Osteoporosis.* }\end{array}$ \\
\hline Blood & $\begin{array}{l}\text { Submit sample for bacteriologic, viral, and } \\
\text { serologic study (p. 102). }\end{array}$ & Usually, sterile culture. \\
\hline Heart & $\begin{array}{l}\text { Record weight and submit samples for histo- } \\
\text { logic study (p. } 30 \text { ). If heart block was present, } \\
\text { submit samples of conduction system for } \\
\text { histologic study (p. 26). }\end{array}$ & $\begin{array}{l}\text { Pericarditis; } * \text { myocarditis.* } \\
\text { Aortic valve lesions. }\end{array}$ \\
\hline Lungs & $\begin{array}{l}\text { Submit consolidated areas for microbiologic } \\
\text { study (p. 103). Perfuse one lung with formalin } \\
\text { (p. 47). }\end{array}$ & $\begin{array}{l}\text { Pleuritis and pneumonia.* Pulmonary } \\
\text { fibrosis involving upper lobes. }\end{array}$ \\
\hline $\begin{array}{l}\text { Urinary bladder } \\
\text { and urethra }\end{array}$ & For removal of urethra, see p. 60 . & $\begin{array}{l}\text { Erosions, papules, and plaques in urethral } \\
\text { or bladder mucosa. }\end{array}$ \\
\hline Other organs & $\begin{array}{l}\text { Procedures depend on expected findings or } \\
\text { grossly identified abnormalities as listed in } \\
\text { right-hand column. }\end{array}$ & Enteritis. Thrombophlebitis. \\
\hline Eyes & $\begin{array}{l}\text { For removal and specimen preparation, } \\
\text { see p. } 85 \text {. }\end{array}$ & $\begin{array}{l}\text { Conjunctivitis; multifocal choroiditis; } \\
\text { acute anterior uveitis; iritis; keratitis. }\end{array}$ \\
\hline Joints & $\begin{array}{l}\text { For removal, prosthetic repair, and specimen } \\
\text { preparation, see p. } 96 \text {. Consult roentgenograms } \\
\text { (see above under "External examination, skin, } \\
\text { and oral cavity"). }\end{array}$ & $\begin{array}{l}\text { Arthritis* (see above under "External } \\
\text { examination, skin, and oral cavity") } \\
\text { resembling rheumatoid arthritis.* } \\
\text { Nonspecific synovitis. }\end{array}$ \\
\hline
\end{tabular}

\section{References}

1. Romani J, Puig L, Baselga E, De Moragas JM. Reiter's syndrome-like pattern in AIDS-associated psoriasiform dermatitis. Intl J Dermatol 1996; 35:484-488.

2. Magro CM, Crowson AN, Peeling R. Vasculitis as the basis of cutaneous lesions in Reiter's disease. Hum Pathol 1995;26:633-638. 


\section{Syndrome, Respiratory Distress, of Infant}

Related Terms: Hyaline membrane disease; bronchopulmonary dysplasia.

\begin{tabular}{|c|c|c|}
\hline Organs and Tissues & Procedures & Possible or Expected Findings \\
\hline External examination & Prepare chest and abdominal roentgenograms. & $\begin{array}{l}\text { Pneumothorax;* pneumomediastinum;* } \\
\text { pneumoperitoneum. }\end{array}$ \\
\hline Blood & $\begin{array}{l}\text { Submit sample for microbiologic study } \\
\text { (p. 102) if sepsis is suspected. }\end{array}$ & Septicemia. \\
\hline Heart & $\begin{array}{l}\text { Record weight of heart and thickness of } \\
\text { ventricles. }\end{array}$ & $\begin{array}{l}\text { Right ventricular hypertrophy and/or } \\
\text { dilatation. }\end{array}$ \\
\hline $\begin{array}{l}\text { Trachea, major } \\
\text { bronchi, and lungs }\end{array}$ & $\begin{array}{l}\text { Perfuse lungs with formalin at a pressure of } \\
20 \mathrm{~cm} \text { of water (p. } 47) \text {. Submit multiple } \\
\text { sections for histologic study. Submit a } \\
\text { section for culture (p. 103). }\end{array}$ & $\begin{array}{l}\text { Intubation trauma and mural edema and } \\
\text { hemorrhage in trachea; hyaline membrane } \\
\text { disease; pulmonary interstitial emphysema; } \\
\text { bronchopulmonary dysplasia. }\end{array}$ \\
\hline Neck organs & $\begin{array}{l}\text { Prepare cross-sections that include larynx, } \\
\text { thyroid, esophagus, and adjacent structures. }\end{array}$ & Intubation trauma. \\
\hline Brain & $\begin{array}{l}\text { For removal and specimen preparation, } \\
\text { see p. } 66 .\end{array}$ & $\begin{array}{l}\text { Hemorrhages or other evidence of birth } \\
\text { trauma; germinal matrix hemorrhages in } \\
\text { premature infants; infarctions of subcortical } \\
\text { white matter in term infants. }\end{array}$ \\
\hline Eyes & $\begin{array}{l}\text { For removal and specimen preparation, } \\
\text { see p. } 85 \text {. }\end{array}$ & $\begin{array}{l}\text { Retinopathy of prematurity } \\
\text { (a vasoproliferative disorder). }\end{array}$ \\
\hline
\end{tabular}

\section{Reference}

1. Stocker JT. Pathology of hyaline membrane disease and acute, reparative, and long-standing "healed" bronchopulmonary dysplasia. In: Pediatric Pulmonary Disease. Stocker JT, ed. Hemisphere, Washington, DC, 1989, p. 101.

\section{Syndrome, Reye's}

NOTE: Hypoglycemia* may have been present, but that condition is difficult or impossible to confirm after death. An immediate autopsy is indicated (see below under "Liver" and "Pancreas").

\begin{tabular}{|c|c|}
\hline Organs and Tissues & Procedures \\
\hline Vitreous & $\begin{array}{l}\text { Submit sample for sodium, chloride, and urea } \\
\text { nitrogen determination (p. } 85 \text { ). }\end{array}$ \\
\hline Blood & $\begin{array}{l}\text { Submit sample for microbiologic (viral) and } \\
\text { serologic study (p. 102), for ammonia and } \\
\text { bilirubin determination, and for determination } \\
\text { of salicylate levels if there is a history of } \\
\text { treatment with this drug. }\end{array}$ \\
\hline Urine & $\begin{array}{l}\text { Obtain sample for biochemical and toxicologic } \\
\text { analysis. }\end{array}$ \\
\hline
\end{tabular}

Heart

Lungs

Liver
Record weight. Request frozen sections for Sudan stain (p. 173).

Submit fresh tissue for bacterial and viral culture (p. 103).

Request paraffin sections and frozen sections for fat stain (see above under "Heart").

Record weight and photograph; submit sample for microbiologic (viral) study (p. 102). Request frozen sections for fat stain (see above under "Heart").
Possible or Expected Findings

Manifestations of dehydration.*

Influenza;* varicella.*

Manifestations of liver failure. Evidence

of salicylate administration.

Assay for organic acids should rule out acylcoenzyme A dehydrogenase deficiency, and toxicity, e.g., of acetaminophen and valproic $\operatorname{acid}(1)$.

Cardiomegaly; fatty changes of myocardium and patchy myocytolysis.

Viral pneumonia rarely present.

Acute interstitial pneumonia;* bronchitis;* hemorrhages. Lipid-laden histiocytes in alveoli.

Hepatomegaly; microvesicular fatty changes (they are not specific); zonal degeneration and necrosis $(2 ; 3)$. 


\begin{tabular}{lll}
\hline Organs and Tissues & Procedures & Possible or Expected Findings \\
\hline $\begin{array}{l}\text { Liver } \\
\text { (continued) }\end{array}$ & $\begin{array}{l}\text { If tissue can be obtained immediately after } \\
\text { death, (p. 5), prepare sample for electron } \\
\text { microscopic study (p. 132). }\end{array}$ & $\begin{array}{l}\text { Increase of peroxisomes; proliferation of } \\
\text { smooth endoplasmic reticulum; swelling of } \\
\text { mitochondria. }\end{array}$ \\
Pancreas & $\begin{array}{l}\text { If tissue can be obtained immediately after } \\
\text { death, (p. 5), prepare sample electron } \\
\text { microscopic study (p. 132). }\end{array}$ & \\
& $\begin{array}{l}\text { See above under "Liver." } \\
\text { Kidneys }\end{array}$ & $\begin{array}{l}\text { Tubular fatty changes. } \\
\text { Brain and spinal cord }\end{array}$ \\
& $\begin{array}{l}\text { See pp. 66 and 70, respectively. See also } \\
\text { under "Encephalopathy, hepatic." }\end{array}$ & Cerebral edema (5). \\
\hline
\end{tabular}

\section{References}

1. Greene CL, Blitzer MG, Shapira E. Inborn errors of metabolism and Reye's syndrome: differential diagnosis. J Pediatr 11988;113:156-159.

2. Fraser JL, Antonioli DA, Chopra S, Wang HH. Prevalence and nonspecificity of microvesicular fatty changes. Mod Pathol 1995;8:65-70.

3. Kimura S, Kobayashi T, Tanaka Y, Sasaki Y. Liver histopathology in clinical Reye syndrome. Brain Dev 1991;13:95-100.

4. Collins DN. Ultrastructural study of intranuclear inclusions in the exocrine pancreas in Reye's syndrome. Lab Invest 1974;30:333-340.

5. Blisard KS, Davis LE. Neuropathologic findings in Reye syndrome. J Child Neurol 1991;6:41-44.

Syndrome, Sanfilippo's (See "Mucopolysaccharidosis.")

Syndrome, Scheie's (See “Mucopolysaccharidosis.”)

Syndrome, Segawa's (See “Syndrome, dystonia.")

\section{Syndrome, Sézary’s (See “Lymphoma.”)}

\section{Syndrome, Sheehan's}

Synonyms: Postpartum pituitary necrosis; Sheehan's disease.

NOTE: Follow procedures described under "Insufficiency, pituitary." In early stages, the pituitary gland shows subtotal or total infarction; in late stages, fibrosis with residual small nests of normal chromophils is present. For in situ cerebral arteriography, see p. 81.

Syndrome, Shy-Drager (See “Atrophy, multiple system.”) Syndrome, Sick Sinus

\begin{tabular}{lll}
\hline Organs and Tissues & Procedures & Possible or Expected Findings \\
\hline Heart & For histologic study of conduction system, & $\begin{array}{l}\text { Excessive fibrosis of sinus node or adjacent } \\
\text { myocardium. }\end{array}$ \\
\hline
\end{tabular}

\section{Syndrome, Sipple's (See “Neoplasia, multiple endocrine.”)}

\section{Syndrome, Sjögren's}

Related Terms: Mikulicz's disease; sicca complex.

Possible Associated Conditions: Chronic hepatitis;* discoid lupus erythematosus; generalized or pulmonary amyloidosis* (1); Hashimoto's thyroiditis; polyarteritis nodosa (necrotizing arteritis);* polymyositis; primary biliary cirrhosis; rheumatoid arthritis;* systemic lupus erythematosus* $(4)$; systemic sclerosis.*

\begin{tabular}{|c|c|c|}
\hline Organs and Tissues & Procedures & Possible or Expected Findings \\
\hline $\begin{array}{l}\text { External examination } \\
\text { and skin }\end{array}$ & Prepare histologic sections of skin. & Sweat gland atrophy. \\
\hline Blood & $\begin{array}{l}\text { Submit sample for determination of } \operatorname{IgA}, \operatorname{IgM} \text {, } \\
\text { and IgG concentrations and of rheumatoid factor. }\end{array}$ & \\
\hline Heart & $\begin{array}{l}\text { Record volume and appearance of pericardial } \\
\text { fluid. }\end{array}$ & Fibrinous or serofibrinous pericarditis. ${ }^{*}$ \\
\hline $\begin{array}{l}\text { Trachea, bronchi, } \\
\text { and lungs }\end{array}$ & $\begin{array}{l}\text { Submit consolidated areas for microbiologic } \\
\text { study (p. 103). Perfuse one lung with formalin } \\
\text { (p. 47). If much inspissated mucus appears to be } \\
\text { present, perfuse also through pulmonary artery. } \\
\text { Submit samples for histologic study. Request } \\
\text { Verhoeff-van Gieson and amyloid stains } \\
\text { (p. 172). }\end{array}$ & $\begin{array}{l}\text { Mucosal glandular atrophy. Inspissated } \\
\text { mucous secretions. Pulmonary arterial } \\
\text { hypertension;* lymphoma* or pseudo- } \\
\text { lymphoma (1); Bronchopneumonia. } \\
\text { Bronchiolitis obliterans organizing } \\
\text { pneumonia (2); interstitial pulmonary } \\
\text { fibrosis;* amyloidosis.* }\end{array}$ \\
\hline
\end{tabular}




\begin{tabular}{|c|c|c|}
\hline Organs and Tissues & Procedures & Possible or Expected Findings \\
\hline Esophagus & $\begin{array}{l}\text { Submit samples for histologic study (pin on } \\
\text { cork board, fix in formalin, and cut on edge). }\end{array}$ & $\begin{array}{l}\text { Submucosal glandular atrophy. Atrophy of } \\
\text { mucosa with infiltrates of lymphocytes and } \\
\text { plasma cells. }\end{array}$ \\
\hline Stomach and duodenum & $\begin{array}{l}\text { Submit samples for histologic study (pin on } \\
\text { cork board, fix in formalin, and cut on edge). }\end{array}$ & $\begin{array}{l}\text { Chronic atrophic gastritis (3); lymphocytosis } \\
\text { of pyloric and Brunner's glands. }\end{array}$ \\
\hline Liver and spleen & Record weights and sample for histologic study. & $\begin{array}{l}\text { Hepatosplenomegaly. Primary biliary } \\
\text { cirrhosis (3). }\end{array}$ \\
\hline Kidneys & $\begin{array}{l}\text { Follow procedures described under "Glomerulo- } \\
\text { nephritis." }\end{array}$ & $\begin{array}{l}\text { Focal or membranous glomerulonephritis;* } \\
\text { interstitial nephritis;* nephrocalcinosis; } \\
\text { tubular atrophy. }\end{array}$ \\
\hline $\begin{array}{l}\text { Neck organs and } \\
\text { tongue; salivary glands }\end{array}$ & $\begin{array}{l}\text { Thyroid, submaxillary salivary gland, base } \\
\text { of tongue, pharynx, and soft palate should be } \\
\text { sampled for histologic study (p. 4). }\end{array}$ & $\begin{array}{l}\text { Atrophic sialadenitis (see below under } \\
\text { "Eyes and lacrimal glands"); loss of taste } \\
\text { buds of tongue; thyroiditis.* }\end{array}$ \\
\hline Eyes and lacrimal glands & $\begin{array}{l}\text { For removal and specimen preparation of eyes, } \\
\text { see p. } 85 \text {. Submit samples of lacrimal glands } \\
\text { (p. 87) for histologic study. }\end{array}$ & $\begin{array}{l}\text { Keratoconjunctivitis. Lymphocytic, } \\
\text { hyalinizing, atrophic dacryoadenitis with } \\
\text { benign lymphoepithelial lesions (Mikulicz's } \\
\text { disease). }\end{array}$ \\
\hline Skeletal muscles & $\begin{array}{l}\text { For sampling and specimen preparation, } \\
\text { see p. } 80 \text {. }\end{array}$ & Myopathy. Polymyositis (2). \\
\hline Other organs and tissues & $\begin{array}{l}\text { Procedures depend on expected findings or } \\
\text { grossly identified abnormalities as listed in } \\
\text { right-hand column. }\end{array}$ & $\begin{array}{l}\text { Lymphomas (4) and pseudolymphomas. } \\
\text { See also under "Possible Associated } \\
\text { Conditions." }\end{array}$ \\
\hline Brain and spinal cord & $\begin{array}{l}\text { For removal and specimen preparation, } \\
\text { see pp. } 65 \text { and } 67 .\end{array}$ & Transverse myelopathy (5). \\
\hline
\end{tabular}

\section{References}

1. Quismorio FP Jr. Pulmonary involvement in primary Sjögren's syndrome. Curr Opin Pulm Med 1996;2:424-428.

2. Imasaki T, Yoshii A, Tanaka S, Ogura T, Ishikawa A, Takahashi T. Polymyositis and Sjögren's syndrome associated with bronchiolitis obliterans organizing pneumonia. Intern Med 1996;35:231-235.

3. Sheikh SH, Shaw-Stiffel TA. The gastrointestinal manifestations of Sjögren's syndrome. Am J Gastroenterol 1995;90:9-14.

4. Anaya JM, McGuff HS, Banks PM, Talal N. Clinicopathological factors relating malignant lymphoma with Sjögren's syndrome. Semin Arthritis Rheumat 1996;25:337-346.

5. Lyu RK, Chen ST, Tank LM, Chen TC. Acute transverse myelopathy and cutaneous vasculopathy in primary Sjögren's syndrome. Euro Neurol 1995;35:359-362.

\section{Syndrome, Steele-Richardson (See "Disease, Parkinson's.")}

\section{Syndrome, Stevens-Johnson (See "Erythema multiforme.")}

\section{Syndrome, Stiff-Man}

Related Terms: Armadillo disease; continuous muscle fiber activity; neuromyotonia; paraneoplastic opsoclonus (1); quantal squander.

\begin{tabular}{lll}
\hline Organs and Tissues & Procedures & Possible or Expected Findings \\
\hline $\begin{array}{l}\text { Brain, spinal cord, and } \\
\text { peripheral nerves }\end{array}$ & $\begin{array}{l}\text { For removal and specimen preparation, } \\
\text { see pp. 65, 67, and 79, respectively. }\end{array}$ & No diagnostic findings. \\
Skeletal muscles & $\begin{array}{l}\text { For sampling and specimen preparation, } \\
\text { see p. 80. }\end{array}$ & Variable but not diagnostic findings. \\
\hline
\end{tabular}

\section{Reference}

1. Dropcho EJ. Autoimmune central nervous system paraneoplastic disorders: mechanisms, diagnosis, and therapeutic options. Ann Neurol 1995; 37:S102-S113. 


\section{Syndrome, Superior Vena Cava}

Related Term: Superior vena cava obstruction.

\begin{tabular}{|c|c|c|}
\hline Organs and Tissues & Procedures & Possible or Expected Findings \\
\hline Chest cavity & $\begin{array}{l}\text { Dissect superior vena cava and its tributaries } \\
\text { in situ, with head and neck of deceased } \\
\text { well-extended (place wooden block or some } \\
\text { other support under scapulas). Continue } \\
\text { dissection of veins into neck and axillas. } \\
\text { Record and photograph site of thrombosis or } \\
\text { of compression by surrounding pathologic } \\
\text { conditions. Submit samples for histologic study. }\end{array}$ & $\begin{array}{l}\text { Benign or malignant tumors; fibrosing } \\
\text { mediastinitis;* postradiation fibrosis; } \\
\text { infectious disease (tuberculosis,* } \\
\text { histoplasmosis*); thoracic aortic aneurysm;* } \\
\text { chronic constrictive pericarditis;* chest } \\
\text { trauma; arteriovenous fistula between } \\
\text { ascending aorta and superior vena cava; } \\
\text { congenital anomaly of superior vena cava. }\end{array}$ \\
\hline
\end{tabular}

\section{Syndrome, Toxic Shock}

Synonyms and Related Terms: Staphylococcal scarlet fever.

NOTE: (1) Collect all tissues that appear to be infected. (2) Request aerobic and anaerobic cultures. (3) Request Gram stain (p. 172). (4) Usually, no special precautions are indicated. (5) Serologic studies are available from the Centers for Disease Control and Prevention, Atlanta, GA (p. 135). (6) This is a reportable disease.

\begin{tabular}{lll}
\hline Organs and Tissues & Procedures & Possible or Expected Findings \\
\hline $\begin{array}{l}\text { External examination, } \\
\text { skin, oral cavity, } \\
\text { and vagina }\end{array}$ & $\begin{array}{l}\text { Record extent and character of skin and oral } \\
\text { lesions; prepare photographs. }\end{array}$ & $\begin{array}{l}\text { Erythematous, deep red "sun burn" rash; } \\
\text { oral mucosal hyperemia; desquamation; } \\
\text { conjunctival hyperemia. } \\
\text { Infected tampon and vaginal discharge. }\end{array}$ \\
Culture vaginal discharge, if present. & $\begin{array}{l}\text { Culture cervix. Culture tampon, if present. } \\
\text { Procedures depend on expected findings or } \\
\text { grossly identified abnormalities as listed in } \\
\text { right-hand column. }\end{array}$ & $\begin{array}{l}\text { Periportal inflammation of liver; acute } \\
\text { tubular necrosis of kidneys; hyaline } \\
\text { membranes in lungs; evidence of } \\
\text { coagulopathy. }\end{array}$ \\
& $\begin{array}{l}\text { Remove pelvic organs; open vagina and cervix } \\
\text { with uterus in posterior midline; photograph } \\
\text { and sample for histologic study. }\end{array}$ & $\begin{array}{l}\text { Vaginal hyperemia; desquamation/ulceration } \\
\text { of vaginal or cervical mucosa. }\end{array}$ \\
\hline
\end{tabular}

\section{Syndrome, Turcot (See “Polyposis, familial, and related syndromes.")}

\section{Syndrome, Turner}

Synonyms and Related Terms: Gonadal dysgenesis; primary ovarian failure.

\begin{tabular}{lll}
\hline Organs and Tissues & Procedures & Possible or Expected Findings \\
\hline
\end{tabular}

External examination Record body weight and length, stature, and distribution of head, axillary, and pubic hair. Record and prepare photographs of features of face and neck. Prepare skeletal roentgenograms.

Breasts

Blood and fascia lata

Heart and aorta
Submit samples of breast tissues for histologic study.

These specimens should be collected using aseptic technique for tissue culture for chromosome analysis (see Chapter 10).

Procedures depend on expected findings or grossly identified abnormalities as listed in right-hand column.
Premature aging; increased number of pigmented nevi; infantile sex organs; webbed neck; broad chest with wide spacing of nipples.

Short fourth metacarpal; abnormal epiphyseal fusions; osteochondrosis-like changes of spine. Osteoporosis.* Infantile breast tissue.

45, $\mathrm{X}(\mathrm{XO})$.

Bicuspid aortic valve;* coarctation of aorta.* Rarely other anomalies (1). 


\begin{tabular}{|c|c|c|}
\hline Organs and Tissues & Procedures & Possible or Expected Findings \\
\hline Ovaries & Submit for histologic study. & Decreased/absent follicles. \\
\hline Intestinal tract & Submit samples of all portions for histologic study. & Intestinal telangiectases. \\
\hline $\begin{array}{l}\text { Liver and extrahepatic } \\
\text { bile ducts }\end{array}$ & $\begin{array}{l}\text { If biliary atresia is suspected, follow procedures } \\
\text { described under that heading. }\end{array}$ & Biliary atresia.* \\
\hline Kidneys and ureters & $\begin{array}{l}\text { Dissect kidneys and ureters in situ and record } \\
\text { findings. }\end{array}$ & Horseshoe kidney; double ureters. \\
\hline Pelvic organs & $\begin{array}{l}\text { Submit samples of gonads or-if gonads cannot } \\
\text { be identified-equivalent ridges on mesosalpinx } \\
\text { for histologic study. Also submit samples of } \\
\text { endometrium, cervix, and vagina. }\end{array}$ & Streak gonads without germ cells or follicles. \\
\hline Thyroid gland & $\begin{array}{l}\text { Record weight and submit sample for histologic } \\
\text { study. }\end{array}$ & Hashimoto's thyroiditis.* \\
\hline Other organs & $\begin{array}{l}\text { Procedures depend on expected findings or } \\
\text { grossly identified abnormalities as listed in } \\
\text { right-hand column. }\end{array}$ & $\begin{array}{l}\text { Manifestations of diabetes mellitus,* } \\
\text { hypertension,* or thyrotoxicosis. } \\
\text { Neuroblastoma and related tumors (2). }\end{array}$ \\
\hline Eyes & For removal and specimen preparation, see p. 85 . & Keratoconus; retinal detachments (3). \\
\hline
\end{tabular}

\section{References}

1. Oohara K, Yamazaki T, Sakaguchi K, Nakayama M, Kobayashi A. Acute aortic dissection, aortic insufficiency, and a single coronary artery in a patient with Turner's syndrome. J Cardiovasc Surg 1995;36:273-275.

2. Blatt J, Olshan AF, Lee PA, Ross JL. Neuroblastoma and related tumors in Turner's syndrome. J Pediatr 1997;131:666-670.

3. Mason JO III, Tasman W. Turner's syndrome associated with bilateral retinal detachments. Am J Ophthalmol 1996;122:742-743.

\section{Syndrome, Waterhouse-Friderichsen (See "Disease, meningococcal.”)}

\section{Syndrome, Weil’s (See “Leptospirosis.”)}

\section{Syndrome, Wernicke-Korsakoff}

Related Terms: Alcoholic Wernicke's encephalopathy; Korsakoff's psychosis; nonalcoholic Wernicke's encephalopathy $(1,2)$; Wernicke's disease.

\begin{tabular}{lll}
\hline Organs and Tissues & Procedures & Possible or Expected Findings \\
\hline Brain and spinal cord & $\begin{array}{l}\text { For removal and specimen preparation, see } \\
\text { pp. 65 and 67, respectively. For selection } \\
\text { of histologic samples, see right-hand column. } \\
\text { Request LFB stain to highlight areas of acute } \\
\text { necrosis (p. 172). }\end{array}$ & $\begin{array}{l}\text { Most characteristic lesions affect mammillary } \\
\text { bodies, periventricular regions of 3rd } \\
\text { (anterior fornices) and 4th ventricles (dorsal } \\
\text { vagal nucleus) and aequeduct. Hemorrhage } \\
\text { and necrosis are typical of acute stage; } \\
\text { shrinkage and brown discoloration of } \\
\text { mammillary bodies suggest chronic disease. }\end{array}$ \\
& $\begin{array}{l}\text { Procedures depend on expected findings or } \\
\text { grossly identified abnormalities as listed in } \\
\text { right-hand column. }\end{array}$ & $\begin{array}{l}\text { Other manifestations of chronic alcoholism } \\
\text { (see under "Alcoholism and alcohol } \\
\text { intoxication") or of nonalcoholic } \\
\text { steatohepatitis (1,2). }\end{array}$ \\
& $\begin{array}{l}\text { For sampling and specimen preparation, } \\
\text { Peeripheral neuropathy. }\end{array}$ & See also under "Beriberi." \\
\hline
\end{tabular}

\section{References}

1. Christodoulakis M, Maris T, Plaitakis A, Melissas J. Wernicke's encephalopathy after vertical banded gastroplasty for morbid obesity. Eur J Surg 1997;163:473-474.

2. Yamamoto T. Alcoholic and non-alcoholic Wernicke's encephalopathy. Be alert to the preventable and treatable disease. Internal Med 1996;35: 754-755. 


\section{Syndrome, Wiskott-Aldrich (See “Syndrome, primary immunodeficiency.")}

\section{Syndrome, Wolff-Parkinson-White (See “Malformation, Ebstein's” and “Preexcitation, ventricular.”)}

\section{Syndrome, Zellweger}

Synonyms and Related Terms: Adrenoleucodystrophy; cerebro-hepato-renal syndrome; infantile Refsum's disease.*

NOTE: This congenital familial cholestatic syndrome results from impaired assembly of peroxisomes and has its main manifestations in the brain, liver, and kidneys (1). Craniofacial dysmorphia and hepatomegaly with siderosis are typical findings.

\section{Reference}

1. Lindhard A, Graem N, Skovby F, Jeppesen D. Postmortem findings and prenatal diagnosis of Zellweger syndrome. Case report. APMIS 1993;101:226-228.

Syndrome, Zieve (See “Alcoholism and alcohol intoxication" and "Disease, alcoholic liver.")

Syndrome, Zollinger-Ellison

Related Term: Endocrine hyperfunction and ulcer disease.

Possible Associated Condition: Multiple endocrine neoplasia.*

\begin{tabular}{|c|c|c|}
\hline Organs and Tissues & Procedures & Possible or Expected Findings \\
\hline Vitreous & $\begin{array}{l}\text { Submit sample for sodium, chloride, urea } \\
\text { nitrogen, and potassium determination (p. 85). }\end{array}$ & $\begin{array}{l}\text { Manifestations of dehydration* and } \\
\text { hypokalemia. Postmortem values of } \\
\text { potassium are not reliable (p. 114). }\end{array}$ \\
\hline $\begin{array}{l}\text { Esophagus and } \\
\text { gastrointestinal tract }\end{array}$ & $\begin{array}{l}\text { Record character and location of ulcers. } \\
\text { Histologic sections should include ulcers and } \\
\text { all portions of stomach. Before samples are } \\
\text { sectioned, pin stomach and other involved } \\
\text { hollow viscera on corkboard for fixation. } \\
\text { Request PAS-alcian blue stain for sections of } \\
\text { gastric mucosa (p. 173). If there is a tumor in } \\
\text { the gastric or duodenal wall, follow procedures } \\
\text { described below under "Pancreas." }\end{array}$ & $\begin{array}{l}\text { Peptic ulcers in esophagus, stomach, } \\
\text { duodenum, jejunum, and ileum. Usually, } \\
\text { ulcers are at or near duodenal bulb. Parietal } \\
\text { cells in corpus and fundus of stomach may be } \\
\text { increased. } \\
\text { Gastrinoma in cardia/fundus of stomach (1) } \\
\text { or wall of duodenum (2). Fundic argyrophil } \\
\text { carcinoid tumors (in patients with type } 1 \\
\text { multiple endocrine neoplasia) (3). }\end{array}$ \\
\hline Pancreas & $\begin{array}{l}\text { If tumor is not immediately identifiable, } \\
\text { prepare 2-mm sagittal slices of whole organ. } \\
\text { Examine slices under dissecting microscope. } \\
\text { Request aldehyde-thionin stain (p. 172), } \\
\text { which stains islet B cells and frequently } \\
\text { insulinoma cells. Request Grimelius silver } \\
\text { stain (p. 172). Silver techniques for islet } \\
\text { D or A }\left(\mathrm{A}_{1} \text { or } \mathrm{A}_{2} \text { ) cells are also indicated. }\right. \\
\text { Snap-freeze fresh tumor tissue for immuno- } \\
\text { histologic study. Submit tissue samples for } \\
\text { electron microscopy (p. 132). }\end{array}$ & $\begin{array}{l}\text { Gastrinoma or increased number of islets } \\
\text { of Langerhans with high proportion of } \\
\text { non-beta cells. } \\
\text { Insulinomas may give positive aldehyde- } \\
\text { thionin stain. } \\
\text { Gastrinomas give positive Grimelius silver } \\
\text { stain. } \\
\text { Peroxidase-labeled gastrin antibodies seem } \\
\text { to react with cells in all gastrinomas. }\end{array}$ \\
\hline Other organs & $\begin{array}{l}\text { Submit extrapancreatic primary or metastatic } \\
\text { tumor tissue for biochemical and other studies, } \\
\text { as described above. Other procedures depend } \\
\text { on expected findings or grossly identified } \\
\text { abnormalities as listed in right-hand column. }\end{array}$ & $\begin{array}{l}\text { Aberrant gastrinoma may occur at hilus of } \\
\text { spleen. Metastases are found in regional } \\
\text { lymph nodes and liver. There may be } \\
\text { manifestations of multiple endocrine } \\
\text { neoplasia.* }\end{array}$ \\
\hline
\end{tabular}

\section{References}

1. Gibril F, Curtis LT, Termanini B, Fritsch MK, Lubensky IA, Doppman JL, et al. Primary cardiac gastrinoma causing Zollinger-Ellison syndrome. Gastroenterology 1997;112:567-574.

2. Kisker O, Bastian D, Bartsch D, Nies C, Rothmund M. Localization, malignant potential, and surgical management of gastrinoma. World J Surg 1998;22:651-657.

3. Cadiot G, Vissuzaine C, Potet F, Mignon M. Fundic argyrophil carcinoid tumor in a patient with sporadic-type Zollinger-Ellison syndrome. Dig Dis Sci 1995;40:1275-1278. 


\section{Syphilis, Acquired}

Synonym: Treponema pallidum infection.

NOTE: Congenital syphilis is presented below under a separate heading.

(1) Collect all tissues that appear to be infected. (2) Culture methods are not available, but animal inoculation can be performed. Consultation with a microbiology laboratory is recommended. (3) Special stains for Treponema pallidum rarely are positive except with material from fresh lesions of primary or secondary syphilis. Levaditi's stain or Warthin-Starry stain is recommended for paraffin sections (p. 172), and labeled fluorescent antibody techniques are recommended for frozen sections. India ink preparations or the Fontana-Masson silver stain has been used for the study of fresh lesions, and electron microscopy has also been employed. (4) In adult autopsies, no special precautions are indicated (see below under "Liver"). (5) Serologic studies are available from local and state health department laboratories (p. 135). (6) This is a reportable disease.

\begin{tabular}{lll}
\hline Organs and Tissues & Procedures & Possible or Expected Findings
\end{tabular}

External examination

$$
\begin{aligned}
& \text { Record and prepare photographs of all } \\
& \text { abnormalities listed in right-hand column. } \\
& \text { Prepare smears and sections of acute lesions; } \\
& \text { prepare sections of older skin lesions or } \\
& \text { anogenital mucosal lesions. } \\
& \text { Prepare skeletal roentgenograms. }
\end{aligned}
$$

\section{Cerebrospinal fluid}

Lymph nodes

Heart and aorta

Other organs and tissues

Brain and spinal cord

Bones and joints
Obtain sample for laboratiory study (see p. 104).

For coronary arteriography (p. 118), inject contrast medium into the clamped, ascending aorta to show takeoff of coronary arteries. Record competence of aortic valve (p. 29). Leave aorta attached to heart. Request Verhoeff-van Gieson stain for histologic sections of aorta (p. 173).

Procedures depend on expected findings or grossly identified abnormalities. Submit samples for histologic study of small arteries. For removal and specimen preparation, see pp. 65 and 67, respectively.

For removal, prosthetic repair, and specimen preparation, see p. 95 .
Hunterian chancre in primary syphilis; condylomata lata. Noduloulcerative gummas and scarring in later stages.

Syphilitic periostitis; gummas; arthritis (Charcot joints of knees, hips, ankles, and lumbar and thoracic spine).

Lymphocytosis and increased protein concentrations.

Syphilitic lymphadenitis. Intimal proliferation with narrowing of coronary orifices; myocarditis.

Syphilitic aortic valvulitis and aortic insufficiency.* Syphilitic aortitis with arteritis of vasa vasorum. Saccular thoracic aortic aneurysm.*

Meningitis with mononuclear cells mainly in adventitial/perivascular distribution. Infarcts; focal cortical atrophy; gliosis of floor of 4 th ventricle. Tabes dorsalis.* See above under "External examination and skin."

\section{Syphilis, Congenital}

Related Term: Congenital neurosyphilis.*

NOTE: Prior to $20 \mathrm{wk}$ gestation, the destructive effects of syphilis may not be seen. Gummata are rare in neonates. Tabes dorsalis is also uncommon. Serologic diagnosis is difficult in the neonate because of transplacental transfer of maternal $\mathrm{IgG}$ antibodies. Acquired syphilis (syphilis in adulthood) is presented above under a separate heading.

(1) Collect all tissues that appear to be infected. (2) Culture methods are not available, but animal inoculation can be performed. Consultation with a microbiology laboratory is recom- mended. (3) Special stains for Treponema pallidum rarely are positive except with material from fresh lesions of primary or secondary syphilis and of syphilitic hepatitis of the newborn. Levaditi's stain or Warthin-Starry stain is recommended for paraffin sections (p. 172), and labeled fluorescent antibody techniques are recommended for frozen sections. India ink preparations or the Fontana-Masson silver stain has been used for the study of fresh lesions, and electron microscopy has also been employed. (4) In neonates, special precautions are indicated (see below under "Liver") (5) Serologic studies are available from local and state health department laboratories (p. 135). (6) This is a reportable disease.

\begin{tabular}{lll}
\hline Organs and Tissues & Procedures & Possible or Expected Findings \\
\hline Placenta & Record weight and submit samples & Villous edema; plasma cell villitis and \\
& for histologic study. & chorioamnionitis. \\
External examination, & Record and prepare photographs of all & $\begin{array}{l}\text { Growth retardation; jaundice; maculopapular } \\
\text { skin, oral and nasal cavity }\end{array}$ \\
& abnormalities listed in right-hand column. & rash;lae; condylomata lata;
\end{tabular}




\begin{tabular}{|c|c|c|}
\hline Organs and Tissues & Procedures & Possible or Expected Findings \\
\hline \multirow[t]{2}{*}{$\begin{array}{l}\text { External examination, } \\
\text { skin, oral and nasal } \\
\text { cavity (continued) }\end{array}$} & Prepare histologic sections of skin lesions. & $\begin{array}{l}\text { hydrocephalus; }{ }^{*} \text { dental deformities } \\
\text { (Hutchinson's teeth); saddle nose; frontal } \\
\text { bossing of skull; saber shins; snuffles; nasal } \\
\text { septal perforation; rhagades; ulnar deviation } \\
\text { of fingers; hydrops fetalis }(1) \text {. }\end{array}$ \\
\hline & Prepare skeletal roentgenograms. & $\begin{array}{l}\text { Irregular radiolucencies in the metaphyses } \\
\text { and diaphyses (2). }\end{array}$ \\
\hline Cerebrospinal fluid & $\begin{array}{l}\text { Submit samples for serologic biochemical, } \\
\text { cytologic, and microbiologic study (p. 104). }\end{array}$ & $\begin{array}{l}\text { A detectable fluorescent antitreponemal } \\
\text { antibody (absorbed) titer. }{ }^{a}\end{array}$ \\
\hline Blood & Submit sample for serologic study. & $\begin{array}{l}\text { A detectable fluorescent antitreponemal } \\
\text { antibody (absorbed) titer }{ }^{a}\end{array}$ \\
\hline Liver & $\begin{array}{l}\text { Record weight and sample for histologic } \\
\text { study. For special stains and infectious } \\
\text { precautions, see above under "Note." }\end{array}$ & $\begin{array}{l}\text { Syphilitic hepatitis. Histologic sections show } \\
\text { abundance of Treponema organisms. }\end{array}$ \\
\hline Other organs & $\begin{array}{l}\text { Procedures depend on expected findings or } \\
\text { grossly identified abnormalities as listed in } \\
\text { right-hand column. Submit samples for } \\
\text { histologic study. }\end{array}$ & $\begin{array}{l}\text { Fibrosing pneumonia; thymic abscesses; } \\
\text { splenomegaly; thickening of bowel wall by } \\
\text { inflammation and fibrosis }(2) \text {; splenomegaly; } \\
\text { interstitial fibrosis and inflammation of } \\
\text { pancreas (2). }\end{array}$ \\
\hline Brain and spinal cord & $\begin{array}{l}\text { For removal and specimen preparation, } \\
\text { see pp. } 66 \text { and } 70 \text {, respectively. For } \\
\text { histologic sections, request Warthin-Starry } \\
\text { stain for spirochetes (p. 173). }\end{array}$ & $\begin{array}{l}\text { Chronic meningitis, encephalitis, and } \\
\text { myelitis. For details, see under } \\
\text { "Neurosyphilis, congenital." }\end{array}$ \\
\hline Eyes & $\begin{array}{l}\text { For removal and specimen preparations, } \\
\text { see p. } 85 \text {. }\end{array}$ & $\begin{array}{l}\text { Interstitial keratitis; choroiditis; uveitis; } \\
\text { optic atrophy. }\end{array}$ \\
\hline Bones and joints & $\begin{array}{l}\text { For removal, prosthetic repair and specimen } \\
\text { preparation, see p. } 95 \text {. }\end{array}$ & $\begin{array}{l}\text { Mononuclear periostitis; osteochondritis; } \\
\text { "Clutton's joints" (fused joints). }\end{array}$ \\
\hline
\end{tabular}

${ }^{a}$ Immunofluorescent antigen testing is more sensitive than silver staining for the detection of Treponema pallidum (3).

\section{References}

1. Levine Z, Sherer DM, Jacobs A, Rotenberg O. Nonimmune hydrops fetalis due to congenital syphilis associated with negative intrapartum maternal serology screening. Am J Perinatol 1998;15:233-236.

2. Oppenheimer EH, Dahms BB. Congenital syphilis in the fetus and neonate. Perspectives Pediatr Pathol 1981;6:115-138.

3. Rawstron SA, Vetrano J, Tannis G, Bromberg K. Congenital syphilis: detection of Treponema pallidum in stillborns. Clin Infect Dis 1997;24:24-27.

\section{Syringomyelia}

Synonyms and Related Term: Hydromyelia; idiopathic syringomyelia; secondary syringomyelia; syringobulbia.

Possible Associated Conditions: With idiopathic syringomyelia_Arnold Chiari malformation, type I;* basilar impression;* Klippel-Feil syndrome;* spina bifida. With secondary syringomyelia-Intramedullary gliomas (ependymoma, pilocytic astrocytoma) and vascular tumors; spinal arachnoiditis and pachymeningitis; traumatic myelopathy.

\begin{tabular}{ll}
\hline Organs and Tissues & Procedures \\
\hline External examination & $\begin{array}{l}\text { Record and prepare photographs of all } \\
\text { abnormalities as listed in right-hand column. }\end{array}$
\end{tabular}

Prepare roentgenograms of spine and joints.

Brain and spinal cord
For removal and specimen preparation, see pp. 66 and 70, respectively. For histologic sampling, see right-hand column.

\section{Possible or Expected Findings}

Hypertrophy of body parts. Muscle atrophy of upper extremities and hands. Cyanosis, hyperkeratosis, and other trophic changes of hands.

Kyphoscoliosis. Clubfoot deformities. Cervical rib. Traumatic osteoarthropathy (Charcot joints).

Hydrocephalus.* Cervical spinal cord is swollen and tense, with cavitation (syrinx) containing clear fluid. Wall of cavity consists of degenerated glial and neural elements, with marked gliosis. Spinal cord parenchyma is markedly compressed. See also above under "Possible Associated Conditions." 
Tabes Dorsalis

Related Terms: General paralysis; locomotor ataxia; parenchymatous neurosyphilis; taboparesis.

Possible Associated Conditions: Acquired immunodeficiency syndrome.*

\begin{tabular}{|c|c|c|}
\hline Organs and Tissues & Procedures & Possible or Expected Findings \\
\hline \multirow[t]{2}{*}{ External examination } & & Ulcers of feet. \\
\hline & Prepare roentgenograms of major joints. & Degenerative arthritis (Charcot joints). \\
\hline Cerebrospinal fluid & $\begin{array}{l}\text { Submit sample for serologic study, cell count, } \\
\text { and determination of protein concentrations } \\
\text { (p. 104). }\end{array}$ & $\begin{array}{l}\text { Late in the disease, serologic tests for } \\
\text { syphilis* may be negative. Pleocytosis and } \\
\text { increased protein concentrations may } \\
\text { indicate presence of meningitis.* }\end{array}$ \\
\hline $\begin{array}{l}\text { Brain, spinal cord, } \\
\text { spinal ganglia, and } \\
\text { nerves of lumbar plexus }\end{array}$ & $\begin{array}{l}\text { For removal and specimen preparation of } \\
\text { brain, spinal cord, and spinal ganglia, } \\
\text { see pp. } 65,67 \text {, and } 69 \text {, respectively. } \\
\text { Request Luxol fast blue stain for myelin } \\
\text { and Bielschowsky's stain for axons (p. 172). }\end{array}$ & $\begin{array}{l}\text { Syphilitic meningoencephalitis (general } \\
\text { paresis) may also be present. Degeneration } \\
\text { of dorsal root ganglia and posterior nerve } \\
\text { roots (mainly lumbosacral) with Wallerian } \\
\text { degeneration of posterior columns. } \\
\text { Posterior roots are grey and shrunken and the } \\
\text { spinal cord is atrophic with excavated } \\
\text { posterior surface. }\end{array}$ \\
\hline Eyes and optic nerves & $\begin{array}{l}\text { For removal and specimen preparation, } \\
\text { see p. } 85 \text {. }\end{array}$ & Optic nerve atrophy. \\
\hline
\end{tabular}

Talcosis (See "Pneumoconiosis.")

Telangiectasia, Hereditary Hemorrhagic (See "Disease, Osler-Rendu-Weber.")

\section{Tetanus}

Synonym: Clostridium tetani infection; lockjaw.

NOTE: (1) Collect all tissues that appear infected. (2) Request aerobic and anaerobic cultures. However, the presence of tetanus bacilli established in culture is not diagnostic, since spores of $C$. tetani frequently contaminate wounds. (3) Request Gram stain (p. 172). (4) Usually, no special precautions are indicated. (5) Serologic studies are available from the Centers of Disease Control and Prevention, Atlanta, GA (p. 135). (6) This is a reportable disease.

\begin{tabular}{lll}
\hline Organs and Tissues & Procedures & Possible or Expected Findings \\
\hline External examination & $\begin{array}{l}\text { Record body weight and length and appearance } \\
\text { of wound(s); photograph and excise wound(s) } \\
\text { for histologic study. }\end{array}$ & $\begin{array}{l}\text { Evidence of weight loss; subcutaneous } \\
\text { abscesses. }\end{array}$ \\
& $\begin{array}{l}\text { Record evidence of parenteral drug abuse, } \\
\text { especially subcutaneous injection (i.e., } \\
\text { "skin popping"). } \\
\text { Prepare chest roentgenogram. }\end{array}$ & Tetanus may occur in drug addicts. \\
& Submit sample for microbiologic study (p. 104). & $\begin{array}{l}\text { Tension pneumothorax* after mechanical } \\
\text { Centilation. }\end{array}$ \\
& & Bacterial meningitis must be ruled out.
\end{tabular}




\begin{tabular}{lll}
\hline Organs and Tissues & Procedures & Possible or Expected Findings \\
\hline Lungs & $\begin{array}{l}\text { Submit one lobe for microbiologic study } \\
\text { (p. 103). }\end{array}$ & $\begin{array}{l}\text { Aspiration and bronchopneumonia; } \\
\text { embolism;* atelectasis. }\end{array}$ \\
\hline
\end{tabular}

\section{Tetany}

NOTE: See under name of suspected underlying conditions, such as hyperparathyroidism, ${ }^{*}$ malabsorption syndrome, ${ }^{*}$ or vitamin D deficiency. * For interpretation of calcium concentrations in blood and vitreous, see p. 347. Respiratory or metabolic alkalosis* cannot be confirmed after death; determination of blood $\mathrm{pH}$ is not helpful because acidity increases rapidly after death. The concentration of serum phosphates also increases after death.

\section{Tetralogy of Fallot}

Synonym: Large ventricular septal defect with pulmonary stenosis* or atresia.*

NOTE: The basic anomaly consists of subpulmonary stenosis, ventricular septal defect, overriding aorta, and secondary right ventricular hypertrophy. For general dissection techniques, see p. 33. Surgical interventions include modified Blalock-Taussig subclavian-to-pulmonary arterial shunt; complete repair with

patch closure of ventricular septal defect, and reconstruction of right ventricular outflow tract (with a patch or with an extracardial conduit).

Possible Associated Conditions: Origin of left pulmonary artery from aorta; minor abnormalities of the tricuspid valve; absent ductal artery (25\%); atrial septal defect* (in 20\%; pentalogy of Fallot); bicuspid pulmonary valve;* dextroposition of aorta; double aortic arch; hypoplastic pulmonary arteries; patent ductal artery;* patent oval foramen; complete atrioventricular septal defect* (usually with Down's syndrome*); persis-tent left superior vena cava; pulmonary valve atresia (see "Atresia, pulmonary valve, with ventricular septal defect"); right aortic arch (25\%); second ventricular septal defect; origin of left anterior descending (LAD) or right coronary artery (RCA) from contralateral aortic sinus or coronary artery $(5 \%)$; syndrome with absent pulmonary valve and massively dilated pulmonary arteries (rare).

\begin{tabular}{lll}
\hline Organs and Tissues & Procedures & Possible or Expected Findings \\
\hline
\end{tabular}

Chest cavity Record course of superior vena cava and of its tributaries.

Record course of thoracic aorta and of its main branches.

Record origin of pulmonary arteries.

Heart

If infective endocarditis is suspected, follow procedures described under that heading (p.103). For coronary arteriography, see p. 118.

Lungs

Perfuse one lung with formalin (p. 47).

Request Verhoeff-van Gieson stain (p. 173).

Other organs Procedures depend on expected findings or grossly identified abnormalities as listed in right-hand column.

\section{Thalassemia}

Synonyms and Related Terms: Congenital hemolytic anemia; alpha-thalassemia; beta-thalassemia major (Cooley's anemia); beta thalassemia minor (beta-thalassemia trait).

NOTE: The changes described below are observed primarily in beta-thalassemia major.

\begin{tabular}{ll}
\hline Organs and Tissues & Procedures \\
\hline External examination & $\begin{array}{l}\text { Record body weight and length; record and } \\
\text { prepare photographs of other abnormalities as } \\
\text { listed in right-hand column. }\end{array}$
\end{tabular}

Possible or Expected Findings

Evidence of wasting with peculiar brownish skin pigmentation. Hydrops fetalis (1) and limb deformities (2) in rare forms of alphathalassemia. 


\begin{tabular}{lll}
\hline Organs and Tissues & Procedures & Possible or Expected Findings \\
\hline $\begin{array}{l}\text { External examination } \\
\text { (continued) }\end{array}$ & $\begin{array}{l}\text { Prepare roentgenogram of skull and, if } \\
\text { indicated, of deformed extremities. }\end{array}$ & $\begin{array}{l}\text { Malocclusion of jaws due to enlargement of } \\
\text { malar bones; bone deformities of calvaria. }\end{array}$ \\
All organs & $\begin{array}{l}\text { Deformed extremities. } \\
\text { Cardiomegaly and myocardial hemosiderosis } \\
\text { grossly identified abnormalities as listed in } \\
\text { right-hand column. See also under "Anemia, } \\
\text { hemolytic." }\end{array}$ & $\begin{array}{l}\text { with manifestations of congestive heart } \\
\text { failure.* Pancreatic hemosiderosis } \\
\text { (with or without diabetes mellitus); }\end{array}$ \\
& hepatosplenomegaly. \\
\hline
\end{tabular}

\title{
References
}

1. Chui DH, Waye JS. Hydrops fetalis caused by alpha-thalassemia: an emerging health care problem. Blood 1998;91:2213-2222.

2. Chitayat D, Silver MM, O'Brien K, Wyatt P, Waye JS, Chiu DH, et al. Limb defects in homozygous alpha-thalassemia: report of three cases. Am J Med Genet 1997;68:162-167.

\section{Thallium (See "Poisoning, thallium.")}

\section{Thirst (See "Dehydration.")}

Thromboangiitis Obliterans (See “Disease, Buerger's.”)

Thrombocytopenia (See "Purpura, thrombotic thrombocytopenic" and "Syndrome, hemolytic uremic.")

\author{
Thrombophlebitis, Ileofemoral (See "Thrombosis, venous.")
}

\section{Thrombophlebitis Migrans (See "Phlebitis.")}

\section{Thrombosis, Cavernous Sinus (See "Thrombosis, cerebral venous sinus.")}

\section{Thrombosis, Cerebral Venous Sinus}

Related Term: Cavernous sinus thrombosis.

NOTE: Idiopathic recurrent venous thrombosis also may affect the cerebral venous sinuses.

\begin{tabular}{lll}
\hline Organs and Tissues & Procedures & Possible or Expected Findings
\end{tabular}

External examination $\quad$ Record body weight and length and skin turgor.

Prepare photograph of face.

Vitreous and eyes

Cerebrospinal fluid Brain and meninges

Calvaria and base of skull with venous sinuses
If dehydration is suspected, submit samples of vitreous for electrolyte studies (p. 85). For removal and specimen preparation of eyes, see p. 85 .

Submit sample for microbiologic study (p. 104). For removal and specimen preparation, see p. 65.

For exposure of venous sinuses, see p. 71. Submit contents of affected sinuses for microbiologic study. Prepare smears of contents and submit samples of sinus walls for histologic study.
In infants, manifestations of marasmus and dehydration.* Head injury;* infection of skin in upper half of face. Presence of edema of forehead and eyelids, proptosis, and chemosis indicate cavernous sinus thrombosis.

In infants, manifestations of dehydration.*

Thrombosis of angular and superior ophthalmic veins may be associated with cavernous sinus thrombosis.

See below under "Brain and meninges." Cerebral abscess* or tumor; meningitis.* Venous infarction of brain may be caused by superior sagittal sinus thrombosis. Epidural and subdural empyema* may be present. Superior sagittal sinus thrombosis may be associated with terminal diseases with marasmus, with osteomyelitis, * or a tumor of the skull. (See also below under "Systemic veins.") Thrombosis and thrombophlebitis may occur in all venous sinuses. 


\begin{tabular}{lll}
\hline Organs and Tissues & Procedures & Possible or Expected Findings \\
\hline Pituitary gland & $\begin{array}{l}\text { For dissection and specimen preparation, } \\
\text { see p. 71. }\end{array}$ & $\begin{array}{l}\text { Infarction or abscess of pituitary gland may } \\
\text { be caused by cavernous sinus thrombosis. } \\
\text { Paranasal sinuses, } \\
\text { middle ears, and } \\
\text { mastoid cells }\end{array}$ \\
$\begin{array}{l}\text { For exposure of middle ears and paranasal } \\
\text { sinuses, see pp. 72 and 71, respectively. If } \\
\text { there is evidence of infection, prepare smears } \\
\text { of contents and submit for microbiologic study. }\end{array}$ & $\begin{array}{l}\text { Acutis media* and interna; } \\
\text { mastoiditis; paranasal sinusitis. }\end{array}$ \\
& $\begin{array}{l}\text { Procedures depend on expected findings or } \\
\text { grossly identified abnormalities as listed in } \\
\text { right-hand column. }\end{array}$ & $\begin{array}{l}\text { Thrombosis-for instance, of pelvic veins in } \\
\text { presence of pelvic infection. Pelvic infections } \\
\text { and pregnancy may be associated with } \\
\text { superior sagittal sinus thrombosis. }\end{array}$ \\
\hline
\end{tabular}

\section{Thrombosis, Lateral Sinus}

NOTE: Possible causes include cholesteatoma, infections in the neck or pharynx, mastoiditis, and otitis media.* For general autopsy procedures, see "Thrombosis, cerebral venous sinus."

\section{Thrombosis, Portal Vein (See "Hypertension, portal.")}

\section{Thrombosis, Renal Vein}

NOTE: In infants, inquire about birth injury, maternal diabetes mellitus, ${ }^{*}$ toxemia, ${ }^{*}$ or anoxia.

\begin{tabular}{|c|c|c|}
\hline Organs and Tissues & Procedures & Possible or Expected Findings \\
\hline Vitreous & $\begin{array}{l}\text { Submit samples of vitreous of infants for } \\
\text { determination of sodium, chloride, and } \\
\text { urea nitrogen concentrations. }\end{array}$ & In infants, manifestations of dehydration.* \\
\hline Lungs & & Pulmonary embolism.* \\
\hline $\begin{array}{l}\text { Retroperitoneal space } \\
\text { and femoral veins }\end{array}$ & $\begin{array}{l}\text { Procedures depend on expected findings or } \\
\text { grossly identified abnormalities as listed in } \\
\text { right-hand column. For renal venography, see } \\
\text { p. } 59 \text {. Open veins in situ. Dissect testicular } \\
\text { or ovarian veins-particularly on left—and } \\
\text { adrenal veins. For removal of femoral vessels, } \\
\text { see p. } 34 \text {. }\end{array}$ & $\begin{array}{l}\text { Tumor of the kidney* (renal cell carcinoma); } \\
\text { aortic aneurysm; lymphadenopathy; other } \\
\text { mass lesions. Inferior vena cava thrombosis } \\
\text { involving orifice or whole length of renal } \\
\text { veins. Tumor thrombus (e.g., from renal cell } \\
\text { carcinoma). Femoral vein thrombosis. Rare } \\
\text { venous malformations also may cause renal } \\
\text { vein thrombosis }(1) \text {. }\end{array}$ \\
\hline Kidneys & $\begin{array}{l}\text { Unless the cause of the renal vein thrombosis } \\
\text { and the nature of the complicating or underlying } \\
\text { renal disease are known, follow procedures } \\
\text { described under "Glomerulonephritis." }\end{array}$ & $\begin{array}{l}\text { Hemorrhagic infartion. Parenchymal renal } \\
\text { disease with nephrotic syndrome, }{ }^{*} \text { including } \\
\text { amyloidosis* and vasculitis* (these last } \\
\text { conditions may be associated with renal vein } \\
\text { thrombosis). }\end{array}$ \\
\hline Other organs & $\begin{array}{l}\text { Procedures depend on expected findings or } \\
\text { grossly identified abnormalities as listed in } \\
\text { right-hand column. }\end{array}$ & $\begin{array}{l}\text { Acute gastroenteritis in infancy. } \\
\text { Hyperparathyroidism, }{ }^{*} \text { pregnancy, }{ }^{*} \text { trauma, } \\
\text { and other conditions. }\end{array}$ \\
\hline
\end{tabular}

\section{Reference}

1. Lash C, Radhakrishnan J, McFadden JC. Renal vein thrombosis secondary to absent inferior vena cava. Urol 1998;51:829-830.

\section{Thrombosis, Venous}

NOTE: For peripheral venous thrombosis, the autopsy procedures are essentially similar to those described under "Phlebitis." See also under "Hypertension, portal," "Syndrome, Budd-Chiari," "Thrombosis, cerebral venous sinus," "Thrombosis, lateral sinus," and "Thrombosis, renal vein." 


\section{Thymoma (See "Tumor of the thymus.")}

\section{Thyroiditis}

Synonyms and Related Terms: Chronic fibrosing thyroiditis (Riedel's struma); chronic thyroiditis with transient thyrotoxicosis; Hashimoto's thyroiditis; pyogenic thyroiditis; subacute (granulomatous, giant cell, de Quervain's) thyroiditis.

Possible Associated Conditions: With Hashimoto's thyroiditis-autoimmune (chronic) hepatitis, ${ }^{*}$ megaloblastic anemia,* rheumatoid arthritis, ${ }^{*}$ Sjögren's syndrome,* and systemic lupus erythematosus.* With Riedel's struma-retroperitoneal fibrosis, ${ }^{*}$ sclerosing cholangitis, ${ }^{*}$ sclerosing mediastinitis, ${ }^{*}$ and other conditions with idiopathic fibrosis. With subacute thyroiditisviral infection.

\begin{tabular}{|c|c|c|}
\hline Organs and Tissues & Procedures & Possible or Expected Findings \\
\hline Blood & Submit sample for serologic study (p.102). & $\begin{array}{l}\text { Viral antibodies in subacute (de Quervain) } \\
\text { thyroiditis; tissue antibodies in Hashimoto's } \\
\text { thyroiditis. }\end{array}$ \\
\hline Thymus & $\begin{array}{l}\text { Record weight and submit sample for } \\
\text { histologic study. }\end{array}$ & $\begin{array}{l}\text { Enlarged thymus with multiple germinal } \\
\text { centers with Hashimoto's thyroiditis. }\end{array}$ \\
\hline Neck organs & $\begin{array}{l}\text { Remove together with tongue (p. 4). If there } \\
\text { is evidence of pyogenic infection, submit } \\
\text { material for culture. Record weight of } \\
\text { thyroid and of parathyroid glands and } \\
\text { submit samples for histologic study, } \\
\text { together with cervical lymph nodes. } \\
\text { Record presence or absence of compression } \\
\text { of trachea by struma. }\end{array}$ & $\begin{array}{l}\text { Acute suppurative thyroiditis. Acute } \\
\text { nonsuppurative thyroiditis after irradiation. } \\
\text { Struma and lymphadenopathy in } \\
\text { Hashimoto's thyroiditis. Fibrosis with } \\
\text { tracheal compression associated with } \\
\text { Riedel's struma. }\end{array}$ \\
\hline Other organs & $\begin{array}{l}\text { Submit samples of all endocrine glands for } \\
\text { histologic study. }\end{array}$ & $\begin{array}{l}\text { If hypothyroidism* is suspected, see also } \\
\text { under that entry. }\end{array}$ \\
\hline
\end{tabular}

\section{Thyrotoxicosis (See "Hyperthyroidism.”)}

Torticollis, Spasmodic

Related Terms: Dystonia musculorum deformans; torsion dystonia.

\begin{tabular}{lll}
\hline Organs and Tissues & Procedures & Possible or Expected Findings \\
\hline Brain & For removal and specimen preparation, see p. 65. & No diagnostic pathologic lesions. \\
\hline
\end{tabular}

Torulosis (See “Cryptococcosis.”)

\section{Toxemia of Pregnancy}

Related Terms: Eclampsia or preeclampsia; postpartum hemolytic uremic syndrome; postpartum renal failure.

NOTE: See also "Failure, kidney."

\begin{tabular}{|c|c|c|}
\hline Organs and Tissues & Procedures & Possible or Expected Findings \\
\hline External examination & $\begin{array}{l}\text { Record body weight, extent and location of } \\
\text { edema, and level of fundus of uterus. }\end{array}$ & $\begin{array}{l}\text { Edema involving periorbital region, hands, } \\
\text { and ankles; hemorrhagic foci in conjunctivas } \\
\text { and fingernails. }\end{array}$ \\
\hline & Prepare chest roentgenogram. & Infiltrates. \\
\hline Blood & $\begin{array}{l}\text { Submit sample for microbiologic study } \\
\text { (p. 102). Refrigerate sample for possible } \\
\text { serologic, toxicologic, or biochemical study. }\end{array}$ & $\begin{array}{l}\text { Evidence of infection, poisoning, electrolyte } \\
\text { abnormalities, and other conditions. }\end{array}$ \\
\hline Heart & $\begin{array}{l}\text { Record weight; submit samples for histologic } \\
\text { study. }\end{array}$ & $\begin{array}{l}\text { Cardiac hypertrophy; hemorrhagic necroses } \\
\text { caused by small-vessel thromboses. }\end{array}$ \\
\hline Lungs & Submit one lobe for microbiologic study & Hemorrhagic necroses. \\
\hline
\end{tabular}




\begin{tabular}{|c|c|c|}
\hline Organs and Tissues & Procedures & Possible or Expected Findings \\
\hline Liver & $\begin{array}{l}\text { Record weight; submit samples for histologic } \\
\text { study. For the demonstration of fibrin depositis, } \\
\text { request phosphotungstic acid hematoxylin } \\
\text { (PTAH) stain (p. 173). }\end{array}$ & $\begin{array}{l}\text { Periportal fibrin deposition with } \\
\text { hemorrhages; centrilobular and midzonal } \\
\text { necroses or cell dropout. Infarction (1) and } \\
\text { one-time or recurrent hemorrhages (2). }\end{array}$ \\
\hline Adrenal glands & $\begin{array}{l}\text { Submit samples for histologic study } \\
\text { (see also "Liver"). }\end{array}$ & Hemorrhagic necroses. \\
\hline Kidneys & $\begin{array}{l}\text { Follow procedures described under } \\
\text { "Glomerulonephritis." }\end{array}$ & $\begin{array}{l}\text { Thromboses of small vessels. } \\
\text { Glomerulonephritis.* Hemorrhagic } \\
\text { necroses. }\end{array}$ \\
\hline Urine & $\begin{array}{l}\text { Submit sample for determination of protein } \\
\text { concentration; record appearance of sediment. }\end{array}$ & Proteinuria; abnormal sediment. \\
\hline Pelvic organs & $\begin{array}{l}\text { For dissection, fixation, and removal for } \\
\text { preservation of the pregnant uterus, see p. } 60 \text {. }\end{array}$ & $\begin{array}{l}\text { Abruptio placentae may be present; also } \\
\text { thrombotic vascular occlusions. }\end{array}$ \\
\hline $\begin{array}{l}\text { Brain and spinal cord; } \\
\text { pituitary gland }\end{array}$ & $\begin{array}{l}\text { For removal and specimen preparation, } \\
\text { see pp. } 65,67 \text {, and } 71 \text {, respectively. }\end{array}$ & $\begin{array}{l}\text { Thrombotic occlusion of small vessels with } \\
\text { hemorrhagic necroses; anterior lobe of } \\
\text { pituitary gland may contain necroses (see also } \\
\text { "Syndrome, Sheehan's"). }\end{array}$ \\
\hline
\end{tabular}

\section{References}

1. Krueger KJ, Hoffman BJ, Lee WM. Hepatic infarction associated with ecclampsia. Am J Gastroenterol 1990;85:588-592.

2. Greenstein D, Henerson JM, Boyer TD. Liver hemorrhage: recurrent episodes during pregnancy complicated by eclampsia. Gastroenterol 1994; 106:1668-1671.

\section{Toxoplasmosis}

Synonyms: Adult toxoplasmosis; congenital toxoplasmosis; disseminated toxoplasmosis; latent toxoplasmosis; Toxoplasma gondii infection.

NOTE: (1) Collect all tissues that appear to be infected. (2) Culturing requires animal inoculation in specialized laboratories. Consult microbiology laboratory before performing autopsy. (3) Request Giemsa stain (p. 172) and Toxoplasma immunoperoxidase or immunofluorescent stain. (4) No special precautions are indicated. (5) Serologic studies are available from local and state health department laboratories (p. 135). (6) This is not a reportable disease.

Possible Associated Conditions: Acquired immunodeficiency syndrome (AIDS)* $(1,2)$.

\begin{tabular}{|c|c|c|}
\hline$\underline{\text { Organs and Tissues }}$ & Procedures & Possible or Expected Findings \\
\hline External examination & $\begin{array}{l}\text { Record head circumference of infant. } \\
\text { Prepare radiograph of cranium of infants. }\end{array}$ & $\begin{array}{l}\text { Jaundice and hydrocephalus* in congenital } \\
\text { toxoplasmosis. }\end{array}$ \\
\hline Blood & Submit sample for serologic study. & See above under "Note." \\
\hline Heart & $\begin{array}{l}\text { Record weight; submit samples for histologic } \\
\text { study (p. 30) and request PAS stain (p. 173). } \\
\text { Snap-freeze myocardium for immuno- } \\
\text { fluorescent study. }\end{array}$ & $\begin{array}{l}\text { Myocarditis* in adult form of toxoplasmosis. } \\
\text { Trophozoites of Toxoplasma stain well } \\
\text { with PAS. }\end{array}$ \\
\hline Lungs & $\begin{array}{l}\text { Prepare smears and request Giemsa (p. 172) } \\
\text { and immunofluorescent stains. Perfuse one lung } \\
\text { with formalin (p. } 47) \text {. }\end{array}$ & $\begin{array}{l}\text { Interstitial pneumonitis* in adult } \\
\text { toxoplasmosis }(1) \text {. }\end{array}$ \\
\hline \multirow[t]{2}{*}{ Liver } & $\begin{array}{l}\text { Record weight. Submit sample for histologic } \\
\text { study. }\end{array}$ & $\begin{array}{l}\text { Toxoplasma hepatitis, with hepatocellular } \\
\text { giant cell transformation in congenital } \\
\text { toxoplasmosis. }\end{array}$ \\
\hline & $\begin{array}{l}\text { In diagnostically difficult cases, submit material } \\
\text { for electron microscopic study (p. 132). }\end{array}$ & $\begin{array}{l}\text { Electron micrographs allow distinction } \\
\text { between Toxoplasma and Sarcocystis, oval } \\
\text { yeasts, and other organisms. }\end{array}$ \\
\hline Spleen & Record weight. & Splenomegaly in congenital toxoplasmosis. \\
\hline Lymph nodes & Submit samples for histologic study. & $\begin{array}{l}\text { Marked follicular hyperplasia with } \\
\text { histiocytes inside and around follicles (3). }\end{array}$ \\
\hline Skeletal muscles & $\begin{array}{l}\text { For sampling and specimen preparation, } \\
\text { see p. } 80 \text {. }\end{array}$ & Myositis occurs in adult toxoplasmosis. \\
\hline
\end{tabular}
see p. 80. 


\begin{tabular}{lll}
\hline Organs and Tissues & Procedures & Possible or Expected Findings \\
\hline Placenta & Record weight and sample for histologic study. & $\begin{array}{l}\text { Diffuse lymphoplasmacytic villitis with } \\
\text { sclerosis of villi. Cysts may be found. }\end{array}$ \\
Other organs and tissues & $\begin{array}{l}\text { Procedures depend on expected findings or } \\
\text { grossly identified abnormalities as mentioned } \\
\text { in right-hand column. }\end{array}$ & $\begin{array}{l}\text { Infections may occur in many organs } \\
\text { and tissues. }\end{array}$ \\
Brain and spinal cord & $\begin{array}{l}\text { For removal and specimen preparation, } \\
\text { see pp. 65 and 67, respectively. }\end{array}$ & $\begin{array}{l}\text { Cerebral calcifications; periventricular } \\
\text { necrosis. Hydrocephalus* in congenital toxo- } \\
\text { plasmosis; meningoencephalitis in adult form. } \\
\text { Eyes }\end{array}$ \\
\hline
\end{tabular}

\section{References}

1. Nash G, Kerschmann RL, Herndier B, Dubey JP. The pathological manifestations of pulmonary toxoplasmosis in the acquired immunodeficiency syndrome. Hum Pathol 1994;25:652-658.

2. Bertoli F, Espino M, Arosemena JR 5th, Fishback JL, Frenkel JK. A spectrum in the pathology of toxoplasmosis in patients with acquired immunodeficiency syndrome. Arch Pathol Lab Med 1995;119:214-224.

3. Rose I. Morphology and diagnostics of human toxoplasmosis. General Diagn Pathol 1997;142:257-270.

\section{Transfusion (See "Reaction to transfusion.")}

\section{Transplantation, Bone Marrow}

NOTE: If the patient had symptoms of acute or chronic graft-versus-host disease (GVHD), see "Disease, graft-versus-host." If the patient developed recurrent leukemia, see under "Leukemia,..." Cytogenetic and other techniques can be used in such cases to determine whether the leukemic cells are of donor or host origin. If the patient developed post-transplant lymphoproliferative disease (PTLD), see under "Lymphoma."

\begin{tabular}{ll}
\hline Organs and Tissues & Procedures \\
\hline $\begin{array}{l}\text { External examination } \\
\text { and skin }\end{array}$ & Record skin abnormalities and sample for \\
Blood & histologic study. \\
Lungs & Submit sample for microbiologic study (p. 102). \\
& Submit samples for microbiologic (bacterial, \\
& fungal, and viral) and histologic studies (p. 103). \\
& Request Grocott's methenamine silver stain \\
& (p. 172) to detect Pneumocystis carinii \\
& organisms. If complicating toxoplasmosis \\
& is suspected, see under that heading. \\
& Record weight; sample for histologic study.
\end{tabular}

Kidneys $\quad$ If indicated, see also "Failure, kidney."

Other organs and tissues If there is evidence of infection, submit material for microbiologic studies. If there is evidence of recurrent leukemia or lymphoma, sample as described under those headings.

If the patient had symptoms of thrombotic thrombocytopenic purpura (TTP) or hemolytic uremic syndrome (HUS), see these headings.

Possible or Expected Findings

Manifestations of graft-versus-host disease (e.g., scleroderma-like changes).* Septicemia.

Interstitial pneumonia* and cytomegalovirus infection* or human herpesvirus 6 infection (1). Bacterial, fungal, or protozoal infections. Pulmonary veno-occlusive disease (see "Hypertension, pulmonary") (2).

Hepatic veno-occlusive disease. Viral hepatitis (hepatitis $\mathrm{C}$; herpesvirus hepatitis). Cholangitis or ductopenia and other manifestations of GVHD.

Kidney failure* associated with tumor lysis syndrome, hepatorenal syndrome, ${ }^{*}$ cyclosporine nephrotoxicity, or bone marrowtransplant associated nephropathy (3). Bacterial or fungal infections in GVHD.* Other manifestations of GVHD.* Recurrent leukemia,* lymphoma* (including posttransplant, Epstein-Barr virus associated lymphoproliferative disorder). Recurrent solid tumor, e.g., carcinoma of breast, lung (small cell carcinoma), ovary, or testis. Manifestations of TTP, HUS (4), or thrombotic microangiopathy (5). 


\begin{tabular}{lll}
\hline Organs and Tissues & Procedures & Possible or Expected Findings \\
\hline Lymph nodes & $\begin{array}{l}\text { Record average size. Fix specimens in B-5 } \\
\text { fixative (p. 129). Make touch preparations. } \\
\text { Request Giemsa or Wright stain (p. 172). }\end{array}$ & Lymphomatous or leukemic infiltrates. \\
Bone marrow & $\begin{array}{l}\text { For preparation of sections and smears } \\
\text { (imprints), see p. 96. }\end{array}$ & $\begin{array}{l}\text { Myeloid cells may be absent in marrow graft } \\
\text { rejection or nonimmunologic marrow graft } \\
\text { failure. }\end{array}$ \\
$\begin{array}{l}\text { Brain and spinal cord; } \\
\text { peripheral nerves }\end{array}$ & $\begin{array}{l}\text { For removal and specimen preparation, } \\
\text { see pp. 65, 67, and 79, respectively. }\end{array}$ & $\begin{array}{l}\text { Hematomas; hemorrhagic necroses; infarcts; } \\
\text { bacterial or fungal infections; leukoencephal- } \\
\text { opathy; vascular siderocalcinosis; neuro- } \\
\text { axonal spheroids (6). Peripheral neuropathy. }\end{array}$ \\
\hline
\end{tabular}

\section{References}

1. Kadakia MP. Human herpesvirus 6 infection and associated pathogenesis following bone marrow transplantation. Leukemia Lymphoma 1998;31:251-266.

2. Williams LM, Fussell S, Veith RW, Nelson S, Mason CM. Pulmonary veno-occlusive disease in an adult following bone marrow transplantation. Case report and review of the literature. Chest 1996;109:13881391.

3. Pulla B, Barri YM, Anaissie E. Acute renal failure following bone marrow transplantation. Renal Failure 1998;20:421-435.
4. Schriber JR, Herzig GP. Transplantation-associated thrombotic thrombocytopenic purpura and hemolytic uremic syndrome. Semin Hematol 1997;34:126-133.

5. Moake JL, Byrness JJ. Thrombotic microangiopathies associated with drugs and bone marrow transplantation. Hematol Oncol Clin North Am 1996:485-497.

6. Mohrmann RL, Mah V, Vinters HV. Neuropathologic findings after bone marrow transplantation: an autopsy study. Hum Pathol 1990;21: 630-639.

\section{Transplantation, Heart}

\begin{tabular}{|c|c|c|}
\hline Organs and Tissues & Procedures & Possible or Expected Findings \\
\hline External examination & $\begin{array}{l}\text { Record abnormalities, e.g., after high-dose } \\
\text { steroid therapy. }\end{array}$ & $\begin{array}{l}\text { Cushingoid features (see "Syndrome, } \\
\text { Cushing's") after steroid therapy. }\end{array}$ \\
\hline Chest cavity & $\begin{array}{l}\text { Record status of all vascular anstomoses. If } \\
\text { there are hemorrhages, record volume and site. }\end{array}$ & $\begin{array}{l}\text { Suture dehiscence. Hemothorax or } \\
\text { hemomediastinum in recent cases. }\end{array}$ \\
\hline Heart & $\begin{array}{l}\text { Record weight, ventricular thickness, and valve } \\
\text { circumferences. For sampling of myocardium, } \\
\text { see p. } 30 \text {. Cut coronary arteries in cross } \\
\text { sections; request Verhoeff-van Gieson stain } \\
\text { (p. 173). }\end{array}$ & $\begin{array}{l}\text { Left ventricular hypertrophy, from } \\
\text { cyclosporine-related hypertension. Acute } \\
\text { transplant rejection (for grading, see ref. } 1 \text { ). } \\
\text { Chronic transplant vasculopathy with } \\
\text { coronary artery stenosis (2). Old or recent } \\
\text { myocardial infarction. Recurrence of native } \\
\text { cardiac disease (e.g., amyloidosis* or giant } \\
\text { cell myocarditis). Infection. }\end{array}$ \\
\hline Other organs & $\begin{array}{l}\text { Procedures depend on expected findings or } \\
\text { grossly identified abnormalities as listed in } \\
\text { right-hand column. }\end{array}$ & $\begin{array}{l}\text { Post-transplant lymphoproliferative disorder } \\
\text { (1). Opportunistic infection (1). Pneumonia; } \\
\text { septicemia. }\end{array}$ \\
\hline
\end{tabular}

\section{References}

1. Billingham ME, Cary NRB, Hammond ME, Kemnitz J, Marboe C, McCallister HA, et al. A working formulation for the standardization of nomenclature in the diagnosis of heart and lung rejection: Heart and Lung Rejection Study Group. J Heart Transplant 1990;9:587-593.

2. Graham A. Autopsy findings in cardiac transplant patients: a 10-year experience. Am J Clin Pathol 1992;97:369-375.

\section{Transplantation, Kidney}

\begin{tabular}{lll}
\hline Organs and Tissues & Procedures & Possible or Expected Findings
\end{tabular}

External examination

Blood
Record abnormalities, e.g., after high-dose steroid therapy.

Submit sample for bacterial, fungal, and viral cultures (p. 102). Submit samples for tests for hepatitis B and C antigens.
Cushingoid features (see "Syndrome, Cushing's") after steroid therapy. Septicemia (see below under "Other organs"). 


\begin{tabular}{lll}
\hline Organs and Tissues & Procedures & Possible or Expected Findings \\
\hline Other organs & $\begin{array}{l}\text { If systemic infection is suspected, sample } \\
\text { material for microbiologic study. Other } \\
\text { procedures depend on expected findings or } \\
\text { grossly identified abnormalities as listed in } \\
\text { right-hand column. }\end{array}$ & $\begin{array}{l}\text { Bacterial, fungal, or viral infections may be } \\
\text { observed. There may be evidence of post- } \\
\text { transplant lymphoproliferative disorder. }\end{array}$ \\
& $\begin{array}{l}\text { Dissect renal allograft in situ and record } \\
\text { whether vascular and ureteral anastomoses } \\
\text { Were competent. For renal arteriography, see } \\
\text { Kidneys }\end{array}$ & $\begin{array}{l}\text { Leaking anastomoses; infection; acute or } \\
\text { chronic graft rejection. Recurrent primary } \\
\text { disease. }\end{array}$ \\
& $\begin{array}{l}\text { the allograft and the native kidneys (if they } \\
\text { had been left in situ), follow procedures } \\
\text { described under "Glomerulonephritis." }\end{array}$ & \\
& $\begin{array}{l}\text { Fix samples in B-5 solution (p. 129). } \\
\text { For preparation of sections and smears } \\
\text { of bone marrow, see p. 96. }\end{array}$ & $\begin{array}{l}\text { Post-transplant lymphoproliferative } \\
\text { disorder. }\end{array}$ \\
\hline Lymph nodes & & \\
and bone marrow & & \\
\hline
\end{tabular}

\section{Transplantation, Liver}

\begin{tabular}{|c|c|c|}
\hline Organs and Tissues & Procedures & Possible or Expected Findings \\
\hline External examination & $\begin{array}{l}\text { Record abnormalities, e.g., after high-dose } \\
\text { steroid therapy. }\end{array}$ & $\begin{array}{l}\text { Cushingoid features (see "Syndrome, } \\
\text { Cushing's") after steroid therapy. }\end{array}$ \\
\hline Chest organs & $\begin{array}{l}\text { Open right atrium in situ and probe sub- } \\
\text { diaphragmatic inferior vena cava anastomosis; } \\
\text { leave thoracic inferior vena cava with sleeve } \\
\text { of right atrium attached to liver. }\end{array}$ & $\begin{array}{l}\text { Dehiscence or stricture of subdiaphragmatic } \\
\text { vena cava anastomosis. Leave esophagus } \\
\text { attached to stomach, particularly if varices } \\
\text { might be present. }\end{array}$ \\
\hline \multirow[t]{2}{*}{$\begin{array}{l}\text { Liver, hepatic artery, } \\
\text { portal vein, hepatic } \\
\text { veins, and bile ducts }\end{array}$} & $\begin{array}{l}\text { Dissect in situ hepatic artery anastomosis, } \\
\text { portal vein anastomosis, and bile duct } \\
\text { anastomosis. Remove abdominal organs } \\
\text { en block (intestines can be removed earlier } \\
\text { to debulk organ block) and partially open } \\
\text { inferior vena cava to inspect anastomoses } \\
\text { with the graft. }\end{array}$ & Dehiscence or stricture of anastomoses. \\
\hline & $\begin{array}{l}\text { If there is evidence of hepatic infection, sample } \\
\text { material for microbiologic and histologic study. } \\
\text { Perfuse entire liver with formalin (p. 56) or } \\
\text { slice fresh organ horizontally with long-bladed } \\
\text { knive. Obtain multiple samples for histologic } \\
\text { study. }\end{array}$ & $\begin{array}{l}\text { Ascending biliary infections; hematogenous } \\
\text { infections; ischemic lesions, including } \\
\text { infected infarcts; recurrent primary disease } \\
\text { such as primary biliary cirrhosis, viral } \\
\text { hepatitis, or tumors. Acute-cellular or } \\
\text { chronic-ductopenic rejection (for grading } \\
\text { of rejection, see ref. } 1 \text { ). }\end{array}$ \\
\hline $\begin{array}{l}\text { Other organs } \\
\text { and blood }\end{array}$ & $\begin{array}{l}\text { If systemic infection is suspected, sample } \\
\text { material for microbiologic study (p. 102). } \\
\text { Other procedures depend on expected } \\
\text { findings or grossly identified abnormalities } \\
\text { as listed in right-hand column. }\end{array}$ & $\begin{array}{l}\text { Bacterial, fungal, or viral infections may } \\
\text { be observed. Septicemia. } \\
\text { Post-transplant lymphoproliferative } \\
\text { disorder. }\end{array}$ \\
\hline
\end{tabular}

\section{Reference}

1. Anonymous. Banff schema for grading liver allograft rejection: an international consensus document. Hepatology 1997;25:658-663.

\section{Transplantation, Lung}

\begin{tabular}{lll}
\hline Organs and Tissues & Procedures & Possible or Expected Findings \\
\hline External examination & $\begin{array}{l}\text { Record abnormalities, e.g., after high-dose } \\
\text { steroid therapy. }\end{array}$ & $\begin{array}{l}\text { Cushingoid features (see "Syndrome, } \\
\text { Cushing's") after steroid therapy. }\end{array}$
\end{tabular}




\begin{tabular}{|c|c|c|}
\hline Organs and Tissues & Procedures & Possible or Expected Findings \\
\hline Chest cavity & $\begin{array}{l}\text { Record status of all vascular anstomoses. If } \\
\text { there are hemorrhages, record volume and site. }\end{array}$ & $\begin{array}{l}\text { Suture dehiscence. Hemothorax or } \\
\text { hemomediastinum in recent cases. }\end{array}$ \\
\hline Lungs & $\begin{array}{l}\text { Record lung weights separately. If lung infection } \\
\text { is suspected, submit material for microbiologic } \\
\text { study (p. 103). For perfusion of lungs with } \\
\text { formalin, see p. } 47 \text {. Cut lungs in frontal sections. } \\
\text { Submit sections of proximal airways and of } \\
\text { distal parenchyma for histologic study. Request } \\
\text { Verhoeff-van Gieson and Gomori's methenamine } \\
\text { silver stains (p. 173). }\end{array}$ & $\begin{array}{l}\text { Opportunistic infection (in patients with a } \\
\text { single lung transplant, infections may involve } \\
\text { the nontransplant lung, as well). Chronic } \\
\text { bronchitis* and bronchiectasis.* Acute } \\
\text { rejection (rare); chronic airway rejection } \\
\text { (obliterative bronchiolitis); chronic vascular } \\
\text { rejection. (For grading of rejection, see } \\
\text { ref. 1.) Post-transplant lymphoproliferative } \\
\text { disorder. Recurrence of primary disease (e.g., } \\
\text { sarcoidosis,* lymphangioleiomyomatosis). }\end{array}$ \\
\hline Kidneys & Submit samples for histologic study. & Manifestations of cyclosporine toxicity. \\
\hline Other organs & $\begin{array}{l}\text { If infection is expected, submit material for } \\
\text { microbiologic study. Other procedures depend } \\
\text { on expected findings or grossly identified } \\
\text { abnormalities as listed in right-hand column. }\end{array}$ & $\begin{array}{l}\text { Infection (2) or septicemia. Post-transplant } \\
\text { lymphoproliferative disorder. }\end{array}$ \\
\hline
\end{tabular}

\section{References}

1. Billingham ME, Cary NRB, Hammond ME, Kemnitz J, Marboe C, McCallister HA, et al. A working formulation for the standardization of nomenclature in the diagnosis of heart and lung rejection: Heart and Lung Rejection Study Group. J Heart Transplant 1990;9:587-593.

2. Tazelaar HD, Yousem SA. The pathology of combined heart-lung transplantation: an autopsy study. Hum Pathol 1988;19:1403-1416.

\section{Transposition,}

\section{Complete, of the Great Arteries}

NOTE: The basic anomaly is the origin of the aorta from the right ventricle, and of the pulmonary artery from the left ventricle, with a shunt, and usually with a right anterior aorta. There are four major types: (1) with an intact ventricular septum $(65 \%),(2)$ with a ventricular septal defect* $(20 \%),(3)$ with a ventricular septal defect and subvalvular pulmonary stenosis* (10\%), and (4) with an intact ventricular septum and subvalvular pulmonary stenosis* $(5 \%)$. For general dissection techniques, see p. 33. Interventions include atrial septostomy or septectomy; Mustard or Senning atrial switch procedure; Rastelli-type repair with a valved extracardiac conduit; and Jatene arterial switch procedure with LeCompte maneuver.

Possible Associated Conditions: Abnormal origin of coronary arteries $(10 \%)$; atrial septal defect* $(5 \%)$; coarctation of the aorta;* interrution of the aortic arch; * juxtaposition of atrial appendages $(4 \%)$; overriding aorta $(5 \%)$; overriding pulmonary artery $(10 \%)$; patent ductal artery;* patent oval foramen; subvalvular pulmonary stenosis* $(15 \%)$; tubular hypoplasia of the aortic arch;* ventricular septal defect* (30\%), often malalignment type (50\%).

\section{Transposition,}

\section{Congenitally Corrected, of the Great Arteries}

Synonyms: Atrioventricular and ventriculoarterial discordance; L-transposition.

NOTE: The basic anomaly is a mirror-image ventricular inversion, with a left anterior aorta, and with blood flow from right atrium to left ventricle to pulmonary artery, and from left atrium to right ventricle to aorta. For general dissection techniques, see p. 33. Interventions include patch closure of the ventricular septal defect; relief of pulmonary stenosis; relief of tricuspid insufficiency; and insertion of pacemakers.

Possible Associated Conditions: Anterior and posterior AV nodes (100\%), prone to develop complete heart block; dysplasia or Epstein's malformation* of left-sided tricuspid valve (40\%); mirror-image epicardial coronary artery distribution (100\%); right-sided mitral valve anomalies; subvalvular pulmonary stenosis* $(40 \%)$; ventricular septal defect* $(65 \%)$.

\section{Trichinosis}

Synonyms: Trichinella spiralis infection; trichinelliasis; trichiniasis.

NOTE: (1) Collect all tissues that appear infected. (2) Request direct examination for Trichinella. (3) Request Giemsa stain (p. 172). (4) No special precautions are indicated. (5) Serologic studies are available from local and state health department laboratories (p. 135). (6) This is a reportable disease.

\begin{tabular}{|c|c|c|}
\hline Organs and Tissues & Procedures & Possible or Expected Findings \\
\hline $\begin{array}{l}\text { External examination } \\
\text { and skin }\end{array}$ & $\begin{array}{l}\text { Record abnormalities and photopgraph edema } \\
\text { and hemorrhages. }\end{array}$ & $\begin{array}{l}\text { Palpebral and facial edema; splinter } \\
\text { hemorrhages under the nails. }\end{array}$ \\
\hline Blood & $\begin{array}{l}\text { Obtain sample for quantification of } \operatorname{IgE} \text { and } \\
\text { eosinophils. }\end{array}$ & $\begin{array}{l}\text { Increased IgE concentration and } \\
\text { eosinophilia. }\end{array}$ \\
\hline Heart & $\begin{array}{l}\text { Record weight and submit samples of } \\
\text { myocardium for histologic study (p. 30). }\end{array}$ & $\begin{array}{l}\text { Interstitial myocarditis early in the disease; } \\
\text { focal necroses; no cysts can be seen. }\end{array}$ \\
\hline
\end{tabular}




\begin{tabular}{|c|c|c|}
\hline Organs and Tissues & Procedures & Possible or Expected Findings \\
\hline $\begin{array}{l}\text { Duodenum, jejunum, } \\
\text { and ileum }\end{array}$ & $\begin{array}{l}\text { For in situ fixation and preparation for study } \\
\text { under the dissecting microscope, see p. } 54 \text {. } \\
\text { Submit samples for histologic study. }\end{array}$ & $\begin{array}{l}\text { Mild partial villous atrophy; acute and } \\
\text { chronic infiltrate with eosinophils in mucosa } \\
\text { and submucosa; mucosal edema; punctate } \\
\text { hemorrhages; prominent Peyer's plaques. }\end{array}$ \\
\hline \multirow[t]{2}{*}{$\begin{array}{l}\text { Lungs, kidney, liver, } \\
\text { pancreas, } \\
\text { and soft tissues }\end{array}$} & $\begin{array}{l}\text { Submit samples for histologic study. } \\
\text { In older infections, decalcification of cysts } \\
\text { and larvae may be required. }\end{array}$ & $\begin{array}{l}\text { Resorption granulomas around migrating } \\
\text { larvae. }\end{array}$ \\
\hline & Prepare roentgenograms of organs and soft tissues. & Calcified cysts. \\
\hline Kidneys & $\begin{array}{l}\text { Follow procedures described under "Glomerulo- } \\
\text { nephritis." }\end{array}$ & Immune-mediated glomerulonephritis.* \\
\hline Lymph nodes & Submit samples for histologic study. & $\begin{array}{l}\text { Resorption granulomas around migrating } \\
\text { larvae. }\end{array}$ \\
\hline Brain and spinal cord & $\begin{array}{l}\text { For removal and specimen preparation, see } \\
\text { pp. } 65 \text { and } 67 \text {, respectively. For decalcification, } \\
\text { see p. } 97 .\end{array}$ & $\begin{array}{l}\text { Mononuclear meningitis; tiny foci of gliosis } \\
\text { around capillaries; encephalitis. }\end{array}$ \\
\hline \multirow[t]{2}{*}{ Skeletal muscles } & $\begin{array}{l}\text { Submit samples for histologic study, especially } \\
\text { from diaphragm, gastrocnemius, intercostal, } \\
\text { deltoid, gluteus, and pectoral muscles. } \\
\text { For decalcification, see p. } 97 \text {. }\end{array}$ & $\begin{array}{l}\text { Encysted larvae; cysts in varying stages of } \\
\text { lymphocytic and eosinophilic inflammation } \\
\text { and degeneration. }\end{array}$ \\
\hline & Prepare roentgenograms. & Calcified cysts. \\
\hline Bone marrow & $\begin{array}{l}\text { For preparation of sections and smears, } \\
\text { see p. } 96 \text {. }\end{array}$ & Hyperplasia and eosinophilia. \\
\hline
\end{tabular}

Trisomy 21 (See “Syndrome, Down's.")

Truncus Arteriosus (See “Artery, persistent truncal.”)

Trypanosomiasis, African

Synonyms: African sleeping sickness; Trypanosoma brucei gambiense infection (West African trypanosomiasis); Trypanosoma brucei rhodesiense infection (East African trypanosomiasis).

NOTE: (1) Collect all tissues that appear infected. (2) Request direct examination for trypanosomes. (3) Request Giemsa stain (p. 172). (4) No special precautions are indicated. (5) Serologic studies are available from the Centers for Disease Control and Prevention, Atlanta, GA (p. 135). (6) This is not a reportable disease.

\begin{tabular}{|c|c|c|}
\hline Organs and Tissues & Procedures & Possible or Expected Findings \\
\hline External examination & $\begin{array}{l}\text { Record abnormalities and photograph skin } \\
\text { changes. }\end{array}$ & $\begin{array}{l}\text { Cachexia. Facial edema; rash, especially } \\
\text { on rump. }\end{array}$ \\
\hline Cerebrospinal fluid & $\begin{array}{l}\text { Submit sample for biochemical analysis and } \\
\text { prepare sediment (p. 104). }\end{array}$ & $\begin{array}{l}\text { Increased IgM protein concentrations; } \\
\text { trypanosomes may be present, especially in } \\
\text { late Gambian disease; plasma cells with } \\
\text { Russell bodies (Mott cells). }\end{array}$ \\
\hline Chest and abdomen & $\begin{array}{l}\text { Record volume of effusions and prepare } \\
\text { smears of sediment. }\end{array}$ & $\begin{array}{l}\text { Ascites; pleural* and pericardial effusions } \\
\text { with trypanosomes. }\end{array}$ \\
\hline Blood & $\begin{array}{l}\text { Prepare thick, unfixed film and request } \\
\text { Giemsa stain (p. 102). }\end{array}$ & $\begin{array}{l}\text { Trypanosomes may be present, particularly } \\
\text { in Rhodesian disease. }\end{array}$ \\
\hline Heart & $\begin{array}{l}\text { Record weight and submit samples for } \\
\text { histologic study (p. } 30 \text { ). }\end{array}$ & $\begin{array}{l}\text { Acute and chronic pancarditis, or both, with } \\
\text { cardiac hypertrophy* and dilatation. }\end{array}$ \\
\hline Lymph nodes & $\begin{array}{l}\text { Submit touch preparations and material in B-5 } \\
\text { fixative (p. 129) for histologic study. }\end{array}$ & $\begin{array}{l}\text { Reactive hyperplasia in early stages; } \\
\text { perivascular mononuclear infiltration; } \\
\text { fibrosis in later stages. }\end{array}$ \\
\hline Brain and spinal cord & $\begin{array}{l}\text { For removal and specimen preparation, } \\
\text { see pp. } 65 \text { and } 67 \text {, respectively. Histologic } \\
\text { sections should include cortex, basal ganglia, } \\
\text { cerebellum, brain stem, and spinal cord. }\end{array}$ & $\begin{array}{l}\text { Cerebral edema; diffuse perivascular } \\
\text { lymphoplasmacytic meningoencephalitis in } \\
\text { cortex; characteristic are Mott cells (see } \\
\text { above) in brain and spinal cord; inflamed } \\
\text { choroid plexus; hydrocephalus.* }\end{array}$ \\
\hline
\end{tabular}




\section{Trypanosomiasis, American (See “Disease, Chagas.”)}

\section{Tuberculosis}

Synonyms and Related Terms: Mycobacterium tuberculosis, M. bovis, M. africanum infection; scrofula; lupus vulgaris.

NOTE: (1) Collect all tissues that appear infected. (2) Request mycobacterial cultures. (3) Request Ziehl-Neelsen, Kinyoun's, or other acid-fast stains (p. 172). Polymerase chain reaction for mycobacterial DNA may be helpful in the differential diagnosis of granulomas (1). (4) Universal precautions should be strictly followed and aerolization should be avoided (p. 146). (5) Reliable serologic studies are not available. A definite diagnosis requires isolation of the organism. (6) This is a reportable disease.

\begin{tabular}{ll}
\hline Organs and Tissues & Procedures \\
\hline External examination & Record abnormalities and prepare photographs. \\
and skin & Submit sections of skin lesions for histologic \\
& study; if there are fistulas, obtain curettings for \\
& smears for acid fast stains (see "Note" above) \\
& and for culture. Fill fistulas with contrast \\
& medium and prepare roentgenograms. \\
& Prepare chest and skeletal roentgenograms.
\end{tabular}

Chest and abdomen

Lungs with hilar lymph nodes

Other organs

Brain and spinal cord

Eyes

Bones and joints
Record volume of effusions or exudates; submit sections of serosal surfaces for histologic study.

If diagnosis was confirmed clinically, perfuse both lungs with formalin (p. 47); if not, submit consolidated or cavitated areas for culture (p. 103) and histologic study with acid-fast stains. For decalcification procedures, see p. 97. Procedures depend on expected findings or grossly identified abnormalities as listed in right-hand column. See also above under "Lungs with hilar lymph nodes."

For removal and specimen preparation, see pp. 65 and 67, respectively. If material is to be submitted for culture, follow procedures described on p. 389 (meningitis).

For removal and specimen preparation, see p. 85 . Submit sample of synovial fluid for culture (p. 102). For removal, prosthetic repair, and specimen preparation, see p. 96.
Possible or Expected Findings

Tuberculosis of skin (lupus vulgaris).

Pulmonary infiltrates and cavities; effusions; manifestations of tuberculous osteomyelitis and arthritis.

Tuberculous pleuritis, pericarditis, ${ }^{*}$ and peritonitis.

Cavitary, fibrocalcific, miliary, bronchial, and other types of pulmonary tuberculosis; granulomas in hilar lymph nodes.

Most organs and tissues may be involved, including liver, pancreas, spleen, kidneys, adrenal glands and other endocrine glands, gonads, and lymph nodes.

Tuberculous meningitis; tuberculoma.

Iridocyclitis or panophthalmitis. Tuberculous arthritis and synovitis (hips, spine, knee); tuberculous osteomyelitis (anterior aspect of vertebrae; metaphysis of long bones).

\section{Reference}

1. Trauner M, Grasmug E, Stauber RE, Hammer HF, Hoefler G, Reisinger EC. Recurrent Salmonella enteritidis and hepatic tuberculosis. Gut 1995; 37:136-139.

\section{Tularemia}

Synonyms and Related Terms: Francisella tularensis infection; Pasteurella tularensis infection; typhoidal tularemia; ulceroglandular tularemia; rabbit fever.

NOTE: (1) Collect all tissues that appear infected. (2) Request aerobic bacterial cultures. (3) Request Gram stain (p. 172). (4) Special precautions are indicated (p. 146). (5) Serologic studies are available from local and state health department laboratories (p. 135). (6) This is not a reportable disease.

\begin{tabular}{lll}
\hline Organs and Tissues & Procedures & Possible or Expected Findings \\
\hline $\begin{array}{l}\text { External examination, } \\
\text { skin, and eyes }\end{array}$ & $\begin{array}{l}\text { Record abnormalities and photograph skin } \\
\text { changes; submit for histologic study. }\end{array}$ & $\begin{array}{l}\text { Skin ulcers of hands, feet or perineal area; } \\
\text { necrotizing lesions of eye and purulent } \\
\text { conjunctivitis. }\end{array}$
\end{tabular}




\begin{tabular}{|c|c|c|}
\hline Organs and Tissues & Procedures & Possible or Expected Findings \\
\hline Chest and abdomen & $\begin{array}{l}\text { Submit samples of serosal surfaces for histologic } \\
\text { study. }\end{array}$ & Peritonitis; ${ }^{*}$ perisplenitis; pleural effusions. ${ }^{*}$ \\
\hline Heart & $\begin{array}{l}\text { If infective endocarditis is suspected, follow } \\
\text { procedures described on p. } 103 \text {. }\end{array}$ & Infective endocarditis $; *$ pericarditis. $*$ \\
\hline Lungs & $\begin{array}{l}\text { Record lung weights. Submit consolidated areas } \\
\text { for bacterial culture (p. 103). }\end{array}$ & Necrotizing bronchopneumonia. \\
\hline Liver and spleen & $\begin{array}{l}\text { Record weights. Submit samples for histologic } \\
\text { study. }\end{array}$ & $\begin{array}{l}\text { Hepatosplenomegaly; characteristic } \\
\text { granulomas. }\end{array}$ \\
\hline Lymph nodes & $\begin{array}{l}\text { Submit enlarged lymph nodes (particularly } \\
\text { those with draining skin lesions) for histologic } \\
\text { and microbiologic study (p. 102). Prepare smears } \\
\text { for Gram stain (p. 172). }\end{array}$ & $\begin{array}{l}\text { Lymphadenopathy; granulomatous } \\
\text { lymphadenitis. }\end{array}$ \\
\hline Brain and spinal cord & $\begin{array}{l}\text { For removal and specimen preparation, } \\
\text { see pp. } 65 \text { and } 67 \text {, respectively. }\end{array}$ & Meningitis.* \\
\hline Nasopharynx & $\begin{array}{l}\text { Remove neck organs together with portions } \\
\text { of pharynx. Nasal cavities will be accessible } \\
\text { after removal of brain (p. 71). }\end{array}$ & Necrotizing nasopharyngeal lesions. \\
\hline Bones & & Osteomyelitis.* \\
\hline
\end{tabular}

Tumor, Carcinoid (See “Syndrome, carcinoid.”)

Tumor, Endocrine (See "Neoplasia, multiple endocrine," "Syndrome, carcinoid," and "Tumor, of the [name of affected gland].”)

\section{Tumor, Malignant, Any Type}

NOTE: If the tumor had been treated by surgery, irradiation, chemotherapy, or other means (the most common situation at autopsy), record possible adverse treatment effects and presence or absence of recurrent or metastatic malignancy. If patient had participated in a treatment trial, contact investigator or consult study protocol to provide optimal autopsy documentation.

For classification and terminology of tumors and their histologic features, the tumor fascicles of the Armed Forces Institute of Pathology are recommended references. Of course, many other excellent textbooks of tumor pathology are available.
For some tumors, possible associated or underlying conditions are listed. However, many additional associations do or might exist and therefore, careful documentation of all autopsy findings is recommended, even if abnormalities do not appear clearly tumor-related.

\section{Tumor of the Adrenal Gland(s)}

NOTE: See also "Tumor, malignant, any type."

Possible Associated Conditions: With adrenocortical adenoma-Conn's syndrome (primary hyperaldosteronism); Cushing's syndrome* with virilization. With adrenocortical carcinoma-Cushing's syndrome;* hypoglycemia;* virilization. With pheochromocytoma-cerebellar hemangioblastoma; erythrocytosis; hypercalcemia; hypertension, ${ }^{*}$ multiple endocrine neoplasia* (with medullary carcinoma of the thyroid in types $2 \mathrm{a}$ and $2 \mathrm{~b}$ and with hyperparathyroidism in type $2 \mathrm{a}$ ); neurofibromatosis* (von Recklinghausen's disease); von HippelLindau disease.*

\begin{tabular}{lll}
\hline Organs and Tissues $\quad$ Procedures & Possible or Expected Findings
\end{tabular}

External examination

Record body weight and abnormal features. Photograph skin changes.

Heart and arteries

Record heart weight and thickness of ventricles. For histologic sampling of myocardium, see p. 30 .

Gallbladder Urine
Record contents of gallbladder.

Refrigerate sample for biochemical studyfor instance, of catecholamines in cases with pheochromocytoma, or 17-ketosteroids and 17-hydroxy-corticosteroids with adrenocortical carcinoma.
Cachexia. Virilization or cushingoid features (see above under "Possible Associated Conditions.")

Focal myocarditis.* Hypertensive cardiovascular disease (See "Hypertension [arterial], all types or type unspecified"). Myocardial infarction without severe coronary artery disease (with pheochromocytoma). Cholelithiasis* with pheochromocytoma. Abnormal metabolites. 


\begin{tabular}{|c|c|c|}
\hline$\underline{\text { Organs and Tissues }}$ & Procedures & Possible or Expected Findings \\
\hline Retroperitoneal space & $\begin{array}{l}\text { Photograph and record size of tumor(s). } \\
\text { Snap-freeze portion of fresh tumor tissue for } \\
\text { biochemical study. Submit samples of both } \\
\text { tumor and adjacent tissues for histologic } \\
\text { study. For fixation in Orth's solution and } \\
\text { gross staining procedures for pheochromo- } \\
\text { cytoma, see pp. } 131 \text { and 134, respectively. }\end{array}$ & $\begin{array}{l}\text { Pheochromocytoma may be bilateral and } \\
\text { multiple. The tumor may also occur in other } \\
\text { sites of the retroperitoneal space (organ of } \\
\text { Zuckerkandl) and pelvis. }\end{array}$ \\
\hline Other organs and tissues & $\begin{array}{l}\text { Chemodectomas and carotid body tumors rarely } \\
\text { may produce large amounts of catecholamines. } \\
\text { Tumors of this type must be searched for if } \\
\text { adrenal glands appear normal. }\end{array}$ & $\begin{array}{l}\text { Pheochromocytoma may occur in para- } \\
\text { vertebral areas of thorax and neck and, } \\
\text { rarely, in the urinary bladder. Widespread } \\
\text { metastases may occur with pheochro- } \\
\text { mocytoma and with adrenocortical } \\
\text { carcinoma. }\end{array}$ \\
\hline Bone marrow & $\begin{array}{l}\text { For preparation of sections and smears, } \\
\text { see p. } 96 .\end{array}$ & $\begin{array}{l}\text { Hyperplasia in association with pheochro- } \\
\text { mocytoma. Extramedullary hematopoiesis } \\
\text { may also be present. Hyperplasia would } \\
\text { indicate the presence of an erythropoiesis- } \\
\text { stimulating factor in tumor and plasma. }\end{array}$ \\
\hline
\end{tabular}

\section{Tumor of the Bile Ducts (Extrahepatic or Hilar or of Papilla of Vater)}

NOTE: The address of an appropriate Registry is Hepatic and Gastrointestinal Pathology, Armed Forces Institute of Pathology (p. 148). See also "Tumor, malignant, any type."

Possible Associated Conditions: Clonorchiasis;* fibropolycystic disease of the liver and biliary tract;* inflammatory bowel disease;* primary sclerosing cholangitis.*

\begin{tabular}{|c|c|c|}
\hline Organs and Tissues & Procedures & Possible or Expected Findings \\
\hline External examination & Record body weight. & Cachexia; jaundice. \\
\hline Duodenum & $\begin{array}{l}\text { Open in situ for inspection and cholangiography } \\
\text { (p. 56). }\end{array}$ & Tumor of papilla of Vater. \\
\hline Bile ducts & $\begin{array}{l}\text { Expose extrahepatic bile ducts in situ. } \\
\text { Record width of lumen at area of obstruction } \\
\text { and proximal and distal to it. } \\
\text { Record and collect contents of bile duct } \\
\text { (sludge, concrements, parasites). }\end{array}$ & $\begin{array}{l}\text { Usually, bile ducts proximal to the } \\
\text { obstruction are dilated. Choledochal cyst* } \\
\text { (1). Primary sclerosing cholangitis.* } \\
\text { Infestation with Clonorchis sinensis or } \\
\text { Opisthorchis viverrini (rarely observed } \\
\text { in North America) (2). }\end{array}$ \\
\hline Lymph nodes & $\begin{array}{l}\text { Dissect all hepatoduodenal lymph nodes and } \\
\text { submit samples for histologic study, even if } \\
\text { no metastatic tumor is grossly evident. }\end{array}$ & $\begin{array}{l}\text { Lymph nodes seldom compress bile ducts } \\
\text { to such an extent that they cause bile duct } \\
\text { obstruction. }\end{array}$ \\
\hline Portal vein & Dissect vein in situ. & $\begin{array}{l}\text { Thrombosis* (blood clot or tumor or both); } \\
\text { pylephlebitis. }\end{array}$ \\
\hline Gallbladder & $\begin{array}{l}\text { Record volume and character of contents. } \\
\text { Search for primary tumor (with or without } \\
\text { cholelithiasis) or tumor infiltration of gallbladder. }\end{array}$ & $\begin{array}{l}\text { Dilatation of gallbladder (Courvoisier's } \\
\text { sign); cholecystitis;* cholelithiasis.* } \\
\text { White bile. }\end{array}$ \\
\hline Liver & $\begin{array}{l}\text { Record weight. Submit samples for histologic } \\
\text { and microbiologic study (p. 102). }\end{array}$ & $\begin{array}{l}\text { Ascending cholangitis. Cholangitic and } \\
\text { pylephlebitic abscesses; cholestasis. Primary } \\
\text { sclerosing cholangitis* (PSC) with or without } \\
\text { biliary cirrhosis. Secondary (obstructive) } \\
\text { biliary cirrhosis without PSC. Intrahepatic } \\
\text { metastases. }\end{array}$ \\
\hline Colon & $\begin{array}{l}\text { Procedures depend on expected findings or } \\
\text { grossly identified abnormalities as listed in } \\
\text { right-hand column. }\end{array}$ & $\begin{array}{l}\text { Chronic ulcerative colitis may be associated } \\
\text { with carcinoma of bile ducts, typically arising } \\
\text { in PSC.* }\end{array}$ \\
\hline Other organs & $\begin{array}{l}\text { Procedures depend on expected findings or } \\
\text { grossly identified abnormalities as listed in } \\
\text { right-hand column. }\end{array}$ & $\begin{array}{l}\text { Metastases common in regional lymph nodes } \\
\text { and lungs. }\end{array}$ \\
\hline
\end{tabular}




\section{References}

1. Fieber SS, Nance FC. Choledochal cyst and neoplasm: a comprehensive review of 106 cases and presentation of two original cases. Am Surgeon 1997;63:982-987.

2. Elkins DB, Mairiang E, Sithithaworn P, Mairiang P, Chaiyakum J, Chamadol N, et al. Cross sectional patterns of hepatobiliary abnormalities and possible precursor conditions of cholangiocarcinoma associated with Opisthorchis viverrini infections in humans. Am J Trop Med Hyg 1996;55: 295-301.

\section{Tumor of Bone or Cartilage}

NOTE: The address of an appropriate registry is Orthopedic Pathology, Armed Forces Institute of Pathology (p. 148). See also "Tumor, malignant, any type."

Possible Associated Conditions: Bone infarction; chronic osteomyelitis; ${ }^{*}$ fibrous dysplasia of bone; Paget's disease of bone.*

\begin{tabular}{lll}
\hline Organs and Tissues & Procedures & Possible or Expected Findings \\
\hline External examination & Record body weight. & Cachexia. \\
Vitreous & Submit for determination of electrolyte & Evidence of hypercalcemia (particularly in \\
& concentrations. Postmortem calcium value in & presence of osteolytic metastases).
\end{tabular}

Bones and joints blood is unreliable.

For removal, prosthetic repair, and specimen Prepare roentgenograms or review clinical films. Metastases to bone (e.g., from carcinoma of preparation, see p. 85. For decalcification procedures, see p. 97. If osteoblastic metastases appear to be present, search for primary tumor in prostate and breast, carcinoid tumors and Hodgkin's lymphoma.

Other organs Procedures depend on expected findings or grossly identified abnormalities as listed in prostate, breast, bronchi, thyroid gland, kidney, or urinary bladder) usually involve red bone marrow. Therefore, distal extremities are rarely involved by metastatic tumors in adults.

right-hand column.

\section{Tumor of the Brain}

NOTE: The address of an appropriate registry is Neuropathology, Armed Forces Institute of Pathology (p. 148). See also

"Tumor, malignant, any type." For pituitary tumors or tumors of the spinal cord, see under these headings.

Possible Associated Conditions: Neurofibromatosis;* tuberous sclerosis;* von Hippel-Lindau Disease.*

\begin{tabular}{lll}
\hline Organs and Tissues & Procedures & Possible or Expected Findings \\
\hline External examination & Record body weight. & Cachexia. \\
Brain and spinal cord & $\begin{array}{l}\text { For removal and specimen preparation, see } \\
\text { pp. 65 and 67, respectively. For cerebral } \\
\text { arteriography, see p. 80. }\end{array}$ & \\
& $\begin{array}{l}\text { If tumor showed endocrine activity, submit } \\
\text { fresh sample (snap-freeze) for biochemical } \\
\text { study. }\end{array}$ & $\begin{array}{l}\text { Cerebellar hemangioblastoma with erythro- } \\
\text { poiesis-stimulating factor. Other endocrine- } \\
\text { active tumors. See also "Tumor of the } \\
\text { pituitary gland." }\end{array}$ \\
\hline
\end{tabular}

\section{Tumor of the Breast}

NOTE: The address of an appropriate registry is Gynecologic/Breast Pathology, Armed Forces Institute of Pathology (p. 148). See also "Tumor, malignant, any type."

Possible Associated Conditions: Acanthosis nigricans; cerebellar cortical degeneration;* dermatomyositis; * subacute spinocerebellar degeneration.* See also below under "Possible or Expected Findings."

\begin{tabular}{ll}
\hline Organs and Tissues & Procedures \\
\hline External examination & $\begin{array}{l}\text { Record body weight. Record skin abnormalities, } \\
\text { prepare photographs of these lesions, and sample } \\
\text { and skin }\end{array}$ \\
$\begin{array}{l}\text { for histologic study. } \\
\text { Breasts and axillary } \\
\text { lymph nodes }\end{array}$ & $\begin{array}{l}\text { tumor tissue for histologic study. Srossly } \\
\text { uninvolved breast tissue as well as sentinel and } \\
\text { other axillary lymph nodes of both sides should } \\
\text { be cut into thin slices to detect tumor. }\end{array}$
\end{tabular}

\section{Possible or Expected Findings}

Cachexia. Acanthosis nigricans; herpes

zoster infection;* dermatomyositis.*

Carcinoma metastases to skin.

Metastases or secondary primary tumor may occur in opposite breast. 


\begin{tabular}{|c|c|c|}
\hline Organs and Tissues & Procedures & Possible or Expected Findings \\
\hline $\begin{array}{l}\text { Breasts and axillary } \\
\text { lymph nodes } \\
\text { (continued) }\end{array}$ & $\begin{array}{l}\text { If a mastectomy or other breast surgery had } \\
\text { been done, explore site for local recurrence. }\end{array}$ & Local recurrence of breast tumor. \\
\hline Other organs & $\begin{array}{l}\text { Histologic samples should include right } \\
\text { and left supraclavicular and retrosternal } \\
\text { lymph nodes, lungs, liver, bone marrow, and } \\
\text { endocrine (pituitary) glands. }\end{array}$ & $\begin{array}{l}\text { Regional and systemic metastases frequent at } \\
\text { sites listed in middle column. Eosinophilic } \\
\text { infiltrates may be present in many tissues. }\end{array}$ \\
\hline Brain and spinal cord & $\begin{array}{l}\text { For removal and specimen preparation, } \\
\text { see pp. } 65 \text { and } 67 \text {, respectively. }\end{array}$ & $\begin{array}{l}\text { Cerebellar cortical degeneration.* Subacute } \\
\text { spinocerebellar degeneration.* }\end{array}$ \\
\hline Skeletal muscles & $\begin{array}{l}\text { For sampling and specimen preparation, } \\
\text { see p. } 80 .\end{array}$ & Myopathy;* dermatomyositis.* \\
\hline
\end{tabular}

\section{Tumor of the Colon}

NOTE: The address of an appropriate registry is Hepatic and Gastrointestinal Pathology, Armed Forces Institute of Pathology (p. 148). See also "Tumor, malignant, any type."

Possible Associated Conditions: With adenocarcinoma of the colon-Barrett's esophagus (1); chronic ulcerative colitis; Crohn's disease;* familial colonic polyposis;* Gardner's syndrome; juvenile polyposis; non-polyposis syndrome; Peutz-Jeghers syndrome;* Turcot's syndrome.

\begin{tabular}{|c|c|c|}
\hline Organs and Tissues & Procedures & Possible or Expected Findings \\
\hline External examination & Record body weight. & Cachexia. \\
\hline Blood and vitreous & $\begin{array}{l}\text { Submit blood sample for microbiologic study } \\
\text { (p. 102). Submit vitreous for determination of } \\
\text { calcium and glucose concentration. Postmortem } \\
\text { calcium values in blood are unreliable. } \\
\text { Circulating carcinoembryonic antigen can } \\
\text { be determined in blood sample. }\end{array}$ & $\begin{array}{l}\text { Increased incidence of colonic cancer in the } \\
\text { presence of } S \text {. bovis bacteremia. Hyper- } \\
\text { calcemia. Hypoglycemia* may be present but } \\
\text { usually cannot be diagnosed at autopsy. } \\
\text { Carcinoembryonic antigen not specific for } \\
\text { carcinoma of the colon. }\end{array}$ \\
\hline Heart & $\begin{array}{l}\text { If endocarditis is suspected, see under that } \\
\text { heading. }\end{array}$ & $\begin{array}{l}\text { Increased incidence of colonic cancer in the } \\
\text { presence of S.bovis endocarditis. }\end{array}$ \\
\hline Colon & $\begin{array}{l}\text { Record exact location, size, and shape of tumor } \\
\text { and width of lumen in area of tumor and } \\
\text { proximal and distal to it. } \\
\text { Record presence of ureterosigmoidostomy } \\
\text { (for congenital extrophy of bladder). }\end{array}$ & $\begin{array}{l}\text { See above under "Possible Associated } \\
\text { Conditions." Muscular hypertrophy of colon } \\
\text { proximal to tumor. } \\
\text { Increased incidence of colon cancer after } \\
\text { ureterosigmoidostomy. }\end{array}$ \\
\hline Other organs & $\begin{array}{l}\text { Procedures depend on expected findings or } \\
\text { grossly identified abnormalities as listed in } \\
\text { right-hand column. For decalcification methods, } \\
\text { see p. } 97 \text {. }\end{array}$ & $\begin{array}{l}\text { Metastatic calcification in patients with } \\
\text { hypercalcemia. Eosinophilia. Myopathy.* } \\
\text { Metastases in liver and regional lymph nodes. } \\
\text { See also above under "Possible Associated } \\
\text { Conditions." Malakoplakia (rare) (2). }\end{array}$ \\
\hline
\end{tabular}

\section{References}

1. Howden CW, Hornung CA. A systematic review of the association between Barrett's esophagus and colon neoplasm. Am J Gastroenterol 1995;90: 1814-1819.

2. Bates AW, Dev S, Baithun SI. Malakoplakia and colorectal adenocarcinoma. Postgrad Med J 1997;73:171-173.

\section{Tumor of the Esophagus}

NOTE: The address of an appropriate registry is Hepatic and Gastrointestinal Pathology, Armed Forces Institute of Pathology (p. 148). See also "Tumor, malignant, any type."

Possible Associated Conditions: Barrett's esophagus;* Plummer-Vinson syndrome;* tylosis of palms and soles. See also below under "Possible or Expected Findings."

\begin{tabular}{lll}
\hline Organs and Tissues & Procedures & Possible or Expected Findings \\
\hline External examination & Record body weight. & Cachexia. \\
and skin & $\begin{array}{l}\text { Record skin changes, prepare photographs, } \\
\text { and sample for histologic study. }\end{array}$ & $\begin{array}{l}\text { Congenital hyperkeratosis and pitting of the } \\
\text { palms and soles (tylosis of palms and soles). }\end{array}$
\end{tabular}




\begin{tabular}{|c|c|c|}
\hline Organs and Tissues & Procedures & Possible or Expected Findings \\
\hline \multirow[t]{2}{*}{ Chest } & $\begin{array}{l}\text { Record volume and character of fluid in } \\
\text { pleural cavities. }\end{array}$ & Pleural empyema.* \\
\hline & $\begin{array}{l}\text { For demonstration of tracheoesophageal fistula, } \\
\text { see p. } 45 \text { and Fig. } 4-1, \text { p. } 46 \text {. See also below } \\
\text { under "Esophagus with neck organs. } \\
\text { Submit lymph nodes for histologic study. }\end{array}$ & $\begin{array}{l}\text { Tracheoesophageal fistula. Mediastinitis, } \\
\text { with or without mediastinal emphysema. } \\
\text { Metastases. }\end{array}$ \\
\hline \multirow[t]{2}{*}{$\begin{array}{l}\text { Esophagus with neck } \\
\text { organs and stomach }\end{array}$} & $\begin{array}{l}\text { Remove neck organs with tongue together with } \\
\text { esophagus (p. 4). Open pharynx and esophagus } \\
\text { in posterior midline. If fistulas and abscesses are } \\
\text { suspected, dissect esophagus but leave attached } \\
\text { to mediastinum, stomach and diaphragm. }\end{array}$ & $\begin{array}{l}\text { Esophageal web and glossitis in Plummer- } \\
\text { Vinson syndrome.* }\end{array}$ \\
\hline & $\begin{array}{l}\text { Record width of lumen of esophagus at various } \\
\text { levels. Photograph and record size and location } \\
\text { of tumor; sample tumor and uninvolved } \\
\text { esophagus for histologic study. Request PAS } \\
\text { stain (p. 173) of uninvolved esophagus (sample } \\
\text { from all levels). }\end{array}$ & $\begin{array}{l}\text { Esophagus dilated proximal to obstruction, } \\
\text { with or without retained food or medications } \\
\text { Stricture or total luminal occlusion by tumor } \\
\text { Reflux esophagitis (distal) and Barrett's } \\
\text { esophagus* with low-grade and high-grade } \\
\text { dysplasia (distal or at all levels). }\end{array}$ \\
\hline Other organs & $\begin{array}{l}\text { Procedures depend on expected findings or } \\
\text { grossly identified abnormalities as listed in } \\
\text { right-hand column. }\end{array}$ & $\begin{array}{l}\text { Metastases in regional lymph nodes } \\
\text { and lungs. }\end{array}$ \\
\hline
\end{tabular}

\section{Tumor of the Gallbladder}

NOTE: Follow procedures described under "Tumor of the bile ducts (extrahepatic or hilar or of papilla of Vater").

\section{Tumor of the Heart}

NOTE: The address of an appropriate registry is Cardiovascular Pathology, Armed Forces Institute of Pathology (p. 148). See also "Tumor, malignant, any type."

Possible Associated Conditions: Carney's syndrome with cardiac myxomas; LAMB syndrome (lentigines, atrial myxoma, blue nevi); NAME syndrome (pigmented nevi, atrial myxoma, myxoid neurofibroma, and ephelids); also with myxoma of the heart: Adrenal cortical nodules with or without Cushing's syndrome;* pituitary adenomas; and testicular tumors. With cardiac rhabdomyoma(s): Adenoma sebaceum; benign kidney tumors;* tuberous sclerosis.*

\begin{tabular}{|c|c|c|}
\hline Organs and Tissues & Procedures & Possible or Expected Findings \\
\hline External examination & Record and prepare photographs of skin lesions. & $\begin{array}{l}\text { Freckles (ephelides); pigmented spots } \\
\text { (lentigines) or pigmented nevi; clubbing of } \\
\text { fingers (with cardiac myxoma). }\end{array}$ \\
\hline Heart & $\begin{array}{l}\text { If rhabdomyoma(s) are suspected, submit } \\
\text { tumor samples in absolute alcohol (p. 129) } \\
\text { or other water-free fixative for demonstration } \\
\text { of glycogen. Record size and location of } \\
\text { tumor(s). If tumor is within a heart chamber } \\
\text { (usually a myxoma), record extent of mobility } \\
\text { and capability of tumor to obstruct a valvular } \\
\text { orifice. Submit samples of tumor(s) for histo- } \\
\text { logic study and, particularly if the tumor is of } \\
\text { unknown type, for immunohistochemical study } \\
\text { and electron microscopy (p. 132). }\end{array}$ & $\begin{array}{l}\text { Glycogen in rhabdomyoma is extractable } \\
\text { with dilute trichloracetic acid. Tumor types } \\
\text { include fibroma, lipoma, myxoma; primary } \\
\text { or metastatic sarcoma; lymphoma;* } \\
\text { metastatic carcinoma or melanoma. } \\
\text { Secondary cardiac effects by tumors include } \\
\text { carcinoid heart disease, amyloid heart disease } \\
\text { in multiple myeloma, and lymphocytic } \\
\text { myocarditis in pheochromocytoma. } \\
\text { Treatment effects such as adriamycin } \\
\text { cardiotoxicity may be noted also. }\end{array}$ \\
\hline $\begin{array}{l}\text { Other organs and } \\
\text { peripheral arteries }\end{array}$ & $\begin{array}{l}\text { Procedures depend on expected findings or } \\
\text { grossly identified abnormalities as listed in } \\
\text { right-hand column. }\end{array}$ & $\begin{array}{l}\text { Tumor (myxoma) emboli in pulmonary or } \\
\text { peripheral vessels. Multiple aneurysms* of } \\
\text { cerebral and other arteries may rarely be } \\
\text { associated with atrial myxomas. }\end{array}$ \\
\hline
\end{tabular}

Tumor of the Hematopoietic or Lymphatic Tissue (See "Leukemia" or "Lymphoma.")

Tumor of the Intestines (See "Tumor of the colon" and "Tumor of the small intestine.") 


\section{Tumor of the Kidney(s)}

NOTE: The address of an appropriate registry is Genitourinary Pathology, Armed Forces Institute of Pathology (p. 148). See also "Tumor, malignant, any type."

Possible Associated Conditions: With adult renal cell carcinoma-amyloidosis, * hepatomegaly (Stauffer's syndrome), von Hippel Lindau disease;* also leukemoid reaction and plasmacytosis; with either adult renal cell carcinoma or nephroblastomamanifestations of hypertension* or polycythemia;* with Wilms tumor-polycythemia* $(1)$; with renal medullary carcinomasickle cell disease* (2). See also below under "Possible or Expected Findings."

\begin{tabular}{ll}
\hline Organs and Tissues & Procedures \\
\hline External examination & Record body weight. \\
and skin & $\begin{array}{l}\text { Record skin changes, prepare photographs, } \\
\text { and sample for histologic study. }\end{array}$
\end{tabular}

Blood

Lungs

Retroperitoneal space and kidneys

Other organs
Submit sample for biochemical study. Inspect lumen of pulmonary arteries prior to dissection (fresh emboli may fall out). Renal veins and inferior vena cava should be opened in situ or after removal of organ block. For dissection technique, see p. 59 and Fig. 5-8, p. 60. Photograph tumor; record size of tumor and extent of tumor invasion. Snap-freeze portion of tumor tissue for possible biochemical study. For arteriography of kidneys, see p. 59.

Procedures depend on expected findings or grossly identified abnormalities as listed above and in right-hand column.
Possible or Expected Findings

Cachexia.

Eczematoid dermatitis with adult renal cell carcinoma. Cushing's syndrome,* galactorrhea or feminization or masculinization in some cases of renal cell carcinoma.

Evidence of hyperalcemia.

Pulmonary tumor embolism after invasion of renal vein and inferior vena cava.

Acquired renal cystic disease (mainly in dialysis patients) with renal cell carcinoma (3). Tumor thrombus in renal vein and inferior vena cava.

Erythropoietin, gonadotropins, parathyroid hormone, prolactin, renin, and prostaglandins in some renal cell carcinomas.

See above under "Possible Associated Conditions." Metastases are common in lungs and regional lymph nodes.

\section{References}

1. Lal A, Rice A, al Mahr M, Kern IB, Marshall GM. Wilms tumor associated with polycythemia: case report and review of the literature. J Pediatr Hematol/Oncol 1997;19:263-265.

2. Wesche WA, Wilimas J, Khare V, Parham DM. Renal medullary carcinoma: a potential sickle cell nephropathy of children and adolescents. Pediatr Pathol Lab Med 1998;18:97-113.

3. Levine E. Acquired cystic kidney disease. Radiol Clin North Am 1996;34:947-964.

\section{Tumor of the Liver}

NOTE: The address of an appropriate registry is Hepatic and Gastrointestinal Pathology, Armed Forces Institute of Pathology (p. 148). See also "Tumor, malignant, any type."

Possible Associated Conditions: With hepatocellular carcinoma (HCC)-Alagille's syndrome (arteriohepatic dysplasia), alpha ${ }_{1}$-antitrypsin deficiency, ${ }^{*}$ alpha-fetoproteinemia, ataxia telangiectasia, Byler's disease, carcinoid syndrome,* cirrhosis* of any type (mostly nonbiliary), congenital hepatic fibrosis, ${ }^{*}$ Cushing's syndrome, ${ }^{*}$ erythrocytosis, genetic hemochromatosis, ${ }^{*}$ glycogen storage disease (type I), ${ }^{*}$ hepatitis B or $\mathrm{C}$ virus infection, hereditary tyrosinemia (type I), ${ }^{*}$ hypercalcemia, hypercholesterolemia, hypoglycemia, ${ }^{*}$ neurofibromatosis, ${ }^{*}$ Osler-Rendu-Weber disease* (hereditary hemorrhagic telangiectasia), polycythemia, ${ }^{*}$ porphyria (acute intermittent and porphyria cutanea tarda), ${ }^{*}$ pseudohyperparathyroidism, ${ }^{*}$ and thorium (thorotrast) deposition.

With bile duct carcinoma (cholangiocarcinoma)-Clonorchis sinensis or Opisthorchis viverrini infection, fibropolycystic liver and biliary tract disease, ${ }^{*}$ hepatolithiasis, hypercalcemia, primary sclerosing cholangitis, ${ }^{*}$ and thorium (thorotrast) deposition.

With hepatoblastoma-Alpha-fetoproteinemia, cardiac and renal malformations, cleft palate, diaphragmatic hernia,* Down's syndrome, ${ }^{*}$ familial colonic polyposis, ${ }^{*}$ hemihypertrophy, nephroblastoma.

With angiosarcoma-Thorium (thorotrast) deposition. See also below under "Possible or Expected Findings."

\begin{tabular}{lll}
\hline Organs and Tissues & Procedures & Possible or Expected Findings \\
\hline External examination & Record body weight. & Cachexia. \\
and skin & Record abnormal features as listed in & Precocious puberty. Feminization and \\
& right-hand column; prepare photographs. & gynecomastia in rare cases of HCC. \\
& & Spider angiomas; clubbing of fingers. \\
Blood & Refrigerate sample for possible biochemical & See above under "Possible Associated \\
& study. & Conditions."
\end{tabular}




\begin{tabular}{lll}
\hline Organs and Tissues & Procedures & Possible or Expected Findings \\
\hline Abdominal cavity & $\begin{array}{l}\text { Record volume and character of contents; } \\
\text { determine hematocrit of hemorrhagic fluid. }\end{array}$ & $\begin{array}{l}\text { Hemoperitoneum or ascites (which may be } \\
\text { hemorrhagic). } \\
\text { Tiver }\end{array}$ \\
$\begin{array}{l}\text { For hepatic angiography, see p. 56. } \\
\text { Record weight and size of liver and size and } \\
\text { location of tumor(s). Describe and photograph } \\
\text { cut surfaces. }\end{array}$ & $\begin{array}{l}\text { portal veins. Hemorrhages after rupture of } \\
\text { tumor (HCC and angiosarcoma). }\end{array}$ \\
& $\begin{array}{l}\text { Sample tumor and nonneoplastic liver for } \\
\text { histologic study. }\end{array}$ & $\begin{array}{l}\text { Evidence of chronic viral hepatitis B or C; } \\
\text { cirrhosis* of any type (mostly nonbiliary). }\end{array}$ \\
& $\begin{array}{l}\text { If thorium deposition is suspected, prepare } \\
\text { roentgenograms of liver slices and submit } \\
\text { samples for energy-dispersive x-ray micro- } \\
\text { analysis of paraffin sections. }\end{array}$ & $\begin{array}{l}\text { Thorotrast storage may cause cirrhosis, HCC, } \\
\text { bile duct carcinoma, or angiosarcoma. }\end{array}$ \\
& $\begin{array}{l}\text { Procedures depend on expected findings or } \\
\text { grossly identified abnormalities as listed } \\
\text { above and in right-hand column. }\end{array}$ & $\begin{array}{l}\text { See above under "Possible Associated } \\
\text { Conditions." Metastases most common in } \\
\text { lungs and regional lymph nodes. }\end{array}$ \\
\hline
\end{tabular}

\section{Tumor of the Lung or Bronchus}

NOTE: The address of an appropriate registry is Pulmonary and Mediastinal Pathology, Armed Forces Institute of Pathology (p. 148). See also "Tumor, malignant, any type."

Possible Associated Conditions: Abnormal concentrations of hormons or other metabolites in blood and tumor tissue (adrenocorticotropic, antidiuretic, growth hormone, parathyroid-like substances, or 5-hydroxyindolacetic acid); acanthosis nigricans; acromegaloid features; carcinoid syndrome;* Cushing's syndrome;* dermal hyperpigmentation; feminization; hyperglycemia; hypercalcemia; hypoglycemia;* hypokalemia; hyponatremia; precocious puberty. For syndromes affecting the brain, peripheral nerves or muscles, see below under "Possible or Expected Findings." (Most paracarcinomatous syndromes are associated with small cell or other types of bronchogenic carcinoma.)

\begin{tabular}{ll}
\hline Organs and Tissues & Procedures \\
\hline External examination & Record body weight. \\
and skin & Record abnormal features as listed in right-hand \\
& column; prepare photographs. Prepare histologic \\
& sections of normal and grossly abnormal skin. \\
& Prepare skeletal roentgenograms.
\end{tabular}

Blood and vitreous

Heart

Lungs

Other organs and tissues

Peripheral veins Brain and spinal cord
Submit samples of vitreous for study of electrolyte and sugar concentrations. Submit sample of serum for possible hormon assay. Inspect valves and prepare photographs and sections of vegetations.

For pulmonary arteriography and bronchography, see p. 50. Record size and location of tumor(s). If there was evidence of endocrine activity (see above), snap-freeze portion of fresh tumor for hormone assay. For demonstration of asbestos bodies, see p. 52.

Perfuse lungs with formalin (p. 47). Sample neoplastic and non-neoplastic tissue for histologic study. Procedures depend on expected findings or grossly identified abnormalities as listed above and in right-hand column.

For removal and specimen preparation, see p. 34. For removal and specimen preparation, see pp. 65 and 67 , respectively.
Possible or Expected Findings

Cachexia. Skin metastases.

Clubbing of fingers; spider angiomas. For other rare tumor-related changes, see above under "Possible Associated Conditions." Hypertrophic osteoarthropathy;* pachydermoperiostosis. Bone marrow metastases. See above under "Possible Associated Conditions." Note that hypoglycemia* generally cannot be confirmed at autopsy. Nonbacterial thrombotic endocarditis.*

Carcinoma may be associated with asbestosis or other types of pneumoconiosis, * chronic bronchitis, ${ }^{*}$ emphysema, ${ }^{*}$ interstitial pneumonia,* and many other bronchopulmonary diseases.

See above under "Possible Associated Conditions." Metastases (regional lymph nodes, liver, bones, brain, and many other sites) and metastatic calcification.

Migratory thrombophlebitis.* Encephalomyelitis;* cerebellar corticoid degeneration;* subacute spinocerebellar degeneration.* 


\begin{tabular}{lll}
\hline Organs and Tissues & Procedures & Possible or Expected Findings \\
\hline Pituitary gland & For removal and specimen preparation, see p. 71. & Crooke cell hyperplasia. \\
$\begin{array}{l}\text { Skeletal muscles and } \\
\text { peripheral nerves }\end{array}$ & $\begin{array}{l}\text { For removal and specimen preparation, } \\
\text { see p. } 80 \text { and 79, respectively. }\end{array}$ & $\begin{array}{l}\text { Myasthenic syndrome (Eaton-Lambert } \\
\text { syndrome); myopathy;* dermatomyositis.* } \\
\text { Bones }\end{array}$ \\
For removal and specimen preparation, & $\begin{array}{l}\text { Peripheral neuropathy. } \\
\text { See above under "External examination and } \\
\text { skin." Bones (with red marrow) are common } \\
\text { sites of metastases. }\end{array}$ \\
\hline
\end{tabular}

\section{Tumor of the Ovary (or Ovaries)}

NOTE: The address of an appropriate registry is Gynecologic/Breast Pathology, Armed Forces Institute of Pathology (p. 148). See also "Tumor, malignant, any type."

Possible Associated Conditions: Cushing's syndrome, ${ }^{*}$ dermal hyperpigmentation; dermatomyositis. * See also below under "Possible or Expected Findings."

\begin{tabular}{lll}
\hline Organs and Tissues & Procedures & Possible or Expected Findings \\
\hline $\begin{array}{c}\text { External examination } \\
\text { and skin }\end{array}$ & $\begin{array}{l}\text { Record body weight. } \\
\text { Record and prepare photographs of abnormal } \\
\text { features as listed in right-hand column. } \\
\text { Prepare histologic sections of normal and } \\
\text { grossly abnormal skin. }\end{array}$ & $\begin{array}{l}\text { Cachexia. } \\
\text { Dermal hyperpigmentation; dermato- } \\
\text { myositis.* Cushingoid features. Gangrene } \\
\text { of fingers (1). }\end{array}$ \\
$\begin{array}{l}\text { Submit samples for electrolyte analysis. Post- } \\
\text { mortem calcium values in blood are unreliable. }\end{array}$ & Hypercalcemia. \\
$\begin{array}{l}\text { Abdominal cavity } \\
\text { and pelvic organs }\end{array}$ & $\begin{array}{l}\text { Record appearance of peritoneum and volume } \\
\text { and character of intraabdominal fluid. }\end{array}$ & Peritoneal carcinomatosis; ascites. \\
& $\begin{array}{l}\text { If possible, remove pelvic organs with tumor(s) } \\
\text { en block. Record size, weight, and appearance } \\
\text { of ovarian tumor. }\end{array}$ & $\begin{array}{l}\text { Tumors may be bilateral or may be so large } \\
\text { (e.g., cystadenocarcinoma) that they are } \\
\text { difficult to remove with pelvic organs. }\end{array}$ \\
$\begin{array}{l}\text { For sampling and specimen preparation, } \\
\text { See p. 80. }\end{array}$ & $\begin{array}{l}\text { See above under "Possible Associated } \\
\text { Conditions." } \\
\text { muscles }\end{array}$ \\
$\begin{array}{l}\text { Peripheral veins } \\
\text { Brain and spinal cord }\end{array}$ & $\begin{array}{l}\text { For phlebography and removal of femoral veins, } \\
\text { see pp. 120 and 34, respectively. } \\
\text { For removal and specimen preparation, } \\
\text { see pp. 65 and 67, respectively. }\end{array}$ & Venous thromboses.* \\
\hline
\end{tabular}

\section{Reference}

1. Chow SF, McKenna CH. Ovarian cancer and gangrene of the digits: case report and review of the literature. Mayo Clin Proc 1996;71:253-258.

\section{Tumor of the Pancreas}

NOTE: The address of an appropriate registry is Hepatic and Gastrointestinal Pathology, Armed Forces Institute of Pathology (p. 148). See also "Tumor, malignant, any type."

Possible Associated Conditions: With carcinoma of the exocrine pancreas-Cushing's syndrome;* diabetes mellitus* (rare); hypercalcemia; hyperglycemia; dermal hyperpigmentation; pemphigus* (1); Peutz-Jeghers syndrome* (2); venous thromboses or thrombophlebitis.

With islet cell tumor-Abnormal concentrations of hormons in blood and tumor tissue (see below under "pancreas"); carcinoid syndrome;* Cushing's syndrome;* diabetes mellitus;* hypoglycemia;* hypokalemia; Zollinger-Ellison syndrome.*

\begin{tabular}{ll}
\hline Organs and Tissues & Procedures \\
\hline External examination & Record body weight. \\
and skin & Record abnormal features as listed in right- \\
& hand column; prepare photographs. Prepare \\
& histologic sections of normal and grossly \\
& abnormal skin.
\end{tabular}

Possible or Expected Findings

Cachexia; jaundice.

Cushingoid features. Dermal hyperpigmentation. For other rare tumor-related changes, see above under "Possible Associated Conditions." 


\begin{tabular}{|c|c|c|}
\hline Organs and Tissues & Procedures & Possible or Expected Findings \\
\hline Blood and vitreous & $\begin{array}{l}\text { Submit samples of vitreous for determination } \\
\text { of electrolyte and glucose concentrations } \\
\text { (p. 114) Blood values are often unreliable. } \\
\text { Snap-freeze serum for possible hormone assay. }\end{array}$ & $\begin{array}{l}\text { See above under "Possible Associated } \\
\text { Conditions." Note that hypoglycemia } \\
\text { generally cannot be confirmed at autopsy. }\end{array}$ \\
\hline Heart & $\begin{array}{l}\text { Inspect valves and prepare photographs and } \\
\text { sections of vegetations. }\end{array}$ & Nonbacterial thrombotic endocarditis. ${ }^{*}$ \\
\hline $\begin{array}{l}\text { Esophagus and } \\
\text { gastrointestinal tract }\end{array}$ & Record or estimate volume of blood in lumen. & $\begin{array}{l}\text { Esophageal varices.* } \\
\text { Gastrointestinal hemorrhage. }\end{array}$ \\
\hline \multirow[t]{2}{*}{ Pancreas } & $\begin{array}{l}\text { For pancreatography, see p. } 57 \text {. Dissect } \\
\text { common bile duct in situ. Record size and } \\
\text { location of tumor in relationship to head, } \\
\text { body, and tail of pancreas. }\end{array}$ & $\begin{array}{l}\text { Biliary obstruction caused by tumor in head } \\
\text { of pancreas. }\end{array}$ \\
\hline & $\begin{array}{l}\text { Portions of primary or metastatic endocrine } \\
\text { tumors should be snap-frozen for biochemical } \\
\text { and histochemical study and for hormone } \\
\text { assay. For preparation of tissue for electron } \\
\text { microscopy, see p. } 132 \text {. }\end{array}$ & $\begin{array}{l}\text { Islet cell tumor with adrenocorticotropic } \\
\text { hormone, gastrin, glucagon, insulin, or other } \\
\text { peptide hormones. }\end{array}$ \\
\hline Other organs & $\begin{array}{l}\text { Procedures depend on expected findings or } \\
\text { grossly identified abnormalities as listed } \\
\text { above and in right-hand column. }\end{array}$ & $\begin{array}{l}\text { See above under "Possible Associated } \\
\text { Conditions." Regional lymph nodes and liver } \\
\text { are common sites of metastases. }\end{array}$ \\
\hline Veins & $\begin{array}{l}\text { For phlebography and removal of femoral } \\
\text { veins, see pp. } 120 \text { and 34, respectively. }\end{array}$ & $\begin{array}{l}\text { Venous thrombosis or migratory } \\
\text { thrombophlebitis associated with carcinoma } \\
\text { of exocrine pancreas. }\end{array}$ \\
\hline
\end{tabular}

\section{References}

1. Matz H, Milner Y, Frusic-Zlotkin M, Brenner S. Paraneoplastic pemphigus associated with pancreatic carcinoma. Acta-Dermato-Venereol 1997;77:289-291.

2. Pauwels M, Delcenserie R, Yzet T, Duchmann JC, Capron JP. Pancreatic cystadenocarcinoma in Peutz-Jeghers syndrome. J Clin Gastroenterol 1997;25:485-486.

\section{Tumor of the Peripheral Nerves}

NOTE: The address of an appropriate registry is Neuropathology, Armed Forces Institute of Pathology (p. 148). See also "Tumor, malignant, any type."

Possible Associated Conditions: Abnormal concentrations of metabolites in urine and tumor tissue (with ganglioneuroma or neuroblastoma); neurofibromatosis;* pheochromocytoma.

\begin{tabular}{|c|c|c|}
\hline Organs and Tissues & Procedures & Possible or Expected Findings \\
\hline $\begin{array}{l}\text { External examination } \\
\text { and skin }\end{array}$ & $\begin{array}{l}\text { Record abnormal pigmentations and presence } \\
\text { of skin tumors. }\end{array}$ & Manifestations of neurofibromatosis.* \\
\hline Urine & $\begin{array}{l}\text { If ganglioneuroma or neuroblastoma is } \\
\text { suspected, submit sample for determination } \\
\text { of catecholamin concentration. }\end{array}$ & $\begin{array}{l}\text { Abnormal concentrations of catecholamine } \\
\text { in association with ganglioneuroma } \\
\text { or neuroblastoma. }\end{array}$ \\
\hline $\begin{array}{l}\text { Peripheral nerves } \\
\text { and tumor tissue }\end{array}$ & $\begin{array}{l}\text { Record size and location. If biochemical study } \\
\text { is intended, snap-freeze tumor tissue. } \\
\text { For removal and specimen preparation of } \\
\text { peripheral nerves, see p. } 79 \text {. }\end{array}$ & $\begin{array}{l}\text { Catecholamine may be found in } \\
\text { ganglioneuroma or neuroblastoma. }\end{array}$ \\
\hline Other organs and tissues & $\begin{array}{l}\text { Procedures depend on expected findings or } \\
\text { grossly identified abnormalities as listed } \\
\text { above. }\end{array}$ & $\begin{array}{l}\text { See above under "Possible Associated } \\
\text { Conditions." }\end{array}$ \\
\hline
\end{tabular}

\section{Tumor of the Pituitary Gland}

NOTE: See also "Tumor, malignant, any type."

Possible Associated Conditions: Acromegaly;* Cushing's syndrome.* See also below under "Possible or Expected Findings."

\begin{tabular}{lll}
\hline Organs and Tissues & Procedures & Possible or Expected Findings \\
\hline External examination & $\begin{array}{l}\text { Record abnormal features as listed in } \\
\text { right-hand column. }\end{array}$ & $\begin{array}{l}\text { Features of acromegaly* or of Cushing's } \\
\text { syndrome.* }\end{array}$
\end{tabular}




\begin{tabular}{lll}
\hline Organs and Tissues & Procedures & Possible or Expected Findings \\
\hline Pituitary gland & $\begin{array}{l}\text { For removal and specimen preparation, see } \\
\text { p. 71. Record size, weight, and boundaries } \\
\text { of tumor; photograph tumor in situ and after } \\
\text { removal. If hormone assay is intended, } \\
\text { snap-freeze portion of tumor. Prolactin and } \\
\text { growth hormone cells can be localized by the } \\
\text { immunoperoxidase method. If an adenoma of } \\
\text { unknown type is suspected, submit sample for } \\
\text { electron microscopic study (p. 132). }\end{array}$ & $\begin{array}{l}\text { Carcinoma metastases in the pituitary } \\
\text { most commonly originate from breast } \\
\text { carcinoma. Usually, metastases are found in } \\
\text { the posterior lobe, whereas adenomas are } \\
\text { anterior lobe tumors. }\end{array}$ \\
& $\begin{array}{l}\text { Procedures depend on expected findings or } \\
\text { grossly identified abnormalities as listed in } \\
\text { right-hand column. }\end{array}$ & $\begin{array}{l}\text { Manifestations of pituitary insufficiency* } \\
\text { or of excessive hormone production } \\
\text { (acromegaly,* Cushing's syndrome*). }\end{array}$ \\
\hline
\end{tabular}

\section{Tumor of the Pleura}

NOTE: The address of an appropriate registry is Pulmonary and Mediastinal Pathology, Armed Forces Institute of Pathology (p. 148). See also "Tumor, malignant, any type."

\begin{tabular}{|c|c|c|}
\hline Organs and Tissues & Procedures & Possible or Expected Findings \\
\hline External examination & $\begin{array}{l}\text { Record abnormal features as listed in right- } \\
\text { hand column. Prepare roentgenograms of chest } \\
\text { and extremities. }\end{array}$ & $\begin{array}{l}\text { Hypertrophic osteoarthropathy* (with } \\
\text { pleural mesothelioma). }\end{array}$ \\
\hline \multirow[t]{2}{*}{ Chest cavity } & $\begin{array}{l}\text { Record character and volume of pleural } \\
\text { effusions. Record size and location of tumor(s). }\end{array}$ & Pleural effusions.* \\
\hline & $\begin{array}{l}\text { Submit sample of tumor tissue and of non- } \\
\text { neoplastic lung tissue for analysis of asbestos } \\
\text { bodies (p. 52). }\end{array}$ & $\begin{array}{l}\text { Asbestosis may be complicated by pleural } \\
\text { mesothelioma. }\end{array}$ \\
\hline Other organs and tissue & $\begin{array}{l}\text { Document absence of tumor that might have } \\
\text { metastasized to pleurae. }\end{array}$ & $\begin{array}{l}\text { Pleural metastases from distant primary } \\
\text { tumors may mimic mesothelioma. }\end{array}$ \\
\hline
\end{tabular}

\section{Tumor of the Prostate}

NOTE: The address of an appropriate registry is Genitourinary Pathology, Armed Forces Institute of Pathology (p. 148). See also "Tumor, malignant, any type."

Possible Associated Conditions: Cushing's syndrome;* disseminated intravascular coagulation;* hemolytic uremic syndrome* (1); osteomalacia* (2).

\begin{tabular}{|c|c|c|}
\hline Organs and Tissues & Procedures & Possible or Expected Findings \\
\hline \multirow[t]{3}{*}{ External examination } & Record body weight. & Cachexia. \\
\hline & $\begin{array}{l}\text { Record abnormal features as listed in right- } \\
\text { hand column. }\end{array}$ & $\begin{array}{l}\text { Dermal hyperpigmentation; Cushingoid } \\
\text { features. }\end{array}$ \\
\hline & $\begin{array}{l}\text { Prepare roentgenograms of chest, thoracic } \\
\text { and lumbar spine, and extremities. }\end{array}$ & $\begin{array}{l}\text { Osteomalacia (2). Osteoblastic bone } \\
\text { metastases. }\end{array}$ \\
\hline \multirow[t]{2}{*}{$\begin{array}{l}\text { Pelvic organs with } \\
\text { prostate; testes }\end{array}$} & For dissection of pelvic organs, see p. 59. & $\begin{array}{l}\text { Infiltrating carcinoma of prostate may cause } \\
\text { obstructive uropathy and other complications }\end{array}$ \\
\hline & Record presence or absence of testes. & $\begin{array}{l}\text { Testes may have been surgically removed to } \\
\text { achieve androgen deprivation. }\end{array}$ \\
\hline Other organs & $\begin{array}{l}\text { Procedures depend on expected findings or } \\
\text { grossly identified abnormalities as listed in } \\
\text { right-hand column. }\end{array}$ & $\begin{array}{l}\text { Urinary obstruction and hydronephrosis.* } \\
\text { Osteoblastic metastases, particularly in } \\
\text { vertebral bodies. See also above under } \\
\text { "Possible Associated Conditions." }\end{array}$ \\
\hline
\end{tabular}

\section{References}

1. Muller NJ, Pestalozzi BC. Hemolytic uremic syndrome in prostatic carcinoma. Oncol 1998;55:174-176.

2. Reese DM, Rosen PJ. Oncogenic osteomalacia associated with prostatic cancer. J Urol 1997;158:887. 


\section{Tumor of the Small Intestine}

NOTE: The address of an appropriate registry is Hepatic and Gastrointestinal Pathology, Armed Forces Institute of Pathology (p. 148). See also "Tumor, malignant, any type."

Possible Associated Conditions: Acquired immunodeficiency syndrome* (AIDS) in patients with small bowel lymphoma;* Carcinoid syndrome;* familial polyposis and related syndromes* (Cronkhite-Canada syndrome; Gardner's syndrome); PeutzJeghers syndrome.*

\begin{tabular}{ll}
\hline Organs and Tissues & Procedures \\
\hline External examination & $\begin{array}{l}\text { Record body weight. Record abnormal features } \\
\text { as listed above. }\end{array}$
\end{tabular}

Small and large bowel

For mesenteric angiography, see p. 55. For in situ fixation of small intestine, see p. 54. If there is a history of carcinoid syndrome,* see under that entry. A frozen section diagnosis of the tumor may help to determine how to process the tumor tissue and what stains to order. Submit sample of non-neoplastic small bowel for histologic study.

Other organs and tissues Procedures depend on expected findings or grossly identified abnormalities as listed above.

Possible or Expected Findings

Cachexia.

Mucocutaneous pigmentations associated with Peutz-Jeghers syndrome.*

Carcinoid tumor.

Lymphoma (see also above under "Possible Associated Conditions"). Familial polyposis or related syndrome.* Celiac sprue.* Crohn's disease.*

See above under "Possible Associated Conditions." Regional lymph nodes and liver are common sites of metastases.

\section{Tumor of the Soft Tissues}

NOTE: The address of an appropriate registry is Soft Tissue Pathology, Armed Forces Institute of Pathology (p. 148). See also "Tumor, malignant, any type."

The possible sites and characteristics of soft tissue tumors vary so much that no universally applicable autopsy techniques can be presented. In all instances, the size, weight, and location of the tumor(s) must be recorded and tissue must be sampled for histologic study. If the tumor had not been classified prior to death, samples should be snap-frozen for immunohistochemical study. Other samples should be prepared for electron microscopic study (p. 132). Evidence of paraneoplastic syndromes (see below) may require additional procedures.

Possible Associated Conditions: Only a few paraneoplastic syndromes or systemic complications can be presented here. For the type of soft tissue tumor that was associated with each condition, see title of reference. Kasabach-Merritt syndrome (1) (thrombocytopenia, microangiopathic hemolytic anemia, and acute or chronic coagulopathy associated with a rapidly enlarging hemangioma); liver function abnormalities (2); neurofibromatosis (3); osteomalacia (4).

\section{References}

1. Esterly NB. Kasabach Merritt syndrome in infants. J Am Acad Dermatol 1983;8:504-513.

2. Sharara AI, Panella TJ, Fitz JG. Paraneoplastic hepatopathy associated with soft tissue sarcoma. Gastroenterol 1992;103:330-332.

3. Hartley AL, Birch JM, Marsden HB, Harris M, Blair V. Neurofibromatosis in children with soft tissue sarcoma. Pediatr Hematol Oncol 1988;5:7-16.

4. Zura RD, Minasi JS, Kahler DM. Tumor-induced osteomalacia and symptomatic looser zones secondary to mesenchymal chondrosarcoma. J Surg Oncol 1999;71:58-62.

\section{Tumor of the Spinal Cord}

NOTE: The address of an appropriate registry is Neuropathology, Armed Forces Institute of Pathology (p. 148). See also "Tumor, malignant, any type."

Possible Associated Conditions: With angioma-cerebellar hemangioblastoma; segmental cutaneous vascular nevi; with hemangioblastoma-von Hippel-Lindau disease;* with arteriovenous malformation—vertebral hemangioma(s).

\begin{tabular}{lll}
\hline Organs and Tissues & Procedures & Possible or Expected Findings \\
\hline External examination & Record abnormal features; photograph and & Segmental cutaneous vascular nevi \\
and skin & submit nevi for histologic study. & (associated with spinal cord angiomas). \\
Brain and spinal cord & For removal and specimen preparation, see & Subarachnoid hemorrhage.* Spinal cord \\
& pp. 65 and 67, respectively. See also below & compression; ischemic spinal cord changes. \\
& under "Vertebral column." Describe gross & See also above under "Possible Associated \\
& appearance, location, and size of spinal cord & Conditions."
\end{tabular}




\begin{tabular}{lll}
\hline Organs and Tissues & Procedures & Possible or Expected Findings \\
\hline Vertebral column & $\begin{array}{l}\text { Record and photograph changes listed in } \\
\text { right-hand column. }\end{array}$ & $\begin{array}{l}\text { Bone erosion and calcification of spinal } \\
\text { canal. Vertebral hemangiomas may be } \\
\text { associated with arteriovenous malformation } \\
\text { of spinal cord. } \\
\text { Other organs and tissues } \\
\text { disease.* }\end{array}$ \\
\hline
\end{tabular}

\section{Tumor of the Stomach}

NOTE: The address of an appropriate registry is "Hepatic and Gastrointestinal Pathology, Armed Forces Institute of Pathology (p. 148). See also "Tumor, malignant, any type."

Possible Associated Conditions: Hypoglycemia;* megaloblastic anemia;* skin changes (as listed under "Possible or Expected Findings); venous thromboses.

\begin{tabular}{lll}
\hline Organs and Tissues & Procedures & Possible or Expected Findings \\
\hline $\begin{array}{l}\text { External examination } \\
\text { and skin }\end{array}$ & $\begin{array}{l}\text { Record body weight. } \\
\text { Record abnormal features; photograph and } \\
\text { submit samples of normal and abnormal skin } \\
\text { for histologic study. }\end{array}$ & $\begin{array}{l}\text { Cachexia. } \\
\text { Acanthosis nigricans; hyperkeratosis } \\
\text { palmaris and plantaris (1). Pyoderma } \\
\text { gangrenosum. Dermatomyositis;* herpes } \\
\text { zoster.* Periumbilical metastases. }\end{array}$ \\
Blood and vitreous & $\begin{array}{l}\text { In most instances, determination of vitreous } \\
\text { sugar concentration and of blood group } \\
\text { is not indicated. }\end{array}$ & $\begin{array}{l}\text { Hypoglycemia may have been present but } \\
\text { at autopsy. Blood group A is more common } \\
\text { in patients with carcinoma of stomach than in }\end{array}$ \\
controls.
\end{tabular}

\section{References}

1. Murata I, Ogami Y, Nagai Y, Furuma K, Yoshikawa I, Otsuli M. Carcinoma of the stomach with hyperkeratosis palmaris and plantaris and acanthosis of the esophagus. Am J Gastroenterol 1998;93:449-451.

2. Wotherspoon AC. Gastric lymphoma of mucosa-associated lymphoid tissue and Helicobacter pylori. Ann Rev Med 1998;49:289-299.

\section{Tumor of the Testis}

NOTE: The address of an appropriate registry is Genitourinary Pathology, Armed Forces Institute of Pathology (p. 148). See also "Tumor, malignant, any type."

Possible Associated Conditions: Demyelinating neuropathy (1); dermatomyositis* (2); Down's syndrome;* eosinophilia; herpes zoster;* megaloblastic anemia.* 


\begin{tabular}{|c|c|c|}
\hline Organs and Tissues & Procedures & Possible or Expected Findings \\
\hline \multirow[t]{3}{*}{ External examination } & Record body weight. & Cachexia. \\
\hline & $\begin{array}{l}\text { Record genital abnormalities as listed in right- } \\
\text { hand column. }\end{array}$ & Cryptorchism; hypospadia. \\
\hline & Submit breast tissue for histologic study. & Gynecomastia. \\
\hline Blood and urine & Freeze samples for hormone assay. & $\begin{array}{l}\text { Increased concentrations of alpha- } \\
\text { fetoprotein and human chorionic } \\
\text { gonadotropin. }\end{array}$ \\
\hline Kidneys & $\begin{array}{l}\text { If indicated, follow procedures described } \\
\text { under "glomerulonephritis." }\end{array}$ & $\begin{array}{l}\text { Glomerulonephritis; }{ }^{*} \text { developmental } \\
\text { anomalies (3). }\end{array}$ \\
\hline Testes & $\begin{array}{l}\text { Record location, size, and weight of both testes } \\
\text { and of testicular tumor. Submit samples of } \\
\text { tumor and of ininvolved testis and epididymis } \\
\text { for histologic study. Snap-freeze tumor tissue } \\
\text { for hormone assay. }\end{array}$ & $\begin{array}{l}\text { Cryptorchid testis with tumor or contralateral } \\
\text { to testicular tumor. Testicular microlithiasis. } \\
\text { Secondary testicular tumors (metastases to } \\
\text { the testes) are rare, except in association with } \\
\text { leukemia* in children. }\end{array}$ \\
\hline \multirow[t]{2}{*}{ Other organs } & $\begin{array}{l}\text { Procedures depend on expected findings or } \\
\text { grossly identified abnormalities as listed in } \\
\text { right-hand column. }\end{array}$ & $\begin{array}{l}\text { Pulmonari embolism.* Paraneoplastic } \\
\text { diseases as listed above under "Possible } \\
\text { Associated Conditions." }\end{array}$ \\
\hline & $\begin{array}{l}\text { For dissection of the thoracic duct (for search } \\
\text { of tumor cell clusters), see p. } 34 \text {. }\end{array}$ & $\begin{array}{l}\text { Metastases are found primarily in retro- } \\
\text { peritoneal lymph nodes, left supraclavicular } \\
\text { lymph nodes, and lungs. }\end{array}$ \\
\hline
\end{tabular}

\section{References}

1. Greenspan BN, Felice KJ. Chronic inflammatory demyelinating polyneuropathy (CIDP) associated with seminoma. Eur Neurol 1998;39:57-58.

2. Hayami S, Kubota Y, Sasagawa I, Suzuki H, Nakada N, Motoyama T. Dermatomyositis associated with intratubular germ cell tumor and metastatic germ cell cancer. J Urol 1998;159:2096-2097.

3. Klein EA, Chen RN, Levin HS, Rackley RR, Williams BR. Testicular cancer in association with developmental renal anomalies and hypospadias. Urol 1996;47:82-87.

\section{Tumor of the Thymus}

NOTE: The address of an appropriate registry is Hematologic and Lymphatic Pathology, Armed Forces Institute of Pathology (p. 148). See also "Tumor, Malignant, any type."

Possible Associated Conditions: Anemia (autoimmune hemolytic or aplastic);* Cushing's syndrome;* dermal hyperpigmentation; hypogammaglobulinemia (and other immunoglobulin abnormalities); myasthenia gravis;* pancytopenia;* pemphigus foliaceus; polymyositis;* Sjögren's syndrome;* thrombotic thrombocytopenic purpura* (1). See also below under "Other organs."

\begin{tabular}{|c|c|c|}
\hline Organs and Tissues & Procedures & Possible or Expected Findings \\
\hline External examination & $\begin{array}{l}\text { Record body weight. } \\
\text { Record and prepare photographs of skin } \\
\text { abnormalities; sample for histologic study. }\end{array}$ & $\begin{array}{l}\text { Cachexia. } \\
\text { Dermal hyperpigmentation. } \\
\text { Pemphigus foliaceus (rare). }\end{array}$ \\
\hline Blood & Submit samples for protein analysis. & $\begin{array}{l}\text { Hypogammaglobulinemia and other } \\
\text { immunoglobulin abnormalities. }\end{array}$ \\
\hline Chest & $\begin{array}{l}\text { Photograph and dissect tumor in situ. } \\
\text { Record size, weight, gross appearance, and } \\
\text { relationship to thoracic veins, pericardium, } \\
\text { lungs, and other tissues. Sample for histologic } \\
\text { and electron microscopic study (p. 132). }\end{array}$ & $\begin{array}{l}\text { Usually, thymoma presents as an infiltrating } \\
\text { anterior mediastinal mass that rarely } \\
\text { metastasizes. Carcinoid tumor, malignant } \\
\text { lymphoma* (Hodgkin's disease), and } \\
\text { metastases from carcinoma of the breast* an } \\
\text { other tumors also may occur in this location }\end{array}$ \\
\hline Heart & $\begin{array}{l}\text { Record weight. Submit samples for histologic } \\
\text { study (p. 30). }\end{array}$ & Idiopathic granulomatous myocarditis.* \\
\hline Kidneys & $\begin{array}{l}\text { Follow procedures described under } \\
\text { "Glomerulonephritis." }\end{array}$ & $\begin{array}{l}\text { Minimal-change or membranous } \\
\text { nephropathy; extracapillary glomerulo- } \\
\text { nephritis* }(2) \text {. }\end{array}$ \\
\hline Other organs & $\begin{array}{l}\text { Submit samples of lymph nodes, spleen, } \\
\text { Peyer's plaques, and bone marrow (p. } 96 \text { ) } \\
\text { for histologic study. }\end{array}$ & $\begin{array}{l}\text { Viral (e.g., herpes simplex*) and fungal } \\
\text { infections (e.g., candidiasis*) due to } \\
\text { thymoma-related immunodeficiency (3). }\end{array}$ \\
\hline
\end{tabular}




\begin{tabular}{lll}
\hline Organs and Tissues & Procedures & Possible or Expected Findings \\
\hline Other organs & Other procedures depend on expected findings & Manifestations of paraneoplastic diseases \\
(continued) & $\begin{array}{l}\text { or grossly identified abnormalities as listed in } \\
\text { right-hand column. }\end{array}$ & $\begin{array}{l}\text { and conditions as listed above under } \\
\text { "Possible Associated Conditions." }\end{array}$ \\
\hline
\end{tabular}

\section{References}

1. Hatama S, Kumagai H, Iwato K, Fujiwara M, Fujishima M. Thrombotic thrombocytopenic purpura accompanied by transient pure red cell aplasia and thymoma. Clin Nephrol 1998;49:193-197.

2. Valli G, Fogazzi GB, Cappelari A, Rivolta E. Glomerulonephritis associated with myasthenia gravis. Am J Kidney Dis 1998;31:350-355.

3. Sicherer SH, Cabana MD, Perlman EJ, Lederman HM, Matsakis RR, Winkelstein JA. Thymoma and cellular immune deficiency in an adolescent. Pediatr Allergy Immunol 1998;9:49-52.

\section{Tumor of the Thyroid Gland}

NOTE: See also "Tumor, malignant, any type."

Possible Associated Conditions: With papillary carcinoma-Familial adenomatous polyposis* (1); with medullary thyroid carcinoma-Multiple endocrine neoplasia (MEN, type 2A or 2B).*

\begin{tabular}{|c|c|c|}
\hline Organs and Tissues & Procedures & Possible or Expected Findings \\
\hline External examination & Record abnormal features. & Acromegaly* (2). \\
\hline $\begin{array}{l}\text { Neck organs with } \\
\text { thyroid gland }\end{array}$ & $\begin{array}{l}\text { Leave thyroid gland and tumor attached to } \\
\text { trachea until degree of tracheal compression } \\
\text { can be recorded. Identify exact location of } \\
\text { cervical lymph nodes that are submitted for } \\
\text { histologic study. }\end{array}$ & $\begin{array}{l}\text { Upper airway obstruction }(3) \text {. Benign nodular } \\
\text { goiter or adenoma(s); carcinoma or } \\
\text { lymphoma. Hashimoto's thyroiditis with } \\
\text { lymphoma. }\end{array}$ \\
\hline & $\begin{array}{l}\text { If medullary carcinoma is suspected, snap- } \\
\text { freeze portion of fresh tumor for hormone assay. }\end{array}$ & $\begin{array}{l}\text { Thyrocalcitonin in medullary carcinoma } \\
\text { of thyroid. }\end{array}$ \\
\hline Other organs & $\begin{array}{l}\text { Samples of thymic tissue, lymph nodes, and } \\
\text { endocrine glands should be submitted for } \\
\text { histologic study. Other procedures depend } \\
\text { on expected findings or grossly identified } \\
\text { abnormalities as listed in right-hand column. }\end{array}$ & $\begin{array}{l}\text { Manifestations of hyperthyroidism,* which } \\
\text { may be associated with metastasizing } \\
\text { follicular carcinoma. Manifestations of MEN } \\
\text { (see above under "Possible Associated } \\
\text { Conditions"). }\end{array}$ \\
\hline
\end{tabular}

\section{References}

1. Cetta F, Toti P, Petracci M, Montalto G, Disanto A, Lore F, Fusco A. Thyroid carcinoma associated with familial adenomatous polyposis. Histopathology 1997;31:231-236.

2. Balkany C, Cushing GW. An association between acromegaly and thyroid carcinoma. Thyroid 1995;5:47-50.

3. Carter N, Milroy CM. Thyroid carcinoma causing fatal laryngeal obstruction. J Laryngol Otol 1996;110:1176-1178.

\section{Tumor of the Urinary Bladder}

NOTE: The address of an appropriate registry is Genitourinary Pathology, Armed Forces Instituite of Pathology (p. 148). See also "Tumor, malignant, any type."

\begin{tabular}{lll}
\hline Organs and Tissues & Procedures & Possible or Expected Findings \\
\hline $\begin{array}{l}\text { External examination } \\
\text { Kidneys and ureters }\end{array}$ & $\begin{array}{l}\text { Record body weight. } \\
\text { Leave these organs attached to urinary bladder, } \\
\text { particularly if hydronephrosis and hydroureter } \\
\text { are noted. En block removal of abdominal } \\
\text { organs generally is the best approach (p. 3). }\end{array}$ & $\begin{array}{l}\text { Cachexia. } \\
\text { Hydronephrosis* (obstructive uropathy) and } \\
\text { hydroureter, usually caused by distal ureteral } \\
\text { obstruction. Recurrent nephrolithiasis* or } \\
\text { pyelitis may have been present and is a risk } \\
\text { factor for urinary bladder carcinoma. }\end{array}$ \\
$\begin{array}{l}\text { Pelvic organs with } \\
\text { urinary bladder }\end{array}$ & $\begin{array}{l}\text { For in situ fixation and dissection of the urinary } \\
\text { bladder, see p. 59. } \\
\text { Sample bladder tumor and uninvolved urinary } \\
\text { bladder for histologic study. }\end{array}$ & $\begin{array}{l}\text { Chronic urocystitis; infestation with } \\
\text { Schistosoma haematobium (1) (uncommon } \\
\text { in North America). } \\
\text { Manifestations of uremia (see "Failure, } \\
\text { kidney"). }\end{array}$ \\
\hline Other organs & &
\end{tabular}




\section{Reference}

1. Bedwani R, Renganathan E, El Kwhsky F, Braga C, Abu Seif HH, Abul Azm T, et al. Schistosomiasis and the risk of bladder cancer in Alexandria, Egypt. Br J Canc 1998;77:1186-1189.

\section{Tumor of the Uterus (with Cervix)}

NOTE: The address of an appropriate registry is Gynecologic/Breast Pathology, Armed Forces Institute of Pathology (p. 148). See also "Tumor, malignant, any type."

Possible Associated Conditions: Acquired immunodeficiency syndrome*(AIDS) (1). With carcinoma of the uterus-Cerebellar cortical degeneration;* with carcinoma of the cervix-Myopathy.*

\begin{tabular}{|c|c|c|}
\hline Organs and Tissues & Procedures & Possible or Expected Findings \\
\hline External examination & Record body weight. & Cachexia. \\
\hline Vitreous & $\begin{array}{l}\text { Submit samples for determination of calcium } \\
\text { concentrations. Postmortem calcium values in } \\
\text { blood are unreliable. }\end{array}$ & Evidence of hypercalcemia. \\
\hline Kidneys and ureters & $\begin{array}{l}\text { Leave these organs attached to urinary } \\
\text { bladder, particularly if there is evidence of } \\
\text { hydronephrosis and hydroureter. En block } \\
\text { removal of abdominal organs generally is } \\
\text { the best approach (p. } 3 \text { ). }\end{array}$ & $\begin{array}{l}\text { Hydronephrosis* (obstructive uropathy) and } \\
\text { hydroureter, usually caused by distal ureteral } \\
\text { obstruction. }\end{array}$ \\
\hline Pelvic organs & $\begin{array}{l}\text { Record size and location of tumor; sample } \\
\text { tumor and non-neoplastic uterus and cervix } \\
\text { for histologic study. If indicated, submit } \\
\text { samples for electron microscopic study. } \\
\text { If hormone assay is intended, snap-freeze portion } \\
\text { of tumor. }\end{array}$ & $\begin{array}{l}\text { Fistulas to urinary bladder or rectum or both. } \\
\text { Human papilloma virus infection (2) or } \\
\text { herpesvirus infection (3) with invasive } \\
\text { cervical carcinoma. } \\
\text { Erythropoietin may be found in some tumors. }\end{array}$ \\
\hline Veins & For removal of femoral veins, see p. 34. & Thrombosis.* \\
\hline Skeletal muscles & $\begin{array}{l}\text { For sampling and specimen preparation, } \\
\text { see p. } 80 \text {. }\end{array}$ & $\begin{array}{l}\text { Myopathy* may be associated with } \\
\text { carcinoma of the cervix. }\end{array}$ \\
\hline Brain and spinal cord & $\begin{array}{l}\text { For removal and specimen preparation, } \\
\text { see pp. } 65 \text { and } 67 \text {, respectively. }\end{array}$ & $\begin{array}{l}\text { Cerebellar cortical degeneration* may be } \\
\text { associated with carcinoma of the uterus. }\end{array}$ \\
\hline Other organs & $\begin{array}{l}\text { Procedures depend on expected findings or } \\
\text { grossly identified abnormalities as listed in } \\
\text { right-hand column. }\end{array}$ & $\begin{array}{l}\text { Manifestations of uremia (see "Failure, } \\
\text { kidney"). Manifestations of acquired } \\
\text { immunodeficiency syndrome* (AIDS). }\end{array}$ \\
\hline
\end{tabular}

\section{References}

1. Chin KM, Sidhu JS, Janssen RS, Weber JT. Invasive cervical cancer in human immunodeficiency virus-infected and uninfected hospital patients. Obstetr Gynecol 1998;92:83-87.

2. Ursic-Vrscaj M, Kovacic J, Poljak M, Marin J. Association of risk factors for cervical cancer and human papilloma viruses in invasive cervical cancer. Eur J Gynaecol Oncol 1996;17:368-371.

3. Koffa M, Koumantakis E, Ergazaki M, Tsatsanis C, Spandidos DA. Association of herpesvirus infection with the development of genital cancer. Intl J Canc 1995;63:58-62.

\section{Tumor, Wilms (See “Tumor of the kidney(s).”)}

\section{Tyrosinemia}

Synonyms and Related Terms: Fumarylacetoacetate hydrolase deficiency; aminoaciduria.*

\begin{tabular}{lll}
\hline Organs and Tissues & Procedures & Possible or Expected Findings \\
\hline $\begin{array}{l}\text { External examination } \\
\text { and skin }\end{array}$ & Record body weight. Note odor. & $\begin{array}{l}\text { Growth delay. The body may have a } \\
\text { "fishy" odor. }\end{array}$ \\
& $\begin{array}{l}\text { Sample skin for histologic study. } \\
\text { Prepare skeletal roentgenograms (especially } \\
\text { of epiphyses). } \\
\text { Fascia lata }\end{array}$ & $\begin{array}{l}\text { Hyperkeratosis of skin (1). } \\
\text { Hypophosphatemic rickets. }\end{array}$ \\
technique for tissue culture for biochemical
\end{tabular}




\begin{tabular}{|c|c|c|}
\hline Organs and Tissues & Procedures & Possible or Expected Findings \\
\hline Blood & $\begin{array}{l}\text { Submit samples for culture (p. 102) and } \\
\text { biochemical analysis. }\end{array}$ & $\begin{array}{l}\text { Sepsis. } \\
\text { Increased concentrations of methionine, } \\
\text { tyrosine, alpha-fetoprotein, and delta- } \\
\text { aminolevulinic acid. }\end{array}$ \\
\hline Urine & Submit sample for biochemical analysis. & $\begin{array}{l}\text { Evidence of aminoaciduria (see above under } \\
\text { "Blood"); tyrosine metabolites. }\end{array}$ \\
\hline Liver & $\begin{array}{l}\text { Record weight, photograph cut surfaces, and } \\
\text { sample for histologic study (include nodules } \\
\text { that might be neoplastic). }\end{array}$ & $\begin{array}{l}\text { Enlarged liver with lobular disarray, fibrosis } \\
\text { or cirrhosis;* steatosis; cholestasis; } \\
\text { hepatocellular carcinoma ( } 2 \text { ). }\end{array}$ \\
\hline Kidneys & $\begin{array}{l}\text { Weigh both kidneys and submit for histologic } \\
\text { study. }\end{array}$ & Tubular ectasia; tubular calcification. \\
\hline Other organs & $\begin{array}{l}\text { Procedures depend on expected findings or } \\
\text { grossly identified abnormalities as listed in } \\
\text { right-hand column. }\end{array}$ & $\begin{array}{l}\text { Evidence of bleeding. Islet cell hyperplasia } \\
\text { and mineralization of pancreas; hepatic } \\
\text { encephalopathy.* }\end{array}$ \\
\hline Bones & $\begin{array}{l}\text { Prepare sections of epiphyses for histologic } \\
\text { study (p. 95). }\end{array}$ & See above under "External examination." \\
\hline
\end{tabular}

\section{References}

1. Benoldi D, Orsoni JB, Allegra F. Tyrosinemia type II: a challenge for ophthalmologists and dermatologists. Ped Dermatol 1997;14:110-112.

2. Dehner LP, Snover DC, Sharp HL, Ascher N, Nakhleh R, Day DL. Hereditary tyrosinemia type I (chronic form): Pathologic findings in the liver. Hum Pathol 1989;20:149-158. 


\section{Ulcer, Peptic, of Stomach or Duodenum}

Possible Associated Conditions: Multiple endocrine neoplasia;* rheumatoid arthritis;* Zollinger-Ellison syndrome.*

\begin{tabular}{ll}
\hline Organs and Tissues & Procedures \\
\hline External examination & Prepare roentgenograms of chest and abdomen. \\
Peritoneal cavity & $\begin{array}{l}\text { If peritonitis is present, submit exudate for } \\
\text { bacteriologic study (p. 102). Record volume } \\
\text { of exudate and location of perforation. }\end{array}$ \\
Heart & $\begin{array}{l}\text { See "Disease, ischemic heart." }\end{array}$
\end{tabular}

Possible or Expected Findings

Free air in abdomen suggests perforation of ulcer.

Peritonitis.* Perforation of ulcer.

Coronary atherosclerosis and manifestations of coronary insufficiency are commonly associated with peptic ulcer disease.

Other procedures depend on grossly identified abnormalities as listed in right-hand column.

Lungs Procedures depend on expected findings or grossly identified abnormalities as listed in right-hand column. Perfuse on lung with formalin (p. 47).

Stomach and duodenum For celiac arteriography, see p. 55. Open stomach and duodenum in situ and record site of perforation or penetration. Record measured or estimated volume of blood in gastrointestinal tract. Rinse ulcer with saline to locate eroded vessel(s). Pin stomach and duodenum on corckboard (serosa toward board) and fix specimen in formalin before sectioning.

Prepare histologic sections of ulcer(s) and of remainder of stomach. Request WarthinStarry stain (p. 173) for H. pylori.

Other organs Procedures depend on expected findings or grossly identified abnormalities as listed in right-hand column. In rare instances, pericardial fistula may be present from ulcer in hiatus hernia. Peptic ulcers may be associated with emphysema, ${ }^{*}$ tuberculosis, ${ }^{*}$ and other chronic pulmonary diseases.

Perforating or penetrating peptic ulcer. Infiltrating and ulcerating carcinoma or lymphoma of stomach.* Gastrointestinal hemorrhage.*

Chronic gastritis (with H. pylori infection) and duodenitis.

Manifestations of multiple endocrine neoplasia;* Zollinger-Ellison syndrome,* and rheumatoid arthritis.*

\section{Uncinariasis (See “Ancylostomiasis.”)}

\section{Uremia (See "Failure, kidney.")}

Uropathy, Obstructive (See "Hydronephrosis.")

Urticaria Pigmentosa of Childhood (See "Mastocytosis, systemic.”) 


\section{Valve, Congenitally Bicuspid Aortic}

Possible Associated Conditions: Acute aortic dissection;* aneurysma(s) of cerebral arteries; aortic insufficiency; ${ }^{*}$ calcific aortic stenosis, ${ }^{*}$ coarctation of the aorta;* infective endocarditis;* Shone's syndrome; Turner's syndrome.*

\begin{tabular}{lll}
\hline Organs and Tissues & Procedures & Possible or Expected Findings \\
\hline Heart & If infective endocarditis is suspected, see p. 103. & Infective endocarditis* of bicuspid aortic \\
& Open heart in cross-sections (p. 22). & valve. Aortic valvular insufficiency* may \\
& Photograph aortic valve and test valvular & \\
& competence (p. 29). Prepare histologic & \\
& section of aortic valve, if infected; request & \\
& Gram and Grocott's methenamine silver \\
& stains (p. 172). \\
\hline
\end{tabular}

Valve, Congenitally Bicuspid Pulmonary

Possible Associated Conditions: Double outlet left ventricle; tetralogy of Fallot;* complete or congenitally corrected transposition of the great arteries; $*$ tricuspid atresia;* congenitally bicuspid aortic valve.*

\section{Valve, Congenitally Quadricuspid Aortic}

NOTE: The condition may be complicated by infective endocarditis.* Follow procedures described under that heading.

\section{Varicella}

Synonyms and Related Terms: Chickenpox; congenital varicella syndrome; varicella gangrenosa; varicella-zoster virus infection.

\section{NOTE:}

Reye's syndrome* is a possible postviral complication of varicella that must be distinguished from varicella encephalitis. Varicella may also cause exacerbation of tuberculosis.*

(1) Collect all tissues that appear infected. (2) Request viral cultures. (3) Usually, special stains are not helpful. (4) Special precautions are indicated (p. 146). (5) Serologic studies are available from state health department laboratories (p. 135). (6) This is not a reportable disease.

Possible Associated Conditions: Human immunodeficiency virus (HIV) infection (1); leukemia;* lymphoma;* other immunodeficient conditions. See also above under "Note."

\begin{tabular}{|c|c|c|}
\hline Organs and Tissues & Procedures & Possible or Expected Findings \\
\hline $\begin{array}{l}\text { External examination, } \\
\text { skin, and oral cavity }\end{array}$ & $\begin{array}{l}\text { Record extent and character of skin and oral } \\
\text { mucosal lesions; photograph lesions and } \\
\text { submit samples for histologic study } \\
\text { (preferably lesions without evidence of } \\
\text { superinfection). }\end{array}$ & $\begin{array}{l}\text { Vesicular crusting rash; vesicles with type A } \\
\text { intranuclear inclusions in surrounding } \\
\text { epithelial cells, endothelial cells and } \\
\text { fibroblasts; evidence of disseminated } \\
\text { intravascular coagulation;* purpura } \\
\text { fulminans.* (See also below under "Eyes, } \\
\text { orbitae, and surrounding skin.") }\end{array}$ \\
\hline Cerebrospinal fluid & $\begin{array}{l}\text { Submit sample for viral culture and for cell } \\
\text { count (p. 104). }\end{array}$ & Evidence of meningitis. \\
\hline Chest cavity & Record volume of fluid. & Pleural effusions.* \\
\hline Blood & Submit sample for microbiologic study (p. 102). & $\begin{array}{l}\text { Septicemia (e.g., group A beta-hemolytic } \\
\text { streptococcus; Staphylococcus aureus). }\end{array}$ \\
\hline Heart & Submit samples for histologic study (p. 30). & Pancarditis (usually mild). \\
\hline
\end{tabular}




\begin{tabular}{|c|c|c|}
\hline Organs and Tissues & Procedures & Possible or Expected Findings \\
\hline Lungs & $\begin{array}{l}\text { Record weights. Submit consolidated areas for } \\
\text { bacterial and viral cultures (p. 103). Perfuse } \\
\text { lungs with formalin (p. 47). }\end{array}$ & $\begin{array}{l}\text { Varicella pneumonia, with or without } \\
\text { bacterial superinfection; intranuclear } \\
\text { inclusions in epithelial, mesothelial, } \\
\text { and endothelial cells; pulmonary edema; } \\
\text { hemorrhages and abscesses; fibrosis and } \\
\text { calcification in late stages. }\end{array}$ \\
\hline Liver & $\begin{array}{l}\text { Record weight and submit samples for } \\
\text { histologic study. }\end{array}$ & Varicella hepatitis. \\
\hline Spleen & $\begin{array}{l}\text { Inspect carefully in situ to detect evidence } \\
\text { of rupture. Record weight and consistency; } \\
\text { sample for histologic study. }\end{array}$ & Splenitis, with or without rupture of spleen. \\
\hline Stomach & $\begin{array}{l}\text { Examine as soon as possible to minimize } \\
\text { autolysis. Submit sections for histologic study. }\end{array}$ & Ulcerative gastritis. \\
\hline Kidneys & $\begin{array}{l}\text { Follow procedures described under } \\
\text { "Glomerulonephritis." }\end{array}$ & Glomerulonephritis.* \\
\hline Testes & $\begin{array}{l}\text { Record weights; submit samples for histologic } \\
\text { study. }\end{array}$ & Orchitis. \\
\hline Neck organs & $\begin{array}{l}\text { Open in posterior midline. (See also under } \\
\text { "Laryngitis.") }\end{array}$ & Bacterial epiglottitis (2). \\
\hline Brain and spinal cord & $\begin{array}{l}\text { For removal and specimen preparation, } \\
\text { see pp. } 65 \text { and } 67 \text {, respectively. }\end{array}$ & $\begin{array}{l}\text { Encephalitis with cerebral edema; petechial } \\
\text { hemorrhages; perivenous demyelination; } \\
\text { acute cerebellitis; aseptic meningitis;* } \\
\text { transverse myelitis.* }\end{array}$ \\
\hline $\begin{array}{l}\text { Eyes, orbitae, and } \\
\text { surrounding skin }\end{array}$ & $\begin{array}{l}\text { For removal and specimen preparation, } \\
\text { see p. } 85 \text {. }\end{array}$ & $\begin{array}{l}\text { Keratitis; vesicular conjunctivitis; } \\
\text { optic neuritis (3). Periorbital varicella } \\
\text { gangrenosa (4). }\end{array}$ \\
\hline Peripheral nerves & $\begin{array}{l}\text { For removal and specimen preparation, } \\
\text { see p. } 79 .\end{array}$ & Acute motor axonal neuropathy (5). \\
\hline $\begin{array}{l}\text { Skeletal muscles } \\
\text { and soft tissues }\end{array}$ & $\begin{array}{l}\text { Procedures depend on expected findings or } \\
\text { grossly identified abnormalities as listed in } \\
\text { right-hand column. For specimen preparation } \\
\text { of muscles, see p. } 80 \text {. }\end{array}$ & $\begin{array}{l}\text { Rhabdomyolysis; necrotizing fasciitis } \\
\text { (varicella gangrenosa). }\end{array}$ \\
\hline Joints & $\begin{array}{l}\text { For removal, prosthetic repair, and specimen } \\
\text { preparation, see p. } 96 .\end{array}$ & Arthritis.* \\
\hline
\end{tabular}

\section{References}

1. Gershon AA, Mervish N, LaRussa P, Steinberg S, Lo SH, Hodes D, et al. Varicella-zoster virus infection in children with underlying immunodeficiency virus infection. J Infect Dis 1997;176:1496-1500.

2. Belfer RA. Group A beta-hemolytic streptococcal epiglottitis as a complication of varicella infection. Pediatr Emerg Care 1996;12:202-204.

3. Lee CC, Venketasubramanian N, Lam MS. Optic neuritis: a rare complication of primary varicella infection. Clin Infect Dis 1997;24:515-516.

4. Tornervy NR, Fomsgaard A, Nielsen NV. HSV-1-induced acute retinal necrosis syndrome presenting with severe inflammatory orbitopathy, proptosis, and optic nerve involvement. Opthal 2000;107:397-400.

5. Picard F, Gericke CA, Frey M, Collard M. Varicella with acute motor axonal neuropathy. Euro Neurol 1997;38:68-71.

\section{Varices, Esophageal}

NOTE: See also under "Hypertension, portal."

\begin{tabular}{lll}
\hline Organs and Tissues & Procedures & Possible or Expected Findings \\
\hline Chest & Dissect major veins in situ. & $\begin{array}{l}\text { Superior vena cava obstruction; other venous } \\
\text { abnormalities such as unilateral pulmonary } \\
\text { vein atresia. }\end{array}$ \\
Esophagus and stomach & $\begin{array}{l}\text { Remove esophagus and stomach together as } \\
\text { one specimen. Record volume and character } \\
\text { of blood in stomach. For demonstration }\end{array}$ & $\begin{array}{l}\text { Esophageal varices with or without evidence } \\
\text { of rupture. }\end{array}$
\end{tabular}

of esophageal varices, see p. 53. 


\begin{tabular}{|c|c|c|}
\hline Organs and Tissues & Procedures & Possible or Expected Findings \\
\hline $\begin{array}{l}\text { Esophagus and stomach } \\
\text { (continued) }\end{array}$ & $\begin{array}{l}\text { Record effects of sclerotherapy or evidence } \\
\text { of surgical esophageal transection. }\end{array}$ & $\begin{array}{l}\text { Evidence of sclerotherapy or esophageal } \\
\text { transection surgery may be found. }\end{array}$ \\
\hline Intestinal tract & $\begin{array}{l}\text { Record measured or estimated amount of blood } \\
\text { in lumen. }\end{array}$ & Blood in intestinal tract. \\
\hline Portal vein system & $\begin{array}{l}\text { Dissect all accessible veins in situ. Submit } \\
\text { samples of veins for histologic study. } \\
\text { Request Verhoeff-van Gieson stain (p. 173). } \\
\text { If surgical shunts had been created, record } \\
\text { type, location, and patency of anastomoses. }\end{array}$ & $\begin{array}{l}\text { Portal vein thrombosis; other conditions } \\
\text { causing portal vein obstruction. Sclerosis } \\
\text { associated with idiopathic portal } \\
\text { hypertension. } \\
\text { Shunt surgery (portacaval and proximal or } \\
\text { distal splenorenal shunts.) }\end{array}$ \\
\hline Liver & $\begin{array}{l}\text { Record weight and submit samples for } \\
\text { histologic study. If a transjugular intrahepatic } \\
\text { portasystemic shunt had been placed, document } \\
\text { location and patency. For portal venography, } \\
\text { see p. } 56 \text {. }\end{array}$ & $\begin{array}{l}\text { Cirrhosis;* chronic alcoholic hepatitis; } \\
\text { congenital hepatic fibrosis* and other } \\
\text { fibropolycystic liver diseases;* nodular } \\
\text { regenerative hyperplasia, veno-occlusive } \\
\text { disease, and other liver diseases. }\end{array}$ \\
\hline Spleen & Record weight. & Congestive splenomegaly. \\
\hline
\end{tabular}

Vasculitis (See "Aortitis," "Arteritis, ...," "Phlebitis," and "Purpura,...")

\section{Ventricle, Double Inlet Left}

Synonyms: Single functional ventricle; univentricular heart; univentricular atrioventricular connection; Holmes heart.

NOTE: The basic anomaly is the connection of both atrioventricular valves to the left ventricle, often with transposed great arteries and a restrictive ventricular septal defect. There are four major types, based on the ventriculoarterial connection: (1) with congenitally corrected transposition (60\%); (2) with complete transposition (30\%); (3) with normally related great arteries (Holmes heart; 5\%); and (4) double outlet, persistent truncal artery, or pulmonary atresia $(5 \%)$. For general dissection techniques, see p. 33.

Possible Associated Conditions: Bicuspid pulmonary valve; bilateral mirror-image mitral valves (without tricuspid morphology); subvalvular aortic stenosis, ${ }^{*}$ often with hypoplasia, coarctation, or interruption of the aortic arch; subvalvular pulmonary stenosis; * dual AV nodes and progressive heart block in patients with congenitally corrected transposition.

\section{Ventricle, Double Outlet Right}

Synonym: Origin of both great arteries from right ventricle; Taussig-Bing anomaly.

NOTE: The basic anomaly is the origin of the aorta and pulmonary artery primarily from the right ventricle, usually with a ventricular septal defect, and often with subpulmonary stenosis. For general dissection techniques, see p. 33.
Possible Associated Conditions: Complete atrioventricular septal defect (often with asplenia syndrome); muscular discontinuity between aortic and mitral valves; right ventricular infundibular stenosis; ventricular septal defect* that may be subaortic, subpulmonary, doubly committed, or remote.

Virus, Respiratory Syncytial

(See "Pneumonia, all types or type unspecified.")

Virus, Salivary Gland

(See "Infection, cytomegalovirus.")

Vitamin A (See "Deficiency, vitamin A" and "Hypervitaminosis A.")

Vitamin B1 (Thiamine) (See "Syndrome, Wernicke-Korsakoff.”)

Vitamin B6 (See "Beriberi.")

Vitamin B12 (See “Anemia, megaloblastic.”)

Vitamin C (See "Deficiency, vitamin C.")

Vitamin D (See "Deficiency, vitamin D" and "Hypervitaminosis D.")

Whooping Cough (See "Pertussis.")

Xanthoma Tuberosum (See "Hyperlipoproteinemia.") 